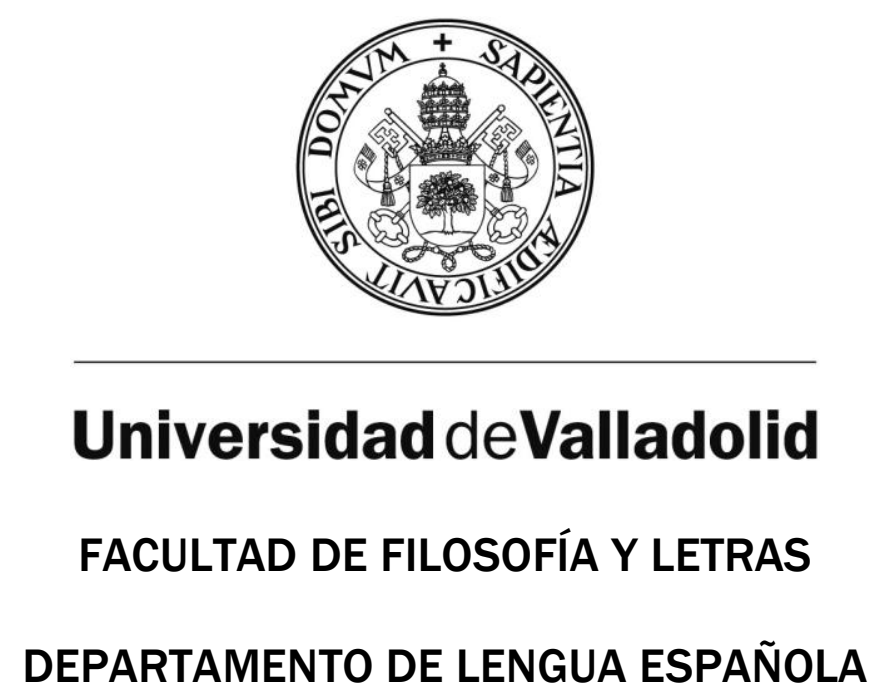

TESIS DOCTORAL

\title{
Análisis contrastivo de la cortesía verbal en Español y Malayo en la realización de tres actos de habla; petición, mandato y rechazo
}

Presentada por Radhiah Binti Ismail para optar al grado de Doctor por la Universidad de Valladolid

\author{
Dirigida por: \\ Dr. Emilio Ridruejo Alonso
}





\section{AGRADECIMIENTOS}

En primer lugar deseo expresar mi agradecimiento al director de esta tesis doctoral, el profesor Dr. Emilio Ridruejo Alonso, por la confianza que me ha ofrecido desde que llegué a la Facultad de Filosofía y Letras de la Universidad de Valladolid, por la dedicación y apoyo que ha brindado a este trabajo en todo momento y por el respeto a mis sugerencias e ideas, a las que siempre ha facilitado dirección y rigor.

Asimismo, agradezco a los profesores del Departamento de Lengua Española de La Universidad de Valladolid, su apoyo personal y humano, agradecimiento que dedico especialmente a los docentes del Programa de Doctorado de Lingüística Española y sus Aplicaciones, con quien he compartido proyectos e ilusiones durante estos años.

Un trabajo de investigación es siempre fruto de ideas, proyectos y esfuerzos previos que corresponden a otras personas. En este 
sentido, quiero dejar constancia de mi más sincero agradecimiento a los profesores del Centro de Idiomas de la Universidad de Valladolid y de la Universidad de Malasia Terengganu, con cuyo trabajo estaré siempre en deuda. Gracias por su amabilidad y por aportarme su tiempo, su conocimiento y sus ideas.

Por su atención y colaboración en mis cuestionarios, quiero dar las gracias también a los profesores de la Escuela Técnica Superior de Ingenieros de Telecomunicación y de la Facultad de Ciencias, de la Universidad de Valladolid, así como a los profesores de la Facultad de Administración de Empresas y Estudios Económicos y de la Facultad de Ciencias de la Universidad de Malasia Terengganu (Malasia), y a los alumnos de la Escuela Universitaria de Estudios Empresariales de la Universidad de Valladolid y de la Facultad de Desarrollo Social de la Universidad de Malasia Terengganu (Malasia). Finalmente, quiero agradecerles a Carolina Regidor y Diego Fonseca la cuidadosa revisión que han realizado de este texto y sus valiosas sugerencias en momentos de duda.

Pero un trabajo de investigación es también fruto del reconocimiento y del apoyo vital que nos ofrecen las personas que nos estiman, sin el cual no tendríamos la fuerza y energía que nos anima a crecer como personas y como profesionales. 
Gracias a mis padres, Ismail Mohd y Salma Ibrahim, a mis hermanos y a mis amigos, que siempre me han prestado un gran apoyo moral y humano, necesarios en los momentos difíciles de este trabajo y esta profesión. Pero, sobre todo, gracias a mi marido, Abd. Rahman Abdullah y a mis tres hijos, Nur Insyirah, Nur Habibah y Abdullah Yasir, por su paciencia, comprensión y solidaridad con este proyecto, por el tiempo que me han concedido, un tiempo robado a la historia familiar. Sin su apoyo este trabajo nunca se habría escrito y, por eso, este trabajo es también el suyo.

A todos, muchas gracias. 



\section{TABLA DE CONTENIDOS}

AGRADECIMIENTOS ...........................................................

TABLA DE CONTENIDOS................................................... v

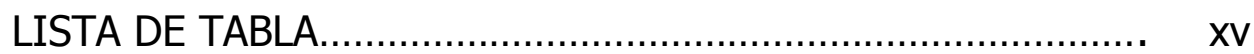

LISTA DE FIGURA........................................................... XXV

CAPÍTULO 1 INTRODUCCIÓN................................................. 1

$1.1 \quad$ Planteamiento de Problema..................................... 1

$1.2 \quad$ Objetivos del estudio............................................. 8

1.3 Justificación............................................................... 10

$1.4 \quad$ Estructura del trabajo......................................... 12

CAPÍTULO 2 MARCO TEÓRICO............................................. 15

2.1 La Teoría de los Actos de Habla............................. 16

$2.2 \quad$ La Teoría de la Cortesía.......................................... 28

2.2.1 Las Reglas de Cortesía de Lakoff (1973)................................................... 29

2.2.2 El Principio de Cortesía de Leech (1983) 
2.2.3 La Teoría de Cortesía de Brown y Levinson (1987 [1978])........................... 36

2.3 Los actos de habla de petición y mandato................ 49

2.3.1 Estrategias de petición.............................. 51

2.3.2 Estado de la cuestión acerca de la petición...................................................... 59

2.4 Los actos de habla de rechazo................................ 76

2.4.1 Estrategias de rechazo............................. 78

2.4.2 Investigación del rechazo......................... 87

CAPÍTULO 3 METODOLOGÍA............................................... 105

3.1 Diseño de la encuesta............................................ 105

3.2 Estudio piloto............................................................ 111

3.3 Sujetos........................................................ 114

$3.4 \quad$ Instrumentos ...................................................... 116

3.5 Procedimientos de recogida de datos..................... 122

3.6 Procedimientos de análisis de datos........................ 124

3.6.1 Petición y mandato.................................... 126

3.6.2 Rechazo............................................. 134

CAPÍTULO 4 RESULTADOS Y ANÁLISIS DE DATOS SOBRE LA PETICIÓN............................................... 141

4.1 Análisis cuantitativo............................................ 142

4.1.1 Análisis general..................................... 142

4.1.1.1 Español frente a malayo........... 143

4.1.1.2 Mayor frente a menor.............. 153

4.1.1.3 Varón frente a mujer............... 161 
4.1.2 Análisis situacional.................................. 169

4.1.2.1 Situación 1.............................. 169
A) Español frente malayo..... 170
B) Mayor frente a menor...... 175
C) Varón frente a mujer....... 179

4.1.2.2 Situación 4.............................. 185
A) Español frente a malayo.. 186
B) Mayor frente a menor...... 190
C) Varón frente a mujer....... 196

4.1.2.3 Situación 7............................... 202
A) Español frente a malayo.. 202
B) Mayor frente a menor...... 207
C) Varón frente a mujer....... 212

4.1.2.4 Situación 10............................ 218
A) Español frente a malayo.. 219
B) Mayor frente a menor...... 223
C) Varón frente a mujer....... 230

4.1.2.5 Situación 13............................ 235
A) Español frente a malayo.. 236
B) Mayor frente a menor...... 241
C) Varón frente a mujer....... 248

4.1.2.6 Situación 16............................. 254
A) Español frente a malayo.. 254
B) Mayor frente a menor...... 259 
C) Varón frente a mujer....... 264

4.1.3 La influencia de las variables sociales...... $\quad 271$

4.1.3.1 Estatus social......................... 271

A) Actos principales.............. 272

B) Movimientos de apoyo..... 281

4.1.3.2 Distancia social....................... 292

A) Actos principales............. 292

B) Movimientos de apoyo..... 301

4.2 Análisis del contenido (modificaciones internas)..... 313

4.2.1 Análisis general..................................... 314

4.2.1.1 Modificaciones internas en las peticiones formuladas con una "Interrogación preparatoria"...

4.2.1.2 Modificaciones internas en las peticiones formuladas con una "Presentación/saludo"

4.2.1.3 Fórmulas de deixis social. 335

i) Fórmulas de tratamiento pronominales

ii) Fórmulas de tratamiento nominales

4.2.1.4 Modificaciones gramaticales..... 360

4.2.1.5 Perspectiva de la persona........ 364

4.2.2 Análisis situacional.................................. 369

4.2.2.1 Situación 1............................. 369

4.2.2.2 Situación 4.............................. 376

4.2.2.3 Situación 7.............................. 380 


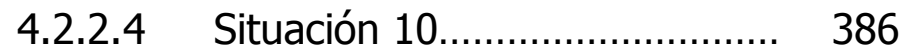

4.2.2.5 Situación 13........................... 391

4.2.2.6 Situación 16............................ 397

4.3 Conclusión........................................................... 402

CAPÍTULO 5 RESULTADOS Y ANÁLISIS DE DATOS SOBRE EL MANDATO ............................................ 411

$5.1 \quad$ Análisis cuantitativo........................................... 412

5.1.1 Análisis general...................................... 412

5.1.1.1 Español frente a malayo........... 412

5.1.1.2 Mayor frente a menor............... 418

5.1.1.3 Varón frente a mujer................ 426

5.1.2 Análisis situacional................................. 432

5.1.2.1 Situación 3............................ 432

A) Español frente a malayo.. 433

B) Mayor frente a menor...... 438

C) Varón frente a mujer....... 445

5.1.2.2 Situación 6................................ 451

A) Español frente a malayo.. 452

B) Mayor frente a menor...... 456

C) Varón frente a mujer....... 462

5.1.2.3 Situación 9................................ 468
A) Español frente a malayo.. 468
B) Mayor frente a menor...... 473
C) Varón frente a mujer....... 478 
5.1.2.4 Situación 12............................. 483

A) Español frente a malayo.. 484

B) Mayor frente a menor...... 488

C) Varón frente a mujer....... 494

5.1.2.5 Situación 15............................... 498

A) Español frente a malayo.. 499

B) Mayor frente a menor...... 503

C) Varón frente a mujer....... 508

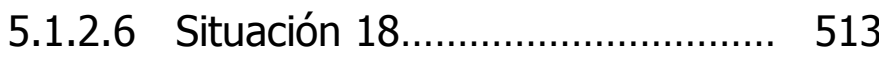
A) Español frente a malayo.. 513
B) Mayor frente a menor...... 518
C) Varón frente a mujer....... 523

5.1.3 La influencia de la distancia social........... 529

A) Actos principales............................... 529

B) Movimientos de apoyo...................... 534

5.2 Análisis del contenido (modificaciones internas)...... 541

5.2.1 Análisis general..................................... 542

5.2.1.1 Modificaciones internas en los mandatos formulados con un "Imperativo" 542

5.2.1.2 Fórmulas de deixis social........ 549

i) Fórmulas de tratamiento pronominales.................. 549

ii) Fórmulas de tratamiento nominales...................... 553

5.2.1.3 Modificaciones gramaticales.... 558 
5.2.1.4 Perspectiva de la persona. 561

5.2.2 Análisis situacional 564

5.2.2.1 Situación 3............................. 564

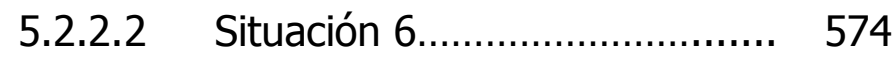

5.2.2.3 Situación 9............................ 583

5.2.2.4 Situación 12........................... 589

5.2.2.5 Situación 15............................. 600

5.2.2.6 Situación 18............................ 608

5.3 Conclusión.............................................................. 616

CAPÍTULO 6 RESULTADOS Y ANÁLISIS DE DATOS SOBRE EI RECHAZO............................................... 627

6.1 Análisis cuantitativo.......................................... 628

6.1.1 Análisis general................................... 628

6.1.1.1 Español frente a malayo........... 628

6.1.1.2 Mayor frente a menor............. 638

6.1.1.3 Varón frente a mujer............... 649

6.1.2 Análisis situacional................................ 658

6.1.2.1 Situación 2............................ 658

A) Español frente a malayo.. 659

B) Mayor frente a menor...... 664

C) Varón frente a mujer....... 669

6.1.2.2 Situación 5............................. 675

A) Español frente a malayo.. 675

B) Mayor frente a menor...... 679 
C) Varón frente a mujer....... 685

6.1.2.3 Situación 8.............................. 690
A) Español frente a malayo.. 690
B) Mayor frente a menor...... 695
C) Varón frente a mujer....... 700

6.1.2.4 Situación 11............................. 705
A) Español frente a malayo.. 705
B) Mayor frente a menor...... 709
C) Varón frente a mujer....... 715

6.1.2.5 Situación 14............................ 720
A) Español frente a malayo.. 720
B) Mayor frente a menor...... 724
C) Varón frente a mujer....... 730

6.1.2.6 Situación 17............................ 735
A) Español frente a malayo.. 735
B) Mayor frente a menor...... 739
C) Varón frente a mujer....... 745

6.1.3 La influencia de las variables sociales...... 752

6.1.3.1 Estatus social........................ 752

6.1.3.2 Distancia social....................... 762

$6.2 \quad$ Análisis del contenido........................................... 771

6.2.1 Resultados y análisis total del contenido de los rechazos analizados...................... 771

6.2.1.1 Análisis general del empleo de la "Excusa"................................. 772 
A) Mayor frente a menor 777

B) Varón frente a mujer....... 780

6.2.2 Análisis situacional del empleo de la "Excusa". 781

6.2.2.1 Situación 2............................. 782

6.2.2.2 Situación 5............................ 786

6.2.2.3 Situación 8............................ 790

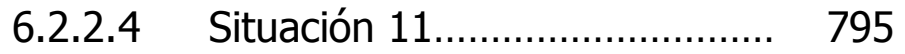

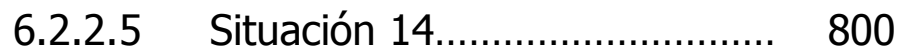

6.2.2.6 Situación 17........................... 805

6.3 Discusión general................................................ 811

6.4 Conclusión............................................................. 816

CAPÍTULO 7 CONCLUCIONES............................................ 827

7.1 Resumen de la investigación..................................... 827

7.2 Resultados principales obtenidos sobre la petición.. 832

7.3 Resultados principales obtenidos sobre el mandato 842

7.4 Resultados principales obtenidos sobre el rechazo.. 852

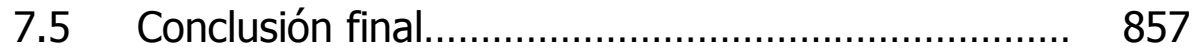

7.6 Aplicaciones de esta investigación........................... 862

7.7 Orientación para futuras investigaciones................ 866

BIBLIOGRAFÍA........................................................... 869

APÉNDICE A: Clasificación de petición de Blum-Kulka (1989). 
APÉNDICE B: Clasificación de rechazos de Beebe et. al (1990)

APÉNDICE C: Clasificación de rechazos de Bardovi-Harlig y Hartford (1991)

APÉNDICE D: Cuestionario en español.

APÉNDICE E: Cuestionario en malayo...................................... 903 


\section{LISTA DE TABLAS}

Tabla 1. Sistema de Cortesía e Imagen de Scollon y Scollon, (2001)

Tabla 2. Distribución de los sujetos en cada grupo: malayo y español.

Tabla 3. Contextualización de los actos de habla investigados en las 18 situaciones del DCT......

Tabla 4. Sub-clasificación de estrategias (9 tipos) según el grado de (in)dirección (Blum-Kulka et al., 1989).

Tabla 5. Estrategias de movimientos de apoyo encontradas en el estudio

Tabla 6. Tabla 6. Estrategias de rechazo utilizadas por los participantes de este estudio

Tabla 7. Distribución de sub-estrategias de "Interrogación preparatoria", según modo, en los datos españoles.

Tabla 8. Distribución de sub-estrategias de "Interrogación preparatoria", según modo, en los datos de los subgrupos españoles. 
Tabla 9. Distribución de sub-estrategias de "Interrogación preparatoria" en los datos malayos.

Tabla 10. Distribución de sub-estrategias de "Interrogación preparatoria" en los datos malayos según edad y sexo.

Tabla 11. Distribución de sub-estrategias de "Interrogación preparatoria" en los datos malayos según edad y sexo.

Tabla 12. Frecuencia del uso de las estrategias de "Presentación/saludo" en los datos españoles.

Tabla 13. Frecuencia del uso de las estrategias de "Presentación/saludo" en los datos malayos.

Tabla 14. Frecuencia de uso de las estrategias de "Presentación/saludo" en los datos españoles según edad.

Tabla 15. Frecuencia de uso de las estrategias de "Presentación/saludo" en los datos españoles según sexo.

Tabla 16. Frecuencia de uso de las estrategias de "Presentación/saludo" en los datos malayos según la edad.

Tabla 17. Frecuencia de uso de las estrategias de "Presentación/saludo" en los datos malayos según el sexo

Tabla 18. Tipos de pronombre personal de segunda persona en malayo

Tabla 19. Distribución del uso de usted en el grupo español según edad en las seis situaciones 
Tabla 20. Distribución del uso de usted en el grupo español según sexo en las seis situaciones

Tabla 21. Distribución de pronombres personales de segunda persona utilizados en las seis situaciones en malayo.

Tabla 22. Distribución de pronombres personales de segunda persona empleados en malayo según subgrupo de edad en las seis situaciones.

Tabla 23. Distribución de pronombres personales de segunda persona empleados en malayo según subgrupo de sexo en las seis situaciones

Tabla 24. Distribución de las fórmulas de tratamiento en los datos de la sociedad española

Tabla 25. Distribución de las fórmulas de tratamiento en los datos de la sociedad malaya.

Tabla 26. Distribución de enunciados, según tipos de fórmulas de tratamiento empleadas por mayores y menores en el grupo español.

Tabla 27. Distribución de enunciados, según tipos de fórmulas de tratamiento empleadas por mayores y menores en el grupo malayo.

Tabla 28. Distribución de enunciados según tipos de fórmulas de tratamiento empleadas por cada subgrupo de género en la sociedad española.

Tabla 29. Distribución de enunciados según tipos de fórmulas de tratamiento empleadas por cada subgrupo de género en la sociedad malaya.

Tabla 30. Distribución del cambio de forma verbal en el grupo español según edad en las seis situaciones. 
Tabla 31. Distribución del cambio de forma verbal en el grupo español según sexo en las seis situaciones...

Tabla 32. Distribución del uso de partículas en las seis situaciones en el grupo malayo

Tabla 33. Distribución del uso de partículas en el corpus malayo, según edad, en las seis situaciones de mandato.

Tabla 34. Distribución del uso de partículas en el corpus malayo, según sexo, en las seis situaciones de mandato.

Tabla 35. Distribución del porcentaje de peticiones con un "Interrogación preparatoria" según la perspectiva de la persona en el corpus malayo.

Tabla 36. Distribución del porcentaje de peticiones con una "Interrogación preparatoria" según la perspectiva de la persona en los subgrupos malayos

Tabla 37. Resultados obtenidos en el caso de español frente a malayo

Tabla 38. Resultados obtenidos en el caso de sujeto mayor frente a sujeto menor.

Tabla 39. Resultados obtenidos en el caso de sujeto mayor frente a sujeto menor.

Tabla 40. Resultados obtenidos en el caso de hombre frente a mujer.

Tabla 41. Resultados obtenidos en el caso de hombre frente a mujer.

Tabla 42. Distribución de los tipos de "Imperativo" utilizados en el estudio por los hablantes de la sociedad malaya en las seis situaciones. 
Tabla 43. Distribución de las formas del "Imperativo" en las seis situaciones en los subgrupos de edad malayos.

Tabla 44. Distribución de las formas del "Imperativo" en las seis situaciones en los subgrupos de sexo malayos.

Tabla 45. Distribución del uso de usted en el grupo español según edad en las seis situaciones.

Tabla 46. Distribución del uso de usted en el grupo español según sexo en las seis situaciones

Tabla 47. Distribución de pronombres personales de segunda persona utilizados en las seis situaciones en malayo.

Tabla 48. Distribución de pronombres personales de segunda persona empleados en malayo según subgrupo de edad en las seis situaciones.

Tabla 49. Distribución de pronombres personales de segunda persona empleados en malayo según subgrupo de sexo en las seis situaciones.

Tabla 50. Distribución de fórmulas nominales empleadas en las seis situaciones en la sociedad española.

Tabla 51. Distribución de fórmulas nominales empleadas en las seis situaciones en la sociedad malaya.

Tabla 52. Distribución de fórmulas nominales en el corpus español según subgrupo de edad en las seis situaciones.

Tabla 53. Distribución de fórmulas nominales en el corpus malayo según subgrupo de edad en las seis situaciones. 
Tabla 54. Distribución de fórmulas nominales en el corpus español según subgrupo de sexo en las seis situaciones......

Tabla 55. Distribución de fórmulas nominales en el corpus malayo según subgrupo de sexo en las seis situaciones.

Tabla 56. Distribución del cambio de forma verbal en el grupo español según edad en las seis situaciones.

Tabla 57. Distribución del cambio de forma verbal en el grupo español según sexo en las seis situaciones

Tabla 58. Distribución del uso de partículas en las seis situaciones en el grupo malayo

Tabla 59. Distribución del uso de partículas en el corpus malayo, según edad, en las seis situaciones de mandato

Tabla 60. Distribución del uso de partículas en el corpus malayo, según sexo, en las seis situaciones de mandato.

Tabla 61. Distribución de enunciados según la perspectiva de persona en las respuestas para las seis situaciones en las dos culturas.

Tabla 62. Distribución de la perspectiva de persona según edad, en las seis situaciones de mandato en las dos culturas.

Tabla 63. Distribución de la perspectiva de persona según subgrupo de sexo de las dos culturas en las seis situaciones de mandato.

Tabla 64. Resultados principales de los datos del mandato en el caso de español frente a malayo. 
Tabla 65. Resultados principales de los datos del mandato en el caso de participante mayor frente a

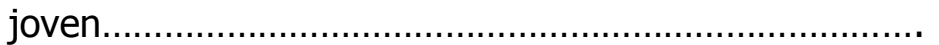

Tabla 66. Resultados principales de los datos del mandato en el caso de hombre frente a mujer

Tabla 67. Frecuencia de las estrategias utilizadas por los informantes en las dos sociedades.

Tabla 68. Estrategias utilizadas en todas las situaciones en cada cultura ordenadas según frecuencia de uso (de mayor a menor).

Tabla 69. Estrategias utilizadas por los hablantes españoles en todas las situaciones ordenadas según frecuencia de uso (de mayor a menor) en cada subgrupo de edad.

Tabla 70. Estrategias utilizadas por los hablantes malayos en todas las situaciones ordenadas según frecuencia de uso (de mayor a menor) en cada subgrupo de edad.

Tabla 71. Estrategias utilizadas por los hablantes españoles y malayos en todas las situaciones ordenadas según frecuencia de uso (de mayor a menor) en cada subgrupo de sexo.

Tabla 72. Estrategias utilizadas en cada cultura en la situación 2 , ordenadas según frecuencia de uso (de mayor a menor).

Tabla 73. Estrategias utilizadas por los hablantes españoles y malayos en la situación 2 ordenadas según frecuencia de uso (de mayor a menor) en cada subgrupo de edad.

Tabla 74. Estrategias utilizadas por los hablantes españoles y malayos en la situación 2 ordenadas según frecuencia de uso (de mayor a menor) en cada subgrupo de sexo. 
Tabla 75. Estrategias utilizadas en la situación 5 en cada cultura ordenadas según frecuencia de uso (de mayor a menor).

Tabla 76. Estrategias utilizadas por los hablantes españoles y malayos en la situación 5 ordenadas según frecuencia de uso (de mayor a menor) en cada subgrupo de edad.

Tabla 77. Estrategias utilizadas por los hablantes españoles y malayos en la situación 5 ordenadas según frecuencia de uso (de mayor a menor) en cada subgrupo de sexo.

Tabla 78. Estrategias utilizadas en la situación 8 en cada cultura ordenadas según frecuencia de uso (de mayor a menor).

Tabla 79. Estrategias utilizadas por los hablantes españoles y malayos en la situación 8 , ordenadas según frecuencia de uso (de mayor a menor) en cada subgrupo de edad.

Tabla 80. Estrategias utilizadas por los hablantes españoles y malayos en la situación 8 , ordenadas según frecuencia de uso (de mayor a menor) en cada subgrupo de sexo.

Tabla 81. Estrategias utilizadas en la situación 11 en cada cultura ordenadas según frecuencia de uso (de mayor a menor)

Tabla 82. Estrategias utilizadas por los hablantes españoles y malayos en la situación 11 ordenadas según frecuencia de uso (de mayor a menor) en cada subgrupo de edad.

Tabla 83. Estrategias utilizadas por los hablantes españoles y malayos en la situación 11 ordenadas según frecuencia de uso (de mayor a menor) en cada subgrupo de sexo. 
Tabla 84. Estrategias utilizadas en la situación 14 en cada cultura ordenadas según frecuencia de uso (de mayor a menor)

Tabla 85. Estrategias utilizadas por los hablantes españoles y malayos en la situación 14 ordenadas según frecuencia de uso (de mayor a menor) en cada subgrupo de edad.

Tabla 86. Estrategias utilizadas por los hablantes españoles y malayos en la situación 14 ordenadas según frecuencia de uso (de mayor a menor) en cada subgrupo de sexo

Tabla 87. Estrategias utilizadas en la situación 17 en cada cultura ordenadas según frecuencia de uso (de mayor a menor)

Tabla 88. Estrategias utilizadas por los hablantes españoles y malayos en la situación 17 ordenadas según frecuencia de uso (de mayor a menor) en cada subgrupo de edad.

Tabla 89. Estrategias utilizadas por los hablantes españoles y malayos en la situación 17 ordenadas según frecuencia de uso (de mayor a menor) en cada subgrupo de sexo.

Tabla 90. Distribución de estrategias utilizadas según estatus social en cada cultura

Tabla 91. Distribución de estrategias utilizadas según estatus social en cada cultura.

Tabla 92. Resultados principales obtenidos en el contraste de español frente a malayo.

Tabla 93. Resultados principales obtenidos en la comparación de sujeto mayor frente a sujeto menor.

Tabla 94. Resultados principales obtenidos en la comparación de sujeto mayor frente a sujeto menor. 
Tabla 95. Resultados principales obtenidos en el caso de la aplicación de la variable hombre frente a mujer.

Tabla 96. Resultados principales obtenidos en el caso de la aplicación de la variable hombre frente a mujer. 


\section{LISTA DE FIGURAS}

Figura 1. Distribución del número de enunciados según los tres grandes tipos de estrategias de petición aplicadas a los actos principales en ambas culturas.

Figura 2. Distribución de los enunciados entre las nueve estrategias de petición (actos principales) en ambas culturas.

Figura 3. Distribución del número de enunciados según el tipo de estrategia empleada en los movimientos de apoyo en ambas culturas

Figura 4. Distribución del número de enunciados producidos como actos principales en las seis situaciones por los hablantes de ambas culturas

Figura 5. Distribución de los enunciados según los tres tipos de estrategias de petición en las seis situaciones en ambas culturas.

Figura 6. Distribución de enunciados (en número) producidos como movimientos de apoyo en cada situación en ambas culturas 
Figura 7. Distribución de enunciados según el grado de (in)dirección de las estrategias de petición empleadas por cada subgrupo de edad.

Figura 8. Distribución de enunciados según las sub-estrategias aplicadas en los actos principales categorías)..

Figura 9. Distribución de los enunciados (movimientos de apoyo) según las estrategias utilizadas por los hablantes de los cuatro subgrupos en ambas culturas.

Figura 10. Distribución de los enunciados (actos principales) según las estrategias de petición utilizadas por los hablantes de los dos sexos en ambas culturas

Figura 11. Distribución de enunciados según estrategias empleadas en actos principales por los hablantes de los dos géneros en ambas culturas.

Figura 12. Distribución de enunciados (movimientos de apoyo) según las estrategias utilizadas por los dos géneros en ambas culturas

Figura 13. Distribución de enunciados según el grado de (in)dirección de las estrategias de petición utilizadas en la situación 1 en ambas culturas.

Figura 14. Distribución de enunciados según las estrategias utilizadas en la producción de actos principales en la situación 1 en ambas culturas.

Figura 15. Distribución de enunciados según las estrategias empleadas en los movimientos de apoyo en la situación 1 en ambas culturas 
Figura 16. Distribución de enunciados según el grado de (in)dirección de las estrategias de petición empleadas en la situación 1 por cada subgrupo.

Figura 17. Distribución de enunciados en función de las estrategias empleadas en los actos de principales en la situación 1 por cada subgrupo

Figura 18. Distribución de enunciados según las estrategias que aparecen en los movimientos de apoyo empleados en las peticiones de la situación 1 en cada subgrupo.

Figura 19. Distribución de enunciados según el grado de (in)dirección de las estrategias de petición empleadas en los actos principales producidos en la situación 1 en cada grupo de género

Figura 20. Distribución de enunciados según las estrategias de petición utilizadas en actos principales en la situación 1 por los hablantes de cada género

Figura 21. Distribución de enunciados según las estrategias utilizadas en los movimientos de apoyo en la situación 1 en cada grupo de género

Figura 22. Distribución de enunciados por uso de estrategias de petición (según el grado de (in)dirección, en la situación 4 en cada cultura.

Figura 23. Distribución de enunciados según las estrategias empleadas en los actos principales de petición en la situación 4 por los hablantes de cada género.

Figura 24. Distribución de enunciados según el tipo de estrategia utilizada por cada grupo en los movimientos de apoyo en la situación 4. 
Figura 25. Distribución de enunciados en función del grado de (in)dirección de las estrategias de petición en la situación 4 en cada subgrupo.

Figura 26. Distribución de enunciados según las estrategias empleadas en la formulación de actos principales para la situación 4 en cada subgrupo.

Figura 27. Distribución de enunciados según estrategias utilizadas en los movimientos de apoyo producidos para la situación 4 en cada subgrupo..............................................

Figura 28. Distribución de enunciados según las estrategias de petición empleadas en los actos principales para la situación 4 en cada grupo de género

Figura 29. Distribución de enunciados (actos principales) según estrategias aplicadas, registrados para la situación 4 en cada grupo de género

Figura 30. Distribución de enunciados (movimientos de apoyo), por tipo de estrategia empleada, producidos por los sujetos de cada grupo de género para la situación 4.

Figura 31. Distribución de enunciados según el grado de (in)dirección de las estrategias de petición empleadas en los actos principales, producidos para la situación 7 en cada cultura.

Figura 32. Distribución de los enunciados producidos como actos principales para la situación 7 en cada cultura, según el tipo de estrategia utilizada

Figura 33. Distribución de enunciados según el tipo de estrategia empleada en los movimientos de apoyo en la situación 7 por los hablantes de cada cultura. 
Figura 34. Distribución de enunciados según el grado de (in)dirección de las estrategias empleadas en los actos principales producidos en la situación 7 por los subgrupos en cada cultura.

Figura 35. Distribución de enunciados (actos principales) según la estrategia de petición empleada en la situación 7 por los hablantes de ambos subgrupos en cada cultura

Figura 36. Distribución de enunciados con movimientos de apoyo según las estrategias empleadas en la situación 7 por los subgrupos de cada cultura

Figura 37. Distribución de enunciados (actos principales) según el grado de (in)dirección de las estrategias de petición empleadas para la situación 7 por los dos géneros en cada cultura

Figura 38. Distribución de enunciados según la estrategia de petición empleada en los actos principales por los hablantes de ambos géneros de cada cultura para la situación 7

Figura 39. Distribución de enunciados según las estrategias empleadas por los hablantes malayos y españoles de ambos géneros en los movimientos de apoyo producidos para la situación 7

Figura 40. Distribución de enunciados (actos principales) según el grado de (in)dirección de las estrategias de petición empleadas para la situación 10, en cada cultura

Figura 41. Distribución de enunciados (actos principales), según las estrategias empleadas para la situación 10, en cada cultura. 
Figura 42. Distribución de enunciados según las estrategias de movimientos de apoyo empleadas para la situación 10 en cada cultura.

Figura 43. Distribución de estrategias de petición empleadas para la situación 10 en cada subgrupo de edad.

Figura 44. Distribución de enunciados (actos principales) producidos para la situación 10 en cada subgrupo de edad, según estrategia seleccionada

Figura 45. Distribución de enunciados según las estrategias empleadas en los movimientos de apoyo para la situación 10, en cada subgrupo.

Figura 46. Distribución de estrategias de petición (según grado de (in)dirección) utilizadas en la situación 10 por los hablantes de cada género en ambas culturas.

Figura 47. Distribución de enunciados (actos principales), según las estrategias empleadas para la situación 10, en cada género y cultura.

Figura 48. Distribución de enunciados (movimientos de apoyo), según estrategias empleadas, producidos para la situación 10 en cada género en ambas culturas.

Figura 49. Distribución de estrategias de petición (actos principales) empleadas para la situación 13 en ambas culturas

Figura 50. Distribución de enunciados (actos principales), según estrategia de petición seleccionada, producidos para la situación 13 en ambas culturas

Figura 51. Distribución de enunciados (movimientos de apoyo) producidos para la situación 13 en ambas culturas según estrategias empleadas 
Figura 52. Distribución de estrategias de petición (en número de enunciados) empleadas para la situación 13 en cada subgrupo en ambas sociedades

Figura 53. Distribución de enunciados (actos principales) producidos para la situación 13 en cada subgrupo de ambas sociedades, según sub-estrategias empleadas

Figura 54. Distribución de enunciados (movimientos de apoyo) producidos para la situación 13 en cada subgrupo en ambas sociedades, según estrategias empleadas.

Figura 55. Distribución de estrategias de petición (actos principales) empleadas para la situación 13 en cada género en ambas sociedades.

Figura 56. Distribución de enunciados (actos principales) producidos por los hablantes de cada género para la situación 13 en ambas sociedades, según estrategias utilizadas

Figura 57. Distribución de enunciados (movimientos de apoyo) producidos para la situación 13 en cada grupo de género en ambas sociedades, según estrategias empleadas

Figura 58. Distribución de estrategias de petición (en número de enunciados) empleadas para la situación 16 en ambas sociedades.

Figura 59. Distribución de enunciados (actos principales) producidos para la situación 16 en ambas sociedades, según sub-estrategias empleadas.

Figura 60. Distribución de enunciados (movimientos de apoyo) producidos en la situación 16 en ambas sociedades, según estrategias empleadas. 
Figura 61. Distribución de estrategias de peticiones (actos principales) formuladas para la situación 16 en cada subgrupo en ambas sociedades

Figura 62. Distribución de enunciados (actos principales), según sub-estrategias empleadas, emitidos para la situación 16 en cada subgrupo en ambas sociedades

Figura 63. Distribución de enunciados (movimientos de apoyo) empleados para la situación 16 en cada subgrupo en ambas sociedades.

Figura 64. Distribución de estrategias de petición (actos principales) para la situación 16 en cada subgrupo de género en ambas culturas, según grado de (in)dirección.

Figura 65. Distribución de enunciados (actos principales), según sub-estrategias de petición utilizadas para la situación 16 en cada género en ambas culturas.

Figura 66. Distribución de enunciados (movimientos de apoyo) producidos para la situación 16 en cada género en ambas culturas, según estrategias empleadas

Figura 67. Distribución de estrategias de petición (número de enunciados en actos principales) según el estatus social en el caso español.

Figura 68. Distribución de estrategias de petición (número de enunciados en actos principales) según el estatus social en el caso malayo.

Figura 69. Distribución de estrategias de petición (número de enunciados en actos principales) según estatus social en el caso de mayor versus menor, en el grupo español. 
Figura 70. Distribución de estrategias de petición (número de enunciados en actos principales) según estatus social en el caso de mayor versus menor, en el grupo malayo

Figura 71. Distribución de estrategias de petición (número de enunciados en actos principales) según estatus social en el caso de varón versus mujer.

Figura 72. Distribución de estrategias de petición (número de enunciados en actos principales) según estatus social en el caso de varón versus mujer.

Figura 73. Distribución de enunciados (movimientos de apoyo) por estrategias, según estatus social en ambas culturas, española y malaya

Figura 74. Distribución de enunciados (movimientos de apoyo) por estrategias, según estatus social en ambas culturas, española y malaya

Figura 75. Distribución de enunciados (movimientos de apoyo) por estrategias, según estatus social en el caso de mayor versus menor, en el grupo español.

Figura 76. Distribución de enunciados (movimientos de apoyo) por estrategias, según estatus social en el caso de mayor versus menor, en el grupo español

Figura 77. Distribución de enunciados (movimientos de apoyo) por estrategias, según estatus social en el caso de mayor versus menor, en el grupo malayo

Figura 78. Distribución de enunciados (movimientos de apoyo) por estrategias, según estatus social en el caso de mayor versus menor, en el grupo

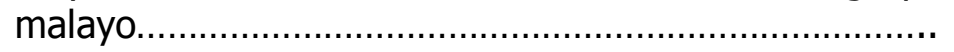


Figura 79. Distribución de enunciados (movimientos de apoyo) por estrategias, según estatus social en el caso de varón versus mujer, en el grupo español...

Figura 80. Distribución de enunciados (movimientos de apoyo) por estrategias, según estatus social en el caso de varón versus mujer, en el grupo español.

Figura 81. Distribución, de enunciados (movimientos de apoyo) por estrategias, según estatus social en el caso de varón versus mujer, en el grupo

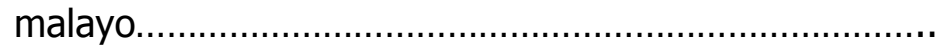

Figura 82. Distribución, de enunciados (movimientos de apoyo) por estrategias, según estatus social en el caso de varón versus mujer, en el grupo

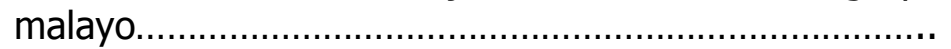

Figura 83. Distribución de enunciados (actos principales), por estrategias de petición, según distancia social en los dos grupos, español y malayo

Figura 84. Distribución de enunciados (actos principales), por estrategias de petición, según distancia social en los dos grupos, español

malayo.

Figura 85. Distribución de enunciados (actos principales) por estrategia de petición seleccionada, según distancia social en el caso de mayor versus menor, en el grupo español.

Figura 86. Distribución de enunciados (actos principales) por estrategia de petición seleccionada, según distancia social en el caso de mayor versus menor, en el grupo malayo. 
Figura 87. Distribución de enunciados (actos principales) por estrategia de petición seleccionada, según distancia social en el caso de varón versus mujer, en el grupo español.

Figura 88. Distribución de enunciados (actos principales) por estrategia de petición seleccionada, según distancia social en el caso de varón versus mujer, en el grupo malayo.

Figura 89. Distribución de enunciados (movimientos de apoyo) por estrategias, según distancia social en los dos grupos, español y malayo

Figura 90. Distribución de enunciados (movimientos de apoyo) por estrategias, según distancia social en los dos grupos, español y malayo.

Figura 91. Distribución, por estrategias, de enunciados (movimientos de apoyo) utilizados por los mayores y los menores según la distancia social en la sociedad española.

Figura 92. Distribución, por estrategias, de enunciados (movimientos de apoyo) utilizados por los mayores y los menores según la distancia social en la sociedad española.

Figura 93. Distribución, por estrategias seleccionadas, de enunciados (movimientos de apoyo) utilizados por los mayores y los menores según la distancia social en la sociedad malaya

Figura 94. Distribución, por estrategias seleccionadas, de enunciados (movimientos de apoyo) utilizados por los mayores y los menores según la distancia social en la sociedad malaya. 
Figura 95. Distribución, por estrategias, de enunciados (movimientos de apoyo) utilizados por los varones y las mujeres según la distancia social en la sociedad española.

Figura 96. Distribución, por estrategias, de enunciados (movimientos de apoyo) utilizados por los varones y las mujeres según la distancia social en la sociedad española.

Figura 97. Distribución, por estrategias, de enunciados (movimientos de apoyo) utilizados por los varones y las mujeres según la distancia social en la sociedad malaya

Figura 98. Distribución, por estrategias, de enunciados (movimientos de apoyo) utilizados por los varones y las mujeres según la distancia social en la sociedad malaya

Figura 99. Distribución de estrategias de mandato (actos principales) según el grado de (in)dirección, utilizadas en ambas culturas.

Figura 100. Distribución de enunciados (actos principales), en las nueve estrategias de mandato en ambas culturas..

Figura 101. Distribución de enunciados (movimientos de apoyo) según el tipo de estrategias utilizadas en los grupos de ambas culturas.

Figura 102. Número de enunciados producidos en cada una de las situaciones por los hablantes de ambas culturas.

Figura 103. Distribución de enunciados (actos principales) según el grado de (in)dirección de las estrategias empleadas por los subgrupos de edad 
Figura 104. Distribución de enunciados (actos principales) según grado de (in)dirección de estrategias en los subgrupos de ambas culturas

Figura 105. Distribución de enunciados (movimientos de apoyo) según grado de (in)dirección de las estrategias empleadas por los subgrupos de ambas culturas.

Figura 106. Distribución de enunciados (actos principales) según el grado de (in)dirección de las estrategias de mandato según sexo, en ambas culturas.

Figura 107. Distribución de enunciados (actos principales) según al grado de (in)dirección de las estrategias empleadas por los sujetos de los dos sexos en ambas culturas.

Figura 108. Distribución de enunciados (movimientos de apoyo) según estrategias empleadas por los dos géneros en ambas culturas.

Figura 109. Distribución de enunciados (actos principales) según estrategias de mandato empleadas para la situación 3, en cada cultura

Figura 110. Distribución de enunciados (actos principales) producidos para la situación 3 en cada cultura, según el grado de (in)dirección de la estrategia empleada.

Figura 111. Distribución de enunciados (movimientos de apoyo) producidos para la situación 3, en cada cultura.

Figura 112. Distribución de enunciados (actos principales) según las estrategias de mandato seleccionadas para la situación 3, en cada subgrupo 
Figura 113. Distribución de enunciados (actos principales) de la situación 3, según estrategias aplicadas por cada subgrupo.

Figura 114. Distribución de enunciados (movimientos de apoyo) producidos para la situación 3, en ambas culturas, según estrategias aplicadas..

Figura 115. Distribución de estrategias de mandato empleadas en los enunciados (actos principales) producidos para la situación 3 por cada grupo de género.

Figura 116. Distribución de enunciados (actos principales) producidos para la situación 3 por cada grupo de género, según grado de (in)dirección de estrategias.

Figura 117. Distribución de enunciados (movimientos de apoyo) producidos para la situación 3 en cada género

Figura 118. Distribución de estrategias de mandato en actos principales producidos para la situación 6 , en ambas culturas.

Figura 119. Distribución de enunciados producidos como actos principales según estrategias empleadas para la situación 6 , en ambas culturas.

Figura 120. Distribución de movimientos de apoyo producidos para la situación 6 , en ambas culturas

Figura 121. Distribución de estrategias de mandato en los subgrupos de edad.

Figura 122. Distribución de enunciados (actos principales) según tipo de estrategia empleada para la situación 6 , en cada subgrupo de género. 
Figura 123. Distribución de enunciados (movimientos de apoyo) según estrategias empleadas para la situación 6 , en ambas culturas.

Figura 124. Distribución de estrategias de mandato (actos principales) empleadas en la situación 6 por cada grupo de género.

Figura 125. Distribución de enunciados (actos principales) según estrategias más o menos directas, empleadas para la situación 6 por cada subgrupo de género.

Figura 126. Distribución de enunciados (movimientos de apoyo) según estrategias empleadas en la situación 10 por cada subgrupo

Figura 127. Distribución de enunciados (actos principales) según estrategias empleadas en los mandatos producidos para la situación 9, en cada cultura.

Figura 128. Distribución de enunciados (actos principales) según sub-categorías de estrategias empleadas para la situación 9, en cada cultura.

Figura 129. Distribución de enunciados (movimientos de apoyo) empleados para la situación 9 por los hablantes de cada cultura, según estrategias aplicadas.

Figura 130. Distribución de estrategias de mandato empleadas para la situación 9, en ambas sociedades.

Figura 131. Distribución de enunciados (actos principales) formulados para la situación 9, en ambas sociedades, según estrategias empleadas

Figura 132. Distribución de enunciados (movimientos de apoyo) producidos para la situación 9, en ambas sociedades, según estrategias empleadas. 
Figura 133. Distribución de estrategias de mandato empleadas para la situación 9, en ambas culturas.

Figura 134. Distribución de enunciados (actos principales) producidos en la situación 9 por los sujetos de ambas culturas, según estrategias empleadas.

Figura 135. Distribución de enunciados (movimientos de apoyo) producidos para la situación 9, en ambas culturas, según estrategias empleadas.

Figura 136. Distribución de estrategias de mandato empleadas para la situación 12 , en cada cultura

Figura 137. Distribución de enunciados (actos principales) producidos para la situación 12 en cada cultura, según las estrategias empleadas.

Figura 138. Distribución de enunciados (movimientos de apoyo) producidos para la situación 12 en cada cultura, según estrategias empleadas.

Figura 139. Distribución de estrategias de mandato empleadas para la situación 12, en ambas sociedades.

Figura 140. Distribución de enunciados (actos principales), producidos para la situación 12 por los sujetos de cada subgrupo de edad, en ambas sociedades, según estrategias empleadas.

Figura 141. Distribución de enunciados (movimientos de apoyo) producidos para la situación 12 por cada subgrupo de edad según estrategias empleadas.

Figura 142. Distribución de estrategias de mandato empleadas para la situación 12 , en cada género 
Figura 143. Distribución de enunciados (actos principales) producidos para la situación 12 en cada género, según el tipo de estrategia empleada.

Figura 144. Distribución de enunciados (movimientos de apoyo) en los dos géneros en ambas culturas, según estrategias empleadas

Figura 145. Distribución de estrategias de mandato empleadas para la situación 15 , en cada cultura.

Figura 146. Distribución de enunciados (actos principales) producidos para la situación 15 en cada cultura, según estrategias empleadas

Figura 147. Distribución de enunciados (movimientos de apoyo) producidos para la situación 15 en cada cultura, según estrategias empleadas

Figura 148. Distribución de estrategias de mandato para la situación 15, en cada subgrupo en ambas sociedades.

Figura 149. Distribución de enunciados (actos principales) producidos para la situación 15 en cada subgrupo en ambas sociedades, según estrategias empleadas.

Figura 150. Distribución de enunciados (movimientos de apoyo) producidos para la situación 15 en cada subgrupo en ambas sociedades, según estrategias empleadas.

Figura 151. Distribución de estrategias de mandato empleadas para la situación 15 en cada subgrupo de género en ambas culturas. 
Figura 152. Distribución de enunciados (estrategias de mandato) producidos para la situación 15 por cada subgrupo en ambas culturas, según selección de

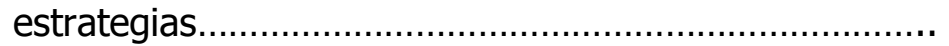

Figura 153. Distribución de enunciados (movimientos de apoyo) producidos para la situación 15 por cada subgrupo de género en ambas culturas, según estrategias empleadas.

Figura 154. Distribución de estrategias empleadas de petición para la situación 16, en ambas sociedades.

Figura 155. Distribución de enunciados (actos principales) producidos para la situación 18 en ambas sociedades, según estrategias empleadas.

Figura 156. Distribución de enunciados (movimientos de apoyo) producidos para la situación 18 en ambas sociedades, según estrategias empleadas

Figura 157. Distribución de estrategias de mandato empleadas para la situación 18 en cada subgrupo, en ambas sociedades.

Figura 158. Distribución, según estrategias empleadas, de enunciados (actos principales) producidos para la situación 18 en cada subgrupo, en ambas sociedades.

Figura 159. Distribución de enunciados (movimientos de apoyo) producidos para la situación 18 en cada subgrupo, en ambas sociedades, según estrategias aplicadas.

Figura 160. Distribución de estrategias de mandato empleadas para la situación 18 en cada género. 
Figura 161. Distribución de enunciados (actos principales) producidos para la situación 18 en cada género, según estrategias empleadas.

Figura 162. Distribución de enunciados (movimientos de apoyo) producidos para la situación 18 en cada género, según estrategias empleadas.

Figura 163. Distribución de estrategias de mandato según distancia social en los dos grupos, español y malayo

Figura 164. Distribución de estrategias de mandato según distancia social y variable de edad, en el grupo español.

Figura 165. Distribución de estrategias de mandato según distancia social variable de edad, en el grupo malayo.

Figura 166. Distribución de estrategias de mandato según distancia social en el grupo español, en cada subgrupo de género.

Figura 167. Distribución de estrategias de mandato según distancia social en el grupo malayo, en cada subgrupo de género.

Figura 168. Distribución de movimientos de apoyo según distancia social en los dos grupos, español y malayo

Figura 169. Distribución de movimientos de apoyo utilizados por los sujetos mayores y menores según la distancia social en la sociedad española.....

Figura 170. Distribución de movimientos de apoyo utilizados por los sujetos mayores y menores según la distancia social en la sociedad malaya. 
Figura 171. Distribución de movimientos de apoyo utilizados por los varones y las mujeres según la distancia social en la sociedad española.

Figura 172. Distribución de movimientos de apoyo utilizados por los varones y las mujeres según la distancia social en la sociedad malaya.

Figura 173. Distribución de enunciados producidos como "Rechazo Directo", "Rechazo Indirecto" y "Adyacentes al rechazo" en cada cultura.

Figura 174. Distribución total de cada sub-estrategia utilizada por los sujetos de las dos culturas en las seis situaciones.

Figura 175. Distribución de enunciados de rechazo en cada grupo en las seis situaciones.

Figura 176. Distribución del número de enunciados según tipos de rechazo en cada subgrupo de edad de cada cultura.

Figura 177. Distribución de enunciados totales según la estrategia utilizada por los hablantes mayores y menores de cada cultura

Figura 178. Distribución de enunciados producidos por los hablantes de cada subgrupo en las seis situaciones examinadas

Figura 179. Distribución de enunciados según el tipo de estrategia de rechazo empleada por los hablantes de cada subgrupo de sexo.

Figura 180. Distribución total de enunciados según las subestrategias utilizadas por los hablantes de cada género en ambos grupos 
Figura 181. Distribución de los enunciados de rechazo producidos por los hablantes de ambos géneros en cada grupo para cada una de las seis situaciones individuales.

Figura 182. Distribución de enunciados producidos en la situación 2 en cada grupo principal según la clasificación general en tres categorías de estrategia de

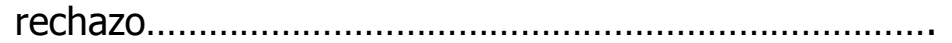

Figura 183. Distribución de sub-estrategias utilizadas en la situación 2 en cada grupo principal...............................

Figura 184. Clasificación de los enunciados, según grado de (in)dirección de las estrategias empleadas, producidos para la situación 2 como expresión de rechazo.

Figura 185. Distribución de cada estrategia, en número de enunciados, utilizada en la situación 2 por los mayores y los menores en cada cultura.

Figura 186. Clasificación de los enunciados, según grado de (in)dirección, producidos para la situación 2 por cada subgrupos de género en cada cultura

Figura 187. Distribución de enunciados según las sub-estrategias utilizadas en la situación 2 por los varones y las mujeres de cada cultura.

Figura 188. Distribución de enunciados, según grado de (in)dirección de las estrategias elegidas, producidos en la situación 5 por los sujetos de los dos grupos principales.

Figura 189. Distribución de enunciados según las sub-estrategias utilizadas en la situación 5 por los sujetos participantes de cada cultura 
Figura 190. Distribución de enunciados, según grado de (in)dirección de las estrategias empleadas, producidos en la situación 5 por los sujetos mayores y menores de cada grupo cultural.

Figura 191. Distribución de enunciados según las sub-estrategias utilizadas en la situación 5 por los sujetos mayores y menores de cada cultura.

Figura 192. Distribución de enunciados, según grado de (in)dirección de las estrategias aplicadas, producidos en la situación 5 por los varones y mujeres de cada grupo cultural.

Figura 193. Distribución de enunciados según las sub-estrategias utilizadas en la situación 5 por los varones y mujeres de cada cultura....

Figura 194. Distribución de enunciados, según grado de (in)dirección de la estrategia seleccionada, producidos en la situación 8 en cada grupo principal.

Figura 195. Distribución de enunciados según las sub-estrategias utilizadas para la situación 8 en cada grupo principal.

Figura 196. Distribución de enunciados según el grado de (in)dirección de las estrategias empleadas en la situación 8 por los hablantes mayores y menores en cada cultura.

Figura 197. Distribución de sub-estrategias utilizadas para la situación 8 por los mayores y los menores en cada cultura.

Figura 198. Distribución de enunciados según estrategias de rechazo empleadas en la situación 8 por los hablantes de cada género en cada cultura. 
Figura 199. Distribución de sub-estrategias utilizadas en la situación 8 por los sujetos de cada género en cada cultura...

Figura 200. Distribución de enunciados formulados como rechazo para la situación 11 en cada sociedad según grado de (in)dirección de la estrategia seleccionada.

Figura 201. Distribución de estrategias utilizadas en la situación 11, según número de enunciados, por los sujetos de cada sociedad.

Figura 202. Clasificación, según grado de (in)dirección de los enunciados de rechazo producidos en la situación 11 por los sujetos mayores y menores en cada cultura...

Figura 203. Distribución de enunciados según las sub-estrategias utilizadas para la situación 11 por los mayores y los menores en cada cultura.

Figura 204. Distribución de enunciados de rechazo producidos en la situación 11 por los hablantes de cada género en cada cultura.

Figura 205. Distribución de sub-estrategias utilizadas en la situación 11 por los sujetos de cada género en cada sociedad

Figura 206. Distribución de estrategias empleadas en la formulación del rechazo en la situación 14 por los sujetos de cada grupo principal

Figura 207. Distribución de sub-estrategias utilizadas en la situación 14 por los hablantes de cada cultura............. 722 
Figura 208. Distribución de enunciados, producidos en la situación 14 por los sujetos mayores y menores de cada cultura, según el grado de (in)dirección de las estrategias empleadas.

Figura 209. Distribución de sub-estrategias utilizadas en la situación 14 por los hablantes mayores y los menores en cada sociedad.

Figura 210. Distribución, según grado de (in)dirección de las estrategias empleadas, de enunciados formulados en la situación 14 por los hablantes de cada género en cada cultura

Figura 211. Distribución de sub-estrategias utilizadas en la situación 14 por los hablantes de cada género en cada cultura.

Figura 212. Distribución de enunciados producidos en la situación 17, según el grado de (in)dirección de las estrategias empleadas por los hablantes de cada grupo principal

Figura 213. Distribución de sub-estrategias utilizadas en la situación 17 por los sujetos de cada grupo principal.

Figura 214. Distribución de enunciados producidos en la situación 17 por los hablantes mayores y menores de cada cultura en su formulación del rechazo, según el grado de (in)dirección de la estrategia elegida.

Figura 215. Distribución de sub-estrategias utilizadas en la situación 17 por los sujetos mayores y menores en cada cultura.

Figura 216. Distribución de enunciados según el grado de (in)dirección de las estrategias de rechazo aplicadas en la situación 17 por los sujetos de ambos géneros en cada cultura. 
Figura 217. Distribución de sub-estrategias utilizadas en la situación 17 por los hablantes de ambos géneros en cada cultura.

Figura 218. Distribución de los enunciados formulados como rechazos según estatus social en el caso de español versus malayo

Figura 219. Distribución de enunciados en las tres categorías de grado de (in)dirección del rechazo, según estatus social en el caso de español versus malayo....................................................................

Figura 220. Distribución de enunciados formulados como rechazos según estatus social en el caso de mayor versus menor.

Figura 221. Distribución de enunciados producidos como rechazos según estatus social en el caso de varón versus mujer.

Figura 222. Distribución de estrategias utilizadas según distancia social en el caso de español versus malayo.

Figura 223. Distribución de enunciados en las tres categorías de rechazo, según grado de (in)dirección) y según distancia social, en el caso de español versus malayo

Figura 224. Distribución de enunciados producidos como rechazo, según distancia social en el caso de mayor versus menor

Figura 225. Distribución de enunciados producidos como rechazos, según distancia social en el caso de varón versus mujer. 
Figura 226. Distribución del número de enunciados formulados como "Excusa" en las respuestas de los españoles y los malayos en las seis situaciones de rechazo.

Figura 227. Distribución del número de enunciados producidos como "Excusa" por los participantes mayores y menores en ambas culturas en las seis situaciones de rechazo.

Figura 228. Distribución del número de enunciados producidos como "Excusa" por los varones y las mujeres en ambas culturas en las seis situaciones de rechazo.

Figura 229. Distribución de los tipos de "Excusa" utilizados en el grupo español y el grupo malayo en la situación 2

Figura 230. Distribución de los tipos de "Excusa" utilizados en el grupo español y el grupo malayo para la situación 5 .

Figura 231. Distribución de los tipos de "Excusa" utilizados en el grupo español y el grupo malayo para la situación 8.

Figura 232. Distribución de los tipos de "Excusa" utilizados en el grupo español y el grupo malayo para la situación 11.

Figura 233. Distribución de los tipos de "Excusa" utilizados en el grupo español y el grupo malayo para la situación 14.

Figura 234. Distribución de los tipos de "Excusa" utilizados en el grupo español y el grupo malayo para la situación 17. 


\section{CAPÍTULO 1}

\section{INTRODUCCIÓN}

\subsection{Planteamiento del problema}

La competencia pragmática, o la capacidad de utilizar actos de habla apropiada y correctamente según el contexto, es un componente esencial de la competencia comunicativa. Los actos de habla incluyen interacciones auténticas (Austin, 1975) y requieren no solo conocimiento del idioma, sino también el uso apropiado de la lengua dentro de una cultura determinada (Searle, 1979). De esta forma, el dominio de la competencia da lugar a una correcta realización e interpretación de los actos de habla como por ejemplo el de saludo, petición, queja, invitación, cumplido o rechazo.

Los actos de habla son difíciles de realizar en una segunda lengua porque es muy posible que los aprendices (al menos en las primeras etapas del aprendizaje) no conozcan, ni, por un lado, las 
expresiones idiomáticas de las que los nativos se valen en la formulación de los mismos, ni, por otro, las normas culturales que rigen la comunicación en el país de la lengua meta. 0 puede que transfieran las reglas de su lengua materna y las normas de comunicación de su propio idioma a la nueva lengua, suponiendo que tales reglas son universales, y arriesgándose así a cometer errores pragmáticos que les lleven a la no consecución del objetivo comunicativo (Thomas, 1984). Como la tendencia natural para los aprendices del idioma es recurrir a lo que saben que es apropiado en su lengua materna, es importante que comprendan exactamente lo que hacen en su lengua nativa para poder reconocer lo que es transferible a otros idiomas. Algo que funciona en español puede no tener el mismo significado cuando se traduce a la segunda lengua. Por ejemplo, la siguiente intervención de un nativo español, cuya intención es la de mostrar un total acuerdo con su interlocutor, podría ser fácilmente malinterpretada por un oyente nativo malayo:

Raquel: "Yo no podría estar más de acuerdo con usted".

Rohana: "A ver...." (Pensando: ¿"Ella no podría estar de acuerdo conmigo? iCreía que pensaba lo mismo que yo)!

Este tipo de transferencia puede evitarse, o al menos minimizarse, si los aprendices alcanzan niveles superiores, y llegan a adquirir, 
además de un profundo conocimiento lingüístico, lo que Thomas (1984) Ilama "competencia pragmática".

Varios estudios pragmáticos transculturales sobre actos de habla han establecido, empíricamente, que los aprendices de una lengua pueden no comunicarse eficazmente (es decir, cometer errores pragmáticos) aún teniendo un excelente conocimiento gramatical y léxico de la lengua en cuestión (Eisenstein y Bodman, 1986; Bodman y Eisenstein, 1988; Robinson, 1992). En otras palabras, pueden aprender varias estrategias para mostrar, por ejemplo, y teniendo en cuenta el caso concreto de nuestra investigación, agradecimiento, disculpa o rechazo, pero pueden no estar seguros de cuándo es apropiado usar una forma u otra para expresarlos (Cohen, 1996).

Según Thomas (1984), hay dos tipos posibles de fracaso pragmático: pragmático-lingüístico y socio-pragmático. Cuando se trata de la realización e interpretación de actos de habla transculturales, el fallo pragmático-lingüístico se produce cuando la codificación que uno hace de la fuerza pragmática es sistemáticamente diferente de la fuerza que un hablante nativo esperaría, o cuando las estrategias del acto de habla son indebidamente transferidas de un idioma al otro. En este caso, los hablantes no nativos pueden saber qué decir, pero carecen de los 
medios lingüísticos necesarios para comunicar sus intenciones claramente. El fracaso socio-pragmático, por el contrario, se produce cuando existen percepciones transculturalmente distintas de lo que constituye una conducta apropiada, debido al conflicto entre diferentes valores y normas sociales. Así pues, quienes quieran interactuar eficazmente con hablantes de otras culturas deben aprender tanto las reglas de la gramática específica de la lengua, como las normas que rigen la comunicación.

Adquirir competencia pragmática comprende varias subtareas, como el aprendizaje de nuevas categorías de actos de habla, nuevas distribuciones contextuales de los actos de habla (como cuándo agradecer, a quién y para qué), nuevos procedimientos y medios para la realización del acto de habla o el funcionamiento de los principios de cortesía en la cultura de la lengua meta (Kasper, 1989). En función de la situación en la que se encuentre, el hablante puede verse obligado también a tener en cuenta: a) la cultura implicada, b) la edad y sexo del oyente, c) su clase social y ocupación y, d) su rol y estatus en la interacción. Por otra parte, es probable que se dé la transferencia pragmática negativa, que causa malentendidos culturales.

Takahashi y Beebe en su artículo "The development of pragmatic competence by Japanese learners of English" (1987), citan 
la anécdota de un malentendido transcultural. En la cumbre entre el presidente Nixon y el antiguo primer ministro japonés, Sato, Nixon le preguntó a Sato si estaría de acuerdo en reducir las exportaciones de tejidos japoneses a los Estados Unidos. Sato contestó, "Zensho shimasu", que se tradujo literalmente al inglés como "Voy a asegurarlo". Con esta respuesta, Nixon pensó que había recibido un compromiso y se puso furioso cuando Sato no puso en marcha ninguna acción. Pero de hecho, Sato no creyó que hubiera llegado a ningún compromiso, ya que este tipo de declaración en la cultura japonesa, no es una promesa sino una manera cortés de rechazar.

Según Gass y Houck (1999), el estudio de actos de habla facilita a los investigadores una gran cantidad de información en relación a la interacción lingüística humana. Blum-Kulka, House y Kasper (1989) afirman que una de las cuestiones centrales que todavía no han sido resueltas es la de la supuesta universalidad en la realización de los actos de habla. Es decir hasta qué punto los modelos de realización de los actos de habla se rigen por principios pragmáticos universales de cooperación y cortesía, y hasta qué punto varían en la conceptualización y verbalización en las diferentes lenguas y culturas (Blum-Kulka et al. 1989). Para contestar a estas preguntas, debe realizarse una investigación pragmática transcultural específica. 
En esta línea, hasta la fecha, ha habido numerosos estudios contrastivos basados en distintos idiomas y culturas, cuyo objetivo general ha sido apreciar las similitudes y diferencias en las realizaciones de un determinado acto de habla en las diferentes lenguas analizadas. Por ejemplo, Takahashi y Beebe (1987) han investigado peticiones en inglés y japonés, Blum-Kulka, House y Kasper (1989) han examinado peticiones y disculpas en siete idiomas diferentes, Gass y Houck (1999) han comparado rechazos en japonés e inglés, Hayashi (2000) ha estudiado peticiones y rechazos en alemán y japonés, Ballesteros (2001) ha analizado peticiones y quejas en inglés británico y español, Nelson, Carson, Al Batal y ElBakary (2002) han investigado rechazos en inglés y árabe, y Siebold (2008) ha contrastado cumplidos en alemán y español. Y podríamos citar muchos otros estudios de similar naturaleza.

Esos trabajos no solo han hecho un tremendo esfuerzo para identificar las normas pragmáticas que se ponen en marcha al realizar un acto de habla específico en una cultura determinada, sino que también han tratado de buscar los valores culturales que subyacen a las diferentes normas pragmáticas de distintas culturas. Como señala Rubin (1983), los actos de habla se guían por reglas sociales y contextuales que determinan cómo se realizan y reflejan valores culturales fundamentales que pueden ser específicos de una comunidad de habla. 
Entre los estudios contrastivos realizados al respecto, no existe ningún estudio empírico que sepamos que haya comparado los actos de habla específicos y los aspectos pragmáticos de la cortesía, entre la lengua española y la malaya. En nuestra opinión, se trata de una línea de estudio que debería ser atendida por los investigadores tanto españoles como malayos, ya que "la dirección de la lingüística contrastiva de la conducta comunicativa tiene evidentes aplicaciones en la enseñanza de lenguas" (Geoffrey N. Leech 1983: 338). Así, este estudio pretende hacer una contribución al campo de la pragmática transcultural en general, presentando datos relativos a la expresión de petición, mandato y rechazo en español y malayo, actos que se consideran amenazadores de la imagen, por lo que son más propensos a malentendidos y, por ello, pueden conducir a errores pragmáticos más serios, que dificulten la comunicación. Este fue el motivo que nos llevó a elegirlos para nuestro estudio.

Como Blum-Kulka (1996: 180) ha señalado, la petición y el mandato son muy interesantes, ya que socialmente presentan un alto grado de exigencia para el oyente en muchos sentidos. En cuanto al rechazo, según Bardovi-Harlig y Hartford (1991) y Beebe, Takashi y Uliss-Weltz (1990), es "un punto de fricción" transcultural fundamental para muchos hablantes no nativos $y$, por lo tanto, se hace muy importante para los implicados en la enseñanza de una segunda lengua o una lengua extranjera. El rechazo se diferencia de 
otros actos de habla en que afecta más al oyente que al hablante. Es decir, implica decir al oyente algo que él o ella no quiere oír. Esto pone al interlocutor que hace la petición en el compromiso de tener que ayudar al hablante, que la rechaza, para evitar que le cause a él mala impresión, es decir, debe salvaguardar su imagen (BardoviHarlig y Hartford, 1991; Beebe, Takashi y Uliss-Weltz, 1990).

\subsection{Objetivos del estudio}

El propósito del presente estudio es, como se ha apuntado brevemente más arriba, investigar el comportamiento lingüístico de dos grupos culturalmente diferentes, malayo y español, tratando de identificar diferencias y semejanzas en los actos de habla de petición, mandato y rechazo, y teniendo en cuenta no solamente el grupo cultural de los sujetos investigados, sino también la edad y el sexo de los mismos. El trabajo pretende, además, examinar y evaluar los efectos de variables sociales, como estatus y distancia, en los modelos de realización de los citados actos de habla de petición, mandato y rechazo, dentro de los dos grupos, malayo y español. Dado que el malayo y español representan dos culturas, oriental y occidental, con diferencias importantes, es de esperar que las expresiones lingüísticas de petición, mandato y rechazo, y el grado 
de (in)dirección de las estrategias empleadas en cada una de las lenguas, también varíen considerablemente.

Podemos decir que, con nuestra investigación, hemos querido dar respuesta a las siguientes preguntas:

1. ¿Cuáles son las diferencias entre los españoles y los malayos en el número de estrategias utilizadas para producir actos de habla de petición, mandato y rechazo?

2. ¿Cuáles son las diferencias en el contenido de las estrategias utilizadas por los españoles y los malayos en la formulación de dichos actos de habla?

3. ¿Hay alguna diferencia entre los sujetos de más edad y los jóvenes, en la producción de esos actos de habla en cada una de las dos culturas?

4. ¿Hay alguna diferencia entre hombres y mujeres, dentro de cada grupo, en la realización de los actos de habla mencionados? 
5. ¿Son el estatus y la distancia social otras variables a tener en cuenta en la elección de las estrategias dentro de cada grupo cultural y de cada subgrupo de edad y sexo?

\subsection{Justificación}

El estudio interlingüístico de actos de habla en malayo y español puede mejorar los métodos de enseñanza de estas dos lenguas como lenguas extranjeras. Las conclusiones del presente estudio pueden facilitar la escritura de materiales de texto más orientados al idioma de destino, y un diseño de libros de texto culturalmente más específico.

Por otra parte, las semejanzas y las diferencias entre ambas lenguas en los patrones de realización de los tres actos de habla investigados, pueden hacer conscientes tanto a estudiantes como a profesores del papel determinante que juegan factores pragmáticos, tales como el ambiente cultural y el entorno social, a la hora de seleccionar las estrategias comunicativas en un contexto concreto.

Esta investigación también puede mejorar la traducción entre malayo y español, sobre todo la traducción escrita y oral de 
trabajos literarios y culturales. Es esencial para los traductores entender las estrategias específicas de una lengua a fin de poder traducir apropiadamente.

Por otra parte este estudio, al realizar una investigación interlingüística, puede proporcionar unos mejores cimientos para el entendimiento de lo que hay de universal en los actos de habla.

Con este trabajo hemos querido, por tanto:

1. Contribuir a la teoría de los actos de habla prestando una atención específica a su realización en un contexto social y cultural diferente de otras investigaciones realizadas hasta el momento.

2. Contribuir al estudio interlingüístico de la expresión de petición, mandato y rechazo, proporcionando datos en malayo y en español.

3. Facilitar la escritura y el diseño de materiales de texto pensados para la enseñanza del malayo y del español como lenguas extranjeras. 
4. Proporcionar estrategias lingüísticas de utilidad para las traducciones malayas y españolas de trabajos literarios y culturales.

\subsection{Estructura del trabajo}

En el capítulo 2 se revisa el marco teórico pertinente a este estudio. Esta revisión comienza con una mirada a la teoría del acto de habla, incluyendo sus aportaciones y sus limitaciones. Inmediatamente después, se entra en el ámbito de la cortesía, desarrollando primero el concepto, y revisando algunos de los estudios que se han realizado hasta el momento, para luego centrarnos en la explicación de la hipótesis que pretendemos demostrar en este trabajo. Por ello, hemos dividido el apartado de la cortesía en cuatro partes: la primera se centra en el concepto de la cortesía desde el punto de vista de Grice, la segunda es una descripción de las "Reglas de Cortesía" formuladas por Lakoff, en la tercera presentamos las ideas acerca de la cortesía verbal propuestas por Leech en su "Principio de Cortesía", y, en la cuarta, examinamos la "Teoría de la Cortesía" de Levinson y Brown que se considera el acercamiento más elaborado e influyente para teorizar sobre la cortesía, y ha recibido gran aceptación entre los investigadores lingüísticos. A continuación, se aborda el tema de la cortesía como elemento esencial dentro de los 
actos sometidos a estudio, para pasar, posteriormente, a examinarlos desde el punto de vista teórico. Por último, se hace una síntesis de los estudios referentes a la importancia de los actos de habla de petición, mandato y rechazo, y su influencia en el presente estudio.

En el capítulo 3 se describe la metodología empleada para llevar a cabo el presente estudio, comenzando con un debate acerca del modelo de encuesta utilizado y el motivo de su elección para nuestro trabajo. Después, se analiza y sintetiza el estudio piloto a la luz de sus implicaciones para la redacción del cuestionario definitivo. También se presenta la selección de participantes, y los procedimientos e instrumentos de recogida de datos. El capítulo finaliza esquematizando la forma en que se analizaron los datos y la explicación de la clasificación de las peticiones, mandatos y rechazos, utilizada en el estudio.

El capitulo 4 está dedicado a exponer, analizar e interpretar los resultados del estudio del acto de habla de petición. Empezaremos con un análisis cuantitativo de los datos obtenidos en el test de rellenado del discurso de la petición, para pasar después a realizar un análisis cualitativo de los mismos. 
En el siguiente capítulo, el 5, se presenta el análisis de los datos y resultados del estudio del segundo acto de habla investigado, es decir, el acto de habla de mandato. La organización del capítulo va a ser la misma que la empleada en el caso del acto de habla de petición, es decir, se expondrá primeramente un análisis cuantitativo, y posteriormente, se mostrará el análisis cualitativo.

A continuación, el capítulo 6 expone el análisis de datos y la interpretación de los resultados del tercer acto examinado, el rechazo. De manera similar a los dos capítulos anteriores, se han recogido, en primer lugar, los resultados correspondientes al análisis cuantitativo, para pasar después a un análisis cualitativo.

Por último, en el capítulo 7 se interpretan los resultados a la luz de los objetivos establecidos y de las investigaciones previas en torno a los actos de habla de petición, mandato y rechazo. El capitulo termina presentando las conclusiones que se pueden aportar una vez realizado el estudio, así como las limitaciones, las posibles áreas de investigación futura y las implicaciones pedagógicas que se derivan de él. 


\section{CAPÍTULO 2 \\ MARCO TEÓRICO}

A la hora de elaborar un marco teórico que sitúe el problema analizado en este estudio dentro de un conjunto de conocimientos y de un estado del arte de la materia, se ha considerado pertinente hacer una revisión de los principales conceptos pragmáticos sobre los

que se sustenta nuestro trabajo, para pasar después a describir la labor desarrollada por algunos investigadores en el campo del análisis pragmático comparativo de la realización de actos de habla en diferentes grupos de hablantes. De esta forma, el presente capítulo comienza examinando la teoría de los actos de habla, y a continuación se presenta el marco teórico relacionado con el principio de cortesía. En la segunda parte, se explica el diseño metodológico y el foco analítico de algunos estudios de actos de habla investigados, los cuales se describen y explican teniendo en cuenta su influencia en el presente estudio. 


\subsection{La Teoría de los Actos de Habla}

La Teoría de Acto de Habla no tiene su origen en la Lingüística, sino en la "Filosofía del Lenguaje" inglesa. Para los filósofos del Lenguaje, la unidad de comunicación lingüística ya no es una "palabra u oración, sino lo que ellos denominan "acto de habla", término acuñado por Searle, quien, siendo discípulo de Austin, perfeccionó las teorías de este, expuestas en su obra How to do things with words, publicada póstumamente en 1962.

Los actos de habla se definen como aquello que hacemos con las palabras cuando hablamos (Austin, 1962), como realizar una petición, disculparse, hacer cumplidos, agradecer, rechazar, saludar, etc. El concepto de actos de habla fue propuesto, en primer término, como se ha dicho más arriba, por filósofos de la lengua como Austin (1962) y Searle $(1969,1975,1976)$, y, posteriormente, el mismo concepto se ha empleado en el análisis del uso de la lengua por investigadores de disciplinas diferentes, como la Sociología, Psicología y Lingüística aplicada.

Austin (1962) comienza observando que algunas declaraciones son también, en sí mismas, actos, que denominó declaraciones "performativas". Al emitir una declaración performativa, el hablante, más que declarar o describir algo, realmente realiza o 
hace un acto. Por ejemplo, con declaraciones como "acepto" ( I do), de uno de los novios en una ceremonia de boda, o "llamo a este barco Reina de Elizabeth" (P. 49), el hablante realiza explícitamente un acto de habla. Por lo tanto, verbos como aceptar (to do) y llamar, entre otros, pertenecen a la categoría de verbos performativos de Austin.

Para Austin, cada acto de habla tiene tres dimensiones: locutiva, ilocutiva y perlocutiva. La dimensión locutiva corresponde al sentido proposicional de la declaración, es decir, lo que la declaración supone, p. ej., "tengo hambre", es una declaración que expresa que el hablante tiene hambre. La dimensión ilocutiva tiene que ver con el "valor" que el hablante otorga al acto locutivo. Por ejemplo, la declaración "tengo hambre" puede expresarse y entenderse simplemente como una declaración sobre el estado físico del hablante, pero también puede ser considerada una petición de algo para comer. Lo que el hablante desea es que la oración contenga un sentido ilocutivo (también llamado "fuerza ilocutiva"). El acto perlocutivo constituye el efecto último que el acto ilocutivo tiene sobre el oyente. En este caso específico, después de oír la declaración anterior "tengo hambre" el oyente podría ofrecer al hablante algo para comer.

Austin propone, entonces, una clasificación provisional de 
los verbos performativos explícitos. Distingue cinco categorías basadas en la noción de fuerza ilocutiva (1962, p. 150-163):

1. Judicativos (Verdictives), que expresan veredictos o evaluaciones emitidas por jueces. Esta categoría incluye verbos como: condenar, exonerar, juzgar, estimar, valorar.

2. Ejercitativos (Exercitives), que se refieren al ejercicio de poderes y derechos. Esto incluye verbos como: votar, designar, excomulgar, pedir o advertir.

3. Compromisorios (Commissives), que expresan compromisos o tareas. Verbos pertenecientes a esta categoría pueden ser, por ejemplo, prometer, garantizar, contratar o cometer.

4. De comportamiento (Behabitives), que tienen que ver con un comportamiento social o reacción. Esta categoría incluye verbos como: agradecer, negarse, pedir perdón, quejarse.

5. Expositivos (expositives), que se utilizan para exponer opiniones, dirigir/llevar argumentos y clarificar referencias. Algunos de los verbos que pertenecen a esta categoría son discutir, conceder, asumir.

Searle (1975), influenciado por Austin, más adelante redefine la noción de actos de habla, y señala seis problemas en la clasificación de los verbos performativos de Austin (ver Flowerdew, 1990), afirmando que (1) esto crea confusión entre verbos ilocutivos 
y actos ilocutivos, (2) no todos los verbos son verbos ilocutivos, (3) hay demasiadas coincidencias en las distintas categorías, (4) existe una gran heterogeneidad dentro de las categorías, (5) muchos de los verbos no encajan en la categoría en la que son clasificados, y (6) de la clasificación no se deriva ningún principio.

Tratando de vencer las dificultades que encontró en la taxonomía de Austin, basada en los verbos performativos, Searle (1975) propone su propia clasificación basada en el "punto ilocutivo", en función de la perspectiva del hablante. De esta forma, distingue entre cinco tipos de actos:

1. Representativos, que incluyen todos los actos que tienen que ver con la veracidad o falsedad de lo dicho, en función de lo considerado por el hablante. Por ejemplo, afirmar, negar, pensar, estimar. Esta categoría corresponde a los verbos expositivos de Austin así como, en parte, a los judicativos.

2. Directivos, que incluyen todos los actos en los cuales el hablante se dirige al oyente para hacer algo. Por ejemplo preguntar, pedir, solicitar.

3. Comisivos, que incluyen todos los actos donde el hablante expresa un compromiso. Por ejemplo, prometer, garantizar, comprometer.

4. Expresivos, que incluyen todos los actos que expresan la 
posición psicológica del hablante. Por ejemplo, pedir perdón, congratular, quejarse.

5. Declarativos, que incluyen todos los actos realizados con éxito. En ellos se corresponde el contenido de las proposiciones y lo que ocurre en la realidad. Por ejemplo, interrogar, dimitir, excomulgar.

Searle entonces elabora la teoría de actos de habla definiendo la estructura de los actos ilocutivos y las reglas que gobiernan la fuerza ilocutiva. Según él, hay ciertas reglas de condiciones (condiciones de felicidad) que deben estar presentes para que un acto de habla sea realizado con éxito. Por ejemplo, las condiciones para realizar el acto de promesa satisfactoriamente son las siguientes:

1. Señalar la realización de un futuro acto por parte del hablante.

2. El hablante debe creer que el oyente considera satisfactorio dicho acto.

3. El acto prometido no debe ser algo que se esperaría que el hablante realizara independientemente de la promesa.

4. El acto de la promesa debe ser llevado a cabo sólo si el hablante tiene la intención de realizar el acto prometido.

5. La producción de la promesa supone una obligación de realizar la acción. 
Además, Searle sostiene que cualquier acto de habla puede ser realizado indirectamente. Los actos de habla indirectos son aquellos que expresan cierto sentido literal, pero que, en realidad, implican algo más. Por ejemplo, la declaración "hace calor aquí" es un acto de habla indirecto porque puede implicar la petición de que se abra una puerta o ventana, o tal vez de que se apague el calentador, algo que se realiza por medio de una declaración directa del hecho.

Aunque la teoría del acto de habla de Austin y Searle se haya apoyado fundamentalmente en aspectos funcionales de la teoría pragmática, también ha sido objeto de crítica. La primera crítica se hizo a la cuestión de la universalidad contra la precisión de la cultura, es decir, hasta qué punto la realización de los actos de habla se gobiernan por principios pragmáticos universales y hasta qué punto varían en su conceptualización y verbalización según lenguas y culturas (Blum-Kulka et al. 1989). Siguiendo a Austin, Searle afirma que hay normas generales para realizar actos de habla y las diferencias transculturales no son tan dispares. Este concepto de la universalidad de los actos de habla también ha sido apoyado por Brown y Levinson (1987), quiénes creyeron que las estrategias para realizar actos de habla son esencialmente las mismas en diferentes culturas, aunque haya cuestiones específicas de cada sociedad en particular. 
Por el contrario, otros especialistas en la materia han sostenido que hay una diferencia considerable en la realización de actos de habla entre culturas. Green (1975) considera que una expresión equivalente a la forma condicional del inglés would no puede ser utilizada para introducir una nueva orden en otras lenguas como el español y el japonés. También indica que formas como "¿usted está listo?" Y "¿usted está interesado?" podrían introducir una petición en el hebreo, pero no en otras lenguas. En el mismo sentido, Blum-Kulka (1989) observa que ciertas estrategias de petición no son comunes entre las distintas lenguas, sino que existen diferencias significativas. Wierzbicka (2003) indica que la mayor parte de los estudios de los actos de habla tienen una perspectiva dominantemente etnocentrista anglosajona. Afirma que la realización actual de actos de habla está basada en normas culturales y por tanto, debería ser diferente en las distintas culturas. Hasta el momento se han producido escasos estudios de actos de habla en lenguas no occidentales, por ello, es esperable que un número más equilibrado de estudios contrastivos entre culturas occidentales y no occidentales ofrezcan una visión más clara de la universalidad o especificidad cultural de los actos de habla.

En segundo lugar, muchos investigadores han señalado que las declaraciones frecuentemente sirven para más de una función, dependiendo de la intención del hablante. Como señala 
Wolfson (1989), "entre hablantes del inglés americano de clase media, un cumplido, por ejemplo, puede servir bien como un saludo o como una expresión de gratitud". Del mismo modo, Flowerdew (1990) puntualiza:

\begin{abstract}
A fundamental question of speech act theory is the relation between function and form, between the speech act and the language used to realize that speech act. As many writers have pointed out, there is no one-to-one relation between the two. A request can be realized by an interrogative such as can you open the window? But also by an imperative, open the window, please. On the other hand, can you open the window? As well as functioning as a request, in different circumstances might function as a question concerning ability.
\end{abstract}

Además, como afirma Cohen (1996), "los últimos 15 años han marcado un cambio, un acercamiento anecdótico, basado intuitivamente en la descripción de un acto de habla a un acto empírico". Olshtain y Cohen (1983), por ejemplo, indican que la teoría tradicional del acto de habla, sobre todo el trabajo de Austin y Searle, no proporciona una definición adecuada de la noción del acto de habla. Por lo tanto, en su estudio de apologías, Olshtain y Cohen amplian la noción del acto de habla y sugieren el término "conjunto del acto de habla", que consiste en el "conjunto potencial máximo de fórmulas semánticas para cada acto" (p. 20).

El término de "fórmula semántica", relacionado con los actos de habla lo utiliza por primera vez Fraser (1980, citado en 
Olshtain y Cohen, 1983) y lo define como una palabra, frase u oración que comprende un criterio semántico particular. En consecuencia, cualquier acto de habla puede ser realizado utilizando un solo acto de habla o una combinación de fórmulas semánticas. Por ejemplo, el acto de habla de rechazo puede consistir en varias fórmulas semánticas, como una disculpa (p. ej., "Perdón"), una negativa (p. ej., "no puedo venir") o una explicación o excusa (p. ej. "no estaré en la ciudad"). Además, los rechazos se pueden expresar a través de declaraciones directas (es decir, diciendo "no" directamente) o indirectas (es decir, intentando disuadir al interlocutor, o prometiendo una aceptación futura), tal y como han propuesto Beebe y Cummings (1996) así como Beebe et al. (1990). Analizar actos de habla en relación con sus fórmulas semánticas dentro de su conjunto proporciona una visión más clara del acto de habla en cuestión.

El tercer problema de la teoría del acto de habla reconsidera el número de actos de habla propuestos por la teoría. El primer trabajo sobre actos de habla de Austin (1962) establece cinco clases de actos de habla: judicativos ejercitativos, compromisorios, de comportamiento y expositivos. Criticando esta división por su inconsecuente criterio de clasificación, y usando la propia introspección de Austin como fuente para estas taxonomías, Searle (1975) agrupa los actos de habla en cinco nuevas categorías: 
representativos, directivos, comisivos, expresivos, y declarativos. Ballmer y Brennenstuhl (1981), más tarde, elevaron a 600 el número de actos de habla. Flowerdew (1990) resume la dificultad para determinar clasificaciones de los actos de habla:

\begin{abstract}
Any approach, however, is likely to suffer from the basis \& theoretical problem of the conflict between an all purpose system which is likely to have defects in relation to the specific situations in which it is applied and a system derived from one narrowly defined situation which is liable to lack applicability to other more general situations (p. 83)
\end{abstract}

Considerando que nunca se ha alcanzado un consenso en el número exacto de actos de habla, Rose (1996) sugiere que lo mejor sería elegir "un conjunto principal de tipos de acto de habla esenciales" y enseñarlos en el aula. Sin embargo, se mantiene el problema de cómo definir y seleccionar ese conjunto principal de actos de habla esenciales.

Un cuarto al problema de la teoría de los actos de habla acerca de la cuestión de la (in)dirección, Searle sostiene que un acto de habla indirecto se realiza en el nivel de la oración simple. Sin embargo, como Ellis (1993) señala, hay muchas situaciones en las cuales un tipo de acto de habla, las peticiones, puede ser realizado únicamente después de varias intervenciones. 
Aparte de las tratadas previamente, hubo otras críticas frente a la teoría de actos de habla. Una de ellas se dirige al hecho de que las taxonomías del acto de habla propuestas por Searle están basadas en su propia introspección y no en estudios empíricos.

A pesar de sus limitaciones, la teoría de los actos de habla ha sido utilizada como una base teórica para muchos estudios transculturales y de la Pragmática de Interlenguaje durante las dos últimas décadas. Achiba (2003) justifica la importancia de la teoría de los actos de habla para los estudios de la Pragmática de esta forma:

\begin{abstract}
According to speech act theory, speakers perform illocutionary acts by producing utterances. An illocutionary act is a particular language function performed by an utterance. That is, through their utterances speakers convey communicative intentions, such as requests, apologies, promises, advice, compliments, offers, refusals, complaints and thanking. The study of speech acts provides a useful means of relating linguistic form and communicative intent (p.2)
\end{abstract}

Además, y con el desarrollo de la noción de "competencia comunicativa", (Hymes, 1972; Canale y Swain, 1980), la influencia de las teorías de Austin y Searle se han extendido a las áreas de enseñanza de segundas lenguas y a la Lingüística Aplicada. Se pueden ver pruebas de esto en el área del diseño de programas de estudio (Wilkins, 1976); en el área de interacción en el aula (Sinclair y Coulthard, 1975); y en el área de la Pragmática de Interlengua en 
la investigación que se centra en las formas en que los actos de habla se seleccionan y realizan por hablantes no nativos (Kasper y Dahl, 1991).

Los investigadores de Pragmática de Interlengua, por ejemplo, están más interesados en las elecciones de los aprendices de una segunda lengua, al realizar o contestar a actos de habla usando dicha lengua, así como en los motivos que están detrás de tales decisiones. Los estudios de actos de habla de interlenguaje que comparan el discurso de hablantes nativos y hablantes no nativos incluyen, entre otros, expresiones de gratitud (Eisenstein y Bodman, 1995), petición (Tello Rueda, 2006), queja (Nakabachi, 1996), disculpa (Tateyama, 2001), invitación (Félix-Brasdefer, 2003), saludos (Jaworski, 1994) y rechazo (Al-Issa, 2003).

Todos los estudios llevados a cabo en esta área concluyeron que los hablantes no nativos podrían dejar de entender y/o producir las declaraciones apropiadas pragmáticamente a pesar de tener un orden gramatical y léxico relativamente bueno del idioma de destino. En otras palabras, la competencia lingüística, por sí sola, no asegura un uso apropiado de la lengua de destino. Para hacerse competentes en una segunda lengua o una lengua extranjera, los aprendices tienen que desarrollar sus habilidades pragmáticas en la realización de acto de habla (es decir, saber cuándo, cómo, a quién, 
y bajo qué condiciones los actos de habla deben ser iniciados y respondidos). También se ha sugerido que la carencia de tales habilidades pragmáticas puede impulsar a los hablantes no nativos a transferir inadecuadamente sus reglas sociolingüísticas natales del habla a la segunda lengua, incrementando así las posibilidades de llegar a un fracaso pragmático.

\subsection{La Teoría de la Cortesía}

A pesar del debate teórico en torno a una definición universal de la cortesía, sigue siendo evidente que la cortesía desempeña un papel significativo en todas las sociedades, ya que sienta las bases para una interacción respetuosa entre seres humanos y para conversaciones correctas. Cuando los interlocutores se comunican entre sí intentan alcanzar objetivos particulares, como mantener o ampliar sus relaciones personales, que, desde luego, solo se pueden alcanzar mediante la cooperación. En cierta medida, el Principio de Cooperación de Grice, que expone en su publicación "Lógica y Conversación" en 1967, sirve como punto de partida para el desarrollo de algunas aproximaciones teóricas al estudio pragmático y sociolingüístico de la cortesía en el uso de la lengua. Las teorías fundadoras de la cortesía surgen del principio de cooperación en la conversación expuesto por Grice (1967 [1989]). Según Leech (1983), 
las máximas conversacionales de Grice podrían ampliarse con una máxima de cortesía que establece los principios que los/as hablantes deben respetar en ese aspecto para ser cooperativos/as: sé cortes" (Bravo, 2004).

A continuación, se presenta una revisión breve de tres propuestas pioneras y destacas de la cortesía, empezando por las reglas de cortesía de Lakoff (1973), y siguiendo con los principios de cortesía de Leech (1983) y la teoría de la cortesía de Brown y Levinson (1987).

\subsubsection{Las Reglas de Cortesía de Lakoff (1973)}

Como afirman varios investigadores, el trabajo de Lakoff es pionero en procurar explicar el fenómeno de la cortesía (Bravo, 2004). Lakoff (1973) adopta el Principio de Cooperación de Grice (1967 [1989]) para elaborar una serie de ideas principales de la cortesía. Sin embargo, subraya que las máximas de Grice tendrían que ser reformuladas como unas reglas pragmáticas según las cuales un enunciado podría ser clasificado como bien formado o no:

[...] so we should like to have some kind of pragmatic rules, dictating whether an utterance is pragmatically well formed or not, and the extent to which it deviates if it does (Lakoff 1973: 296). 
Sin embargo, en realidad, la gente no obedece necesariamente a las reglas del Principio de Cooperación y formula sus declaraciones de manera diferente a su verdadero significado, en particular para ser menos directos y corteses. Como la comunicación humana no tiene como fin simplemente proporcionar información clara, sino sobre todo las relaciones interpersonales y la expresión de ideas, la gente articula sus declaraciones de forma no literal, tal y como se les supone según el Principio de Cooperación. De hecho, se tiende a formular los mensajes menos claramente $y$, por consiguiente, de forma menos ofensiva, para mostrar más respeto y aprecio hacia el destinatario y mantener una relación personal basada en la armonía y estima mutua.

Debido al hecho de que "si surge un conflicto entre la intención del actor de ser claro y su voluntad de ser cortés, es más importante para el actor ser cortés y evitar ofender al interlocutor que conseguir claridad en la comunicación", Lakoff ve la existencia de un nuevo principio, en particular en conversaciones informales en las cuales la charla real es más importante que el contenido. Por lo tanto, introduce "una regla de cortesía" que está relacionada con el Principio de Cooperación de Grice y combina los principios de la conversación humana con cuestiones sociales, como el efecto que una declaración tiene en la relación entre los interlocutores. 
En contraste con los principios conversacionales de Grice, que son únicamente "pautas para el uso 'racional' de la lengua en la conversación", y que tienen una importancia relativa, las Reglas de la Competencia Pragmática y las Reglas de la Cortesía de Lakoff deberían seguirse a fin de evitar ofensas y conflictos interpersonales y mantener relaciones sociales armoniosas. Estas reglas de la Competencia Pragmática establecidas por Lakoff son, ser claro y ser cortés. Estas dos reglas, sin embargo, son contradictorias porque ser claro a menudo no se considera como cortés y puede resultar ofensivo y grosero.

Como las Reglas de la Competencia Pragmática de Lakoff están en conflicto entre sí, en la mayor parte de las situaciones diarias de comunicación, Lakoff crea tres sub-reglas adicionales, las Reglas de la Cortesía: 1 . No impongas, 2. Da opciones y 3. Haz sentir bien - sé amistoso. El primer principio, "no impongas", se aplica cuando se requiere distancia social y cortesía formal o impersonal, es decir, en conversaciones en las cuales los compañeros ilocutivos procuran guardar una distancia formal y, así, sin crear un ambiente de confianza, mantener su libertad sobre todo cuando se trata de lo que Lakoff llama "bienes no libres", que se refieren a temas muy íntimos como el sexo o los ingresos. Los dispositivos lingüísticos para evitar imposición son, por ejemplo, las construcciones pasivas y otras expresiones impersonales. 
El segundo principio "da opciones" se usa en conversaciones más informales y pretende dejar opciones abiertas para que el destinatario conserve su derecho a tomar decisiones por sí mismo. Muletillas como "supongo" o coletillas interrogativas son un medio lingüístico para dejar la decisión final y su propia formación de opinión abierta al destinatario, restar fuerza a la aseveración del propio hablante y "dar al interlocutor la opción de no dar su conformidad sin el miedo al castigo" (Lakoff)

Finalmente, el tercer principio "Haz sentir bien" es "la regla que produce una sensación de compañerismo entre hablante e interpelado" (Lakoff), por ejemplo usando nombres o apodos, haciendo cumplidos, usando palabras tabú así como partículas sin sentido aparente como "asi", "ya sé" y "quiero decir" que hacen que el destinatario se sienta implicado más íntimamente en la conversación. Así, la tercera regla se hace relevante con respecto a la cortesía íntima.

Lakoff concluye que estas Reglas de la Cortesía son universales en la interacción humana y tienen prioridad sobre las del Principio de Cooperación de Grice. Sin embargo, las culturas valoran la importancia de cada regla de manera diferente, y priorizan al aplicar una regla en vez de otra según la organización de las sociedades y los principios (distancia, deferencia, o compañerismo) 
que predominan en sus respectivas vidas sociales. En otras palabras, las diferentes tradiciones y creencias llevan al hecho de que las diferentes culturas apliquen estrategias de cortesía diferentes. Sin embargo, Lakoff no define el término "cortesía" detalladamente y desprovee al lector de la información sobre cómo el hablante o el oyente pueden determinar el nivel requerido de cortesía y qué reglas deben aplicarse en una situación de discurso dada.

\subsubsection{El Principio de Cortesía de Leech (1983)}

De un modo parecido al de Lakoff, Leech condensa y desarrolla teóricamente el Principio de Cooperación de Grice en un conjunto de principios subsumidos bajo su idea de Principio de Cortesía. En su teoría diferencia entre los "objetivos ilocutivos" de un hablante (qué acto de habla tiene intención de transmitir el hablante mediante su declaración) y "los objetivos sociales" de un hablante (qué posición toma el hablante al ser veraz, cortés, irónico etc.). Dicha clasificación puede estar relacionada con dos conjuntos de principios conversacionales: la "retórica textual", que determina la forma gramatical y estilística de una declaración y, por tanto, "los objetivos ilocutivos" de hablante, y la "retórica interpersonal", que incluye "los objetivos sociales" de un hablante y tiene en cuenta el nivel apropiado de cortesía, mientras que simultáneamente sirve como un 
medio para descifrar el sentido comunicativo real de una declaración más allá de "la retórica textual".

Las dos formas de retórica incluyen una variedad de máximas y sub-máximas. Sin embargo, es en la esfera de la "retórica interpersonal" en la que la cortesía se hace relevante. Consta de las máximas mencionadas en el Principio de Cooperación de Grice, así como de las máximas interpersonales de Tacto, Generosidad, Aprobación, Modestia, Acuerdo, y Compasión. Estas máximas, por su parte, se subsumen bajo un único principio que hace la siguiente de manda al hablante: "minimiza la expresión de opiniones descorteses [y] maximiza la expresión de opiniones corteses". Esto, por tanto, exige el uso de más expresiones favorables al oyente y reduce la cantidad de expresiones desfavorables para el oyente. Además, Leech proporciona un conjunto de escalas para tasar el grado de Tacto o Acuerdo necesario en una situación de discurso dada.

El Principio de Cooperación (The Cooperative Principle o CP) y el Principio de Cortesía (The Politeness Principle o PP) son principios estrechamente interrelacionados, y que se complementan entre sí, dado que, a diferencia del PP, el CP no puede explicar por qué los participantes de una conversación no obedecen a sus máximas y articulan sus declaraciones sin que sean tan informativas, relevantes y verdaderas como requeriría dicho principio y, por tanto, 
deja de tener en cuenta el aspecto interpersonal de la conversación.

Como las máximas del Principio de Cortesía funcionan como reglas normativas del comportamiento, "el concepto de la cortesía de Leech trata de evitar conflicto." Por eso, Leech define la cortesía como un medio para perseguir objetivos sociales como Tacto, Generosidad, Aprobación, etc. a fin de evitar declaraciones desfavorables y asegurar la armonía y la cooperación en las interacciones sociales. Ya que el acto de habla es por sí mismo crucial para el uso de la cortesía, Leech también distingue entre "Cortesía Negativa", que minimiza la descortesía de declaraciones fundamentalmente descorteses (p.ej. órdenes), y "Cortesía Positiva", que maximiza la cortesía de actos ilocutivos naturalmente corteses (p.ej. ofertas).

Leech indica que cada sociedad tiene normas diferentes para "ser cortés." En otras palabras, en las diferentes sociedades operan máximas de modos diferentes, privilegiando la máxima del principio de cortesía sobre otras. Por ejemplo, parece que en la sociedad japonesa, la máxima de modestia es más poderosa que en las sociedades de habla inglesa, donde se piensa que es más cortés aceptar un cumplido agradeciéndoselo al hablante que no aceptarlo, tal y como harían la mayoría de los japoneses. Sin embargo, la diferencia estricta establecida por Leech entre actos ilocutivos 
intrínsecamente corteses y descorteses no es aplicable en todas las situaciones, como indica Fraser (Fraser, 1990). Por lo tanto, Leech tampoco proporciona la teoría más apropiada y elaborada sobre la cortesía.

\subsubsection{La Teoría de la Cortesía de Brown y Levinson (1987 [1978])}

En contraste con la perspectiva de las máximas conversacionales apoyada por Grice, Lakoff y Leech, la Teoría de la Cortesía de Brown y Levinson propone la idea de la cortesía como salvaguarda de la propia imagen, basándose en el concepto de Goffman de imagen como una autoimagen pública, y en la definición de cortesía como "una forma del control emocional que sirve como medio para conservar la imagen" en la interacción social. Brown y Levinson asumen que aunque la conversación humana tenga la intención de ser cooperativa y trate de cumplir con las máximas de Grice, se desvía del Principio de Cooperación porque les preocupa más la protección de su propia imagen, ya que dependen del otro para lograr sus objetivos. La conocida teoría de Brown y Levinson se considera el acercamiento más elaborado e influyente para teorizar sobre la cortesía y ha recibido gran aceptación entre los lingüistas. 
La Teoría de la Cortesía de Brown y Levinson afirma que cada hablante competente de una lengua, (a Model Person), tiene una "imagen", es decir, una autoimagen pública que quiere mantener en la comunicación con otros. Según Goffman (1967), "Face may be defined as the positive social value a person effectively claims for himself by the line others assume he has taken during a particular contact" $y$, por lo tanto, "refers to that emotional and social sense of self that everyone has and expects everyone else to recognize" (Goffman, 1967). Cada persona que se relaciona con otros en la comunicación humana tiene necesidades de imagen (face wants) que se plasman en dos tipos de deseos que procura satisfacer y también quiere que sean percibidos por sus interlocutores, y que, según Brown y Levinson tienen que ver con los conceptos de imagen negativa e imagen positiva.

Mientras que el concepto de la imagen negativa describe el deseo del individuo de que sus actos no se impidan injustificadamente, la noción de imagen positiva se refiere a la necesidad que individuo tiene que la imagen positiva que posee de sí mismo sea reconocida y reforzada por el resto de miembros de la sociedad (Henk Haverkate, 1994). En una conversación, hablante y oyente deben estar interesados en la defensa de su imagen positiva y negativa así como en proteger la imagen de la otra persona, a fin de evitar que nadie vea deteriorada públicamente su imagen y ello 
haga fracasar su relación personal. Por lo tanto, emplean ciertas estrategias de cortesía y usan la cortesía como un medio para salvaguardar la imagen de cada uno. La cortesía, así entendida, es solamente una cuestión de imagen.

Sin embargo, tanto la imagen del oyente como la del hablante, que está relacionada con sus emociones implicadas en una situación lingüística, pueden estar amenazadas en la mayor parte de los actos de habla que "por su naturaleza actúan en sentido contrario a las necesidades de imagen (face wants) del destinatario y/o del hablante" (Brown y Levinson, 1987). Estos actos de habla se llaman actos amenazadores de la imagen o Face-Threatening Acts en inglés (FTA), y tienen lugar en situaciones lingüísticas en las cuales el hablante amenaza la imagen positiva del oyente ( $y$, por tanto, su necesidad de ser apreciado y aceptado), por ejemplo insultándolo, criticándolo, o desaprobándolo, o en aquellas en que el hablante daña la imagen negativa del oyente, $y$, con ella, su necesidad de autonomía y libertad de acción, por ejemplo al pedir un favor o incluso al sugerir o aconsejar. Pero no solo la imagen del oyente puede ser dañada en actos de habla específicos: también la imagen positiva del hablante puede ser amenazada, por ejemplo, al pedir perdón $\mathrm{o}$ al responder a un cumplido, o, su imagen negativa puede verse afectada, por ejemplo, al recibir una oferta o al expresar agradecimiento. Algunos actos que amenazan la imagen, como 
quejas, interrupciones, y expresiones fuertes de emociones, pueden incluso dañar al mismo tiempo tanto la imagen positiva como la negativa.

Según la teoría de Brown y Levinson, la mayoría de los actos de habla pueden suponer amenazas a la imagen, ya sea a la negativa, a la positiva, o a ambas. Dado que cada individuo, sin embargo, está interesado en preservar su propia imagen así como la de los otros, las estrategias de cortesía se aplican a fin de mitigar potenciales amenazas de dicha imagen. Las estrategias de cortesía, así, sirven a la vez como un método para debilitar tanto actos de habla que amenazan la imagen como actos que la salvaguardan. Por consiguiente, usando ciertas estrategias de cortesía, los hablantes pueden comunicar mensajes comprometidos sin arriesgase a ser descorteses y ofender a su interlocutor.

En la mayor parte de los actos de habla a menudo es inevitable amenazar la imagen de la otra persona. Por lo tanto, el hablante tiene que calcular de antemano el grado de amenaza potencial de su declaración. A este respecto, Brown y Levinson distinguen entre las siguientes estrategias principales para llevar a cabo este tipo de actos: 
1. Hacer el acto amenazante (on-record) abierta y francamente (sin desagravio): esta estrategia incluye declaraciones directas e inequívocas sin usar ninguna estrategia de cortesía particular.

2. Hacer el acto amenazante del registro abiertamente y con desagravio usando cortesía positiva: esta estrategia pretende salvaguardar la imagen positiva del oyente e implica la expresión de compañerismo, sentimientos positivos y empatía.

3. Hacer el acto amenazante del registro abiertamente y con desagravio usando cortesía negativa: esta estrategia se ocupa de la imagen negativa del oyente e incluye una expresión de pesar por la intromisión o interrupción, así como expresiones de disculpa a fin de mostrar respeto.

4. Hacer el acto amenazante usando cortesía indirecta fuera del registro (off-record): esta estrategia se realiza mediante insinuaciones y con expresiones indirectas (p.ej. mediante la utilización de ironía, metáforas, o preguntas retóricas) en vez de enunciar directamente un mensaje.

5. No hacer el acto amenazante: esta estrategia procura evitar absolutamente una amenaza de la imagen, lo cual sin embargo es casi imposible en la mayor parte de las situaciones cotidianas. 
Si un hablante, sin embargo, no puede evitar un acto de habla que amenace la imagen, pero no quiere ofender a su interlocutor, puede aplicar estrategias de cortesía diferentes, a fin de reparar la amenaza de imagen. Tiene la opción de elegir entre aplicar estrategias del registro (on-record) o fuera del registro (offrecord). Puede hacerlo fuera del registro (off-record), como en el ejemplo siguiente, emitido para hacer una petición: "Vaya, mi coche se estropeó anoche y ahora no sé cómo conseguiré ir a trabajar hoy".

En declaraciones que se hacen fuera del registro (offrecord), es decir de tal modo que no es posible atribuir una única intención comunicativa clara al acto, a menudo se comunica más de lo literalmente dicho. En el ejemplo señalado el hablante tiene la intención de que el oyente capte su deseo de que le preste su coche, pero no lo expresa claramente.

Si el destinatario interpreta este indicio correctamente, esta manera de expresar el acto amenazante se percibe de manera mucho más cortés que una declaración del registro (on-record) y franca, como: "Préstame tu coche hoy."

La (in)dirección, por tanto, es un importante medio lingüístico para expresar la cortesía. Sin embargo, entre miembros iguales de un grupo social particular, usar una expresión del registro 
(on-record) y franca no necesariamente se considera como descortés. Por el contrario, una expresión de cortesía "extrema" podría ser considerada como insincera o hipócrita. Los recursos de mitigación como "por favor" y "¿podrías?", sin embargo, se pueden usar para debilitar la franqueza de una declaración del registro (onrecord) y franca. Dado que la amenaza potencial sobre la imagen, sin embargo, es bastante alta cuando se usan estrategias explícitas, a menudo parece más apropiado emplearlas acompañadas de una reparación de la amenaza sobre la imagen del destinatario, lo cual requiere el uso de cortesía positiva o negativa. Las cinco estrategias propuestas por Brown y Levinson pretenden "incrementar la cortesía, siendo la forma menos cortés las expresiones directas sin desagravio, y la omisión del acto amenazante la más cortés".

Brown y Levinson afirman que su teoría puede ofrecer un marco para comparar diferencias transculturales en la cortesía. Con el fin de elegir una estrategia de cortesía apropiada para el contexto el hablante tiene que valorar previamente la amenaza de imagen potencial de un acto de habla. En otras palabras, calcular el peso potencial (weightiness) del acto de habla (W) sobre la base de las tres variables incluidas en la siguiente fórmula:

$$
W=P(H, S) D(H, S) R
$$


La variable $\mathrm{P}$ describe la diferencia de poder percibida mutuamente entre el oyente y el hablante, es decir hasta qué punto los interlocutores pueden tener un mayor control sobre la realidad (p.ej. dinero) y/o bienes inmateriales (p.ej. conocimiento, papel social), sin tener en cuenta los planes y necesidades de imagen del otro. Un estudiante, por ejemplo, tiene que considerar el estatus superior del profesor y de las autoridades académicas en su relación de alumno-profesor durante una conversación. La variable D define la distancia social percibida entre ambos interlocutores y se valora sobre la base del intercambio de gestos de aprobación, y de "la frecuencia de la interacción y la clase de (...) bienes intercambiados" (Brown y Levinson, 1987) entre ellos. En otras palabras, el grado de cortesía depende de lo cerca que se sientan el hablante y el destinatario, el uno del otro, y si su relación es íntima o distante. Finalmente, la variable $\mathrm{R}$ representa el ranking del acto de habla según su amenaza potencial sobre la imagen y su grado de imposición, y depende de cómo se percibe y valora la amenaza de la imagen en una cultura específica.

El peso (the weightiness) de un acto de habla específico "determinará finalmente el grado de cortesía que el hablante determine que se requiere para la comunicación del acto" (Fraser, 1990) y aumenta de acuerdo con el crecimiento de las variables. Por lo tanto, "las personas que interactúan se preocupan cada vez más 
por la protección de la imagen y menos por la claridad transaccional" según aumente el peso (the weightiness) del acto. Finalmente, el contexto y la relación social entre el hablante y el oyente, valorados de acuerdo con los criterios de poder y distancia social, así como el ranking del acto de habla, son cruciales para la selección de estrategias de cortesía, es decir, si el hablante opta por una estrategia del registro (on-record) o prefiere una de las estrategias de compensación, mediante el uso de cortesía positiva o negativa. Mientras que se elige la cortesía positiva para comunicarse con quien los hablantes se sienten emocionalmente vinculados, como pueden ser los amigos y miembros de la familia, por lo general se prefiere el uso de la cortesía negativa en la interacción social con aquellas personas con las que existe una mayor distancia social y emocional, o una mayor diferencia de poder, como desconocidos, compañeros de trabajo o jefes. Ya que la cortesía está muy relacionada con la estratificación de una sociedad según la posición social, edad, sexo y otras variables, su uso socialmente apropiado varía con los contextos sociales de modo que "lo que resulta descortés en un contexto formal $y$ dirigido a un superior puede pasar desapercibido en conversaciones relajadas entre amigos" (Yule, 1997).

Pero aunque la Teoría de la Cortesía de Brown y Levinson puede ser aplicada a todas las sociedades, las reglas y las normas del comportamiento cortés y los dispositivos lingüísticos de 
expresiones corteses son culturalmente diversos. Además, el significado y la valoración de cada variable, sin embargo, son diferentes en cada cultura ya que hay valores subyacentes diversos que determinan la relación de poder y la distancia social entre hablante y oyente. Por ejemplo, se piensa que las sociedades asiáticas valoran la diferencia de poder y la distancia social como factores muy importantes para la elección de un lenguaje cortés, incluso entre miembros de una misma familia. Se educa a los niños malayos, por ejemplo, para que usen estrategias de cortesía mediante expresiones de fórmulas de tratamiento adecuadas, para mostrar deferencia cuando se dirigen a los miembros de familiares más mayores como los padres, los abuelos, los tíos, los hermanos mayores y etc., como, la prohibición de usar la forma de awak (el pronombre de la segunda persona que equivale a $t(\hat{\imath})$ para dirigirse a dichas personas, que serían consideradas como exageradas en culturas occidentales. En contraste con las culturas asiáticas, los estadounidenses se concentran en valores como la solidaridad, el trato informal, y el compañerismo, mientras que las culturas europeas tienden a utilizar estrategias que alejan, a fin de guardar un grado apropiado de distancia social.

Sobre todo, las diferencias culturales entre culturas orientales y occidentales parecen ser muy extremas cuando entra en juego la estratificación social y el uso socialmente apropiado de las 
estrategias de cortesía. Sin embargo, incluso en culturas occidentales diferentes, existen distintos valores y normas sociales que determinan lo que se considera como cortés y descortés. En culturas de cortesía negativa se piensa que la gravedad de ciertos actos de habla es muy alta, dado que los valores sociales vinculados a poder social, distancia y ranking, son grandes y de mucha trascendencia, en tanto que la jerarquía social se considera preeminente y tiene que ser conservada en todas las relaciones. En culturas de cortesía positiva, sin embargo, se piensa que la gravedad es menor y las variables sociales, poder, distancia, y ranking se tienen menos en cuenta, dado que se destaca la solidaridad y la proximidad social.

Brown y Levinson hacen predicciones sobre la distribución típica de estrategias de cortesía en la cultura mediante la identificación de la importancia relativa de poder y distancia social que operan como pareja social predominante de una cultura (1978, p. 248).

Thus cultures can be distinguished between positive politeness cultures and negative politeness cultures. In negative politeness cultures, the general level of Wx tends to be high, impositions are considered to be large, and the values for social distance and relative power are high. Negative politeness cultures are those lands of Standoffish creatures like the British (in the eyes of the Americans), the Japanese (in the eyes of the British), (Brown and Levinson, 1978, p. 250). 
Sociedades como la coreana y la china también pertenecen a la categoría de culturas con cortesía negativa. Por el contrario, sociedades como la norteamericana, pertenecen al grupo que emplea la cortesía positiva. En estas culturas, los niveles generales del peso (the weightiness) tienden a permanecer bajos, se considera que la carga que suponen los actos de habla es escasa, y el valor que se otorga al poder relativo y la distancia social es relativamente pequeño. Por lo tanto, según Brown y Levinson, en culturas de cortesía positiva, los hablantes utilizarán más frecuentemente estrategias de cortesía positiva que de cortesía negativa, mientras que en una cultura de cortesía negativa como la de Corea, se recurrirá preferiblemente a estrategias de cortesía negativa.

Scollon y Scollon (2001) introducen términos diferentes para caracterizar los sistemas de cortesía. Así, aplican el de "implicación" donde Brown y Levinson hablaban de "cortesía positiva" e "independencia" para referirse a la "cortesía negativa". Dentro de su esquema, un sistema de implicación también emplearía probablemente estrategias de las denominadas bajas (explícitas y directas y cortesía positiva), mientras un sistema de independencia probablemente empleará estrategias denominadas altas (cortesía negativa, implícita, o evitación del acto amenazante). 
A diferencia de Brown y Levinson, quienes afirman que la imagen solo puede ser proyectada por el hablante a los oyentes, y no por el hablante con respecto a sí mismo, Scollon y Scollon (2001) sugieren que la implicación presta atención no solo a la imagen positiva del oyente, sino que también refuerza la imagen positiva del hablante, porque dicha implicación, en cuanto que manifiesta afinidad y empatía, involucra tanto al oyente como al hablante. La imagen negativa, por el contrario, sólo puede ser salvaguardada con respecto al oyente en cuanto que se minuscaba la del hablante. "To the extent that I grant the freedom of unimpeded activity to my hearer I lose my own. To the extent I assert my own right to autonomy, my own negative face; I risk that of my hearer (p. 176)". La tabla que se presenta a continuación muestra esta diferencia entre la imagen negativa y positiva, y los correspondientes sistemas de cortesía:

Tabla 1. Sistema de Cortesía e Imagen de Scollon y Scollon, (2001)

\begin{tabular}{|l|c|c|c|c|}
\hline & $\begin{array}{c}\text { La imagen } \\
\text { positiva del } \\
\text { hablante }\end{array}$ & $\begin{array}{c}\text { La imagen } \\
\text { negativa del } \\
\text { hablante }\end{array}$ & $\begin{array}{c}\text { La imagen } \\
\text { negativa del } \\
\text { Oyente }\end{array}$ & $\begin{array}{c}\text { La imagen } \\
\text { positiva del } \\
\text { Oyente }\end{array}$ \\
\hline Independencia & - & - & + & \\
\hline Participación & - & + & - & - \\
\hline
\end{tabular}




\subsection{Los actos de habla de petición y mandato}

Según Searle (1969), las acciones de mandar, ordenar, pedir etc. pertenecen a la categoría de actos de habla directivos, que son "actos ilocutivos que están destinados a producir algún efecto a través de una acción del oyente" (Searle, 1969).

Searle (1969) define las peticiones como "actos de habla cuyo contenido proposicional implica un hablante que quiere que el oyente realice un acto en el futuro". El emisor de la petición actúa como si no tuviese autoridad ni poder para obligar a su cumplimiento, por lo que no va a insistir ni se enfadará a causa de un rechazo (Green 1988: 121).

En cambio, "los mandatos tienen la regla preparatoria adicional, en virtud de la cual el hablante debe estar en una posición de autoridad sobre el oyente" (Searle, 1969). En consecuencia, la condición esencial para un mandato sería que la declaración se considere como un intento de conseguir que el destinatario realice el acto en virtud de la autoridad que el hablante tiene sobre él, por ejemplo, cuando un policía dice a un conductor "muéstreme su carnet de conducir". 
Como se indica en el estudio de Brown y Levinson (1987: 65), "los mandatos y las peticiones son los actos que más amenazan la imagen negativa del destinatario", porque, al realizar este acto de habla, el hablante interfiere en la libertad de acción del destinatario. Estos actos, capaces de amenazar la imagen, realizados por el hablante al destinatario podrían provocar su desobediencia, por lo que también amenazan los deseos de la imagen del hablante. Por esta razón, en lugar de realizar los actos de habla de la manera más directa posible, los hablantes recurren a estrategias de cortesía y añaden diversas formas de reparación para reducir la imposición sobre las necesidades de salvaguardar la imagen del destinatario (Searle, 1979; Brown y Levinson, 1987).

En cuanto a las peticiones, hemos de decir que son los actos de habla más frecuentemente estudiados. El trabajo teórico sobre las peticiones ha demostrado que la relación de forma, significado y usos pragmáticos de las peticiones es compleja, y que a menudo se encuentran implicados factores sociales para el hablante y el oyente en la elección de una opción lingüística.

Según Blum-Kulka, House y Kasper (1989: 11), las peticiones son actos preventivos que "expresan expectativas de los hablantes" en relación al oyente con respecto a una acción prospectiva, verbal o no verbal. En las peticiones, es principalmente 
el hablante (la persona que hace la petición) quien se beneficia de la acción que al oyente (la persona a la cual se dirige la solicitud) se le pide llevar a cabo. Blum-Kulka, House y Kasper (1989) señalan que al realizar una petición, los hablantes pueden sentir que están invadiendo la libertad de acción de los oyentes y a menudo se puede dudar si llevarla o no a cabo, por temor de parecer necesitados o imponerse al oyente. Pero existen muchas maneras de mitigar las peticiones, reduciendo así el grado de imposición, lo que se refleja en una variedad de estrategias con diferentes grados de dirección, a las que los hablantes pueden recurrir a la hora de formular sus peticiones. La elección de una u otra estrategia da lugar a tres actos de habla de petición diferentes, según sus grados de (in)dirección.

\subsubsection{Estrategias de petición}

El marco teórico de la presente investigación ha partido principalmente de Blum-Kulka y Olshtain (1984) y Blum Kulka, House y Kasper (1989), que han estudiado las diferentes estrategias que pueden servir para variar la imposición inherente a las peticiones. El empleo de estas estrategias da lugar a tres tipos de acto de habla:

Acto directo: Se logra cuando, por defecto, hay congruencia entre la forma lingüística utilizada por los hablantes y la 
fuerza ilocucionaria del acto de habla que se realiza a través de tal forma (por ejemplo, una pregunta para pedir información o un imperativo para solicitar una acción).

Acto indirecto convencional: Se logra cuando formas lingüísticas convencionalmente aceptadas (es decir, diferentes de las formas no marcadas, por defecto, destacadas, congruentes) se utilizan para alcanzar la fuerza ilocucionaria de un acto de habla (por ejemplo, una pregunta utilizada para llevar a cabo una petición).

Acto indirecto no convencional: Se logra cuando el conocimiento compartido de las personas que interactúan determina la fuerza ilocucionaria del acto de habla. Este tipo de (in)dirección, es a veces no lingüística (por ejemplo, uso de insinuaciones en lugar de formas lingüísticas para realizar un acto de habla).

El acto indirecto convencional se basa en "convenciones del lenguaje", que incluyen el "contenido proposicional" (significado literal) y la "forma pragmalingüística" para señalar una fuerza ilocutiva. El indirecto no convencional, sin embargo, se centra en el "contexto sociolingüístico" y queda, por tanto, indefinido en términos de contenido proposicional, forma lingüística y fuerza pragmática.

Por otro lado, hemos de señalar, además, que muy a 
menudo las peticiones constan de dos elementos: (a) actos principales (head acts) y (b) movimientos de apoyo (supportive moves). Los actos principales (AP) son los elementos fundamentales y se refieren a la propia petición o a la estrategia principal empleada para realizar la petición. Los movimientos de apoyo son elementos periféricos que pueden modificar la intensidad de las peticiones. $\mathrm{Si}$ se producen en la misma frase que lleva la propia petición, se llaman movimientos de apoyo internos (MAI), pero si se producen en otras oraciones que preceden o siguen la oración de petición, se les denomina movimientos de apoyo externos (MAE). Los movimientos de apoyo (MA) no siempre son obligatorios y su uso depende en gran medida de la percepción de los hablantes del grado de formalidad de una situación (es decir, de la seriedad situacional percibida). Por el contrario, los actos principales de petición son obligatorios; no es posible realizar peticiones que carezcan de actos principales. Tomemos el ejemplo siguiente, en que un estudiante pide a su profesor más tiempo para realizar una tarea en la que ya lleva retraso:

Movimiento 1 (ME): Tengo que pedirle un favor.

Acto Principal (AP): Necesito algo más de tiempo para acabar la tarea.

Movimiento 2 (ME): Verá, he estado enfermo varios días y no he podido terminarla en el plazo previsto. 
En este ejemplo, el estudiante comienza con un movimiento de apoyo al discurso externo pre-secuencial (un preparador) y luego pronuncia el acto principal de petición. Después, continúa con un movimiento de apoyo al discurso externo postsecuencial (una excusa). Incluso dentro del acto principal en sí, es posible incluir modificaciones gramaticales y léxicas (es decir, un discurso con modificaciones internas). Así, la estructura general de una petición se puede ilustrar con la siguiente fórmula:

Petición $=($ modificación externa pre-secuencial $)+$ acto principal + (modificación externa post-secuencial)

En su clasificación de actos principales de petición, BlumKulka, et al. (1989) diferencia entre tres tipos de actos, según el grado de (in)dirección de las estrategias empleadas: estrategias directas, estrategias convencionalmente indirectas y estrategias no convencionalmente indirectas. Los actos principales directos emplean una de las siguientes estrategias: (a) Modo imperativo (Imperative mode) (b) Performativos (Performatives) (c) Performativos evasivos (Hedge performatives) (d) Declaraciones de obligación (Obligation statement) o (e) Declaraciones de deseo (Want statement). Los actos principales convencionalmente indirectos usan cualquiera de las dos estrategias siguientes: (a) Preparador de interrogación (Query preparatory) o (b) Fórmula de sugerencia (Suggestory 
formula). Los actos principales no convencionalmente indirectos emplean un "Indicio", que puede ser fuerte o suave. Pasamos a explicar, a continuación, cada una de estas estrategias (adaptado de Blum-Kulka et al, 1989):

\section{Estrategias directas}

a) Modo imperativo: Es el modo gramatical de la locución que convencionalmente determina su fuerza ilocucionaria como una petición. La forma prototípica es el imperativo.

Por ejemplo: Arregla ese desorden.

b) Performativos: La intención ilocucionaria para hacer una petición está explícitamente mencionada por un verbo relevante.

Por ejemplo: Te pido que arregles el desorden.

c) Performativos evasivos: El verbo ilocucionario es modificado por algunos verbos modales o verbos que expresan la intención.

Por ejemplo: Te pediría que te calles.

d) Declaraciones de obligación: El intento ilocucionario es directamente derivable de la intención semántica de locución.

Por ejemplo: Tendrá usted que mover el coche. 
e) Declaraciones de deseo: La declaración expresa el deseo del hablante (que el acto pedido debe ser llevado a cabo).

Por ejemplo: Quiero que me entregue la tarea al final de esta semana.

\section{Estrategias convencionalmente indirectas}

a) Fórmula de sugerencia: La intención ilocucionaria se formula como una sugerencia.

Por ejemplo: ¿Y si limpias la casa esta semana y yo lo hago la próxima?

b) Interrogación preparatoria: La expresión contiene una referencia a las condiciones preparatorias, como la capacidad o la voluntad.

Por ejemplo: ¿Podrías dejarme tus apuntes de clase un par de horas?

\section{Estrategias no convencionalmente indirectas}

a) Indicio fuerte: La locución se refiere en parte a los elementos pertinentes de la petición.

Por ejemplo: Su coche está bloqueando el mío.

b) Indicio suave: La expresión no contiene ninguna relevancia inmediata como petición.

Por ejemplo: No encuentro un lugar para aparcar. 
Blum-Kulka y Olshtain (1984) también han introducido la idea de elementos agravantes (upgraders) y mitigadores (downgraders) en el estudio de las peticiones. Mediante el uso de los mitigantes, la persona que hace petición puede minimizar el grado de imposición, y su efecto amenazante. Los mitigantes se alcanzan a fuerza de ser vacilante o dubitativo sobre cumplimiento de la petición. Esto se puede alcanzar a través del uso de elementos negativos, interrogativos, tiempos pasados o modales, especialmente en tiempos pasados. Por otro lado, los agravantes se consiguen asumiendo la persona que hace la petición un rol dominante. A veces una petición elevada puede parecer un mandato.

\section{Ejemplos de mitigantes}

¿Le importaría que coja su paraguas para salir?

Me pregunto si puedes ayudarme con las matemáticas.

Quería pedirle un aumento.

\section{Ejemplos de agravantes}

Cierre la puerta.

Usted todavía no ha cerrado la puerta.

Otro parámetro utilizado por Blum-Kulka et al (1984) en la clasificación de peticiones es el de la perspectiva de la persona. 
Many request realizations include reference to the requestor ( $T$ the speaker), the requestee ('you' the hearer), and the action to be performed. The speaker might choose different ways to refer to any of these elements, manipulating by his or her choice the perspective $s /$ he wishes the request to take. For example the difference between 'could you do it' and 'could we have it done' is one of perspective-'could you ...' emphasizes the role of the hearer in the speech event, while 'could we. ..' stresses that of the speaker. Given the fact that in requests it is the hearer who is 'under threat', any avoidance in naming the addressee as the principal performer of the act serves to soften the impact of the imposition. We call this dimension of the analysis request perspective... (Blum-Kulka, 1984, p. 203)

En relación con la perspectiva, una petición puede ser de

los siguientes tipos:

1. Orientada al oyente (con énfasis en el rol del oyente):

¿Le importaría venir a cenar conmigo esta noche?

2. Orientada al hablante (con énfasis en el rol del hablante):

¿Puedo usar su cámara un día?

3. Orientado hacia el hablante y el oyente (incluyendo a ambos):

Terminemos las tareas antes de que regrese.

4. Neutra (una petición impersonal puede presentarse como una petición indirecta no convencional.)

Las plantas necesitan que las rieguen. 


\subsubsection{Estado de la cuestión acerca de la petición}

Siguiendo el esquema de codificación y el diseño de método de CCSARP, (Blum-Kulka et al, 1989) se han llevado a cabo muchos estudios transculturales e interlingüísticos sobre la petición (estudios interculturales: Economidou-Kogetsidis, 2010; Ogierma, 2009; FélixBrasdefer, 2009; Chen, 2007; Tello Rueda, 2006; Marti, 2006; Díaz Pérez, 2006; Nuria Lorenzo-Dusmy Bou-Franch, 2003; Márquez Reiter, 2002; Hayashi, 2000; Izaki, 2000; Fukushima, 2000. Generalmente se ha dicho que, si bien existen diferencias en cómo los factores contextuales determinan la realización de actos de habla en todas las culturas, hay una preferencia universal por estrategias convencionalmente indirectas sobre los otros dos tipos de estrategia (directas e indirectas no convencionales) a la hora de hacer peticiones (Blum-Kulka et al, 1989; Brown y Levinson, 1978, 1987, Chung, 1995; García, 1996; Liao et al, 1996; Chen, 2007; Márquez Reiter et al, 2005; Sifianou, 1992, Hong, 1993; Yu, 1999; Zhang, 1995, etc.). En cuanto a las modificaciones de las peticiones, las investigaciones han demostrado sistemáticamente que los hablantes de distintas lenguas modifican sus peticiones de manera diferente, $y$ los tipos y las frecuencias de las estrategias de petición varían en función de factores contextuales tales como estatus social, distancia social y género. 
La mayoría de los estudios de la bibliografía científica sobre actos de habla se han centrado principalmente en la elección de los tipos de estrategia y los dispositivos de la modificación, y su relación con la noción de cortesía. Al profundizar en la idea de la convencionalidad en las estrategias indirectas, Blum-Kulka (1989) llama nuestra atención sobre la importancia de las formas lingüísticas o los artículos que se utilizan al servicio de unas u otras funciones pragmáticas específicas. La cuestión de la asignación de formafunción es especialmente importante cuando están involucrados los procesos indirectos convencionales o no convencionales, ya que está en la naturaleza de estas estrategias hacer uso de formas lingüísticas determinadas para servir a funciones que se apartan de sus funciones canónicas. Por ejemplo, mientras que la función canónica de una oración interrogativa es pedir información, las peticiones indirectas convencionales "¿Puedes comprarme algo de beber?" o "¿Me podría pasar la sal?" funcionan como mandatos en lugar de preguntas, a pesar de que están expresadas en forma interrogativa y su significado literal parece preguntar acerca de la capacidad del oyente y la voluntad de realizar el acto, respectivamente.

Al examinar cuidadosamente las estrategias indirectas convencionales en los datos de peticiones de CCSARP, proporcionados por los hablantes de cuatro grupos de idiomas (inglés australiano, francés canadiense, hebreo y español de 
Argentina), Blum-Kulka (1989) encuentra que es rara una "verdadera equivalencia pragmática" de formas entre las diferentes lenguas. Por ejemplo, mientras que en inglés la pregunta sobre la capacidad "Can you give me a lift home?" conlleva "dualidad pragmática", es decir, se puede interpretar como una pregunta o una petición, el cambio de "can" a "could" la deja solo con la interpretación de petición. Por el contrario, en hebreo un cambio de tiempo del verbo equivalente "yaxol" de presente a pasado convierte la interrogación en una sencilla pregunta factual sobre un hecho pasado.

La segunda conclusión acerca de la comparación transcultural, es que diferentes lenguas tienen un orden preferente distinto para el uso de sub-estrategias específicas o formas lingüísticas. Por ejemplo, mientras que el orden preferente para las fórmulas de preparación de la pregunta en inglés es can/could you > will/would you > would you mind, en hebreo la primera opción es puede, que es seguido de una expresión de posibilidad (como en Would it be possible if I...?) y will you.

La tercera variación transcultural señalada por Blum-Kulka es que si bien los hablantes de todas las lenguas utilizan preguntas de capacidad en todas las situaciones, otras sub-estrategias están limitadas por el idioma y la situación. Un ejemplo ilustrativo de este punto consiste en las diferentes variantes de "¿te importaría?", que 
aparece en forma convencionalizada en hebreo y en inglés de Australia, pero no en español ni francés. Además, si bien se emplea con bastante frecuencia en el Inglés de Australia $(10,4 \%)$, solo el $1,2 \%$ de expresiones hebreas se encuentran en esta forma.

Los estudios de petición en castellano peninsular muestran que las estrategias indirectas convencionales son las más frecuentemente empleadas por los encuestados (Mir, 1993; VázquezOrta, 1995; Le Pair, 1996; Palencia, 1998; Díaz Pérez, 1999; Ballesteros Martín, 2001; Curcó y De Fina, 2002; Márquez Reiter, 2002; Hernández Flores, 2003). A continuación, pasamos a hacer una revisión de cinco estudios de peticiones en español de España que guardan una estrecha relación con la presente investigación (Mir, 1993; Le Pair, 1996; Díaz Pérez, 1999; Ballesteros Martín, 2001; Márquez Reiter, 2002).

Uno de los primeros estudios en analizar la producción de peticiones con forma de pregunta por parte de hablantes nativos de español peninsular fue realizado por Mir (1993). Mir ha comparado la producción y la percepción de peticiones de tres grupos de participantes: 37 hablantes nativos de español de España, 34 hablantes nativos de inglés americano y un grupo de 33 hablantes nativos de español estudiantes de inglés de nivel intermedio alto en España. Se pidió a todos los participantes que completaran un $D C T$ 
con 24 escenarios de petición en los que se controlaba el grado de familiaridad y la relación de poder.

Los resultados muestran que los tres grupos de participantes utilizaron una petición convencionalmente indirecta en la mayor parte de los casos y Mir señala que los hablantes nativos de inglés utilizan menos estrategias directas que los grupos españoles. Mir encuentra que, mientras que los tres grupos prefieren las preguntas sobre capacidad (ipuedes, podría usted?), la segunda estrategia preferida por los hablantes nativos de inglés es la pregunta de solicitud de permiso (ipuedo, podría...?), mientras que los participantes españoles, tanto en sus actuaciones de la primera lengua como de la segunda utilizan la forma de pregunta sobre la voluntad (¿verdad?, ¿le importaría?). Mir también observa diferencias relevantes entre las elecciones que hace cada grupo.

Los hablantes nativos de español utilizan podrías (34\%) y puedes (26\%) con la misma frecuencia, mientras que los hablantes nativos de inglés prefieren claramente could you (38\%) antes que can you (8\%). Se encuentra otra diferencia en el uso de la forma ¿me permite?, que rara vez se emplea en español, aunque aparece con frecuencia en los datos ingleses. Además, los hablantes nativos de inglés utilizan poco las estrategias interrogativas sobre la voluntad, que son utilizadas a menudo por los hablantes nativos de 
español. Como explica Mir, las formas inglesas will you y would you se pueden interpretar como predicción o como volición y, por consiguiente, su significado no está claro.

Las formas equivalentes en español no tienen un significado de predicción. Te importaría aparece con frecuencia en español, mientras que los hablantes nativos de inglés lo utilizan rara vez. Quieres es otro ejemplo de voluntad que casi nunca se utiliza en inglés, ya que suena más como una sugerencia u oferta. Mir señala que los hablantes nativos de español plantean más modificaciones orientadas hacia el oyente, como los minimizadores del grado de imposición, que los hablantes nativos de inglés, que utilizan principalmente modificaciones orientadas hacia el hablante, al explicar el motivo de la petición. A continuación se presenta un ejemplo de Mir.

Hablante nativo de español: "¿Me prestas los apuntes? Te los devolveré de inmediato".

Hablante nativo de inglés: "I didnt't come to class yesterday because I was sick, could you lend me your notes?" ( No vine a clase ayer porque estaba enfermo, ¿podrías prestarme los apuntes?') 
En este ejemplo, el hablante nativo de inglés se centra en presentar excusas, motivos orientados hacia el hablante por el hecho de no tener los apuntes, mientras que el hablante nativo de español toma en cuenta al oyente al decir que él/ella quiere los apuntes solo por un momento, lo que funciona como un minimizador del grado de imposición hacia el oyente.

Le Pair (1996) ha llevado a cabo un proyecto de investigación transcultural sobre el uso de estrategias de petición en español de España, con el fin de investigar la producción de habla de español por parte de hablantes españoles y holandeses. El estudio concluye que los hablantes nativos de español son más directos en sus peticiones, y llegan a usar aproximadamente dos veces más estrategias directas que los hablantes no nativos holandeses, hecho que se manifiesta en frecuencias más altas de imperativos, declaraciones de obligación y declaraciones de deseo.

Los datos también muestran que los estudiantes holandeses de español recurren, en buena medida, a estrategias convencionales utilizadas por hablantes nativos. Esto, según Le Pair, apoya la hipótesis de que en cierta medida, la (in)dirección convencional es un tipo de estrategia compartida por ambas culturas. 
Con respecto a los medios convencionales, Le Pair observa que parece haber convenciones compartidas por las dos culturas, principalmente en el amplio uso de enunciados que preparan las condiciones para las preguntas, tales como la capacidad y la voluntad del destinatario de llevar a cabo el acto pedido. Pero las fórmulas de sugerencia no son similares en ambas culturas, y los hablantes no nativos holandeses muestran sólo un acceso limitado a este tipo de estrategias. Se ha encontrado la misma tendencia en declaraciones que atañen a la condición preparatoria de no obviedad (que predicen un acto futuro del oyente).

Le Pair también señala que los hablantes no nativos utilizan preguntas sobre la capacidad del oyente mucho más frecuentemente que los hablantes nativos, y aplican las relativas a la voluntad del oyente con menos frecuencia que ellos. Además, las formas utilizadas en la estrategia de voluntad difieren hasta tal punto que Le Pair afirma que deben ser entendidas como específicas de cada cultura antes que como universales. Le Pair concluye que los hablantes nativos de español son más sensibles a la distancia social, al usar más estrategias de salvaguarda de la imagen pública en situaciones de distancia social relativamente alta.

En un estudio sobre peticiones en español, Díaz Pérez (1999), investiga la relación entre deixis de tiempo y persona y la 
expresión de cortesía verbal en la formulación de peticiones en inglés y español. Aparte de contrastar los datos en los casos del inglés y español como lengua materna, también se establece una comparación entre las peticiones producidas por los hablantes nativos y no nativos de inglés.

Setenta y cinco hablantes nativos de inglés británico y setenta y cinco hablantes no nativos de inglés cuya lengua materna es el español de España actúan como sujetos en este estudio. A efectos comparativos, los datos en español como lengua materna se recogieron también de otros setenta y cinco sujetos. Todos ellos eran estudiantes universitarios en las universidades de Leeds, Stirling y Jaén, con edades comprendidas entre veinte y veinticinco años.

El test de rellenado de discurso utilizado en este estudio se compone de cinco situaciones socialmente diferenciadas que varían en la relación del hablante y (sujeto participante) con el interlocutor, es decir, en las dimensiones de dominio o poder social y distancia social o familiaridad. Las situaciones descritas son las siguientes: 
- S1 Estás en clase y pides a otro estudiante que te preste sus apuntes.

- S2 Estás en el despacho de uno de tus profesores y recuerdas que tienes que hacer una llamada telefónica urgente. No hay teléfono público cerca y le pides a tu profesor que te permita utilizar el teléfono del despacho.

- S3 Necesitas un libro de la biblioteca para hacer un artículo, pero ya está prestado. Ves a un estudiante desconocido con el libro y le pides que te preste el libro para fotocopiar unos capítulos.

- S4 Tienes que entregar un trabajo para una de tus asignaturas y descubres que hay un nuevo profesor en la escuela a quien nunca has visto antes y que es un especialista en el tema del trabajo. Vas a su oficina para que él/ella lea un esbozo del trabajo y te dé algunas referencias bibliográficas.

- S5 Estás en la biblioteca universitaria. Quieres coger un libro de un estante, pero está demasiado alto. Le pides a un compañero de clase más alto que tú que te lo coja.

En este estudio, se han observado diferencias relevantes entre el grupo de hablantes nativos de inglés y los otros dos grupos de encuestados, con respecto a la adopción de perspectiva en sus peticiones. Mientras que la mayoría de las peticiones producidas por los hablantes nativos de inglés están orientadas hacia el hablante (el 
$45,6 \%)$, tanto los hablantes de español $(87,8 \%)$ como los hablantes no nativos de inglés $(79,7 \%)$ recurren más frecuentemente a peticiones orientadas hacia el oyente. La segunda opción preferida por los hablantes nativos de inglés es la de la perspectiva orientada hacia el oyente $(43,4 \%)$, mientras que la perspectiva hacia el hablante, con el $11,9 \%$ y $19,7 \%$ respectivamente, es la preferida por los hablantes españoles y los hablantes no nativos de inglés. Por último, en cuanto a la adopción del tercer tipo de perspectiva, la impersonal, se han observado diferencias importantes en cuanto a los porcentajes de aplicación: un $11,0 \%$ de los casos en el grupo de los hablantes nativos de inglés (significativamente mayor que el resto) $y$, en los otros dos grupos, un $0,3 \%$ en el de hablantes españoles y un $0,5 \%$ en los hablantes no nativos de inglés. Las diferencias son estadísticamente significativas en todos los casos, excepto entre los hablantes españoles y hablantes no nativos de inglés, en la categoría de perspectiva impersonal.

Díaz Pérez interpreta los resultados de su estudio como prueba de que la cortesía verbal en inglés está más orientada hacia la imagen negativa del oyente, mientras que los hablantes españoles y los hablantes no nativos de inglés no conceden tanta importancia al hecho de no interferir con la autonomía personal del oyente. 
Ballesteros Martín (2001) ha analizado qué tipo de estrategias conversacionales utiliza un grupo de nativos españoles y otro de británicos cuando llevan a cabo la emisión de un ruego o de un mandato y pretenden mitigar cortésmente el carácter impositivo de tal emisión.

El corpus de su estudio consiste en 360 unidades de ruego y mandato, 180 en español y 180 en inglés, extraídas de unos cuestionarios que se basan en la técnica de obtención de datos denominada DCT (Discourse Completion Test). Cada individuo completó seis encuestas que responden a las seis situaciones potenciales en las que las coordenadas que configuran el poder y la distancia social existente entre los participantes difieren entre sí.

\begin{tabular}{lrr}
\hline Situación 1 & + Distancia Social & $\mathrm{x}=\mathrm{y}$ \\
\hline Situación 2 & - Distancia Social & $\mathrm{x}=\mathrm{y}$ \\
\hline Situación 3 & + Distancia Social & $\mathrm{x}<\mathrm{y}$ \\
\hline Situación 4 & + Distancia Social & $\mathrm{x}>\mathrm{y}$ \\
\hline Situación 5 & - Distancia Social & $\mathrm{x}<\mathrm{y}$ \\
\hline Situación 6 & - Distancia Social & $\mathrm{x}>\mathrm{y}$
\end{tabular}

X (emisor), Y (receptor), +/- (la presencia de distancia social); (Ballesteros Martín, 2001).

El cálculo de porcentajes demuestra que tanto los españoles como los británicos prefieren, en primer lugar, las formas 
convencionales indirectas, seguidas de las formas directas y de las formas indirectas no convencionales, en último lugar.

Con respecto a las estrategias directas, se ha encontrado que los sujetos españoles usan estrategias directas en mayor porcentaje en aquellas situaciones en las que el emisor ostenta mayor grado de poder social que el receptor (en un $66,66 \%$ en la situación 4 y un 73,33\% en la situación 6). Los ingleses, sin embargo, optan por estas estrategias solo si además existe distancia social entre los interlocutores (el 70\% en la situación 4). En casos en los que existe cierto grado de familiaridad, como en la situación 6, prefieren seguir recurriendo a las formas indirectas convencionales (76,66\%), ya que sólo hay un 23,33\% de estrategias directas.

Con estos primeros datos, y de forma provisional, Ballesteros Martín avanza que para los sujetos británicos el factor determinante a la hora de optar o no por una estrategia gramatical directa parece ser en mayor medida el de la distancia social. Para los españoles, sin embargo, es el de poder social. Según Ballesteros Martín, esta afirmación podría ser arriesgada, ya que las variables de poder y distancia social no siempre son constantes, y en las mismas situaciones el poder social ostentado por uno de los interlocutores puede llegar a invertirse, en casos específicos. 
Se ha encontrado que el nivel de oscilación de las estrategias directas dentro de las situaciones en las que prevalecen es mínimo, con tan sólo un $6,67 \%$ de diferencia entre los porcentajes de incidencia en las situaciones 4 y 6 del corpus español. No obstante, según el investigador, existen situaciones en las que los encuestados descartan abiertamente la exposición directa de sus deseos exhortativos. Se trata de la situación 3, en el corpus español, y de las situaciones 1,3 y 5 , en el corpus inglés. En todas ellas la presencia de estrategias directas es nula, con un $0 \%$ de incidencia.

A continuación Ballesteros Martín observa que en situaciones en las que existe distancia social y el emisor es socialmente inferior al receptor (S3), los nativos de ambas sociedades descartan el uso de formas gramaticales directas. Los nativos ingleses, además, desechan esta posibilidad en situaciones en las que hay distancia social y ambos afectados ostentan el mismo poder (S1), y cuando, a pesar de existir cierto grado de familiaridad o conocimiento previo, el receptor es más poderoso (S5). En las dos últimas situaciones descritas, los españoles también prefieren estrategias convencionalmente indirectas, aunque las formas directas están presentes en un $16,66 \%$ de los casos.

Los resultados del estudio demuestran que los actos de rogar y de mandar no se realizan de un modo que pueda 
considerarse equivalente en ambas culturas. Por extensión, se podría incluso afirmar que la gran mayoría de intercambios comunicativos, salvo los que fueran meramente informativos, no resultarían totalmente transferibles en ambas lenguas, dado que existen valores émicos propios de cada sociedad, que necesariamente afloran al utilizar la lengua nativa.

Ballesteros Martín concluye que tales diferencias con respecto a las preferencias estructurales no justifican que se hable de una sociedad como más impositiva o menos cordial que la otra. Los estereotipos negativos presentes en ambas sociedades del tipo "los españoles son maleducados" o "los ingleses son hipócritas" no se ajustan a la realidad. Se trata tan solo de opciones lingüísticas diferentes que, en el fondo, pueden esconder las mismas intenciones pragmáticas, puesto que aunque sintácticamente se trate de estrategias directas, estas se atenúan con mecanismos de cortesía.

Otro estudio comparativo es el llevado a cabo por Márquez Reiter (2002), que examina las similitudes y las diferencias en la realización de peticiones convencionalmente indirectas en español peninsular (en adelante EP) y español uruguayo (en adelante EU). Los participantes de su estudio son 64 estudiantes posgrados universitarios uruguayos (31 mujeres y 33 varones) y 23 estudiantes de postgrado universitarios españoles (18 mujeres y 5 varones). Los 
datos se recogieron a través de una simulación abierta no preceptiva.

Las seis situaciones de la simulación varían en función del poder social relativo entre los participantes, el ranking de la imposición y la distancia social entre los interlocutores. La simulación se compone de seis escenarios que representan situaciones sociales cotidianas que se espera sean familiares para ambos grupos.

Los resultados de este estudio revelan similitudes y diferencias en la forma en que los hablantes de español peninsular y uruguayo realizan peticiones convencionalmente indirectas. A pesar de que los españoles tienden a ser vistos como más directos y bruscos que los latinoamericanos, este estudio ha demostrado que no hay diferencias en el nivel de la codificación lingüística de los enunciados analizados. Según Reiter, este estudio ha proporcionado apoyo adicional a la correlación negativa hallada entre distancia social o familiaridad y el grado de (in)dirección, pues tanto los estudiantes universitarios españoles como los uruguayos han demostrado ser indirectos con personas con las que no están familiarizados.

Los resultados también han señalado que una de las posibles explicaciones de por qué los españoles se consideran más directos podría estar en la falta de provisionalidad transmitida por 
sus peticiones en relación con otras variedades del español. Se observa que los hablantes americanos prefieren un mayor grado de modificación externa e interna de tipo degradante, con lo que sus peticiones son más largas y más indecisas que las de los hablantes de EP. La indecisión expresada en EU, como opuesta a la del EP, se refleja en niveles ligeramente más altos de formalidad expresados por fórmulas propias del EU y un mayor grado de conciencia de los espacios propio y ajeno.

Por último, Reiter sostiene que las diferencias en las fórmulas lingüísticas son las que crean la base para las generalizaciones. Al igual que los españoles podrían interpretar el uso de los verbos de disculpa como mecanismos para llamar la atención un poco formales, los uruguayos los ven como habituales, ya que en su variedad lingüística se han empleado con normalidad en esos contextos y para tales fines. Del mismo modo, los uruguayos pueden considerar el uso de marcadores de discurso como "oye" como un mecanismo para captar la atención demasiado intrusiva, ya que en el EU la partícula ha conservado su significado semántico completo. Así, según Reiter, parecería que las generalizaciones negativas del tipo descrito se derivan de las distintas funciones pragmáticas que unidades léxicas similares desempeñan en diferentes culturas. 
En conclusión, los resultados de los estudios mencionados anteriormente muestran que a la hora de hacer peticiones, el tipo de estrategia más frecuente entre los encuestados es el de las convencionalmente indirectas. Los resultados también revelan que los españoles tienden a utilizar cortesía positiva y son más directos que los ingleses, europeos y latinoamericanos al hacer peticiones.

\subsection{Los actos de habla de rechazo}

El rechazo, como un acto amenazante para la imagen del interlocutor, ha sido conocido como "un punto de fricción" entre culturas. Al investigar el arte de decir "No", Takahashi y Beebe, que realizan varios estudios sobre el rechazo, señalan que "la incapacidad de decir "No" de forma clara y educada [...] ha llevado a muchos hablantes no nativos a ofender a sus interlocutores" (Takahashi y Beebe, 1987, p. 133). Cuando se necesita utilizar un acto de rechazo, este suele implicar cierto grado de (in)dirección para reducir el riesgo sobre la imagen. El grado y la manifestación de la (in)dirección varía entre lenguas y culturas. Los estudiantes de idiomas se encuentran en gran riesgo de ofender a sus interlocutores al llevar a cabo un rechazo, porque la barrera lingüística ya existente se complica aún más por la naturaleza amenazante del acto de habla. En la transmisión de un rechazo, se contradicen las expectativas del 
interlocutor; por lo tanto, se requiere un alto nivel de competencia pragmática para llevarlo a cabo de la manera adecuada. Esta competencia es especialmente difícil de lograr para los hablantes de una lengua extranjera.

Brown y Levinson (1978) señalan que los rechazos, por su naturaleza, tienden a ser muy sutiles en muchos casos, por lo que a veces es difícil reconocerlos incluso en la propia lengua materna. Por esta razón es muy importante conocer las pautas sociolingüísticas específicas de la sociedad para interpretar correctamente los significados expresados en el habla. Además, como los rechazos son intrínsecamente amenazas sobre la imagen, los actos de habla de rechazo emplean muchas estrategias de salvaguarda de la imagen, que resultan interesantes desde el punto de vista sociolingüístico.

El rechazo se diferencia de otros actos de habla en que afecta más al oyente que al hablante. En otras palabras, implica decir al oyente algo que no quiere oír. Esto le pone en el compromiso de tener que ayudar al hablante para evitar causarle mala impresión (salvaguarda de imagen). Según Gass y Houck (1999), el rechazo es conversacionalmente complejo y pragmáticamente un reto, no solo porque decir "no" puede ser incómodo en cualquier lengua, sino también porque el rechazo a menudo requiere un alto grado de negociación. Además, el rechazo requiere un esfuerzo por parte del 
hablante para lograr el objetivo comunicativo del acto (es decir, la aceptación del destinatario del rechazo), y hacerlo sin ofender.

\subsubsection{Estrategias de rechazo}

Beebe et al. han llevado a cabo una serie de estudios sobre el acto de habla del rechazo (Beebe y Cummings, 1996; Takahashi y Beebe, 1987, Beebe, Takahashi y Uliss Weltz 1990). Por lo tanto, las estrategias de rechazo que se recogen en el presente estudio se analizan sobre la base de una taxonomía desarrollada por Beebe et al. (1990). Beebe et al. han dividido los rechazos en tres tipos: rechazos directos, indirectos y adyacentes al rechazo. Este sistema de clasificación ha sido utilizado y adaptado ampliamente para examinar el rechazo entre hablantes nativos y no nativos en diferentes idiomas (Bardovi-Harlig y Hartfort, 1991; Ramos, 1991; Gass y Houck, 1999; Nelson et al, 2002; Félix-Brasdefer, 2002). A continuación se describen estas clasificaciones.

\section{A) Rechazos directos}

Según Gudykunst y Ting-Toomy (1988), el estilo verbal directo se refiere a "los mensajes verbales que encarnan e invocan las verdaderas intenciones de los hablantes" en todo cuanto atañe a sus 
preferencias, necesidades y deseos en el proceso de discurso (p. 100). El continuum directo consiste en las siguientes estrategias:

i. Performativos: según Leech (1983), los performativos son "expresiones de auto-denominación, en la que el verbo performativo, por lo general, se refiere al acto en que el hablante está implicado en el momento del discurso" (p. 215). Por ejemplo:

a. Rechazo todas las sugerencias.

b. Me niego a vivir contigo.

\section{ii. Declaración negativa mediante la negación}

- Negación explicita, "No": el hablante rechaza directamente la petición diciendo "no" con alguna modificación interna. La palabra "no" es un tipo directo de rechazo, un acto que amenaza la imagen. Por ejemplo:
a. №, gracias por tu invitación.
b. $\quad$ №, no te los puedo dejar.

- Buena voluntad/capacidad negativa: el hablante rechaza indirectamente la petición expresando negaciones sobre su incapacidad para cumplir lo pedido. La negación se puede expresar por la partícula negativa "no", o utilizando cualquier palabra que semánticamente niega una proposición. 
Por ejemplo:

a. Lo siento, pero eso no es posible, ya que sería injusto.

b. No puedo porque no tengo dinero.

\section{B) Rechazos indirectos}

Gudykunst y Ting-Toomey (1988) afirman que el estilo verbal indirecto "se refiere a los mensajes verbales que camuflan y ocultan las verdaderas intenciones de los hablantes en cuanto a sus deseos, necesidades y metas en la situación discursiva" (p. 100). El continuum indirecto consiste en las siguientes estrategias:

i. Disculpa: el hablante rechaza la petición expresando disculpas o pidiendo perdón, para mitigar (o suavizar) el rechazo. Por ejemplo:

a. Lo siento, Carmen, pero no voy a poder ir a la fiesta

b. Perdona, en este momento estoy ocupado

ii. Deseo: el hablante rechaza la petición indicando un deseo favorable al interlocutor. Por ejemplo:
a. Espero que sea un día maravilloso para ti y para tu novio
b. Te deseo mucha felicidad y prosperidad en tu matrimonio 
iii. Excusa: el hablante rechaza la petición proporcionando una excusa, motivo o explicación sobre su rechazo que puede ser general o específica. Por ejemplo:

a. Lo siento, precisamente acabo de quedar con un amigo que ya me está esperando

b. Estoy cansado y necesito ir a casa

iv. Declaración de alternativa: el hablante rechaza la petición sugiriendo una alternativa a la petición, o un conjunto de posibilidades, con el objetivo de mantener la imagen positiva con el interlocutor y negociar la respuesta. Por ejemplo:

a. ¿Por qué no se los pides a María?

b. Te propongo que nos quedemos en la residencia para ver esa película

\section{v. Establecimiento de condiciones para una aceptación} pasada o futura: el hablante rechaza la petición utilizando una condición hipotética que pretende dirigir el rechazo a una situación en que hubiera sido mejor que la persona hiciera la petición de manera anticipada. Por ejemplo:

a. Si me hubieras avisado un poco antes hubiera ido, pero ya he quedado con otras personas. 
b. Lo siento. Tengo una reunión ahora, de haberlo sabido con antelación no habría problema y me podría quedar, pero ya no puedo cancelarlo.

v. Promesa de aceptación futura: el hablante rechaza la petición prometiendo que será llevada a cabo en algún momento posterior, cuando se den las condiciones favorables para su ejecución. Por ejemplo:

a. Muchas gracias, pero no puedo, este fin de semana estoy comprometida. iA ver si la siguiente no me la pierdo!

b. La verdad es que me gustaría ir, pero precisamente este fin de semana he quedado con unos amigos para irnos a la montaña. A la próxima no faltaré.

vi. Declaración de principios/filosofía: el hablante rechaza la petición declarando una actitud general o conjunto de creencias que ha mantenido durante mucho tiempo. Por ejemplo:

a. $\quad$ No me parece muy oportuno, como profesora, participar en una fiesta de alumnos.

b. Me gusta tratar a todos mis alumnos en igualdad de condiciones. 
viii.Amenaza o declaración de consecuencias negativas para

el emisor: el hablante rechaza la petición haciendo algunas amenazas que pueden tener un impacto negativo sobre sí mismo o en el interlocutor, si aceptara realizar la tarea. Por ejemplo:
a. No puedo, además no entenderías mi letra.
b. No conozco a tus amigos, además sería una situación algo incómoda.

ix. Declaración de sentimiento negativo: el hablante rechaza la petición aduciendo sentimientos negativos, incluidos la crítica a la petición y la estrategia de hacer sentir culpable al otro. Por ejemplo:

a. No, ven más a clase y no tengas tanta cara dura.

b. No puedo hacer excepciones, sería un agravio para el resto de tus compañeros.

x. Petición de comprensión: el hablante rechaza la petición pidiendo al interlocutor que considere o evalúe los argumentos que le impiden cumplir con la invitación o la petición. Por ejemplo:
a. Si no te importa, creo que me quedaré en casa.
b. Espero que lo entiendas. 
xi.Garantía de satisfacción futura del interlocutor: el hablante rechaza la petición dando garantía de satisfacción futura del interlocutor. Por ejemplo:

a. Te prometo que lo limpio mañana, no te preocupes.

b. Mañana lo primero que haré será ordenar, te lo prometo.

xii. Autodefensa: el hablante rechaza la petición defendiéndose a sí mismo y enfatizando de alguna manera lo que la petición tiene de injusto. Por ejemplo:

a. Mira, la verdad es que no entraba dentro de mis planes esta asignatura.

b. Creo que no la voy a coger. No puede ser, porque un inglés de ese nivel no entra dentro de mi especialidad.

xiif.Repetición de parte de la petición: el hablante rechaza la petición repitiendo una porción del discurso anterior mencionado en la petición o la invitación del destinatario, que funciona para distraer la atención lejos del interlocutor y retrasar el rechazo. Por ejemplo:
a. ¿A tu boda?
b. La semana que viene ... a verr 
xiv.Aplazamiento: el hablante rechaza la petición posponiendo lo que se pide a un tiempo posterior inespecífico. Por ejemplo:
a. Luego lo limpio.
b. Estoy cansado en ese momento, lo haré más tarde.

xv. Evasivas: el hablante rechaza la petición dando una respuesta confusa o vaga, incierta o indecisa. Por ejemplo:
a. $\quad$ No sé si podré ir, estoy muy ocupada estos días.
b. Muchas gracias, pero no te lo puedo confirmar. Tengo trabajo acumulado y necesito descansar.

\section{C) Adyacentes al rechazo}

Estas estrategias incluyen adyacentes que funcionan como modificaciones suplementarias para proteger la imagen positiva del hablante.

i. Declaración de opinión/sentimiento positivo: el hablante rechaza la petición proporcionando expresiones positivas que indican que el deseo del hablante es ser capaz de cumplir con la petición o la invitación. Por ejemplo:

a. Me gustaría mucho ir pero no puedo porque ya tenía otros planes. 
b. Me encantaría ir, pero entre semana no puedo hacer planes.

ii. Declaración de empatía: el hablante rechaza la petición empatizando con el interlocutor, mostrando cierta identificación con él y mostrando comprensión de la situación, sentimientos y motivos del interlocutor. Por ejemplo:
a. iEs una lástima, ya me contaréis como ha ido!
b. iQué pena! No puedo ir, tengo que estudiar.

ii. Muletillas: el hablante rechaza la petición comenzando su respuesta con expresiones como "pues, vaya, a ver...". Por ejemplo:
a. Pues lo siento, pero hoy no voy en esa dirección.
b. Vaya, es una pena.

iv. Agradecimiento: el hablante rechaza la petición dando las gracias para no ofender la imagen del interlocutor. Por ejemplo:
a. Muchas gracias, Fernando, pero ya tengo otros planes.
b. Le agradezco mucho su opinión. 


\subsubsection{Investigación del rechazo}

Un rechazo es, por definición, una respuesta negativa a una oferta, petición, invitación, etc. Si debemos evitar ofender a nuestro interlocutor, debemos expresar nuestras respuestas negativas óptimamente. Decir "no" resulta muy difícil para hablantes no nativos. A menudo yerran al intentar proporcionar una respuesta negativa de una manera aceptable para hablantes nativos. Según Rubin (1983), la forma de decir que no es más importante en muchas sociedades que la respuesta en sí misma. Por lo tanto, enviar y recibir un mensaje negativo requiere una habilidad considerable. El interlocutor debe conocer la relación entre la función pretendida y la forma apropiada, los elementos sociales que comprenden el acto de habla, y debe entender los valores del grupo cultural lingüístico. Esto que hemos señalado tiene una importancia enorme porque la incapacidad de decir "no" de manera clara y cortés, aunque no demasiado directamente, ha llevado a muchos hablantes no nativos a ofender a sus interlocutores (Takahashi y Beebe, 1987).

El rechazo no ha recibido mucha atención entre los investigadores principalmente debido al hecho de que el rechazo es un acto de habla complejo para ser investigado. Como Rubín (1983) señala, las respuestas de rechazo no son fáciles de identificar incluso 
en la propia lengua materna. Esta situación se hace más compleja al investigar el rechazo en otra lengua o cultura. Una investigación exitosa en este campo requiere que el investigador tenga un conocimiento aceptable de las reglas sociolingüísticas que imperan en las formas de rechazo, y un sentido en relación con el funcionamiento de las lenguas investigadas. Rubín (1983) señala que, "a veces es difícil reconocer rechazos en la propia lengua materna..., sin embargo en muchos encuentros el sentido está claro si se sabe leer o interpretar las señales apropiadas" (p.10).

El estado de la cuestión sobre el rechazo incluye las siguientes investigaciones: Rubín, 1983; Beebe y Cummings, 1996; Takahashi y Beebe, 1987; Beebe, Takahashi y Ullis-Weltz, 1990; Robinson, 1992; Bardovi-Harlig y Hartford, 1991; Al—Shalawi, 1997); Bresnahan, Ohashi, Liu, Nebashi y Liao, 1999; Al--Issa, 2003; Nelson, Carson, Al Batal, y Bakary, 2002; García, 2007; FélixBrasdefer, 2006; Chang, 2009). En nuestra revisión se ha considerado central la investigación de Rubín (1983) sobre rechazos entre culturas. A pesar de que la investigación de este acto no está basada en datos empíricos, constituye un antecedente fundamental de la pertinencia del estudio del acto de habla del rechazo entre personas cultural y lingüísticamente diversas. Rubín indica que el desconocimiento en cuanto a las formas de rechazo, su sentido y, lo que es más importante, los valores sociales que le sirven de base, 
causa problema intercultural entre personas de distintos trasfondos culturales.

Saying "no" is not simply finding the proper form-function relation. Rather, that is only the tip of the iceberg, and visitors to an unfamiliar country need to probe more deeply if they are to express themselves adequately and interpret messages sent by a native. (p.17)

Rubín proporciona una taxonomía con nueve formas para expresar el rechazo, que más tarde sería la base de la mayor parte de los estudios sobre el rechazo. Afirma que existen algunas formas que pueden encontrarse en casi cualquier cultura (p. 12-13): Mantener silencio, Ofrecer una alternativa, Aplazamiento, Dejar caer la culpa sobre un tercero o sobre algo al margen del propio control, Evitación, La oferta y La aceptación general y, Divertir y distraer al destinatario, La aceptación general con una excusa, y Señalar la inadecuación de lo ofrecido.

Para continuar la investigación sobre el rechazo, Beebe et al. (1990) estudiaron rechazos en relación con la noción de transferencia pragmática en rechazos de inglés como segunda lengua entre aprendices japoneses de inglés. Sesenta sujetos, divididos en tres grupos, participaron en este estudio: 20 japoneses hablando japonés, 20 japoneses hablando inglés y 20 americanos hablando 
inglés. El objetivo de este estudio era descubrir si los rechazos dados por el segundo grupo se correspondían más con los del grupo de hablantes del idioma de destino. Los datos se obtuvieron mediante un test de rellenado de discurso (Discourse Completion Test o DCT).

En este estudio los investigadores usaron doce situaciones de $D C T$ a las cuales tuvieron que responder los 60 sujetos. Las situaciones se diseñaron de tal modo que solo las respuestas de rechazo resultaran apropiadas. Se pretendía obtener rechazo a tres peticiones, tres invitaciones, tres ofertas y tres sugerencias. En cada grupo de situaciones, la persona que debía recibir la respuesta de rechazo tenía diferente posición social respecto al hablante (más alto, más bajo o mismo estatus). Los investigadores analizaron los datos como si se tratara de fórmulas semánticas basándose en la taxonomía de rechazo desarrollada y utilizada por Beebe y Cummings (1985).

El análisis cualitativo de los datos mostró que la transferencia pragmática negativa de los aprendices japoneses de inglés era evidente en el orden de las fórmulas semánticas, su frecuencia y el contenido de las mismas. Además, aunque el uso de excusas era común en los sujetos de ambas lenguas, las excusas de los hablantes japonesas en su lengua nativa eran menos específicas que las de los estadounidenses en inglés (p.ej. en el rechazo de una 
invitación, ellos sólo dijeron que estaban ocupados, mientras que los estadounidenses especificaron qué les impidió aceptar). Además, los hablantes japoneses eran más sensibles a la posición social y se expresaron de manera más formal en sus respuestas que los estadounidenses de habla inglesa.

A pesar de sus muchos resultados significativos en cuanto a la transferencia pragmática de primera lengua a segunda lengua, el estudio de Beebe presenta varias limitaciones en términos de su diseño y metodología. En primer lugar, los investigadores no mostraron cómo se seleccionaron los sujetos, es decir, no se presenta ninguna descripción del criterio usado en dicha selección. Por lo tanto, no sabemos nada sobre la edad de los participantes, su sexo o su habilidad lingüística (sobre todo en su segunda lengua).

En segundo lugar, este estudio carece de detalles adicionales en cuanto a cómo se creó y desarrolló el instrumento de obtención de datos (DCT). Las situaciones presentadas en el mismo parecen estar implícitamente basadas en las intuiciones de los investigadores, en cuanto a cuándo se producen los rechazos. Esto, por supuesto, puede estar influido por el propio contexto de los investigadores, sus experiencias o sus preferencias. Además, los investigadores asumieron que los sujetos estaban familiarizados con tales situaciones. Para asegurar que los participantes estaban 
familiarizados con las situaciones del $D C T$, los investigadores podrían haber preguntado a los sujetos si habían estado o no en situaciones similares. Otro camino podría haber sido realizar una prueba piloto del DCT seleccionado, con el fin de modificarlo si hubiera sido necesario. En tercer lugar, a partir de las pruebas proporcionadas por este estudio, no podemos determinar si la transferencia pragmática de aprendices japoneses se debía al impacto de sus normas de habla de la primera lengua o debido a su carencia de conocimiento o habilidad lingüística en inglés, o una mezcla de ambas cosas. Un modo de averiguarlo es entrevistar a los aprendices después de que terminan de rellenar el DCT. Las entrevistas individuales pueden dotarnos de una comprensión más profunda sobre posibles factores que motivan los comportamientos de discurso de los aprendices.

Bardovi-Harlig y Hartford (1990-1991) investigaron el rechazo en lengua nativa y no nativa en sesiones de asesoramiento académico. Fueron grabadas 32 entrevistas de sesiones de asesoramiento en un programa de postgrado lingüístico universitario. Tres miembros de la facultad, siete hablantes nativos de inglés americano así como 18 estudiantes de inglés como segunda lengua de 10 contextos lingüísticos diferentes (el árabe incluido), participaron en el estudio. Los investigadores afirman que existían diferencias entre las estrategias para preservar el estatus usadas por hablantes nativos y hablantes no nativos en términos de su 
competencia pragmática, que determinarían el éxito de las entrevistas de asesoramiento. Descubrieron que la fórmula semántica "Explicación" se usó muy comúnmente tanto por nativos como por no nativos para mostrar rechazo. Sin embargo, se diferenciaron en el empleo de la segunda fórmula más común, que es "Alternativa". Los hablantes no nativos emplearon muchas menos "Alternativas" que los nativos. En cambio, los hablantes no nativos usaron una estrategia de "Evitación". Además, los hablantes nativos parece que hicieron un uso más amplio de estrategias de pregunta y emplearon una variedad más amplia de fórmulas semánticas en sus rechazos que los hablantes no nativos. Sin embargo, como BardoviHarlig y Harford indican, han tenido más éxito cuando han seleccionado sus estrategias de entre un conjunto más pequeño usado por los hablantes nativos. Sobre la base de su corpus, que incluye estrategias encontradas solo en su estudio, Bardovi-Harlig y Hartford (1991) desarrollan una taxonomía ligeramente diferente del rechazo (ver el Apéndice C).

El valor de este estudio reside en el análisis del acto de habla dentro del contexto en que se produce el discurso. Sin embargo, se puede criticar por no proporcionar controles de hablante nativo, de modo que los efectos de transferencia posibles podrían no haber sido identificados. Además, Kasper y Dahl (1991) han señalado que la posibilidad de comparación transcultural es limitada 
dado que las sesiones de asesoramiento están "ligadas a una institución concreta y, por tanto, los acontecimientos de discurso específicos de cultura no tienen ningún equivalente (directo) en otro contexto cultural" (p. 231).

En otro estudio sobre el rechazo, Robinson (1992) investigó rechazos en inglés estadounidense de estudiantes japonesas de nivel intermedio y avanzado de inglés como segunda lengua que cursaban inglés en la Universidad de Hawái. Se seleccionaron once sujetos femeninos para este estudio. El objetivo principal del estudio era investigar el papel de los métodos de informe verbal para obtener datos sobre el procesamiento cognitivo del rechazo en el inglés estadounidense. Se presentaron a los sujetos seis escritos de DCT solicitando mostrar rechazo a peticiones e invitaciones en inglés. Robinson encontró pruebas de transferencia pragmática en las respuestas de rechazo de sus sujetos que indicaron la influencia de las normas culturales de su lengua nativa.

A pesar de su diseño cuidadoso y de conseguir resultados significativos en cuanto al papel del procedimiento de informe verbal para la obtención de información cognitiva sobre cómo rechazar en una segunda lengua, el estudio de Robinson ha revelado varios problemas metodológicos. Tal y como reconoció Robinson, los sujetos experimentaron dificultad para su verbalización así como 
para expresar lo que realmente querían decir porque usaron el inglés en vez de su lengua materna para expresarlo o porque no entendieron los procedimientos de informe verbal. Además, Robinson no proporciona ningún dato de control acerca de cómo rechazaría una japonesa en su lengua materna.

Liao y Bresnahan (1996), en su studio, $A$ contrastive pragmatic study on American English and Mandarin refusal strategies, contrastó respuestas hechas por estudiantes universitarios norteamericanos y chinos a seis peticiones. Los escenarios propuestos para proporcionar una respuesta fueron : (1) la petición de ayuda de un maestro a un alumno para preparar un mostrador de recepción en un congreso, (2) la petición de un compañero de clase que le pide prestadas al sujeto notas de clase, (3) la petición de un amigo antiguo para que le ayude a mudarse (4) la petición de un amigo que le pide prestado un coche para unas vacaciones, (5) la petición de un amigo que le pide prestada una pequeña cantidad de dinero para comprar un libro de texto, y (6) la petición de un miembro de la familia que le pide prestada una cantidad substancial de dinero. Los sujetos eran 570 estudiantes universitarios en la Universidad de Feng Chia en Taiwán y 516 en la Universidad de Michigan. Se pidió a los sujetos que respondieran a uno de los seis escenarios de petición rellenándolos con sus respuestas. Las respuestas fueron codificadas según el número de estrategias 
utilizadas en cada respuesta para examinar diferencias de etnia y género.

Los patrones de rechazo indicaron que ambos grupos rechazaron las peticiones de un maestro más fácilmente que las de un amigo o un miembro de la familia, pero los chinos dieron razones más específicas que los norteamericanos. Las mujeres tendieron a utilizar más estrategias que los hombres para rechazar a personas de estatus más alto. Fue común, en el caso de los norteamericanos empezar un rechazo con una respuesta positiva, seguido por un rechazo, como "me gustaría, pero...". Sin embargo, fue raro para los chinos utilizar esta estrategia. Para los estudiantes chinos encontraron que fue difícil rechazar las peticiones de miembros de la familia, mientras que los norteamericanos encontraron más dificultad para rechazar las peticiones de amigos. Al no acceder a dejar notas de clase a un amigo, los estudiantes norteamericanos tendieron más que los chinos a agregar un comentario de lo impropio de la petición. Los norteamericanos estuvieron más dispuestos a dejar una pequeña cantidad de dinero a su amigo, mientras que los chinos se mostraron más resistentes a rechazar la petición de un miembro de la familia de una gran cantidad de dinero. En comparación con los estudiantes chinos, los norteamericanos, especialmente los sujetos masculinos, tuvieron más dificultades para rechazar una petición para ayudar a alguien a mudarse pero en casos donde los norteamericanos 
rechazaron dejar sus coches a sus amigos, proporcionaron una "Declaración de principios" como excusa, mientras que los chinos fueron más económicos al utilizar estrategias en tales rechazos, siguiendo un principio de "dian-dao-wei-zhi" (tocar el punto marginalmente).

Bresnahan, Ohashi, Liu, Nebashi, y Liao publican en 1999 un estudio titulado "Una comparación de estilos de respuesta en Singapur y Taiwán". En él examinan si los hablantes de chino de Singapur y los hablantes de chino de Taiwán respondían de manera diferente a peticiones hechas por amigos, y también si los estudiantes masculinos y femeninos mostraban preferencias diferentes en la táctica de respuesta. Un total de 300 estudiantes chinos de la Universidad Tecnológica Nanyang en Singapur y 297 estudiantes chinos en la Universidad Feng Chia de Taiwán fueron reunidos para completar test de rellenado de discurso, con tres escenarios, los cuales representaban niveles diferentes de imposición. También se repartió un cuestionario de evaluación de la autoestima (self-construal) y controles de manipulación. Los tipos de respuesta se tasaron y se dividieron en "conformidad con" y "rechazo de" la petición. Las variables independientes que se tuvieron en cuenta fueron la nacionalidad, la autoestima (self-construal), el género, y el nivel de imposición, mientras que las variables dependientes eran el número de estrategias y el grado de franqueza 
en los rechazos, asociado con la estrategia que favorece al colectivo en contraposición a las necesidades de los individuos.

Los resultados indican que aunque la autoestima independiente se relacionó con el rechazo más explícito y concernió más a claridad, pero no se relacionó con cumplimiento y asunto de interés para los sentimientos de otros. Las diferencias en el nivel de imposición en una petición estuvieron relacionadas con el tipo de respuesta. Las respuestas a peticiones de imposición inferior tendieron a obedecer; las respuestas a peticiones de imposición más alta tendieron a rechazar las peticiones. En general, los hombres eran más dóciles que las mujeres. Las personas de sexo masculino de Singapur indicaban una mayor preferencia por cumplir con la petición de un amigo que las personas de sexo masculino en Taiwán. Pero los de Taiwán utilizaban más estrategias de rechazo indirectas y empleaban mecanismos para suavizar el tono de la voz. Cuando los participantes de Singapur usaban rechazos, eran más directos y usaban menos estrategias a la hora de negarse que sus homólogos taiwaneses. El estudio concluyó que los estilos de respuesta de las personas de sexo masculino en Singapur y Taiwán eran diferentes.

Al--Issa, (2003) investigó el fenómeno de la transferencia sociocultural y sus factores de motivación dentro de los distintos modelos de rechazo en la realización del acto de habla por 
aprendices jordanos de inglés como lengua extranjera (English as Foreign Language). Los datos se recogieron realizando un test de rellenado de discurso (en inglés, $D C 7$ ), que se diseñó y desarrolló basándose en datos registrados en una campaña de observación. A continuación se realizaron entrevistas semi-estructuradas. Usando fórmulas semánticas como unidades de análisis, las respuestas de rechazo de los participantes se compararon con datos similares extraídos de encuestas a hablantes nativos de inglés que respondían en inglés y de hablantes nativos del árabe que utilizaban el árabe. Los resultados mostraron tres áreas en las cuales la transferencia sociocultural pareció influir en la elección de fórmulas semánticas por parte de los principiantes de inglés como lengua extranjera, el contenido de las mismas y la longitud de sus respuestas. Se vio que los casos de transferencia reflejaban valores culturales traspasados del árabe al inglés. Tomando como base los datos de la entrevista, se determinó que la seguridad de los aprendices en su primera lengua, sus percepciones en la segunda lengua, y sus valores religiosos desempeñaban un papel en la transferencia sociocultural encontrada.

En el estudio de la estrategia en rechazos ingleses-árabes y estadounidenses-egipcios, Nelson, Carson, Al Batal y Al Bakary, (2002) investigaron semejanzas y diferencias entre rechazos ingleses-árabes y estadounidenses-egipcios utilizando una versión modificada del test de rellenado de discurso (DCT) desarrollada por 
Beebe et al. (1990). Los rechazos se seleccionaron porque se consideraron un acto que supone una amenaza a la imagen en árabe, ya que los egipcios son más conscientes del estatus que los estadounidenses. Se dieron 10 situaciones en las cuales se podía mostrar rechazo: 2 peticiones, 3 invitaciones, 3 ofertas, y 2 sugerencias. 30 entrevistas de estadounidenses contenían 298 rechazos, y 25 entrevistas egipcias, 250. Un entrevistador leyó cada situación en voz alta a los sujetos y les pidió responder verbalmente realizando una grabación. Los datos orales se consideraron más consecuentes con el comportamiento árabe, teniendo en cuenta la diferencia entre el árabe hablado y escrito. Cada rechazo se dividió en función de la estrategia utilizada (ver p. 171). Los datos se analizaron para comparar las medias de frecuencia de las estrategias directas e indirectas (el motivo, la consideración de los sentimientos del interlocutor, las sugerencias de buena voluntad, dejar al interlocutor libre de responsabilidad, declaración de pesar, rodeos utilizados, declaración de principios, criticando la petición, la repetición de parte de la petición), las medias de frecuencia de estrategias indirectas específicas, y el efecto del estatus del interlocutor en el uso de las estrategias entre los distintos grupos. Dos situaciones fueron eliminadas - la petición al patrón de un aumento de salario y la solicitud de un estudiante a un profesor. Los resultados indicaron que ambos grupos utilizaban estrategias similares con frecuencia en la producción de rechazos, en contra de 
los resultados obtenidos en la investigación de Al-Issa, donde los jordanos usaron más estrategias indirectas que los estadounidenses. Los resultados, sin embargo, sugieren que aunque los métodos como el DCT puedan ser apropiados para obtener datos pragmalingüísticos, no llegan a revelar la complejidad sociopragmática de los actos que suponen una amenaza a la imagen a través de los rechazos. Los egipcios indicaron que ellos no dirían que no la propuesta del interlocutor en algunas situaciones, como, por ejemplo, en el caso de una invitación del jefe.

García, (1992), investigó las diferencias existentes en el empleo de las estrategias de rechazos entre el español de España y del Perú mientras que Félix-Brasdefer, (2005), investigó estrategias de rechazos entre españoles de España y de Méjico. García estudió las estrategias usadas por hablantes españoles peruanos masculinos y femeninos como sujetos participantes de dos acontecimientos: hacer petición para un servicio y responderlo. Además, se fijaron algunas semejanzas entre géneros y/o diferencias. A la hora de clasificar las estrategias utilizadas por hablantes peruanos, se pueden distinguir dos: en primer lugar el modelo de Blum-Kulka et al. (1989), que consiste en diferenciar entre actos principales y movimientos de apoyo, $y$, en segundo lugar, el marco de estrategias de cortesía de Brown y Levinson (1978). El análisis reveló que las estrategias usadas por los hablantes peruanos al hacer una petición 
mostraron una actitud de deferencia hacia el interlocutor, sin mostrar cercanía. Sin embargo, al responder a la petición, prefirieron el establecimiento de una mayor complicidad con el interlocutor. También se vio que, aunque hubiera algunas diferencias entre la participación masculina y femenina, esta distinción no era estadísticamente significativa. Aunque los resultados no se puedan generalizar a todos los hablantes españoles, los resultados deberían servir como referencia para entender las reglas preferidas en el uso de la lengua de hablantes españoles y peruanos.

Félix-Brasdefer (2002) en su estudio de estrategias lingüísticas empleadas por hablantes nativos monolingües de español-mejicano, enfocó tres aspectos de la cortesía: (1) grado de formalidad; (2) sistemas de cortesía y uso de estrategias; y (3) cortesía y la noción de imagen en México. 20 estudiantes de universidad mejicanos del sexo masculino participaron en cuatro interacciones de juego de rol; cada participante se relacionó con dos hablantes nativos del español, con uno en situaciones formales y con el otro en situaciones informales. Los datos resultantes fueron complementados con informes verbales para examinar las percepciones de los hablantes sobre el rechazo. Las conclusiones muestran que las respuestas de cortesía en la comunidad se realizan por medio de fórmulas empleadas para negociar la imagen (Watts, 2003). Un análisis de las interacciones de rechazo indica que, entre 
estos hablantes, la negociación de la imagen se lleva a cabo, en gran parte, mediante varias tentativas indirectas a través de la (re)negociación de una resolución acertada. Además, las necesidades de imagen son orientadas hacia el grupo, enfatizando la participación sobre la independencia (Scollon y Scollon, 2001). Finalmente, la noción de imagen negativa, según lo propuesto por Brown y Levinson (1987), se reexamina a la luz de los datos.

Finalmente, Chang (2009), llevó a cabo un estudio en la transferencia pragmática en rechazos formulados por hablantes nativos del mandarín que hablan inglés, con la finalidad de saber hasta qué punto la transferencia se realiza bajo la influencia del nivel de los aprendices en la segunda lengua. El instrumento utilizado para la recogida de datos fue el test de rellenado de discurso desarrollado por Beebe et al. (Beebe, Takahashi, Uliss-Weltz, 1990). Con los participantes en este estudio se formaron cuatro grupos: 35 estudiantes universitarios estadounidenses, 41 estudiantes de último año de inglés, 40 estudiantes de primer año de inglés, y 40 estudiantes de segundo año de mandarín. Todos los estudiantes estadounidenses fueron los hablantes nativos de inglés, mientras que los demás fueron los de mandarín. Las respuestas de rechazo se analizaron en términos de (1) la frecuencia de fórmulas semánticas, y (2) en función del contenido de las fórmulas semánticas empleadas. Se percibió que, mientras todos los grupos emplearon 
una variedad similar de fórmulas semánticas al responder a los rechazos derivados de actos de iniciación diferentes, los informantes se diferenciaron en la frecuencia y el contenido de las fórmulas semánticas.

Para concluir, en base a lo anteriormente citado, y teniendo en cuenta el núcleo central de la investigación, los estudios realizados en torno al acto de habla de rechazo se podrían dividir ampliamente en dos clases: de una parte, los que examinan el comportamiento de rechazo de una cultura específica o comparó el acto de habla de rechazo entre grupos culturales; de otro, los que investigan las características de los rechazos del hablante no nativo en inglés. Varios investigadores han comparado el acto de habla de rechazo entre grupos culturales y convinieron que, mientras que las estrategias de rechazo son universales, tanto la frecuencia de las estrategias utilizadas como el contenido de las mismas, es específico de cada cultura. 


\section{CAPÍTULO 3}

\section{METODOLOGÍA}

Este capítulo describe la metodología utilizada en el presente estudio. En primer lugar, la investigadora introduce el debate examinando el diseño de encuesta utilizado y el motivo de su elección en este trabajo. A continuación, se analiza y sintetiza el estudio piloto a la luz de sus implicaciones para el mismo. Las secciones siguientes presentan la selección de participantes, instrumentos de recogida de datos y procedimientos, $\mathrm{y}$, para finalizar, el marco para el análisis de datos de cada acto de habla.

\subsection{Diseño de la encuesta}

Brown y Levinson (1978) sostienen que la evaluación del grado de actos amenazadores de la imagen o face-threatening act (FTA) 
implica la distancia social y el poder relativo entre un hablante y un oyente en muchas, o, quizás, todas las culturas. El instrumento de estimulación del Proyecto Intercultural de Realización de Actos de Habla o The Cross Cultural Speech Act Realization Project (CCSARP) (Blum-Kulka, House y Kasper, 1989) también empleó los factores de distancia social y dominio social para investigar la variación intercultural e interlingüística en dos actos de habla: ruego y disculpa. Algunos estudios del CCSARP (Wolfson, Marmor, y Jones, 1989, Blum-Kulka y House, 1989, Olshtain, 1989, y Vollmer y Olshtain, 1989) han mostrado que las dos variables de dominio y distancia social, junto con otros factores circunstanciales, influyen en la elección de estrategias lingüísticas. Blum-Kulka y House (1989) encontraron que la percepción de la dominación social estaba correlacionada con el nivel de (in)dirección de la petición. La (in)dirección y la cortesía están interrelacionadas positivamente, aunque no se relacionen necesariamente de una forma lineal (BlumKulka, 1987). Searle (1975) sostiene que la cortesía es la motivación más habitual para emplear actos de habla indirectos. Cuanta más cortesía exijan los factores circunstanciales, más indirecta debe ser la declaración.

Scollon y Scollon (1983) teorizan que el estilo indirecto aumenta con la distancia social, y disminuye con el poder social. Olshtain (1989) encuentra una correlación negativa entre la posición 106 
social y el nivel de intensificación interna; es decir, cuanto más bajo sea el estatus del ofensor en comparación con el ofendido, más deberá intensificar el hablante la expresión de disculpa. Beebe y sus colegas (Takahashi y Beebe, 1987; Beebe et al., 1990) señalan que el estatus de los interlocutores es, con mucho, el factor condicionante más fuerte en el idioma japonés, mientras que el grado de familiaridad o el factor de distancia social es el más importante para los americanos. Wolfson también sostiene que la distancia social es el factor más determinante en las variaciones que se producen en el habla de los americanos.

Wolfson, Marmor, y Jones (1989) sostienen que la investigación hecha sobre la lengua y el género durante los últimos años ha mostrado que el género de los interlocutores también influye en su comportamiento lingüístico. Muestran que, en el caso de los datos recabados sobre hablantes americanos, existen diferentes roles de género entre los participantes en las situaciones usadas para provocar disculpas: siempre es un varón quien debe ofrecer la disculpa en el caso de relaciones distantes. Sin embargo, BlumKulka, Danet, y Gherson (1985) consideran que el género no tiene un peso demasiado significativo en la elección de estrategias de ruego. 
En la presente investigación, al igual que en otros muchos estudios sobre la cortesía lingüística (Holmes, 1995), sí se ha considerado la variable de sexo, ya que se han propuesto diversas hipótesis acerca del sexo como aspecto relevante en las tendencias y preferencias en la realización del acto del habla (Talbot, 1998). Por otro lado, la elección de las variables de distancia social y estatus social se basó en los numerosos estudios que demuestran que estos dos factores parecen ser los más importantes para determinar la variación lingüística.

En las situaciones propuestas en el cuestionario, cuando se prueba la variable de distancia social se omite la de estatus, y viceversa. Por ejemplo, los interlocutores no reciben información acerca de la distancia social que existe entre ellos, cuando se manipula la variable del estatus, como ocurre en la situación 13, en la que el director de una empresa hace una petición a uno de sus trabajadores. Y de la misma forma en los casos en los que se quiere analizar la influencia de la distancia social, no hay ninguna mención al estatus, tal y como ocurre en la situación 1 , en la que el sujeto se dirige a uno de sus vecinos.

El método de estimulación usado para la recogida de datos en este estudio es el Test de rellenado de discurso o Discourse Completion Test (en adelante DCT). El DCT es un formulario 108 
estándar en el cual se presenta una situación, y se pide al sujeto que complete la conversación. El DCT fue desarrollado en principio por Blum-Kulka (1982), y ha sido ampliamente utilizado después para la recogida de datos sobre la realización de actos de habla, ya sea en grupos homogéneos o heterogéneos lingüísticamente.

Beebe y Cummings (1996), en su estudio sobre procedimientos de recogida de datos, sostienen que los DCTs son un medio muy efectivo para recopilar una gran cantidad de datos eficazmente y crear una clasificación inicial de fórmulas semánticas y estrategias que se producen en el habla natural. Además, los DCTs son útiles para estudiar las exigencias estereotípicas de una respuesta socialmente apropiada (aunque no necesariamente cortés), así como para comprender mejor factores sociales y psicológicos que probablemente influirán en la interpretación del acto de habla. También son efectivos para determinar qué códigos mentales manejan los hablantes de esa lengua para expresar rechazo, disculpa, despedida, y otros actos de habla. Además, permiten comparar la actuación comunicativa de los sujetos de distintas culturas en determinadas situaciones. Las variables de interés pueden ser manipuladas con el fin de obtener las respuestas que pueden ser más validas para cada trabajo. Los datos que suministran los sujetos a través del DCT proporcionan una 
concepción útil de qué respuestas consideran apropiadas para las situaciones dadas.

El DCT obtiene respuestas escritas, por lo cual hay una distorsión en los datos, y se hace muy difícil recoger el tipo de respuestas que habitualmente encontramos en interacciones que ocurren de forma natural (Hartford y Bardovi-Harlig, 1992). Debido a estas limitaciones inherentes a la metodología, algunos investigadores (Wolfson, 1986) declaran que el mejor método para recoger datos sobre los actos de habla es recabar un discurso espontáneo en contextos naturales. Sin embargo, el $D C T$ era el método más conveniente para el presente estudio, que ha investigado las diferencias en el uso de estrategias de petición, mandato y rechazo entre dos culturas diferentes, por lo que el análisis se ha basado en la comparación de normas aplicadas en dichos actos de habla por los participantes de cada sociedad. Esta comparación intercultural exige respuestas estereotipadas, las cuales pueden ser obtenidas con eficacia mediante técnicas escritas de estimulación. Era necesario recoger una gran cantidad de datos para comparar comportamientos de habla socio-culturales en grupos diferentes, y es prácticamente imposible hacer esto solo mediante habla espontánea. 
Por otra parte, recoger los datos en contextos naturales es muy difícil, ya que la existencia de ciertos actos de habla es arbitraria e incierta. Sería casi imposible y muy poco eficaz para recoger datos suficientes a fin de analizar el comportamiento de habla en relación con las variables de interés. Así, teniendo en cuenta la necesidad de supervisión experimental y eficacia práctica, el DCT se ha considerado el instrumento metodológico más apropiado para nuestra investigación.

\subsection{Estudio piloto}

Antes de administrar el cuestionario definitivo a los sujetos seleccionados, se completó un estudio piloto con un primer test elaborado para determinar la reacción del sujeto y la participación, el tiempo requerido para completarlo, y para evaluar posibles problemas o confusiones en cuanto a la claridad de las preguntas y la redacción del cuestionario. Este estudio piloto resultó ser beneficioso y proporcionó ideas e información no tenida en cuenta antes del estudio, como se explicará más adelante.

Diez estudiantes de posgrado, cinco malayos y cinco españoles, fueron seleccionados como muestra para este experimento. Dos estudiaban en la Universidad Politécnica de 
Madrid, dos en la Universitat Autonoma de Barcelona y la Universitat de Barcelona, respectivamente, y el resto eran estudiantes de la Universidad de Valladolid. Se trataba de estudiantes de disciplinas diversas, como Literatura y Humanidades, Ciencias y Tecnología, Gestión y Dirección de Empresas, y otros, cuyas edades oscilaban entre los 26 y los 36 años de edad.

El instrumento de estimulación usado para la recogida de datos fueron dos cuestionarios en forma de Test de rellenado de discurso o Discourse Completion Tests ampliables (DCT). La investigadora desarrolló dos cuestionarios diferenciados (para españoles y malayos), que entonces se administraron en los dos contextos de lengua materna (España y Malasia). El cuestionario consistía en 18 escenarios, cada uno de los cuales implicaba una situación que requería la formulación de una petición, mandato o rechazo.

Los cuestionarios se administraron en España en diciembre de 2009. Fueron distribuidos por la investigadora y se pidió que los sujetos los completaran en su presencia. La investigadora garantizó a los estudiantes que su participación era completamente voluntaria y que sus respuestas serían totalmente confidenciales. Los participantes, que utilizaron siempre su lengua 
materna, se animaron a hacer sugerencias y comentarios para mejorar la autenticidad y la claridad del $D C T$.

La reacción directa de los diez estudiantes en el estudio piloto conllevó mejoras relevantes e indicó la necesidad de algunas modificaciones en la primera versión del cuestionario. Por ejemplo, algunos estudiantes observaron que varios aspectos del cuestionario no tenían una redacción clara. Eso ayudó a la investigadora a realizar algunos cambios. Las personas encuestadas solicitaron más explicaciones de algunas situaciones, lo cual se tuvo en cuenta en la versión final. Con respecto a la extensión del cuestionario, los encuestados utilizaron un promedio de 15 minutos para rellenar el formulario, tiempo que no consideraron excesivo, de lo que se dedujo que la extensión del instrumento parecía ser satisfactoria.

En general, este estudio piloto permitió a la investigadora una mejor comprensión, y sirvió de práctica para saber cómo administrar el cuestionario final. Además, fruto de este estudio piloto, y de la observación minuciosa de la investigadora, ambas versiones del cuestionario (malaya y española) fueron remodeladas. 


\subsection{Sujetos}

Los sujetos del estudio definitivo pertenecen a dos grupos principales: 60 hablantes nativos de malayo y 60 hablantes nativos de español. Los sujetos malayos se dividen en dos subgrupos: 30 de menor edad (quince del sexo masculino y quince del sexo femenino) y 30 de más edad (también quince del sexo masculino y quince del sexo femenino). Las edades de los menores oscilaban entre los 19 y los 39 años, mientras que las de los mayores estaban entre los 40 y los 60. Los menores eran estudiantes universitarios en Malasia; se trataba de estudiantes de la Facultad de Ciencia y Tecnología de la Universidad de Malasia Terengganu. Los participantes mayores eran profesores de la misma universidad.

Se dividió asimismo el grupo de sujetos españoles: 30 menores (quince del sexo masculino y quince del sexo femenino) y 30 mayores (también quince del sexo masculino y quince del sexo femenino). Las edades comprendían los mismos intervalos. Los españoles menores eran estudiantes de la Escuela Universitaria de Estudios Empresariales de la Universidad de Valladolid, mientras que los mayores, al igual que en el caso malayo, eran profesores de la misma universidad. También contribuyeron, de forma voluntaria, completando todas las situaciones de estimulación del cuestionario. 
Se seleccionó a estudiantes y profesores universitarios de dichas universidades como sujetos de los dos grupos porque se trataba de la población más accesible para la investigadora (el cuestionario plantea, por tanto situaciones basadas en la vida cotidiana de un estudiante y un profesor universitario, o de cualquier persona, en general). Se advirtió a todos ellos que la participación era completamente voluntaria y que podrían retirarse en cualquier momento. La distribución de los sujetos que hemos explicado se resume en la tabla siguiente.

Tabla 2. Distribución de los sujetos en cada grupo: malayo y español

\begin{tabular}{|c|c|c|c|c|c|c|c|}
\hline \multicolumn{8}{|c|}{120 Sujetos } \\
\hline \multicolumn{4}{|c|}{60 Malayos } & \multicolumn{4}{|c|}{60 Españoles } \\
\hline \multicolumn{2}{|c|}{$\begin{array}{c}30 \text { Menores } \\
\text { (19-39 años) }\end{array}$} & \multicolumn{2}{|c|}{$\begin{array}{c}30 \text { Mayores } \\
\text { (40-60 años) }\end{array}$} & \multicolumn{2}{|c|}{$\begin{array}{c}30 \text { Menores } \\
\text { (19-39 años) }\end{array}$} & \multicolumn{2}{|c|}{$\begin{array}{c}30 \text { Mayores } \\
\text { (40-60 años) }\end{array}$} \\
\hline $15 \mathrm{~V}$ & $15 \mathrm{M}$ & $15 \mathrm{~V}$ & $15 \mathrm{M}$ & $15 \mathrm{~V}$ & $15 \mathrm{M}$ & $15 \mathrm{~V}$ & $15 \mathrm{M}$ \\
\hline
\end{tabular}

El equilibrio en la distribución según edad y sexo se tomó en consideración, ya que dichos factores sociales forman parte de las variables consideradas para el análisis, es decir, igualamos el número de sujetos de ambos grupos de edad y sexo con el propósito de observar la diferencia provocada por dichas variables en el resultado. 


\subsection{Instrumentos}

Para investigar las estrategias utilizadas en los actos de habla producidos por los participantes de ambos grupos, se administraron dos cuestionarios diferentes en dos escenarios de lengua materna. La redacción del cuestionario implicó varios pasos: primero, se emprendió una revisión crítica completa de la bibliografía relacionada para adquirir una sólida base y conocimiento aplicable al estudio para la elaboración de cuestionario. Y en segundo lugar, se diseñó el cuestionario en forma de Test de rellenado de discurso o Discourse Completion Test. En el diseño del mismo, la investigadora tuvo en cuenta, en buena medida, cuestionarios utilizados anteriormente por otros investigadores (p.ej, Blum-Kulka et al., 1989 y Beebe et al., 1990). En tercer lugar, la investigadora consultó con lingüistas para recibir sus comentarios, sugerencias y opiniones. La versión preliminar en inglés del cuestionario se tradujo a malayo y español. Por último, la investigadora probó la claridad y validez del cuestionario repartiéndolo entre diez estudiantes, cinco malayos y cinco españoles.

El $D C T$ es un formulario estándar en el que se presenta una situación, seguida de un breve diálogo y se pide al sujeto que complete la conversación. Pero, en nuestro trabajo no se plantea ningún dialogo sino que se crean situaciones provocativas y se pide a 116 
los encuestados que respondan en esas situaciones. El formulario consta de tres partes: una breve introducción del estudio y las instrucciones para responder a las preguntas, una breve sección destinada a recoger información demográfica sobre los propios sujetos, como el sexo, la edad, la carrera, la profesión, el nivel de educación y su lengua nativa, y 18 escenarios en los que se plantea una situación que requiere un mandato, petición o rechazo (véase apéndices $D$ y $E$ ).

El cuestionario plantea 18 situaciones diferentes en las que se suponía que se encontraba el encuestado, y en tal situación se les pedía que cumplimentaran una actuación verbal. Se les dio tanto tiempo como necesitaran para completar el cuestionario (no había un tiempo limitado), de modo que los sujetos pudieran responder con la extensión que desearan.

Las 18 situaciones de estimulación se dividen en tres tipos que responden a distintos actos de habla: seis para la expresión de mandatos (situaciones 3, 6, 9, 12, 15, y 18), seis para la formulación de peticiones (situaciones $1,4,7,10,13$, y 16 ) y seis para la de rechazos (situaciones $2,5,8,11,14$, y 17). Las situaciones elegidas están basadas en las la vida cotidiana de un malayo y un español. La contextualización de los actos de habla investigados en las 18 situaciones del $D C T$ se presenta en la Tabla 3. 
Tabla 3. Contextualización de los actos de habla investigados en las 18 situaciones del $D C T$

\begin{tabular}{|c|c|c|c|}
\hline Situación & Acto & Variable Social & Contexto \\
\hline 1 & Petición & $\begin{array}{l}\text { Distancia: } \\
\text { No conocido }\end{array}$ & $\begin{array}{l}\text { Escalera: } \\
\text { El hablante acaba de cambiarse de casa y } \\
\text { no tiene escalera para arreglar una } \\
\text { lámpara, así que se la quiere pedir } \\
\text { prestada a su vecino. }\end{array}$ \\
\hline 2 & Rechazo & $\begin{array}{l}\text { Distancia: } \\
\text { No conocido }\end{array}$ & $\begin{array}{l}\text { Agente: } \\
\text { El hablante no quiere comprar el nuevo } \\
\text { paquete del servicio que un agente de una } \\
\text { compañía de telefonía móvil le intenta } \\
\text { vender. }\end{array}$ \\
\hline 3 & Mandato & $\begin{array}{l}\text { Distancia: } \\
\text { No conocido }\end{array}$ & $\begin{array}{l}\text { Secretario: } \\
\text { El hablante es un directivo en una firma } \\
\text { famosa y quiere que su nuevo secretario } \\
\text { haga fotocopias de algunos documentos. }\end{array}$ \\
\hline 4 & Petición & $\begin{array}{l}\text { Distancia: } \\
\text { Conocido }\end{array}$ & $\begin{array}{l}\text { Ir a comprar: } \\
\text { El hablante piensa ir a comprar y quiere } \\
\text { que su compañero de piso le acompañe. }\end{array}$ \\
\hline 5 & Rechazo & $\begin{array}{l}\text { Distancia: } \\
\text { Conocido }\end{array}$ & $\begin{array}{l}\text { Portátil: } \\
\text { El hablante es un estudiante universitario, } \\
\text { no quiere prestar su portátil a su } \\
\text { compañero de curso. }\end{array}$ \\
\hline 6 & Mandato & $\begin{array}{l}\text { Distancia: } \\
\text { Conocido }\end{array}$ & $\begin{array}{l}\text { Llegar a la hora: } \\
\text { El hablante es profesor en una universidad } \\
\text { y quiere que su alumno llegue a la hora a } \\
\text { clase. }\end{array}$ \\
\hline 7 & Petición & $\begin{array}{l}\text { Distancia: } \\
\text { Muy conocido }\end{array}$ & $\begin{array}{l}\text { Hacer compañía: } \\
\text { El hablante está solo en casa y quiere que } \\
\text { su mejor amigo venga a hacerle compañía. }\end{array}$ \\
\hline 8 & Rechazo & $\begin{array}{l}\text { Distancia: } \\
\text { Muy conocido }\end{array}$ & $\begin{array}{l}\text { Acompañar a una fiesta: } \\
\text { El hablante no quiere acompañar a su } \\
\text { hermano menor a la fiesta de cumpleaños } \\
\text { de su amigo. }\end{array}$ \\
\hline
\end{tabular}




\begin{tabular}{|c|c|c|c|}
\hline 9 & Mandato & $\begin{array}{c}\text { Distancia: } \\
\text { Muy conocido }\end{array}$ & $\begin{array}{l}\text { Salir con amigos: } \\
\text { El hablante le permite a su hijo, que está } \\
\text { llegando a la adolescencia, salir con sus } \\
\text { amigos. Pero quiere que vuelva pronto a } \\
\text { casa. }\end{array}$ \\
\hline 10 & Petición & $\begin{array}{l}\text { Estatus: } \\
\text { Superior }\end{array}$ & $\begin{array}{l}\text { Carta de recomendación: } \\
\text { El hablante necesita una carta de } \\
\text { recomendación para solicitar un trabajo y } \\
\text { piensa pedírselo a un antiguo profesor } \\
\text { suyo de la universidad. }\end{array}$ \\
\hline 11 & Rechazo & $\begin{array}{l}\text { Estatus: } \\
\text { Igual }\end{array}$ & $\begin{array}{l}\text { Pescar: } \\
\text { El hablante no quiere ir a pescar con su } \\
\text { colega a un río. }\end{array}$ \\
\hline 12 & Mandato & $\begin{array}{l}\text { Distancia: } \\
\text { No conocido }\end{array}$ & $\begin{array}{l}\text { Cambiar asignatura: } \\
\text { El hablante es profesor en una universidad } \\
\text { y quiere que un nuevo alumno a su cargo } \\
\text { cambie una de las asignaturas elegidas por } \\
\text { otra. }\end{array}$ \\
\hline 13 & Petición & $\begin{array}{l}\text { Estatus: } \\
\text { Inferior }\end{array}$ & $\begin{array}{l}\text { Caviar: } \\
\text { El hablante es director de una empresa. } \\
\text { Quiere pedir a uno de sus trabajadores que } \\
\text { va a hacer un viaje de negocios a Rusia, } \\
\text { que le compre una lata de caviar. }\end{array}$ \\
\hline 14 & Rechazo & $\begin{array}{l}\text { Estatus: } \\
\text { Inferior }\end{array}$ & $\begin{array}{l}\text { Tesis: } \\
\text { El hablante es profesor en una universidad. } \\
\text { No quiere prestar a un alumno suyo una } \\
\text { tesis de un estudiante anterior que se } \\
\text { guarda en su despacho. }\end{array}$ \\
\hline 15 & Mandato & $\begin{array}{l}\text { Distancia: } \\
\text { Conocido }\end{array}$ & $\begin{array}{l}\text { Restaurante: } \\
\text { El hablante es el encargado de un } \\
\text { restaurante. Un cliente ha pedido que le } \\
\text { lleven la comida a su oficina, y quiere que } \\
\text { uno de sus trabajadores se encargue de } \\
\text { hacerlo. }\end{array}$ \\
\hline 16 & Petición & $\begin{array}{l}\text { Estatus: } \\
\text { Igual }\end{array}$ & $\begin{array}{l}\text { Móvil: } \\
\text { El hablante quiere utilizar el móvil de su } \\
\text { amigo para hacer una llamada porque no } \\
\text { le queda saldo en el suyo. }\end{array}$ \\
\hline
\end{tabular}




\begin{tabular}{|c|l|l|l|}
\hline 17 & Rechazo & $\begin{array}{l}\text { Estatus: } \\
\text { Superior }\end{array}$ & $\begin{array}{l}\text { Método de estudio: } \\
\text { El hablante es un estudiante universitario } \\
\text { que no quiere cambiar el método del } \\
\text { estudio propuesto por su director de tesis. }\end{array}$ \\
\hline 18 & Mandato & $\begin{array}{l}\text { Distancia: } \\
\text { Muy conocido }\end{array}$ & $\begin{array}{l}\text { Ver la tele: } \\
\text { Es medianoche. El hablante quiere que su } \\
\text { hijo, que aún está viendo la tele, se } \\
\text { acueste. }\end{array}$ \\
\hline
\end{tabular}

Aunque las situaciones elegidas en los cuestionarios sean comunes en la vida de los sujetos de ambas culturas, el proceso de traducción de los cuestionarios implicó la transposición cultural al sistema social específico de cada cultura, cuando resultaba necesario. Por ejemplo, el "agente de una compañía de teléfono móvil" en español, se sustituyó por un "agente de una compañía de seguros" en malayo, ya que la visita del agente de una compañía de teléfono móvil a casa no es habitual en Malasia. En la situación 13, en cuya versión española un director pide a un trabajador que va a hacer un viaje de negocios a Rusia que le compre una lata de caviar, en la versión malaya se sustituyó "Rusia" por "Indonesia" y "caviar" por "buah salak" ('la fruta de salak"'). Se eligió la opción de "Indonesia" y "buah salak", en vez de "Rusia" y "caviar" de las

\footnotetext{
${ }^{1}$ Salak (zalacca de salacca) es una especie de palmera (de la familia Arecaceae) que tiene su origen en Indonesia (Wikipedia, 2011). Se trata de una fruta muy apreciada y muy cara en Malasia.
} 
situaciones españolas, para equipararlo con la cultura malaya en la cual no es habitual que la gente coma caviar. De hecho, los malayos no saben de su existencia. Los nombres y los lugares también se modificaron para conseguir que las circunstancias en que se produce el acto de habla fueran las idóneas en cada cultura.

Cada grupo de situaciones, excepto las propuestas para la producción del mandato, jugaba con dos variables diferentes: estatus (inferior, igual, más elevado) y distancia social (desconocido, conocido, muy conocido). Estas dos variables han mostrado ser factores importantes para provocar variaciones lingüísticas en otros estudios (p.ej., Brown y Levinson, 1978; Wolfson, Marmor, y Jones, 1989; Blum-Kulka y House, 1989). Las situaciones de mandato están ordenadas según la variable de distancia social solamente, porque los mandatos son realizados únicamente de personas superiores a inferiores. No existen situaciones en las que el mandato se dirija de personas de un estatus inferior a personas de estatus superior. Asimismo, se examinaron las diferencias entre hombres y mujeres, $y$, menores y mayores, en cada grupo, en la producción de los actos de habla estudiados.

Para representar a una persona de posición social superior se eligieron las figuras de profesor, jefe, director y padre o madre; para las personas de posición social inferior, se eligió a un 
estudiante, un trabajador y un hijo; y para un estatus igual, un amigo, un compañero de piso, y un compañero de curso. En cuanto a la distancia social, la menor viene representada por los papeles de hijo, buen amigo y hermano; la distancia social media es la que se establece en el cuestionario entre un alumno y su profesor, un trabajador y su jefe, un compañero de piso, y un compañero de curso; y la mayor distancia la representan un nuevo vecino, un nuevo alumno con respecto al profesor, un nuevo secretario y un agente de negocios desconocido hasta entonces.

\subsection{Procedimientos de recogida de datos}

Los datos del presente estudio se recogieron en dos entornos socioculturales diferentes. Ocho ayudantes participaron en la recogida de datos. De ellos, dos mujeres ayudaron en la distribución de los cuestionarios en Malasia, y dos hombres y dos mujeres prestaron ayuda a la investigadora en España. Cada ayudante fue recompensado por su participación en el estudio.

En este estudio participaron 60 malayos de Malasia: 30 estudiantes de la Universidad de Malasia Terengganu y 30 profesores de la misma universidad, y el mismo número de españoles de 
España: 30 estudiantes de la Universidad de Valladolid y 30 profesores de la misma universidad.

Las pruebas para sujetos malayos se administraron en Malasia en abril de 2011. Dos profesoras de Lingüística ayudaron a distribuir los cuestionarios. Una, de 40 años de edad y otra, de 31 años, del Departamento de Lenguas y Comunicación de la Universidad de Malasia Terengganu. Ambas son colegas de la investigadora. Previamente a la distribución de los cuestionarios, fueron completamente instruidas sobre el presente estudio por la investigadora para asegurarse de que cada una de ellas usaba el enfoque apropiado en la recogida de datos.

Las pruebas para los sujetos españoles se hicieron en España durante el mes de marzo de 2011. Los cuestionarios fueron distribuidos por la propia investigadora y algunos amigos (dos profesores españoles, y dos amigos españoles) que también ayudaron en la recogida de las respuestas a los cuestionarios. Igual que en el caso del grupo malayo, los ayudantes para el grupo español también fueron instruidos sobre el fondo del presente estudio, previamente a su colaboración en la recogida de datos.

Se solicitó a todos los sujetos de ambos grupos que rellenaran un cuestionario ampliable de Test de rellenado de discurso 
- Discourse Completion Task (DCT) en sus lenguas maternas (malayo y español). Se les pidió que escribieran en forma de oración tantos modos de realizar cada acto de habla como se les ocurrieran. Se les instó a que indicaran lo que ellos dirían realmente en esas situaciones, más que lo que pensaran que deberían decir. Se les comunicó que sus respuestas serían guardadas de forma estrictamente confidencial y que no había ninguna necesidad de que hicieran constar sus nombres. A la mayor parte de los sujetos les llevó entre 15 y 20 minutos cumplimentar los cuestionarios.

\subsection{Procedimientos de análisis de datos}

Los datos se clasificaron utilizando un esquema semejante al desarrollado en el marco del análisis de CCSARP (Blum-Kulka, House y Kasper, 1989). Este esquema de clasificación de CCSARP es apropiado para examinar el conocimiento de los actos de habla de los estudiantes de una lengua. El CCSARP ha sido utilizado ampliamente en investigación de Pragmática de la interlengua. La unidad de análisis de este estudio es cualquier respuesta en malayo y español que un sujeto individual produce para efectuar una petición, un mandato o un rechazo, en cada grupo. La investigadora, con ayuda de dos nativos, clasificó la información de cada sujeto, y se compararon las codificaciones. En el caso de las expresiones que 124 
la investigadora y los nativos codificaron de manera distinta se discutió sobre el problema hasta que se alcanzó un acuerdo. Después de codificar cada respuesta, se calculó el número total de enunciados producidos en la expresión de la petición, el mandato y el rechazo de cada categoría según el esquema aplicado. La frecuencia de uso de cada estrategia constituye la parte cuantitativa del análisis. Pero se presta más atención a la parte cualitativa, compuesto por el análisis del contenido lingüístico de las peticiones, mandatos y rechazos expresados por los participantes. También se examinaron los patrones de las realizaciones de los actos de habla. Es decir, fueron identificados los modelos generales que se encuentran en las producciones de los hablantes malayos, y fueron examinadas las de los hablantes españoles, para determinar cómo se diferenciaban unas de otras. Los datos se analizaron aplicando el paquete estadístico de las ciencias sociales (SPSS), versión 15. Se empleó el análisis de Tabla de Contingencia (Crosstabulation Analisys) y la prueba de Chi-cuadrado $\left(X^{2}\right)$ para comparar los promedios del uso de estrategias entre los grupos y los subgrupos analizados. El nivel de probabilidad se determinó en 0.05 . El sistema de codificación utilizado para este estudio se describe en la siguiente sección. 


\subsubsection{Petición y mandato}

El primer paso para analizar una petición y un mandato es identificar, en su expresión, actos principales y movimientos de apoyo. Aparte de esto, hay, además, otros elementos, tales como las alertas en una realización de actos de habla, pero este estudio se centrará solamente en los actos principales y movimientos de apoyo.

Actos principales: Un acto principal es la unidad mínima y nuclear que se necesita para realizar un acto de habla determinado. Por ejemplo, en la expresión: "José, ¿podrías abrir la ventana? Hace mucho calor aquí".

El acto principal, o, dicho de otra forma, la unidad central, es "¿podrías abrir la ventana?", que es una petición. Las otras partes ("José" y "hace mucho calor aquí") son movimientos de apoyo, es decir, partes no esenciales para la petición. Un movimiento de apoyo, por lo tanto, es un elemento adicional al acto principal que, o bien agrava o mitiga la fuerza de dicho acto. En el ejemplo anterior, "hace calor aquí" es un movimiento de apoyo, ya que proporciona una explicación de por qué el hablante hace la petición de que José abra la ventana y por lo tanto, reduce la fuerza impositiva de la petición. 
Se desarrollaron múltiples categorías para codificar las estrategias de acto principal y movimientos de apoyo para este estudio. Las categorías se desarrollaron sobre la base del CCSARP (Blum-Kulka, House, y Kasper, 1989). El CCSARP enumera nueve estrategias de petición exclusiva, de acuerdo con el grado de dirección, reflejadas en la Tabla 4. En el CCSARP, la dirección se definió como "el grado en que la intención ilocutiva del hablante se desprende de la locución". En otras palabras, la persona a la que se le hace la petición puede identificar el significado de un enunciado como tal con más facilidad, si aumenta el grado de dirección. En el caso de los indicios, la intención del hablante de efectuar una petición no se muestra explícitamente en el enunciado, sino que está oculta (por ejemplo, si dice "En esta habitación hace calor" como una petición de que se abra una ventana). 
Tabla 4. Sub-clasificación de estrategias (9 tipos) según el grado de (in)dirección (Blum-Kulka et al., 1989)

\begin{tabular}{|c|c|c|}
\hline \multicolumn{2}{|c|}{ Estrategias } & Definición y Ejemplo \\
\hline \multirow{5}{*}{ Directas } & Imperativo & $\begin{array}{l}\text { El modo gramatical de la locución } \\
\text { convencional determina su fuerza } \\
\text { ilocucionaria como una petición. La forma } \\
\text { prototípica es el imperativo. } \\
\text { Por ejemplo: } \\
\text { iLimpia la cocina! }\end{array}$ \\
\hline & Performativo & $\begin{array}{l}\text { La intención ilocucionaria para hacer una } \\
\text { petición va explícitamente mencionada por } \\
\text { un verbo relevante. } \\
\text { Por ejemplo: } \\
\text { Te pido/pedimos que limpies la cocina. }\end{array}$ \\
\hline & $\begin{array}{l}\text { Performativo } \\
\text { evasivo }\end{array}$ & $\begin{array}{l}\text { El verbo ilocucionario es modificado por } \\
\text { algunos verbos modales o verbos que } \\
\text { expresan la intención. } \\
\text { Por ejemplo: } \\
\text { Me gustaría pedirte que limpies la cocina. } \\
\text { Tengo que pedirte que limpies la cocina. }\end{array}$ \\
\hline & $\begin{array}{c}\text { Declaración } \\
\text { de obligación }\end{array}$ & $\begin{array}{l}\text { El intento ilocucionario es directamente } \\
\text { derivable de la intención semántica de la } \\
\text { locución. } \\
\text { Por ejemplo: } \\
\text { Deberías/tendrías que limpiar la cocina. }\end{array}$ \\
\hline & $\begin{array}{c}\text { Declaración } \\
\text { de deseo }\end{array}$ & $\begin{array}{l}\text { La declaración expresa el deseo del } \\
\text { hablante (que el acto pedido debe ser } \\
\text { llevado a cabo). } \\
\text { Por ejemplo: } \\
\text { Me gustaría/quiero/deseo que limpies la } \\
\text { cocina. }\end{array}$ \\
\hline
\end{tabular}




\begin{tabular}{|c|l|l|}
\hline \multirow{2}{*}{$\begin{array}{c}\text { Convencionalmente } \\
\text { indirectas }\end{array}$} & $\begin{array}{c}\text { Fórmula de } \\
\text { sugerencia }\end{array}$ & $\begin{array}{l}\text { La intención ilocucionaria se formula como } \\
\text { una sugerencia. } \\
\text { Por ejemplo: } \\
\text { ¿Qué tal si limpiamos la cocina? }\end{array}$ \\
\cline { 2 - 3 } & $\begin{array}{c}\text { Interrogación } \\
\text { preparatoria }\end{array}$ & $\begin{array}{l}\text { La expresión contiene una referencia a las } \\
\text { condiciones preparatorias, como la } \\
\text { capacidad o la voluntad. } \\
\text { Por ejemplo: } \\
\text { ¿Puedes / podrías limpiar la cocina? }\end{array}$ \\
\hline No & Indicio fuerte & $\begin{array}{l}\text { La locución se refiere, en parte, a los } \\
\text { elementos pertinentes de la petición. } \\
\text { Por ejemplo: } \\
\text { La cocina está hecha un desastre. }\end{array}$ \\
\cline { 2 - 4 } indirectas & Indicio suave & $\begin{array}{l}\text { La expresión no contiene ninguna } \\
\text { relevancia inmediata como petición de la } \\
\text { locución destinada. } \\
\text { Por ejemplo: } \\
\text { ¿A quién le toca hoy? }\end{array}$ \\
\hline
\end{tabular}

Las nueve estrategias de petición arriba mencionadas están ordenadas de mayor a menor grado de (in)dirección, y se pueden agrupar en tres categorías: (a) petición directa, (b) petición convencionalmente indirecta, (c) petición no convencional indirecta, (Blum-Kulka, et al. 1989). Estas tres categorías (directa, convencionalmente indirecta y no convencionalmente indirecta) se subdividen, a su vez, en las nueve estrategias exclusivas de petición mostradas en la Tabla 5. La elección de estas estrategias ha sido comparada entre los dos grupos de sujetos, en el análisis de datos. 
La primera estrategia, el "Imperativo", se considera la más directa, es decir, en la que el hablante muestra su intención de manera más explícita. La siguiente categoría, "Performativo" también expresa la intención del hablante con claridad, pero de una manera menos directa que el "Imperativo". En el caso del "Performativo evasivo", el nombramiento de la fuerza ilocutiva se modifica al utilizar expresiones evasivas, como "me gustaría". La declaración de obligación establece la obligación del oyente mediante el uso de un verbo modal, como "usted tiene que". Una "Declaración de deseo" transmite el deseo de los hablantes de que el oyente lleve a cabo el acto. Una "Fórmula de sugerencia" contiene una sugerencia para el oyente, como "¿por qué no?", o "¿qué tal si...?". Una sentencia preparatoria de una pregunta contiene una referencia a las condiciones de preparación, tales como "¿puede/podría usted...?". Un "Indicio fuerte" incluye un enunciado que contenga referencia parcial al objeto, como se ha expuesto en la tabla anteriormente "la cocina está hecha un desastre", mientras que un "Indicio suave" no incluye ninguna referencia en absoluto, por ejemplo, "¿a quién le toca hoy?".

Movimientos de apoyo: LoS movimientos de apoyo son expresiones utilizadas para mitigar o agravar la fuerza impositiva de una petición, y pueden preceder o suceder al acto principal. Se establecen las siguientes categorías: 
Tabla 5. Estrategias de movimientos de apoyo encontradas en el estudio

\begin{tabular}{|c|c|}
\hline Estrategias & Definición y Ejemplo \\
\hline $\begin{array}{l}\text { Fórmulas de } \\
\text { preparación }\end{array}$ & $\begin{array}{l}\text { El hablante prepara al oyente para la petición, } \\
\text { peguntándole sobre su disponibilidad potencial, o } \\
\text { pidiéndole permiso para hacerle la petición. } \\
\text { Por ejemplo: } \\
\text {-Me gustaría preguntarte algo: ¿Vives en mi misma } \\
\text { calle? (antes de pedir que le lleven). } \\
\text {-Tengo que pedirte un favor. }\end{array}$ \\
\hline $\begin{array}{l}\text { Búsqueda de un } \\
\text { compromiso }\end{array}$ & $\begin{array}{l}\text { Al verificar una posibilidad de rechazo potencial antes } \\
\text { de hacer una petición, el hablante trata de } \\
\text { comprometer a su oyente antes de decirle a él /ella lo } \\
\text { que le está exponiendo. } \\
\text { Por ejemplo: } \\
\text {-¿Podría hacerme un favor? } \\
\text {-Voy a Turquía en vacaciones: ¿Puedo pedirle un } \\
\text { favor? }\end{array}$ \\
\hline Razones & $\begin{array}{l}\text { El hablante da las razones, explicaciones o } \\
\text { justificaciones para su petición. } \\
\text { Por ejemplo: } \\
\text {-Me perdí la clase de ayer. ¿Me puedes prestar tus } \\
\text { apuntes? } \\
\text {-Tengo que dormir. Por favor, no hagáis ruido. }\end{array}$ \\
\hline Previsión de objeciones & $\begin{array}{l}\text { El hablante intenta eliminar las objeciones posibles que } \\
\text { el oyente podría plantear. } \\
\text { Por ejemplo: } \\
\text { Yo sé que no te gusta prestar tus apuntes, pero } \\
\text { ¿podrías hacer una excepción esta vez? } \\
\text { Sé que me toca a mí, pero ¿puedes limpiar tú hoy el } \\
\text { piso? }\end{array}$ \\
\hline $\begin{array}{l}\text { Promesa de } \\
\text { recompensa/reparación }\end{array}$ & $\begin{array}{l}\text { Se ofrece una recompensa por el cumplimiento de la } \\
\text { petición que se anuncia. El hablante promete reparar } \\
\text { la pérdida que es causada por la petición. } \\
\text { Por ejemplo: } \\
\text { ¿Podrías prestarme tus apuntes? Te invito a comer. } \\
\text { Venga, ya lo hago yo la próxima vez, pero por favor } \\
\text { limpia el piso tú hoy. }\end{array}$ \\
\hline
\end{tabular}




\begin{tabular}{|c|c|}
\hline $\begin{array}{l}\text { Minimización de la } \\
\text { imposición }\end{array}$ & $\begin{array}{l}\text { El hablante intenta reducir la imposición de la petición } \\
\text { sobre el oyente. } \\
\text { Por ejemplo: } \\
\text { ¿Puedes llevarme? Sí te pilla de camino, vamos. } \\
\text { ¿Sería un problema que me dejaras tu ordenador? Solo } \\
\text { lo voy a usar hoy y te lo devuelvo. }\end{array}$ \\
\hline $\begin{array}{c}\text { Invocación de principios } \\
\text { generales }\end{array}$ & $\begin{array}{l}\text { Para dar más credibilidad a su petición, el hablante } \\
\text { invoca máximas morales generales. } \\
\text { Por ejemplo: } \\
\text { Si uno comparte un piso, tiene que estar preparado } \\
\text { para limpiarlo como es debido, así que sigue } \\
\text { limpiando. } \\
\text { iSilencio! ¿No ves que es de madrugada y vas a } \\
\text { molestar a todo el mundo? La gente a estas horas está } \\
\text { durmiendo. }\end{array}$ \\
\hline $\begin{array}{l}\text { Reconocimiento de la } \\
\text { imposición }\end{array}$ & $\begin{array}{l}\text { El hablante reconoce la imposición creada por la } \\
\text { petición. } \\
\text { Por ejemplo: } \\
\text { Oye, mira, perdona por la molestia, pero me } \\
\text { preguntaba si tendrías una copia de este libro que me } \\
\text { puedas prestar. } \\
\text { Siento pedirte este favor habiendo trabajo en la } \\
\text { tienda, pero quería cogerme una semana de } \\
\text { vacaciones. }\end{array}$ \\
\hline Preocupación & $\begin{array}{l}\text { El hablante muestra su preocupación por la capacidad } \\
\text { del oyente, la voluntad, o la disponibilidad para llevar a } \\
\text { cabo la petición. } \\
\text { Por ejemplo: } \\
\text { Si no importa, ¿puedo usar el ordenador? } \\
\text { Me gustaría pedirte el portátil hasta la semana que } \\
\text { viene, si te parece bien. }\end{array}$ \\
\hline Apreciación & $\begin{array}{l}\text { El hablante expresa su agradecimiento por el } \\
\text { cumplimiento del oyente con la petición antes de que } \\
\text { se lleve a cabo. } \\
\text { Por ejemplo: } \\
\text {-Gracias. } \\
\text {-Le agradecería que me enviaran un folleto. }\end{array}$ \\
\hline
\end{tabular}




\begin{tabular}{|c|l|}
\hline Promesa de devolución & $\begin{array}{l}\text { El hablante promete al oyente devolverle lo que le ha } \\
\text { pedido prestado. } \\
\text { Por ejemplo: } \\
\text { Te devolveré mañana el portátil. } \\
\text { ¿Puedes prestar tu portátil? } \\
\text { Lo voy a cuidar, no te preocupes, y te lo devuelvo } \\
\text { pronto. }\end{array}$ \\
\hline Promesa de no & $\begin{array}{l}\text { El hablante promete al oyente que él/ella no hará la } \\
\text { misma petición de nuevo. } \\
\text { repetición }\end{array}$ \\
\hline Por ejemplo: \\
No te lo voy a pedir más veces. \\
¿Limpias tú por mí hoy? Será la última vez...
\end{tabular}




\subsubsection{Rechazo}

Las estrategias de rechazo del presente estudio se analizaron como parte de una secuencia de fórmulas semánticas, siguiendo a Beebe et al. (1990). Las fórmulas semánticas representan los medios por los cuales un acto de habla concreto se lleva a cabo, en términos del contenido primario de una declaración, como pueden ser una razón, una explicación, o una alternativa (Bardovi-Harlig y Hartford, 1991). Por ejemplo, la respuesta de encuestado al que se ha solicitado ayuda y rechaza la petición diciendo "Lo siento, pero tengo cosas que hacer, si me lo hubieras dicho antes lo habría hecho", se analizó como [expresión de la pena] [excusa] [conjunto de condiciones para la aceptación futura o pasada]. En el caso de un encuestado que rechaza la invitación de un amigo a una fiesta diciendo "No, no puedo asistir a tu fiesta este fin de semana. Ojalá pudiera", la respuesta fue analizada como: [no] [buena voluntad/capacidad negativa] [deseo]. En este estudio la fórmula de "declaración de principios" fue combinada con la estrategia de "declaración de la filosofía", dado que se manejaba la tesis de que ambas estrategias eran realmente las mismas.

Los datos se analizaron cuantitativamente (la frecuencia de la fórmula) y cualitativamente (el contenido de la fórmula). El análisis comenzó con la clasificación de las fórmulas utilizadas por 134 
cada uno de los encuestados, en cada grupo y para cada una de las situaciones de rechazo. Es decir, se determinó la frecuencia de cada fórmula, como por ejemplo el número de "Excusas" empleadas. Se calculó la frecuencia de cada fórmula en cada situación, para comparar las diferencias entre las estrategias de rechazo de ambas culturas. La frecuencia relativa de las fórmulas empleadas en cada situación se obtuvo tomando el número total de enunciados con un tipo concreto de fórmula, dividido entre el número total de enunciados utilizados para dicha situación. Por ejemplo, si se empleó la fórmula "Excusa" 38 veces en las respuestas de los malayos en la situación 1, el porcentaje de la fórmula sería el 33.0 \% (el número total de "Excusas", 38, dividido por 115, el número total de enunciados en la situación 1).

Se concluyó el análisis examinando el detalle de los contenidos de cada estrategia, es decir, indicando su exactitud y seguridad. Por ejemplo, tanto ejemplos como "tengo cosas que hacer" o "tengo que cuidar de mi madre, que está en el hospital" se catalogaron como motivos/explicaciones; sin embargo, se diferencian en que la primera es una explicación vaga, mientras que la segunda ofrece una motivación específica. Se anotaron estas diferencias y se codificaron en los datos. El análisis de la frecuencia y el contenido de las fórmulas empleadas por los sujetos se llevó a cabo para revelar y destapar cualquier semejanza o diferencia en las formas y modelos 
elegidos, así como su uso en las diversas situaciones sociales. El contenido de las respuestas ayudó a interpretar las diferencias sutiles en las estrategias de rechazo que no se pueden recoger mediante cifras. A continuación mostramos los subtipos de estrategias de rechazo propuestos por Beebe et al. (1990), con algunas modificaciones, en los que pueden subdividirse los tres grandes bloques de estrategias de rechazo (directas e indirectas y adyacentes al rechazo).

Tabla 6. Estrategias de rechazo utilizadas por los participantes de este estudio

\begin{tabular}{|c|c|c|}
\hline \multicolumn{2}{|c|}{ Estrategia } & Definición y Ejemplo \\
\hline \multirow{3}{*}{ Directa } & Uso de Performativo & $\begin{array}{l}\text { "Expresiones de auto-denominación, en las } \\
\text { que el verbo performativo, por lo general, se } \\
\text { refiere al acto en que el hablante está } \\
\text { implicado en el momento del discurso" Leech } \\
\text { (1983). } \\
\text { Por ejemplo: } \\
\text { a. Rechazo cambiar la fecha. } \\
\text { b. Me niego a vivir contigo. }\end{array}$ \\
\hline & No & $\begin{array}{l}\text { El hablante rechaza indirectamente la } \\
\text { petición diciendo "no" con alguna } \\
\text { modificación interna. La palabra "no" es un } \\
\text { tipo directo de rechazo, un acto que } \\
\text { amenaza la imagen del oyente. } \\
\text { Por ejemplo: } \\
\text { a. № , gracias por tu invitación. } \\
\text { b. №, no te los puedo dejar. }\end{array}$ \\
\hline & Capacidad negativa & $\begin{array}{l}\text { El hablante rechaza indirectamente la } \\
\text { petición expresando negaciones. La negación } \\
\text { se puede expresar por la partícula negativa } \\
\text { "no", o utilizando cualquier palabra que } \\
\text { semánticamente niega una proposición. } \\
\text { Por ejemplo: } \\
\text { a. Lo siento, pero eso no es posible ya que } \\
\text { sería injusto. } \\
\text { b. No puedo porque no tengo dinero. }\end{array}$ \\
\hline
\end{tabular}




\begin{tabular}{|c|c|c|}
\hline \multirow{5}{*}{ Indirecta } & Disculpa & $\begin{array}{l}\text { El hablante rechaza indirectamente la } \\
\text { petición empleando excusas, expresando } \\
\text { disculpas o pidiendo perdón, para mitigar (o } \\
\text { suavizar) el rechazo. } \\
\text { Por ejemplo: } \\
\text { a. Lo siento, Carmen, pero no voy a poder } \\
\text { ir a la fiesta. } \\
\text { b. Perdona, en este momento estoy } \\
\text { ocupado }\end{array}$ \\
\hline & Deseo & $\begin{array}{l}\text { El hablante rechaza indirectamente la } \\
\text { petición o indicando un deseo. } \\
\text { Por ejemplo: } \\
\text { a. Espero que sea un día maravilloso para ti } \\
\text { y para tu novio. } \\
\text { b. Te deseo mucha felicidad y prosperidad } \\
\text { en tu matrimonio. }\end{array}$ \\
\hline & Excusa & $\begin{array}{l}\text { El hablante rechaza indirectamente la } \\
\text { petición proporcionando una excusa, motivo } \\
\text { o explicación que puede ser general o } \\
\text { específica. } \\
\text { Por ejemplo: } \\
\text { a. Lo siento, precisamente acabo de quedar } \\
\text { con un amigo que ya me está } \\
\text { esperando. } \\
\text { b. Estoy cansado y necesito ir a casa. }\end{array}$ \\
\hline & $\begin{array}{l}\text { Declaración de } \\
\text { alternativa }\end{array}$ & $\begin{array}{l}\text { El hablante rechaza indirectamente la } \\
\text { petición sugiriendo una alternativa o un } \\
\text { conjunto de posibilidades con el objetivo de } \\
\text { mantener una imagen positiva con el } \\
\text { interlocutor y negociar la respuesta. } \\
\text { Por ejemplo: } \\
\text { a. ¿Por qué no se los pides a María? } \\
\text { b. Te propongo que nos quedemos en la } \\
\text { residencia a ver esa película. }\end{array}$ \\
\hline & $\begin{array}{c}\text { Establecimiento de } \\
\text { condiciones para una } \\
\text { aceptación pasada o } \\
\text { futura }\end{array}$ & $\begin{array}{l}\text { El hablante rechaza indirectamente la } \\
\text { petición utilizando una condición hipotética } \\
\text { que pretende dirigir el rechazo a una } \\
\text { situación en que hubiera sido mejor que la } \\
\text { persona hiciera la petición de manera } \\
\text { anticipada. } \\
\text { Por ejemplo: } \\
\text { a. Si me hubieras avisado un poco antes } \\
\text { hubiera ido, pero ya he quedado con } \\
\text { otras personas. } \\
\text { b. Lo siento. Tengo una reunión ahora, de } \\
\text { haberlo sabido con antelación no habría } \\
\text { problema y me podría quedar, pero ya } \\
\text { no puedo cancelarlo. }\end{array}$ \\
\hline
\end{tabular}




\begin{tabular}{|c|c|c|}
\hline \multirow{5}{*}{ Indirecta } & $\begin{array}{l}\text { Declaración de } \\
\text { principios/filosofía }\end{array}$ & $\begin{array}{l}\text { El hablante rechaza indirectamente la } \\
\text { petición declarando una actitud general o } \\
\text { conjunto de creencias que ha mantenido } \\
\text { durante mucho tiempo. A veces se utilizan } \\
\text { frases de estilo filosófico para declarar esos } \\
\text { principios. } \\
\text { Por ejemplo: } \\
\text { a. No me parece muy oportuno, como } \\
\text { profesora, participar en una fiesta de } \\
\text { alumnos. } \\
\text { be gusta tratar a todos mis alumnos en } \\
\text { igualdad de condiciones. }\end{array}$ \\
\hline & $\begin{array}{c}\text { Amenaza o declaración } \\
\text { de consecuencias } \\
\text { negativas para el } \\
\text { emisor }\end{array}$ & $\begin{array}{l}\text { El hablante rechaza indirectamente la } \\
\text { petición haciendo algunas amenazas que } \\
\text { pueden tener un impacto negativo sobre sí } \\
\text { mismo o en el interlocutor, si consiente en } \\
\text { realizar la tarea. } \\
\text { Por ejemplo: } \\
\text { a. No puedo, además no entenderías mi } \\
\text { letra. } \\
\text { b. No conozco a tus amigos, además sería } \\
\text { una situación algo incómoda. }\end{array}$ \\
\hline & $\begin{array}{c}\text { Declaración de } \\
\text { sentimiento negativo }\end{array}$ & $\begin{array}{l}\text { El hablante rechaza indirectamente la } \\
\text { petición aduciendo sentimientos negativos, } \\
\text { incluidos la crítica de la petición y la } \\
\text { estrategia de hacer sentir culpable al otro. } \\
\text { Por ejemplo: } \\
\text { a. No, ven más a clase y no tengas tanta } \\
\text { cara dura. } \\
\text { b. No puedo hacer excepciones, sería un } \\
\text { agravio para el resto de tus compañeros. }\end{array}$ \\
\hline & $\begin{array}{l}\text { Petición de } \\
\text { comprensión }\end{array}$ & $\begin{array}{l}\text { El hablante rechaza indirectamente la } \\
\text { petición pidiendo al interlocutor que } \\
\text { considere o evalúe los argumentos que le } \\
\text { impiden cumplir con la invitación o la } \\
\text { petición. } \\
\text { Por ejemplo: } \\
\text { a. Si no te importa, creo que me quedaré } \\
\text { en casa. } \\
\text { b. Espero que lo entiendas. }\end{array}$ \\
\hline & $\begin{array}{l}\text { Garantía de satisfacción } \\
\text { futura del interlocutor }\end{array}$ & $\begin{array}{l}\text { El hablante rechaza indirectamente la } \\
\text { petición pidiendo tranquilidad al interlocutor. } \\
\text { Por ejemplo: } \\
\text { a. Te prometo que lo limpio mañana, no te } \\
\text { preocupes. } \\
\text { b. Mañana lo primero que haré será } \\
\text { ordenar, te lo prometo. }\end{array}$ \\
\hline
\end{tabular}




\begin{tabular}{|c|c|c|}
\hline \multirow{4}{*}{ Indirecta } & Autodefensa & $\begin{array}{l}\text { El hablante rechaza indirectamente la } \\
\text { petición defendiéndose a sí mismo y } \\
\text { enfatizando de alguna manera lo que la } \\
\text { petición tiene de injusto. } \\
\text { Por ejemplo: } \\
\text { a. Mira, la verdad es que no entraba dentro } \\
\text { de mis planes esta asignatura. } \\
\text { b. Creo que no la voy a coger. No puede } \\
\text { ser, porque un inglés de ese nivel no } \\
\text { entra dentro de mi especialidad. }\end{array}$ \\
\hline & $\begin{array}{l}\text { Repetición de parte de } \\
\text { la petición }\end{array}$ & $\begin{array}{l}\text { El hablante rechaza indirectamente la } \\
\text { petición repitiendo una porción del discurso } \\
\text { anterior mencionado en la petición o la } \\
\text { invitación del destinatario, que funciona para } \\
\text { distraer la atención lejos del interlocutor y } \\
\text { retrasar el rechazo. } \\
\text { Por ejemplo: } \\
\text { a. ¿A tu boda? } \\
\text { b. La semana que viene ... hum }\end{array}$ \\
\hline & Aplazamiento & $\begin{array}{l}\text { El hablante rechaza indirectamente la } \\
\text { petición posponiendo lo que se pide a un } \\
\text { tiempo posterior inespecífico. } \\
\text { Por ejemplo: } \\
\text { a. Luego lo limpio. } \\
\text { b. Estoy cansado en ahora, lo haré más } \\
\text { tarde. }\end{array}$ \\
\hline & Evasivas & $\begin{array}{l}\text { El hablante rechaza indirectamente la } \\
\text { petición dando una respuesta confusa } \\
\text { vaga, incierta o indecisa. } \\
\text { Por ejemplo: } \\
\text { a. No sé si podré ir, estoy muy ocupada } \\
\text { estos días. } \\
\text { b. Muchas gracias, pero no te lo puedo } \\
\text { confirmar. Tengo trabajo acumulado y } \\
\text { necesito descansar. }\end{array}$ \\
\hline $\begin{array}{l}\text { Adyacentes al } \\
\text { rechazo }\end{array}$ & $\begin{array}{c}\text { Declaración de } \\
\text { opinión/sentimiento } \\
\text { positivo }\end{array}$ & $\begin{array}{l}\text { El hablante rechaza indirectamente la } \\
\text { petición proporcionando expresiones } \\
\text { positivas que indican que el deseo del } \\
\text { hablante es ser capaz de cumplir con la } \\
\text { petición o la invitación. } \\
\text { Por ejemplo: } \\
\text { a. Me gustaría mucho ir pero no puedo } \\
\text { porque ya tenía otros planes. } \\
\text { b. Me encantaría ir, pero entre semana no } \\
\text { puedo hacer planes. }\end{array}$ \\
\hline
\end{tabular}




\begin{tabular}{|c|c|c|}
\hline \multirow{5}{*}{$\begin{array}{l}\text { Adyacentes al } \\
\text { rechazo }\end{array}$} & Declaración de empatía & $\begin{array}{l}\text { El hablante rechaza indirectamente la } \\
\text { petición empatizando con el interlocutor, } \\
\text { mostrando cierta identificación con él y } \\
\text { comprendiendo la situación, sentimientos y } \\
\text { motivos del interlocutor. } \\
\text { Por ejemplo: } \\
\text { a. iEs una lástima, ya me contaréis como } \\
\text { ha ido! } \\
\text { b. iQué pena! No puedo ir, tengo que } \\
\text { estudiar. }\end{array}$ \\
\hline & Uso de muletillas & $\begin{array}{l}\text { El hablante rechaza indirectamente la } \\
\text { petición comenzando su respuesta con } \\
\text { expresiones como "pues, vaya, a ver...". } \\
\text { Por ejemplo: } \\
\text { a. Pues lo siento, pero hoy no voy en esa } \\
\text { dirección. } \\
\text { b. Vaya, es una pena. }\end{array}$ \\
\hline & Agradecimiento & $\begin{array}{l}\text { El hablante rechaza indirectamente la } \\
\text { petición diciendo "gracias" para no ofender } \\
\text { al interlocutor. } \\
\text { Por ejemplo: } \\
\text { a. Muchas gracias, Fernando, pero ya tengo } \\
\text { otros planes. } \\
\text { b. Le agradezco mucho su opinión. }\end{array}$ \\
\hline & $\begin{array}{l}\text { Uso del honorífico de } \\
\text { fórmulas de } \\
\text { tratamiento }\end{array}$ & $\begin{array}{l}\text { Por ejemplo: } \\
\text { a. Profesor... } \\
\text { b. Señor X... }\end{array}$ \\
\hline & $\begin{array}{c}\text { Saludos/despedidas } \\
\text { corteses }\end{array}$ & $\begin{array}{l}\text { Por ejemplo: } \\
\text { a. Buenos días... } \\
\text { b. Hasta luego... }\end{array}$ \\
\hline
\end{tabular}




\section{CAPÍTULO 4}

\section{RESULTADOS Y ANÁLISIS DE DATOS SOBRE}

\section{LA PETICIÓN}

Este capítulo comprende el análisis del acto de habla de petición. El objetivo principal será tratar de identificar las diferencias y las similitudes entre las dos comunidades de habla, española y malaya, en las estrategias empleadas en la formulación de peticiones. Como hemos explicado en el capítulo dedicado a la fundamentación metodológica (véase capítulo 3, apartado 3.6.1), para clasificar las respuestas de los sujetos en la formulación de peticiones hemos utilizado la clasificación de CCSARP (Blum-Kulka, House, y Kasper, 1989), al igual que en el caso del mandato que se va a analizar en el capítulo que sigue. El análisis se ha realizado, por tanto, en términos de actos principales y movimientos de apoyo. En primer lugar, los datos se han analizado estadísticamente, haciendo una interpretación adecuada de la comparación entre las respuestas de 
los diferentes grupos de hablantes, y, posteriormente, se ha realizado un análisis del contenido (análisis cualitativo) de las peticiones formuladas en dichas respuestas.

\subsection{Análisis cuantitativo}

En este apartado vamos a exponer, en primer lugar, la distribución estadística general de las estrategias aplicadas por los participantes en la formulación del acto de habla de petición. A continuación, expondremos el análisis de las respuestas facilitadas por los participantes en las seis situaciones que conforman el cuestionario. Los datos fueron examinados teniendo en cuenta, por un lado, los actos principales, y, por otro, los movimientos de apoyo.

\subsubsection{Análisis general}

El análisis contrastivo en la frecuencia del empleo de ciertas estrategias en la expresión de la petición, lo hemos subdividido en tres secciones. En la primera, se presentan de manera general las diferencias entre los dos grupos principales, español y malayo. A continuación, se investigan las diferencias entre los subgrupos de 
edad, mayor y menor. En la parte final, se muestran las diferencias entre varones y mujeres en ambas culturas.

\subsubsection{Español frente a malayo}

En conjunto, y como respuesta a las seis situaciones establecidas, los sujetos españoles produjeron un total de 1.430 enunciados, de los que un $25 \%(n=363)$ fueron actos principales y un $75 \%(n=$ 1.067), movimientos de apoyo. Por su parte, los sujetos malayos formularon un total de 1.471 enunciados, de los que también un $25 \%(n=365)$ fueron actos principales y un $75 \%(n=1.106)$, movimientos de apoyo.

Empezaremos nuestro análisis por la frecuencia de los enunciados que corresponden a los actos principales, y teniendo en cuenta los tres tipos de estrategias de petición establecidos según el grado de (in)dirección: "Directas", "Convencionalmente indirectas" y "No convencionalmente indirectas". Los datos recogidos muestran que, tanto los españoles como los malayos, tendieron, en su mayoría, a utilizar las formas convencionales indirectas (el $65 \%$ de los enunciados españoles y el $66 \%$ de los malayos), seguidas de las formas directas (el $22 \%$ por el $25 \%$ ), y de formas indirectas no convencionales, (el $13 \%$ y el $9 \%$, respectivamente). Esta distribución 
es parecida a la obtenida en estudios de naturaleza similar efectuados con actos directivos en inglés. Así ocurre, por ejemplo, en el proyecto CCSARP, según citan Blum-Kulka, House y Kasper (1989: 125). La figura 1, que presentamos a continuación, refleja la distribución del uso de dichas estrategias en las intervenciones de los hablantes de cada una de las culturas estudiadas.

Figura 1. Distribución del número de enunciados según los tres grandes tipos de estrategias de petición aplicadas a los actos principales en ambas culturas

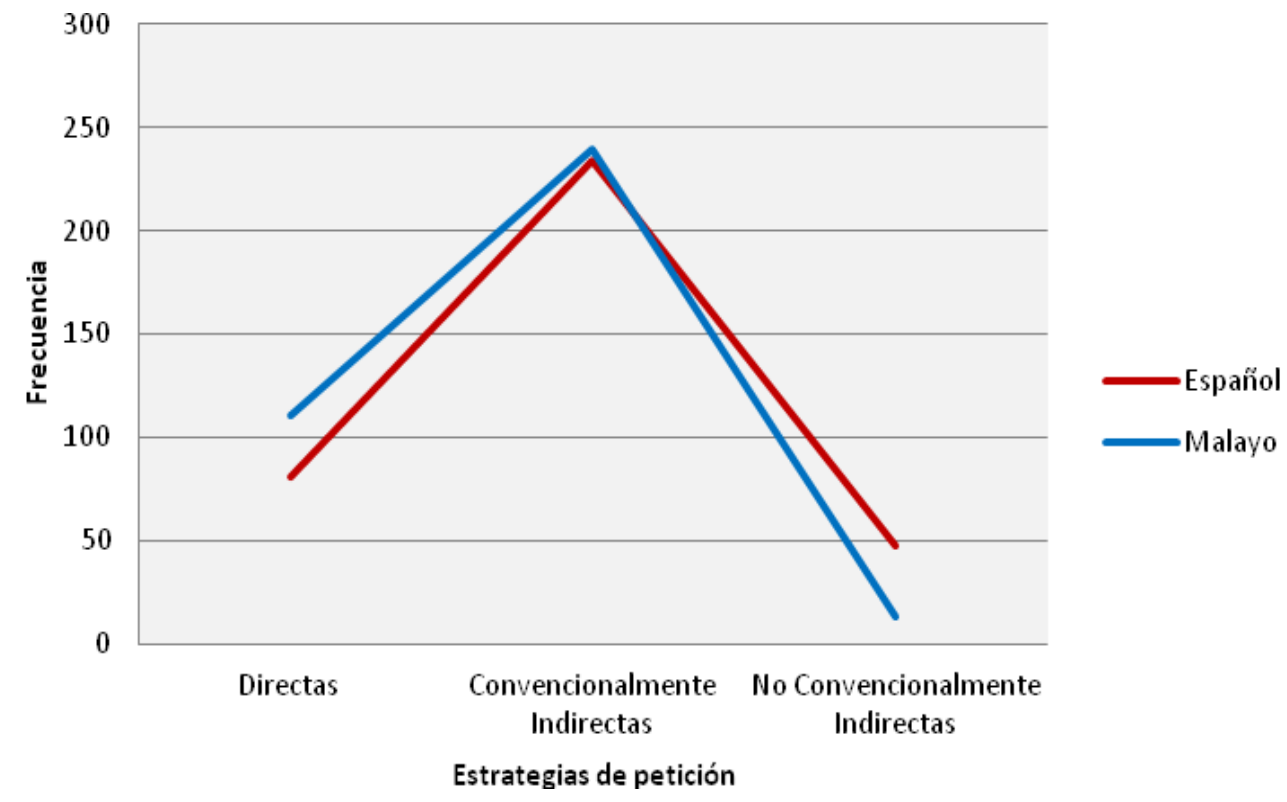

Los sujetos españoles utilizaron menos estrategias "Directas" que los malayos (81 casos españoles frente a 111 malayos). Además, los españoles aplicaron menos estrategias "Convencionalmente indirectas" (234 enunciados españoles y 240 malayos). Sin embargo, los españoles emplearon un mayor número 
de estrategias "No convencionalmente indirectas" que los malayos (47 enunciados, en comparación con 13 de los malayos). En la comparación de los promedios de las categorías aplicadas se halló una diferencia significativa: $X^{2}=24.025 p=.000(p<.05)$.

Por otro lado, al analizar los datos de nuestra investigación aplicando la sub-clasificación de las estrategias de petición establecida por Blum-Kulka, que abarca de las más directas a las más indirectas (véase el capítulo 3), obtuvimos los resultados que aparecen en la siguiente figura:

Figura 2. Distribución de los enunciados entre las nueve estrategias de petición (actos principales) en ambas culturas

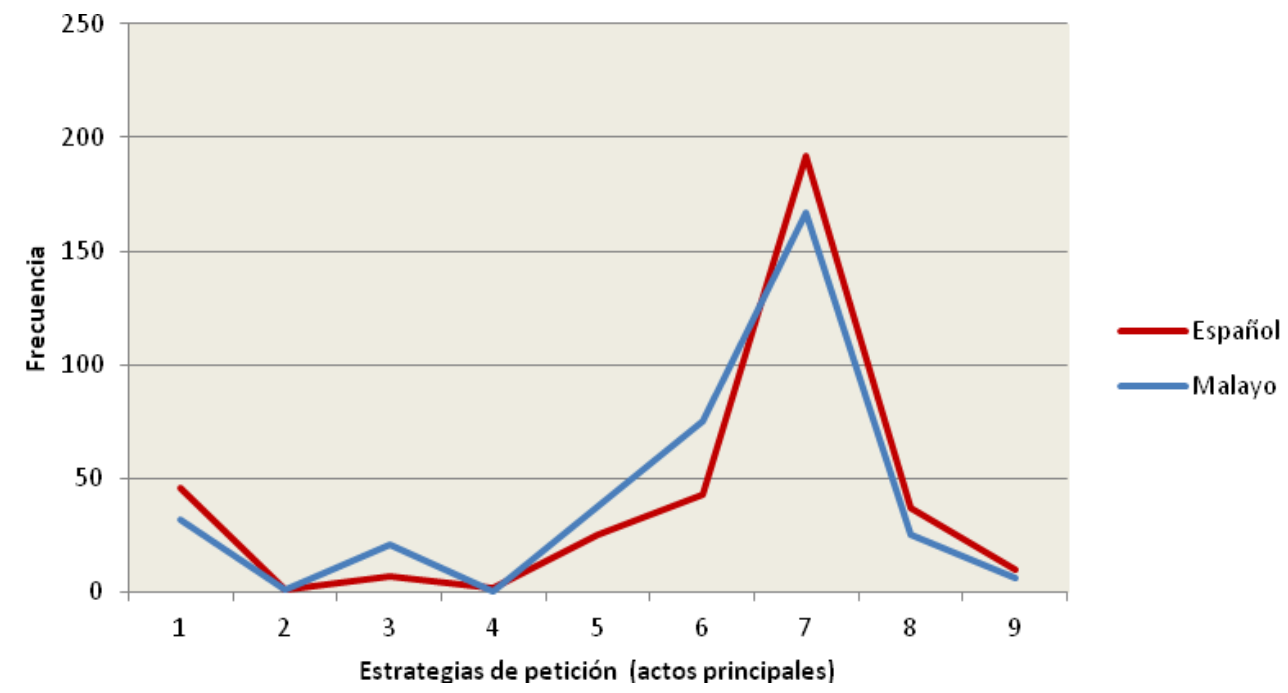

1.Imperativo 2.Performativo 3.Performativo evasivo 4.Declaración de obligación 5.Declaración de deseo 6.Fórmula de sugerencia 7.Interrogación preparatoria 8. Indicio fuerte 9. Indicio suave 
Los datos reflejados en la figura muestran que en las dos sociedades los informantes prefirieron expresar sus peticiones a través de enunciados en los que se emplea una "Interrogación preparatoria" (192 de los españoles y 167 de los malayos). En el caso de los sujetos españoles, la segunda estrategia más utilizada fue el modo "Imperativo" (46 veces), seguida del uso de una "Fórmula de sugerencia" (43 veces) y de un "Indicio fuerte" (37 veces). En el caso de los sujetos malayos, las estrategias más utilizadas, por detrás del "Interrogación preparatoria", fueron la de "Fórmula de sugerencia" (75 veces), "Declaración de deseo" (38 veces) y el uso del "Modo por defecto" (32 veces). Hay que señalar, además que la estrategia de "Declaración de obligación" no apareció en los datos malayos, pero en los datos españoles se utilizó en dos ocasiones.

Las diferencias estadísticamente más llamativas entre los sujetos de ambas sociedades aparecen en el uso de la estrategia de "Fórmula de sugerencia" (los españoles recurrieron a ella 43 veces, en comparación con los 75 ejemplos de los malayos), la de "Interrogación preparatoria" (192 casos españoles por 167 de los malayos), y la de "Performativo evasivo" (tan solo 7 registros de los españoles frente a 21 de los malayos). El contraste de los promedios entre las estrategias empleadas en los actos principales mostró una diferencia significativa: $X^{2}=58.799 p=.000(p<.05)$. 
En cuanto a los movimientos de apoyo, los sujetos de ambas lenguas aplicaron 16 estrategias diferentes para modificar la intensidad ilocutiva de sus peticiones. En la figura 3, que aparece a continuación, se expone la distribución de uso de dichas estrategias.

Figura 3. Distribución del número de enunciados según el tipo de estrategia empleada en los movimientos de apoyo en ambas culturas

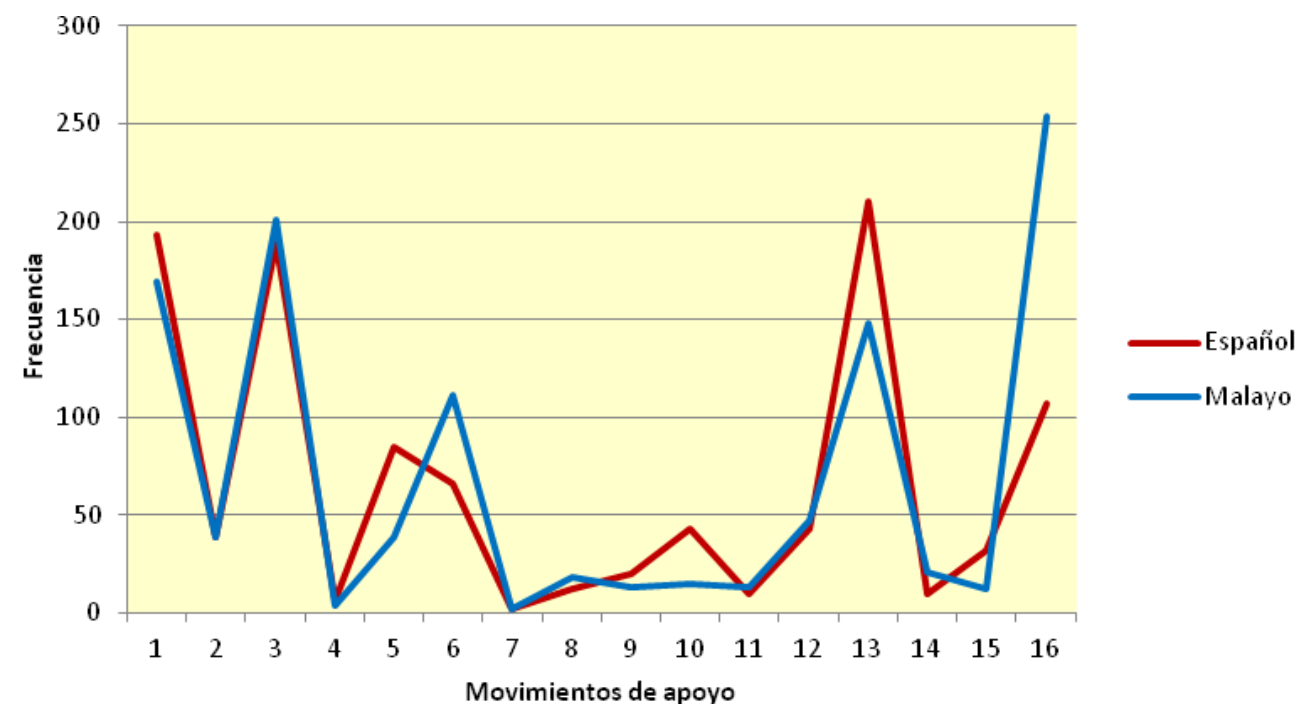

1.Fórmulas de preparación 2.Búsqueda de un compromiso 3.Razones 4.Previsión de objeciones 5.Promesa de recompensa/reparación 6.Minimización de la imposición 7.Invocación de principios generales 8. Reconocimiento de la imposición 9.Preocupación 10.Apreciación 11.Promesa de devolución 12.Gravedad/urgencia 13.Presentación/saludo 14.Petición de la opinión del oyente 15.Disculpa 16.Fórmulas de tratamiento

Los españoles prefirieron, en orden decreciente de frecuencia (solo se mencionan las cuatro más comúnmente utilizadas), la estrategia de "Presentación/saludo" en primer lugar (con una frecuencia de 210 veces), la de "Fórmulas de preparación" en segundo lugar (193 veces), la opción de "Razones" en el tercero 
(189), y la de "Fórmulas de tratamiento", en último lugar (107 veces). En las respuestas de los malayos, en cambio, predomina el uso de la estrategia de "Fórmulas de tratamiento" (254 veces), seguida de la de "Razones" (201 veces), la de "Fórmulas de preparación" (169 veces), y la de "Presentación/saludo" (148 veces). La estrategia de "Invocación de principios generales" fue la menos utilizada por los sujetos de los dos grupos culturales estudiados (solamente 2 veces en cada caso).

Así pues, las estrategias en cuyo uso se refleja una diferencia más notable en las intervenciones de los hablantes de una y otra cultura son las cinco siguientes:

- Fórmulas de tratamiento: fue la preferida por los informantes malayos, con una gran diferencia respecto a los españoles (254 y 107 enunciados, respectivamente)

- Presentación/saludo: los hablantes españoles fueron los que la usaron con mayor frecuencia (210 veces frente a 148 de los malayos)

- Promesa de recompensa/reparación: también más utilizada por los españoles ( 85 casos frente a los 39 de los malayos)

- Minimización de imposición: los informantes malayos la emplearon en una proporción más elevada (111 ejemplos por 66 de los españoles) 
- Apreciación: los españoles la utilizaron en mayor medida que los malayos (45 y 15 veces, respectivamente)

La diferencia entre los promedios de las estrategias de los movimientos de apoyo aplicados fue significativa: $X^{2}=130.569$ $\mathrm{p}=.000(\mathrm{p}<.05)$.

Otro posible punto de vista del análisis de datos es el que tiene en cuenta las estrategias empleadas por los hablantes de las dos culturas en cada situación individual. Los resultados obtenidos en relación al número de enunciados producidos como actos principales en cada contexto presentado en el cuestionario, son los que aparecen representados en la gráfica de la figura 4.

Figura 4. Distribución del número de enunciados producidos como actos principales en las seis situaciones por los hablantes de ambas culturas

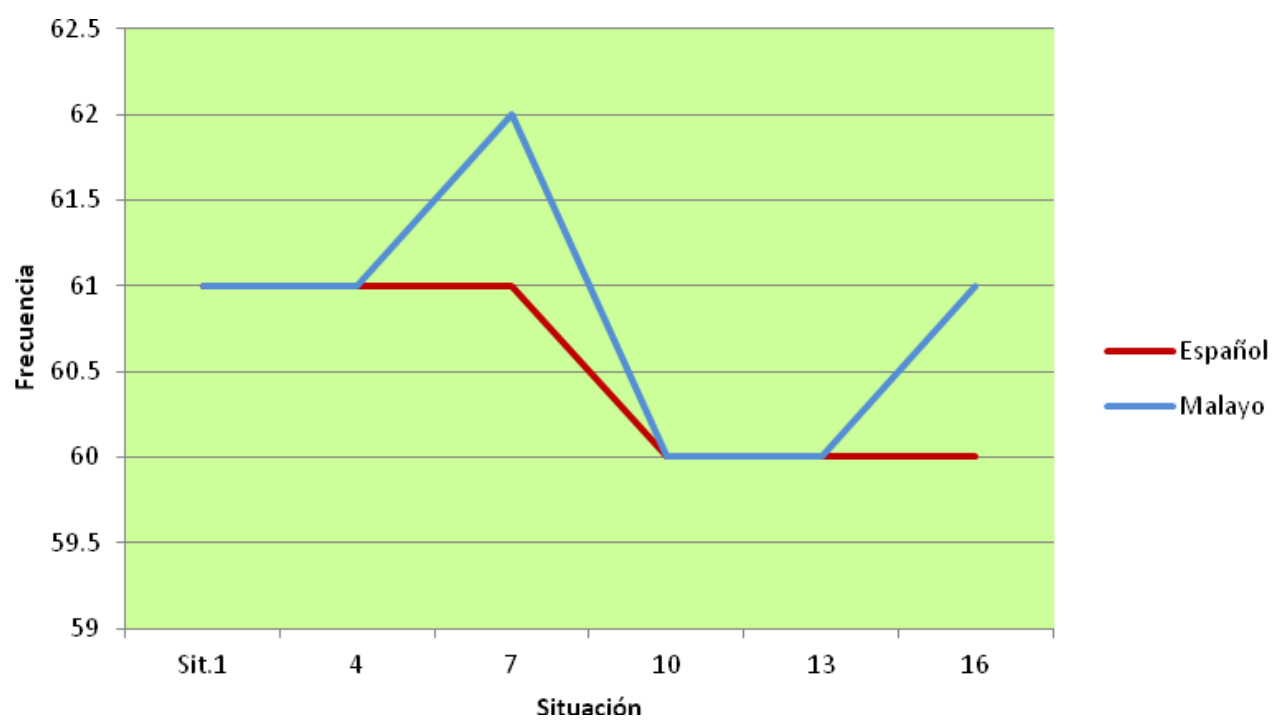


Los sujetos que participaron en el presente experimento, tal y como muestra la tabla, no mostraron diferencias relevantes en el número de enunciados formulados en cada contexto, ya que la frecuencia fue muy similar en las seis situaciones. Sin embargo, al tener en cuenta la clasificación de las estrategias de petición utilizadas en "Directas", "Convencionalmente indirectas" y "No convencionalmente indirectas", sí que aparecen algunas variaciones entre las dos culturas investigadas, algo que también ocurre al clasificar los enunciados de cada situación establecida para provocar la petición. La distribución de dichos datos se muestra en la figura 5.

Figura 5. Distribución de los enunciados según los tres tipos de estrategias de petición en las seis situaciones en ambas culturas

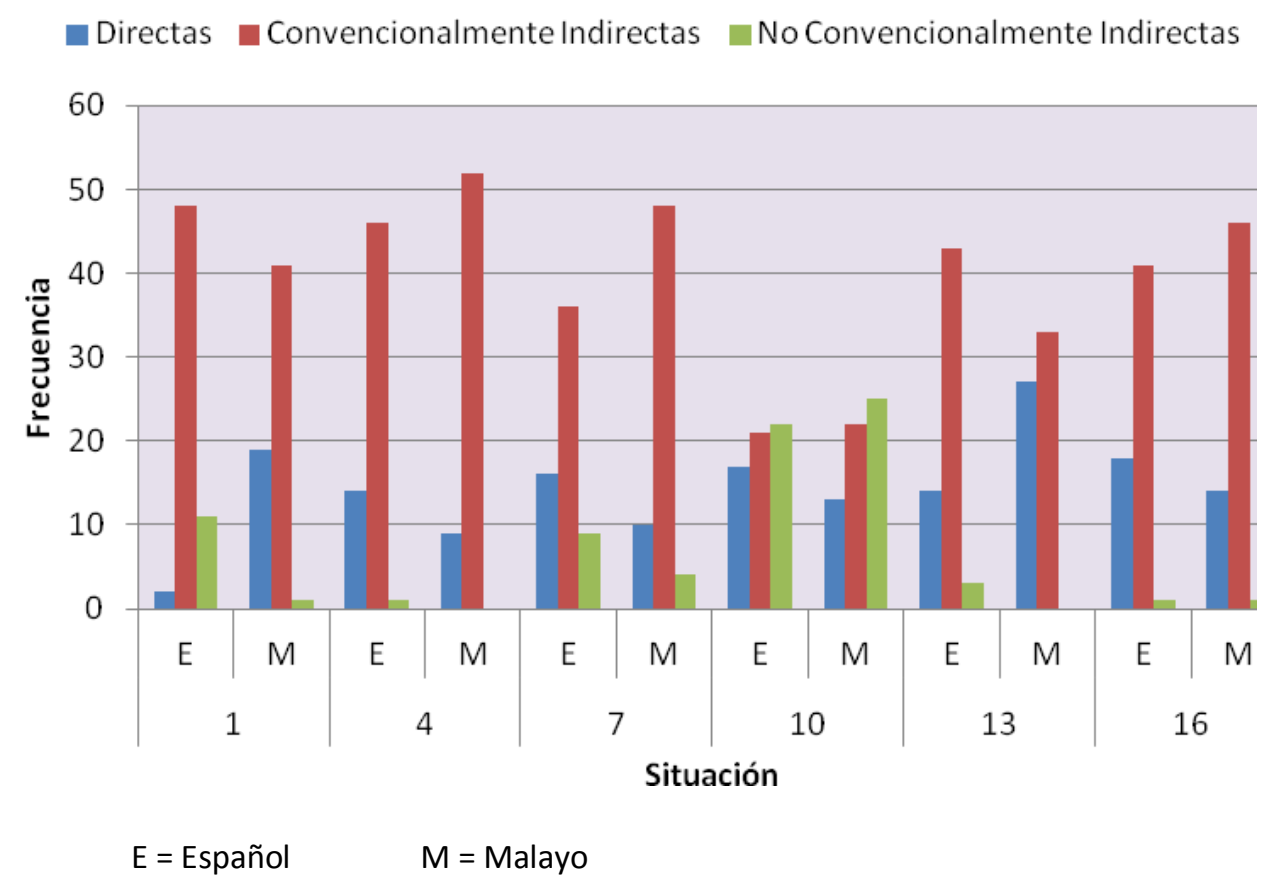


La diferencia más significativa se da, en las seis situaciones, entre el uso de estrategias "Directas" y "No convencionalmente indirectas". Pero los sujetos de las dos culturas mostraron un patrón bastante similar con respecto al uso de las estrategias "Convencionalmente indirectas". En lo que atañe a las "Directas", los españoles recurrieron a ellas con mayor frecuencia en la situación 16 (18 veces), en la que el sujeto pide a un amigo que le preste su móvil, mientras que los malayos las utilizaron en mayor proporción en la situación 1 (19 veces), cuando el informante pide a un vecino que le preste prestada una escalera. En el caso de las estrategias "Convencionalmente indirectas", es en la situación 1 en la que aparecen en mayor medida en los enunciados de los españoles (48 veces). Por su parte, en el grupo malayo, es en la situación 4 en la que el hablante le pide a un compañero de piso que lo acompañe a comprar, donde aparecen con mayor frecuencia (52 veces). Respecto a la tercera categoría, es decir, las estrategias "No convencionalmente indirectas", los nativos de ambas culturas las utilizaron en mayor medida en la situación 10, es decir, al pedir a un profesor universitario una carta de recomendación (22 casos en los informantes españoles y 25 en los malayos).

Por lo que refiere a la utilización de los movimientos de apoyo, el patrón de uso es bastante diferente en las respuestas de 
los sujetos de cada país en cada situación. Los datos correspondientes aparecen recogidos en la figura 6.

Figura 6. Distribución de enunciados (en número) producidos como movimientos de apoyo en cada situación en ambas culturas

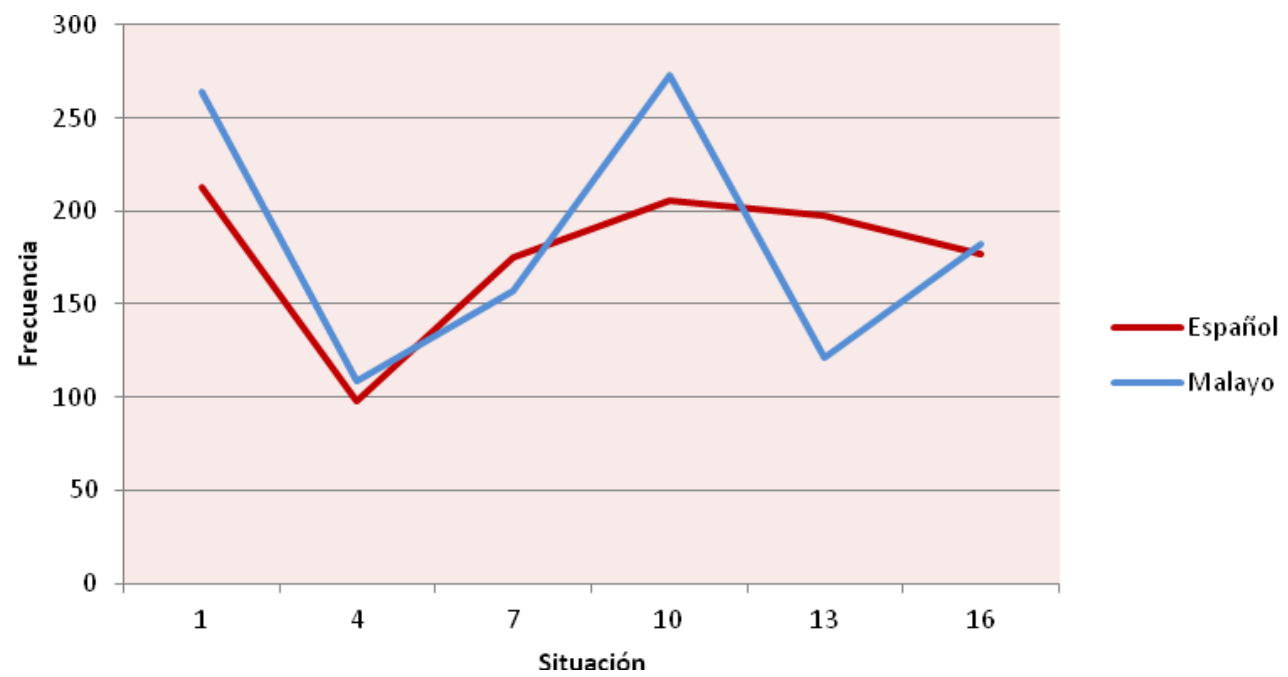

Los españoles utilizaron más movimientos de apoyo que los malayos en dos situaciones, 7 y 13, y menos en la $1,4,10$ y 16 . Es en la situaciones 1,10 y 13 donde se puede ver una mayor diferencia en las producciones de los dos grupos. Así, en la situación 1, que es, de las seis propuestas, en la que más enunciados han producido los españoles, encontramos 264 ejemplos en malayo, pero 213 en español; en la situación 10, en la que los malayos se han mostrado más productivos, se han registrado 273 enunciados en malayo y 206 en español, y, en la situación 13, se han recogido 121 de los malayos frente a 198 de los españoles. En ambos grupos culturales el menor índice de frecuencia está en las respuestas dadas 
para la situación 4, con 109 enunciados en malayo, y 98 en español. Hubo una diferencia significativa entre los promedios de los enunciados producidos en las diferentes situaciones proporcionadas: $X^{2}=25.846 p=.000(p<.05)$.

\subsubsection{Mayor frente a menor}

En el análisis de datos realizado tomando como criterio la variable de edad, el resultado estadístico de las estrategias utilizadas por los sujetos encuestados para llevar a cabo el acto de habla de petición muestra un patrón muy similar en los dos subgrupos de edad de ambas culturas.

En el caso de los hablantes de español, de los 763 enunciados producidos por los hablantes de más edad, un $24 \%$ ( $n=$ 181) fueron actos principales y un $76 \%(n=582)$, movimientos de apoyo. Los jóvenes por su parte, produjeron un total de 667 enunciados, de los que un $27 \%(n=182)$ fueron actos principales y un $73 \%(n=485)$, movimientos de apoyo.

En el grupo de hablantes de la cultura malaya, los participantes de mayor edad formularon un total de 776 enunciados, de los que un $24 \%$ ( $n=183)$ fueron actos principales y un $76 \%$ ( $n=$ 
593), movimientos de apoyo. En las producciones de los de menos edad, encontramos un total de 695 enunciados, con actos principales en un $26 \%$ ( $n=182)$ de los casos, y con movimientos de apoyo en un $74 \%(n=513)$. As en general, los hablantes mayores de las dos culturas produjeron más enunciados que los menores al realizar la petición.

Para llevar a cabo el análisis, dentro del grupo de enunciados que funcionan como actos principales, se ha establecido una primera clasificación de estrategias de petición basada en el mayor o menor grado de (in)dirección. De esta forma, en el análisis de los enunciados de cada subgrupo, en ambas culturas, se han obtenido los siguientes resultados:

Figura 7. Distribución de enunciados según el grado de (in)dirección de las estrategias de petición empleadas por cada subgrupo de edad

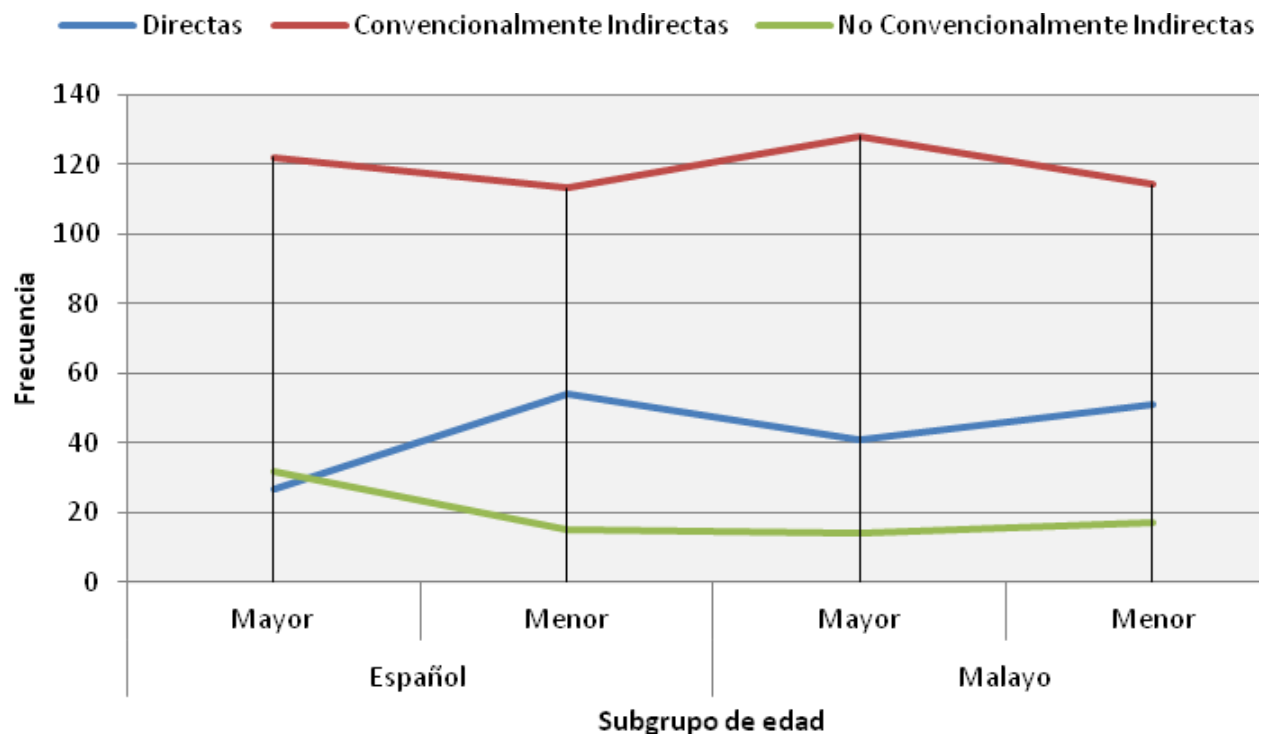


En ambas culturas los sujetos de los dos subgrupos, excepto los mayores españoles, prefirieron emplear las formas "Convencionalmente indirectas", seguidas de formas "Directas" y de formas "No convencionalmente indirectas". Los mayores del grupo español también prefirieron utilizar las formas "Convencionalmente indirectas" en primer lugar, pero la segunda preferencia fueron las formas "No convencionalmente indirectas", mientras que las formas "Directas" fueron las que menos veces se utilizaron.

Como se aprecia en el resultado presentado, pese a que ambos subgrupos hayan mostrado preferencia por dichas categorías, fueron los españoles de más edad los que mostraron mayor tendencia a emitir peticiones de tipo "Convencionalmente indirecto" $y$ "No convencionalmente indirecto", con un número de muestras de 122, frente a 113 de los jóvenes, en el primer caso, y 32 en los mayores por 15 en los menores, en el segundo, y utilizaron menos estrategias "Directas" que los jóvenes ( 27 y 54, respectivamente). En lo que respecta a los hablantes malayos, los participantes mayores produjeron más enunciados con estrategias "Convencionalmente indirectas" (128, frente a las 114 del otro subgrupo), pero menos con formas "Directas" y "No convencionalmente indirectas" que los menores (41 casos, en comparación con 51 de los sujetos menores, en el primer caso, y 14 por 17 , en el segundo). Por último, hay que mencionar que la comparación de los promedios de las categorías 
empleadas indicó una diferencia significativa tanto en el grupo español: $X^{2}=15.412 p=.000(p>.05)$, como en el malayo: $X^{2}=7.118$ $p=.028(p>.05)$.

En cuanto a las nueve sub-categorías establecidas para el análisis de las estrategias empleadas en los actos principales de petición según el grado de (in)dirección, todos los subgrupos mostraron la misma preferencia por la de "Interrogación preparatoria" para realizar la petición. La figura 8 que se presenta a continuación, muestra la distribución de las estrategias empleadas por todos los subgrupos de ambas culturas.

Figura 8. Distribución de enunciados según las estrategias aplicadas en los actos principales (9 categorías)

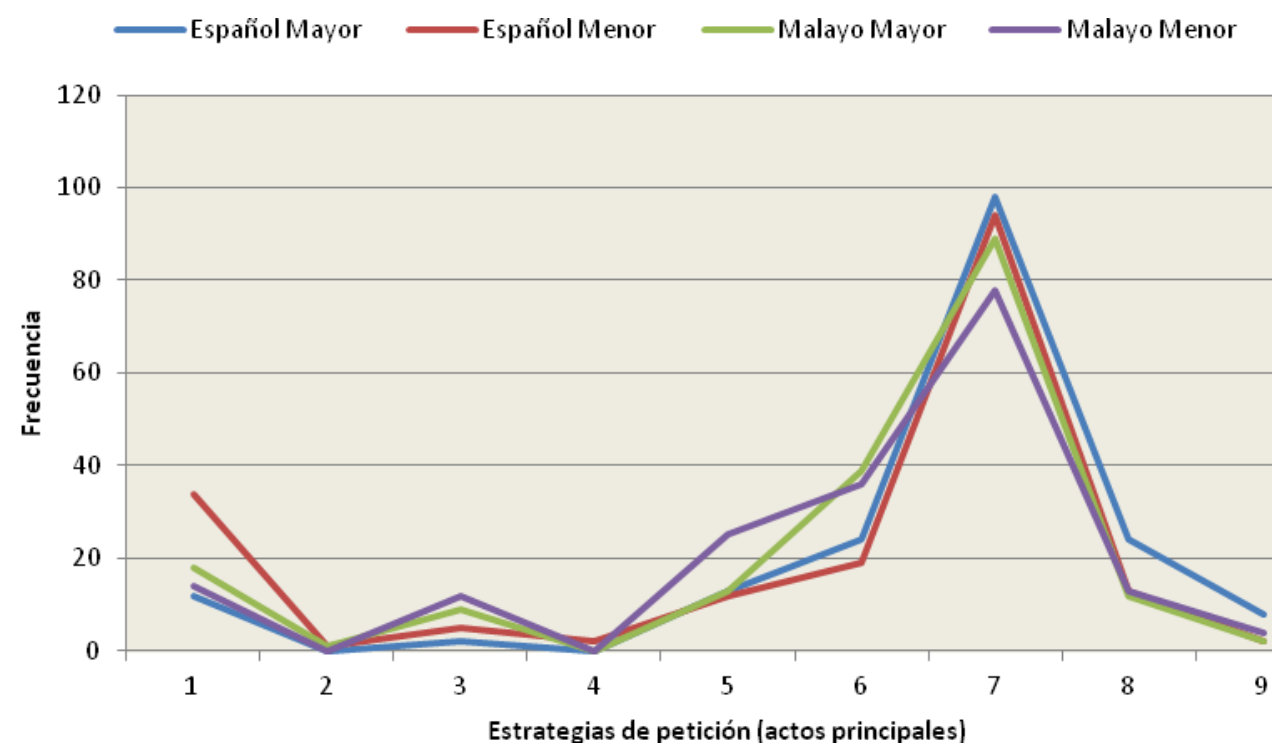

1.Imperativo 2.Performativo 3.Performativo evasivo 4.Declaración de obligación 5.Declaración de deseo 6.Fórmula de sugerencia 7.Interrogación preparatoria 8. Indicio fuerte 9.Indicio suave 
La mayoría de los enunciados se concentró en la categoría de "Interrogación preparatoria". En el subgrupo de hablantes españoles mayores, en cuyas respuestas utilizan siete tipos de estrategia diferentes, además de la estrategia de "Interrogación preparatoria", las más utilizadas, por orden de frecuencia, fueron "Fórmula de sugerencia", "Indicio fuerte", "Declaración de deseo", "Imperativo", "Indicio suave" y "Performativo evasivo". Las estrategias de "Performativo" y "Declaración de obligación" no aparecieron en los datos de dicho subgrupo. Los jóvenes españoles por su parte, utilizaron todas y cada una de las nueve estrategias de la matriz de clasificación, pero la frecuencia de uso de cada una de ellas fue diferente a la del grupo de mayores. Así, por ejemplo, emplearon con mayor frecuencia la estrategia de "Interrogación preparatoria", seguida, en este orden, de "Imperativo", "Fórmula de sugerencia", "Indicio fuerte", "Declaración de deseo", "Performativo evasivo", "Declaración de obligación", "Indicio suave" y "Performativo".

Por otro lado, en el grupo malayo, además de la estrategia de "Interrogación preparatoria", los encuestados de más edad usaron otras siete, que fueron, por orden de frecuencia, las siguientes: "Fórmula de sugerencia", "Imperativo", "Declaración de deseo", "Indicio fuerte", "Performativo evasivo", "Indicio suave", y "Performativo"; en ningún caso recurrieron a la estrategia de 
"Declaración de obligación". Los participantes menores, por su parte, utilizaron siete de las estrategias, mostrando preferencia por la de "Interrogación preparatoria", seguida de "Fórmula de sugerencia", "Declaración de deseo", "Imperativo", "Indicio fuerte", "Performativo evasivo" e "Indicio suave". Ningún menor malayo recurrió a las estrategias de "Performativo" y "Declaración de obligación".

Al comparar entre los subgrupos de edad los promedios de las estrategias aplicadas, la diferencia fue significativa en ambos grupos: $X^{2}=22.380 p=.004(p<.05)$, en el grupo español, $y$ en el grupo malayo: $X^{2}=14.980 \mathrm{p}=.036(\mathrm{p}<.05)$.

Por otro lado, en el análisis de las estrategias aplicadas en los enunciados producidos como movimientos de apoyo en las respuestas de los hablantes de los dos subgrupos de edad de cada cultura, obtuvimos los datos que aparecen en la figura 9. 
Figura 9. Distribución de los enunciados (movimientos de apoyo) según las estrategias utilizadas por los hablantes de los cuatro subgrupos en ambas culturas

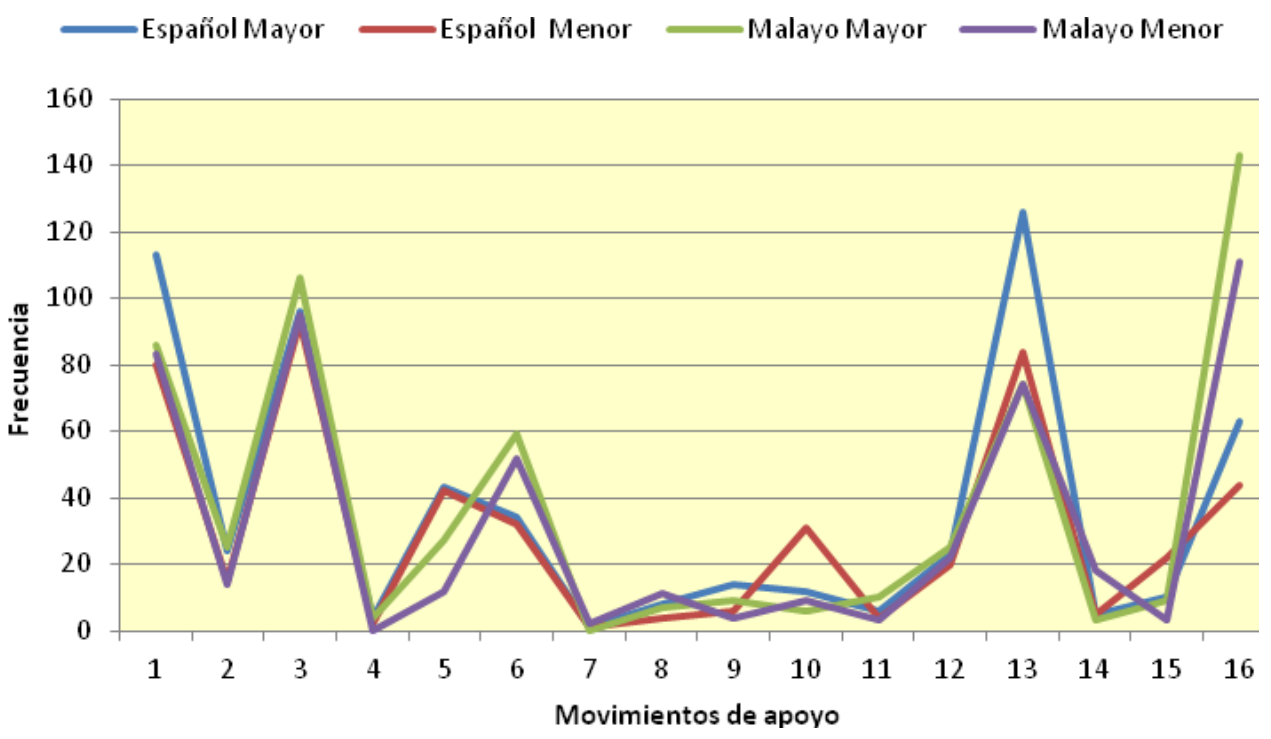

1.Fórmulas de preparación 2.Búsqueda de un compromiso 3.Razones 4.Previsión de objeciones 5.Promesa de recompensa/reparación 6.Minimización de la imposición 7.Invocación de principios generales 8. Reconocimiento de la imposición 9.Preocupación 10.Apreciación 11.Promesa de devolución 12.Gravedad/urgencia 13.Presentación/saludo 14.Petición de la opinión del oyente 15.Disculpa 16. Fórmulas de tratamiento

Los sujetos de los cuatro subgrupos utilizaron estrategias relativamente variadas en los movimientos de apoyo. La más comúnmente usada por los españoles del subgrupo de más edad fue la de "Presentación/saludo", mientras que la que menos veces aparece en sus intervenciones es la de "Invocación de principios generales". Los sujetos más jóvenes, por su parte, optaron más frecuentemente por la estrategia de "Razones", y la menos utilizada en sus respuestas, como en el caso de los mayores, fue la de "Invocación de principios generales". 
Los subgrupos malayos comparados coincidieron en utilizar mayoritariamente la estrategia de "Fórmulas de tratamiento". Sin embargo, la estrategia menos empleada en ambos subgrupos fue diferente, de manera que la estrategia menos utilizada por los encuestados de más edad fue la de "Petición de la opinión del oyente", mientras que los jóvenes casi no recurrieron a la de "Invocación de principios generales" (que no fue utilizada por ninguno de los mayores). En los datos de los jóvenes, en cambio, no encontramos ningún ejemplo de estrategia de "Previsión de objeciones".

Analizando con más detalle cada caso, nos damos cuenta de que las diferencias más destacadas estadísticamente entre los sujetos mayores y menores españoles se dan en seis estrategias: "Fórmulas de preparación" (113 registros de los mayores frente a solo 80 de los menores), "Preocupación" (14 de los mayores en comparación con 6 de los menores), "Apreciación" (12 de los mayores por 31 de los menores), "Presentación/saludo" (126 de los mayores frente a 84 de los menores), "Disculpa" (solo 10 de los mayores, en contraste con 22 de los menores) y "Fórmulas de tratamiento" (63 y 44, respectivamente). Por otro lado, en los datos malayos los dos subgrupos de edad difirieron notablemente en el uso de las estrategias de "Promesa de recompensa/reparación" (27 enunciados de los sujetos mayores en comparación con 12 de los 
menores), "Preocupación" (9 de los mayores frente a 4 de los menores), "Promesa de devolución" (encontramos 10 en los mayores por 3 en los menores), "Petición de la opinión del oyente" (tan solo 3 registros de los mayores frente a 18 de los menores), "Disculpa" (9 de los mayores en contraste con solo 3 de los menores) y "Fórmulas de tratamiento" (143 y 111, respectivamente). Por último, hemos de decir que, en los promedios de las estrategias aplicadas en los movimientos de apoyo por los hablantes de los distintos subgrupos de edad, la diferencia fue significativa en los datos de los dos países: $X^{2}=29.746 \mathrm{p}=.013 \quad(\mathrm{p}<.05)$ en el español, y $X^{2}=35.486 \mathrm{p}=.002$ $(p<.05)$.

\subsubsection{Varón frente a mujer}

Los resultados del análisis realizado tomando como referencia la variable de sexo, demuestran que tanto hombres como mujeres, en ambas sociedades, optaron, de manera preferente, por las estrategias de petición "Convencionalmente indirectas", seguidas de las "Directas" y las "No convencionalmente indirectas", en último lugar. Tanto los varones españoles como los malayos utilizaron menos enunciados que las mujeres, para hacer la petición. Los varones del grupo español produjeron un total de 675 enunciados a lo largo de las seis situaciones del cuestionario, de los que un $27 \%$ 
( $n=182)$ fueron actos principales y un $73 \%(n=493)$, movimientos de apoyo. De las respuestas de las mujeres se extrajeron un total de 755 enunciados, de los que un $24 \%$ ( $n=181)$ eran actos principales y un $76 \%(n=574)$, movimientos de apoyo.

En la sociedad malaya, los varones formularon un total de 703 enunciados, de los que un $26 \%(n=184)$ fueron actos principales y un 74\% $(n=519)$, movimientos de apoyo. Las mujeres, por su parte, produjeron un total de 768 enunciados, de los que un $24 \%(n=181)$ fueron actos principales y un $76 \%(n=587)$, movimientos de apoyo.

Por otra parte, al prestar atención al grado de (in)dirección de las estrategias de petición utilizadas por los hablantes de cada género en ambas sociedades, se obtuvieron los resultados que ofrecemos a continuación, en la figura 10. 
Figura 10. Distribución de los enunciados (actos principales) según las estrategias de petición utilizadas por los hablantes de los dos sexos en ambas culturas

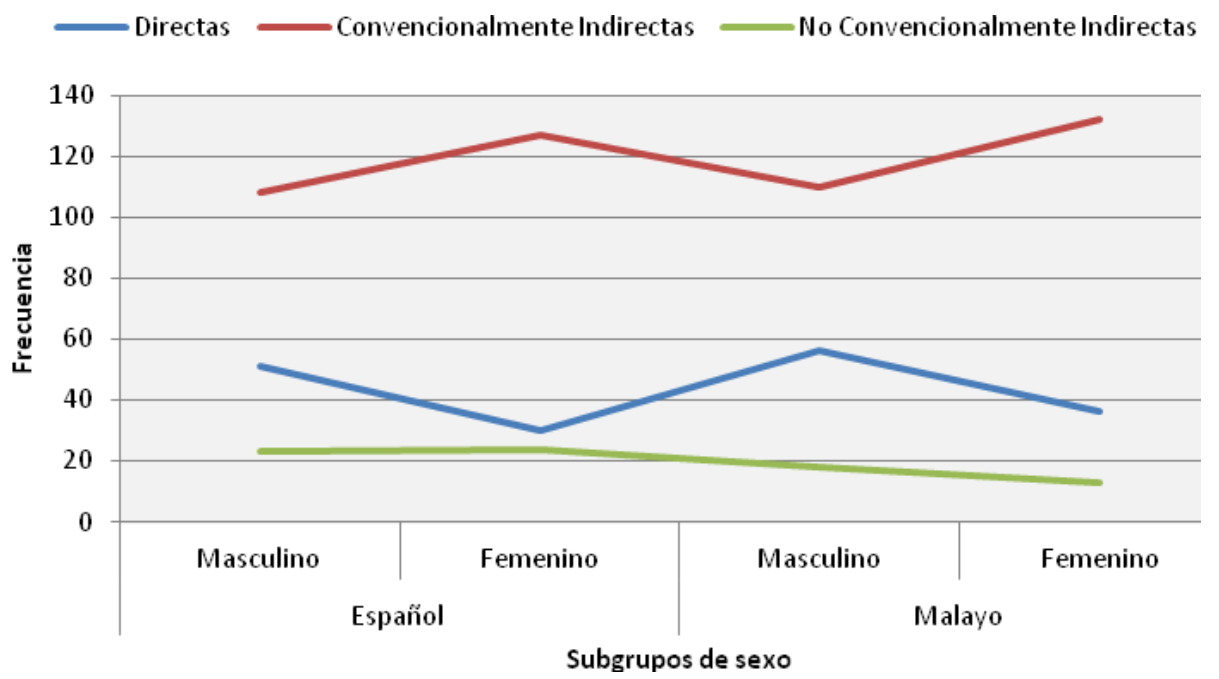

Los varones de ambos grupos utilizaron formas "Directas" en mayor medida que las mujeres (encontramos 51 ejemplos de los varones y 30 de las mujeres, en el grupo español, y 56 de los varones y 306 de las mujeres en el grupo malayo). En cuanto a las formas "Convencionalmente indirectas", las mujeres de los dos grupos las emplearon más que los varones (127 casos registrados en los datos de las mujeres por 108 en los de los varones en el primer grupo, y 132 frente a 110, respectivamente, en el segundo). El tercer tipo de estrategias, las "No convencionalmente indirectas", los participantes de ambos géneros de cada cultura las utilizaron casi con la misma frecuencia ( 23 enunciados de los hombres y 24 de las mujeres, en la cultura española, y 18 por 13 , respectivamente, en la malaya). Al igual que ocurrió en el caso de los subgrupos de edad, en este caso, la comparación de los promedios de las categorías 
empleadas también indicó una diferencia significativa en ambas sociedades: $X^{2}=7.175 p=.028(p>.05)$ en el grupo español, mientras que: $X^{2}=6.289 p=.043(p>.05)$ en el grupo malayo.

Al clasificar las estrategias utilizadas por los hablantes en los actos principales siguiendo las nueves categorías de Blum-Kulka (véase capítulo 3), se observa que en cada grupo hubo tendencia por parte de ambos sexos a utilizar más la de "Interrogación preparatoria", al formular la petición. La figura 84 que presentamos a continuación, expone la distribución de las estrategias a las que recurrieron los sujetos de cada género de los dos grupos culturales en la producción de actos principales.

Figura 11. Distribución de enunciados según estrategias empleadas en actos principales por los hablantes de los dos géneros en ambas culturas

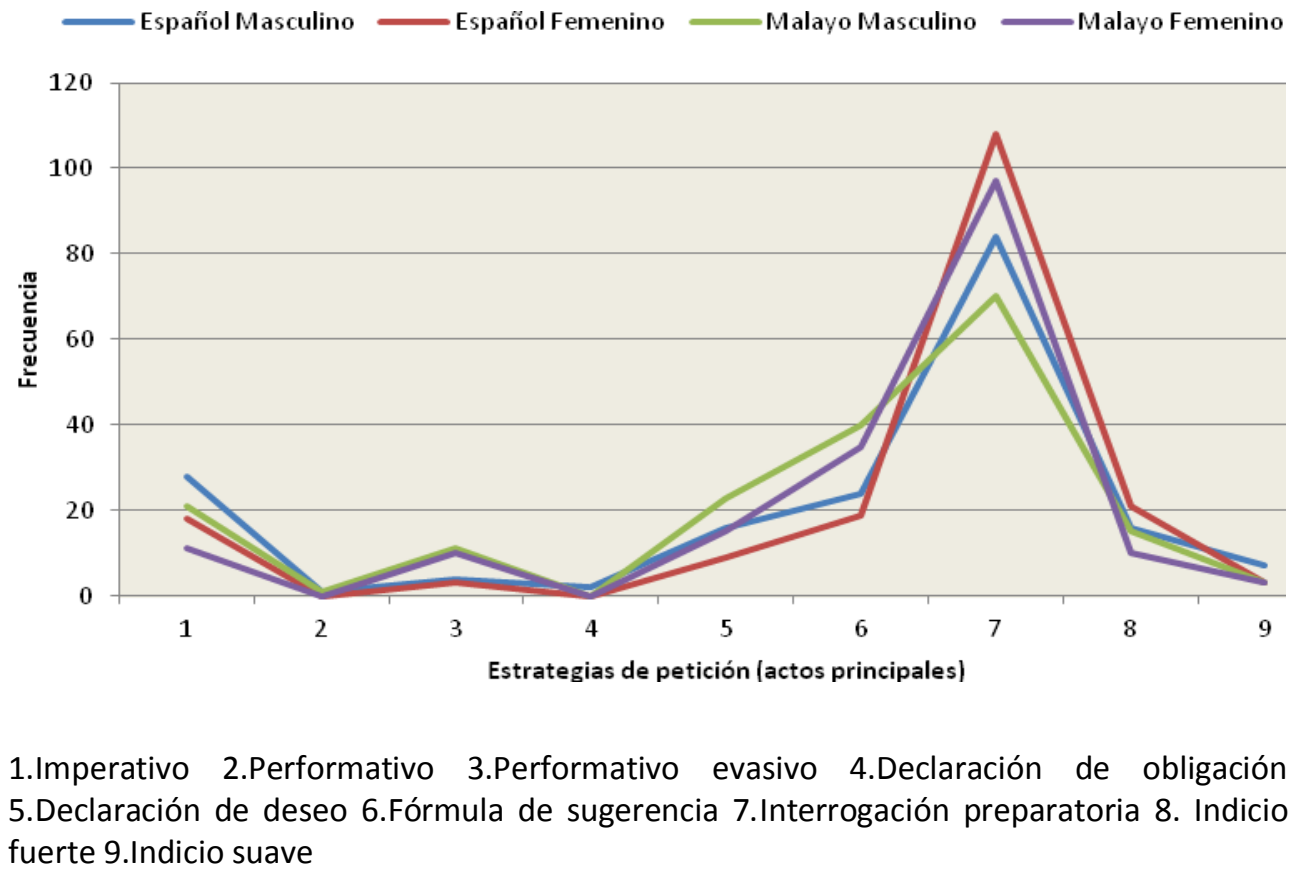


Los datos de la grafica reflejan que los varones españoles sí utilizaron las nueve estrategias, mientras que las mujeres optaron solo por siete (no utilizaron la estrategia de "Performativo" ni la de "Declaración de obligación").

Las estrategias que utilizaron más los varones españoles en comparación con las mujeres de su misma cultura, fueron las de "Imperativo" (28 enunciados de los varones y 18 de las mujeres), "Performativo evasivo" (4 y 3, respectivamente), "Declaración de deseo" (16 de los varones frente a 9 de las mujeres), "Fórmula de sugerencia" (24 enunciados recogidos de los varones por 19 de las mujeres) e "Indicio suave" (7 y 3 respectivamente). Respecto a las estrategias de "Interrogación preparatoria" e "Indicio fuerte", se presentaron con mayor frecuencia en las respuestas de las mujeres que en las de los varones (la primera en 108 enunciados, frente a 84 de los hombres, y la segunda en 21 y 16, respectivamente).

En lo referente a la sociedad malaya, al igual que en la española, los varones utilizaron más estrategias diferentes que las mujeres, en los actos principales (8 frente a 7). Ningún varón malayo utilizó la estrategia de "Declaración de obligación" en sus peticiones, mientras que, las de "Performativo" y "Declaración de obligación" son las que no aparecen en los datos de las mujeres. Al igual que en el grupo español, los varones malayos también mostraron una mayor 
tendencia que las mujeres al uso de la estrategia de "Imperativo" (21 registros de los varones frente a 11 de las mujeres), la de "Performativo evasivo" (11 y 10, respectivamente), "Declaración de deseo" (23 en los varones por 15 en las mujeres) y "Fórmula de sugerencia" (40 de los varones y 35 de las mujeres). En el caso de los indicios, los varones malayos utilizaron con mayor frecuencia que las mujeres los indicios fuertes (se registraron 15 y 10 casos, respectivamente). Sin embargo los indicios suaves aparecen el mismo número de veces en las intervenciones de ambos géneros malayos (3 veces en ambos). Entre los promedios de las estrategias aplicadas por los sujetos de los subgrupos de sexo la diferencia no fue significativa en el grupo español, algo que, en cambio, sí ocurre en el grupo malayo: $X^{2}=17.331 \mathrm{p}=.015(\mathrm{p}<.05)$.

Al contrastar los datos recogidos teniendo en cuenta las estrategias aplicadas en los movimientos de apoyo por los sujetos participantes de cada género, encontramos que, dentro de cada cultura, hombres y mujeres emplearon las 16 estrategias pero, en total, fueron las mujeres las que produjeron más enunciados que los varones en ambas culturas ( 519 de las mujeres frente a 493 de los varones en el grupo español, y 587 de las mujeres en comparación con 574 de los varones en el grupo malayo). 
En la gráfica que presentamos a continuación aparecen reflejados los resultados numéricos del análisis de los movimientos de apoyo, en relación con el uso más o menos frecuente de cada una de las 16 estrategias, según el género y el grupo cultural de los hablantes.

Figura 12. Distribución de enunciados (movimientos de apoyo) según las estrategias utilizadas por los dos géneros en ambas culturas

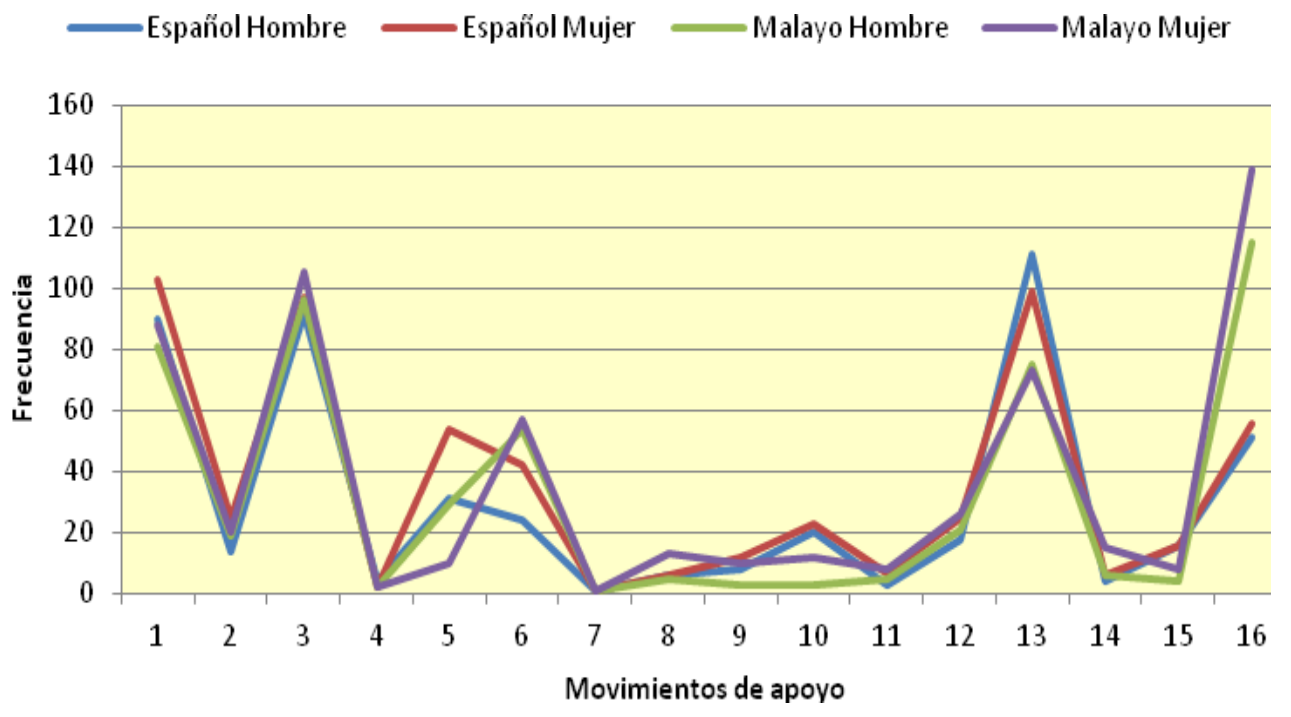

1.Fórmulas de preparación 2.Búsqueda de un compromiso 3.Razones 4.Previsión de objeciones 5.Promesa de recompensa/reparación 6.Minimización de la imposición 7.Invocación de principios generales 8.Reconocimiento de la imposición 9.Preocupación 10.Apreciación 11.Promesa de devolución 12.Gravedad/urgencia 13.Presentación/saludo 14.Petición de la opinión del oyente 15.Disculpa 16.Fórmulas de tratamiento

Los varones españoles muestran mayor tendencia a utilizar frecuentemente la estrategia de "Presentación/saludo", seguida de la de "Razones", "Fórmulas de preparación", "Fórmulas de tratamiento" y "Promesa de recompensa/reparación" (estas son 
las cinco más frecuentemente utilizadas). Las mujeres, por su parte, prefirieron mayoritariamente la de "Fórmulas de preparación", seguida de "Presentación/saludo", "Razones", "Fórmulas de tratamiento" y "Promesa de recompensa/reparación". El resto de estrategias también se utilizaron, pero en menor medida.

En el corpus malayo, al realizar sus peticiones los sujetos de ambos sexos recurrieron con más frecuencia a la estrategia de "Fórmulas de tratamiento", seguida de las de "Razones", "Fórmulas de preparación", "Presentación/saludo" y "Minimización de la imposición" (son las cinco más frecuentemente utilizadas). Por otro lado, hay que señalar que las de "Invocación de principios generales" y "Previsión de objeciones" fueron las menos utilizadas por los participantes de los dos géneros en ambas culturas.

Otro de los puntos del análisis es el de las estrategias que fueron más utilizadas por un género que por el otro. En el grupo español, los varones emplearon con mayor frecuencia que las mujeres dos estrategias, a saber, "Previsión de objeciones" y "Presentación/saludo", mientras que el resto de categorías fue más utilizado por las mujeres. Algo similar ocurre en el caso malayo, ya que, en las respuestas de los varones malayos también se hace un uso mayor de dos estrategias ("Promesa de recompensa/reparación" y "Presentación/saludo"), respecto a las mujeres. En el resto de los 
casos, también fueron las mujeres la que proporcionaron un mayor número de ejemplos. En cualquier caso, es evidente que los cuatro subgrupos de género utilizaron estrategias de movimientos de apoyo relativamente variadas. La comparación de los promedios entre las estrategias de los movimientos de apoyo aplicadas según el sexo no mostró una diferencia significativa en el corpus español, pero en el malayo fue significativa: $X^{2}=27.413 p=.026(p<.05)$.

\subsubsection{Análisis situacional}

En las líneas que siguen, se van a detallar los resultados del análisis de las producciones de los sujetos en cada una de las seis situaciones de petición del cuestionario (situaciones 1, 4, 7, 10, 13 y 16). Los datos se van a analizar y presentar teniendo en cuenta las tres variables: grupo cultural (español frente a malayo), edad (mayor versus menor) y género (varón frente a mujer).

\subsubsection{Situación 1}

En la situación 1, en la que un interlocutor pide a un vecino desconocido que le preste una escalera, la distancia social entre los interlocutores es grande, y la familiaridad, baja (no conocido). 
A continuación, pasamos a analizar los enunciados formulados por los sujetos de ambas culturas en este contexto situacional.

\section{A) Español frente a malayo}

Al igual que en apartados anteriores del estudio, comenzaremos el análisis clasificando las estrategias de petición en tres grandes bloques según el grado de (in)dirección. En las respuestas formuladas por los sujetos en este contexto, nos damos cuenta de que los dos grupos, malayos y españoles, tendieron a utilizar estrategias "Convencionalmente indirectas" al hacer la petición, tal y como se aprecia en la gráfica de la figura 13:

Figura 13. Distribución de enunciados según el grado de (in)dirección de las estrategias de petición utilizadas en la situación 1 en ambas culturas

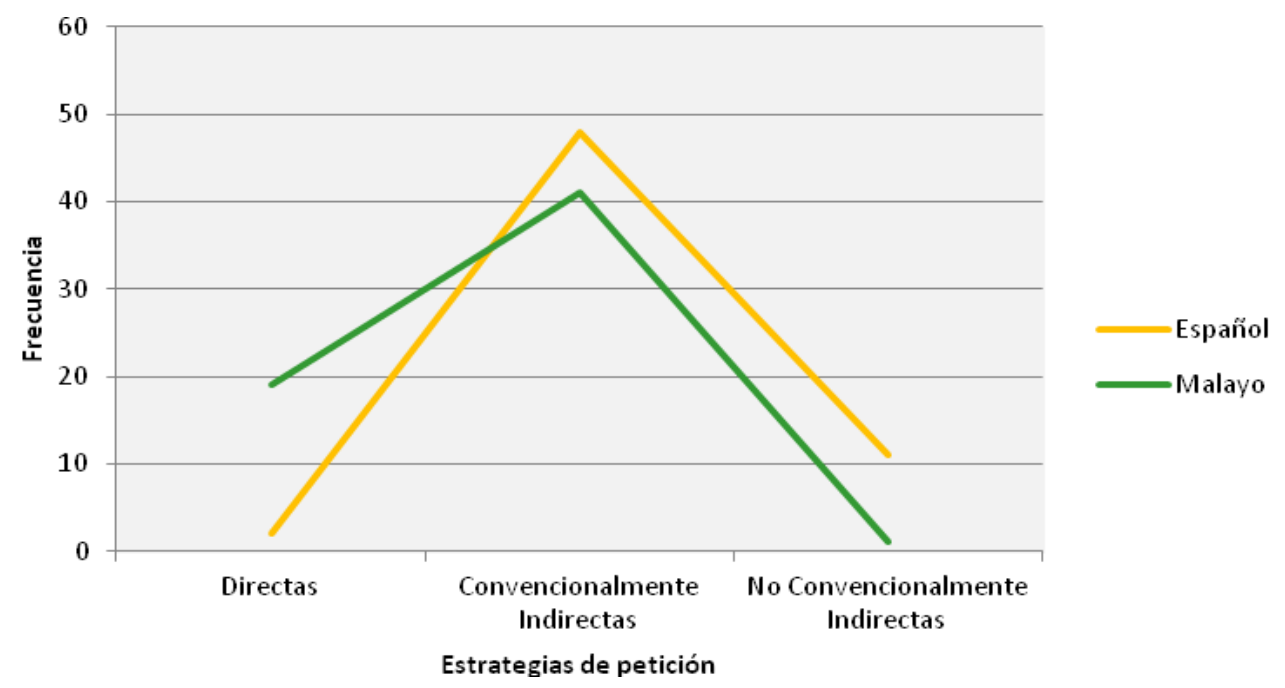


Las estrategias elegidas por los hablantes en segundo lugar fueron, sin embargo, diferentes en ambos grupos. Los sujetos españoles optaron en más ocasiones por el empleo de las "No convencionalmente indirectas", y, en menos, por el uso de las "Directas", mientras que los malayos emplearon estrategias "Directas" en un mayor número de enunciados respecto a las "No convencionalmente indirectas", que son las que menos veces aparecen en sus respuestas. El resultado de cada comunidad de habla difiere significativamente: $X^{2}=22.646 p=.000(p<.05)$.

En el análisis detallado de los enunciados, clasificándolos en función del uso de cada una de las nueve sub-categorías de estrategias aplicadas a los actos principales, se obtuvieron los siguientes resultados:

Figura 14. Distribución de enunciados según las estrategias utilizadas en la producción de actos principales en la situación 1 en ambas culturas

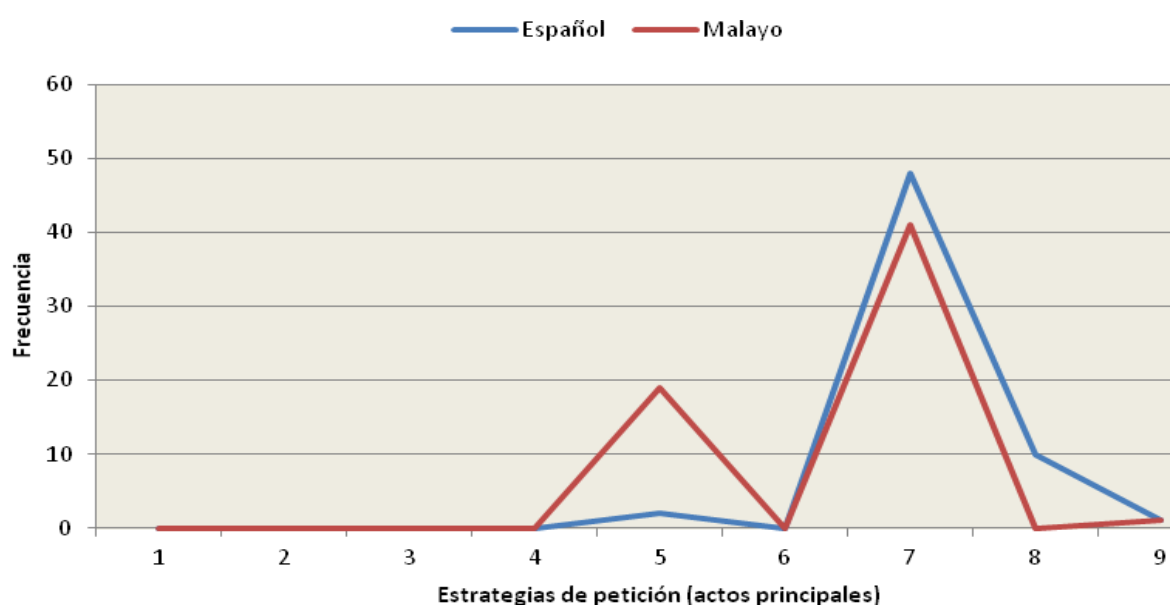

1.Imperativo 2.Performativo 3.Performativo evasivo 4.Declaración de obligación 5.Declaración de deseo 6. Fórmula de sugerencia 7.Interrogación preparatoria 8. Indicio fuerte 9.Indicio suave 
La estrategia a la que recurren en sus peticiones con más frecuencia los encuestados de ambas culturas es la de "Interrogación preparatoria", aunque se han recogido más enunciados de los españoles que de los malayos (48 frente a 41).

En las respuestas de los españoles en este contexto, se encontraron cuatro estrategias diferentes ("Interrogación preparatoria", "Declaración de deseo", "Indicio fuerte" e "Indicio suave"), mientras que en las de los sujetos malayos hay solamente tres, que coinciden con una parte de las utilizadas por el otro grupo (excepto la de "Indicio fuerte", que aparece solo en las respuestas de los hablantes malayos). La diferencia más notable entre las dos culturas aparece en el empleo de la estrategia de "Declaración de deseo", al encontrar tan solo 2 casos en los datos españoles, en comparación con los 19 de los malayos. Cabe subrayar que los índices indicaron que existieron diferencias significativas entre las medias obtenidas entre España y Malasia en los actos principales: $X^{2}=24.312 p=.000(p<.05)$.

En cuanto al uso de los movimientos de apoyo, los hablantes de ambas comunidades muestran diferencias en algunos aspectos. De manera general, los españoles emplearon menos enunciados que los malayos (213 de los españoles frente a 264 de los malayos), y también menos estrategias diferentes ( 9 , frente a los 
13 tipos aplicados por los malayos). En relación con las estrategias concretas utilizadas, cabe mencionar que los dos grupos mostraron la misma preferencia por el uso de la estrategia de "Presentación/saludo" (94 apariciones en el caso de los españoles y 92, en el de los malayos). Ningún español aplicó las estrategias de "Invocación de principios generales", "Preocupación", "Petición de la opinión del oyente" y "Fórmulas de tratamiento", que sí se recogieron, en cambio, en las respuestas de los sujetos malayos. Por último, y con respecto a las estrategias de "Minimización de la imposición" y "Disculpa", estas son las que marcan una mayor diferencia entre las dos sociedades. Respecto a la primera, fueron los malayos los que la aplicaron con mayor frecuencia (31 registros, frente a tan solo 12 de los españoles). En cambio, los españoles utilizaron la estrategia de "Disculpa" en un mayor número de ocasiones en comparación con los malayos (18 enunciados encontrados por tan solo 3 en los malayos).

En la Figura 15 aparece la representación gráfica de los datos mencionados. 
Figura 15. Distribución de enunciados según las estrategias empleadas en los movimientos de apoyo en la situación 1 en ambas culturas

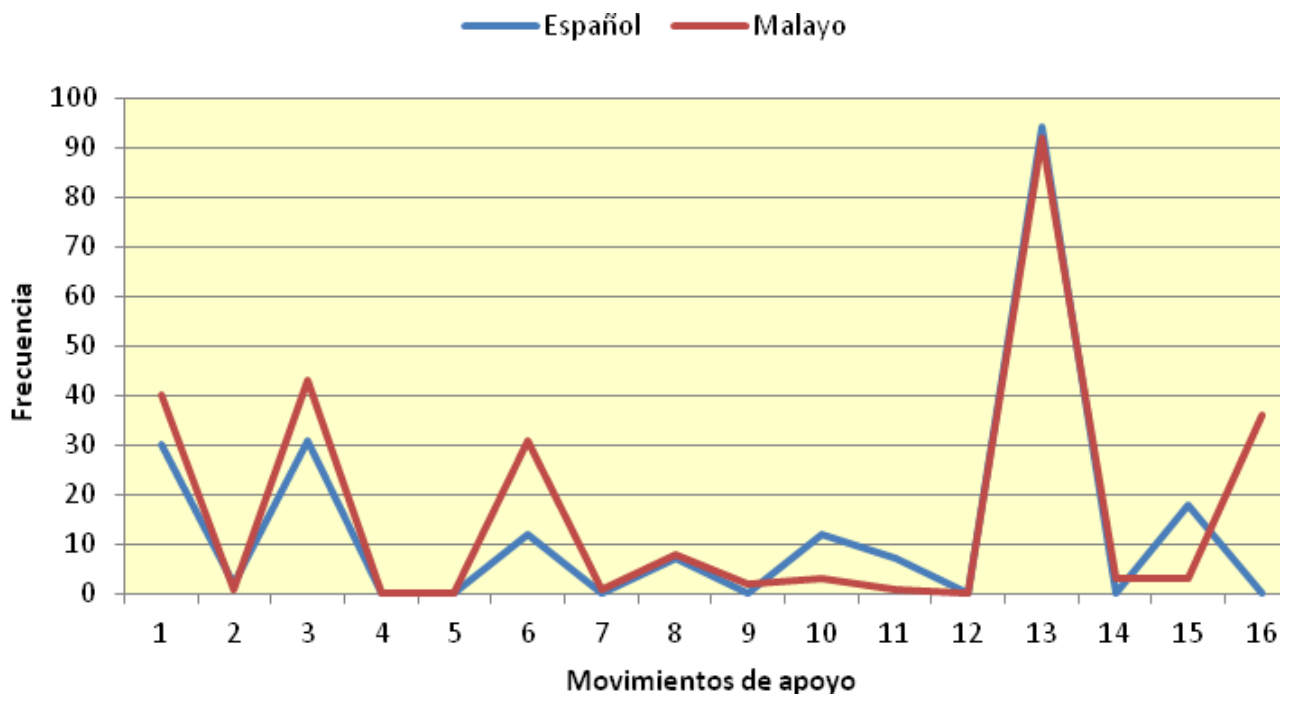

1.Fórmulas de preparación 2.Búsqueda de un compromiso 3.Razones 4.Previsión de objeciones 5.Promesa de recompensa/reparación 6.Minimización de la imposición 7.Invocación de principios generales 8.Reconocimiento de la imposición 9.Preocupación 10.Apreciación 11.Promesa de devolución 12.Gravedad/urgencia 13.Presentación/saludo 14.Petición de la opinión del oyente 15.Disculpa 16.Fórmulas de tratamiento

Las tres estrategias más frecuentemente aplicadas para formular la petición a un vecino desconocido en los dos grupos de hablantes, fueron, así pues, las de "Presentación/saludo" (94 registros de los españoles y 92 de los malayos), "Razones" (31 y 43, respectivamente) y "Fórmulas de preparación" (30 en los españoles por 40 en los malayos), mientras que la menos utilizada en ambos grupos fue la de "Búsqueda de un compromiso" (2 apariciones en los enunciados de los españoles y 1 en la de los malayos). La diferencia entre los grupos examinados en las medias de las estrategias de movimientos de apoyo aplicadas fue significativa: $X^{2}=70.155 p=.000$ $(p<.05)$. 
Comenzamos de nuevo el análisis teniendo en cuenta el grado de (in)dirección de las estrategias utilizadas en las peticiones formuladas en la situación 1 de los cuestionarios. La clasificación obtenida al aplicar la variable de edad es la que se refleja en la tabla siguiente:

Figura 16. Distribución de enunciados según el grado de (in)dirección de las estrategias de petición empleadas en la situación 1 por cada subgrupo

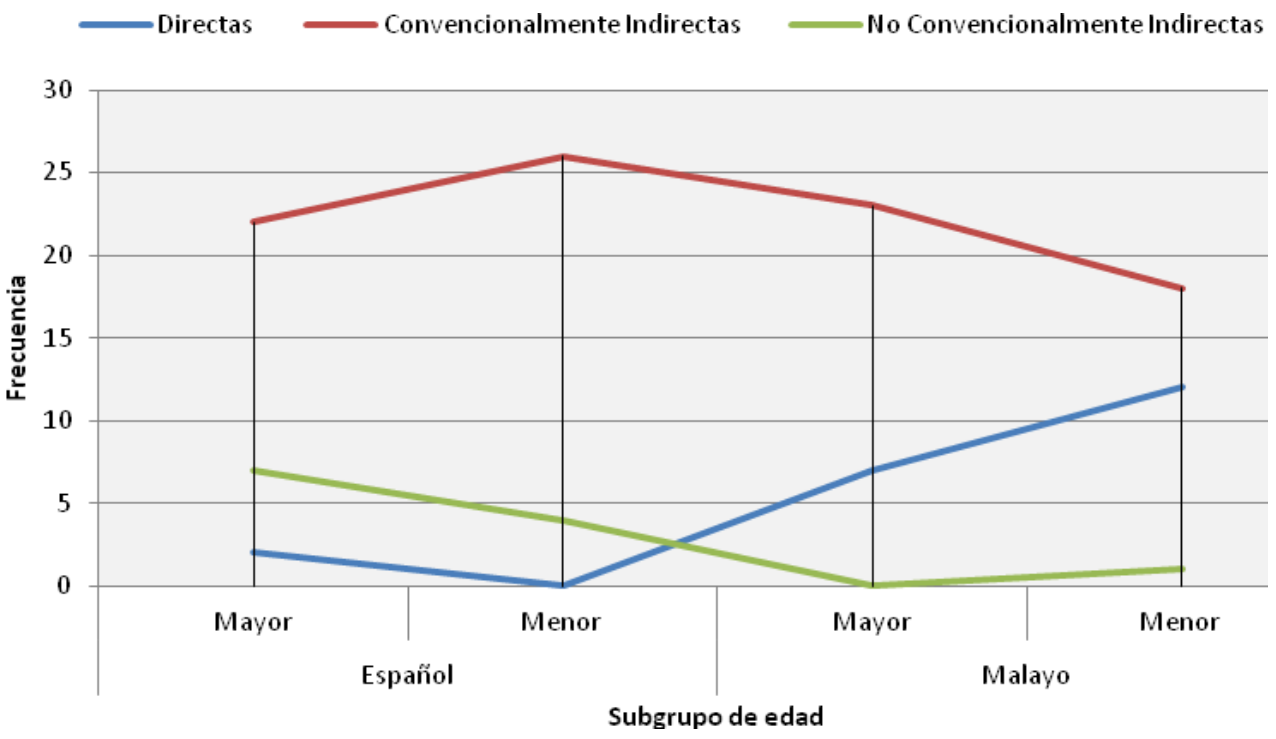

Los sujetos mayores y menores de ambas culturas mostraron las mismas preferencias al formular sus peticiones. Todos recurrieron con mayor frecuencia a las estrategias del tipo "Convencionalmente indirectas", pero los sujetos de las dos sociedades mostraron diferentes preferencias en segundo y tercer 
lugar. Los dos subgrupos españoles utilizaron las "No convencionalmente indirectas" en segundo lugar, mientras que ambos subgrupos malayos emplearon las "Directas". Finalmente, las diferencias entre los subgrupos de edad en ambas culturas a través de la comparación de los promedios de las formas utilizadas no fueron significativas.

Respecto al uso de estrategias en los actos principales de las peticiones formuladas en la situación 1 por los hablantes de los cuatro subgrupos estudiados, tanto los mayores como los menores de ambas sociedades tendieron a utilizar más frecuentemente la estrategia de "Interrogación preparatoria", tal y como se refleja en el siguiente gráfico:

Figura 17. Distribución de enunciados en función de las estrategias empleadas en los actos de principales en la situación 1 por cada subgrupo

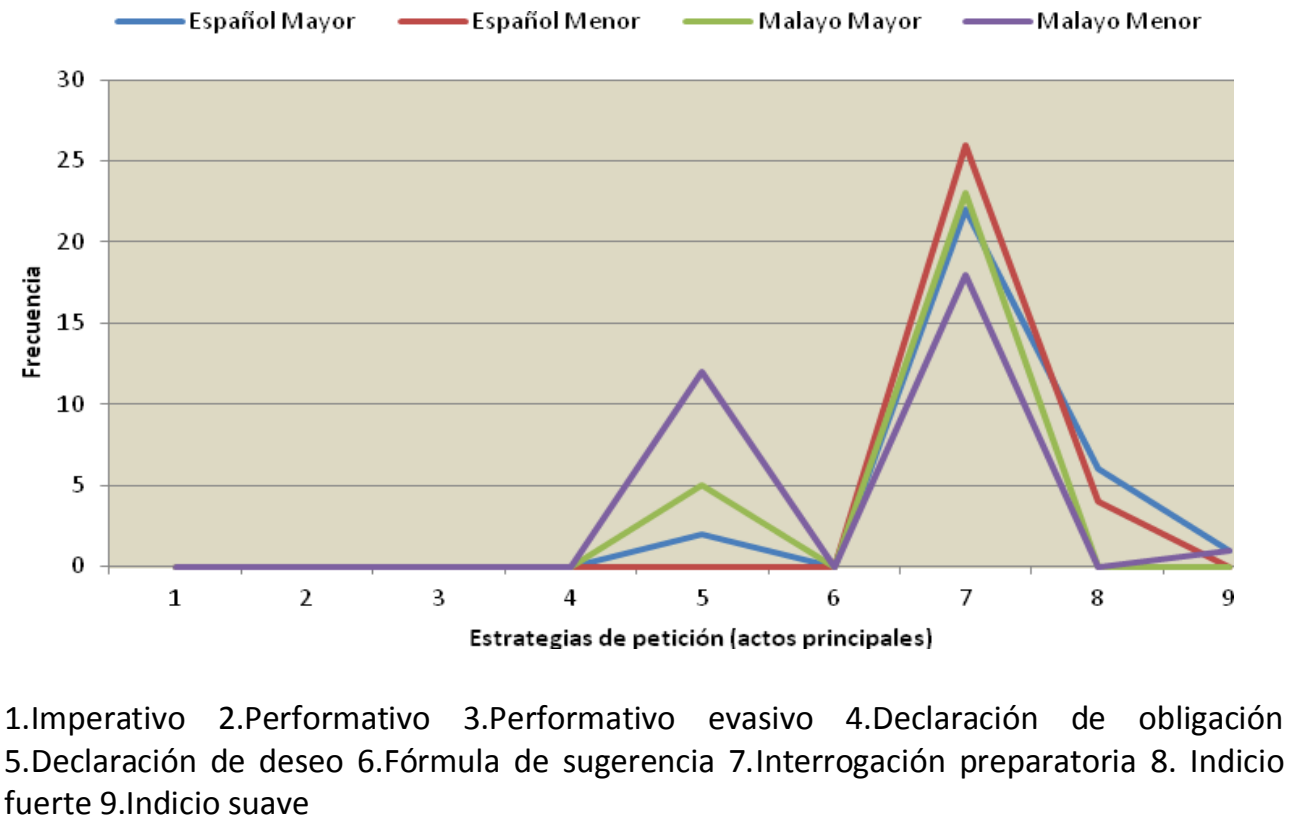


En la sociedad española, como vemos en la tabla, fueron los jóvenes los que aplicaron con más frecuencia dicha estrategia, pero la proporción no indica una gran diferencia con los mayores (26 ejemplos de los hablantes menores y 22 de los mayores). Por el contrario, en la sociedad malaya, fueron los participantes de más edad los que la utilizaron con más frecuencia, pero la proporción tampoco marcó una llamativa diferencia con los menores (23 ejemplos registrados de los mayores y 18 de los menores).

Otra diferencia importante es la referida al número de estrategias diferentes utilizadas por los mayores y los menores en ambos grupos. En el grupo español, los mayores emplearon más estrategias diferentes que los jóvenes (4, frente a 2 de los menores) cuando la petición se dirigía a un extraño. En cambio, los de más edad del grupo malayo usaron menos estrategias diferentes que los menores ( 2 y 3 estrategias, respectivamente). Al comparar los promedios de las estrategias usadas entre los hablantes mayores y los menores, la diferencia no fue significativa en los datos de ambos grupos.

Respecto al uso de movimientos de apoyo, se registraron más enunciados en las respuestas de los participantes mayores que en las de los menores (114 frente a 99, en el grupo español, y 149 por 115 , en el grupo malayo). El número de estrategias utilizadas en 
dichos enunciados también fue diferente en función de la edad. Los mayores del grupo español emplearon ocho estrategias diferentes de movimientos apoyo, mientras que los menores aplicaron nueve. En el grupo malayo, los hablantes de más edad utilizaron once estrategias diferentes, mientras que en las respuestas de los jóvenes aparecen solamente diez, como muestra la figura 18.

Figura 18. Distribución de enunciados según las estrategias que aparecen en los movimientos de apoyo empleados en las peticiones de la situación 1 en cada subgrupo

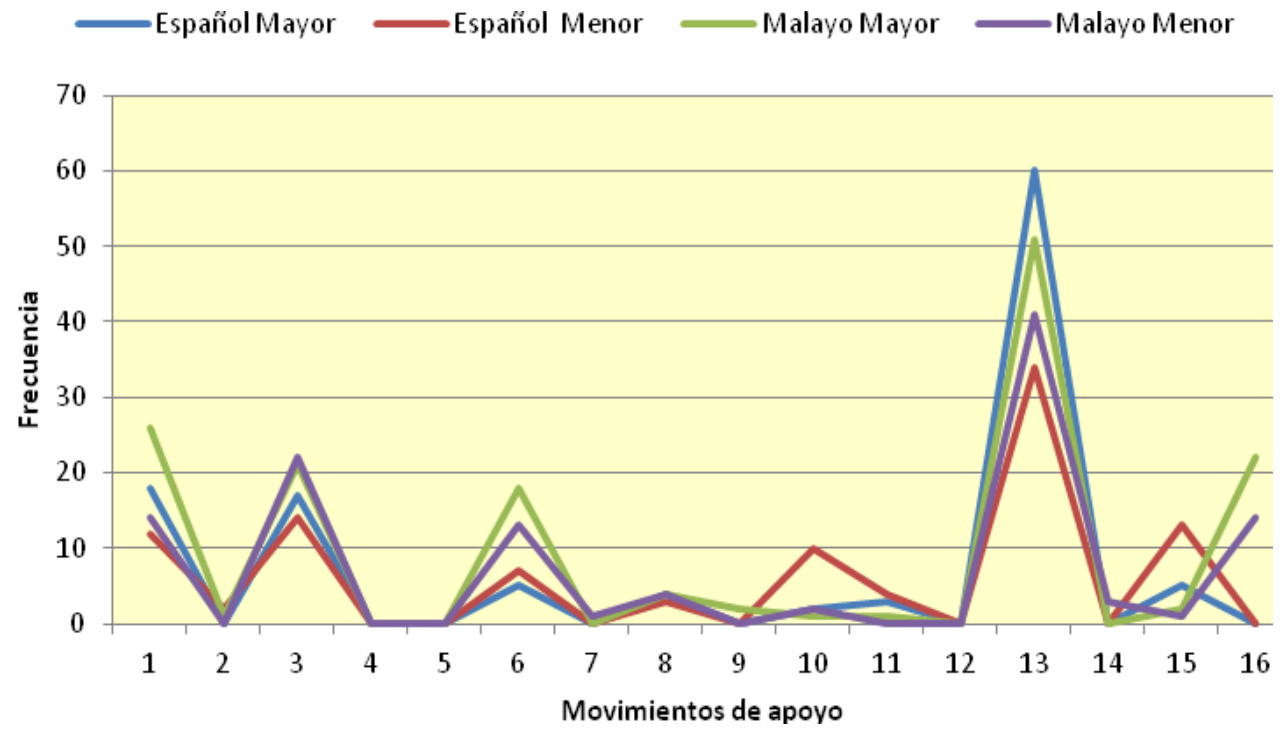

1.Fórmulas de preparación 2.Búsqueda de un compromiso 3.Razones 4.Previsión de objeciones 5.Promesa de recompensa/reparación 6.Minimización de la imposición 7.Invocación de principios generales 8.Reconocimiento de la imposición 9.Preocupación 10.Apreciación 11.Promesa de devolución 12.Gravedad/urgencia 13.Presentación/saludo 14.Petición de la opinión del oyente 15.Disculpa 16. Fórmulas de tratamiento

Los hablantes de los dos subgrupos de edad en ambas lenguas, tal y como aparece reflejado en el gráfico, utilizaron más 
frecuentemente la estrategia de "Presentación/saludo", seguida de las de "Razones" y "Fórmulas de preparación" (son las tres más utilizadas). La estrategia que se presenta en menor medida en los datos proporcionados por los sujetos menores españoles, y que no aparece en los datos de los mayores, fue la de "Búsqueda de un compromiso".

En el caso del malayo, las estrategias que sí aparecen en las respuestas de los sujetos del grupo de mayores, pero que no aparecen en los datos de los menores, son las de "Búsqueda de un compromiso", "Preocupación", "Promesa de devolución" y "Disculpa". $\mathrm{Y}$, por el contrario, aquellas que aparecen en las respuestas de los menores pero no existen en los enunciados del otro subgrupo son las de "Invocación de principios generales" y "Petición de la opinión del oyente". La comparación de los promedios entre los movimientos de apoyo empleados entre los subgrupos de edad indicó una diferencia significativa en el corpus español: $X^{2}=19.229 p=.014(p<.05)$, pero no, en el corpus malayo.

\section{C) Varón frente a mujer}

Si analizamos desde el punto de vista del género de los hablantes las respuestas proporcionadas por los encuestados para la situación 1, 
los resultados que se obtienen, en relación al grado de (in)dirección de las estrategias de petición utilizadas, son los que aparecen a continuación, en la figura 19.

Figura 19. Distribución de enunciados según el grado de (in)dirección de las estrategias de petición empleadas en los actos principales producidos en la situación 1 en cada grupo de género

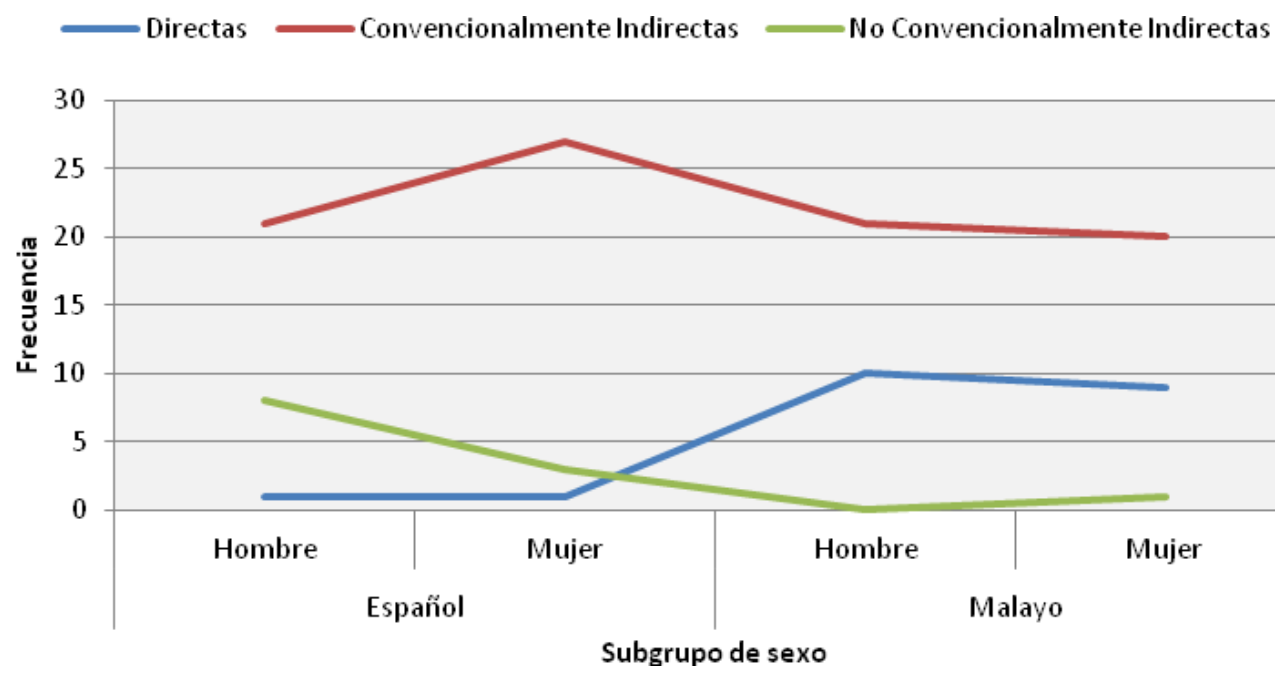

En esta situación todos los subgrupos de género, excepto los varones malayos, expusieron el mismo patrón en lo relativo al grado de (in)dirección en sus peticiones. Ningún varón malayo utilizó formas "No convencionalmente indirectas" al hacer la petición, mientras que sí aparecen en las respuestas de los hablantes de los otros subgrupos de género. Aunque no hay una gran diferencia en la proporción en que cada subgrupo utiliza cada tipo de estrategias, se puede señalar que fueron los varones españoles los que usaron las estrategias de petición "No convencionalmente indirectas" con mayor 
frecuencia, con 8 registros, en comparación con 3 de las mujeres españolas y 1 de las mujeres malayas. Las "Convencionalmente indirectas", fueron las mujeres españolas quienes las aplicaron con más frecuencia, con 27 casos encontrados, frente a 21 de los varones españoles y malayos, y 20 de las mujeres malayas. Respecto a las estrategias de petición "Directas", los varones malayos las emplearon un mayor número de veces que los encuestados del resto de los subgrupos (10 ejemplos encontrados, frente a los 9 de las mujeres malayas, y 1 caso recogido en cada subgrupo de género español). Según indicó el valor estadístico, no existe diferencia significativa entre las medias de ambos sexos en este caso en ninguno de los dos países.

Al analizar los datos teniendo en cuenta los nueve tipos de estrategias aplicables a los actos principales, se obtuvieron, en cada subgrupo de género de ambas lenguas, los resultados que se presentan a continuación: 
Figura 20. Distribución de enunciados según las estrategias de petición utilizadas en actos principales en la situación 1 por los hablantes de cada género

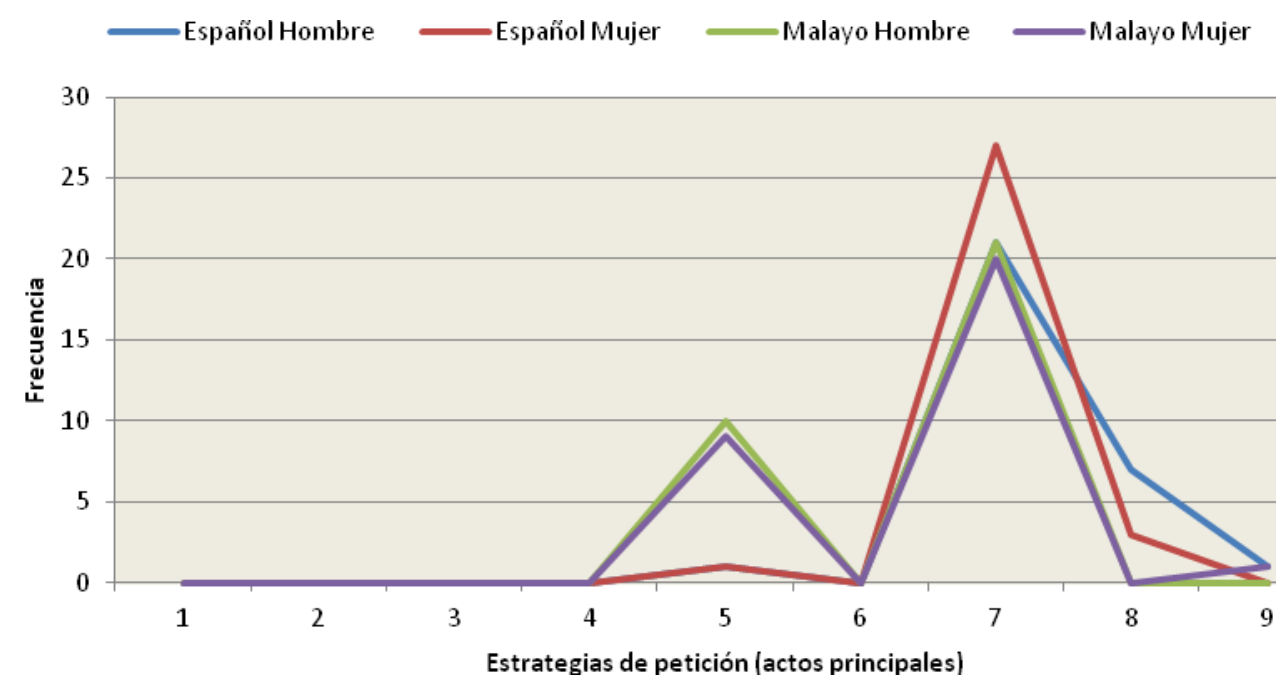

1.Imperativo 2.Performativo 3.Performativo evasivo 4.Declaración de obligación 5.Declaración de deseo 6.Fórmula de sugerencia 7.Interrogación preparatoria 8. Indicio fuerte 9 .Indicio suave

En lo que concierne al uso de estrategias en los actos principales, en ambas culturas los sujetos de los dos sexos mostraron preferencia por la estrategia de "Interrogación preparatoria". Los varones de la sociedad española recurrieron a cuatro estrategias diferentes, mientras que las mujeres aplicaron solamente tres tipos. En el grupo malayo, los varones emplearon solo dos estrategias diferentes frente a los tres tipos utilizados por las mujeres. Ninguna mujer española aplicó la de "Indicio suave", pero aparece una vez en las respuestas de los varones. En cambio, ningún varón malayo usó dicha estrategia, aunque sí se presenta en 9 ocasiones en los datos de las mujeres. Por otro lado, todas las estrategias que utilizaron las 
mujeres españolas, también aparecen en las respuestas de los varones. En este contexto, la diferencia indicada entre las medias de ambos sexos en los dos países tampoco fue significativa.

Respecto a los movimientos de apoyo, fueron las mujeres de las dos culturas las que utilizaron más: 106 enunciados frente a 107 de los hombres, en el caso español, y 146 por 136, respectivamente, en el malayo. Presentamos a continuación la distribución de dichos enunciados según el tipo de estrategia utilizada:

Figura 21. Distribución de enunciados según las estrategias utilizadas en los movimientos de apoyo en la situación 1 en cada grupo de género

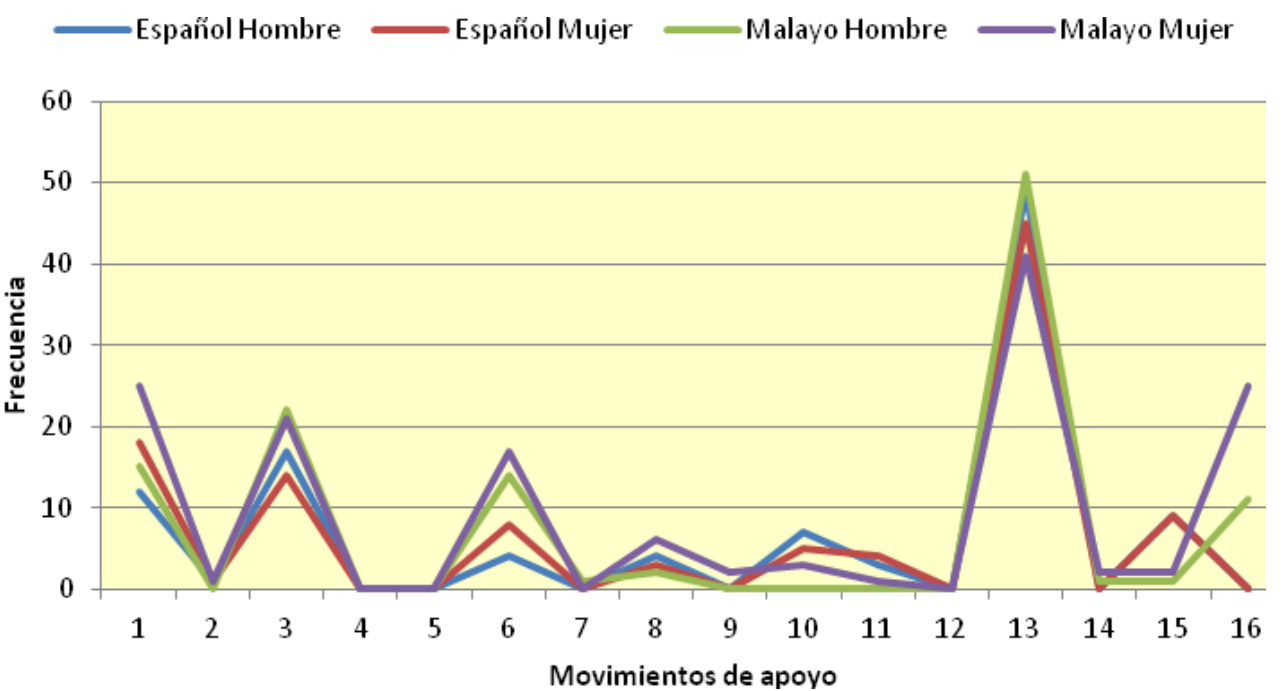

1.Fórmulas de preparación 2.Búsqueda de un compromiso 3.Razones 4.Previsión de objeciones 5.Promesa de recompensa/reparación 6.Minimización de la imposición 7.Invocación de principios generales 8.Reconocimiento de la imposición 9.Preocupación 10.Apreciación 11.Promesa de devolución 12.Gravedad/urgencia 13.Presentación/saludo 14.Petición de la opinión del oyente 15.Disculpa 16.Fórmulas de tratamiento 
En el grupo español, tanto los varones como las mujeres utilizaron nueve estrategias diferentes en los movimientos de apoyo empleados cuando pidieron a un vecino desconocido que les prestase una escalera. En el grupo malayo, en cambio, los varones aplicaron menos estrategias diferentes que las mujeres (9 diferentes en las respuestas de los varones frente a las 12 encontradas en las producciones de las mujeres).

Si nos fijamos en los datos del gráfico, vemos que los hablantes de los dos sexos, en ambos grupos, tendieron a acompañar su petición de la estrategia de "Presentación/saludo". Aunque la diferencia de frecuencia de uso entre los géneros no fue grande, ni en el grupo español ni en el malayo, fueron los varones los que la emplearon más frecuentemente, con una proporción de 49 ejemplos recogidos en sus respuestas, frente a 45 de las mujeres, en la cultura española, y 51 de los hombres por 41 de las de las mujeres, en la otra cultura.

En este escenario los sujetos españoles de los dos géneros utilizaron estrategias similares en los movimientos de apoyo de su petición. Además de la de "Presentación/saludo", otras estrategias aplicadas en mayor medida por los dos subgrupos fueron las de "Fórmulas de preparación", "Razones" y "Disculpa" (mencionamos solamente las más empleadas). En el grupo malayo, 
en cambio, sí que se pueden ver algunas diferencias entre los varones y las mujeres. Por ejemplo, la estrategia de "Invocación de principios generales" solo se encuentra en las producciones de los encuestados varones. Otras, en cambio, están presentes solamente en los enunciados de las mujeres encuestadas, como las de "Búsqueda de un compromiso", "Preocupación", "Apreciación" y "Promesa de devolución". Al igual que en el caso de los actos principales, en el uso de los movimientos de apoyo tampoco se han encontrado diferencias estadísticas significativas entre los subgrupos de ambos sexos de los dos países.

\subsubsection{Situación 4}

En la situación 4, en la que el sujeto le pide a un compañero de piso que le acompañe a comprar, el grado de familiaridad es alto, ya que se trata de alguien conocido. No hay, por tanto, dominio jerárquico, lo que nos llevará a realizar el análisis teniendo en cuenta únicamente la distancia social. 


\section{A) Español frente a malayo}

Al analizar las respuestas proporcionadas en esta situación por los encuestados de ambas culturas en función del grado de (in)dirección de sus peticiones, nos damos cuenta de que, al igual que en la situación 1 , los sujetos de las dos sociedades prefirieron realizar la petición con estrategias del tipo "Convencionalmente indirectas", seguidas de las "Directas". Solamente los hablantes españoles recurrieron, en algunos casos, a las estrategias "No Convencionalmente indirectas".

En la gráfica que mostramos a continuación aparecen recogidos los datos numéricos obtenidos en el análisis de los cuestionarios, en relación con este punto:

Figura 22. Distribución de enunciados por uso de estrategias de petición (según el grado de (in)dirección, en la situación 4 en cada cultura

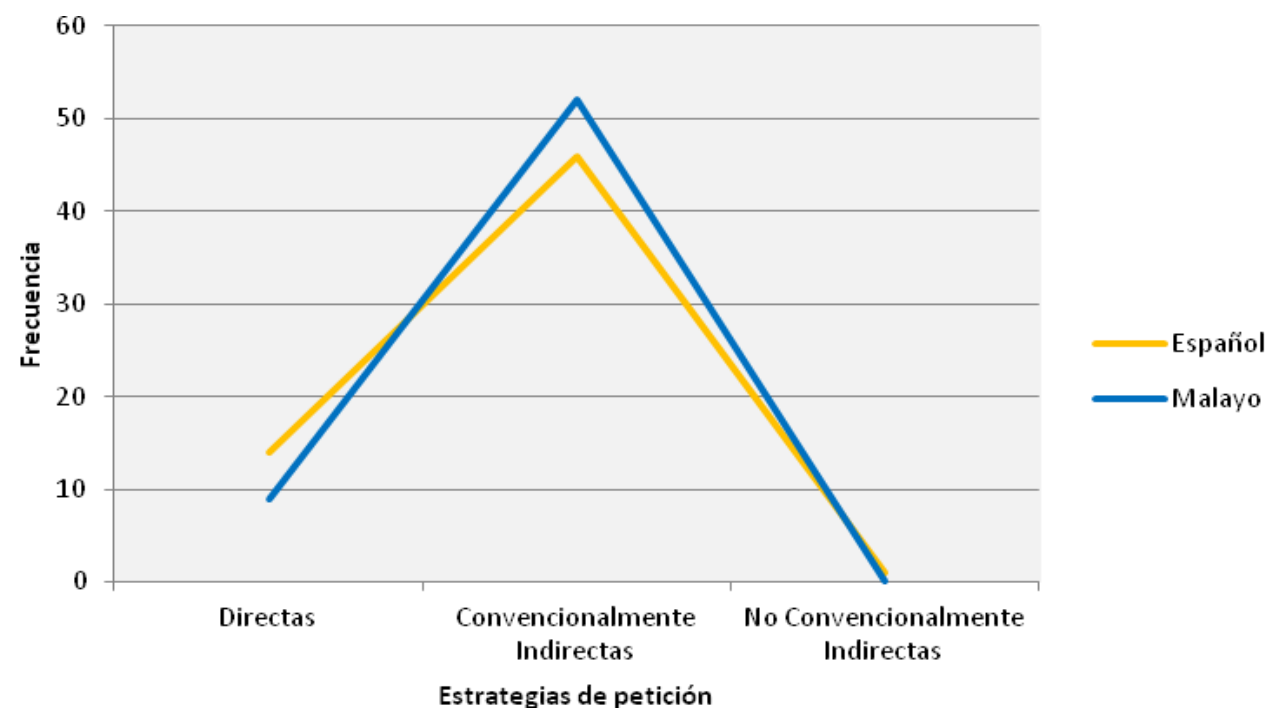


Como se ilustra en la figura 22, fueron los malayos los que utilizaron las formas del tipo "Convencionalmente indirectas" con mayor frecuencia (52 casos encontrados en comparación con 46 de los españoles). En cambio, por lo que respecta a las "Directas", fueron los españoles los que las aplicaron con más frecuencia (14 registros frente a 9 de los malayos). Al comparar los promedios de las categorías aplicadas la diferencia no fue significativa.

La distribución de dichas estrategias entre las nueve subcategorías con las que estamos trabajando en el análisis de los actos principales, es la que se representa en la siguiente gráfica:

Figura 23. Distribución de enunciados según las estrategias empleadas en los actos principales de petición en la situación 4 por los hablantes de cada género

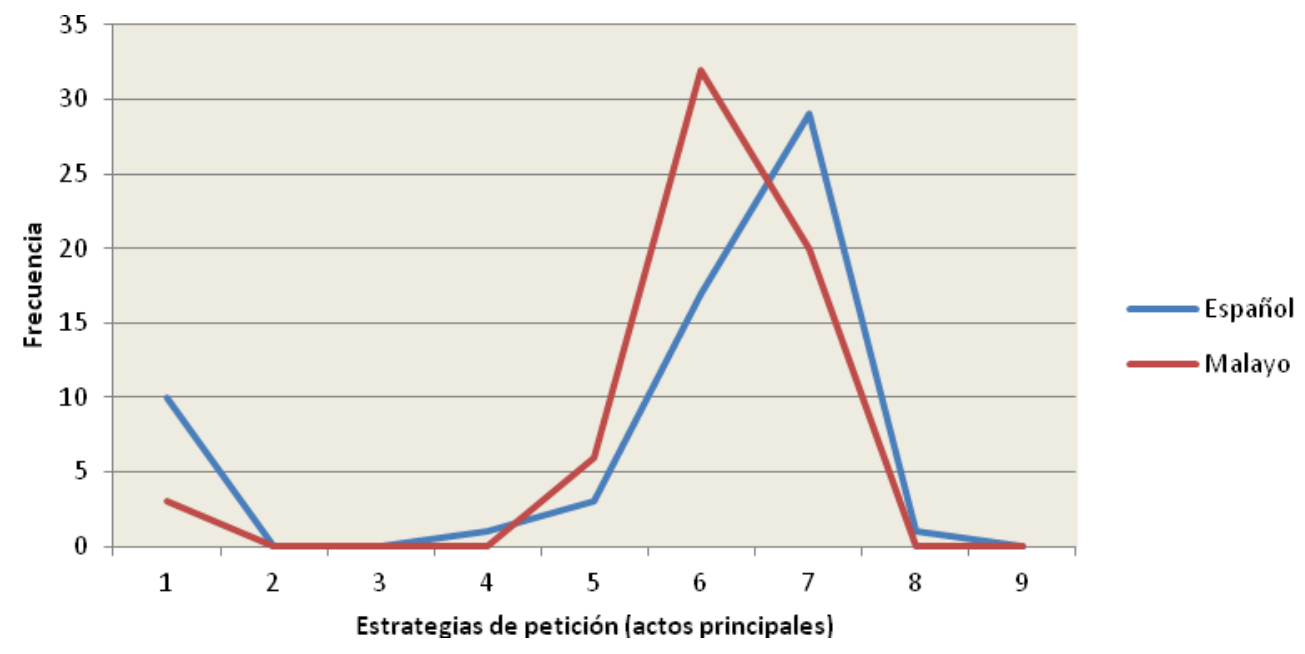

1.Imperativo 2.Performativo 3.Performativo evasivo 4.Declaración de obligación 5.Declaración de deseo 6.Fórmula de sugerencia 7.Interrogación preparatoria 8. Indicio fuerte 9.Indicio suave 
En las respuestas proporcionadas en este contexto, ambos grupos de hablantes se diferenciaron visiblemente en algunos aspectos. En primer lugar, los españoles aplicaron un mayor número de estrategias que los malayos (6 frente a 4 utilizadas por los malayos). En segundo lugar, con respecto al tipo de fórmulas empleadas, encontramos que ningún malayo recurrió al empleo de las de "Declaración de obligación" e "Indicio fuerte" en su petición, aunque sí que aparecen una vez en los datos españoles. Por último, en lo que se refiere a la estrategia dominante en las respuestas de cada grupo, los españoles prefirieron mayoritariamente la de "Interrogación preparatoria" al realizar su petición a un compañero de piso, mientras que los malayos tendieron a usar más frecuentemente la estrategia de "Fórmula de sugerencia" en su petición al mismo interlocutor. En este apartado, las pruebas estadísticas mostraron que las dos culturas analizadas se diferenciaron significativamente en la comparación de los promedios de los actos principales formulados: $X^{2}=13.014 p=.023(p<.05)$.

En lo referente a las estrategias utilizadas en los movimientos de apoyo, los encuestados españoles recurrieron a más formas diferentes que el otro grupo (12, los españoles y 10 , los malayos), aunque repartidas en un número menor de enunciados (98 de los españoles por 109 de los malayos). Por otro lado, hay cuatro estrategias, a saber, "Reconocimiento de la imposición", 
"Promesa de devolución", "Gravedad/urgencia" y "Disculpa", que no aparecen en las respuestas de los hablantes de ninguna de las sociedades. De las doce restantes, en la figura siguiente podemos observar cuáles fueron las más utilizadas en los movimientos de apoyo por unos y otros en la situación 4 .

Figura 24. Distribución de enunciados según el tipo de estrategia utilizada por cada grupo en los movimientos de apoyo en la situación 4

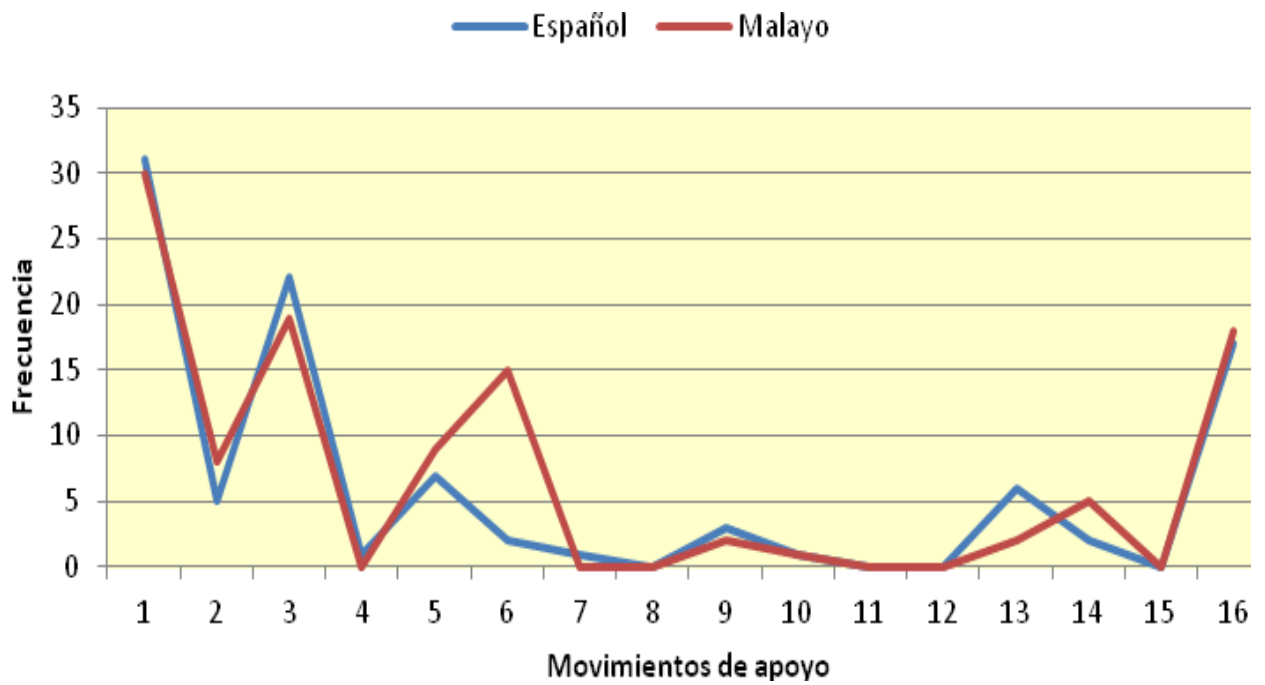

1.Fórmulas de preparación 2.Búsqueda de un compromiso 3.Razones 4.Previsión de objeciones 5.Promesa de recompensa/reparación 6.Minimización de la imposición 7.Invocación de principios generales 8.Reconocimiento de la imposición 9.Preocupación 10.Apreciación 11.Promesa de devolución 12.Gravedad/urgencia 13.Presentación/saludo 14.Petición de la opinión del oyente 15.Disculpa 16.Fórmulas de tratamiento

Las estrategias de "Previsión de objeciones" y "Invocación de principios generales" solo se encuentran en los datos españoles, mientras que todas las estrategias utilizadas por los malayos en esta situación existen también en los datos españoles. 
Según el resultado estadístico, respecto al uso de las estrategias de "Fórmulas de preparación", "Razones" y "Fórmulas de tratamiento" (las tres más empleadas), ambos grupos de nativos casi no se diferenciaron. Sin embargo, la frecuencia del uso de la estrategia de "Minimización de la imposición" muestra una diferencia estadística notable, ya que, frente a 15 sujetos malayos, tan solo 2 españoles la empleó. A diferencia del análisis de actos principales, en este caso, los promedios comparados no indicaron ninguna diferencia significativa.

\section{B) Mayor frente a menor}

El estudio del grado de (in)dirección de las estrategias de petición aplicadas por los sujetos de cada subgrupo de edad, revela que pese a que ambos subgrupos en cada sociedad mostraron la misma preferencia por las "Convencionalmente indirectas" a la hora de hacer la petición, fueron los encuestados mayores los que optaron por expresarse a través de dichas formas en un mayor número de casos, con 25 registros de los mayores españoles frente a 21 de los jóvenes y, 28 de los malayos mayores por 24 de los jóvenes, tal como queda reflejado en la tabla que ofrecemos a continuación: 
Figura 25. Distribución de enunciados en función del grado de (in)dirección de las estrategias de petición en la situación 4 en cada subgrupo

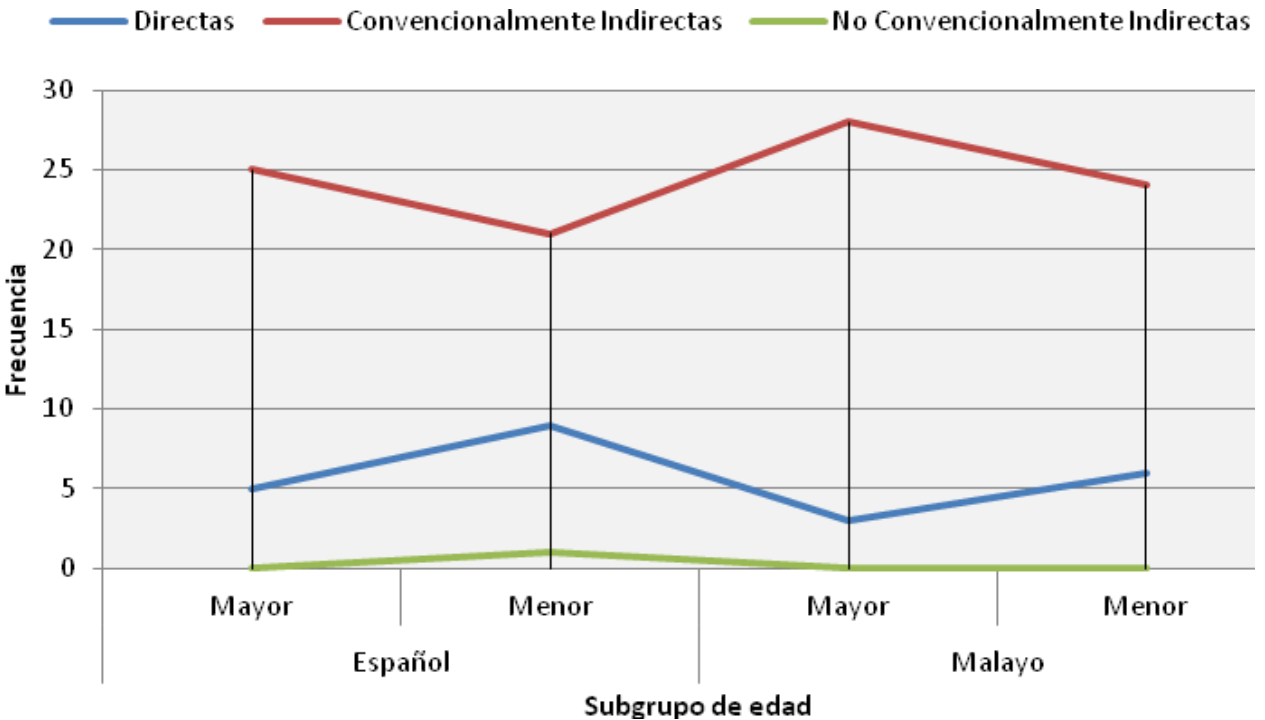

Respecto al uso de las estrategias "Directas", los hablantes menores las emplearon más que los mayores en ambas culturas ( 5 y 9 , respectivamente, en la cultura española, y 3 y 6 , en cada subgrupo de edad, en la malaya), mientras que el tipo "No convencionalmente indirectas", solo está registrado una vez en el corpus de respuestas de los jóvenes españoles. En este contexto, los promedios comparados no indicaron ninguna diferencia significativa en los dos países.

Los resultados obtenidos del análisis efectuado para conocer cómo varía el tipo de estrategia utilizada por los dos subgrupos de edad en los actos principales, son los que se exponen en la tabla siguiente: 
Figura 26. Distribución de enunciados según las estrategias empleadas en la formulación de actos principales para la situación 4 en cada subgrupo

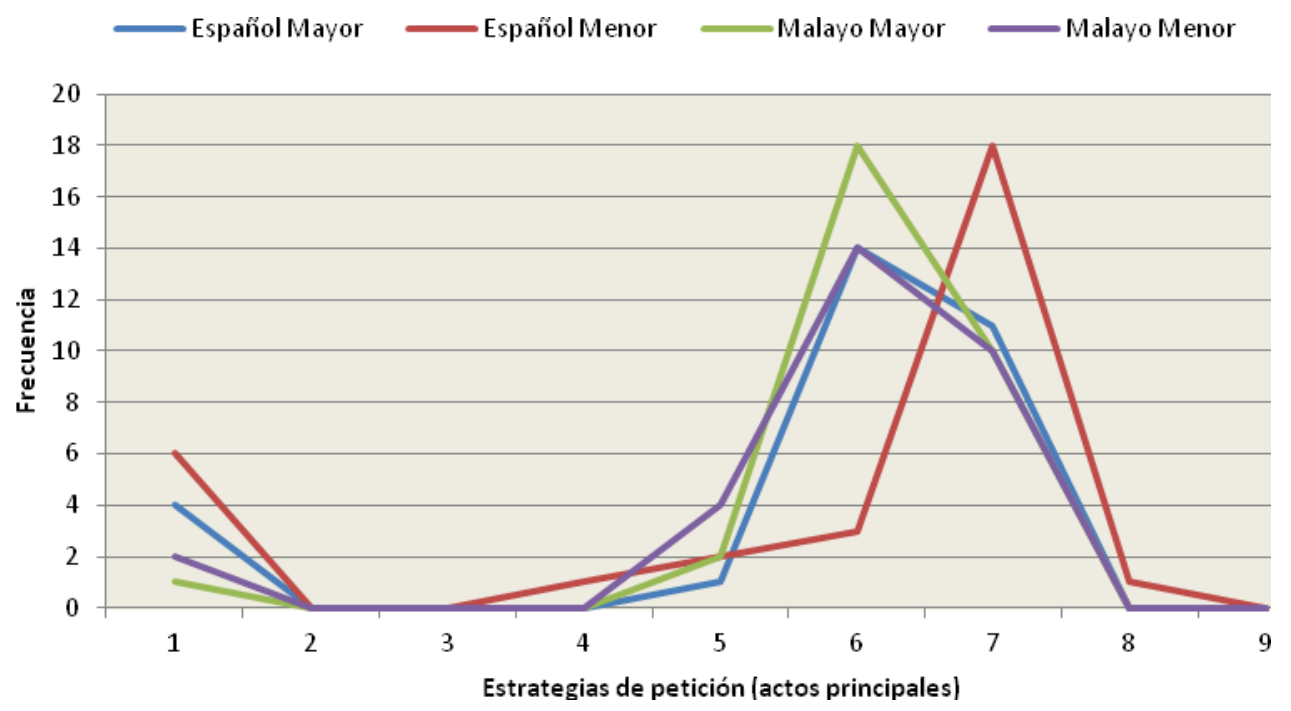

1.Imperativo 2.Performativo 3.Performativo evasivo 4.Declaración de obligación 5.Declaración de deseo 6.Fórmula de sugerencia 7.Interrogación preparatoria 8. Indicio fuerte 9 .Indicio suave

La diferencia estadística entre los subgrupos españoles fue más pronunciada que entre los malayos, especialmente en el uso de la "Fórmula de sugerencia" (los españoles mayores emplean este recurso cuatro veces más que los jóvenes). En lo que se refiere a la variación de estrategias utilizadas, fueron los jóvenes los que recurrieron a más opciones (6 estrategias distintas empleadas por los menores frente a 4 de los mayores). En el caso malayo, los sujetos de los dos subgrupos de edad coinciden en el número de estrategias elegidas en la formulación de los actos principales (ambos utilizaron 4). 
En cuanto a la fórmula elegida en un mayor número de casos, los dos subgrupos españoles y el subgrupo malayo de mayores coinciden en presentar una mayor tendencia a realizar la petición a un compañero de piso con una "Fórmula de sugerencia" (18 ejemplos recogidos de los ancianos malayos y, 14 tanto de los menores malayos como de los mayores españoles). Los menores españoles, por su parte, tendieron a utilizar más en sus enunciados una "Interrogación preparatoria", en su petición al mismo interlocutor (en 18 de los casos). Ninguno de los sujetos españoles mayores empleó las estrategias de "Declaración de obligación" e "Indicio fuerte", pero sí que las encontramos en los datos de los menores. Ahora bien, también hay que decir que todas las estrategias utilizadas por los participantes de más edad, también están registradas en las respuestas de los jóvenes. Por otra parte, en los enunciados del corpus malayo, tanto mayores como jóvenes, utilizaron las mismas estrategias en sus peticiones. La comparación de los promedios entre las categorías empleadas entre ambos subgrupos de edad mostró una diferencia considerable en el material español $\left(X^{2}=11.527 \mathrm{p}=.042(\mathrm{p}<.05)\right.$, mientras que en el material malayo la diferencia no fue significativa.

Respecto a las estrategias utilizadas en los movimientos de apoyo por cada subgrupo al realizar sus peticiones, en el caso español, los sujetos mayores recurren más (casi el doble) a los 
movimientos de apoyo que los jóvenes (60 enunciados, frente a 38 de los jóvenes), y, al mismo tiempo, son también los que utilizan mayor variedad de estrategias (11 tipos diferentes), mientras que los jóvenes optan solamente por 8 de entre todas las opciones posibles. En el caso malayo, en cambio, se ha registrado un número muy similar de enunciados de movimiento de apoyo (58 de los mayores y 51 de los jóvenes), y también es casi idéntico el número de estrategias diferentes utilizadas ( 9 los mayores frente a 8 , los jóvenes).

En la figura que presentamos a continuación aparecen reflejados los resultados obtenidos en el análisis detallado de los distintos tipos de estrategias empleadas por los hablantes de los cuatro subgrupos, en los movimientos de apoyo empleados en la situación estudiada en este apartado: 
Figura 27. Distribución de enunciados según estrategias utilizadas en los movimientos de apoyo producidos para la situación 4 en cada subgrupo

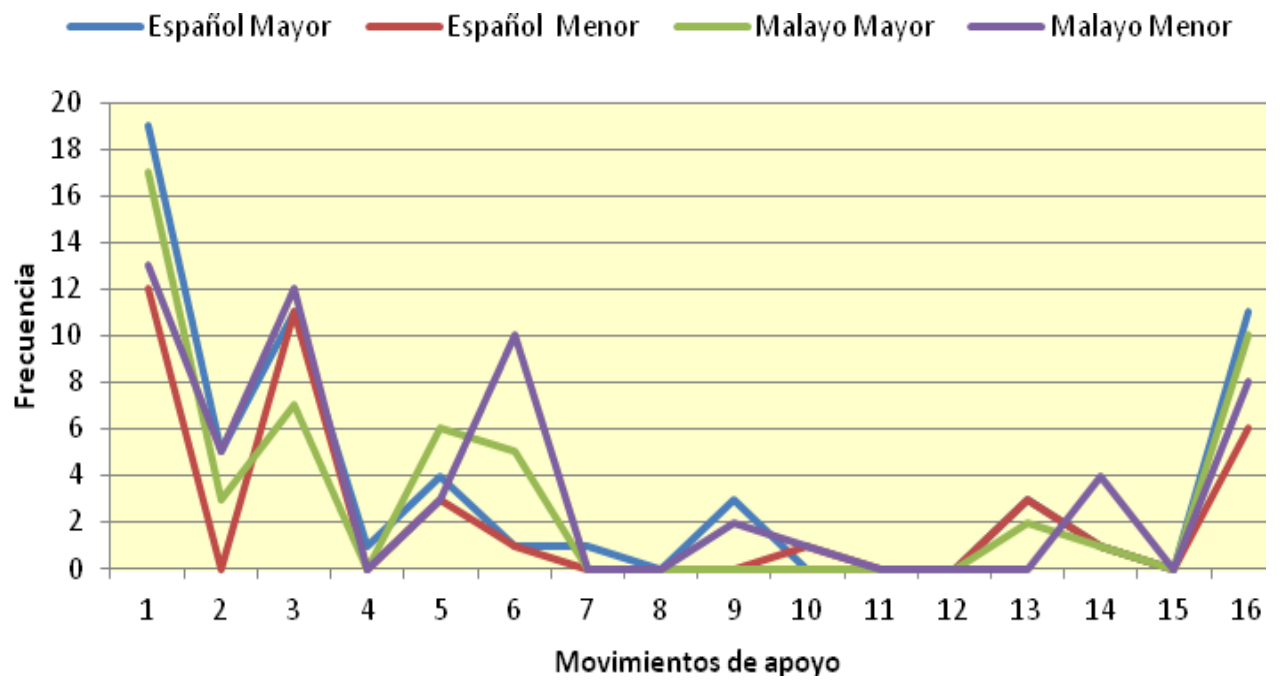

1.Fórmulas de preparación 2.Búsqueda de un compromiso 3.Razones 4.Previsión de objeciones 5.Promesa de recompensa/reparación 6.Minimización de la imposición 7.Invocación de principios generales 8.Reconocimiento de la imposición 9.Preocupación 10.Apreciación 11.Promesa de devolución 12.Gravedad/urgencia 13.Presentación/saludo 14.Petición de la opinión del oyente 15.Disculpa 16.Fórmulas de tratamiento

Los subgrupos comparados en ambas sociedades, mostraron una preferencia similar hacia el uso de la estrategia de "Fórmulas de preparación" a la hora de elaborar los movimientos de apoyo en su petición. Pese a que los encuestados en ambos grupos optaron, en mayor grado, por dicha estrategia a la hora de formular la petición en este escenario, fueron los mayores los que mostraron una mayor tendencia hacia el empleo de dicha forma, con 19 enunciados encontrados en las respuestas de los mayores frente a 12 en las de los menores, en el caso español, y 17 por 13, respectivamente, en el malayo. Las estrategias que se encuentran en 
los datos de los participantes mayores españoles pero no se presentan en los de los menores son "Búsqueda de un compromiso", "Previsión de objeciones", "Invocación de principios generales" y "Preocupación". En cambio, los movimientos con "Apreciación" solamente aparecen registrados en las respuestas de los menores, y con un ejemplo nada más. Por otro lado, en el caso malayo, hay estrategias que solamente fueron empleadas por los hablantes del grupo de los menores ("Preocupación" y "Apreciación"), y otras que solo aparecen en los datos de los mayores ("Presentación/saludo"). En este contexto, tampoco se observó una diferencia significativa en ambos subgrupos de edad en ninguna de las dos culturas.

\section{C) Varón frente a mujer}

Al clasificar los enunciados producidos por los hablantes de ambos géneros en una y otra cultura, teniendo en cuenta el grado de (in)dirección de las estrategias empleadas en la formulación de actos principales, se obtuvieron los resultados siguientes: 
Figura 28. Distribución de enunciados según las estrategias de petición empleadas en los actos principales para la situación 4 en cada grupo de género

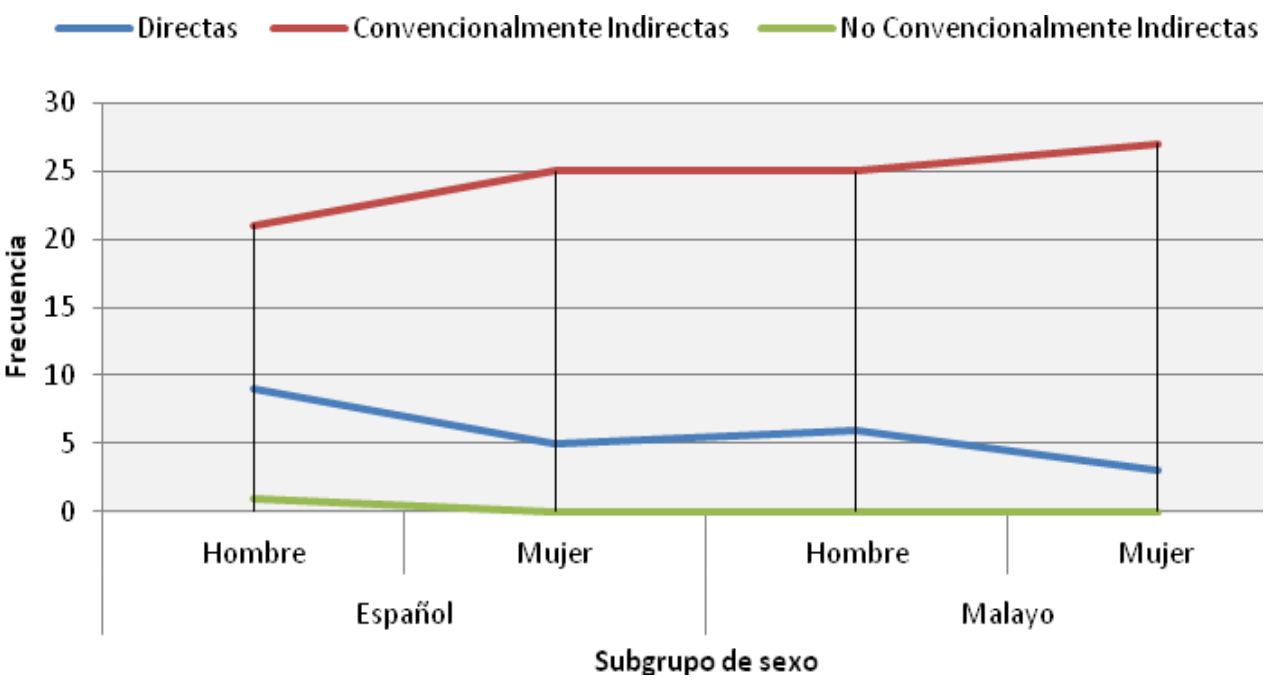

Los hablantes de ambos sexos del grupo español y malayo coinciden en revelar una mayor utilización de las estrategias "Convencionalmente indirectas", pero la preferencia mostrada por parte de las mujeres fue un poco más alta que la de los varones, con 25 enunciados de los varones y 21 de las mujeres en el grupo español y 27 y 25 respectivamente en el malayo. Por el contrario, fueron los varones los que usaron las estrategias directas en una proporción más elevada, con 9 enunciados registrados (5 de las mujeres) en la primera cultura, y 6 en la segunda (frente a 3 de las mujeres en dicho subgrupo). Las estrategias "No convencionalmente indirectas" solo aparecen en los datos de los varones del grupo español y, además, con un único ejemplo. La diferencia entre los 
promedios de las estrategias empleadas por hombres y mujeres, no fue significativa ni en el resultado español ni en el malayo.

Si aplicamos a los enunciados analizados anteriormente la clasificación en nueve categorías con la que venimos trabajando, la gráfica que obtenemos es la que aparece a continuación:

Figura 29. Distribución de enunciados (actos principales) según estrategias aplicadas, registrados para la situación 4 en cada grupo de género

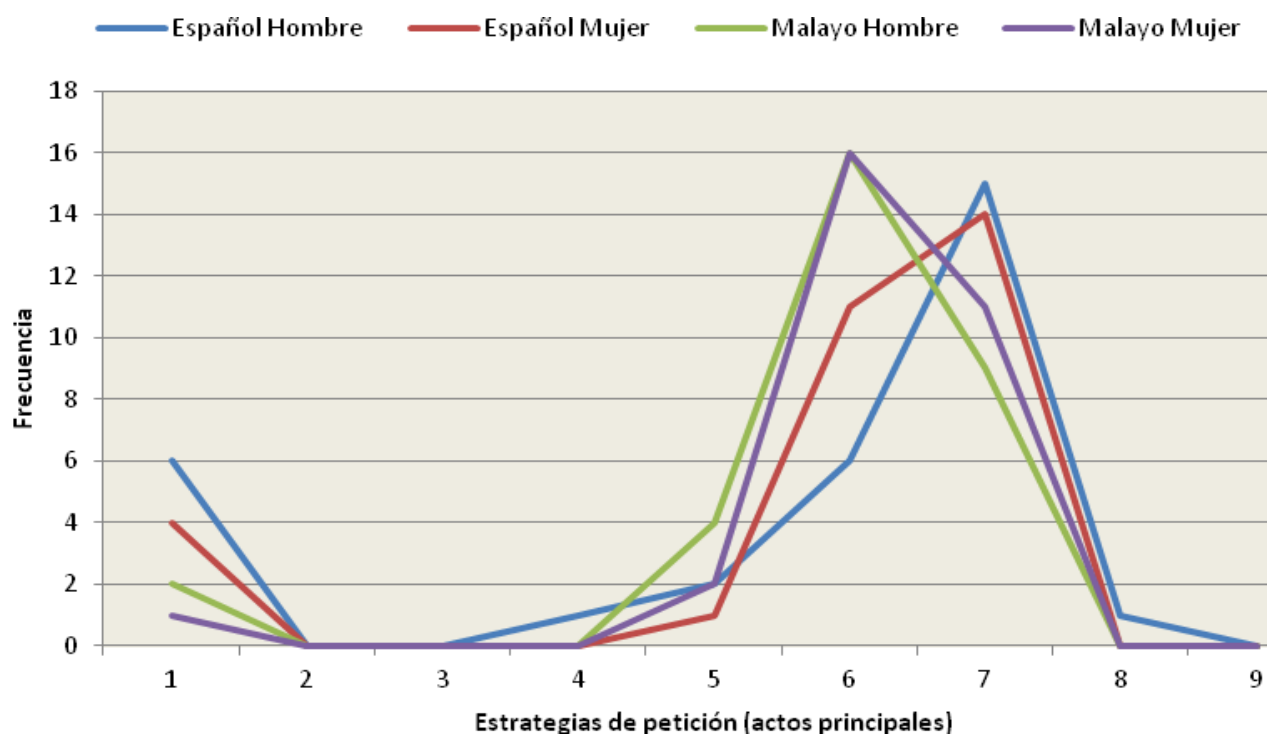

1.Imperativo 2.Performativo 3.Performativo evasivo 4.Declaración de obligación 5.Declaración de deseo 6.Fórmula de sugerencia 7.Interrogación preparatoria 8. Indicio fuerte 9 .Indicio suave

Como se observa en la tabla anterior, la forma dominante, con 15 ejemplos recogidos en el corpus de los varones españoles, y 14 en el de las mujeres, fue la "Interrogación preparatoria". En la sociedad malaya, en cambio, la opción más elegida correspondió a la 
estrategia de "Fórmula de sugerencia", con 16 enunciados producidos por los hablantes de cada grupo de género.

Al contrastar, en el caso español, las peticiones formuladas por los hablantes de ambos géneros, encontramos que los varones aplicaron más estrategias diferentes en los actos principales que las mujeres ( 6 enunciados de los varones frente a 4 de las mujeres). Hay que mencionar, además, que en los datos masculinos aparecen dos estrategias, "Declaración de obligación" e "Indicio fuerte", que no fueron registradas en los datos femeninos. En cambio, todas las estrategias utilizadas por las mujeres están también presentes en el corpus de los varones. Por otro lado, en el caso malayo, los sujetos de los dos sexos mostraron una tendencia muy similar, no solo en la variedad de estrategias aplicadas, sino también en su distribución estadística según el número de enunciados en los que se utiliza cada una. En ninguno de los dos casos, ni actos principales ni movimientos de apoyo, que se presentarán a continuación, se detectaron diferencias estadísticas significativas entre los varones y las mujeres en los promedios de los enunciados producidos.

A continuación presentamos el esquema que recoge las estrategias empleadas en los enunciados producidos como movimientos de apoyo: 
Figura 30. Distribución de enunciados (movimientos de apoyo), por tipo de estrategia empleada, producidos por los sujetos de cada grupo de género para la situación 4

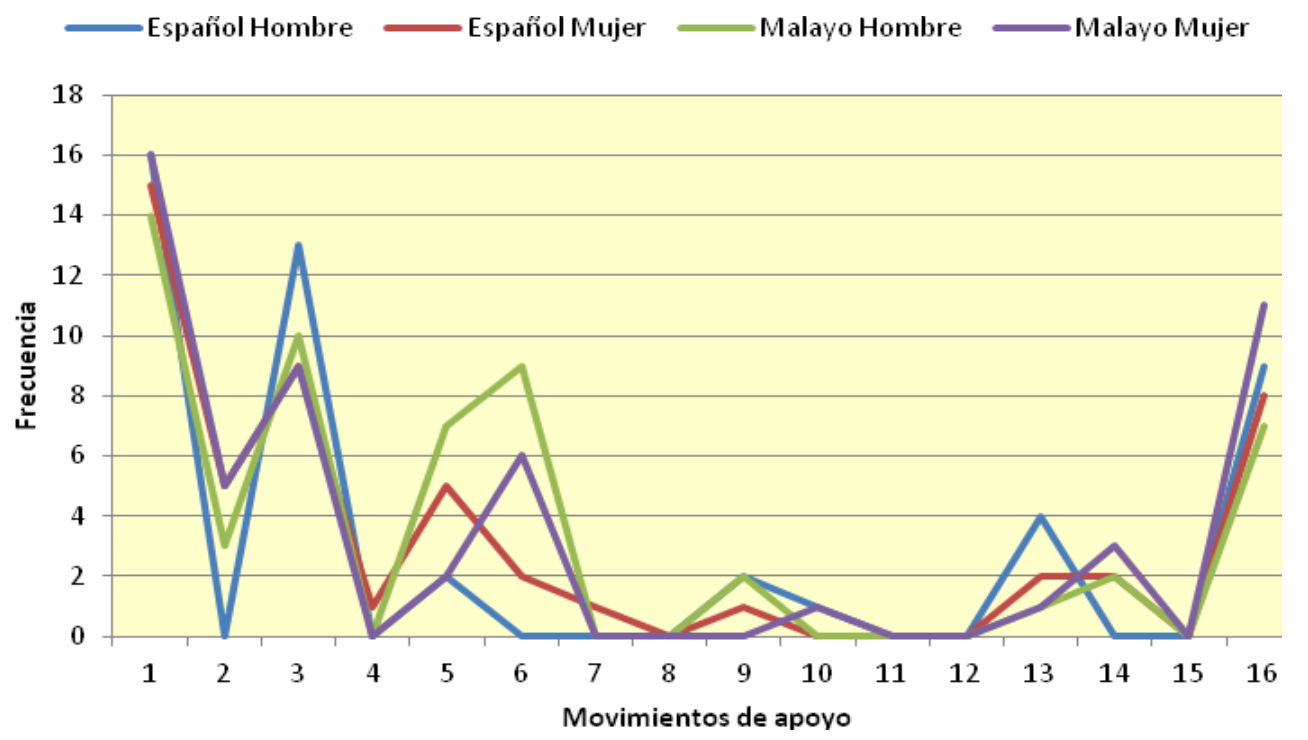

1.Fórmulas de preparación 2.Búsqueda de un compromiso 3.Razones 4.Previsión de objeciones 5.Promesa de recompensa/reparación 6.Minimización de la imposición 7.Invocación de principios generales 8.Reconocimiento de la imposición 9.Preocupación 10.Apreciación 11.Promesa de devolución 12.Gravedad/urgencia 13.Presentación/saludo 14.Petición de la opinión del oyente 15.Disculpa 16.Fórmulas de tratamiento

El análisis revela que tanto los varones como las mujeres prefirieron, en ambas lenguas, mitigar la petición a su compañero de piso con "Fórmulas de preparación", usándola más los hombres españoles que las mujeres (16 ejemplos recogidos, frente a 15), pero más las mujeres malayas que los varones de dicha sociedad (16 frente a 14).

En lo que concierne al número de enunciados producidos en esta situación, las mujeres españoles utilizaron más que los varones (51 ejemplos de las mujeres y 47 de los varones). Asimismo, 
los sujetos femeninos usaron más estrategias diferentes que los varones (11 de las mujeres frente a 7 de los varones). Cabe mencionar que ningún varón español aplicó la de "Apreciación" pero sí aparece una vez en los datos de las mujeres. En cambio, las de "Búsqueda de un compromiso", "Previsión de objeciones", "Minimización de la imposición", "Invocación de principios generales" y "Petición de la opinión del oyente" solo aparecen en las respuestas de las mujeres, pero no se encontró ningún caso de dichas estrategias en las de los varones.

Por otro lado, en el caso malayo, no hubo diferencias notables respecto a la frecuencia, ya que los varones produjeron 55 enunciados y, las mujeres, 54. Y en estos enunciados, los hablantes de ambos subgrupos emplearon nueve estrategias diferentes al hacer la petición a una persona conocida.

En lo que se refiere a las estrategias recogidas en los datos de ambos géneros, los varones aplicaron 2 veces la de "Preocupación", mientras que en los datos del otro subgrupo no se encontró ningún caso. La de "Apreciación", en cambio, está presente en el corpus de las mujeres, pero no hay ningún registro en el de los varones. Del resto de estrategias hay ejemplos en las respuestas de ambos sexos, varones y mujeres. 


\subsubsection{Situación 7}

En la situación 7 el hablante le pide a su mejor amigo que vaya a su casa a hacerle compañía. El grado de familiaridad es, por tanto, alto (muy conocido), y no hay dominio jerárquico, por lo que el análisis desde el punto de vista de las variables sociales quedará reducido únicamente al de la distancia social.

\section{A) Español frente a malayo}

Al analizar el grado de (in)dirección de las estrategias empleadas en los actos principales, el resultado es que, de manera similar a las situaciones anteriores, la mayoría de las estrategias utilizadas para formular la petición en este escenario pertenecen al grupo de las llamadas "Convencionalmente indirectas". La segunda opción preferida fueron las "Directas" $y$, la tercera, las "No convencionalmente indirectas", como muestra la grafica de la figura 31. 
Figura 31. Distribución de enunciados según el grado de (in)dirección de las estrategias de petición empleadas en los actos principales, producidos para la situación 7 en cada cultura

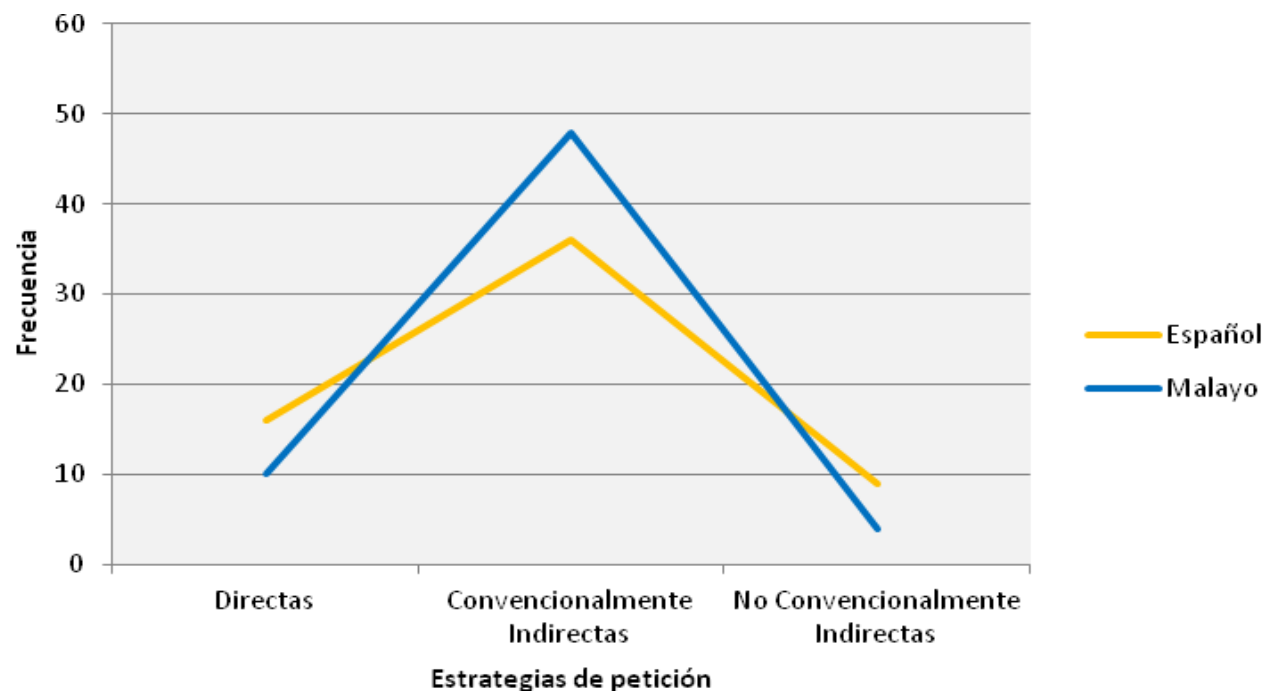

Pese a que los encuestados optaron, en mayor grado, por estrategias "Convencionalmente indirectas", fueron los malayos, como vemos en el gráfico, los que utilizaron con mayor frecuencia dicha forma: 48 ejemplos recogidos frente a 36 de los españoles. En cambio, los españoles recurrieron a las "Directas" y las "No convencionalmente indirectas" en mayor medida: 16 enunciados, por 10 de los malayos, en el primer caso y, 9, frente a 4 de los malayos, en el segundo. Al comparar los promedios de las categorías aplicadas por ambas sociedades, la diferencia no fue significativa.

A continuación, pasamos a presentar la distribución detallada de dichas estrategias en la nueves sub-categorías de BlumKulka (véase capítulo 3). 
Figura 32. Distribución de los enunciados producidos como actos principales para la situación 7 en cada cultura, según el tipo de estrategia utilizada

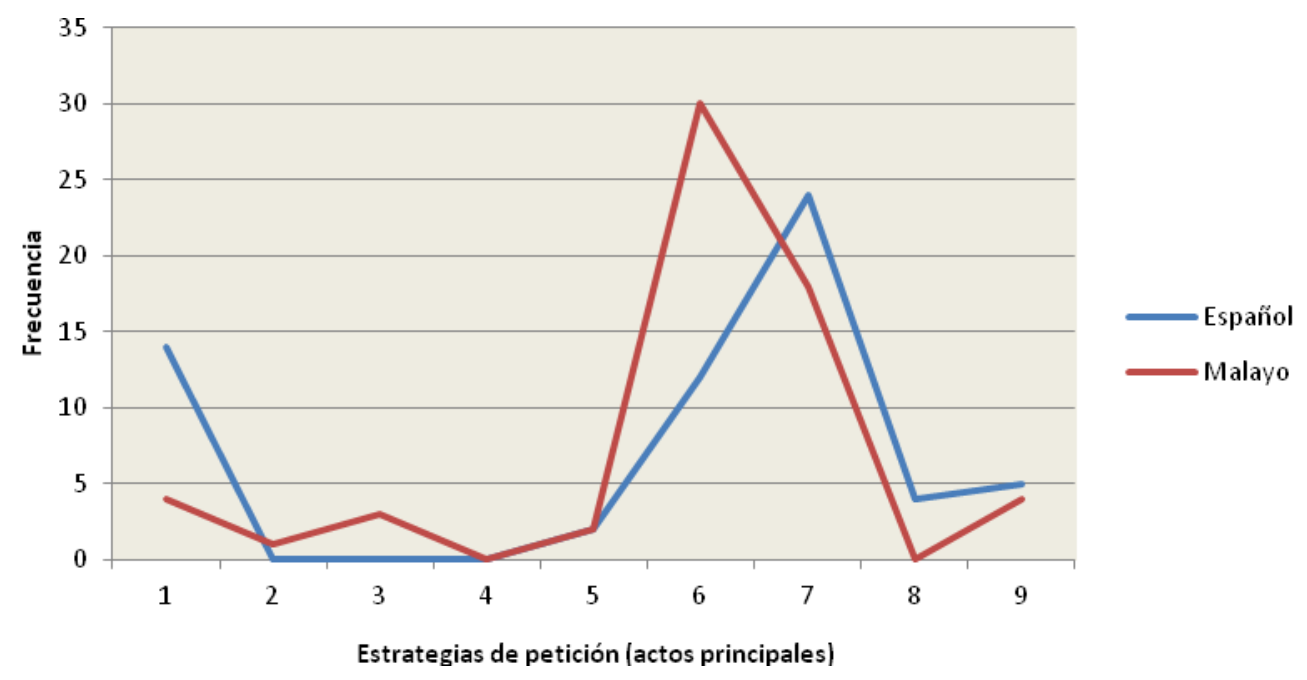

1.Imperativo 2.Performativo 3.Performativo evasivo 4.Declaración de obligación 5.Declaración de deseo 6.Fórmula de sugerencia 7.Interrogación preparatoria 8. Indicio fuerte 9 .Indicio suave

La distribución de las estrategias de los actos principales formulados en esta situación se concentró en distintas opciones. Los españoles mostraron preferencia por la fórmula de "Interrogación preparatoria", mientras que los malayos revelaron una mayor tendencia hacia el uso de una "Fórmula de sugerencia", al hacer la petición a una persona intima. Respecto a la diferencia en las estrategias seleccionadas, los nativos españoles emplearon 6 opciones distintas para hacer la petición en este contexto, mientras que los malayos optaron por 7 fórmulas diferentes. Las estrategias de "Performativo" y "Performativo evasivo" solo las utilizaron los malayos, quienes, por el contrario, no aplicaron en ningún caso la 
estrategia de "Indico fuerte", que sí apareció en los datos españoles en 4 ocasiones. Las pruebas estadísticas señalaron diferencias significativas entre las medias obtenidas por España y Malasia: $X^{2}=22.231 \mathrm{p}=.002(\mathrm{p}<.05)$.

Al llevar a cabo el análisis sobre los movimientos de apoyo empleados por los dos grupos en sus peticiones, encontramos que las dos comunidades de habla utilizaron variedades relativamente variadas de movimientos de apoyo, como podemos ver en la siguiente gráfica:

Figura 33. Distribución de enunciados según el tipo de estrategia empleada en los movimientos de apoyo en la situación 7 por los hablantes de cada cultura
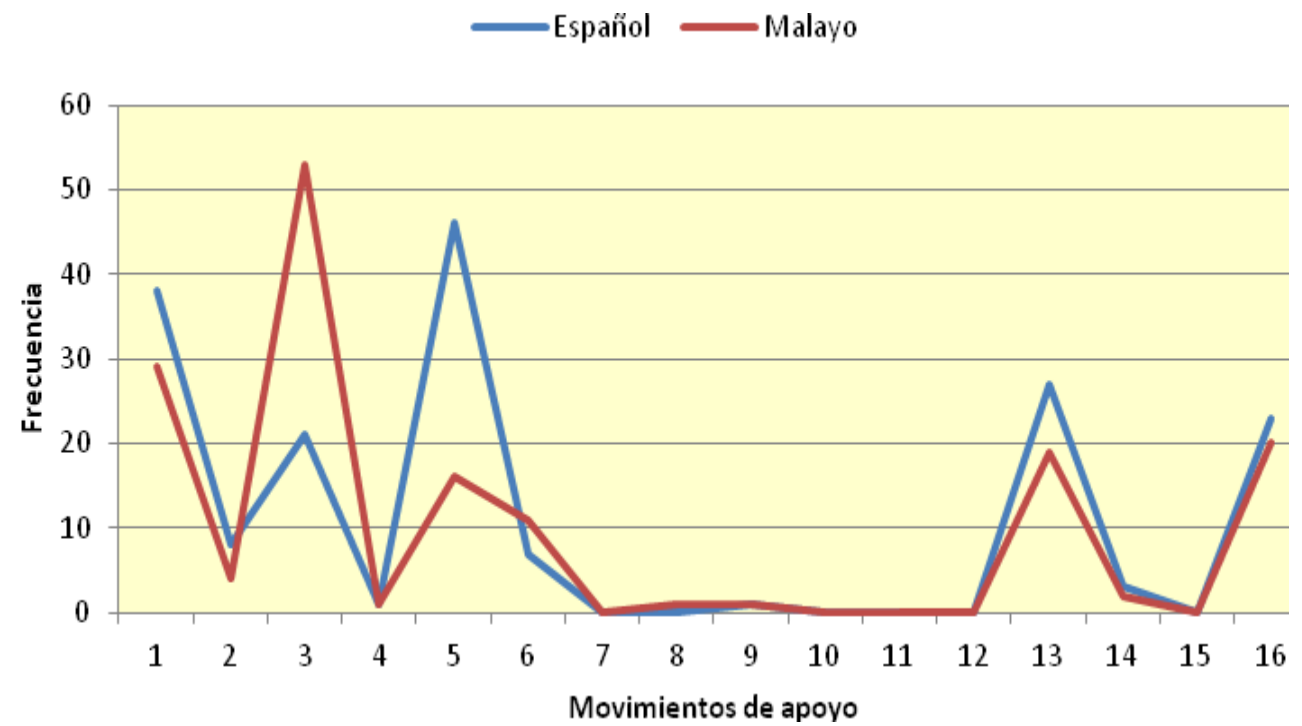

1.Fórmulas de preparación 2.Búsqueda de un compromiso 3.Razones 4.Previsión de objeciones 5.Promesa de recompensa/reparación 6.Minimización de la imposición 7.Invocación de principios generales 8.Reconocimiento de la imposición 9.Preocupación 10.Apreciación 11.Promesa de devolución 12.Gravedad/urgencia 13.Presentación/saludo 14.Petición de la opinión del oyente 15.Disculpa 16.Fórmulas de tratamiento 
Al pedir el hablante a su mejor amigo que vaya a casa para hacerle compañía, la estrategia preferida por los hablantes españoles fue la de "Promesa de recompensa/reparación", seguida de las de "Fórmulas de preparación" y "Presentación/saludo" (solo se mencionan las tres más utilizadas). Por otro lado, la fórmula por la que se inclinaron los malayos fue la de "Razones", seguida de las de "Fórmulas de preparación" y "Presentación/saludo" (otra vez, solo se mencionan las tres más empleadas).

En cuanto al número total de enunciados formulados, fueron los españoles los que produjeron un mayor número (175 frente a 157 de los malayos). Ahora bien, con respecto a la utilización de estrategias diferentes, aunque con solo una de diferencia, fueron los malayos los que presentaron un repertorio más variado: 11 fórmulas diferentes, frente a las 10 de los españoles. En este caso, las pruebas estadísticas también señalaron diferencias significativas entre las medias de los datos de los dos países: $X^{2}=33.709 p=.000(p<.05)$. 
El cálculo de frecuencia llevado a cabo revela que, tanto los mayores como los jóvenes en ambos grupos, prefirieron, en primer lugar, las formas "Convencionalmente indirectas", con el mismo número de ejemplos en los dos subgrupos de cada cultura. Estos datos aparecen reflejados en la Figura 34.

Figura 34. Distribución de enunciados según el grado de (in)dirección de las estrategias empleadas en los actos principales producidos en la situación 7 por los subgrupos en cada cultura

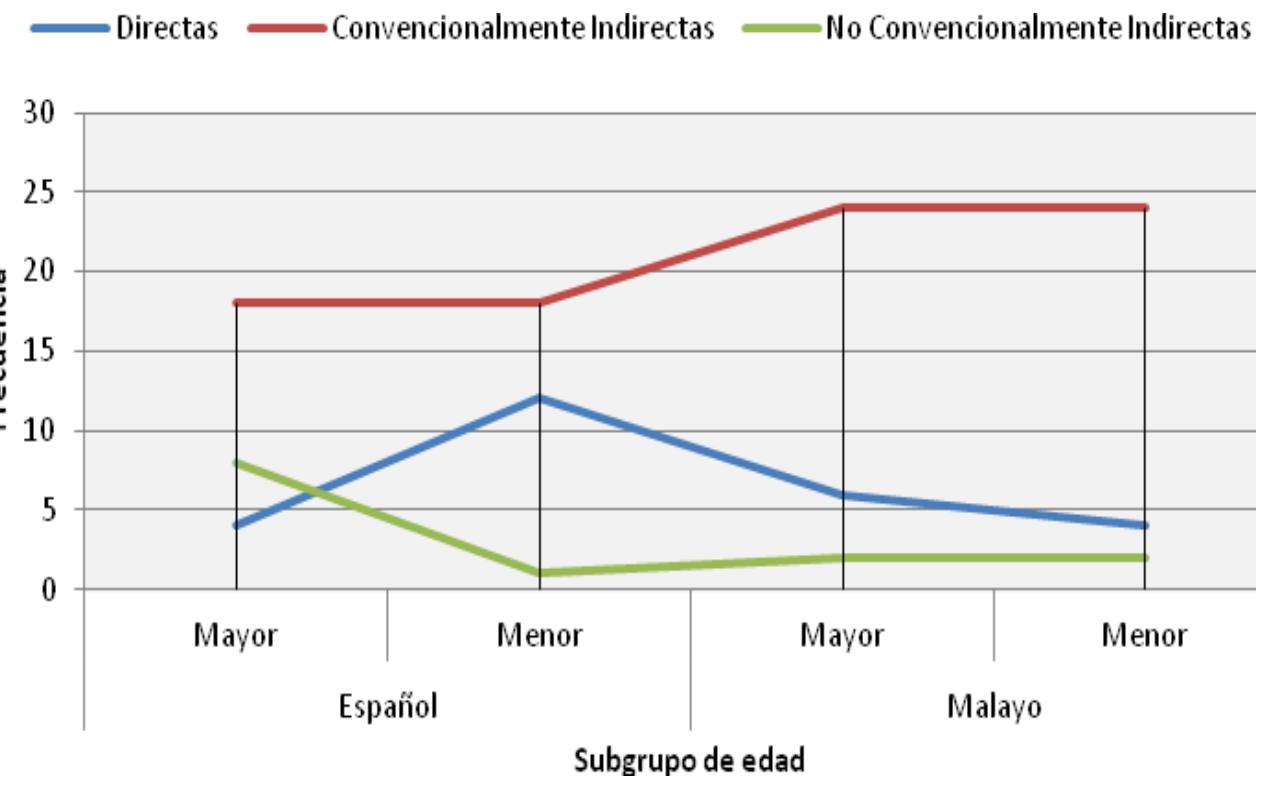

Las formas "Directas" ocupan, entonces, el segundo lugar en las preferencias de los menores españoles y, en las de los dos subgrupos de edad malayos, pero están en tercer lugar en el corpus de los mayores españoles, mientras que en el caso de las "No 
convencionalmente indirectas" ocurrió justo lo contrario, ya que son los mayores españoles los que más recurren a ellas. La comparación de los promedios de las categorías empleadas indicó una diferencia significativa en el grupo español: $X^{2}=9.431 \mathrm{p}=.009(\mathrm{p}>.05)$, pero no en el malayo.

En relación con la distribución de los enunciados analizados anteriormente teniendo en cuenta la sub-clasificación de estrategias empleadas en los nueve tipos propuestos por Blum-Kulka (véase capítulo3), los dos subgrupos de edad, en ambas culturas, no se diferenciaron ni en la estrategia más frecuentemente utilizada ni en el número de enunciados en los que se presenta. Ambos, los sujetos españoles mayores, y también los más jóvenes, se inclinaron, en mayor medida, por el uso de la "Interrogación preparatoria" en su petición (12 veces). Por otra parte, en el subgrupo malayo, tanto los jóvenes como los de más edad mostraron preferencia por la "Fórmula de sugerencia" (15 veces) cuando realizaron la petición a un amigo íntimo. Estos resultados aparecen en la grafica expuesta en la figura 35. 
Figura 35. Distribución de enunciados (actos principales) según la estrategia de petición empleada en la situación 7 por los hablantes de ambos subgrupos en cada cultura

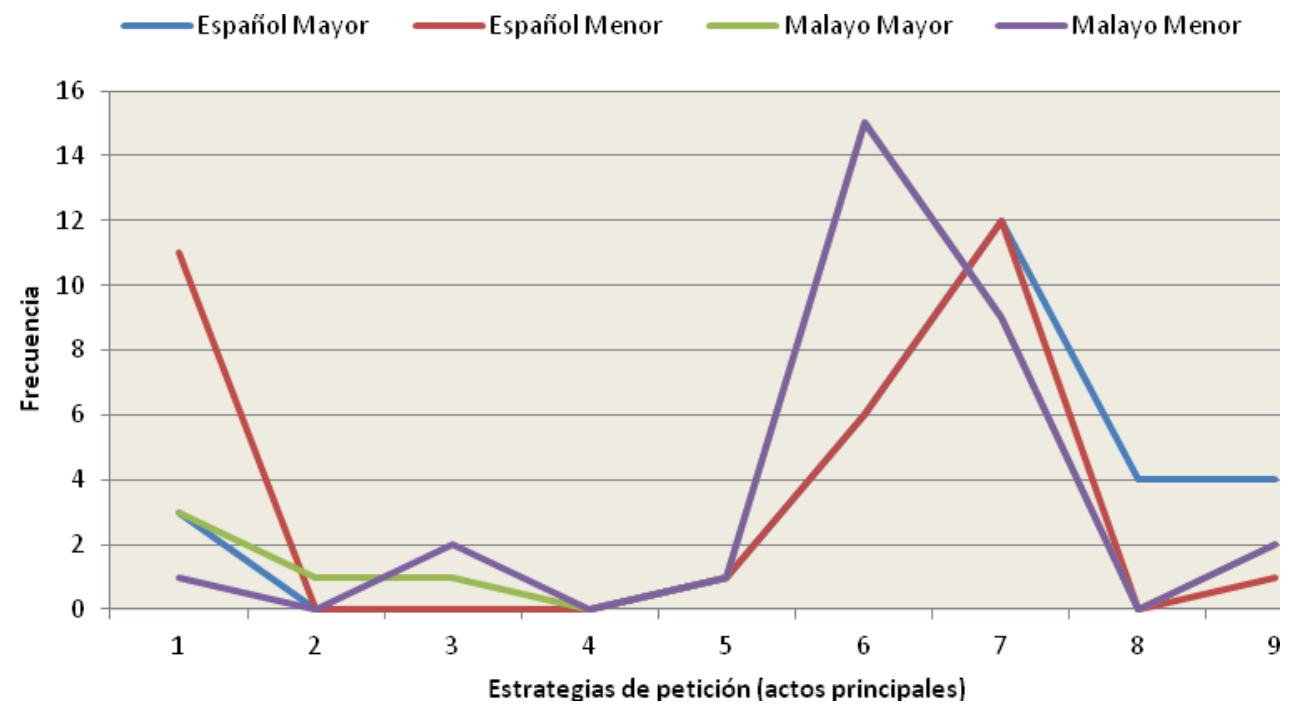

1.Imperativo 2.Performativo 3.Performativo evasivo 4.Declaración de obligación 5.Declaración de deseo 6.Fórmula de sugerencia 7.Interrogación preparatoria 8. Indicio fuerte 9.Indicio suave

En el grupo español, los mayores aplicaron 6 estrategias diferentes, mientras que los jóvenes usaron 7. Por otro lado, en el grupo malayo, los mayores emplearon 5 y los menores utilizaron 6 . Todas las estrategias encontradas en las respuestas de los sujetos menores en el grupo español, también las utilizaron los mayores. En cambio, en el caso del "Indicio fuerte", no se encontró ningún caso en los datos de los menores, pero aparece en los datos mayores en 4 ocasiones. En el grupo malayo, por su parte, el "Performativo" está presente en los datos de los mayores, pero ningún joven lo utilizó. Los valores de la media confirman que no hay diferencia significativa entre los dos subgrupos de edad comparados, que tampoco existirá, 
como veremos, ni en el estudio de las nueve sub-categorías de estrategias, ni en los resultados obtenidos acerca de los de movimientos de apoyo, que se presentarán a continuación.

En los resultados obtenidos en la investigación, y que presentamos en la tabla de la figura 108 , vemos que, al comparar el empleo de movimientos de apoyo por mayores y menores de ambas sociedades en esta situación, en los dos casos son los participantes de edad más avanzada los que emplean un mayor número de enunciados (92 de los sujetos mayores frente a 83 de los menores en el caso español, y 79 frente a 78, en el malayo). En cuanto a las estrategias aplicadas, en ninguno de los casos fueron empleadas todas las opciones posibles, ya que los participantes de todos los subgrupos de edad utilizaron 9 (de las 16 posibles), excepto los sujetos mayores españoles que solamente emplearon 8. 
Figura 36. Distribución de enunciados (movimientos de apoyo) según las estrategias empleadas en la situación 7 por los subgrupos de cada cultura

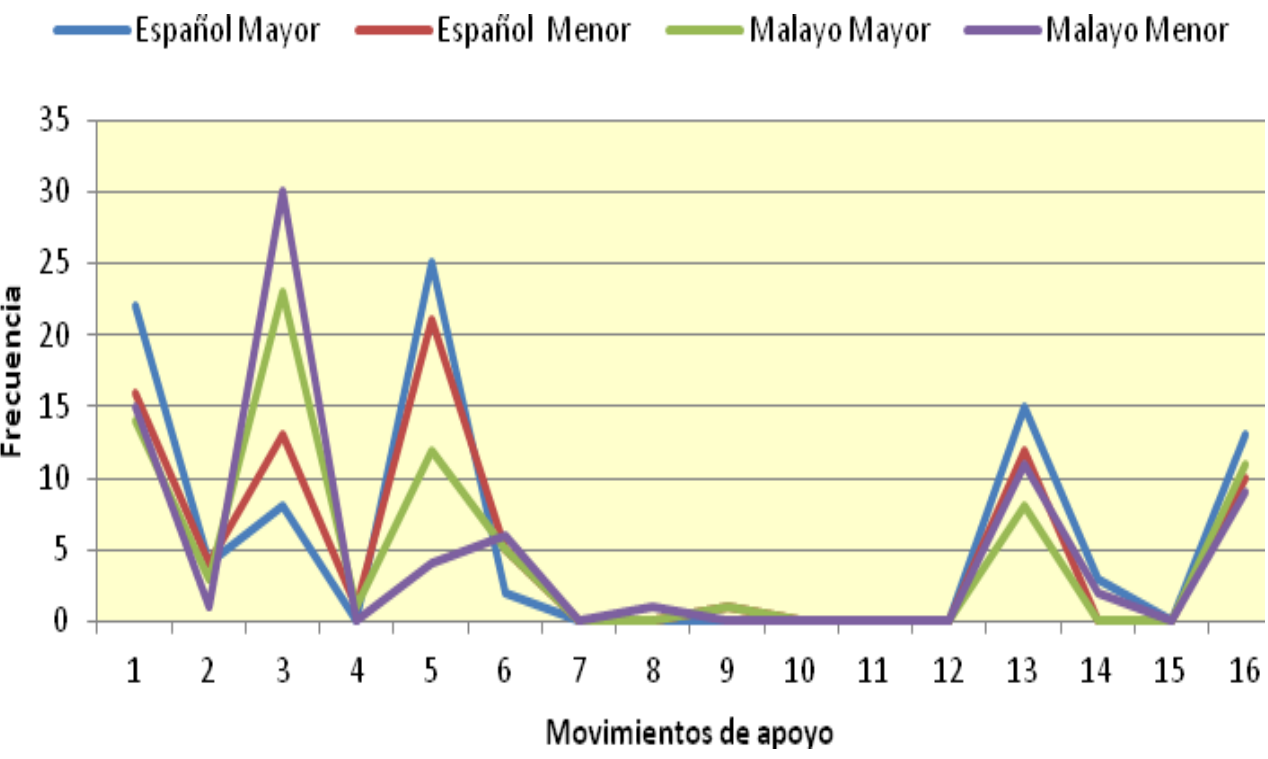

1.Fórmulas de preparación 2.Búsqueda de un compromiso 3.Razones 4.Previsión de objeciones 5.Promesa de recompensa/reparación 6.Minimización de la imposición 7.Invocación de principios generales 8.Reconocimiento de la imposición 9.Preocupación 10.Apreciación 11.Promesa de devolución 12.Gravedad/urgencia 13.Presentación/saludo 14.Petición de la opinión del oyente 15.Disculpa 16.Fórmulas de tratamiento

Tal y como se refleja en los resultados estadísticos de la gráfica anterior, en la sociedad española ambos subgrupos de edad no se diferenciaron mucho en las estrategias más elegidas: 25 enunciados de los mayores y 21 de los menores con "Promesa de recompensa/reparación" y, 22 y 16, respectivamente, con "Fórmulas de preparación". En el grupo malayo, la estrategia preferida por ambos subgrupos fue la de "Razones", con 23 ejemplos recogidos de los mayores y 30 de los jóvenes. 
Pero también encontramos algunas diferencias destacables en el uso de las estrategias en los datos españoles y los malayos. Así, en el caso español, las estrategias de "Previsión de objeciones" y "Preocupación" aparecen en las respuestas de los menores, pero ningún hablante del subgrupo de mayores las aplicó. En el caso malayo, por el contrario, estas mismas estrategias solo se encuentran en el corpus de los mayores pero no hay registros en el de los menores. En cambio, la de "Petición de la opinión del oyente", que solo utilizan los mayores del grupo español, en el caso malayo solamente aparece en las respuestas de los menores, al igual que la de "Reconocimiento de la imposición".

\section{C) Varón frente a mujer}

Tras analizar las respuestas de hombres y mujeres de ambas sociedades, vimos que los encuestados de los dos géneros, en ambos grupos, aplicaron en sus peticiones distintos grados de dirección. La distribución correspondiente de los enunciados formulados como actos principales, se presenta a continuación en la figura 37. 
Figura 37. Distribución de enunciados (actos principales) según el grado de (in)dirección de las estrategias de petición empleadas para la situación 7 por los dos géneros en cada cultura

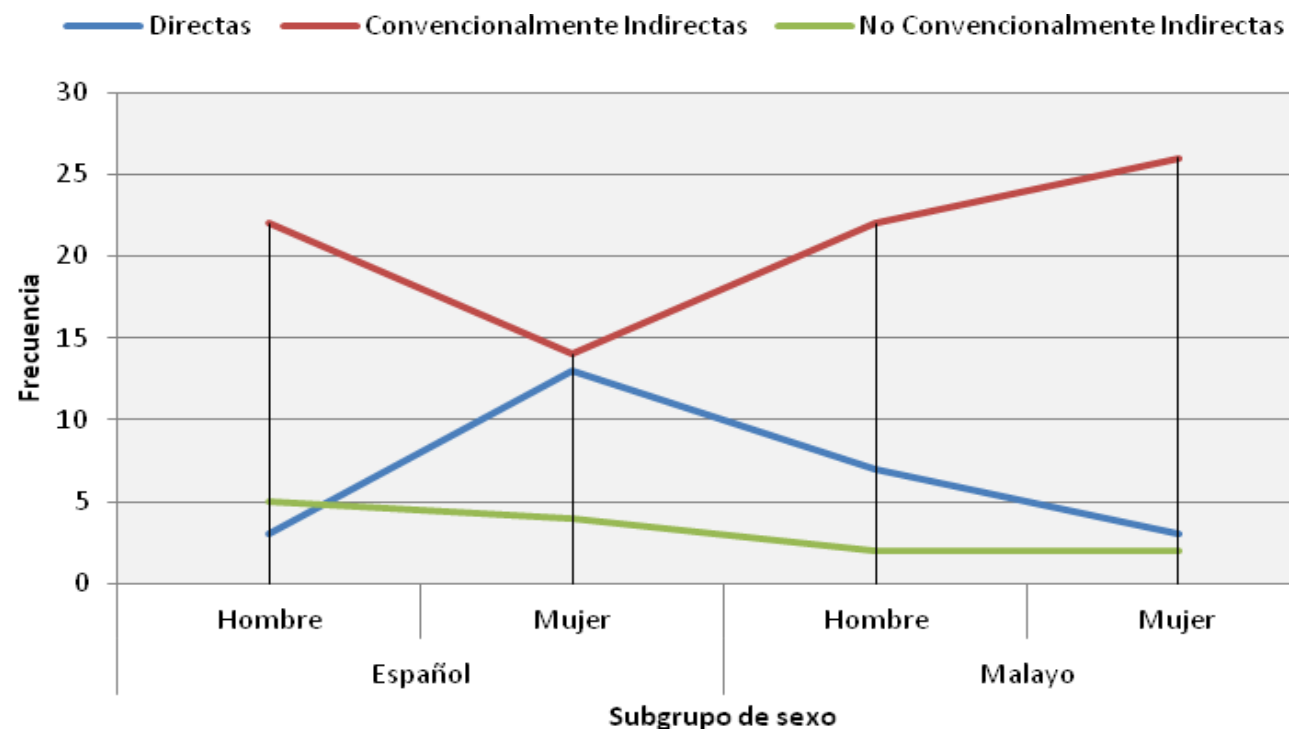

Los varones y las mujeres de ambos grupos mostraron preferencia, en el contexto establecido, por realizar sus peticiones utilizando las estrategias del tipo "Convencionalmente Indirectas". Las estrategias "Directas" son las segundas más utilizadas por las mujeres españoles, y también por los hablantes de los dos géneros malayos, pero ocupan el tercer lugar en las respuestas de los varones españoles. Por el contrarío, las formas "No convencionalmente indirectas" son las menos empleadas por los tres primeros subgrupos, pero ocupan el segundo lugar en el cuarto.

Las estrategias "Convencionalmente indirectas", las más empleadas en este contexto, fueron más utilizadas por los varones que por las mujeres, en la sociedad española, (22 ejemplos de los 
varones frente a 14 de las mujeres). En cambio, las mujeres se inclinaron más hacia las "Directas" (13 enunciados, en comparación con solo 3 de los varones). Fueron los varones los que aplicaron con mayor frecuencia formas "No convencionalmente indirectas" (5 registros de los varones y 4 de las mujeres).

En el caso malayo, al revés que en el caso anterior, fueron las mujeres las que hicieron peticiones con estrategias "Convencionalmente indirectas" con mayor frecuencia que los varones ( 26 enunciados de las mujeres frente de 22 de los varones). Pero, los varones aplicaron más que las mujeres las "Directas" (7 ejemplos de los varones frente a 3 de las mujeres). Respecto a las "No convencionalmente indirecta", los dos subgrupos, varones y mujeres, las emplearon con la misma frecuencia (ambos las usaron 2 veces). Al comparar los promedios de las estrategias aplicadas entre los subgrupos de sexo, la diferencia fue significativa en el resultado del grupo español: $X^{2}=8.125 p=.017(p<.05)$, pero no en el grupo malayo.

Si prestamos atención a la clasificación de las estrategias de los actos principales en las nueve sub-categorías de Blum-Kulka, nos damos cuenta de que en el grupo de hablantes de cada género se muestra una tendencia distinta, tal y como se refleja en la tabla de la figura 38. 
Figura 38. Distribución de enunciados según la estrategia de petición empleada en los actos principales por los hablantes de ambos géneros de cada cultura para la situación 7

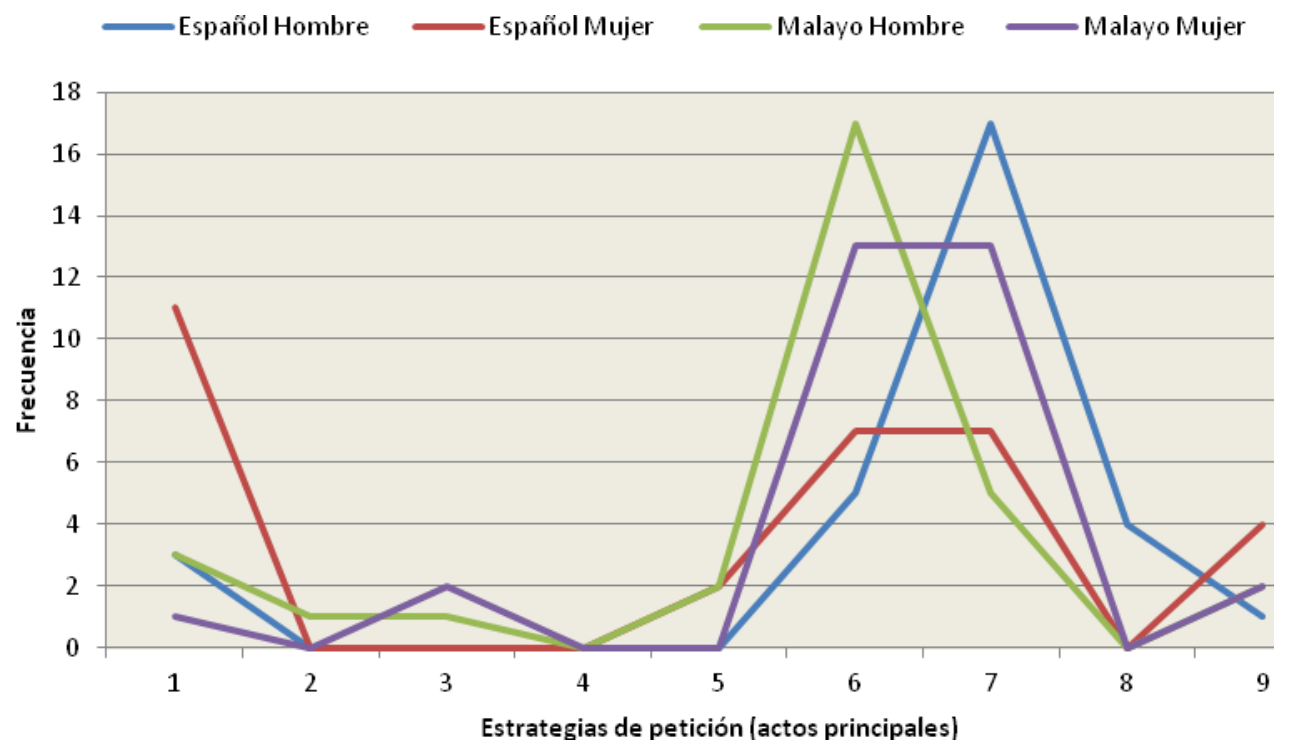

1.Imperativo 2.Performativo 3.Performativo evasivo 4.Declaración de obligación 5.Declaración de deseo 6.Fórmula de sugerencia 7.Interrogación preparatoria 8. Indicio fuerte 9.Indicio suave

Como se puede ver en la gráfica, los varones españoles tendieron a utilizar más la estrategia de "Interrogación preparatoria", mientras que la estrategia que usaron con más frecuencia las mujeres fue la de "Imperativo". En la sociedad malaya, los varones se inclinaron por elegir una "Fórmula de sugerencia" al realizar sus peticiones, mientras que las mujeres emplearon mayoritariamente las de "Fórmula de sugerencia" y "Interrogación preparatoria".

Los hablantes españoles de los dos sexos utilizaron el mismo número de estrategias diferentes (ambos aplicaron 5 estrategias). En cambio, en el otro grupo, los varones emplearon 
más estrategias diferentes que las mujeres (se recogieron enunciados con 7 estrategias de los varones frente a 5 de las mujeres). En este escenario, ningún varón español aplicó la estrategia de "Declaración de deseo", pero sí aparece 2 veces en el corpus de mujer. Pero no se encontró ningún caso del uso de "Indicio fuerte" en los datos de las mujeres, que sí aparece en el corpus de los varones en 4 ocasiones. Por otra parte, en los datos malayos, las estrategias que se presentan en las respuestas de los varones, pero no se encuentran en los datos de las mujeres fueron las de "Performativo" y "Declaración de deseo", mientras que todas las aplicadas por las mujeres están también presentes en los enunciados de los varones. En este caso, la diferencia de los promedios comparados de las estrategias empleadas también fue significativa entre los subgrupos de sexo españoles: $X^{2}=16.860$ $\mathrm{p}=.005(\mathrm{p}<.05)$, y tampoco significativa en el grupo malayo.

Por último, vamos a pasar a examinar la distribución de estrategias en los enunciados de los movimientos de apoyo producidos por los hablantes de los dos géneros en ambas sociedades. Los resultados numéricos obtenidos en el análisis de los cuestionarios son los siguientes: 
Figura 39. Distribución de enunciados según las estrategias empleadas por los hablantes malayos y españoles de ambos géneros en los movimientos de apoyo producidos para la situación 7
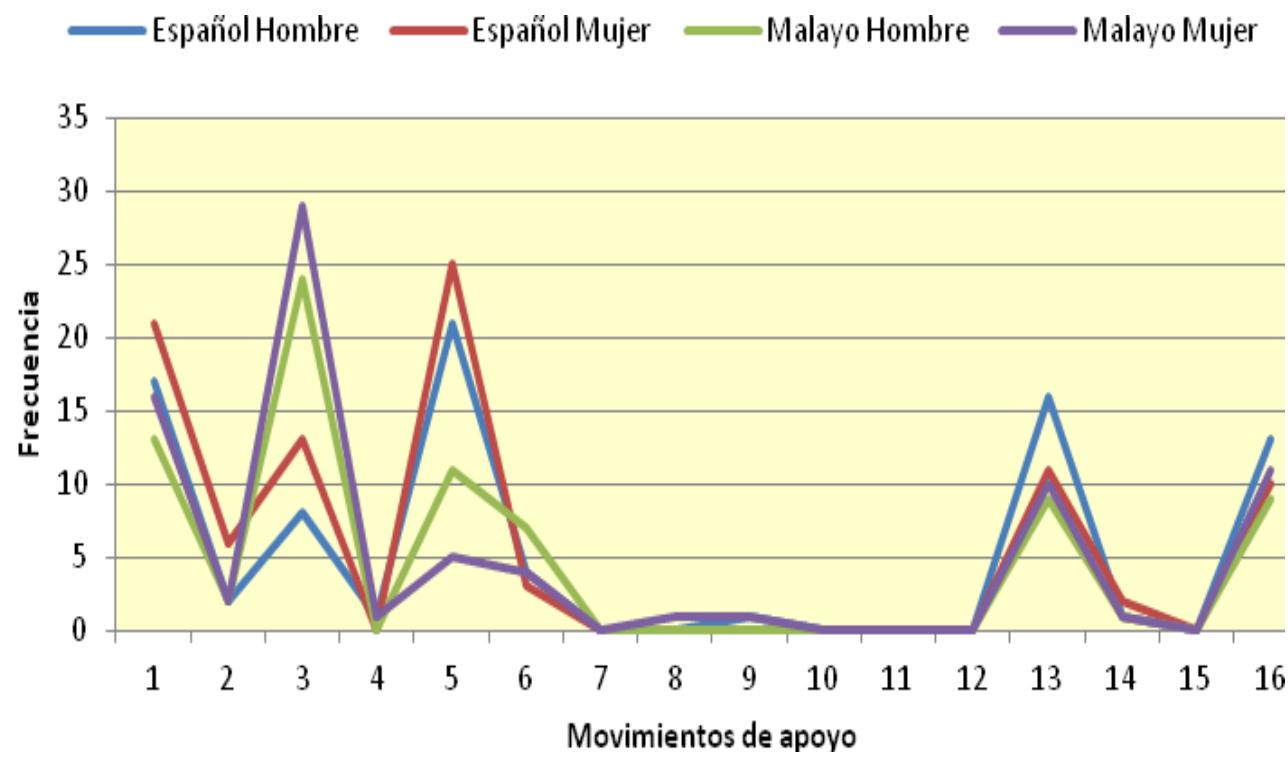

1.Fórmulas de preparación 2.Búsqueda de un compromiso 3.Razones 4.Previsión de objeciones 5.Promesa de recompensa/reparación 6.Minimización de la imposición 7.Invocación de principios generales 8.Reconocimiento de la imposición 9.Preocupación 10.Apreciación 11.Promesa de devolución 12.Gravedad/urgencia 13.Presentación/saludo 14.Petición de la opinión del oyente 15.Disculpa 16.Fórmulas de tratamiento

Los sujetos españoles de ambos sexos mostraron la misma preferencia hacia el uso de la estrategia de "Promesa de recompensa/reparación" para agravar sus peticiones, mientras que los hablantes malayos coinciden en mostrar preferencia por la de "Razones". En esta situación, tanto las mujeres españolas como las malayas utilizaron más estrategias de movimientos de apoyo que los varones. Y los varones españoles aplicaron más variedad de estrategias que las mujeres (10 tipos distintos, frente a los 8 de las mujeres). En cambio, las mujeres malayas emplearon más opciones diferentes que los varones (11, frente a 8 de los varones). 
Hay que mencionar que, en el grupo español, ninguna mujer recurrió a la estrategia de "Preocupación", pero sí se encontró un caso en los datos de los varones. $\mathrm{Y}$ todas las estrategias registradas en los datos de las mujeres también aparecen en los enunciados de los varones. Por otra parte, en el caso malayo, ningún varón aplicó las de "Previsión de objeciones", "Reconocimiento de la imposición" y "Preocupación", pero sí que aparecen una vez cada una en los datos del otro subgrupo, y todas las estrategias utilizadas por los varones también las aplicaron las mujeres. Según las pruebas estadísticas, los subgrupos de sexo de ambas culturas no se diferencian significativamente.

\subsubsection{Situación 10}

En la situación 10, un alumno pide a un antiguo profesor de la universidad una carta de recomendación para solicitar un trabajo. El dominio de poder social es del interlocutor, puesto que en este contexto específico, los informantes se sitúan en una posición inferior frente al profesor. Esta situación se establece para examinar el poder social, no la distancia. 


\section{A) Español frente a malayo}

A diferencia de las tres situaciones analizadas anteriormente, en los enunciados producidos como actos principales para la situación 10 los informantes de las dos sociedades tendieron a aplicar más las formas "No convencionalmente indirectas" al hacer la petición, seguidas de las "Convencionalmente indirectas" y de las "Directas", tal y como puede observarse en la siguiente tabla:

Figura 40. Distribución de enunciados (actos principales) según el grado de (in)dirección de las estrategias de petición empleadas para la situación 10, en cada cultura

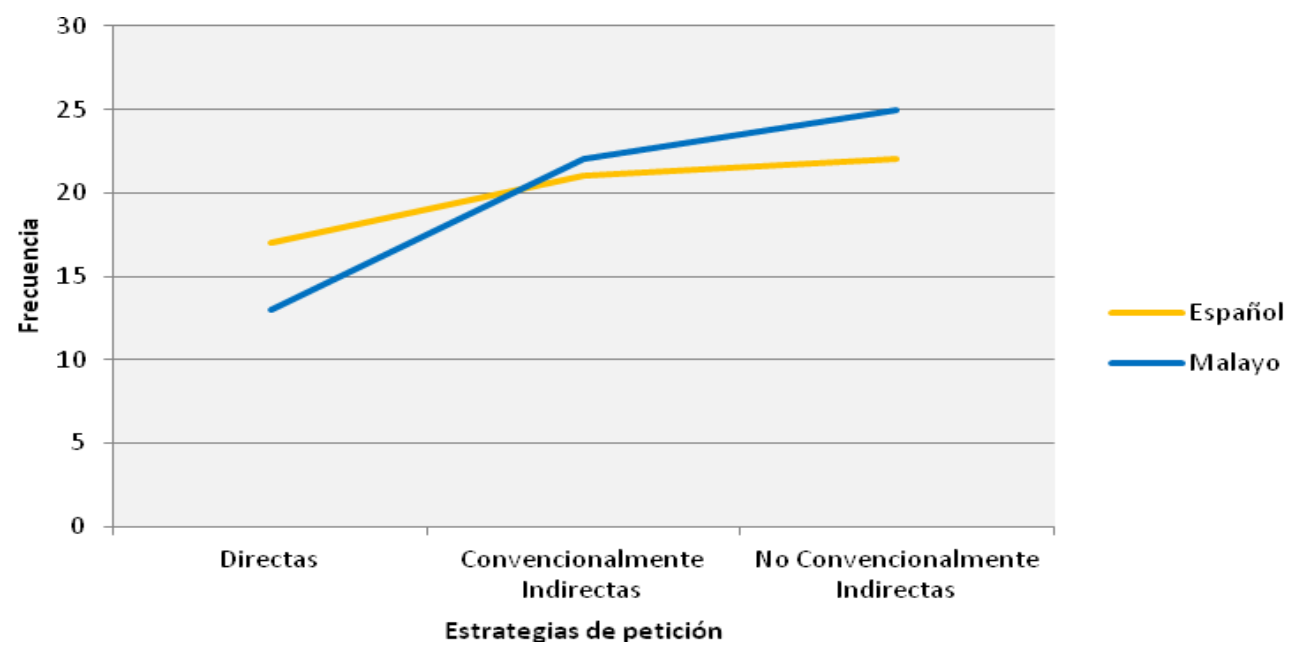

Aunque no hubo una gran diferencia en el número de enunciados producidos en cada caso, fueron los malayos los que utilizaron las formas "Convencionalmente indirectas" y "No convencionalmente indirectas" en un mayor número de enunciados 
que los españoles ( 21 y 22 respectivamente, en el primer caso, y 22 y 25 respectivamente, en el segundo). En cambio, las "Directas", fueron los españoles los que más se inclinaron hacia su uso (17 enunciados de los españoles frente a 13 de los malayos). Fue significativa la diferencia entre los promedios de las categorías aplicadas por cada grupo de hablantes: $X^{2}=13.823 p=.001(p<.05)$.

Respecto a la sub-clasificación de los enunciados analizados anteriormente, según las nueve categorías con las que estamos trabajando (véase capítulo 3), los resultados obtenidos en el estudio son estos:

Figura 41. Distribución de enunciados (actos principales), según las estrategias empleadas para la situación 10, en cada cultura

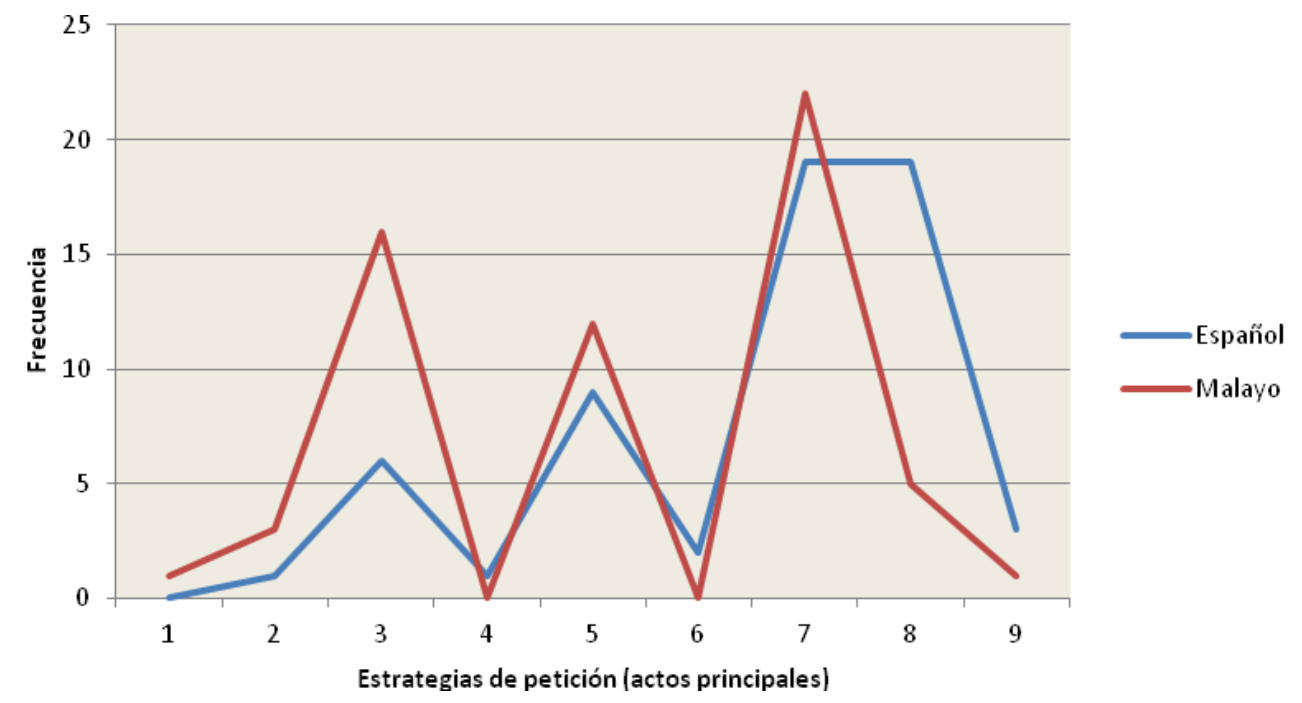

1.Imperativo 2.Performativo 3.Performativo evasivo 4.Declaración de obligación 5.Declaración de deseo 6.Fórmula de sugerencia 7.Interrogación preparatoria 8. Indicio fuerte 9.Indicio suave 
Los participantes españoles utilizaron principalmente las estrategias de "Interrogación preparatoria" e "Indicio fuerte", seguidas de "Declaración de deseo", "Performativo evasivo", "Indicio suave", "Fórmula de sugerencia", "Declaración de obligación" y "Performativo". Los sujetos malayos también emplearon más la de "Interrogación preparatoria", seguida de "Performativo evasivo", "Declaración de deseo" e "Indicio fuerte". En este caso, los españoles utilizaron ocho estrategias diferentes en comparación con las seis utilizadas por los malayos. Las estrategias de "Performativo", "Declaración de obligación" y "Fórmula de sugerencia" aparecen en los datos españoles, pero ningún malayo las utilizó. Sin embargo, todas las opciones encontradas en los datos malayos están también presentes en los datos españoles. El resultado de las pruebas estadísticas en este caso indicó una diferencia significativa entre los españoles y los malayos: $X^{2}=19.360 p=.013(p<.05)$.

En el análisis de los enunciados producidos como movimientos de apoyo, se ha registrado un mayor número en el corpus malayo, con 273, frente a los 206 de los españoles. La distribución de las estrategias empleadas en dichos enunciados es la que aparece en la tabla que sigue: 
Figura 42. Distribución de enunciados según las estrategias de movimientos de apoyo empleadas para la situación 10 en cada cultura

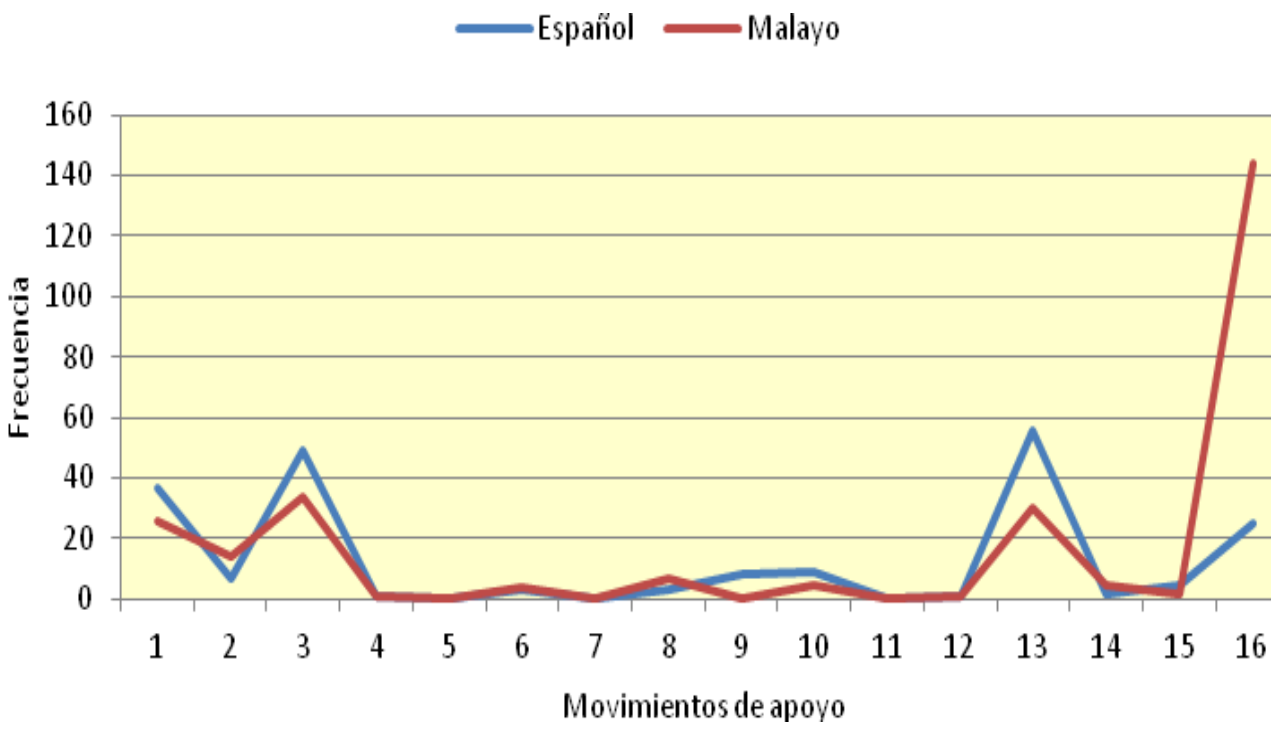

1.Fórmulas de preparación 2.Búsqueda de un compromiso 3.Razones 4.Previsión de objeciones 5.Promesa de recompensa/reparación 6.Minimización de la imposición 7.Invocación de principios generales 8.Reconocimiento de la imposición 9.Preocupación 10.Apreciación 11.Promesa de devolución 12.Gravedad/urgencia 13.Presentación/saludo 14.Petición de la opinión del oyente 15.Disculpa 16.Fórmulas de tratamiento

Los españoles recurrieron a más formas diferentes que los malayos (13 registradas de los españoles y 12 de los malayos). Para pedir una carta de recomendación a un ex profesor, los españoles emplearon más frecuentemente la estrategia de "Presentación/saludo", seguida de "Razones", "Fórmulas de preparación" y "Fórmulas de tratamiento" (solo se mencionan las cuatro más aplicadas). Los malayos, por su parte, se inclinaron mayoritariamente hacia las "Fórmulas de tratamiento", seguidas de "Razones", "Presentación/saludo" y "Fórmulas de preparación" (solo se mencionan las cuatro más aplicadas). Ningún malayo utilizó la 
estrategia de "Preocupación", pero en los datos españoles se encontraron 8 ejemplos. Sin embargo, todas las estrategias encontradas en el corpus malayo están también presentes en el corpus español. Las diferencias más importantes entre las dos sociedades las encontramos en las "Fórmulas de tratamiento", con 144 enunciados de los malayos en comparación con tan solo 25 de los españoles, la "Búsqueda de un compromiso" (14 registros de los malayos frente a 7 de los españoles) y la "Presentación/saludo", con 56 enunciados de los españoles en contraste con los 30 de los malayos. En este caso el resultado de las pruebas estadísticas también mostró una diferencia significativa entre los dos países: $X^{2}=104.753 p=.000(p<.05)$.

\section{B) Mayor frente a menor}

Los resultados numéricos obtenidos al analizar las producciones de cada subgrupo de edad en cada cultura, en relación al tipo de estrategias utilizadas según el grado de (in)dirección, son los que se muestran en la siguiente tabla: 
Figura 43. Distribución de estrategias de petición empleadas para la situación 10 en cada subgrupo de edad

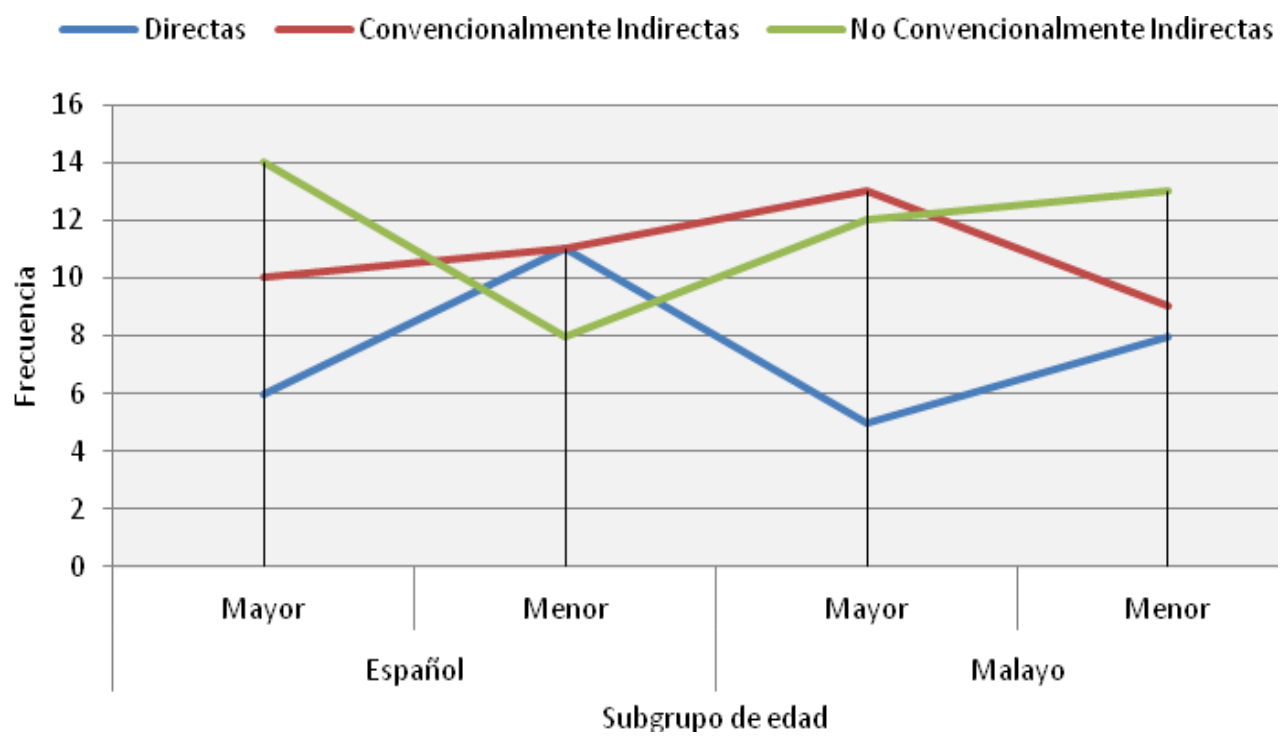

Las preferencias de cada subgrupo en las dos culturas fueron diferentes. En la cultura española, en las respuestas de los mayores hubo más formas "No convencionalmente indirectas" cuando realizaron la petición, seguidas, en orden de frecuencia de uso, de las "Convencionalmente indirectas", y las "Directas", en este orden. Los menores por su parte, tendieron más al uso de las estrategias "Convencionalmente indirectas" y "Directas" (con el mismo número de casos), seguidas de las "No convencionalmente indirectas".

Por otro lado, en la cultura malaya, los hablantes mayores aplicaron mayoritariamente las formas "Convencionalmente indirectas", seguidas de las de "No convencionalmente indirectas", y 
de las "Directas". En cambio, la mayoría de los jóvenes recurrieron más frecuentemente a las "No convencionalmente indirectas", seguidas de las "Convencionalmente indirectas" y de las "Directas". Por último, la comparación de los promedios de las categorías empleadas no indicó una diferencia significativa en el grupo español, pero en el malayo la diferencia fue significativa: $X^{2}=6.852 p=.033$ $(p>.05)$.

Al llevar a cabo el análisis teniendo en cuenta las nueve estrategias con las que venimos trabajando, la distribución de número de enunciados es la que sigue:

Figura 44. Distribución de enunciados (actos principales) producidos para la situación 10 en cada subgrupo de edad, según estrategia seleccionada

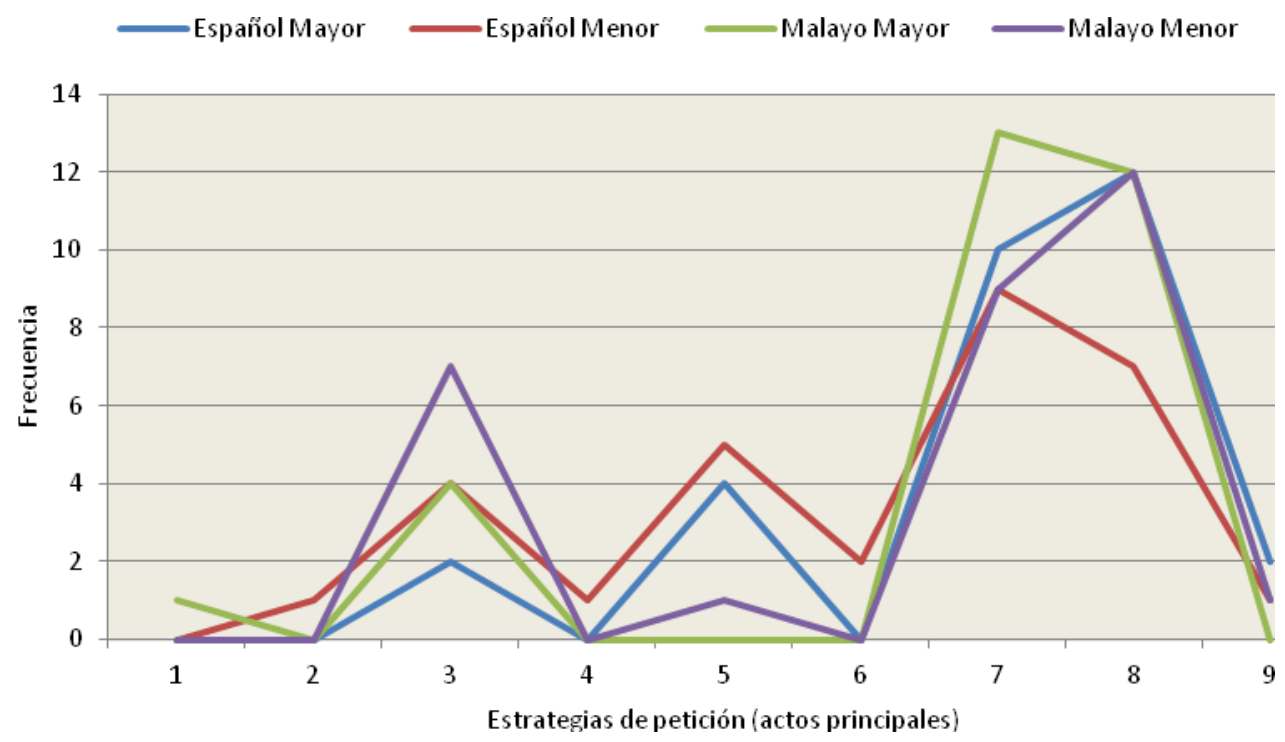

1.Imperativo 2.Performativo 3.Performativo evasivo 4.Declaración de obligación 5.Declaración de deseo 6.Fórmula de sugerencia 7.Interrogación preparatoria 8. Indicio fuerte 9 .Indicio suave 
Como vemos en la tabla, hay una diferencia considerable entre el uso de las estrategias 7 y 8 , y el resto, en todos los subgrupos. Y resulta un tanto curiosa la similitud entre las estrategias empleadas por los hablantes de los dos subgrupos en cada una de las variables (edad/cultura). Y es que la estrategia más comúnmente utilizada en las respuestas de los mayores españoles fue la de "Indicio fuerte", que también fue la más frecuentemente aplicada por los menores malayos, mientras que la estrategia por cuyo uso se inclinaron los menores españoles y los mayores malayos fue la de "Interrogación preparatoria".

En este escenario, tanto los mayores españoles como los malayos utilizaron menos estrategias diferentes que los menores (5 de los jóvenes frente a 8 de los adultos, en los datos españoles, y 4 por 5 en los malayos). Por otra parte, en el grupo español, los de menos edad emplearon las estrategias de "Performativo", "Declaración de obligación" y "Fórmula de sugerencia" al hacer la petición, pero en los datos del otro subgrupo no se encontró ningún caso. Sin embargo, todas las estrategias presentes en las respuestas de los mayores, aparecen también en las de los más jóvenes. En el grupo malayo, por su parte, ningún hablante mayor utilizó las de "Declaración de deseo" e "Indicio suave", pero dichas estrategias sí que se documentan en los datos de los menores. En cambio, no se 
encontró ningún caso de "Imperativo" en los datos de los jóvenes, pero aparece una vez en los datos de los encuestados mayores.

Los sujetos españoles de más edad emplearon tres de las estrategias, "Interrogación preparatoria", "Indicio fuerte" y "Indicio suave" en un mayor número de enunciados que los jóvenes. En cambio, las de "Performativo evasivo" y "Declaración de deseo", fueron los menores los que las aplicaron con mayor frecuencia. En el otro grupo, el malayo, los participantes mayores utilizaron con más frecuencia que los menores solamente una estrategia, que fue la de "Interrogación preparatoria", y los menores emplearon más que los mayores la de "Performativo evasivo". En el caso de la de "Indicio fuerte" se recogieron el mismo número de enunciados en los dos subgrupos de edad. Al contrario del caso anterior, la comparación de los promedios de las categorías empleadas indicó una diferencia significativa en el grupo español: $X^{2}=17.727 p=.007(p>.05)$, pero no en el malayo.

En cuanto al uso de estrategias en los movimientos de apoyo, el análisis recoge, en el grupo español, más enunciados producidos por los mayores que por los menores (113, frente a 93 de los menores), aunque con menos estrategias diferentes que los menores (10 y 13, respectivamente). En el caso malayo también hay registrados más enunciados de los encuestados de edad más 
avanzada (147, frente a 126 de los menores) y además con un mayor número de estrategias diferentes que los menores (11 y 10 respectivamente), tal y como se refleja en la siguiente gráfica, que ilustra los resultados numéricos de esta parte del estudio:

Figura 45. Distribución de enunciados según las estrategias empleadas en los movimientos de apoyo para la situación 10, en cada subgrupo

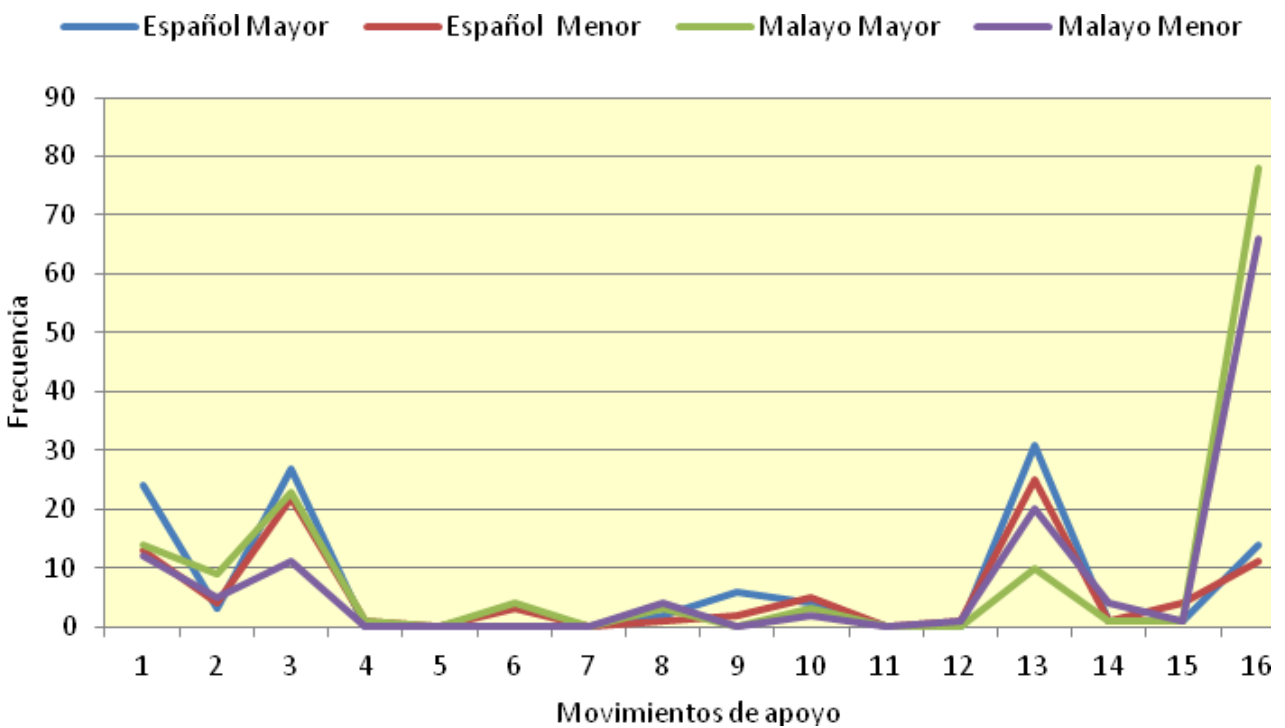

1.Fórmulas de preparación 2.Búsqueda de un compromiso 3.Razones 4.Previsión de objeciones 5.Promesa de recompensa/reparación 6.Minimización de la imposición 7.Invocación de principios generales 8.Reconocimiento de la imposición 9.Preocupación 10.Apreciación 11.Promesa de devolución 12.Gravedad/urgencia 13.Presentación/saludo 14.Petición de la opinión del oyente 15.Disculpa 16. Fórmulas de tratamiento

Para hacer sus peticiones más relevantes, los participantes mayores y menores españoles utilizaron mayoritariamente la opción "Presentación/saludo", mientras que los sujetos de los dos subgrupos malayos aplicaron preferentemente "Fórmulas de tratamiento". Ningún hablante mayor del grupo español aplicó las estrategias de 
"Previsión de objeciones", "Minimización de la imposición" y "Gravedad/urgencia", pero sí que se encuentran en los datos de los jóvenes, que emplearon todas las estrategias encontradas en los datos de los mayores. Por otro lado, en el grupo malayo, ningún sujeto del grupo de más edad usó la "Gravedad/urgencia", pero sí aparece en las respuestas de los sujetos menores. En cambio, no se encontró ningún caso de "Previsión de objeciones" y "Minimización de la imposición" en los enunciados de los encuestados jóvenes, pero sí en los de más edad.

Hay que mencionar que los participantes de más edad de la sociedad española utilizaron con más frecuencia que los de menos edad 5 estrategias: "Fórmulas de preparación", "Razones", "Preocupación", "Presentación/saludo" y "Fórmulas de tratamiento". En cambio, las de "Búsqueda de un compromiso", "Apreciación" y "Disculpa", fueron más empleadas por los menores. La estrategia de "Petición de la opinión del oyente", aparecen con la misma frecuencia en los enunciados de los dos grupos de hablantes, mayores y jóvenes. En el grupo de mayores malayos, las estrategias dominantes fueron las de "Fórmulas de preparación", "Búsqueda de un compromiso", "Razones" y "Fórmulas de tratamiento", mientras que en el de los jóvenes fueron las de, "Reconocimiento de la imposición", "Presentación/saludo" y "Petición de la opinión del oyente". Ambos grupos mostraron la misma frecuencia en el uso de 
la "Disculpa". Los valores de los promedios propusieron que en este caso no existieron diferencias estadísticas significativas entre los mayores y los jóvenes en ambos grupos.

\section{C) Varón frente a mujer}

Al analizar los enunciados formulados como actos principales, teniendo en cuenta el género de los hablantes de ambas culturas, y en función del grado de (in)dirección de las estrategias empleadas, se obtuvieron los resultados que presentamos en la siguiente gráfica:

Figura 46. Distribución de estrategias de petición (según grado de (in)dirección) utilizadas en la situación 10 por los hablantes de cada género en ambas culturas

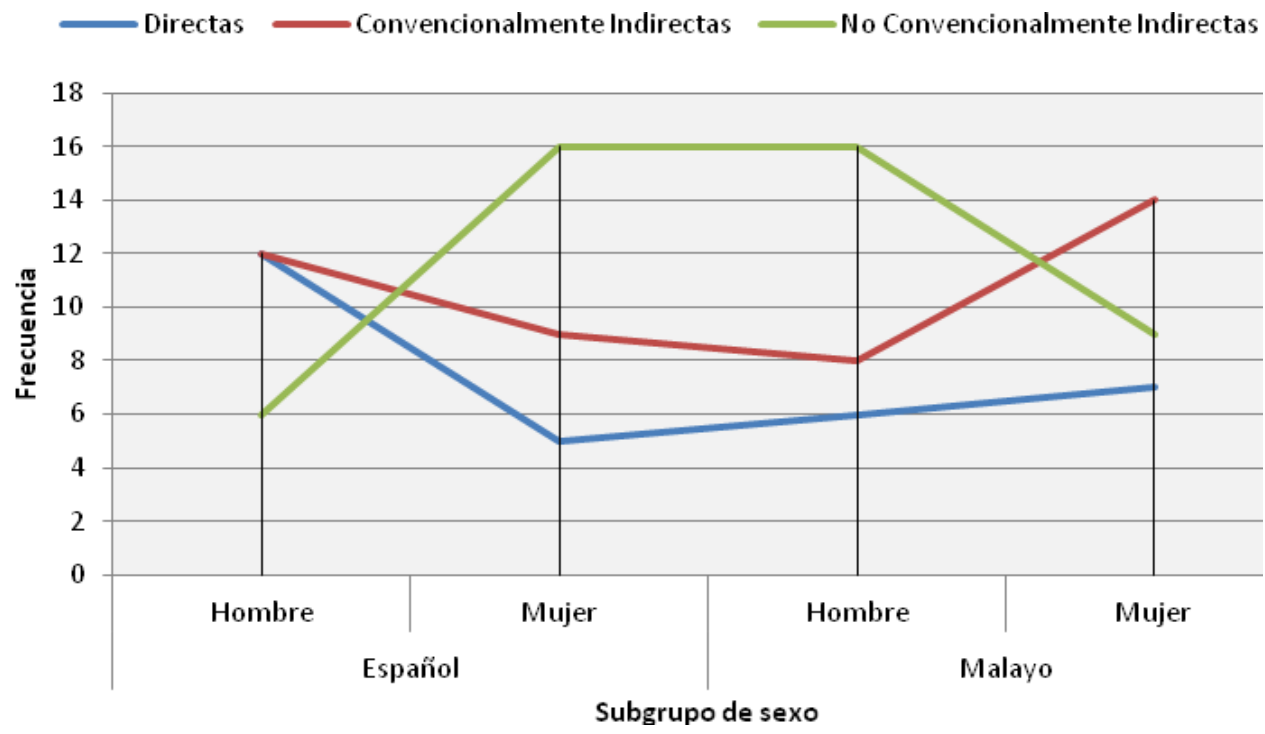


Encontramos que, en este contexto, los hablantes de uno y otro género de ambos grupos no solo se diferenciaron en sus preferencias sino también en la frecuencia de uso (es decir, en el número de enunciados en los que aparecen). Los varones españoles mostraron cierta tendencia hacia las formas "Directas" y "Convencionalmente indirectas", seguidas de las "No convencionalmente indirectas". En cambio, las mujeres prefirieron las "No convencionalmente indirectas", seguidas de las "Convencionalmente indirectas" y "Directas". Por otro lado, en los varones malayos se da una mayor preferencia por las "No convencionalmente indirectas", seguidas de las "Convencionalmente indirectas" y "Directas", mientras que las formas preferidas por las mujeres fueron las "Convencionalmente indirectas", seguidas de las "No convencionalmente indirectas" y "Directas". Al comparar los promedios de las categorías aplicadas entre los subgrupos de sexo, la diferencia fue significativa en el resultado de los dos corpus: $X^{2}=7.613 p=.022(p<.05)$ en el corpus español, $y: X^{2}=7.636 p=.022$ $(p<.05)$ en el malayo.

Teniendo en cuenta la sub-clasificación de estrategias en los nueve tipos establecidos por Blum-Kulka (véase capítulo 3), la distribución de estos enunciados producidos como actos principales, queda como sigue: 
Figura 47. Distribución de enunciados (actos principales), según las estrategias empleadas para la situación 10, en cada género y cultura

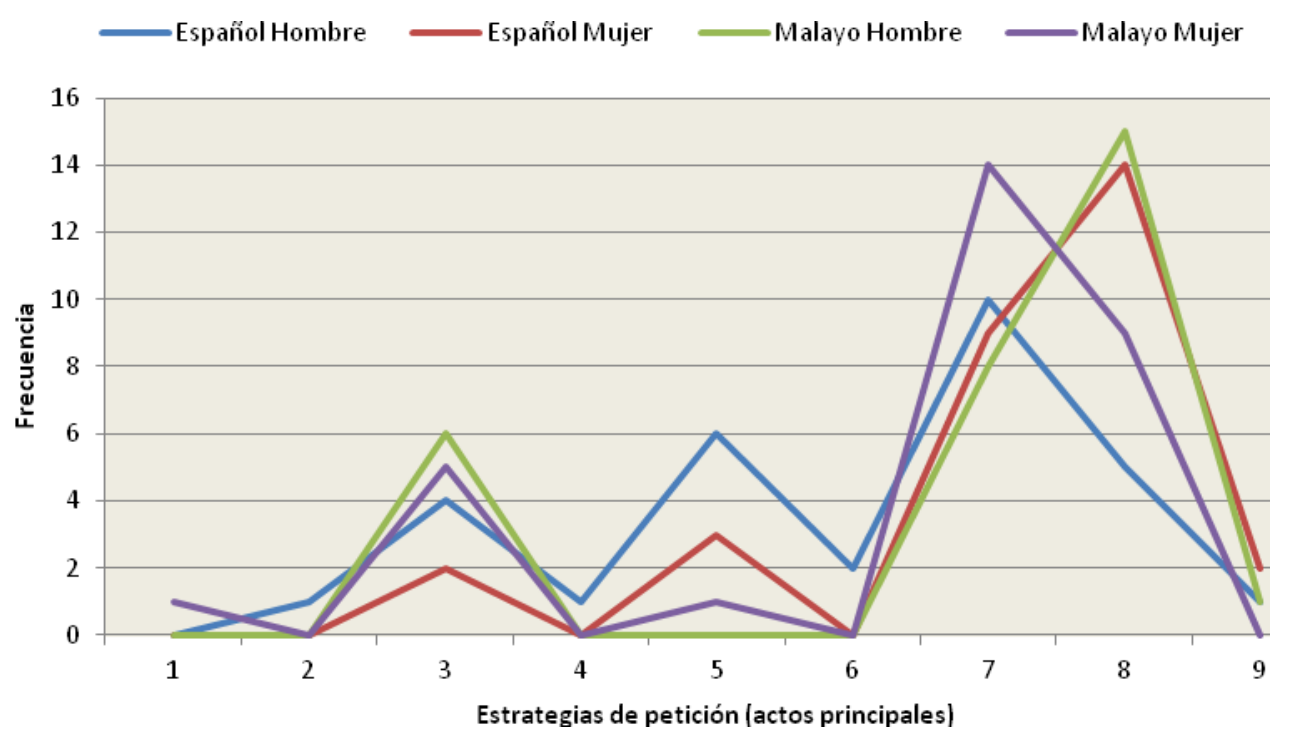

1.Imperativo 2.Performativo 3.Performativo evasivo 4.Declaración de obligación 5.Declaración de deseo 6.Fórmula de sugerencia 7.Interrogación preparatoria 8. Indicio fuerte 9 .Indicio suave

La estrategia más empleada por los varones españoles fue la de "Interrogación preparatoria", seguida de "Declaración de deseo" e "Indicio fuerte" (solo se mencionan las tres más frecuentemente utilizadas). En cambio, la de "Indicio fuerte" fue la más comúnmente aplicada por las mujeres, seguida de "Interrogación preparatoria" y "Declaración de deseo". En el grupo malayo, los varones recurrieron mayoritariamente al uso de un "Indicio fuerte", de una "Interrogación preparatoria" y de un "Performativo evasivo", en este orden de frecuencia. En cambio, las mujeres eligieron en mayor medida la estrategia de "Interrogación 
preparatoria", seguida de la de "Indicio fuerte" y de "Performativo evasivo".

En lo que atañe al número de estrategias diferentes empleadas, los varones del grupo español utilizaron más que las mujeres ( 8 de los varones por 5 de las mujeres). Tres de ellas, "Performativo", "Declaración de obligación" y "Fórmula de sugerencia", solo aparecen en los datos de los varones pero no se encontró ningún caso en las mujeres. Pero los varones usaron todas las estrategias encontradas en los datos de las mujeres. Por otra parte, en el grupo malayo fueron las mujeres las que emplearon más estrategias diferentes que los varones ( 4 de las mujeres y 5 de los varones). Al hacer la petición, ningún varón malayo utilizó ni el "Imperativo" ni la "Declaración de deseo", pero sí que hay ejemplos de las dos en el corpus de las mujeres. En cambio, no se encontró ningún caso de "Indicio suave" en las peticiones de los sujetos del subgrupo femenino, pero dicha estrategia sí que aparece en el corpus del otro subgrupo.

Por último, al analizar la distribución de los movimientos de apoyo aplicados por los hablantes de los dos géneros en ambas culturas, los resultados obtenidos, según el número de enunciados producidos aplicando cada una de las estrategias, fueron estos: 
Figura 48. Distribución de enunciados (movimientos de apoyo), según estrategias empleadas, producidos para la situación 10 en cada género en ambas culturas

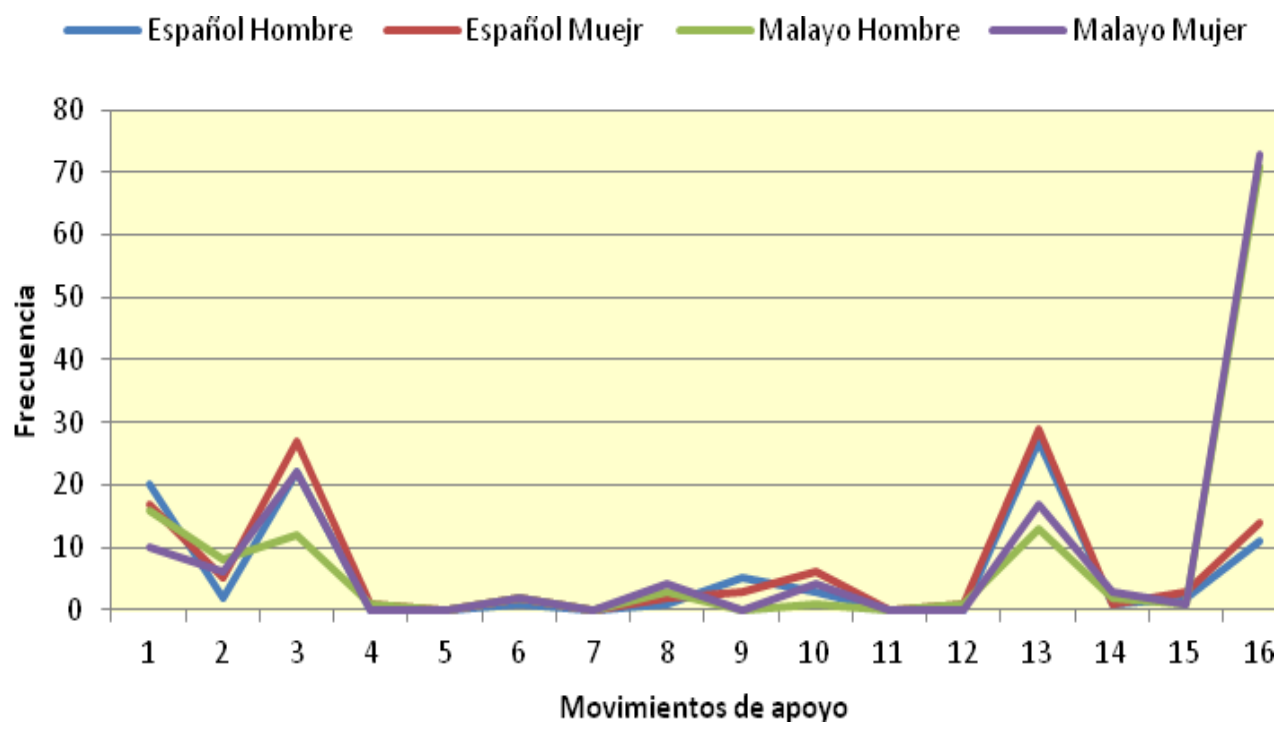

1.Fórmulas de preparación 2.Búsqueda de un compromiso 3.Razones 4.Previsión de objeciones 5.Promesa de recompensa/reparación 6.Minimización de la imposición 7.Invocación de principios generales 8.Reconocimiento de la imposición 9.Preocupación 10.Apreciación 11.Promesa de devolución 12.Gravedad/urgencia 13.Presentación/saludo 14.Petición de la opinión del oyente 15.Disculpa 16. Fórmulas de tratamiento

Los hablantes de ambos géneros de la sociedad española coincidieron en presentar una mayor inclinación hacia el empleo de la estrategia de "Presentación/saludo" para reforzar su petición a un profesor universitario. En el caso malayo, tanto los varones como las mujeres mostraron la misma preferencia hacia el uso de "Fórmulas de tratamiento" al hacer la petición. En este escenario, los varones españoles no solo produjeron menos enunciados que las mujeres (95 de los varones en comparación con 111 de las mujeres) sino que también aplicaron menos estrategias diferentes que las mujeres (11 y 13 respectivamente). No se encontró ningún caso de "Previsión de 
objeciones" y "Gravedad/urgencia" en el corpus de los varones, pero sí que aparecen en el corpus de las mujeres. Sin embargo, las mujeres usaron todas las opciones presentes en los datos de los varones. Por su parte, los varones de la sociedad malaya también se mostraron menos productivos que las mujeres (131 enunciados de los varones frente a 142 de las mujeres), ahora bien, utilizaron más estrategias diferentes que las mujeres (12 de los varones y 10 de las mujeres). En contraposición con el grupo español, ninguna mujer malaya aplicó las estrategias de "Previsión de objeciones" y "Gravedad/urgencia", pero sí que las encontramos en los datos de los varones, quienes, además, utilizaron todas las estrategias aplicadas por las mujeres. La comparación de los promedios de las estrategias utilizadas en los dos casos, actos principales y movimientos de apoyo, no mostró una diferencia significativa entre ambos sexos, ni en el resultado español ni en el malayo.

\subsubsection{Situación 13}

En la situación 13, el director de una empresa pide a uno de sus trabajadores, que va a hacer un viaje de negocios a Rusia (versión española) o Indonesia (versión malaya), que le compre una lata de caviar (versión española) o buah salak (versión malaya). El interlocutor de los sujetos analizados en este escenario (el director 
de la empresa) se sitúa en una posición social más alta, puesto que en el contexto se especifica que el interlocutor es el que dirige el equipo al que pertenecen (supuestamente) los encuestados. No se evalúa la distancia social en este escenario sino solo el poder social.

\section{A) Español frente a malayo}

Al tener en cuenta el grado de (in)dirección de las estrategias empleadas en los enunciados producidos como actos principales en la situación 13, observamos que al igual que en las situaciones anteriores, la mayoría de los hablantes recurren a las formas "Convencionalmente indirectas", tal y como se refleja en la siguiente gráfica:

Figura 49. Distribución de estrategias de petición (actos principales) empleadas para la situación 13 en ambas culturas

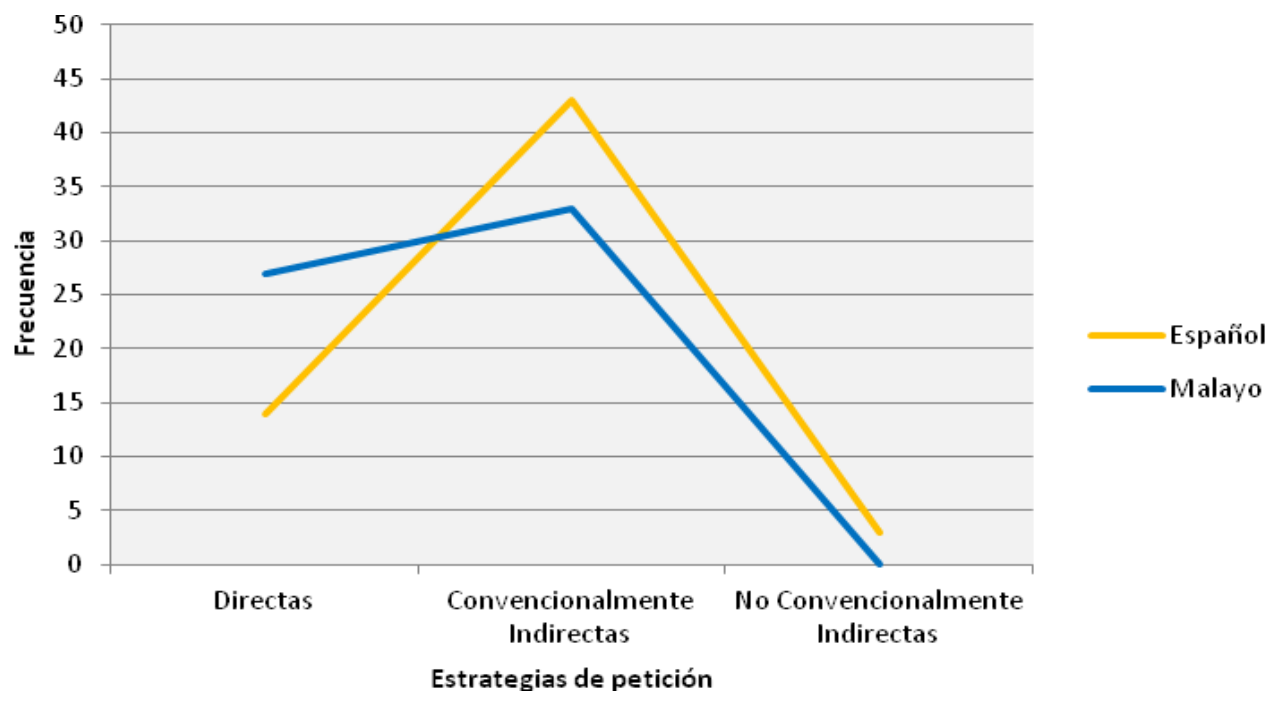


Fueron los participantes españoles los que emplearon con más frecuencia esas estrategias "Convencionalmente indirectas", con 43 enunciados registrados, frente a los 33 de los malayos. Las "Directas" se sitúan estadísticamente en el segundo lugar en ambos países, ahora bien, fueron los malayos los que las aplicaron en un mayor número de ocasiones (27 enunciados de los malayos y 14 de los españoles). Y, en lo referente a las "No convencionalmente indirectas", estas fueron empleadas solamente por 3 de los hablantes españoles, y no se encontró ningún caso en el corpus malayo. La comparación de los promedios entre las estrategias empleadas por los grupos de ambos países indicó una diferencia significativa: $X^{2}=8.727 p=.013(p<.05)$.

Respecto a la distribución de los enunciados emitidos como actos principales según los 9 subtipos de estrategia con los que venimos trabajando en nuestro estudio, ambos grupos de hablantes, españoles y malayos, en este contexto prefirieron realizar las peticiones utilizando la estrategia de "Interrogación preparatoria" (34 enunciados de los españoles y 20 de los malayos), como muestra la figura 50. 
Figura 50. Distribución de enunciados (actos principales), según estrategia de petición seleccionada, producidos para la situación 13 en ambas culturas

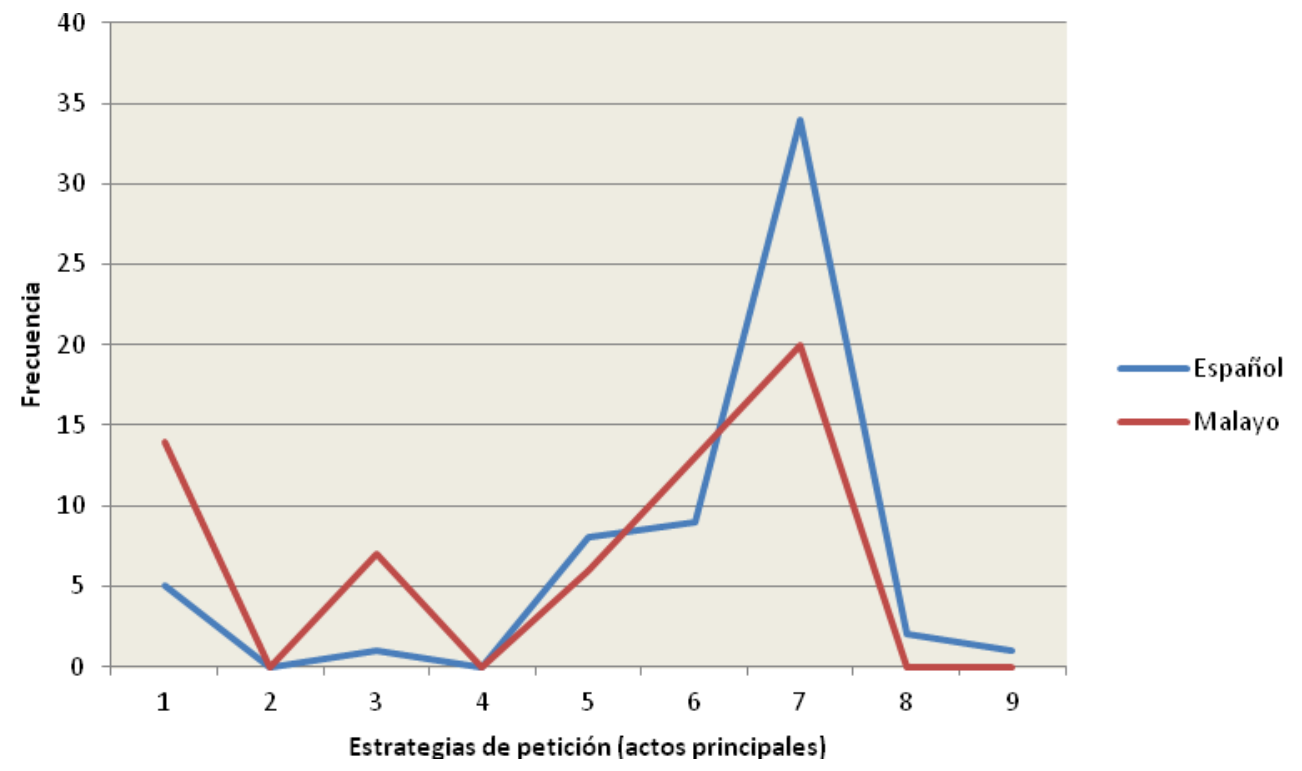

1.Imperativo 2.Performativo 3.Performativo evasivo 4.Declaración de obligación 5.Declaración de deseo 6.Fórmula de sugerencia 7.Interrogación preparatoria 8. Indicio fuerte 9 .Indicio suave

Junto al uso de "Fórmulas de preparación", las otras estrategias más utilizadas por los hablantes españoles son las de "Fórmula de sugerencia" (9), "Declaración de deseo" (8) e "Imperativo", con un menor porcentaje (5) (solo se mencionan algunas más frecuentes). Por otro lado, la segunda forma más repetida en los enunciados de los malayos fue el "Imperativo" (14), seguido del empleo de "Fórmulas de sugerencia" (13), la estrategia de "Performativo evasivo" (7) y la de "Declaración de deseo" (5) (solo se mencionan las que aparecen en un mayor número de enunciados). 
El "Imperativo" no fue un recurso muy común en las producciones de los participantes españoles, ya que, a diferencia de lo que ocurre en los datos malayos, es escaso el número de enunciados en los que se emplea dicha estrategia en los datos españoles (5). Otra diferencia que cabe destacar entre los dos grupos culturales, es que, mientras que ningún malayo aplicó las estrategias de "Indicio fuerte" e "Indicio suave", sí que las encontramos en las respuestas de los sujetos españoles, en las que aparecen dos casos de la primera y uno de la segunda. Al comparar los promedios de las fórmulas empeladas la diferencia entre los grupos analizados sí que fue significativa: $X^{2}=16.406 \mathrm{p}=.012$ $(p<.05)$. Sin embargo, en el caso de los movimientos de apoyo, que analizaremos a continuación, la diferencia entre las medias obtenidas no fue muy importante.

Respecto al empleo de movimientos de apoyo, la distribución de estrategias empleadas, según el número de enunciados encontrados en los datos de cada una de las sociedades, queda como sigue: 
Figura 51. Distribución de enunciados (movimientos de apoyo) producidos para la situación 13 en ambas culturas, según estrategias empleadas

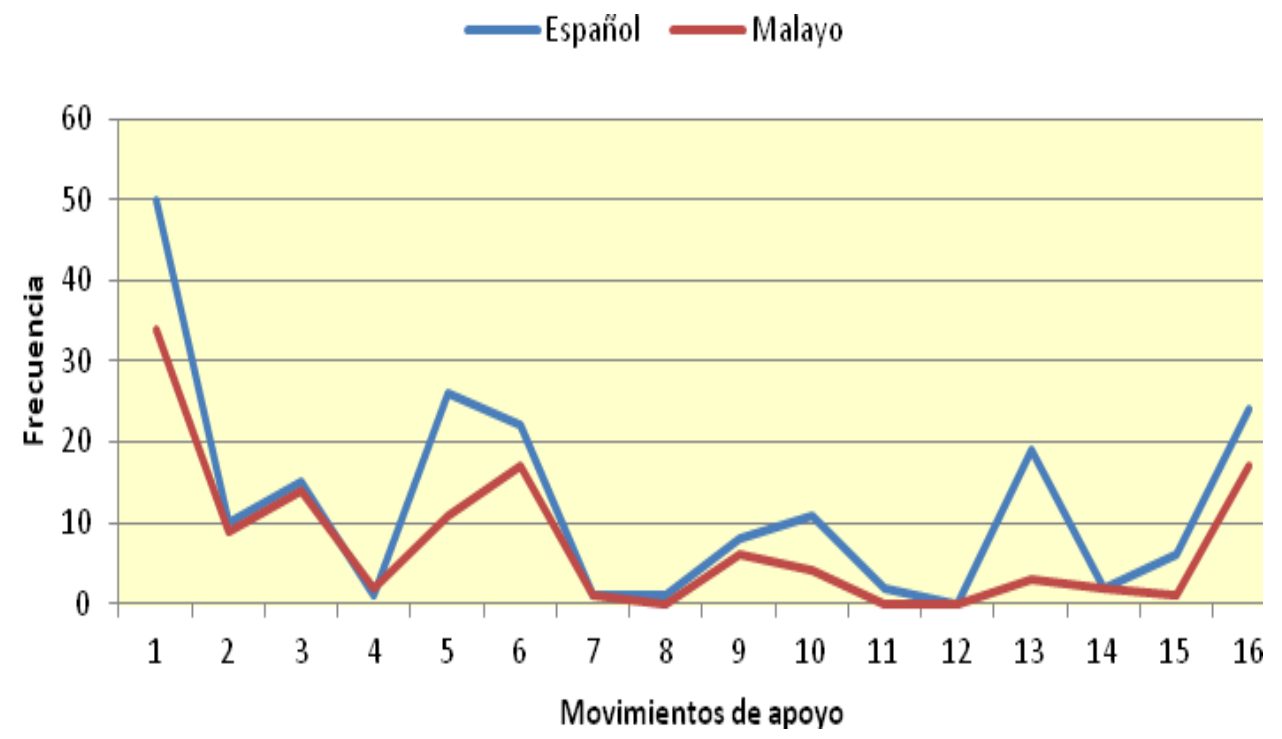

1.Fórmulas de preparación 2.Búsqueda de un compromiso 3.Razones 4.Previsión de objeciones 5.Promesa de recompensa/reparación 6.Minimización de la imposición 7.Invocación de principios generales 8.Reconocimiento de la imposición 9.Preocupación 10.Apreciación 11.Promesa de devolución 12.Gravedad/urgencia 13.Presentación/saludo 14.Petición de la opinión del oyente 15.Disculpa 16. Fórmulas de tratamiento

Los sujetos que participaron en el cuestionario proporcionaron una gran variedad de respuestas en la petición hecha a un trabajador para que compre algo en su viaje. Así, por ejemplo, los españoles emplearon 15 tipos diferentes de estrategias (en 198 enunciados formulados como movimientos de apoyo), y los malayos, 13 (en 121). Dicha diversidad de respuestas queda reflejada en la distribución estadística de las mismas. Así, la estrategia de "Fórmulas de preparación" es la que aparece con más frecuencia en los datos de ambos países. Y, mientras que en el material español aparece la estrategia de "Reconocimiento de la imposición" (un enunciado) y 
"Promesa de devolución" (2 enunciados), en el malayo no se encontró ningún caso.

En este contexto, los españoles recurrieron con más frecuencia que los malayos a todas las estrategias, excepto en el caso del "Previsión de objeciones". Las de "Invocación de principios generales" y "Petición de la opinión del oyente", ambos grupos de hablantes las emplearon con la misma frecuencia. Las diferencias estadísticas más destacadas entre las dos culturas contrastadas se hicieron patentes en el empleo de "Fórmulas de preparación" (50 enunciados de los españoles frente a 34 de los malayos), "Promesa de recompensa/reparación" (26 de los españoles en comparación con solo 11 de los malayos), "Apreciación" (11 aplicadas en los españoles por solo 4 en los malayos) y "Presentación/saludo" (19 de los españoles frente a tan solo 3 de los malayos).

\section{B) Mayor frente a menor}

Al tener en cuenta la diferencia de edad entre los sujetos de uno y otro grupo cultural, la distribución de enunciados según el grado de (in)dirección de las estrategias empleadas en los actos principales queda de la siguiente manera: 
Figura 52. Distribución de estrategias de petición (en número de enunciados) empleadas para la situación 13 en cada subgrupo en ambas sociedades

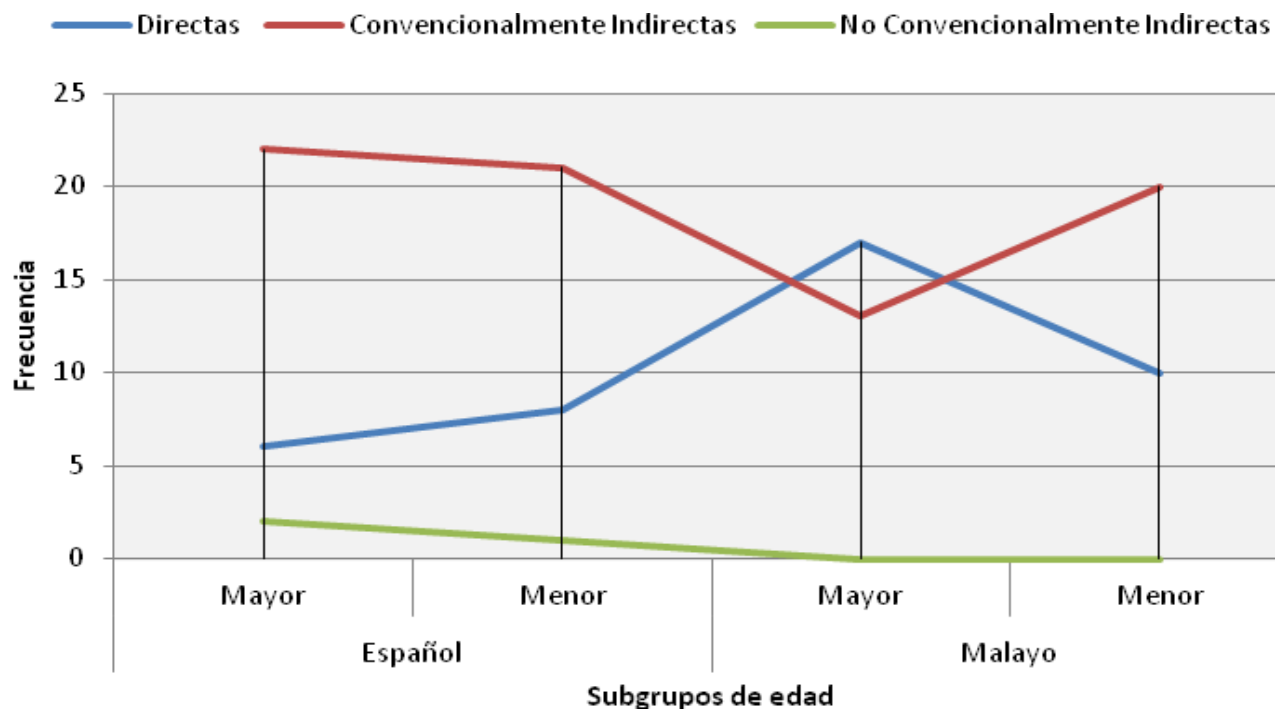

Los dos subgrupos de edad de la sociedad española coinciden en mostrar preferencia por las formas "Convencionalmente indirectas". Pero en el subgrupo de los mayores la frecuencia de uso es un poco más alta que en el de los menores, con 22 enunciados recogidos en las respuestas de los de más edad y 21 de los de menos edad. Con respecto a la sociedad malaya, los hablantes mayores eligieron mayoritariamente realizar las peticiones utilizando estrategias "Directas", con 20 casos documentados. Por el contrario, los jóvenes optaron en mayor medida por las "Convencionalmente indirectas" a la hora de formular sus peticiones (13 casos encontrados). 
Y al analizar estos mismos actos principales desde la subclasificación en 9 tipos de estrategias, los resultados obtenidos, según la distribución en número de enunciados, son estos:

Figura 53. Distribución de enunciados (actos principales) producidos para la situación 13 en cada subgrupo de ambas sociedades, según estrategias empleadas

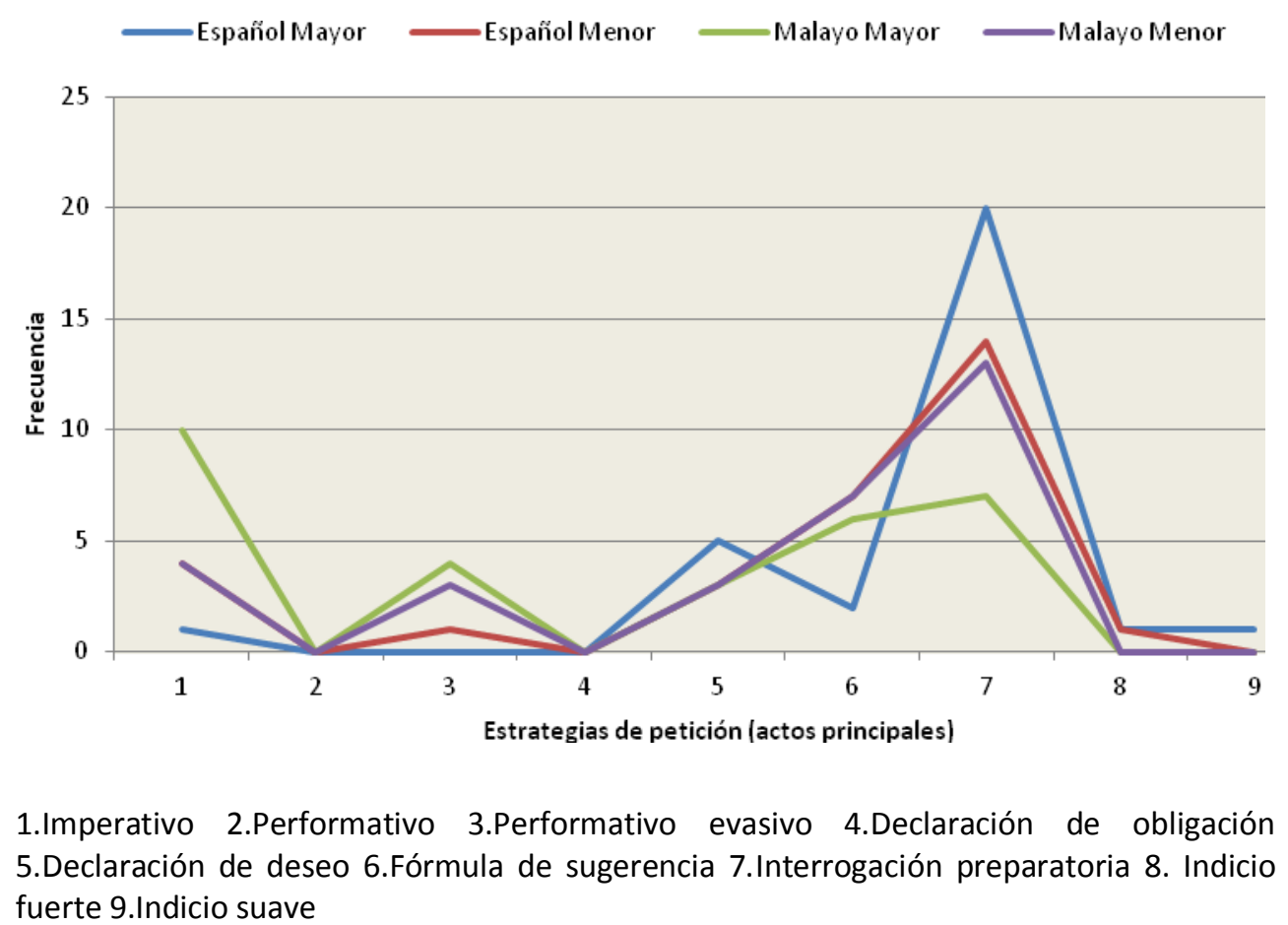

En este escenario los subgrupos españoles mostraron una tendencia patente hacia el empleo de la estrategia de "Interrogación preparatoria", es decir, prefieren el uso de las preguntas, con 20 enunciados en el caso de los sujetos mayores y 14 en el de los jóvenes. Ahora bien, el orden de frecuencia en cada subgrupo varía, ya que, mientras que en el caso de los mayores españoles la segunda más repetida fue la estrategia de "Declaración de deseo", 
seguida del uso de una "Fórmula de sugerencia", de "Imperativo", "Indicio fuerte" e "Indicio suave", en el caso de los jóvenes la segunda más utilizada fue la de "Fórmula de sugerencia", seguida de "Imperativo", "Declaración de deseo", "Performativo evasivo" e "Indicio fuerte".

Al contrastar el uso de estos subtipos de estrategias entre los mayores y los menores del grupo malayo, observamos que los sujetos de más edad prefirieron realizar sus peticiones con un "Imperativo", mientras que los menores mostraron su preferencia por los "Interrogación preparatoria". También encontramos en las respuestas de ambos subgrupos proporciones distintas en otras fórmulas porcentualmente mayoritarias: por un lado, mientras la de "Interrogación preparatoria" ocupa el segundo lugar preferido en los datos de los mayores, seguida de la de "Fórmula de sugerencia", "Performativo evasivo" y "Declaración de deseo", en los menores aparecen, en este orden, la de "Fórmula de sugerencia", seguida de "Imperativo", "Performativo evasivo" y "Declaración de deseo".

En esta situación, el número de estrategias diferentes utilizadas por ambos subgrupos en las dos lenguas fue similar ( 6 en el caso español, y 5 en el caso malayo). Encontramos que ningún sujeto mayor español aplicó la fórmula de "Performativo evasivo", pero sí se presenta en los datos de los menores en 3 ocasiones. En 
cambio, no se encontró ningún caso de "Inicio suave" en los datos de los menores, pero sí aparece en los de los mayores en 9 ocasiones. Por otra parte, en el grupo malayo, los mayores y los menores no se diferenciaron en los tipos diferentes de estrategias empleadas.

En la producción de movimientos de apoyo, acompañando a los actos principales formulados para esta situación, cabe mencionar la mayor frecuencia con la que los utilizan los hablantes mayores en ambas sociedades (106 enunciados registrados frente a los 92 de los menores en la sociedad española, y 66 en comparación con 55, en la otra sociedad). Además, los encuestados españoles del subgrupo de más edad utilizaron más estrategias diferentes que los más jóvenes (13 y 12, respectivamente. Los subgrupos malayos, por su parte, aplicaron el mismo número de tipos de estrategia (11) tal y como refleja la siguiente tabla de resultados: 
Figura 54. Distribución de enunciados (movimientos de apoyo) producidos para la situación 13 en cada subgrupo en ambas sociedades, según estrategias empleadas
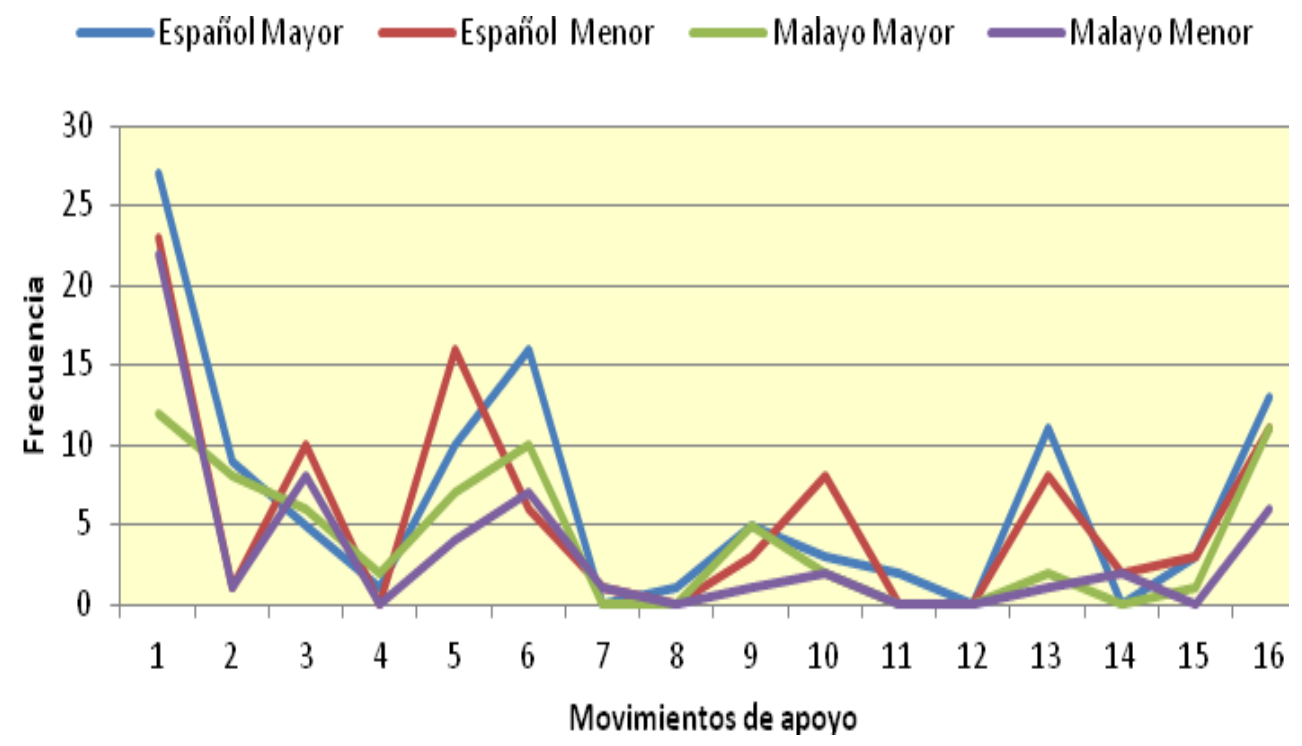

1.Fórmulas de preparación 2.Búsqueda de un compromiso 3.Razones 4.Previsión de objeciones 5.Promesa de recompensa/reparación 6.Minimización de la imposición 7.Invocación de principios generales 8.Reconocimiento de la imposición 9.Preocupación 10.Apreciación 11.Promesa de devolución 12.Gravedad/urgencia 13.Presentación/saludo 14.Petición de la opinión del oyente 15.Disculpa 16. Fórmulas de tratamiento

En lo que concierne a la estrategia más empleada, los subgrupos de ambas sociedades mostraron un resultado similar estadísticamente: la forma dominante fue la de "Fórmulas de preparación" ( 27 y 23 casos, respectivamente, de los españoles y, 12 por 22, de los malayos). Pero la segunda estrategia más usada fue diferente: mientras que para los mayores españoles las de "Minimización de la imposición" (16) y "Fórmulas de tratamiento" (13) fueron las preferidas, en el otro subgrupo de hablantes las de "Promesa de recompensa/reparación" (16) y "Fórmulas de tratamiento" (11) se sitúan, porcentualmente, en este segundo lugar. 
La segunda opción más repetida en los datos de los sujetos mayores malayos, por su parte, fue la de "Fórmulas de tratamiento", seguida de "Minimización de la imposición", mientras que la que se sitúa en el segundo lugar en las respuestas de los jóvenes es la de "Razones", seguida de "Minimización de la imposición".

Es interesante destacar que ningún hablante menor en el corpus español hizo uso de "Previsión de objeciones", "Reconocimiento de la imposición" y "Promesa de devolución", pero los de más edad sí que las utilizaron. En cambio, no se encontró ningún caso de las estrategias de "Invocación de principios generales" y "Petición de la opinión del oyente" en los datos de los sujetos mayores, aunque sí aparecen en los datos de los menores. Por otro lado, en ninguna de las respuestas de los sujetos mayores malayos aparecen las de "Invocación de principios generales" y "Petición de la opinión del oyente", pero sí están presentes en los datos de los jóvenes. Por el contrario, sí que hay ejemplos de las de "Previsión de objeciones" y "Disculpa" en los datos de los mayores, pero no en los de los menores. Los promedios comparados entre ambas sociedades respecto a los actos principales y los movimientos de apoyo no resultaron significativos. 


\section{C) Varón frente a mujer}

Si tenemos en cuenta la variable de género, el análisis de los enunciados producidos como actos principales nos da como resultado la siguiente distribución numérica, según el grado de (in)dirección de las estrategias empleadas:

Figura 55. Distribución de estrategias de petición (actos principales) empleadas para la situación 13 en cada género en ambas sociedades

Directas ConvencionalmenteIndirectas $=N_{0}$ Convencionalmente Indirectas

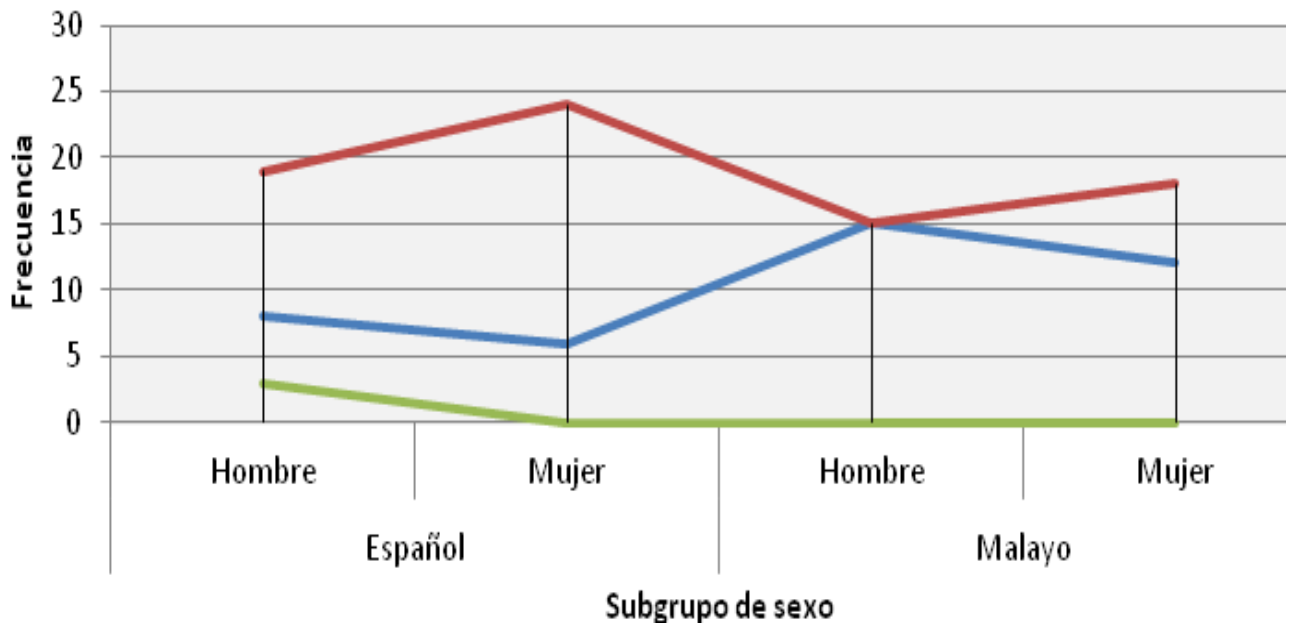

La mayoría de los hablantes españoles de ambos sexos, al formular una petición en la situación facilitada, lo hacen por medio de estrategias "Convencionalmente indirectas", con 24 casos registrados en el corpus de las mujeres y 19 en el de los varones. El segundo lugar en frecuencia de uso está ocupado por la categoría de estrategias "Directas", seguida de las "No convencionalmente 
indirectas". Ahora bien, ninguna mujer española usó las "No convencionalmente indirectas" en sus peticiones.

Por otro lado, los varones malayos mostraron la misma preferencia hacia las estrategias "Directas" y "Convencionalmente indirectas", mientras que en las respuestas de las mujeres de dicha sociedad encontramos, según orden de preferencia, las "Convencionalmente indirectas" en primer lugar, seguidas de las "Directas". En este escenario, ninguno de los sujetos malayos, ni hombre ni mujer, aplicó ninguna estrategia del tipo "No convencionalmente indirectas". La diferencia entre los promedios de las categorías aplicadas no fue significativa en ninguno de los dos grupos en los tres parámetros utilizados, ni en grado de (in)dirección de la petición, ni en estrategias aplicadas a los actos principales ni en los movimientos de apoyo empleados, como se verá más adelante.

Si clasificamos los mismos enunciados producidos como actos principales teniendo en cuenta los 9 subtipos de estrategias, también desde el punto de vista de su grado de mayor o menor (in)dirección, los resultados son los siguientes: 
Figura 56. Distribución de enunciados (actos principales) producidos por los hablantes de cada género para la situación 13 en ambas sociedades, según estrategias utilizadas

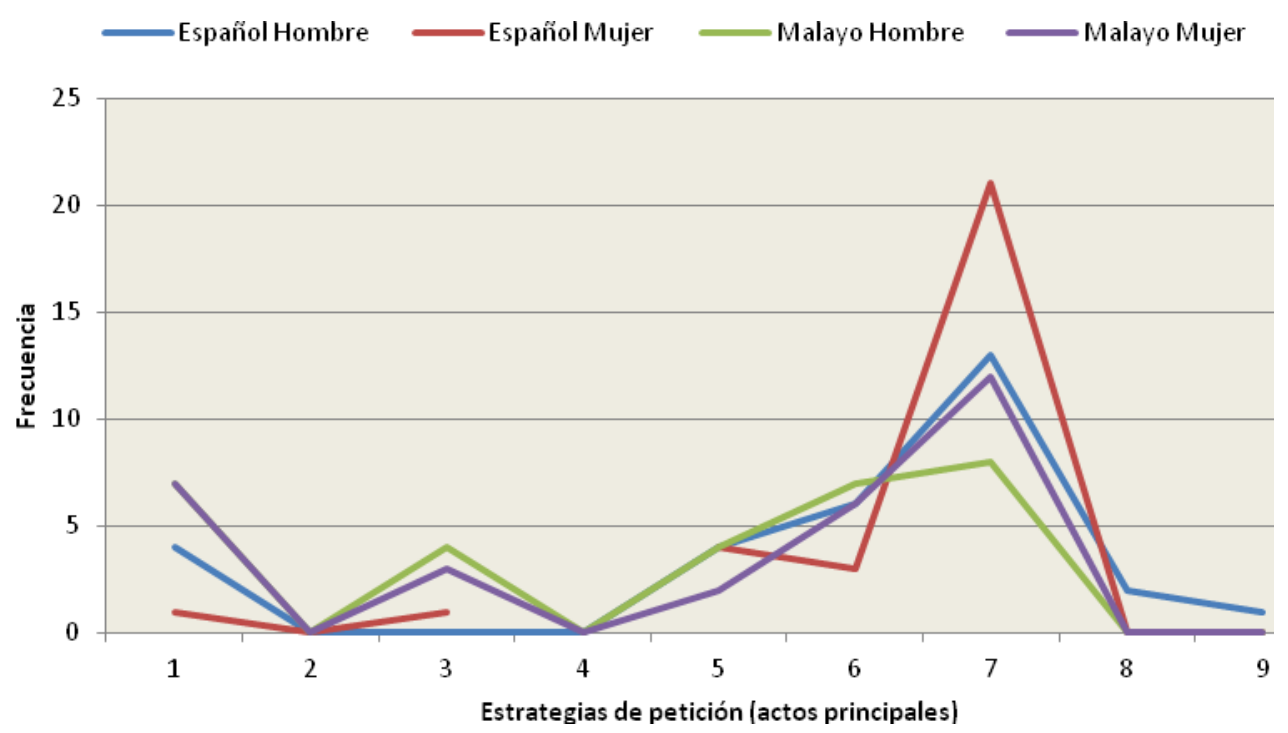

1.Imperativo 2.Performativo 3.Performativo evasivo 4.Declaración de obligación 5.Declaración de deseo 6.Fórmula de sugerencia 7.Interrogación preparatoria 8. Indicio fuerte 9 .Indicio suave

Como era de esperar, hay una cierta similitud entre los hablantes de los dos sexos en ambas comunidades de habla. Todos los encuestados, tanto hombres como mujeres, prefirieron realizar las peticiones con una "Interrogación preparatoria". Pese a que los hablantes de dos sexos coincidieran en mostrar preferencias por la estrategia mencionada, fueron los informantes del sexo femenino quienes las emplearon un mayor número de veces en comparación con los varones, en ambos grupos (21 enunciados frente a 13 respectivamente en el grupo español y, 12 por 8 en el malayo). 
En cuanto al empleo de diferentes tipos de estrategias, encontramos que los varones en el grupo español aplicaron más que las participantes del otro sexo (6, frente a 5 de las mujeres). Por otra parte, en el grupo malayo, no se hallaron diferencias entre los varones y las mujeres al aplicar las estrategias, ya que ambos utilizaron 5 fórmulas distintas. Mientras que los varones de la sociedad española analizados emplearon las de "Indicio fuerte" e "Indicio suave", en los datos de las mujeres no se encontró ningún caso. Pero ocurre lo contrario con la de "Performativo evasivo", que sí fue utilizada por las mujeres españolas para realizar sus peticiones y, en cambio, no la encontramos en los datos producidos por los varones. En el caso malayo, los hablantes de los dos sexos recurrieron a las mismas estrategias.

Respecto al empleo de los movimientos de apoyo, los sujetos femeninos de ambos grupos se mostraron más productivos que los varones. En total, las mujeres españolas incluyeron en sus respuestas 115 enunciados, en comparación con los 83 empleados por los varones. En el caso de los dos subgrupos malayos de género, la diferencia fue menos destacable que la de los españoles, con 64 enunciados registrados en el corpus de las mujeres y 57 de los varones. Hay que mencionar, sin embargo, que las mujeres en el grupo español usaron menos estrategias diferentes que los varones (12, por 13 de los varones). En cambio, en el grupo malayo, las 
mujeres utilizaron más variedad que los varones (12 y 10 respectivamente). Todos estos datos aparecen reflejados en la figura 57 que se muestra a continuación:

Figura 57. Distribución de enunciados (movimientos de apoyo) producidos para la situación 13 en cada grupo de género en ambas sociedades, según estrategias empleadas

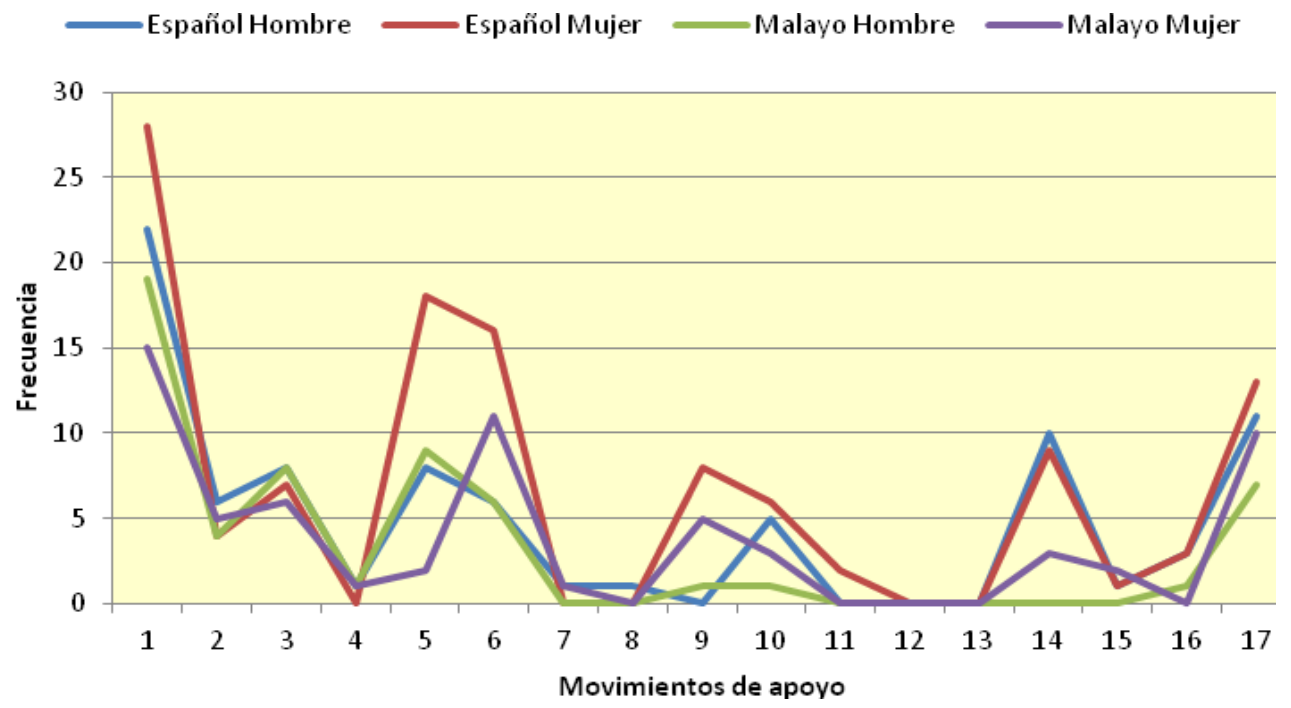

1.Fórmulas de preparación 2.Búsqueda de un compromiso 3.Razones 4.Previsión de objeciones 5.Promesa de recompensa/reparación 6.Minimización de la imposición 7.Invocación de principios generales 8.Reconocimiento de la imposición 9.Preocupación 10.Apreciación 11.Promesa de devolución 12.Gravedad/urgencia 13.Presentación/saludo 14.Petición de la opinión del oyente 15.Disculpa 16. Fórmulas de tratamiento

Los hablantes de los dos subgrupos de género de ambas sociedades coinciden, una vez más, en utilizar con mayor frecuencia la fórmula del "Fórmulas de preparación" para formular su petición en este escenario, con 22 casos de los varones y 28 de las mujeres en español y 19 y 15, respectivamente, en malayo. La segunda estrategia más empleada en los enunciados de los varones españoles 
es la de "Fórmulas de tratamiento" (11), seguida de "Presentación/saludo" (13), mientras que en las mujeres aparece la de "Promesa de recompensa/reparación" (18), seguida de "Minimización de la imposición" (16). Por otro lado, la segunda opción mayoritaria en los varones malayos fue la de "Promesa de recompensa/reparación" (9), seguida de "Razones" (8), mientras que la "Minimización de la imposición" (11) se sitúa porcentualmente en el segundo lugar en los datos femeninos, seguida de las "Fórmulas de tratamiento" (10).

Cabe señalar que ningún varón español usó las formas de "Preocupación" y "Promesa de devolución", pero las mujeres sí lo hicieron. No obstante, con las estrategias de "Previsión de objeciones", "Invocación de principios generales" y "Reconocimiento de la imposición" ocurrió lo contrario, es decir, fueron las participantes del subgrupo femenino quienes la emplearon. En el grupo malayo, los varones utilizaron la fórmula de "Disculpa", pero en los datos del otro sexo no se encontró ningún caso. Por el contrario, ningún varón empleó las de "Invocación de principios generales" y "Presentación/saludo", pero sí están presentes en las peticiones de los sujetos de sexo femenino. 


\subsubsection{Situación 16}

En la situación 16, el sujeto pide a un amigo que le preste su móvil para hacer una llamada. Hay, por tanto, igualdad de poder social entre los interlocutores, puesto que en este contexto que se les ha proporcionado a los encuestados se sitúan socialmente en la misma posición que su amigo. Lo que evaluamos en esta situación es el estatus social, no la distancia social.

\section{A) Español frente a malayo}

En el análisis de las estrategias empleadas por los hablantes de cada grupo cultural en la enunciación de los actos principales, la distribución, según el grado de (in)dirección es la siguiente:

Figura 58. Distribución de estrategias de petición (en número de enunciados) empleadas para la situación 16 en ambas sociedades

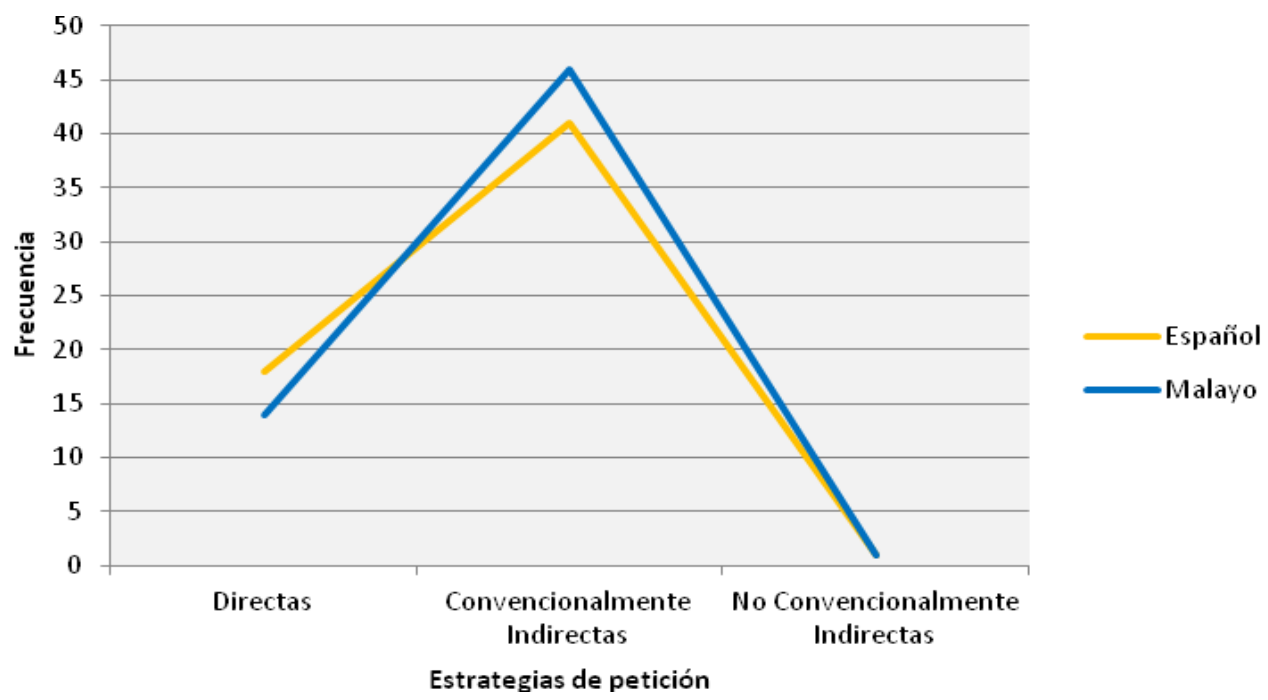


Como bien indica el gráfico, en lo que atañe al uso de las estrategias de petición, los grupos estudiados mostraron un resultado muy similar, no solo en la variedad sino también en su distribución estadística. Los hablantes utilizaron, en orden decreciente de frecuencia, las tres formas siguientes: las estrategias "Convencionalmente indirectas" (41 enunciados de los españoles y 46 de los malayos) en primer lugar, las "Directas" (18 de los españoles frente a 14 de los malayos) en segundo lugar, y las "No convencionalmente indirectas" (con un solo caso en cada grupo) en último lugar. En este contexto, los promedios comparados no indicaron ninguna diferencia significativa.

Respecto a la distribución de estos enunciados (actos principales) teniendo en cuenta los 9 subtipos de estrategias establecidas por Blum-Kulka (véase capítulo 3), el análisis realizado muestra los siguientes resultados: 
Figura 59. Distribución de enunciados (actos principales) producidos para la situación 16 en ambas sociedades, según estrategias empleadas

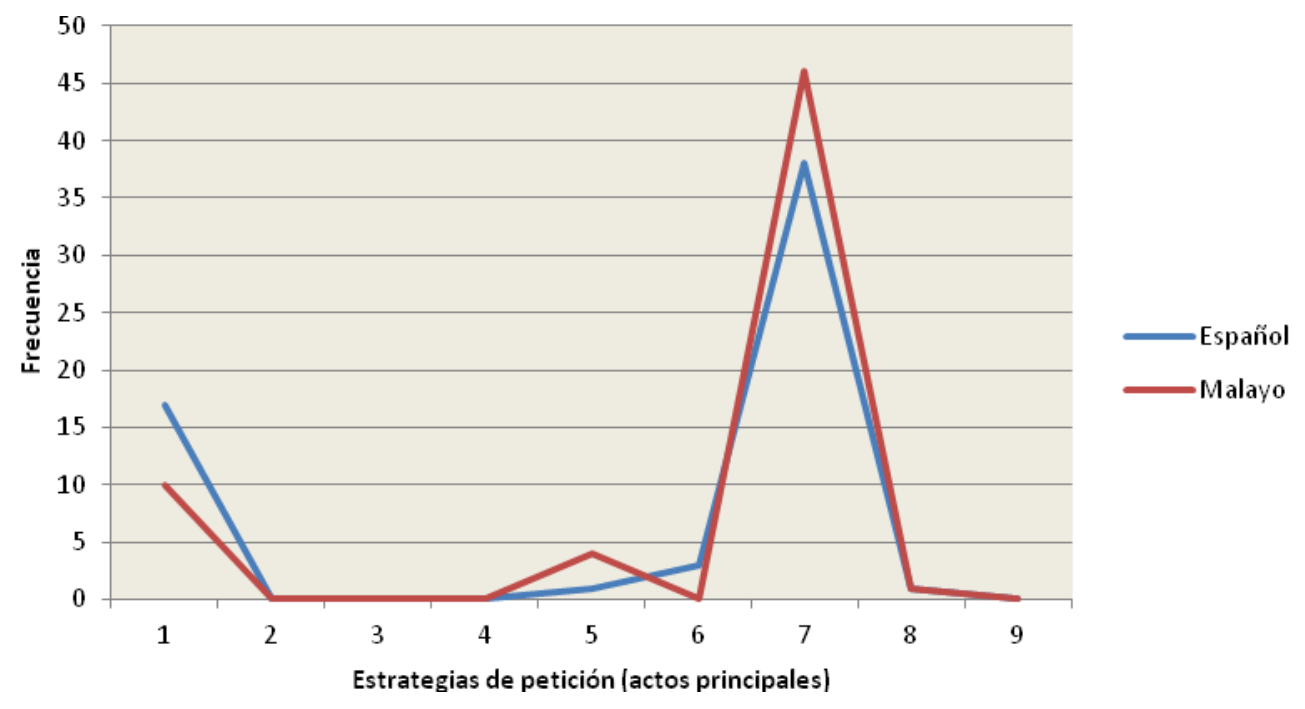

1.Imperativo 2.Performativo 3.Performativo evasivo 4.Declaración de obligación 5.Declaración de deseo 6.Fórmula de sugerencia 7.Interrogación preparatoria 8. Indicio fuerte 9 .Indicio suave

El resultado estadístico de las estrategias principales para llevar a cabo el acto de habla de la petición muestra un patrón muy similar en ambas culturas. La fórmula dominante en los dos grupos fue la de "Interrogación preparatoria", pero fueron los encuestados malayos los que optaron por ella en un mayor número de ocasiones (46 casos frente a 38 de los españoles). La segunda estrategia más usada fue la de "Imperativo". Nos parece interesante destacar el elevado número de enunciados con dicha estrategia de los informantes españoles (17), lo cual corresponde a la mayor frecuencia de dicha fórmula en los resultados de las seis situaciones de petición. En el caso de los malayos encontramos 10 casos, que fue el segundo número más alto después del registrado en la 
situación 13. Ningún malayo utilizó la "Fórmula de sugerencia" al efectuar la petición a un amigo, pero sí aparece en los datos españoles en 3 ocasiones. Tampoco hubo una diferencia significativa entre las estrategias empleadas en ambos grupos en la comparación de los promedios.

Por último, al examinar la distribución de los movimientos de apoyo empleados en este escenario por los informantes españoles y los malayos, los resultados obtenidos fueron los siguientes:

Figura 60. Distribución de enunciados (movimientos de apoyo) producidos en la situación 16 en ambas sociedades, según estrategias empleadas

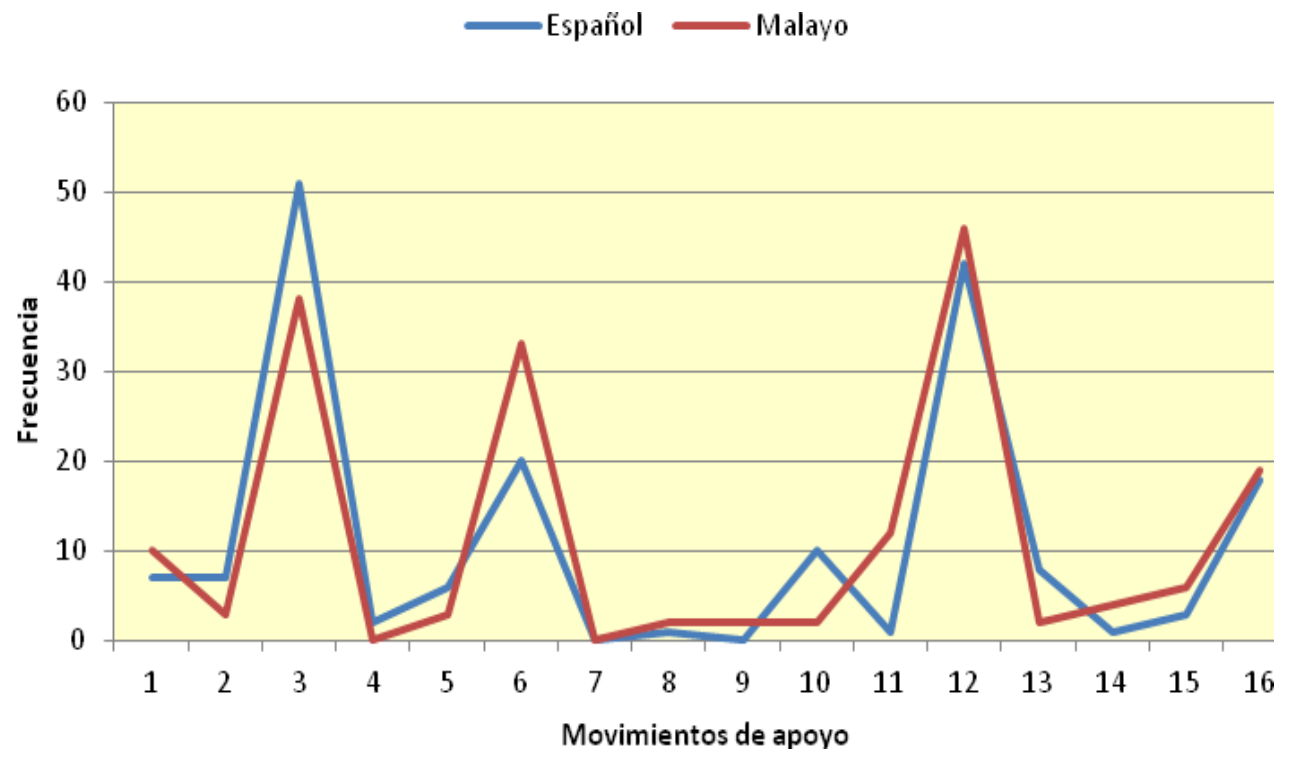

1.Fórmulas de preparación 2.Búsqueda de un compromiso 3.Razones 4.Previsión de objeciones 5.Promesa de recompensa/reparación 6.Minimización de la imposición 7.Invocación de principios generales 8.Reconocimiento de la imposición 9.Preocupación 10.Apreciación 11.Promesa de devolución 12.Gravedad/urgencia 13.Presentación/saludo 14.Petición de la opinión del oyente 15.Disculpa 16.Fórmulas de tratamiento 
Lo significativo de este resultado es que hay una gran variedad en los movimientos de apoyo formulados por los hablantes de ambas comunidades a la hora de realizar la petición a una persona del mismo estatus. En ambas culturas fue similar el número de estrategias diferentes empleadas (14 fórmulas diferentes en cada grupo). Sin embargo, en general, en los datos de los malayos encontramos un mayor número de enunciados producidos como movimientos de apoyo (182, frente a los 177 de los españoles).

En los resultados obtenidos se evidencia que la opción más recurrente para formular peticiones fue la de "Razones" en los españoles y la "Gravedad/urgencia" en los malayos. Nos parece interesante destacar que la segunda opción porcentualmente mayoritaria en las respuestas de los hablantes españoles es la estrategia preferida por los malayos, mientras que la segunda más repetida por los malayos corresponde a la primera más utilizada por los españoles. Los españoles usaron la estrategia de "Previsión de objeciones" en sus peticiones, pero en los datos malayos no se encontró ningún caso. En cambio, mientras que la fórmula de "Preocupación" aparece en los datos malayos en 2 ocasiones, no encontramos ningún ejemplo en el corpus español. A diferencia del análisis de actos principales, en este caso, los promedios comparados indicaron una diferencia significativa: $X^{2}=33.737 p=.002$ $(p<.05)$ 


\section{B)}

\section{Mayor frente a menor}

Las estrategias más utilizadas por los hablantes de todos los subgrupos de edad en la enunciación de los actos principales, son, como se ha visto ya al estudiar los datos de las dos sociedades (apartado A), y como se refleja en la gráfica que sigue, las "Convencionalmente indirectas":

Figura 61. Distribución de estrategias de peticiones (actos principales) formuladas para la situación 16 en cada subgrupo en ambas sociedades

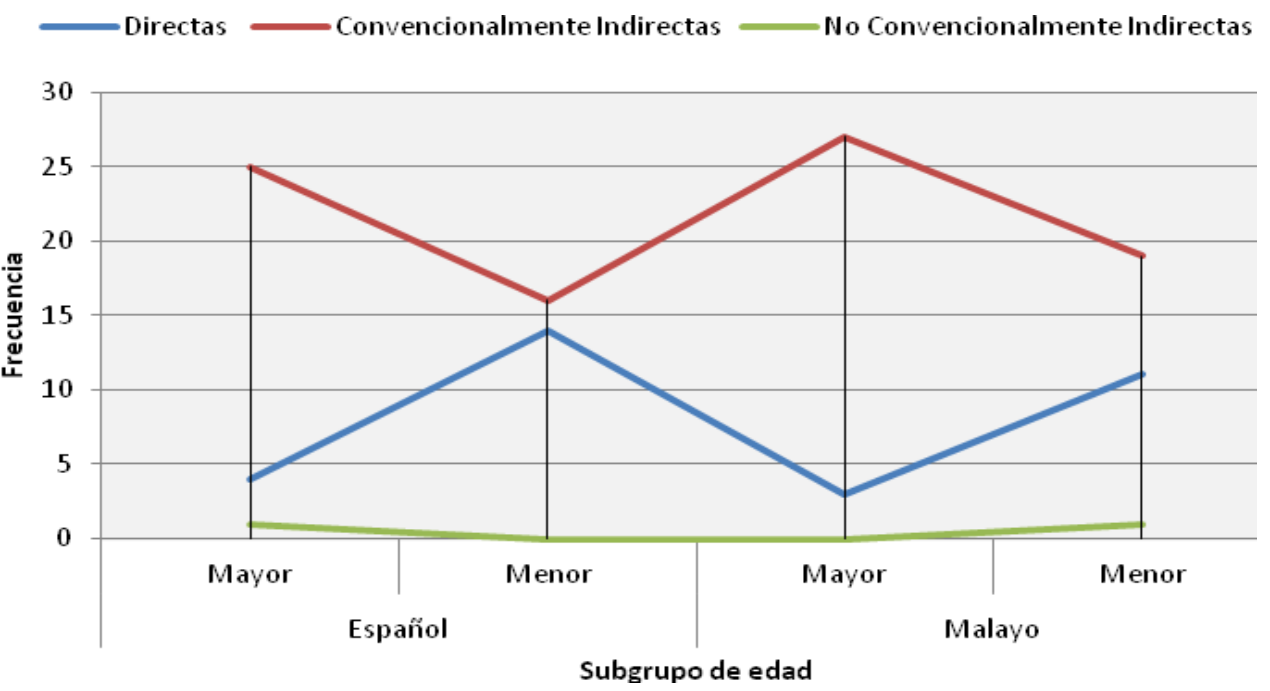

Pese a que todos los subgrupos optaron, en mayor grado, por las estrategias "Convencionalmente indirectas" a la hora de formular la petición en este escenario, fueron los de mayor edad los que mostraron una tendencia más destacada hacia dicha forma, con 25 enunciados frente a 16 de los de menos edad del grupo español 
y, 27 por 19 respectivamente, del malayo. En cambio, en cuanto a la segunda categoría más utilizada, las "Directas", fueron los sujetos jóvenes los que las eligieron en un mayor número de casos: 14 de los jóvenes frente a 4 de los mayores en el primer grupo y, 11 frente 3 de los sujetos de más edad en el segundo. Respecto a las "No convencionalmente indirectas", aparecen una vez en los datos de los mayores españoles y de los menores malayos, pero no se encontró ningún caso de dicha forma en los otros dos subgrupos de edad. La diferencia de los promedios de las categorías comparadas no fue significativa en los datos de ningún subgrupo.

Al comprobar la distribución de los mismos enunciados producidos como actos principales en cada subgrupo en ambas culturas, según los nueve subtipos de estrategias de Blum-Kulka (véase capítulo 3), aparece una clara preferencia (más marcada en el subgrupo de mayores de ambas culturas) por el uso de "Fórmulas de preparaciones" de interrogación, como queda patente en la siguiente gráfica de resultados: 
Figura 62. Distribución de enunciados (actos principales), según estrategias empleadas, emitidos para la situación 16 en cada subgrupo en ambas sociedades

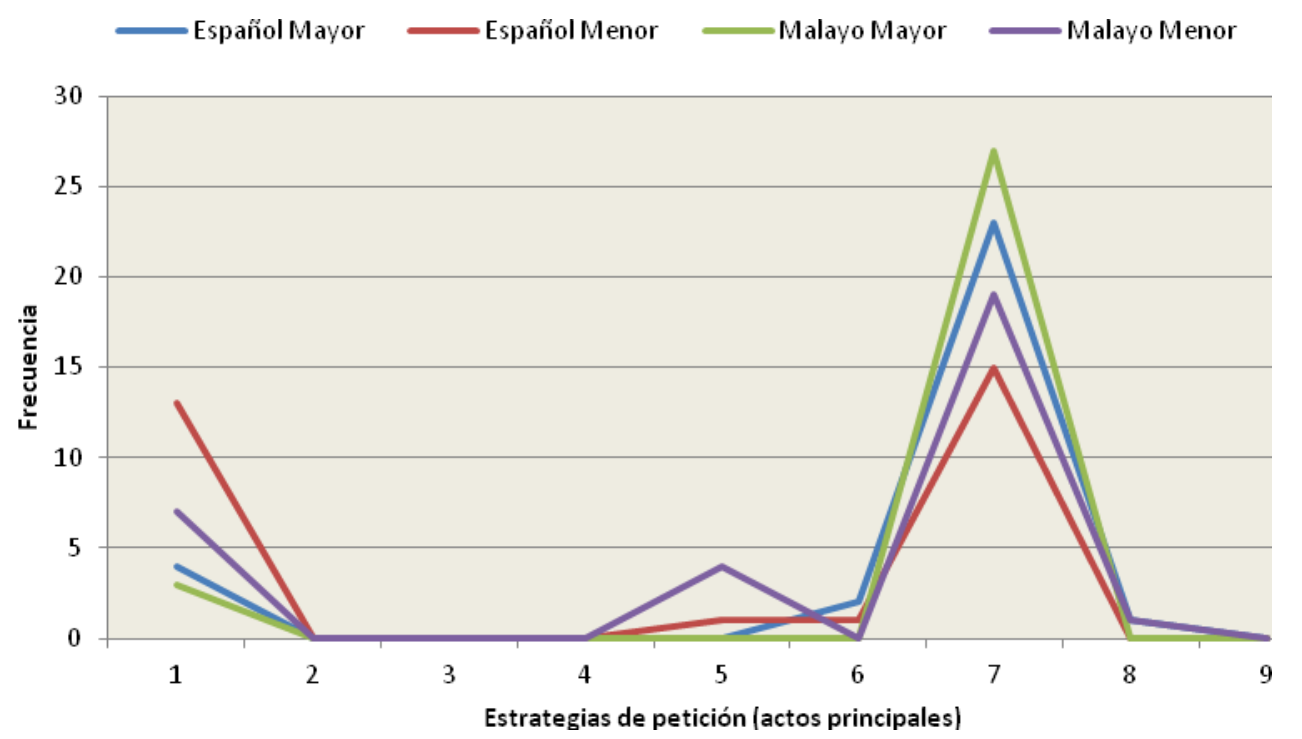

1.Imperativo 2.Performativo 3.Performativo evasivo 4.Declaración de obligación 5.Declaración de deseo 6.Fórmula de sugerencia 7.Interrogación preparatoria 8. Indicio fuerte 9.Indicio suave

Frente a los 23 y 27 enunciados con una "Fórmula de preparación", de los subgrupos mayores españoles y malayo, respectivamente, aparecen solamente 15 de los participantes jóvenes en el material español, y 19 en el malayo. Pero ocurre lo contrario con el "Imperativo", que es la segunda estrategia más repetida. En este caso, fueron los de menos edad los que más lo utilizaron (13 enunciados por tan solo 4 de los mayores, en los datos españoles, y 7 frente 3, en los malayos). Asimismo, ambos subgrupos de la cultura española aplicaron 4 estrategias diferentes al hacer la petición. 
En el caso malayo, los jóvenes mostraron mayor variedad en las fórmulas utilizadas (4 tipos diferentes en comparación con solo 2 de los participantes maduros). Hay que mencionar, también, que la estrategia de "Indicio fuerte" aparece en los datos de los participantes mayores españoles, pero no está presente en los de los menores. Por el contrario, la de "Declaración de deseo" existe en los datos de los jóvenes pero ninguno de los hablantes de más edad la utilizó. Por otro lado, en el grupo malayo, ninguno de los sujetos del grupo de mayores aplicó las estrategias de "Declaración de deseo" e "Indicio fuerte", pero los jóvenes sí lo hicieron (4 casos de la primera, y solamente uno de la segunda). Ahora bien, todas las que fueron utilizadas por los de más edad, fueron encontradas también en las respuestas del otro subgrupo. La comparación de los promedios entre las categorías empleadas entre ambos subgrupos de edad mostró una diferencia considerable en el material malayo $\left(X^{2}=7.977 p=.046(p<.05)\right.$, mientras que en el material español la diferencia no fue significativa.

Pasamos a examinar a continuación, el empleo de movimientos de apoyo, así como de las estrategias empleadas en los mismos, en las respuestas de los sujetos de los dos subgrupos de edad en ambas culturas: 
Figura 63. Distribución de enunciados (movimientos de apoyo) empleados para la situación 16 en cada subgrupo en ambas sociedades

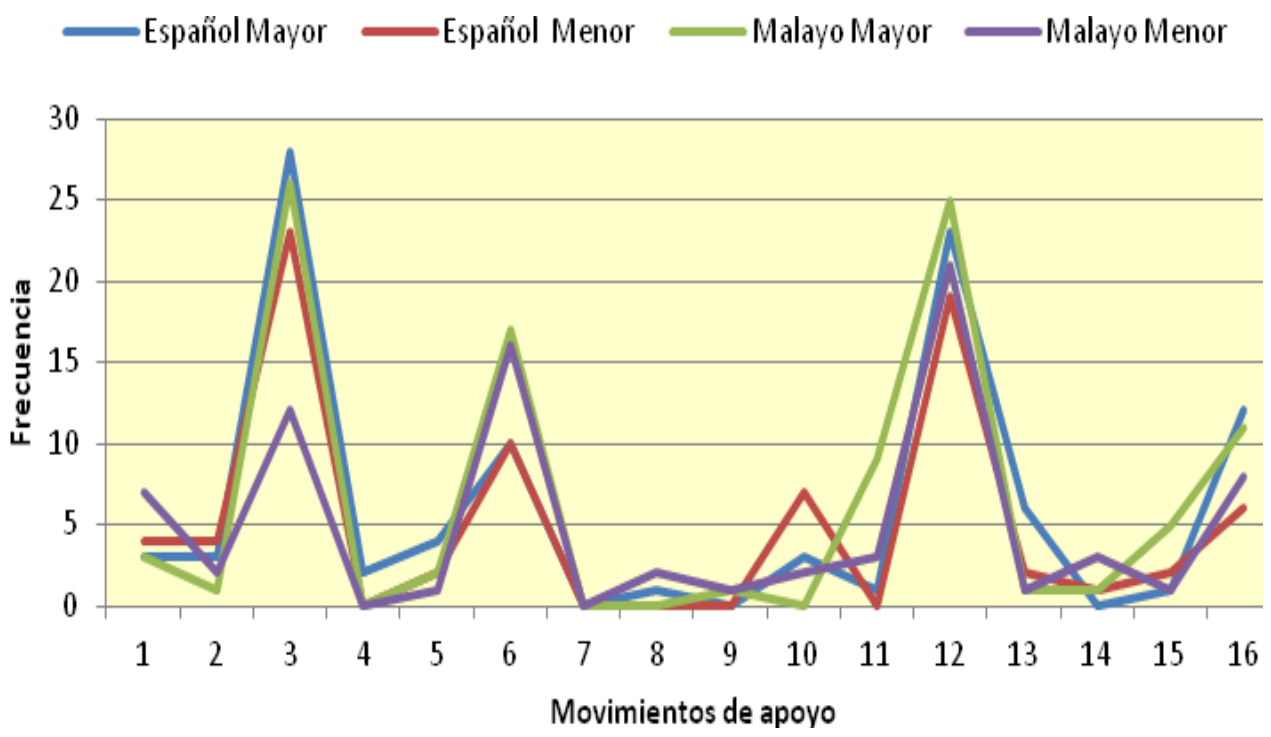

1.Fórmulas de preparación 2.Búsqueda de un compromiso 3.Razones 4.Previsión de objeciones 5.Promesa de recompensa/reparación 6.Minimización de la imposición 7.Invocación de principios generales 8.Reconocimiento de la imposición 9.Preocupación 10.Apreciación 11.Promesa de devolución 12.Gravedad/urgencia 13.Presentación/saludo 14.Petición de la opinión del oyente 15.Disculpa 16.Fórmulas de tratamiento

En total, fueron los hablantes mayores, tanto malayos como españoles, los que se mostraron más productivos, con 97 enunciados recogidos en el subgrupo español (frente a 80 de los menores), y 102 en el malayo (por 80 de los jóvenes). Además, los sujetos mayores españoles aplicaron más tipos diferentes de estrategias que los jóvenes (13, en comparación con 11 de los jóvenes), pero, en el caso malayo, fue al contrario, con 14 estrategias diferentes empleadas por los menores, frente a las 12 de los mayores. $\mathrm{Y}$ todos los subgrupos mostraron la misma preferencia por la estrategia de "Razones" al realizar la petición a un amigo, 
excepto los jóvenes malayos que prefirieron utilizar la de "Gravedad/urgencia".

En esta situación, ningún mayor del grupo español utilizó la estrategia de "Petición de la opinión del oyente", pero sí la encontramos una vez en el corpus de los menores. En cambio, no se encontró ningún caso de las de "Previsión de objeciones", "Reconocimiento de la imposición" y "Promesa de devolución" en los datos de los de más edad, pero sí se presentan en los del otro subgrupo con 2, 1 y 11 casos, respectivamente. En las respuestas en malayo, por su parte, no hay ningún ejemplo de "Reconocimiento de la imposición" y "Apreciación" en los enunciados de los mayores, pero los jóvenes aplicaron cada una de ellas en 2 ocasiones. Sin embargo, todas las estrategias encontradas en los datos de los mayores, están también presentes en los datos de los menores.

\section{C) Varón frente a mujer}

Al realizar el análisis de las respuestas formuladas para la situación 16 desde el punto de vista del sexo de los sujetos participantes de cada cultura, vemos que los datos obtenidos en este escenario no revelaron diferencia entre los informantes varones y mujeres respecto a sus preferencias a la hora de elegir una estrategia más o 
menos directa o indirecta para formular los enunciados correspondientes a los actos principales.

Figura 64. Distribución de estrategias de petición (actos principales) para la situación 16 en cada subgrupo de género en ambas culturas, según grado de (in)dirección

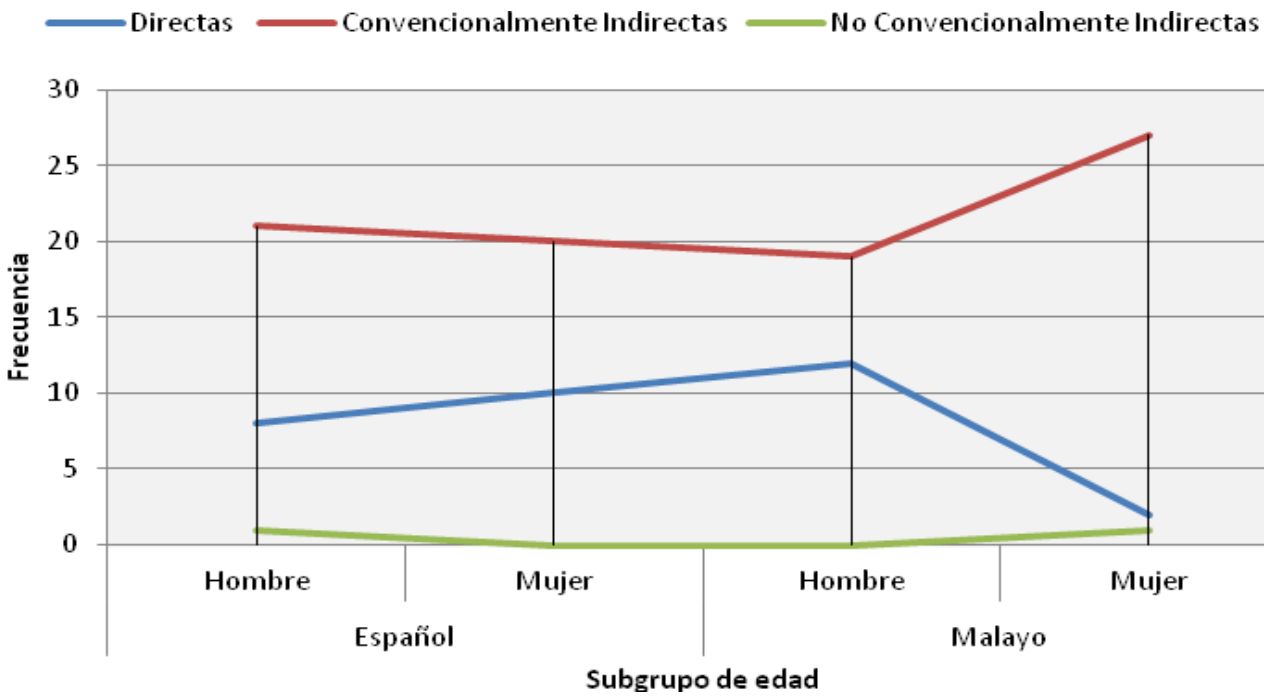

Los sujetos de ambos sexos optaron por hacer la petición principalmente a través de estrategias "Convencionalmente indirectas". El segundo tipo más utilizado fue el de las "Directas", y, en tercer lugar, el de las "No convencionalmente indirectas", empleadas solamente una vez por uno de los varones españoles y una de las mujeres malayas (ninguna mujer española ni varón malayo las aplicó). Cabe señalar que las diferencias encontradas entre los hablantes malayos de ambos géneros en el número de enunciados en los que emplean las estrategias de los dos tipos dominantes fueron más notables que entre los españoles. Al 
comparar los promedios de las categorías aplicadas entre los subgrupos de sexo, la diferencia fue significativa en el resultado malayo: $X^{2}=9.520 p=.009(p<.05)$, pero no en el español.

Y al volver a analizar los mismos enunciados, pero teniendo en cuenta las nueve sub-categorías de estrategias con las que estamos trabajando en nuestro estudio, se obtuvieron los siguientes resultados:

Figura 65. Distribución de enunciados (actos principales), según estrategias de petición utilizadas para la situación 16 en cada género en ambas culturas

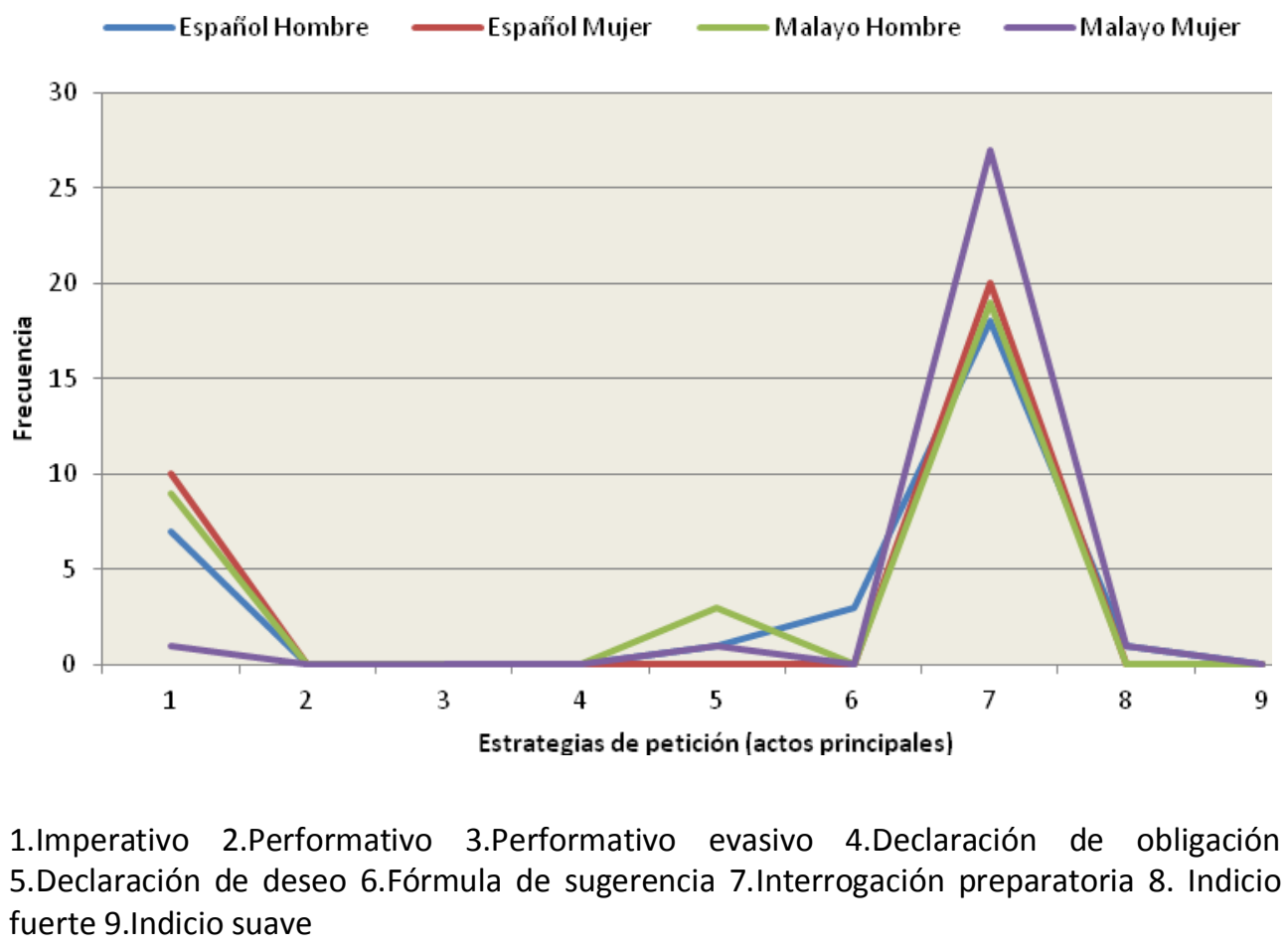


Pese a que los encuestados de ambos géneros hayan mostrado preferencia por el uso de una "Interrogación preparatoria", fueron los sujetos femeninos los que utilizaron este recurso en un mayor número de ocasiones. Así, se recogieron 20 casos en las respuestas de las mujeres, por 18 encontrados en las de los varones del grupo español, y 27 frente a 19, respectivamente, en el otro grupo. En cuanto al "Imperativo", en la sociedad española fueron las mujeres las que mostraron una tendencia remarcable hacia dicha forma, con 10 enunciados registrados frente a los 7 de los varones. En cambio, en la sociedad malaya, ocurrió justo al revés: fueron los varones los que utilizaron imperativos con mayor frecuencia que las mujeres ( 9 casos frente a solo uno en las mujeres).

Con respecto a la cantidad de estrategias diferentes empleadas por los sujetos de cada subgrupo, el análisis revela que, en la sociedad española, los varones aplicaron más que las mujeres (5 tipos frente a 2 de las mujeres). En cambio, en la malaya, las mujeres recurrieron a más variedad que los varones $(4$ y 3 , respectivamente). Las opciones utilizadas por los varones españoles pero no por las mujeres fueron las de "Declaración de deseo", "Minimización de la imposición" y "Reconocimiento de la imposición". Pero todas las estrategias encontradas en las mujeres, están también presentes en las respuestas de los varones. En el grupo malayo, ningún varón recurrió a la "Declaración de deseo", pero sí la 
encontramos una vez en los datos de las mujeres. En cambio, no hay ningún caso de "Declaración de obligación" en el corpus femenino, pero sí en el de los varones. Al igual que en el caso anterior, la comparación de los promedios entre las estrategias usadas también muestra una diferencia significativa en los datos de subgrupos malayos: $X^{2}=9.778 p=.021 \quad(p<.05)$, pero no en los subgrupos españoles.

Por último, respecto al empleo de movimientos de apoyo, según el resultado estadístico, las mujeres de ambas culturas utilizaron más que los sujetos del otro sexo (99 enunciados frente a 78 de los varones en el caso español, y 100 de las mujeres en comparación con 82 de los varones, en el caso malayo). Además, las mujeres mostraron más variedad de estrategias (12 frente a 11 de los hombres en el caso español y 14 , frente a 11 , en el otro grupo), tal y como se refleja en la siguiente tabla de resultados: 
Figura 66. Distribución de enunciados (movimientos de apoyo) producidos para la situación 16 en cada género en ambas culturas, según estrategias empleadas
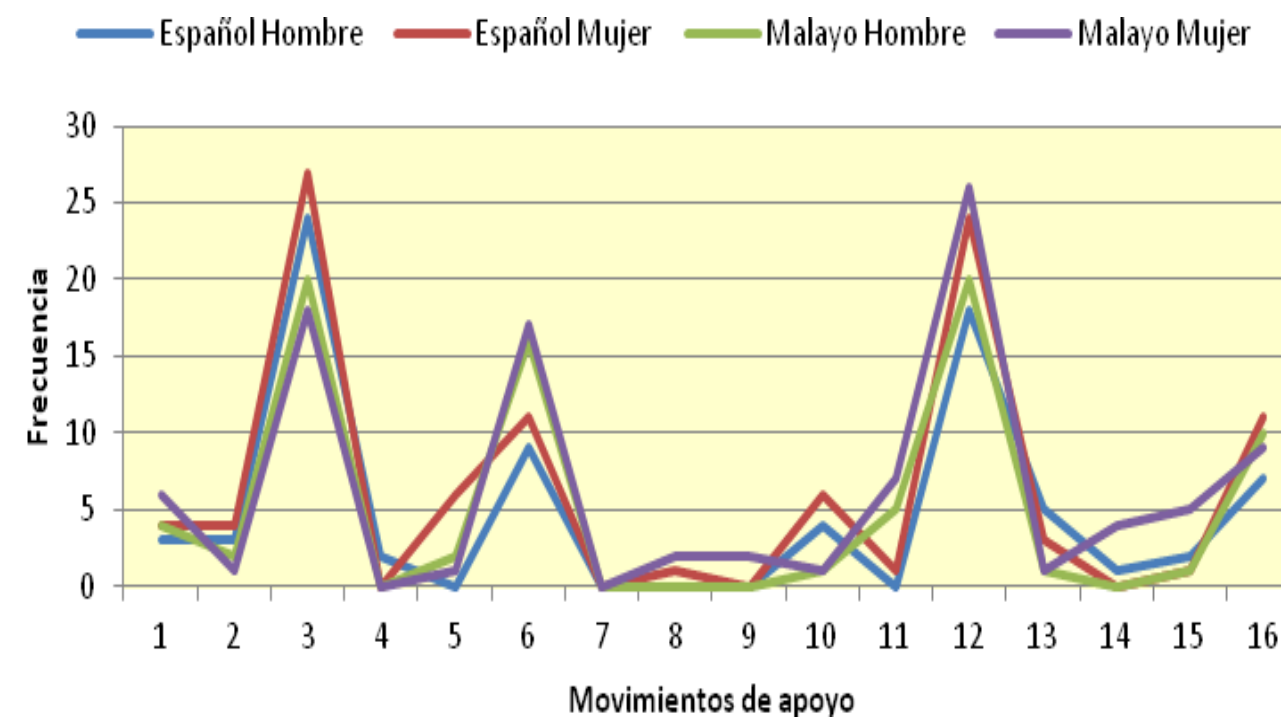

1.Fórmulas de preparación 2.Búsqueda de un compromiso 3.Razones 4.Previsión de objeciones 5.Promesa de recompensa/reparación 6.Minimización de la imposición 7.Invocación de principios generales 8. Reconocimiento de la imposición 9.Preocupación 10.Apreciación 11.Promesa de devolución 12.Gravedad/urgencia 13.Presentación/saludo 14.Petición de la opinión del oyente 15.Disculpa 16.Fórmulas de tratamiento

Los sujetos de ambos sexos del grupo español y los varones del grupo malayo coinciden en su tendencia hacia un mayor uso de las "Razones", con 24 enunciados recogidos de los sujetos varones y 27 de los femeninos, en el corpus español, y 20 de los varones malayos. Ahora bien, los varones malayos mostraron prferencia, además, por la estrategia de "Gravedad/urgencia", que emplearon en 20 ocasiones. También la mayoría de las mujeres malayas mostraron su inclinación hacia esta misma estrategia, que aplicaron en 26 de sus enunciados. Es, asimismo, la estrategia de "Gravedad/urgencia", la segunda más empleada por los sujetos españoles de ambos géneros, con 18 enunciados de los varones y 24 
de las mujeres, mientras que la de "Minimización de la imposición" fue la segunda más repetida en los varones malayos (aparece en 16 ocasiones). La opción que ocupa la primera posición en los tres subgrupos mencionados, se sitúa en el segundo lugar en las mujeres malayas.

Hay que señalar, además, que en el material español, los varones analizados no aplicaron las siguientes formas: "Promesa de recompensa/reparación", "Reconocimiento de la imposición" y "Promesa de devolución", pero sí se encontraron en los datos de las mujeres, con 6 casos de la primera y uno de cada una de la otras dos. En cambio, los varones usaron las estrategias de "Previsión de objeciones" y "Petición de la opinión del oyente", pero en el corpus femenino no se encontró ningún ejemplo. Por otro lado, en el grupo malayo, ningún varón realizó sus peticiones utilizando las estrategias de "Reconocimiento de la imposición", "Preocupación" y "Petición de la opinión del oyente", pero sí se registraron en los datos de mujeres, con 2 casos de las dos primeras y 4 de la tercera. Sin embargo, todas las estrategias empleadas por los varones, fueron también seleccionadas por las mujeres. A diferencia del análisis realizado sobre las estrategias empleadas en los actos principales, los promedios comparados entre los subgrupos de sexo en ambas sociedades respecto a los movimientos de apoyo no resultaron significativos. 


\subsubsection{La influencia de las variables sociales}

Esta sección tiene como objetivo profundizar en la comparación específica de los resultados según las variables sociales configuradas en los escenarios. Asimismo, revisaremos las diferencias o similitudes que muestran los datos de ambos países al formular las peticiones dependiendo del estatus y la distancia social.

\subsubsection{Estatus social}

Para descubrir los efectos del poder social de un interlocutor sobre otro y la ausencia de autoridad entre los hablantes del mismo nivel al ejecutar una petición favorable, examinaremos el resultado estadístico obtenido a través de la categorización de 3 situaciones según el estatus social. En primer lugar, el análisis se realizará teniendo en cuenta los actos principales, y, posteriormente, atendiendo a los movimientos de apoyo. 
Las dos figuras que se presentan a continuación representan el nivel de frecuencia de uso de las tres categorías principales de estrategias de peticiones según el estatus social.

Figura 67. Distribución de estrategias de petición (número de enunciados en actos principales) según el estatus social en el caso español

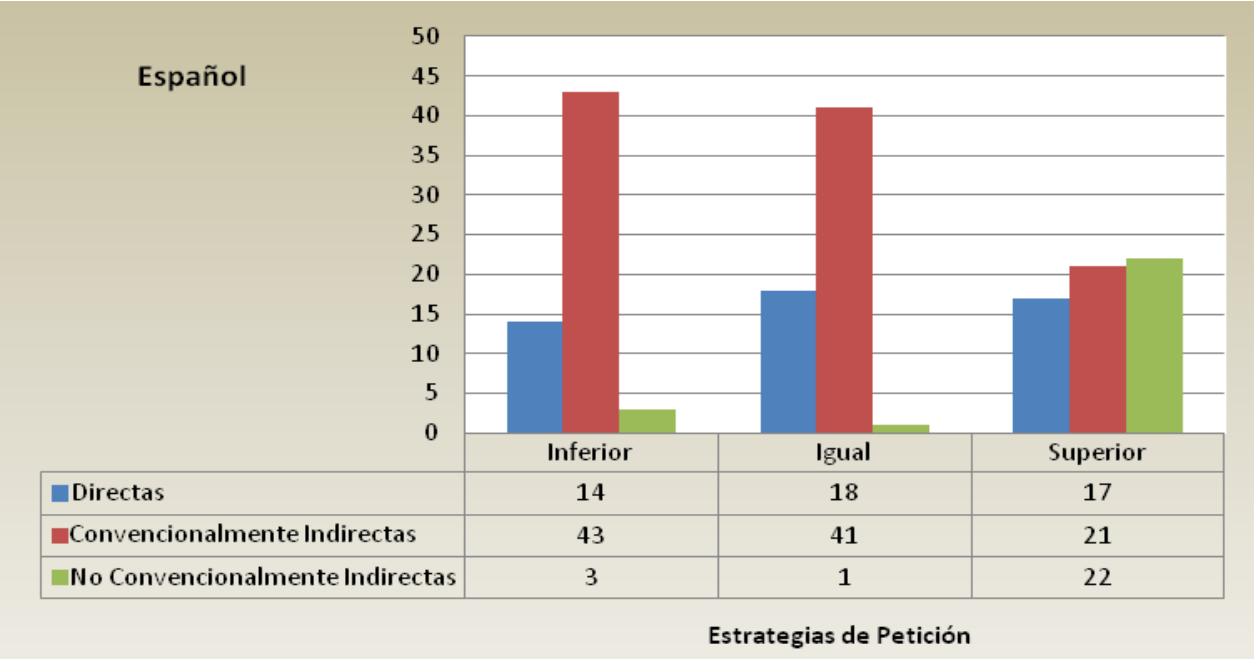

Figura 68. Distribución de estrategias de petición (número de enunciados en actos principales) según el estatus social en el caso malayo

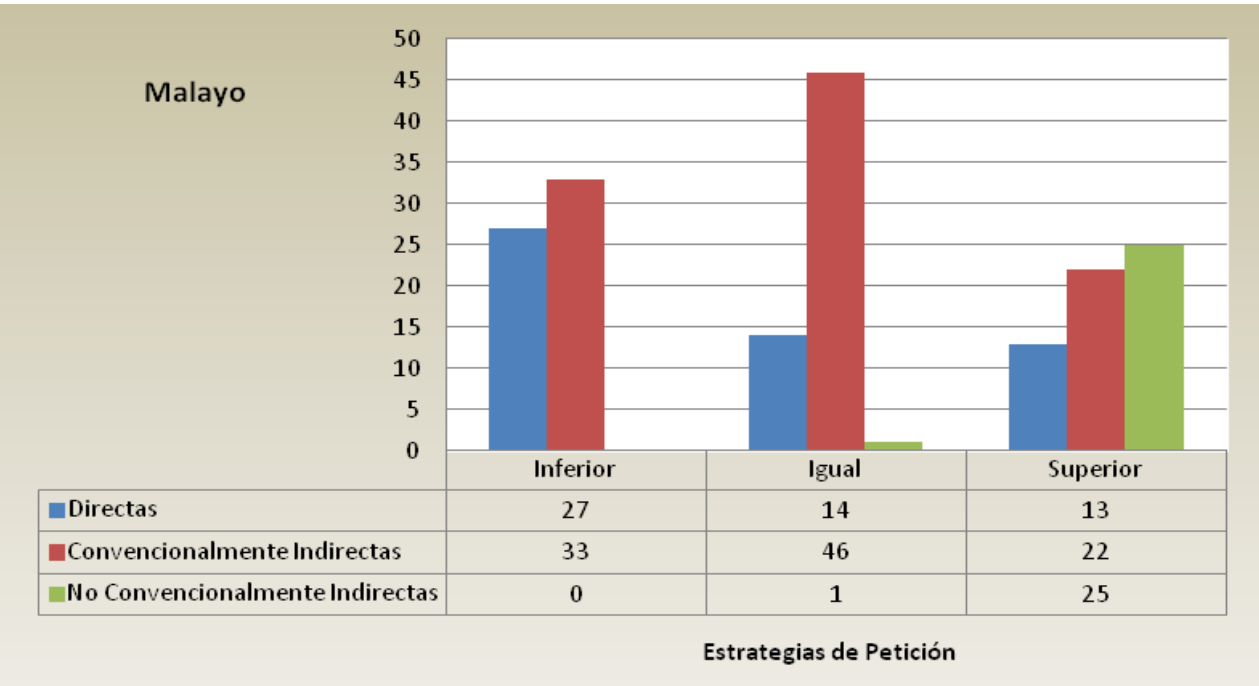


A la luz de los resultados presentados en las gráficas, deducimos, en primer lugar, que los hablantes españoles utilizaron con mayor frecuencia las llamadas "Directas" al hacer la petición a una persona del mismo estatus, menos en los casos en los que el poder relativo se inclina hacia los destinatarios $y$, en menor medida, al realizar la petición a personas de un estatus inferior. Por el contrario, los hablantes malayos aplicaron dicha forma principalmente en sus peticiones a una persona de posición social más baja, algo menos al producir la petición a destinatarios de la misma posición $y$, en un menor número de ocasiones cuando realizaron la petición a personas de una posición más elevada.

Con respecto a las formas "Convencionalmente indirectas", los españoles las utilizaron con más frecuencia en las peticiones a una persona de estatus inferior, un poco menos con personas del mismo nivel y, las menos veces, cuando formularon la petición a un oyente de posición más alta. En cambio, los malayos emplearon más este tipo de estrategias en sus peticiones a una persona del mismo estatus, menos hacia aquellos de una posición inferior $y$, muy pocas veces, al dirigirse a interlocutores de una posición social superior.

Los grupos comparados mostraron comportamientos similares respecto a las estrategias "No convencionalmente 
indirectas", puesto que los sujetos participantes de ambas culturas las usaron más frecuentemente al colocarse en una posición superior frente a los encuestados. Los hablantes españoles utilizaron menos en sus peticiones las formas mencionadas con personas de nivel más bajo, y todavía en menos ocasiones al dirigirse a personas de la misma posición social. En cambio, los malayos las aplicaron menos en la situación en la que los destinatarios eran del mismo estatus, y, en ningún caso, en sus peticiones a personas de estatus inferior. La diferencia entre los promedios de las formas aplicadas en español y malayo fue significativa $X^{2}=21.064 p=.000(p<.05)$.

Si realizamos el análisis teniendo en cuenta los subgrupos de edad, los resultados obtenidos acerca del grado de (in)dirección de las estrategias empleadas en los distintos contextos son los que se presentan a continuación:

Figura 69. Distribución de estrategias de petición (número de enunciados en actos principales) según estatus social en el caso de mayor versus menor, en el grupo español

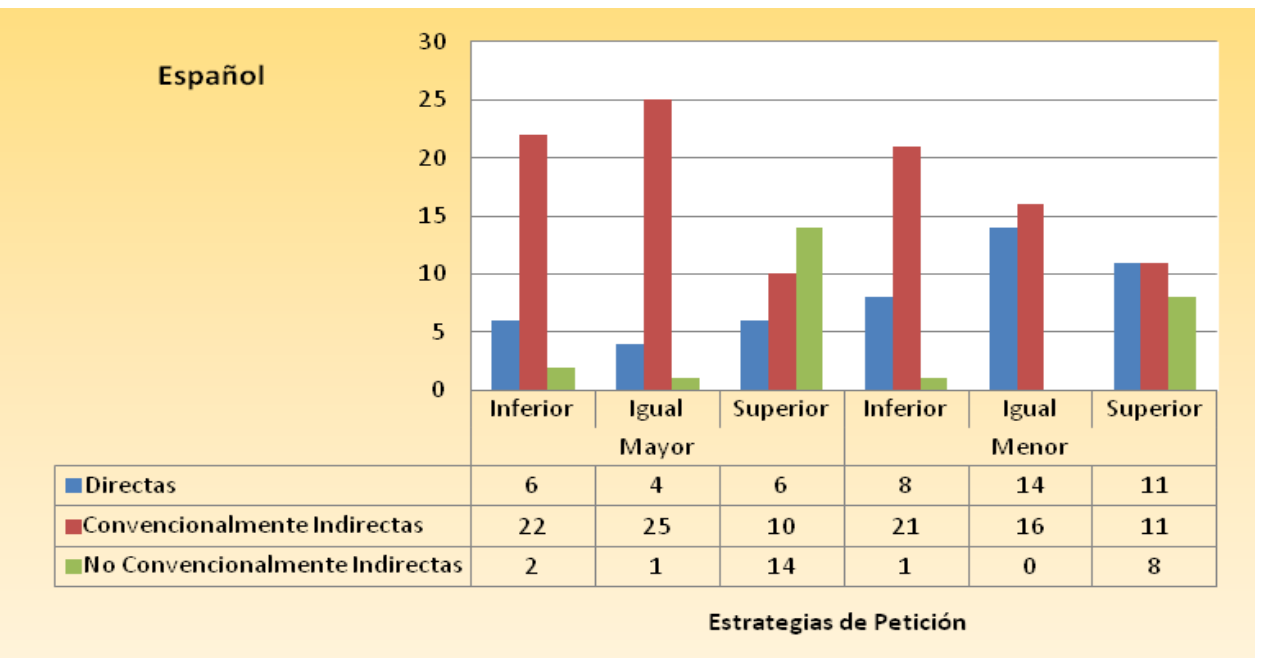


Figura 70. Distribución de estrategias de petición (número de enunciados en actos principales) según estatus social en el caso de mayor versus menor, en el grupo malayo

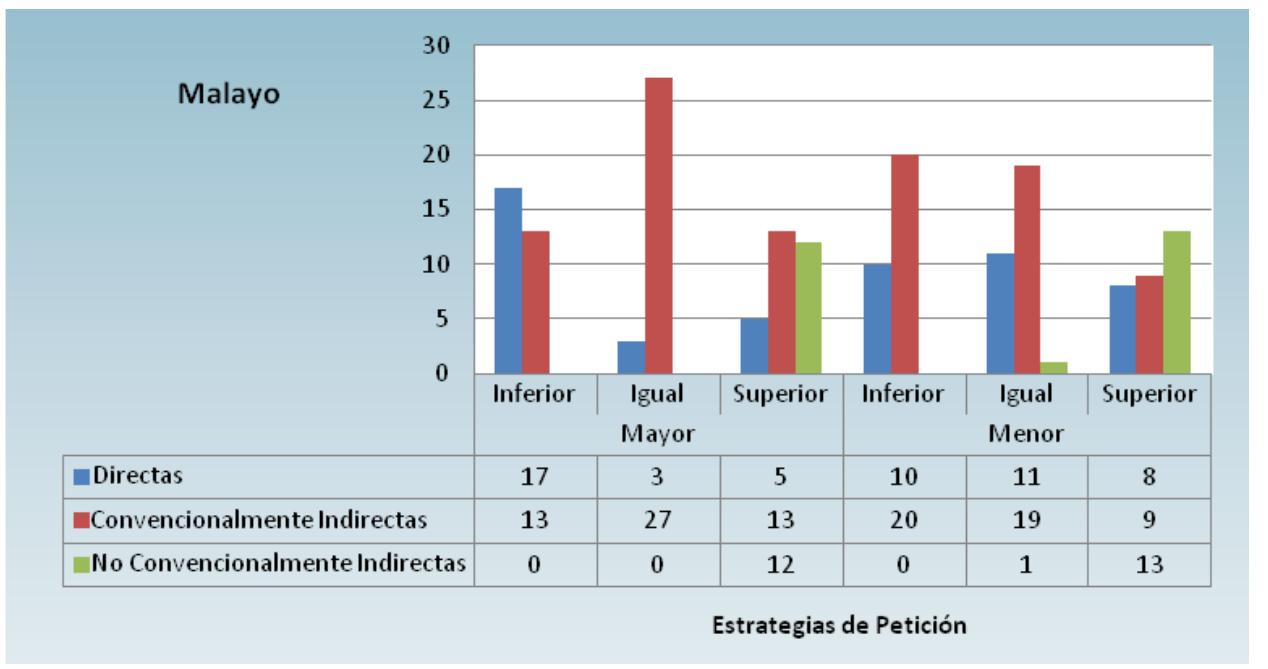

Los mayores españoles utilizaron más formas "Directas" al hacer la petición a una persona de nivel superior e inferior (se obtuvieron el mismo número de enunciados en ambos casos), y menos con interlocutores del mismo estatus. Los jóvenes, por el contrario, aplicaron más formas "Directas" al formular sus peticiones a una persona del mismo nivel, menos cuando realizaron la petición a una persona de posición más elevada, y el menor número de dichas formas aparece en el contexto en el que se dirigen a un interlocutor socialmente inferior (situación 13). Por otra parte, en el grupo malayo, los mayores aplicaron más las formas "Directas" cuando estaban hablando con personas de un estatus más bajo, y encontramos una disminución de su aparición en el caso de los interlocutores que se sitúan en una posición social más alta, siendo al hacer la petición a una persona del mismo nivel social cuando se 
emplean en menos ocasiones. En cambio, los menores se inclinaron más por las formas "Directas" con interlocutores del mismo estatus, menos con una persona de uno inferior, y el menor número de casos aparece cuando se trata de destinatarios de una posición social superior.

Los subgrupos comparados mostraron patrones diferentes en el uso de las formas "Convencionalmente indirectas". Además, los resultados obtenidos fueron opuestos a los obtenidos en el caso de las "Directas". Los mayores españoles recurrieron más veces a dicha forma al hacer la petición a una persona del mismo estatus, menos a personas de una posición social más baja, y en un número menor de ocasiones al dirigirse a oyentes socialmente superiores. Los de menos edad, en cambio, emplearon más formas "Convencionalmente indirectas" con los de una posición inferior y menos al colocarse en la misma posición social de los oyentes. Con los interlocutores socialmente superiores, redujeron al máximo el uso de dicha forma en sus peticiones. Por otro lado, el patrón mostrado por los subgrupos malayos fue similar al de los españoles. Los hablantes mayores usaron en mayor medida las estrategias "Convencionalmente indirectas" cuando elaboraron la petición para una persona del mismo estatus, y menos cuando lo hicieron para personas de estatus social inferior o superior (encontramos el mismo número de enunciados en uno y otro caso). Los jóvenes, por su 
parte, recurrieron a esas estrategias, en la mayor parte de los casos, con personas de una posición social inferior, pero también, aunque menos, con las personas del mismo estatus o de estatus superior.

Por último, los dos subgrupos en ambas sociedades mostraron el mismo patrón respecto a la utilización de las estrategias "No convencionalmente indirectas". Tanto los sujetos mayores españoles como los menores las aplicaron con mayor frecuencia cuando formularon la petición a personas de un estatus superior, algo menos al tratar con personas de nivel social igual o inferior. Ahora bien, ningún menor utilizó este tipo de estrategias al dirigirse a gente de la misma posición. En cambio, en el corpus malayo, los participantes de los dos subgrupos de edad utilizaron más dicha forma en sus peticiones a interlocutores de una posición superior. Sin embargo, no se encontró ningún caso de dichas formas con personas de posición igual o inferior en los datos de los sujetos de más edad, mientras que en los de los más jóvenes solo aparece una vez al realizar la petición a una persona del mismo estatus. La diferencia entre los participantes mayores y los menores respecto al uso de las tres formas de petición con estatus social diferente no fue estadísticamente significativa ni en el corpus español ni en el malayo. 
Al estudiar la influencia del estatus social en las formas de petición utilizadas entre los subgrupos de sexo, encontramos la siguiente distribución de estrategias:

Figura 71. Distribución de estrategias de petición (número de enunciados en actos principales) según estatus social en el caso de varón versus mujer

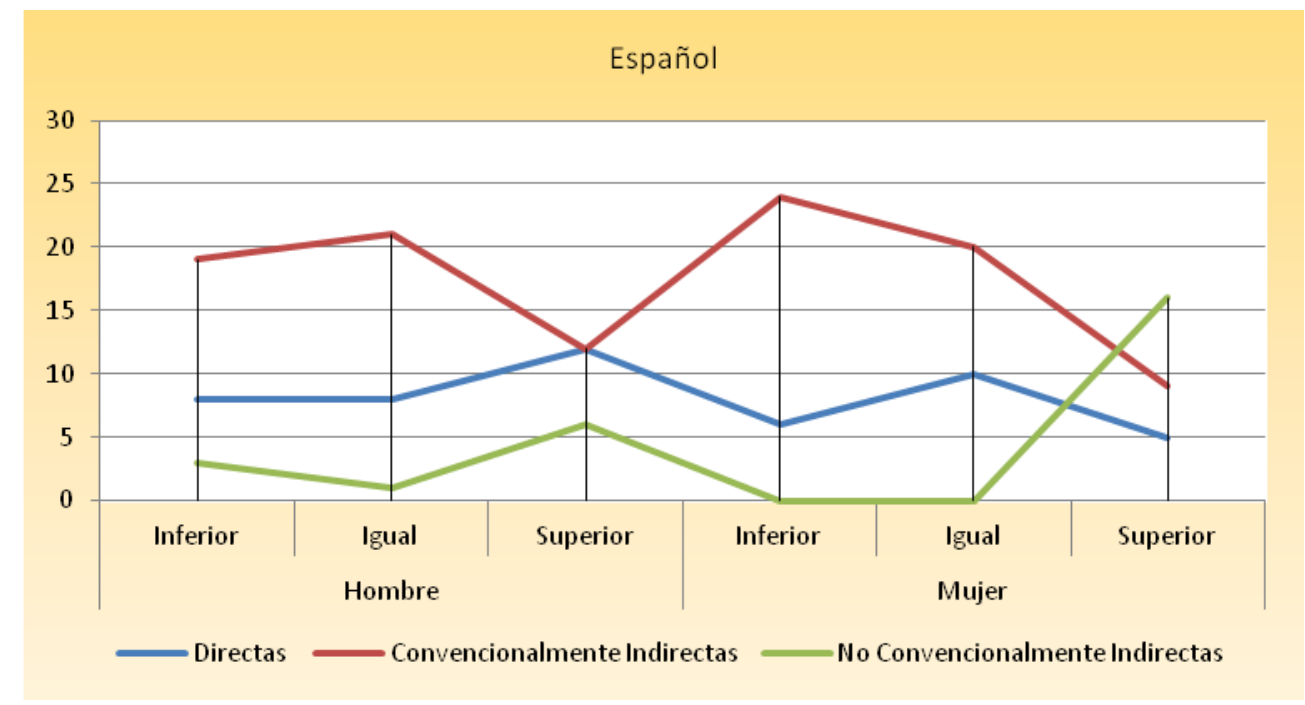

Figura 72. Distribución de estrategias de petición (número de enunciados en actos principales) según estatus social en el caso de varón versus mujer

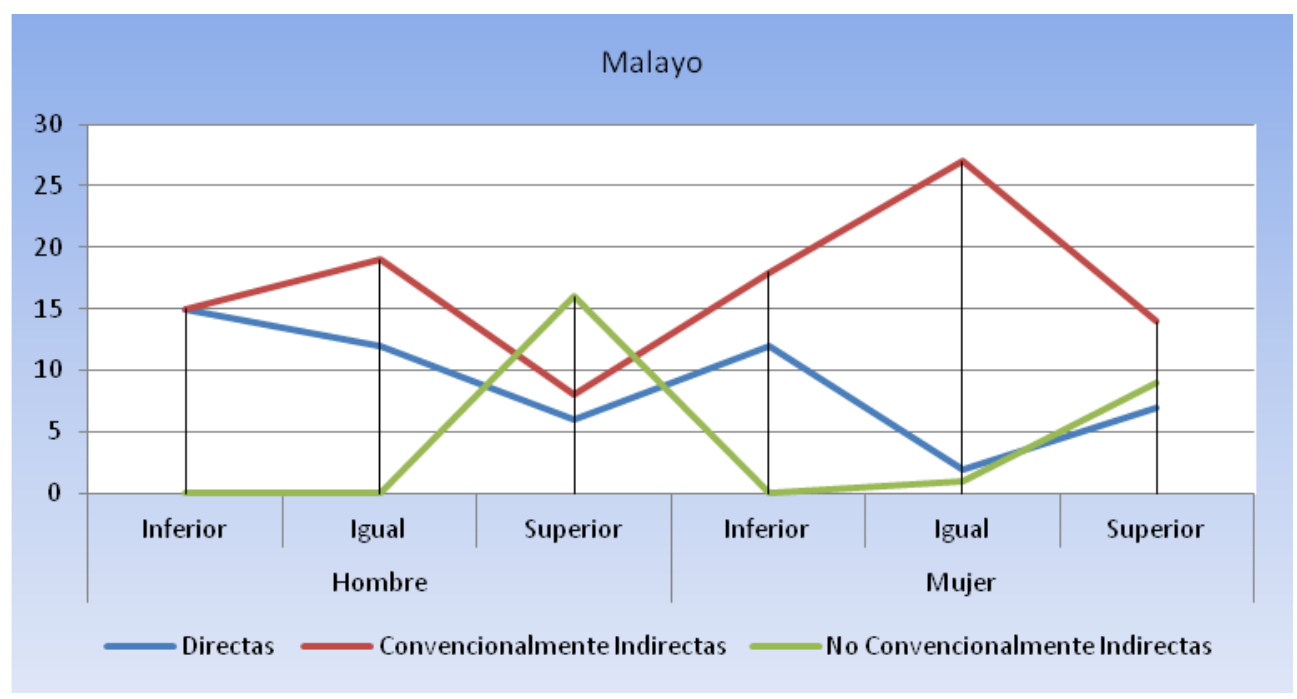


Los varones españoles tendieron a emplear las formas "Directas" en la mayor parte de los casos al dirigirse a una persona de estatus superior, en un menor número de ocasiones con personas de la misma posición y todavía menos veces, al hacer la petición a los interlocutores socialmente inferiores. En cambio, las mujeres utilizaron dichas estrategias en mayor proporción al hablar con una persona del mismo estatus, menos al dirigirse a los inferiores, y el menor número de casos se dio en las peticiones a una persona socialmente superior. En la sociedad malaya, por su parte, los varones recurrieron a las formas "Directas" fundamentalmente con personas del mismo estatus, aunque también, en menos ocasiones, al hablar con personas socialmente inferiores y aún menos veces al dirigirse a personas de posición más elevada. Por el contrarío, las mujeres tendieron a utilizar más formas "Directas" con una persona de nivel socialmente más bajo y menos con una persona de posición social más alta, aunque el menor número de dichas formas aparece en las peticiones formuladas a interlocutores de su mismo estatus.

Los resultados recogidos sobre el empleo de las formas "Convencionalmente indirectas" mostraron que los varones analizados en el grupo español las utilizaron en sus peticiones a destinatarios principalmente del mismo estatus. En los casos en los que los interlocutores están en una posición social inferior, se observa una reducción de la frecuencia de uso. Pero cuando menos 
utilizan este tipo de categoría es al realizar la petición a personas de una posición social más alta. Las mujeres por su parte, recurrieron más a las "Convencionalmente indirectas" cuando dirigieron la petición a una persona de un rango social inferior, algo menos al hablar con personas del mismo estatus, $y$, las menos veces, al tratar con personas de posición más elevada. Por otro lado, tanto los varones como las mujeres de la sociedad malaya aplicaron dichas formas en más ocasiones con personas del mismo estatus, y con menos frecuencia con personas inferiores, siendo el contexto en el que el interlocutor está en una posición superior cuando menos las emplearon.

Con respecto a las "No convencionalmente indirectas", los varones de la sociedad española prefirieron utilizarlas, sobre todo, con personas de estatus más alto y las eligieron en menos ocasiones cuando realizaron la petición a personas de uno más bajo, aunque el menor número de enunciados en los que emplean esta categoría de estrategia es en sus peticiones a los interlocutores del mismo estatus. En cambio, las mujeres solo aplicaron dichas formas al hacer la petición a los oyentes de un rango social superior. Ninguna mujer española las usó para formular su petición con una persona de posición social inferior ni con personas del mismo estatus. En la otra sociedad, la malaya, los hombres las emplearon únicamente con interlocutores de nivel superior, mientras que las mujeres recurrieron 
a ellas en sus peticiones a una persona socialmente superior $y$ menos con una persona del mismo estatus. Tampoco se encontró ningún ejemplo de dichas formas en las peticiones de las mujeres hacia los interlocutores de una posición inferior. La comparación de promedios en las categorías aplicadas por los hablantes de ambos sexos no señaló una diferencia significativa ni en el caso español ni en el malayo.

\section{B) Movimientos de apoyo}

El análisis de los movimientos de apoyo según el poder social en las respuestas proporcionadas por los hablantes de ambos países ha resultado muy interesante, puesto que las preferencias mostradas fueron diferentes y variadas, como se manifiesta en las siguientes gráficas: 
Figuras 73 y 74. Distribución de enunciados (movimientos de apoyo) por estrategias, según estatus social en ambas culturas, española y malaya
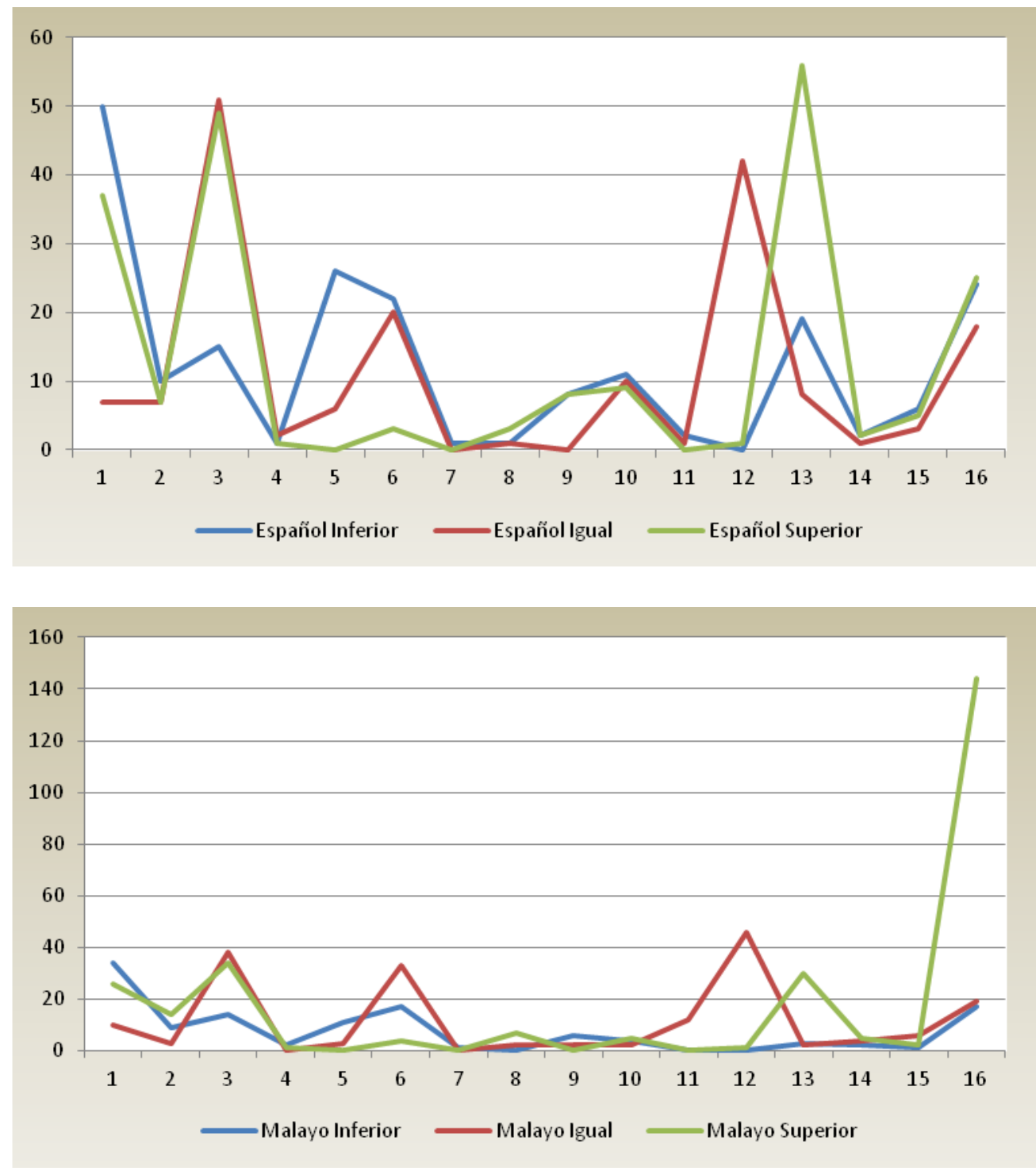

1.Fórmulas de preparación 2.Búsqueda de un compromiso 3.Razones 4.Previsión de objeciones 5.Promesa de recompensa/reparación 6.Minimización de la imposición 7.Invocación de principios generales 8.Reconocimiento de la imposición 9.Preocupación 10.Apreciación 11.Promesa de devolución 12.Gravedad/urgencia 13.Presentación/saludo 14.Petición de la opinión del oyente 15.Disculpa 16.Fórmulas de tratamiento

Los nativos españoles tendieron a realizar sus peticiones a una persona de posición social inferior a través de la estrategia de "Fórmulas de preparación". Pero, cuando expresaron la petición a personas del mismo estatus, prefirieron utilizar la de "Razones". Y, al 
realizar la petición a personas de un rango más elevado, utilizaron mayoritariamente la de "Presentación/saludo". Por su parte, y de manera similar, los nativos malayos también optaron mayoritariamente por hacer la petición a personas inferiores a través de "Fórmulas de preparación", mientras que en sus peticiones hacia personas del mismo nivel se inclinaron por la de "Gravedad/urgencia", y utilizaron "Fórmulas de tratamiento" más que otras estrategias cuando dirigieron la petición a una persona de estatus socialmente superior.

A continuación, pasamos a examinar hasta qué punto los dos grupos analizados mostraron diferencias significativas en las estrategias menos utilizadas en las interacciones, dependiendo de la posición social existente entre los interlocutores. Al hacer la petición a una persona de estatus inferior los informantes españoles utilizaron menos las de "Previsión de objeciones", "Invocación de principios generales" y "Reconocimiento de la imposición" (cada una aparece solamente una vez), mientras que al dirigirse a una persona del mismo estatus, los españoles emplearon menos las de "Reconocimiento de la imposición", "Promesa de devolución" y "Petición de la opinión del oyente" (un ejemplo registrado de cada una). Y, cuando realizaron la petición a alguien de estatus más elevado, aplicaron menos "Previsión de objeciones", y "Gravedad/urgencia" (una vez cada una). Por otra parte, en el grupo 
malayo, las estrategias menos utilizadas por los informantes cuando formularon las peticiones a una persona socialmente inferior fueron "Invocación de principios generales" y "Disculpa" (ambas aparecen una vez). En la situación en la que el oyente pertenecía al mismo estatus, recurrieron menos a "Reconocimiento de la imposición", "Preocupación", "Apreciación" y "Presentación/saludo" (dos veces cada una). $\mathrm{Y}$, en sus peticiones a una persona de rango superior aplicaron menos "Previsión de objeciones" y "Gravedad/urgencia" (una vez cada una). La diferencia entre las dos comunidades de habla investigadas en el uso de los movimientos de apoyo con personas de estatus social diferente fue estadísticamente significativa: $X^{2}=28.006 p=.000(p<.05)$.

Si analizamos, también teniendo en cuenta la posición social de los interlocutores, las diferencias en el uso de las estrategias empleadas en los movimientos de apoyo entre los sujetos mayores y los menores, los resultados numéricos que se obtienen son los que aparecen en las siguientes tablas: 
Figuras 75 y 76. Distribución de enunciados (movimientos de apoyo) por estrategias, según estatus social en el caso de mayor versus menor, en el grupo español
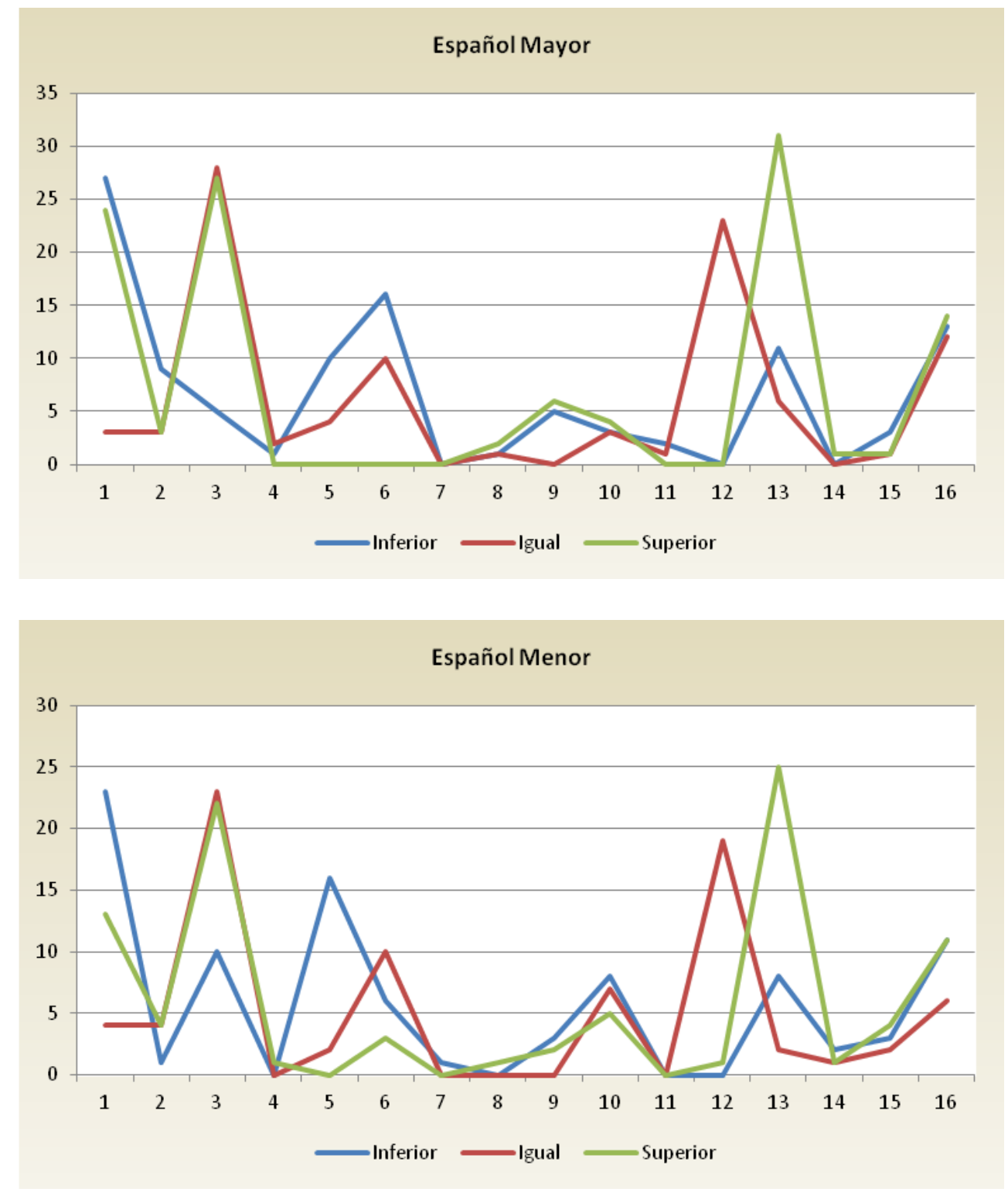

1.Fórmulas de preparación 2.Búsqueda de un compromiso 3.Razones 4.Previsión de objeciones 5.Promesa de recompensa/reparación 6.Minimización de la imposición 7.Invocación de principios generales 8.Reconocimiento de la imposición 9.Preocupación 10.Apreciación 11.Promesa de devolución 12.Gravedad/urgencia 13.Presentación/saludo 14.Petición de la opinión del oyente 15.Disculpa 16. Fórmulas de tratamiento

El análisis que queda de manifiesto en las gráficas anteriores revela que no existen diferencias entre los subgrupos 
españoles respecto a la utilización de las estrategias de los movimientos de apoyo según el poder social. De hecho, los resultados obtenidos fueron similares a los de los grupos principales. Sin embargo, los mayores y los jóvenes se diferenciaron en las estrategias menos utilizadas al hacer la petición a personas de distinto estatus. Mientras que los participantes de mayor edad utilizaron menos las de "Previsión de objeciones" y "Reconocimiento de la imposición" con personas de nivel social más bajo, los de menos edad aplicaron las estrategias de "Búsqueda de un compromiso" y "Invocación de principios generales". Al realizar la petición a una persona del mismo estatus, los sujetos de más edad usaron menos el "Reconocimiento de la imposición" y la "Disculpa". En cambio, los jóvenes, recurrieron menos a la "Petición de la opinión del oyente". Por último, en sus peticiones a una persona socialmente superior, los adultos maduros aplicaron menos las formas de "Petición de la opinión del oyente" y "Disculpa", y los menores las de "Previsión de objeciones", "Reconocimiento de la imposición", "Gravedad/urgencia" y "Petición de la opinión del oyente".

Respecto a la distribución de las estrategias empleadas en los movimientos de apoyo según el poder social en los subgrupos malayos de edad, los resultados obtenidos, teniendo en cuenta el 
número de enunciados producidos en cada caso, quedan de la siguiente manera:

Figuras 77 y 78. Distribución de enunciados (movimientos de apoyo) por estrategias, según estatus social en el caso de mayor versus menor, en el grupo malayo
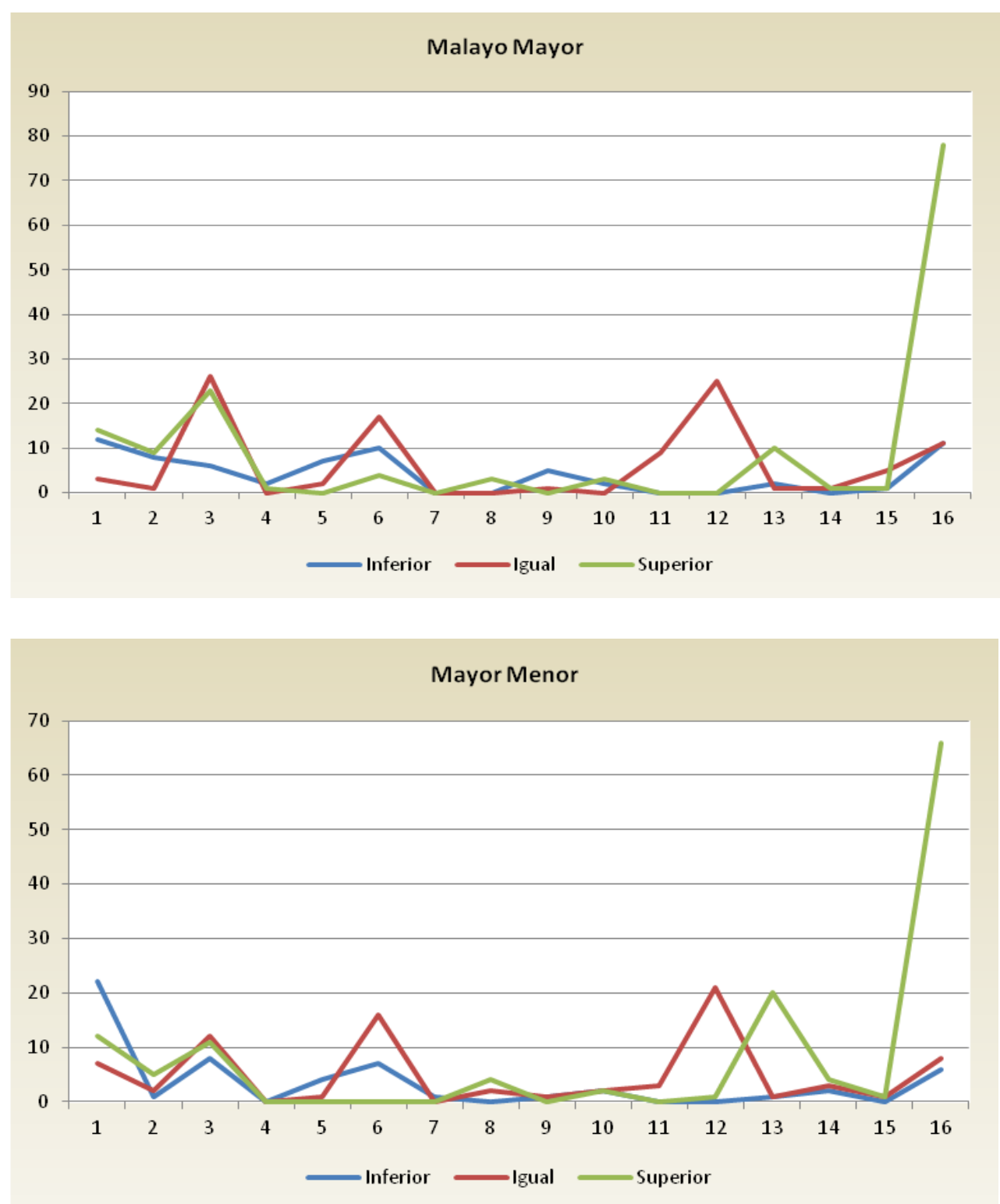

1.Fórmulas de preparación 2.Búsqueda de un compromiso 3.Razones 4.Previsión de objeciones 5.Promesa de recompensa/reparación 6.Minimización de la imposición 7.Invocación de principios generales 8.Reconocimiento de la imposición 9.Preocupación 10.Apreciación 11.Promesa de devolución 12.Gravedad/urgencia 13.Presentación/saludo 14.Petición de la opinión del oyente 15.Disculpa 16.Fórmulas de tratamiento 
A primera vista, el patrón de los resultados estadísticos es similar entre ambos subgrupos. Para hacer la petición a una persona de posición social inferior, los sujetos de los dos subgrupos, mayores y menores, mostraron la misma preferencia por el uso de "Fórmulas de preparación" y ambos utilizaron más "Fórmulas de tratamiento" en sus peticiones a las personas de posición más elevada. Sin embargo, con una persona del mismo estatus, los mayores aplicaron mayoritariamente la estrategia de "Razones", mientras que los menores recurrieron preferentemente a la de "Gravedad/urgencia". En cuanto a las estrategias menos aplicadas, los dos subgrupos analizados no mostraron diferencias importantes, ya que ambos emplearon en menor proporción las mismas fórmulas al hacer la petición a los interlocutores de distinto nivel social. La diferencia entre los promedios de los movimientos de apoyo utilizados no fue significativa en ninguno de los subgrupos de edad de ambos países.

Al igual que en el caso de los subgrupos de edad, al estudiar la distribución de las estrategias empleadas por los sujetos de los dos subgrupos de sexo españoles en los movimientos de apoyo, tampoco surgieron diferencias relevantes, puesto que las estrategias utilizadas por los varones y las mujeres para ejecutar la petición con personas de distintos estatus sociales fueron similares entre sí y también respecto a las aplicadas por los hablantes de los subgrupos de edad, como vemos en estos gráficos que presentan la 
distribución de los movimientos de apoyo según el poder social en

los dos sexos en cada país:

Figuras 79 y 80 . Distribución de enunciados (movimientos de apoyo) por estrategias, según estatus social en el caso de varón versus mujer, en el grupo español
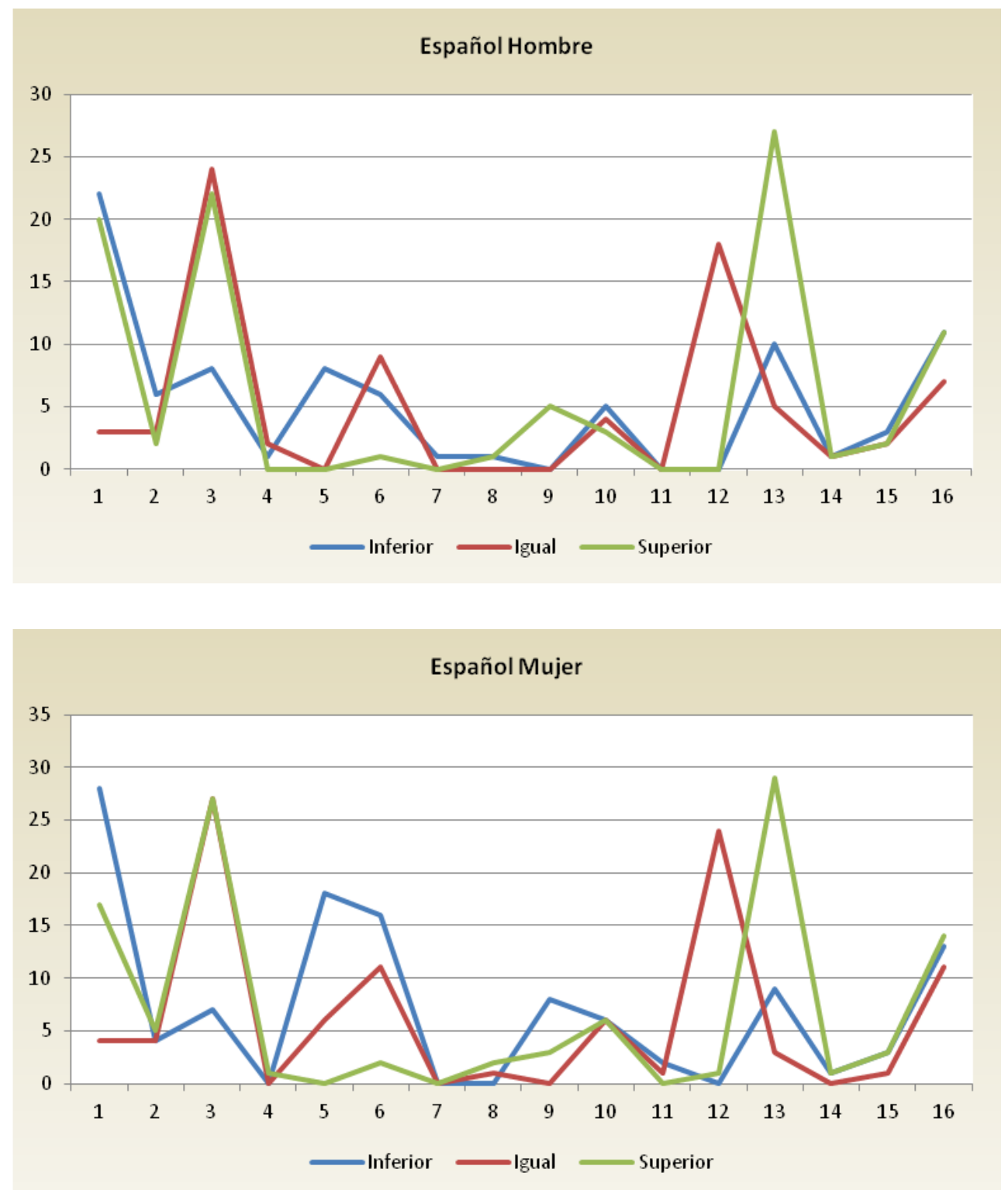

1.Fórmulas de preparación 2.Búsqueda de un compromiso 3.Razones 4.Previsión de objeciones 5.Promesa de recompensa/reparación 6.Minimización de la imposición 7.Invocación de principios generales 8.Reconocimiento de la imposición 9.Preocupación 10.Apreciación 11.Promesa de devolución 12.Gravedad/urgencia 13.Presentación/saludo 14.Petición de la opinión del oyente 15.Disculpa 16.Fórmulas de tratamiento 
Como se puede ver en las tablas anteriores, no hubo diferencias notables entre las estrategias menos empleadas por los participantes españoles de ambos géneros. $Y$ en los datos de los subgrupos de género de la sociedad malaya, como en el caso de los españoles, tampoco se encontraron diferencias llamativas con respecto a la utilización de los movimientos de apoyo según el poder social, como vamos a ver a continuación.

En el grupo malayo, las preferencias mostradas al dirigirse a personas de diferente posición social fueron muy similares entre hombres y mujeres, aunque eligieron distintas estrategias según el estatus social del oyente. Además, esta tendencia coincide con la de los grupos principales y los subgrupos de edad. Tampoco hubo una diferencia notable en las fórmulas menos usadas con personas de distintos niveles sociales, como vemos en las tablas de los datos numéricos: 
Figuras 81 y 82 . Distribución, de enunciados (movimientos de apoyo) por estrategias, según estatus social en el caso de varón versus mujer, en el grupo malayo
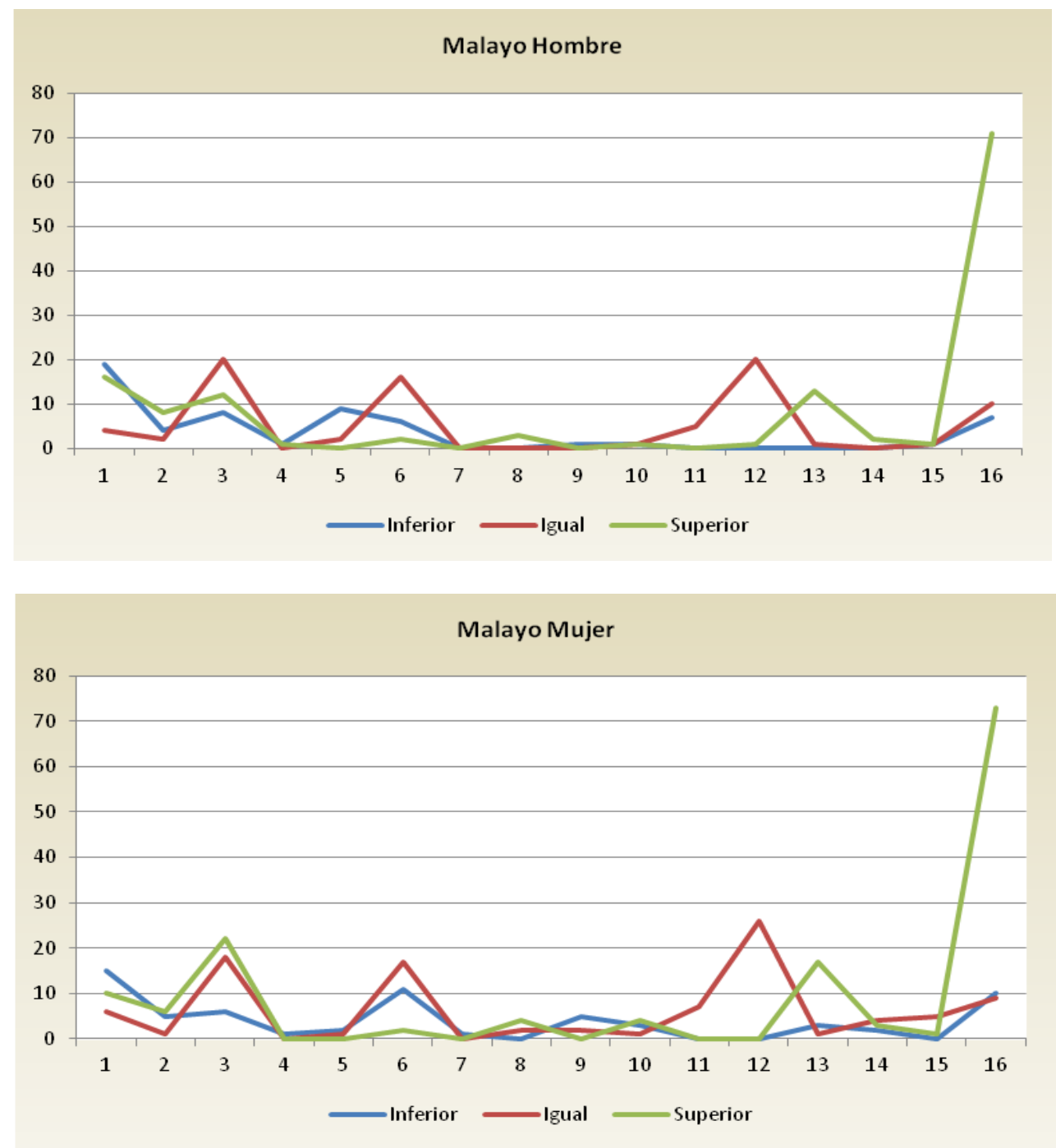

1.Fórmulas de preparación 2.Búsqueda de un compromiso 3.Razones 4.Previsión de objeciones 5.Promesa de recompensa/reparación 6.Minimización de la imposición 7.Invocación de principios generales 8.Reconocimiento de la imposición 9.Preocupación 10.Apreciación 11.Promesa de devolución 12.Gravedad/urgencia 13.Presentación/saludo 14.Petición de la opinión del oyente 15.Disculpa 16.Fórmulas de tratamiento

Al comparar los promedios de los movimientos de apoyo utilizados, la diferencia no fue significativa en ninguno de los subgrupos de sexo de ambos países. 


\subsubsection{Distancia social}

Con el fin de averiguar cómo varían las peticiones bajo la influencia de la distancia social, analizaremos las tres situaciones según el grado de familiaridad que se supone en los escenarios del cuestionario. De manera similar al caso del poder social, los datos se examinarán en términos de actos principales y movimientos de apoyo.

\section{A) Actos principales}

Respecto a la distribución de enunciados según el grado de (in)dirección de las estrategias empleadas, teniendo en cuenta la variable de grupo cultural, quedaría de la siguiente forma:

Figuras 83 y 84 . Distribución de enunciados (actos principales), por estrategias de petición, según distancia social en los dos grupos, español y malayo

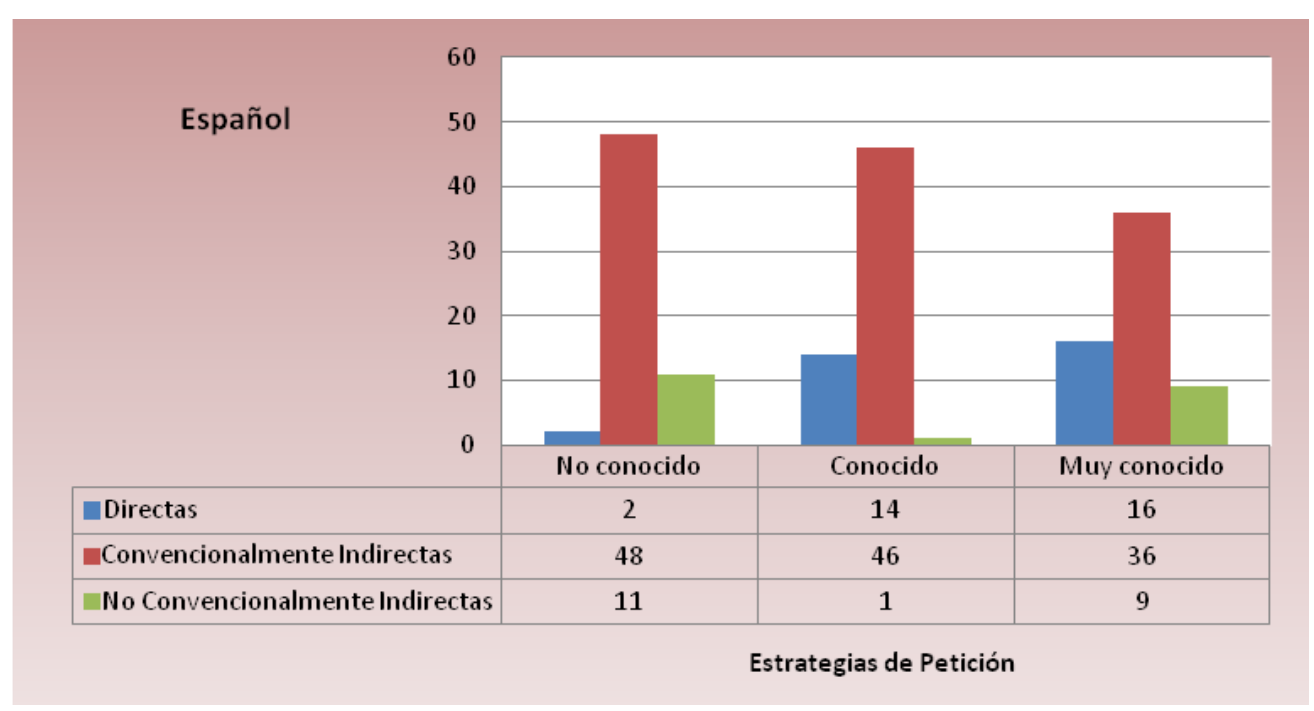




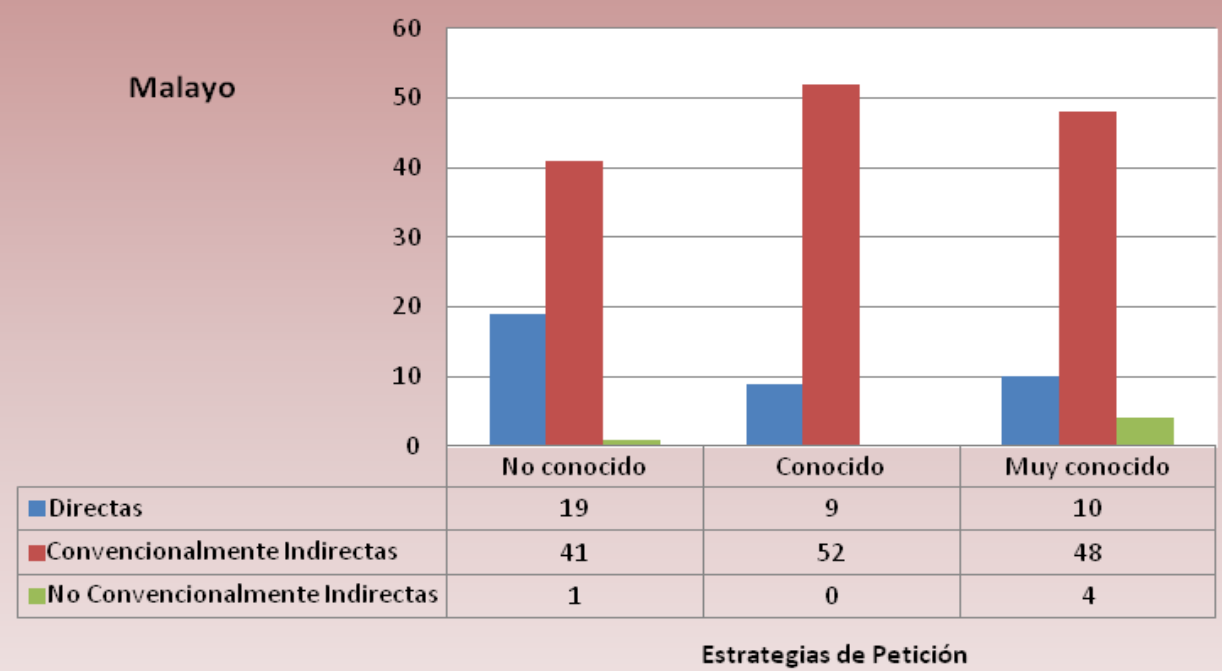

Los hablantes españoles emplearon más formas "Directas" cuando existe un bajo grado de distancia social entre los interlocutores, menos si hay poca distancia social entre los interlocutores y el menor número de dicha forma en situaciones en las que el grado de distancia social es alto. Por el contrario, los malayos emplearon con mayor frecuencia las "Directas" al dirigir su petición a destinatarios con los que existía más distancia social, disminuyeron su uso en sus peticiones a personas de las que les separaba menor distancia, y produjeron el menor número de enunciados aplicando dichas formas con los oyentes de los que los separaba una corta distancia social.

Con respecto a las formas "Convencionalmente indirectas", los españoles las emplearon con mayor frecuencia en los contextos en los que el grado de familiaridad entre los interlocutores 
es bajo, algo menos cuando se trata de una persona conocida y el menor número del casos se da al formular la petición a individuos con los que hay un alto nivel de familiaridad. En cambio, los malayos prefirieron aplicar las formas "Convencionalmente indirectas" en sus peticiones hacia personas conocidas, menos con personas muy conocidas, y, en un menor porcentaje, en la petición a extraños.

En el tercer caso, el de las estrategias "No convencionalmente indirectas", los españoles tendieron a aplicarlas más al dirigirse a un extraño, algo menos con personas muy conocidas y, las menos veces, con interlocutores conocidos. Los malayos, por su parte, mostraron su tendencia a usar más las "No convencionalmente indirectas" cuando percibieron cercanía, y menos cuando se trataba de un desconocido. Sin embargo, no se encontró ningún caso de dicha forma en las peticiones de los malayos a personas conocidas.

En el análisis llevado a cabo para identificar las posibles diferencias entre el empleo de estrategias más o menos directas en los enunciados producidos como actos principales por los mayores y los menores de cada cultura, según la distancia social, se obtuvieron los resultados que presentamos a continuación: 
Figura 85. Distribución de enunciados (actos principales) por estrategia de petición seleccionada, según distancia social en el caso de mayor versus menor, en el grupo español

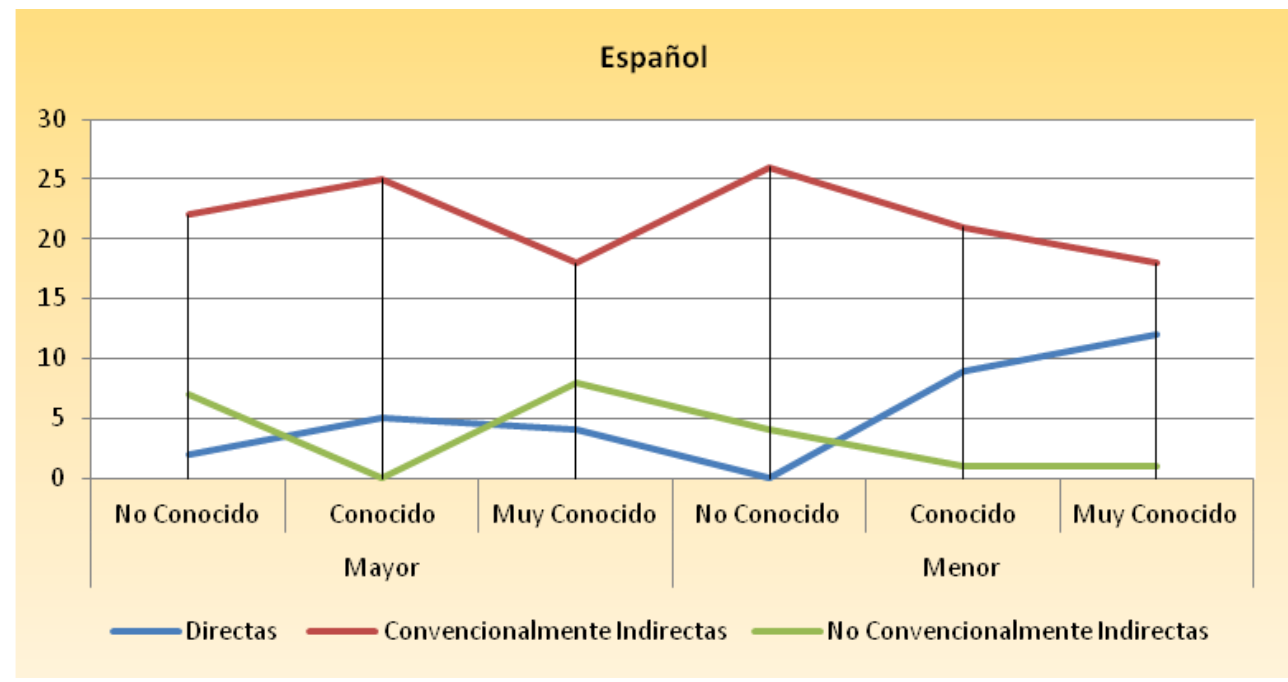

Figura 86. Distribución de enunciados (actos principales) por estrategia de petición seleccionada, según distancia social en el caso de mayor versus menor, en el grupo malayo

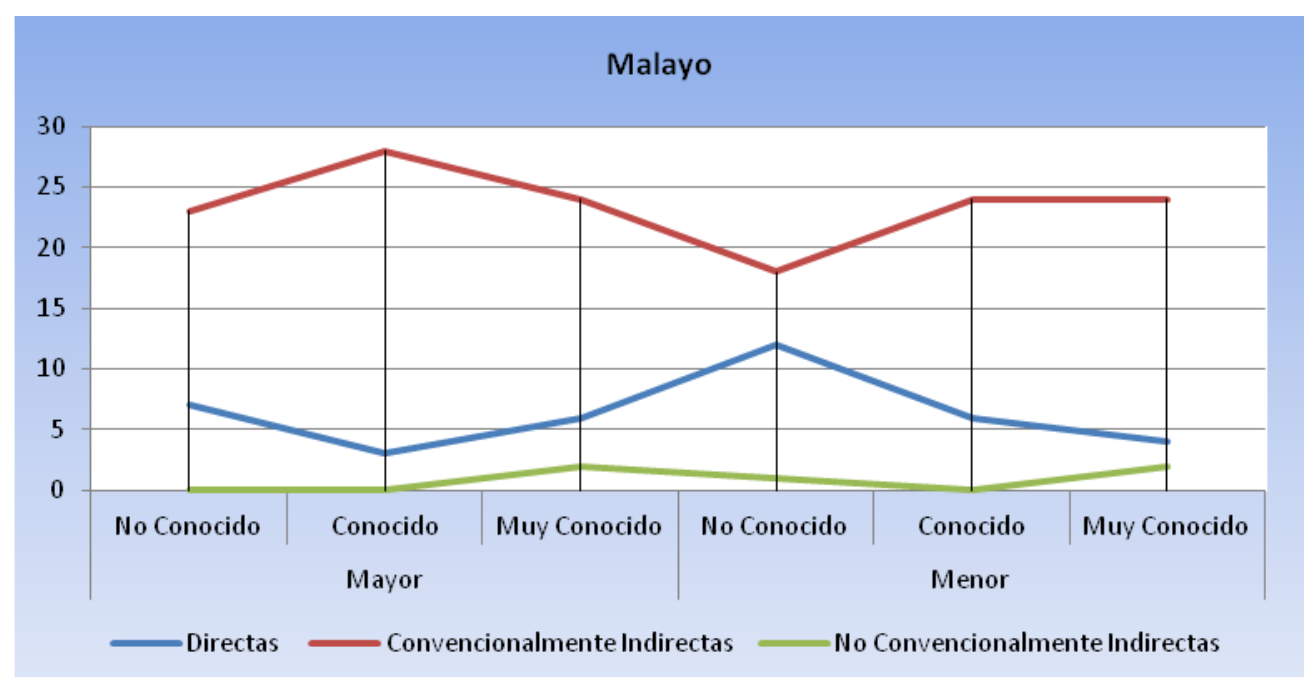

Los españoles de más edad utilizaron mayoritariamente las formas "Directas" cuando formularon la petición a personas conocidas, redujeron su uso en las situaciones en las que el grado de familiaridad entre los interlocutores era alto y, en los contextos de 
muy poca familiaridad, las aplicaron al mínimo. En cambio, los participantes menores aplicaron más formas "Directas" en situaciones de corta distancia social entre los interlocutores, y menos al tratar con personas conocidas. Ahora bien, ningún joven español aplicó estas formas con los extraños. En cambio, los subgrupos malayos investigados exponen un patrón bastante similar entre sí en el uso de las tres formas examinadas. Tanto los sujetos mayores como los jóvenes aplicaron más estrategias "Directas" al realizar la petición a extraños. Pero ambos subgrupos se diferenciaron respecto a los destinatarios con las que menos las emplearon. Así, mientras que los mayores redujeron el uso de dichas formas, en primer lugar, con personas muy conocidas y, en último, con personas conocidas, los más jóvenes las utilizaron menos con personas conocidas y, en el menor número de casos, en peticiones a gente muy conocida.

En lo que atañe a las formas "Convencionalmente indirectas", al igual que en el caso anterior, los participantes mayores españoles las utilizaron más con las personas conocidas, menos cuando se realizó la petición a las desconocidas y el menor número de dichas formas al realizar la petición a los destinatarios muy conocidos. En cambio, los jóvenes aplicaron más las "Convencionalmente indirectas" con extraños, menos con personas conocidas y el menor número de enunciados con dichas formas aparece al dirigirse a personas muy conocidas. En este aspecto, los 
subgrupos malayos no se diferenciaron, ya que tanto los participantes de más edad como los de menos, las emplearon más con personas conocidas, y algo menos con personas muy conocidas y con extraños (estos con los que menos).

Los dos subgrupos de edad también mostraron diferencias en el uso de las estrategias "No convencionalmente indirectas". Los mayores usaron las formas mencionadas sobre todo cuando hicieron la petición a personas muy conocidas, y menos al dirigirse a un extraño. Ahora bien, ningún mayor las usó para hacer la petición a personas conocidas. Los jóvenes, por el contrario, aplicaron más las "No convencionalmente indirectas" con gente desconocida, menos con una persona conocida y, aún en un número menor de ocasiones, con una muy conocida. En el otro grupo, encontramos que los encuestados mayores solo emplearon estas estrategias al dirigir la petición a interlocutores con los que tenían una relación íntima. No se encontró ningún caso en sus peticiones a personas conocidas ni desconocidas. Por otro lado, los de menos edad las utilizaron más al hablar con personas muy conocidas, y menos con extraños. Sin embargo, ningún joven las aplicó con personas conocidas.

Los resultados obtenidos al analizar la influencia de la distancia social en la elección de las estrategias de petición utilizadas por los varones y las mujeres en las dos sociedades, no difieren 
mucho de las encontradas en el estudio de los subgrupos de edad de ambas comunidades, como vemos en las siguientes tablas de resultados:

Figura 87. Distribución de enunciados (actos principales) por estrategia de petición seleccionada, según distancia social en el caso de varón versus mujer, en el grupo español

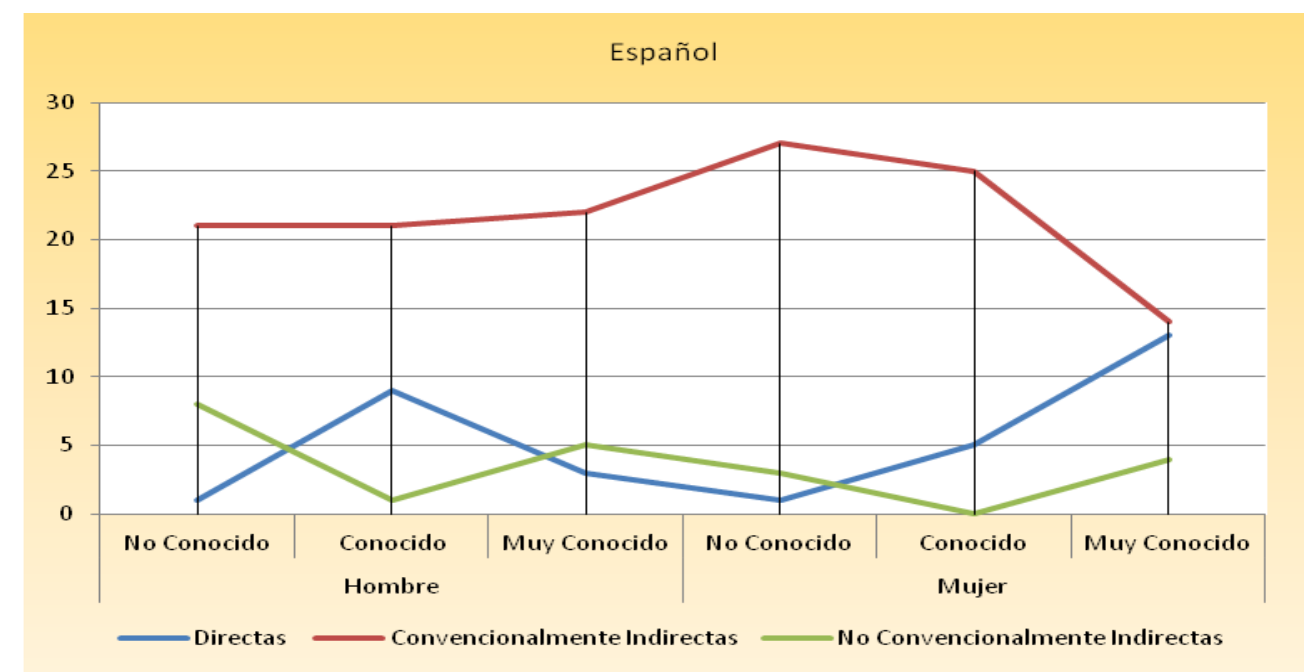

Figura 88. Distribución de enunciados (actos principales) por estrategia de petición seleccionada, según distancia social en el caso de varón versus mujer, en el grupo malayo

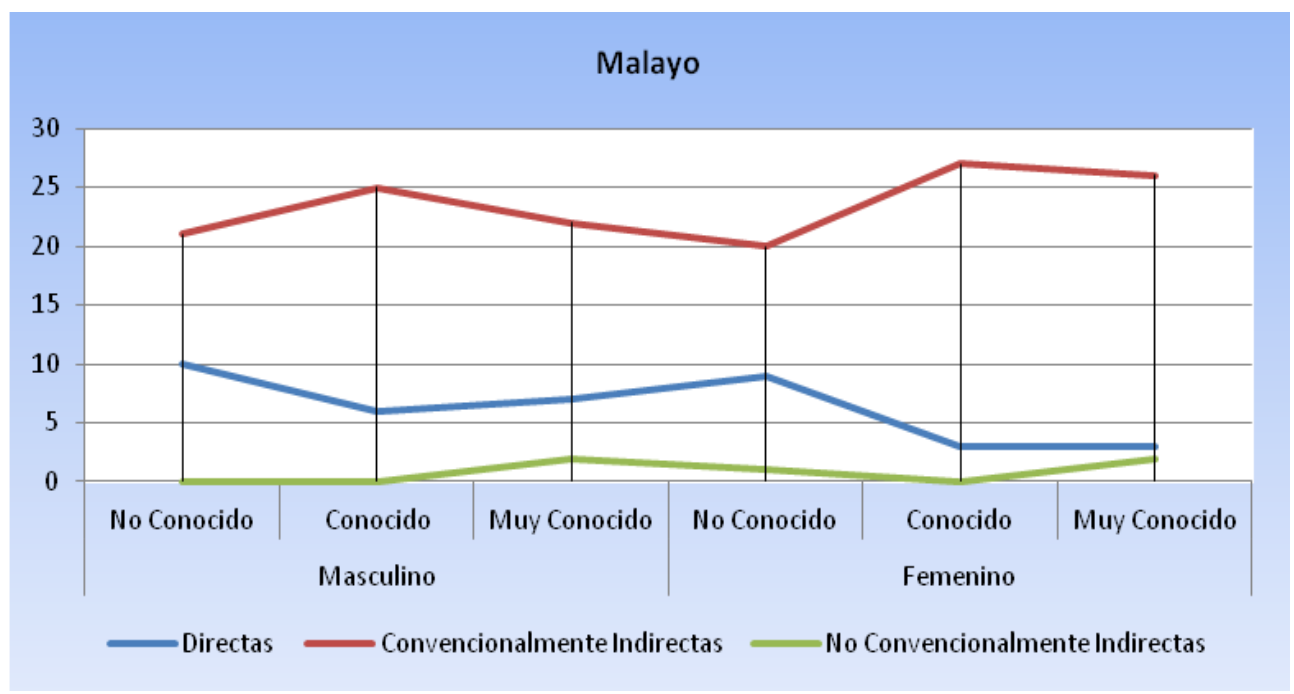


En el grupo español, los varones tendieron a utilizar mayoritariamente las formas "Directas" al hacer la petición a personas conocidas, menos con personas muy conocidas y el menor número de enunciados los encontramos cuando formularon la petición a un extraño. Las mujeres, por su parte, también mostraron mayor preferencia por las estrategias "Directas" en sus peticiones a personas muy conocidas, menos cuando se dirigieron a personas conocidas y, aún en menos ocasiones al hablar con extraños.

En el grupo malayo, como vemos en la figura 156, los varones utilizaron mayoritariamente estrategias "Directas" con extraños, menos con personas muy conocidas y el menor número de enunciados se encuentra en las peticiones a personas conocidas. Las mujeres, por su parte, mostraron la misma inclinación hacia el uso de las formas "Directas", en primer lugar, con extraños, y, en menos casos, con personas conocidas y muy conocidas.

Respecto al empleo de las "Convencionalmente indirectas", igual que en el análisis de los subgrupos de edad, los varones del grupo español mostraron mayor preferencia por ellas al hablar con gente con la que existía una relación intima, y algo menos al dirigirse a extraños y personas conocidas (encontramos el mismo número de enunciados en cada caso). En cambio, las mujeres españolas tendieron a aplicarlas mayoritariamente al formular su 
petición a gente desconocida, un poco menos al hablar con una conocida $\mathrm{y}$, todavía en un menor número de ocasiones, con una intima. En el corpus malayo, en cambio, encontramos, como vemos en la segunda gráfica, que varones y mujeres utilizaron dicha forma en mayor medida cuando realizaron la petición a destinatarios conocidos, y menos a los muy conocidos, aunque es al hacer la petición a extraños cuando encontramos el menor número de enunciados con este tipo de estrategia.

Por lo que se refiere a las últimas formas, las "No convencionalmente indirectas", los varones españoles las emplearon más con gente desconocida, menos con una persona muy conocida Y, en el menor número de casos, con una conocida. $Y$, las mujeres también las aplicaron más al dirigirse a personas muy conocidas, aunque casi lo mismo que al hablar con extraños (solamente hemos encontrado un ejemplo menos en este contexto). Sin embargo, ninguna mujer española empleó las "No convencionalmente indirectas" en sus peticiones a personas conocidas. En cambio, en la sociedad malaya, ambos sexos aplicaron más la categoría mencionada anteriormente con los íntimos; ahora bien, ningún varón utilizó estas estrategias con extraños ni con personas conocidas, mientras que las mujeres las usaron menos con extraños, y no se encontró ningún caso en sus peticiones a los conocidos. 
Siguiendo con el estudio de la influencia de la distancia social en la selección de las estrategias de petición empleadas, pasamos ahora a realizar, desde este punto de vista, el análisis de los movimientos de apoyo empleados por los sujetos de los dos grupos culturales, y en cada uno de los subgrupos de género y de edad.

Respecto a las estrategias más o menos directas elegidas por los sujetos participantes de las dos culturas estudiadas, los resultados numéricos obtenidos son los que se recogen en estos gráficos:

Figuras 89 y 90. Distribución de enunciados (movimientos de apoyo) por estrategias, según distancia social en los dos grupos, español y malayo

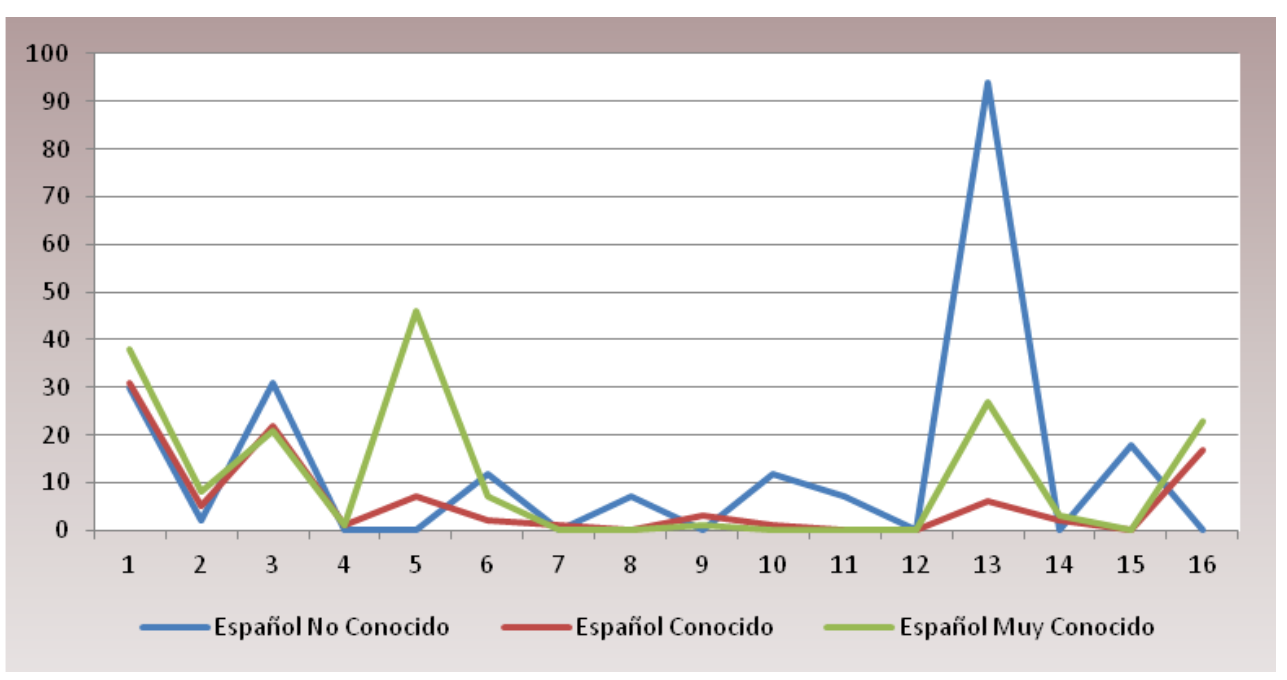




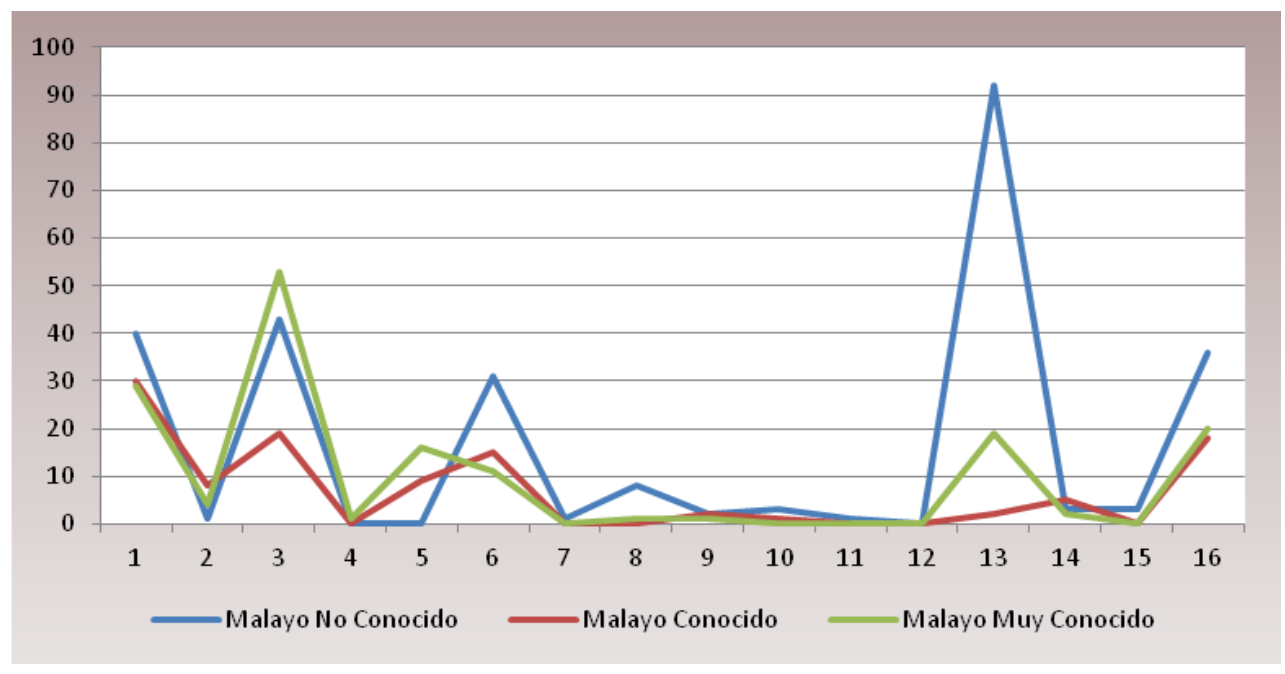

1.Fórmulas de preparación 2.Búsqueda de un compromiso 3.Razones 4.Previsión de objeciones 5.Promesa de recompensa/reparación 6.Minimización de la imposición 7.Invocación de principios generales 8.Reconocimiento de la imposición 9.Preocupación 10.Apreciación 11.Promesa de devolución 12.Gravedad/urgencia 13.Presentación/saludo 14.Petición de la opinión del oyente 15.Disculpa 16. Fórmulas de tratamiento

Lo más significativo de los datos obtenidos es que los dos grupos emplearon formas similares al dirigirse a interlocutores en contextos de distinta distancia social. En la situación en la que el grado de familiaridad entre los interlocutores es bajo (situación 1), y, por tanto, la distancia social es grande, los hablantes de ambos países mostraron preferencia por la estrategia de "Presentación/saludo". Cuando se trata de una persona conocida (situación 4), los hablantes de los dos grupos de nativos tendieron a utilizar mayoritariamente "Fórmulas de preparación". Sin embargo, en la situación donde la distancia es corta (situación 7), sí que hubo diferencias entre los sujetos analizados, ya que los españoles tendieron a utilizar más la "Promesa de recompensa/reparación", 
mientras que los malayos mostraron mayor preferencia por las "Razones".

En cuanto a las estrategias menos utilizadas en las dos sociedades, en la situación en la que hay distancia social grande entre los interlocutores, los informantes españoles mostraron menor preferencia por la de "Búsqueda de un compromiso", mientras que aparte de dicha estrategia, los malayos también optaron en menor grado por las de "Invocación de principios generales" y "Promesa de devolución". Cuando las peticiones se dirigieron a una persona conocida, los españoles aplicaron menos las de "Previsión de objeciones", "Invocación de principios generales" y "Apreciación", mientras que los malayos utilizaron menos las de "Preocupación", "Apreciación" y "Presentación/saludo". Y, en sus peticiones a gente de alta familiaridad, los españoles usaron menos las de "Previsión de objeciones" y "Preocupación", mientras que los malayos, por su parte, las que emplearon en un menor número de enunciados, además de la de "Previsión de objeciones", fueron las de "Reconocimiento de la imposición" y "Preocupación".

Al analizar las estrategias a las que recurrieron en sus movimientos de apoyo los sujetos de los subgrupos de edad de ambas culturas, los resultados obtenidos no fueron muy distintos a los obtenidos al estudiar los dos grupos generales, como puede verse 
en las siguientes gráficas correspondientes a los datos españoles, y

se verá después en las de los datos malayos:

Figuras 91 y 92. Distribución, por estrategias, de enunciados (movimientos de apoyo) utilizados por los mayores y los menores según la distancia social en la sociedad española
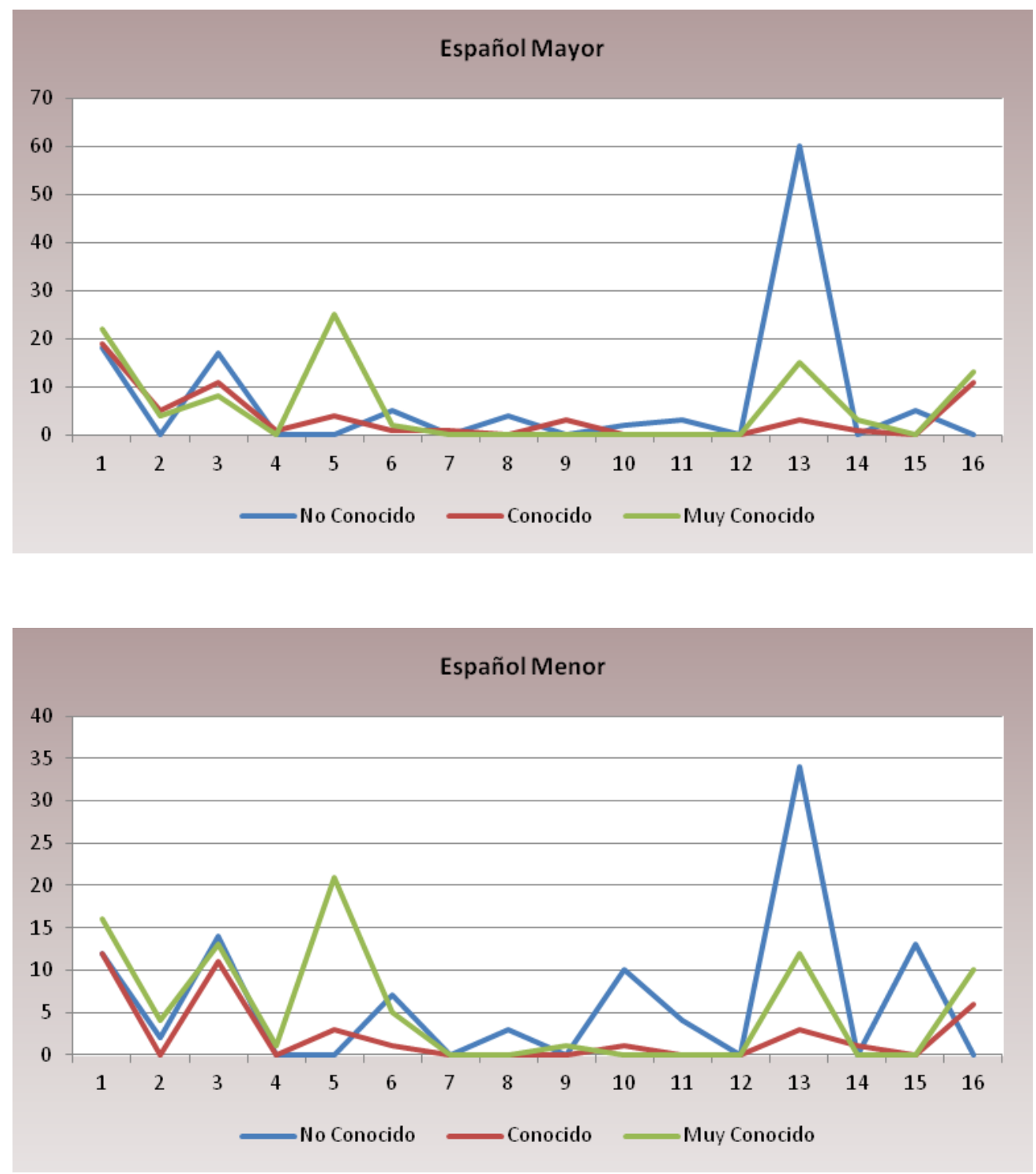

1.Fórmulas de preparación 2.Búsqueda de un compromiso 3.Razones 4.Previsión de objeciones 5.Promesa de recompensa/reparación 6.Minimización de la imposición 7.Invocación de principios generales 8.Reconocimiento de la imposición 9.Preocupación 10.Apreciación 11.Promesa de devolución 12.Gravedad/urgencia 13.Presentación/saludo 14.Petición de la opinión del oyente 15.Disculpa 16. Fórmulas de tratamiento 
Los participantes españoles, así como los malayos, tendieron a utilizar mayoritariamente las mismas estrategias que las aparecidas al comparar los datos generales de las dos sociedades en cada una de las situaciones planteadas, con una distancia social diferente entre los interlocutores. Pero, en las estrategias menos utilizadas, sí que se encontraron diferencias entre los subgrupos aunque no muy llamativas. En el escenario donde los encuestados contaron con mayor familiaridad con sus interlocutores, los mayores españoles utilizaron menos la "Minimización de la imposición", mientras que en el caso de los sujetos más jóvenes fueron las estrategias de "Previsión de objeciones" y "Preocupación" las que aparecieron en un menor número de ocasiones. Cuando se realizó la petición a personas conocidas, los hablantes de más edad aplicaron menos las de "Previsión de objeciones", "Minimización de la imposición", "Invocación de principios generales" y "Petición de la opinión del oyente", y los de menos edad las de "Minimización de la imposición", Apreciación" y "Pedir la opinión al oyente". Al formular la petición a los oyentes con los que existía poca familiaridad, los participantes mayores emplearon menos la "Apreciación", y los menores, por su parte, utilizaron menos la "Búsqueda de un compromiso".

A continuación, pasamos a estudiar la influencia de la distancia social en el uso de los movimientos de apoyo en el caso de 
los subgrupos de edad malayos. Los resultados numéricos obtenidos al analizar las estrategias elegidas por los sujetos encuestados son los que presentamos a continuación:

Figuras 93 y 94. Distribución, por estrategias seleccionadas, de enunciados (movimientos de apoyo) utilizados por los mayores y los menores según la distancia social en la sociedad malaya
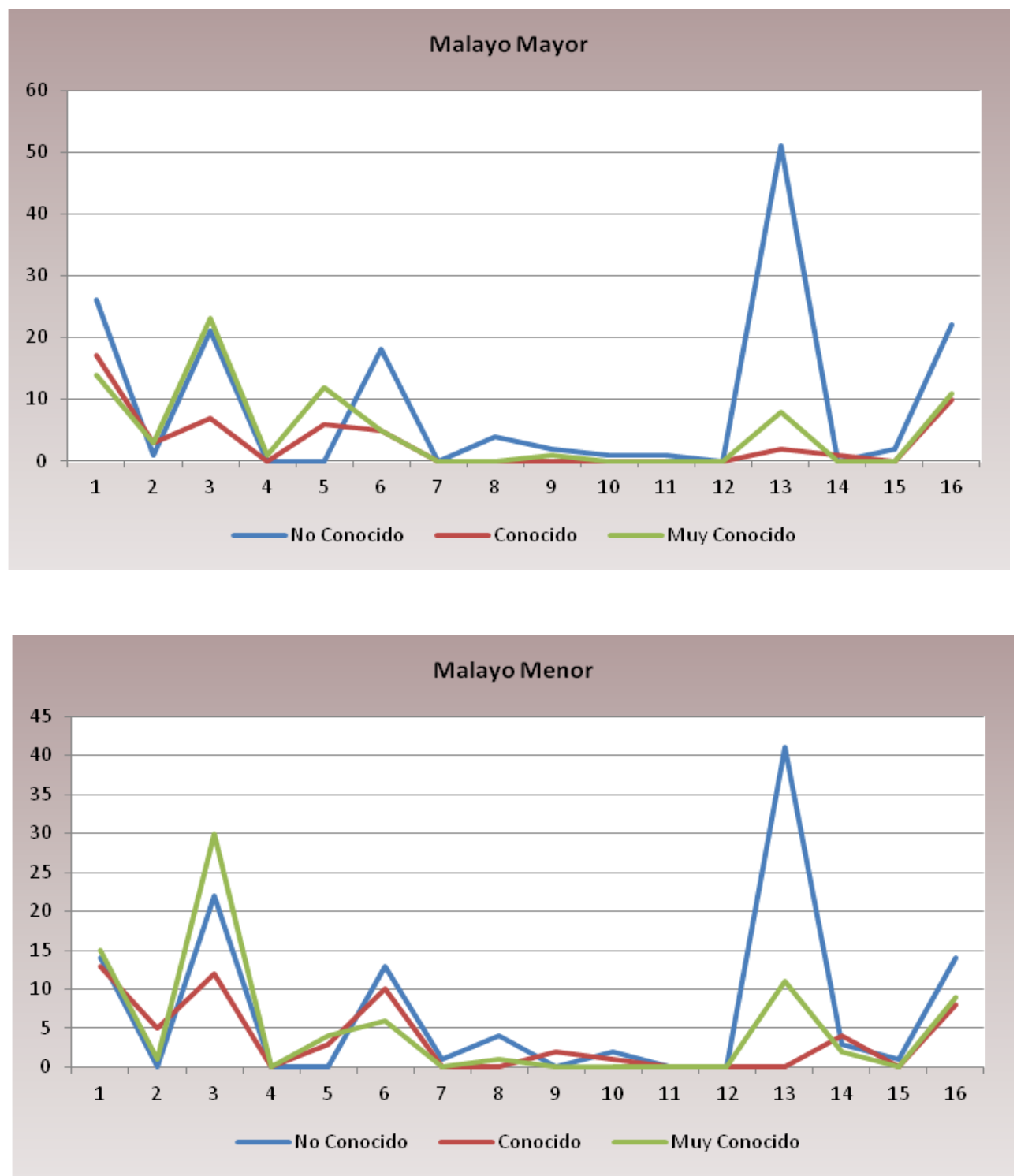

1.Fórmulas de preparación 2.Búsqueda de un compromiso 3.Razones 4.Previsión de objeciones 5.Promesa de recompensa/reparación 6.Minimización de la imposición 7.Invocación de principios generales 8.Reconocimiento de la imposición 9.Preocupación 10.Apreciación 11.Promesa de devolución 12.Gravedad/urgencia 13.Presentación/saludo 14.Petición de la opinión del oyente 15.Disculpa 16. Fórmulas de tratamiento 
Al igual que los subgrupos españoles, los malayos también mostraron el mismo patrón que el del grupo principal. Por eso, no nos parece interesante comentar los resultados correspondientes, puesto que fueron similares a los mencionados anteriormente. No obstante, sí que nos vamos a detener en el análisis de las estrategias menos empleadas, donde sí hay diferencias.

En primer lugar, en el contexto donde la distancia social es corta, las estrategias menos utilizadas por los mayores fueron las de "Búsqueda de un compromiso", "Apreciación" y "Promesa de devolución". Por otro lado, las estrategias menos aplicadas por los menores en el mismo contexto fueron las de "Invocación de principios generales" y "Disculpa". Por otro lado, cuando la familiaridad entre los interlocutores es normal, es la "Petición de la opinión del oyente" la menos empleada en los datos de los mayores y la "Apreciación" en los de los jóvenes. Por último, en la situación de alto grado de familiaridad, los encuestados del subgrupo de más edad utilizaron menos las estrategias de "Previsión de objeciones" y "Preocupación", mientras que los de menos edad optaron por usar muy poco las de "Búsqueda de un compromiso" y "Reconocimiento de la imposición", de las que solamente se ha registrado un ejemplo de cada una. 
Respecto a las diferencias en el empleo de las estrategias de los movimientos de apoyo en función del subgrupo de género al que pertenecen los sujetos, las siguientes tablas recogen la distribución de los datos numéricos, en número de enunciados, según la distancia social, en la cultura española:

Figuras 95 y 96 . Distribución, por estrategias, de enunciados (movimientos de apoyo) utilizados por los varones y las mujeres según la distancia social en la sociedad española
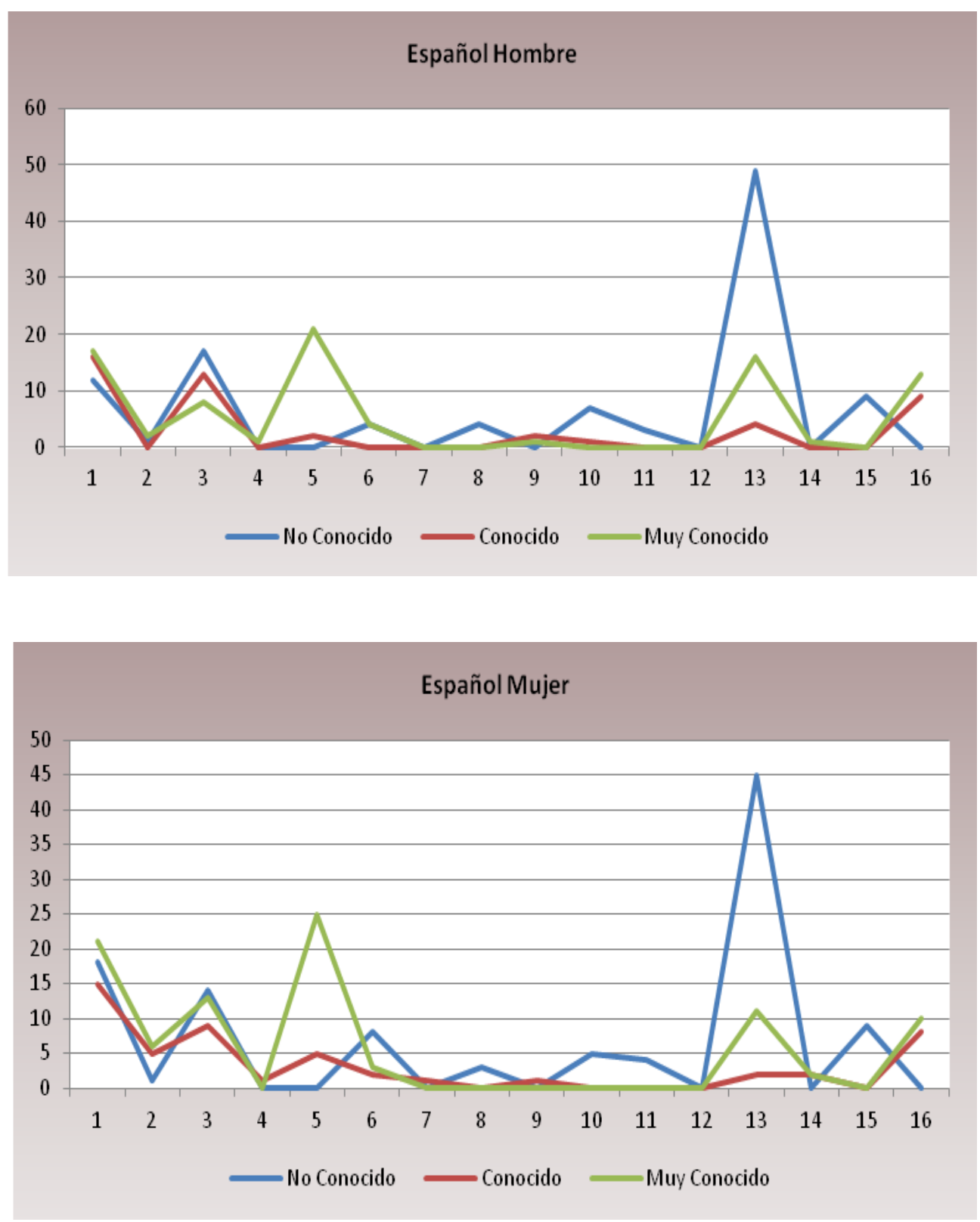
1.Fórmulas de preparación 2.Búsqueda de un compromiso 3.Razones 4.Previsión de objeciones 5.Promesa de recompensa/reparación 6.Minimización de la imposición 7.Invocación de principios generales 8. Reconocimiento de la imposición 9.Preocupación 10.Apreciación 11.Promesa de devolución 12.Gravedad/urgencia 13.Presentación/saludo 14.Petición de la opinión del oyente 15.Disculpa 16.Fórmulas de tratamiento

Como era de esperar, el patrón mostrado por los sujetos de ambos sexos fue similar al de los subgrupos de edad en la selección de unas u otras estrategias en función del grado de familiaridad. Es decir, los participantes españoles de los dos sexos tendieron a realizar la petición a los oyentes con los que existía un grado de familiaridad bajo con una "Presentación/saludo". Con destinatarios conocidos aplicaron mayoritariamente la estrategia de "Fórmulas de preparación", y en sus peticiones hacia personas de alta familiaridad, prefirieron la "Promesa de recompensa/reparación"

Con respecto a las estrategias menos utilizadas, en el escenario en el que el grado de familiaridad es bajo, tanto los varones como las mujeres aplicaron menos la "Búsqueda de un compromiso". Pero, en sus interacciones con las personas conocidas, los sujetos de ambos géneros sí que se diferenciaron en sus respuestas: los varones utilizaron menos la "Apreciación", mientras que las estrategias menos aplicadas por las mujeres fueron las de "Previsión de objeciones", "Invocación de principios generales" y "preocupación". Y, en el contexto en el que se establece una estrecha distancia social, los varones mostraron una menor 
preferencia por las de "Previsión de objeciones", "Preocupación" y "Petición de la opinión del oyente", y las mujeres por el empleo de una "Petición de la opinión del oyente".

En el caso de la sociedad malaya, los datos numéricos correspondientes a las estrategias de los movimientos de apoyo, según subgrupo de género y distancia social, fueron estos:

Figuras 97 y 98. Distribución, por estrategias, de enunciados (movimientos de apoyo) utilizados por los varones y las mujeres según la distancia social en la sociedad malaya
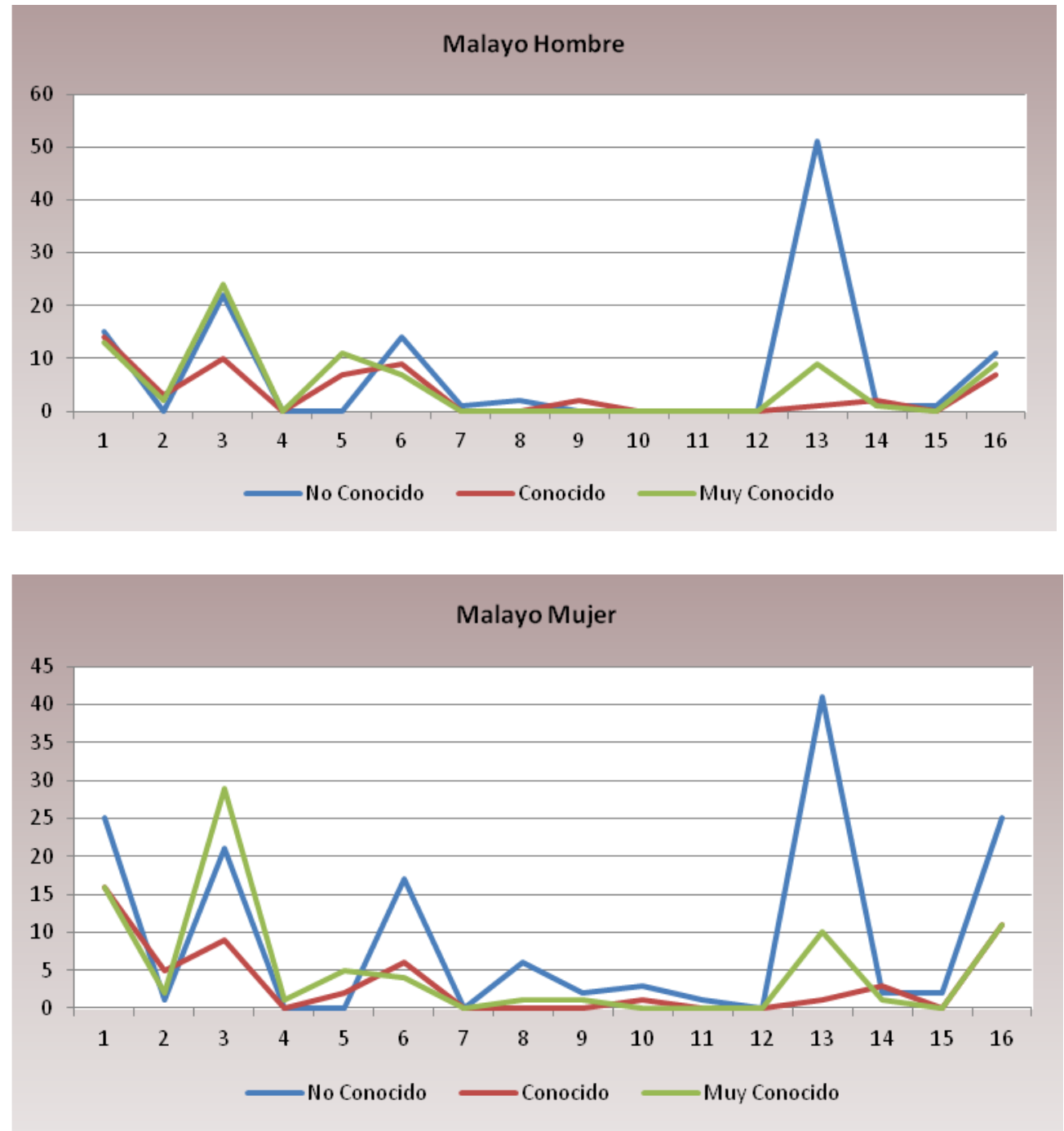
1.Fórmulas de preparación 2.Búsqueda de un compromiso 3.Razones 4.Previsión de objeciones 5.Promesa de recompensa/reparación 6.Minimización de la imposición 7.Invocación de principios generales 8. Reconocimiento de la imposición 9.Preocupación 10.Apreciación 11.Promesa de devolución 12.Gravedad/urgencia 13.Presentación/saludo 14.Petición de la opinión del oyente 15.Disculpa 16.Fórmulas de tratamiento

Cabe mencionar, que, como queda reflejado en los gráficos, los datos obtenidos en este caso también mostraron resultados parecidos a los anteriores, es decir, los participantes de ambos géneros coinciden en revelar una mayor utilización de la "Presentación/saludo" con interlocutores extraños, siendo la preferencia mostrada por parte de los varones más alta que la de las mujeres (51 enunciados de los varones y 41 de las mujeres). En sus peticiones hacia personas conocidas, utilizaron mayoritariamente la estrategia de "Fórmulas de preparación", y optaron por usar en mayor medida las "Razones" cuando existe un alto grado de cercanía entre los interlocutores.

"Invocación de principios generales", "Petición de la opinión del oyente" y "Disculpa" fueron las estrategias menos utilizadas por los varones en el contexto de mayor distancia social entre los interlocutores. Las mujeres, en cambio, en el mismo caso, mostraron la menor tendencia hacia las de "Búsqueda de un compromiso" y "Promesa de devolución". En la situación en la que hay poca distancia social entre los interlocutores, los varones usaron menos la estrategia de "Presentación/saludo", mientras que las 
mujeres casi no recurrieron a las de "Apreciación" y "Presentación/saludo". Finalmente, cuando se trata de destinatarios muy cercanos, los varones aplicaron menos la "Petición de la opinión del oyente", mientras que en los enunciados de las mujeres las menos frecuentes fueron las estrategias de "Previsión de objeciones", "Reconocimiento de la imposición", "Preocupación" y "Petición de la opinión del oyente".

La diferencia de los promedios de las categorías aplicadas según distintos grados de familiaridad no fue significativa en ninguno de los dos grupos en los tres parámetros utilizados, ni en grado de (in)dirección de la petición, ni en estrategias aplicadas a los actos principales ni en los movimientos de apoyo empleados. 


\subsection{Análisis del contenido (modificaciones internas)}

Esta sección contiene los resultados que derivan del análisis de la petición, basado en el examen del uso de las modificaciones internas en los enunciados producidos por los encuestados, es decir, el análisis de los marcadores de modalidad que, aplicados a los actos principales, sirven para reducir la intensidad ilocutiva del acto. En los distintos puntos que conforman este apartado iremos presentando cada uno de estos recursos. Analizaremos tanto el uso de las fórmulas de deixis social (pronominales y nominales), como las modificaciones gramaticales (el cambio del modo verbal en los datos españoles y el uso de partículas y sufijos en los datos malayos) y la perspectiva de la persona (orientada al hablante/oyente/los dos/neutro), en el corpus de ambas comunidades de habla. En primer lugar nos ocuparemos del análisis general, es decir, haremos referencia a los resultados totales obtenidos del estudio de las respuestas facilitadas por los sujetos participantes en todas las situaciones del cuestionario planteadas para el acto de habla de la petición, y pasaremos después al análisis situacional, o, lo que es lo mismo, al estudio pormenorizado de los enunciados formulados en cada uno de los contextos propuestos. Explicaremos detalladamente las modificaciones encontradas en nuestros datos con ejemplos que pertenecen a cada categoría. En cuanto a los datos malayos, se presentan los ejemplos en el idioma original acompañados de dos 
traducciones: una literal, que sirve para poder apreciar las diferencias estructurales existentes entre el español y el malayo, y otra más acorde con el español estándar (en cursiva), que ayuda al lector a comprender el significado real de cada respuesta.

\subsubsection{Análisis general}

Como se ha mencionado más arriba, se trata de una revisión general que tiene como objetivo obtener una perspectiva más amplia con respecto a la modificación interna aplicada en las peticiones, y descubrir así la tendencia general mostrada por cada comunidad de habla.

\subsubsection{Modificaciones internas en las peticiones formuladas con una "Interrogación preparatoria"}

El estudio revela que la estrategia de petición más comúnmente utilizada tanto por los hablantes españoles como por los malayos fue la de "Interrogación preparatoria", con 192 enunciados recogidos de los datos españoles y 167 de los malayos. En el caso español, en la aplicación de dicha estrategia, los sujetos recurren a una gran variedad de formas convencionalizadas (sub-estrategias) que 
podemos agrupar en tres grandes bloques según el fundamento con el que es planteada la petición: capacidad/posibilidad, buena voluntad y predicción de acción futura del oyente. Entre los malayos, en cambio, todas las formas empleadas en las respuestas a los cuestionarios pertenecen al modo capacidad/posibilidad, como se verá más adelante.

La distribución según el fundamento de las formas de "Interrogación preparatoria" observadas en los datos españoles es la que se refleja en la Tabla 7, que presentamos a continuación. 
Tabla 7. Distribución de sub-estrategias de "Interrogación preparatoria", según modo, en los datos españoles

\begin{tabular}{|c|c|c|c|}
\hline Fundamento & Formas de Interrogación & $\mathbf{F}$ & $\%$ \\
\hline \multirow{4}{*}{$\begin{array}{c}\text { Capacidad/ } \\
\text { posibilidad } \\
(52 \%)\end{array}$} & $\begin{array}{l}\text { Condicional + poder } \\
\text { ¿Podrías prestarme una escalera? }\end{array}$ & 65 & $31 \%$ \\
\hline & $\begin{array}{l}\text { Poder - } \\
\text { ¿Puedes prestarme la tuya? }\end{array}$ & 28 & $14 \%$ \\
\hline & $\begin{array}{l}\text { Pregunta de disposición } \\
\text { ¿Tienes una escalera? }\end{array}$ & 4 & $2 \%$ \\
\hline & $\begin{array}{l}\text { Condicional + verbo de disposición } \\
\text { ¿Tendría usted una escalera? }\end{array}$ & 4 & $3 \%$ \\
\hline \multirow{8}{*}{$\begin{array}{l}\text { Buena voluntad } \\
\qquad(28 \%)\end{array}$} & $\begin{array}{l}\text { Condicional +Importar } \\
\text { ¿Le importaría hacérmela? }\end{array}$ & 13 & $8 \%$ \\
\hline & $\begin{array}{l}\text { Apetecer - } \\
\text { ¿Te apetece acompañarme? }\end{array}$ & 12 & $7 \%$ \\
\hline & $\begin{array}{l}\text { Ser tan amable } \\
\text { ¿Sería tan amable de dejarme una escalera? }\end{array}$ & 11 & $6 \%$ \\
\hline & $\begin{array}{l}\text { Querer } \\
\text { ¿Quieres venir a comprar conmigo? }\end{array}$ & 7 & $4 \%$ \\
\hline & $\begin{array}{l}\text { Importar - } \\
\text { ¿Te importa dejarme tu móvil? }\end{array}$ & 4 & $2 \%$ \\
\hline & $\begin{array}{l}\text { Condicional + Gustar } \\
\text { ¿Te gustaría pasarte? }\end{array}$ & 2 & $1 \%$ \\
\hline & $\begin{array}{l}\text { Condicional + Apetecer } \\
\text { ¿No te apetecería acompañarme? }\end{array}$ & 1 & $1 \%$ \\
\hline & $\begin{array}{l}\text { Condicional + Querer } \\
\text { ¿Querría hacerme un pequeño encargo? }\end{array}$ & 1 & $1 \%$ \\
\hline $\begin{array}{l}\text { Predicción de } \\
\text { acción futura del } \\
\text { oyente } \\
(20 \%)\end{array}$ & $\begin{array}{l}\text { Me dejas } \\
\text { ¿Me dejas hacer una llamada corta? } \\
\text { Me prestas } \\
\text { ¿Me prestas tu móvil? }\end{array}$ & 40 & $20 \%$ \\
\hline
\end{tabular}


Los nativos españoles prefirieron referirse a la capacidad o la posibilidad del oyente para llevar a cabo la petición en sus interacciones. Aplicaron mayoritariamente (en el 64\% de los casos) el verbo poder en la forma del Condicional. Por ejemplo, en la situación en que un interlocutor pide a un vecino desconocido que le

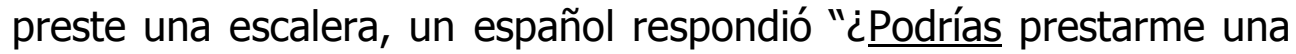
escalera?", y otro dijo "¿Me podrías dejar la tuya?", mientras otros dijeron "¿Me podría dejar una escalera?", o "¿Me podría usted dejar una?".

La segunda sub-estrategia más frecuente dentro del modo Capacidad/posibilidad fue el verbo poder nudo, con un porcentaje del $28 \%$, mientras que solo en el $4 \%$ de los casos aparece el verbo de disposición tener, como en "¿ ¿Tienes una escalera?" en la petición de una escalera prestada a un vecino desconocido. En el $4 \%$ restante la fórmula empleada es el verbo tener en Condicional, como en el ejemplo "¿Tendría inconveniente en hacérmela usted?", en la petición de una carta de recomendación para solicitar un trabajo, formulada a un profesor universitario. Los españoles recurrieron a esta fórmula para ser más corteses, 0 , en otras palabras, con el objetivo de mitigar la imposición de sus peticiones.

Además de preguntar sobre la capacidad o la posibilidad, los españoles también tendieron a preguntar sobre la buena voluntad 
del oyente para responder de manera afirmativa a la petición. Como se muestra en la figura correspondiente, el $28 \%$ de los participantes españoles emplearon este tipo de estrategia al formular sus peticiones. En esta categoría encontramos una mayor variedad de fórmulas en comparación con la primera. Así, se registraron 8 subestrategias (había solo 4 en la primera) que fueron querer, querer en Condicional o Imperfecto de Subjuntivo, importar, importar en Condicional, ser tan amable, apetecer, apetece en Condicional, y gustar en Condicional. Aplicaron mayoritariamente importar en Condicional ( $8 \%)$, como ocurre, por ejemplo, en la situación en la que, en una empresa, un director pide a uno de sus trabajadores que va a hacer un viaje de negocios a Rusia, que le compre una lata de caviar, contexto en el que un encuestado contestó "¿Te importaría traerme una lata de caviar?", y otro respondió "¿Te importaría comprarme una lata de caviar?".

El último bloque de peticiones realizadas mediante la estrategia de "Interrogación preparatoria" es el que agrupa a los enunciados orientados hacia la "Predicción de acción futura del oyente" (20\%). En la lengua española, pedir algo, tanto para los objetos como para las acciones que se van a llevar a cabo, se puede hacer mediante fórmulas como "¿Me dejas hacer una llamada?", "¿Me prestas tu móvil?", "¿Vienes a mi casa?", etc. Pero este mismo recurso no tiene sentido de petición si se utiliza en la lengua malaya. 
Por ejemplo, si se dice en malayo "Awak datang rumah saya?" ( Tú venir casa yo?/¿Vienes a mi casa?') significa que el hablante quiere confirmar que la acción de "venir a mi casa" ocurrió realmente en el pasado, no es una petición.

Si examinamos el patrón expuesto por los sujetos de los subgrupos en el empleo de las sub-estrategias de "Interrogación preparatoria", la distribución, según el fundamento de las fórmulas de petición empleadas, queda de la siguiente manera:

Tabla 8. Distribución de sub-estrategias de "Interrogación preparatoria", según modo, en los datos de los subgrupos españoles

\begin{tabular}{|l|c|c|c|}
\hline \multirow{2}{*}{ Subgrupos } & \multicolumn{3}{|c|}{ Estrategias de Interrogación preparatoria } \\
\cline { 2 - 4 } & Capacidad/posibilidad & $\begin{array}{c}\text { Buena } \\
\text { voluntad }\end{array}$ & $\begin{array}{c}\text { Predicción de acción } \\
\text { futura del oyente }\end{array}$ \\
\hline Mayor & $58 \%$ & $24 \%$ & $18 \%$ \\
\hline Menor & $45 \%$ & $33 \%$ & $22 \%$ \\
\hline Varón & $52 \%$ & $32 \%$ & $16 \%$ \\
\hline Mujer & $51 \%$ & $25 \%$ & $24 \%$ \\
\hline
\end{tabular}

Pese a que los dos subgrupos de edad españoles mostraron preferencia por las formas de "Capacidad/posibilidad", aparecen aún con mayor frecuencia en el caso de los hablantes de más edad, con un $58 \%$ de los enunciados totales frente al $45 \%$ de los más jóvenes. La segunda opción más elegida tanto por los sujetos mayores como por los menores españoles, fue la categoría 
de "Buena voluntad", con el $24 \%$ de los enunciados en el primer subgrupo y el $33 \%$ en el segundo. La opción que se situó porcentualmente en tercer lugar en los datos proporcionados por ambos subgrupos, fue la de "Predicción de acción futura del oyente", presente en un $18 \%$ de los enunciados de los mayores con "Fórmulas de preparación", en comparación con un 22\% de los menores.

El patrón mostrado por los subgrupos de género fue similar al de los subgrupos de edad. Tanto las mujeres como los varones españoles, prefirieron realizar la petición utilizando las formas de "Capacidad/posibilidad" (esta opción no muestra una diferencia estadística importante entre los géneros, ya que la frecuencia con la que aparece en los datos de los varones fue de un $52 \%$ y en las mujeres de un $51 \%$ ), seguida de las de "Buena voluntad" (32\% de los enunciados de los varones frente al $25 \%$ de las mujeres) y de "Predicción de acción futura del oyente" (el 16\% del total, en las respuestas de los varones por el $24 \%$ en las de las mujeres). En este caso, fueron los informantes varones quienes emplearon cada opción en una proporción más elevada, excepto la tercera, que fueron las mujeres quienes recurrieron a ella en un mayor número de ocasiones. 
En lo que respecta a las sub-estrategias empleadas en los enunciados con una "Interrogación preparatoria" en la lengua malaya, todas ellas se agrupan dentro de la categoría de peticiones orientadas a la "Capacidad/posibilidad" (en el caso del malayo, capacidad o posibilidad del oyente/hablante, ambos, e incluso impersonal), como se refleja en la Tabla 9, que se muestra a continuación: 
Tabla 9. Distribución de sub-estrategias de "Interrogación preparatoria" en los datos malayos

\begin{tabular}{|c|c|c|c|}
\hline Fundamento & Formas de Interrogación & $\mathbf{F}$ & $\%$ \\
\hline \multirow{9}{*}{$\begin{array}{l}\text { Capacidad/ } \\
\text { posibilidad } \\
(100 \%)\end{array}$} & $\begin{array}{l}\text { Boleh - (Poder -) } \\
\text { Boleh saya pinjam tangga? } \\
\text { ('Poder yo pedir prestado escalera?/¿'Te puedo pedir } \\
\text { prestada la escalera?') }\end{array}$ & 89 & $53 \%$ \\
\hline & $\begin{array}{l}\text { Boleh + tak (Poder + no) } \\
\text { Boleh tak pinjam tangga? } \\
\text { ('Poder no pedir prestado escalera?/¿No se podría } \\
\text { pedir prestada la escalera?') }\end{array}$ & 46 & $27 \%$ \\
\hline & $\begin{array}{l}\text { Boleh + kah (Poder + kah) } \\
\text { Bolehkah saya pinjam tangga? } \\
\text { ('Poderkah yo pedir prestado escalera?/¿'Puedo } \\
\text { pedirte prestada la escalera, verdad?') }\end{array}$ & 11 & $6 \%$ \\
\hline & $\begin{array}{l}\text { Boleh + tak + hendak (Poder + kah + querer) } \\
\text { Boleh tak saya hendak pinjam tangga? } \\
\text { ('Poder no yo querer pedir prestado escalera?/¿'No } \\
\text { podría pedirte prestada la escalera?') }\end{array}$ & 8 & $5 \%$ \\
\hline & $\begin{array}{l}\text { Boleh }+ \text { tak }+ \text { tolong (Poder + no + ayudar) } \\
\text { Boleh tak tolong pinjamkan saya tangga? } \\
\text { ('Poder no ayudar prestarkan yo escalera?/¿No se } \\
\text { podría hacerme el favor de prestarme la escalera?') }\end{array}$ & 6 & $4 \%$ \\
\hline & $\begin{array}{l}\text { Boleh + tolong (Poder + ayudar) } \\
\text { Boleh tolong beli saya buah salak? } \\
\text { ('Poder ayudar comprar yo fruta salak?/¿Puedes } \\
\text { hacerme el favor de comprarme salak?') }\end{array}$ & 3 & $2 \%$ \\
\hline & $\begin{array}{l}\text { Boleh + minta + tolong (Poder + pedir + ayuda) } \\
\text { Boleh minta tolong beri sokongan? } \\
\text { ('Poder pedir ayudar dar apoyo?/¿Le puedo pedir su } \\
\text { ayuda?') }\end{array}$ & 2 & $1 \%$ \\
\hline & $\begin{array}{l}\text { Boleh + kah + ingin (Poder + kah + querer) } \\
\text { Bolehkah saya ingin meminjam tangga? } \\
\text { ('Poderkah yo querer pedir prestado } \\
\text { escalera?/Quería pedirle prestada la escalera, } \\
\text { ¿puedo?') }\end{array}$ & 1 & $1 \%$ \\
\hline & $\begin{array}{l}\text { Boleh + beri (Poder }+ \text { dar) } \\
\text { Boleh beri saya pinjam tangga? } \\
\text { ('Poder dejar yo pedir prestado escalera?/¿Me } \\
\text { permitiría pedirle prestada la escalera?') }\end{array}$ & 1 & $1 \%$ \\
\hline
\end{tabular}


Los sujetos malayos de nuestro estudio emplearon nueve variedades distintas de fórmulas de petición (en el caso de la estrategia de "Interrogación preparatoria"). Aparte del uso de solo el verbo boleh ('poder ), se utilizaron ocho combinaciones de dicho verbo con varios elementos (tanto con otros verbos como con algunas partículas). Es preciso señalar que la lengua malaya no tiene tiempos verbales. Por eso, se combina boleh ('poder) con otros elementos, como es, por ejemplo, la partícula tak, que literalmente se traduce como no. El uso de tak con boleh (' poder) es como dar la opción al oyente para responder no, e indirectamente reducir la imposición de la petición. En la cultura malaya, se considera más cortés si un hablante le da al oyente la opción tanto para aceptar como para rechazar la petición.

Además de la combinación de boleh ('poder) con tak (`no ), también se utilizó la combinación boleh + kah en los datos malayos, como en "Bolehkah saya pinjam tangga?" (' pedir prestado escalera?(¿Puedo pedirte prestada la escalera? ). Kah es una partícula que se utiliza en las preguntas malayas con el fin de poner énfasis y, en el caso de la petición, se aplica para agravar indirectamente la imposición. A veces el agravante de kah se suaviza combinándolo con el verbo ingin ('querer), como en "Bolehkah saya ingin meminjam tangga?" ('Poderkah querer pedir prestado escalera?/Quería pedirle prestada la escalera, ¿puedo?'). El uso de 
ingin en esa frase implica que la pregunta gira, en realidad, en torno a la posibilidad o la capacidad de querer, no de pedir prestado. También, el uso de hendak junto a la combinación boleh + tak como

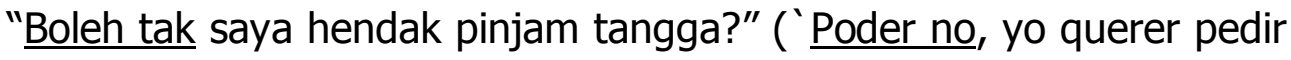
prestado escalera?/ ¿No podría pedirte prestada la escalera? ), tiene un sentido similar al caso anterior. Las dos palabras ingin y hendak se traducen al español como querer pero ingin es más formal y más literaria.

También apareció en el corpus malayo la combinación del verbo boleh ('poder) con el verbo tolong ('ayuda ), como "Boleh tolong beli saya buah salak?" ('Poder ayudar yo comprar fruta salak?/¿Puedes hacerme el favor de comprarme salak?'). Es muy común en la sociedad malaya usar la palabra tolong en una pregunta para subir la imposición de la petición. Y, para que la imposición de la petición sea más alta, se añade el verbo minta ('pedir) a la combinación de boleh + tolong, como en "Boleh minta tolong beri sokongan?" ('Poder pedir ayudar dar apoyo?/cLe puedo pedir ayuda?'). En la cultura malaya, rechazar una petición de ayuda es algo indignante. Por eso se usa tolong, sobre todo con minta, para doblar la fuerza de la petición y también para comprometer al oyente a que lleve a cabo la petición. 
Por último, se usa, además, la combinación de boleh con beri ('dejar) en las peticiones malayas, como "Boleh beri saya pinjam tangga?" ( 'Poder dejar yo pedir prestada escalera?/ ¿Me permitiría pedirle prestada la escalera?'). Los malayos suelen utilizar beri en las preguntas para reducir la imposición de sus peticiones. Beri significa dejar o permitir. Preguntar con la fórmula boleh beri ('se puede dejar o permitir') implica que el hablante solo quiere saber si se le deja o se le permite a él o a ella hacer algo, y en el contexto de pedir prestada una escalera (situación 1), la petición de los hablantes se basaba en la solicitud del permiso de su interlocutor para pedir prestada la escalera, no directamente sobre la petición de la escalera misma. En ese caso, si el oyente responde "sí, se permite", entonces el hablante va a plantear otra pregunta como "¿Me puedes dejar prestada una escalera?". Funciona como una fase preliminar que recae sobre el permiso para hacer la petición antes de hacer la petición propiamente.

Los resultados numéricos y porcentuales relativos a la distribución de todas estas sub-estrategias, según el subgrupo de edad y sexo al que pertenecen los sujetos que las emplearon, se presentan a continuación: 
Tabla 10 y 11. Distribución de sub-estrategias de "Interrogación preparatoria" en los datos malayos según edad y sexo

\begin{tabular}{|c|c|c|c|c|c|}
\hline \multirow{2}{*}{ Fundamento } & \multirow{2}{*}{$\begin{array}{c}\text { Formas de } \\
\text { Interrogación }\end{array}$} & \multicolumn{2}{|c|}{ Mayor } & \multicolumn{2}{|c|}{ Menor } \\
\hline & & $\mathbf{F}$ & $\%$ & $\mathbf{F}$ & $\%$ \\
\hline \multirow{9}{*}{$\begin{array}{c}\text { Capacidad/ } \\
\text { posibilidad } \\
(100 \%)\end{array}$} & $\begin{array}{l}\text { Boleh - } \\
\text { ('Poder -') }\end{array}$ & 47 & $53 \%$ & 42 & $54 \%$ \\
\hline & $\begin{array}{l}\text { Boleh + tak } \\
\text { ('Poder + no') }\end{array}$ & 33 & $37 \%$ & 13 & $17 \%$ \\
\hline & $\begin{array}{l}\text { Boleh }+ \text { kah } \\
\text { ('Poder }+ \text { kah') }\end{array}$ & 4 & $5 \%$ & 7 & $9 \%$ \\
\hline & $\begin{array}{l}\text { Boleh + tak + hendak } \\
\text { ('Poder + tak + querer') }\end{array}$ & 1 & $1 \%$ & 7 & $9 \%$ \\
\hline & $\begin{array}{l}\text { Boleh + tak + tolong } \\
\text { ('Poder + no + ayudar') }\end{array}$ & 2 & $2 \%$ & 4 & $5 \%$ \\
\hline & $\begin{array}{l}\text { Boleh + tolong } \\
\text { ('Poder + ayudar') }\end{array}$ & - & $0 \%$ & 3 & $4 \%$ \\
\hline & $\begin{array}{l}\text { Boleh + minta }+ \text { tolong } \\
\text { ('Poder }+ \text { pedir }+ \text { ayuda') }\end{array}$ & 1 & $1 \%$ & - & $0 \%$ \\
\hline & $\begin{array}{l}\text { Boleh + beri } \\
\text { ('Poder }+ \text { dar') }\end{array}$ & 1 & $1 \%$ & 1 & $1 \%$ \\
\hline & $\begin{array}{l}\text { Boleh + kah + ingin } \\
(\text { 'Poder }+ \text { kah + querer') }\end{array}$ & - & $0 \%$ & 1 & $1 \%$ \\
\hline
\end{tabular}

$\mathrm{F}=$ Frecuencia

\begin{tabular}{|c|c|c|c|c|c|}
\hline \multirow{2}{*}{ Fundamento } & \multirow{2}{*}{$\begin{array}{c}\text { Formas de } \\
\text { Interrogación }\end{array}$} & \multicolumn{2}{|c|}{ Hombre } & \multicolumn{2}{|c|}{ Mujer } \\
\hline & & $\mathbf{F}$ & $\%$ & $\mathbf{F}$ & $\%$ \\
\hline \multirow{9}{*}{$\begin{array}{c}\text { Capacidad/ } \\
\text { posibilidad } \\
(100 \%)\end{array}$} & $\begin{array}{l}\text { Boleh - } \\
\text { ('Poder -') }\end{array}$ & 43 & $62 \%$ & 46 & $48 \%$ \\
\hline & $\begin{array}{l}\text { Boleh + tak } \\
\text { ('Poder + no') }\end{array}$ & 16 & $23 \%$ & 30 & $31 \%$ \\
\hline & $\begin{array}{l}\text { Boleh + kah } \\
\left.\text { ('Poder }+k a h^{\prime}\right)\end{array}$ & 2 & $3 \%$ & 9 & $9 \%$ \\
\hline & $\begin{array}{l}\text { Boleh + tak + hendak } \\
\text { ('Poder + tak + querer') }\end{array}$ & 2 & $3 \%$ & 6 & $6 \%$ \\
\hline & $\begin{array}{l}\text { Boleh + tak + tolong } \\
\text { ('Poder + no + ayudar') }\end{array}$ & 4 & $6 \%$ & 2 & $2 \%$ \\
\hline & $\begin{array}{l}\text { Boleh + tolong } \\
\text { ('Poder + ayudar') }\end{array}$ & 1 & $1 \%$ & 2 & $2 \%$ \\
\hline & $\begin{array}{l}\text { Boleh + minta + tolong } \\
\text { ('Poder + pedir + ayuda') }\end{array}$ & 1 & $1 \%$ & - & $0 \%$ \\
\hline & $\begin{array}{l}\text { Boleh }+ \text { beri } \\
\text { ('Poder }+ \text { dar') }\end{array}$ & 1 & $1 \%$ & 1 & $1 \%$ \\
\hline & $\begin{array}{l}\text { Boleh + kah + ingin } \\
\text { ('Poder }+k a h+\text { querer') }\end{array}$ & - & $0 \%$ & 1 & $1 \%$ \\
\hline
\end{tabular}

$\mathrm{F}=$ Frecuencia 
El análisis según el factor edad y sexo en este aspecto nos revela que no hubo diferencias relevantes ni entre sujetos mayores y menores ni entre hombres y mujeres, ya que todos los subgrupos mostraron preferencia hacia la misma forma. Ahora bien, en el caso de los hombres el índice de frecuencia fue más alto, con un $62 \%$ de los casos, en comparación con el de las mujeres, que fue del $48 \%$. Con respecto a la segunda forma más aplicada, boleh + tak, su mayor frecuencia de uso aparece en el corpus de los hablantes mayores, con un número de casos de $33(37 \%)$, frente a los hablantes menores que la utilizaron en un $17 \%$ de los casos; en el caso de los subgrupos de sexo, fueron las mujeres las que la usaron con mayor frecuencia (31\%) en comparación con los hombres (23\%).

\subsubsection{Modificaciones internas en las peticiones formuladas con una "Presentación/saludo"}

Para empezar las interacciones, la mayoría de los participantes en las dos sociedades utilizaron la estrategia de "Presentación/saludo", es decir, se saludaron (con fórmulas como "Hola, buenos días", etc.) o se presentaron ("Soy su vecino, mi nombre es...", etc.) a los destinatarios antes de hacer la petición. Las diferentes formas empleadas por los sujetos españoles y malayos para presentarse o 
saludar se recogen, junto con la frecuencia de uso (en número e enunciados y en porcentaje respecto del total), en las siguientes tablas:

Tabla 12. Frecuencia del uso de las estrategias de "Presentación/saludo" en los datos españoles

\begin{tabular}{|c|c|c|}
\hline Saludos y Presentaciones Españolas & Frecuencia & $\%$ \\
\hline ¡Hola! & 49 & $34 \%$ \\
\hline ¡Buenos días/tardes! & 25 & $17 \%$ \\
\hline ¡Hola! + presentación & 21 & $15 \%$ \\
\hline ¡Buenos días! + presentación & 15 & $10 \%$ \\
\hline Presentación & 15 & $10 \%$ \\
\hline ¡Hola, buenos días/tardes! + presentación & 5 & $4 \%$ \\
\hline ¡Hola, buenos días/tardes! & 3 & $2 \%$ \\
\hline ¡Hola!, ¿Qué tal? & 3 & $2 \%$ \\
\hline ¡Hey! & 3 & $2 \%$ \\
\hline ¡Hola, Buenos! + presentación & 2 & $1 \%$ \\
\hline ¡Buenos días! ¿Qué tal? & 2 & $1 \%$ \\
\hline ¿Qué tal? & 2 & $1 \%$ \\
\hline ¿Qué tal? + presentación & 1 & $1 \%$ \\
\hline Total & 146 & $100 \%$ \\
\hline
\end{tabular}

Tabla 13. Frecuencia del uso de las estrategias de "Presentación/saludo" en los datos malayos

\begin{tabular}{|l|c|c|}
\hline \multicolumn{1}{|c|}{ Saludos y Presentaciones Malayas } & Frecuencia & $\%$ \\
\hline Assalamualaikum & 36 & $34 \%$ \\
\hline Assalamualaikum + presentación & 25 & $23 \%$ \\
\hline Salam & 9 & $8 \%$ \\
\hline Hello & 8 & $7 \%$ \\
\hline Salam + presentación & 4 & $4 \%$ \\
\hline Selamat pagi/petang ('buenos días/tardes') & 4 & $4 \%$ \\
\hline Presentación & 4 & $4 \%$ \\
\hline Hai ('hola') & 3 & $3 \%$ \\
\hline Hi ('hola') & 2 & $2 \%$ \\
\hline Apa khabar ('qué tal') + presentación & 2 & $2 \%$ \\
\hline Assalamualaikum, hai ('hola') & 1 & $1 \%$ \\
\hline Assalamualaikum, salam sejahtera & 1 & $1 \%$ \\
\hline Assalamualaikum, apa khabar ('qué tal') & 1 & $1 \%$ \\
\hline Assalamualaikum, selamat datang ('bienvenido') & 1 & $1 \%$ \\
\hline Assalamualikum, salam perkenalan ('encantado') & 1 & $1 \%$ \\
\hline Hello + presentación & 1 & $1 \%$ \\
\hline Salam perkenalan ('encantado') & 1 & $1 \%$ \\
\hline Salam, hai ('hola') & 1 & $1 \%$ \\
\hline Apa khabar ('encantado') & 106 & $1 \%$ \\
\hline & & $100 \%$ \\
\hline
\end{tabular}


Como se indica en la primera de las tablas, se encontraron 13 estrategias diferentes de "Presentación/saludo" en los datos españoles. La mayoría de los sujetos españoles aplicaron hola en primer lugar (en el 34\% de los casos), como en el ejemplo "ㅂola, ¿dónde andas? Estoy sola en casa...", seguida de buenos días/tardes (17\%), que lo emplearon mayoritariamente al dirigirse a los interlocutores de estatus social superior (situación 10), como en "Buenos días, necesitaría que me hiciera un favor...", y hola + presentación $(15 \%)$, que se usó con mayor frecuencia al hacer la petición a personas no conocidas (situación 1), como en "ㅂola, soy tu nueva vecina, Carmen".

Por otro lado, se encontraron 19 fórmulas distintas en los datos malayos. Los sujetos malayos aplicaron mayoritariamente la palabra assalamualaikum (en un $34 \%$ de sus enunciados), como en "Assalamualaikum, boleh saya pinjam tangga?" ( 'La paz sea con $\underline{\text { ustedes, }}$ poder yo pedir prestada escalera?/ La paz sea con usted, ¿le puedo pedir prestada la escalera?'), seguida de assalamualaikum + presentación (23\%), como en "Assalamualaikum, saya adalah jiran sebelah, boleh saya pinjam tangga?" ( 'La paz sea con ustedes, yo ser vecina al lado, poder yo pedir prestado escalera?/ La paz sea con usted, soy la vecina de al lado, cile puedo pedir prestada la escalera? ), excepto en la situación 1 en la que usaron en mayor medida assalamualaikum + presentación (42\%) al dirigirse a los 
interlocutores no conocidos, y la situación 16 en la cual optaron con mayor frecuencia por salam (100\%) al hacer la petición a personas del mismo estatus. Assalamualaikum es una palabra árabe que los malayos utilizan muchísimo en su comunicación diaria como saludo, por la influencia del Islam. Por ley, todos los malayos son musulmanes, por eso se emplean muchas palabras árabes (del Corán) sobre todo en los contextos religiosos específicos, como la oración ('salat') y etc. Otro de los saludos empleados es la palabra salam (en el $9 \%$ de los casos), como en "Salam prof, saya dapat tawaran temuduga, tapi nak kena ada surat sokongan" ( 'La paz prof., yo tener oferta entrevista, pero hay que tener carta recomendación/La paz sea con Vd., Prof. Tengo una entrevista de trabajo, pero necesito una carta de recomendación ') que en realidad es una forma abreviada de la palabra assalamualaikum. Además, aparecen hello, hai, y hi, como en "Hello, buat apa?" (' $\underline{\text { Hello, }}$, hacer qué?/Hola, ¿qué haces? ), "Hai, boleh teman saya pergi membeli belah?" (' $\underline{\text { Hai, }}$ poder acompañar yo ir hacer compras?/Hola, ¿puedes acompañarme a hacer unas compras? ), "ㅂi, anda adalah sahabat baik saya." (' $\underline{\mathrm{Hi}}$, tú ser amigo mejor yo/Hola, eres mi mejor amigo ), que se utilizan en la sociedad malaya de manera muy habitual por la influencia del inglés, que es la segunda lengua del país. 
Respecto al uso de los saludos y las presentaciones en los subgrupos de género y edad, hay en todos los casos (mayores, menores, varones y mujeres) la misma preferencia por saludar con hola o buenos días/tardes. Así, en las respuestas de los sujetos de más edad, se utiliza hola en el $40 \%$ de los enunciados y buenos días/tardes, en un 17\%, mientras que en el subgrupo de los más jóvenes, el porcentaje de uso es de un $22 \%$ y un $21 \%$, en cada caso. Y, en los subgrupos de género, los varones utilizan hola en el $32 \%$ de los casos y buenos días/tardes en el $16 \%$, frente a las mujeres que lo hacen en un $32 \%$ y $22 \%$ de sus enunciados, respectivamente. En las tablas que presentamos a continuación se recogen los datos numéricos y porcentuales españoles relativos al uso de las diferentes fórmulas de "Presentación/saludo". 
Tabla 14. Frecuencia de uso de las estrategias de "Presentación/saludo" en los datos españoles según edad

\begin{tabular}{|c|c|c|c|c|}
\hline \multirow{2}{*}{ Saludos y Presentaciones Españolas } & \multicolumn{2}{|c|}{ Mayor } & \multicolumn{2}{|c|}{ Menor } \\
\hline & $F$ & $\%$ & $F$ & $\%$ \\
\hline ¡Hola! & 33 & $40 \%$ & 16 & $25 \%$ \\
\hline ¡Buenos días/tardes! & 14 & $17 \%$ & 11 & $17 \%$ \\
\hline ¡Hola! + presentación & 13 & $16 \%$ & 8 & $13 \%$ \\
\hline ¡Buenos días! + presentación & 11 & $13 \%$ & 4 & $6 \%$ \\
\hline Presentación & 8 & $10 \%$ & 7 & $11 \%$ \\
\hline ¡Hola, buenos días/tardes! + presentación & 2 & $2 \%$ & 3 & $5 \%$ \\
\hline ¡Hola, buenos días/tardes! & 1 & $1 \%$ & 2 & $3 \%$ \\
\hline ¡Hola!, ¿Qué tal? & 0 & $0 \%$ & 3 & $5 \%$ \\
\hline ¡Hey! & 0 & $0 \%$ & 3 & $5 \%$ \\
\hline ¡Hola, Buenos! + presentación & 1 & $1 \%$ & 1 & $2 \%$ \\
\hline ¡Buenos días! ¿Qué tal? & 0 & $0 \%$ & 2 & $3 \%$ \\
\hline ¿Qué tal? & 0 & $0 \%$ & 2 & $3 \%$ \\
\hline ¿Qué tal? + presentación & 0 & $0 \%$ & 1 & $2 \%$ \\
\hline Total & 83 & $100 \%$ & 63 & $100 \%$ \\
\hline
\end{tabular}

$\mathrm{F}=$ Frecuencia

Tabla 15. Frecuencia de uso de las estrategias de "Presentación/saludo" en los datos españoles según sexo

\begin{tabular}{|l|c|c|c|c|}
\hline \multirow{2}{*}{ Saludos y Presentaciones Españolas } & \multicolumn{2}{|c|}{ Hombre } & \multicolumn{2}{c|}{ Mujer } \\
\cline { 2 - 5 } & $F$ & $\%$ & $F$ & $\%$ \\
\hline ¡Hola! & 25 & $34 \%$ & 24 & $34 \%$ \\
\hline ¡Buenos días/tardes! & 10 & $14 \%$ & 15 & $21 \%$ \\
\hline ¡Hola! + presentación & 13 & $17 \%$ & 8 & $11 \%$ \\
\hline ¡Buenos días! + presentación & 9 & $12 \%$ & 6 & $9 \%$ \\
\hline Presentación & 6 & $8 \%$ & 9 & $13 \%$ \\
\hline iHola, buenos días/tardes! + presentación & 4 & $5 \%$ & 1 & $1 \%$ \\
\hline ¡Hola, buenos días/tardes! & 2 & $3 \%$ & 1 & $1 \%$ \\
\hline ¡Hola!, ¿Qué tal? & 1 & $1 \%$ & 2 & $3 \%$ \\
\hline ¡Hey! & 3 & $4 \%$ & 0 & $0 \%$ \\
\hline ¡Hola, Buenos! + presentación & 0 & $0 \%$ & 2 & $3 \%$ \\
\hline ¡Buenos días! ¿Qué tal? & 0 & $0 \%$ & 2 & $3 \%$ \\
\hline ¿Qué tal? & 1 & $1 \%$ & 1 & $1 \%$ \\
\hline ¿Qué tal? + presentación & 1 & $1 \%$ & 0 & $0 \%$ \\
\hline & 75 & $100 \%$ & 71 & $100 \%$ \\
\hline
\end{tabular}

$\mathrm{F}=$ Frecuencia 
En el caso malayo, por su parte, los hablantes del subgrupo de edad más avanzada prefirieron, en primer lugar, la forma combinada assalamualaikum + presentación (aparece en un $27 \%$ de los casos), seguida de assalamualaikum (en el $19 \%$ ). Por el contrario, los participantes del otro subgrupo mostraron mayor preferencia por el empleo de assalamualaikum (47\%), seguida de assalamualaikum + presentación. Con respecto a los subgrupos de género, los varones mostraron la misma preferencia por assalamualaikum y la forma combinada assalamualaikum + presentación, que aparecen, en ambos casos, en el $24 \%$ de los enunciados, mientras que las mujeres recurrieron más a assalamualaikum (43\%), seguida de assalamualaikum + presentación (23\%). Estos datos, así como los referentes al empleo de otras fórmulas de "Presentación/saludo" en las respuestas de los participantes malayos, se muestran en las siguientes tablas: 
Tabla 16. Frecuencia de uso de las estrategias de "Presentación/saludo" en los datos malayos según la edad

\begin{tabular}{|l|c|c|c|c|}
\hline \multirow{2}{*}{ Saludos y Presentaciones Malayas } & \multicolumn{2}{|c|}{ Mayor } & \multicolumn{2}{c|}{ Menor } \\
\cline { 2 - 5 } & $F$ & $\%$ & $F$ & $\%$ \\
\hline Assalamualaikum & 10 & $20 \%$ & 26 & $46 \%$ \\
\hline Assalamualaikum + presentación & 14 & $27 \%$ & 11 & $20 \%$ \\
\hline Salam & 6 & $11 \%$ & 3 & $5 \%$ \\
\hline Hello & 4 & $8 \%$ & 4 & $7 \%$ \\
\hline Salam + presentación & 3 & $6 \%$ & 1 & $2 \%$ \\
\hline Selamat pagi/petang ('buenos días/tardes') & 4 & $8 \%$ & 0 & $0 \%$ \\
\hline Presentación & 3 & $6 \%$ & 1 & $2 \%$ \\
\hline Hai ('hola') & 3 & $6 \%$ & 0 & $0 \%$ \\
\hline Hi ('hola') & 2 & $4 \%$ & 0 & $0 \%$ \\
\hline Apa khabar ('qué tal') + presentación & 0 & $0 \%$ & 2 & $4 \%$ \\
\hline Assalamualaikum, hai ('hola') & 0 & $0 \%$ & 1 & $2 \%$ \\
\hline Assalamualaikum, salam sejahtera & 0 & $0 \%$ & 1 & $2 \%$ \\
\hline Assalamualaikum, apa khabar ('qué tal') & 0 & $0 \%$ & 1 & $2 \%$ \\
\hline Assalamualaikum, selamat datang ('bienvenido') & 0 & $0 \%$ & 1 & $2 \%$ \\
\hline Assalamualikum, salam perkenalan ('encantado') & 0 & $0 \%$ & 1 & $2 \%$ \\
\hline Hello + presentación & 1 & $2 \%$ & 0 & $0 \%$ \\
\hline Salam perkenalan ('encantado') & 0 & $0 \%$ & 1 & $2 \%$ \\
\hline Salam, hai ('hola') & 1 & $2 \%$ & 0 & $0 \%$ \\
\hline Apa khabar ('encantado') & 0 & $0 \%$ & 1 & $2 \%$ \\
\hline & 51 & $100 \%$ & 55 & $100 \%$ \\
\hline
\end{tabular}

$\mathrm{F}=$ Frecuencia

Tabla 17. Frecuencia de uso de las estrategias de "Presentación/saludo" en los datos malayos según el sexo

\begin{tabular}{|l|c|c|c|c|}
\hline \multirow{2}{*}{ Saludos y Presentaciones Malayas } & \multicolumn{2}{|c|}{ Hombre } & \multicolumn{2}{c|}{ Mujer } \\
\cline { 2 - 5 } & $F$ & $\%$ & $F$ & $\%$ \\
\hline Assalamualaikum & 12 & $24 \%$ & 24 & $44 \%$ \\
\hline Assalamualaikum + presentación & 12 & $24 \%$ & 13 & $24 \%$ \\
\hline Salam & 6 & $12 \%$ & 3 & $5 \%$ \\
\hline Hello & 4 & $7 \%$ & 4 & $7 \%$ \\
\hline Salam + presentación & 3 & $5 \%$ & 1 & $2 \%$ \\
\hline Selamat pagi/petang ('buenos días/tardes') & 1 & $2 \%$ & 3 & $5 \%$ \\
\hline Presentación & 0 & $0 \%$ & 4 & $7 \%$ \\
\hline Hai ('hola') & 1 & $2 \%$ & 2 & $4 \%$ \\
\hline Hi ('hola') & 2 & $4 \%$ & 0 & $0 \%$ \\
\hline Apa khabar ('qué tal') + presentación & 2 & $4 \%$ & 0 & $0 \%$ \\
\hline Assalamualaikum, hai ('hola') & 1 & $2 \%$ & 0 & $0 \%$ \\
\hline Assalamualaikum, salam sejahtera & 1 & $2 \%$ & 0 & $0 \%$ \\
\hline Assalamualaikum, apa khabar ('qué tal') & 1 & $2 \%$ & 0 & $0 \%$ \\
\hline Assalamualaikum, selamat datang ('bienvenido') & 1 & $2 \%$ & 0 & $0 \%$ \\
\hline Assalamualikum, salam perkenalan ('encantado') & 0 & $0 \%$ & 1 & $2 \%$ \\
\hline Hello + presentación & 1 & $2 \%$ & 0 & $0 \%$ \\
\hline Salam perkenalan ('encantado') & 1 & $2 \%$ & 0 & $0 \%$ \\
\hline Salam, hai ('hola') & 1 & $2 \%$ & 0 & $0 \%$ \\
\hline Apa khabar ('encantado') & 1 & $2 \%$ & 0 & $0 \%$ \\
\hline & 51 & $100 \%$ & 55 & $100 \%$ \\
\hline
\end{tabular}

$\mathrm{F}=$ Frecuencia 


\subsubsection{Fórmulas de deixis social}

i) Fórmulas de tratamiento pronominales

Frente a las dos formas de tratamiento de la segunda persona en español, tú y usted, el malayo tiene básicamente cinco, que recogemos en la tabla que sigue:

Tabla 18. Tipos de pronombre personal de segunda persona en malayo

\begin{tabular}{|c|c|}
\hline Pronombre & Uso \\
\hline Tuanku & $\begin{array}{l}\text { Se aplica exclusivamente cuando alguien se dirige al rey } \\
\text { ('sultán') y sus familiares. } \\
\text { Ejemplo: "Tuanku amat dikasihi oleh rakyat" ('Tuanku muy } \\
\text { es querido por gente/A Tuanku le quiere mucho la gente') }\end{array}$ \\
\hline Anda & $\begin{array}{l}\text { Se usa para dirigirse a personas a las que acaban de } \\
\text { conocer. Se utiliza igualmente con personas de estatus social } \\
\text { más bajo y del mismo estatus, con personas de la misma } \\
\text { edad y se usa en un entorno formal, en publicidad y en el } \\
\text { discurso hablado y escrito. Normalmente se recurre a esta } \\
\text { forma para crear intimidad. } \\
\text { Ejemplo: "Siapa nama anda?" ('Quién nombre usted?/¿Cómo } \\
\text { se llama usted?') }\end{array}$ \\
\hline Awak & $\begin{array}{l}\text { Su uso es más genérico, se usa tanto con personas muy } \\
\text { conocidas como con las que se acaban de conocer, personas } \\
\text { del mismo estatus y de estatus inferior, en situaciones } \\
\text { informales. } \\
\text { Ejemplo: "Apa khabar awak hari ini?" ( 'Qué tal tú hoy?/¿Qué } \\
\text { tal estás hoy?') }\end{array}$ \\
\hline Engkau/kau & $\begin{array}{l}\text { Se usa con Dios, personas íntimas, con personas que tienen } \\
\text { relación muy estrecha con el hablante, personas del mismo } \\
\text { estatus, y en entornos no formales. } \\
\text { Ejemplo: "Boleh aku pinjam telefon kau?" ( 'Poder yo pedir } \\
\text { prestado teléfono tú?/ ¿Te puedo pedir prestado tu } \\
\text { teléfono?") }\end{array}$ \\
\hline
\end{tabular}




\begin{tabular}{|l|l|}
\hline Kamu & $\begin{array}{l}\text { Lo utilizan normalmente los adultos al dirigirse a } \\
\text { interlocutores de la misma o menor edad que ellos, con } \\
\text { personas conocidas, personas inferiores, y tanto en la } \\
\text { conversación formal como no formal. } \\
\text { Ejemplo: "Mengapa kamu memilih kursus ini?" ( 'Por qué tú } \\
\text { eligir curso este?/¿Por qué eliges esta asignatura?') }\end{array}$ \\
\hline
\end{tabular}

En general, las formas de los pronombres personales de segunda persona en malayo se dividen en dos grupos: las que se utilizan al dirigirse al rey y sus familiares, y las que sirven para tratar a la gente con la que alguien se relaciona a diario (Nik Safiah Karim: 1993). Como se ve en la Tabla 18, tuanku es la forma del pronombre personal de segunda persona que se usa exclusivamente con los familias reales, mientras que anda, awak, engkau/kau dan kamu se utilizan al dirigirse a la gente corriente. Con respecto al uso de estos pronombres hay diferencias en el empleo de cada forma, dependiendo del contexto, como ha quedado reflejado en la tabla anterior.

Por otro lado, el pronombre de segunda persona, tú, en español, se usa con amigos, animales, Dios, niños, compañeros y en situaciones sociales en las que participa gente de aproximadamente la misma edad y clase social. En cambio usted es más formal e implica respeto por la persona o por su oficio. 
Basándonos en nuestros datos sobre el uso de las fórmulas de tratamiento pronominales, solo un $26 \%$ de los hablantes españoles utilizaron la forma de usted en sus peticiones, lo que significa que tú (usado en $74 \%$ de los casos) fue el tratamiento preferido al dirigirse a los interlocutores. Lo que resulta interesante es la aparición de la forma de usted en los datos de los jóvenes con unos porcentajes más altos en comparación con los de los hablantes mayores (véase la Tabla 19). En cuanto a la comparación por subgrupo de sexo, y, como era de esperar, las mujeres fueron las que la usaron con mayor frecuencia (53\%) en comparación con los hombres (47\%) (véase la Tabla 20).

Tablas 19. Distribución del uso de usted en el grupo español según edad en las seis situaciones

\begin{tabular}{|c|c|c|c|}
\hline \multicolumn{2}{|c|}{ Mayor } & \multicolumn{2}{c|}{ Menor } \\
\hline Frecuencia & $\%$ & Frecuencia & $\%$ \\
\hline 40 & $43 \%$ & 53 & $57 \%$ \\
\hline
\end{tabular}

Tablas 20. Distribución del uso de usted en el grupo español según sexo en las seis situaciones

\begin{tabular}{|c|c|c|c|}
\hline \multicolumn{2}{|c|}{ Hombre } & \multicolumn{2}{c|}{ Mujer } \\
\hline Frecuencia & $\%$ & Frecuencia & $\%$ \\
\hline 44 & $47 \%$ & 49 & $53 \%$ \\
\hline
\end{tabular}

En el caso del malayo, se destaca el dominio de la forma awak en las expresiones de la petición, que aparece en el $61 \%$ de 
los enunciados. La forma engkau/kau es la que está en segundo lugar por orden de frecuencia (15\%) y, la forma anda y kamu queda en último lugar (12\%). La distribución de formas mencionada queda reflejada en la siguiente tabla:

Tabla 21. Distribución de pronombres personales de segunda persona utilizados en las seis situaciones en malayo

\begin{tabular}{|c|c|c|}
\hline Formas & Frecuencia & $\%$ \\
\hline Awak & 79 & $61 \%$ \\
\hline Engkau/kau & 19 & $15 \%$ \\
\hline Anda & 16 & $12 \%$ \\
\hline Kamu & 16 & $12 \%$ \\
\hline
\end{tabular}

Entre los subgrupos de edad, el tratamiento de awak fue el dominante tanto en el caso de los informantes mayores (51\%) como de los jóvenes (69\%), como se puede observar en la tabla de datos que presentamos a continuación:

Tabla 22. Distribución de pronombres personales de segunda persona empleados en malayo según subgrupo de edad en las seis situaciones

\begin{tabular}{|c|c|c|c|c|}
\hline \multirow{2}{*}{ Formas } & \multicolumn{2}{|c|}{ Mayor } & \multicolumn{2}{c|}{ Menor } \\
\cline { 2 - 5 } & Frecuencia & $\%$ & Frecuencia & $\%$ \\
\hline Awak & 31 & $51 \%$ & 48 & $69 \%$ \\
\hline Engkau/kau & 11 & $18 \%$ & 8 & $12 \%$ \\
\hline Anda & 12 & $20 \%$ & 4 & $6 \%$ \\
\hline Kamu & 7 & $11 \%$ & 9 & $13 \%$ \\
\hline
\end{tabular}


La inclinación de los sujetos de menos edad hacia el uso de la forma awak fue más firme que la de los de más edad. Y también utilizaron más la forma kamu. Pero, en el caso del uso de las formas engkau/kau y anda, fueron los sujetos mayores los que las aplicaron en un mayor número de ocasiones. Con respecto a la distribución de dichas formas entre los subgrupos de sexo, hemos hallado que pese a que los sujetos de los dos sexos mostraran una mayor tendencia hacia el empleo de la forma awak, llama la atención la mayor frecuencia con la que aparece en el corpus de mujeres, con un número de casos de $54(75 \%)$, frente a los hombres que lo emplean en un $42 \%$ de los casos. Ahora bien, los hombres recurrieron a las formas engkau/kau, anda y kamu en mayor número de ocasiones que el otro sexo, tal y como se refleja en la tabla que sigue:

Tabla 23. Distribución de pronombres personales de segunda persona empleados en malayo según subgrupo de sexo en las seis situaciones

\begin{tabular}{|c|c|c|c|c|}
\hline \multirow{2}{*}{ Formas } & \multicolumn{2}{|c|}{ Hombre } & \multicolumn{2}{c|}{ Mujer } \\
\cline { 2 - 5 } & Frecuencia & $\%$ & Frecuencia & $\%$ \\
\hline Awak & 25 & $42 \%$ & 54 & $75 \%$ \\
\hline Engkau/kau & 13 & $22 \%$ & 6 & $9 \%$ \\
\hline Anda & 10 & $17 \%$ & 6 & $9 \%$ \\
\hline Kamu & 11 & $19 \%$ & 5 & $7 \%$ \\
\hline
\end{tabular}




\section{ii) Fórmulas de tratamiento nominales}

Una de las diferencias más notables entre los informantes españoles y los malayos al realizar sus actos de habla de petición se puede observar en la estrategia de "Fórmulas de tratamiento", tanto en la frecuencia con la que es utilizada por los hablantes de las dos sociedades analizadas, como en los términos con los que se dirigen al oyente, encontrados en los datos de ambos grupos. Como ya se ha mostrado en la sección anterior (véase el análisis cuantitativo), los malayos emplearon dicha estrategia dos veces más que los españoles (254 enunciados recogidos de los datos malayos frente a tan solo 107 de los españoles). Esta destacada diferencia se puede explicar por la diferencia transcultural entre los españoles y los malayos. Los malayos son muy sensibles al estatus en sus comunicaciones. Por ejemplo, tienden a aplicar fórmulas de tratamiento nominales, como profesor o encik/puan ('señor/a), cuando hablan con una persona de posición social más elevada, y la repiten una y otra vez (Asmah haji Omar, 2002), en los casos en los que, en español, se recurriría al pronombre usted, precisamente para no repetir esa forma nominal. Esto coincide con los datos malayos obtenidos en este estudio, que señalan una mayor tendencia al empleo de fórmulas de tratamiento en la situación del cuestionario en la que los informantes se sitúan en una posición inferior frente a una persona de estatus superior (situación 10). En dicho contexto, 
un alumno pide a su ex profesor universitario una carta de recomendación para solicitar un trabajo. En las respuestas de los sujetos analizados se aplicaron muy frecuentemente esas fórmulas (en el $57 \%$ de los casos) y se emplearon de manera repetitiva, como "Salam Prof. Ingat tak lagi pada saya Prof.? Saya bekas anak murid Prof. Saya nak minta bantuan Prof. untuk buatkan surat sokongan pekerjaan. Harap Prof. boleh bantu saya" ( 'La paz prof. Recordar no más a yo Prof? Yo ex alumno Prof. Yo querer pedir ayuda Prof para hacerkan carta recomendación trabajo. Ojalá Prof poder ayudar yo/ La paz sea con Vd., profesor. ¿Ya no se acuerda de mí? Soy un antiguo alumno suyo, y quería pedirle si podría escribirme una carta de recomendación para un trabajo. Espero que pueda ayudarme'). Otro ejemplo fue "Assalamualaikum Prof. Maaflah mengambil masa prof. sedikit. Saya nak minta tolong sikit dengan prof. Prof., boleh tak saya nak minta prof. buat surat sokongan untuk saya. Ni untuk memohon pekerjaan." ('La paz sea con ustedes prof. Lamento/ah tomar tiempo prof poco. Yo querer pedir ayuda poco de prof. Prof, poder no yo querer pedir prof hacer carta recomendación para yo. Es para solicitar trabajo/La paz sea con Vd., profesor. Perdone por quitarle un poco de tiempo. Quería pedirle su ayuda para hacerme una carta de recomendación. Pero no sé si Vd. podría preparármela. Es para solicitar un trabajo ). 
En los datos españoles, por su lado, no se encontró ningún uso reiterativo de ninguna fórmula de tratamiento. En cambio, se recurrió al pronombre usted, como en "Estimado profesor, recurro a usted porque necesito una carta de presentación para un trabajo. ¿Sería tan amable de hacérmela usted?", o "Buenos días profesor, ¿Qué tal? He venido a verle porque necesito una carta de recomendación y había pensando que usted podría ayudarme.", y se utilizó la forma de la tercera persona singular del verbo, como "Profesor X, buenas tardes. ¿Se acuerda de mí? Mire, estoy pendiente de un trabajo y necesitaría una carta de recomendación suya.", o la forma de la tercera persona singular del Condicional, por ejemplo "Señor profesor, ¿Podría redactarme una carta de recomendación para un trabajo que pido?" o "Buenos días profesor, estoy buscando trabajo y me preguntaba si me podría dar una carta de recomendación para este puesto. Gracias".

En las Tablas 24 y 25, mostramos la distribución numérica y porcentual de las fórmulas de tratamiento en los datos de las dos culturas. 
Tabla 24. Distribución de las fórmulas de tratamiento en los datos de la sociedad española

\begin{tabular}{|l|l|c|c|}
\hline Fórmulas de tratamiento españolas & \multicolumn{1}{|c|}{ Ejemplos } & $F$ & $\%$ \\
\hline Nombre de pila & Carmen, Enrique... & 65 & $61 \%$ \\
\hline Término ocasional & Tío, amigo... & 14 & $13 \%$ \\
\hline Término de cortesía + nombre de pila & Señor Manuel... & 7 & $7 \%$ \\
\hline Título & Profesor... & 6 & $5 \%$ \\
\hline Hipocorístico & Pepe... & 6 & $5 \%$ \\
\hline Título + nombre de pila & Profesor Juan... & 3 & $3 \%$ \\
\hline Término de cortesía + título & Señor profesor... & 3 & $3 \%$ \\
\hline Término de respeto & Estimado profesor.. & 1 & $1 \%$ \\
\hline Término de cortesía + Hipocorístico & Don Pepe... & 1 & $1 \%$ \\
\hline Apellido & Gómez... & 1 & $1 \%$ \\
\hline & & 107 & $100 \%$ \\
\hline
\end{tabular}

Tabla 25. Distribución de las fórmulas de tratamiento en los datos de la sociedad malaya

\begin{tabular}{|l|l|c|c|}
\hline \multicolumn{1}{|c|}{ Fórmulas de tratamiento malayas } & \multicolumn{1}{|c|}{ Ejemplos } & F & $\%$ \\
\hline Título & Profesor... & 133 & $52 \%$ \\
\hline Término de cortesía & Tuan, puan, encik... & 42 & $17 \%$ \\
\hline Nombre de pila & Fatimah, Nadia... & 38 & $15 \%$ \\
\hline Hipocorístico & Mat, man, jo... & 30 & $12 \%$ \\
\hline Término parentesco & Abang, kak... & 6 & $2 \%$ \\
\hline Término ocasional & Bro... & 3 & $1,2 \%$ \\
\hline Término de cortesía + título & Tuan profesor... & 1 & $0,4 \%$ \\
\hline Término afectivo & Sayang... & 1 & $0,4 \%$ \\
\hline & \multicolumn{1}{|c}{ Total } & 254 & $100 \%$ \\
\hline
\end{tabular}

$\mathrm{F}=$ Frecuencia

Las Tablas 24 y 25 muestran qué categoría de fórmula de tratamiento prevalece en cada grupo al hacer las peticiones en este estudio. En primer lugar, desde el punto de vista de la estimación general del resultado, podemos subrayar, a diferencia de lo visto hasta ahora, una clara diferencia entre ambas culturas. Se aprecia que mientras que los datos producidos por los informantes españoles se concentran en el empleo del nombre de pila, con un porcentaje 
que alcanza el $61 \%$ (constituyen un total de 65 casos), en los datos malayos la misma categoría se sitúa en el tercer lugar (con el 15\% de los enunciados). Por el contrario, la categoría a la que más se recurrió en el corpus malayo, fue la de "Título" (empleada en el 52\% de los casos), que en los datos españoles estaba en el cuarto lugar, según frecuencia de uso, con un porcentaje de tan solo el 5\%. La segunda opción porcentualmente mayoritaria en el corpus español es el uso del "Término ocasional", que aparece en el $13 \%$ de los enunciados. Dicha opción ocupa el sexto lugar en los datos malayos $(1,2 \%)$. Es interesante el hecho de que la opción que se sitúa en el segundo lugar en los datos malayos, la de "Término de cortesía" (17\%), no aparece en los datos españoles, es decir, ningún español investigado la aplicó para dirigirse a los interlocutores. Ahora bien, sí que se utiliza dicha opción en los datos españoles, pero en combinación con el "Nombre de pila" (Señor Manuel), con un "Título" (Señor profesor) o con un "Hipocorístico" (Don Pepe). Dicho de otro modo, la categoría preferida por los nativos españoles corresponde a la menos elegida por los malayos, y viceversa.

También encontramos una diferencia interesante en la utilización de fórmulas combinadas de tratamiento en los dos grupos contrastados. En las peticiones del grupo español se utilizaron tres formas combinadas, que fueron las siguientes: 
- "Término de cortesía + nombre de pila", por ejemplo "Hola Señor José, necesito una carta de recomendación y había pensado que tal vez usted podría proporcionármela. Es para un trabajo, ¿le importaría redactarla?"

- "Título + nombre de pila", como en "iBuenos días Profesor Manuel! Quería que me hiciera un favor. Necesito una carta de recomendación para solicitar un trabajo"2.

- "Término de cortesía + hipocorístico", por ejemplo "iBuenos días Don Pepe! Estoy buscando trabajo y me preguntaba si usted podría redactar una carta para recomendarme".

En el grupo malayo, en cambio, se observó solo un tipo de forma combinada que fue "Término de cortesía + título", como en el ejemplo "Saya telah mohon satu jawatan di sebuah syarikat dan untuk menyokong permohonan saya ini, saya mohon satu surat sokongan dari tuan profesor." ('Yo solicitar un puesto en una empresa y para apoyar solicitud yo este, yo pedir una carta recomendación de señor profesor/He solicitado un puesto en una empresa y para avalar mi solicitud, le pido una carta de recomendación ').

En lo que concierne al uso de las variedades de "Fórmulas de tratamiento" los encuestados españoles prefirieron dirigirse a los

\footnotetext{
${ }^{2}$ Algunos informantes han introducido en sus respuestas esta variante de la fórmula habitual "Título + apellido".
} 
destinatarios por el nombre de pila (en el $61 \%$ de las ocasiones), por ejemplo en "María, voy a ir de compras. ¿Me acompañas?", "Pedro, ¿te vienes a echar una play o a ver una peli a mi casa? Que estoy solo", "Peter por favor, tengo que llamar para un asunto, déjame hacer una llamada con tu móvil", etc. Nos parece interesante destacar, que los informantes españoles también utilizaron el nombre de pila para dirigirse a una persona de estatus superior, como en la situación 10 , cuando un alumno pide a su ex profesor universitario una carta de recomendación para solicitar un trabajo. En este escenario, un español respondió "Buenas tardes, Valentín. Perdone que le interrumpa. Pero necesito que me haga un favor. Voy a solicitar un trabajo en la empresa $\mathrm{X}$ y me piden dos cartas de recomendación. He pensado en usted, dado que conoce cómo trabajo en el laboratorio. ¿Sería posible?". Y otro dijo "Hola César. Voy a solicitar este trabajo y me piden una carta de recomendación. ¿Podrías hacérmela tú, por favor?". En cambio, no se encontró ningún caso del uso de nombre de pila en la misma situación en los datos malayos. Esto es debido a que, en la cultura malaya, llamar a alguien por su nombre solo se practica entre familiares o entre amigos, pero solo en el caso de una persona superior hacia una inferior o entre las del mismo estatus. Dirigirse a una persona de estatus más elevado por su nombre en la cultura malaya es un gesto de mala educación; de hecho, es un tabú. 
También hay que destacar la aparición de "Términos ocasionales" en los datos españoles con unos porcentajes bastante altos en comparación con los del otro grupo (véanse las tablas 11 y 12). Este tipo de fórmula se emplea en el corpus español en las situaciones 4,7 y 16 , en las que la petición va dirigida a una persona conocida, muy conocida y del mismo estatus, respectivamente. Los sujetos malayos, por su parte, solo utilizaron dichos términos con destinatarios de una posición social superior, y en los casos en los que los interlocutores disfrutaban del mismo estatus (situaciones 7 y 16, respectivamente). Un aspecto llamativo en los resultados del empleo de términos ocasionales es la aparición de diferentes variedades en los datos españoles, en comparación con solo una única variedad en los datos malayos. Además, dichos términos se encontraron en los datos de todos los subgrupos españoles, al realizar la petición a los interlocutores conocidos o muy conocidos y a los del mismo estatus. En cambio, solo los aplicaron los jóvenes y los varones de la sociedad malaya en situaciones de alto grado de familiaridad y al dirigirse a los interlocutores del mismo estatus. No se encontró ningún término ocasional ni en los datos de los de más edad ni en los de las mujeres en el grupo malayo.

Respecto a las expresiones utilizadas por los encuestados de las dos sociedades como "Términos ocasionales" vemos, por ejemplo, que en la situación 4, en la que los participantes tienen que 
hacer una petición a una persona conocida, un español mayor dijo: "Venga, tío, vamos. Échame una mano, que hay que traer muchas cosas", y un menor respondió: "iOye, macho! Tenemos la nevera vacía. Vente conmigo a comprar, que luego te quejas si no compro nada que te guste". En la situación 7, en la que el sujeto tiene que pedir a una persona muy conocida que vaya a hacerle compañía, un español varón respondió: "iHola, amigo! Estoy solo, ¿Por qué no te acercas a casa? Así nos preparamos algo de cena", y una mujer dijo: "¿Qué haces, colega? ¿Estás tan aburrido como yo? Te invito a cerveza y peli si te animas a venir", y otro dijo "Amigo, ¿Podrías venir a casa esta tarde? Estoy sola y podríamos montarnos una partida a la play station". Y en la situación 16, en la que los encuestados se colocan en la misma posición social que el interlocutor, un español menor dijo "iOye, tío! Hazme un favor y déjame el teléfono, que necesito hacer una llamada", y otro dijo "iHey, galán! Déjame el móvil, porfa, que tengo que llamar". De los ejemplos expuestos podemos extraer algunas variedades de los "Términos ocasionales" empleados por los españoles, como "tío", "amigo", "colega", "macho" y "galán". En cambio, en los datos malayos solo se encontró una variedad de dicha forma que fue bro como en los siguientes ejemplos: "Bro, datang rumah, aku boring" ( 'Bro, venir casa yo, yo aburrido/Bro, ven a mi casa, que estoy aburrido ') y "Bro, jom lepak rumah aku. Ada citer baru” (' Bro, vamos a casa yo. Hay pelí nueva / Bro, vamos a mi casa. Tengo una peli nueva ') (situación 7), y "Bro, 
aku nak guna kredit hang sikit, urgent la." ('Bro, yo querer utilizar saldo tú poquito, es urgente/Bro, necesito usar tu móvil. Es urgente') (situación 16). La expresión de bro deriva de la palabra inglesa brother ('hermano). Se suele utilizar en Malasia en las comunicaciones de los jóvenes entre sí y también entre personas muy conocidas. Es una expresión muy vulgar.

Los datos presentados en la Tabla 12 revelan que los participantes malayos tendieron a dirigirse a sus interlocutores refiriéndose al título o rol profesional de los destinatarios (así fue en el $52 \%$ de los enunciados producidos), por ejemplo el uso de profesor en la situación 10, como "Assalamualaikum, prof. saya nak minta kerja. Jadi boleh tak kalau saya nak minta surat sokongan dari prof?" ('La paz sea con ustedes prof, yo querer solicitar trabajo. Entonces, poder no, si yo querer pedir carta recomendación de prof?/La paz sea con usted, profesor, quiero solicitar un trabajo. ¿No podría pedirle una carta de recomendación? ). La segunda opción más elegida por los hablantes nativos malayos fueron los "Términos de cortesía" (en el 17\% de los casos). En Malasia, la gente suele dirigirse a un extraño con tuan/puan ('señor/señora ), o encik/cik ('señor/señorita ). Si el extraño parece una persona de la misma edad se le puede llamar saudara/saudari (literalmente `hermano/hermana ). Por ejemplo, en la situación 1, cuando se tiene que pedir a un vecino desconocido una escalera prestada, un 
malayo dijo "Assalamualaikum, apa khabar? Boleh saya ingin meminjam tangga tuan sebentar kerana saya ingin membaiki lampu rumah saya?" ( 'La paz sea con ustedes, qué tal? Poder yo querer pedir prestada escalera señor un momento porque yo querer arreglar lámpara casa yo?/ La paz sea con usted, ¿qué tal? ¿Podría pedirle prestada la escalera un momento, señor? Es que quiero arreglar una lámpara de mi casa'), mientras otros respondieron "Assalamualaikum, puan ada tangga? Boleh saya pinjam tangga tersebut? Lampu rumah saya rosak. Saya jiran baru puan. Saya baru pindah ke sini semalam." ('La paz sea con ustedes, señora tener escalera? Poder yo pedir prestada escalera respectiva? Lámpara casa yo estropeado. Yo vecino nuevo señora. Yo acabar mudar aquí ayer/La paz sea con usted: Señora, ¿Tiene usted escalera? ¿Se la puedo pedir prestada? Tengo una lámpara estropeada. Soy un vecino nuevo, señora. Me acabo de mudar aquí ayer'), "Boleh saya pinjam tangga encik? Saya nak baiki lampu rumah saya" ( 'Poder yo pedir prestada escalera señor? Yo querer arreglar lámpara casa yo/¿Puedo pedirle prestada la escalera, señor? Quiero arreglar una lámpara de mi casa'), o "Assalamualaikum, maaf mengganggu cik. Saya baru berpindah ke kawasan ini. Kebetulan pula lampu di rumah saya rosak, bolehkah kalau saya meminjam tangga di rumah cik?" ( 'La paz sea con ustedes, siento molestar señorita. Yo acabar mudar aquí. Por casualidad lámpara en casa yo estropeado, poderkah yo pedir prestada escalera en casa señorita?/La paz sea con usted, 
siento molestarla, señorita. Me acabo de mudar aquí. De repente se me ha estropeado una lámpara. ¿Puedo pedirle prestada la escalera de su casa?').

A continuación, las opciones que se situaron porcentualmente en el tercer y el cuarto lugar en los datos proporcionados por los sujetos malayos, fueron las de "Nombre de pila" (15\%) e "Hipocorístico" (12\%). En Malasia existe la costumbre de utilizar los hipocorísticos (nicks, en inglés) para dirigirse a algunas personas de cierta confianza o con las que une cierta amistad. Es una forma cariñosa de tratar a los amigos. En este estudio, se pueden ver muchos hipocorísticos en el corpus malayo en las situaciones en las que se tiene que hacer la petición a un conocido (situación 4), a otro muy conocido (situación 7) y a una persona del mismo estatus (situación 16). Por ejemplo, en la petición que el sujeto participante hace a un compañero de piso para que le acompañe a hacer compras (los interlocutores son conocidos), se encontraron expresiones como "Din, temankan aku beli barang." (' 'Din, acompáñar kan yo comprar cosas/Din, acompáñame a comprar unas cosas'), o "Mat, jom kita pergi supermarket." (' Mat, vamos nosotros ir supermercado/ Mat, vamos al supermercado'). En la situación en la que el sujeto le pide a su mejor amigo (muy conocido) que vaya a hacerle compañía, un malayo dijo "Man, kalau ada kelapangan, saya nak jemput datang ke rumah." ('Man, si hay 
libertad, yo querer invitar venir a casa/Man, si estás libre, quiero invitarte a venir a mi casa') y otro respondió "Man, kau sibuk tak masa ni. Kalau tak, apa kata kau datang rumah aku." ('Man, tú ocupado no ahora? Si no, qué decir tú venir casa yo/ Man, estás ocupado ahora? Si no, ¿qué dices de venir a mi casa?'). En la situación en que se tiene que hacer una petición a una persona del mismo estatus (nos referimos a la situación 16, en la que se pide prestado el móvil a un amigo para hacer una llamada urgente), se registraron expresiones como "Mat, pinjam telefon kejap. Kredit aku habislah." ('Mat, prestar teléfono un momento. Saldo yo terminarlah/Mat, préstame el teléfono un momento. Se me ha terminado el saldo '), o "Salam, Mat, pinjam telefon sekali. Kredit aku habislah." ( 'La paz sea contigo, Mat, prestar teléfono una vez. Saldo yo terminarlahl La paz sea con usted, Mat, préstame un momento el teléfono. Se me ha terminado el saldo ').

Como se ve en los ejemplos recogidos más arriba, hubo muchos enunciados en los que los participantes malayos emplearon Mat como hipocorístico. Mat es, en realidad, una forma abreviada del nombre de pila Muhammad, que es el nombre típico de los hombres malayos. Al dirigirse a alguien que se llame Muhammad los malayos suelen utilizar la forma breve de Mat. Esto se hace, por un lado, para que la expresión sea más corta y, por otro, para reducir la formalidad entre los interlocutores. Por eso, no se encontró ningún caso de 
"Hipocorístico" en los casos en los que la petición se dirigía a una persona superior o a un extraño. Además de Mat, también se encontraron otros tipos de "Hipocorístico" como Din y Man. Din procede de los nombres que acaban en Din en su forma original, por ejemplo, Khairuddin, Zaharuddin, Azizuddin, etc., que son también nombres típicos de los hombres malayos. El otro "Hipocorístico", Man, es una abreviación de los nombres malayos de hombre que terminan con Man, por ejemplo Azman, Rosman, Rahman, etc.

Con respecto a la utilización de las fórmulas de tratamiento a las que recurrieron los sujetos de los dos subgrupos de edad, pese a que todos mostraran, en ambas culturas, preferencia por el mismo tipo de fórmulas, sí que se produjeron diferencias en su distribución, como se refleja en las tablas siguientes, que recogen los datos numéricos y porcentuales tanto de los subgrupos de edad españoles como de los malayos: 
Tabla 26. Distribución de enunciados, según tipos de fórmulas de tratamiento empleadas por mayores y menores en el grupo español

\begin{tabular}{|l|c|l|c|}
\hline \multicolumn{1}{|c|}{ Fórmulas } & Mayor & \multicolumn{1}{|c|}{ Fórmulas } & Menor \\
\hline Nombre de pila & $39(62 \%)$ & Nombre de pila & $26(59 \%)$ \\
\hline Término ocasional & $8(12.5 \%)$ & Término ocasional & $6(14 \%)$ \\
\hline Hipocorístico & $5(8 \%)$ & $\begin{array}{l}\text { Término de cortesía + } \\
\text { nombre de pila }\end{array}$ & $4(9 \%)$ \\
\hline $\begin{array}{l}\text { Término de cortesía + } \\
\text { nombre de pila }\end{array}$ & $3(5 \%)$ & Título & $3(7 \%)$ \\
\hline Título & $3(5 \%)$ & $\begin{array}{l}\text { Término de cortesía + } \\
\text { título }\end{array}$ & $2(2 \%)$ \\
\hline Título + nombre de pila & $2(3 \%)$ & Hipocorístico & $1(2 \%)$ \\
\hline $\begin{array}{l}\text { Término de cortesía + } \\
\text { título }\end{array}$ & $1(1.5 \%)$ & Título + nombre de pila & $1(2 \%)$ \\
\hline Término de respeto & $1(1.5 \%)$ & Apellido & $1(2 \%)$ \\
\hline $\begin{array}{l}\text { Término de cortesía + } \\
\text { Hipocorístico }\end{array}$ & $1(1.5 \%)$ & Término de respeto & $0(0 \%)$ \\
\hline Apellido & $0(0 \%)$ & $\begin{array}{l}\text { Término de cortesía + } \\
\text { Hipocorístico }\end{array}$ & $0(0 \%)$ \\
\hline \multicolumn{2}{|c|}{ Total } & $63(100 \%)$ & \multicolumn{2}{c}{ Total } & $44(100 \%)$ \\
\hline
\end{tabular}

Tabla 27. Distribución de enunciados, según tipos de fórmulas de tratamiento empleadas por mayores y menores en el grupo malayo

\begin{tabular}{|l|c|l|c|}
\hline \multicolumn{1}{|c|}{ Fórmulas } & Mayor & \multicolumn{1}{c|}{ Fórmulas } & Menor \\
\hline Título & $72(50 \%)$ & Título & $61(55 \%)$ \\
\hline Término de cortesía & $27(19 \%)$ & Nombre de pila & $22(20 \%)$ \\
\hline Hipocorístico & $25(17 \%)$ & Término de cortesía & $15(14 \%)$ \\
\hline Nombre de pila & $16(11 \%)$ & Hipocorístico & $5(4 \%)$ \\
\hline Término parentesco & $1(1 \%)$ & Término parentesco & $5(4 \%)$ \\
\hline $\begin{array}{l}\text { Término de cortesía + } \\
\text { título }\end{array}$ & $1(1 \%)$ & Término ocasional & $3(3 \%)$ \\
\hline Término afectivo & $1(1 \%)$ & $\begin{array}{l}\text { Término de cortesía + } \\
\text { título }\end{array}$ & $0(0 \%)$ \\
\hline Término ocasional & $0(0 \%)$ & Término afectivo & $0(0 \%)$ \\
\hline \multicolumn{1}{|c|}{ Total } & $143(100 \%)$ & & $111(100 \%)$ \\
\hline
\end{tabular}


Tanto los sujetos mayores como los jóvenes de las dos comunidades de habla mostraron la misma preferencia por dirigirse a los interlocutores utilizando, en el caso español, el "Nombre de pila" (aparece en el $62 \%$ de los enunciados de los mayores y en el $59 \%$ de los menores) y, en el malayo, un "Título" (en un 50\% y un 55\%, respectivamente). En lo que concierne al segundo tipo más utilizado, los participantes de la comunidad española de ambos grupos de edad emplearon un "Término ocasional", con un $12.4 \%$ del total de los enunciados producidos por los sujetos de más edad y un $14 \%$ de los más jóvenes. Por otro lado en los datos de los encuestados mayores de la comunidad malaya, encontramos en el segundo lugar, según la frecuencia de uso, los "Términos de cortesía", mientras que en las peticiones de los jóvenes son los "Nombres de pila", con un $20 \%$ de los casos, la fórmula más empleada por detrás de los "Títulos".

En relación con las fórmulas de las que no se encontraron ejemplos de uso, o que se usaron menos, en los datos españoles ningún mayor aplicó el "Apellido" para dirigirse a los interlocutores, aunque sí apareció en el corpus de los menores con una frecuencia del $2 \%$. En cambio, no se encontró ningún caso con un "Término de respeto" ni con "Término de cortesía + hipocorístico" en las peticiones de los jóvenes, pero los del otro subgrupo los aplicaron una vez cada uno, lo que representa, respectivamente, el $1.5 \%$ de 
los enunciados totales. Por otra parte, no apareció ningún ejemplo de "Término ocasional" en los mayores malayos, pero los jóvenes sí lo hacen en un $30 \%$ de los casos. Por el contrario, ningún menor malayo se dirigió a sus destinatarios, al realizar la petición, con un "Término de cortesía" unido a un "Título" ni con un "Término afectivo", pero estos tipos de saludo sí están presentes en las respuestas dadas por los mayores, aunque tan solo en el $1 \%$ de los casos. Aún así, se trata de una diferencia destacable.

Según el resultado estadístico respecto al uso de las fórmulas de tratamiento en los subgrupos de género, y de manera similar al caso anterior, los varones y las mujeres coinciden en su tendencia hacia un mayor uso del "Nombre de pila" en el corpus español, y de un "Título" en el malayo. Ahora bien, los sujetos participantes de los dos géneros se diferenciaron, en ambas sociedades, en la frecuencia con la que aplicaron las fórmulas. Las tablas 28 y 29 que se presentan a continuación demuestran dichas diferencias. 
Tabla 28. Distribución de enunciados según tipos de fórmulas de tratamiento empleadas por cada subgrupo de género en la sociedad española

\begin{tabular}{|l|c|l|c|}
\hline \multicolumn{1}{|c|}{ Fórmulas } & Varón & \multicolumn{1}{c|}{ Fórmulas } & Mujer \\
\hline Nombre de pila & $23(45 \%)$ & Nombre de pila & $42(75 \%)$ \\
\hline Término ocasional & $11(21 \%)$ & $\begin{array}{l}\text { Término de cortesía + } \\
\text { nombre de pila }\end{array}$ & $4(7 \%)$ \\
\hline Hipocorístico & $5(10 \%)$ & Título & $4(7 \%)$ \\
\hline $\begin{array}{l}\text { Término de cortesía + } \\
\text { nombre de pila }\end{array}$ & $3(6 \%)$ & Término ocasional & $3(5 \%)$ \\
\hline $\begin{array}{l}\text { Término de cortesía + } \\
\text { título }\end{array}$ & $3(6 \%)$ & Hipocorístico & $1(2 \%)$ \\
\hline Título & $2(4 \%)$ & Título + nombre de pila & $1(2 \%)$ \\
\hline Título + nombre de pila & $2(4 \%)$ & Término de respeto & $1(1 \%)$ \\
\hline $\begin{array}{l}\text { Término de cortesía + } \\
\text { Hipocorístico }\end{array}$ & $1(2 \%)$ & $\begin{array}{l}\text { Término de cortesía + } \\
\text { título }\end{array}$ & $0(0 \%)$ \\
\hline Apellido & $1(2 \%)$ & $\begin{array}{l}\text { Término de cortesía + } \\
\text { Hipocorístico }\end{array}$ & $0(0 \%)$ \\
\hline Término de respeto & $0(0 \%)$ & Apellido & $0(0 \%)$ \\
\hline \multicolumn{2}{|c|}{ Total } & $51(100 \%)$ & \multicolumn{2}{c}{ Total } & $56(100 \%)$ \\
\hline
\end{tabular}

Tabla 29. Distribución de enunciados según tipos de fórmulas de tratamiento empleadas por cada subgrupo de género en la sociedad malaya

\begin{tabular}{|l|c|l|c|}
\hline \multicolumn{1}{|c|}{ Fórmulas } & Varón & \multicolumn{1}{c|}{ Fórmulas } & Mujer \\
\hline Título & $63(55 \%)$ & Título & $70(50 \%)$ \\
\hline Hipocorístico & $22(19 \%)$ & Nombre de pila & $31(22 \%)$ \\
\hline Término de cortesía & $15(13 \%)$ & Término de cortesía & $27(19 \%)$ \\
\hline Nombre de pila & $7(6 \%)$ & Hipocorístico & $8(6 \%)$ \\
\hline Término parentesco & $4(3.4 \%)$ & Término parentesco & $2(2 \%)$ \\
\hline Término ocasional & $3(2.6 \%)$ & Término afectivo & $1(1 \%)$ \\
\hline $\begin{array}{l}\text { Término de cortesía + } \\
\text { título }\end{array}$ & $1(1 \%)$ & Término ocasional & $0(0 \%)$ \\
\hline Término afectivo & $0(0 \%)$ & $\begin{array}{l}\text { Término de cortesía + } \\
\text { título }\end{array}$ & $0(0 \%)$ \\
\hline \multicolumn{2}{|c|}{ Total } & $115(100 \%)$ & \multicolumn{2}{|c}{ Total } & $139(100 \%)$ \\
\hline
\end{tabular}


Como se observa en las tablas de datos, pese a que los dos grupos españoles de género examinados exhiban su preferencia por el uso de "Nombres de pila", llama la atención la mayor frecuencia con la que aparecen en el corpus de las mujeres, con 42 casos (el $75 \%$ de los enunciados totales), frente a los sujetos varones, que los emplean en un $45 \%$ de los casos. En cambio, los dos subgrupos de género malayos no se diferenciaron mucho, ya que en un $55 \%$ de las peticiones de los varones y en un $50 \%$ de las mujeres aparece un "Título". En la segunda forma más empleada, sí que encontramos diferencias entre los sujetos de ambos géneros, tanto españoles como los malayos, ya que los varones españoles eligieron la opción del "Término ocasional" y las mujeres la del "Término de cortesía + nombre de pila", mientras que en el grupo malayo, los varones utilizaron la fórmula del "Hipocorístico" y las mujeres la del "Nombre de pila".

Otra diferencia relevante entre los dos subgrupos de género españoles es la que tiene que ver con el uso de "Términos ocasionales", que los varones emplearon cuatro veces más que las mujeres (aparece en el $21 \%$ de las respuestas de los varones en comparación con solo el $5 \%$ de las mujeres). Por otro lado, en los subgrupos malayos, hay una diferencia importante en la utilización de los "Hipocorísticos" y los "Nombres de pila", ya que los varones aplicaron la primera forma tres veces más que las mujeres (la 
encontramos en el $19 \%$ de las respuestas de los varones y en el $6 \%$ de las mujeres). Pero en el caso de los "Nombres de pila" fue al revés, ya que las mujeres los utilizaron casi cuatro veces más que los varones (representan el $22 \%$ de las fórmulas empleadas por las mujeres frente al $6 \%$ de los varones).

Respecto a las opciones que no fueron seleccionadas por los sujetos participantes, o que aparecen en muy pocas ocasiones, no hay ningún ejemplo de "Término de respeto" en los datos de los varones españoles, pero sí está presente en las peticiones de las mujeres. Y, mientras que no se encontró ningún caso de "Término de cortesía + título", "Término de cortesía + hipocorístico" y "Apellido" en los datos de las mujeres, sí que se utilizan en los de los hombres, representando, la primera de las fórmulas mencionadas, el $6 \%$ de los enunciados totales y, cada una de las otras dos, el $2 \%$. En el grupo malayo, por su parte, ningún varón usó un "Término afectivo", pero las mujeres sí lo hicieron en un $1 \%$ de casos. En cambio, no se encontró ningún caso de "Término ocasional" y "Término de cortesía + título" en los datos de las mujeres, aunque sí estaban presentes en el $2,6 \%$ y en el $1 \%$, respectivamente, de las peticiones de los varones. 


\subsubsection{Modificaciones gramaticales}

En lo referente al empleo de las formas Condicional/Imperfecto de Subjuntivo/Imperfecto de Indicativo en los datos españoles, se han encontrado un total de 177 casos, que representan el $49 \%$ de los enunciados. El mayor o menor uso que hacen de estas formas en sus respuestas los sujetos participantes de nuestro cuestionario, teniendo en cuenta las variables de sexo y edad, queda reflejado en las siguientes tablas:

Tablas 30. Distribución del cambio de forma verbal en el grupo español según edad en las seis situaciones

\begin{tabular}{|c|c|c|c|}
\hline \multicolumn{2}{|c|}{ Mayor } & \multicolumn{2}{c|}{ Menor } \\
\hline Frecuencia & $\%$ & Frecuencia & $\%$ \\
\hline 97 & $55 \%$ & 80 & $45 \%$ \\
\hline
\end{tabular}

Tablas 31. Distribución del cambio de forma verbal en el grupo español según sexo en las seis situaciones

\begin{tabular}{|c|c|c|c|}
\hline \multicolumn{2}{|c|}{ Hombre } & \multicolumn{2}{c|}{ Mujer } \\
\hline Frecuencia & $\%$ & Frecuencia & $\%$ \\
\hline 82 & $46 \%$ & 95 & $54 \%$ \\
\hline
\end{tabular}

Fueron los hablantes mayores los que optaron en mayor medida por las formas Condicional/Imperfecto de Subjuntivo/Imperfecto de Indicativo (las emplearon en un 55\% de los casos) en comparación con los menores (45\%). En la 
comparación entre los enunciados de hombres y mujeres, descubrimos que el grado de aparición de dichas formas fue estadísticamente más alto en las respuestas de las mujeres, de manera que, mientras que, en su caso, las encontramos en un $54 \%$ de los enunciados recogidos, en el de los hombres el porcentaje se reduce al $46 \%$.

A continuación, pasamos a examinar cómo modificaron sintácticamente los nativos malayos sus peticiones, teniendo en cuenta que no existe un sistema comparable en el malayo, ya que no hay conjugación verbal. En cambio, en el malayo se usan normalmente algunas partículas o sufijos para modificar las expresiones de forma que causen un mayor impacto en los oyentes. En las respuestas de los participantes malayos, se han detectado siete formas diferentes de modificación, cuyo índice de frecuencia presentamos en la siguiente tabla: 
Tabla 32. Distribución del uso de partículas en las seis situaciones en el grupo malayo

\begin{tabular}{|c|c|c|}
\hline Tipo & Frecuencia & $\%$ \\
\hline $\begin{array}{l}\text { Verbo + kan } \\
\text { "Saya perlukan surat sokongan untuk memohon pekerjaan" } \\
\text { ('Yo necesitarkan carta recomendación para solicitar } \\
\text { trabajo/Necesito una carta de recomendación para pedir un } \\
\text { trabajo') }\end{array}$ & 88 & $46 \%$ \\
\hline $\begin{array}{l}\text { Boleh + tak ('Poder + no') } \\
\text { “Boleh tak pinjam tangga?" } \\
\text { ('Poder no pedir prestado escalera?/¿No se podría pedir } \\
\text { prestada la escalera?') }\end{array}$ & 54 & $27 \%$ \\
\hline $\begin{array}{l}\text { Verbo + lah } \\
\text { "Datanglah rumah" } \\
\text { ('Venirlah casa/Ven a casa') }\end{array}$ & 20 & $10 \%$ \\
\hline $\begin{array}{l}\text { Boleh + tak ('Poder + no') + Verbo + kan } \\
\text { “Boleh tak temankan saya?” } \\
\text { ('Poder no acompañar yo?/¿No podrías acompañarme?’) }\end{array}$ & 15 & $8 \%$ \\
\hline $\begin{array}{l}\text { Verbo + kah } \\
\text { “Bolehkah kau teman aku malam ni?" } \\
\text { ('Poderkah acompañar yo noche esta?/¿'Puedes acompañarme } \\
\text { esta noche?') }\end{array}$ & 12 & $6 \%$ \\
\hline $\begin{array}{l}\text { Verbo + kah + Verbo + kan } \\
\text { “Bolehkah anda tolong belikan buah salak?” } \\
\text { ('Poderkah tú ayudar comprarkan fruta salak?/¿Puedes } \\
\text { hacerme el favor de comprarme salak?') }\end{array}$ & 3 & $2 \%$ \\
\hline $\begin{array}{l}\text { Verbo + lah + Verbo + kan } \\
\text { "Jomlah temankan saya shopping" } \\
\text { ('Vamos/ah acompañarkan yo hacer compras/Vamos, } \\
\text { acompáñarme a hacer compras') }\end{array}$ & 1 & $1 \%$ \\
\hline Total & 193 & $100 \%$ \\
\hline
\end{tabular}

La modificación mayoritaria, como queda patente en los resultados obtenidos en nuestro análisis, consiste en el uso del sufijo kan detrás del verbo (en el $46 \%$ de los casos), seguida de las formas boleh + no (27\%) y verbo + lah (10\%). Al comparar la frecuencia de uso de estas tres formas los enunciados producidos por los hablantes 
de más edad y los de menos edad, las diferencias no resultan llamativas. Ahora bien, cuando contrastamos las respuestas de hombres y mujeres, la tendencia marcada por los primeros hacia el uso de kan fue más firme que la de las segundas, es decir, las diferencias entre los sexos fueron más notables que las diferencias entre los subgrupos de edad con respecto a la forma mayoritaria (véanse las Tablas 33 y 34).

Tablas 33. Distribución del uso de partículas en el corpus malayo, según edad, en las seis situaciones de mandato

\begin{tabular}{|c|c|c|c|c|}
\hline \multirow{2}{*}{ Tipo } & \multicolumn{2}{|c|}{ Mayor } & \multicolumn{2}{|c|}{ Menor } \\
\hline & $\mathbf{F}$ & $\%$ & $\mathbf{F}$ & $\%$ \\
\hline Verbo + kan & 43 & $44 \%$ & 45 & $48 \%$ \\
\hline Boleh + tak ('Poder + no') & 29 & $29 \%$ & 25 & $27 \%$ \\
\hline Verbo + lah & 10 & $10 \%$ & 10 & $11 \%$ \\
\hline Boleh + tak ('Poder + no') + Verbo + kan & 10 & $10 \%$ & 5 & $5 \%$ \\
\hline Verbo + kah & 6 & $6 \%$ & 6 & $6 \%$ \\
\hline Verbo + kah + Verbo + kan & 0 & $0 \%$ & 3 & $3 \%$ \\
\hline Verbo + lah + Verbo + kan & 1 & $1 \%$ & 0 & $0 \%$ \\
\hline Total & 99 & $100 \%$ & 94 & $100 \%$ \\
\hline
\end{tabular}

Tablas 34. Distribución del uso de partículas en el corpus malayo, según sexo, en las seis situaciones de mandato

\begin{tabular}{|c|c|c|c|c|}
\hline \multirow{2}{*}{ Tipo } & \multicolumn{2}{|c|}{ Hombre } & \multicolumn{2}{|c|}{ Mujer } \\
\hline & $\mathbf{F}$ & $\%$ & $\mathbf{F}$ & $\%$ \\
\hline Verbo + kan & 42 & $51 \%$ & 46 & $41 \%$ \\
\hline Boleh + tak ('Poder + no') & 22 & $27 \%$ & 32 & $29 \%$ \\
\hline Verbo + lah & 10 & $12 \%$ & 10 & $9 \%$ \\
\hline Boleh + tak ('Poder + no') + Verbo + kan & 5 & $6 \%$ & 10 & $9 \%$ \\
\hline Verbo + kah & 3 & $4 \%$ & 9 & $8 \%$ \\
\hline Verbo + kah + Verbo + kan & 0 & $0 \%$ & 3 & $3 \%$ \\
\hline Verbo + lah + Verbo + kan & 0 & $0 \%$ & 1 & $1 \%$ \\
\hline Total & 82 & $100 \%$ & 111 & $100 \%$ \\
\hline
\end{tabular}




\subsubsection{Perspectiva de la persona}

Sin duda alguna, es muy destacable la diferencia mostrada entre los españoles y los malayos en la perspectiva de la persona (' person perspective ) al hacer sus peticiones. Como ya se ha mencionado en el capítulo 2 (véase la página 57), con respecto a la perspectiva de la persona, una expresión de petición puede ser de varios tipos: Orientada al oyente (con énfasis en el rol del oyente, por ejemplo, "¿Me dejas tu portátil?"), Orientada al hablante (con énfasis en el rol del hablante, por ejemplo, "¿Puedo utilizar tu portátil?"), Orientada hacia el hablante y el oyente (incluyendo a ambos, por ejemplo, "¿Podemos limpiarlo ahora?) y Neutra (una petición impersonal puede presentarse como una petición indirecta no convencional, por ejemplo, "Hay que limpiarlo."). Todas las peticiones españolas en las que se usa una "Interrogación preparatoria", fueron del tipo Orientada al oyente, es decir, las expresiones en las peticiones pusieron el énfasis solo en el rol del oyente, como "¿puedes venir a

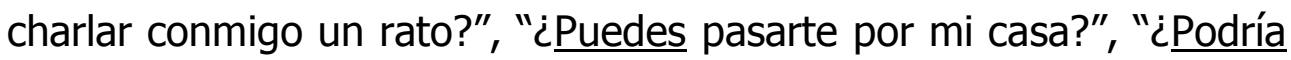
realizarme una carta de recomendación?", "¿uedes traerme una lata de caviar?", "Puedes prestarme la tuya?", "¿Me acompañas a la compra?", etc. No se encontró ningún caso de petición Orientada al hablante ni Orientada hacia el hablante y el oyente ni Neutra en los datos españoles. 
En cambio, los malayos incluyeron 3 tipos de perspectiva de la persona en sus expresiones de petición con una "Interrogación preparatoria": expresiones orientadas al hablante, al oyente $y$ neutras. La distribución de las peticiones del grupo malayo según estos tres tipos de perspectiva se muestra en la tabla que presentamos a continuación:

Tabla 35. Distribución del porcentaje de peticiones con una "Interrogación preparatoria" según la perspectiva de la persona en el corpus malayo

\begin{tabular}{|l|c|}
\hline \multicolumn{2}{|c|}{ Malayo } \\
\hline Orientada al hablante & $40 \%$ \\
\hline Orientada al oyente & $20 \%$ \\
\hline Orientado hacia el hablante y el oyente & $0 \%$ \\
\hline Neutro & $40 \%$ \\
\hline Total & $100 \%$ \\
\hline
\end{tabular}

De acuerdo con los datos presentados en la Tabla 35, el $40 \%$ de las expresiones en las peticiones con una "Interrogación preparatoria" estaban orientadas hacia el hablante, como en "Boleh saya pinjam tangga?" ('Poder yo pedir prestada escalera?/¿Puedo pedir prestada la escalera?'), "Boleh saya dapatkan surat sokongan prof?" ( 'Poder yo tomar carta recomendación prof?/¿ Puedo obtener una carta de recomendación suya?'), "Boleh saya kirim buah salak?" ('Poder yo pedir comprar fruta salak?/¿Puedo pedirte que me compres salak?'), "Boleh saya pinjam telefon awak?" ('Poder yo pedir prestado móvil tú?/¿¿Puedo pedir prestado tu teléfono?'), etc. 
El otro $40 \%$ fueron del tipo neutro, como "Boleh pinjam tangga?" (' Poder pedir prestado escalera?/¿Se podría pedir prestada la escalera?'), "Boleh teman saya pergi membeli belah?" (' acompañar yo ir hacer compras?/¿Se podría acompañarme a hacer compras?'), "Boleh temankan saya di rumah?" (' yo en casa?/¿Se puede acompañarme en casa?'), "Boleh tak belikan

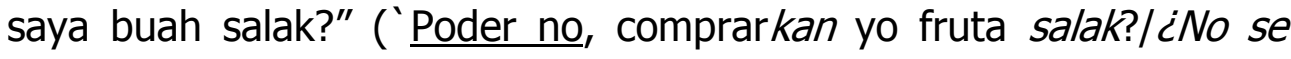
podría comprarme salak?'), "Boleh tak tolong saya?" (' ayudar yo?(¿No se me podría ayudar?'), etc. Por último, el $20 \%$ de las expresiones en las peticiones malayas del mismo contexto estaban orientadas al oyente, como "Boleh tak awak teman saya shopping hari ini?" ( este?/¿No puedes acompañarme a hacer compras hoy?'), "Boleh awak temankan saya malam ni?" ( ' Poder tú acompañarkan yo noche esta?/¿Puedes acompañarme esta noche?'), "Boleh tak prof buat surat sokongan untuk saya?" ( 'Poder no prof, hacer una carta recomendación para yo?/¿No podría profesor hacerme una carta de recomendación?'), "Boleh tak awak belikan saya buah salak?" ('Poder no, tú comprarkan yo fruta salak?/¿No podrías comprarme salak?'), etc.

En el caso del grupo malayo se muestra una mayor inclinación al empleo de expresiones orientadas al hablante, puesto que poner énfasis en el oyente se considera menos cortés en esa 
cultura al implicar la obligación de los destinatarios de hacer lo que les pidan los emisores. Asimismo, si los oyentes rechazan la petición, no se va a perder tanto su imagen social, ya que el énfasis está puesto en la parte del hablante no en la parte del oyente. Hay que recordar también que, como ya se ha dicho antes, la lengua malaya no tiene tiempos verbales. Por tanto, para que una expresión sea cortés, se utilizan diferentes recursos, como la combinación con ciertas partículas, como se ha visto anteriormente, o el uso de la orientación hacia el hablante, aplicada con el fin de salvaguardar la imagen del oyente. En cambio, en la cultura española, al tener, por ejemplo, la forma del Condicional, no se percibe esa falta de cortesía en las peticiones orientadas al oyente. Además, nos parece que, desde el punto de vista de los españoles, preguntar utilizando la perspectiva de orientación al oyente tampoco se ve como descortés, porque generalmente, o quizás naturalmente, los españoles son más directos en sus expresiones diarias en comparación con los malayos.

A continuación, pasamos a examinar la distribución de la perspectiva de persona aplicada en las expresiones de las peticiones de nuestro estudio, según los subgrupos de sexo y edad. Al contrario que en el caso anterior, solo se van a analizar los tipos de perspectiva en las peticiones de los sujetos de los subgrupos malayos, dado que solo se encontró una categoría de perspectiva en los datos españoles. 
Tabla 36. Distribución del porcentaje de peticiones con una "Interrogación preparatoria" según la perspectiva de la persona en los subgrupos malayos

\begin{tabular}{|l|c|c|c|c|}
\hline \multirow{2}{*}{$\begin{array}{c}\text { Subgrupos } \\
\text { Malayos }\end{array}$} & $\begin{array}{c}\text { Orientada al } \\
\text { hablante }\end{array}$ & $\begin{array}{c}\text { Orientada al } \\
\text { oyente }\end{array}$ & $\begin{array}{c}\text { Orientado } \\
\text { hacia el } \\
\text { hablante y el } \\
\text { oyente }\end{array}$ & Neutro \\
\hline Mayor & $48 \%$ & $17 \%$ & $0 \%$ & $35 \%$ \\
\hline Menor & $31 \%$ & $24 \%$ & $0 \%$ & $45 \%$ \\
\hline Varón & $36 \%$ & $17 \%$ & $0 \%$ & $47 \%$ \\
\hline Mujer & $43 \%$ & $23 \%$ & $0 \%$ & $34 \%$ \\
\hline
\end{tabular}

Los sujetos mayores malayos mostraron preferencia por las expresiones orientadas al hablante (aparecen en el $48 \%$ de sus enunciados), seguidas de las neutras (35\%) y de las orientadas al oyente (17\%). Los jóvenes, por su parte, mostraron una mayor tendencia hacia el uso de las neutras (45\%), seguidas de las orientadas al hablante (31\%) y las orientadas al oyente (24\%). Por otro lado, el patrón demostrado por los sujetos de los subgrupos de sexo fue similar al de los subgrupos de edad. La mayoría de las expresiones de las peticiones formuladas por los varones malayos fueron neutras (47\%), pero también, en buena medida, orientadas al hablante (36\%) y, en bastantes menos casos, orientadas al oyente (17\%). Mientras que las mujeres prefirieron, en primer, lugar realizar su petición con una expresión centrada en el hablante (lo hacen en el $43 \%$ de los enunciados), también eligen en buen número de casos la perspectiva neutra (34\%) y la orientación al oyente (23\%). No se encontró ninguna expresión orientada hacia hablante y oyente en los datos de todos los subgrupos en este contexto. 


\subsubsection{Análisis situacional}

En esta sección se van a mostrar los resultados del análisis pormenorizado de las respuestas formuladas por los sujetos participantes en las 6 situaciones de petición que constituyen el cuestionario.

\subsubsection{Situación 1}

En esta situación el grado de familiaridad entre los interlocutores es bajo, ya que el hablante es nuevo en el barrio y tiene que pedir prestada una escalera al oyente, que es uno de sus vecinos.

Como era de esperar, la mayoría de las peticiones en esta situación, tanto españolas como malayas, estuvo encabezada de un saludo o presentación (así fue en el $62 \%$ de los enunciados de los españoles y en el $87 \%$ de los de los malayos), como en los ejemplos que presentamos a continuación:

Ejemplos españoles:

(1) Hola, soy el vecino de enfrente.

(2) Buenas tardes, soy su vecino.

(3) Hola soy su vecino de al lado. 
Ejemplos malayos:

(4) Assalamualaikum, saya jiran baru.

('La paz sea con ustedes, yo vecino nuevo/ La paz sea con ustedes, soy el vecino nuevo')

(5) Assalamualaikum, saya baru pindah.

('La paz sea con ustedes, yo acabar mudar/ La paz sea con usted, yo me acabo de mudar')

(6) Assalamualaikum, saya Ahmad.

('La paz sea con ustedes, yo Ahmad/ La paz sea con usted. Soy Ahmad')

Más de la mitad de los hablantes españoles (el 79\%) formuló sus peticiones en esta situación por medio de la estrategia de "Interrogación preparatoria". Y, la mayoría de las preguntas realizadas por los informantes españoles están formuladas con un fundamento de "Capacidad/posibilidad", utilizando el verbo poder en Condicional en un $81 \%$ de los casos. Por otro lado, la opción mayoritaria en los enunciados de los hablantes malayos coincidió con la de los españoles, aunque en su caso el porcentaje de uso fue del $67 \%$. Y el $100 \%$ de los hablantes participantes que utilizaron este modo para emitir una petición, lo hicieron con la forma boleh ('poder ) (78\% de los casos). 
Ejemplos españoles:

(7) ¿Podrías prestarme una escalera?

Ejemplos malayos:

(8) Boleh saya pinjam tangga?

('Poder yo pedir prestado escalera?/¿Te puedo pedir prestada una escalera?')

Según nuestros datos, no se han registrado variaciones importantes en el número de peticiones formuladas con el fundamento de "Capacidad/posibilidad" ni al comparar los datos de los sujetos mayores y sujetos menores, ni los de hombres y mujeres, en ambas culturas. Aun así, hay que decir que fueron los jóvenes del grupo español los que fundamentaron sus peticiones de esa manera en un mayor número de casos, ya que esto ocurre en el $54 \%$ de sus enunciados, frente al $46 \%$ del otro subgrupo de edad. $Y$, por otro lado, fueron las mujeres quienes más recurrieron a este tipo estrategia (la encontramos en el $59 \%$ de las respuestas de las mujeres frente al $41 \%$ de las de los varones). Lo interesante es que ocurrió al revés en el grupo malayo, puesto que los mayores la utilizaron en un mayor número de ocasiones en comparación con los menores (está presente en el $65 \%$ de las peticiones de los mayores frente al $35 \%$ de los menores), mientras que, en el caso de los subgrupos de sexo, fueron los hombres los que se inclinaron a 
expresar su petición de esta manera (en un 55\% de los casos, frente al $45 \%$ de las mujeres).

Es notable la diferencia mostrada entre ambas culturas con respecto al uso de las "Fórmulas de tratamiento", ya que, mientras que no se encuentran ejemplos en los datos de los españoles, sí que apareció dicha estrategia en los datos malayos en 36 ocasiones. Ahora bien, el "Término de cortesía" fue el recurso más usado por los sujetos malayos (lo vemos en el $83 \%$ de los enunciados) para dirigirse a su vecino desconocido. Por ejemplo, emplearon encik/puan ('señor/señora '), como en:

(9) Boleh saya pinjam tangga encik?

('Poder yo pedir prestado escalera señor?/¿Le puedo pedir prestada una escalera?')

(10) Kalau encik ada tangga, boleh saya pinjam sekejap?

( 'Si señor tener escalera, poder yo pedir prestado un segundo?/Si tiene una escalera, ¿puedo pedírsela prestada?')

(11) Saya perlu pinjam tangga jika puan ada.

('Yo necesitar pedir prestado escalera si señora tener/Yo necesitaría pedirle prestada una escalera, si Vd. tiene') 
Puan, boleh saya pinjam tangga?

( 'Señora, poder yo pedir prestado escalera?/Señora, ¿Le puedo pedir prestada una escalera?')

Cuando se subdividió el análisis en los subgrupos correspondientes, se encontró que fueron los participantes mayores los que prefirieron dirigirse a su destinatario utilizando un "Término de cortesía", con un porcentaje de muestras del $70 \%$, en contraste con el $30 \%$ de los menores, $y$, en el otro caso, las mujeres lo emplearon en un mayor número que los varones (en el $77 \%$ de sus respuestas, en comparación con solo el $23 \%$ de los varones).

Cabe mencionar también el uso de usted que aparece en la mitad de las fórmulas pronominales empleadas para dirigirse al interlocutor en este escenario (53\%). Por otro lado, en el grupo malayo, la forma awak fue la mayoritaria entre los encuestados (51\%). En los dos grupos, español y malayo, la tendencia hacia el uso de dichas formas fue más firme en los jóvenes en comparación con los mayores (aparece en el $59 \%$ y $40 \%$ de las respuestas, respectivamente, en el grupo español, y en el $61 \%$ y $39 \%$, en el otro), y más notable en las mujeres, en contraste con los hombres (lo emplearon en un $56 \%$ y $43 \%$ de casos, respectivamente, en el primer grupo, y en un $68 \%$ y $31 \%$ en el segundo). 
Según los resultados obtenidos, el $83 \%$ de los participantes españoles aplicaron la forma Condicional del verbo en sus peticiones. Las diferencias en la frecuencia de uso de este tiempo verbal entre los participantes de más edad y los de menos, y entre los hombres y las mujeres, fueron insignificantes. En cambio, en el corpus malayo, no hubo muchas modificaciones hechas por los informantes, excepto en el caso de de la utilización de tak, que aparece en el $15 \%$ de las respuestas. Tampoco se han observado diferencias importantes entre las respuestas recogidas de cada uno de los subgrupos, ni de edad ni de sexo.

Ejemplos españoles:

(13) ¿No tendrías una escalera para poder colgar una lámpara?

(14) Quería saber si me podría prestar una escalera.

(15) ¿Le importaría prestarme una escalera?

Ejemplos malayos:

(16) Boleh tak pinjamkan saya tangga?

('Poder no prestarkan yo escalera?/¿No podría prestarme una escalera?')

(17) Boleh tak saya nak pinjam tangga?

('Poder no yo querer pedir prestado escalera?/¿No me permitiría pedirle prestada una escalera?') 
Por último, en cuanto a la perspectiva de la persona, todas las expresiones de las peticiones españolas estaban orientadas al oyente $(100 \%)$. En cambio, la orientación mayoritaria de las expresiones de petición malaya correspondió al hablante (68\%). En este contexto, no hubo diferencias relevantes ni entre los subgrupos de edad ni entre los de sexo, en ambas culturas.

Ejemplos españoles:

(18) ¿Podrías prestarme la escalera tuya?

(19) ¿Tienes una escalera?

(20) ¿Me dejas una escalera?

Ejemplos malayos:

(21) Boleh saya pinjam tangga?

('Poder yo pedir prestada escalera?/¿'iPuedo pedirte prestada la escalera?')

(22) Boleh tak saya nak pinjam tangga?

( 'Poder no yo querer pedir prestada escalera?/¿Quería pedirte prestada una escalera, ¿puedo?') 


\subsubsection{Situación 4}

En esta situación se trata de formular una petición a un compañero de piso, por eso el grado de familiaridad es alto. Los informantes de ambos países prefirieron iniciar sus peticiones directamente con los actos principales, es decir, con las peticiones en sí mismas. Aun así, los nativos de ambas sociedades mostraron preferencia por distintas estrategias: los españoles tendieron hacia el uso de la de "Interrogación preparatoria" (aparece en el $47 \%$ de los casos) y los malayos hacia la de "Fórmula de sugerencia" (aparece en el 52\% de sus enunciados). Hay que subrayar que el fundamento mayoritario de la estrategia mencionada en el corpus español corresponde al de "Predicción de acción futura del oyente" (48\%). Por otra parte, respecto al uso de "Fórmula de sugerencia" en el corpus malayo, casi todas las peticiones se hicieron mediante la forma de "Jom ('vamos')".

Ejemplos españoles:

(24) ¿Me acompañas a la compra?

Ejemplos malayos:

(25) Jom kita shopping. 
('Vamos nosotros hacer compras/Vamos a hacer compras')

(26) Jom pergi bandar, aku nak beli barang sikit.

( ' Vamos ir centro, yo querer comprar cosas/Vamos al centro, que quiero comprar algunas cosas')

(27) Jom temankan saya membeli belah.

( 'Vamos acompañarkan yo hacer compras/Acompáñame a hacer compras')

Al contrastar los subgrupos respectivos, observamos que los jóvenes españoles se sirvieron de las fórmulas de "Predicción de acción futura del oyente" más que los de mayor edad (aparece en el $64 \%$ de las ocasiones, en comparación con un $36 \%$ de los enunciados de los participantes mayores), mientras que los varones y las mujeres lo aplicaron con la misma frecuencia (ambos sexos en el 50\%). No hubo diferencias interesantes entre los subgrupos malayos en lo referente a la estrategia preferida.

Cabe destacar que ningún sujeto español utilizó la forma de usted en sus peticiones en esta situación, mientras que en el corpus malayo, la forma awak siguió siendo la más usada. En lo que concierne al uso de "Fórmulas de tratamiento", encontramos tres distintas en los datos españoles para dirigirse a un compañero de piso: "Nombre de pila" (aparece en el 52\% de sus respuestas), que 
es lo más usado, "Término ocasional" (24\%) e "Hipocorístico" (24\%). Por otro lado, los sujetos malayos se dirigieron a su oyente únicamente mediante dos formas: "Nombre de pila" (61\%) e "Hipocorístico" (39\%). Los ejemplos que aparecen abajo recogen las fórmulas de tratamiento que pertenecen a dichas categorías:

Ejemplos españoles:

(28) $\underline{x}$ (representa el nombre), voy a ir a compras, ¿me acompañas?

(29) iHola compañero! Voy a ir a hacer la compra. ¿Por qué no me acompañas?

(30) Fulano (representa el Hipocorístico), tengo que ir a la tienda. ¿Me echas una mano?

Ejemplos malayos:

(31) Farah (nombre de pila) jom teman saya membeli belah.

(' Farah vamos acompañar yo hacer compras/Farah, acompáñame a hacer unas compras')

(32) Ina (Hipocorístico), saya nak pergi beli belah di pasaraya. Boleh temankan tidak?

( Ina, yo querer ir hacer compras en supermercado, poder acompañarkan no?/Ina, quiero ir al supermercado a hacer unas compras, ¿puedes acompañarme, no?') 
No hubo diferencias significativas entre los datos de los subgrupos de edad españoles respecto a las fórmulas utilizadas para dirigirse a los destinatarios, pero sí las encontramos al comparar los enunciados producidos por los hablantes de uno y otro sexo. Así, las mujeres se inclinaron más hacia el uso del nombre propio (aparece en el $87 \%$ de sus respuestas), mientras que los hombres lo hicieron por el "Hipocorístico", que aparece en el $45 \%$ de los casos. En el grupo malayo, por otra parte, los dos subgrupos analizados, edad y sexo, demostraron distinta tendencia. Se aprecia que, mientras que los informantes mayores se concentraron en la forma de "Hipocorístico" (73\%), en los datos de los jóvenes la preferencia la encontramos en el uso del "Nombre de pila" (86\%). En el caso de las diferencias según el sexo, el tratamiento de "Hipocorístico" fue el más común entre los hombres (86\%), mientras que se evidenció la preferencia de las mujeres por el "Nombre de pila" (89\%).

En esta situación, no existe una gran tendencia a modificar las peticiones por el uso de la forma Condicional del verbo en los datos españoles, ya que solo aparece en el $15 \%$ de los enunciados. Y tampoco aparece una gran modificación sintáctica en los datos malayos, con solo un $18 \%$ del uso de kah y un $10 \%$ de tak.

Finalmente, al examinar qué orientación siguieron las expresiones realizadas en la presente situación, los grupos 
comparados mostraron algunas diferencias significativas. De forma similar a la situación anterior, los españoles mostraron una fuerte tendencia a la orientación hacia el oyente (en el $88 \%$ de los casos), en cambio, en los datos malayos la preferencia estuvo marcada por la orientación impersonal (67\%).

Ejemplos españoles:

(33) ¿Podría acompañarme?

(34) ¿Te vienes conmigo a comprar?

(35) ¿Quieres venir conmigo a comprar?

Ejemplos malayos:

(36) Boleh teman saya beli-belah?

('Poder acompañar yo hacer compras?/¿Se me puede acompañar a hacer unas compras?')

(37) Boleh teman saya keluar?

('Poder acompañar yo salir?/¿Se me puede acompañar?')

\subsubsection{Situación 7}

En esta situación, el grado de familiaridad entre los interlocutores es bastante alto, ya que en el cuestionario se especifica que el interlocutor es el mejor amigo del sujeto. De manera similar a la 
situación 4, la estrategia de "Interrogación preparatoria" sigue siendo la dominante entre los españoles (así lo hacen en el $40 \%$ de sus respuestas), y los malayos siguieron optando en mayor medida por la estrategia de "Fórmula de sugerencia" (50\%). A diferencia de la situación anterior, en esta las preguntas porcentualmente mayoritarias de las peticiones de los hablantes españoles tuvieron como fundamento la "Buena voluntad" (54\%), y la mayoría de las sugerencias hechas por los malayos incluían la palabra jom ( vamos ). Los ejemplos siguientes ilustran dichas formas:

Ejemplos españoles:

(38) ¿Quieres venir a casa a jugar una partida a la wii?

(39) ¿Te apetece venir a mi casa a ver la tele?

(40) Estoy solo en casa ¿te gustaría pasarte...?

Ejemplos malayos:

(41) Jom datang rumah aku sekarang

('Vamos venir casa yo ahora/Venga, ven ahora a mi casa')

(42) Jom teman aku kat rumah

('Vamos acompañar yo en casa/Venga, acompáñame a casa')

(43) Jom datang rumah, kita masak-masak!

('Vamos venir casa, nosotros cocinar-cocinar/Vamos a mi casa a cocinar') 
Ahora bien, al contrastar la preferencia mostrada por los subgrupos españoles, vemos que las preguntas que produjeron los sujetos mayores incluían mayoritariamente la forma de "Predicción de acción futura del oyente" (en el $42 \%$ de sus enunciados), mientras que los jóvenes mostraron mayor inclinación hacia las formas de "Buena voluntad" (30\%). En los subgrupos de sexo, mientras que los varones mostraron la tendencia hacia la "Buena voluntad" (aparece en el $41 \%$ de los casos), todas las mujeres emplearon la "Predicción de acción futura del oyente" al hacer las peticiones.
(44) ¿Te pasas por casa?
(45) ¿Vienes a mi casa a tomar un café?"
(46) ¿Te apetece venir a echar unas partidas?
(47) ¿Te apetece una peli y palomitas?

Debido a que la cercanía que se supone con el interlocutor es máxima, ya que se trataba del mejor amigo del sujeto participante, era de esperar la ausencia de la forma usted en el corpus español. Por otro lado en el corpus malayo, la forma awak fue la más aplicada (46\%). Respecto al análisis de las fórmulas de tratamiento, este revela que la forma dominante, que llega a aparecer en el $78 \%$ de los enunciados del corpus español y en un 
$50 \%$ del malayo, es la del "Nombre de pila". Por ejemplo, la mayoría de los informantes españoles respondieron:

(48) ¿Qué tal Raúl? ¿Qué haces? ¿Te apetece venir a mi casa?

(49) Hola María, me encuentro fatal ¿Puedes pasarte por mi casa?

(50) Ernesto ¿Vienes a mi casa? Estoy sola y me aburro.

Mientras que los malayos contestaron:

(51) Farah, aku boring kat rumah sorang-sorang. Jom datang temankan aku.

( 'Farah, yo aburrida en casa sola-sola. Vamos venir acompañar yo/Farah, estoy en casa sola y aburrida. Venga, ven a estar conmigo un rato ')

(52) Nadia, boleh temankan saya di rumah?

( Nadia, Poder acompañar yo en casa?/Nadia, ¿puedes venir a mi casa a hacerme compañía?')

(53) Fatimah... awak sibuk tak petang ni? Kalau tak, nak minta awak temankan saya kat rumah.

( ' Fatimah... tú ocupada no esta tarde? Si no, quiero pedir tú acompañar yo en casa/Fátima, ¿no estás ocupada esta tarde, no? Es que quería pedirte que vinieras a casa a hacerme compañía') 
Según nuestros datos, no se han producido diferencias importantes en el empleo de las fórmulas nominales en ninguno de los subgrupos de los sujetos españoles. En cambio, en el grupo malayo, si los participantes de más edad prefirieron dirigirse a los interlocutores mediante la forma del "Hipocorístico" (55\%), los de menos edad mostraron preferencia por el uso del "Nombre de pila" (67\%). Por otro lado, mientras que los hombres tendieron a aplicar un "Hipocorístico" para dirigirse a sus oyentes (y así lo hacen en el $67 \%$ de sus enunciados), las mujeres se inclinaron más hacia el empleo del "Nombre de pila" (aparece en un $82 \%$ de casos).

(54) Leha, tolong datang ke rumah aku boleh tak malam ni. ('Leha, ayudar venir a casa yo poder no noche esta/Leha, hazme el favor de venir esta noche a mi casa')

(55) Man, kalau ada kelapangan, saya nak jemput datang ke rumah.

('Man, si estar libre, yo querer invitar a casa/Man, si estás libre, quiero invitarte a casa')

Al igual que en el resultado de la situación 4, el uso de la forma Condicional del verbo entre los españoles en esta situación fue bajo, tan solo se encuentra en 10 casos, que corresponden al $16 \%$ del total. En los datos malayos, por otra parte, se ha notado el uso 
de la partícula lah con mayor frecuencia (está presente en el $43 \%$ de los enunciados) en comparación con otras situaciones.

(56) Jika berkalapangan, datanglah rumah aku.

('Si estar libre, venlah casa yo/Si estás libre, ven a mi casa')

(57) Jomlah teman aku kat rumah.

('Vamos/ah acompañar yo en casa/Ven a casa a estar conmigo')

Para terminar con el análisis de las respuestas producidas en la tercera situación planteada para el estudio de la petición, analizaremos la orientación elegida por cada grupo de nativos. Los españoles orientaron mayoritariamente las expresiones de sus peticiones hacia el oyente (así ocurre en el $72 \%$ de los enunciados), mientras que los malayos prefirieron ser neutros, es decir, prefirieron no marcar su orientación hacia ninguno de los interlocutores (69\%).

Ejemplos españoles:

(58) ¿Quieres venir a casa a jugar una partida de la wii?

(59) ¿Te vienes a tomar una cerveza en casa?

(60) ¿Podrías venir a casa esta tarde? 
Ejemplos malayos:

(61) Boleh datang rumah aku?

('Poder venir casa yo?/¿Puedes venir a mi casa?')

(62) Boleh temankan aku?

('Poder acompañarkan yo?/¿Puedes acompañarme?')

\subsubsection{Situación 10}

En este contexto, los informantes se sitúan en una posición inferior frente al profesor. Así pues, no nos sorprende que el 93\% de los encuestados españoles y el $50 \%$ de los malayos comenzaran su petición con los saludos y presentaciones. Los hablantes de ambas sociedades coincidieron en mostrar preferencia por la estrategia de "Interrogación preparatoria", presente en un 32\% de los enunciados de los españoles y en un $36 \%$ de los malayos. La mayoría de los informantes españoles formularon sus preguntas mediante formas de "Capacidad/posibilidad" (74\%), empleando el verbo poder en Condicional al formular su petición a un interlocutor de estatus social superior. Por otro lado, los informantes malayos aplicaron mayoritariamente la variedad de boleh $+\operatorname{tak}((p o d e r+n o)$. 
Algunos ejemplos de las peticiones producidas por los hablantes de ambas sociedades en la situación 10, y en los que aparecen las estrategias mencionadas son:

Ejemplos españoles:

(63) Buenos días, fui alumno suyo hace casi dos años... ¿ ¿Podría realizarme una carta de recomendación?

(64) Hola, soy un ex alumno suyo... Por favor, me piden un informe de recomendación, ¿me lo podría hacer usted?

(65) Buenos día, soy su antiguo alumno... ¿Podría redactarme una carta de recomendación para un trabajo que voy a pedir?

Ejemplos malayos:

(66) Assalamualaikum. Boleh tak saya mendapat surat sokongan daripada prof?

('La paz sea con ustedes. Poder no, yo tomar carta recomendación de profesor?/La paz sea con usted. ¿No podría hacerme, profesor, una carta de recomendación?')

(67) Assalamualaikum, Boleh tak profesor tolong sain surat sokongan ni?

( La paz sea con ustedes, Poder no, profesor ayuda firma carta de recomendación?/La paz sea con usted. ¿No podría, profesor, hacerme el favor de firmarme una carta de recomendación?') 
No se produjo ninguna diferencia significativa ni entre los subgrupos de edad ni entre los subgrupos de género, en este aspecto, en ambas culturas.

En este contexto, en el que existe jerarquía social, una gran mayoría de los encuestados malayos recurrieron al empleo de un "Título" (lo hicieron en el 92\% de los casos) para dirigirse a su profesor. Los españoles, por su parte, utilizaron el tratamiento de "Título" en un $24 \%$ de sus enunciados, y recurrieron a las formas de "Término de cortesía + nombre de pila" en la misma proporción (24\%).

Ejemplos españoles:

(68) Hola profesor, le quedaría muy agradecido si pudiera redactarme una carta de recomendación para un puesto de trabajo que voy a solicitar".

(69) Señor X (X representa el nombre de pila), me han pedido una carta de recomendación para un trabajo que me interesa mucho y me preguntaba si le importaría hacérmela usted".

Ejemplos malayos:

(70) Prof. boleh saya memohon bantuan? Saya nak dapatkan surat sokongan Prof. kerana saya ada temuduga lusa. 
('Prof, poder yo pedir ayuda? Yo querer tomarkan carta recomendación Prof porque yo tener entrevista pasado mañana/Profesor, ¿puedo pedirle ayuda? Necesito una carta de recomendación, profesor, porque tengo una entrevista pasado mañana').

(71) Prof, saya ingin memohon kerja, jadi saya ingin minta tolong Prof buat surat sokongan untuk saya.

('Prof, yo querer solicitar trabajo, entonces yo querer pedir ayudar Prof hacer carta recomendación para yo/Profesor, quiero solicitar un trabajo, y quería pedirle una carta de recomendación ').

Al examinar la variedad dominante en cada subgrupo, no se encontraron diferencias muy significativas ni entre los subgrupos de edad ni entre los de sexo, en ninguno de los dos países.

Hay que mencionar el alto porcentaje de utilización de la forma Condicional del verbo en los datos de los hablantes españoles, con un $85 \%$ de casos, lo cual corresponde a la mayor frecuencia de dicha forma en los resultados de las seis situaciones de petición. En cuanto a la modificación hecha en las peticiones malayas, encontramos que el sufijo kan fue la forma más usada entre los elementos presentes en los datos malayos, con un $58 \%$ de los casos. 
En este aspecto, tampoco se notan diferencias entre los subgrupos, ni de edad ni de sexo, en ninguna de las dos culturas.

Por último, examinamos la orientación elegida por los hablantes en sus peticiones a una persona de rango superior. La tendencia dominante de la comunidad de habla española sigue siendo la misma que las situaciones previas, es decir, hacia el oyente (82\%). En cambio, a diferencia de lo que mostraron anteriormente, la orientación mayoritaria de los malayos fue hacia el hablante (74\%). No hubo diferencias importantes en este contexto entre las respuestas de los participantes de ninguno de los subgrupos.

Ejemplos españoles:

(72) ¿Podría redactarme una carta de recomendación?

(73) ¿Podría usted hacerme una?

(74) ¿Le importaría hacérmela?

Ejemplos malayos:

(75) Boleh saya dapatkan surat sokongan daripada Prof?

('Poder yo tomarkan carta recomendación de Prof?/¿Puedo obtener de usted una carta de recomendación?') 
(76) Prof, saya perlukan surat sokongan untuk mendapat kerja.

('Prof, yo necesitarkan carta recomendación para trabajo/ Prof, necesito una carta de recomendación para un trabajo').

\subsubsection{Situación 13}

Los informantes de ambas sociedades coincidieron, una vez más, en un mayor porcentaje de utilización de la estrategia de "Interrogación preparatoria" para realizar las peticiones en este escenario (aparece en el $57 \%$ de los datos en español y en el $33 \%$ de los datos malayos). Los participantes españoles fundamentaron mayoritariamente sus preguntas en la "Capacidad/posibilidad" (71\%) y mostraron una tendencia destacada hacia la variedad de poder + Condicional (83\%). Por otro lado, los participantes malayos mostraron que, en este contexto, prefirieron realizar las preguntas utilizando las variedades de boleh + tak ( poder + no ), con un $35 \%$ de los enunciados, y boleh (' poder '), con un 30\%. En este caso, no se han hallado diferencias significativas entre los sujetos de todos los subgrupos en ninguna de las sociedades.

En este escenario, los sujetos de ambas sociedades emplearon, para empezar las peticiones, dos estrategias 
mayoritarias. En el grupo español, algunos sujetos comenzaron su petición con la estrategia de "Fórmulas de preparación" (35\%), es decir, comprobando la disponibilidad del oyente para completar la petición, mientras que algunos utilizaron "Saludos/presentaciones" (32\%). Por otra parte, algunos sujetos malayos también iniciaron su petición con "Fórmulas de preparación" (43\%), mientras que algunos prefirieron formular directamente la petición sin ningún movimiento de apoyo previo (38\%). Presentamos algunos ejemplos representativos de las tendencias que acabamos de describir, en el mismo orden en que han sido mencionadas.

Ejemplos españoles:

(77) Aprovechando que vas a viajar a Rusia, ¿me podrías hacer el favor de comprarme una lata de caviar?

(78) ¿Tienes ya todo preparado para el viaje? ¿Podrías comprarme una lata de caviar?

(79) Hola, me he enterado de que vas a hacer un viaje a Rusia... ¿Podrías traerme una lata de caviar?

Ejemplos malayos:

(80) Boleh tak belikan saya sedikit buah salak?

( ' Poder no comprarkan yo poco fruta salak?/¿No podría comprarme salak?')

(81) Boleh tak belikan saya buah salak masa pulang nanti? 
( ' $\underline{\text { Poder no }}$ comprarkan yo fruta salak cuando volver?/¿No podrías comprarme salak antes de volver?')

(82) Awak nak ke Indonesia, kan? Boleh tak belikan saya buah salak?

( ' Tú querer a Indonesia, verdad? Poder no comprarkan yo fruta salak?/¿Quieres ir a Indonesia, verdad? ¿No podrías comprarme salak?')

Como era de esperar, para dirigirse a un empleado normalmente se usa simplemente el nombre propio. Así pues, en este escenario, el "Nombre de pila" fue la fórmula preferida entre los participantes en los dos países. Pese a que los grupos coincidieran en mostrar preferencia por el tratamiento mencionado, fueron los españoles los que lo aplicaron con una frecuencia destacada en comparación con los malayos (en el $88 \%$ de los enunciados españoles, frente al $53 \%$ de los malayos). Los malayos también mostraron cierta tendencia hacia el empleo del "Hipocorístico", pero en menor grado que la primera forma, con un $41 \%$ de los casos. Del tratamiento pronominal, solo se han hallado 9 casos del uso de usted en el corpus español, que corresponde al $15 \%$ de las respuestas. Es lógico, puesto que en este escenario se hace una petición a una persona de estatus social más bajo. En el corpus malayo por su parte, se nota el incremento del uso de la forma awak, con un 33\% de los casos. 
Ejemplos españoles con nombres de pila fueron:

(83) Hola Enrique,...me han dicho que hay un caviar exquisito, ¿podrías traerme algo? Gracias.

(84) Hola Manuel, ya me he enterado que te vas a Rusia... ¿me podrías traer una lata de caviar?

(85) Hola Rubén, me han comentado que sales hacia Rusia este lunes, ¿podrías comprarme una latita de caviar?

Por otro lado, en los datos malayos se encontraron nombres como:

(86) Saleha, awak nak ke Indonesia atas urusan kerja, boleh belikan saya buah salak sebanyak $1 / 2 \mathrm{~kg}$ ?

('Saleha, tú querer a Indonesia sobre gestión trabajo, poder comprarkan yo fruta salak $1 / 2 \mathrm{~kg}$ ?/Saleha, vas a Indonesia por cuestiones del trabajo, ¿Puedes comprarme medio kilo de salak?')

(87) Azman, nanti tolong belikan buah salak untuk saya.

('Azman, luego ayudar comprarkan fruta salak para yo/ Azman, hazme luego el favor de comprarme salak')

(88) Ahmad, minggu depan awak ke Indonesia tak? Lepas tu nak minta belikan buah salak sikit, boleh?

(`Ahmad, semana viene tú a Indonesia no? luego querer pedir comprarkan fruta salak poco, poder?/ Ahmad, la 
semana que viene vas a Indonesia ino? Quería pedirte que me compraras luego un poco de salak').

Y también se emplearon "Hipocorísticos" como:

(89) Man, jangan lupa belikan saya buah salak indonesia

( 'Man, no olvidar comprarkan yo fruta salak Indonesia/Man, no olvides comprame salak en Indonesia')

(90) Mat, aku nak minta tolong engkau belikan salak Indonesia... ('Mat, yo querer pedir ayuda tú comprarkan salak Indonesia/Mat, quiero pedirte el favor de comprar salak de Indonesia')

(91) Wan, nanti awak dah pergi Indonesia tu, tolong belikan saya buah salak dekat sana.

( 'Wan, luego tú ya ir Indonesia, ayúda comprarkan fruta salak allí/Wan, cuando vayas a Indonesia, cómprame salak')

Aunque el índice de la frecuencia de uso de la forma usted entre los españoles en esta situación es bajo, la utilización de la forma Condicional del verbo se mantiene alta (en el $78 \%$ de las respuestas). Por otro lado, en el grupo malayo, el uso del sufijo kan sigue siendo la forma más empleada, de hecho, el porcentaje de uso es más alto en esta situación en comparación con el resto de las 
situaciones. Algunos ejemplos del empleo de kan aparecen recogidos en los enunciados precedentes (desde el número 86 hasta el 91).

Al examinar la perspectiva de la persona, encontramos que la preferencia mostrada por los informantes de ambos países es la misma de otras situaciones, es decir, los informantes españoles mostraron tendencia a orientar su expresión de petición hacia el oyente (así lo hicieron en el $70 \%$ de los casos), y los malayos prefirieron la orientación impersonal (68\%), es decir, no se marcó el sujeto en sus expresiones.

Ejemplos españoles:

(92) ¿Podrías traerme una lata de caviar?

(93) ¿Podrías comprarme una lata de caviar?

(94) ¿Me traes una lata de caviar del viaje?

Ejemplos malayos:

(95) Boleh belikan saya buah salak?

('Poder comprarkan yo fruta salak?/¿Se me puede comprar salak?')

(96) Tolong belikan saya buah salak!

('iAyudar comprakan yo fruta salak!/iCómprame salak!') 


\subsubsection{Situación 16}

En la situación 16 hay igualdad de estatus social entre los interlocutores, puesto que el oyente es un amigo del mismo estatus. De forma similar a los casos anteriores, la tendencia dominante de cada comunidad de habla fue hacia el empleo de la estrategia de "Interrogación preparatoria" (la emplean el 63\% de los españoles y el $75 \%$ de los malayos). Y, los participantes españoles formularon las preguntas mayoritariamente (en el $45 \%$ de los casos) mediante el verbo poder en Condicional, es decir, utilizando una forma de "Capacidad/posibilidad". En esta situación, los hablantes de los dos países optaron por comenzar sus peticiones con las expresiones de petición en sí mismas. Por ejemplo, los españoles contestaron:

(97) ¿Puedes dejarme el móvil, que me he quedado sin saldo?

(98) ¿Me puedes dejar tu móvil un momento?

(99) ¿Puedes prestarme tu móvil para llamar?

Por otro lado, los hablantes malayos mostraron que, en este contexto, prefirieron formular las preguntas utilizando la forma de boleh + tak ( poder + no ), en un $48 \%$ de ocasiones y la de boleh (' poder ), en un $44 \%$. 
(100) Boleh tak saya pinjam telefon sekejap? Mustahak ni.

('Poder no yo pedir prestado teléfono en segundo? urgente este/¿iNo puedo pedir prestado el teléfono un segundo? Es urgente')

(101) Boleh tak saya pinjam kredit awak dulu?.

(' Poder no yo pedir prestado saldo tú primero?/¿No puedo pedir prestado tu teléfono un momento?')

(102) Boleh tak saya guna telefon awak kejap?

('Poder no yo utilizar teléfono tú momento?/¿No puedo utilizar tu teléfono un momento?')

No hubo diferencias considerables en el uso de las modificaciones internas en la estrategia de "Interrogación preparatoria" en los subgrupos contrastados, ni de edad ni de sexo, en ninguna de las dos culturas.

Según los datos obtenidos en lo referente a la utilización de los tratamientos nominales, los nativos españoles, de forma similar a otros contextos, utilizaron frecuentemente el "Nombre de pila" (72\%) para dirigirse a los interlocutores de la misma posición. Los malayos, por su parte, mostraron preferencia por dos formas, "Hipocorístico" (el 48\%) y "Nombre de pila" (42\%). El análisis de las fórmulas pronominales nos revela que solo hubo un caso de usted en los datos españoles, es decir, el tratamiento preferido entre los 
españoles en este contexto fue el de tú (98\%). En el caso de los malayos también la forma del pronombre personal de la segunda persona awak se aplicó con mayor frecuencia (76\%).

Por ejemplo, los españoles contestaron:

(103) Oye Manuel, necesito hacer una llamada urgente y no tengo saldo en el móvil. ¿Podrías prestarme el tuyo?

(104) Julián,... me he quedado sin saldo en móvil. ¿Me dejas utilizar el tuyo?

(105) Peter por favor, tengo que llamar para un asunto. Déjame hacer una llamada con tú móvil.

En los enunciados malayos en los que se empleó un "Hipocorístico", se encontraron ejemplos como:

(106) Man, telefon aku tiada kredit. Aku perlu buat call penting.

( 'Man, teléfono yo no tener saldo. Yo necesitar hacer llamada importante/Man, mi teléfono no tiene saldo. Necesito hacer una llamada importante')

(107) Fiza, boleh tak saya pinjam hand phone awak?

('Fiza, Poder no yo pedir prestado móvil tú?/Fiza, ¿No podría pedirte prestado el móvil?')

(108) Siti, boleh tak saya guna telefon awak kejap? 
(`Siti, poder no yo utilizar teléfono tú momento?/Siti, ¿No podría utilizar tu teléfono un momento?')

En cuanto al uso del "Nombre de pila", hemos encontrado respuestas como estas:

(109) Jamal, boleh saya guna hand phone kamu tak?

('Jamal, poder yo utilizar móvil tú?/Jamal, ¿Puedo utilizar tu móvil?')

(110) Mamat, boleh aku pinjam kredit kau?

( Mamat, Poder yo pedir prestado saldo tú?/Mamat ¿Puedo pedirte prestado el teléfono?')

(111) Aisyah, boleh pinjam kredit?

('Aisyah, poder pedir prestado saldo?/Aisyah, ¿puedo pedirte prestado el teléfono?')

Según nuestros datos, no se han hallado variaciones importantes en el uso de "Fórmulas de tratamiento" entre los subgrupos, ni de edad ni de sexo. Sin embargo, los subgrupos malayos comparados se diferencian considerablemente en el resultado estadístico de su empleo. Con respecto al subgrupo de edad, más de la mitad de los participantes mayores utilizaron el "Hipocorístico" (60\%), mientras que los jóvenes optaron por el "Nombre de pila" (67\%). En los subgrupos de sexo, por su parte, los 
hombres prefirieron el "Hipocorístico" (64\%) para dirigirse a los interlocutores, mientras que las mujeres se dirigieron preferentemente a los oyentes por el "Nombre de pila" (62\%).

Finalmente, los españoles, al igual que ocurrió en otras situaciones, siguieron mostrando su tendencia a la orientación hacia el oyente en las expresiones aplicadas al formular sus peticiones. En cambio, en esta situación, la mayoría estaban orientadas hacia el hablante o eran neutras (en un $48 \%$ de los casos cada tipo).

Ejemplos españoles:

(112) ¿Puedes dejarme el móvil, que me he quedado sin saldo?

(113) ¿Me dejas hacer una llamada corta?

Ejemplos malayos:

(114) Boleh saya pinjam telefon awak?

('Poder yo pedir prestado teléfono tú?/¿Puedo pedir prestado tu teléfono?')

(115) Boleh pinjamkan saya telefon awak?

('Poder prestarkan yo teléfono tú?/¿Se me puede prestar tu teléfono?')

(116) Boleh pinjam telefon, kredit lebih tak?

('Poder pedir prestado teléfono, saldo más no?/¿Se puede pedir prestado tu teléfono? ¿Te queda saldo?') 
En este contexto, no hay diferencias destacables entre los enunciados de los subgrupos españoles, pero en los datos malayos sí, ya que los participantes de más edad tendieron a orientar sus expresiones hacia el hablante, pero los jóvenes mostraron preferencia por la orientación impersonal. Por otro lado, mientras que los varones mostraron una mayor tendencia hacia la orientación impersonal, las mujeres prefirieron las expresiones de petición orientadas hacia el hablante.

\subsection{Conclusión}

En general, las dos sociedades mostraron preferencia por las estrategias "Convencionalmente indirectas". Esto coincide con los resultados de estudios anteriores realizados sobre otras lenguas, en los que las "Convencionalmente indirectas" fueron también las estrategias más utilizadas (Blum-Kulka, et. Al., 1989, Felíx-Brasdefer, 2005; García, 1993; Hassall, 1999; Le Pair, 1996; Marquez-Reiter, 2002).

El análisis de los actos principales demostró que los sujetos de los dos grupos examinados utilizaron mayoritariamente la estrategia de "Interrogación preparatoria" para realizar las peticiones. $Y$ fueron los españoles los que mostraron una mayor 
tendencia hacia dicha forma. Además, se diferenciaron en las fórmulas convencionalizadas específicas utilizadas. Los sujetos españoles formularon las preguntas mediante tres tipos de subestrategias, que fueron la de "Capacidad/posibilidad", la "Buena voluntad" y la "Predicción de acción futura del oyente". En cambio, en los datos malayos todas las formas empleadas fueron del tipo "Capacidad/posibilidad". Todas las preguntas hechas por los sujetos españoles se formularon desde la perspectiva de "Orientada hacia el oyente", mientras que las de los malayos eligieron mayoritariamente la de "Orientada hacia el hablante". Los españoles mostraron la cortesía utilizando el verbo en Condicional en sus preguntas, mientras que los malayos lo hicieron combinando el verbo con algunas partículas, sufijo y con ciertas palabras.

Los resultados obtenidos demostraron que, en general, los malayos aplicaron las estrategias "Directas" en un mayor número de casos que los españoles. Aun así, los españoles fueron los que más emplearon el "Imperativo" (la estrategia más directa). En nuestro estudio, los españoles formularon el "Imperativo" de la manera más directa, es decir, utilizando la forma verbal correspondiente. En cambio, los malayos produjeron el "Imperativo" mediante la combinación del verbo con algunas partículas, dado que la lengua malaya, en sí misma, no tiene forma verbal de Imperativo. 
En las estrategias de los movimientos de apoyo, sí que hubo diferencias entre las preferencias de ambos grupos. Los españoles revelaron una cierta tendencia a reforzar sus peticiones mediante el uso de una presentación o saludo, mientras que los malayos prefirieron apoyar sus peticiones en "Fórmulas de tratamiento"

Al contrastar los datos de los sujetos de los dos subgrupos de edad en ambas culturas, vemos que los dos subgrupos mostraron preferencia hacia las mismas estrategias, pero se diferenciaron en el orden de frecuencia. Los encuestados mayores utilizaron más enunciados que los jóvenes y realizaron las peticiones de forma más indirecta. Por otra parte, el patrón presentado por los varones y las mujeres fue muy similar al obtenido en el caso de los subgrupos de edad. Es decir, pese a que los participantes de ambos géneros mostraran preferencia por las mismas estrategias, fueron las mujeres las que las aplicaron más que los varones, y también las que fueron menos directas al formular sus peticiones.

Según los resultados obtenidos, los grupos contrastados mostraron comportamientos similares respecto al uso de las expresiones de solidaridad cuando hablante y oyente son del mismo estatus. En todos los casos los enunciados producidos fueron más cortos que en las situaciones en las que existe una relación diferente 
entre los interlocutores, y se empleó un menor número de estrategias. En cambio, en los casos en los que el poder relativo se inclina hacia los destinatarios, las expresiones formuladas fueron más largas y con un mayor número de estrategias. En las situaciones en las que el grado de familiaridad entre los interlocutores es alto, los hablantes de ambas sociedades muestran preferencia hacia enunciados más breves y el empleo de menos estrategias. Cuando la distancia social es alta (distancia social + ), se obtuvieron los resultados opuestos.

El presente estudio muestra que las situaciones proporcionadas en el cuestionario determinaron los patrones de petición empleados por los sujetos de los dos grupos de nativos. Así, los patrones que se utilizaron en una situación fueron diferentes de los de otras situaciones. En todas las situaciones, la estrategia de "Interrogación preparatoria" fue la preferida por los españoles, mientras que en el grupo de los malayos las dos estrategias más frecuentemente utilizadas fueron las de "Interrogación preparatoria" y "Fórmula de sugerencia". Por último, las diferencias encontradas entre las respuestas de los sujetos de los subgrupos examinados en cada cultura, no fueron tan diferentes en comparación con las que se observaron entre las respuestas de los participantes de una misma cultura. 
Para terminar este capítulo, presentamos, en las tablas

siguientes, los resultados principales obtenidos en el análisis de los

datos de la petición:

Tabla 37. Resultados obtenidos en el caso de español frente a malayo

\begin{tabular}{|c|c|c|c|c|}
\hline Análisis & Artículos & Detalles & Español & Malayo \\
\hline \multirow{10}{*}{ Cuantitativo } & \multirow{2}{*}{ Frecuencia } & AP & \multicolumn{2}{|c|}{ Similar } \\
\hline & & $\mathrm{MA}$ & Menos & Más \\
\hline & \multicolumn{2}{|c|}{ (In)dirección } & Más directas & Menos directas \\
\hline & \multirow{2}{*}{$\begin{array}{l}\text { Estrategia } \\
\text { más usada }\end{array}$} & AP & \multicolumn{2}{|c|}{ Interrogación preparatoria } \\
\hline & & MA & $\begin{array}{c}\text { Presentación/sa } \\
\text { ludos }\end{array}$ & $\begin{array}{l}\text { Fórmulas de } \\
\text { tratamiento }\end{array}$ \\
\hline & \multirow{3}{*}{ Estatus Social } & Superior & \multicolumn{2}{|c|}{ No Convencionalmente indirectas } \\
\hline & & Igual & \multicolumn{2}{|c|}{ Convencionalmente indirectas } \\
\hline & & Inferior & \multicolumn{2}{|c|}{ Convencionalmente indirectas } \\
\hline & \multirow{2}{*}{ Distancia social } & Corta & \multicolumn{2}{|c|}{ Convencionalmente indirectas } \\
\hline & & Larga & \multicolumn{2}{|c|}{ Convencionalmente indirectas } \\
\hline \multirow{6}{*}{ Cualitativo } & \multirow{4}{*}{$\begin{array}{c}\text { Modificaciones } \\
\text { internas }\end{array}$} & $\begin{array}{l}\text { Fórmulas } \\
\text { nominales }\end{array}$ & Nombre de pila & Título \\
\hline & & $\begin{array}{c}\text { Fórmulas } \\
\text { pronominales }\end{array}$ & Tú & Awak \\
\hline & & $\begin{array}{c}\text { Modificación } \\
\text { sintáctica }\end{array}$ & \multicolumn{2}{|c|}{ Mínima } \\
\hline & & Orientación & Oyente & Hablante \\
\hline & \multicolumn{2}{|c|}{ Contenido de estrategias } & $\begin{array}{c}\text { Más específico y } \\
\text { detallado }\end{array}$ & $\begin{array}{c}\text { Menos } \\
\text { específico y } \\
\text { detallado }\end{array}$ \\
\hline & \multicolumn{2}{|c|}{ Estructura } & $M A+A P+M A$ & $M A+A P+M A$ \\
\hline
\end{tabular}

$\mathrm{AP}=$ Acto Principal $\mathrm{MA}=$ Movimiento de Apoyo 
Tablas 38 y 39. Resultados obtenidos en el caso de sujeto mayor frente a sujeto menor

\begin{tabular}{|c|c|c|c|c|}
\hline \multicolumn{5}{|c|}{ Español } \\
\hline Análisis & Artículos & Detalles & Mayor & Joven \\
\hline \multirow{10}{*}{ Cuantitativo } & \multirow{2}{*}{ Frecuencia } & AP & \multicolumn{2}{|c|}{ Similar } \\
\hline & & MA & Más & Menos \\
\hline & \multicolumn{2}{|c|}{ (In)dirección } & Menos directa & Más directa \\
\hline & \multirow[b]{2}{*}{$\begin{array}{l}\text { Estrategia } \\
\text { más usada }\end{array}$} & AP & \multicolumn{2}{|c|}{ Interrogación preparatoria } \\
\hline & & MA & $\begin{array}{c}\text { Saludos/ } \\
\text { presentaciones }\end{array}$ & Razones \\
\hline & \multirow[t]{3}{*}{ Estatus Social } & Superior & $\begin{array}{c}\text { No } \\
\text { Convencionalmen } \\
\text { te indirectas }\end{array}$ & $\begin{array}{c}\text { Convencionalmen } \\
\text { te indirectas }\end{array}$ \\
\hline & & Igual & \multicolumn{2}{|c|}{ Convencionalmente indirectas } \\
\hline & & Inferior & \multicolumn{2}{|c|}{ Convencionalmente indirectas } \\
\hline & \multirow{2}{*}{ Distancia social } & Corta & \multicolumn{2}{|c|}{ Convencionalmente indirectas } \\
\hline & & Larga & \multicolumn{2}{|c|}{ Convencionalmente indirectas } \\
\hline \multirow{6}{*}{ Cualitativo } & \multirow{4}{*}{$\begin{array}{l}\text { Modificaciones } \\
\text { internas }\end{array}$} & $\begin{array}{c}\text { Fórmulas } \\
\text { nominales }\end{array}$ & $\begin{array}{l}\text { Más nombre de } \\
\text { pila }\end{array}$ & $\begin{array}{c}\text { Menos nombre } \\
\text { de pila }\end{array}$ \\
\hline & & $\begin{array}{c}\text { Fórmulas } \\
\text { pronominales }\end{array}$ & Más tú & Menos tú \\
\hline & & $\begin{array}{c}\text { Modificación } \\
\text { sintáctica }\end{array}$ & \multicolumn{2}{|c|}{ Mínima } \\
\hline & & Orientación & \multicolumn{2}{|c|}{ Oyente } \\
\hline & \multicolumn{2}{|c|}{ Contenido de estrategias } & $\begin{array}{c}\text { Más específico y } \\
\text { detallado }\end{array}$ & $\begin{array}{c}\text { Menos específico } \\
\text { y detallado }\end{array}$ \\
\hline & \multicolumn{2}{|c|}{ Estructura } & $M A+A P+M A$ & $M A+A P+M A$ \\
\hline
\end{tabular}

\begin{tabular}{|c|c|c|c|c|}
\hline \multicolumn{5}{|c|}{ Malayo } \\
\hline Análisis & Artículos & Detalles & Mayor & Joven \\
\hline \multirow{10}{*}{ Cuantitativo } & \multirow{2}{*}{ Frecuencia } & AP & \multicolumn{2}{|c|}{ Similar } \\
\hline & & MA & Más & Menos \\
\hline & \multicolumn{2}{|c|}{ (In)dirección } & Menos directa & Más directa \\
\hline & \multirow{2}{*}{$\begin{array}{l}\text { Estrategia } \\
\text { más usada }\end{array}$} & AP & \multicolumn{2}{|c|}{ Interrogación preparatoria } \\
\hline & & MA & \multicolumn{2}{|c|}{ Fórmulas de tratamiento } \\
\hline & \multirow{3}{*}{ Estatus Social } & Superior & $\begin{array}{l}\text { Convencionalmen } \\
\text { te indirectas }\end{array}$ & $\begin{array}{c}\text { No } \\
\text { Convencionalmen } \\
\text { te indirectas }\end{array}$ \\
\hline & & Igual & \multicolumn{2}{|c|}{ Convencionalmente indirectas } \\
\hline & & Inferior & Directas & $\begin{array}{c}\text { Convencionalmen } \\
\text { te indirectas }\end{array}$ \\
\hline & \multirow{2}{*}{ Distancia social } & Corta & \multicolumn{2}{|c|}{ Convencionalmente indirectas } \\
\hline & & Larga & \multicolumn{2}{|c|}{ Convencionalmente indirectas } \\
\hline \multirow{6}{*}{ Cualitativo } & \multirow{4}{*}{$\begin{array}{l}\text { Modificaciones } \\
\text { internas }\end{array}$} & $\begin{array}{l}\text { Fórmulas } \\
\text { nominales }\end{array}$ & Más título & Menos título \\
\hline & & $\begin{array}{c}\text { Fórmulas } \\
\text { pronominales }\end{array}$ & Menos awak & Más awak \\
\hline & & $\begin{array}{c}\text { Modificación } \\
\text { sintáctica }\end{array}$ & \multicolumn{2}{|c|}{ Mínima } \\
\hline & & Orientación & Hablante & Neutro \\
\hline & \multicolumn{2}{|c|}{ Contenido de estrategias } & Menos genérico & Más genérico \\
\hline & \multicolumn{2}{|c|}{ Estructura } & $M A+A P+M A$ & $M A+A P+M A$ \\
\hline
\end{tabular}

$\mathrm{AP}=$ Acto Principal

MA = Movimiento de Apoyo 
Tablas 40 y 41 . Resultados obtenidos en el caso de hombre frente a mujer

\begin{tabular}{|c|c|c|c|c|}
\hline \multicolumn{5}{|c|}{ Español } \\
\hline Análisis & Artículos & Detalles & Hombre & Mujer \\
\hline \multirow{10}{*}{ Cuantitativo } & \multirow{2}{*}{ Frecuencia } & AP & \multicolumn{2}{|c|}{ Similar } \\
\hline & & MA & Menos & Más \\
\hline & \multicolumn{2}{|c|}{ (In)dirección } & Más directa & Menos directa \\
\hline & \multirow[b]{2}{*}{$\begin{array}{l}\text { Estrategia } \\
\text { más usada }\end{array}$} & $\mathrm{AP}$ & \multicolumn{2}{|c|}{ Interrogación preparatoria } \\
\hline & & MA & $\begin{array}{c}\text { Saludos/ } \\
\text { presentaciones }\end{array}$ & $\begin{array}{l}\text { Fórmulas de } \\
\text { preparación }\end{array}$ \\
\hline & \multirow[t]{3}{*}{ Estatus Social } & Superior & $\begin{array}{l}\text { Convencionalmente } \\
\text { indirectas }\end{array}$ & $\begin{array}{c}\text { No } \\
\text { Convencionalm } \\
\text { ente indirectas }\end{array}$ \\
\hline & & Igual & \multicolumn{2}{|c|}{ Convencionalmente indirectas } \\
\hline & & Inferior & \multicolumn{2}{|c|}{ Convencionalmente indirectas } \\
\hline & \multirow{2}{*}{ Distancia social } & Corta & \multirow{2}{*}{\multicolumn{2}{|c|}{$\begin{array}{l}\text { Convencionalmente indirectas } \\
\text { Convencionalmente indirectas }\end{array}$}} \\
\hline & & Larga & & \\
\hline \multirow{6}{*}{ Cualitativo } & \multirow{4}{*}{$\begin{array}{l}\text { Modificaciones } \\
\text { internas }\end{array}$} & $\begin{array}{c}\text { Fórmulas } \\
\text { nominales }\end{array}$ & $\begin{array}{l}\text { Menos nombre de } \\
\text { pila }\end{array}$ & $\begin{array}{l}\text { Más nombre de } \\
\text { pila }\end{array}$ \\
\hline & & $\begin{array}{c}\text { Fórmulas } \\
\text { pronominales }\end{array}$ & Más tú & Menos tú \\
\hline & & $\begin{array}{l}\text { Modificación } \\
\text { sintáctica }\end{array}$ & \multicolumn{2}{|c|}{ Mínima } \\
\hline & & Orientación & \multicolumn{2}{|c|}{ Oyente } \\
\hline & \multicolumn{2}{|c|}{ Contenido de estrategias } & $\begin{array}{c}\text { Menos específico y } \\
\text { detallado }\end{array}$ & $\begin{array}{c}\text { Más específico } \\
\text { y detallado }\end{array}$ \\
\hline & \multicolumn{2}{|c|}{ Estructura } & $M A+A P+M A$ & $M A+A P+M A$ \\
\hline
\end{tabular}

MA = Movimiento de Apoyo

\begin{tabular}{|c|c|c|c|c|}
\hline \multicolumn{5}{|c|}{ Malayo } \\
\hline Análisis & Artículos & Detalles & Hombre & Mujer \\
\hline \multirow{10}{*}{ Cuantitativo } & \multirow{2}{*}{ Frecuencia } & AP & \multicolumn{2}{|c|}{ Similar } \\
\hline & & MA & Menos & Más \\
\hline & \multicolumn{2}{|c|}{ (In)dirección } & Más directa & Menos directa \\
\hline & \multirow{2}{*}{$\begin{array}{l}\text { Estrategia } \\
\text { más usada }\end{array}$} & AP & \multicolumn{2}{|c|}{ Interrogación preparatoria } \\
\hline & & MA & \multicolumn{2}{|c|}{ Fórmulas de tratamiento } \\
\hline & \multirow[t]{3}{*}{ Estatus Social } & Superior & $\begin{array}{c}\text { No } \\
\begin{array}{c}\text { Convencionalmente } \\
\text { indirectas }\end{array} \\
\end{array}$ & $\begin{array}{l}\text { Convencionalm } \\
\text { ente indirectas }\end{array}$ \\
\hline & & Igual & \multicolumn{2}{|c|}{ Convencionalmente indirectas } \\
\hline & & Inferior & \multicolumn{2}{|c|}{ Convencionalmente indirectas } \\
\hline & \multirow{2}{*}{ Distancia social } & Corta & \multicolumn{2}{|c|}{ Convencionalmente indirectas } \\
\hline & & Larga & \multicolumn{2}{|c|}{ Convencionalmente indirectas } \\
\hline \multirow{6}{*}{ Cualitativo } & \multirow{4}{*}{$\begin{array}{c}\text { Modificaciones } \\
\text { internas }\end{array}$} & $\begin{array}{l}\text { Fórmulas } \\
\text { nominales }\end{array}$ & Menos título & Más título \\
\hline & & $\begin{array}{c}\text { Fórmulas } \\
\text { pronominales }\end{array}$ & Menos awak & Más awak \\
\hline & & $\begin{array}{c}\text { Modificación } \\
\text { sintáctica }\end{array}$ & \multicolumn{2}{|c|}{ Mínima } \\
\hline & & Orientación & Neutro & Hablante \\
\hline & \multicolumn{2}{|c|}{ Contenido de estrategias } & Más genérico & Menos genérico \\
\hline & \multicolumn{2}{|c|}{ Estructura } & $M A+A P+M A$ & $M A+A P+M A$ \\
\hline
\end{tabular}


En base a estos resultados, la conclusión a la que podemos llegar es que las peticiones realizadas por los informantes españoles fueron más directas que las de los malayos, las expresiones que emplearon estaban más orientadas hacia el oyente, las expresiones fueron más específicas y detalladas, fueron sensibles al estatus social pero no a la distancia y la estructura común fue "Movimiento de apoyo + acto principal + movimiento de apoyo". Las peticiones malayas, por su parte, fueron menos directas que los españoles, las expresiones que aplicaron tenían una orientación mayoritaria hacia el hablante, se expresaron de manera más genérica y vaga, también fueron sensibles al estatus social pero no a la distancia, y la estructura típica también fue "Movimientos de apoyo + acto principal + movimientos de apoyo".

En relación con la realización de peticiones según la edad, se puede concluir que los sujetos mayores españoles fueron menos directos que los jóvenes, ya que utilizaron menos estrategias directas pero más de movimientos de apoyo. Además, sus peticiones fueron más específicas y detalladas; ahora bien, la estructura general aplicada por los participantes de los dos subgrupos fue similar: "Movimientos de apoyo + acto principal + movimientos de apoyo".

Al igual que en el caso español, los hablantes mayores malayos también fueron menos directos que los jóvenes por la 
misma razón. Así, aplicaron menos estrategias directas pero más movimientos de apoyo que los jóvenes y fueron menos genéricos y vagos, aunque la estructura mayoritaria de petición en ambos casos fue similar, es decir, "Movimientos de apoyo + acto principal + movimientos de apoyo".

Finalmente, respecto al análisis de la formulación de peticiones según el sexo, en el corpus español los hombres fueron más directos que las mujeres, ya que usaron más estrategias directas y menos movimientos de apoyo que ellas, y sus expresiones fueron menos específicas y menos detalladas. Ahora bien, la estructura común de las peticiones producidas por los participantes de ambos sexos fue "Movimientos de apoyo + acto principal+ movimientos de apoyo".

Ocurrió lo mismo en los subgrupos de sexo malayos: las peticiones de los hombres fueron más directas que las de las mujeres, con un mayor uso de las estrategias directas y una menor aplicación de los movimientos de apoyo. Las expresiones hechas por los hombres fueron menos genéricas que las de los participantes del otro sexo, y la estructura general de peticiones en las respuestas tanto de unos como de otros fue "Movimientos de apoyo + acto principal + movimientos de apoyo". 


\section{CAPÍTULO 5}

\section{RESULTADOS Y ANÁLISIS DE DATOS SOBRE}

\section{EL MANDATO}

El presente capítulo está dedicado a exponer, analizar e interpretar los resultados del estudio del segundo acto de habla investigado, esto es, el de mandato. El procesamiento de las respuestas aportadas por los sujetos participantes en las situaciones del test planteadas para la producción de mandatos, es el mismo que se ha aplicado en el caso de la petición (capítulo 4), es decir, empezaremos con un análisis cuantitativo de los datos obtenidos para pasar después a realizar un análisis cualitativo de los mismos. 


\subsection{Análisis cuantitativo}

En este apartado se han recogido, en primer lugar, los resultados correspondientes al análisis general de todos los enunciados producidos por los informantes en la formulación de mandatos, y, después, se ha llevado a cabo un análisis situacional. Para terminar, mostraremos la influencia de la distancia social en la selección de las estrategias empleadas por los sujetos de cada grupo investigado.

\subsubsection{Análisis general}

Al llevar a cabo el análisis general de lo datos obtenidos para la expresión del mandato, procederemos de manera similar al caso anterior, es decir, el análisis del acto de habla de petición, estableciendo las comparaciones entre los datos obtenidos en torno a tres aspectos: la cultura (en nuestro caso, español versus malayo), la edad (mayor frente a menor), y el sexo (varón versus mujer).

\subsubsection{Español frente a malayo}

Al analizar los actos principales de los mandatos formulados, vemos que, a diferencia de lo que ocurrió en el caso de petición, los 
participantes de España y Malasia coinciden en una mayor utilización de las estrategias "Directas", pero la preferencia mostrada por parte de los malayos fue más alta que la de los españoles, con 239 ejemplos recogidos de los malayos y 199 de los españoles. La segunda categoría más empleada por los nativos de ambos países es la de las estrategias "Convencionalmente indirectas": 105 enunciados de los españoles y 100 de los malayos. Las estrategias a las que recurrieron menos veces los hablantes de las dos sociedades fueron las "No convencionalmente indirectas", con 58 casos de los españoles y 26 de los malayos. La diferencia entre los promedios de las categorías aplicadas fue, en este caso, significativa: $X^{2}=15.953$ $p=.000(p<.05)$.

Figura 99. Distribución de estrategias de mandato (actos principales) según el grado de (in)dirección, utilizadas en ambas culturas

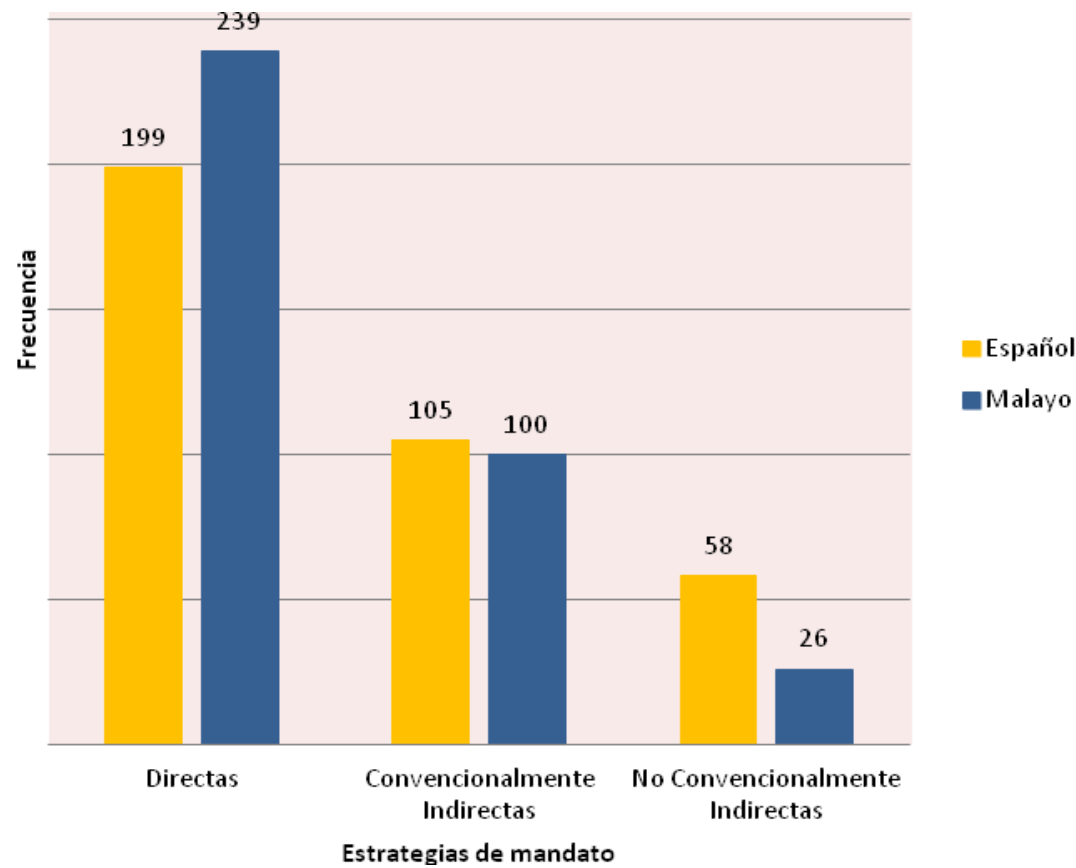


Si aplicamos sobre estos mismos enunciados analizados más arriba, la sub-clasificación en nueve categorías de estrategias propuesta por Blum-Kulka, se evidencia una preferencia absoluta por el uso del "Imperativo" en las dos sociedades, aunque sí hay una diferencia significativa en el número de enunciados recogidos en cada caso (145 de los malayos frente a 94 del grupo español). La estrategia de "Fórmula de sugerencia", que se utiliza en 70 de las respuestas en español y en 62 de los hablantes malayos, es la segunda más empleada, seguida, en los datos españoles, de la "Declaración de obligación", que aparece en 53 ocasiones, y, en los malayos, de la "Declaración de deseo", con 51 ejemplos registrados.

Figura 100. Distribución de enunciados (actos principales), en las nueve estrategias de mandato en ambas culturas

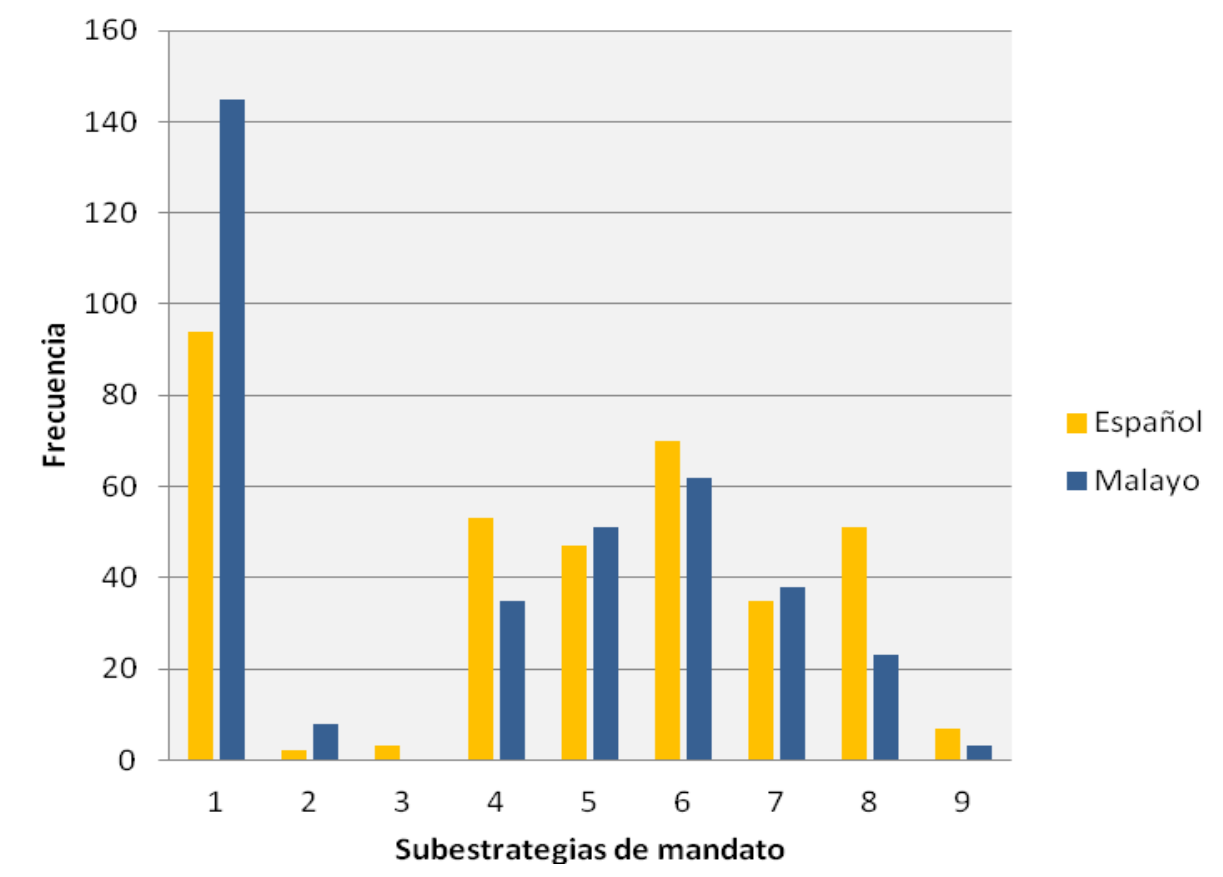

1.Imperativo 2.Performativo 3.Performativo evasivo 4.Declaración de obligación 5.Declaración de deseo 6.Fórmula de sugerencia 7.Interrogación preparatoria 8. Indicio fuerte 9. Indicio suave 
Uno de los aspectos diferenciadores entre ambas comunidades de habla se encuentra en el uso del "Performativo evasivo", con 3 ejemplos de los españoles, pero ninguno de los malayos. La comparación de los promedios entre las estrategias empleadas en los actos principales mostró también en este caso una diferencia significativa: $X^{2}=34.119 p=.000(p<.05)$.

En cuanto a los movimientos de apoyo, de manera general se puede decir que fueron más empleados por los españoles que por los malayos (765 enunciados recogidos de los españoles frente a 659 de los malayos). Esta diferencia se corresponde, asimismo, con la variedad de estrategias empleadas, que también es mayor en las producciones de los españoles (15 estrategias diferentes, frente a las 13 de los malayos), como se refleja en la tabla de resultados que presentamos a continuación: 
Figura 101. Distribución de enunciados (movimientos de apoyo) según el tipo de estrategias utilizadas en los grupos de ambas culturas

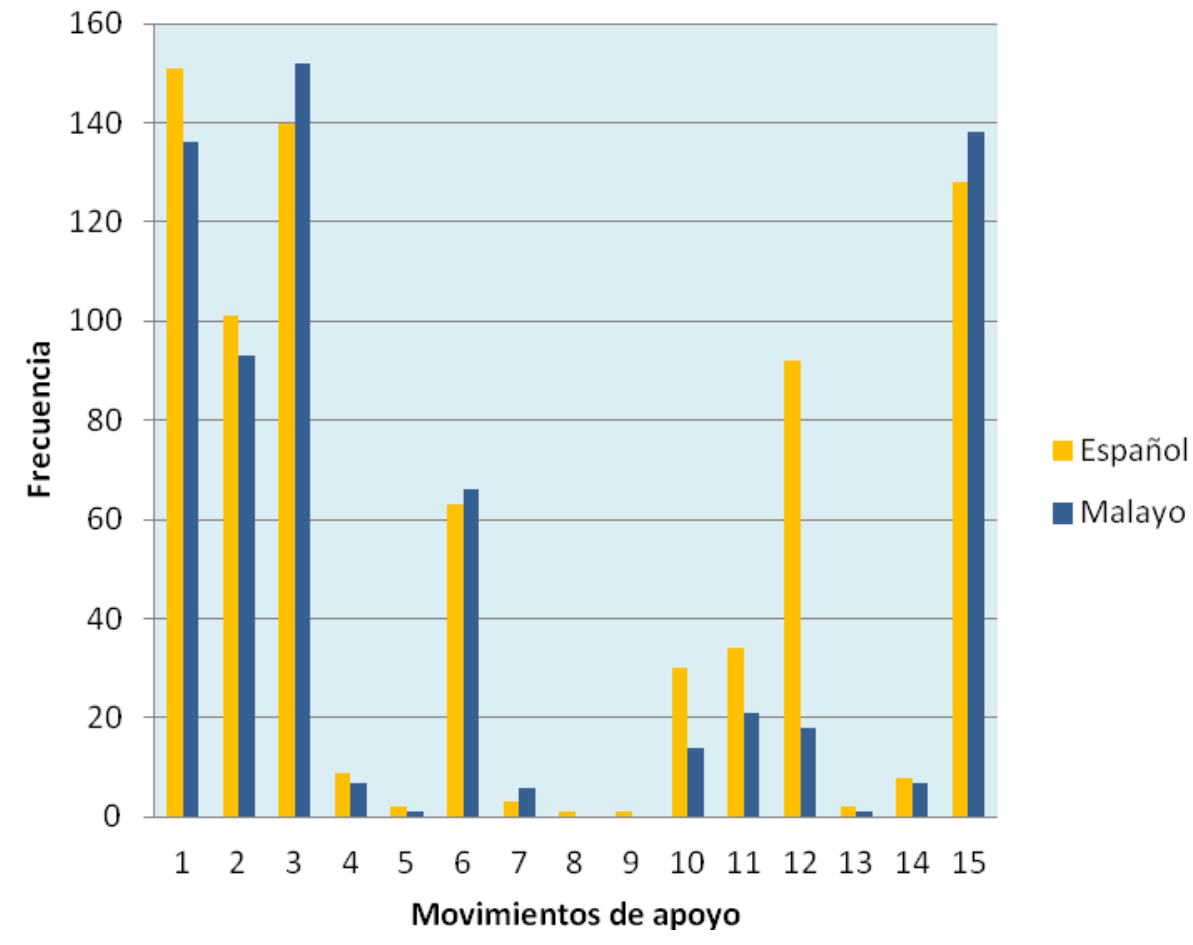

1.Fórmulas de preparación 2.Búsqueda de un compromiso 3.Razones 4.Previsión de objeciones 5.Promesa de recompensa/reparación 6.Minimización de la imposición 7.Invocación de principios generales 8.Reconocimiento de la imposición 9.Preocupación 10.Apreciación 11.Gravedad/urgencia 12.Presentación/saludo 13.Petición de la opinión del oyente 14.Disculpa 15.Fórmulas de tratamiento

Las preferencias por una u otra estrategia varían de una cultura a otra. De esta forma, mientras que los enunciados producidos por los informantes españoles se concentran en el uso de preparadores, con 151 casos, en los datos malayos la misma estrategia se sitúa en el tercer lugar, según la frecuencia de uso (136 enunciados). En cambio, la estrategia de "Razones" que es la más recurrente en el corpus malayo (152 veces), ocupa el segundo lugar en los datos españoles, con 140 apariciones. Y, la tercera opción 
porcentualmente mayoritaria entre los hablantes españoles es el uso de las "Fórmulas de tratamiento" (128 casos), que fue la segunda más empleada por los sujetos del grupo malayo (138 registros).

Pero las diferencias estadísticamente más significativas entre los dos grupos de informantes, se aprecian en el caso de la estrategia de "Presentación/saludo", que aparece en 92 de los enunciados en español, pero en solo 18 de los malayos. Al comparar los promedios de los movimientos aplicados la diferencia fue significativa: $X^{2}=57.283 p=.000(p<.05)$.

Si se hace un cómputo general del número de enunciados producidos por los sujetos de una y otra cultura en cada una de las seis situaciones propuestas en el cuestionario, vemos que, en el caso español, es en la situación 3, en la que un directivo pide a su nuevo secretario que haga fotocopias de algunos documentos importantes, en la que se produce un mayor número de enunciados (286), mientras que en la situación 6, en la cual un profesor universitario le pide a su alumno que llegue a la clase a la hora, solamente se han recogido 156. En el grupo malayo, en cambio, el mayor número de enunciados (209) se concentra en la situación 18, donde el sujeto pide a su hijo que se acueste enseguida, mientras que el número más bajo se registró en la situación 15, en la que el encargado de un restaurante le pide a uno de sus trabajadores que envíe un pedido 
de comida a la oficina de un cliente. En la situación 9, donde se pide a un hijo que vuelva pronto a casa, los informantes de ambas sociedades produjeron el mismo número de enunciados (185). Encontramos, así pues, una diferencia significativa en los promedios de los enunciados producidos en las diferentes situaciones proporcionadas: $X^{2}=20.984 p=.001(p<.05)$.

Figura 102. Número de enunciados producidos en cada una de las situaciones por los hablantes de ambas culturas

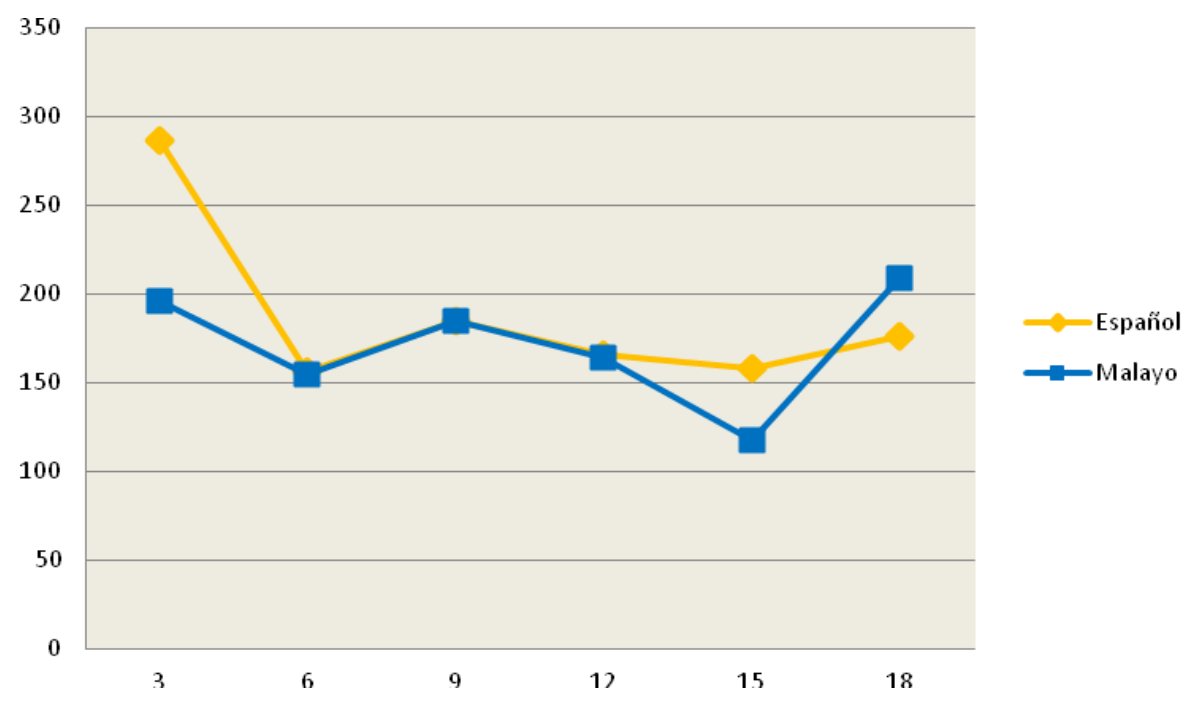

\subsubsection{Mayor frente a menor}

Al analizar las estrategias empleadas en los actos principales por los hablantes de cada grupo de edad de cada sociedad, teniendo en cuenta el mayor o menor grado de (in)dirección, vemos que los hablantes más jóvenes presentan una mayor tendencia al empleo de 
las formas directas, tanto en el grupo español como en el malayo. Así, en el estudio, se han recogido 105 ejemplos de los menores y 94 de los mayores en el grupo español y, 130 y 109, respectivamente, en el grupo malayo. En cambio, las estrategias menos empleadas son, en ambos grupos de edad y en ambas sociedades, las no convencionalmente indirectas, con 35 apariciones en los mayores y 23 en los jóvenes del grupo español, y 18 y 8, respectivamente, del grupo malayo. Con respecto a las formas convencionalmente indirectas, los subgrupos de edad no se diferenciaron tanto: 52 enunciados de los mayores y 53 de los jóvenes en las producciones en español, y 55 de los mayores y 45 de los menores en los datos malayos. Por último, hay que mencionar que la comparación de los promedios de las categorías empleadas no indicó una diferencia significativa en el grupo español: $X^{2}=3.100 p=.212(p>.05)$, pero en el malayo la diferencia fue significativa: $X^{2}=6.689 p=.035(p>.05)$. 
Figura 103. Distribución de enunciados (actos principales) según el grado de (in)dirección de las estrategias empleadas por los subgrupos de edad

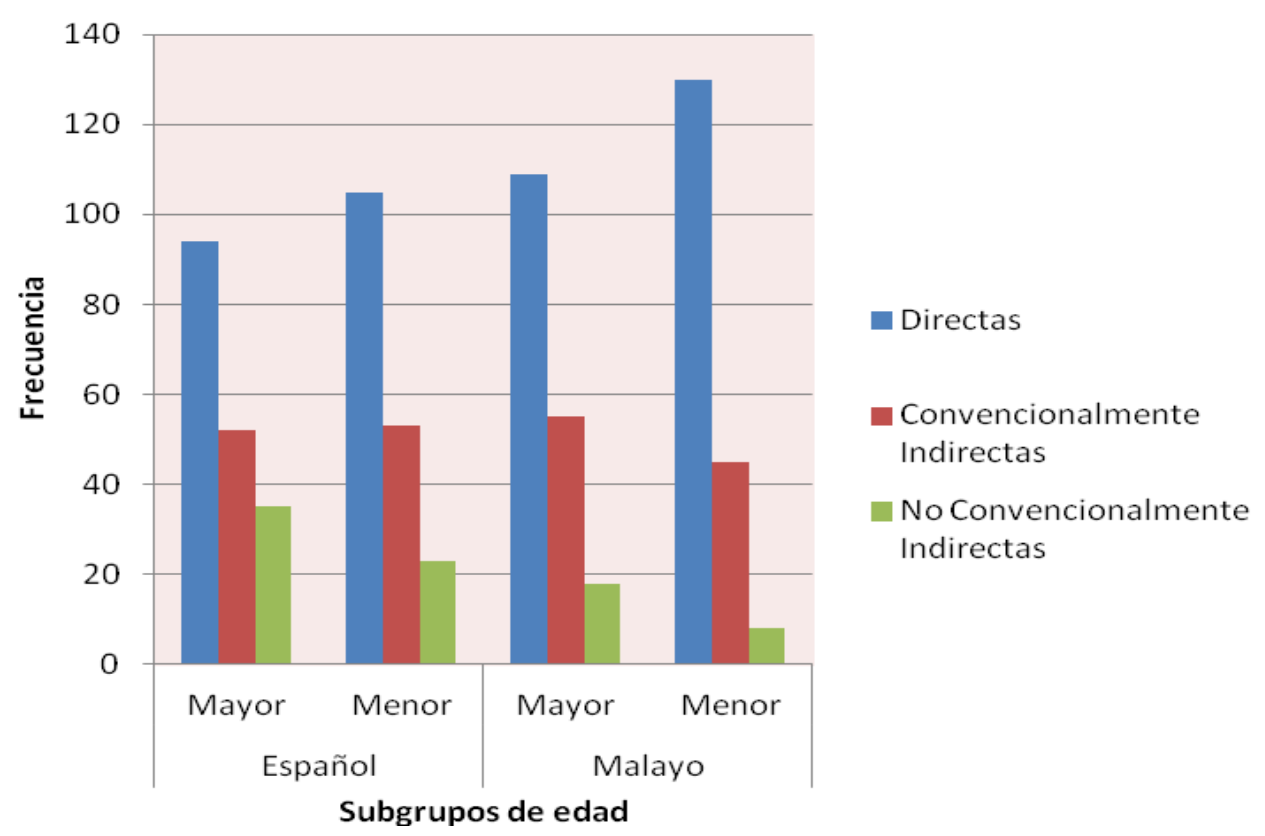

Al aplicar a los mismos enunciados la sub-clasificación en nueve tipos de estrategias, para dar un mayor o menor grado de dirección al mandato, se hace evidente que el Imperativo es la preferida por los hablantes malayos de cualquier edad, aunque los más jóvenes se mostraron más productivos que los mayores, con 85 ejemplos, frente a los 60 de los mayores. El Imperativo fue también la estrategia más utilizada por los participantes españoles jóvenes, y la segunda más empleada por los mayores de ese subgrupo, por detrás de las fórmulas de sugerencia y con tan solo un enunciado de diferencia, como muestra la siguiente gráfica: 
Figura 104. Distribución de enunciados (actos principales) según grado de (in)dirección de estrategias en los subgrupos de ambas culturas

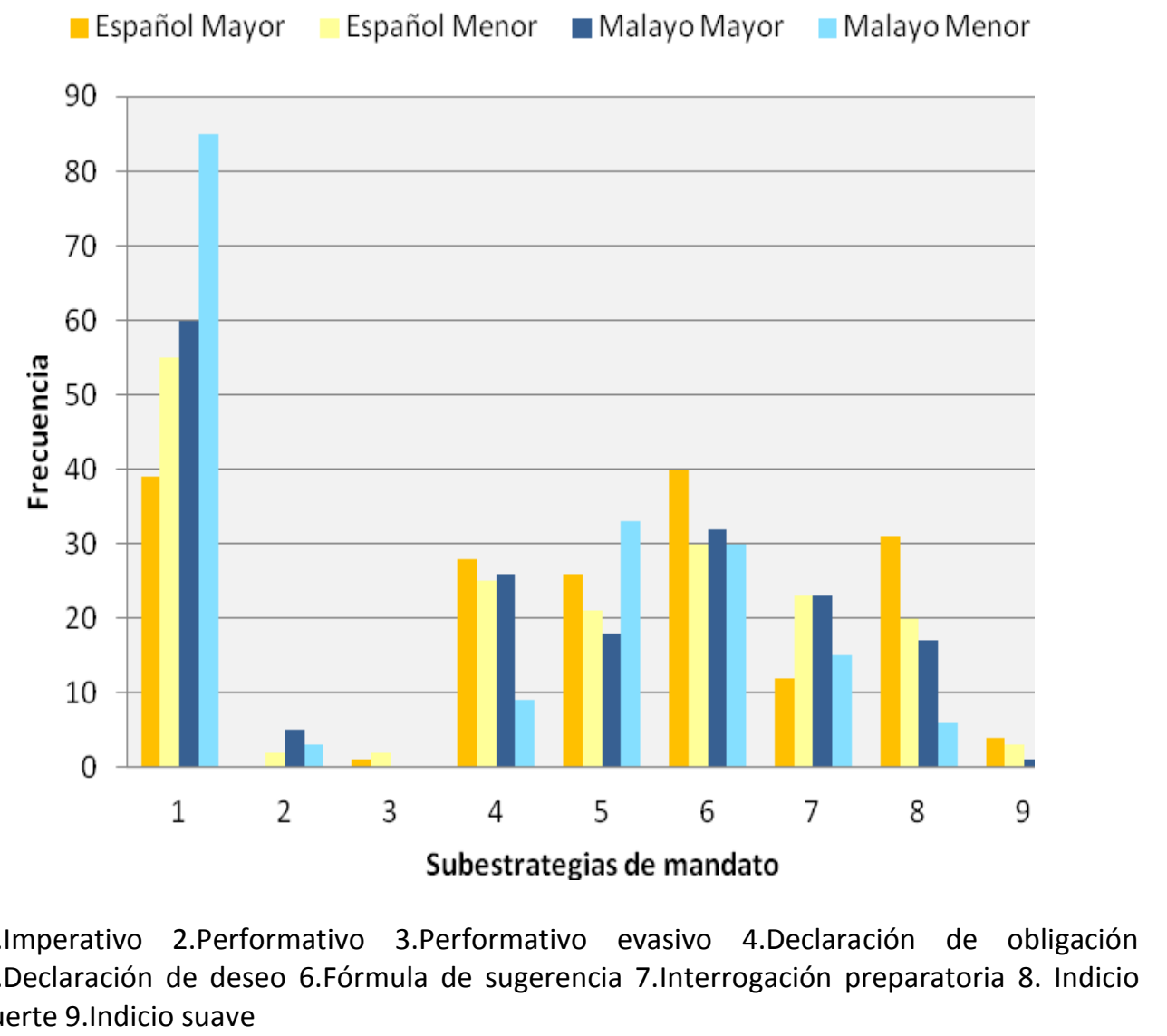

La segunda estrategia más utilizada por los malayos mayores fue la de "Fórmula de sugerencia", con 32 casos, seguida de la "Declaración de obligación" (26), mientras que la segunda más empleada por los menores fue la "Declaración de deseo" (33), seguida del uso de fórmulas de sugerencia, con 30 ejemplos recogidos. En el caso de los españoles mayores, como ya hemos mencionado anteriormente, la segunda más repetida fue la de "Imperativo", con 39 registros, seguida de la de "Indicio fuerte" con 31 apariciones, mientras que la estrategia que ocupó el segundo 
lugar en las preferencias de los menores fue la de "Fórmula de sugerencia" (30), seguida de la "Declaración de obligación" (25).

En la figura se aprecia, además, que los subgrupos malayos se diferenciaron más significativamente entre sí en la frecuencia con la que aplicaron cada estrategia, en comparación con los subgrupos españoles, sobre todo en la estrategia de "Declaración de obligación" que fue casi tres veces más utilizada por los mayores que por los menores, con 26 ejemplos de los mayores frente a tan solo 9 de los menores. También existe una destacada diferencia entre los dos subgrupos malayos en el uso de la estrategia de "Indicio fuerte", casi tres veces más empleada por los encuestados de más edad (17 casos, frente a tan solo 6 de los de menos edad). En cambio, en las intervenciones de los hablantes de los subgrupos españoles no hubo una diferencia tan marcada, excepto en el uso de la estrategia de "Performativo", de la que se encontraron dos ejemplos en los datos de los menores, pero ninguno en los de los mayores. Por otra parte, contrastando entre los subgrupos de edad los promedios de las estrategias aplicadas, la diferencia no fue significativa en el grupo español, algo que, en cambio, sí ocurre en el grupo malayo: $X^{2}=24.820 p=.001(p<.05)$.

Respecto al uso de movimientos de apoyo, los informantes mayores fueron los que se mostraron más productivos. Así, se 
recogieron un total de 425 enunciados de los españoles mayores frente a 340 de los jóvenes y, 354 de los malayos de más edad por 306 de los menores. Además, los de más edad del grupo español utilizaron una mayor variedad de estrategias (14 estrategias diferentes) en comparación con los jóvenes (11). En cambio, en el grupo malayo, los sujetos mayores, aun siendo también los más productivos, emplearon menos estrategias diferentes (11 tipos, frente a los 13 de los menores).

Los resultados numéricos obtenidos en relación a esas diferentes estrategias empleadas por cada subgrupo de edad de ambas sociedades en los movimientos de apoyo, son los que se recogen en la figura siguiente: 
Figura 105. Distribución de enunciados (movimientos de apoyo) según grado de (in)dirección de las estrategias empleadas por los subgrupos de ambas culturas

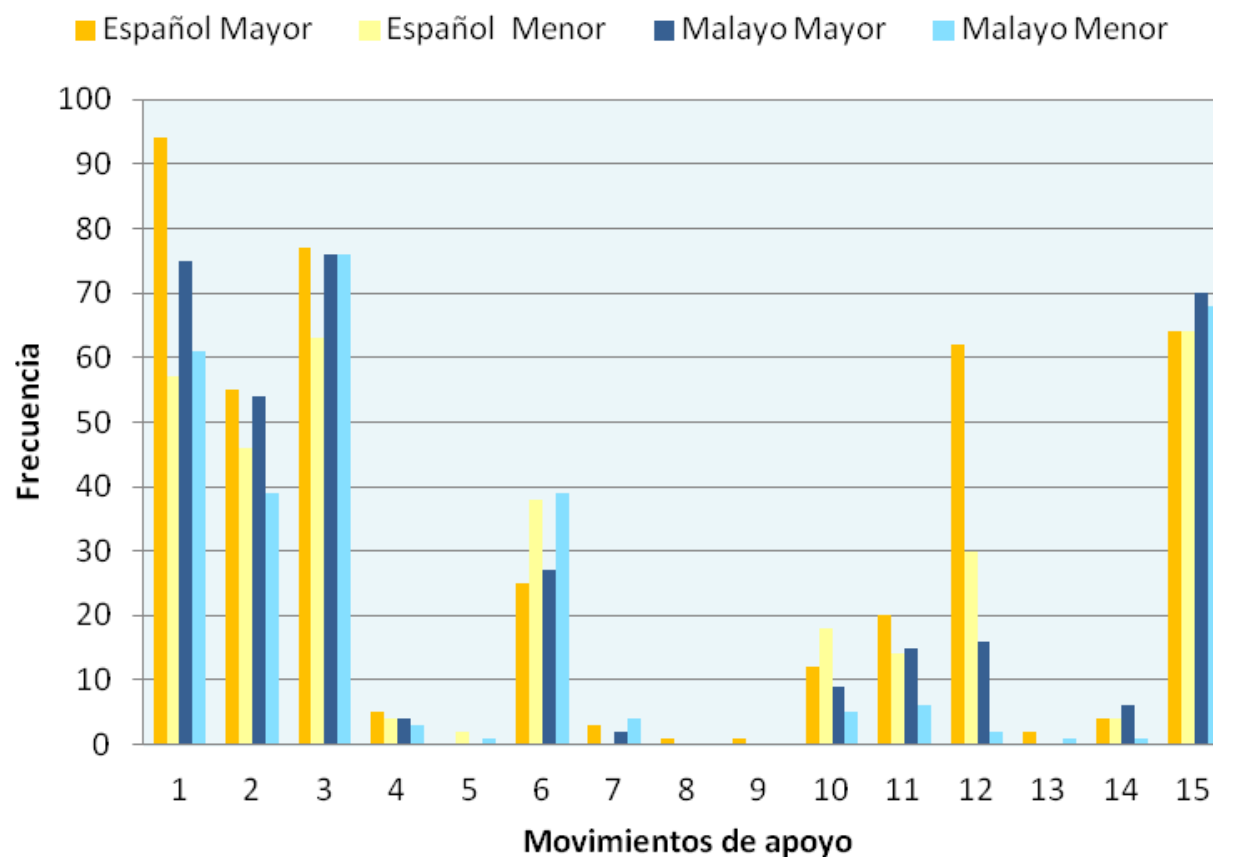

1.Fórmulas de preparación 2.Búsqueda de un compromiso 3.Razones 4.Previsión de objeciones 5.Promesa de recompensa/reparación 6.Minimización de la imposición 7.Invocación de principios generales 8.Reconocimiento de la imposición 9.Preocupación 10.Apreciación 11.Gravedad/urgencia 12.Presentación/saludo 13.Petición de la opinión del oyente 14.Disculpa 15.Fórmulas de tratamiento

Mientras que los enunciados producidos por los españoles mayores se concentran en el empleo de "Fórmulas de preparación", con 94 casos, los jóvenes mostraron preferencia por las "Fórmulas de tratamiento", que aparecen en 64 ocasiones. Es interesante señalar que la estrategia más utilizada por los primeros se situó en el tercer lugar de preferencia en las respuestas de los segundos (57), y viceversa, la opción más repetida en los de menor edad ocupó el tercer lugar en el otro subgrupo (64). Con respecto a la segunda preferencia, ambos subgrupos de edad coincidieron en recurrir a la 
estrategia de "Razones", con 77 registros de los mayores y 63 de los jóvenes.

Por otro lado, los subgrupos malayos mostraron la misma tendencia hacia el empleo de las "Razones", que aparece con la misma frecuencia en los datos de jóvenes y mayores (76 registros). La estrategia a la que recurren, en segundo lugar, los informantes de más edad, es la de "Fórmulas de preparación" (75 enunciados), seguida de las "Fórmulas de tratamiento" (70). En el caso de los de menos edad ocurre justo lo contrario: las "Fórmulas de tratamiento" ocupan el segundo lugar en la lista de frecuencias, con 68 casos, mientras que los preparadores, que se utilizan en 61 ocasiones, ocupan el tercero.

Hay que destacar la notable diferencia constatada entre los subgrupos de ambos países con respecto a la estrategia de "Presentación/saludo". Los participantes españoles de más edad aplicaron dicha estrategia dos veces más que los de menos edad (62, frente a tan solo 30 en los menores), y los malayos mayores la utilizaron ocho veces más que los menores (16 ejemplos, en comparación con los 2 registros de los jóvenes). Por otro lado, los informantes de cada subgrupo emplean algunas estrategias que no aparecen en los datos del otro subgrupo. Por ejemplo, las de "Invocación de principios generales", "Reconocimiento de la 
imposición", "Preocupación" y "Petición de la opinión del oyente", presentes en los datos de los españoles mayores, no fueron empleadas por ninguno de los españoles jóvenes. En cambio, estos aplicaron la de "Promesa de recompensa/reparación", de la que no se encontró ningún caso en los datos mayores. En el caso del grupo malayo, por el contrario, todas las estrategias empleadas por los malayos mayores, también fueron encontradas en los datos de los participantes menores. Sin embargo, las de "Promesa de recompensa/reparación" y "Petición de la opinión del oyente" aparecieron en el corpus de los menores, pero ningún sujeto mayor las aplicó. Por último, hemos de decir que, al comparar los promedios de las estrategias aplicadas en los movimientos de apoyo por los hablantes de los distintos subgrupos de edad, la diferencia no fue significativa en los datos de ninguno de los dos países.

\subsubsection{Varón frente a mujer}

En el análisis de datos llevado a cabo, desde el punto de vista del género de los sujetos, sobre los enunciados producidos como actos principales, se observó que, a la hora de emplear estrategias más o menos directas en la producción de los mandatos, los dos sexos en ambos países prefirieron, mayoritariamente, recurrir a formas "Directas". En el grupo español, fueron los varones los que utilizaron 
en mayor medida dicha forma, con 102 enunciados registrados, mientras que en los datos de las mujeres se recogieron 97. En cambio, en el otro grupo (el malayo), fueron las mujeres las que más las emplearon: 122 enunciados, frente a 117 de los varones. En lo que atañe a la segunda forma más utilizada, las estrategias "Convencionalmente Indirectas", las mujeres de España y Malasia coincidieron en manifestar un mayor uso de dicha categoría que los varones, con 58 y 47 enunciados recogidos, respectivamente, en el grupo español y 52 y 48 , en el malayo. Al revés que en el caso anterior, los varones de ambas culturas produjeron un mayor número de enunciados aplicando estrategias "No convencionalmente indirectas", en comparación con las mujeres, con 32 y 26 ejemplos, respectivamente en los datos españoles, y 16 por 10 en los malayos.

Figura 106. Distribución de enunciados (actos principales) según el grado de (in)dirección de las estrategias de mandato según sexo, en ambas culturas

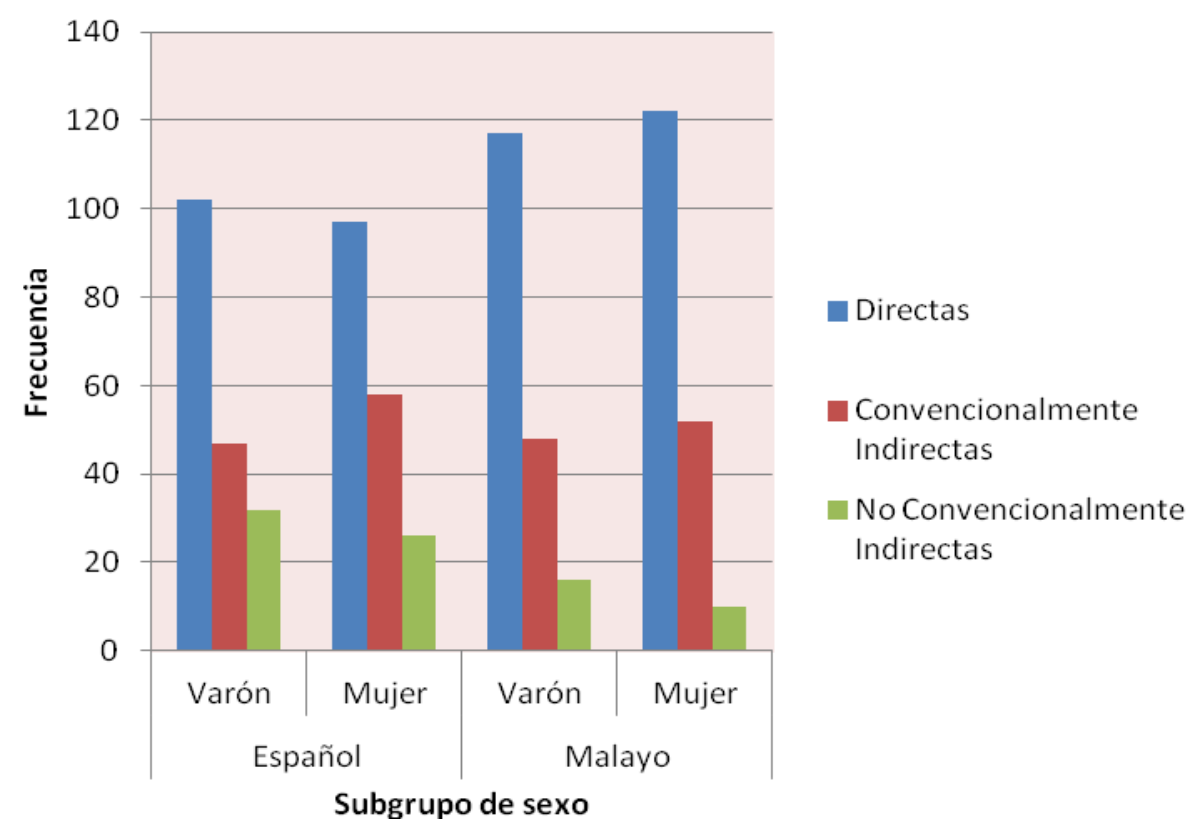


La diferencia entre los promedios de las categorías aplicadas por los hablantes de los dos sexos no fue significativa en los datos de ninguna de las dos culturas.

Si aplicamos a los mismos enunciados analizados más arriba, la sub-clasificación en nueve tipos de estrategia, tal y como hemos venido haciendo a lo largo de nuestro estudio, los resultados que se obtienen son los siguientes:

Figura 107. Distribución de enunciados (actos principales) según al grado de (in)dirección de las estrategias empleadas por los sujetos de los dos sexos en ambas culturas

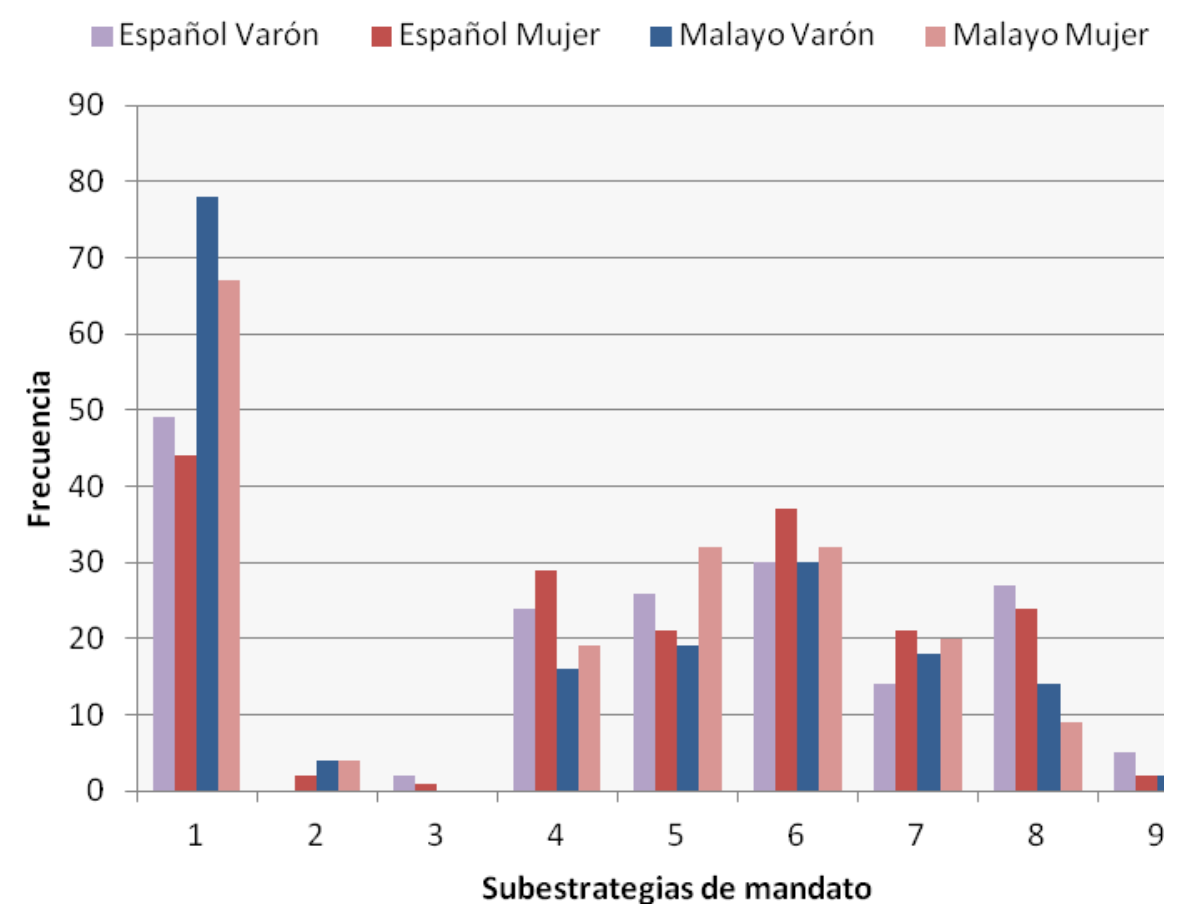

1.Imperativo 2.Performativo 3.Performativo evasivo 4.Declaración de obligación 5.Declaración de deseo 6.Fórmula de sugerencia 7.Interrogación preparatoria 8. Indicio fuerte 9.Indicio suave 
No hay una diferencia estadística muy significativa entre las preferencias de uno y otro sexo en cada cultura. En todos los casos coincidieron en mostrar preferencia por el uso del "Imperativo", y, además, lo hicieron en un número de enunciados muy similar: 49 de los varones y 44 de las mujeres en la cultura española, y 78 y 67 , respectivamente, en la malaya. En lo que concierne a la segunda estrategia más empleada, ambos sexos también optaron por la misma, que fue la de "Fórmula de sugerencia", pero fueron las mujeres de ambas sociedades quienes más recurrieron a ella, con 37 enunciados registrados (30 de los varones) en la sociedad española, y 32 (30 de los varones) en la malaya. Las mujeres, además, también mostraron cierta preferencia por la "Declaración de deseo" (32 enunciados). Cabe mencionar, asimismo, que sí hay diferencias en la tercera estrategia más empleada por cada subgrupo. Así, la de "Indicio fuerte" fue la tercera más utilizada por los varones españoles (27 registros), mientras que las mujeres optaron por la "Declaración de obligación" (29). Y, en el grupo malayo, los varones aplicaron la "Declaración de deseo" en 19 ocasiones, y las mujeres una "Interrogación preparatoria" en 20 casos. La comparación de los promedios entre las estrategias empleadas en la producción de actos principales por los hablantes de ambos sexos no presenta una diferencia significativa en los datos de ninguno de los países. 
Respecto a los movimientos de apoyo, y como era de esperar, en ambas sociedades las mujeres fueron más productivas que los varones, y así, se recogieron 401 enunciados de las intervenciones de las mujeres españolas frente a 364 de los varones, y 376 enunciados y 284, respectivamente, en las intervenciones de los hablantes malayos. Pero, a pesar de esta diferencia, la variedad de estrategias aplicadas por los hablantes de ambos sexos, en los dos grupos, es la misma, ya que, en el caso español, tanto hombres como mujeres usaron 13 estrategias diferentes, y, en el caso malayo, 12, tal y como puede verse en la tabla que presentamos a continuación:

Figura 108. Distribución de enunciados (movimientos de apoyo) según estrategias empleadas por los dos géneros en ambas culturas

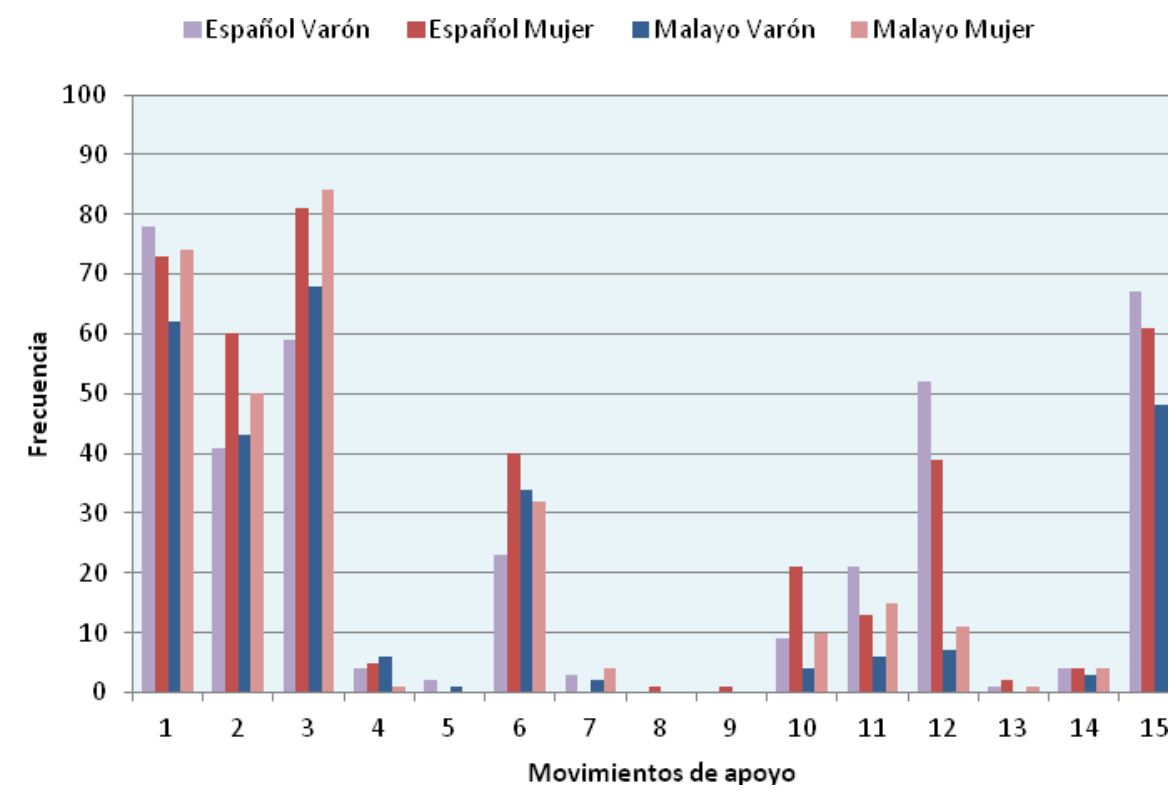

1.Fórmulas de preparación 2.Búsqueda de un compromiso 3.Razones 4.Previsión de objeciones 5.Promesa de recompensa/reparación 6.Minimización de la imposición 7.Invocación de principios generales 8.Reconocimiento de la imposición 9.Preocupación 10.Apreciación 11.Gravedad/urgencia 12.Presentación/saludo 13.Petición de la opinión del oyente 14.Disculpa 15.Fórmulas de tratamiento 
Las estrategias utilizadas más repetidamente por los varones españoles fueron, en orden decreciente, las de "Fórmulas de preparación" (78 ejemplos), seguida de "Fórmulas de tratamiento" (67) y "Razones" (59). En cambio, las mujeres mostraron preferencia por la de "Razones" (81), seguida de "Fórmulas de preparación" (73) y "Fórmulas de tratamiento" (61). En la sociedad malaya, los varones tendieron a utilizar mayoritariamente las "Razones", con 68 apariciones, seguidas del uso de "Fórmulas de preparación" (62) y de "Fórmulas de tratamiento" (48), mientras que las mujeres manifestaron mayor tendencia hacia el empleo de "Fórmulas de tratamiento" (90), seguidas de "Razones" y de la estrategia de "Fórmulas de preparación", con 84 y 74 enunciados recogidos, respectivamente.

El análisis revela, además, que, en la sociedad española, los varones investigados no emplearon ningún "Reconocimiento de la imposición" ni tampoco ninguna "Preocupación" en su mandato, mientras que estas dos estrategias sí que aparecieron una vez en los datos de mujer. En cambio, la estrategia de "Promesa de recompensa/reparación" apareció en los datos de los varones pero ninguna mujer la utilizó. En la sociedad malaya, por su parte, hay dos estrategias en el corpus del subgrupo de un sexo pero no en el del otro, y al revés. De esta forma, la estrategia de "Promesa de recompensa/reparación", que fue aplicada por los varones, no 
aparece en el corpus de mujer. Y la "Petición de la opinión del oyente", de la que sí hay registros en los datos de las mujeres, no aparece en los de los hombres.

Respecto a los valores de las medias, en este caso tampoco hay diferencias estadísticas significativas entre los sujetos españoles y malayos de los dos sexos.

\subsubsection{Análisis situacional}

A continuación, se va a presentar individualmente la distribución de los datos recogidos en cada una de las seis situaciones de mandato proporcionadas en el cuestionario (situaciones $3,6,9,12,15$ y 18), teniendo en cuenta los tres variables: cultural (español frente a malayo), edad (sujetos mayores frente a jóvenes) y género (hombre frente a mujer).

\subsubsection{Situación 3}

En la situación 3, que es la primera presentada en el cuestionario para la formulación de mandatos, un directivo de una firma famosa pide a su nuevo secretario que haga fotocopias de algunos 
documentos. La distancia social entre los interlocutores es grande, y, por tanto, la familiaridad es baja puesto que nunca se han encontrado antes.

\section{A) Español frente a malayo}

Al analizar los enunciados producidos como actos principales de mandato en la situación 3, observamos que la tendencia más habitual es el uso de estrategias "Directas" (37 ejemplos en los datos españoles y 39 en los malayos), seguidas de las "Convencionalmente indirectas", con 22 ejemplos de los españoles y 20 de los malayos, y, a una distancia mayor, por las "No convencionalmente indirectas" (1 registro en ambos casos). Por lo tanto, el resultado de cada comunidad de habla no difiere significativamente. 
Figura 109. Distribución de enunciados (actos principales) según estrategias de mandato empleados para la situación 3, en cada cultura

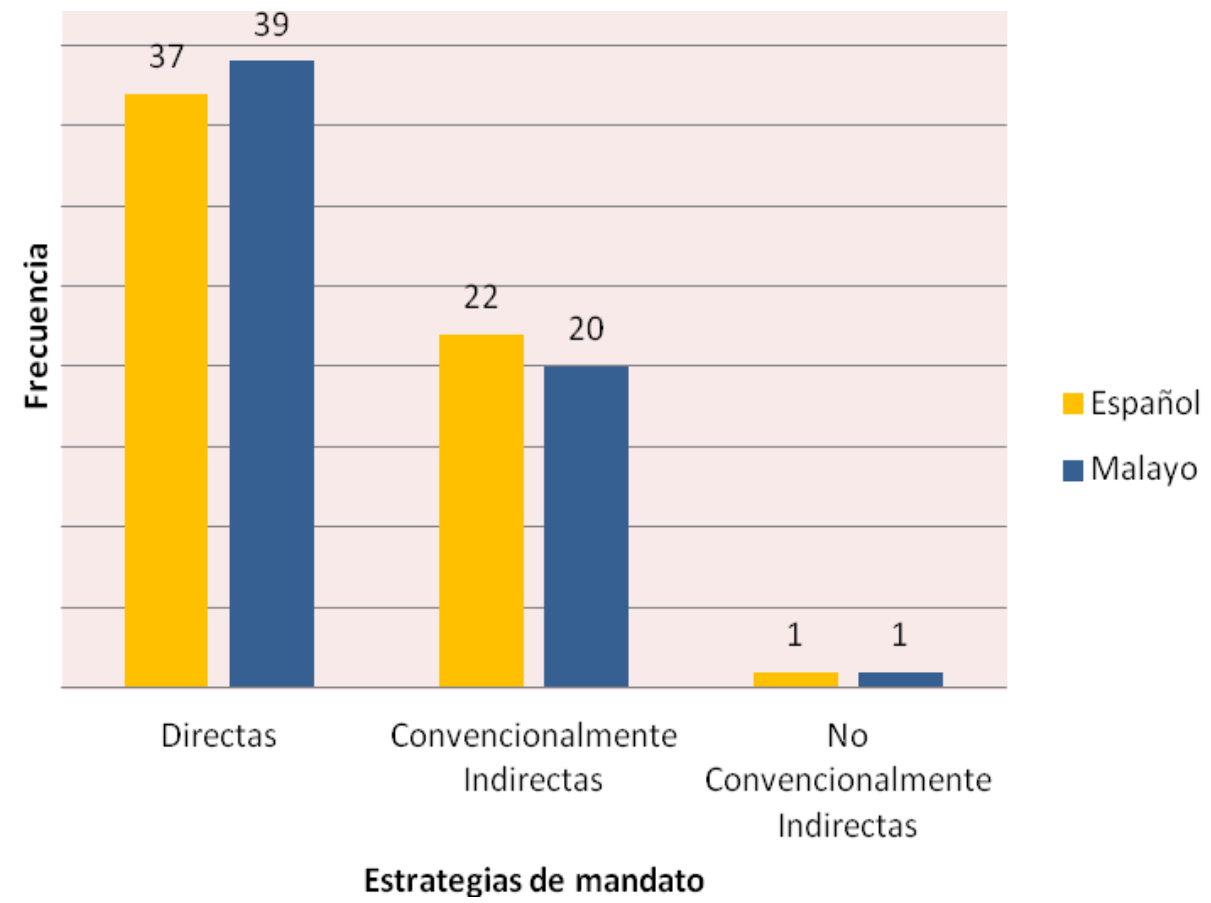

Respecto a la sub-clasificación en nueve tipos de estrategia (la propuesta por Blum Kulka et alter., 1989), es notable la diferencia mostrada entre los hablantes de una y otra cultura, tal y como refleja la figura que mostramos a continuación: 
Figura 110. Distribución de enunciados (actos principales) producidos para la situación 3 en cada cultura, según el grado de (in)dirección de la estrategia empleada

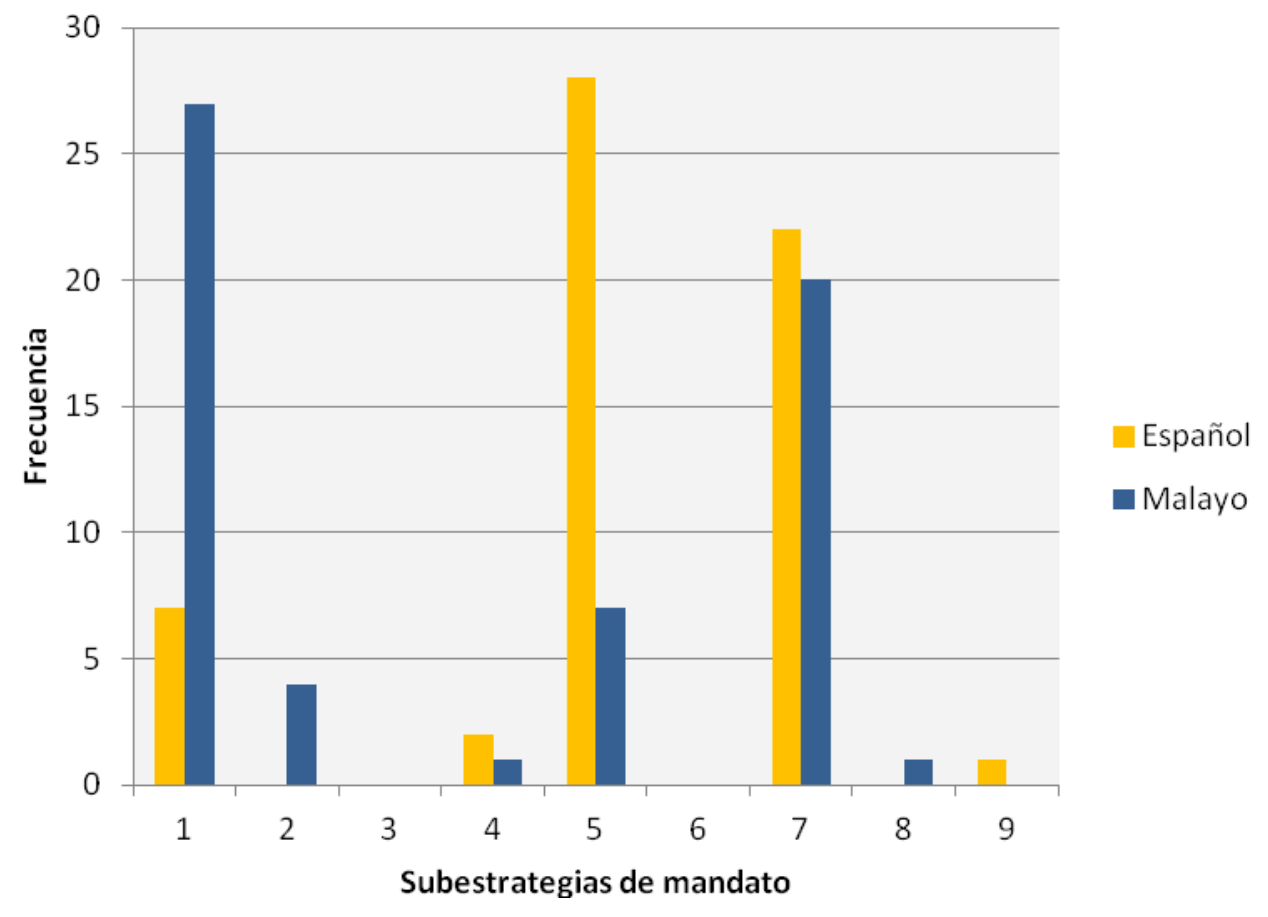

1.Imperativo 2.Performativo 3.Performativo evasivo 4.Declaración de obligación 5.Declaración de deseo 6.Fórmula de sugerencia 7.Interrogación preparatoria 8. Indicio fuerte 9 .Indicio suave

Los nativos españoles se inclinan hacia el empleo de la "Declaración de deseo", con 28 enunciados recogidos, en comparación con tan solo 7 de los malayos con esa misma estrategia. Los nativos malayos, por su parte, tendieron a realizar su mandato utilizando un "Imperativo", del que se han encontrado 27 ejemplos, en contraste con los 7 de los españoles. Sin embargo, en cuanto a la segunda estrategia más frecuente, los dos grupos coincidieron en optar por la de "Interrogación preparatoria" (22 enunciados en los datos de los españoles y 20 en los malayos). 
En relación al número de estrategias diferentes utilizadas, vemos que los españoles presentan menor variedad que los malayos, con 5 estrategias empleadas frente a las 6 de los malayos. En este escenario, ningún español aplicó las estrategias de "Performativo" e "Indicio fuerte", mientras que en los datos malayos aparecieron las dos, la primera en 4 ocasiones y la segunda tan solo en una. En cambio, no se encontró ningún caso de "Indicio suave" en los datos malayos, pero los españoles sí la utilizaron una vez. Cabe subrayar que los índices indicaron diferencias significativas entre las medias obtenidas entre España y Malasia en lo que respecta al uso de los actos principales: $X^{2}=30.793 p=.000(p<.05)$.

Respecto a los movimientos de apoyo, en total, los españoles produjeron un mayor número de enunciados que los malayos (226 frente 136 de los malayos). Además, utilizaron un mayor número de tipos diferentes de estrategia que los malayos: 11 y 10, respectivamente. En la tabla que presentamos a continuación, queda recogido el número de enunciados en los que se ha empleado cada uno de los tipos de estrategia, en las producciones de cada grupo de hablantes: 
Figura 111. Distribución de enunciados (movimientos de apoyo) producidos para la situación 3, en cada cultura

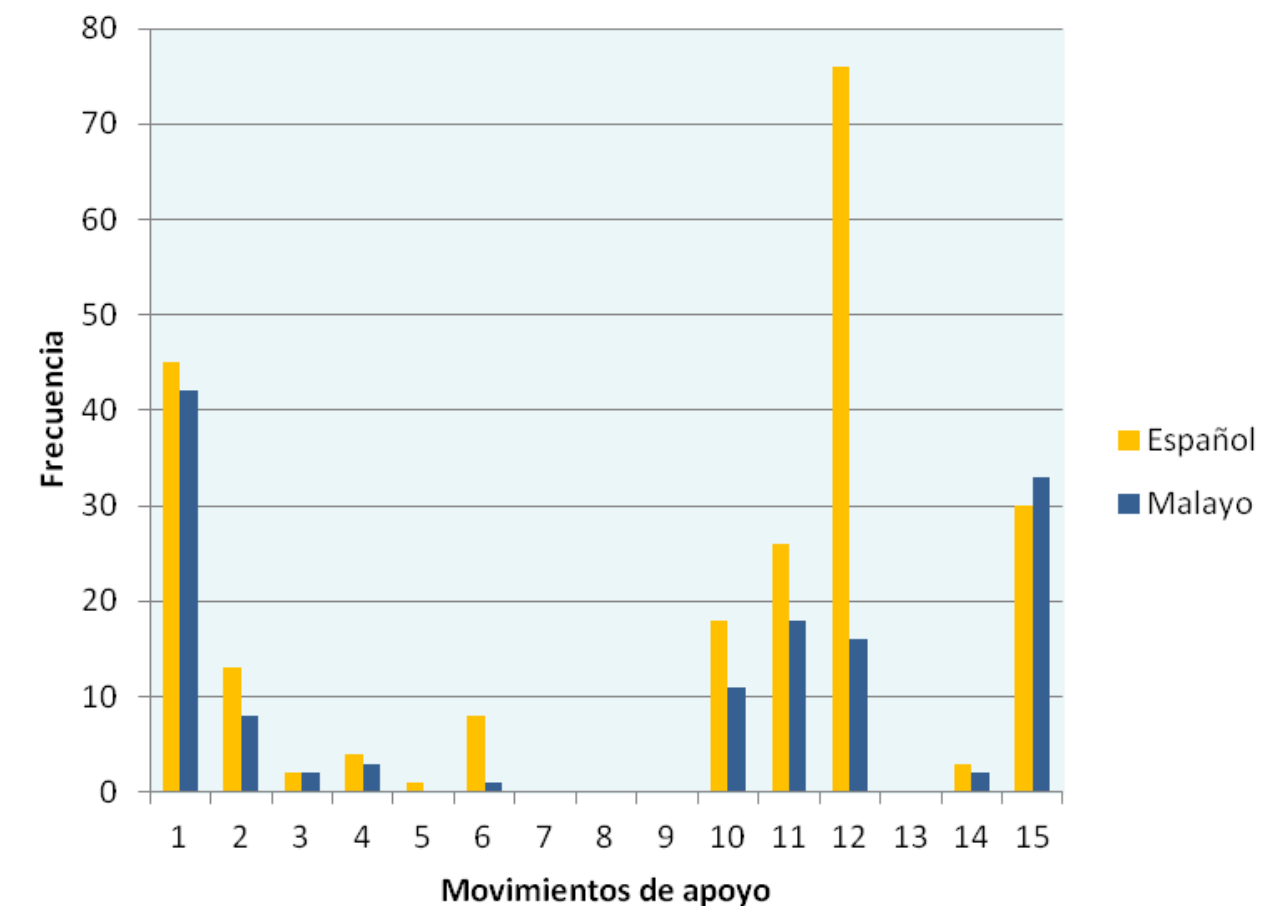

1.Fórmulas de preparación 2.Búsqueda de un compromiso 3.Razones 4.Previsión de objeciones 5.Promesa de recompensa/reparación 6.Minimización de la imposición 7.Invocación de principios generales 8.Reconocimiento de la imposición 9.Preocupación 10.Apreciación 11.Gravedad/urgencia 12.Presentación/saludo 13.Petición de la opinión del oyente 14.Disculpa 15.Fórmulas de tratamiento

Llama la atención en la gráfica la alta frecuencia con la que aparece la estrategia de "Presentación/saludo" en el corpus español, que está presente en 76 enunciados, frente a los tan solo 16 ejemplos de los malayos, lo que la sitúa en cuarto lugar en el índice de frecuencia de uso, en las respuestas de los hablantes de esta cultura. La estrategia que ocupa la segunda posición entre las más repetidas en las respuestas de los españoles, es la de "Fórmulas de preparación", con 45 ejemplos, que fue, por otro lado, la más empleada por los malayos (en 42 ocasiones). La tercera opción más 
aplicada entre los sujetos españoles, la de "Fórmulas de tratamiento" (con 30 enunciados), ocupa el segundo lugar en los datos de los malayos (33), y, la cuarta, "Gravedad/urgencia", con 26 ejemplos en español, se situó en el tercer lugar en el corpus de los malayos (18). La diferencia entre las medias de las estrategias de movimientos de apoyo aplicadas por los hablantes de los grupos examinados fue significativa: $X^{2}=29.976 p=.001(p<.05)$.

\section{B) Mayor frente a menor}

Si analizamos los actos principales producidos para la situación 3, teniendo en cuenta el criterio de la edad, vemos que ambos subgrupos en las dos sociedades mostraron preferencia por el uso de estrategias "Directas". En el caso español, fueron los mayores los que prefirieron ejecutar los mandatos de manera directa, con 21 muestras, frente a las 16 de los jóvenes. En la sociedad malaya, por el contrario, fueron los jóvenes los que utilizaron las estrategias "Directas" en mayor medida (23 enunciados de los jóvenes frente a 16 de los mayores).

El segundo tipo de estrategia más empleado fue el de las "Convencionalmente indirectas", más utilizadas en la sociedad española por los jóvenes que por los mayores (13 y 9 enunciados, 
respectivamente). En los subgrupos malayos, en cambio, fueron los mayores los que mostraron una tendencia más destacada hacia el empleo de dicha forma: 14 ejemplos recogidos frente a tan solo 6 de los jóvenes.

Respecto a las estrategias "No convencionalmente indirectas", no aparecen en los registros de los mayores (ni españoles ni malayos), y solamente una vez en los de los jóvenes de las dos sociedades.

Figura 112. Distribución de enunciados (actos principales) según las estrategias de mandato seleccionadas para la situación 3, en cada subgrupo

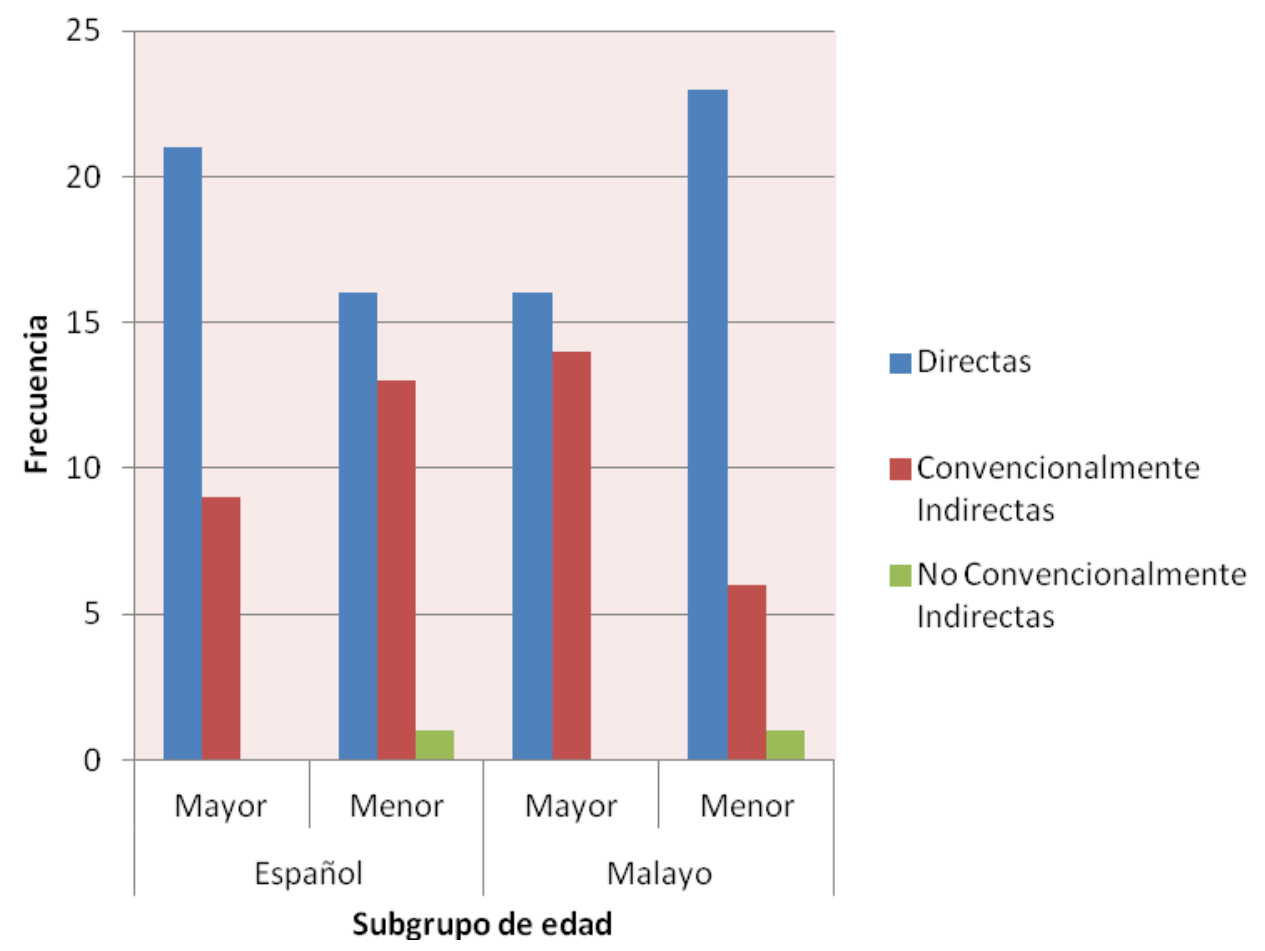


Finalmente se encontró que las diferencias entre los subgrupos de edad en ambas culturas a través de la comparación de los promedios de las formas utilizadas no fueron significativas.

Al aplicar la sub-clasificación en nueve tipos de estrategia que estamos utilizando en nuestro estudio para el análisis del grado de (in)dirección de los enunciados producidos como actos principales, los resultados numéricos obtenidos son los que aparecen en la siguiente gráfica:

Figura 113. Distribución de enunciados (actos principales) de la situación 3, según estrategias aplicadas por cada subgrupo

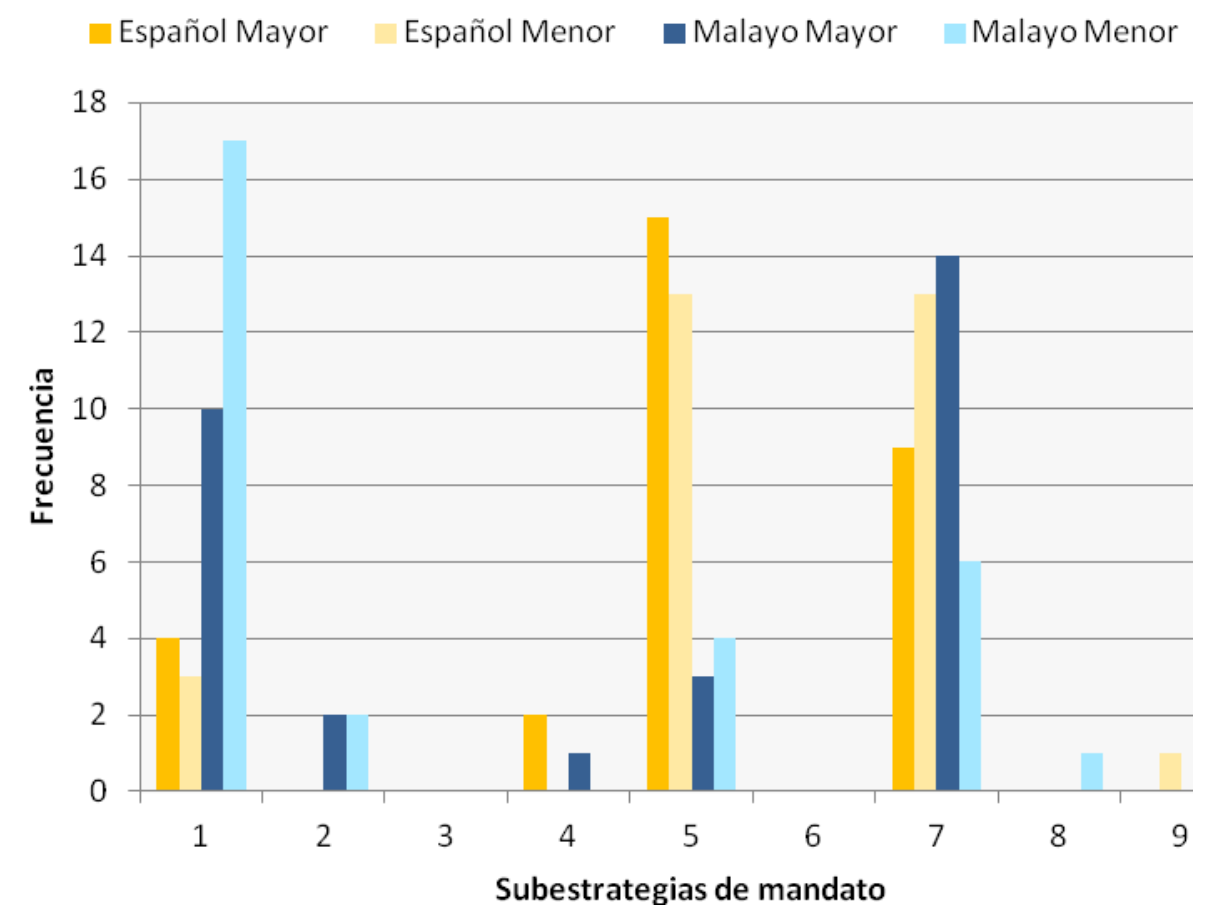

1.Imperativo 2.Performativo 3.Performativo evasivo 4.Declaración de obligación 5.Declaración de deseo 6.Fórmula de sugerencia 7.Interrogación preparatoria 8. Indicio fuerte 9.Indicio suave 
La estrategia de "Declaración de deseo" fue la elegida de forma mayoritaria en ambos subgrupos españoles, aunque fueron los mayores los que la utilizaron en un mayor número de ocasiones: 15 enunciados registrados frente a 13 de los jóvenes. Ahora bien, los jóvenes también mostraron cierta tendencia hacia el uso de una "Interrogación preparatoria" con la misma frecuencia. Por otro lado, en las preferencias mostradas por los subgrupos malayos al hacer los mandatos, se aprecia que, mientras que los mandatos producidos por los mayores malayos se concentraron en el empleo de una "Interrogación preparatoria" (14 enunciados), en los datos de los menores la preferencia viene marcada por el uso del "Imperativo" (17).

En cuanto a la variación de estrategias aplicada por cada subgrupo al producir los mandatos, tanto los subgrupos de la sociedad española como los de la malaya utilizaron el mismo número de estrategias diferentes ( 4 en la primera, y 5 en la segunda). Sin embargo, hubo algunas estrategias que están presentes en un subgrupo pero no en el otro. Así, por ejemplo, en el corpus de los mayores del grupo español se encontró la estrategia de "Declaración de obligación" (4 enunciados), pero no hay ningún registro en el de los jóvenes. En cambio, en el corpus de los jóvenes apareció un "Indicio suave", estrategia de la que no se encontró ningún caso en los datos de los mayores. En el caso del grupo malayo, ningún sujeto 
del grupo de mayores aplicó indicios fuertes en su mandato, pero sí que aparecen una vez en los datos de los menores. Y los menores no emplearon ninguna "Declaración de obligación", pero sí se encontró dicha estrategia en las respuestas de los mayores en una ocasión. La diferencia entre los promedios de las estrategias usadas por los hablantes mayores y los menores no fue significativa en los datos de ninguno de los grupos.

En el caso de los movimientos de apoyo, la clasificación de las estrategias empleadas en los enunciados producidos como tales en la situación 3, se presenta como sigue:

Figura 114. Distribución de enunciados (movimientos de apoyo) producidos para la situación 3, en ambas culturas, según estrategias aplicadas

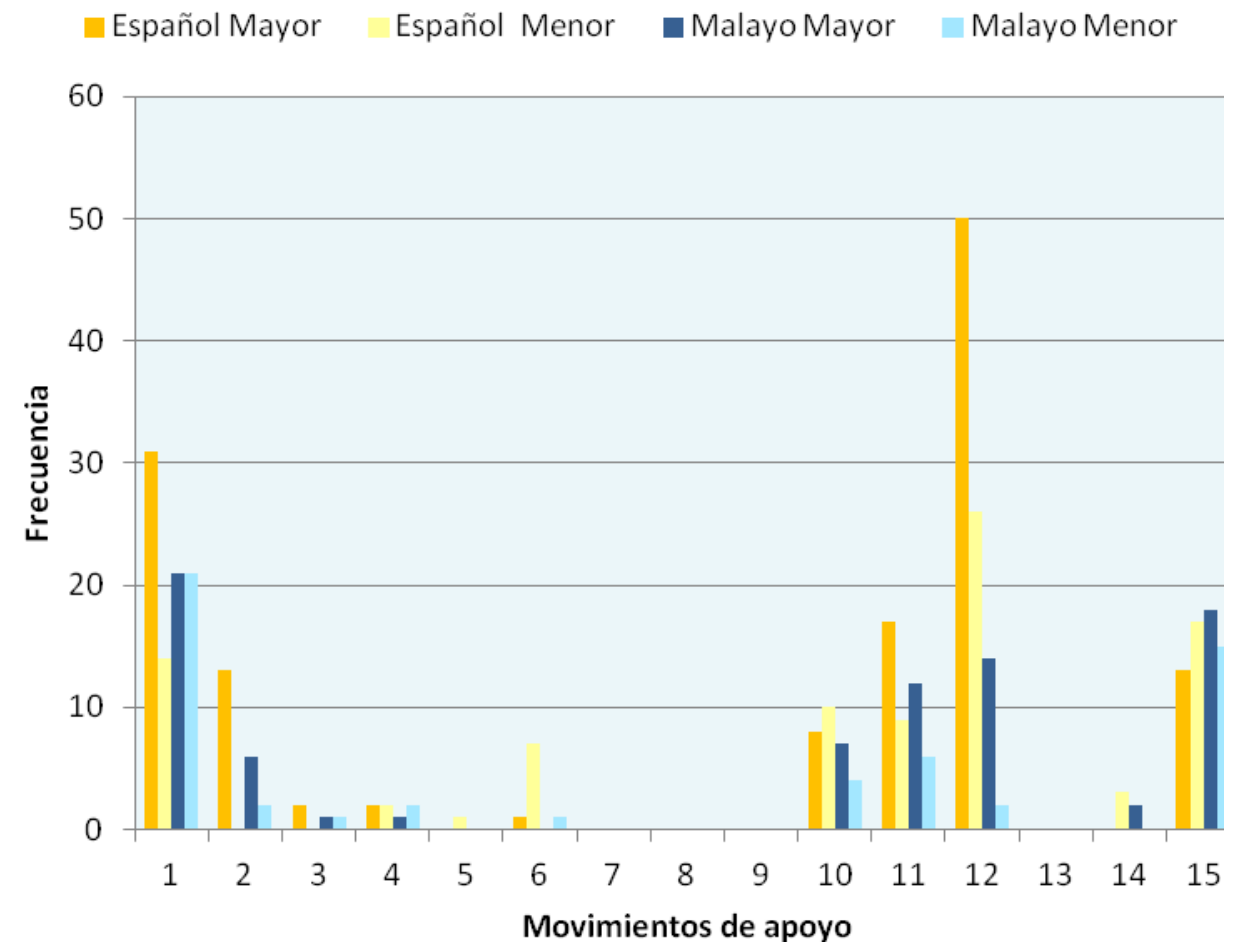


1.Fórmulas de preparación 2.Búsqueda de un compromiso 3.Razones 4.Previsión de objeciones 5.Promesa de recompensa/reparación 6.Minimización de la imposición 7.Invocación de principios generales 8. Reconocimiento de la imposición 9.Preocupación 10.Apreciación 11.Gravedad/urgencia 12.Presentación/saludo 13.Petición de la opinión del oyente 14.Disculpa 15.Fórmulas de tratamiento

Según refleja la gráfica, tanto los hablantes españoles de más edad como los de menos, recurrieron en mayor medida a la opción de "Presentación/saludo". Pese a que los dos subgrupos examinados mostraron preferencia por dicha estrategia, llama la atención la diferencia en el número de enunciados en la que es utilizada por los mayores (50), en comparación con los jóvenes (26). Aunque la estrategia más utilizada fue la misma en ambos subgrupos, sí que se da una cierta diferencia en el orden de preferencia de otras estrategias. De esta forma, mientras que, en el caso de los mayores la segunda opción más elegida es la de "Fórmulas de preparación" (31 casos), en el subgrupo de los menores fue la estrategia de "Fórmulas de tratamiento" (17). Además, los españoles de más edad emplearon también las estrategias de "Búsqueda de un compromiso" (13) y "Previsión de objeciones" (2), de las cuales no se encontró ningún caso en las respuestas de los menores. En el material proporcionado por los menores, y como se ha dicho más arriba, la estrategia de "Fórmulas de tratamiento" (17 enunciados) fue la segunda más empleada, pero en los datos mayores fue la cuarta opción más elegida, con 13 registros. La tercera forma preferida por los más jóvenes, la de 
"Fórmulas de preparación", aparece también, con 13 registros en la cuarta posición por orden de frecuencia, de las respuestas de los mayores. Por otro lado, en las respuestas de los menores se encontraron las estrategias de "Disculpa" (3 veces) y "Promesa de recompensa/reparación" (una vez), que no se registraron en las de los mayores.

En el grupo malayo, por su parte, los dos subgrupos de edad no solo mostraron la misma preferencia por la estrategia de "Fórmulas de preparación", sino que también la utilizaron en el mismo número de enunciados (21). Respecto a la segunda opción más empleada, ambos subgrupos también optaron por la misma estrategia, la de "Fórmulas de tratamiento", con 18 casos entre las respuestas de los mayores y 15 en las de los menores. Sin embargo, los malayos mayores y los menores se diferenciaron bastante respecto al uso de las estrategias de "Gravedad/urgencia" y "Presentación/saludo", puesto que mientras 12 de los informantes mayores utilizaron la primera, solamente 6 de los menores recurrieron a la misma estrategia, $y$, respecto a la segunda, aparece en 14 de las respuestas de los mayores en comparación con tan solo 2 de los menores. Además, ningún sujeto mayor empleó la "Minimización de la imposición", pero la encontramos una vez en los datos de los menores. En cambio, de la "Disculpa" sí que hay ejemplos de uso en los sujetos de más edad (2 veces), pero no hay 
ningún registros en las respuestas de los menores. La comparación de los promedios entre los movimientos de apoyo empleados entre los subgrupos de edad no indicó una diferencia significativa en el corpus malayo, pero sí en el español: $X^{2}=31.966 p=.000(p<.05)$.

\section{C) Varón frente a mujer}

Al comparar los enunciados producidos como actos principales en las respuestas de los encuestados varones y mujeres en el grupo español, se observa que, los primeros, mostraron una mayor tendencia a usar estrategias "Directas" (21 de los varones frente a 16 de las mujeres). En cambio, en el otro grupo, fueron las mujeres las que más utilizaron este tipo de estrategias, con 22 ejemplos recogidos, frente a los 17 de los varones. En lo referente al empleo de las "Convencionalmente indirectas", el resultado fue el contrario, es decir, los varones del grupo español las aplicaron más que las mujeres (13 y 9, respectivamente), y en el grupo malayo, fueron las mujeres las que la usaron en mayor medida (22 de las mujeres frente a 17 de los varones). Y, sobre las "No Convencionalmente Indirectas", hay que decir que solo están presentes en los datos mujeres españolas y en los varones malayos, con una sola aparición. Según indicó el valor estadístico, no existe diferencia 
significativa entre las medias de ambos sexos en este caso, en ninguno de los dos países.

Figura 115. Distribución de estrategias de mandato empleadas en los enunciados (actos principales) producidos para la situación 3 por cada grupo de género

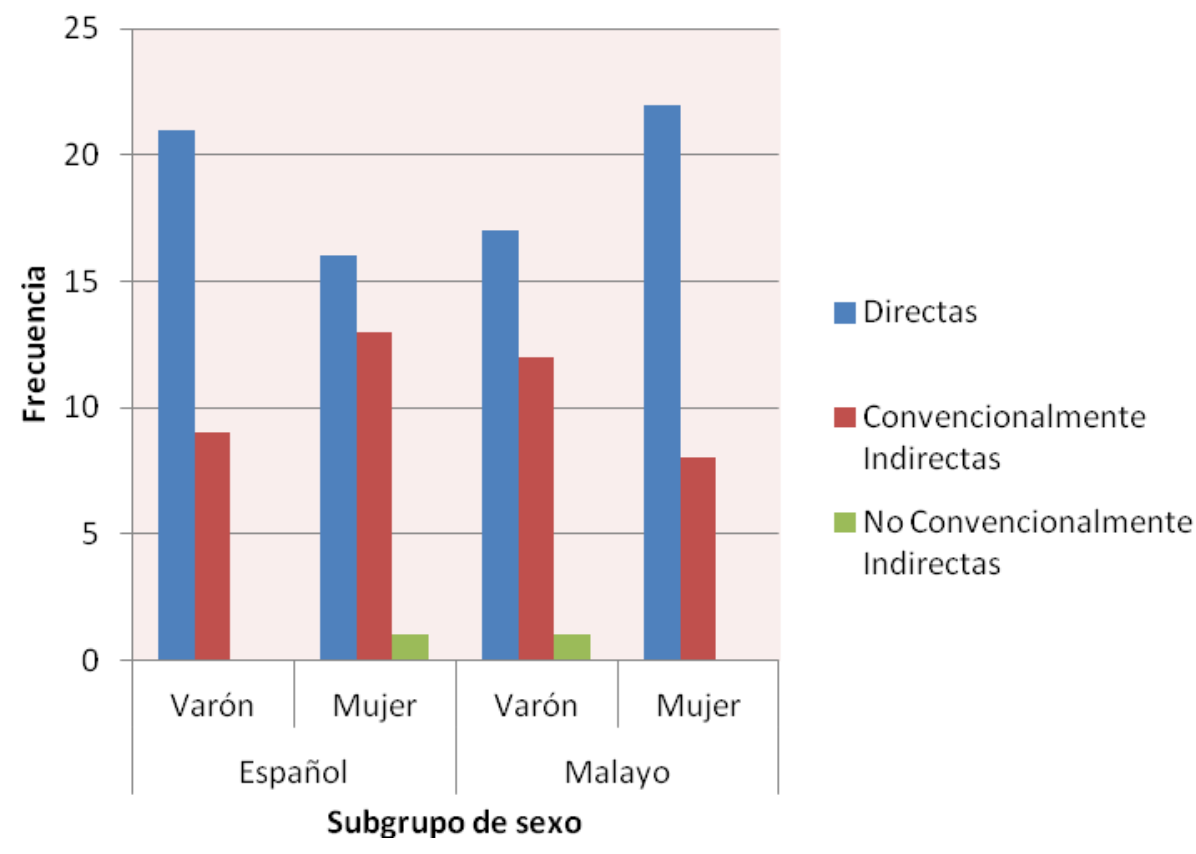

Si aplicamos a esos mismos enunciados (es decir, a los actos principales) la sub-clasificación de estrategias propuesta por Blum-Kulka, los resultados numéricos que se obtienen son los que se presentan en la siguiente gráfica: 
Figura 116. Distribución de enunciados (actos principales) producidos para la situación 3 por cada grupo de género, según grado de (in)dirección de estrategias

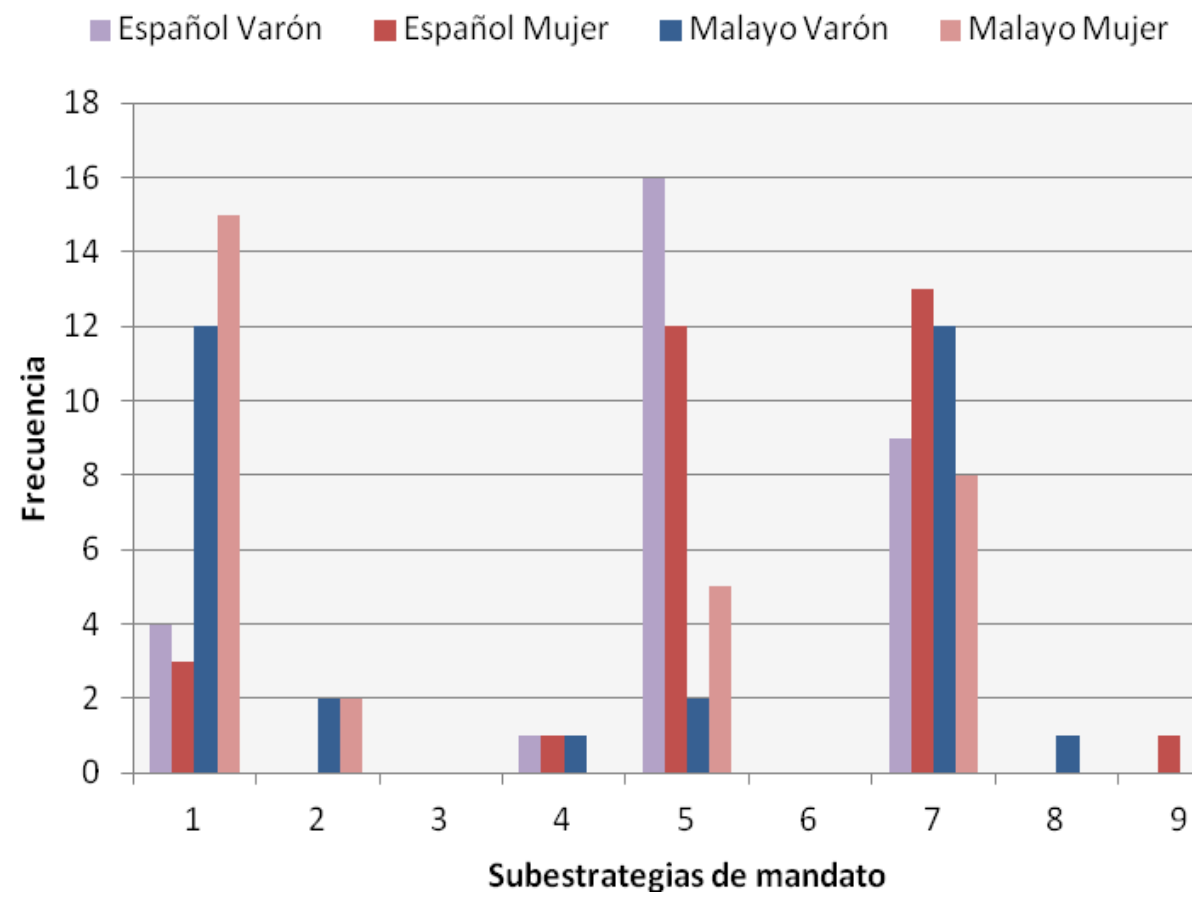

1.Imperativo 2.Performativo 3.Performativo evasivo 4.Declaración de obligación 5.Declaración de deseo 6.Fórmula de sugerencia 7.Interrogación preparatoria 8. Indicio fuerte 9 .Indicio suave

En este escenario los varones españoles prefirieron hacer el mandato a través de una "Declaración de deseo" (16 enunciados), siendo el uso de una "Interrogación preparatoria" la segunda estrategia más empleada por dicho grupo (9 registros). En las mujeres se invierte este orden de preferencia, y así, hay 13 respuestas con una "Interrogación preparatoria" y 12 con una "Declaración de deseo". Hay que mencionar, además, que los varones españoles aplicaron 4 estrategias diferentes frente a las 5 utilizadas por las mujeres. Así, ningún varón usó la de "Indicio 
suave" en sus mandatos, pero apareció una vez en los datos femeninos.

En el grupo malayo por su parte, los varones emplearon más variedad de estrategias que las mujeres (6 diferentes frente a las 4 aplicadas por las mujeres), de forma que algunas de ellas, como la "Declaración de obligación" y el "Indicio fuerte", aparecen una vez en las intervenciones de los sujetos varones, pero no se encontró ningún caso de dichas fórmulas en el corpus de las mujeres. En este contexto, la diferencia indicada entre las medias de ambos sexos en los dos países tampoco fue significativa.

En la recopilación de los movimientos de apoyo que acompañan a los actos principales analizados arriba, se obtuvieron un total de 116 enunciados de los varones españoles y 110 de las mujeres del mismo grupo, enunciados en los que los dos sexos aplicaron el mismo número de estrategias diferentes (10), aunque no se trata de las mismas opciones. Por ejemplo, en los datos de las mujeres, las "Razones" aparecen en 3 ocasiones, pero no encontramos ningún ejemplo en las respuestas de los varones. En cambio, no se encontró ninguna "Promesa de recompensa/reparación" en los datos de las mujeres, pero los varones sí la emplearon una vez. 
En el grupo malayo por su parte, fueron las mujeres las que produjeron más enunciados como movimientos de apoyo (81 de las mujeres frente a 55 de los varones). Con respecto a las estrategias empleadas, fueron los varones quienes usaron una mayor variedad: 10 tipos diferentes frente a los 8 empleados por las mujeres. De esta forma, mientras que los varones aplicaron la estrategia de "Previsión de objeciones" en 3 ocasiones, ninguna mujer la utilizó en sus mandatos. Ahora bien, todas las estrategias empleadas por las mujeres, también fueron utilizadas por los varones.

Al igual que en el caso de los actos principales, en el uso de los movimientos de apoyo tampoco se han encontrado diferencias estadísticas significativas entre los subgrupos de ambos sexos de los dos países.

Respecto a las estrategias más utilizadas en la producción de estos movimientos de apoyo, la tabla que presentamos a continuación recoge la distribución de uso (según número de enunciados) por cada subgrupo de participantes: 
Figura 117. Distribución de enunciados (movimientos de apoyo) producidos para la situación 3 en cada género

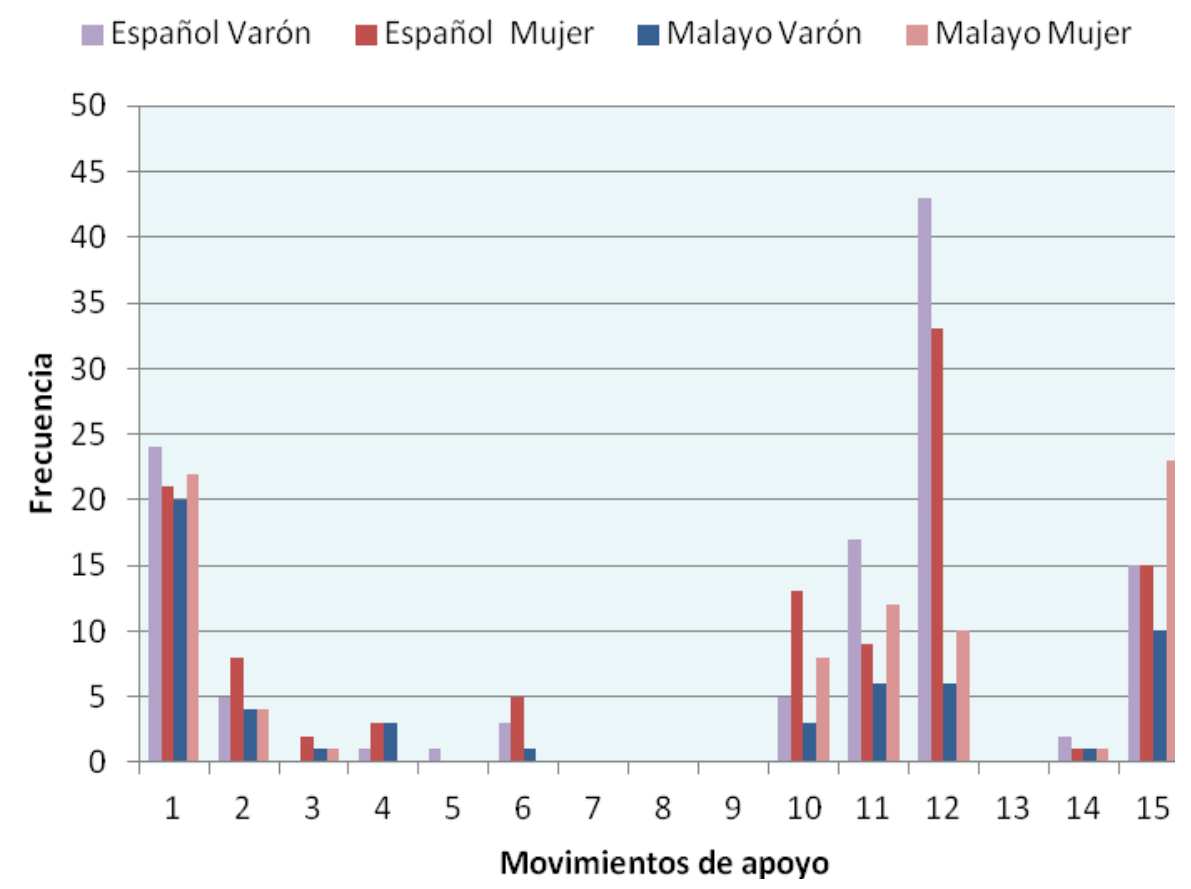

1.Fórmulas de preparación 2.Búsqueda de un compromiso 3.Razones 4.Previsión de objeciones 5.Promesa de recompensa/reparación 6.Minimización de la imposición 7.Invocación de principios generales 8.Reconocimiento de la imposición 9.Preocupación 10.Apreciación 11.Gravedad/urgencia 12.Presentación/saludo 13.Petición de la opinión del oyente 14.Disculpa 15.Fórmulas de tratamiento

En lo referente a la estrategia más empleada, los sujetos españoles de los dos sexos se inclinaron, mayoritariamente, hacia el uso de una "Petición de la opinión del oyente" (43 ejemplos en el corpus de los varones y 33 en el de las mujeres. $Y$ en cuanto a la segunda y la tercera estrategia más usada por cada subgrupo, los resultados obtenidos también fueron similares: los participantes de ambos sexos optaron por "Fórmulas de preparación" en el primer caso (24 hombres y 21 mujeres), y recurrieron al empleo de 
"Fórmulas de tratamiento", en el segundo (15 enunciados tanto de hombres como de mujeres).

En cambio, en los dos subgrupos malayos sí que encontramos ciertas diferencias en la elección de estrategia. La forma dominante en las producciones de los varones fue la de "Fórmulas de preparación", con 20 ejemplos recogidos, mientras que las mujeres utilizaron mayoritariamente "Fórmulas de tratamiento" (23). Con respecto a la segunda más repetida, es interesante remarcar que, en los datos de los varones, fue la estrategia de "Fórmulas de preparación", con 22 enunciados, mientras que en las respuestas de las mujeres fue la de "Fórmulas de tratamiento", con 10 registros.

\subsubsection{Situación 6}

En la situación 6, un profesor amonesta a uno de sus estudiantes que llega tarde a clase y le ordena que sea puntual. Los interlocutores son, entonces, conocidos. 


\section{A) Español frente a malayo}

En el análisis de las estrategias empleadas en los actos principales producidos en esta situación, existe una clara diferencia entre ambas culturas, como podemos observar en la siguiente gráfica:

Figura 118. Distribución de estrategias de mandato en actos principales producidos para la situación 6 , en ambas culturas

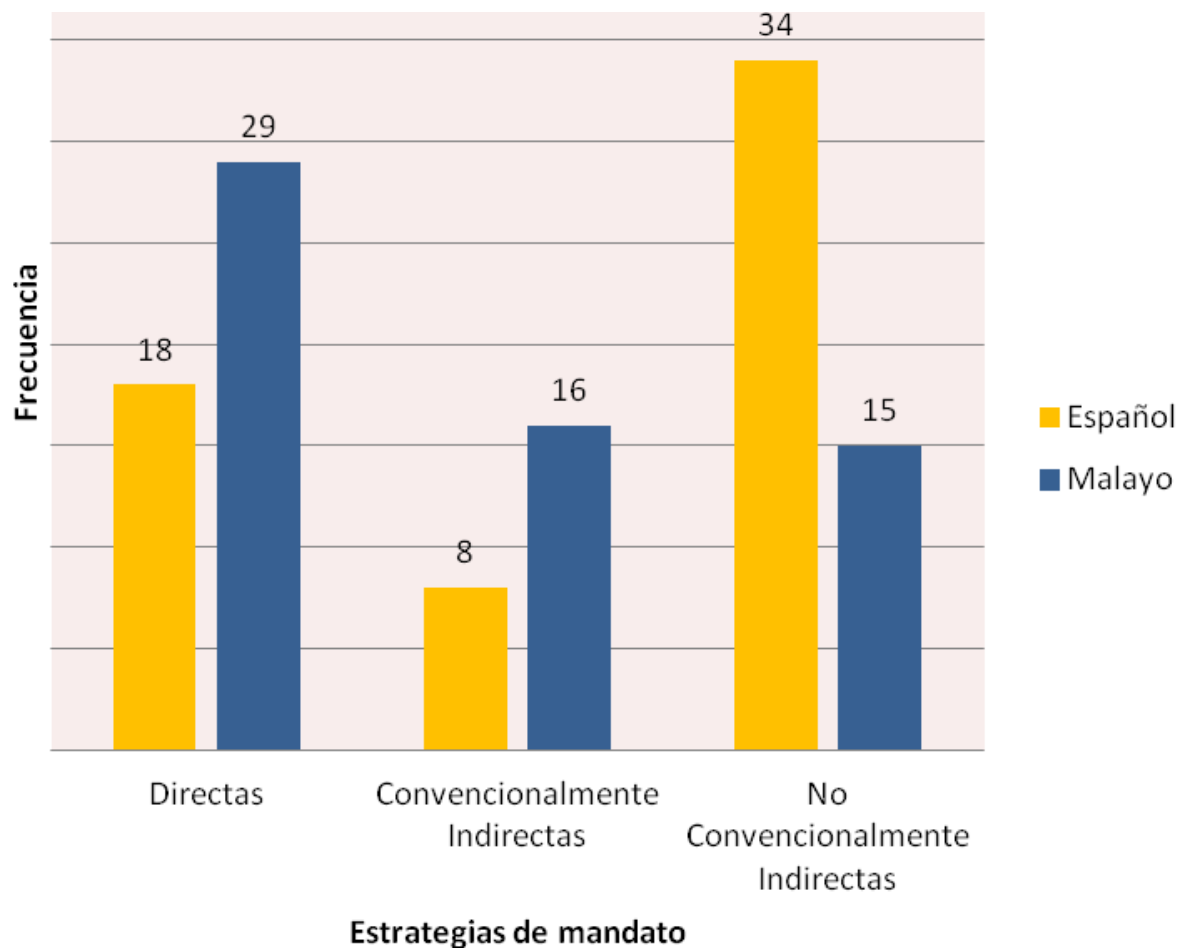

Mientras que las producciones de los informantes españoles se concentran en el uso de estrategias "No convencionalmente indirectas", con 34 ejemplos, en los datos malayos la misma categoría fue la menos elegida (con 15). Es decir, 
la categoría preferida por los nativos españoles es la menos elegida por los malayos. La segunda estrategia más utilizada por los españoles es la de las "Directas", con 18 enunciados producidos, y fue la forma más utilizada por los malayos (aparece 29 veces). Las llamadas "Convencionalmente indirectas" son las que menos aparecen en el corpus español de esta situación (8 registros), pero las segundas más empleadas por los malayos (16 ejemplos). La diferencia obtenida entre los promedios de las categorías aplicadas sí fue significativa: $X^{2}=12.608 p=.002(p<.05)$.

Si aplicamos a estas estrategias que acabamos de analizar la sub-clasificación de Blum-Kulka, vemos que hay una gran diferencia en las tendencias de cada una de las sociedades estudiadas: 
Figura 119. Distribución de enunciados producidos como actos principales según estrategias empleadas para la situación 6 , en ambas culturas

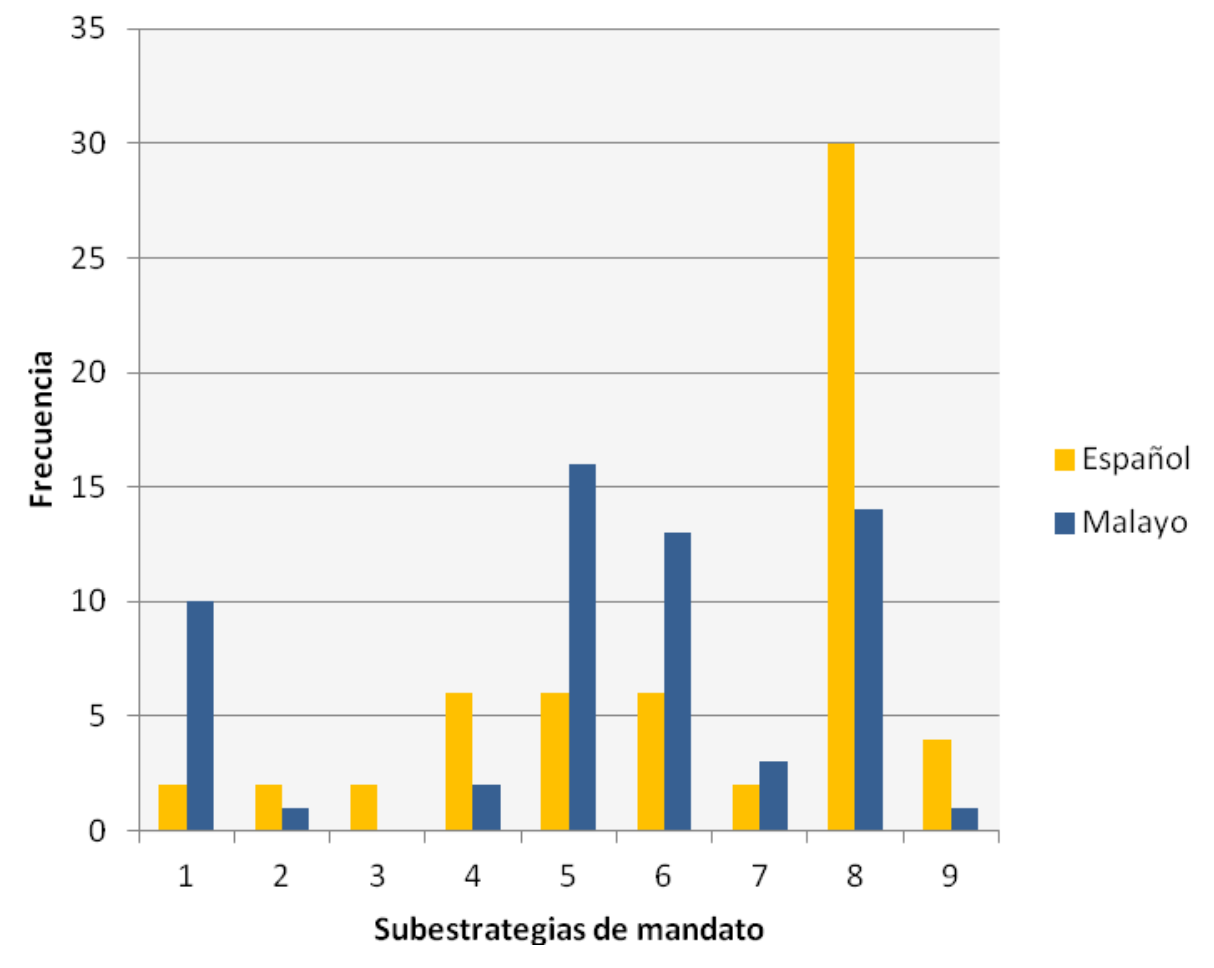

1.Imperativo 2.Performativo 3.Performativo evasivo 4.Declaración de obligación 5.Declaración de deseo 6.Fórmula de sugerencia 7.Interrogación preparatoria 8. Indicio fuerte 9 . Indicio suave

Como se aprecia en la tabla, la estrategia dominante del grupo español fue la de "Indicio fuerte", con 30 casos, seguida de "Declaración de obligación", "Declaración de deseo" y "Fórmula de sugerencia" (6 enunciados registrados con cada una). El grupo malayo, en cambio, prefirió usar en la mayoría de las ocasiones una declaración de deseo (16 enunciados), además de otras estrategias como las de "Indicio fuerte" (14) y "Fórmula de sugerencia" (13). Los informantes españoles utilizaron las nueve estrategias de actos principales, pero en el grupo malayo sí que hubo una estrategia, la 
de "Performativo evasivo", de la que no se encontró ningún ejemplo de uso. Cabe destacar, en este apartado, que las pruebas estadísticas mostraron que las dos culturas analizadas se diferenciaron significativamente en la comparación de los promedios de los actos principales formulados: $X^{2}=24.609 p=.002(p<.05)$.

Figura 120. Distribución de movimientos de apoyo producidos para la situación 6 , en ambas culturas

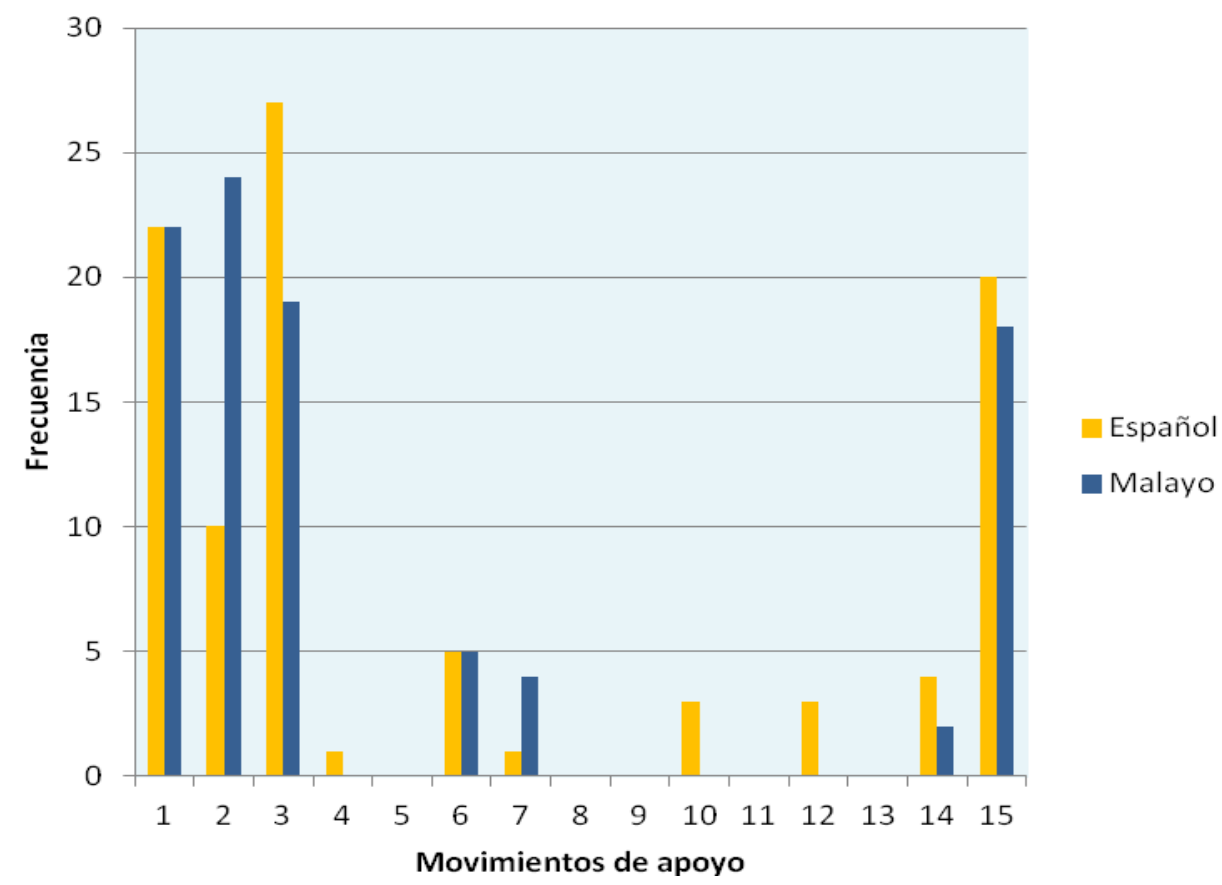

1.Fórmulas de preparación 2.Búsqueda de un compromiso 3.Razones 4.Previsión de objeciones 5.Promesa de recompensa/reparación 6.Minimización de la imposición 7.Invocación de principios generales 8.Reconocimiento de la imposición 9.Preocupación 10.Apreciación 11.Gravedad/urgencia 12.Presentación/saludo 13.Petición de la opinión del oyente 14.Disculpa 15.Fórmulas de tratamiento

Los grupos estudiados no mostraron diferencias muy significativas en el número de enunciados producidos (96 de los españoles y 94 de los malayos). Ahora bien, los participantes 
españoles aplicaron un mayor número de estrategias diferentes, con 10 tipos distintos en comparación con los 7 utilizados por los malayos. En cuanto a la estrategia empleada por la mayoría de sujetos, los dos grupos mostraron una tendencia distinta. Así, en el corpus español, la estrategia más utilizada fue la de "Razones" (27 registros), seguida de la de "Fórmulas de preparación" (22) y la de "Fórmulas de tratamiento" (20). En cambio, la mayoría de los participantes malayos optaron por la "Búsqueda de un compromiso", de la que encontramos 24 casos, seguida del uso de "Fórmulas de preparación" (22) y de "Razones" (19). Hay que señalar la ausencia de tres estrategias en los datos malayos, "Previsión de objeciones", "Apreciación" y "Presentación/saludo", de las que sí que se han recogido ejemplos en los datos españoles (1 de "Previsión de objeciones", y 3 de cada una de las otras dos). A diferencia del análisis de actos principales, en este caso, los promedios comparados no indicaron ninguna diferencia significativa.

\section{B) Mayor frente a menor}

Al contrastar las respuestas de los sujetos de los subgrupos de edad formuladas en la situación 6, analizando el grado de (in)dirección de las estrategias empleadas en los actos principales, los resultados numéricos obtenidos fueron los que presentamos a continuación: 
Figura 121. Distribución de estrategias de mandato en los subgrupos de edad

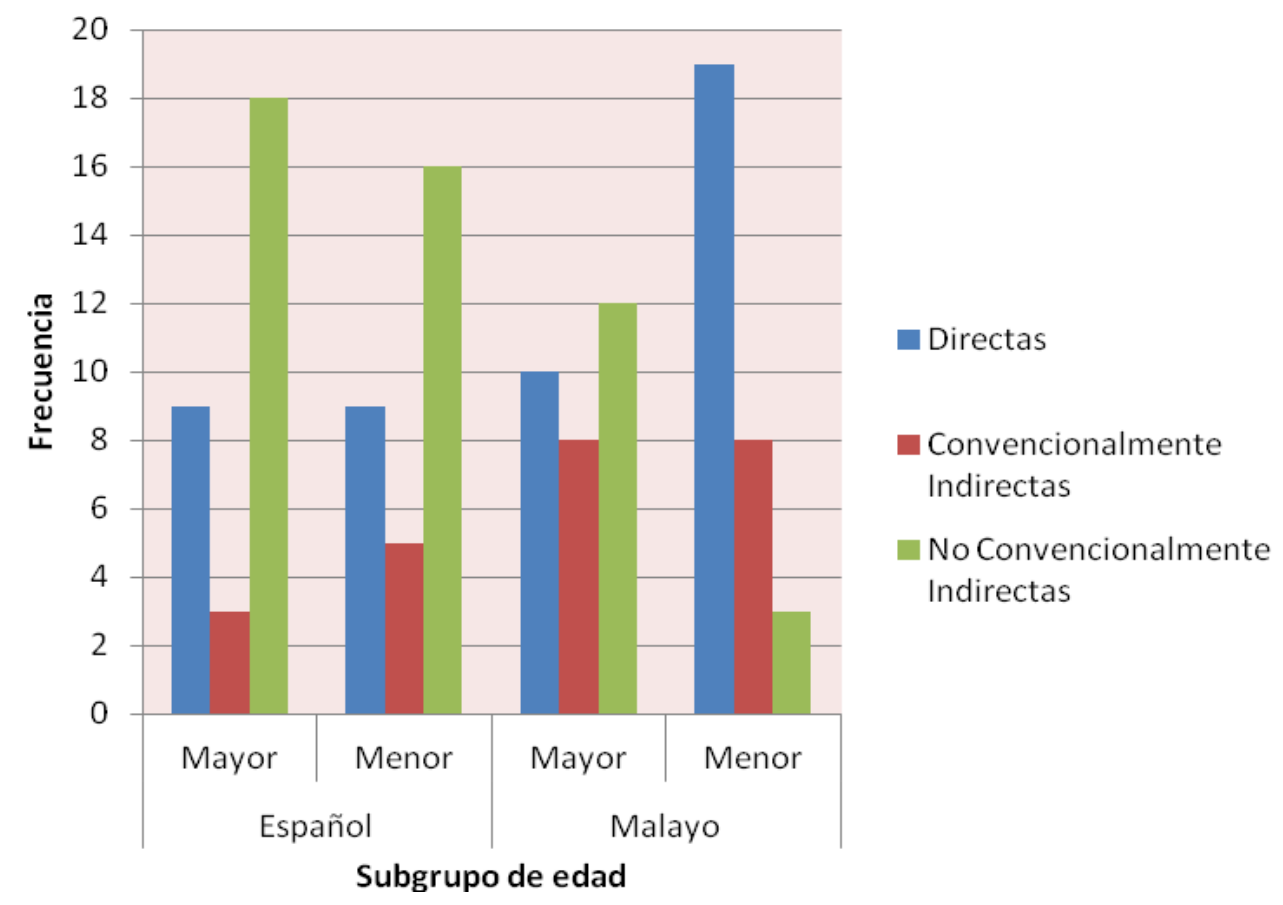

Los hablantes de todas las edades de la sociedad española coincidieron en mostrar preferencia por las estrategias "No convencionalmente indirectas" (18 enunciados de los mayores y 16 de los menores), seguidas de las "Directas" (9 en ambos casos) y las "Convencionalmente indirectas" (3 de los mayores y 5 de los menores). Por otro lado, en la sociedad malaya, sí que hay una diferencia considerable entre las preferencias mostradas por los hablantes de los dos subgrupos. De esta forma, mientras que los hablantes mayores se inclinaron mayoritariamente hacia el uso de estrategias "No convencionalmente indirectas" (12), los menores recurrieron a ellas en solamente 3 ocasiones. En cambio, en los datos de los menores, encontramos 19 ejemplos de estrategias 
"Directas", que los mayores utilizaron en solo 10 casos. Y en ambos subgrupos encontramos la misma frecuencia de uso en lo que concierne a las "Convencionalmente Indirectas", con 8 ejemplos de cada uno. La comparación de los promedios entre las categorías empleadas entre ambos subgrupos de edad mostró una diferencia considerable en el material malayo $\left(X^{2}=8.193 \mathrm{p}=.017 \quad(\mathrm{p}<.05)\right.$, mientras que en el material español la diferencia no fue significativa.

Al subdividir estos primeros tres grandes bloques de estrategias aplicando las 9 sub-categorías de Blum-Kulka, la clasificación de los enunciados queda tal y como figura en el grafico 122: 
Figura 122. Distribución de enunciados (actos principales) según tipo de estrategia empleada para la situación 6 , en cada subgrupo de género

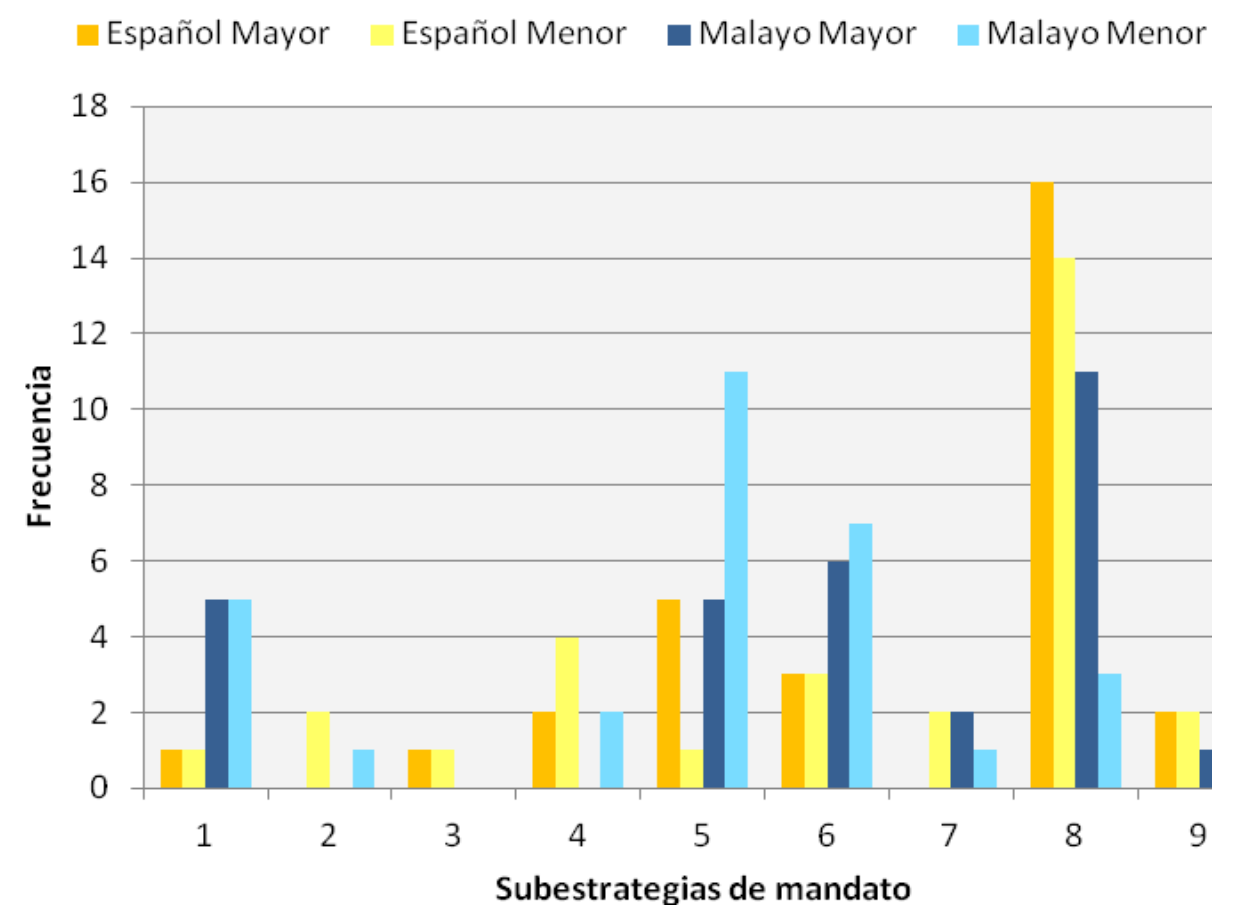

1.Imperativo 2.Performativo 3.Performativo evasivo 4.Declaración de obligación 5.Declaración de deseo 6.Fórmula de sugerencia 7.Interrogación preparatoria 8. Indicio fuerte 9.Indicio suave

Los dos subgrupos españoles no se diferenciaron entre sí en la estrategia más empleada, puesto que tanto los sujetos mayores como los jóvenes prefirieron realizar su mandato a través de un "Indicio fuerte" (16 enunciados de los mayores, 14 de los jóvenes). Ahora bien, en lo relativo a la variedad de las estrategias utilizadas, sí hubo un comportamiento distinto, ya que los mayores aplicaron 7 estrategias diferentes, mientras que los jóvenes se quedaron en 9, aunque sí que encontramos dos estrategias en los datos de los menores y que ninguno de los mayores utilizó, que son las de "Performativo" e "Interrogación preparatoria". 
Por otra parte, en el grupo malayo, los mayores se inclinaron por el uso de indicios fuertes (11 en comparación con tan solo 3 de los menores), pero los jóvenes mostraron cierta tendencia hacia la "Declaración de deseo", con 11 ejemplos, y de la que tan solo se registran 5 casos de los mayores. A diferencia del grupo español, los mayores aplicaron menos estrategias diferentes que los menores (6 y 7, respectivamente), aunque sí que recurrieron al uso de las de "Performativo" y "Declaración de obligación" (con 1 y 2 casos respectivamente), de las que no se encontró ningún en los datos de los jóvenes. La diferencia de los promedios de las estrategias empleadas entre los informantes mayores y los jóvenes, no fue significativa ni en el resultado español ni en el malayo.

Respecto a los movimientos de apoyo, en esta situación los dos subgrupos de mayores fueron más productivos que los jóvenes, con 55 enunciados registrados (frente a 41 de los jóvenes) en las respuestas de los españoles, y 51 y 43 respectivamente, en las de los malayos. En cuanto a la variedad de estrategias aplicada, los sujetos mayores y los menores emplearon el mismo número de estrategias diferentes: 8 estrategias por cada subgrupo español y 6 por cada subgrupo malayo. $\mathrm{Y}$, en relación con las fórmulas empleadas, los subgrupos de edad en ambas sociedades no se diferenciaron al mostrar su preferencia. 
Figura 123. Distribución de enunciados (movimientos de apoyo) según estrategias empleadas para la situación 6, en ambas culturas

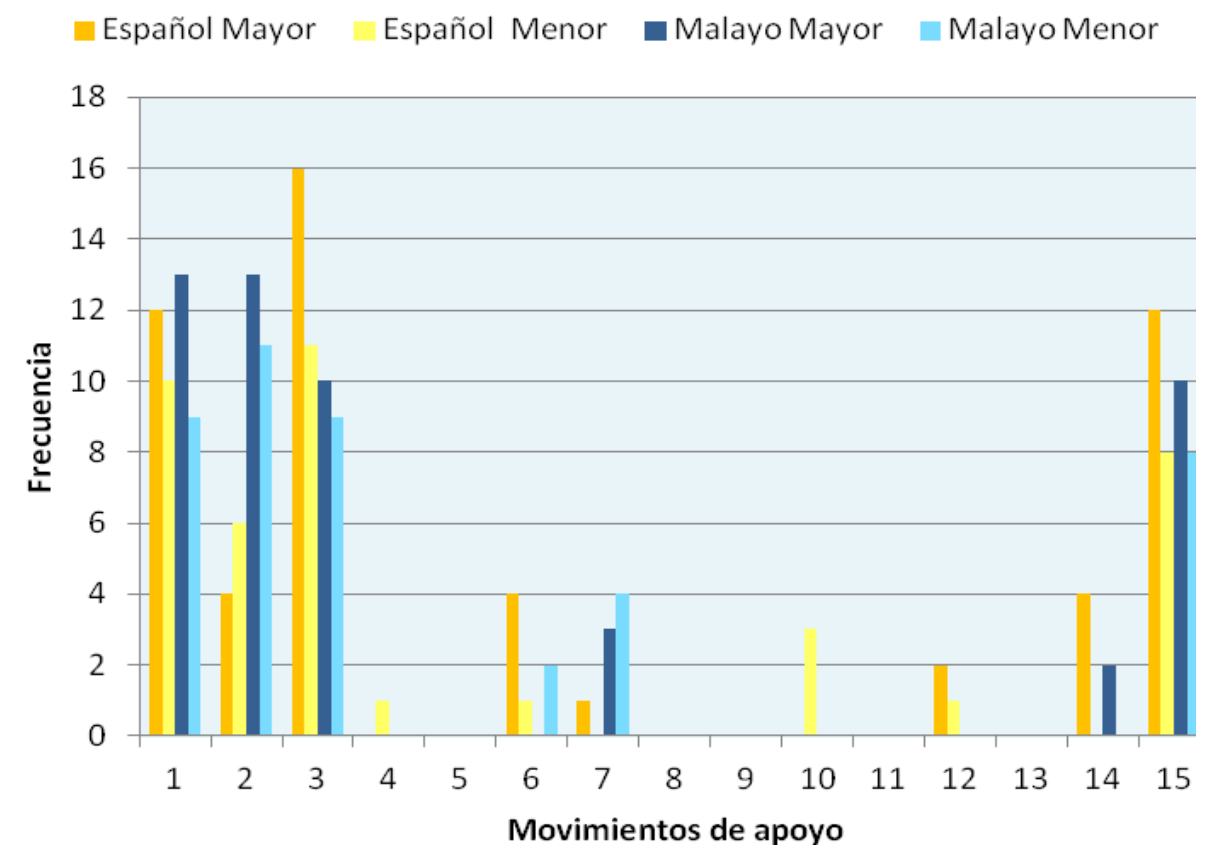

1.Fórmulas de preparación 2.Búsqueda de un compromiso 3.Razones 4.Previsión de objeciones 5.Promesa de recompensa/reparación 6.Minimización de la imposición 7.Invocación de principios generales 8.Reconocimiento de la imposición 9.Preocupación 10.Apreciación 11.Gravedad/urgencia 12.Presentación/saludo 13.Petición de la opinión del oyente 14.Disculpa 15.Fórmulas de tratamiento

Los hablantes mayores y los jóvenes de la sociedad española coincidieron en mostrar preferencia por la estrategia de "Razones" (16 ejemplos de los mayores y 11 de los jóvenes), seguida de la de "Fórmulas de preparación" (12 y 10, respectivamente) y las "Fórmulas de tratamiento", con 12 enunciados registrados en el corpus de los mayores y 8 en el de los jóvenes. Por otro lado, ambos subgrupos malayos optaron mayoritariamente por el uso de la "Búsqueda de un compromiso" (13 casos de los mayores y 11 de los jóvenes). Además de dicha estrategia, los mayores también eligieron 
"Fórmulas de preparación" con la misma frecuencia. Y, por detrás de ellas, aparecen las de "Razones" y "Fórmulas de tratamiento" (10 veces cada una), mientras que en los jóvenes hay otra coincidencia numérica en el número de veces en las que se usan las de "Fórmulas de preparación" y "Razones", con 9 apariciones en ambos casos. En este contexto, tampoco se observó una diferencia significativa en ambos subgrupos de edad en ninguna de las dos culturas, española y malaya.

\section{C) Varón frente a mujer}

En el análisis de los mismos datos con los que venimos trabajando (los correspondientes a la situación 6), y tomando como referencia la variable del sexo de los sujetos, encontramos que los varones y las mujeres de ambos grupos mostraron la misma tendencia. Los sujetos de los dos sexos del grupo español mostraron preferencia por las formas "No convencionalmente indirectas" (19 de los varones y 15 de las mujeres), seguidas de las "Directas" (8 y 10, respectivamente) y las "Convencionalmente indirectas" ( 3 de los varones y 5 de las mujeres). En el grupo malayo, por su parte, ambos sexos presentaron una mayor tendencia hacia el empleo de la categoría de "Directas", con 16 ejemplos de los varones y 13 de las mujeres. La segunda forma más aplicada fue, en el caso de los varones la de las 
estrategias "No convencionalmente indirectas" (9 casos), seguidas de las "Convencionalmente indirectas" (5). En cambio, las mujeres eligieron, en segundo lugar, las formas "Convencionalmente indirectas" (11 veces), seguidas de las "No convencionalmente indirectas", con 6 casos.

Figura 124. Distribución de estrategias de mandato (actos principales) empleadas en la situación 6 por cada grupo de género

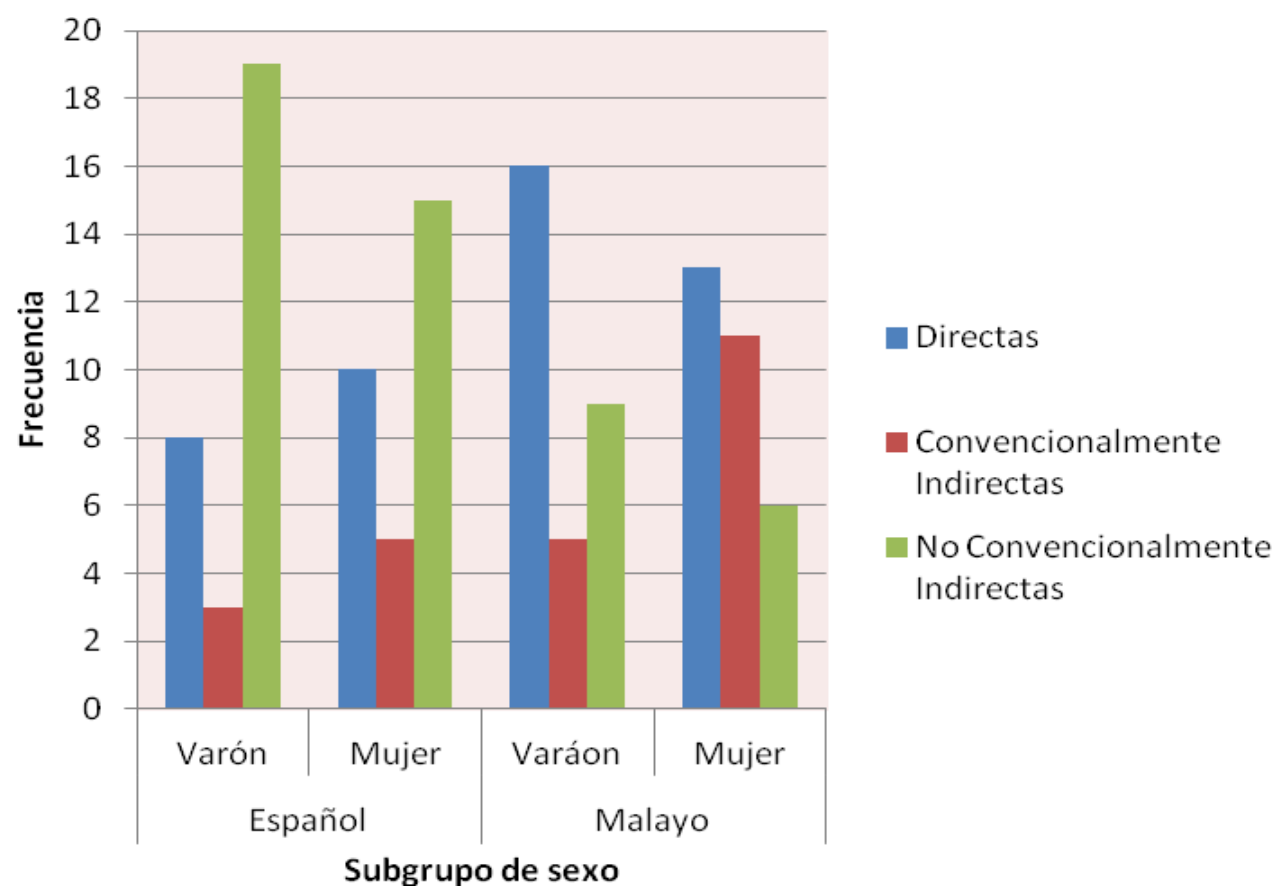

Respecto a los tipos de estrategias elegidas por los hablantes de cada subgrupo de género a la hora de formular su mandato a un estudiante conocido de manera más o menos directa, la siguiente gráfica presenta los resultados numéricos obtenidos: 
Figura 125. Distribución de enunciados (actos principales) según estrategias más o menos directas, empleadas para la situación 6 por cada subgrupo de género

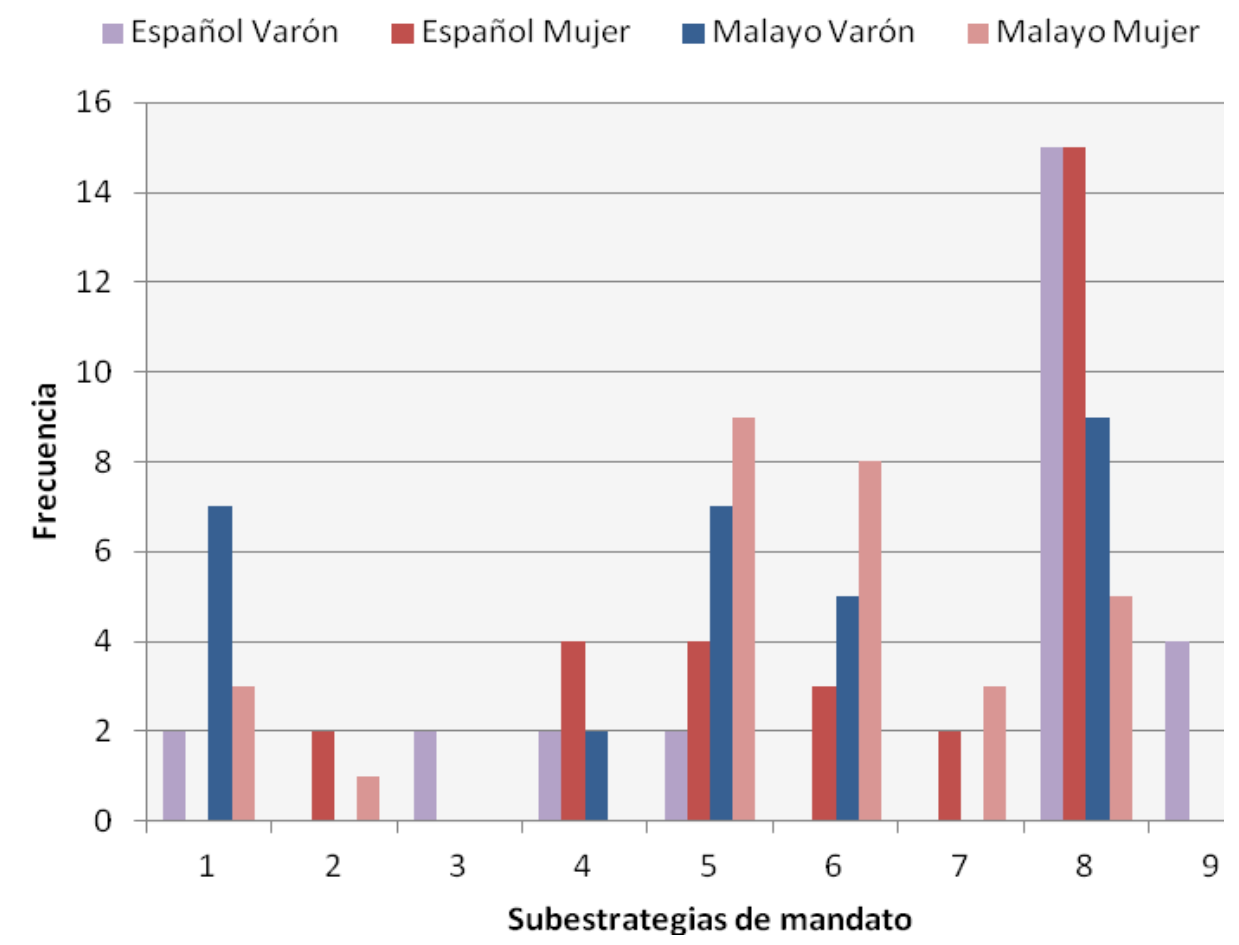

1.Imperativo 2.Performativo 3.Performativo evasivo 4.Declaración de obligación 5.Declaración de deseo 6.Fórmula de sugerencia 7.Interrogación preparatoria 8. Indicio fuerte 9. Indicio suave

La Tabla 125 refleja la similitud entre los dos subgrupos españoles de género. Así, las mujeres y los varones españoles no solo emplearon más frecuentemente un "Indicio fuerte", sino que, además, coinciden en el número de respuestas en las que lo emplearon: 15 casos en los dos géneros. Y también utilizaron el mismo número de estrategias diferentes (6). Ahora bien, aparecieron tres estrategias en cada subgrupo que no aparecieron en el otro. Por ejemplo, las de "Imperativo", "Performativo evasivo" e "Indicio suave" están presentes en los datos de los varones, pero no se ha 
encontrado ningún caso de dichas estrategias en las producciones de las mujeres. En cambio, las de "Performativo", "Fórmula de sugerencia" y "Interrogación preparatoria" fueron empleadas por las mujeres, pero no por los hombres.

En el caso malayo, sí que se encuentran más diferencias entre los dos subgrupos de género. Como ocurría con los españoles, los varones malayos prefirieron realizar su mandato a través de un indicio fuerte" (9 casos), mientras que las mujeres tendieron a utilizar mayoritariamente la "Declaración de deseo" en sus mandatos (también 9). Además, se diferenciaron en la variedad de estrategias empleadas: los varones emplearon solo 5 tipos diferentes frente a los 7 de las mujeres. Así, la estrategia de "Declaración de obligación" aparece en el corpus de los varones ( 2 veces) pero ninguna mujer la aplicó. En cambio, las de "Performativo", "Interrogación preparatoria" e "Indicio suave" aparecieron en el corpus de mujer, pero no se encontró ningún caso en el corpus de los varones.

Respecto a los movimientos de apoyo que acompañaron a los actos principales analizados arriba, podemos decir, en general, que tanto las mujeres españolas como las mujeres malayas emplearon una mayor cantidad: 51 enunciados de las mujeres frente a 45 de los varones en el grupo español, y 52 y 42 respectivamente, en el caso malayo. Sin embargo, los varones españoles usaron más 
estrategias diferentes que las mujeres ( 11 frente a solo 7 de las mujeres), aunque, en el grupo malayo, fueron también las mujeres quienes emplearon más estrategias distintas (7 tipos, frente a los 6 que aparecen en las respuestas de los varones).

Figura 126. Distribución de enunciados (movimientos de apoyo) según estrategias empleadas en la situación 10 por cada subgrupo

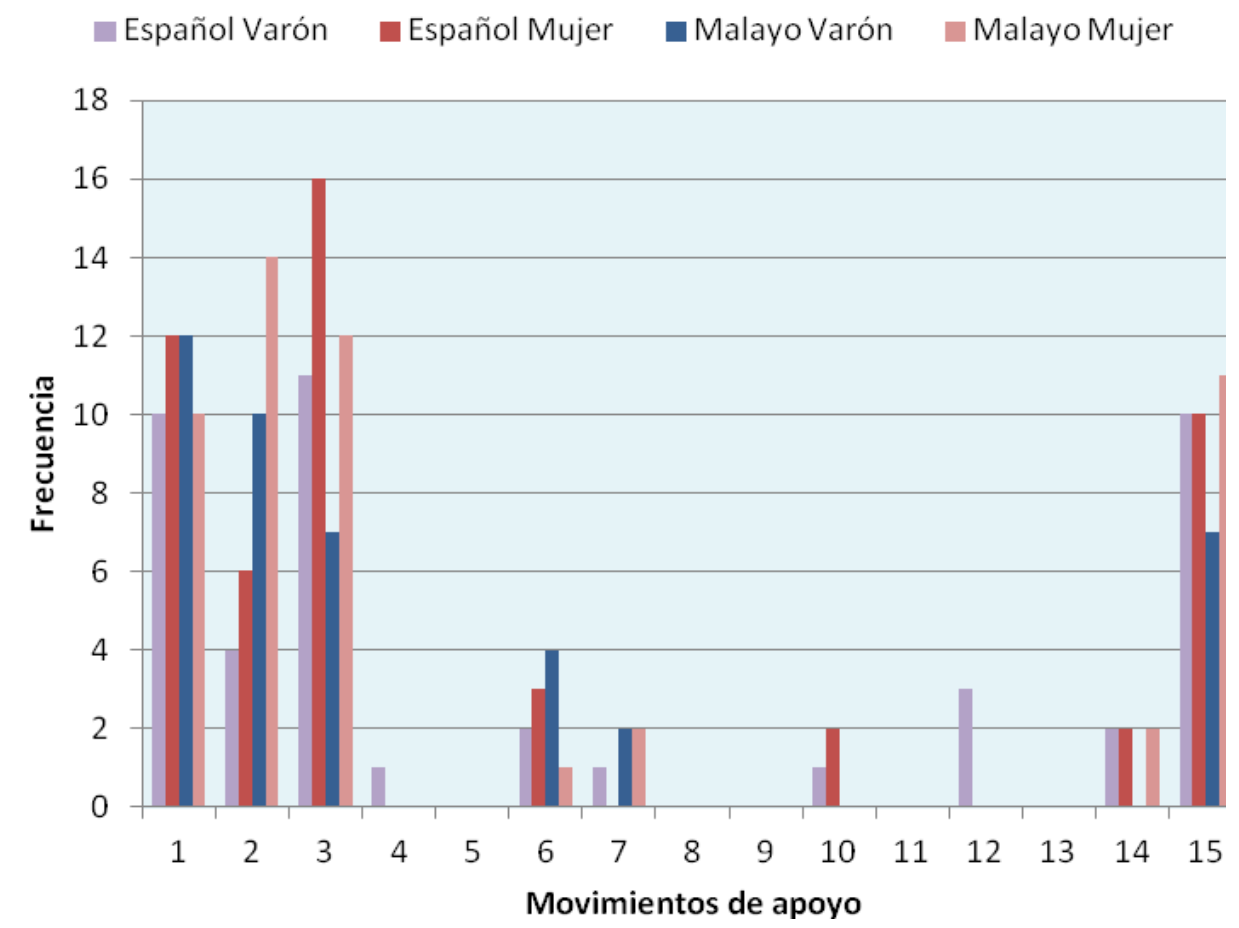

1.Fórmulas de preparación 2.Búsqueda de un compromiso 3.Razones 4.Previsión de objeciones 5.Promesa de recompensa/reparación 6.Minimización de la imposición 7.Invocación de principios generales 8.Reconocimiento de la imposición 9.Preocupación 10.Apreciación 11.Gravedad/urgencia 12.Presentación/saludo 13.Petición de la opinión del oyente 14.Disculpa 15. Fórmulas de tratamiento

Ambos subgrupos españoles de género coincidieron en mostrar su tendencia hacia el empleo de "Razones" (11 casos en las respuestas de los varones y 16 en las de las mujeres), de "Fórmulas 
de preparación" (10 de los varones y 12 de las mujeres) y de "Fórmulas de tratamiento" (10 en ambos casos). Además, tres estrategias, "Previsión de objeciones", "Invocación de principios generales" y "Presentación/saludo", se dan en los datos de los varones pero ninguna mujer las usó. Los dos subgrupos malayos, por su parte, también se diferenciaron en sus preferencias. Los varones utilizaron mayoritariamente la estrategia de "Fórmulas de preparación" (12 ejemplos), seguida de "Búsqueda de un compromiso" (10) y, en tercer lugar, de "Razones" y "Fórmulas de tratamiento" (7 enunciados con cada una). En cambio, la mayoría de las mujeres malayas recurrieron a la estrategia de "Búsqueda de un compromiso" (encontrada 14 veces), seguida de "Razones" (12) y de "Fórmulas de tratamiento" (11). Hay que señalar, además, que emplearon 2 veces la estrategia de "Disculpa", de la que no se encontró ningún caso en los varones. En ninguno de los tres casos (movimientos de apoyo, estrategias de mandato, estrategias de actos principales), se detectaron diferencias estadísticas significativas entre los varones y las mujeres en los promedios de los enunciados producidos. 


\subsubsection{Situación 9}

En la situación 9, el grado de familiaridad es alto, ya que los encuestados toman el papel de padre/madre de un hijo/a adolescente, al que deben mandarle que vuelva pronto a casa.

\section{A) Español frente a malayo}

Al analizar el grado de (in)dirección de las estrategias empleadas en los enunciados producidos como actos principales en la situación planteada, pese a que todos los encuestados optaron, en mayor grado, por las formas "Directas", fueron los malayos los que mostraron una tendencia destacada hacia dicha forma: 56 enunciados frente a 46 de los españoles. Ahora bien, en cuanto al segundo tipo de estrategias más utilizado, las "Convencionalmente indirectas", fueron los españoles los que las aplicaron en mayor proporción ( 9 veces por 4 de los malayos). Y la tercera forma más empleada, las estrategias "No convencionalmente indirectas", también aparece en más enunciados españoles que malayos (5 frente a 2). La diferencia entre los promedios de las categorías aplicadas por ambas sociedades no fue significativa. 
Figura 127. Distribución de enunciados (actos principales) según estrategias empleadas en los mandatos producidos para la situación 9, en cada cultura

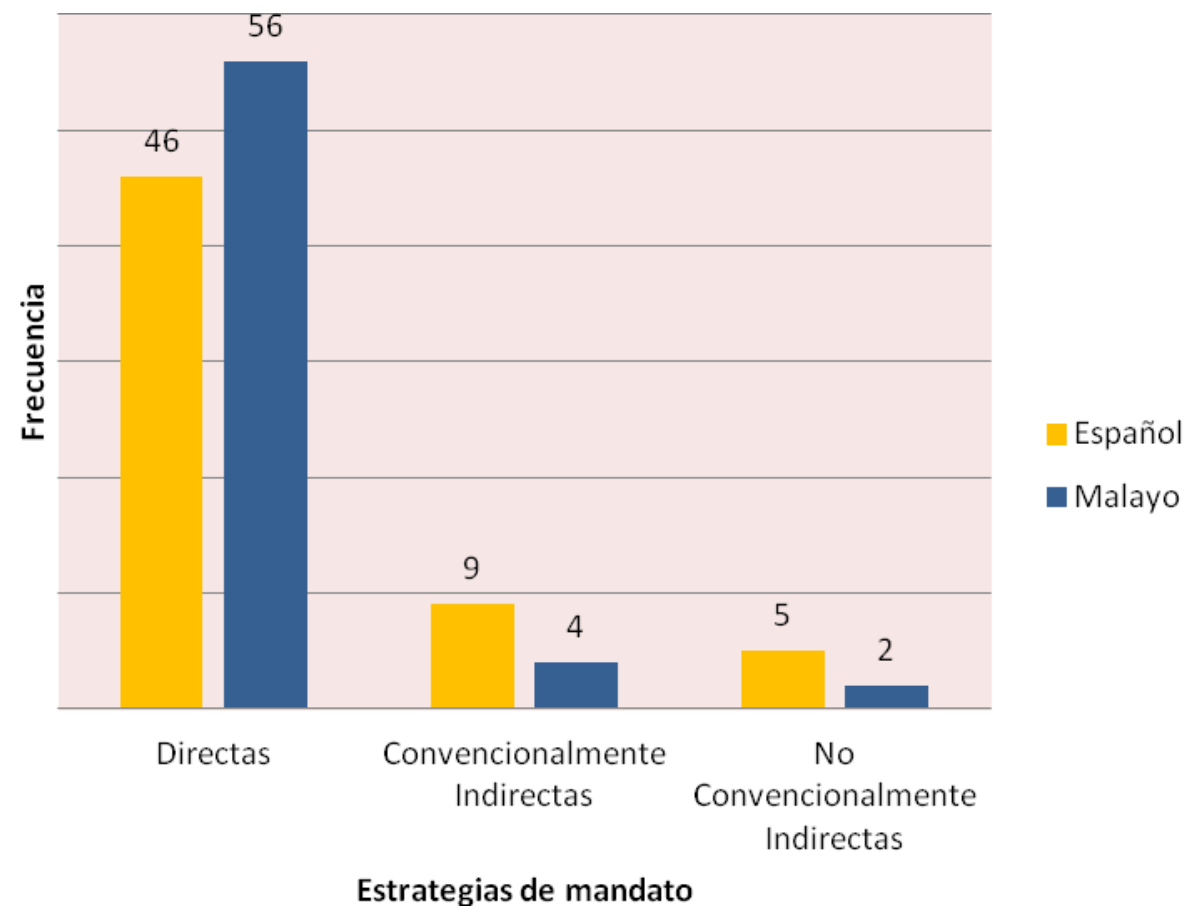

Los enunciados contenidos dentro de estos tres grandes bloques de estrategias representados en la tabla anterior, pueden ser clasificados también según las nueve sub-categorías de estrategias de petición establecidas por el CCSARP (véase cap.3). De esta nueva clasificación se obtuvieron los siguientes resultados: 
Figura 128. Distribución de enunciados (actos principales) según sub-categorías de estrategias empleadas para la situación 9, en cada cultura

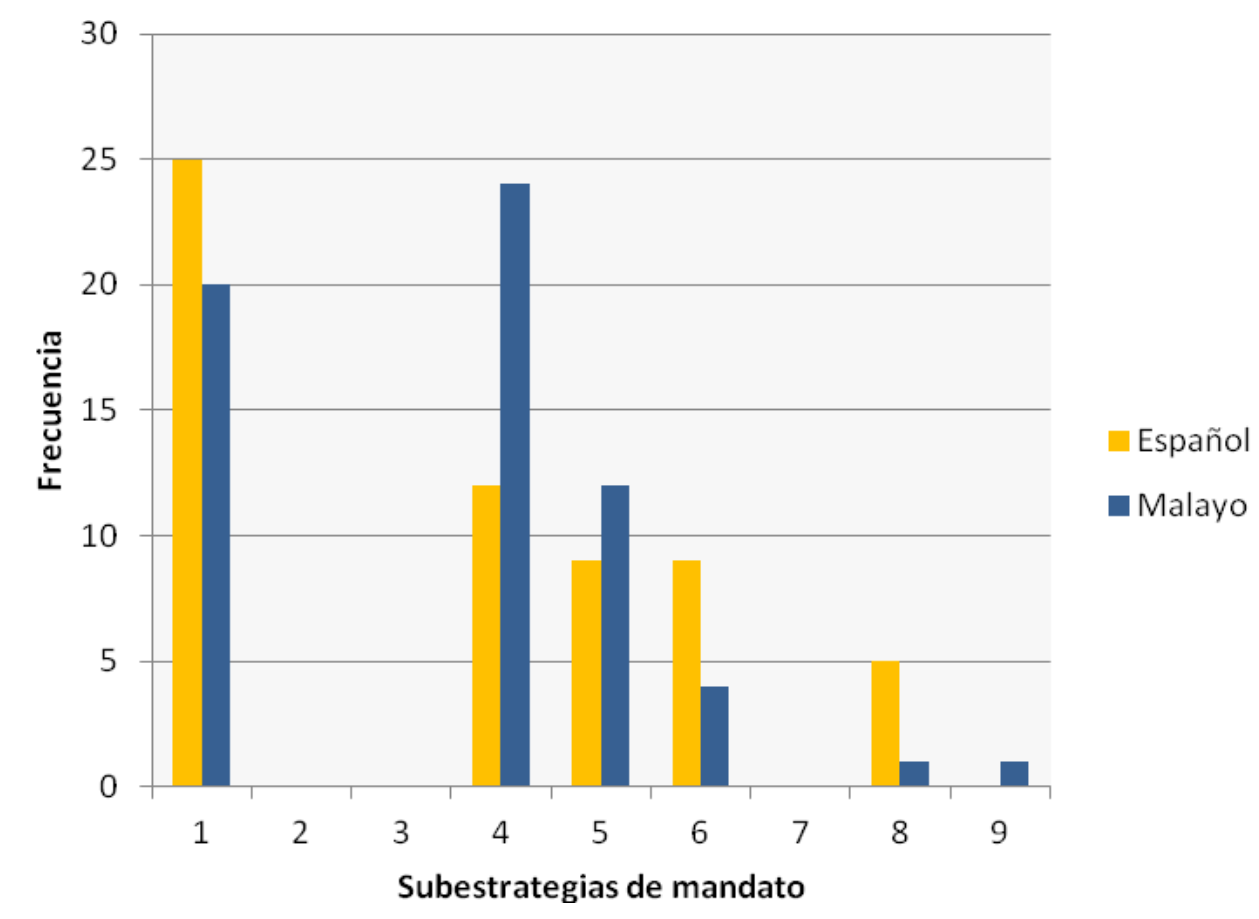

1.Imperativo 2.Performativo 3.Performativo evasivo 4.Declaración de obligación 5.Declaración de deseo 6.Fórmula de sugerencia 7.Interrogación preparatoria 8. Indicio fuerte 9.Indicio suave

Al dar una orden a un hijo adolescente, los españoles prefirieron utilizar el "Imperativo" (en 25 ocasiones), seguido, en frecuencia de uso, de la "Declaración de obligación" (12). En cambio, los malayos tendieron mayoritariamente a formular su mandato usando una declaración de obligación (24 casos registrados), seguida del "Imperativo" (20). En los datos españoles, de las nueve opciones posibles, solamente aparecen 5, mientras que en los datos malayos se encontraron 6 estrategias diferentes. No hay ningún ejemplo de uso del "Indicio suave" en el grupo español, pero sí que apareció una vez en el otro grupo. Tampoco en este caso hay una diferencia 
significativa en la comparación de promedios de los actos principales utilizados en ambos grupos.

Las estrategias empleadas en los movimientos de apoyo que acompañaron a los actos principales analizados en las dos tablas anteriores, se pueden clasificar de la siguiente forma:

Figura 129. Distribución de enunciados (movimientos de apoyo) empleados para la situación 9 por los hablantes de cada cultura, según estrategias aplicadas

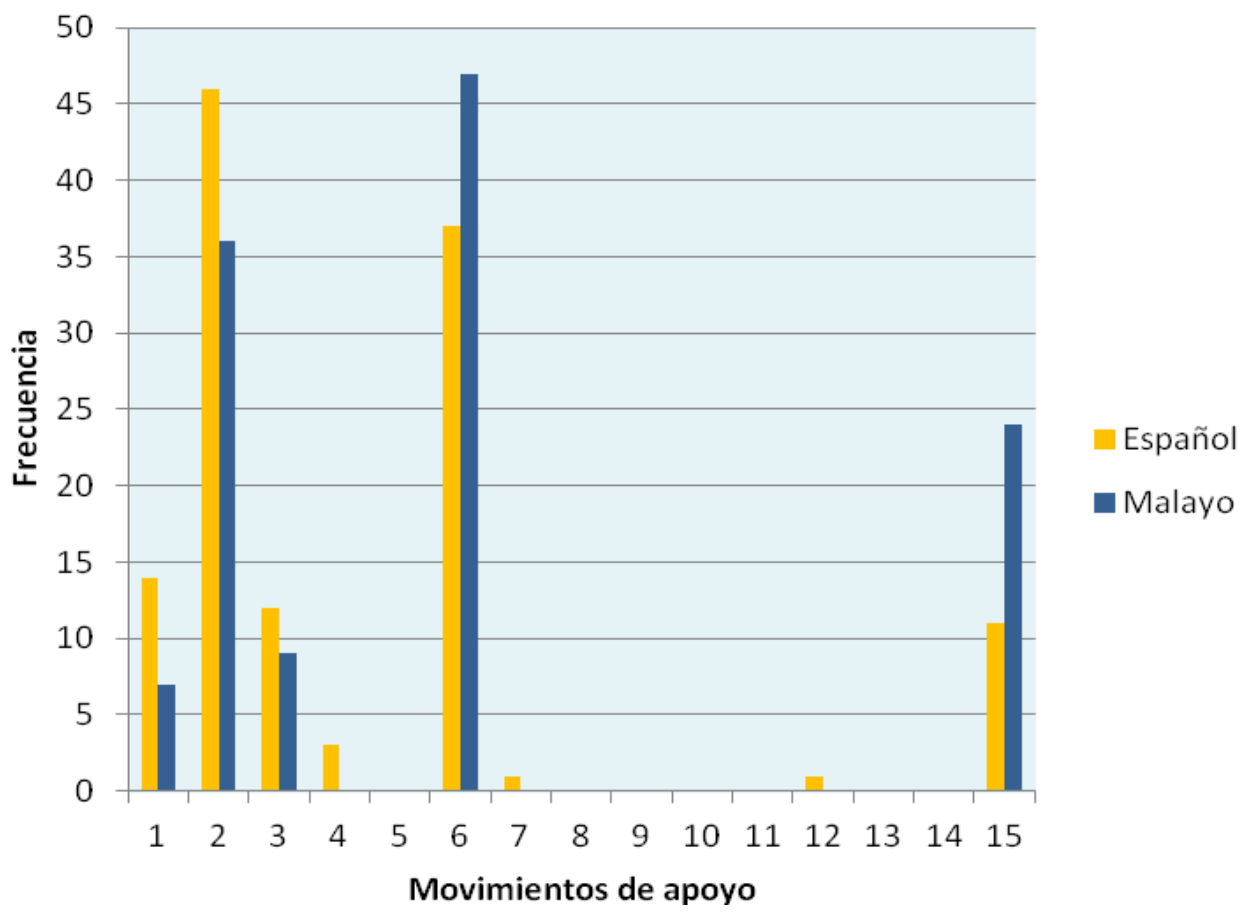

1.Fórmulas de preparación 2.Búsqueda de un compromiso 3.Razones 4.Previsión de objeciones 5.Promesa de recompensa/reparación 6.Minimización de la imposición 7.Invocación de principios generales 8.Reconocimiento de la imposición 9.Preocupación 10.Apreciación 11.Gravedad/urgencia 12.Presentación/saludo 13.Petición de la opinión del oyente 14.Disculpa 15.Fórmulas de tratamiento 
La mayoría de los sujetos españoles mostraron preferencia por el uso de la "Búsqueda de un compromiso", con 46 ejemplos recogidos. La segunda estrategia que aparece en un mayor número de enunciados es la de "Minimización de la imposición" (37), seguida de la de "Fórmulas de preparación" (14). Por otro lado, los sujetos malayos se inclinaron hacia el uso de la "Minimización de la imposición" (en 47 enunciados), seguida de "Búsqueda de un compromiso" (en 36) y "Fórmulas de tratamiento" (en 24). Los españoles aplicaron más variedad de fórmulas en comparación con los malayos: 8 estrategias diferentes frente a las 5 de los malayos. No obstante, en lo que concierne al número de enunciados formulados, los dos grupos no se diferencian mucho estadísticamente: 125 en el material español y 123 en el malayo. Y tres estrategias, "Previsión de objeciones", "Invocación de principios generales" y "Presentación/saludo", fueron encontradas en los datos españoles, pero no en los malayos. Las pruebas estadísticas señalaron diferencias significativas entre las medias de las estrategias elegidas por los sujetos españoles y malayos: $X^{2}=14.985$ $p=.036(p<.05)$. 


\section{B) Mayor frente a menor}

Si llevamos a cabo el mismo análisis de enunciados del apartado anterior, pero teniendo en cuenta el criterio de la edad, vemos, que, en primer lugar, en lo que respecta al grado de (in)dirección de las estrategias empleadas en la formulación de actos principales, las producciones de los subgrupos no difirieron mucho entre sí, estadísticamente, como se observa en el gráfico que sigue:

Figura 130. Distribución de estrategias de mandato empleadas para la situación 9, en ambas sociedades

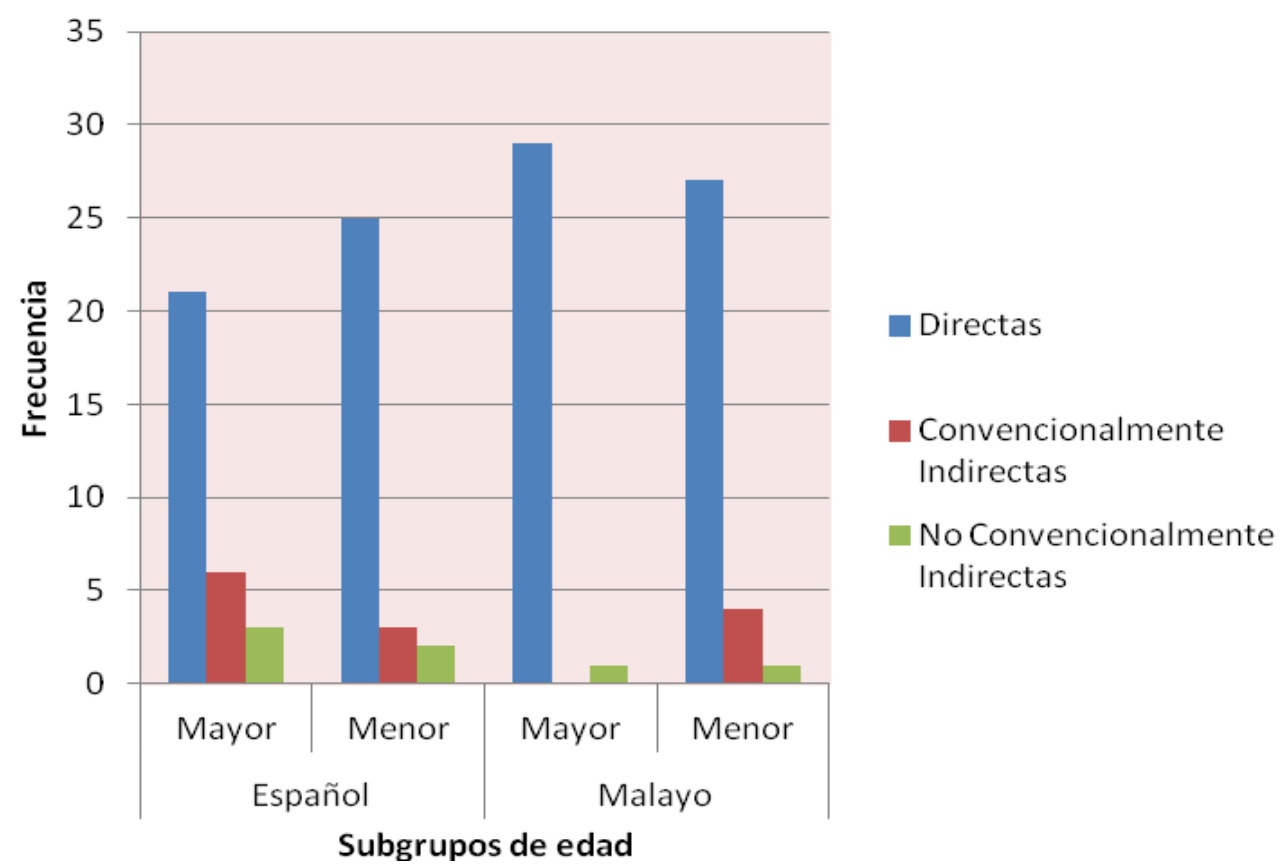


Tanto los hablantes de los subgrupos españoles como los de los malayos optaron por realizar el mandato a través de las formas "Directas": 21 de los mayores y 25 de los jóvenes en España, y 29 y 27, respectivamente, en Malasia. Con respecto a la segunda opción más empleada, todos los subgrupos en ambos países, excepto el subgrupo de malayo mayor, aplicaron formas "Convencionalmente indirectas" (6 los mayores y 3 los menores, en el grupo español, y 4 de los malayos menores), seguidas de las "No convencionalmente indirectas" (en 3 y 2 enunciados, respectivamente, de los subgrupos españoles, y en 1 de los malayos menores). En cambio, en los malayos mayores las estrategias "No convencionalmente indirectas" ocupan el segundo lugar en frecuencia de utilización, mientras que no se encontró ningún ejemplo de las "Convencionalmente indirectas" en sus mandatos. Los valores de la media confirman que no hay diferencia significativa entre los dos subgrupos de edad comparados, que tampoco existirá, como veremos, ni en el estudio de las nueve sub-categorías de estrategias, ni en los resultados del estudio de los de movimientos de apoyo, que se presentarán a continuación.

En el análisis de los enunciados producidos como actos principales, al aplicar las nueve sub-categorías de Blum-Kulka (véase cap. 3), los resultados numéricos obtenidos fueron los que presentamos en la tabla que se muestra a continuación: 
Figura 131. Distribución de enunciados (actos principales) formulados para la situación 9, en ambas sociedades, según estrategias empleadas

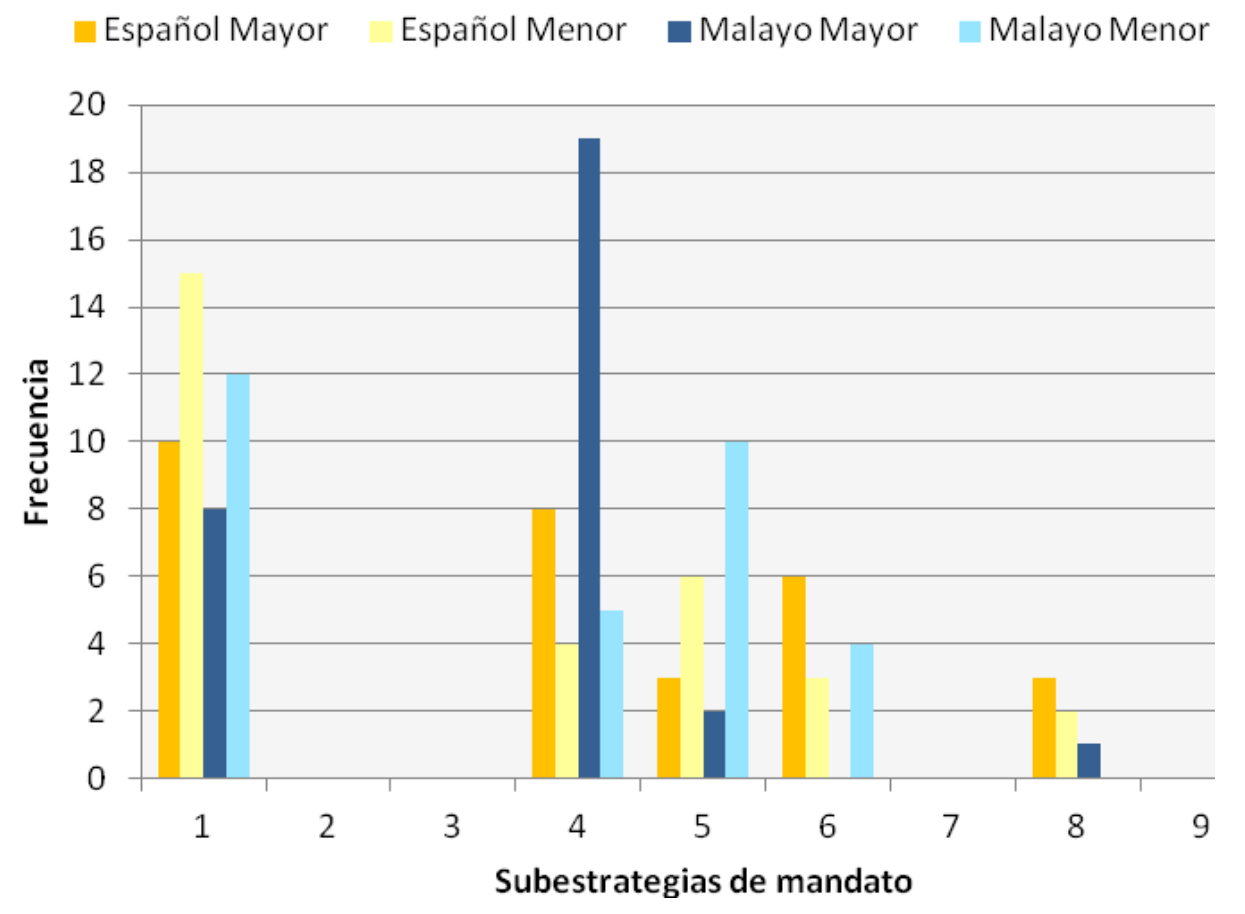

1.Imperativo 2.Performativo 3.Performativo evasivo 4.Declaración de obligación 5.Declaración de deseo 6.Fórmula de sugerencia 7.Interrogación preparatoria 8. Indicio fuerte 9.Indicio suave

Existen diferencias estadísticamente significativas entre los subgrupos de edad dentro de cada cultura. Aunque en la sociedad española, ambos subgrupos mostraron la misma preferencia hacia la estrategia de "Imperativo", con 10 enunciados de los mayores y 15 de los menores, en el uso de otras estrategias se diferenciaron mucho entre sí. La segunda más aplicada en el corpus de sujetos mayores, la "Declaración de obligación", con 8 casos encontrados, fue la tercera más empleada en el corpus de los jóvenes, con tan solo 4 ejemplos. Y, la tercera más empleada por los informantes de 
más edad, la "Fórmula de sugerencia" (presente en 6 enunciados), fue la cuarta más utilizada por los jóvenes, con tan solo 3 casos. En cambio, la segunda estrategia más común en los jóvenes, la de "Declaración de deseo" (aparece en 6 enunciados), se situó en el cuarto lugar, según frecuencia de uso, en los datos de los mayores.

En la sociedad malaya, aún son más notables las diferencias entre los subgrupos examinados. Llama la atención la mayor frecuencia de la estrategia de "Declaración de obligación" en los datos de los sujetos mayores, con 19 enunciados, en comparación con los 5 de los jóvenes. La segunda fórmula preferida por los mayores fue la de "Imperativo", con 8 casos, que fue, a su vez, la más empleada por los jóvenes (12 enunciados). La segunda opción más recurrente entre los informantes menores, la "Declaración de deseo", de la que hay 10 ejemplos recogidos, apareció solo 2 veces en los mayores, ocupando el tercer lugar en el orden de frecuencia de uso. Por otro lado, en los datos de los mayores no hay ningún ejemplo de "Fórmula de sugerencia", pero sí se encontró dicha estrategia en los datos de los jóvenes, utilizada en 4 ocasiones. En cambio, ningún joven usó la de "Indicio fuerte", aunque sí está presente en el corpus de mayores.

En cuanto a la producción de movimientos de apoyo por los sujetos de ambos subgrupos, podemos decir que los participantes 
jóvenes emplearon un mayor número: 66 enunciados, frente a 59 de los mayores en el grupo español, y 69 y 54 , respectivamente, en el otro grupo. Y las estrategias que emplearon en su formulación fueron, en el caso español, más variadas en el subgrupo de mayores (8 diferentes, por 6 de los menores), coincidiendo, en cambio, el número de estrategias diferentes empleadas por los dos subgrupos malayos (5 en cada caso).

Figura 132. Distribución de enunciados (movimientos de apoyo) producidos para la situación 9, en ambas sociedades, según estrategias empleadas

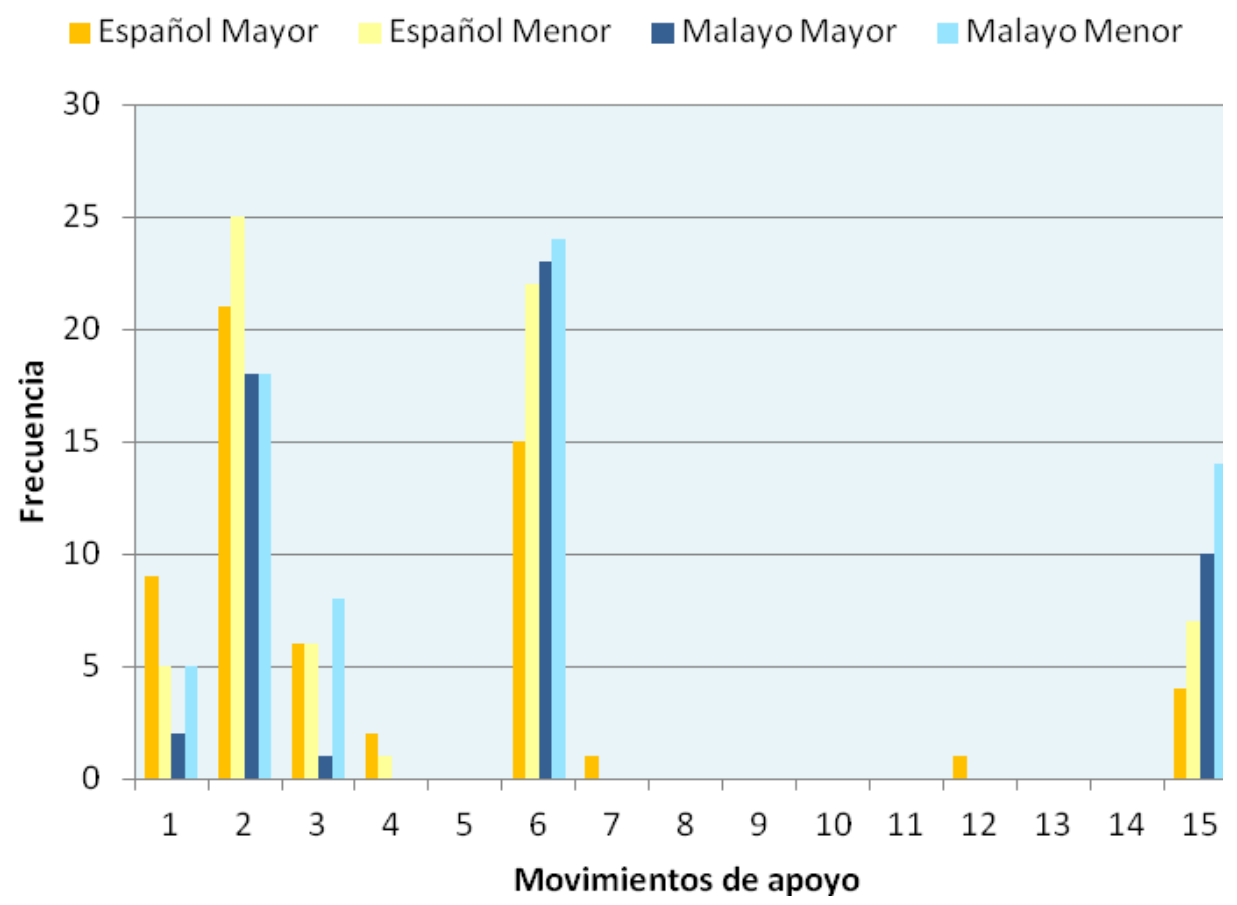

1.Fórmulas de preparación 2.Búsqueda de un compromiso 3.Razones 4.Previsión de objeciones 5.Promesa de recompensa/reparación 6.Minimización de la imposición 7.Invocación de principios generales 8.Reconocimiento de la imposición 9.Preocupación 10.Apreciación 11.Gravedad/urgencia 12.Presentación/saludo 13.Petición de la opinión del oyente 14.Disculpa 15.Fórmulas de tratamiento 
Los sujetos de ambos subgrupos españoles aplicaron comúnmente la estrategia de "Búsqueda de un compromiso" (en 21 casos los mayores, y 25 los menores), seguida de "Minimización de la imposición" (15 y 22, enunciados, respectivamente). Por el contrario, los dos subgrupos malayos emplearon más frecuentemente la "Minimización de la imposición" (23 ejemplos de los mayores y 24 de los menores), seguida de la "Búsqueda de un compromiso" (18 en cada subgrupo).

\section{C) Varón frente a mujer}

Pasamos ahora a realizar el análisis tanto de actos principales como de movimientos de apoyo producidos para la situación 6 por los participantes de cada grupo de sexo de cada sociedad.

Respecto a los actos principales, la primera clasificación de los enunciados, según el grado de (in)dirección de las estrategias empleadas, nos lleva a la presentación de los siguientes resultados: 
Figura 133. Distribución de estrategias de mandato empleadas para la situación 9, en ambas culturas

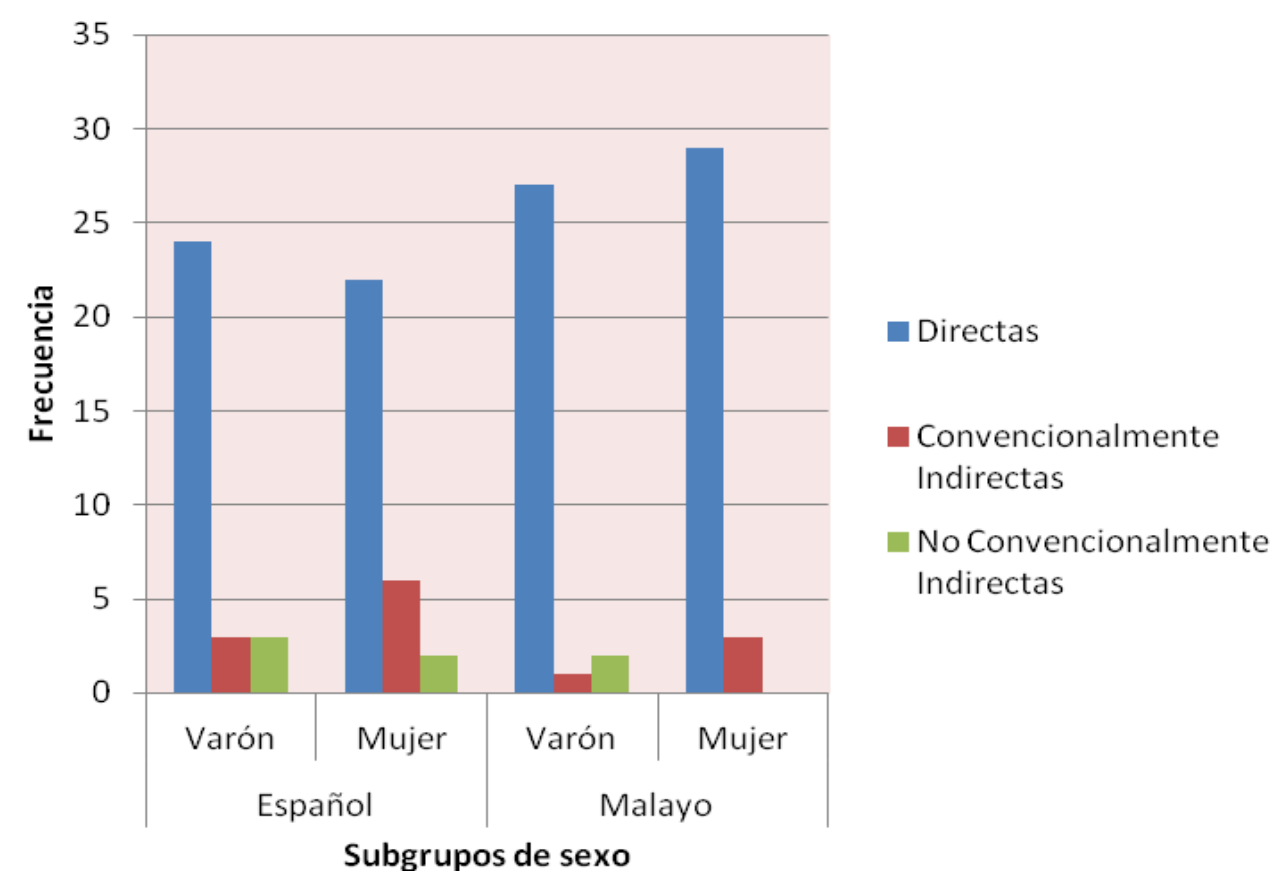

Al igual que lo observado en el análisis contrastivo de las respuestas de los participantes según el subgrupo de edad, los subgrupos de sexo tampoco mostraron diferencias estadísticas importantes entre sí, ya que el número de enunciados en los que aparecen las estrategias más utilizadas, las "Directas", en los datos españoles, fue de 24 en el corpus de los varones y de 22 en el de las mujeres, y en los datos malayos se encontraron 27 y 29 , respectivamente. Con respecto a las formas "Convencionalmente indirectas", fueron las mujeres en ambos grupos las que las emplearon con mayor frecuencia: 6 ejemplos recogidos, frente a 3 de los varones en el grupo español, y 3 por 1 en el malayo. Mientras que las "No convencionalmente indirectas" se utilizaron 3 y 2 veces 
respectivamente en los dos subgrupos españoles, y en los malayos solo fue aplicada, en dos ocasiones, por los varones (ninguna mujer las empleó). Según las pruebas estadísticas, los subgrupos de sexo de ambas culturas no se diferencian significativamente.

Respecto a la aplicación de las nueve sub-categorías de estrategia establecidas por Blum-Kulka, la distribución de enunciados se concentra en algunas de ellas, mientras que no se encuentra ningún ejemplo de otras, como se refleja en este gráfico:

Figura 134. Distribución de enunciados (actos principales) producidos en la situación 9 por los sujetos de ambas culturas, según estrategias empleadas

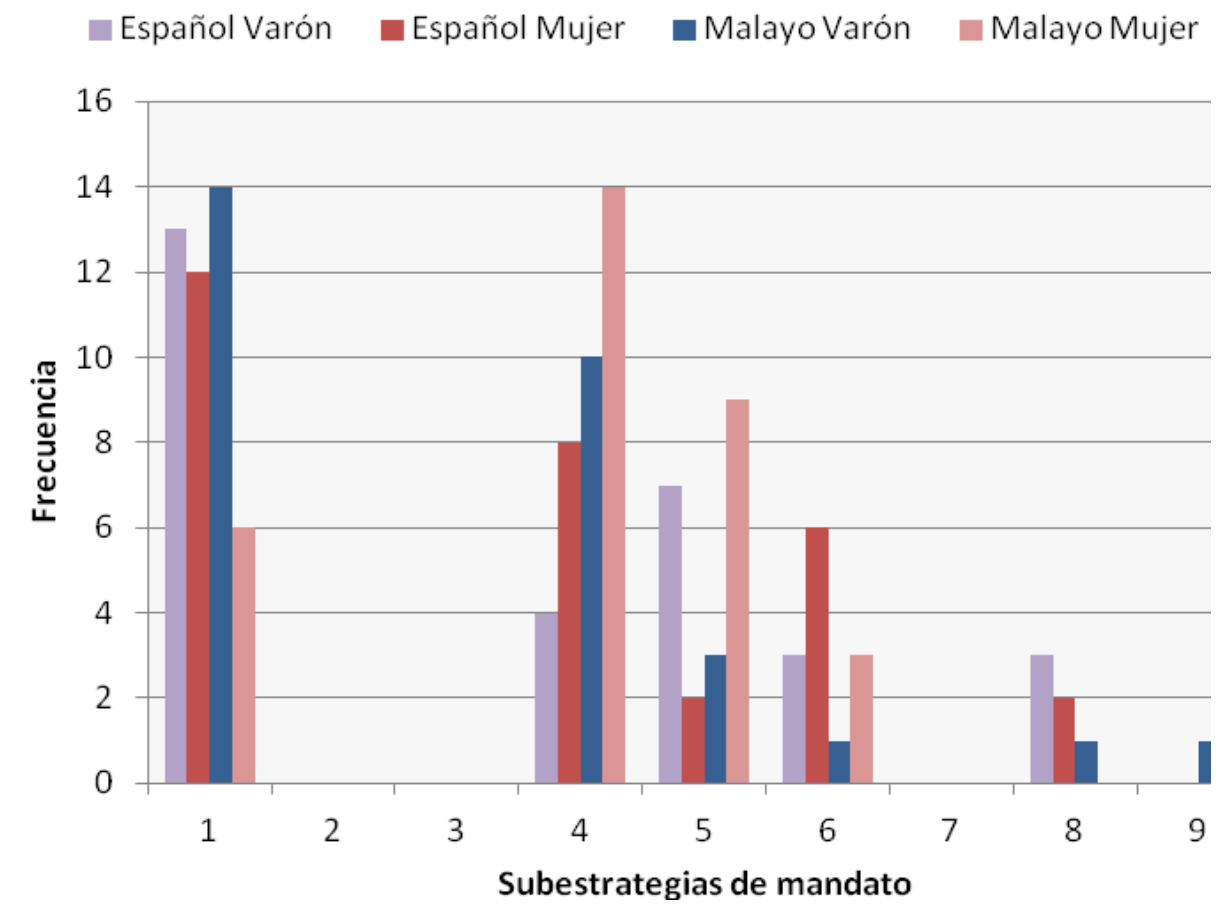

1.Imperativo 2.Performativo 3.Performativo evasivo 4.Declaración de obligación 5.Declaración de deseo 6.Fórmula de sugerencia 7.Interrogación preparatoria 8. Indicio fuerte 9.Indicio suave 
De manera similar al caso anterior, ambos, varones y mujeres, en el grupo español, recurrieron mayoritariamente al "Imperativo" al dar el mandato a una persona con la que tiene un alto grado de familiaridad. Aun así, la segunda preferencia mostrada por los participantes de los dos sexos fue diferente: los varones utilizaron una "Declaración de deseo" (en 7 ocasiones), mientras que las mujeres emplearon una "Declaración de obligación" (8). En cambio, los subgrupos malayos de los dos sexos se diferenciaron en su tendencia. Los varones optaron mayoritariamente por el "Imperativo" (aparece en 14 ocasiones), y la "Declaración de obligación" (en 10). Las mujeres, por su parte, usaron principalmente la "Declaración de obligación" (14 casos), y la "Declaración de deseo" (9). Al comparar los promedios de las estrategias aplicadas entre los subgrupos de edad la diferencia no fue significativa en el resultado del grupo español, pero sí en el grupo malayo: $X^{2}=20.257 \mathrm{p}=.001(\mathrm{p}<.05)$.

El análisis de los movimientos de apoyo revela, en primer lugar, que fueron las mujeres de ambos grupos las que emplearon más: 72, frente a 53 de los varones, en el grupo español, y 76 y 47, respectivamente, en el malayo. Ahora bien, la variedad de estrategias registrada en los datos de cada sexo fue similar en ambos grupos: los sujetos de ambos sexos españoles utilizaron 7 
estrategias diferentes, mientras que los dos subgrupos malayos se

quedaron en 5.

Figura 135. Distribución de enunciados (movimientos de apoyo) producidos para la situación 9, en ambas culturas, según estrategias empleadas

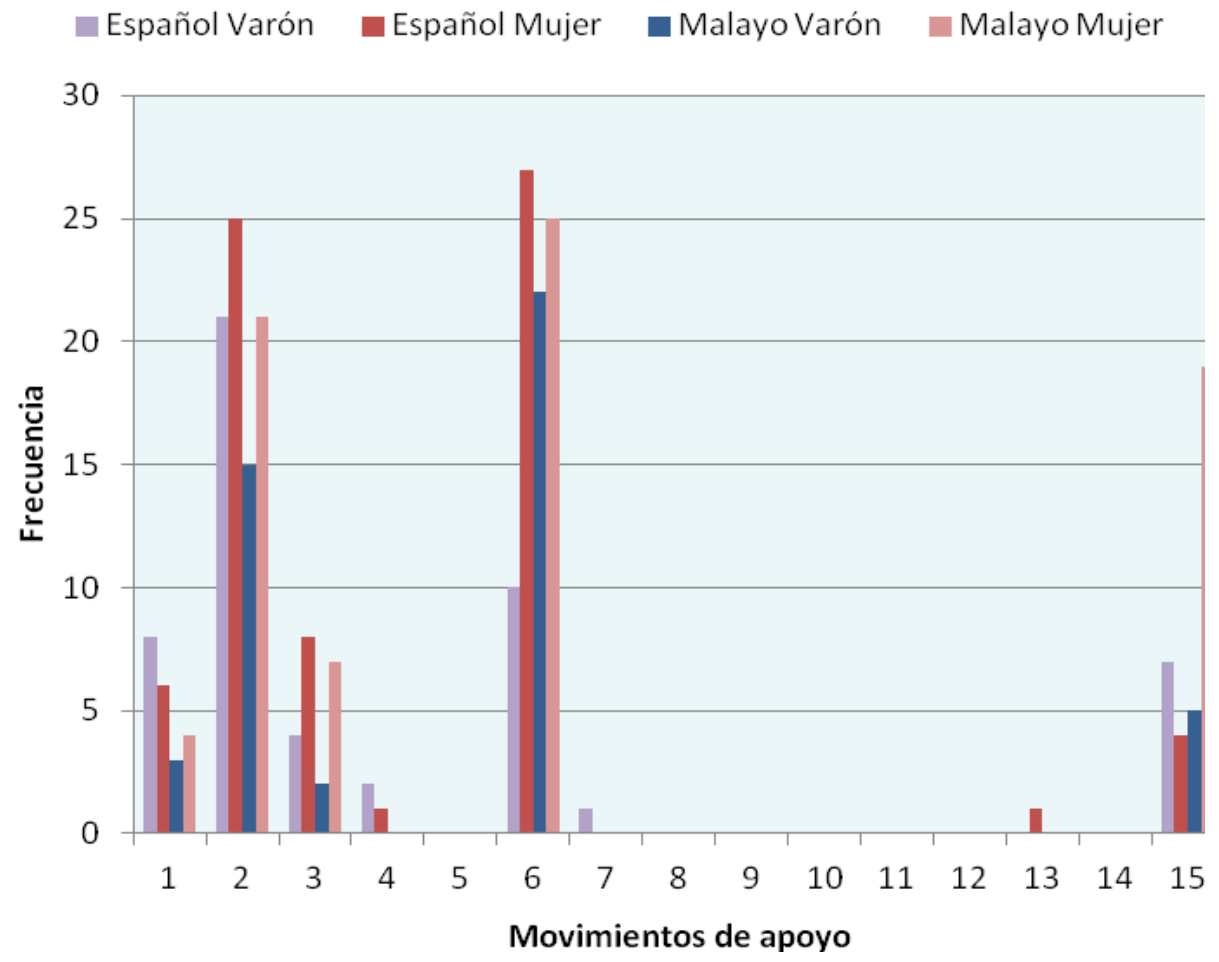

1.Fórmulas de preparación 2.Búsqueda de un compromiso 3.Razones 4.Previsión de objeciones 5.Promesa de recompensa/reparación 6.Minimización de la imposición 7.Invocación de principios generales 8.Reconocimiento de la imposición 9.Preocupación 10.Apreciación 11.Gravedad/urgencia 12.Presentación/saludo 13.Petición de la opinión del oyente 14.Disculpa 15. Fórmulas de tratamiento

En el grupo español los varones prefirieron la "Búsqueda de un compromiso" (elegida en 21 ocasiones), la "Minimización de la imposición" (en 10) y el uso de "Fórmulas de preparación" (en 8). Al contrario, las mujeres tendieron a aplicar frecuentemente la 
"Minimización de la imposición" (27 ejemplos recogidos), seguida de la "Búsqueda de un compromiso" (22), y del empleo de "Razones" (8).

Por otro lado, la tendencia de los dos subgrupos de género malayos fue similar. Tanto los varones como las mujeres, usaron mayoritariamente la "Minimización de la imposición" con 22 y 25 enunciados, respectivamente, seguida de la "Búsqueda de un compromiso" (15 y 21 casos). Cabe destacar el alto número de casos en los que aparece la tercera estrategia más empleada por las mujeres malayas, es decir, las "Fórmulas de tratamiento", que aparecen en 19 ocasiones, en comparación con el número de enunciados en las que aparece en el corpus de los varones (tan solo 5). El resultado de las pruebas estadísticas en este caso tampoco indicó una diferencia significativa entre los hombres y las mujeres.

\subsubsection{Situación 12}

En la situación 12, la distancia social entre los interlocutores es grande, puesto que en este contexto específico se pidió a los encuestados que actuaran como un profesor universitario que debía hacer el mandato a un nuevo alumno a su cargo, al que ve por primera vez. 


\section{A) Español frente a malayo}

Al hablar sobre el grado de (in)dirección de las estrategias empleadas por los sujetos en la formulación de los actos principales en esta situación, es preciso señalar que es el único contexto en el que los participantes de ambos grupos recurrieron mayoritariamente a las formas "Convencionalmente indirectas". Pero fueron los españoles los que utilizaron en mayor medida dicha forma, con 51 casos encontrados, mientras que en los datos malayos aparece en 36 de los enunciados totales. La segunda tipología de estrategias más utilizada por los informantes de ambos países fue la de las "Directas" y, la tercera, las "No convencionalmente indirectas". En cualquier caso, fueron los informantes malayos los que produjeron un mayor número de enunciados con estos dos tipos de estrategias: 18, frente a tan solo 6 de los españoles, con estrategias "Directas", y 3 y 6 , respectivamente, con las "No convencionalmente indirectas". La diferencia entre los promedios de las categorías utilizadas en las respuestas de ambos grupos de hablantes fue bastante significativa: $X^{2}=9.586 \mathrm{p}=.008(\mathrm{p}<.05)$. 
Figura 136. Distribución de estrategias de mandato empleadas para la situación 12 , en cada cultura

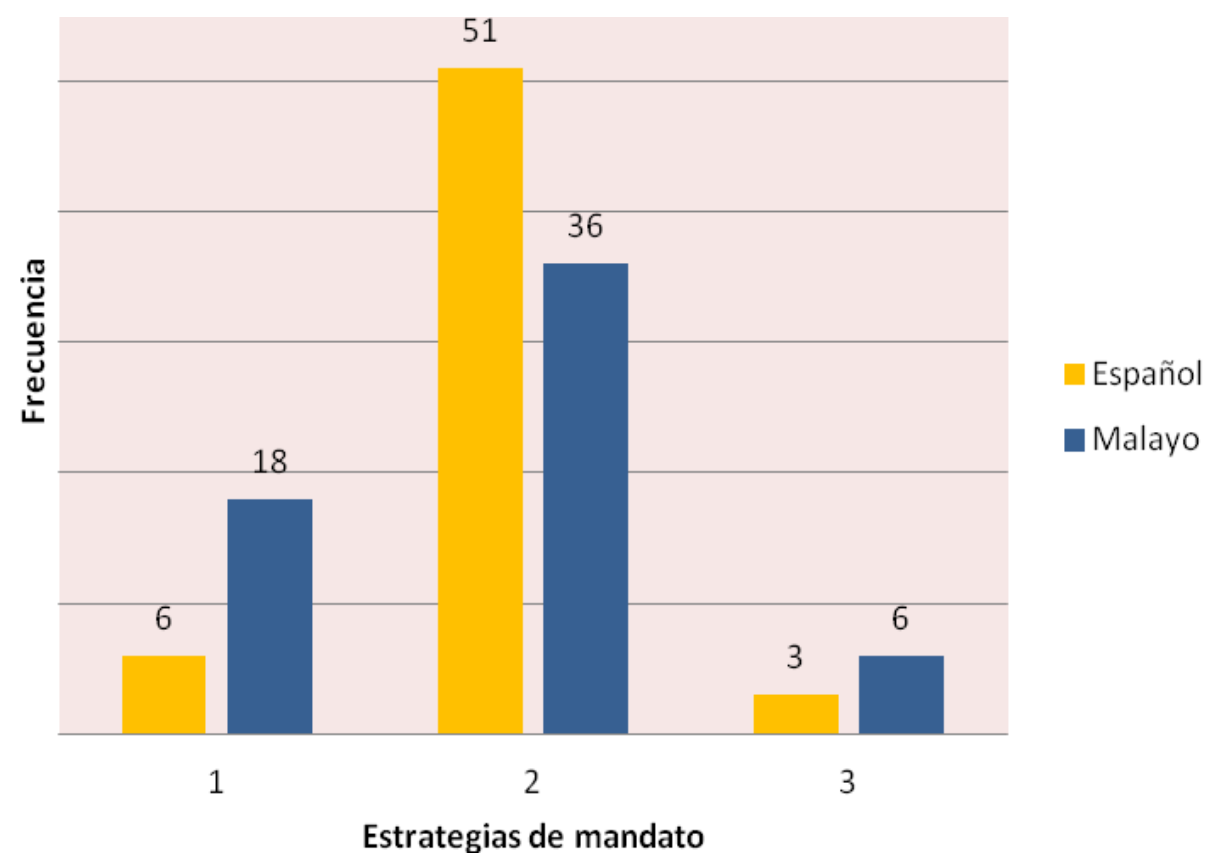

Si aplicamos a los enunciados del análisis anterior, la subclasificación de estrategias en las nueve categorías con las que se está trabajando en nuestro estudio (véase cap.3), los resultados numéricos obtenidos, en función del número de enunciados en los que se aplica cada una de dichas categorías, son los que se presentan en el siguiente gráfico: 
Figura 137. Distribución de enunciados (actos principales) producidos para la situación 12 en cada cultura, según las estrategias empleadas

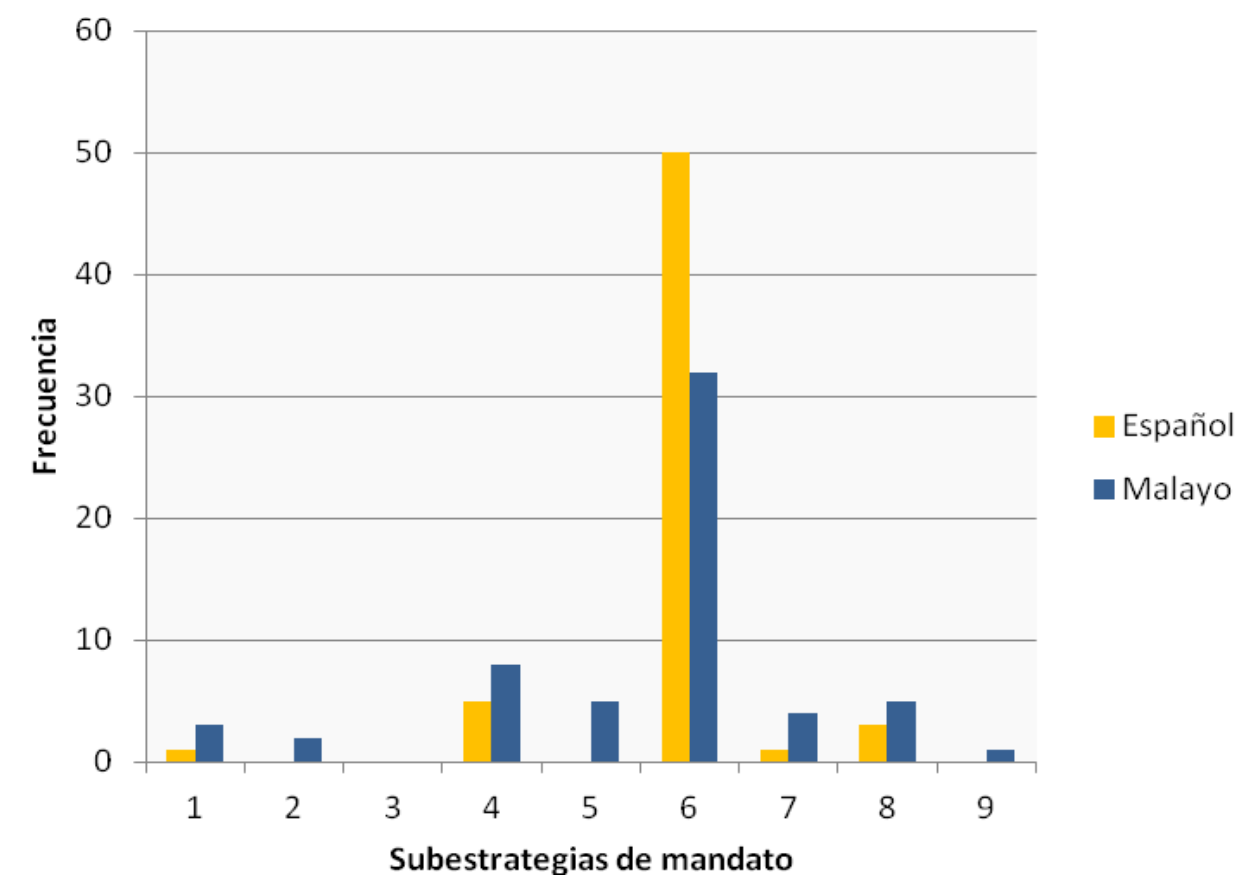

1.Imperativo 2.Performativo 3.Performativo evasivo 4.Declaración de obligación 5.Declaración de deseo 6.Fórmula de sugerencia 7.Interrogación preparatoria 8. Indicio fuerte 9.Indicio suave

Como se aprecia en la figura previa, pese a que los grupos coincidieron en mostrar preferencia por el uso de una "Fórmula de sugerencia", fueron los informantes españoles quienes las aplicaron en un porcentaje más alto en comparación con los malayos (en el $83.3 \%$ de los enunciados españoles frente al $53.3 \%$ de los malayos). Este resultado se debe a que el grupo español marca una tendencia clara hacia algunas estrategias determinadas (solo se usaron 5 estrategias diferentes), mientras que el grupo malayo se caracteriza por el uso generalizado de estrategias más variadas (hubo 8 estrategias distintas). En este caso, la comparación de los promedios 
entre las estrategias empleadas por los grupos de ambos países también indicó una diferencia significativa: $X^{2}=15.944 \quad \mathrm{p}=.026$ $(p<.05)$. Sin embargo, en el caso de los movimientos de apoyo, que analizaremos a continuación, la diferencia entre las medias obtenidas no fue muy importante.

El análisis de los movimientos de apoyo nos lleva a afirmar, de manera general, que los hablantes de ambos países produjeron prácticamente el mismo número de enunciados como movimientos de apoyo (106 de los españoles y 104 de los malayos), y también utilizaron casi el mismo número de estrategias diferentes (8 y 7 , respectivamente).

Figura 138. Distribución de enunciados (movimientos de apoyo) producidos para la situación 12 en cada cultura, según estrategias empleadas

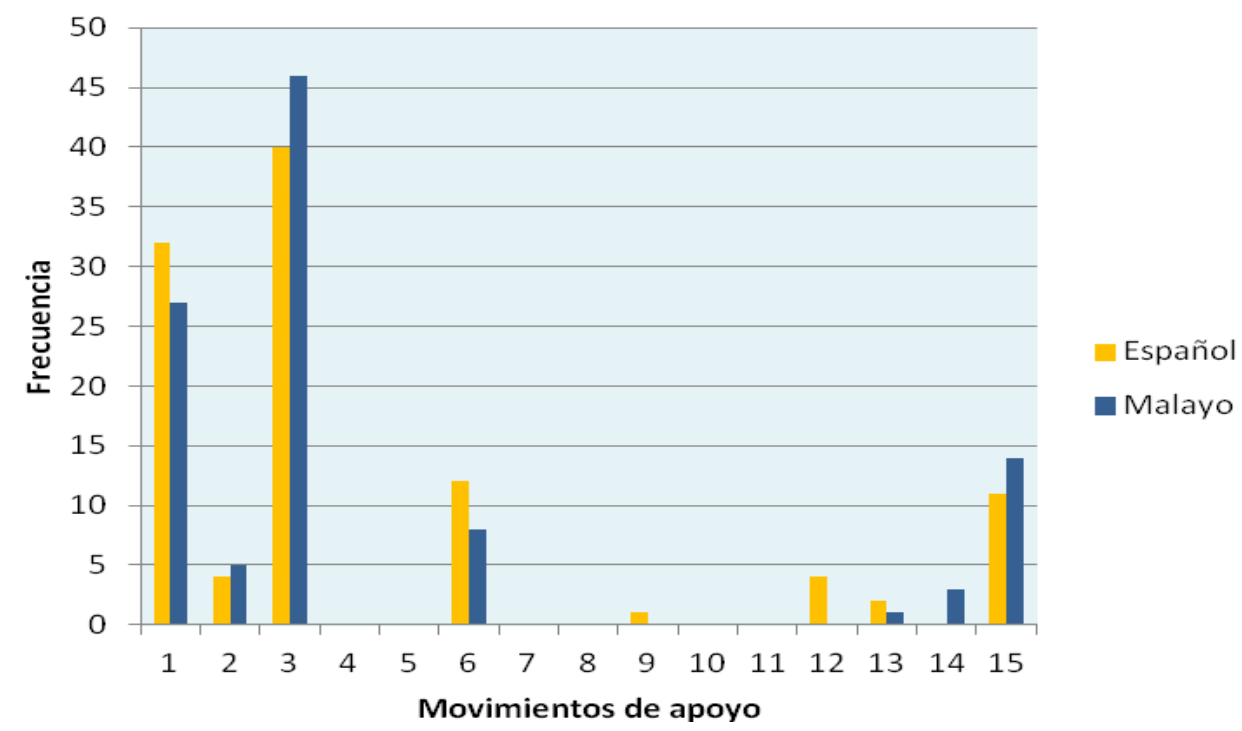


1.Fórmulas de preparación 2.Búsqueda de un compromiso 3.Razones 4.Previsión de objeciones 5.Promesa de recompensa/reparación 6.Minimización de la imposición 7.Invocación de principios generales 8.Reconocimiento de la imposición 9.Preocupación 10.Apreciación 11.Gravedad/urgencia 12.Presentación/saludo 13.Petición de la opinión del oyente 14.Disculpa 15. Fórmulas de tratamiento

Los sujetos de las dos sociedades coincidieron en mostrar preferencia por el uso de "Razones" (40 enunciados en español y 46 en malayo), seguido del empleo de "Fórmulas de preparación", con 32 casos de los españoles y 27 de los malayos, y de "Fórmulas de tratamiento" (11 ejemplos de los españoles frente a 14 de los malayos). No hay, entonces, mucha diferencia entre las preferencias de los dos grupos, y también, como se ha dicho más arriba, españoles y malayos utilizaron casi el mismo número de estrategias diferentes ( 8 y 7 , respectivamente).

\section{B) Mayor frente a menor}

En el análisis de las estrategias empleadas en los actos principales por los sujetos de los distintos subgrupos de edad, casi no se observaron diferencias estadísticas. La categoría más utilizada por todos fue la de las estrategias "Convencionalmente indirectas", siendo los datos de los encuestados de más edad los que presentan un número algo más alto que los de los hablantes de menos edad, 
en ambas sociedades. Así, aparecen 26 enunciados con este tipo de estrategias en las respuestas de los mayores españoles y 25 en las de los jóvenes, frente a los 19 y 17, respectivamente, en las de los malayos. El estudio estadístico respecto al uso de las formas "Directas" e "Indirectas no convencionales", tampoco mostró diferencias significativas. En el caso de las "Directas", los mayores españoles las aplican en una ocasión, frente a los 5 registros de los menores. Y, en el corpus malayo, se registraron 8 y 10 enunciados, en los correspondientes subgrupos. De las estrategias "Indirectas no convencionales", se encontraron tres ejemplos en las respuestas de cada subgrupo, excepto en el de los jóvenes españoles. Al contrastar los promedios de las categorías aplicadas entre los mayores y los menores en este caso, y, como veremos más adelante, en el análisis de las estrategias aplicadas en los actos principales, según subcategorías, y en los movimientos de apoyo, la diferencia no fue significativa en el resultado de ambos grupos. 
Figura 139. Distribución de estrategias de mandato empleadas para la situación 12 , en ambas sociedades

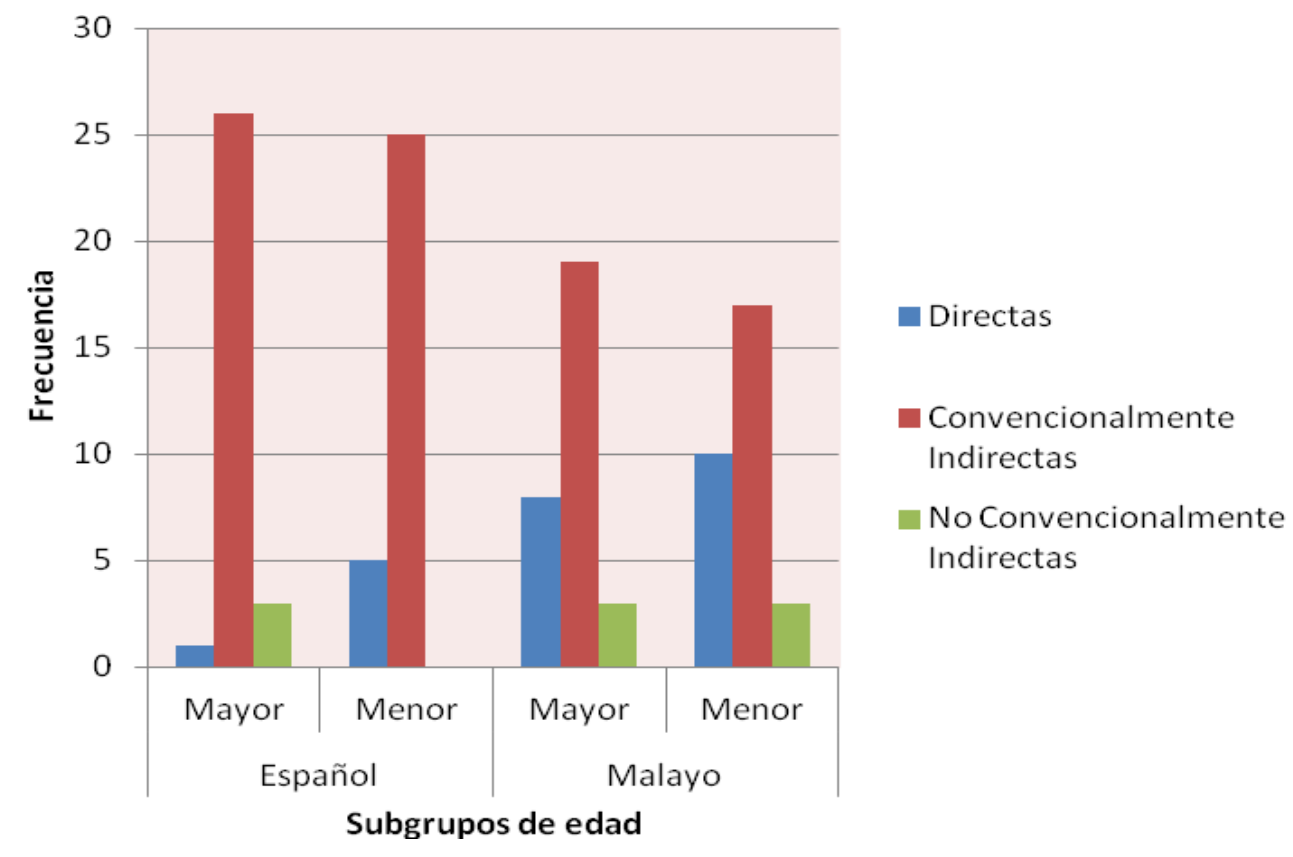

Al aplicar la sub-clasificación en nueve categorías de estrategias a esos mismos enunciados producidos como actos principales, los resultados numéricos obtenidos no muestran diferencias notables entre los subgrupos en ambas sociedades, como se refleja en la tabla que presentamos a continuación: 
Figura 140. Distribución de enunciados (actos principales), producidos para la situación 12 por los sujetos de cada subgrupo de edad, en ambas sociedades, según estrategias empleadas

- Español Mayor Español Menor @ Malayo Mayor Malayo Menor

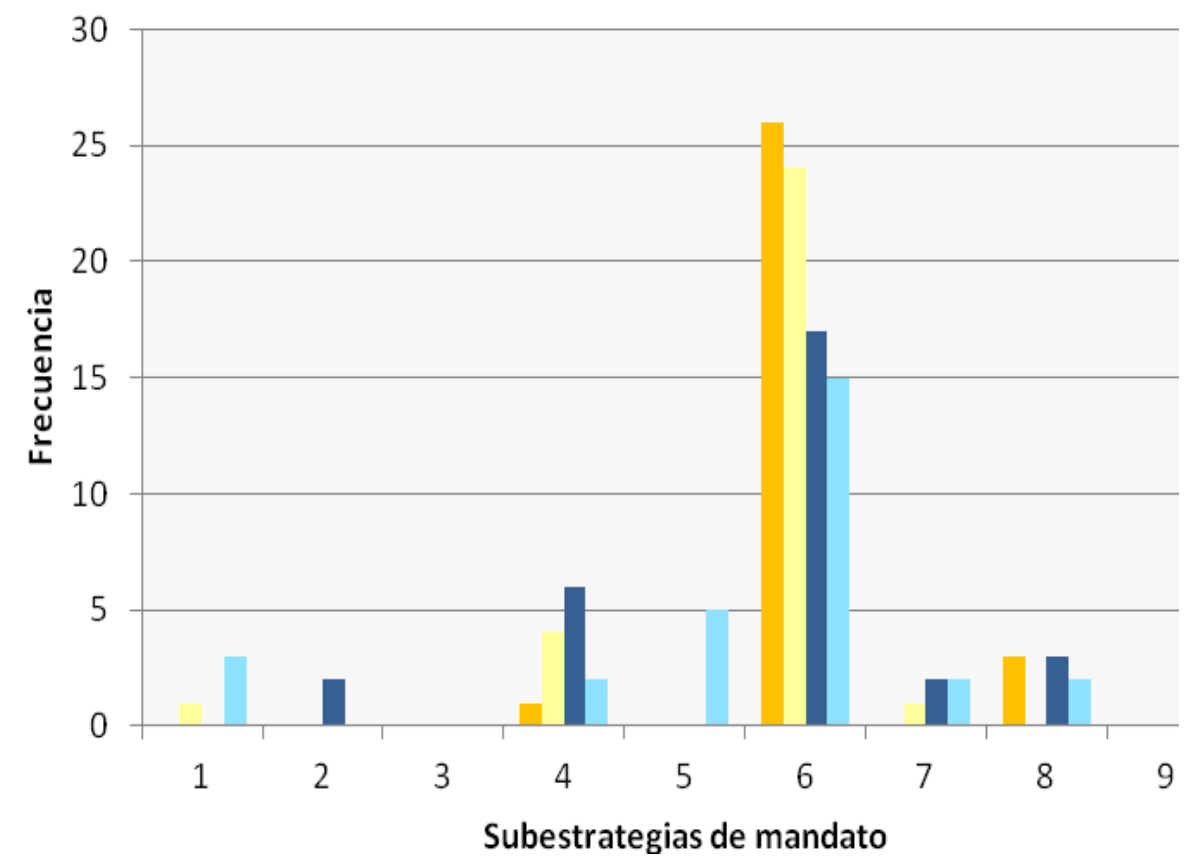

1.Imperativo 2.Performativo 3.Performativo evasivo 4.Declaración de obligación 5.Declaración de deseo 6.Fórmula de sugerencia 7.Interrogación preparatoria 8. Indicio fuerte 9 .Indicio suave

Tanto los encuestados mayores como los menores mostraron preferencia por realizar su mandato a través de una "Fórmula de sugerencia", que aparece en 26 enunciados de los mayores y 24 de los menores, en la sociedad española, y en 7 y 15 , respectivamente, en la malaya. Y la variación en el número de estrategias diferentes empleadas por todos subgrupos tampoco es destacable, ya que los españoles mayores solo utilizaron 3 estrategias diferentes y los jóvenes, 4 , y, en el otro grupo, los 
malayos mayores aplicaron 5 estrategias distintas mientras que los jóvenes recurrieron a 7 .

Respecto a los movimientos de apoyo, los mayores se mostraron más productivos que los jóvenes. Sin embargo, en los subgrupos de edad españoles encontramos una diferencia todavía más marcada que en los malayos. Así, en el grupo español, se recogieron 57 enunciados de hablantes mayores frente a 49 de los menores, y, en el malayo, 53 y 51 , respectivamente. $Y$, en cuanto al número de estrategias empleadas para formularlos, los españoles de mayor edad expusieron más variedad, con 8 tipos diferentes, frente a los 6 de los menores, pero los malayos mayores utilizaron menos que los jóvenes (5 estrategias diferentes, frente a las 7 de los jóvenes). 
Figura 141. Distribución de enunciados (movimientos de apoyo) producidos para la situación 12 por cada subgrupo de edad según estrategias empleadas

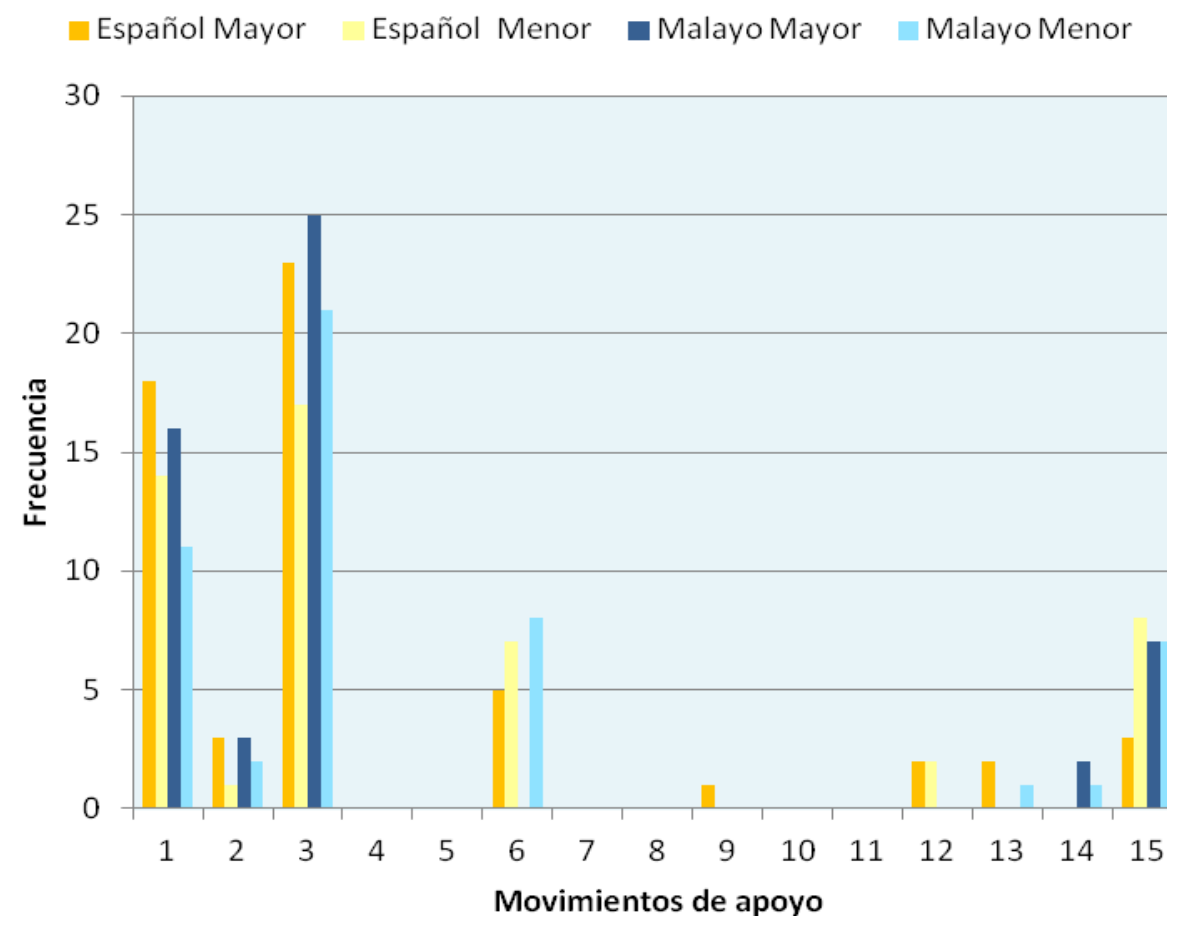

1.Fórmulas de preparación 2.Búsqueda de un compromiso 3.Razones 4.Previsión de objeciones 5.Promesa de recompensa/reparación 6.Minimización de la imposición 7.Invocación de principios generales 8.Reconocimiento de la imposición 9.Preocupación 10.Apreciación 11.Gravedad/urgencia 12.Presentación/saludo 13.Petición de la opinión del oyente 14.Disculpa 15.Fórmulas de tratamiento

Los dos subgrupos de hablantes, mayores y jóvenes, en ambas culturas, prefirieron, en primer lugar, la estrategia de "Razones". Ahora bien, fueron los mayores los que la aplicaron con mayor frecuencia: 23 casos frente a 17 de los jóvenes en la cultura española, y 25 y 21, respectivamente, en la malaya. La segunda estrategia más recurrente en los cuatro subgrupos es la de "Fórmulas de preparación", con 18 ejemplos recopilados de las respuestas de los españoles mayores y 14 de los menores, y 16 de los malayos mayores y 11 de los jóvenes. 


\section{C) Varón frente a mujer}

Como era de esperar, los subgrupos de género tampoco se diferenciaron estadísticamente en sus mandatos al elegir las estrategias de formulación de actos principales. Los dos géneros mostraron la misma tendencia hacia el uso de formas "Convencionalmente indirectas", seguidas de las "Directas" y las "No convencionalmente indirectas". Pese a que ambos grupos de género recurrieron, en la mayor parte de los casos, a las estrategias "Convencionalmente indirectas", fueron las mujeres del grupo español las que las utilizaron con mayor medida (27 casos, frente a 24 de los varones). Pero, en el grupo malayo, la frecuencia con la que los hablantes de ambos sexos utilizaron cada una de las tres formas fue similar.

La diferencia entre los varones y las mujeres en los promedios de las categorías aplicadas tampoco fue significativa en el resultado de ambos grupos en este caso. Ni tampoco lo fue, como veremos más adelante, en el análisis ni de actos principales según la sub-clasificación de las estrategias en 9 categorías, ni en el de las estrategias empleadas en los movimientos de apoyo. 
Figura 142. Distribución de estrategias de mandato empleadas para la situación 12 , en cada género

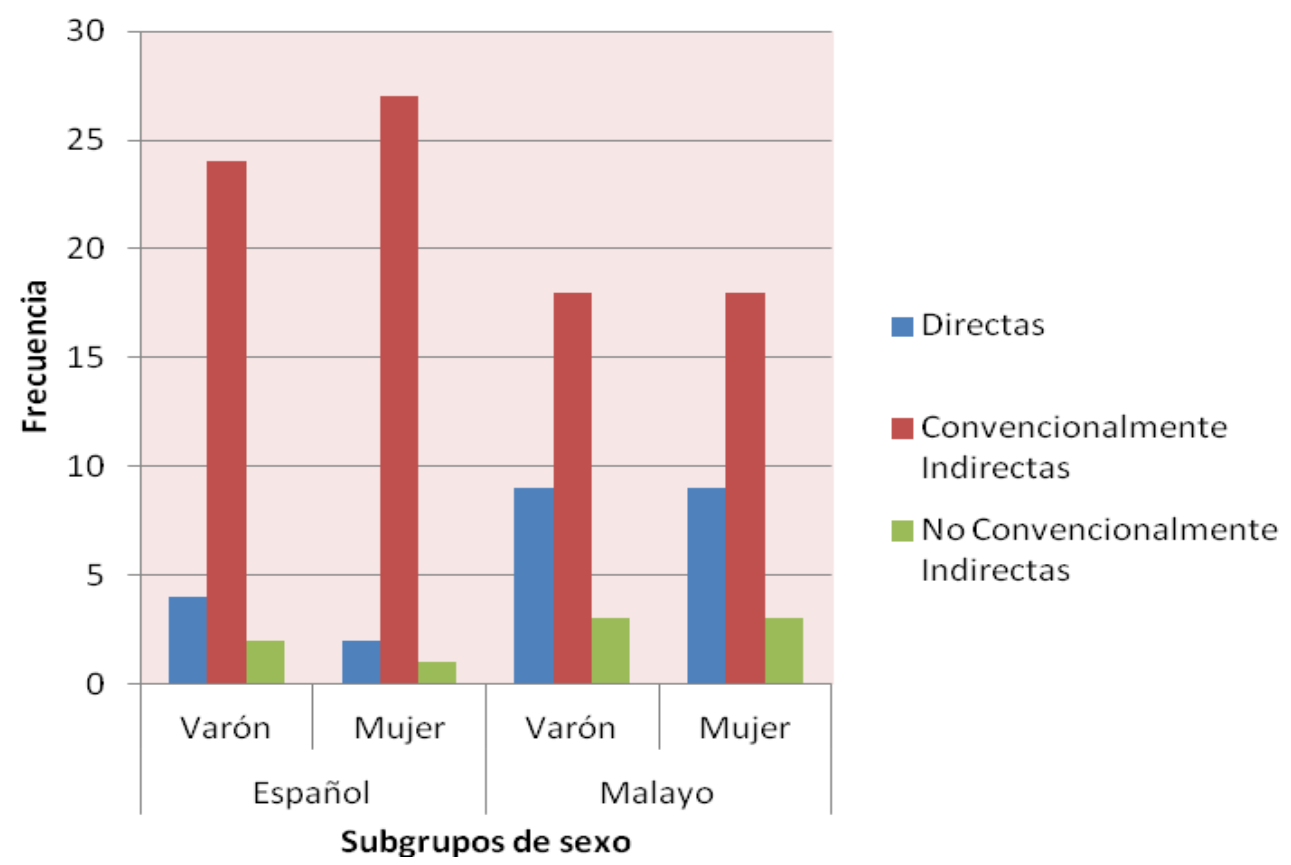

Si aplicamos la sub-clasificación en 9 tipos de estrategias, según el grado de (in)dirección, vemos que a la hora de hacer mandatos, no se aprecia ninguna diferencia importante entre los datos masculinos y los femeninos, como se refleja en la representación gráfica de los resultados numéricos que incluimos a continuación: 
Figura 143. Distribución de enunciados (actos principales) producidos para la situación 12 en cada género, según el tipo de estrategia empleada

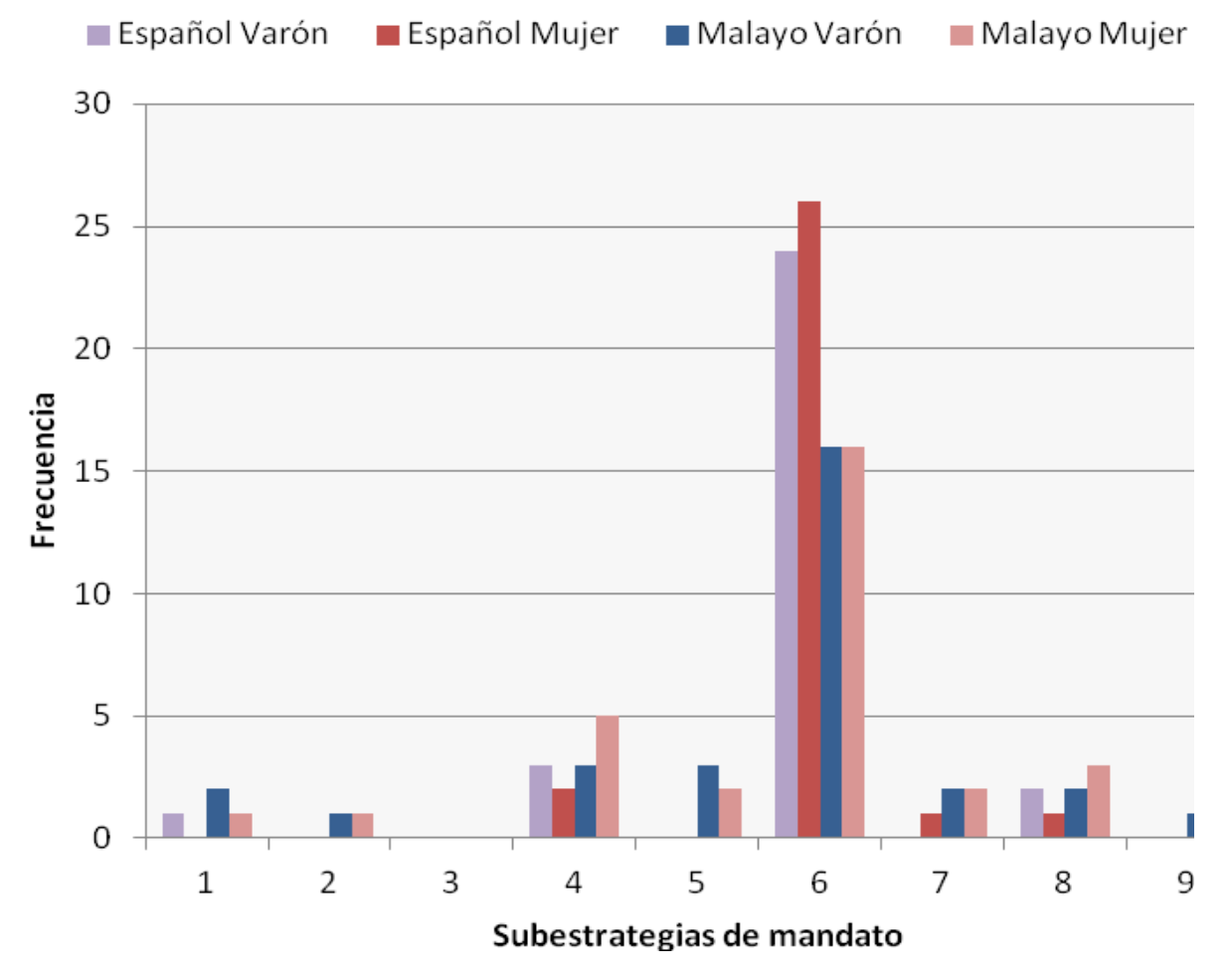

1.Imperativo 2.Performativo 3.Performativo evasivo 4.Declaración de obligación 5.Declaración de deseo 6.Fórmula de sugerencia 7.Interrogación preparatoria 8. Indicio fuerte 9 .Indicio suave

La estrategia dominante en el corpus de los varones y en el de las mujeres, en ambos países, es la de "Razones", con 24 enunciados recogidos de los varones y 26 de las mujeres, en España, y 16 de cada uno de los subgrupos de género malayos.

Con respecto al número de movimientos de apoyo empleados por los dos sexos, la diferencia observada tampoco fue notable, puesto que el número de enunciados recogidos de los sujetos de cada subgrupo español de género fue de 50 (hombres) y 
56 (mujeres), $y$, de los subgrupos malayos, 49 y 55, respectivamente. En cualquier caso, en cada grupo fueron las mujeres las que produjeron un mayor número de movimientos de apoyo, y quizá por ello, son también las que aplicaron más variedad de estrategias: 8 diferentes frente a las 7 de los varones en el grupo español, y 7 y 6 , respectivamente, en el malayo.

Figura 144. Distribución de enunciados (movimientos de apoyo) en los dos géneros en ambas culturas, según estrategias empleadas

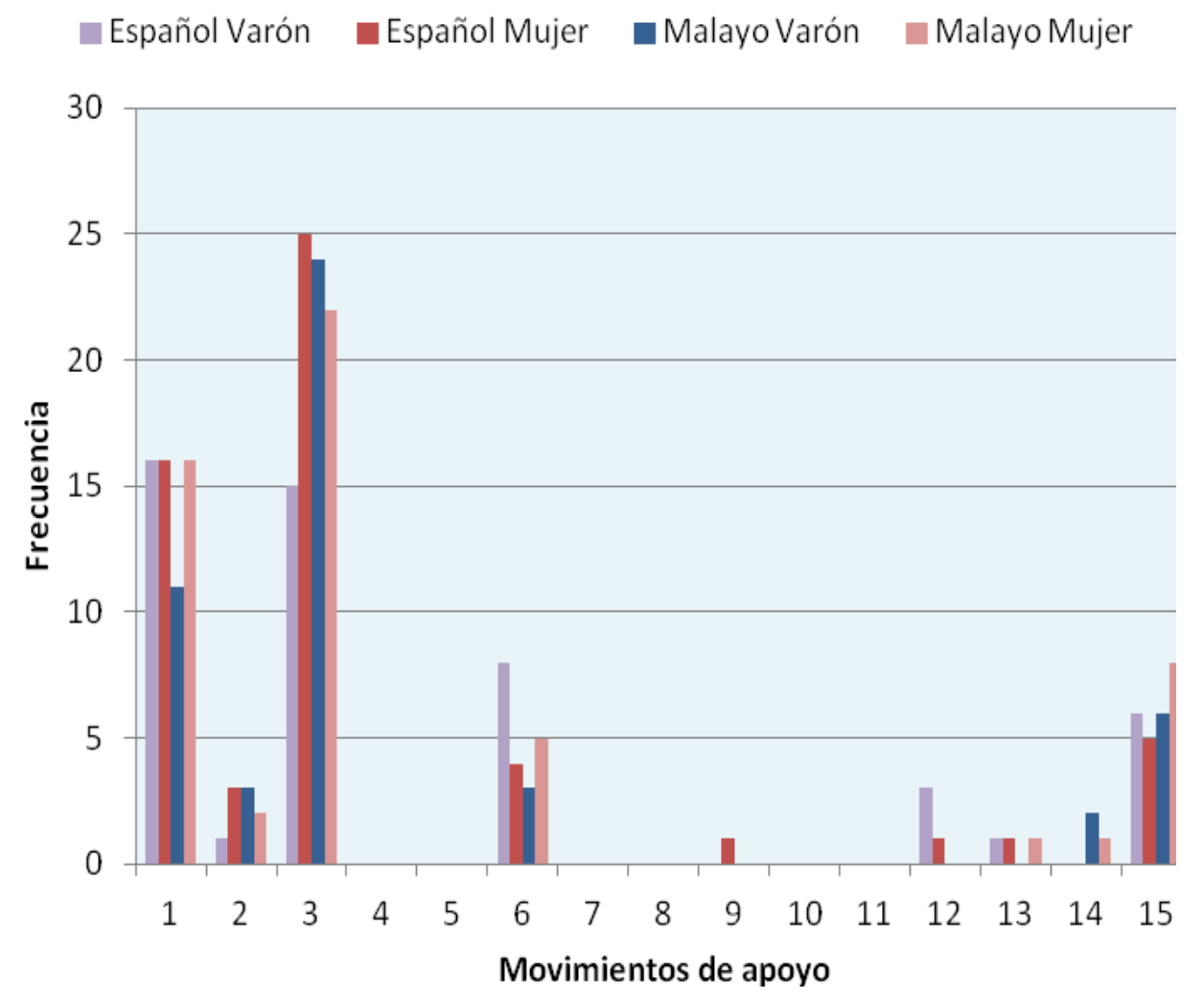

1.Fórmulas de preparación 2.Búsqueda de un compromiso 3.Razones 4.Previsión de objeciones 5.Promesa de recompensa/reparación 6.Minimización de la imposición 7.Invocación de principios generales 8.Reconocimiento de la imposición 9.Preocupación 10.Apreciación 11.Gravedad/urgencia 12.Presentación/saludo 13.Petición de la opinión del oyente 14.Disculpa 15.Fórmulas de tratamiento 
Como se puede ver en la figura, los informantes de ambos géneros no se diferenciaron visiblemente en las estrategias más aplicadas, que son las de "Razones" y "Fórmulas de preparación". Y tampoco es muy relevante la distribución estadística de dichas opciones según el sexo de los sujetos, ya que, por ejemplo, en el caso del uso de las "Razones", es empleada en 24 casos en el corpus de los varones malayos y 22 en el de las mujeres, aunque es verdad que en el caso español hay una diferencia mayor, con 25 enunciados de las mujeres y 15 de los varones. La segunda estrategia a la que se ha recurrido más veces es la de "Fórmulas de preparación", con una coincidencia en el número de enunciados (16) en los dos subgrupos españoles y en el de las mujeres malayas, y dejando una diferencia de 5 con los de los varones malayos, de los que se registraron 11 casos.

\subsubsection{Situación 15}

En la situación 15, el encargado de un restaurante manda a un trabajador a tiempo parcial que envíe un pedido a la oficina de un cliente. La distancia social entre los interlocutores es corta ya que se conocen. 


\section{A) Español frente a malayo}

Si nos fijamos en el grado de (in)dirección de las estrategias empleadas en los enunciados transmitidos como actos principales para la situación descrita, teniendo en cuenta el grupo cultural al que pertenecen los informantes, nos damos cuenta de que encontramos un resultado similar estadísticamente en todos los casos, siendo la forma dominante la de las estrategias "Directas" (48 ejemplos recogidos en cada grupo), seguidas de las "Convencionalmente indirectas" (11 en cada caso) y las "No convencionalmente indirectas" ( 2 ejemplos en el grupo español y 1 en el malayo). La diferencia de los promedios de las categorías comparadas no fue significativa en los datos de ningún grupo.

Figura 145. Distribución de estrategias de mandato empleadas para la situación 15 , en cada cultura

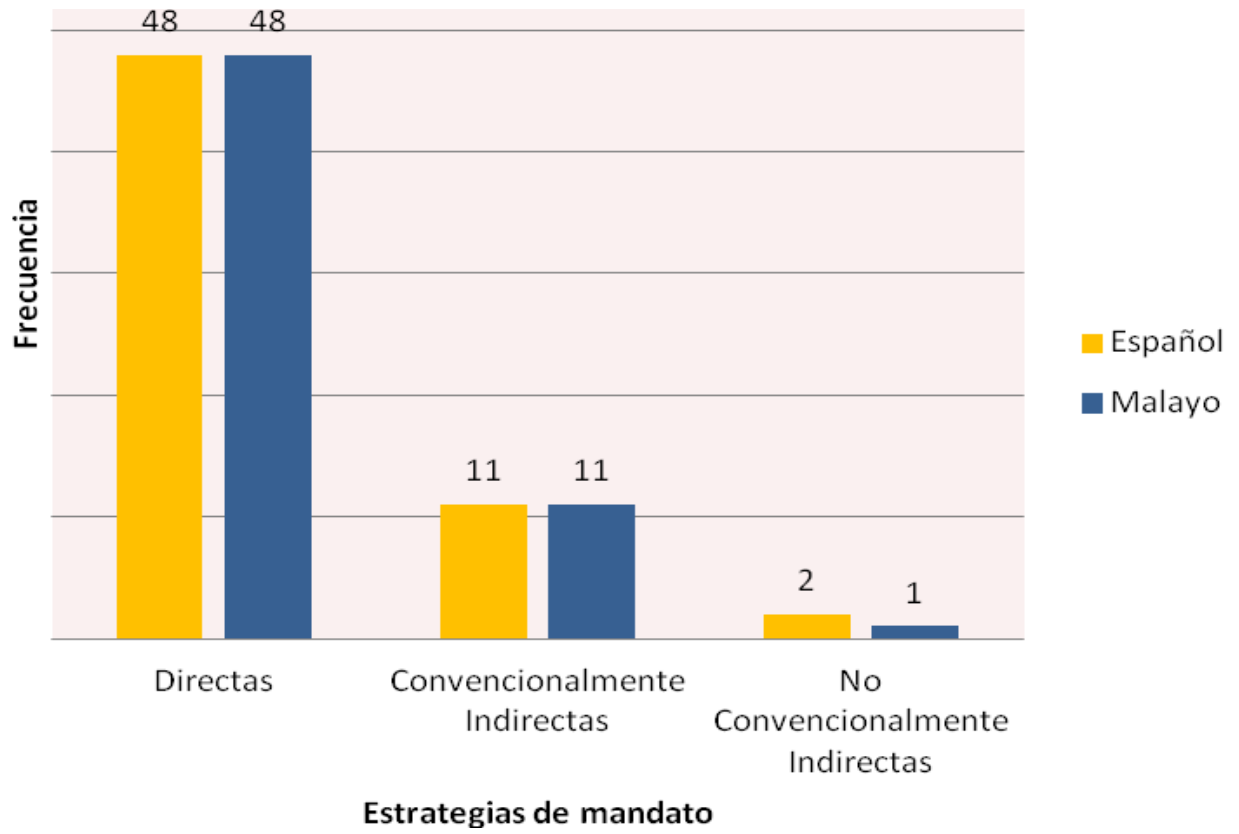


Pero al analizar esos mismos actos principales teniendo en cuenta la sub-clasificación de estrategias de Blum-Kulka (véase cap.3), sí que se aprecian algunas diferencias, como puede verse en la siguiente gráfica que presentamos a continuación:

Figura 146. Distribución de enunciados (actos principales) producidos para la situación 15 en cada cultura, según estrategias empleadas

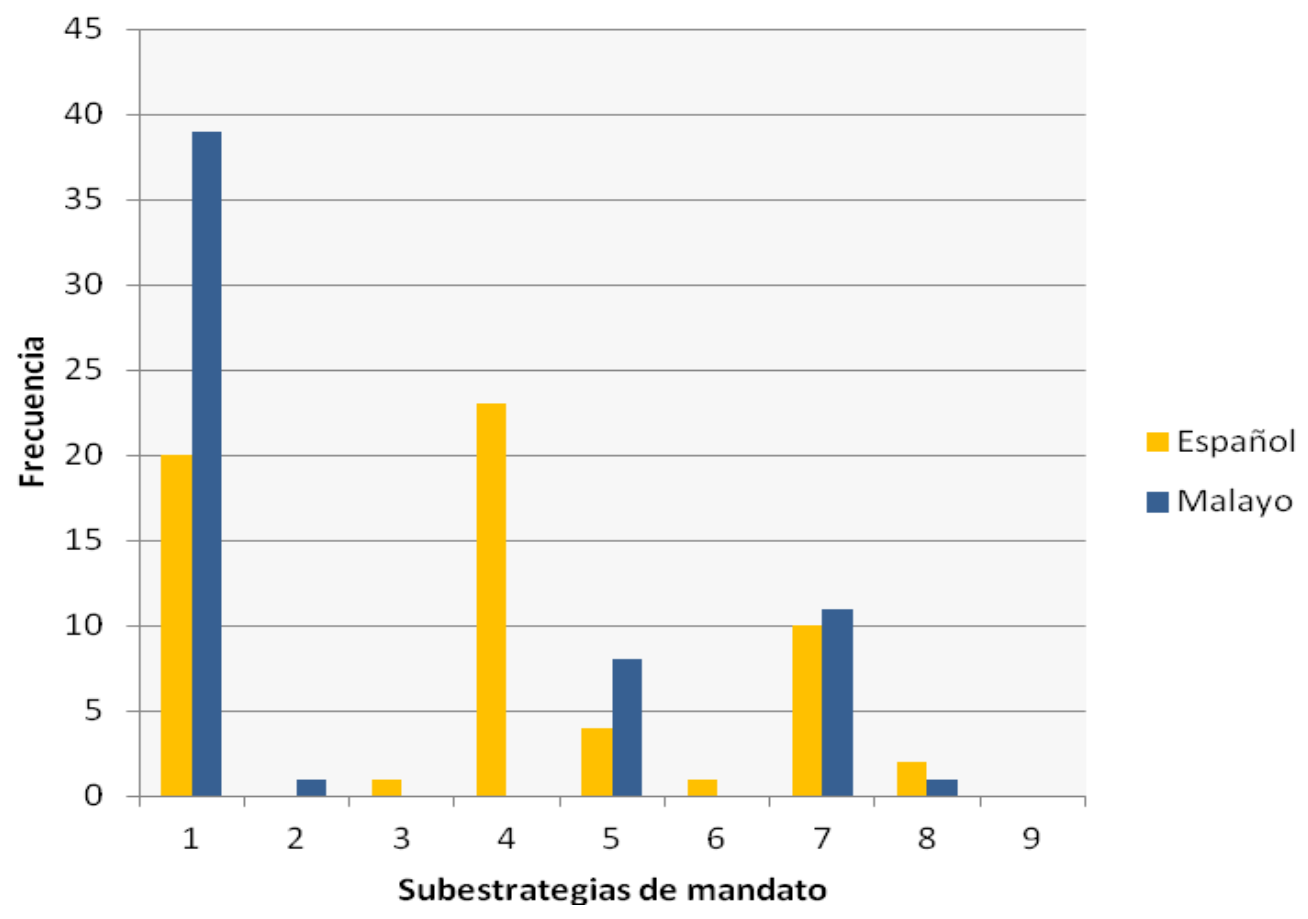

1.Imperativo 2.Performativo 3.Performativo evasivo 4.Declaración de obligación 5.Declaración de deseo 6.Fórmula de sugerencia 7.Interrogación preparatoria 8. Indicio fuerte 9.Indicio suave

Hay algunas estrategias de las que encontramos mayor frecuencia de uso en las respuestas de los nativos españoles. Es el caso de la estrategia de "Declaración de obligación", con 23 apariciones, de la que no se encontró ningún ejemplo en el corpus 
malayo, por lo que se puede señalar una diferencia estadística importante entre los grupos contrastados. Por otro lado, la estrategia preferida por el grupo malayo fue la del "Imperativo", con 39 casos registrados, mientras que de la misma estrategia solo se encontraron 20 casos de los españoles. Asimismo, cabe mencionar la frecuencia de "Declaración de deseo" que aparece 8 veces en el corpus malayo, dos veces más que en el español. La comparación de los promedios entre las estrategias empleadas nos indica una diferencia significativa en los datos de ambos países: $X^{2}=33.827 p=.000(p<.05)$.

Respecto a la producción de movimientos de apoyo, los españoles utilizaron más estrategias que los malayos, con 97 enunciados recogidos de los españoles por solo 57 de los malayos. Ahora bien, los dos grupos examinados aplicaron el mismo número de estrategias diferentes (10 en cada caso). 
Figura 147. Distribución de enunciados (movimientos de apoyo) producidos para la situación 15 en cada cultura, según estrategias empleadas

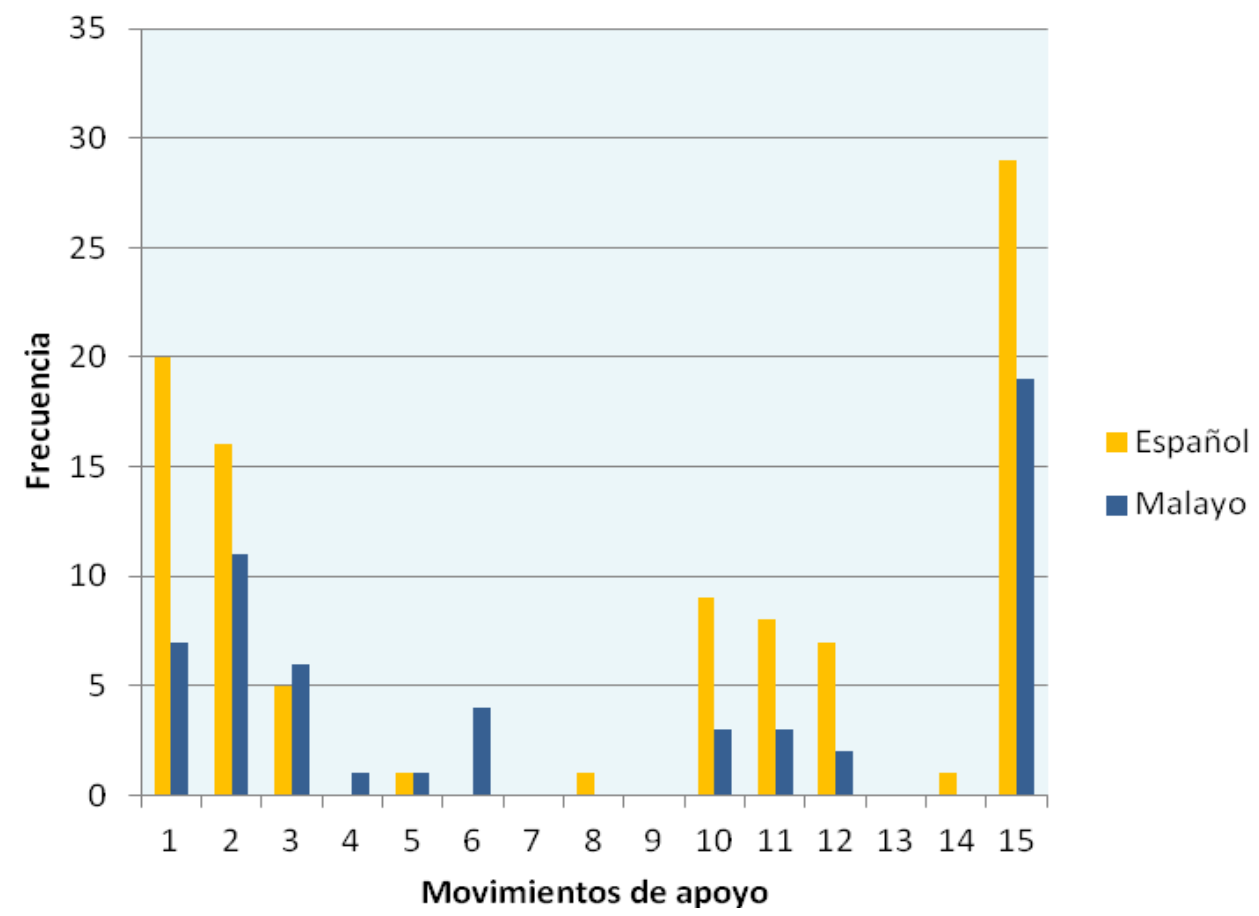

1.Fórmulas de preparación 2.Búsqueda de un compromiso 3.Razones 4.Previsión de objeciones 5.Promesa de recompensa/reparación 6.Minimización de la imposición 7.Invocación de principios generales 8.Reconocimiento de la imposición 9.Preocupación 10.Apreciación 11.Gravedad/urgencia 12.Presentación/saludo 13.Petición de la opinión del oyente 14.Disculpa 15.Fórmulas de tratamiento

El empleo de "Fórmulas de tratamiento" fue el recurso mayoritario en ambos países, aunque fueron los españoles los que recurrieron a ellas en mayor medida (29 enunciados de los españoles frente a 19 de los malayos). La segunda estrategia más utilizada por los informantes españoles fue la de "Fórmulas de preparación" (20) y la tercera, la "Búsqueda de un compromiso" (16). En los datos malayos, por su parte, ocurre lo contrario, es decir, la segunda estrategia más empleada fue la "Búsqueda de un compromiso", con 11 casos y la de "Fórmulas de preparación" se situó estadísticamente 
en el tercer lugar, con 7. En este caso, la diferencia de las medias de las estrategias usadas entre ambos grupos no resultó significativa.

\section{B) Mayor frente a menor}

Al llevar a cabo el análisis de estrategias, según el grado de (in)dirección, empleadas en la formulación de los actos principales de los mandatos producidos en la situación 15 , y teniendo en cuenta la variable de edad, los subgrupos contrastados mostraron un resultado muy similar en su distribución estadística. En este contexto, los hablantes utilizaron las tres formas siguientes en orden decreciente: las estrategias "Directas" en primer lugar (25 casos de los mayores y 23 de los jóvenes en los datos españoles, y 24 en cada subgrupo malayo), las "Convencionalmente indirectas" en segundo lugar (4 y 7, respectivamente, en el grupo español, y 5 y 6 en el malayo) y las "No convencionalmente indirectas" en último lugar (en 2 enunciados de los mayores de ambas sociedades, y ninguno en los datos de los jóvenes).

Los valores de las medias muestran, además, que no hay diferencias estadísticas significativas entre los mayores y los jóvenes ni en el grupo español ni en el malayo. 
Figura 148. Distribución de estrategias de mandato empleadas en la situación 15 en cada subgrupo, en ambas sociedades

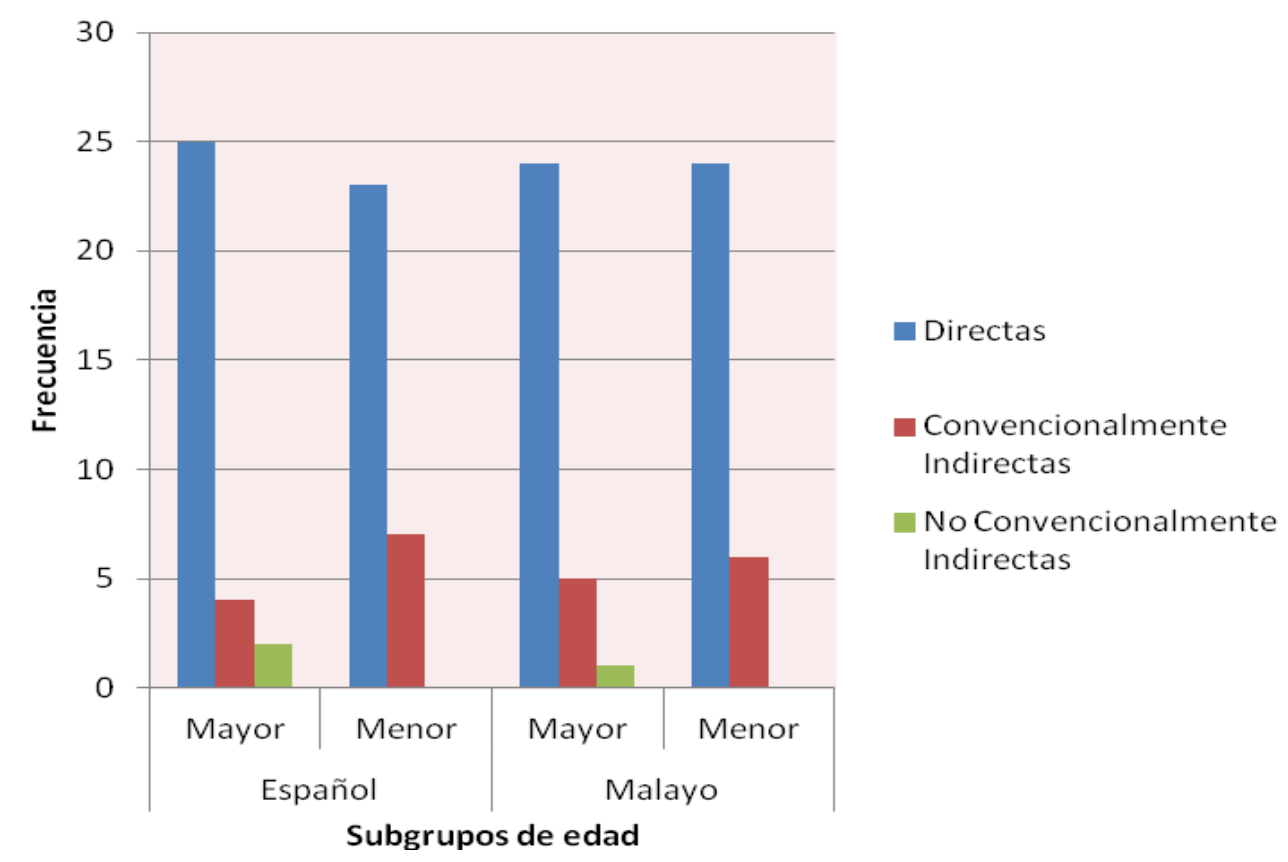

Al aplicar los nueve tipos de estrategias con los que estamos trabajando en nuestro estudio (véase el capítulo 3 de fundamentación metodológica), a la clasificación de los enunciados analizados arriba, resulta que la mayoría de los hablantes españoles de mayor edad formuló sus mandatos en esta situación por medio de la estrategia "Declaración de obligación" (13 casos encontrados), seguida del "Imperativo" (9). En cambio, los hablantes de menos edad se expresaron utilizando, en la mayor parte de los casos, un imperativo (11) o una declaración de obligación (10). En la sociedad malaya, por su parte, la opción mayoritaria en las respuestas de los hablantes mayores coincidió con la de los jóvenes. Pese a que los encuestados malayos optaron, en mayor grado, por la estrategia de 
"Imperativo" a la hora de expresar su mandato en este escenario, fueron los de menos edad los que mostraron una tendencia destacada hacia dicha forma, con 23 casos frente a los 16 de los de más edad. Hay que subrayar la presencia de solo dos opciones de estrategia empleadas en el corpus de los jóvenes, en comparación con los cinco tipos encontrados en el de los mayores. Además, mientras que ningún joven aplicó la estrategia de "Interrogación preparatoria", en los datos de los mayores apareció en 5 ocasiones. En este caso tampoco existieron diferencias estadísticas significativas entre los mayores y los jóvenes en ambos grupos en los valores de los promedios.

Figura 149. Distribución de enunciados (actos principales) producidos para la situación 15 en cada subgrupo de ambas sociedades, según estrategias empleadas

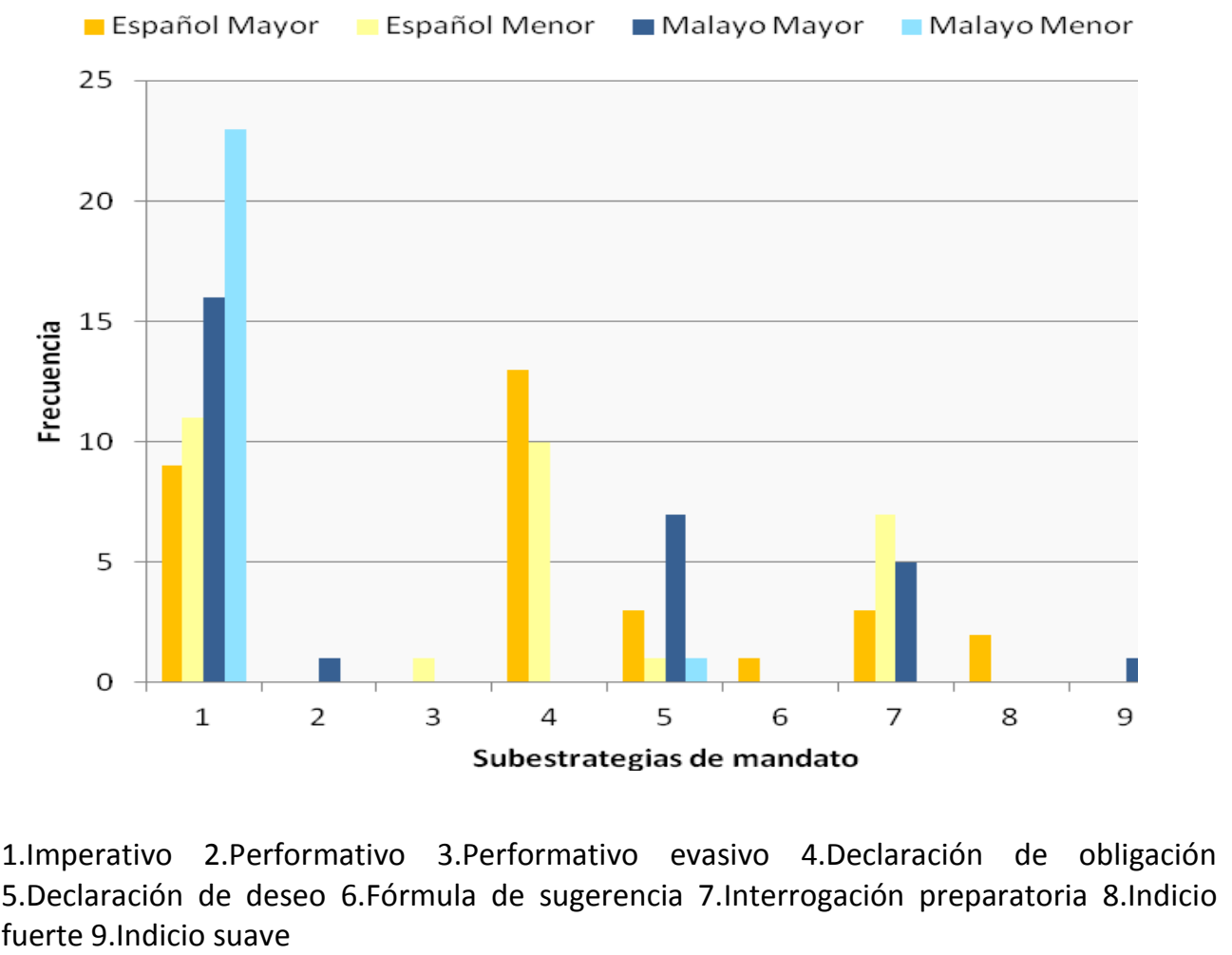


En relación con los movimientos de apoyo formulados, cabe mencionar que, en total, los participantes mayores en los dos casos, español y malayo, produjeron un mayor número de enunciados que los menores: 55 y 42 , respectivamente, en el caso español, y 35 frente a 22, en el malayo. La tabla que presentamos a continuación nos muestra cuáles fueron las estrategias más utilizadas en estos movimientos de apoyo por los sujetos de cada subgrupo.

Figura 150. Distribución de enunciados (movimientos de apoyo) producidos para la situación 15 en cada subgrupo de ambas sociedades, según estrategias empleadas

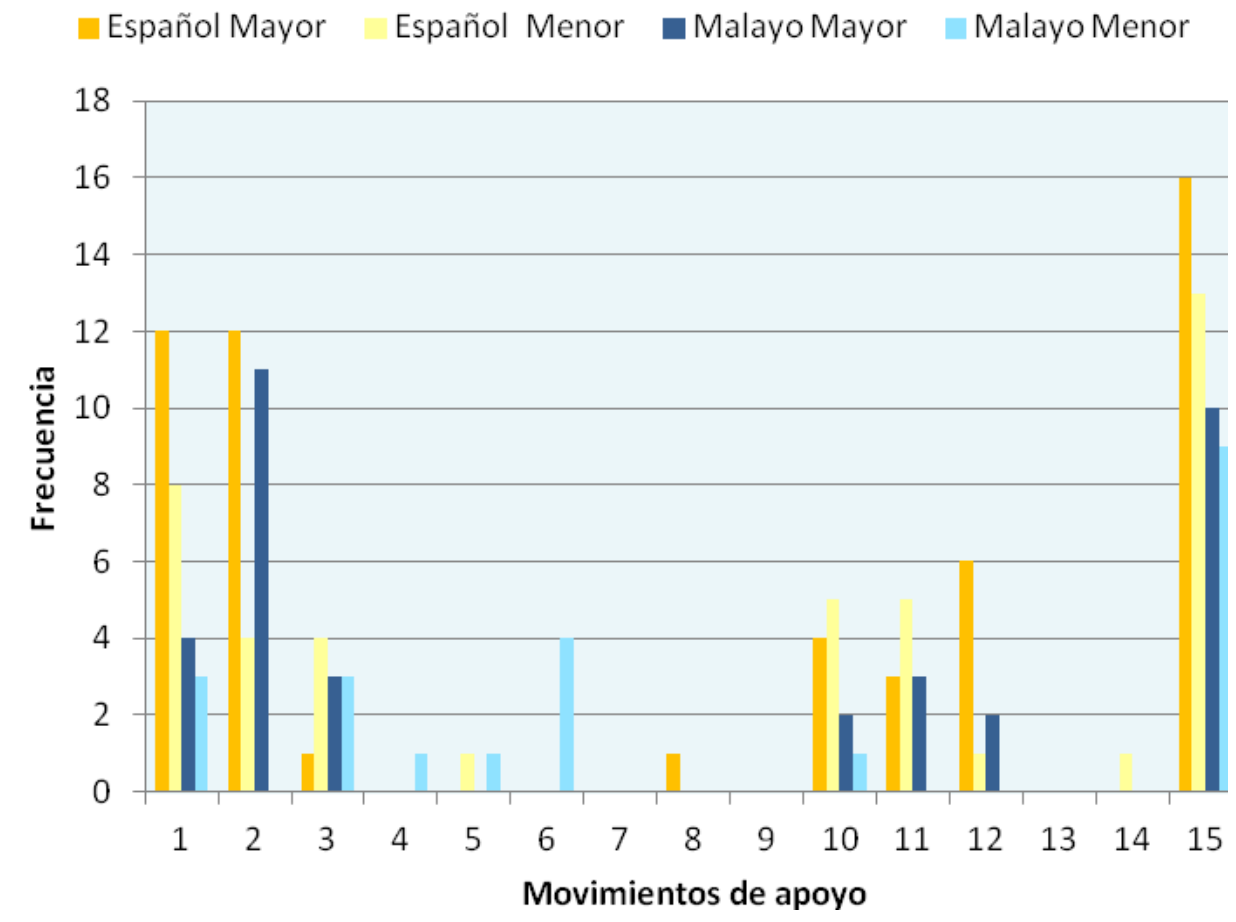

1.Fórmulas de preparación 2.Búsqueda de un compromiso 3.Razones 4.Previsión de objeciones 5.Promesa de recompensa/reparación 6.Minimización de la imposición 7.Invocación de principios generales 8.Reconocimiento de la imposición 9.Preocupación 10.Apreciación 11.Gravedad/urgencia 12.Presentación/saludo 13.Petición de la opinión del oyente 14.Disculpa 15.Fórmulas de tratamiento 
Los informantes de todas las edades del grupo español coincidieron en su tendencia hacia el empleo de las "Fórmulas de tratamiento" (16 casos encontrados en los mayores y 13 en los menores). El resto de las estrategias encontradas en los datos producidos por los mayores se presentó de la siguiente manera: el segundo lugar, según índice de frecuencia, lo ocuparon las estrategias de "Fórmulas de preparación" y "Búsqueda de un compromiso" (10 ejemplos de cada una), seguidas de la de "Presentación/saludo" (6). La segunda estrategia más aplicada por los jóvenes fue también la de "Fórmulas de preparación" (8 enunciados), seguida de "Apreciación" y "Gravedad/urgencia" (5 muestras de cada una).

Por otro lado, la mayoría de los mayores malayos estudiados, al hacer un mandato en la situación facilitada, lo hacen por medio de la "Búsqueda de un compromiso" (11 casos) y "Fórmulas de tratamiento" (10). Llama la atención la diferencia entre ambos subgrupos respecto a la primera estrategia, que apareció en el corpus de los mayores 11 veces, pero ningún joven la utilizó. El segundo lugar en el orden de preferencia por una u otra estrategia está ocupado por el "Imperativo" (en 4 enunciados), seguida de las "Razones" (en 3). Los menores también mostraron preferencia por el empleo de las "Fórmulas de tratamiento" (9 ejemplos), pero también por la "Minimización de la imposición" y "Gravedad/urgencia" (se 
encontraron 3 casos de cada una). Al comparar los promedios de las categorías aplicadas entre los subgrupos de edad, la diferencia fue significativa en el resultado malayo: $X^{2}=20.637 \mathrm{p}=.014(p<.05)$, pero no en el español.

\section{C) Varón frente a mujer}

Al analizar las estrategias empleadas en la producción de actos principales, según su grado de (in)dirección, y teniendo en cuenta la variable de género, vemos que, en los mandatos que se expresaron en esta situación, al igual que ocurrió en el caso anterior (análisis según variable de edad), los varones y las mujeres que participaron en el presente estudio no mostraron una diferencia relevante con respecto al empleo de las estrategias "Directas", ya que la frecuencia de uso fue muy similar en ambos sexos ( 24 en cada subgrupo en España, y 26 y 22, respectivamente, en Malasia). Ocurre prácticamente lo mismo en al caso de las "Convencionalmente indirectas", con 5 casos en las respuestas de los varones españoles, y 6 en las de las mujeres, y 4 y 7 , respectivamente, en las de los malayos, mientras que en el caso de las "No convencionalmente indirectas", vemos que solamente recurrieron a ellas los varones españoles (en 2 ocasiones) y las mujeres malayas (en 1), pero 
ninguna mujer española ni ningún varón malayo la aplicó en su mandato.

Figura 151. Distribución de estrategias de mandato empleadas para la situación 15 en cada subgrupo de género en ambas culturas

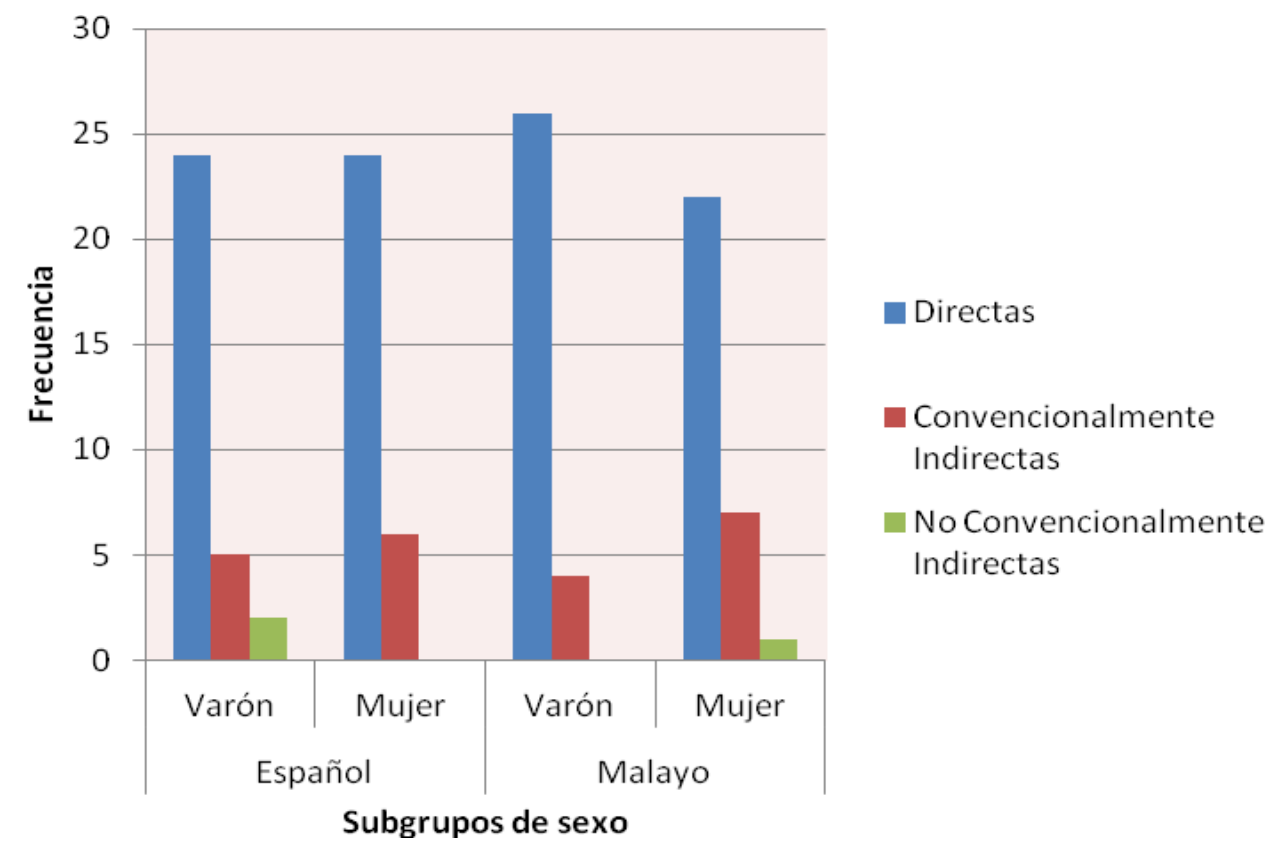

Al aplicar a los enunciados producidos como actos principales las nueves sub-categorías de estrategias, según el grado de (in)dirección, establecido por Blum-Kulka (véase cap.3), la distribución numérica queda como se presenta en el gráfico siguiente: 
Figura 152. Distribución de enunciados (estrategias de mandato) producidos para la situación 15 por cada subgrupo en ambas culturas, según selección de estrategias

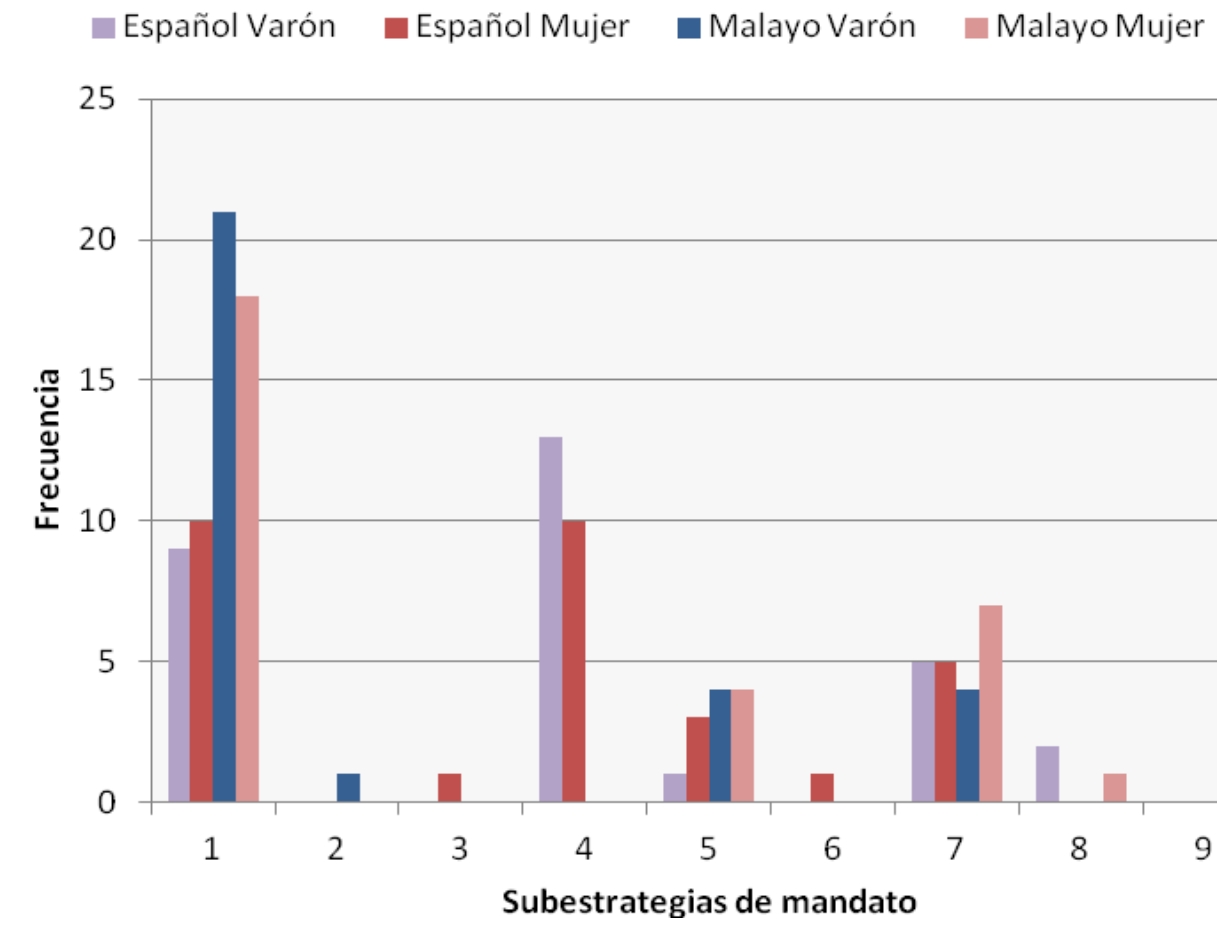

1.Imperativo 2.Performativo 3.Performativo evasivo 4.Declaración de obligación 5.Declaración de deseo 6.Fórmula de sugerencia 7.Interrogación preparatoria 8.Indicio fuerte 9.Indicio suave

El resultado estadístico de las estrategias elegidas en más ocasiones para llevar a cabo el acto de habla de mandato en esta situación mostró un patrón similar en los dos subgrupos de género de las dos culturas. Así, tanto los varones españoles como las mujeres prefirieron ejecutar sus mandatos utilizando una "Declaración de obligación" (13 ejemplos de los varones y 10 de las mujeres) y un "Imperativo" (9 y 10 casos, respectivamente). Por otro lado, los informantes malayos de ambos sexos tendieron a realizar su mandato a través de un "Imperativo" (en 21 enunciados 
de los hombres y 18 de las mujeres) y de "Interrogación preparatoria" (en 4 de los varones y 7 de las mujeres).

En lo que atañe a la variedad de estrategias, se recogieron 2 casos de la de "Indicio fuerte" en los datos de los varones españoles, pero no se encontró ningún ejemplo de dicha estrategia en el otro sexo. En cambio, las de "Performativo evasivo" y "Fórmula de sugerencia" aparecieron en los datos de las mujeres (una vez cada una) pero ningún varón las aplicó. En el grupo malayo, por su parte, la estrategia de "Performativo" está presente en el material de los varones (en un enunciado), pero ninguna mujer la empleó. Y, mientras que no se encontró ningún caso de "Indicio fuerte" en el material de los varones, en el de las mujeres sí que se registró en una ocasión.

En el análisis de los movimientos de apoyo que acompañaron a los actos principales analizados arriba, se registró un mayor número de enunciados en el corpus de las mujeres españolas (54, frente a 43 de los varones). Al contrario, en la otra sociedad, fueron los varones los que produjeron más (32 frente a 25 de las mujeres). Y respecto a las preferencias mostradas por cada sexo en la aplicación de estrategias, y que presentamos en la Figura 226 (véase más abajo), notamos que ambos sexos, tanto en el corpus español como en el malayo, eligieron mayoritariamente "Fórmulas de 
tratamiento" en sus expresiones (en 14 enunciados de los varones y en 15 de las mujeres, en el corpus español, y en 7 y 12 , respectivamente, en el malayo). Hay que mencionar la alta frecuencia de la estrategia de "Búsqueda de un compromiso" en las respuestas de las mujeres españolas, con 12 casos, en comparación con tan solo 4 de los varones. En el grupo malayo, por otro lado, se nota la ausencia de la estrategia de "Gravedad/urgencia" en los datos de los varones, pero se encontraron 3 ejemplos en los de las mujeres.

Figura 153. Distribución de enunciados (movimientos de apoyo) producidos para la situación 15 por cada subgrupo de género en ambas culturas, según estrategias empleadas

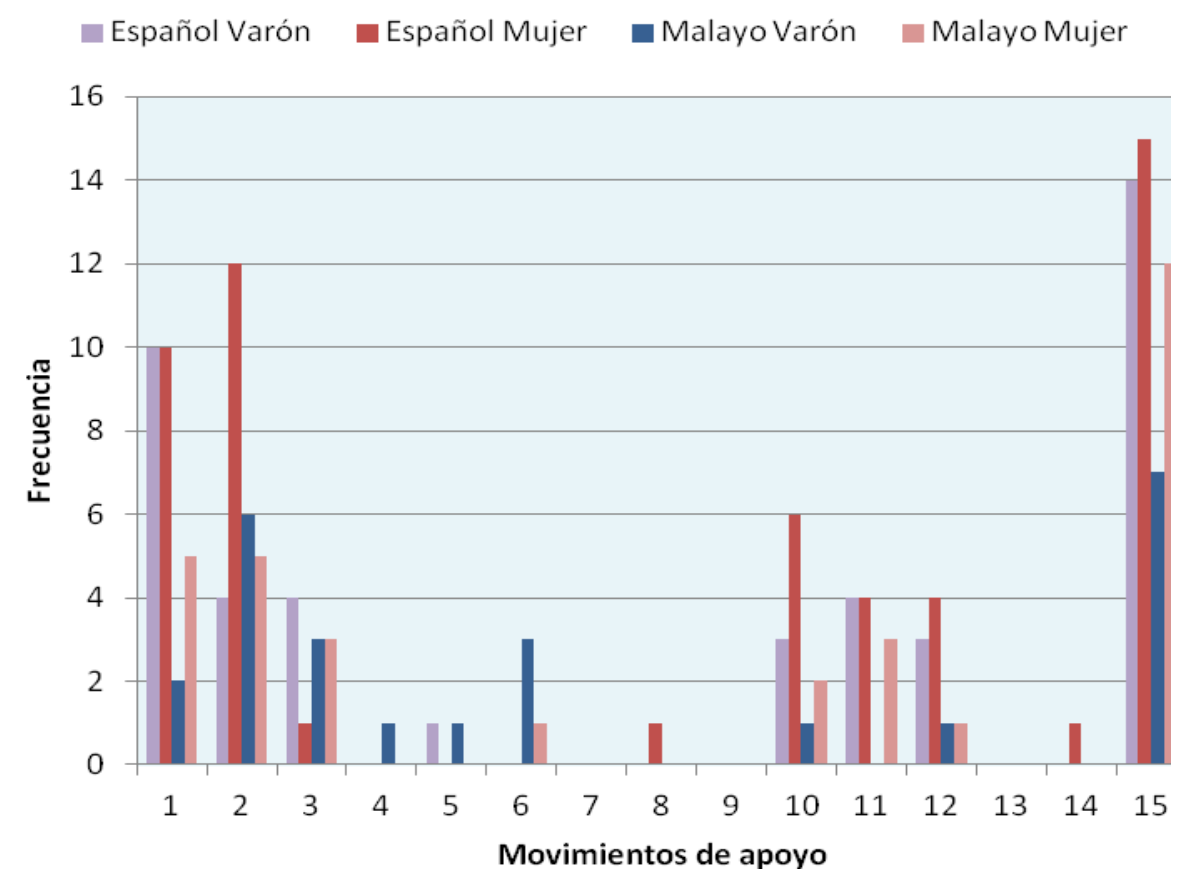

1.Fórmulas de preparación 2.Búsqueda de un compromiso 3.Razones 4.Previsión de objeciones 5.Promesa de recompensa/reparación 6.Minimización de la imposición 7.Invocación de principios generales 8.Reconocimiento de la imposición 9.Preocupación 10.Apreciación 11.Gravedad/urgencia 12.Presentación/saludo 13.Petición de la opinión del oyente 14.Disculpa 15.Fórmulas de tratamiento 
Al comparar los promedios de las formas utilizadas en los tres casos, la diferencia no fue significativa entre ambos sexos, ni en el resultado español ni en el malayo.

\subsubsection{Situación 18}

En la situación 18 un padre o una madre manda a su hijo, que está viendo la tele a medianoche, que se acueste enseguida. El grado de la familiaridad entre los interlocutores es muy alto puesto que son padres e hijo.

\section{A) Español frente a malayo}

En la clasificación de las estrategias empleadas por los hablantes de una y otra sociedad al producir los actos principales de su mandato en la situación descrita anteriormente, pese a que ambos grupos muestran preferencia por la categoría de "Directas", fueron los participantes malayos los que más las emplearon, con un número de casos de 49, frente a los 44 de los españoles. En segundo lugar, es relevante la diferencia estadística que aparece entre los grupos con relación a las estrategias "Convencionalmente indirectas", ya que, mientras que los malayos las emplearon en 13 de sus enunciados, 
solo aparecen 4 veces en los de los españoles. En cambio, el resultado respecto a la tercera categoría, las "No convencionalmente indirectas", fue el contrario, es decir, los participantes españoles las utilizaron con mayor frecuencia que los malayos (en 13 ocasiones, frente a tan solo un caso en el corpus de los malayos). En los promedios de las fórmulas empleadas, la diferencia entre los grupos analizados sí que fue significativa: $X^{2}=15.291 \mathrm{p}=.000(\mathrm{p}<.05)$.

Figura 154. Distribución de estrategias de mandato empleadas para la situación 16 , en ambas sociedades

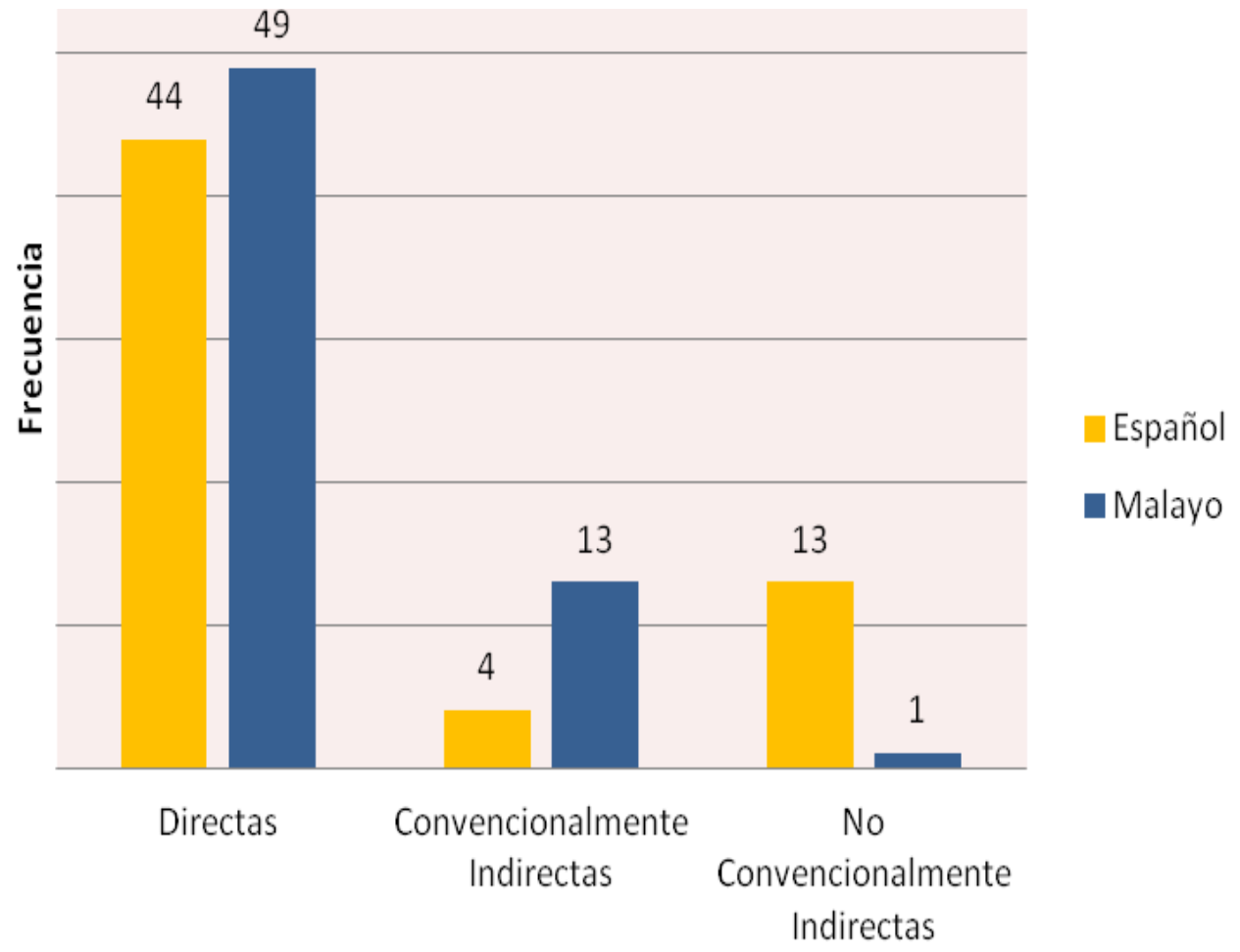

Estrategias de mandato 
En relación al empleo de las nueve sub-categorías de estrategias, según su grado de (in)dirección, los resultados numéricos obtenidos se muestran en la tabla que presentamos a continuación:

Figura 155. Distribución de enunciados (actos principales) producidos para la situación 18 en ambas sociedades, según estrategias empleadas

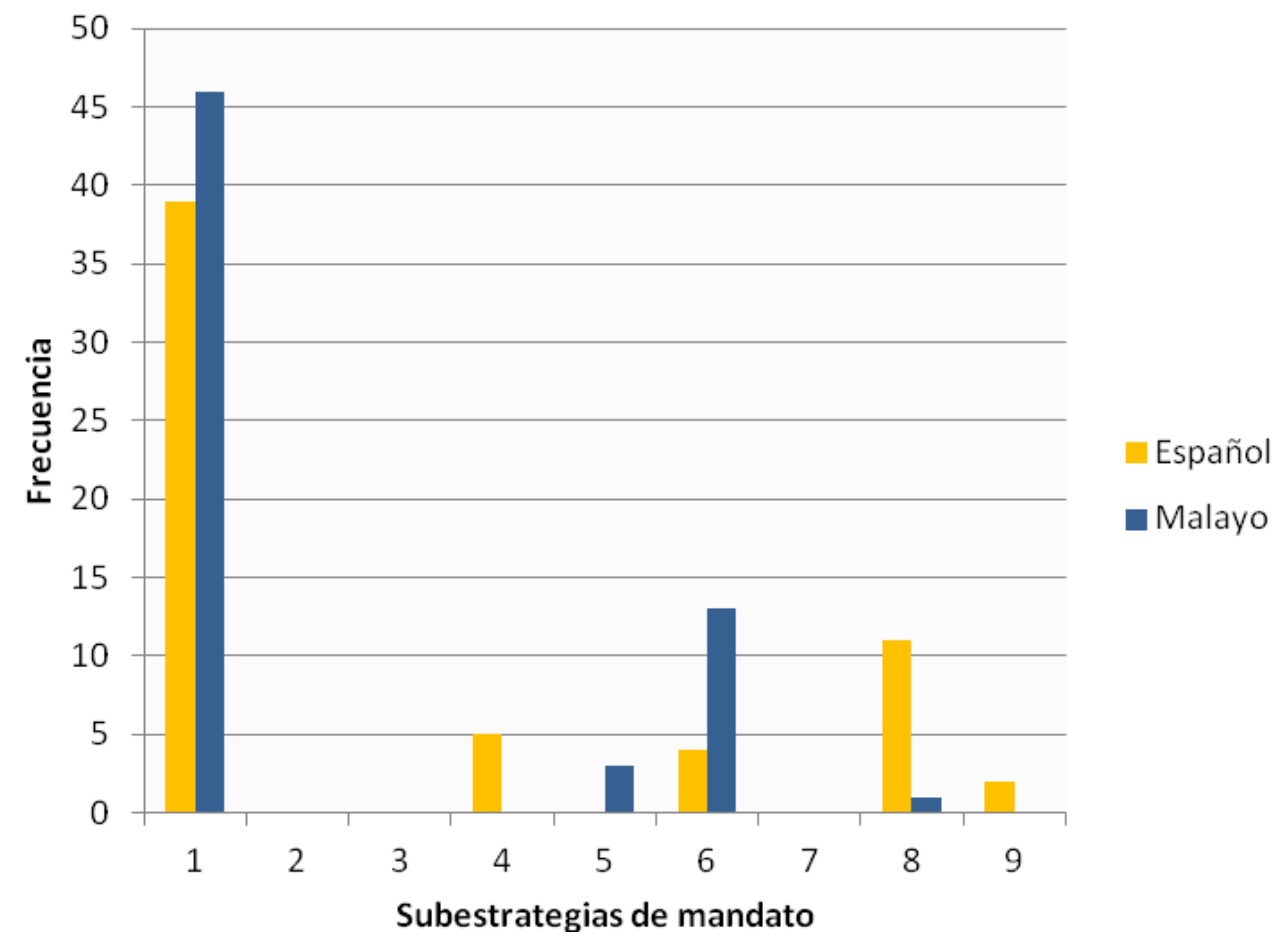

1.Imperativo 2.Performativo 3.Performativo evasivo 4.Declaración de obligación 5.Declaración de deseo 6.Fórmula de sugerencia 7.Interrogación preparatoria 8.Indicio fuerte 9.Indicio suave

De acuerdo con los datos de la figura, la estrategia más empleada tanto por los sujetos españoles como por los malayos fue la de "Imperativo". Ahora bien, fueron los malayos los que recurrieron a ella más que los españoles (46 ejemplos registrados de 
los malayos frente a 39 de los españoles). Hay que subrayar la alta frecuencia de uso de las "Fórmulas de sugerencia" en las respuestas de los sujetos malayos, empleada en 13 ocasiones, en comparación con las solo 4 veces en las que son utilizadas por los españoles. Por otro lado, la estrategia de "Indicio fuerte", que aparece en 11 enunciados de los españoles, lo hizo solo una vez en los datos malayos. Y, mientras que ningún malayo usó la "Declaración de obligación", se registraron 5 casos de dicha estrategia en los sujetos españoles. Asimismo, ningún malayo empleó la de "Indicio suave", pero los españoles la utilizaron 2 veces. En cambio, la estrategia de "Declaración de deseo" está presente en los datos malayos, pero no se encontró ningún caso en los españoles. Al igual que en el caso anterior, la comparación de los promedios entre las estrategias usadas también muestra una diferencia significativa en los datos de ambos países: $X^{2}=23.648 \mathrm{p}=.000(\mathrm{p}<.05)$.

Respecto a las estrategias empleadas en la formulación de los movimientos de apoyo, se obtuvieron los siguientes resultados: 
Figura 156. Distribución de enunciados (movimientos de apoyo) producidos para la situación 18 en ambas sociedades, según estrategias empleadas

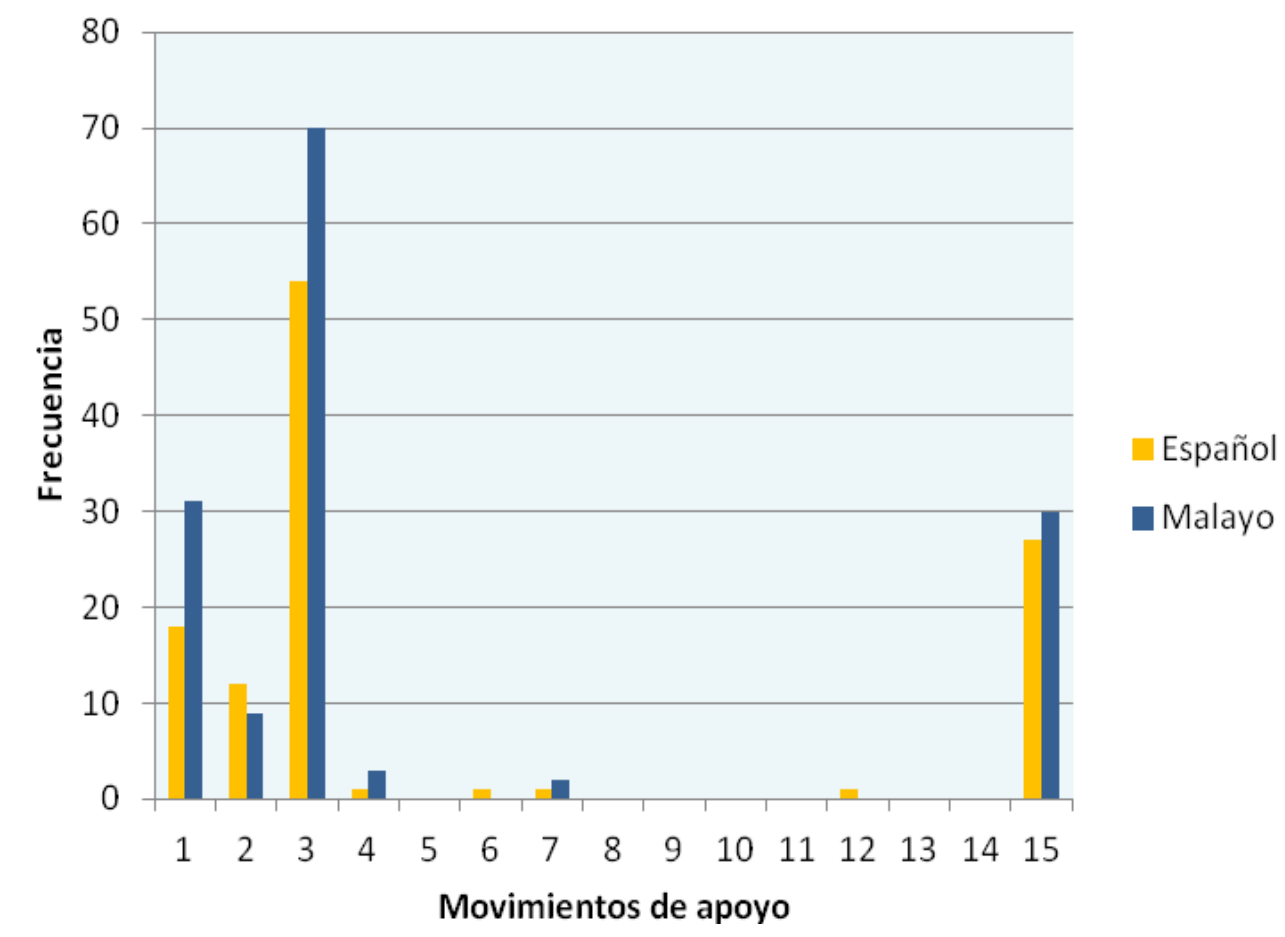

1.Fórmulas de preparación 2.Búsqueda de un compromiso 3.Razones 4.Previsión de objeciones 5.Promesa de recompensa/reparación 6.Minimización de la imposición 7.Invocación de principios generales 8. Reconocimiento de la imposición 9.Preocupación 10.Apreciación 11.Gravedad/urgencia 12.Presentación/saludo 13.Petición de la opinión del oyente 14.Disculpa 15.Fórmulas de tratamiento

Pese a que los grupos coincidieron en mostrar preferencia por la estrategia de "Razones", fueron los informantes malayos quienes la emplearon con más frecuencia, en comparación con los españoles (70 casos, frente a solo 54 de los españoles). Además, los malayos manifestaron una tendencia más fuerte hacia el uso de "Fórmulas de preparación", con 31 casos, en comparación con los solo 18 de los españoles. Por otro lado, la preferencia marcada por los españoles respecto a la utilización de la estrategia de "Búsqueda de un compromiso", fue más firme que la de los otros (se utiliza en 
12 enunciados frente a solo 9 de los malayos). Ahora bien, por lo que refiere al uso de "Fórmulas de tratamiento", ninguno de los grupos mostró una diferencia significativa (aparece 27 veces en el corpus de los españoles, y 30 en el de los malayos). A diferencia del análisis realizado sobre las estrategias empleadas en los actos principales, los promedios comparados entre ambas sociedades relativos a los movimientos de apoyo no resultaron significativos.

\section{B) Mayor frente a menor}

En el análisis del mayor o menor grado de dirección de las estrategias empleadas en los actos principales, desde la variable de edad, se observa que fueron los hablantes de menos edad los que más utilizaron las estrategias "Directas", con 27 casos, frente a 17 de los mayores en el grupo español, y 27 por 22, en el malayo. Ocurrió al contrario en el caso de las "Convencionalmente indirectas", es decir, los hablantes mayores fueron los que las usaron con mayor frecuencia (en 4 enunciados en los datos de España y en 9 de Malasia) en comparación con los jóvenes (ningún caso en el corpus español y 4 en el malayo). Y el análisis de las "No convencionalmente indirectas", reveló también un mayor empleo por parte de los hablantes de más edad, que las utilizaron en 9 ocasiones (4 ejemplos de los menores) en el grupo español. En los datos 
malayos solo aparecieron una vez en los datos de los sujetos mayores, pero ningún joven las empleó.

Según el resultado de las pruebas estadísticas, la diferencia entre los subgrupos de edad en ambos países no fue muy significativa, no solo en esta parte del análisis, sino tampoco, como veremos a continuación, en el apartado relativo a las estrategias y los movimientos de apoyo.

Figura 157. Distribución de estrategias de mandato empleadas para la situación 18 en cada subgrupo, en ambas sociedades

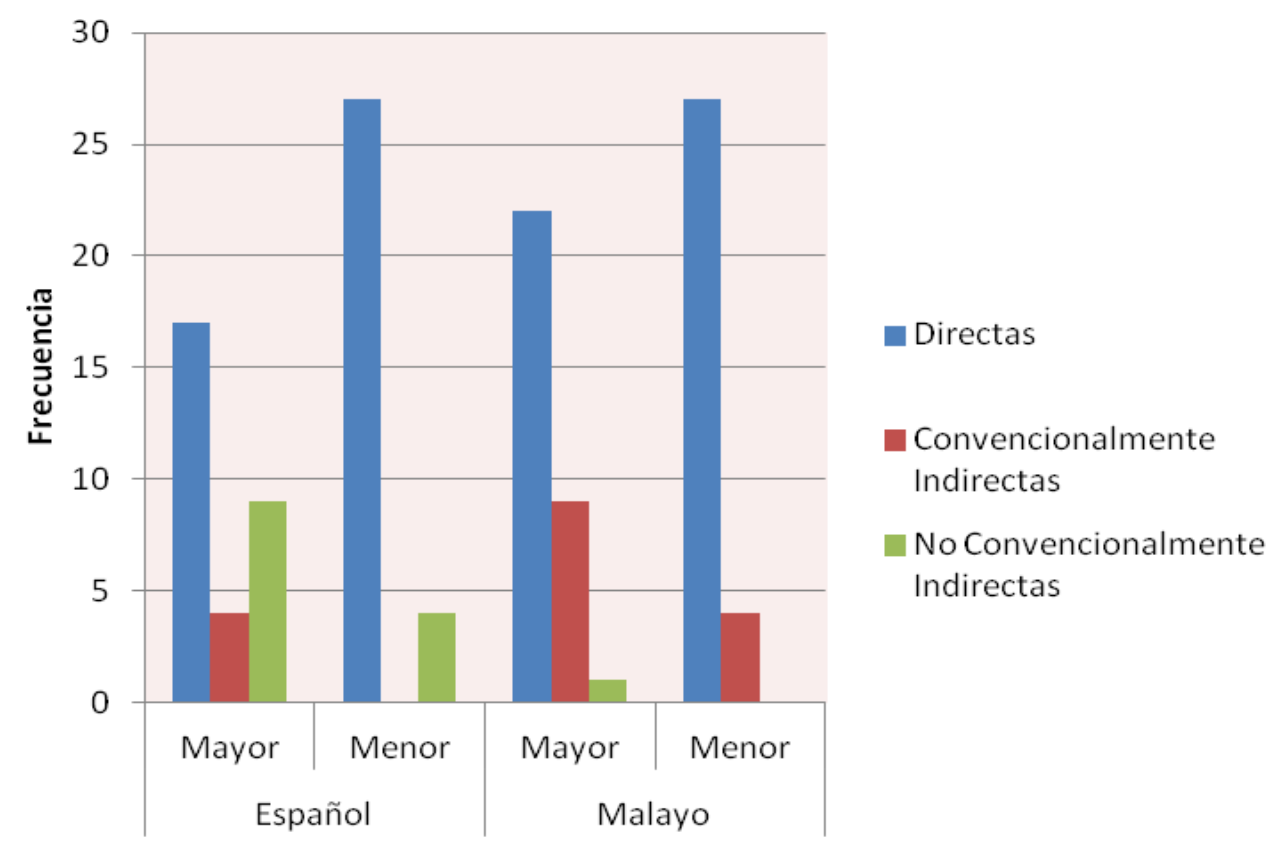

Subgrupos de edad

Si se aplica sobre los mismos enunciados la subclasificación de Blum-Kulka (véase cap.3), vemos que los mayores y jóvenes de ambas sociedades coincidieron en mostrar cierta 
tendencia hacia un mayor uso del "Imperativo", siendo en la sociedad malaya donde hay una diferencia menor, ya que se encontraron 21 casos en los mayores y 25 en los menores. En el caso español, aunque sigue siendo la estrategia más empleada por los dos subgrupos, sí que se da una diferencia considerable en el número de enunciados en los que aparece (15 de los mayores, frente a 24 de los menores). Como bien refleja la figura que presentamos a continuación, dicha estrategia fue la dominante, registrada con mayor frecuencia en ambos grupos.

Figura 158. Distribución, según estrategias empleadas, de enunciados (actos principales) producidos para la situación 18 en cada subgrupo, en ambas sociedades

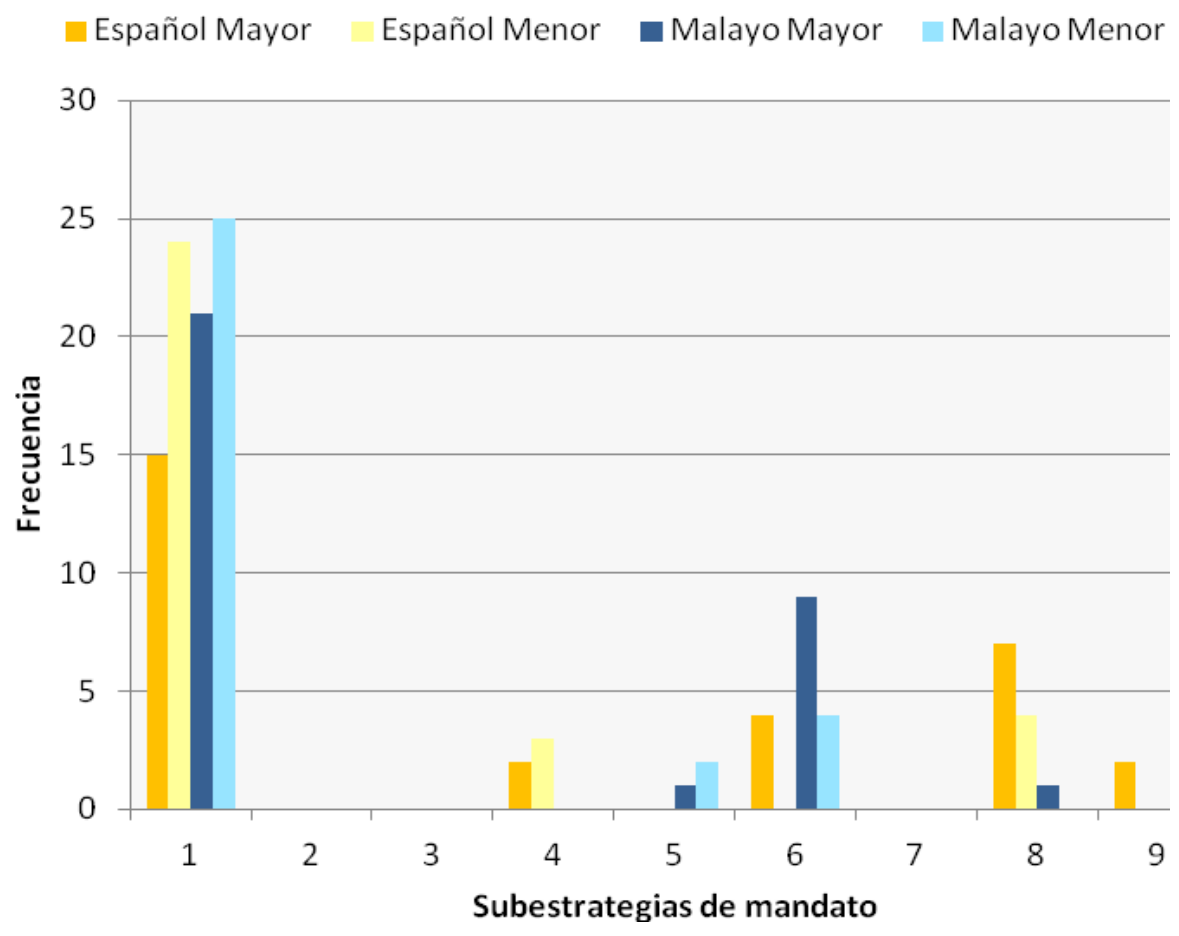

1.Imperativo 2.Performativo 3.Performativo evasivo 4.Declaración de obligación 5.Declaración de deseo 6.Fórmula de sugerencia 7.Interrogación preparatoria 8.Indicio fuerte 9 .Indicio suave 
En relación a la formulación de movimientos de apoyo por los hablantes mayores y menores, los resultados recogidos nos llevan a afirmar que tanto los mayores españoles como malayos fueron más productivos que los jóvenes, con 62 enunciados registrados en las respuestas del grupo español de más edad, frente a 53 de los jóvenes, y 79 y 67, respectivamente, en el malayo. Además, los informantes de mayor edad de ambos grupos recurrieron a estrategias más variadas: 7 formas diferentes encontramos en las respuestas de los mayores, frente a las 5 de los menores, en el grupo español, y 7 y 4 , respectivamente, en el grupo malayo. La gráfica que presentamos a continuación refleja cuáles fueron esas estrategias seleccionadas por cada subgrupo, y en qué medida fueron empleadas. 
Figura 159. Distribución de enunciados (movimientos de apoyo) producidos para la situación 18 en cada subgrupo, en ambas sociedades, según estrategias aplicadas

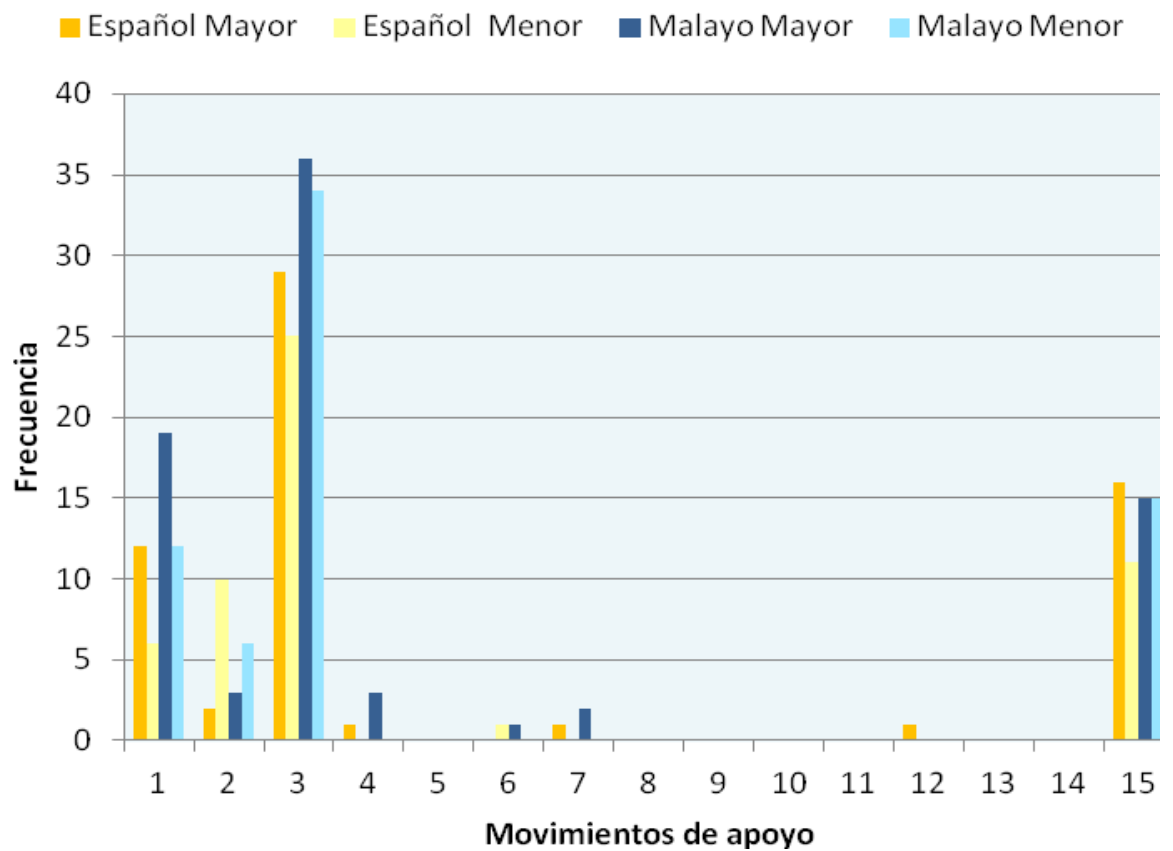

1.Fórmulas de preparación 2.Búsqueda de un compromiso 3.Razones 4.Previsión de objeciones 5.Promesa de recompensa/reparación 6.Minimización de la imposición 7.Invocación de principios generales 8.Reconocimiento de la imposición 9.Preocupación 10.Apreciación 11.Gravedad/urgencia 12.Presentación/saludo 13.Petición de la opinión del oyente 14.Disculpa 15.Fórmulas de tratamiento

En lo que se refiere a la estrategia más utilizada, los subgrupos contrastados mostraron un resultado similar. La forma dominante fue la de "Razones", y fueron los de más edad los que mostraron una tendencia más destacada hacia la aplicación de dicha forma, con 29 casos encontrados, frente a los 25 de los jóvenes, en el grupo español, y 36 y 34, respectivamente, en los datos malayos. La segunda estrategia más utilizada por los subgrupos españoles fue la de "Fórmulas de tratamiento" (16 ejemplos de los mayores y 11 de los menores). Pero estrategia que ocupó el tercer lugar de 
preferencia en el grupo español fue diferente en cada subgrupo: mientras que para los de más edad fue la de "Fórmulas de preparación" (encontrada en 12 enunciados), para los de menos edad fue la "Búsqueda de un compromiso" (en 10). Por otro lado, en el grupo malayo, la segunda estrategia más común en los mayores fue la de "Fórmulas de preparación" (19 ejemplos recogidos), seguida de "Fórmulas de tratamiento" (15). Por el contrario, en los datos de los jóvenes, la estrategia de "Fórmulas de tratamiento" ocupó el segundo lugar (con 15 ejemplos) y la de "Fórmulas de preparación" se situó en el tercer lugar (con 12).

\section{C) Varón frente a mujer}

Al llevar a cabo el análisis del grado de (in)dirección de las estrategias empleadas en los actos principales de los mandatos expresados en la situación 18, teniendo en cuenta la variable de género, vemos que los participantes varones y las mujeres de España y Malasia coincidieron en revelar una mayor utilización de las estrategias "Directas", pero la preferencia mostrada por parte de las mujeres fue un poco más alta que la de los varones, con 23 casos de las mujeres españolas y 21 de los varones, y 22 de las mujeres malayas frente a 27 de los varones. Pero, el resultado de las estrategias "Convencionales indirectas" fue al revés, es decir, fueron 
los varones de ambos países los que las aplicaron en un mayor número de ocasiones: 3 y 1, respectivamente, en España, y 8 por 5 en Malasia. Con respecto a las "No convencionales indirectas", la diferencia entre los sexos de cada grupo no fue llamativa. Así, encontramos 6 ejemplos en los varones y 7 en las mujeres, en el grupo español $y$, en el grupo malayo, mientras que los varones la usaron una vez, ninguna mujer recurrió a ellas. La diferencia entre los promedios de las categorías aplicadas no fue significativa en los dos grupos en los tres términos analizados.

Figura 160. Distribución de estrategias de mandato empleadas para la situación 18 en cada género

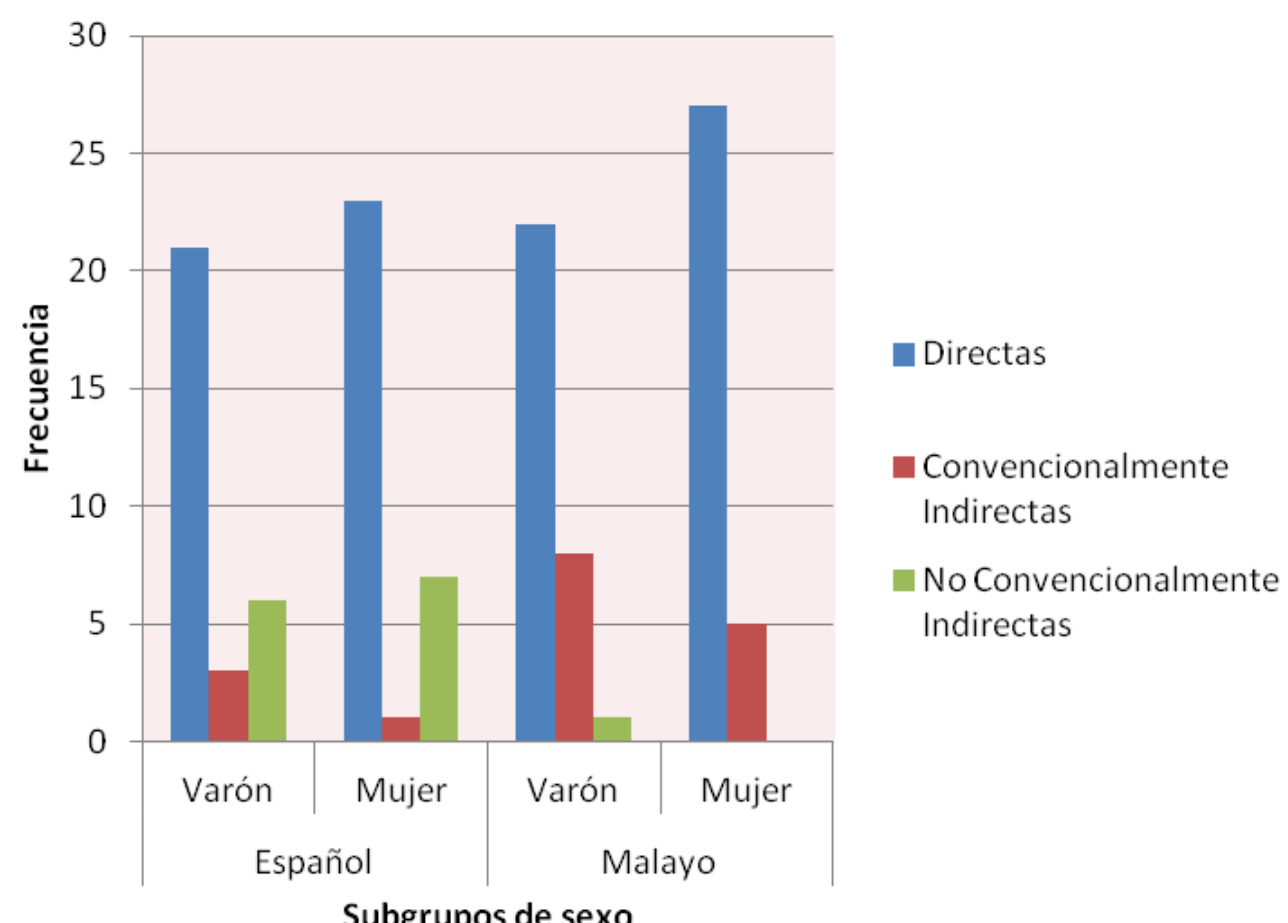


En cuanto a las nueve sub-categorías de estrategias con las que también venimos analizando la formulación de actos principales, los resultados numéricos obtenidos en el análisis de los datos de los cuatro subgrupos, son los que se presentan en la gráfica siguiente:

Figura 161. Distribución de enunciados (actos principales) producidos para la situación 18 en cada género, según estrategias empleadas

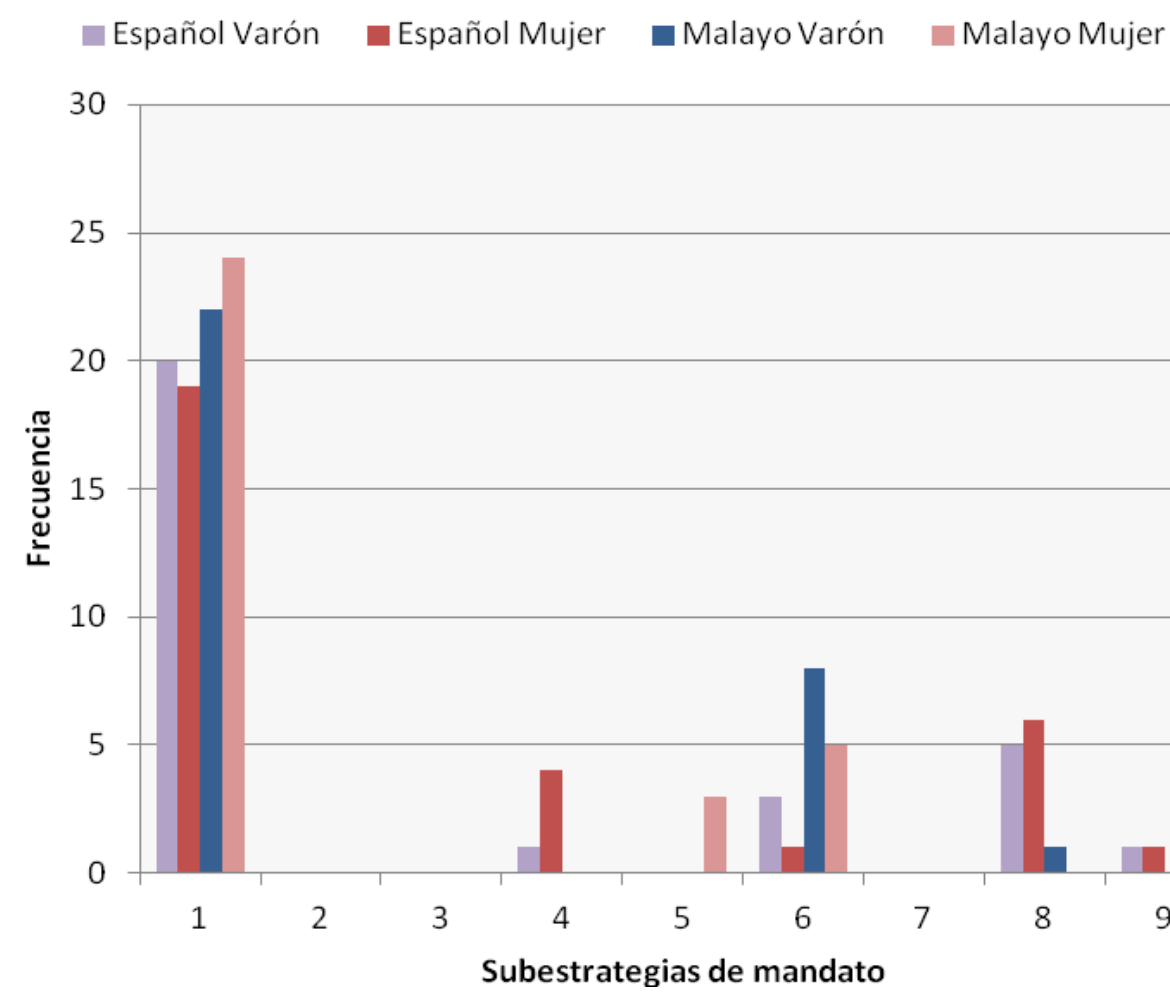

1.Imperativo 2.Performativo 3.Performativo evasivo 4.Declaración de obligación 5.Declaración de deseo 6.Fórmula de sugerencia 7.Interrogación preparatoria 8.Indicio fuerte 9 .Indicio suave 
Tal y como se refleja en el gráfico, los sujetos de ambos sexos no se diferenciaron mucho en la selección de estrategias, ya que, por ejemplo, en el grupo español, en 20 de los enunciados de los varones y en 19 de las mujeres se utiliza un "Imperativo", que apareció también en 22 y 24 de los enunciados producidos por los hombres y las mujeres malayas, respectivamente. Los varones y las mujeres también coincidieron en la segunda estrategia más utilizada: en ambos subgrupos españoles fue la de "Indicio fuerte" (con 5 y 6 casos, respectivamente) y en el corpus de los malayos fue la de "Fórmula de sugerencia" (con 8 enunciados de los varones y 5 de las mujeres). Y respecto a la variedad empleada por cada subgrupo de sexo, los varones y las mujeres españolas utilizaron cinco estrategias diferentes, mientras que, en el caso malayo, aplicaron solamente tres estrategias distintas en cada uno de los subgrupos.

En el empleo de movimientos de apoyo, en general, los varones y las mujeres españolas no mostraron una diferencia notable en el número de enunciados producidos: 57 los hombres y 58 las mujeres. Tampoco se diferenciaron con respecto a la variedad de estrategias empleadas, ya que los varones emplearon 6 tipos diferentes y las mujeres 7. En cambio, en los dos subgrupos de género malayos sí se aprecia una diferencia más importante, ya que las mujeres produjeron un total de 80 enunciados, frente a solo 66 de los varones. Y, al igual que en el caso español, los varones 
malayos usaron 6 estrategias diferentes, mientras que las mujeres emplearon 7. La gráfica siguiente muestra el número de enunciados en los que cada subgrupo de género de una y otra cultura, empleó cada una de las estrategias:

Figura 162. Distribución de enunciados (movimientos de apoyo) producidos para la situación 18 en cada género, según estrategias empleadas

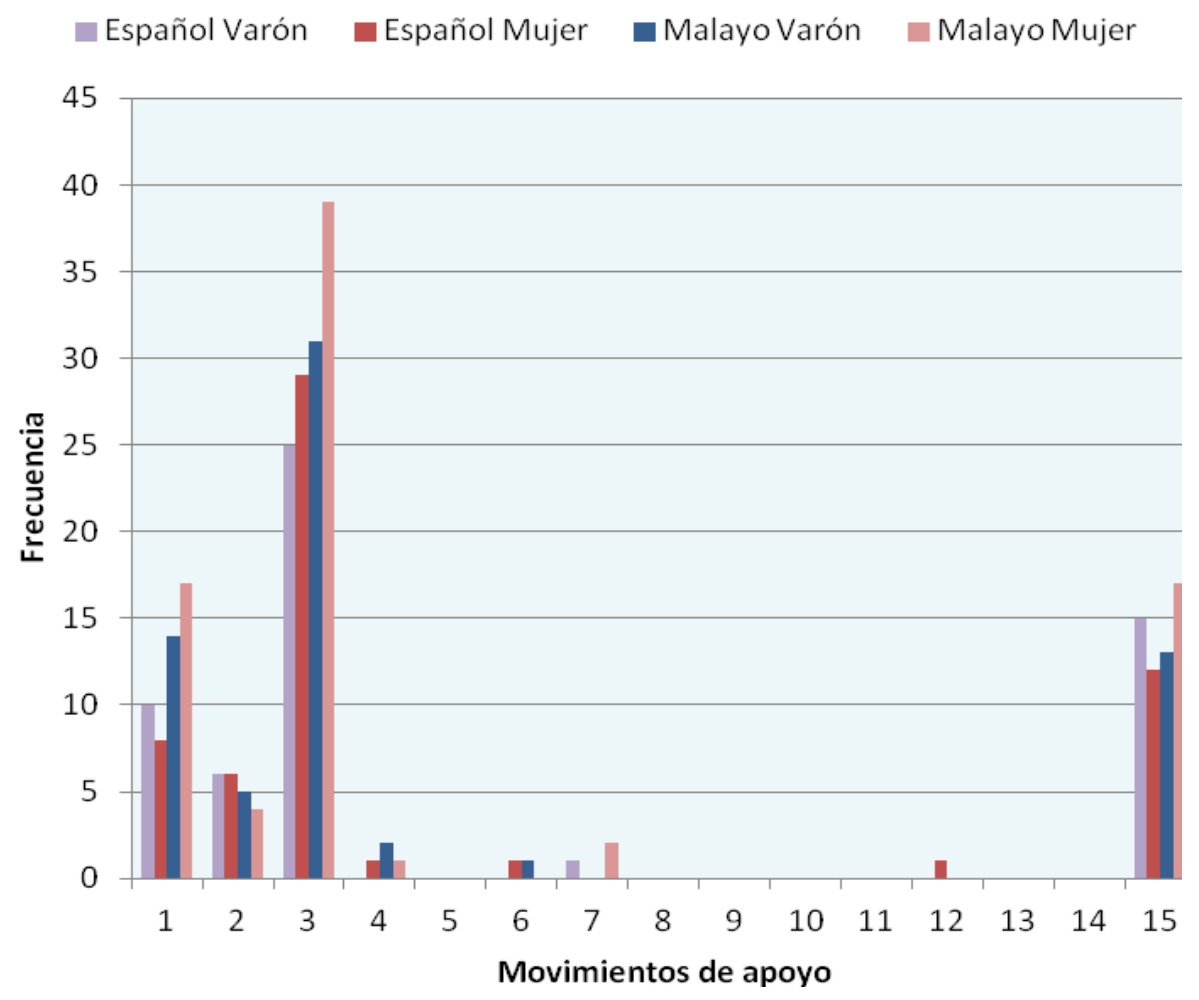

1.Fórmulas de preparación 2.Búsqueda de un compromiso 3.Razones 4.Previsión de objeciones 5.Promesa de recompensa/reparación 6.Minimización de la imposición 7.Invocación de principios generales 8.Reconocimiento de la imposición 9.Preocupación 10.Apreciación 11.Gravedad/urgencia 12.Presentación/saludo 13.Petición de la opinión del oyente 14.Disculpa 15.Fórmulas de tratamiento 
Tanto en los datos de los varones como en los de las mujeres, la estrategia de movimientos de apoyo con mayor frecuencia de aparición fue la de "Razones", con 25 casos de los varones frente a 29 de las mujeres, en el grupo español, y 31 de los varones por 39 de las mujeres, en el malayo, con lo cual, concluir que las mujeres dieron mayor preeminencia a dicha estrategia. En la segunda y tercera estrategia más utilizada, no hubo mucha diferencia entre ambos sexos. En el corpus español utilizaron, por detrás de la estrategia de "Razones", la de "Fórmulas de tratamiento" (15 ejemplos de los varones y 12 de las mujeres respectivamente), seguida de la de "Fórmulas de preparación" (en 10 enunciados de los varones y 8 de las mujeres). En los subgrupos malayos, la estrategia de "Fórmulas de preparación" se situó en el segundo lugar, con 14 casos de los varones y 17 de las mujeres, y la de "Fórmulas de tratamiento" ocupó el tercer lugar (con 13 y 17 casos encontrados, respectivamente). 


\subsubsection{La influencia de la distancia social}

Esta sección examina los efectos de la distancia social en la elección de las estrategias empleadas, tanto en el grupo malayo como en el grupo español, al realizar el mandato. Examinaremos las seis situaciones según el grado de familiaridad que se supone en los escenarios del cuestionario. Los datos se analizarán en términos de actos principales y movimientos de apoyo.

\section{A) Actos principales}

Figura 163. Distribución de estrategias de mandato según distancia social en los dos grupos, español y malayo

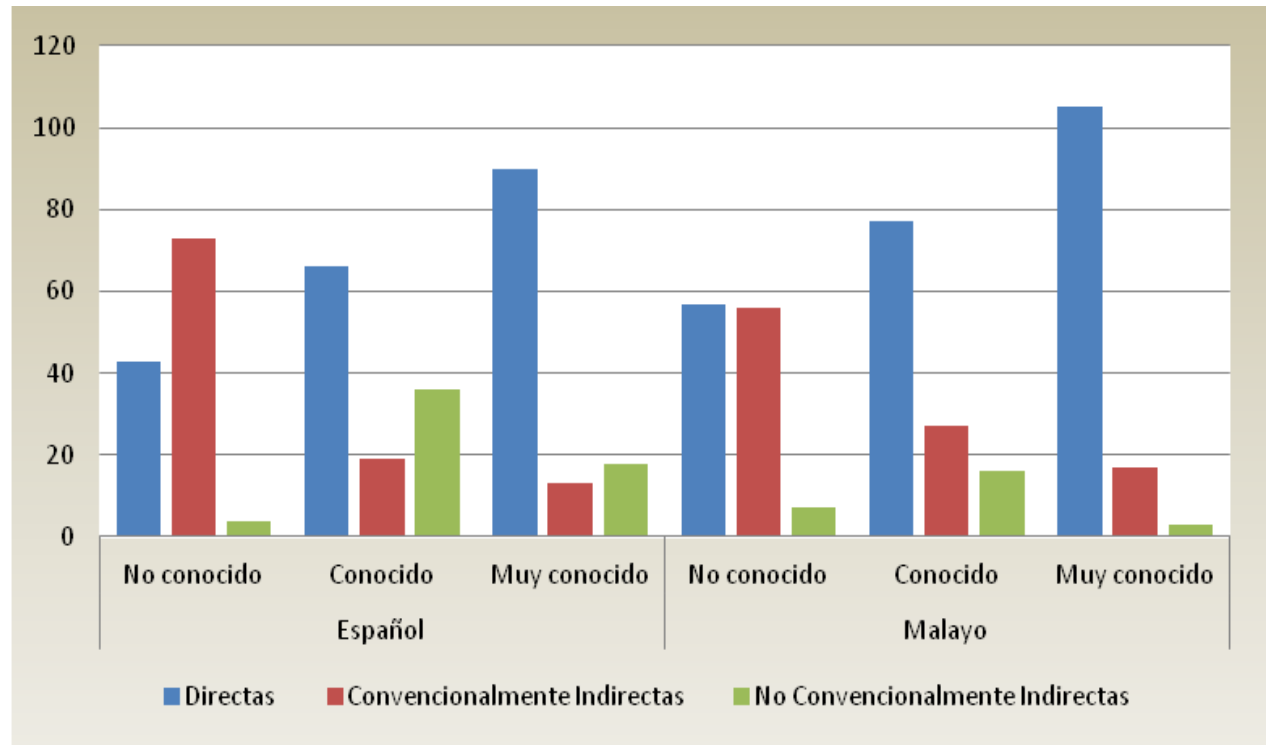


El resultado estadístico que aparece en la gráfica revela que, cuando la distancia social entre interlocutores es grande, los nativos analizados tendieron a realizar el mandato a través de las estrategias "Convencionalmente indirectas", mientras que cuando la distancia social es corta, los nativos prefirieron formular el acto utilizando las "Directas", seguidas de las "No convencionalmente indirectas". La diferencia entre los promedios de las formas aplicadas fue significativa, tanto en el resultado español como en el malayo: $X^{2}=105.889 p=.000(p<.001)$, en el caso del análisis de los datos españoles y $X^{2}=49.195 p=.000(p<.001)$ en el de los datos malayos.

Al considerar la variable de edad en cada uno de los grupos, la distribución de enunciados según el grado de (in)dirección de las estrategias empleadas, resulta como sigue:

Figura 164. Distribución de estrategias de mandato según distancia social y variable de edad, en el grupo español

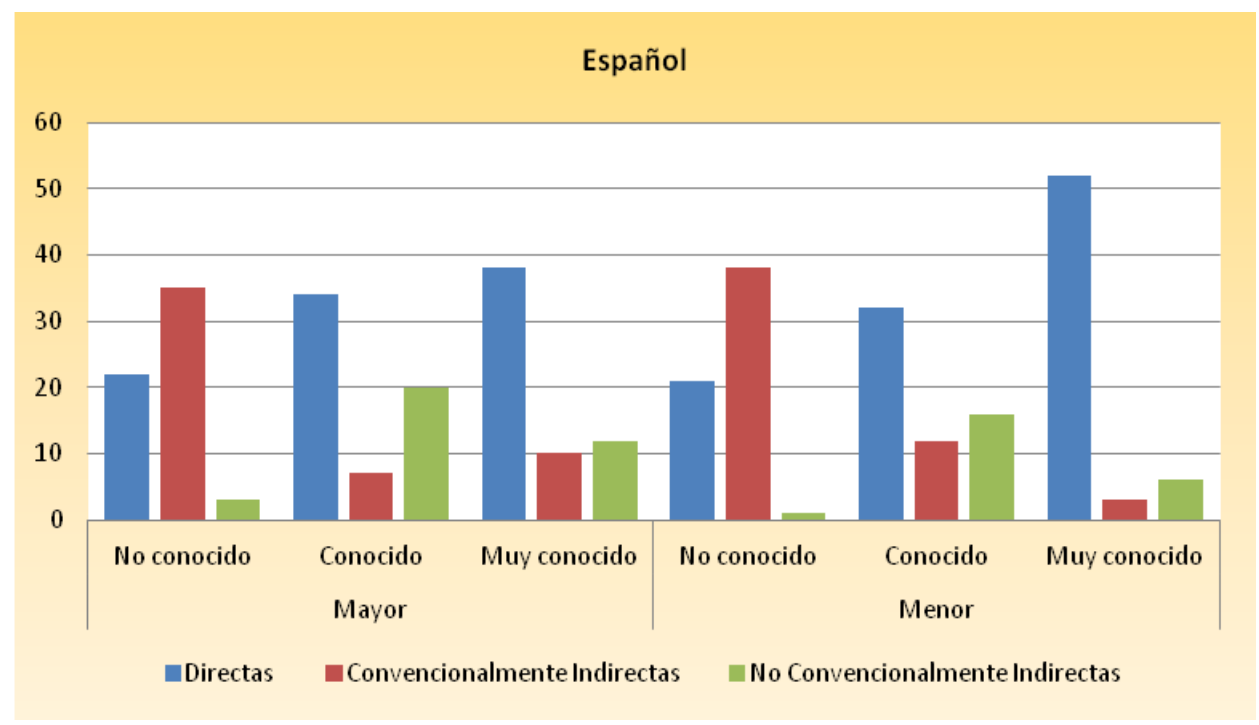


Figura 165. Distribución de estrategias de mandato según distancia social variable de edad, en el grupo malayo

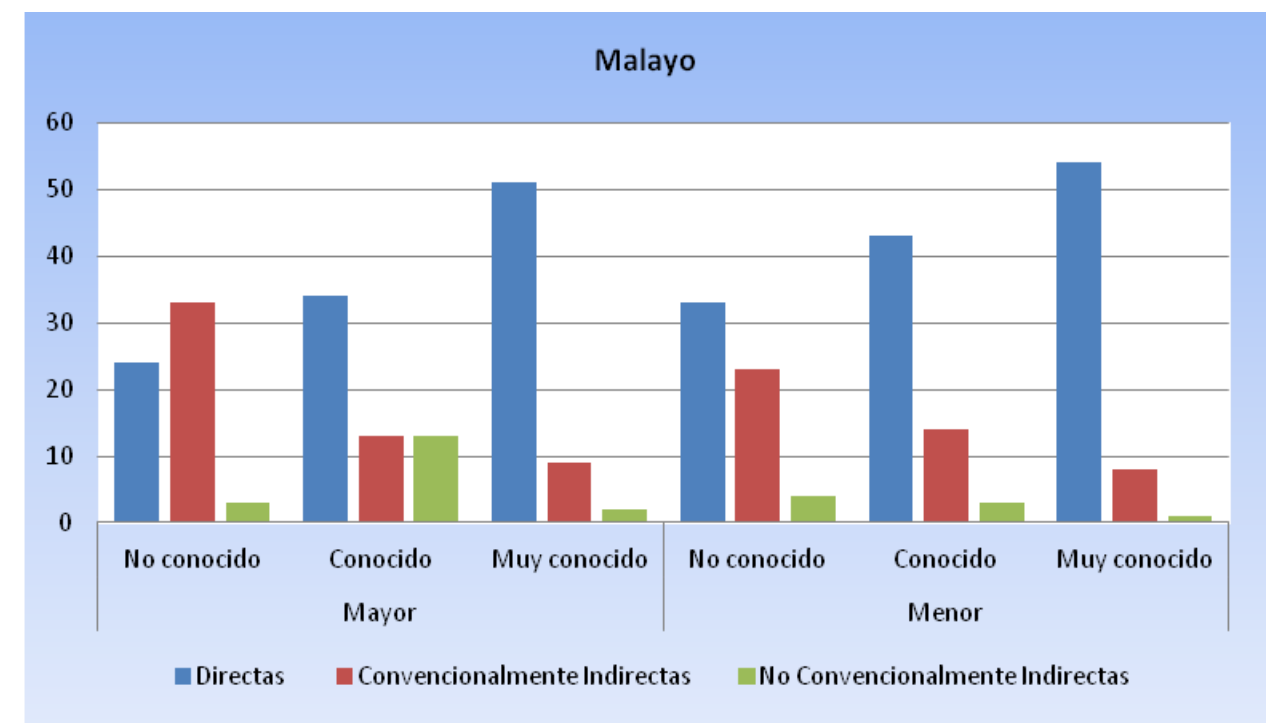

Como se observa en la primera figura (fig. 164), en el caso español, los participantes mayores y los menores no se diferenciaron, ya que la mayoría de los dos subgrupos optaron por las formas "Directas" al realizar su mandato con personas con las que tienen un alto grado de familiaridad. Cuando se trata de personas entre las que existe un bajo grado de familiaridad, ambos, los mayores y los menores, tendieron a utilizar estrategias "Convencionalmente Indirectas". Ocurrió lo mismo con el caso malayo (figura 165), donde los hablantes mayores y los jóvenes prefirieron realizar los mandatos utilizando expresiones "Directas" con oyentes dentro de un contexto de alta familiaridad. Ahora bien, en las situaciones en las que había poca familiaridad entre los hablantes, sí que se mostraron diferencias entre los dos subgrupos. 
Mientras que los mayores mostraron preferencia por las "Convencionalmente Indirectas", los jóvenes eligieron usar las "Directas", de manera similar al caso de alta familiaridad. La diferencia entre los participantes mayores y los menores respecto al uso de las tres formas de mandato con distintos grados de familiaridad no fue estadísticamente significativa ni en el corpus español ni en el malayo.

Al llevar a cabo el análisis de los enunciados en cada subgrupo de género, teniendo en cuenta la distancia social, los resultados obtenidos fueron los siguientes:

Figura 166. Distribución de estrategias de mandato según distancia social en el grupo español, en cada subgrupo de género

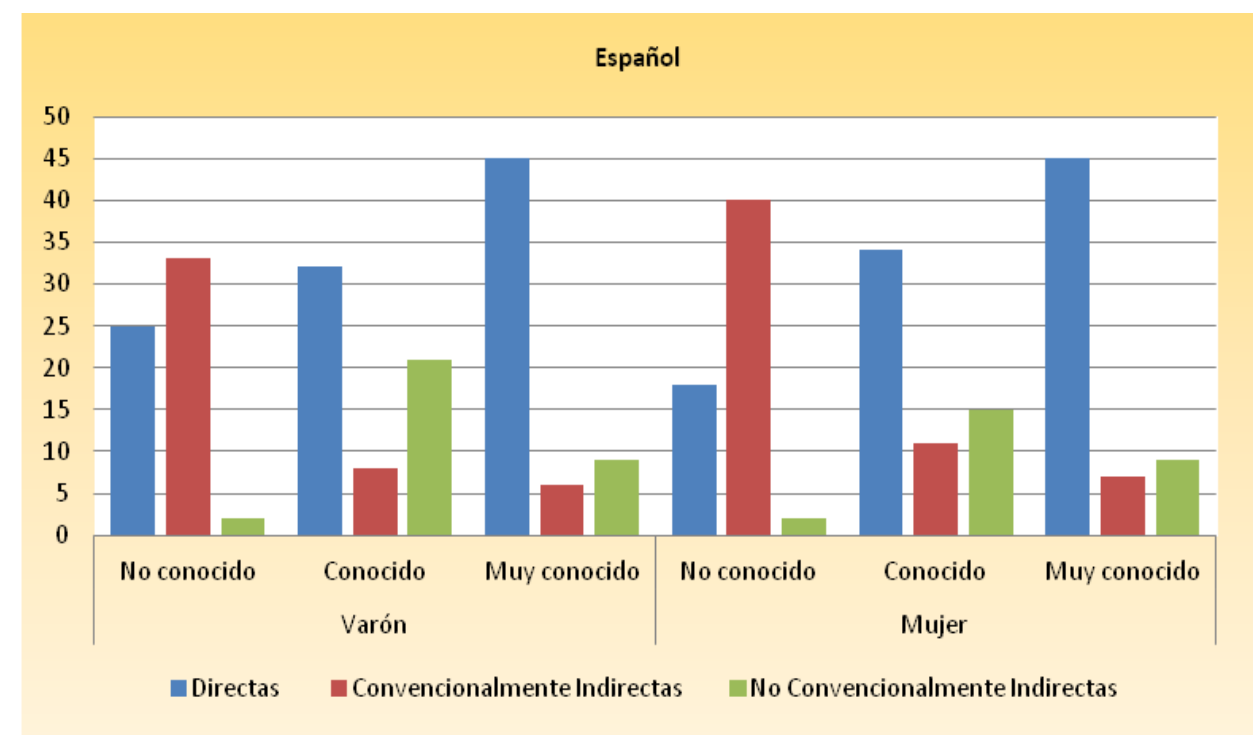


Figura 167. Distribución de estrategias de mandato según distancia social en el grupo malayo, en cada subgrupo de género

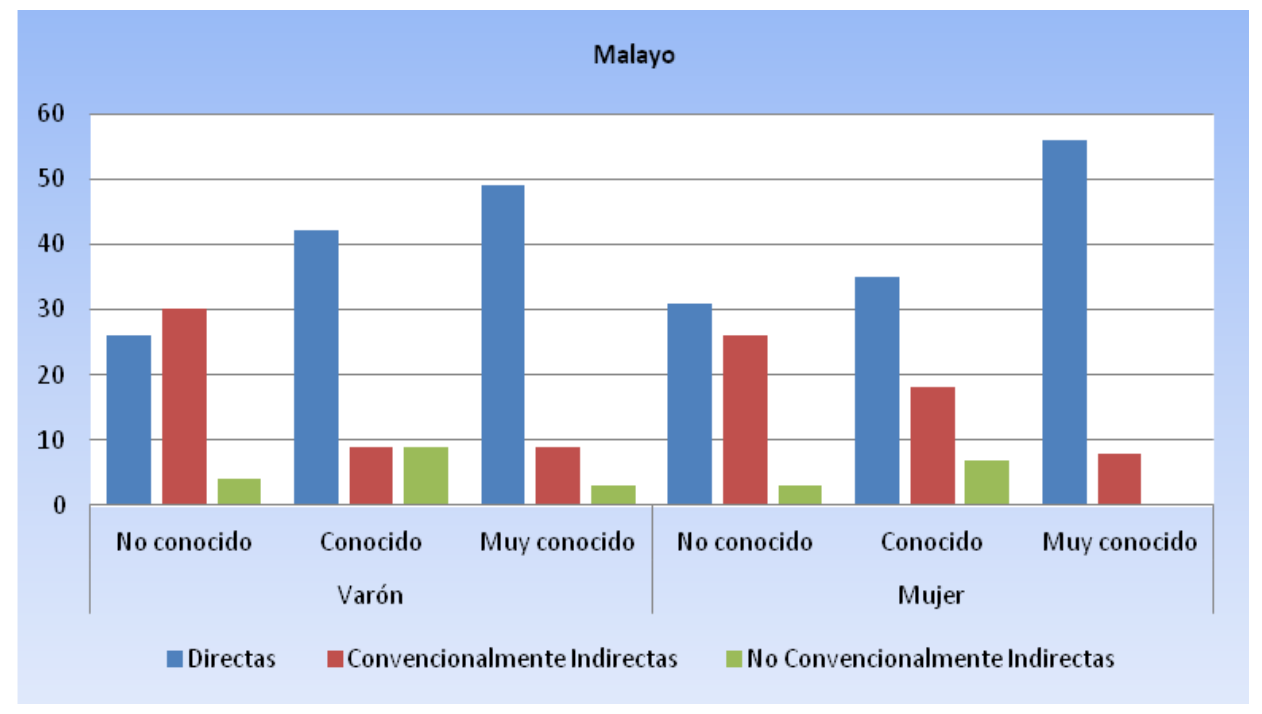

En las respuestas en español no se manifestaron diferencias notables respecto al grado de familiaridad. El patrón mostrado por los hablantes españoles de ambos sexos fue similar al resultado de la distribución de enunciados en los subgrupos de edad. Por lo tanto, en situaciones con un alto grado de cercanía entre los interlocutores, tanto los varones como las mujeres de la sociedad española tendieron a realizar el mandato a través de las estrategias "Directas". Pero, en los casos en los que el grado de familiaridad entre los interlocutores era bajo, los hablantes de ambos sexos optaron por las "Convencionalmente Indirectas".

De manera similar al caso español, tampoco hay diferencias importantes entre los hablantes de los dos subgrupos de 
género malayos. Varones y mujeres coincidieron en mostrar su preferencia por las estrategias "Directas" en situaciones en las que no había una gran distancia social entre los interlocutores. Sin embargo en contextos con una mayor distancia social los varones recurrieron en mayor medida a estrategias "Convencionalmente Indirectas", mientras que las mujeres siguieron mostrando una mayor preferencia por las "Directas". Entre los promedios de las categorías aplicadas en ambos sexos la diferencia no fue significativa ni en el resultado de los españoles ni en el resultado de los malayos.

\section{B) Movimientos de apoyo}

Respecto a la distribución de los movimientos de apoyo, teniendo en cuenta la distancia social en cada grupo cultural, los resultados obtenidos son los que se muestran en la siguiente gráfica: 
Figura 168. Distribución de movimientos de apoyo según distancia social en los dos grupos, español y malayo

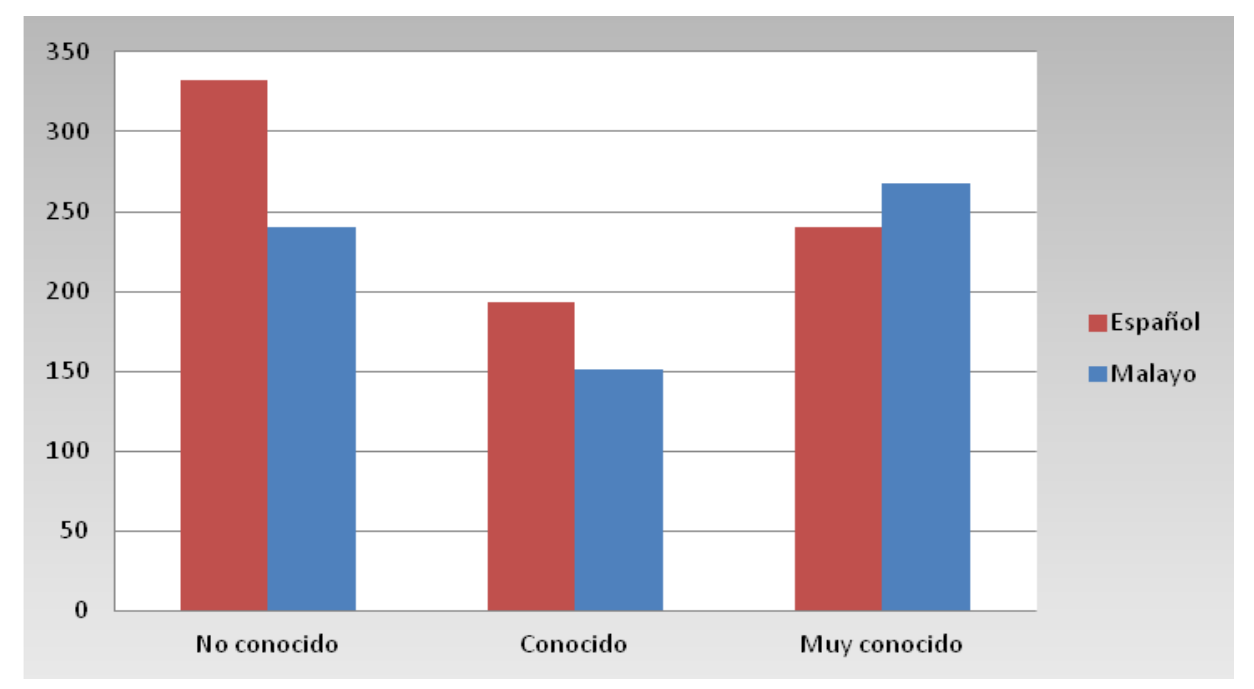

Como se evidencia en los resultados presentados, los españoles utilizaron mayoritariamente los movimientos de apoyo en sus interacciones con personas de poca familiaridad (332 enunciados) y disminuyeron su uso en los escenarios donde existía una mayor familiaridad entre los entrevistados y sus interlocutores (240 enunciados con personas muy conocidas y 193 con las conocidas). Al contrario, los malayos tendieron a aplicar mayoritariamente los movimientos de apoyo en casos en los que había un alto grado de familiaridad entre los interlocutores (268 enunciados), y en los casos de una relación de poca familiaridad se redujo su utilización (240 casos con personas desconocidas y 151 con las conocidas). La diferencia entre las dos comunidades de habla investigadas en el uso de los movimientos de apoyo con personas de 
distinta distancia social fue estadísticamente significativa: $X^{2}=13.916$ $p=.001(p<.005)$.

Al analizar la distribución de esos mismos enunciados emitidos como movimientos de apoyo, teniendo en cuenta los subgrupos de edad, los resultados numéricos obtenidos en relación al mayor o menor uso en función de la distancia social son los siguientes:

Figura 169. Distribución de movimientos de apoyo utilizados por los sujetos mayores y los menores según la distancia social en la sociedad española

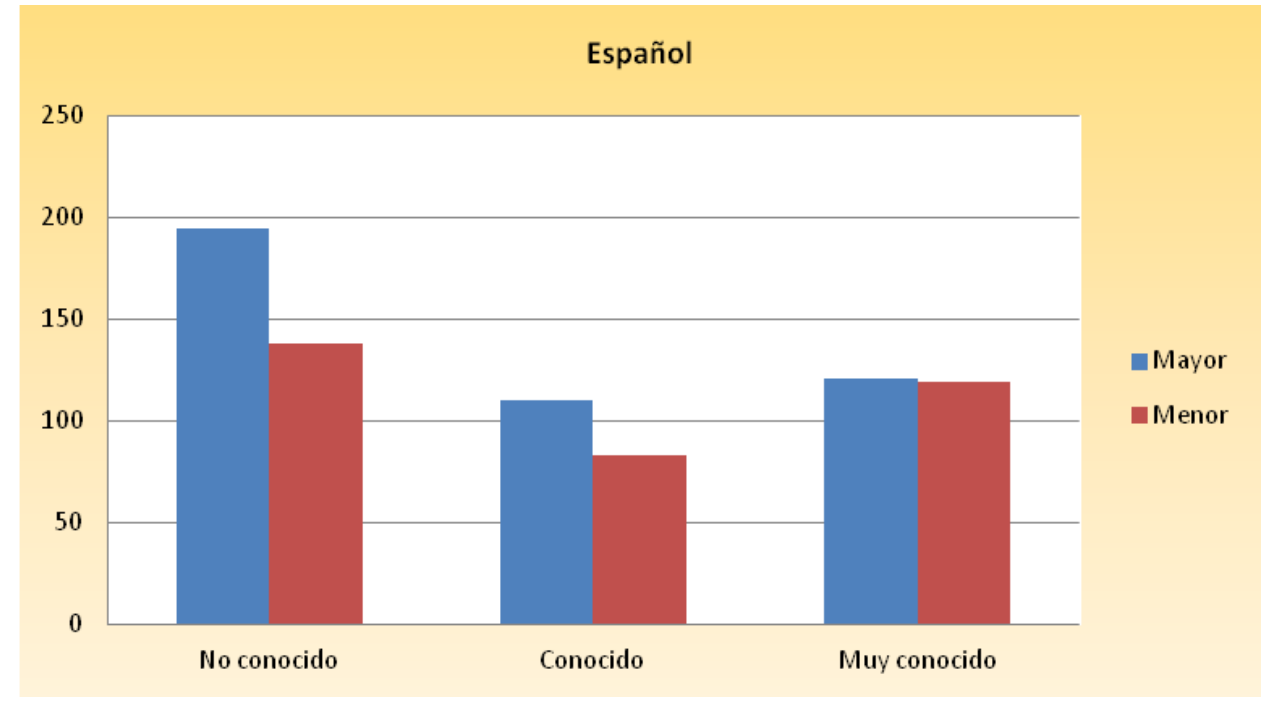


Figura 170. Distribución de movimientos de apoyo utilizados por los sujetos mayores y menores según la distancia social en la sociedad malaya

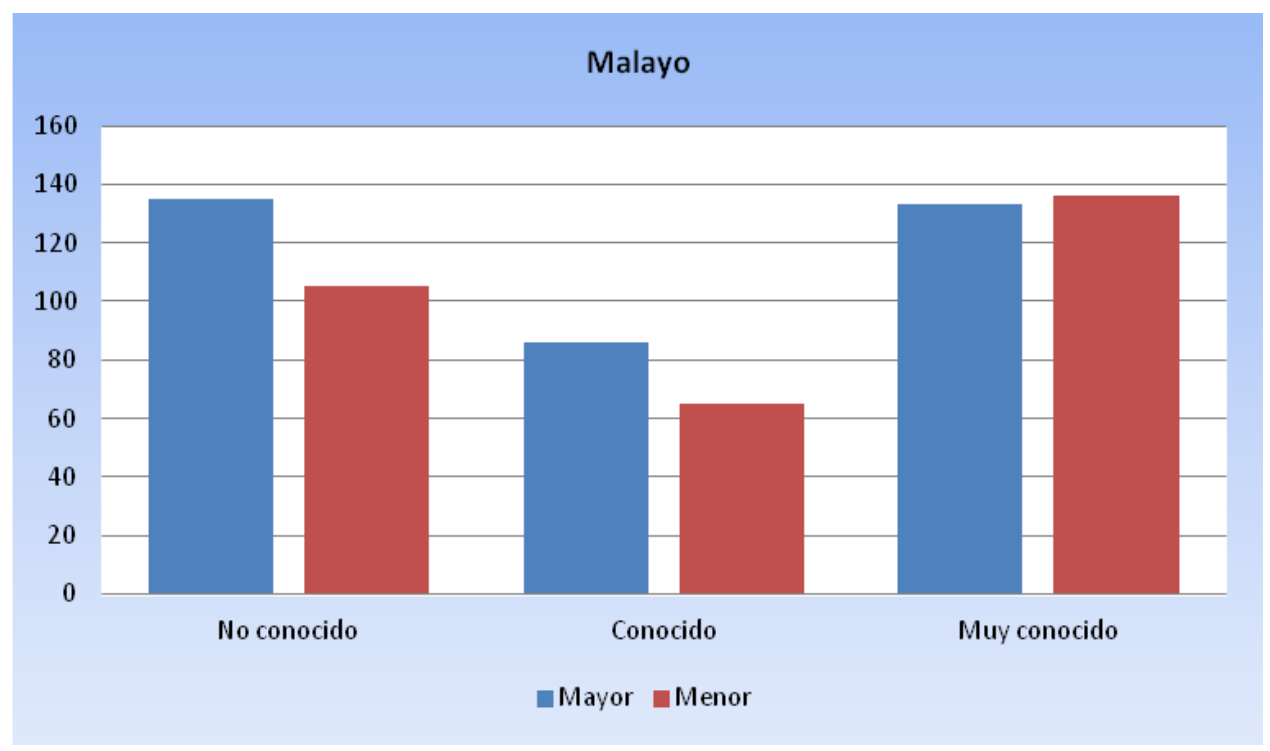

Según los resultados conseguidos, los subgrupos de edad españoles coinciden en revelar una mayor tendencia al uso de los movimientos de apoyo en las situaciones en las que la distancia social entre los interlocutores es grande (194 de los mayores frente a 138 de los jóvenes). Pero su utilización se redujo en los casos en los que había una relación más estrecha entre los hablantes, con 121 de los mayores y 119 de los jóvenes, al dirigirse a personas muy conocidas, y 110 y 83 , respectivamente, con personas conocidas.

En la sociedad malaya, por su parte, sí se hace evidente una diferencia entre los participantes mayores y jóvenes. Cabe subrayar que los malayos mayores utilizaron un mayor número de movimientos de apoyo en sus mandatos a oyentes desconocidos y 
también a otros con los que existía un alto grado de familiaridad (135 y 133, respectivamente), y lo hicieron en menor medida al dirigirse a personas conocidas (86). Los jóvenes, en cambio, utilizaron con más frecuencia movimientos de apoyo en sus mandatos a personas de las que los separaba poca distancia social (136). En los escenarios en los que había una gran distancia social entre los hablantes, los aplicaron en menor grado: 105 casos con personas desconocidas y solo 65 casos con personas conocidas. Al comparar los promedios de los movimientos de apoyo utilizados, la diferencia no fue significativa en ninguno de los subgrupos de edad de ambos países.

Al llevar a cabo el análisis teniendo en cuenta el sexo de los hablantes, los resultados numéricos obtenidos, en relación al número de enunciados producidos como movimientos de apoyo fueron los siguientes: 
Figura 171. Distribución de movimientos de apoyo utilizados por los varones y las mujeres según la distancia social en la sociedad española

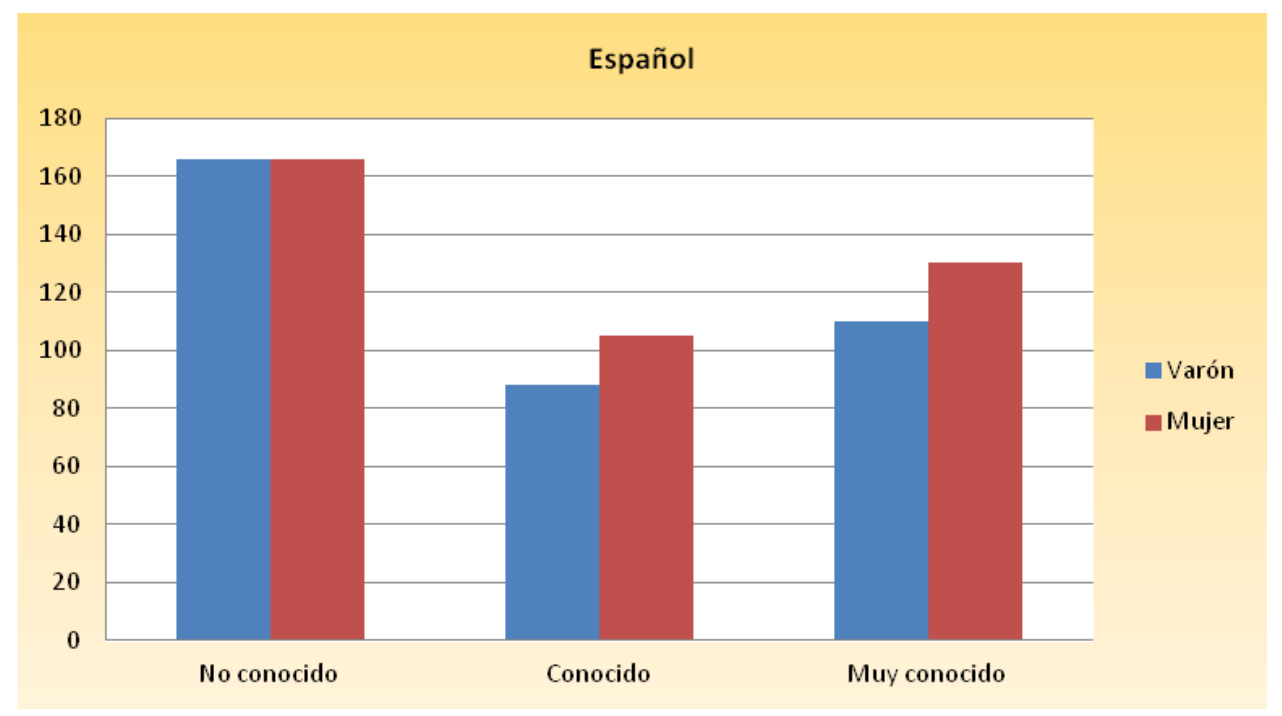

Figura 172. Distribución de movimientos de apoyo utilizados por los varones y las mujeres según la distancia social en la sociedad malaya

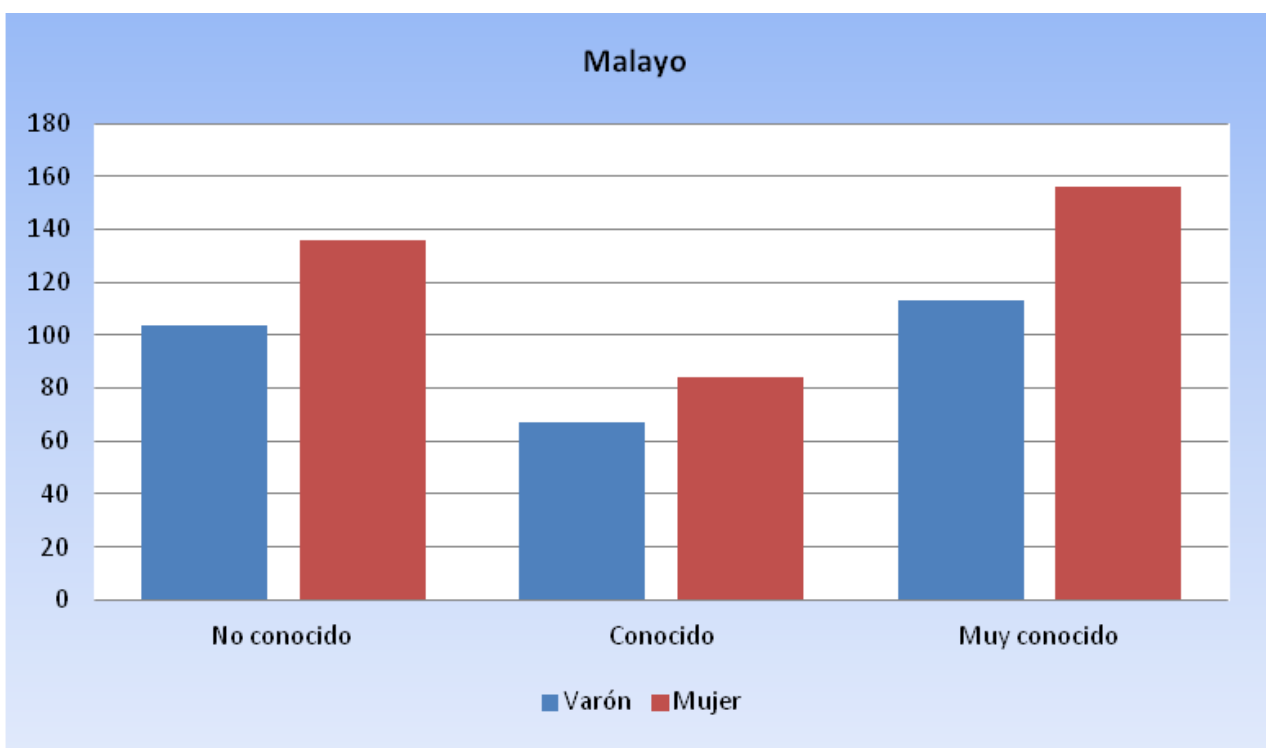


Cuando la distancia social con los destinatarios era grande, las mujeres y los varones analizados hicieron un gran uso de movimientos de apoyo (166), en comparación con sus interacciones con destinatarios de los que les separaban una menor distancia social (110 y 88 de los varones y, 130 y 105 de las mujeres). En cambio, los hablantes malayos de ambos sexos los utilizaron con más frecuencia en los casos en los que la cercanía entre los hablantes era máxima (156 de los varones y 113 de las mujeres), mientras que en escenarios en los que se daba una mayor distancia social, mostraron una menor recurrencia a los movimientos de apoyo (104 y 67 en los varones, y 136 y 84 en las mujeres). Las diferencias entre los varones y las mujeres en los movimientos de apoyo aplicados en sus mandatos no fueron significativas. 


\subsection{Análisis del contenido (modificaciones internas)}

Los resultados presentados en esta sección se centran en las cuestiones relativas al uso de las modificaciones internas en las respuestas de los participantes, es decir, en aquellos marcadores de modalidad que, aplicados a los actos principales, sirven tanto para mitigar como para agravar la imposición. Se trata de analizar, por tanto, el uso de las fórmulas de deixis social (pronominales y nominales), las modificaciones gramaticales (el cambio del modo verbal en los datos españoles y el uso de partículas y sufijos en los datos malayos) y la perspectiva de la persona (orientada al hablante/oyente/los dos/neutra) en los datos de ambos grupos. Para ilustrar cada categoría se presentan ejemplos representativos extraídos de las repuestas formuladas por los sujetos de cada grupo cultural en las seis situaciones de mandato. Como hemos mencionado ya en el capítulo 4 (véase 4.2), los ejemplos malayos aparecen acompañados de dos versiones de traducción al español, una literal y otra más libre (en cursiva) pero acorde con las normas del español estándar. 


\subsubsection{Análisis general}

En primer lugar, se realizó la observación general sobre las modificaciones empleadas en total por los sujetos de ambas sociedades. A continuación, se pasó a realizar el análisis de los datos de cada una de las situaciones.

\subsubsection{Modificaciones internas en los mandatos formulados en "Imperativo"}

Según los resultados obtenidos en el presente estudio, el "Imperativo" fue la estrategia más recurrente para formular mandatos en ambas sociedades. Pese a que las dos comunidades de habla analizadas mostraron preferencia por el uso de la estrategia del "Imperativo", fueron los malayos los que la utilizaron con mayor frecuencia (145 casos frente a 94 de los españoles). Es interesante revisar la llamativa diferencia entre las dos lenguas con respecto al modo "Imperativo". El malayo no tiene forma de género gramatical ni marca de plural (el plural se forma mediante la repetición de la palabra o de una parte de la palabra, a veces con alguna modificación), y no hay flexión verbal. La formulación del imperativo malayo se realiza simplemente mediante la forma del Infinitivo del verbo. Además, hay algunas partículas, sufijos y el uso del verbo 
tolong ('ayudar ), delante del verbo correspondiente, para mitigar la fuerza impositiva inherente al imperativo. Así, los malayos pueden formular una petición como "teman aku membeli belah" ('acompañar yo hacer compras/acompáñame a hacer compras') de varias maneras:

- Verbo + sufijo kan

- Tolong + verbo

- Tolong + Partícula lah + verbo

- Tolong + verbo + sufijo kan
Temankan aku membeli belah ('Acompañarkan yo hacer compras'/iacompáñame a hacer compras!)

Tolong teman aku membeli belah ('Ayudar acompañar yo hacer compras'/Por favor, acompáñame a hacer compras)

Tolonglah teman aku membeli belah ('Ayudarlah acompañar yo hacer compras'/Acompáñame a hacer compras)

Tolong temankan aku membeli belah ('Ayudar acompañarkan yo hacer compras'/Por favor, iacompáñame a hacer compras!)

El sufijo kan detrás del verbo sirve para dar énfasis y se utiliza para subrayar el verbo acompañado para que el oyente lleve a cabo la acción esperada (Tatabahasa Dewan, 2011), mientras que, la partícula lah detrás de tolong ('ayudar) o detrás de cualquier verbo, como "Tolonglah teman aku membeli belah" ('Ayudarlah acompañar yo hacer compras/Acompáñame a hacer compras'), también da énfasis, pero añade la idea de súplica al oyente para que responda satisfactoriamente a la petición (Tatabahasa Dewan, 2011). 
Es más suave que kan, que tiene un sentido más cercano al del mandato.

En cambio, el español posee una forma gramatical especializada en el mandato. Es la forma del Imperativo (canta), que en prohibiciones o mandatos negativos es reemplazada por el Presente de Subjuntivo (no cantes), lo mismo que cuando va dirigido a una tercera persona (que cante). Expresiones como "Acompáñame a hacer compras", "Pásate por mi casa", "Cómprame una lata de caviar", "Préstame tu móvil", etc. se pueden aplicar como formas directas para formular un mandato en español sin tener en cuenta la situación, pero los nativos malayos pueden interpretarlo como algo descortés. En la cultura malaya, ese tipo de petición solo puede realizarla alguien que tenga autoridad, o personas de estatus más elevado, a personas de un estatus inferior. Los datos obtenidos en este caso revelaron una diferencia interesante en los patrones empleados por los nativos españoles y malayos. En la tabla que presentamos a continuación, se recoge la frecuencia con la que los hablantes del grupo malayo utilizaron cada una de las posibles formas malayas del imperativo, en la formulación de sus mandatos. 
Tabla 42. Distribución de los tipos de "Imperativo" utilizados en el estudio por los hablantes de la sociedad malaya en las seis situaciones

\begin{tabular}{|l|c|c|}
\hline \multicolumn{1}{|c|}{ Tipo } & Frecuencia & $\%$ \\
\hline $\begin{array}{l}\text { Tolong ('ayudar') + verbo } \\
\text { "Tolong hantar makanan ke pejabat ini" ('Ayudar enviar comida } \\
\text { a oficina esta/Por favor, envía la comida a esta oficina') }\end{array}$ & 48 & $33 \%$ \\
\hline $\begin{array}{l}\text { Verbo } \\
\text { "Masuk tidur dengan segera" ('Entrar dormir en seguida/Vete a } \\
\text { dormir en seguida') }\end{array}$ & 37 & $26 \%$ \\
\hline $\begin{array}{l}\text { Tolong ('ayudar') + verbo + sufijo kan } \\
\text { "Tolong buatkan fotokopi ni" ('Ayudar hacerkan fotocopia } \\
\text { esta/iHazme una fotocopia!') }\end{array}$ & 18 & $12 \%$ \\
\hline $\begin{array}{l}\text { Jangan ('no') + verbo } \\
\text { "Jangan balik lambat sangat" ('No volver tarde muy/No vuelvas } \\
\text { muy tarde') }\end{array}$ & 13 & $9 \%$ \\
\hline $\begin{array}{l}\text { Pergi ('ir') + verbo } \\
\text { "Pergi tidur sekarang" ('Ir dormir ahora/Vete a dormir ya') }\end{array}$ & 12 & $8 \%$ \\
\hline $\begin{array}{l}\text { Verbo + partícula lah } \\
\text { "Tukarlah kepada kursus lain" ('Cambiarlah a curso } \\
\text { otro/Cámbiate de asignatura') }\end{array}$ & 6 & $4 \%$ \\
\hline $\begin{array}{l}\text { Sila + verbo } \\
\text { "Sila fotokopi dokumen ini" ('Ale, fotocopiar documento } \\
\text { este/Fotocopia este documento inmediatamente') }\end{array}$ & 5 & $4 \%$ \\
\hline $\begin{array}{l}\text { Pergi ('ir') + partícula lah + verbo } \\
\text { "Pergilah tidur" ('Irlah dormir/Vete a dormir') }\end{array}$ & 4 & $3 \%$ \\
\hline $\begin{array}{l}\text { Verbo + sufijo kan } \\
\text { "Bawakan makanan yang telah ditempah ke pejabat pelanggan" } \\
\text { ('Llevarkan comida que reservada a oficina cliente/iLleva esta } \\
\text { comida reservada a la oficina del cliente!') }\end{array}$ & 2 & $1 \%$ \\
\hline \multicolumn{1}{|c|}{ Total } & 145 & $100 \%$ \\
\hline
\end{tabular}

La mayoría de los "Imperativos" producidos por los encuestados malayos en el caso del mandato, correspondió a la combinación de tolong ('ayudar ) + verbo (33\%). Por ejemplo, los malayos contestaron "Tolong hantar makanan ini ke pelanggan" ( 'Ayudar enviar comida esta a cliente/Por favor envía esta comida al cliente'), "Tolong hantar makanan ini ke pejabat sebelah" ('Ayudar enviar comida esta a oficina al lado/Por favor envía esta comida a la oficina de al lado'), "Tolong hantar ke alamat ini" ( 'Ayudar enviar a dirección esta/Por favor envía a esta dirección'), etc., en la situación 
en la que un encargado le pide a uno de sus trabajadores que envíe la comida encargada por un cliente. En el escenario en el que un directivo pide a su nuevo secretario que haga fotocopias, la mayoría de los malayos respondieron "Tolong fotokopi dokumen ni" ( fotocopiar documento este/Por favor, fotocopia este documento'), "Tolong buat fotokopi dokumen-dokumen ni" ('Ayuda hacer fotocopia documento-documento este/Por favor, haz fotocopias de estos documentos'), "Tolong fotostat dokumen ni dua salinan" ( 'Ayuda fotocopiar documento este dos copias/Por favor, hazme dos copias de este documento'), etc.

En la cultura malaya, la gente suele empezar sus mandatos con el verbo tolong ('ayudar) con el fin de agravar la imposición del acto. El uso de la palabra tolong ('ayudar) es una manipulación lingüística, ya que responder negativamente a una petición de ayuda es algo que causa indignación en la cultura malaya. Muy a menudo un mandato se formula con solo un verbo, excepto en los casos en los que el grado de familiaridad entre los interlocutores es muy alto, por lo que es en las situaciones 9 y 18 en las que encontramos con mayor frecuencia otro tipo de formulación, ya que en ellas la distancia social figurada es corta, al tener que tomar los sujetos participantes el papel de padre/madre del interlocutor. Por ejemplo, en la situación 9, en la que un padre/madre pide a su hijo/a que vuelva pronto a casa, un malayo 
dijo "...balik sebelum magrib" ( '...volver antes ocaso/...vue/ve antes de que anochezca'), otros contestaron "...pulang awal" (' ... regresar pronto/...regresa pronto'), "...balik sebelum pukul enam petang" ( '...volver antes seis tarde/ vuelve antes de las seis de la tarde'), etc. En la situación 18, en la cual se manda a un/a hijo/a que se acueste enseguida, los informantes malayos respondieron "...masuk tidur!" ( '... entrar dormir!/i vete a dormir!'), "... tutup tv!" (' ... apagar tele!/i...apaga la tele! ), y "...tidur sekarang!" ( '...dormir ahora!/i... Duérmete ya!').

Al examinar las diferencias entre los subgrupos malayos en lo referente al uso de las formas del imperativo, hemos encontrado que los subgrupos de edad muestran una diferencia más llamativa entre sí, en comparación con los de sexo. Las tablas que se presentan a continuación recogen la información sobre qué forma prevalece en cada subgrupo al hacer los imperativos. 
Tabla 43. Distribución de las formas del "Imperativo" en las seis situaciones en los subgrupos de edad malayos

\begin{tabular}{|l|c|c|c|c|}
\hline \multirow{2}{*}{ Tipo } & \multicolumn{2}{c|}{ Mayor } & \multicolumn{2}{c|}{ Menor } \\
\cline { 2 - 5 } & F & $\%$ & F & $\%$ \\
\hline Tolong ('ayudar') + verbo & 20 & $34 \%$ & 28 & $33 \%$ \\
\hline Verbo & 21 & $35 \%$ & 16 & $19 \%$ \\
\hline Tolong ('ayudar') + verbo + partícula kan & 9 & $15 \%$ & 9 & $11 \%$ \\
\hline Jangan ('no') + verbo & 5 & $8 \%$ & 8 & $9 \%$ \\
\hline Pergi ('ir') + verbo & 5 & $8 \%$ & 7 & $8 \%$ \\
\hline Verbo + partícula lah & 0 & $0 \%$ & 6 & $7 \%$ \\
\hline Sila ('adelante') + verbo & 0 & $0 \%$ & 5 & $6 \%$ \\
\hline Pergi ('ir') + verbo + partícula lah & 0 & $0 \%$ & 4 & $5 \%$ \\
\hline Verbo + partícula kan & 0 & $0 \%$ & 2 & $2 \%$ \\
\hline & 60 & $100 \%$ & 85 & $100 \%$ \\
\hline
\end{tabular}

Tabla 44. Distribución de las formas del "Imperativo" en las seis situaciones en los subgrupos de sexo malayos

\begin{tabular}{|l|c|c|c|c|}
\hline \multicolumn{1}{|c|}{ Tipo } & \multicolumn{2}{c|}{ Varón } & \multicolumn{2}{c|}{ Mujer } \\
\cline { 2 - 5 } & F & $\%$ & F & $\%$ \\
\hline Tolong ('ayudar') + verbo & 25 & $32 \%$ & 23 & $34 \%$ \\
\hline Verbo & 17 & $22 \%$ & 20 & $30 \%$ \\
\hline Tolong ('ayudar') + verbo + partícula kan & 11 & $14 \%$ & 7 & $10 \%$ \\
\hline Jangan ('no') + verbo & 10 & $13 \%$ & 3 & $4 \%$ \\
\hline Pergi ('ir') + verbo & 6 & $8 \%$ & 6 & $9 \%$ \\
\hline Verbo + partícula lah & 5 & $6 \%$ & 1 & $2 \%$ \\
\hline Sila ('adelante') + verbo & 1 & $1 \%$ & 4 & $6 \%$ \\
\hline Pergi ('ir') + verbo + partícula lah & 2 & $3 \%$ & 2 & $3 \%$ \\
\hline Verbo + partícula kan & 1 & $1 \%$ & 1 & $2 \%$ \\
\hline & 78 & $100 \%$ & 67 & $100 \%$ \\
\hline
\end{tabular}


Pese a que los dos subgrupos mostraran preferencia hacia el empleo de la misma forma, los jóvenes aplicaron más variación que los participantes mayores ( 9 formas diferentes de los jóvenes frente a solo 5 de los mayores). Por otra parte, de acuerdo con lo expuesto en la Tabla 44, no se produjeron variaciones importantes en la utilización del imperativo entre hombres y mujeres.

\subsubsection{Fórmulas de deixis social}

\section{i) Fórmulas de tratamiento pronominales}

El análisis de esta investigación nos revela que el tratamiento de usted fue la variante minoritaria, ya que no supera en mucho la tercera parte de las respuestas analizadas (tan solo se usa usted en el $13 \%$ de los casos, frente al $87 \%$ con $t u \hat{)}$. Cuando se comparan las respuestas de los informantes de más edad con las de los jóvenes, y las de los hombres y las mujeres, se notan pequeñas diferencias, tanto en los subgrupos de edad como en los subgrupos de sexo, tal y como se puede observar en las tablas que se presentan a continuación. 
Tablas 45. Distribución del uso de usted en el grupo español según edad en las seis situaciones

\begin{tabular}{|c|c|c|c|}
\hline \multicolumn{2}{|c|}{ Mayor } & \multicolumn{2}{c|}{ Menor } \\
\hline Frecuencia & $\%$ & Frecuencia & $\%$ \\
\hline 21 & $44 \%$ & 27 & $56 \%$ \\
\hline
\end{tabular}

Tablas 46. Distribución del uso de usted en el grupo español según sexo en las seis situaciones

\begin{tabular}{|c|c|c|c|}
\hline \multicolumn{2}{|c|}{ Hombre } & \multicolumn{2}{c|}{ Mujer } \\
\hline Frecuencia & $\%$ & Frecuencia & $\%$ \\
\hline 20 & $42 \%$ & 28 & $58 \%$ \\
\hline
\end{tabular}

Si bien las diferencias entre los subgrupos analizados no fueron importantes, fueron los menores los que aplicaron la forma de usted en un mayor número de enunciados que los mayores, y fueron las mujeres las que utilizaron dicha forma en mayor medida que los hombres.

En relación al empleo de los pronombres personales de segunda persona en el corpus malayo (véase al capítulo 4: 4.1.2.3), encontramos 83 casos del uso de awak, 18 casos de anda y 18 casos de kamu en las respuestas examinadas. La distribución de dichas formas, en función de la cantidad de enunciados en los que aparecen, queda reflejada en la tabla que sigue. 
Tabla 47. Distribución de pronombres personales de segunda persona utilizados en las seis situaciones en malayo

\begin{tabular}{|c|c|c|}
\hline Formas & Frecuencia & $\%$ \\
\hline Awak & 83 & $70 \%$ \\
\hline Anda & 18 & $15 \%$ \\
\hline Kamu & 18 & $15 \%$ \\
\hline
\end{tabular}

Al comparar los datos de los encuestados mayores con los de los jóvenes, se encontraron diferencias significativas en el uso de dos formas, awak y anda, mientras que el tratamiento kamu se empleó con la misma frecuencia en los dos subgrupos. A continuación, en la Tabla 48, se expone la distribución de los pronombres personales de segunda persona en los subgrupos de edad.

Tabla 48. Distribución de pronombres personales de segunda persona empleados en malayo según subgrupo de edad en las seis situaciones

\begin{tabular}{|c|c|c|c|c|}
\hline \multirow{2}{*}{ Formas } & \multicolumn{2}{|c|}{ Mayor } & \multicolumn{2}{c|}{ Menor } \\
\cline { 2 - 5 } & Frecuencia & $\%$ & Frecuencia & $\%$ \\
\hline Awak & 34 & $59 \%$ & 49 & $80 \%$ \\
\hline Anda & 15 & $26 \%$ & 3 & $5 \%$ \\
\hline Kamu & 9 & $15 \%$ & 9 & $15 \%$ \\
\hline Total & 58 & $100 \%$ & 61 & $100 \%$ \\
\hline
\end{tabular}

Los dos subgrupos de edad mostraron una mayor tendencia hacia el uso de la forma awak, pero fueron los menores los que la emplearon más que los mayores, con el $80 \%$ de los casos 
en comparación con un $59 \%$ en los mayores. En cambio, la forma anda, los mayores la aplicaron en un mayor número de ocasiones que los menores (el $26 \%$ de los enunciados de los mayores frente a solo el $5 \%$ de los menores).

Ocurrió lo mismo en los subgrupos de sexo, al recurrir la mayoría de los hombres y las mujeres más frecuentemente a la forma de awak, aunque las mujeres la aplicaron en más casos que los hombres (aparece en el $77 \%$ de los enunciados de las mujeres frente al $60 \%$ de los de los hombres). La segunda más elegida entre los hombres fue la forma de anda con un $27 \%$ de los enunciados, pero en las mujeres la misma forma ocupó el tercer lugar, en el orden de preferencia. Por el contrario, la segunda opción más aplicada entre las mujeres, kamu, ocupó la tercera posición en las preferencias de los hombres. La tabla que se presenta a continuación recoge esta distribución de los pronombres utilizados por los hablantes de los subgrupos de sexo malayos.

Tabla 49. Distribución de pronombres personales de segunda persona empleados en malayo según subgrupo de sexo en las seis situaciones

\begin{tabular}{|c|c|c|c|c|}
\hline \multirow{2}{*}{ Formas } & \multicolumn{2}{|c|}{ Hombre } & \multicolumn{2}{c|}{ Mujer } \\
\cline { 2 - 5 } & Frecuencia & $\%$ & Frecuencia & $\%$ \\
\hline Awak & 32 & $60 \%$ & 51 & $77 \%$ \\
\hline Anda & 14 & $27 \%$ & 4 & $6 \%$ \\
\hline Kamu & 7 & $13 \%$ & 11 & $17 \%$ \\
\hline Total & 53 & $100 \%$ & 66 & $100 \%$ \\
\hline
\end{tabular}




\section{ii) Fórmulas de tratamiento nominales}

En los casos en los que los hablantes se dirigieron a sus interlocutores utilizando fórmulas de tratamiento nominales, no se han apreciado diferencias importantes entre los grupos de informantes, excepto en el uso de términos ocasionales, que solo aparecen en los datos españoles, y de los "Términos afectivos", que solo aplicaron los malayos.

Tabla 50. Distribución de fórmulas nominales empleadas en las seis situaciones en la sociedad española

\begin{tabular}{|l|l|c|c|}
\hline \multicolumn{1}{|c|}{ Fórmulas de tratamiento } & \multicolumn{1}{|c|}{ Ejemplos } & F & \% \\
\hline Nombre de pila & Manuel, Luis & 109 & $85 \%$ \\
\hline Término de cortesía + nombre de pila & Señor Manuel & 8 & $6 \%$ \\
\hline Término de parentesco & Hijo/a & 5 & $4 \%$ \\
\hline Término ocasional & Muchacho, enano & 2 & $1 \%$ \\
\hline Término de cortesía & Señor/a & 2 & $2 \%$ \\
\hline Hipocorístico & Pepe, fulano & 2 & $2 \%$ \\
\hline \multicolumn{1}{|c|}{ Total } & 128 & $100 \%$ \\
\hline
\end{tabular}

Tabla 51. Distribución de fórmulas nominales empleadas en las seis situaciones en la sociedad malaya

\begin{tabular}{|l|l|c|c|}
\hline \multicolumn{1}{|c|}{ Fórmulas de tratamiento } & \multicolumn{1}{|c|}{ Ejemplos } & F & \% \\
\hline Nombre de pila & Fatimah, Nadia... & 90 & $65 \%$ \\
\hline Término de parentesco & $\begin{array}{l}\text { Abang/kak ('hermano } \\
\text { mayor/hermana mayor') }\end{array}$ & 17 & $12 \%$ \\
\hline Término de cortesía & $\begin{array}{l}\text { Tuan/puan ('señor/señora'), } \\
\text { encik/cik ('señor/señorita') }\end{array}$ & 16 & $11 \%$ \\
\hline Hipocorístico & Mat, man, jo & 7 & $6 \%$ \\
\hline Término afectivo & Sayang ('cariño') & 5 & $4 \%$ \\
\hline $\begin{array}{l}\text { Término de cortesía + nombre } \\
\text { de pila }\end{array}$ & Cik Fatimah & 3 & $2 \%$ \\
\hline \multicolumn{1}{|c|}{ Total } & 138 & $100 \%$ \\
\hline
\end{tabular}


Al igual que en el caso de la petición, el "Nombre de pila" sigue siendo mayoritario entre los hablantes españoles al dirigirse a los interlocutores (85\%). Los malayos también usaron mayoritariamente el nombre de pila para dirigirse a los oyentes en sus mandatos (65\%), pero, a diferencia de los españoles, no mostraron la misma tendencia en el caso de la petición, cuando el nombre de pila ocupó el tercer lugar después del título y el término de cortesía.

Lo llamativo en este aspecto es el uso de "Términos afectivos", que es exclusivo del corpus malayo. Hubo 5 casos en las respuestas de los participantes malayos, la mayoría en la situación 18, en la que un padre/madre manda a su hijo/a que se acueste pronto, como en el ejemplo "...esok nak bangun awal, pergi masuk tidur ya sayang" ( '...mañana querer madrugar, ir entrar dormir vale cariño'/...si mañana quieres madrugar, tienes que ir a dormir ya, ¿vale, cariño?) o en "...masuk tidur cepat sayang, hari dah larut malam..." ('...entrar dormir pronto cariño, día ya demasiado tarde.../... vete a dormir pronto, cariño, que ya es muy tarde'). Por otro lado, mientras que en el corpus español se registraron 2 casos de la forma de "Término ocasional", los dos en la situación 18, no se encontró, en cambio, ningún caso en el corpus malayo. Por ejemplo, un español dijo "Muchacho, el sueño es sagrado y mañana tienes que madrugar...". 
Con respecto a la utilización de las formas nominales entre los hablantes mayores y los jóvenes al dirigirse a los interlocutores en su formulación del mandato, no hubo diferencias destacadas entre los subgrupos de edad, ni en el grupo español ni en el malayo. Ahora bien, en el grupo malayo, el uso del "Nombre de pila" fue mucho más frecuente entre los menores (54 casos) en comparación con los mayores (36 casos), mientras que la frecuencia registrada en el empleo de las formas de "Término de parentesco" y "Término de cortesía" fue mayor en el grupo de más edad (13 apariciones en las respuestas de los mayores frente a 4 de los menores en el primer caso y, 11 y 5 ocasiones, respectivamente, en el segundo caso).

Tablas 52. Distribución de fórmulas nominales en el corpus español según subgrupo de edad en las seis situaciones

\begin{tabular}{|c|c|c|c|c|}
\hline \multirow{2}{*}{ Fórmulas de tratamiento } & \multicolumn{2}{|c|}{ Mayor } & \multicolumn{2}{|c|}{ Menor } \\
\hline & $\mathbf{F}$ & $\%$ & $\mathbf{F}$ & $\%$ \\
\hline Nombre de pila & 58 & $91 \%$ & 51 & $81 \%$ \\
\hline Término de cortesía + nombre de pila & 1 & $1 \%$ & 7 & $11 \%$ \\
\hline Término de parentesco & 1 & $1 \%$ & 3 & $6 \%$ \\
\hline Término ocasional & 1 & $1 \%$ & 1 & $1 \%$ \\
\hline Término de cortesía & 1 & $1 \%$ & 1 & $1 \%$ \\
\hline Hipocorístico & 2 & $5 \%$ & 0 & $0 \%$ \\
\hline Total & 64 & $100 \%$ & 64 & $100 \%$ \\
\hline
\end{tabular}


Tablas 53. Distribución de fórmulas nominales en el corpus malayo según subgrupo de edad en las seis situaciones

\begin{tabular}{|c|c|c|c|c|}
\hline \multirow{2}{*}{ Fórmulas de tratamiento } & \multicolumn{2}{|c|}{ Mayor } & \multicolumn{2}{|c|}{ Menor } \\
\hline & $\mathbf{F}$ & $\%$ & $\mathbf{F}$ & $\%$ \\
\hline Nombre de pila & 36 & $51 \%$ & 54 & $79 \%$ \\
\hline Término de parentesco & 13 & $19 \%$ & 4 & $6 \%$ \\
\hline Término de cortesía & 11 & $16 \%$ & 5 & $7 \%$ \\
\hline Hipocorístico & 5 & $7 \%$ & 2 & $3 \%$ \\
\hline Término afectivo & 3 & $4 \%$ & 2 & $3 \%$ \\
\hline Término de cortesía + nombre de pila & 2 & $3 \%$ & 1 & $2 \%$ \\
\hline Total & 70 & $100 \%$ & 68 & $100 \%$ \\
\hline
\end{tabular}

En los resultados obtenidos en el análisis de las respuestas de hombres y mujeres en ambas sociedades, ocurrió lo mismo, es decir, no se observó una gran diferencia entre los subgrupos de sexo en el grupo español, aunque en los del grupo malayo sí se vieron algunas. En primer lugar, aunque los dos subgrupos de hablantes, hombres y mujeres, mostraran preferencia por la forma del "Nombre de pila", llama la atención la mayor frecuencia de uso con la que aparece en el corpus de mujer, con 63 casos (el $70 \%$ de los enunciados), frente al de los hombres, en el que se registraron solamente 27 (56\%). En segundo lugar, es importante señalar que, excepto el "Nombre de pila", que ocupa la primera posición en las respuestas de los dos sexos por orden de frecuencia de aparición, el resto de fórmulas ocupan una posición diferente en cada grupo de sexo. Así, por ejemplo, el "Término de parentesco" ocupa la segunda posición entre los hombres pero la tercera entre las mujeres. Al 
contrario, el "Término de cortesía" fue la segunda más empleada entre las mujeres pero ocupa la cuarta posición en el ranking de los hombres. Del "Hipocorístico" hubo 7 casos en los datos de los hombres, pero ninguna mujer lo utilizó.

Tablas 54. Distribución de fórmulas nominales en el corpus español según subgrupo de sexo en las seis situaciones

\begin{tabular}{|c|c|c|c|c|}
\hline \multirow{2}{*}{ Fórmulas de tratamiento } & \multicolumn{2}{|c|}{ Hombre } & \multicolumn{2}{|c|}{ Mujer } \\
\hline & $\mathbf{F}$ & $\%$ & $\mathbf{F}$ & $\%$ \\
\hline Nombre de pila & 57 & $86 \%$ & 52 & $85 \%$ \\
\hline Término de cortesía + nombre de pila & 3 & $6 \%$ & 5 & $8 \%$ \\
\hline Término de parentesco & 1 & $1 \%$ & 3 & $6 \%$ \\
\hline Término ocasional & 2 & $3 \%$ & 0 & $0 \%$ \\
\hline Término de cortesía & 1 & $1 \%$ & 1 & $1 \%$ \\
\hline Hipocorístico & 2 & $3 \%$ & 0 & $0 \%$ \\
\hline Total & 67 & $100 \%$ & 61 & $100 \%$ \\
\hline
\end{tabular}

Tablas 55. Distribución de fórmulas nominales en el corpus malayo según subgrupo de sexo en las seis situaciones

\begin{tabular}{|c|c|c|c|c|}
\hline \multirow[t]{2}{*}{ Fórmulas de tratamiento } & \multicolumn{2}{|c|}{ Hombre } & \multicolumn{2}{|c|}{ Mujer } \\
\hline & $\mathbf{F}$ & $\%$ & $\mathbf{F}$ & $\%$ \\
\hline Nombre de pila & 27 & $56 \%$ & 63 & $70 \%$ \\
\hline Término de parentesco & 7 & $15 \%$ & 10 & $11 \%$ \\
\hline Término de cortesía & 5 & $10 \%$ & 11 & $12 \%$ \\
\hline Hipocorístico & 7 & $15 \%$ & 0 & $0 \%$ \\
\hline Término afectivo & 2 & $4 \%$ & 3 & $4 \%$ \\
\hline Término de cortesía + nombre de pila & 0 & $0 \%$ & 3 & $3 \%$ \\
\hline Total & 48 & $100 \%$ & 90 & $100 \%$ \\
\hline
\end{tabular}




\subsubsection{Modificaciones gramaticales}

En lo que concierne al cambio del modo verbal, hemos encontrado 79 casos en total (el $22 \%$ de los enunciados) del uso de las formas Condicional/Imperfecto de Subjuntivo/Imperfecto de Indicativo en los datos españoles de las seis situaciones de mandato. Según los datos obtenidos, no existen diferencias importantes en el cambio de la forma verbal ni entre mayores y menores, ni entre hombres y mujeres, tal como se ve en las tablas siguientes:

Tablas 56. Distribución del cambio de forma verbal en el grupo español según edad en las seis situaciones

\begin{tabular}{|c|c|c|c|}
\hline \multicolumn{2}{|c|}{ Mayor } & \multicolumn{2}{c|}{ Menor } \\
\hline Frecuencia & $\%$ & Frecuencia & $\%$ \\
\hline 39 & $49 \%$ & 40 & $51 \%$ \\
\hline
\end{tabular}

Tablas 57. Distribución del cambio de forma verbal en el grupo español según sexo en las seis situaciones

\begin{tabular}{|c|c|c|c|}
\hline \multicolumn{2}{|c|}{ Hombre } & \multicolumn{2}{c|}{ Mujer } \\
\hline Frecuencia & $\%$ & Frecuencia & $\%$ \\
\hline 40 & $51 \%$ & 39 & $49 \%$ \\
\hline
\end{tabular}

Como la lengua malaya solo tiene el modo indicativo, puesto que es una lengua aglutinante como ya hemos mencionado anteriormente, es imposible hacer una comparación sobre el mismo aspecto. Así, las modificaciones examinadas se basan en la 
utilización de partículas como kah y lah, sufijos como kan y el uso de la palabra tak, que se han hallado en las respuestas malayas para bajar o subir la imposición, y cuya distribución de uso se presenta en la tabla que aparece a continuación.

Tabla 58. Distribución del uso de partículas en las seis situaciones en el grupo malayo

\begin{tabular}{|c|c|c|}
\hline Tipo & Frecuencia & $\%$ \\
\hline $\begin{array}{l}\text { Verbo + kan } \\
\text { "Saya cadangkan awak tukar kursus ini kepada kursus lain" } \\
\text { ('yo sugerirkan tú cambiar asignatura esta por asignatura } \\
\text { otra/lo mejor sería cambiar esta asignatura por esta otra') }\end{array}$ & 56 & $60 \%$ \\
\hline $\begin{array}{l}\text { Verbo + lah } \\
\text { "Pergilah masuk tidur, nanti besok bangun lambat" } \\
\text { ('Irlah entrar dormir, mañana levantarse tarde/iVete a dormir } \\
\text { ya, o mañana te vas a levantar tarde!') }\end{array}$ & 22 & $23 \%$ \\
\hline $\begin{array}{l}\text { Boleh + tak (no) } \\
\text { "Boleh tak awak fotostat dokumen-dokumen ini?" } \\
\text { ('Poder no tú fotocopiar documentos estos?/¿Puedes } \\
\text { fotocopiar estos documentos?') }\end{array}$ & 12 & $13 \%$ \\
\hline $\begin{array}{l}\text { Verbo + kah } \\
\text { “Bolehkah awak hantar makanan ini ke pejabat pelanggan?” } \\
\text { ('Poderkah tú llevar comida esta a oficina cliente?/¿Puedes } \\
\text { llevar esta comida a la oficina del cliente?') }\end{array}$ & 4 & $4 \%$ \\
\hline Total & 94 & $100 \%$ \\
\hline
\end{tabular}

La modificación más común en las respuestas malayas fue la adición de kan detrás del verbo. Kan es un sufijo que sirve para subir la imposición del verbo acompañado, como en el ejemplo de la Tabla 59, en el que esta partícula hace que el verbo cadang ('sugerir') resulte más fuerte e intente convencer al interlocutor. Pragmáticamente se utiliza para mostrar seriedad en las expresiones 
hechas, $y$, en el caso del mandato, para subir la imposición de dicho acto. Igual que kan, la partícula kah también sirve para dar énfasis a los verbos utilizados. Ahora bien, kah solo se usa en las frases interrogativas para dar énfasis al predicado, como se puede comprobar en el ejemplo dado en la tabla anterior. La partícula kah sirve para reforzar el verbo boleh que funciona como un predicado. Por el contrario, las partículas lah y tak se utilizan para atenuar el mandato. Además, lah también sirve gramaticalmente para dar énfasis al predicado, mientras que tak se usa en las frases interrogativas para que las preguntas suenen más suaves. Su existencia implica que no hay obligación de completar el mandato, ya que al oyente se le da la opción de responder no, e, indirectamente, rechazar el mandato.

Si se contrasta el uso de los instrumentos de atenuación entre los subgrupos de hablantes dentro de cada cultura, los resultados revelan que no hubo diferencias destacadas ni entre los subgrupos de edad ni entre los de sexo, como ha quedado reflejado en las tablas que se presentan a continuación: 
Tablas 59. Distribución del uso de partículas en el corpus malayo, según edad, en las seis situaciones de mandato

\begin{tabular}{|c|c|c|c|c|}
\hline \multirow{2}{*}{ Tipo } & \multicolumn{2}{|c|}{ Mayor } & \multicolumn{2}{|c|}{ Menor } \\
\hline & $\mathbf{F}$ & $\%$ & $\mathbf{F}$ & $\%$ \\
\hline Verbo + kan & 30 & $65 \%$ & 26 & $54 \%$ \\
\hline Verbo + lah & 8 & $18 \%$ & 14 & $29 \%$ \\
\hline Boleh + tak ('Poder + no') & 7 & $15 \%$ & 5 & $11 \%$ \\
\hline Verbo $+k a h$ & 1 & $2 \%$ & 3 & $6 \%$ \\
\hline Total & 46 & $100 \%$ & 48 & $100 \%$ \\
\hline
\end{tabular}

Tablas 60. Distribución del uso de partículas en el corpus malayo, según sexo, en las seis situaciones de mandato

\begin{tabular}{|c|c|c|c|c|}
\hline \multirow{2}{*}{ Tipo } & \multicolumn{2}{|c|}{ Varón } & \multicolumn{2}{|c|}{ Mujer } \\
\hline & $\mathbf{F}$ & $\%$ & $\mathbf{F}$ & $\%$ \\
\hline Verbo + kan & 31 & $65 \%$ & 25 & $54 \%$ \\
\hline Verbo + lah & 13 & $27 \%$ & 9 & $20 \%$ \\
\hline Boleh + tak ('Poder + no') & 3 & $6 \%$ & 9 & $20 \%$ \\
\hline Verbo $+k a h$ & 1 & $2 \%$ & 3 & $6 \%$ \\
\hline Total & 48 & $100 \%$ & 46 & $100 \%$ \\
\hline
\end{tabular}

\subsubsection{Perspectiva de la persona}

Según los datos recogidos, en lo que se refiere a la perspectiva de la persona, los españoles tendieron a orientar sus expresiones hacia el oyente (lo que ocurre en 214 casos, que corresponden al 59\% de los enunciados), mientras que los malayos prefirieron que sus expresiones fueran neutras, algo que se muestra en 170 casos (el $47 \%$ de los enunciados). 
Tablas 61. Distribución de enunciados según la perspectiva de persona en las respuestas para las seis situaciones en las dos culturas

\begin{tabular}{|l|c|c|c|c|}
\hline \multirow{2}{*}{ Perspectiva de persona } & \multicolumn{2}{c|}{ Español } & \multicolumn{2}{c|}{ Malayo } \\
\cline { 2 - 5 } & Frecuencia & $\%$ & Frecuencia & $\%$ \\
\hline Orientada al hablante & 103 & $29 \%$ & 83 & $23 \%$ \\
\hline Orientada al oyente & 214 & $59 \%$ & 107 & $30 \%$ \\
\hline Orientada al hablante y al oyente & 2 & $1 \%$ & - & $0 \%$ \\
\hline Neutro & 41 & $11 \%$ & 170 & $47 \%$ \\
\hline
\end{tabular}

La segunda perspectiva preferida entre los informantes españoles fue la orientación hacia el hablante (103 casos), seguida de la neutra (41 casos) y la orientación hacia los dos, hablante y oyente (solo 2 casos). Por otro lado, la segunda orientación a la que más recurrieron los malayos fue al oyente (107 apariciones), seguida de la orientación hacia el hablante (en 83 ocasiones). No se encontró ningún caso de expresión orientada hacia los dos, hablante y oyente, en los datos de este grupo cultural.

Mientras que en el grupo malayo, las diferencias entre los mayores y los menores en cada cultura en el aspecto de la perspectiva de la persona fueron insignificantes, en el grupo español sí se notó alguna diferencia más entre las respuestas de los dos subgrupos de edad. La Tabla 62 que se presenta a continuación, recoge la información sobre la frecuencia con la que los participantes mayores y los menores de cada grupo emplearon una u otra orientación: 
Tablas 62. Distribución de la perspectiva de persona según edad, en las seis situaciones de mandato en las dos culturas

\begin{tabular}{|l|c|c|c|c|}
\hline \multirow{2}{*}{ Perspectiva de persona } & \multicolumn{2}{|c|}{ Español } & \multicolumn{2}{c|}{ Malayo } \\
\cline { 2 - 5 } & Mayor & Menor & Mayor & Menor \\
\hline Orientada al hablante & $58(32 \%)$ & $45(25 \%)$ & $39(22 \%)$ & $44(24 \%)$ \\
\hline Orientada al oyente & $92(51 \%)$ & $122(68 \%)$ & $55(30 \%)$ & $52(29 \%)$ \\
\hline $\begin{array}{l}\text { Orientada al hablante y al } \\
\text { oyente }\end{array}$ & $2(1 \%)$ & - & - & - \\
\hline Neutro & $28(16 \%)$ & $13(7 \%)$ & $86(48 \%)$ & $84(47 \%)$ \\
\hline
\end{tabular}

Ocurrió justo lo contrario con los resultados obtenidos en el análisis de las respuestas de los sujetos de los subgrupos de sexo desde esta misma perspectiva, al aparecer diferencias más significativas entre los enunciados de los hombres y las mujeres malayos, que entre los de los españoles. La tabla que sigue así lo confirma.

Tablas 63. Distribución de la perspectiva de persona según subgrupo de sexo de cada cultura, en las seis situaciones de mandato

\begin{tabular}{|l|c|c|c|c|}
\hline \multirow{2}{*}{ Perspectiva de persona } & \multicolumn{2}{|c|}{ Español } & \multicolumn{2}{c|}{ Malayo } \\
\cline { 2 - 5 } & Hombre & Mujer & Hombre & Mujer \\
\hline Orientada al hablante & $49(27 \%)$ & $54(30 \%)$ & $40(22 \%)$ & $43(24 \%)$ \\
\hline Orientada al oyente & $105(58 \%)$ & $109(61 \%)$ & $45(25 \%)$ & $62(34 \%)$ \\
\hline $\begin{array}{l}\text { Orientada al hablante y } \\
\text { al oyente }\end{array}$ & $1(1 \%)$ & $1(1 \%)$ & - & - \\
\hline Neutro & $25(14 \%)$ & $16(8 \%)$ & $95(53 \%)$ & $75(42 \%)$ \\
\hline
\end{tabular}




\subsubsection{Análisis situacional}

En esta sección se van a analizar pormenorizadamente los resultados del análisis de las respuestas proporcionadas por los sujetos participantes en cada una de las 6 situaciones de mandato que constituyen el cuestionario.

\subsubsection{Situación 3}

Al formular un mandato a un nuevo secretario, que representa a un interlocutor con el que existe un grado de familiaridad bajo, la mayoría de los españoles eligieron realizarlo mediante la estrategia de "Declaración de deseo" (46.7\%), mientras que los malayos prefirieron la estrategia de "Imperativo" (45\%). Nos encontramos que el tolong + verbo fue usado de forma mayoritaria en los datos malayos. Ahora bien, los subgrupos de edad comparados mostraron un resultado distinto en la variedad de formas de "Imperativo". Los hablantes mayores utilizaron solamente dos formas, tolong + verbo y tolong + verbo + kan, mientras que los jóvenes emplearon las cuatro formas siguientes en orden decreciente: tolong + verbo, tolong + verbo + kan, sila + verbo y verbo. Con respecto a los subgrupos de sexo, no se han notado diferencias interesantes entre los hombres y las mujeres en el uso de dicha estrategia. A 
continuación, se presentan algunos ejemplos pertenecientes a cada uno de los tipos de respuesta mencionados en los dos grupos según el orden de aparición:

Ejemplos españoles:

(117) Necesito que me hagas estas fotocopias.

(118) Necesito que me fotocopies estos documentos.

(119) Necesito unas fotocopias de estos documentos.

Ejemplos malayos:

(120) Tolong fotokopi dokumen-dokumen ni!

( Ayudar fotocopiar documentos estos!/iFotocópiame estos documentos!')

(121) Tolong buatkan saya empat salinan dokumen ni!

(`Ayúdar hacerkan yo cuatro copias documento este!/iHazme cuatro copias de este documento!')

(122) Sila fotokopi dokumen ni!

('Ale fotocopiar documento este!/iFotocopia este documento inmediatamente!')

(123) Buat fotokopi!

('Hacer fotocopia!/!Hazme fotocopias!') 
El mayor uso del "Imperativo" en los datos malayos en comparación con los de los españoles se puede explicar por la distinta sensibilidad hacia el estatus social entre los hablantes de uno y otro grupo cultural. Como en la cultura malaya un directivo o un jefe suele tratar a sus trabajadores como personas inferiores, tiende a formular los mandatos a través de una forma directa. En cambio, en la cultura española, un jefe suele tratar a sus trabajadores como compañeros de trabajo, más que como empleados. Por lo tanto, en vez de aplicar el Imperativo, emplearon comúnmente la estrategia de "Declaración de deseo" en sus mandatos a un empleado al que acababan de conocer.

Parece que el aspecto cultural de tratar a los empleados como compañeros de trabajo también se reflejó en las respuestas de los españoles al utilizar en mayor número la estrategia de "Presentación/saludo" (33.6\%) como movimiento de apoyo, en comparación con la parte correspondiente de las respuestas de los malayos (tan solo el 11.8\%). El presentarse y el saludar mitigan a menudo la fuerza impositivita de un mandato, por lo que el mandato resulta más cortés. Por eso, en esta situación la mayoría de los españoles empezaron su mandato con saludos y presentaciones, como: 
(124) Hola, me llamo Lorena y vas a trabajar conmigo...

(125) Hola, me llamo Eric y soy su nuevo director...

(126) Hola, yo soy Miguel. En estos próximos años trabajaras como secretario mío...

Para iniciar los mandatos, los participantes malayos expusieron más variedad de fórmulas, por lo que es muy difícil determinar una estrategia dominante. Algunos comenzaron con "Fórmulas de preparación", mientras que otros lo hicieron con el mandato en sí mismo. Quizá los malayos sintieran que no es necesario ser corteses con los trabajadores. Para mitigar la imposición de los mandatos, los malayos examinados aplicaron frecuentemente la estrategia de "Fórmulas de preparación" (30.9\%), seguida de "Imperativo".

(127) Cik, tolong buat fotokopi dokumen ni untuk saya

('Señorita, ayudar hacer fotocopia documento este para yo/Señorita, por favor hágame una fotocopia de este documento') 
(128) Awak baru bekerja? Saya nak bagi tugas sikit, boleh tak awak buat fotokopi beberapa dokumen penting?

('Tú empezar trabajar? Yo querer dar tarea un poco, poder tú hacer fotocopia algunos documentos importantes?/¿Empiezas a trabajar? Quiero que hagas una cosa, ¿podrías hacer unas fotocopias de algunos documentos importantes? )

(129) Tolong buat fotokopi dokumen-dokumen ini.

('Ayudar hacer fotocopia documento-documento esto/ $\underline{\text { Por }}$ favor haz fotocopias de estos documentos ')

En cuanto a la utilización de los recursos de deixis social, descubrimos que en este escenario, con interlocutores desconocidos, la mayoría de los españoles emplearon el "Nombre de pila" al dirigirse a los destinatarios (87\%), mientras que los participantes malayos cuando se dirigieron a los oyentes desconocidos, aplicaron mayoritariamente dos formas, el "Nombre de pila" y un "Término de cortesía" (42\% y 40\%, respectivamente). Aunque el uso del "Nombre de pila" con los desconocidos no es normal en la cultura malaya, en este caso sí hay una presencia destacada, por el estatus y el poder de los hablantes.

No se han encontrado variaciones importantes entre los subgrupos de edad y los de sexo, en la sociedad española en los resultados sobre este aspecto. En cambio, la comparación entre los 
subgrupos de edad malayos en la utilización de las "Fórmulas de tratamiento", revela que el "Término de cortesía" fue la fórmula más común entre los mayores (56\%), mientras que los jóvenes prefirieron dirigirse a sus interlocutores por el "Nombre de pila" (50\%). En el caso de los subgrupos de sexo, por su parte, excepto la aparición exclusiva de la forma de "Término de cortesía + nombre de pila" en el material de las mujeres, no se han notado diferencias significativas entre los dos sexos, puesto que ambos recurrieron a las formas de "Nombre de pila" y "Término de cortesía" con la misma frecuencia (un $50 \%$ de los enunciados con cada forma en los datos de hombres y un $43 \%$ con cada forma en los de mujeres).

En lo que respecta al empleo de las fórmulas de tratamiento pronominales, en el grupo español un $70 \%$ de los hablantes empleó la forma de tú y un 30\% la de usted al tratar con sus interlocutores. El análisis del uso de las formas pronominales en cada subgrupo muestra que los hablantes mayores del grupo español optaron por el uso de usted en un mayor número de ocasiones que los jóvenes ( $56 \%$ y $44 \%$ respectivamente), y entre los subgrupos de sexo, fueron las mujeres las que utilizaron dicha forma con más frecuencia, con un $61 \%$ de casos en comparación con solo un 39\% de los hombres. 
(130) Hola, buenos días Manuel. Soy Andrés, que ocupo el puesto de director y tú vas a ser mi nuevo secretario. ...

(131) Buenos días Fernando, necesito unas copias de estos documentos...

Por otro lado, en el grupo malayo, un $22 \%$ de los sujetos empleó la forma de awak, un 7\% la de kamu y se encontró solamente un caso del uso de anda. La comparación establecida en el uso de los pronombres personales de segunda persona entre los participantes mayores y los jóvenes, nos revela que los mayores tendieron más a utilizar anda, con un $67 \%$ de casos, mientras que los jóvenes mostraron una mayor inclinación hacia el uso de awak, que alcanza un $92 \%$ de frecuencia. Los subgrupos de sexo, por otra parte, coincidieron en mostrar su preferencia hacia el empleo de awak, ahora bien, las mujeres lo hicieron con mayor frecuencia que los hombres, con un $88 \%$ de casos frente al $56 \%$ de los hombres.

(132) Siti, boleh awak buatkan saya satu salinan dokumen ni?

('Siti, poder tú hacerkan yo una fotocopia documento este?/Siti, ¿puedes hacerme una fotocopia de este documento?')

(133) Cik baru bertukar ke sini ka?

('Señorita acabar cambiar aquí verdad?/Señorita ¿acaba de cambiarse aquí? ) 
Como se ha señalado anteriormente, el uso de Condicional/Imperfecto de Subjuntivo/Imperfecto de Indicativo para disminuir la intensidad ilocucionaria es normal en la realización del acto de habla español, pero no en el malayo. En este escenario (situación 3) se encuentran 23 casos de la utilización del Condicional en los datos españoles. Según nuestros datos, no se han observado diferencias importantes en este aspecto ni entre mayores y jóvenes, ni entre hombres y mujeres, dentro del grupo español.

(134) ¿Me podrías fotocopiar estos documentos?

(135) ¿Podrías hacerme unas fotocopias de estos documentos?

(136) Necesitaría que me hiciera unas fotocopias.

(137) ¿Te importaría hacerme unas fotocopias de unos documentos?

En el caso del malayo, no hay construcción comparable, ya que no hay conjugación verbal. Sin embargo, encontramos el uso de las partículas kah (un caso) y tak (4 casos) en los mandatos malayos, aplicadas con el fin de bajar la imposición, y el sufijo kan (9 casos) utilizado con el objetivo contrario, es decir, para subirla. Con respecto a la utilización de esos elementos entre los participantes de más y menos edad, no se nota mucha diferencia, pero fueron los mayores los que aplicaron el sufijo kan con mayor frecuencia que los menores $(75 \%$ de los enunciados de los mayores frente al $50 \%$ de los menores), mientras que la partícula kah solo apareció en los 
datos de menores (en un 17\%) y ningún sujeto mayor la utilizó. Por otro lado, las diferencias en el uso de dichas partículas y del sufijo mencionado entre los hombres y las mujeres, no fueron relevantes, excepto en el caso de la partícula kah que solo emplearon los hombres (en un $13 \%$ de sus respuestas) y de la que no se encuentra ningún ejemplo de uso en los datos de las mujeres.

(138) Bolehkah awak tolong buat beberapa dokumen penting?

('Poderkah tú ayudar hacer fotocopias algunos documentos importantes?/¿Me puedes ayudar a hacer fotocopias de algunos documentos importantes?')

(139) Boleh tak anda membuat fotokopi beberapa dokumen ini? ('Poder no usted hacer fotocopias algunos documentos estos?/¿Podría usted hacerme algunas fotocopias de estos documentos?')

(140) Tolong fotostatkan saya dokumen ni!

('Ayudar fotocopiarkan yo documento este!/iPor favor fotocópiame este documento! )

Para terminar el análisis de las respuestas aportadas en la primera situación de mandato planteada en nuestro estudio, analizaremos qué tipo de perspectiva de persona se ha empleado en cada grupo y cada subgrupo. El análisis revela que las expresiones en los mandatos españoles se orientaron hacia hablante y oyente 
casi con la misma frecuencia (en el $48 \%$ y $50 \%$ de los enunciados, respectivamente), pero sí que hubo diferencias tanto entre los subgrupos de edad como entre los de sexo. Así, mientras que los mayores mostraron cierta tendencia a orientar las expresiones de sus mandatos hacia el hablante (en el $53 \%$ de los casos), los jóvenes prefirieron orientarlos hacia el oyente (56\%). Por otro lado, y teniendo en cuenta la diferencia de sexo, los hombres mostraron una mayor inclinación hacia la orientación al hablante (53\%), mientras que, en el caso de las mujeres, fue hacia el oyente (56\%). Por otro lado, la mayoría de las expresiones de los mandatos malayos en este escenario fueron de tipo neutro $(57 \%)$, y, a diferencia del grupo español, no se han hallado diferencias llamativas en dicho aspecto, ni entre los subgrupos de edad ni entre los de sexo. Todos los subgrupos recurrieron a la perspectiva de persona de tipo neutro. A continuación, exponemos algunos de los ejemplos que aparecen en las respuestas dadas tanto en malayo como en español en la situación 3:

Ejemplos españoles:

(141) Necesito unas copias de estos documentos.

(142) Necesito que me hagas unas fotocopias.

(143) ¿Podrías hacerme estas fotocopias? 
Ejemplos malayos:

(144) Tolong fotostat dokumen ni!

( 'Ayuda fotocopiar documento este!/ iFotocópiame este documento!')

(145) Boleh buat fotokopi dokumen ni?

('Poder hacer fotocopia documento este?/¿Podría hacer una fotocopia de este documento?')

\subsubsection{Situación 6}

Cuando los encuestados se situaron en la posición de un profesor universitario y tuvieron que mandar a un estudiante que siempre llega tarde que fuera a la hora a clase, 0 , en otras palabras, en un escenario en el que los interlocutores se conocían pero no tenían una relación de familiaridad entre sí, también se hallaron diferencias considerables entre las respuestas de los informantes españoles y los malayos al seleccionar las estrategias de los actos principales para formular el mandato. La mayoría de los españoles utilizaron un "Indicio fuerte" (lo encontramos en el $50 \%$ de los casos) como estrategia en los actos principales, mientras que los malayos, por su parte, aplicaron mayoritariamente la estrategia de "Declaración de deseo" (27\%). 
Ejemplos españoles:

(146) La próxima vez que llegues tarde vete directamente a tomar un café.

(147) El próximo día que, por el motivo que sea, no puedas llegar a tiempo, por favor, no entres.

(148) A partir de hoy, todo el que llegue cuando se hayan cerrado las puertas del aula, que no entre.

(149) Si no puedes llegar puntual es mejor que no entres.

(150) De ahora en adelante, si no vas a venir a clase puntualmente es mejor que no vengas.

Ejemplos malayos:

(151) Saya nak awak datang awal.

('Yo querer tú venir pronto/Quiero que vengas pronto')

(152) Lepas ni saya nak kamu puntual

('La próxima vez yo querer tú puntual/ La próxima vez quiero que seas puntual )

(153) Lepas ni saya nak awak datang awal 10 minit ke kelas...

('La próxima vez yo querer tú venir pronto 10 minutos a clase/ La próxima vez quiero que vengas 10 minutos antes a clase')

A diferencia de la situación anterior, en esta, no se ve, en ninguna de las dos sociedades, la tendencia a comenzar los 
mandatos con saludos ni presentaciones. En el corpus español solo se han registrado 3 ejemplos, mientras que en el malayo no se ha encontrado ningún caso. La mayoría de los participantes de ambos grupos empezaron el mandato con los actos principales en sí mismos.

Ejemplos españoles:

(154) Si no puedes llegar puntual es mejor que no entres. Distraes a tus compañeros y me interrumpes a mí.

(155) Intente llegar puntual a mis clases. No me gusta que interrumpa en mitad de una de ellas.

(156) Te agradecería que no vuelvas a llegar tarde a clase. Es una simple cuestión de respeto hacia todos.

Ejemplos malayos:

(157) Kelas akan datang saya nak awak datang awal, jika lewat saya akan kenakan tindakan.

('Clase siguiente yo querer tú venir pronto, si tarde yo castigar/Para la próxima clase quiero que vengas pronto o te castigaré si llegas tarde')

(158) Lepas ni saya nak awak datang awal 10 minit ke kelas. Saya tidak suka pelajar datang lambat kerana ia mengganggu kosentrasi pengajaran saya. 
( 'Después esto yo querer tú venir pronto 10 minutos a clase. Yo no gusta alumno llegar tarde porque molestar concentración enseñanza yo/La próxima vez quiero que lleques 10 minutos antes de clase. No me gusta que un alumno llegue tarde porque molesta el ritmo de la clase')

(159) Saya harap awak tidak akan datang lewat lagi ke kelas saya. Ini amaran terakhir saya.

('Yo esperar tú no venir tarde más a clase yo. Este aviso último yo/Espero que no vuelvas a llegar tarde a clase. Este es el último aviso').

En ambas culturas la utilización del "Nombre de pila" para dirigirse a los interlocutores es bastante frecuente, especialmente en el caso de los malayos, que lo utilizan en el $100 \%$ de 18 casos, en comparación con los españoles, que solamente lo hacen en el $80 \%$ de 20 casos. Además, la mayoría de los ejemplos españoles y malayos mostraron la preferencia de los hablantes por la variante informal del pronombre personal de segunda persona para tratar a los alumnos conocidos. Así, aparece tú en 40 casos frente a los 20 casos de usted, en los datos españoles, y awak (16 casos), anda (4 casos) y kamu (un caso), en los malayos.

La tendencia de los dos subgrupos de edad en el uso de formas nominales de cortesía fue similar, tanto en el corpus español 
como en el malayo. En lo que concierne a las formas pronominales, a diferencia de lo que pasaba en la situación anterior, esta vez fueron los menores del grupo español los que utilizaron la forma de usted en un mayor número de ocasiones que los mayores (en el $47 \%$ de los enunciados de los menores, frente al $20 \%$ de los mayores). Y la comparación entre subgrupos de sexo revela que las mujeres, al igual que ocurría en la situación 3, emplearon la forma de usted más que los hombres (en el $40 \%$ y $26 \%$ de sus enunciados, respectivamente).

(160) $\underline{X}$ (la sustitución del nombre de pila), no vuelvas a llegar tarde a clase, porque es la última vez que te dejo entrar tarde. iControla tu tiempo!

(161) $\underline{X}$, no me gusta su impuntualidad. A partir de ahora deberá llegar a la hora que comienza la clase.

(162) Señor $\mathrm{X}$, ilas normas son para todos y hay que cumplirlas!

En el grupo malayo, ambos, mayores y jóvenes, y hombres y mujeres, mostraron la misma preferencia hacia el uso de awak. Sin embargo, los jóvenes lo aplicaron más que los mayores (lo encontramos en el $43 \%$ de las respuestas de los jóvenes en comparación con solo el $16 \%$ de los mayores), y las mujeres más que los hombres (en el $37 \%$ de los enunciados de las mujeres frente al $23 \%$ de los hombres). 
(163) $\underline{x}$, lain kali saya nak awak datang kuliah awal. Saya tidak suka pelajar saya lewat datang kuliah....

( $\underline{X}$, próximo día yo querer tú venir a clase pronto. Yo no gusta alumno yo tarde llegue clase/ $X$, quiero que el próximo día llegues a clase pronto. No me gusta que mis alumnos lleguen tarde a clase').

(164) $\underline{X}$, kalau boleh saya tak nak tengok awak lewat lagi.

( $\underline{X}$, si poder, yo no querer ver tú llegar tarde más $X$, si puedes, no quiero ver que vuelves a llegar tarde)

(165) $\underline{X}$, awak mesti datang tepat ke kelas saya.

( $~ \underline{X}$, tú deber venir puntual a clase yo/ $X$, debes venir puntual a mi clase)

Otra manera de reducir la imposición es la de cambiar la forma del verbo. En el corpus español se han hallado 11 casos (el $18 \%$ de los enunciados) de uso del Condicional, un número más bajo que el registrado en la situación anterior. Por otro lado, en el corpus malayo hemos detectado dos partículas diferentes utilizadas para disminuir la fuerza de la imposición, que son lah (7 casos), tak (3 casos) y un caso del sufijo kan, que funciona de forma contraria, es decir, para aumentar la imposición del mandato.

Si en la situación 3 casi no hubo diferencias en el uso de la forma Condicional/Imperfecto de Subjuntivo/Imperfecto de 
Indicativo entre los subgrupos estudiados, en esta situación sí se hicieron evidentes, puesto que fueron utilizadas por el $23 \%$ de los informantes mayores, pero solamente por el $13 \%$ de los jóvenes. Se da el mismo fenómeno en los datos de los subgrupos de sexo, ya que sí que hay una diferencia perceptible entre el uso que hacen de este recurso las mujeres (lo aplican en un $23 \%$ de los casos) y los hombres (en un 13\%). Con respecto a la modificación sintáctica en los subgrupos malayos, no hubo diferencias importantes en la frecuencia de uso ni entre sujetos mayores y menores, ni entre hombres y mujeres. Pero el sufijo kan solo apareció en los datos de los mayores, y en la comparación entre hombres y mujeres, se halla que solo los hombres lo utilizaron, mientras que el tak sí que apareció en los datos de mujeres, pero no se encuentra ningún caso entre los hombres. Los mandatos siguientes ilustran estas modificaciones:

Ejemplos españoles:

(166) X, sería conveniente que en el futuro no te retrases porque no me gusta que me interrumpan la clase.

(167) Perdone $X$, pero le agradecería que llegara puntual para no molestar el ritmo de la clase.

(52) Espero que tenga usted un buen motivo para legar tarde a las clases. En caso contrario, le rogaría que se quedase fuera para no interrumpir ni a sus compañeros ni a mí. 
Ejemplos malayos:

(168) Harap tepatlah lain kali, ok?

('Ojalá que puntual/ah próximo, vale?/Espero que seas puntual la próxima vez' ¿vale?)

(169) X, boleh tak lain kali awak datang kuliah tepat pada masa?

( $X$, poder no, el próximo día tú venir clase puntualmente?/ $X$, ¿no podrías llegar puntual a clase el próximo día?')

(170) Ini amaran terakhir untuk awak. Jika awak datang lewat sekali lagi, nama awak akan digugurkan dari kursus saya.

(`Este aviso último para tú. Si tú llegar tarde otra vez, tu nombre se va a eliminarkan de curso yo/Este es el último aviso para ti. Si vuelves a llegar tarde, no te volveré a dejar entrar en mi clase ).

En lo que concierne a la orientación a la persona, la mayoría de las expresiones de los mandatos españoles, en este caso, están orientadas hacia el oyente (el 58\%), mientras que los mandatos malayos fueron mayoritariamente del tipo "Orientado al hablante" (38\%), al contrario de lo que ocurría en la situación 3. En este aspecto, la inclinación mostrada por los hablantes de todas las edades fue uniforme, es decir la mayoría de las expresiones de sus mandatos estaban orientadas hacia el oyente; ahora bien, llama la atención la mayor frecuencia de su existencia en el corpus de los 
jóvenes, ya que aparece en el $80 \%$ de los casos, frente a una frecuencia del $36 \%$ en los enunciados de los mayores.

Ejemplos españoles:

(171) Si no te importa, la próxima vez que llegues tarde vete directamente a tomar un café.

(172) Hoy solo te aviso, a partir de mañana si no llegas puntual no te dejaré entrar.

(173) De ahora en adelante, si no vas a venir a clase puntualmente es mejor que no vengas.

Ejemplos malayos:

(174) Saya gembira jika awak datang kuliah lebih awal.

('Yo contento si tú venir clase más pronto/Estoy contento si vienes a clase más pronto')

(175) Kelas akan datang saya nak awak datang awal, jika lewat, saya akan kenakan tindakan..

('Próxima clase yo querer tú venir pronto, si tarde, yo castigar/Para la próxima clase quiero que vengas pronto o te castigaré si llegas tarde ') 
(176) X, lain kali saya mahu awak datang awal ke kelas kerana bila wak lewat, awak telah mengganggu pelajar-pelajar lain.

( $X$, próxima vez yo querer tú venir pronto a clase porque si tú tarde, tú molestar alumno-alumno otro/X, la próxima vez quiero que vengas pronto a clase porque, si llegas tarde, vas a molestar a los otros alumnos ).

\subsubsection{Situación 9}

En esta situación se especifica que los encuestados adoptan el papel de padre/madre del interlocutor (el hijo/la hija adolescente) y tienen que mandarle que vuelva pronto a casa, cuando pide permiso para salir con sus amigos. El grado de familiaridad entre los interlocutores es muy alto ya que se trata de padres e hijos. $Y$, al formular su mandato, sí que se observan diferencias entre los hablantes de ambas culturas analizados en las estrategias seleccionadas. Mientras que los hablantes españoles que participaron en la investigación tendieron a realizar los mandatos utilizando el "Imperativo" (41.7\%), los hablantes malayos analizados mostraron preferencia por realizar los mandatos a través de una "Declaración de obligación" (38.7\%). 
Ejemplos españoles:

(177) iVuelve pronto a casa!

(178) iEstate a las 11 en casa!

(179) iNo llegues muy tarde!

Ejemplos malayos:

(180) Mesti balik sebelum pukul 5 petang.

(`Deber volver antes 5 tarde/Debes volver antes de las 5 de la tarde')

(181) Awak perlu pulang ke rumah sebelum malam.

('Tú tener que volver a casa antes noche/Tienes que volver a casa entes de la noche')

(182) Mesti pulang awal.

('Deber volver pronto'/Debes volver pronto)

Sin embargo, en el corpus malayo el "Imperativo" ocupó el segundo lugar de preferencia, con un $32 \%$ de casos. Lo interesante es que la mayoría de los imperativos expresados por los hablantes malayos van en forma negativa, "Jangan ('no') + verbo" (60\%). Y, el porcentaje más elevado de utilización de este tipo de imperativo corresponde al subgrupo de jóvenes (aparece en un 22\% de sus enunciados), en comparación con el de mayores (17\%), y al subgrupo de hombres (30\%) frente al de mujeres (9\%), aunque en todos los casos es la forma mayoritariamente seleccionada. 
(183) Jangan balik lambat sangat!

('No volver tarde muy!/ iNo vuelvas muy tarde!')

(184) Jangan lupa pulang awal!

('No olvidar volver pronto!/iNo olvides volver pronto!')

(185) Jangan lupa balik sebelum magrib!

('No olvidar volver antes ocaso!/iNo olvides volver antes de que anochezca')

Como era de esperar, no hay saludos ni presentaciones como encabezado del mandato en ninguno de los grupos, sino que la mayoría de los sujetos prefirieron iniciarlos minimizando la imposición del mandato en sí mismo. Presentamos algunos ejemplos que aparecen en la situación 9 encabezados con una minimización de la imposición:

Ejemplos españoles:

(186) De acuerdo, pero tienes que llegar a la hora o la próxima vez, iya veremos!

(187) Vale, te dejo salir, pero quiero que vuelvas pronto.

(188) Vale, puedes salir pero a las $22 \mathrm{~h}$ en casa ¿vale? 
Ejemplos malayos:

(189) Ayah izinkan keluar tapi jangan lupa pulang awal.

('Padre dejarkan salir pero no olvidar volver pronto/Te dejo salir pero no olvides volver pronto').

(190) Boleh, tapi jangan balik lewat.

('Poder, pero no volver tarde'/Puedes, pero no vuelvas tarde).

(191) Boleh keluar, tapi pastikan sebelum pukul 12 malam dah ada di rumah.

('Poder salir, pero asegurarkan antes 12 noche ya estar en casa'/Puedes salir, pero asegúrate de estar en casa antes de las 12 de la noche).

Como en esta situación la formulación del mandato supone dirigirse a un hijo, es decir, se trata de un interlocutor íntimo, se nota la aparición del "Término de parentesco" en las respuestas de los sujetos de las dos sociedades, pero el uso del "Hipocorístico" y "Términos afectivos", se registró solamente en el corpus malayo. Ahora bien, el "Nombre de pila" ha sido elegido mayoritariamente en ambos países para dirigirse a los destinatarios. Es interesante señalar la aparición del "Término de parentesco" solamente en los jóvenes del grupo español. Aparte de eso, no se ha encontrado ninguna diferencia llamativa ni entre las respuestas de los mayores y los jóvenes, ni entre las de los hombres y las mujeres. En los subgrupos 
de edad malayos, hallamos que el "Hipocorístico" y los "Términos afectivos" solo aparecieron en el corpus de los mayores, mientras que ningún menor los aplicó. Y en la comparación entre los hombres y mujeres, se observa que los hombres aplicaron el "Hipocorístico" pero las mujeres no, y los "Términos afectivos" fueron utilizadas por las mujeres pero no por los hombres.

Con respecto a las fórmulas nominales y las modificaciones sintácticas, hay que mencionar que no se ha encontrado ningún caso de uso de usted en los mandatos españoles, ni tampoco ningún verbo en Condicional, mientras que en los malayos se ha registrado un caso de uso de anda (fue usado por un hombre mayor) y dos casos de kamu (que solo utilizaron un hombre y una mujer joven). $Y$, respecto a la modificación sintáctica, encontramos 7 casos (el $12 \%$ del total) del empleo de la partícula kan, que es utilizada por el $20 \%$ de los hablantes mayores, frente a tan solo el 3\% de los jóvenes. Al comparar la frecuencia de uso en las respuestas de los hombres y las mujeres, los datos revelan que la diferencia fue prácticamente insignificante (el 13\% de los hombres y el $10 \%$ de las mujeres).

Ejemplos españoles:

(192) A ver hijo, pásatelo bien hoy, no hagas imprudencias y vuelve pronto a casa. 
(193) Hijo, puedes salir con tus amigos, pero ven pronto a casa ¿vale?

(194) Vale $\underline{X}$, puedes salir, pero no llegues más tarde de las 11 .

Ejemplos malayos:

(195) Balik dengan cepat anakku.

('Volver con rapidez hijo yo/Por favor vuelve pronto, hijo mío').

(196) Okey Man boleh keluar tapi pastikan balik sebelum pukul 12 malam.

('Vale Man poder salir pero asegurakan volver antes 12 noche/ Vale, Man, puedes salir pero asegúrate de volver antes de las 12 de la noche')

(197) Nurain nanti keluar dengan kawan-kawan, balik cepat sikit, ya.

( 'Nurain cuando salir con amigo-amigo, volver pronto, vale/ Nurain cuando salgas con los amigos, vuelve pronto, ¿vale?').

Finalmente, respecto a la perspectiva de la persona, al igual que ocurría en la situación 6, las expresiones de los mandatos españoles pusieron el énfasis en el rol del oyente en la mayor parte de los casos. Por otro lado, los malayos prefirieron el tipo neutro. Según nuestros datos, no se han hallado diferencias importantes ni entre sujetos mayores y menores ni entre hombres y mujeres de cada sociedad. 
Ejemplos españoles:

(198) Si quieres salir más veces, estate a las 11 en casa.

(199) Llega pronto a casa si quieres salir otro día.

(200) Debes volver a la hora prevista.

Ejemplos malayos:

(201) Boleh keluar, tapi kena pulang awal.

('Poder salir, pero haber que volver pronto/Puedes salir, pero hay que volver pronto ).

(202) Pastikan pulang sebelum jam 10.00 malam.

( 'Asegurarkan volver antes hora 10.00 noche/Aseqúrate de volver antes de las 10 de la noche').

(203) Boleh keluar dengan kawan tapi mesti balik sebelum pukul 5 petang.

('Poder salir con amigo pero deber volver antes 5 tarde/ Puedes salir con los amigos pero debes volver antes de las 5 de la tarde').

\subsubsection{Situación 12}

Al analizar los resultados de la situación 12 , en la cual un profesor manda a un nuevo alumno a su cargo, al que ve por primera vez, que cambie una de las asignaturas elegidas por otra, los informantes 
de ambas sociedades coincidieron en utilizar en un mayor porcentaje una "Fórmula de sugerencia". Aun así, el grado de precisión en dicha estrategia fue diferente. Las sugerencias españolas fueron más específicas que las sugerencias malayas, puesto que incluían más detalles sobre qué asignatura se tenía que cambiar, por ejemplo:

(204) Es preferible que curses $\underline{X}$ en lugar de $Y$.

(205) Creo que sería más adecuado que te matriculases de la asignatura $\underline{W}$ que de la $\mathrm{Z}$.

(206) Yo te aconsejaría, más bien, elegir la signatura $\underline{Z}$.

(207) Creo que la mejor es que cambies la asignatura A por la $\underline{B}$.

(92) Yo le recomendaría que cogiese esta asignatura en vez de esta.

La mayoría de los malayos investigados solo sugirieron que se cambiara la asignatura por otra, sin mencionar específicamente el nombre. Algunas de las respuestas de los malayos fueron, por ejemplo:

(208) Saya cadangkan awak mengambil kursus yang lebih sesuai dengan program awak.

('Yo recomendarkan tú coger curso más adecuado con programa tú/ Te recomiendo que cojas otra asignatura que es más adecuada a tu programa') 
(209) Saya rasa baik awak tukar.

('Yo creer bueno tú cambiar/Creo que lo mejor es que cambies')

(210) Saya cadangkan awak tukar kepada kursus lain.

('Yo sugerir tú cambiar a curso otro/ Te sugiero que cambies a otra asignatura')

(211) Saya rasa kursus ini perlu ditukar kepada kursus lain untuk semester ini.

('Yo creer curso este tener que cambiar a curso otro para semestre este/Creo que esta asignatura hay que cambiarla por esta otra para este semestre')

Para que las sugerencias planteadas fueran más relevantes, los encuestados de ambas comunidades de habla las reforzaron con excusas o justificaciones. Por lo tanto, la estrategia de movimientos de apoyo más aplicada por ambos grupos de nativos fue la de "Razones". Parece que no solo el grado de precisión en las sugerencias analizadas anteriormente fue diferente entre los dos grupos de nativos, ya que, al igual que en dicho caso, las excusas españolas también fueron más detalladas, mientras que las explicaciones malayas fueron más generales y vagas. Por ejemplo, los españoles tendieron a responder mayoritariamente con enunciados como: 
(212) Porque no te conviene nada con tus aptitudes y tu futuro laboral.

(213) Creo que para tu futuro profesional cursar B será más fácil que la saques.

(214) Porque coincide más con la tipología general de asignaturas que has elegido de forma global.

(215) Que se te de mejor, esta te va a dar problemas debido a los horario.

(216) Que es un poco incompatible con tu currículo y planificación.

Por el contrario, la mayoría de los malayos mostraron tendencia a responder con frases como:

(101) Kerana kursus ini kurang sesuai.

('Porque curso este menos adecuado/Porque esta asignatura no es tan adecuada')

(102) Kerana kursus ini susah.

('Porque curso este difícil/ Porque esta asignatura es difícil')

(103) Sebab kursus baru lebih relevan.

('Porque curso nuevo más relevante/Porque la nueva asignatura es más relevante')

(104) Sebab lagi banyak benda yang kamu akan belajar.

('Porque más mucha cosa que tú ir a aprender/Porque aprenderás más cosas') 
(105) Kursus ini mungkin lebih sesuai diambil semester depan.

('Curso este a lo mejor más adecuado se coge semestre próximo/A lo mejor es más adecuado escoger esta asignatura el próximo semestre')

Hay que destacar que, en esta situación, tanto los participantes españoles como los malayos tendieron a comenzar sus mandatos con la estrategia de "Fórmulas de preparación", es decir, antes de realizar el mandato se comprueba primeramente la posible disponibilidad del oyente para llevar a cabo el acto. Los ejemplos que se presentan a continuación sirven para ilustrar las formas mencionadas de las respuestas de los sujetos de cada uno de los países:

Ejemplos españoles:

(105) He estado revisando las asignaturas que has seleccionado y he pensado que, tal vez, fuera mejor para usted matricularse de esta asignatura en lugar de esta otra.

(106) Te voy a dar mi opinión, tú me escuchas y luego haces lo que te parezca mejor. Desde mi punto de vista, es mejor que cojas esta asignatura en vez de esta otra.

(107) ¿Te puedo aconsejar? Te recomendaría que te matricules en esta asignatura en vez de esta otra porque tendrá más utilidad en el futuro para ti. 
(108) ¿Has pensado bien tu elección? ¿y si cambias esta asignatura?

(109) Solo es un consejo, puedes hacer lo que tú quieras, pero te recomendaría que cambiaras esta asignatura por otra.

Ejemplos malayos:

(110) Saya rasa kursus ini tak sesuai dengan kamu. Kamu kena tukar atau pilih kursus lain, ya?

('Yo creer curso este no adecuado con tú. Tú tener que cambiar o elegir curso otro, vale?/Creo que esta asignatura no es adecuada para ti. Tienes que cambiar o elegir otra asignatura, ¿'vale?')

(111) Kenapa awak mendaftar kursus ni? Bukankah kursus ini tidak begitu relatif dengan pengkhususan awak? Saya cadangkan awak mendaftar kursus yang akan menambah nilai kepada ijazah awak nanti.

(`Por qué tú matricularse curso este? Nokah curso este no tan relativo con especialización tú? Yo sugerirkan tú matricularse curso que ir a añadir valor a licenciatura tú luego/¿Por qué te has matriculado en este curso? ¿No piensas que este curso no tiene tanta relación con tu carrera? Te recomendaría que te matricularas en un curso que sirviera más para tu carrera ').

(112) Saya nak tanya, kenapa awak pilih kursus ni? Saya rasa kursus ni kurang sesuai. Awak patut gantikan dengan kursus lain. 
('Yo querer preguntar, por qué tú elegir curso este? Yo creer curso este menos adecuado. Tú deber sustituirkan con curso otro/Te quería preguntar, ¿por qué has elegido esta asignatura? Creo que esta asignatura no es adecuada. Debes cambiarla por otra').

El "Nombre de pila" sigue siendo la fórmula más empleada, tanto en los datos españoles (aparece en el $90 \%$ de casos) como en los malayos (en el $100 \%$ de casos), para dirigirse a los interlocutores. Así pues, sus diferencias de uso fueron insignificantes tanto entre los encuestados mayores y jóvenes como entre los hombres y las mujeres de cada país. Cabe señalar, eso sí, la presencia de un caso de uso de "Termino de cortesía + nombre de pila" en el subgrupo de las mujeres menores españolas. Con respecto a la utilización de las fórmulas de tratamiento pronominales, los participantes de ambos países recurrieron en un mayor número de ocasiones a la variante informal de la segunda persona, con 55 casos (lo que representa el 92\%) del empleo de tú, frente a tan solo el $8 \%$ de usted en el grupo español, y 37 casos de awak, que corresponden al $60 \%$ del total, frente al empleo de kamu en 8 casos (13\%) y anda (12\% de casos), en el malayo. En este último grupo cultural, tampoco se han notado diferencias significativas entre los subgrupos, ni de edad ni de sexo, ya que la mayoría de los mayores 
y jóvenes, y de los hombres y mujeres, optaron por dirigirse a los interlocutores a través de la forma de awak.

Ejemplos españoles:

(113) $\underline{X}$, pienso que deberías cambiar esta asignatura, ya que tendría mejor quizás esta otra, está más encaminada hacia lo que tú quieres hacer al terminar la carrera.

(114) Señor X, esta asignatura no te conviene. Elige esta que te conviene más.

(115) Mira $\underline{X}$, creo que necesitas cambiar esa asignatura porque no te conviene nada con tus aptitudes y tu futuro laboral.

Ejemplos malayos:

(116) $\underline{X}$, kursus ni sepatutnya awak tak perlu ambil sebab tak related dengan program awak. Saya cadangkan awak tukar kursus itu dengan kursus lain.

( $\underline{X}$, curso este tener tú no coger porque no relativo con programa tú. Yo sugerirkan tú cambiar curso este con curso otro/ $\underline{X}$ no tendrías que coger esta asignatura porque no tiene relación con tu programa. Te recomendaría que cambiaras esta asignatura por otra').

(117) Balqis, kursus ni tak berapa sesuai untuk jurusan awak. Awak perlu ambil kursus yang sesuai dengan jurusan awak. 
(' $\underline{\text { Balqis, }}$ curso este no tan adecuado para carrera tú. Tú tener coger curso que adecuado con tu carrera/Balqis, esta asignatura no es tan adecuada para tu carrera. Tienes que coger otra que sea más adecuada con tu carrera').

(118) Fendi, pada pendapat saya lebih baik awak tukar je kursus ni. Ambil kursus lain.

(`Fendi, en opinión yo más bien tú cambiar ya este curso. Coger otro curso/Fendi, en mi opinión es mejor cambiar esta asignatura. Coge la otra ).

Debido a la fuerte tendencia al empleo de la estrategia de "Fórmula de sugerencia" en los dos grupos para realizar el mandato, el uso del Condicional entre los sujetos españoles en esta situación fue el más elevado, en comparación con otras situaciones, ya que se utiliza en el $58 \%$ de los casos. Por lo que refiere a la utilización de dicha forma en los subgrupos, encontramos un índice de frecuencia prácticamente similar en los participantes mayores y los menores ( $44 \%$ de los mayores y $45 \%$ de los jóvenes), pero en los subgrupos de sexo, los hombres aplicaron el verbo en Condicional en un porcentaje de enunciados casi dos veces superior al de las mujeres (lo encontramos en el $58 \%$ de los enunciados de los hombres frente al $30 \%$ de las mujeres). Por otro lado, en la sociedad malaya, se nota cierta inclinación a adjuntar a los verbos utilizados el sufijo kan (25\%), que funciona como agravador de la imposición, sin existir 
diferencias importantes en la frecuencia de su uso, ni entre los subgrupos de edad ni entre los de sexo.

Ejemplos españoles:

(119) Te recomendaría que cogieses esta asignatura en vez de esta por varios motivos.

(120) Te aconsejaría cambiar esta asignatura por esta otra.

(121) Si me permites aconsejarte, yo cambiaría esta asignatura por esta otra.

Ejemplos malayos:

(122) Saya cadangkan awak mengambil kursus lain yang lebih sesuai dengan program awak.

('Yo sugerirkan tú coger curso otro que más adecuado con programa tú/Te sugiero que cojas otra asignatura que sea más adecuada para tu programa')

(123) Saya rasa kursus ini kurang sesuai, awak patut gantikan dengan kursus yang lain.

('Yo creer curso este menos adecuado, tú tener sustituirkan con curso otro/Creo que esta asignatura no es tan adecuada, tendrías que sustituirla por otra').

(124) Saya berpendapat lebih elok awak gugurkan kursus ini dahulu dan gantikan dengan kursus lain. 
('Yo opinar más bien tú dejarkan curso este primero y sustituirkan con curso otro/Opino que es mejor que dejes esta asignatura y sustitúyela por otra ).

Finalmente, cabe subrayar que la mayoría de las expresiones de los mandatos en ambos grupos estaban orientadas hacia los hablantes (el $67 \%$ de los españoles y el $60 \%$ de los malayos). Así pues, no se notan diferencias relevantes entre los subgrupos examinados en los dos países, ya que tanto los sujetos mayores como los menores, y tanto hombres como mujeres, coincidieron en orientar las expresiones de sus mandatos hacia el hablante, como en los siguientes ejemplos:

Ejemplos españoles:

(125) Te aconsejo que cambies esta asignatura por esta otra.

(126) Creo que sería más conveniente para ti matricularte de esta asignatura en lugar de la que vas a cursar.

(127) Yo, personalmente, elegiría esta otra. Te vendrá bien por esto y lo otro.

Ejemplos malayos:

(128) Saya rasa elok awak tukar kursus ni.

('Yo creer mejor tú cambiar curso este/Creo que es mejor que cambies esta asignatura ). 
(129) Saya mahu anda menukarnya dengan kursus yang lain.

('Yo querer usted cambiarlo con curso que otro/Quiero que la cambie por otra').

(130) Kursus ini tak sesuai untuk awak. Jadi, saya minta kamu tukar kursus ni.

('Curso este no adecuado para tú. Entonces, yo pedir tú cambiar curso este/Esta asignatura no es adecuada para ti. Entonces, te pido que la cambies').

\subsubsection{Situación 15}

En esta situación el encargado de un restaurante manda a un trabajador que envíe la comida encargada por un cliente, a su oficina. El grado de familiaridad entre los interlocutores es alto pero no demasiado, puesto que el oyente trabaja a tiempo parcial. La estrategia más común en los actos principales de los hablantes españoles fue la de "Declaración de obligación", que aparece en un $38 \%$ de los enunciados, como:

(131) Tienes que llevar esta comida a la oficina de este cliente.

(132) Tiene que llevar este encargo a esta dirección.

(133) Debes llevar la comida a este cliente. 
Los hablantes malayos, por su parte, manifestaron una mayor tendencia hacia el uso de la estrategia de "Imperativo" (65\%). Estos resultados estadísticos coinciden con los de la situación 3 y apoyan la idea mencionada al analizarla, es decir, la de que los malayos tratan a los empleados de manera más firme y estricta en comparación con los españoles, por su alta sensibilidad hacia el estatus social. En cuanto a la variedad de la estrategia de "Imperativo", más de la mitad de los hablantes malayos (en un 54\% de los casos) emplearon la forma de "Tolong + verbo", por la que coincidieron en mostrar preferencia los sujetos de ambos subgrupos (edad y sexo).

(134) Tolong hantar makanan ni ke pelanggan!

( 'Ayuda llevar comida esta a cliente!/Por favor illeva esta comida al cliente!')

(135) Tolong hantar makanan ke alamat ni!

( ' Ayuda llevar comida a dirección esta/Por favor illeva la comida a esta dirección!')

(136) Tolong hantar tempahan ke pejabat pelanggan!

('Ayuda llevar pedido a oficina cliente/Por favor lleva el pedido a la oficina del cliente) )

Al igual que en la situación 6 , en este contexto los encuestados de ambos grupos también mostraron preferencia por 
empezar sus respuestas con los actos principales en sí mismos. De hecho, la mayoría de las respuestas consistió en la formulación de los actos principales, sin acompañarlos de ningún movimiento de apoyo, como ocurre en los siguientes ejemplos:

Ejemplos españoles:

(137) Tienes que llevar esta comida a un cliente a su oficina.

(138) Tienes que llevar este pedido a la oficina de este cliente.

(139) Tiene que llevar este encargo a la siguiente dirección.

Ejemplos malayos:

(140) Saya mahu awak hantar makanan yang dipesan ini ke pejabat pelanggan.

('Yo querer tú llevar comida que pedida esta a oficina cliente/ Quiero que lleves este pedido de comida a la oficina del cliente )

(141) Hantarkan makanan ini ke alamat ini.

( 'Llevarkan comida esta a dirección esta/illeva esta comida a esta dirección! )

(142) Tolong hantarkan makanan ini ke pejabat tersebut.

( Ayuda llevarkan comida esta a oficina correspondiente/Por favor illeva esta comida a la oficina correspondiente!') 
Al dirigirse a los interlocutores, los participantes de ambos grupos aplicaron en mayor medida el "Nombre de pila", igual que en las situaciones anteriores (en las que se utilizaba en un $89 \%$ y un $80 \%$ de los casos, respectivamente). Cabe mencionar la aparición del "Hipocorístico" como una forma de tratamiento en esta situación, al tratarse de conocidos ( 2 casos en los datos españoles y 3 casos en los malayos). Los datos obtenidos no revelan ninguna diferencia interesante de las pautas seguidas ni entre los informantes mayores y menores, ni entre los varones y mujeres de ninguno de los dos grupos. Acerca del empleo de usted o tú, como era de esperar, el corpus español dejó ver que los hablantes utilizaron mayoritariamente la forma de tú (92\%) al dirigirse al oyente, ya que se trata de un mandato de un jefe a un empleado conocido.

(143) Luis, tienes que llevar un pedido a la oficina de un cliente...

(144) Hola Manuel, mira, hay que llevar esta comida que ha reservado el cliente a su oficina...

(145) Hola Pepe, necesito que hagas un recado. Tienes que enviar el pedido a la oficina del cliente.

En el corpus malayo, por su parte, la forma de awak sigue siendo dominante con un $65 \%$ de casos, seguida de kamu (23\%) y anda (12\%). Tampoco hay diferencias importantes con respecto al uso de las formas pronominales entre los subgrupos españoles, 
mientras que, en el grupo malayo, los informantes mayores aplicaron awak más que los menores (el $30 \%$ de los mayores frente a tan solo un $7 \%$ de los menores) y, las mujeres usaron dicha forma más que los hombres, con un $23 \%$ de casos en comparación con un $13 \%$ de los hombres.

(146) Timah, saya ingin awak hantarkan pesanan makanan kepada pelanggan kita di alamat Wisma Kosma.

('Timah, yo querer tú llevarkan pedida comida a cliente nosotras en dirección Wisma Kosma/Timah, quiero que le lleves el pedido de comida a nuestro cliente en Wisma Kosma')

(147) Ali, tolong hantar pesanan ini ke pejabat sebelah tu.

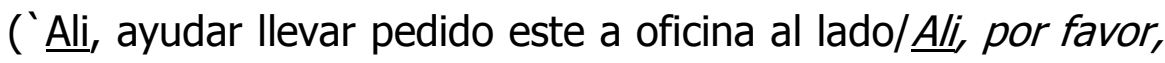
lleva este pedido a la oficina de al lado').

(148) Mat, saya mahu awak hantar makanan ni ke alamat berikut.

('Mat, yo querer tú llevar comida esta a dirección siguiente/Mat, quiero que lleves esta comida a la dirección siguiente').

En esta situación se comprobó un empleo más reducido del verbo en Condicional (solo un 13\%), utilizado para disminuir la imposición del mandato entre los hablantes españoles, en comparación con otras situaciones (excepto en las situaciones 9 y 
18, en las que la comunicación se establece entre familiares). Al analizar las diferencias entre los encuestados de más y menos edad, hubo una ligera diferencia en la frecuencia de uso de la forma mencionada. De todos los verbos en Condicional registrados, los participantes mayores aportaron un 7\% más que los menores, al recurrir a este tiempo verbal en un $17 \%$ de casos, en comparación con el $10 \%$ de los menores. Ocurrió lo mismo en el contraste de las respuestas de los sujetos de los subgrupos de sexo, al optar las mujeres por dicha forma en mayor grado, con un $20 \%$ de casos, frente a solo un $7 \%$ de los hombres.

(149) ¿Estás ocupado? Porque necesitaría que llevaras un encargo a la oficina de uno de nuestros mejores clientes.

(150) X, ¿Podrías llevar la comida de este cliente a su oficina? Gracias.

(151) Necesito que la comida de este cliente llegue a su oficina. ¿Podrías hacerlo?

Por otro lado, en el grupo malayo, se ha notado el aumento del uso del sufijo kan (40\%), cuya función es la de incrementar la intensidad ilocucionaria. Además, aparecen las partículas tak (5 casos) y kah (un caso) que sirven justo para lo contrario, es decir, para minimizar la imposición del mandato. También hubo diferencias entre los subgrupos en el empleo de la 
partícula kan. Son los jóvenes los que más la utilizan, con un porcentaje del $43 \%$ frente al $36 \%$ de los mayores. En la comparación entre subgrupos de sexo, los hombres aplicaron el sufijo kan más que las mujeres (el $47 \%$ de los hombres frente al $33 \%$ de las mujeres). A continuación presentamos algunos ejemplos de uso de cada forma:

(152) Tolong hantarkan pesanan ini kepada pelanggan.

('Ayudar llevarkan pedido este a cliente/Por favor, lleva este pedido al cliente')

(153) Bolehkah anda menghantar makanan yang ditempah pelanggan ke pejabatnya?

('Poderkah usted llevar comida que reservada cliente a oficina su?/¿Puedes llevar la comida reservada por el cliente a su oficina?').

(154) Boleh tak awak tolong saya hantar makanan ini kepada pelanggan kita di pejabatnya?

('Poder no tú ayudar yo llevar comida esta a cliente nosotros en oficina su?/¿Puedes ayudarme a llevar esta comida, a nuestro cliente, a su oficina?')

Para finalizar este punto, hay que subrayar que el $88 \%$ de las expresiones en los mandatos españoles están orientadas hacia el oyente, mientras que el tipo de perspectiva mayoritario en las 
expresiones de los mandatos malayos fue el neutro (un $67 \%$ de los casos). Pese a que todos los subgrupos hayan mostrado preferencia por dicha categoría, fueron los hablantes menores los que prefirieron realizar los mandatos con orientación hacia el oyente en el grupo español (en 27 casos, que representan el $90 \%$ del total, frente a los 26 de los mayores, que sería el $86 \%$ ), y los que seleccionaron en un mayor número de casos los de tipo neutro en el malayo, con 23 enunciados (el 77\% del total) en comparación con los 17 (57\%) de los mayores. En lo que concierne a los subgrupos de sexo en cada cultura, pese a que los dos sexos coincidieran en mostrar preferencia por las perspectivas mencionadas para cada sociedad, fueron los hombres quienes las aplicaron en un porcentaje más alto en comparación con las mujeres $(93 \%$ y $83 \%$ respectivamente, en la cultura española, y $73 \%$ y $60 \%$, respectivamente, en la malaya). Los ejemplos que se presentan a continuación ilustran cada una de las orientaciones mencionadas:

Ejemplos españoles:

(155) Hay un pedido, tienes que llevar este menú al cliente.

(156) ¿Te importa llevar esta comida a la oficina de un cliente?

(157) Debes llevar este pedido a la dirección que aparece en la comanda. 
Ejemplos malayos:

(158) Kita ada tempahan, boleh hantar makanan kepada pelanggan ke pejabatnya?

( Nosotros tener pedido, poder llevar comida a cliente a oficina su?/Tenemos un pedido, ¿puedes llevar la comida al cliente a su oficina?')

(156) Boleh tak tolong hantar makanan ini ke alamat ini?

('Poder o no ayudar llevar comida esta a dirección esta?( ¿Puedes llevar esta comida a esta dirección?')

(157) Boleh tolong hantar makanan ini kepada pelanggan di pejabatnya?

('Poder ayudar llevar comida esta a cliente en oficina su? ( ¿Puedes llevar esta comida al cliente a su oficina?')

\subsubsection{Situación 18}

En este contexto familiar que se les ha proporcionado a los encuestados, y en el que se sitúan como padres frente al hijo/a, a quien tienen que mandarle que se acueste enseguida, hemos hallado que los participantes de España y Malasia coincidieron en revelar una mayor utilización del "Imperativo", pero la preferencia mostrada por parte de los malayos es más alta que la de los españoles, ya que aparece en un $73 \%$ de sus enunciados, frente a un $64 \%$ de los 
españoles. Los ejemplos que aparecen abajo son algunos de los mandatos españoles en los que se utilizó el "Imperativo":

(159) iVete ya a la cama!

(160) iAcuéstate ahora mismo!

(161) iApaga la tele, y a dormir!

Con respecto al empleo del "Imperativo" en los sujetos malayos, la forma dominante fue la del Verbo (en un $52 \%$ de los casos), es decir, el uso del verbo sin ninguna partícula, ni sufijo ni el verbo tolong.

(162) Masuk tidur!

('Entrar dormir!/iVete a la cama!')

(163) Tutup tv!

('Apagar tv!/ iApaga la tele!')

(164) Tidur sekarang!

(`Dormir ahora!/ iDuérmete ya!’)

Al igual que ocurrió en la situación anterior, los españoles estudiados iniciaron sus mandatos con los actos principales en sí mismos. Los malayos por otra parte, prefirieron empezar sus mandatos utilizando la estrategia de "Fórmulas de preparación", y también por los actos principales en sí mismos. 
Ejemplos españoles:

(165) iVete a la cama o este fin de semana te quedas en casa!

(166) iDeja de ver la tele y vete a la cama!

(167) iAcuéstate ahora mismo!

Ejemplos malayos:

(168) Pergi tidur sekarang! hari sudah lewat malam.

('Ir dormir ahora! Día ya tarde noche/iDuérmete ya! es tardísimo')

(169) Tutup televisyen dan masuk tidur!

(`Apagar televisión y entrar dormir!/iApaga la tele y vete a la cama! $!^{\prime}$

(170) Dah pukul berapa ni? Masuk tidur sekarang, esok nak sekolah.

('Ya hora cuánto este? Entrar dormir ahora, mañana querer colegio/¿̨ué hora es ya? Vete a la cama ya, que mañana tendrás que ir clase').

En cuanto a las fórmulas de tratamiento, el aspecto más llamativo tiene que ver con el uso de un "Término afectivo" para dirigirse a los interlocutores, que se registró solamente en el corpus malayo en un $13 \%$ de los casos. También se encontraron ejemplos de uso de un "Término de parentesco" en ambas culturas, con un $7 \%$ de casos en la española y un $30 \%$ en la otra. Ahora bien, al tratarse de un mandato por parte de unos padres a su hijo, era de 
esperar la utilización frecuente del "Nombre de pila", tanto entre los informantes españoles como entre los malayos (se emplea en el $81 \%$ de casos en los datos españoles y en el $50 \%$ en los malayos), y no se ha encontrado ningún caso de la aplicación de usted en el material español, pero en el malayo se recogieron dos casos de uso de kamu. Así pues, no se han hallado variaciones importantes en el empleo de las fórmulas de tratamiento ni nominales ni pronominales entre los subgrupos comparados, de edad y sexo, en las dos sociedades. Aun así, nos parece interesante mencionar que en el grupo malayo, el uso de un "Término afectivo" solo apareció en los datos de los hombres mayores y los de las mujeres menores (50\% de casos en cada uno), pero ningún hombre joven ni mujer mayor usó ninguno. Por otro lado, los "Términos de parentesco" se registraron en el $53 \%$ de los enunciados del corpus de las mujeres mayores. Cabe citar algunos ejemplos de respuesta en los que se aplican las formas mencionadas:

Ejemplos españoles:

(171) Miguel, tienes que dormir, no te acuestes tan tarde.

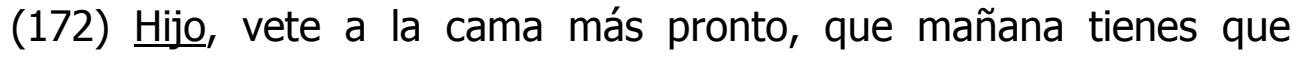
madrugar y no hay quien te levante.

(173) Manuel, ya es tarde, es hora de irse a descansar que mañana hay que ir a clase. 
Ejemplos malayos:

(174) Adam, dah lah tengok tv, dah lewat malam, esok nak sekolah ( Adam, basta ya mirar tv, ya tarde noche, mañana querer colegio/Adam, basta ya de tele, ya es tardísimo, mañana tendrás que ir a clase )

(175) Along, masuk tidur, esok sekolah. Nanti lambat pergi sekolah. ('Along, entrar dormir, mañana colegio. Luego tarde ir colegio/Along, vete a la cama, mañana tienes clase y vas a llegar tarde')

(176) Masuk tidur cepat sayang, hari dah larut malam. Nanti susah nak bangun subuh.

('Entrar dormir pronto cariño, día ya muy noche. Luego difícil querer levantarse madrugada/Vete ya a la cama cariño, ya es tardísimo, que luego cuesta mucho madrugar')

Al examinar el cambio del verbo a la forma del Condicional para reducir la fuerza del acto de habla, hemos hallado solamente un caso en los datos españoles, por lo que resulta irrelevante mencionar las diferencias entre los subgrupos. Por otro lado, en los datos malayos, se ha encontrado en un $93 \%$ de los casos la partícula lah y un caso de tak. Con respecto a la utilización de la partícula lah, fue notable la diferencia en la frecuencia con la que la usaron los hablantes de los distintos subgrupos de edad, ya que los participantes mayores la emplearon en un $20 \%$ más de ocasiones 
que los menores (está en un 33\% de los enunciados de los mayores frente al $13 \%$ de los menores). De los resultados obtenidos en el análisis de datos según el subgrupo de sexo, se deduce que fueron los hombres los que utilizaron en mayor medida dicha partícula, con un $27 \%$ de casos, en comparación con un $20 \%$ de las mujeres.

El único uso de Condicional en los datos españoles es el que aparece en el siguiente ejemplo:

(177) Pablo, deberías irte a la cama. Mañana entras a las 8 y media.

Ejemplos malayos:

(178) Pergilah masuk tidur, esokkan sekolah.

(`Irlah entrar dormir, mañanakan colegio/Vete a la cama, mañana tienes clase')

(179) Sudahlah menonton televisyen tu. Dah malam ni, esok sekolah.

('Dejarlah mirar televisión ese. Ya noche esta, mañana colegio/Deja ya la tele. Ya es tarde, mañana tienes clase')

(180) Mak rasa kesihatan itu penting. Boleh tak kakak masuk tidur untuk rehat yang cukup?

('Madre creer salud esa importante. Poder no hermana mayor entrar dormir para descanso que suficiente?/Creo que la salud es importante. ¿Puedes irte a la cama para que descanses lo suficiente?') 
Finalmente, en relación con la perspectiva de la persona, al igual que en el resto de las situaciones, excepto en la 12 , los españoles siguieron utilizando expresiones de mandato orientadas hacia el oyente, y así lo hicieron en 49 casos (el $82 \%$ del total), mientras que los malayos prefirieron el tipo neutro, que utilizaron en 42 casos (70\%). Según nuestros datos, no hubo diferencias llamativas en el caso de los subgrupos de edad españoles, pero en los de sexo sí se ven diferencias notables. Así, vemos que las mujeres optaron por dicha orientación más que los hombres, con un porcentaje del $90 \%$ frente a un $73 \%$ de los hombres. $Y$ ocurrió al revés en el corpus malayo, donde los hablantes de más edad aplicaron la perspectiva neutro con una mayor frecuencia que los jóvenes (en el $73 \%$ de los enunciados, y en el $66 \%$, respectivamente), $y$, en los subgrupos de sexo, fueron los hombres los que mostraron mayor tendencia hacia dicha categoría, que utilizaron en el $73 \%$ de los casos, frente al $66 \%$ de los enunciados de las mujeres en los que aparece.

Ejemplos españoles:

(181) Vete a la cama o mañana no ves la tele o te quedas sin paga.

(182) iApaga la tele y vete a la cama!

(183) Tienes que dormir, no te acuestes tan tarde. 
Ejemplos malayos:

(184) Ok, tutup tv dan masuk tidur. Dah lewat dan esok nak sekolah.

( Vale, apagar tv y entrar dormir. Ya tarde y mañana querer colegio/Vale, apaga la tele y vete a la cama. Ya es tarde y mañana tienes que ir a clase')

(185) Dah lewat. Masuk tidur. Nanti besok bangun lewat pulak nak ke sekolah.

('Ya tarde. Entrar dormir. Luego mañana levantarse tarde también querer a colegio/Ya es tarde. Vete a la cama, que mañana vas a levantarte tarde para ir al clase')

(186) Ni malam sekolah. Baik masuk tidur cepat, nanti mengantuk dalam kelas.

('Esta noche colegio. Mejor entrar dormir pronto, luego tener sueño en clase/Mañana es día de escuela. Mejor te vas a la cama pronto, que luego vas a tener sueño en clase') 


\subsection{Conclusión}

Si en el caso de la petición los informantes de ambas sociedades mostraron preferencia por el uso de las estrategias "Convencionalmente indirectas", en el mandato, ambos grupos, españoles y malayos, revelaron una mayor tendencia a realizarlo a través de las estrategias directas. Así, se aprecia que, mientras que la estrategia común de los actos principales en ambos países al formular peticiones fue la de "Interrogación preparatoria", las respuestas dadas por los hablantes analizados de las dos lenguas se concentraron en el "Imperativo" en la formulación de los mandatos.

Pese a que las dos comunidades de habla examinadas coincidieran en mostrar preferencia por el uso del "Imperativo" al hacer mandatos, llama la atención la alta frecuencia con la que se presenta en el corpus malayo, con 145 casos, que corresponden al $40 \%$ del total, en comparación con los 94 casos (26\%) del corpus español. Son, así pues, resultados que contrastan con los obtenidos en el contexto de la petición, en el que los informantes españoles emplearon el "Imperativo" en una proporción más elevada que los malayos ( $13 \%$ y $9 \%$, respectivamente).

Si analizamos las diferencias entre los sujetos mayores y los jóvenes teniendo en cuenta solamente la estrategia de 
"Imperativo", vemos que los jóvenes de ambos países la usaron con mayor frecuencia en comparación con los mayores. Asimismo, las diferencias en la frecuencia con la que recurren al "Imperativo" hombres y mujeres, nos revelan que los varones de las dos sociedades utilizaron dicha estrategia más que las mujeres. Ahora bien, si examinamos las diferencias entre los dos subgrupos prestando atención a las estrategias "Directas" en general, los resultados también revelan lo mismo, excepto al contrastar las respuestas de los sujetos de los subgrupos de sexo malayos, donde nos sorprende que las mujeres recurrieran a ellas en mayor medida que los hombres.

En la utilización de los movimientos de apoyo por parte de los dos grupos, hemos hallado que en la formulación de los mandatos, en comparación con el empleo que se hizo de ellos en el caso de la petición, hay una reducción del $21 \%$ en su frecuencia en el material español, y del $46 \%$ en el malayo. Y también a diferencia de lo visto en el acto de petición, en el que los españoles usaron menos movimientos de apoyo que los malayos, en el caso de mandatos, fueron los malayos los que aplicaron movimientos de apoyo con menor frecuencia que los españoles. De todo ello, se puede concluir que los españoles fueron más directos que los malayos al hacer petición, ya que aplicaron más estrategias "Directas" y menos movimientos de apoyo que los del otro grupo, 
pero, al formular los mandatos parece que fueron más directos los malayos, por una mayor utilización de las estrategias "Directas" y menos movimientos de apoyo que los españoles. Con respecto a los subgrupos, los jóvenes de los dos países fueron más directos que los mayores, y los hombres del grupo español más directos que las mujeres, ya que emplearon más estrategias "Directas" y menos movimientos de apoyo que sus contrarios, tanto en las peticiones como en los mandatos. Ahora bien, en el grupo malayo, fueron las mujeres las que se mostraron más directas que los hombres, puesto que aplicaron con mayor frecuencia las estrategias "Directas".

Los participantes malayos tendieron a utilizar solo un movimiento de apoyo o a prescindir de ellos. La complejidad de los mandatos de los sujetos malayos fue mínima. Un mandato típico de este grupo consiste solo en el acto principal o el acto principal con un movimiento de apoyo. Como era de esperar, los jóvenes mostraron una mayor preferencia por hacer su mandato solo con el acto principal, en comparación con los sujetos mayores, y los hombres mostraron mayor tendencia que las mujeres hacia este recurso. Aunque el uso de los movimientos de apoyo en los datos españoles tampoco fue destacado, sí que fue mayor que en los malayos.

Según los resultados obtenidos en lo referente a la estrategia de "Fórmula de sugerencia" (acto principal), los españoles 
fueron más específicos y tendieron a dar más detalles en sus respuestas, mientras que las respuestas malayas fueron más genéricas y vagas. Los resultados del empleo de la estrategia de "Razones" (movimiento de apoyo), también lo confirman, ya que las razones dadas por los españoles fueron más determinadas en comparación con las malayas, que fueron más ambiguas.

En lo que concierne a las modificaciones internas, es decir, a los contenidos de los actos principales o los mandatos en sí mismos, nos parece que los encuestados de ambos grupos no hicieron grandes modificaciones, puesto que en este caso (el de mandato) se sitúan en una posición superior frente a los interlocutores. Como es bien sabido el mandato es un acto que solo realizan las personas superiores a las inferiores o los que tienen autoridad, como los padres, los profesores y los jefes, a los que están bajo su responsabilidad. Sin embargo hay algunas diferencias entre los españoles y los malayos en este caso por la gran diferencia existente en los recursos gramaticales, dado que en malayo el verbo solo tiene la forma de Presente de Indicativo e Infinitivo, sin conjugación temporal o modo. Aun así, sí que se ha notado el uso de partículas y sufijos en los datos malayos para modificar los mandatos. 
Con respecto a la cuestión de cuáles son las formas que usaron los encuestados al dirigirse a sus interlocutores a la hora de hacer mandatos, el análisis nos revela que tanto los españoles como los malayos aplicaron frecuentemente el "Nombre de pila", y el pronombre informal tú (en el español) y awak (en el malayo), cuando se dirigieron a sus oyentes. Pese a que los subgrupos comparados de edad y sexo mostraran preferencia por el uso de dichas formas, fueron los mayores los que las emplearon en mayor medida en comparación con los menores y, también los hombres los que las usaron con mayor frecuencia que las mujeres, en cada grupo.

Los informantes de los dos países se diferenciaron en orientar sus mandatos hacia el hablante u oyente o los dos o nadie (neutro). Los españoles tendieron a orientar sus mandatos al oyente, mientras que los mandatos malayos fueron de tipo neutro. No hubo diferencias importantes entre los subgrupos comparados en ambas culturas, ya que tanto los informantes mayores como los menores, y tanto los hombres como las mujeres, mostraron tendencia hacia la misma orientación.

El resultado estadístico del análisis de la influencia de la distancia social en la elección de las estrategias de mandato revela que, en los casos de una gran distancia social entre los 
interlocutores, los participantes tendieron a realizar el mandato a través de las estrategias "Convencionalmente indirectas", mientras que, con una distancia social corta, los nativos prefirieron formular el mandato utilizando las "Directas", seguidas de las "No convencionalmente indirectas". Así pues, los sujetos de ambos grupos y de todos los subgrupos examinados mostraron cierta coincidencia en sus respuestas en este contexto, por lo que las diferencias entre ellos resultan insignificantes.

Como conclusión a este capítulo, sumamos los resultados principales de los datos del mandato en las tablas que siguen:

Tabla 64. Resultados principales de los datos del mandato en el caso de español frente a malayo

\begin{tabular}{|c|c|c|c|c|}
\hline Análisis & Artículos & Detalles & Español & Malayo \\
\hline \multirow{7}{*}{ Cuantitativo } & \multirow{2}{*}{ Frecuencia } & $\mathrm{AP}$ & \multicolumn{2}{|c|}{ Similar } \\
\hline & & $\mathrm{MA}$ & Más & Menos \\
\hline & \multicolumn{2}{|c|}{ (In)dirección } & Menos directas & Más directas \\
\hline & \multirow{2}{*}{$\begin{array}{l}\text { Estrategia } \\
\text { más usada }\end{array}$} & AP & \multicolumn{2}{|c|}{ Imperativo } \\
\hline & & MA & $\begin{array}{l}\text { Fórmulas de } \\
\text { preparación }\end{array}$ & Razones \\
\hline & \multirow{2}{*}{ Distancia social } & Corta & \multicolumn{2}{|c|}{ Estrategias directas } \\
\hline & & Larga & \multicolumn{2}{|c|}{ Convencionalmente indirectas } \\
\hline \multirow{6}{*}{ Cualitativo } & \multirow{4}{*}{$\begin{array}{c}\text { Modificaciones } \\
\text { internas }\end{array}$} & $\begin{array}{c}\text { Fórmulas } \\
\text { nominales }\end{array}$ & \multicolumn{2}{|c|}{ Nombre de pila } \\
\hline & & $\begin{array}{c}\text { Fórmulas } \\
\text { pronominales }\end{array}$ & Tú & Awak \\
\hline & & $\begin{array}{l}\text { Modificación } \\
\text { sintáctica }\end{array}$ & \multicolumn{2}{|c|}{ Mínima } \\
\hline & & Orientación & Oyente & Neutro \\
\hline & \multicolumn{2}{|c|}{ Contenido } & $\begin{array}{c}\text { Específico y } \\
\text { detallado }\end{array}$ & Genérico y vago \\
\hline & \multicolumn{2}{|c|}{ Estructura } & $M A+A P+M A$ & $\mathrm{MA}+\mathrm{AP}$ \\
\hline
\end{tabular}

$\mathrm{AP}=$ Acto Principal

$\mathrm{MA}=$ Movimiento de Apoyo 
Tabla 65. Resultados principales de los datos del mandato en el caso de participante mayor frente a joven

\begin{tabular}{|c|c|c|c|c|}
\hline \multicolumn{5}{|c|}{ Español } \\
\hline Análisis & Artículos & Detalles & Mayor & Joven \\
\hline \multirow{7}{*}{ Cuantitativo } & \multirow{2}{*}{ Frecuencia } & $\mathrm{AP}$ & \multicolumn{2}{|c|}{ Similar } \\
\hline & & MA & Más & Menos \\
\hline & \multicolumn{2}{|c|}{ (In)dirección } & Menos directa & Más directa \\
\hline & \multirow{2}{*}{$\begin{array}{l}\text { Estrategia } \\
\text { más usada }\end{array}$} & AP & $\begin{array}{l}\text { Fórmula de } \\
\text { sugerencia }\end{array}$ & Imperativo \\
\hline & & MA & $\begin{array}{l}\text { Fórmulas de } \\
\text { preparación }\end{array}$ & $\begin{array}{l}\text { Fórmulas de } \\
\text { tratamiento }\end{array}$ \\
\hline & \multirow{2}{*}{ Distancia social } & Corta & \multicolumn{2}{|c|}{ Estrategias directas } \\
\hline & & Larga & \multicolumn{2}{|c|}{ Convencionalmente indirectas } \\
\hline \multirow{6}{*}{ Cualitativo } & \multirow{4}{*}{$\begin{array}{l}\text { Modificaciones } \\
\text { internas }\end{array}$} & $\begin{array}{c}\text { Fórmulas } \\
\text { nominales } \\
\end{array}$ & $\begin{array}{c}\text { Más nombre de } \\
\text { pila }\end{array}$ & $\begin{array}{c}\text { Menos nombre } \\
\text { de pila }\end{array}$ \\
\hline & & $\begin{array}{c}\text { Fórmulas } \\
\text { pronominales }\end{array}$ & Más tú & Menos tú \\
\hline & & $\begin{array}{c}\text { Modificación } \\
\text { sintáctica }\end{array}$ & \multicolumn{2}{|c|}{ Mínima } \\
\hline & & Orientación & \multicolumn{2}{|c|}{ Oyente } \\
\hline & \multicolumn{2}{|c|}{ Contenido } & $\begin{array}{c}\text { Más específico y } \\
\text { detallado }\end{array}$ & $\begin{array}{c}\text { Menos } \\
\text { específico y } \\
\text { detallado }\end{array}$ \\
\hline & \multicolumn{2}{|c|}{ Estructura } & $\mathrm{MA}+\mathrm{AP}+\mathrm{MA}$ & $M A+A P+M A$ \\
\hline
\end{tabular}

$\mathrm{MA}=$ Movimiento de Apoyo

\begin{tabular}{|c|c|c|c|c|}
\hline \multicolumn{5}{|c|}{ Malayo } \\
\hline Análisis & Artículos & Detalles & Mayor & Joven \\
\hline \multirow{7}{*}{ Cuantitativo } & \multirow{2}{*}{ Frecuencia } & $\mathrm{AP}$ & \multicolumn{2}{|c|}{ Similar } \\
\hline & & MA & Más & Menos \\
\hline & \multicolumn{2}{|c|}{ (In)dirección } & Menos directa & Más directa \\
\hline & \multirow{2}{*}{$\begin{array}{l}\text { Estrategia } \\
\text { más usada }\end{array}$} & AP & \multicolumn{2}{|c|}{ Imperativo } \\
\hline & & MA & \multicolumn{2}{|c|}{ Razones } \\
\hline & \multirow{2}{*}{ Distancia social } & Corta & \multicolumn{2}{|c|}{ Estrategias directas } \\
\hline & & Larga & \multicolumn{2}{|c|}{ Convencionalmente indirectas } \\
\hline \multirow{6}{*}{ Cualitativo } & \multirow{4}{*}{$\begin{array}{l}\text { Modificaciones } \\
\text { internas }\end{array}$} & $\begin{array}{c}\text { Fórmulas } \\
\text { nominales }\end{array}$ & $\begin{array}{c}\text { Menos nombre } \\
\text { de pila }\end{array}$ & $\begin{array}{c}\text { Más nombre de } \\
\text { pila }\end{array}$ \\
\hline & & $\begin{array}{c}\text { Fórmulas } \\
\text { pronominales }\end{array}$ & Menos awak & Más awak \\
\hline & & $\begin{array}{c}\text { Modificación } \\
\text { sintáctica }\end{array}$ & \multicolumn{2}{|c|}{ Mínima } \\
\hline & & Orientación & \multicolumn{2}{|c|}{ Neutro } \\
\hline & \multicolumn{2}{|c|}{ Contenido } & \multicolumn{2}{|c|}{ Genérico y vago } \\
\hline & \multicolumn{2}{|c|}{ Estructura } & $M A+A P+M A$ & $\mathrm{AP}$ \\
\hline
\end{tabular}

AP $=$ Acto Principal

$\mathrm{MA}=$ Movimiento de Apoyo 
Tabla 66. Resultados principales de los datos del mandato en el caso de hombre frente a mujer

\begin{tabular}{|c|c|c|c|c|}
\hline \multicolumn{5}{|c|}{ Español } \\
\hline Análisis & Artículos & Detalles & Hombre & Mujer \\
\hline \multirow{7}{*}{ Cuantitativo } & \multirow{2}{*}{ Frecuencia } & $\mathrm{AP}$ & \multicolumn{2}{|c|}{ Similar } \\
\hline & & MA & Menos & Más \\
\hline & \multicolumn{2}{|c|}{ (In)dirección } & Más directa & Menos directa \\
\hline & \multirow{2}{*}{$\begin{array}{l}\text { Estrategia } \\
\text { más usada }\end{array}$} & AP & \multicolumn{2}{|c|}{ Imperativo } \\
\hline & & MA & $\begin{array}{l}\text { Fórmulas de } \\
\text { preparación }\end{array}$ & Razones \\
\hline & \multirow{2}{*}{ Distancia social } & Corta & \multicolumn{2}{|c|}{ Estrategias directas } \\
\hline & & Larga & \multicolumn{2}{|c|}{ Convencionalmente indirectas } \\
\hline \multirow{6}{*}{ Cualitativo } & \multirow{4}{*}{$\begin{array}{c}\text { Modificaciones } \\
\text { internas }\end{array}$} & $\begin{array}{l}\text { Fórmulas } \\
\text { nominales }\end{array}$ & $\begin{array}{l}\text { Más nombre de } \\
\text { pila }\end{array}$ & $\begin{array}{c}\text { Menos } \\
\text { nombre de } \\
\text { pila }\end{array}$ \\
\hline & & $\begin{array}{c}\text { Fórmulas } \\
\text { pronominales }\end{array}$ & Más tú & Menos tú \\
\hline & & $\begin{array}{l}\text { Modificación } \\
\text { sintáctica }\end{array}$ & \multicolumn{2}{|c|}{ Mínima } \\
\hline & & Orientación & \multicolumn{2}{|c|}{ Oyente } \\
\hline & \multicolumn{2}{|c|}{ Contenido } & $\begin{array}{c}\text { Menos específico } \\
\text { y detallado }\end{array}$ & $\begin{array}{c}\text { Más específico } \\
\text { y detallado }\end{array}$ \\
\hline & \multicolumn{2}{|c|}{ Estructura } & $M A+A P+M A$ & $M A+A P+M A$ \\
\hline
\end{tabular}

\begin{tabular}{|c|c|c|c|c|}
\hline \multicolumn{5}{|c|}{ Malayo } \\
\hline Análisis & Artículos & Detalles & Hombre & Mujer \\
\hline \multirow{7}{*}{ Cuantitativo } & \multirow{2}{*}{ Frecuencia } & $\mathrm{AP}$ & \multicolumn{2}{|c|}{ Similar } \\
\hline & & $\mathrm{MA}$ & Menos & Más \\
\hline & \multicolumn{2}{|c|}{ (In)dirección } & Menos directa & Más directa \\
\hline & \multirow{2}{*}{$\begin{array}{l}\text { Estrategia } \\
\text { más usada }\end{array}$} & AP & \multicolumn{2}{|c|}{ Imperativo } \\
\hline & & MA & Razones & $\begin{array}{l}\text { Fórmulas de } \\
\text { tratamiento }\end{array}$ \\
\hline & \multirow{2}{*}{ Distancia social } & Corta & \multicolumn{2}{|c|}{ Estrategias directas } \\
\hline & & Larga & \multicolumn{2}{|c|}{ Convencionalmente indirectas } \\
\hline \multirow{6}{*}{ Cualitativo } & \multirow{4}{*}{$\begin{array}{l}\text { Modificaciones } \\
\text { internas }\end{array}$} & $\begin{array}{c}\text { Fórmulas } \\
\text { nominales }\end{array}$ & $\begin{array}{c}\text { Menos nombre } \\
\text { de pila }\end{array}$ & $\begin{array}{c}\text { Más nombre } \\
\text { de pila }\end{array}$ \\
\hline & & $\begin{array}{c}\text { Fórmulas } \\
\text { pronominales }\end{array}$ & Menos awak & Más awak \\
\hline & & $\begin{array}{c}\text { Modificación } \\
\text { sintáctica }\end{array}$ & \multicolumn{2}{|c|}{ Mínima } \\
\hline & & Orientación & \multicolumn{2}{|c|}{ Neutro } \\
\hline & \multicolumn{2}{|c|}{ Contenido } & Más genérico & $\begin{array}{c}\text { Menos } \\
\text { genérico }\end{array}$ \\
\hline & \multicolumn{2}{|c|}{ Estructura } & $\mathrm{AP}$ & $\mathrm{MA}+\mathrm{AP}$ \\
\hline
\end{tabular}


Finalmente, concluimos que los mandatos realizados por los participantes españoles fueron directos (pero menos que los de los malayos), con una orientación más hacia el oyente, las expresiones fueron más específicas y detalladas, fueron sensibles a la distancia social y tenían la estructura común de "Movimiento de apoyo + acto principal + movimiento de apoyo". Los mandatos malayos, por su parte, fueron más directos que los españoles, tenían una perspectiva neutra, se expresaron de manera más genérica y vaga, también fueron sensibles a la distancia social (pero menos que los de los españoles), y la estructura típica fue "Movimientos de apoyo + acto principal".

Respecto a los resultados obtenidos en la comparación de la formulación de mandatos entre los subgrupos de edad, los datos recogidos demuestran que los mayores españoles fueron menos directos que los jóvenes, ya que tendieron a realizar sus mandatos a través de la estrategia de "Fórmula de sugerencia", en comparación con los jóvenes que prefirieron formular su mandato mediante la de "Imperativo". Además, sus mandatos fueron más específicos y detallados que los de los jóvenes, aunque la estructura general aplicada por los participantes de los dos subgrupos fue similar: "Movimientos de apoyo + acto principal + movimientos de apoyo". 
Por otro lado, los mayores malayos también fueron menos directos que los jóvenes, aunque los hablantes de los dos subgrupos optaron por formular sus mandatos a través de la estrategia de "Imperativo". El nivel de precisión de sus mandatos fue similar en las respuestas de los dos subgrupos, es decir, todas fueron genéricas y vagas, sin embargo, se diferenciaron en la estructura mayoritaria que, en el caso de los mayores fue "Movimientos de apoyo + acto principal + movimientos de apoyo", mientras que la de los jóvenes consistió solo en el acto principal.

Para finalizar este punto, diremos que pese a que los hombres y las mujeres mostraran preferencia por la estrategia de "Imperativo", los hombres fueron más directos que las mujeres, ya que utilizaron menos movimientos de apoyo, y sus expresiones fueron menos específicas y menos detalladas en comparación con las de aquellas. Ahora bien, la estructura común de los mandatos formulados por los sujetos de ambos sexos fue parecida, es decir, "Movimientos de apoyo + acto principal+ movimientos de apoyo".

En el caso de los subgrupos de sexo malayos, ocurrió al contrario: aunque ambos sexos recurrieron al "Imperativo" como estrategia dominante, los mandatos de las mujeres fueron más directos que los de los hombres, a causa de la cantidad de variantes de estrategias directas aplicadas por ellas, frente a los hombres. Aun 
así, las respuestas dadas por las mujeres fueron menos genéricas que las de los hombres, y la estructura general de sus mandatos fue "Movimientos de apoyo + acto principal", en contraste con la de los hombres, que solo contenía el propio acto principal. 


\section{CAPÍTULO 6}

\section{RESULTADOS Y ANÁLISIS DE DATOS SOBRE EL RECHAZO}

En este capítulo se hará una presentación cuantitativa y un análisis cualitativo de los datos obtenidos a partir de los contextos propuestos en el test de rellenado de discurso para la expresión del rechazo, que fueron proporcionados por 60 hablantes nativos españoles y otros tantos malayos. La organización del capítulo va a ser la misma que la que empleamos en el caso del análisis del acto de habla de petición (véase el capítulo 4) y de mandato (capítulo 5). Ahora bien, en este caso, la clasificación de las respuestas obtenidas en el cuestionario, se hizo a partir del esquema de tipos de estrategia de rechazo establecidos por Beebe at al. (1990), expuesto en el capítulo 3. Los datos fueron analizados en términos de frecuencia, orden, contenido y estructura de las estrategias empleadas por los encuestados. 


\subsection{Análisis cuantitativo}

Esta sección comienza presentando el análisis total de las estrategias utilizadas por los participantes en la producción de actos de habla de rechazo. Posteriormente, se mostrará el análisis de las estrategias aplicadas en cada situación individual, y, finalmente, se expondrá la influencia de las variables sociales tenidas en cuenta en este estudio en la expresión del rechazo en cada grupo.

\subsubsection{Análisis general}

De manera similar a como hemos procedido en los dos capítulos anteriores, llevaremos a cabo nuestro análisis comparando los datos desde tres puntos de vista: las distintas culturas (española versus malaya), las diferentes edades (mayor versus joven), y los distintos sexos (varón versus mujer).

\subsubsection{Español frente a malayo}

El estudio revela que, en total, los españoles utilizaron menos estrategias que los malayos. Encontramos 1.044 fórmulas utilizadas en los rechazos españoles por 1.204 utilizadas en los malayos. La 
figura que presentamos a continuación, muestra el nivel de frecuencia de uso de las tres principales categorías establecidas en la presente investigación, para la clasificación de las estrategas de rechazo.

Figura 173. Distribución de enunciados producidos como "Rechazo directo", "Rechazo indirecto" y "Adyacentes al rechazo" en cada cultura

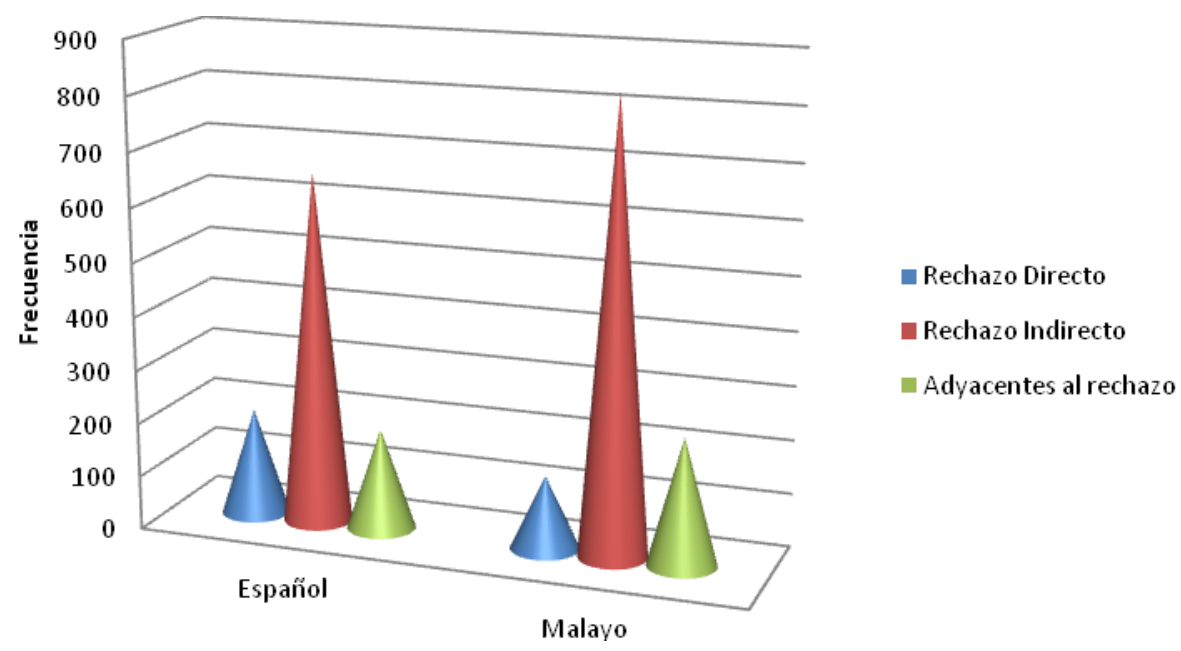

En primer lugar, vamos a examinar el patrón que expusieron los encuestados en el empleo de los "Rechazos directos". Como se aprecia en el resultado presentado en el gráfico, pese a que ambos grupos mostraran preferencia por dicha categoría, fueron los encuestados españoles los que más recurrieron a ella, con un número de enunciados de 199 frente a los 136 de los malayos. 
En segundo lugar, es relevante la diferencia estadística existente entre los grupos con relación a las estrategias indirectas. En este caso fueron los encuestados malayos los que prefirieron el uso de "Rechazos indirectos" y con una diferencia mayor (831 ejemplos de los malayos frente a 657 de los españoles). Y en el último caso, el de "Adyacentes al rechazo", fueron los encuestados malayos los que más los utilizaron (237 casos frente a los 188 de los españoles). La diferencia entre los promedios de las categorías aplicadas fue significativa: $X^{2}=26.591 p=.000(p<.05)$.

Se identificaron veintidós tipos de estrategias diferentes para expresar rechazo a través de seis situaciones, entre los grupos malayo y español. Como se ha descrito en la sección anterior, todas ellas constituyen subdivisiones de los tres grandes bloques de estrategias los que nos hemos referido antes (directas, indirectas y adyacentes al rechazo).

En las siguientes gráficas presentamos la distribución de frecuencia de uso de todas las estrategias utilizadas por los dos grupos de encuestados en la presente investigación. 
Tabla 67. Frecuencia de las estrategias utilizadas por los informantes en las dos sociedades

\begin{tabular}{|c|c|c|}
\hline Estrategias & Español & Malayo \\
\hline Rechazo Directo & 199 & 136 \\
\hline No & 13 & - \\
\hline Buena voluntad/capacidad negativa & 186 & 136 \\
\hline Rechazo Indirecto & 657 & 831 \\
\hline Disculpa & 143 & 249 \\
\hline Deseo & 8 & 2 \\
\hline Excusa & 250 & 315 \\
\hline Declaración de alternativa & 82 & 80 \\
\hline $\begin{array}{l}\text { Conjunto de condiciones para la aceptación } \\
\text { pasada/futura }\end{array}$ & 10 & 26 \\
\hline Declaración de principios & 40 & 27 \\
\hline $\begin{array}{l}\text { Amenaza o declaración de consecuencias negativas para } \\
\text { el emisor }\end{array}$ & 14 & 20 \\
\hline Declaración de sentimiento negativo & 32 & 20 \\
\hline Petición de comprensión & 27 & 21 \\
\hline Garantía de satisfacción futura del interlocutor & 10 & 13 \\
\hline Autodefensa & 24 & 42 \\
\hline Repetición de parte de la petición & 6 & 9 \\
\hline Aplazamiento & 6 & 6 \\
\hline Evasivas & 5 & 1 \\
\hline Adyacentes al rechazo & 188 & 237 \\
\hline Declaración de opinión/sentimiento positivo & 21 & 19 \\
\hline Declaración de empatía & 8 & 1 \\
\hline Uso de muletillas & 34 & 17 \\
\hline Agradecimiento & 49 & 13 \\
\hline Fórmulas de tratamiento & 68 & 187 \\
\hline Saludos/despedidas corteses & 8 & - \\
\hline Total & 1044 & 1204 \\
\hline
\end{tabular}


Figura 174. Distribución total de cada estrategia utilizada por los sujetos de las dos culturas en las seis situaciones

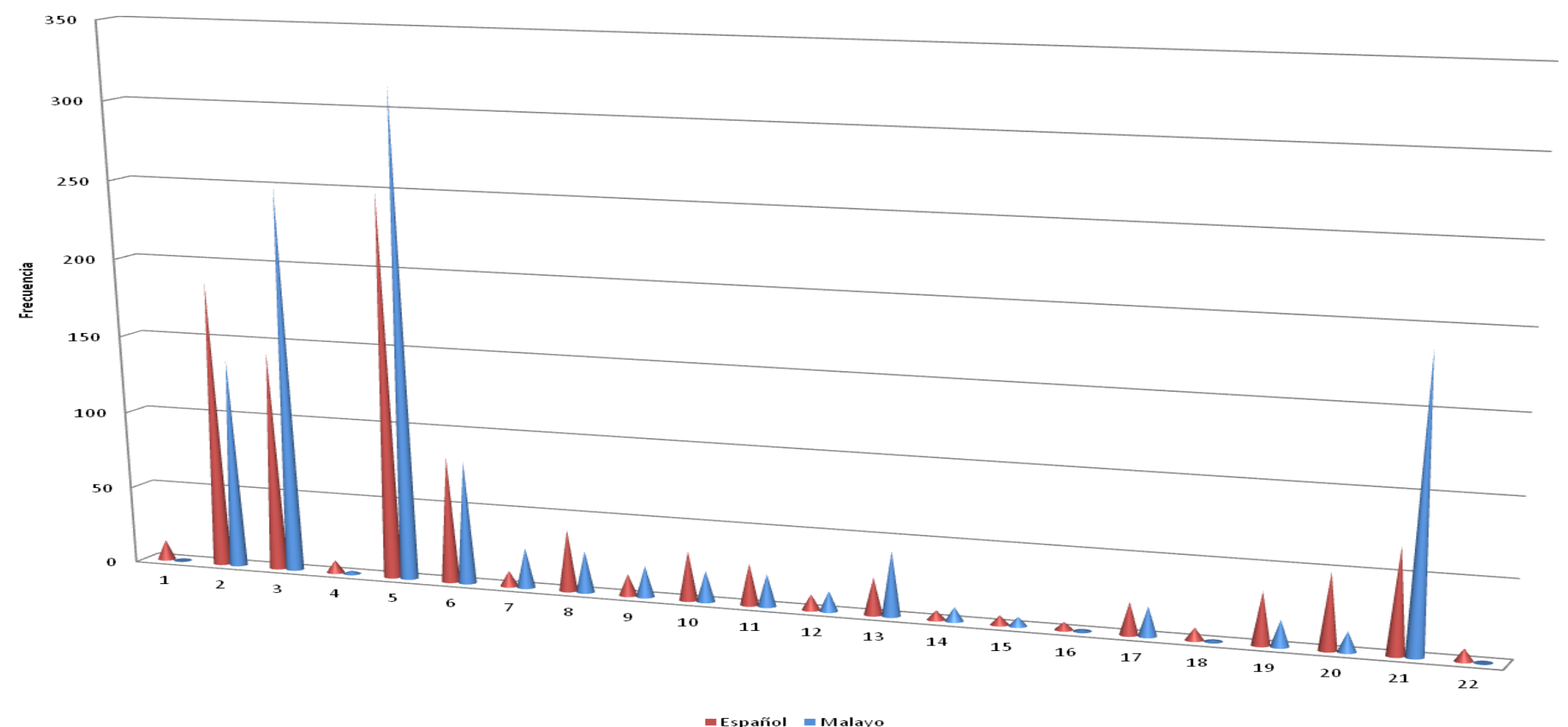

1: No 2: Buena voluntad/capacidad negativa 3: Disculpa 4: Deseo 5: Excusa 6: Declaración de alternativa 7: Conjunto de condiciones para la aceptación pasada/futura 8: Declaración de principios 9: Amenaza o declaración de consecuencias negativas para el emisor 10: Declaración de sentimiento negativo 11: Petición de comprensión 12: Garantía de satisfacción futura del interlocutor 13: Autodefensa 14: Repetición de parte de la petición 15: Aplazamiento 16: Evasivas 17: Declaración de opinión/sentimiento positivo 18: Declaración de empatía 19: Uso de muletillas 20: Agradecimiento 21: Fórmulas de tratamiento 22: parte de la petición 15: Apla
Saludos/despedidas corteses 
Los españoles aplicaron 22 tipos de estrategias diferentes en su formulación de rechazo mientras que los malayos emplearon solo 20 estrategias diferentes. Hay algunas estrategias que se presentan en los datos españoles, pero no se encuentran en los datos malayos, como "No" y "Saludos/despedidas corteses". Sin embargo, todas las estrategias encontradas en los datos malayos, están también presentes en los datos españoles.

Ambos grupos utilizaron actos indirectos al rechazar, pero hubo diferencias entre los grupos en el caso de las respuestas indirectas. Las tres estrategias indirectas más comúnmente utilizadas por los españoles fueron las de "Excusa" (250 veces), "Disculpa" (143) y "Declaración de alternativa" (82). Los malayos, por su parte, utilizaron la de "Excusa" (315 veces) como opción más frecuente, seguida por "Disculpa" (249) y "Fórmulas de tratamiento" (187). Las estrategias indirectas menos empleadas por los españoles fueron las "Evasivas" (5 veces), la "Repetición de parte de la petición" (6 veces) y el "Aplazamiento" (6 veces), mientras que los malayos usaron menos frecuentemente "Evasivas" (una vez), y las estrategias de "Declaración de empatía" (una vez) y "Deseo" (2 veces).

Por lo que atañe a las estrategias directas, ambos grupos prefirieron la fórmula de "Buena voluntad/capacidad negativa" (los españoles, 186 veces y los malayos, 136) para rechazar, mientras 
que la estrategia del "No", con la que el hablante rechaza directamente la petición (p.ej. "№, no te los puedo dejar"), fue utilizada en 13 ocasiones solo por los sujetos españoles.

Como se presenta en la Figura 174, los españoles emplearon con más frecuencia que los malayos once estrategias: "Buena voluntad/capacidad negativa", "Deseo", "Declaración de alternativa", "Declaración de principios", "Declaración de sentimiento negativo", "Petición de comprensión", "Evasivas", "Declaración de opinión/sentimiento positivo", "Declaración de empatía", "Uso de muletillas", y "Agradecimiento". En cambio, los malayos recurrieron más que los españoles a estas nueve estrategias: "Disculpa", "Excusa", "Conjunto de condiciones para la aceptación pasada/futura", "Amenaza o declaración de consecuencias negativas para el emisor", "Garantía de satisfacción futura del interlocutor", "Autodefensa", "Repetición de parte de la petición", "Aplazamiento", y "Fórmulas de tratamiento".

Las diferencias más llamativas entre las dos culturas se notan, principalmente, en seis estrategias: el uso del "No" (13 enunciados de los españoles, 0 de los malayos), la "Buena voluntad/capacidad negativa" (186 de los españoles frente a 136 de los malayos), la "Disculpa" (143 de los españoles por 249 de los malayos), la "Excusa" (250 de los españoles frente a 315 de los 
malayos), la "Declaración de principios" (40 de los españoles en comparación de 27 de los malayos), el "Agradecimiento" (49 de los españoles frente a 13 de los malayos) y las "Fórmulas de tratamiento" (68 de los españoles en contraste con 187 de los malayos). La comparación de los promedios entre las estrategias empleadas en los actos principales mostró una diferencia significativa: $X^{2}=154.295 p=.000(p<.05)$.

En la tabla que aparece a continuación se presenta el ranking de cada estrategia en cada cultura. 
Tabla 68. Estrategias utilizadas en todas las situaciones en cada cultura ordenadas según frecuencia de uso (de mayor a menor)

\begin{tabular}{|c|c|c|}
\hline $\mathbf{0}$ & Español & Malayo \\
\hline 1 & $>$ Excusa & $>$ Excusa \\
\hline 2 & $>$ Buena voluntad/capacidad negativa & $>$ Disculpa \\
\hline 3 & $>$ Disculpa & $>$ Buena voluntad/capacidad negativa \\
\hline 4 & $>$ Declaración de alternativa & $>$ Fórmulas de tratamiento \\
\hline 5 & $>$ Fórmulas de tratamiento & $>$ Declaración de alternativa \\
\hline 6 & $>$ Agradecimiento & $>$ Autodefensa \\
\hline 7 & $>$ Declaración de principios & $>$ Declaración de principios \\
\hline 8 & $>$ Uso de muletillas & $\begin{array}{l}\text { Conjunto de condiciones para la } \\
\text { aceptación pasada/futura }\end{array}$ \\
\hline 9 & $>$ Declaración de sentimiento negativo & $>$ Petición de comprensión \\
\hline 10 & $>$ Petición de comprensión & $\begin{array}{l}\text { Amenaza o declaración de } \\
\text { consecuencias negativas para el } \\
\text { emisor } \\
>\text { Declaración de sentimiento negativo }\end{array}$ \\
\hline 11 & $>$ Autodefensa & $\begin{array}{l}\text { Declaración de opinión/sentimiento } \\
\text { positivo o acuerdo }\end{array}$ \\
\hline 12 & $\begin{array}{l}\text { Declaración de opinión/sentimiento } \\
\text { positivo }\end{array}$ & $>$ Uso de muletillas \\
\hline 13 & $\begin{array}{l}\text { Amenaza o declaración de } \\
\text { consecuencias negativas para el } \\
\text { emisor }\end{array}$ & $\begin{array}{l}>\text { Garantía de satisfacción futura del } \\
\text { interlocutor } \\
>\text { Agradecimiento }\end{array}$ \\
\hline 14 & $>$ No & $>$ Repetición de parte de la petición \\
\hline 15 & $\begin{array}{l}\text { Conjunto de condiciones para la } \\
\text { aceptación pasada/futura } \\
\text { Garantía de satisfacción futura del } \\
\text { interlocutor }\end{array}$ & $>$ Aplazamiento \\
\hline 16 & $\begin{array}{l}>\text { Deseo } \\
>\text { Declaración de empatía } \\
>\text { Saludos/despedidas corteses }\end{array}$ & $>$ Deseo \\
\hline 17 & $\begin{array}{l}>\text { Repetición de parte de la petición } \\
>\text { Aplazamiento }\end{array}$ & $\begin{array}{l}>\text { Evasivas } \\
>\text { Declaración de empatía }\end{array}$ \\
\hline 18 & $>$ Evasivas & - \\
\hline
\end{tabular}


En lo que concierne a la expresión del rechazo en cada situación individual, los españoles emplearon menos enunciados que los malayos en las seis situaciones planteadas. La distribución de la frecuencia de enunciados producidos en cada situación se presenta en la Figura 175.

Figura 175. Distribución de enunciados de rechazo en cada grupo en las seis situaciones

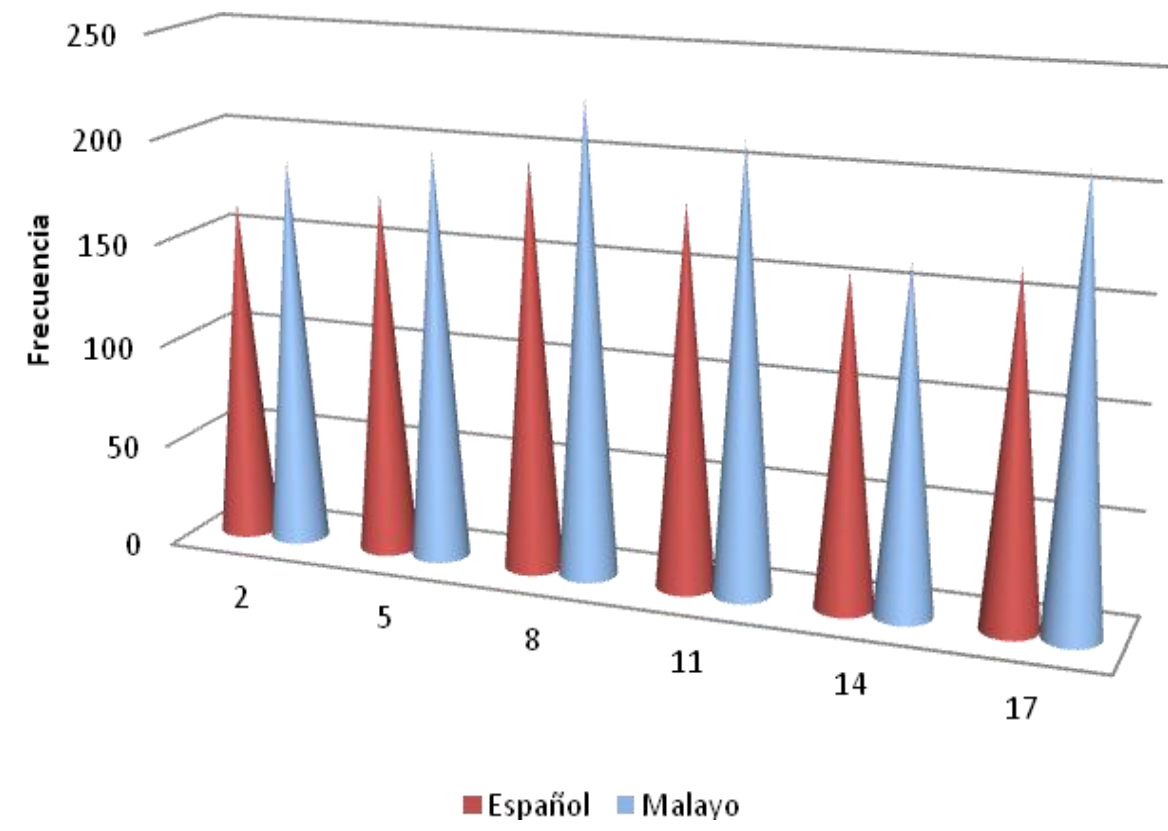

Tanto los informantes españoles como los malayos se mostraron más expresivos en la situación 8 (en la que un hermano menor pide a su hermano mayor que le acompañe a la fiesta de cumpleaños de su amigo), en comparación con el resto de situaciones. Y fue en la situación 14, en la que un estudiante 
universitario pide prestada una tesis de un estudiante anterior que está guardada en el despacho de su profesor, en la que ambos grupos se mostraron menos productivos. Al comparar los promedios de los enunciados producidos en las diferentes situaciones proporcionadas la diferencia no fue significativa.

\subsubsection{Mayor frente a menor}

Al analizar los datos teniendo en cuenta el grupo de edad al que pertenecen los informantes, encontramos que, en total, los mayores españoles formularon un menor número de enunciados con estrategias de rechazo que los menores (521 frente a 523). En el caso de los malayos ocurre justo lo contrario, con 609 enunciados recogidos en el corpus de los mayores en comparación con los 595 de los menores.

En cuanto a los tipos de rechazo, tanto los mayores como los menores de cada grupo cultural, español y malayo, prefirieron recurrir a estrategias indirectas. Como se muestra en la figura que presentamos a continuación, los mayores de los dos grupos formularon menos enunciados que los menores como "Rechazos directos" y "Adyacentes al rechazo", pero más como "Rechazos indirectos". 
Figura 176. Distribución del número de enunciados según tipos de rechazo en cada subgrupo de edad de cada cultura

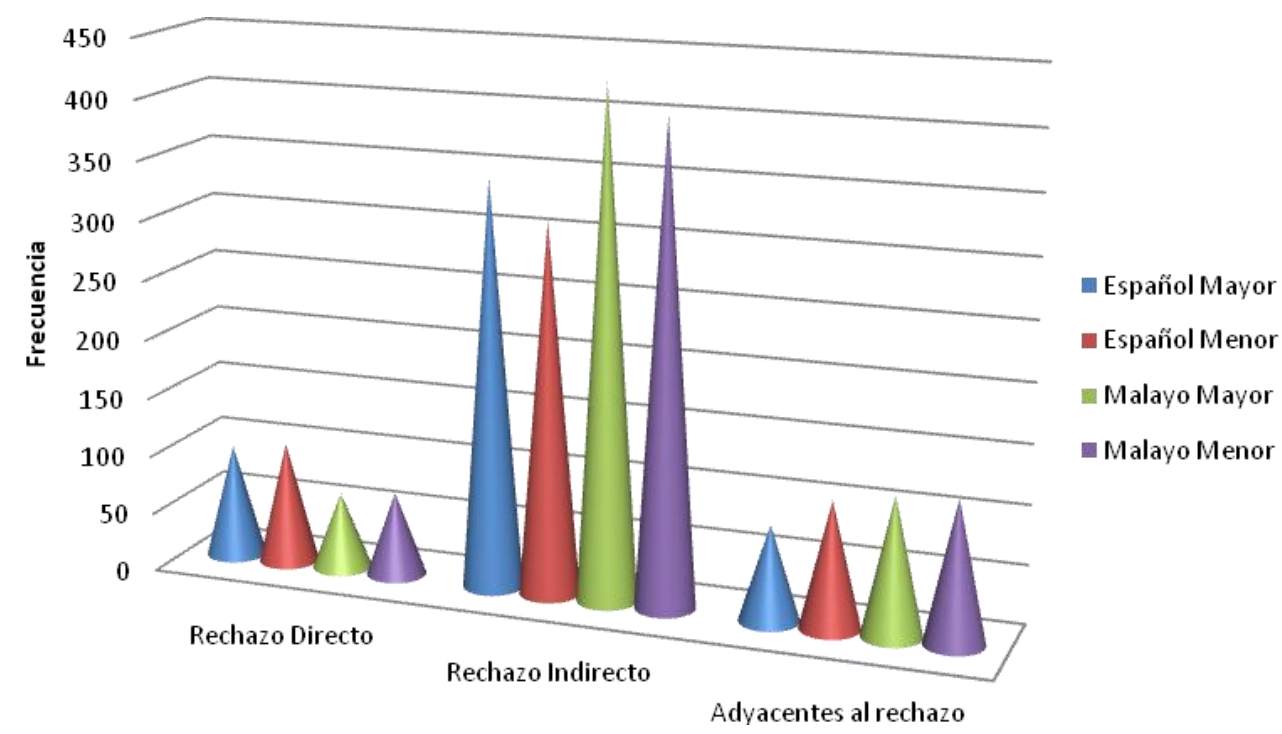

La diferencia entre los subgrupos no fue tan llamativa como la que aparecía al analizar los datos de los grupos principales. Así, la comparación de los promedios de las categorías empleadas indicó una diferencia no significativa ni en el grupo español, ni en el malayo. Esto significa que la cultura tiene más influencia que la edad a la hora de mostrarse más o menos productivo un hablante, en el número de enunciados que formula en el momento de rechazar algo.

Respecto a la distribución de enunciados teniendo en cuenta los tipos de estrategia de rechazo aplicados por los hablantes de cada grupo, el análisis revela que, tanto los sujetos más mayores como los más jóvenes del grupo español, emplearon el mismo 
número de estrategias diferentes al rechazar (ambos utilizaron 22), al igual que en el grupo malayo, siendo, en este caso, 19 los tipos de estrategias diferentes empleadas tanto por mayores como por menores, como reflejan los datos recogidos en la siguiente gráfica: 
Figura 177. Distribución de enunciados totales según la estrategia utilizada por los hablantes mayores y menores de cada cultura

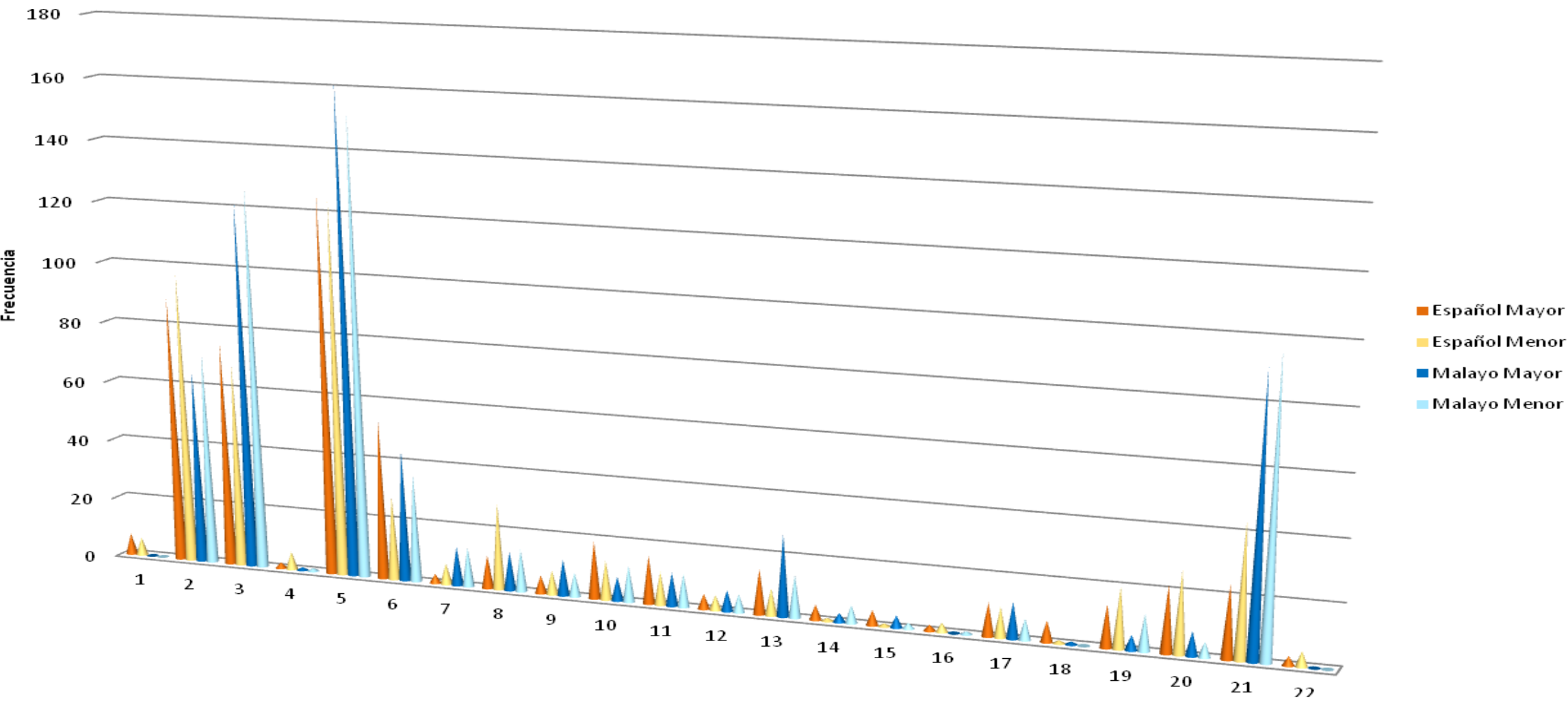

1: No 2: Buena voluntad/capacidad negativa 3: Disculpa 4: Deseo 5: Excusa 6: Declaración de alternativa 7: Conjunto de condiciones para la aceptación pasada/futura 8: Declaración de principios 9: Amenaza o declaración de consecuencias negativas para el emisor 10: Declaración de sentimiento negativo 11: Petición de comprensión 12: Garantía de satisfacción futura del interlocutor 13: Autodefensa 14: Repetición de parte de la petición 15: Aplazamiento 16: Evasivas 17: Declaración de opinión/sentimiento positivo 18: Declaración de empatía 19: Uso de muletillas 20: Agradecimiento 21: Fórmulas de tratamiento 22: Saludos/despedidas corteses 
En general, las tres estrategias más frecuentes aplicadas tanto por los participantes mayores como por los menores españoles fueron las de "Excusa" (126 veces en los datos de los mayores y 124 en los de los menores), "Buena voluntad/capacidad negativa" (89 casos de los mayores y 97 de los menores) y "Disculpa" (75 enunciados de los mayores y 68 de los menores). Por su parte, las tres estrategias preferidas por los mayores y menores malayos fueron las de "Excusa" (162 veces en los datos de los mayores y 153 en los de los menores), "Disculpa" (122 casos de los mayores y 127 de los menores) y "Fórmulas de tratamiento" (91 enunciados de los mayores y 96 de los menores).

En los resultados obtenidos se evidencia que la estrategia más frecuente para formular rechazo de manera indirecta en los cuatro subgrupos fue la de "Excusa". En cambio, las estrategias utilizadas con menos frecuencia en cada subgrupo fueron las de "Evasivas" y "Deseo" en los mayores españoles (aparecen dos veces cada una), las de "Repetición de parte de la petición" y "Aplazamiento" en los menores españoles (solo una vez), las de "Deseo" y "Declaración de empatía" (una vez para cada una) en los mayores malayos y finalmente las de "Deseo" y "Evasivas" (una vez cada una) en los menores malayos. 
Con respecto a los adyacentes al rechazo, los sujetos de los cuatros subgrupos utilizaron la estrategia de "Fórmulas de tratamiento" en la mayor parte de los casos. La de "Saludos/despedidas corteses" fue la estrategia menos utilizada en los mayores españoles (la encontramos en 3 enunciados), mientras que los menores utilizaron menos la "Declaración de empatía" (una vez). En el caso malayo, por su parte, los que tienen más edad aplicaron menos la "Declaración de empatía" (una vez) mientras que el "Agradecimiento" fue la estrategia menos aplicada en los menores (aparece 5 veces).

Para rechazar de manera directa, todos los grupos prefirieron la estrategia de "Buena voluntad/capacidad negativa". Como se indica en la Figura 177, el uso del "No" como una estrategia directa para formular rechazos solo apareció en los datos de los subgrupos españoles. Los subgrupos malayos no utilizaron "No" en ningún caso.

Según la Figura 177, hubo diferencias muy considerables entre los mayores y los menores españoles en el empleo de tres estrategias: "Declaración de alternativa" (54 registros de los mayores frente a solo 28 de los menores), "Declaración de principios/filosofía" (11 de los mayores en comparación con 29 de los menores) y "Fórmulas de tratamiento" (solo 24 de los mayores en contraste con 
44 de los menores). Por otro lado, en los datos malayos se identifica que los hablantes más mayores y los más jóvenes difirieron de manera obvia en el empleo de la "Excusa" (162 casos de los mayores en comparación con 153 de los menores), la "Declaración de alternativa" (44 de los mayores enfrente a 36 de los menores) y la "Autodefensa" (27 en los mayores por 14 en los menores).

Los datos de los españoles mayores presentan un uso más frecuente que los de los menores de once estrategias: "No", "Disculpa", "Excusa", "Declaración de alternativa", "Declaración de sentimiento negativo", "Petición de comprensión", "Autodefensa", "Repetición de parte de la petición", "Aplazamiento", "Declaración de opinión/sentimiento positivo" y "Declaración de empatía". En cambio, las estrategias de "Buena voluntad/capacidad negativa", "Deseo", "Conjunto de condiciones para la aceptación pasada/futura", "Declaración de principios", "Amenaza o declaración de consecuencias negativas para el emisor", "Evasivas", "Uso de muletillas", "Agradecimiento", "Fórmulas de tratamiento" y "Saludos/despedidas corteses", los menores las utilizaron más que los mayores. Respecto a la "Garantía de satisfacción futura del interlocutor", los hablantes de los dos subgrupos españoles la usaron con la misma frecuencia. 
Hubo ocho estrategias que los mayores malayos emplearon con más frecuencia que los menores: "Excusa", "Declaración de alternativa", "Amenaza o declaración de consecuencias negativas para el emisor", "Garantía de satisfacción futura del interlocutor", "Autodefensa", "Aplazamiento", "Declaración de opinión/sentimiento positivo" y "Agradecimiento". Los menores, por su parte, mostraron más tendencia que los mayores al empleo de otras ocho estrategias: "Buena voluntad/capacidad negativa", "Disculpa", "Declaración de principios", "Declaración de sentimiento negativo", "Repetición de parte de la petición", "Uso de muletillas" y "Fórmulas de tratamiento". Los dos subgrupos malayos emplearon el mismo número de enunciados con estrategias de "Deseo", "Conjunto de condiciones para la aceptación pasada/futura" y "Petición de comprensión". La de "Evasivas" solo se encontró en los datos de los menores, mientras que con la de "Declaración de empatía" ocurre lo contrario, ya que sí está en las respuestas de los mayores, pero no en las de los menores. Las de "No" y "Saludos/despedidas corteses" no se encontraron en los datos de ninguno de los grupos. La diferencia entre los promedios de las estrategias aplicadas en los subgrupos de edad fue significativa en el grupo español $X^{2}=41.878$ $p=.004(p<.05)$, pero no en el grupo malayo.

Las siguientes tablas presentan el ranking de cada estrategia empleada: 
Tabla 69. Estrategias utilizadas por los hablantes españoles en todas las situaciones, ordenadas según frecuencia de uso (de mayor a menor) en cada subgrupo de edad

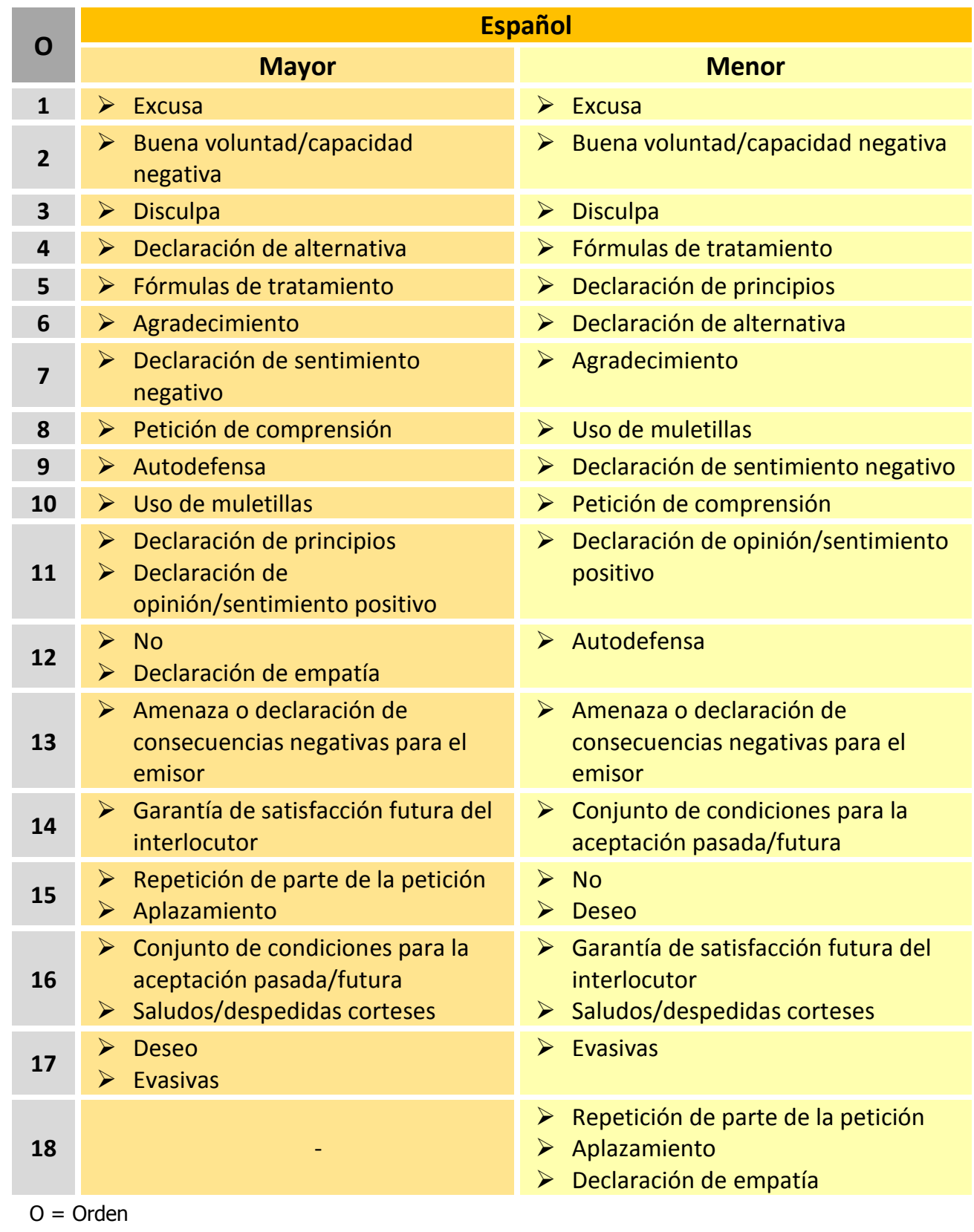


Tabla 70. Estrategias utilizadas por los hablantes malayos en todas las situaciones, ordenadas según frecuencia de uso (de mayor a menor) en cada subgrupo de edad

\begin{tabular}{|c|c|c|c|}
\hline \multirow{2}{*}{$\mathbf{0}$} & \multicolumn{3}{|c|}{ Malayo } \\
\hline & Mayor & & Menor \\
\hline 1 & $>$ Excusa & $>$ & Excusa \\
\hline 2 & $>$ Disculpa & & Disculpa \\
\hline 3 & $>$ Fórmulas de tratamiento & $>$ & Fórmulas de tratamiento \\
\hline 4 & $>$ Buena voluntad/capacidad negativa & $>$ & Buena voluntad/capacidad negativa \\
\hline 5 & $>$ Declaración de alternativa & $>$ & Declaración de alternativa \\
\hline 6 & $>$ Autodefensa & & $\begin{array}{l}\text { Declaración de principios } \\
\text { Autodefensa }\end{array}$ \\
\hline 7 & $\begin{array}{l}\text { Conjunto de condiciones para la } \\
\text { aceptación pasada/futura } \\
>\text { Declaración de principios }\end{array}$ & & $\begin{array}{l}\text { Conjunto de condiciones para la } \\
\text { aceptación pasada/futura }\end{array}$ \\
\hline 8 & $\begin{array}{l}\text { Amenaza o declaración de } \\
\text { consecuencias negativas para el } \\
\text { emisor } \\
\text { Declaración de opinión/sentimiento } \\
\text { positivo }\end{array}$ & & $\begin{array}{l}\text { Declaración de sentimiento negativo } \\
\text { Uso de muletillas }\end{array}$ \\
\hline 9 & $>$ Petición de comprensión & $>$ & Petición de comprensión \\
\hline 10 & $\begin{array}{l}>\text { Declaración de sentimiento negativa } \\
>\text { Agradecimiento }\end{array}$ & $>$ & $\begin{array}{l}\text { Amenaza o declaración de } \\
\text { consecuencias negativas para el } \\
\text { emisor }\end{array}$ \\
\hline 11 & $\begin{array}{l}\text { Garantía de satisfacción futura del } \\
\text { interlocutor }\end{array}$ & & $\begin{array}{l}\text { Garantía de satisfacción futura del } \\
\text { interlocutor } \\
\text { Declaración de opinión/sentimiento } \\
\text { positivo }\end{array}$ \\
\hline 12 & $\begin{array}{l}>\text { Uso de muletillas } \\
>\text { Aplazamiento }\end{array}$ & & $\begin{array}{l}\text { Repetición de parte de la petición } \\
\text { Agradecimiento }\end{array}$ \\
\hline 13 & $>$ Repetición de parte de la petición & $>$ & Aplazamiento \\
\hline 14 & $>$ Deseo & $>$ & Deseo \\
\hline 15 & $>$ Declaración de empatía & & Evasivas \\
\hline
\end{tabular}

Al estudiar las respuestas de los hablantes formuladas para cada situación individual, los resultados totales obtenidos en el número de enunciados recogidos en los datos de los cuatro subgrupos para expresar rechazo, son los que se recogen en la tabla que presentamos a continuación: 
Figura 178. Distribución de enunciados producidos por los hablantes de cada subgrupo en las seis situaciones examinadas

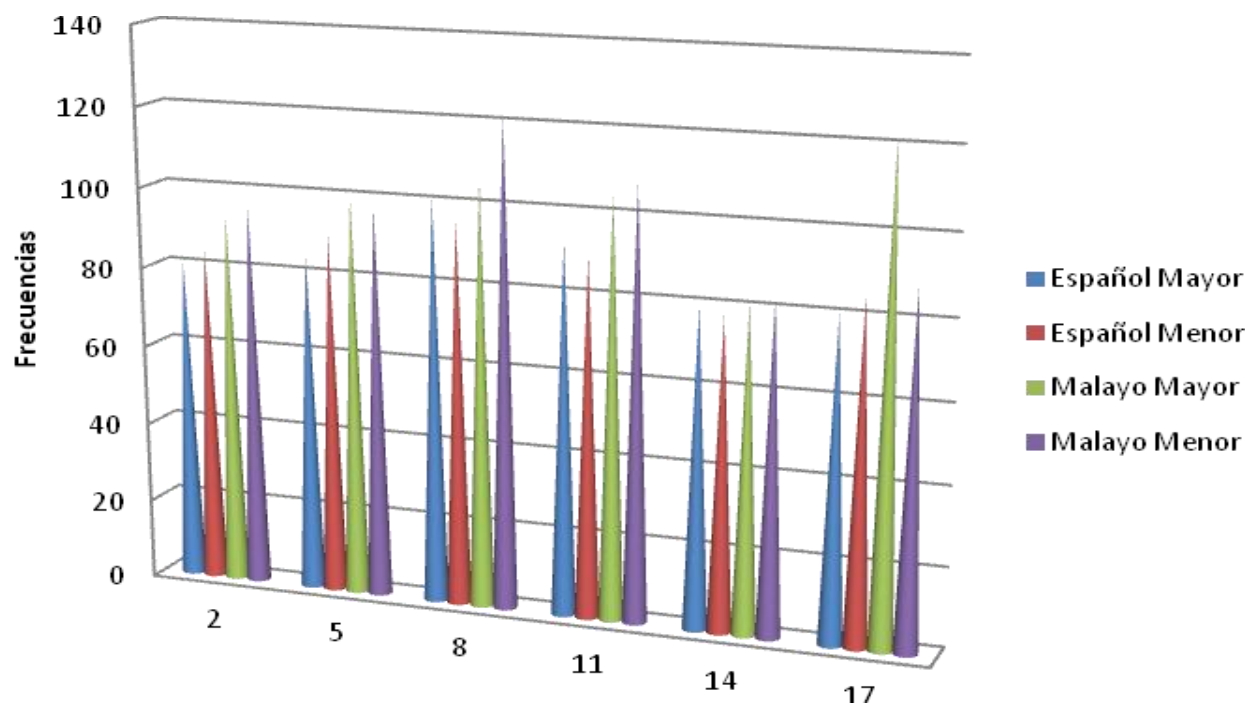

Los mayores españoles produjeron más enunciados que los menores al expresar rechazo en las situaciones 8,11 y 14 , mientras que en las 2, 5 y 17, emplearon menos. En el caso de los malayos, los hablantes mayores formularon más enunciados que los menores en dos situaciones, 5 y 17, mientras que en el resto de situaciones formularon menos.

En lo que concierne a la situación en la que se han registrado más enunciados de cada grupo, tanto los mayores como los menores españoles produjeron más en la situación 8 , en la que un hermano menor pide a su hermano mayor que le acompañe a la fiesta de cumpleaños de su amigo. Por el contrario, la situación 14, en la que un estudiante universitario pide prestada una tesis de un 
estudiante anterior que está guardada en el despacho de su profesor, fue la situación en la que los dos subgrupos se mostraron menos expresivos. Por otra parte, los mayores malayos utilizaron más estrategias en la situación 17, en la que un profesor universitario le pide a un estudiante que está haciendo una investigación bajo su dirección que cambie el método del estudio, mientras que los menores, de manera similar al caso español, usaron más estrategias en la situación 8. Los dos subgrupos malayos también aplicaron menos estrategias en la situación 14. La diferencia entre los promedios de los enunciados producidos en las diferentes situaciones proporcionadas, según los distintos subgrupos de edad, no fue significativa en los datos de ninguno de los países.

\subsubsection{Varón frente a mujer}

El análisis de los datos desde la variable de sexo revela que los sujetos varones utilizaron menos enunciados que las mujeres tanto en el grupo español como en el malayo. Se recogieron 497 enunciados en los rechazos de los varones españoles, por los 547 de las producciones de las mujeres. En el grupo malayo, por su parte, se encontraron 549 enunciados en los rechazos de los varones malayos, en comparación con los 655 de las mujeres. Los varones españoles utilizaron menos enunciados que las mujeres en la 
producción de los tres tipos de rechazo con los que estamos trabajando: "Rechazos directos", "Rechazos indirectos" y "Adyacentes al rechazo". Los varones malayos, en cambio, utilizaron más estrategias directas, pero menos estrategias indirectas y adyacentes al rechazo que las mujeres. Al igual que ocurrió en el caso de los subgrupos de edad, en este caso, la comparación de los promedios de las categorías empleadas tampoco indicó una diferencia significativa en ninguna de las sociedades. Los datos numéricos relativos a la distribución de los tipos de estrategias utilizadas por los hablantes de los cuatros subgrupos, según la clasificación en "Rechazos directos", "Rechazos indirectos" y "Adyacentes al rechazo", son los que se reflejan en la tabla que presentamos a continuación:

Figura 179. Distribución de enunciados según el tipo de estrategia de rechazo empleada por los hablantes de cada subgrupo de sexo

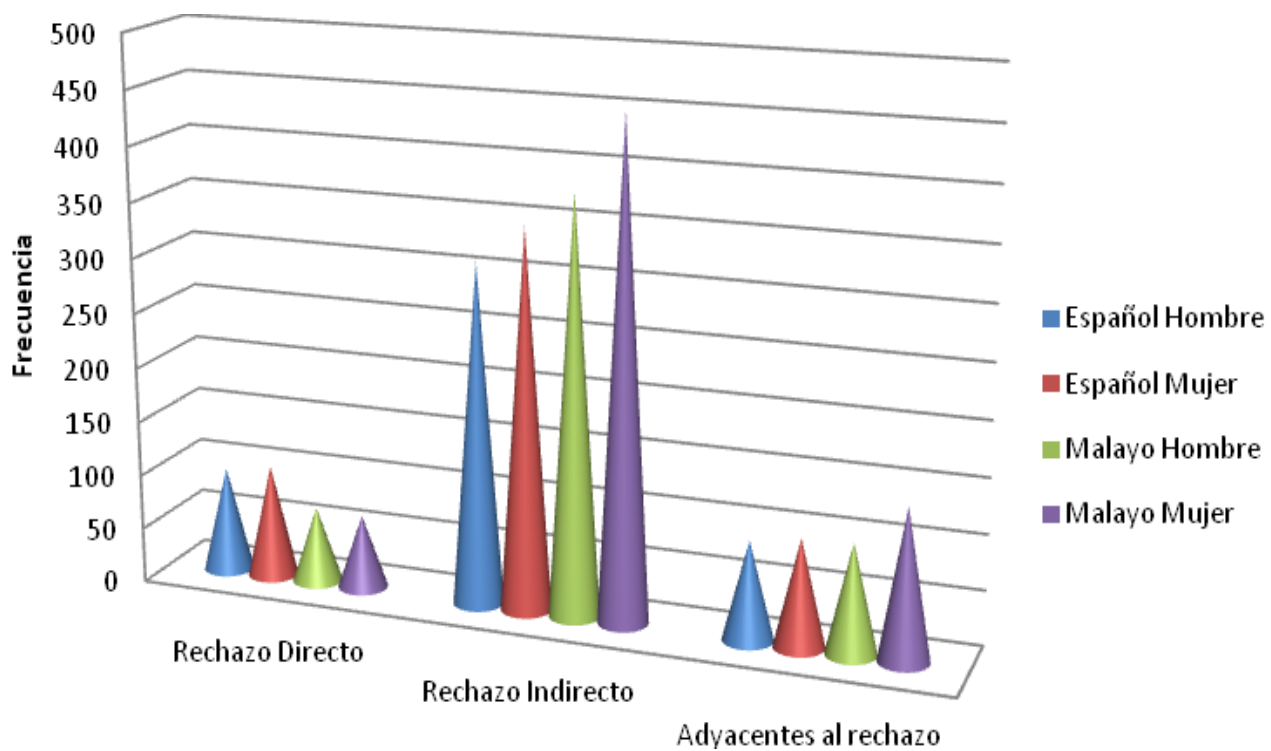


Con respecto a las estrategias utilizadas en la expresión del rechazo, se encuentra que, en general, ambos géneros en cada grupo aplicaron formas similares. Sin embargo, la frecuencia con la que se recurrió a cada una de ellas sí que difirió en cada género. Tanto las mujeres como los varones españoles emplearon 22 tipos diferentes, mientras que en las respuestas de los hablantes de ambos géneros en el grupo malayo se encontraron 19. Los datos correspondientes a esta comparación son los que se presentan en la Figura 180. 
Figura 180. Distribución total de enunciados según las estrategias utilizadas por los hablantes de cada género en ambos grupos

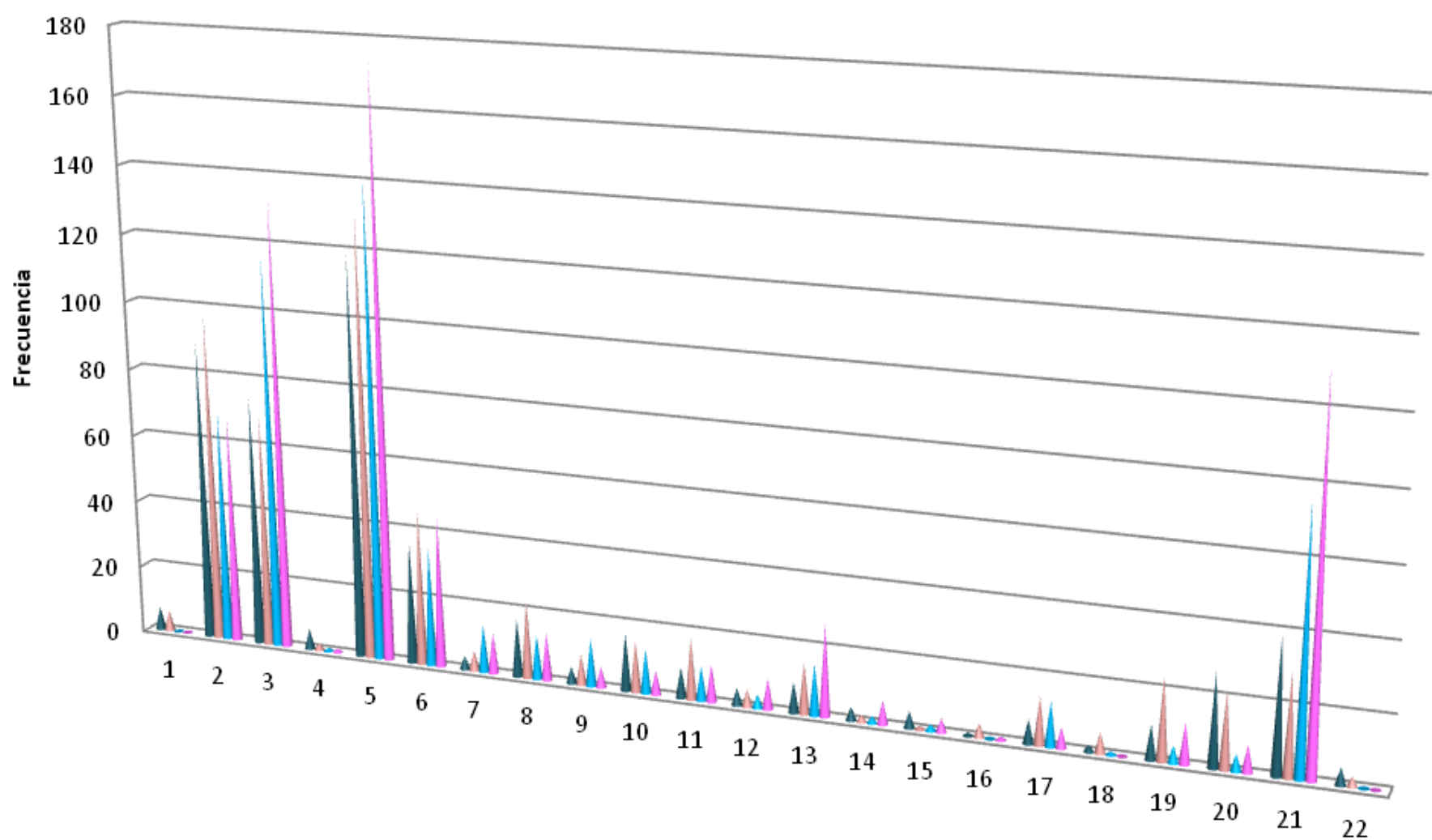

Español Hombre

Español Mujer

Malayo Hombre

Malayo Mujer

1: No 2: Buena voluntad/capacidad negativa 3: Disculpa 4: Deseo 5: Excusa 6: Declaración de alternativa 7: Conjunto de condiciones para la aceptación pasada/futura 8: Declaración de principios 9: Amenaza o declaración de consecuencias negativas para el emisor 10: Declaración de sentimiento negativo 11: Petición de comprensión 12: Garantía de satisfacción futura del interlocutor 13: Autodefensa 14: Repetición de parte de la petición 15: Aplazamiento 16: Evasivas 17: Declaración de opinión/sentimiento positivo 18: Declaración de empatía 19: Uso de muletillas 20: Agradecimiento 21: Fórmulas de tratamiento 22: Saludos/despedidas corteses 
Las tres estrategias más comúnmente utilizadas en las respuestas de los hablantes de ambos géneros españoles fueron las de "Excusa", "Buena voluntad/capacidad negativa" y "Disculpa". Por su parte, las tres más frecuentemente usadas por los sujetos de los dos sexos malayos fueron las de "Excusa", "Disculpa" y "Fórmulas de tratamiento". Las estrategias menos utilizadas fueron, en el caso de los varones, las de "Evasivas" y "Declaración de empatía", mientras que, en el subgrupo de mujeres, fueron las de "Deseo", "Repetición de parte de la petición" y "Aplazamiento". En el grupo malayo, los varones utilizaron menos las de "Deseo", "Declaración de empatía", "Repetición de parte de la petición" y "Aplazamiento", mientras que las estrategias que menos aparecen en las respuestas de las mujeres son las de "Deseo" y "Evasivas". La comparación entre las dos culturas revela que, tanto hombres como mujeres, en el grupo español, emplearon más estrategias diferentes que los malayos, pero cada una de ellas con menos frecuencia de lo que lo hacen en el otro grupo.

La figura 180 presentada más arriba, ilustra que los varones españoles utilizaron con más frecuencia que las mujeres estas ocho estrategias: "No", "Disculpa", "Deseo", "Declaración de sentimiento negativo", "Repetición de parte de la petición", "Aplazamiento", "Agradecimiento", "Fórmulas de tratamiento" y "Saludos/despedidas corteses", mientras que recurren al resto de 
estrategias en igual o menor número de ocasiones que las mujeres. Por su parte, los varones malayos recurrieron con una frecuencia más alta que las mujeres a cinco estrategias: "Buena voluntad/capacidad negativa", "Conjunto de condiciones para la aceptación pasada/futura", "Amenaza o declaración de consecuencias negativas para el emisor", "Declaración de sentimiento negativo" y "Declaración de opinión/sentimiento positivo". En cambio, del resto de estrategias hicieron igual o menor uso que las mujeres. Entre los subgrupos de sexo, la diferencia en los promedios de las estrategias aplicadas tampoco fue significativa en ninguno de los países.

En las tablas que exponemos a continuación se muestra el ranking de las estrategias aplicadas por los hablantes de cada género en los dos grupos: 
Tabla 71. Estrategias utilizadas por los hablantes españoles y malayos en todas las situaciones ordenadas según frecuencia de uso (de mayor a menor) en cada subgrupo de sexo

\begin{tabular}{|c|c|c|}
\hline \multirow{2}{*}{$\mathbf{0}$} & \multicolumn{2}{|c|}{ Español } \\
\hline & Varón & Mujer \\
\hline 1 & $>$ Excusa & $>$ Excusa \\
\hline 2 & $\begin{array}{l}\text { Buena voluntad/capacidad } \\
\text { negativa }\end{array}$ & $>$ Buena voluntad/capacidad negativa \\
\hline 3 & $>$ Disculpa & $>$ Disculpa \\
\hline 4 & $>$ Fórmulas de tratamiento & $>$ Declaración de alternativa \\
\hline 5 & $>$ Declaración de alternativa & $>$ Fórmulas de tratamiento \\
\hline 6 & $>$ Agradecimiento & $>$ Uso de muletillas \\
\hline 7 & $\begin{array}{l}\text { Declaración de principios } \\
\text { Declaración de sentimiento } \\
\text { negativo }\end{array}$ & $>$ Declaración de principios \\
\hline 8 & $>$ Uso de muletillas & $>$ Agradecimiento \\
\hline 9 & $\begin{array}{l}>\text { Petición de comprensión } \\
>\text { Autodefensa }\end{array}$ & $>$ Petición de comprensión \\
\hline 10 & $\begin{aligned}> & \text { No } \\
> & \text { Declaración de } \\
& \text { opinión/sentimiento positivo }\end{aligned}$ & $\begin{array}{l}>\text { Declaración de sentimiento negativo } \\
>\text { Autodefensa }\end{array}$ \\
\hline 11 & $>$ Deseo & $\begin{array}{l}\text { Declaración de opinión/sentimiento } \\
\text { positivo }\end{array}$ \\
\hline 12 & $\begin{array}{l}\text { Amenaza o declaración de } \\
\text { consecuencias negativas para el } \\
\text { emisor } \\
>\text { Garantía de satisfacción futura del } \\
\text { interlocutor } \\
>\text { Aplazamiento } \\
>\text { Saludos/despedidas corteses }\end{array}$ & $\begin{array}{l}\text { Amenaza o declaración de } \\
\text { consecuencias negativas para el } \\
\text { emisor }\end{array}$ \\
\hline 13 & $\begin{array}{l}\text { Conjunto de condiciones para la } \\
\text { aceptación pasada/futura } \\
>\text { Repetición de parte de la petición }\end{array}$ & $\begin{array}{l}>\text { No } \\
>\text { Conjunto de condiciones para la } \\
\text { aceptación pasada/futura } \\
>\text { Declaración de empatía }\end{array}$ \\
\hline 14 & $>$ Declaración de empatía & $\begin{array}{l}\text { Garantía de satisfacción futura del } \\
\text { interlocutor }\end{array}$ \\
\hline 15 & $>$ Evasivas & $>$ Evasivas \\
\hline 16 & - & $>$ Saludos/despedidas corteses \\
\hline 17 & - & $\begin{array}{l}>\text { Deseo } \\
>\text { Repetición de parte de la petición }\end{array}$ \\
\hline 18 & - & $>$ Aplazamiento \\
\hline
\end{tabular}




\begin{tabular}{|c|c|c|}
\hline \multirow{2}{*}{$\mathbf{0}$} & \multicolumn{2}{|c|}{ Malayo } \\
\hline & Varón & Mujer \\
\hline 1 & $>$ Excusa & $>$ Excusa \\
\hline 2 & $>$ Disculpa & $>$ Disculpa \\
\hline 3 & $>$ Fórmulas de tratamiento & $>$ Fórmulas de tratamiento \\
\hline 4 & $\begin{array}{l}\text { Buena voluntad/capacidad } \\
\text { negativa }\end{array}$ & $>$ Buena voluntad/capacidad negativa \\
\hline 5 & $>$ Declaración de alternativa & $>$ Declaración de alternativa \\
\hline 6 & $>$ Autodefensa & $>$ Autodefensa \\
\hline 7 & $\begin{array}{l}\text { Conjunto de condiciones para la } \\
\text { aceptación pasada/futura } \\
\text { Amenaza o declaración de } \\
\text { consecuencias negativas para el } \\
\text { emisor }\end{array}$ & $>$ Declaración de principios \\
\hline 8 & $\begin{array}{l}\text { Declaración de principios } \\
\text { Declaración de sentimiento } \\
\text { negativa } \\
>\text { Declaración de } \\
\text { opinión/sentimiento positivo }\end{array}$ & $\begin{array}{l}\text { Conjunto de condiciones para la } \\
\text { aceptación pasada/futura }\end{array}$ \\
\hline 9 & $>$ Petición de comprensión & $>$ Uso de muletillas \\
\hline 10 & $\begin{array}{l}>\text { Uso de muletillas } \\
>\text { Agradecimiento }\end{array}$ & $>$ Petición de comprensión \\
\hline 11 & $\begin{array}{l}\text { Garantía de satisfacción futura del } \\
\text { interlocutor }\end{array}$ & $\begin{array}{l}\text { Garantía de satisfacción futura del } \\
\text { interlocutor }\end{array}$ \\
\hline 12 & $\begin{array}{l}>\text { Repetición de parte de la petición } \\
>\text { Aplazamiento }\end{array}$ & $>$ Agradecimiento \\
\hline 13 & $\begin{array}{l}>\text { Deseo } \\
>\text { Declaración de empatía }\end{array}$ & $\begin{array}{l}\text { Declaración de sentimiento negativa } \\
>\text { Repetición de parte de la petición }\end{array}$ \\
\hline 14 & - & $\begin{array}{l}\text { Amenaza o declaración de } \\
\text { consecuencias negativas para el } \\
\text { emisor } \\
\text { Declaración de opinión/sentimiento } \\
\text { positivo }\end{array}$ \\
\hline 15 & - & $>$ Aplazamiento \\
\hline 16 & - & $\begin{array}{l}>\text { Deseo } \\
>\text { Evasivas }\end{array}$ \\
\hline
\end{tabular}

En lo que concierne a las estrategias utilizadas en cada situación individual, como se expone en la gráfica que sigue, los varones españoles respondieron con menos enunciados que las mujeres en casi todas las situaciones, excepto en la situación 17. Por 
su parte, en los datos malayos, los varones también emplearon menos enunciados que las mujeres, pero estos sí lo hicieron así en las seis situaciones de rechazo. Igual que en los casos anteriores, la situación en la que hombres y mujeres en cada grupo utilizaron más estrategias fue la 8, en la que un hermano menor pide a su hermano mayor que le acompañe a la fiesta de cumpleaños de su amigo, mientras que la situación en la que aparecieron menos fue la 14, en la que un estudiante universitario pide prestada una tesis de un estudiante anterior que está guardada en el despacho de su profesor. La comparación de los promedios entre los enunciados aplicados en las seis situaciones de rechazo según el sexo no mostró una diferencia significativa ni el corpus español ni en el malayo.

Figura 181. Distribución de los enunciados de rechazo producidos por los hablantes de ambos géneros en cada grupo para cada una de las seis situaciones individuales

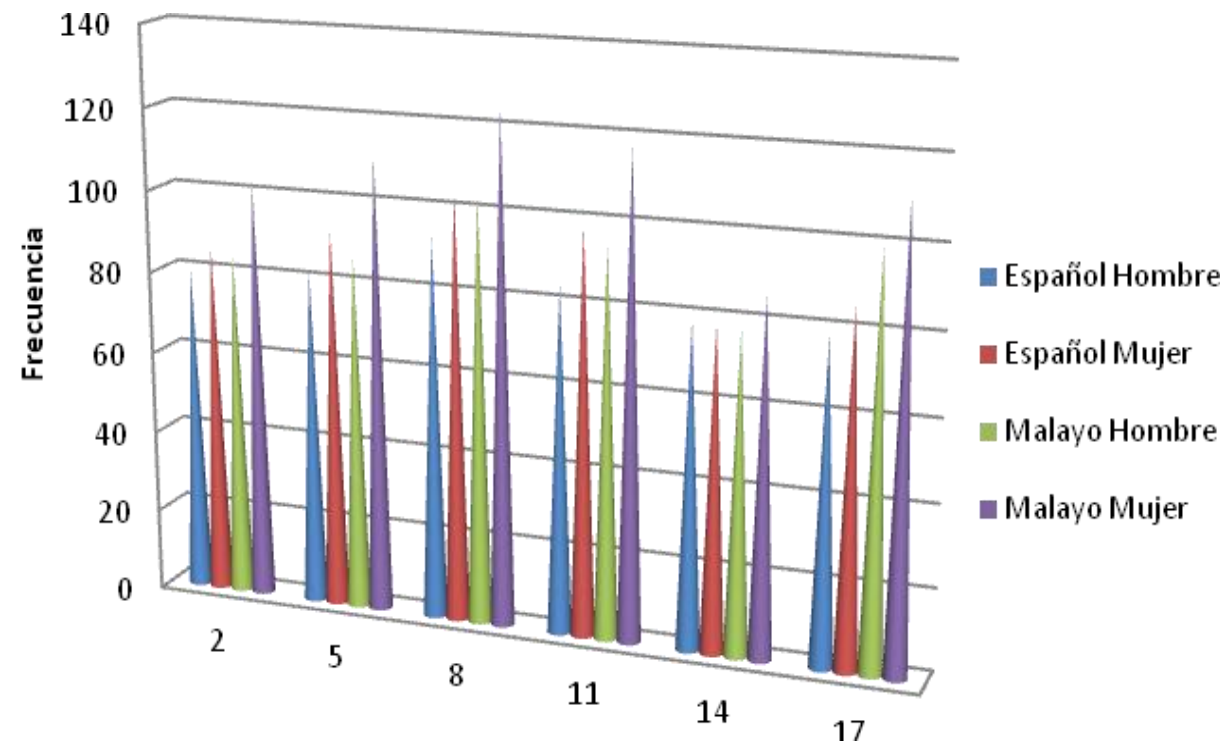




\subsubsection{Análisis situacional}

En esta sección se pormenorizan los resultados del análisis de las respuestas formuladas en las seis situaciones de rechazo que constituyen el cuestionario (situaciones $2,5,8,11,14$ y 17). Tal y como se hizo en el caso del acto de habla de petición y mandato (véase el capítulo 4 y 5), los datos se presentan teniendo en cuenta la diferencia cultural (español frente a malayo), la edad de los sujetos (mayor frente a menor) y el género (varón frente a mujer), y su estudio se llevó a cabo teniendo en cuenta las diferencias en las estrategias elegidas y su frecuencia de uso.

\subsubsection{Situación 2}

En la situación 2, en la que un agente de una compañía de telefonía móvil va a casa del sujeto e intenta convencerle para que se compre el nuevo paquete del servicio, la distancia social entre los interlocutores es grande y la familiaridad es baja (no conocido). En esta situación el análisis solo se concentra en la distancia social sin examinar el estatus social. 


\section{A) Español frente a malayo}

En esta situación, en total, los españoles utilizaron menos enunciados que los malayos (165, frente a los 188 de los malayos). Sin embargo, los españoles usaron más estrategias diferentes que los malayos (17 de los españoles en comparación con 12 de los malayos). En lo que atañe a las estrategias directas, indirectas y adyacentes al rechazo, se nota que los españoles emplearon en muchas más ocasiones que los malayos las estrategias del primer tipo (57 casos de los españoles comparados con solo 24 de los malayos). Las estrategias indirectas, por el contrario, los españoles las utilizaron mucho menos que los malayos (tan solo 61 casos en comparación con los 132 de los malayos), y las adyacentes al rechazo, los sujetos del grupo español las aplicaron más que los del grupo malayo (47 de los españoles frente a 32 de los malayos). El resultado de cada comunidad de habla difiere significativamente: $X^{2}=41.088 p=.000(p<.05)$.

En las tablas que presentamos a continuación se puede observar la distribución de enunciados según las estrategias utilizadas por los hablantes de cada grupo principal en la situación 2: 
Figura 182. Distribución de enunciados producidos en la situación 2 en cada grupo principal según la clasificación general en tres categorías de estrategia de rechazo

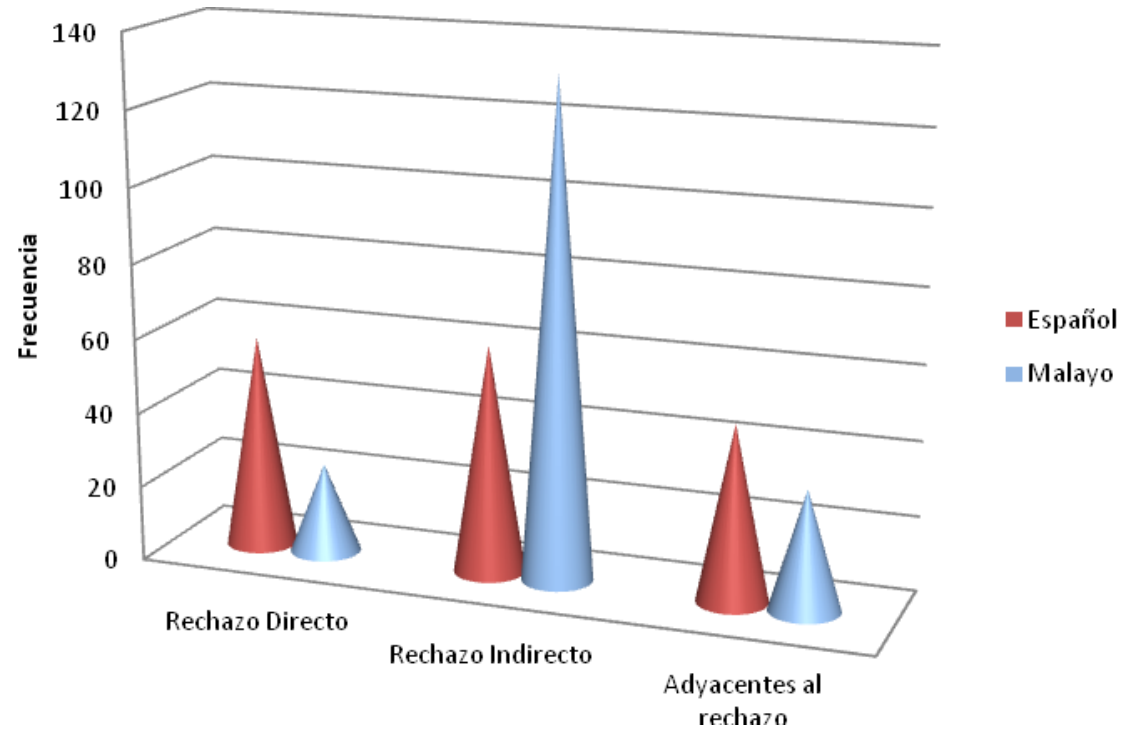


Figura 183. Distribución de estrategias utilizadas en la situación 2 en cada grupo principal

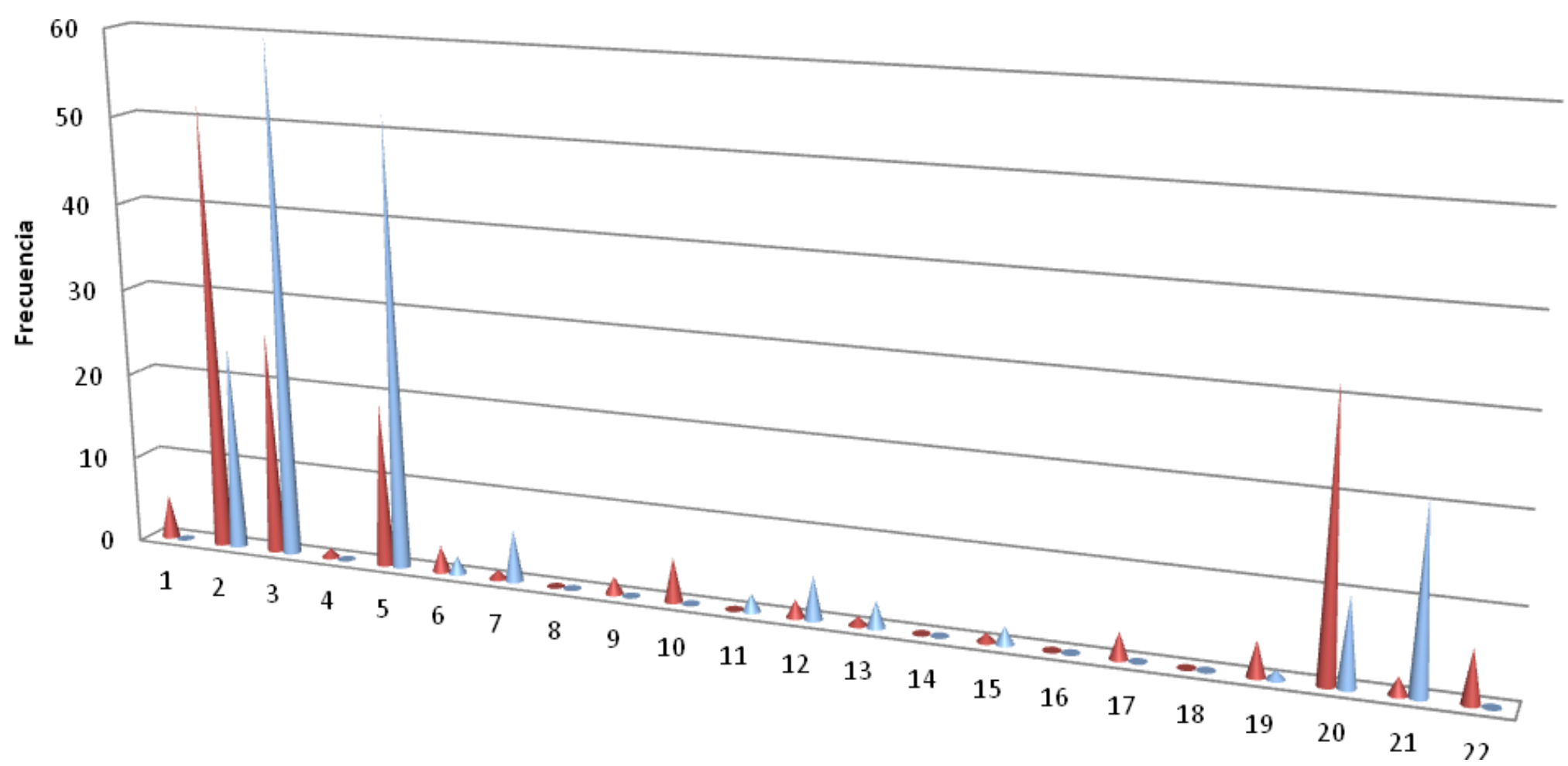

- Español

Malayo

1: No 2: Buena voluntad/capacidad negativa 3: Disculpa 4: Deseo 5: Excusa 6: Declaración de alternativa 7: Conjunto de condiciones para la aceptación pasada/futura 8: Declaración de principios 9: Amenaza o declaración de consecuencias negativas para el emisor 10: Declaración de sentimiento negativo 11: Petición de comprensión 12: Garantía de satisfacción futura del interlocutor 13: Autodefensa 14: Repetición de parte de la petición 15: Aplazamiento 16: Evasivas 17: Declaración de opinión/sentimiento positivo 18: Declaración de empatía 19: Uso de muletillas 20: Agradecimiento 21: Fórmulas de tratamiento 22: Saludos/despedidas corteses 
Como se puede ver en la Tabla 183, hubo numerosas diferencias entre las dos culturas, española y malaya, en el empleo de algunas estrategias, como las de "Buena voluntad/capacidad negativa" (52 casos de los españoles y 24 de los malayos), "Disculpa" (26 de los españoles por 60 de los malayos), "Excusa" (19 de los españoles frente a 50 de los malayos), "Agradecimiento" (32 de los españoles en comparación con tan solo 10 de los malayos) y "Fórmulas de tratamiento" (tan solo 2 ejemplos en los datos de los españoles por 21 encontrados en los de los malayos). Hay que destacar que el uso del "Agradecimiento" en esta situación fue el más alto en comparación con el resto de escenarios.

Las estrategias más aplicadas por los españoles para realizar rechazos, por orden de frecuencia, fueron las de "Buena voluntad/capacidad negativa" (52 veces), "Agradecimiento" (32 veces), "Disculpa" (26 veces) y "Excusa" (19 veces). Por su parte, los malayos prefirieron la de "Disculpa" (60 veces), seguida de las de "Excusa" (52 veces), "Buena voluntad/capacidad negativa" (24 veces) y "Fórmulas de tratamiento" (21 veces). Los índices indicaron que existieron diferencias significativas entre las medias de los grupos culturales en relación con el uso de los estrategias: $X^{2}=97.421 \mathrm{p}=.000(\mathrm{p}<.05)$. 


\section{El ranking de cada estrategia utilizada en cada cultura se}

\section{presenta en la siguiente tabla:}

Tabla 72. Estrategias utilizadas en cada cultura en la situación 2, ordenadas según frecuencia de uso (de mayor a menor)

\begin{tabular}{|c|c|c|}
\hline $\mathbf{0}$ & Español & Malayo \\
\hline 1 & $\begin{array}{l}\text { Buena voluntad/capacidad } \\
\text { negativa }\end{array}$ & $>$ Disculpa \\
\hline 2 & $>$ Agradecimiento & $>$ Excusa \\
\hline 3 & $>$ Disculpa & $>$ Buena voluntad/capacidad negativa \\
\hline 4 & $>$ Excusa & $>$ Fórmulas de tratamiento \\
\hline 5 & $>$ Saludos/despedidas corteses & $>$ Agradecimiento \\
\hline 6 & $\begin{aligned} & \text { No } \\
& \text { Declaración de sentimiento } \\
& \text { negativo }\end{aligned}$ & $\begin{array}{l}\text { Conjunto de condiciones para la } \\
\text { aceptación pasada/futura }\end{array}$ \\
\hline 7 & $>$ Uso de muletillas & $\begin{array}{l}\text { Garantía de satisfacción futura del } \\
\text { interlocutor }\end{array}$ \\
\hline 8 & $\begin{aligned} & \text { Declaración de alternativa } \\
& \text { Declaración de } \\
& \text { opinión/sentimiento positivo }\end{aligned}$ & $>$ Autodefensa \\
\hline 9 & $\begin{array}{l}\text { Amenaza o declaración de } \\
\text { consecuencias negativas para el } \\
\text { emisor } \\
>\text { Garantía de satisfacción futura del } \\
\text { interlocutor } \\
>\text { Fórmulas de tratamiento }\end{array}$ & $\begin{array}{l}>\text { Declaración de alternativa } \\
>\text { Petición de comprensión } \\
>\text { Aplazamiento }\end{array}$ \\
\hline 10 & $\begin{array}{l}>\text { Deseo } \\
\text { Conjunto de condiciones para la } \\
\text { aceptación pasada/futura } \\
>\text { Autodefensa } \\
>\text { Aplazamiento }\end{array}$ & $>$ Uso de muletillas \\
\hline
\end{tabular}




\section{B) Mayor frente a menor}

En el caso de mayor versus menor, tanto los mayores españoles como los mayores malayos emplearon menos estrategias diferentes que los menores (14 de los mayores españoles y 15 de los menores frente a 9 de los mayores malayos y 12 de los menores). Los encuestados de más edad en ambos grupos, español y malayo, utilizaron menos estrategias directas que los de menos edad ( 27 y 30 veces, respectivamente, en el caso español, y 11 y 13 veces en el caso malayo). En cuanto a las estrategias indirectas, tanto los mayores españoles como los malayos las aplicaron más que los menores (37 frente a 24 casos en el primer grupo, y 68 frente a 64 en el segundo). Estrategias del tipo adyacentes al rechazo, fueron menos empleadas por los mayores de los dos grupos principales (17 veces frente a 30, en el grupo español, y 14 frente a 18 en el grupo malayo). La comparación de los promedios entre las tres tipos de estrategias empleados entre los subgrupos de edad indicó una diferencia significativa en el corpus español: $X^{2}=6.472 \quad p=.039$ $(p<.05)$, pero no, en el corpus malayo.

Estos datos, así como los correspondientes a la distribución de enunciados según las estrategias empleadas, se reflejan en las graficas que presentamos a continuación, en las figuras 184 y 185 . 
Figura 184. Clasificación de los enunciados, según grado de (in)dirección de las estrategias empleadas, producidos para la situación 2 como expresión de rechazo

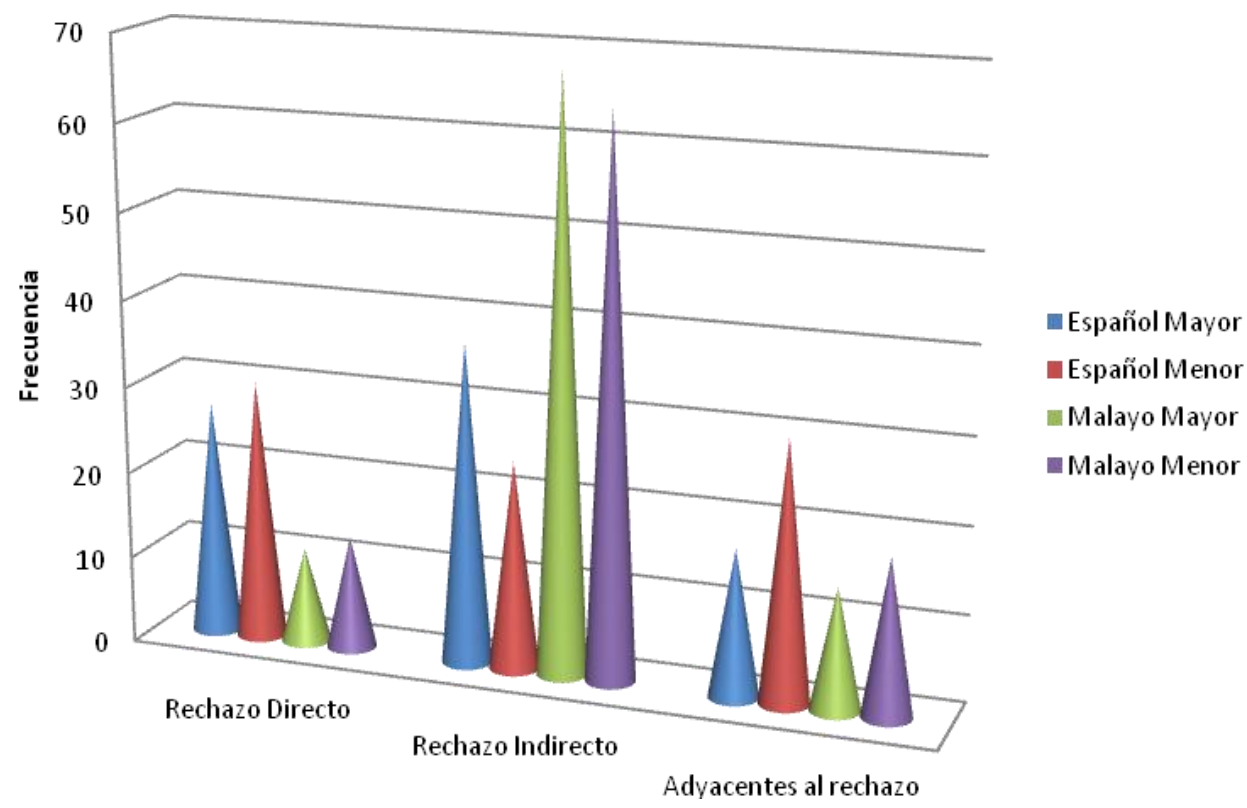


Figura 185. Distribución de cada estrategia, en número de enunciados, utilizada en la situación 2 por los mayores y los menores en cada cultura

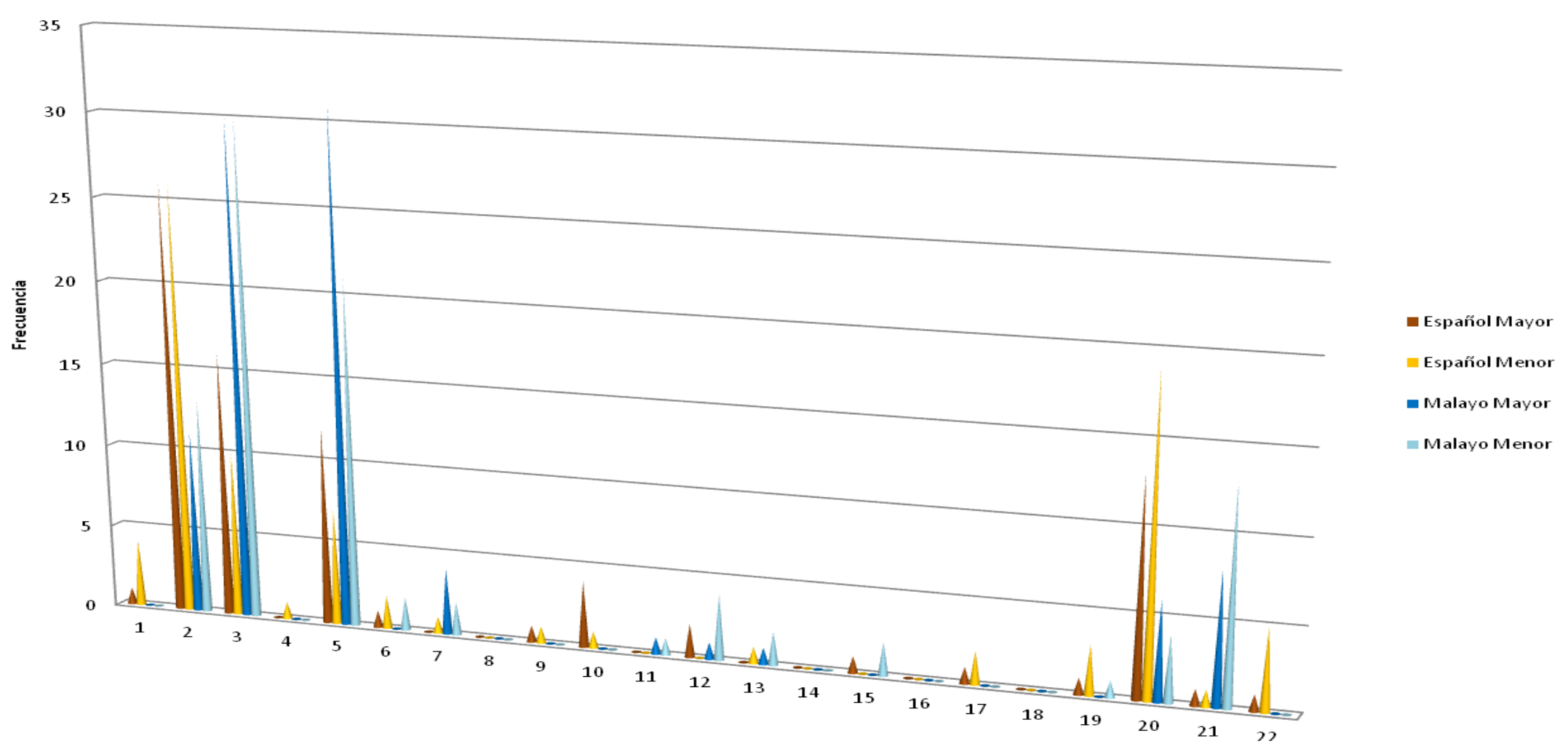

1: No 2: Buena voluntad/capacidad negativa 3: Disculpa 4: Deseo 5: Excusa 6: Declaración de alternativa 7: Conjunto de condiciones para la aceptación pasada/futura 8: Declaración de principios 9: Amenaza o declaración de consecuencias negativas para el emisor 10: Declaración de sentimiento negativo 11: Petición de comprensión 12: Garantía de satisfacción futura del interlocutor 13: Autodefensa 14: Repetición de parte de la petición 15: Aplazamiento 16: Evasivas 17: Declaración de opinión/sentimiento positivo 18: Declaración de empatía 19: Uso de muletillas 20: Agradecimiento 21: Fórmulas de tratamiento 22: Saludos/despedidas corteses 
Las estrategias más comúnmente aplicadas por los mayores españoles fueron las de "Buena voluntad/capacidad negativa" (26 veces), seguidas de "Disculpa" (16 veces), "Agradecimiento" (13 veces) y "Excusa" (12 veces), mientras que los menores utilizaron más frecuentemente las de "Buena voluntad/capacidad negativa" (26 veces), seguidas de "Agradecimiento" (19 veces), "Disculpa" (10 veces) y "Excusa" (7 veces).

Por su parte, los mayores malayos tendieron a utilizar más la estrategia de "Excusa" (31 veces), seguida de "Disculpa" (30 veces), "Buena voluntad/capacidad negativa" (11) y "Fórmulas de tratamiento" (8 veces), en su expresión del rechazo. Por otro lado, los menores malayos prefirieron más la de "Disculpa" (30 veces), seguida de "Excusa" (21 veces), "Buena voluntad/capacidad negativa" y "Fórmulas de tratamiento" (13 veces respectivamente). Al comparar los promedios de las estrategias usadas entre los hablantes mayores y los menores, la diferencia no fue significativa en los datos de ambos grupos.

El ranking de cada estrategia en las respuestas de los hablantes de ambos grupos de edad en cada cultura se presenta en la tabla siguiente: 
Tabla 73. Estrategias utilizadas por los hablantes españoles y malayos en la situación 2, ordenadas según frecuencia de uso (de mayor a menor) en cada subgrupo de edad

\begin{tabular}{|c|c|c|}
\hline \multirow[t]{2}{*}{$\mathbf{0}$} & \multicolumn{2}{|c|}{ Español } \\
\hline & Mayor & Menor \\
\hline 1 & $>$ Buena voluntad/capacidad negativa & $>$ Buena voluntad/capacidad negativa \\
\hline 2 & $>$ Disculpa & $>$ Agradecimiento \\
\hline 3 & $>$ Agradecimiento & $>$ Disculpa \\
\hline 4 & $>$ Excusa & $>$ Excusa \\
\hline 5 & $>$ Declaración de sentimiento negativo & $>$ Saludos/despedidas corteses \\
\hline 6 & $\begin{array}{l}\text { Garantía de satisfacción futura del } \\
\text { interlocutor }\end{array}$ & $>$ No \\
\hline 7 & $\begin{aligned} & \text { No } \\
& \text { Declaración de alternativa } \\
& \text { Amenaza o declaración de } \\
& \text { consecuencias negativas para el emisor } \\
& \text { Aplazamiento } \\
> & \text { Declaración de opinión/sentimiento } \\
& \text { positivo } \\
> & \text { Uso de muletillas } \\
> & \text { Fórmulas de tratamiento } \\
> & \text { Saludos/despedidas corteses }\end{aligned}$ & $>$ Uso de muletillas \\
\hline 8 & - & $\begin{array}{l}\text { Declaración de alternativa } \\
\text { Declaración de opinión/sentimiento } \\
\text { positivo }\end{array}$ \\
\hline 9 & - & $\begin{aligned} & \text { Deseo } \\
& \text { Conjunto de condiciones para la aceptación } \\
& \text { pasada/futura } \\
> & \text { Amenaza o declaración de consecuencias } \\
& \text { negativas para el emisor } \\
> & \text { Declaración de sentimiento negativo } \\
> & \text { Autodefensa } \\
> & \text { Fórmulas de tratamiento }\end{aligned}$ \\
\hline
\end{tabular}

\begin{tabular}{|c|c|c|}
\hline \multirow[t]{2}{*}{$\mathbf{0}$} & \multicolumn{2}{|c|}{ Malayo } \\
\hline & Mayor & Menor \\
\hline 1 & $>$ Excusa & $>$ Disculpa \\
\hline 2 & $>$ Disculpa & $>$ Excusa \\
\hline 3 & $>$ Buena voluntad/capacidad negativa & $\begin{array}{l}>\text { Buena voluntad/capacidad negativa } \\
>\text { Fórmulas de tratamiento }\end{array}$ \\
\hline 4 & $>$ Fórmulas de tratamiento & $\begin{array}{l}>\text { Garantía de satisfacción futura del } \\
\text { interlocutor } \\
>\text { Agradecimiento }\end{array}$ \\
\hline 5 & $>$ Agradecimiento & $\begin{array}{l}>\text { Declaración de alternativa } \\
>\text { Conjunto de condiciones para la aceptación } \\
\text { pasada/futura } \\
>\text { Autodefensa } \\
>\text { Aplazamiento }\end{array}$ \\
\hline 6 & $\begin{array}{l}\text { Conjunto de condiciones para la } \\
\text { aceptación pasada/futura }\end{array}$ & $\begin{array}{l}>\text { Petición de comprensión } \\
>\text { Uso de muletillas }\end{array}$ \\
\hline 7 & $\begin{array}{l}>\text { Petición de comprensión } \\
\text { Garantía de satisfacción futura del } \\
\text { interlocutor } \\
>\text { Autodefensa }\end{array}$ & - \\
\hline
\end{tabular}




\section{C) Varón frente a mujer}

A continuación pasamos a analizar las estrategias empleadas por los varones y las mujeres de cada sociedad (española y malaya), teniendo en cuenta tanto la clasificación en los tres grandes grupos (directas, indirectas y adyacentes al rechazo), como la distribución en las 22 estrategias de Beebe et. al. (1990) utilizadas por los participantes del estudio.

En primer lugar es preciso destacar que, en total, los varones de ambos grupos, español y malayo, aplicaron más estrategias que las mujeres al rechazar ( 80 de los varones y 85 de las mujeres en el grupo español y 85 de los varones frente a 103 de las mujeres en el grupo malayo). En segundo lugar, y teniendo en cuenta el primer nivel de concreción, el estudio de las respuestas proporcionadas por los sujetos en los contextos de rechazo demuestra que los varones españoles utilizaron menos estrategias directas que las mujeres ( 27 y 30 respectivamente). Por el contrario, los varones malayos aplicaron más estrategias directas que las mujeres (15 de los varones y 9 de las mujeres). En cambio, en el caso de las estrategias indirectas, los varones españoles las emplearon más que las mujeres (31 ejemplos recogidos de los varones en comparación con 30 de las mujeres), mientras que los varones malayos aplicaron menos estrategias indirectas que las 
mujeres ( 57 de los varones frente a 75 de las mujeres). Con respecto a los adyacentes al rechazo, los varones españoles los utilizaron menos que las mujeres (22 casos frente a 25 ). Por el contrario, los varones malayos los usaron más que las mujeres (13 de los varones por 9 de las mujeres).

Figura 186. Clasificación de los enunciados, según grado de (in)dirección, producidos para la situación 2 por cada subgrupos de género en cada cultura

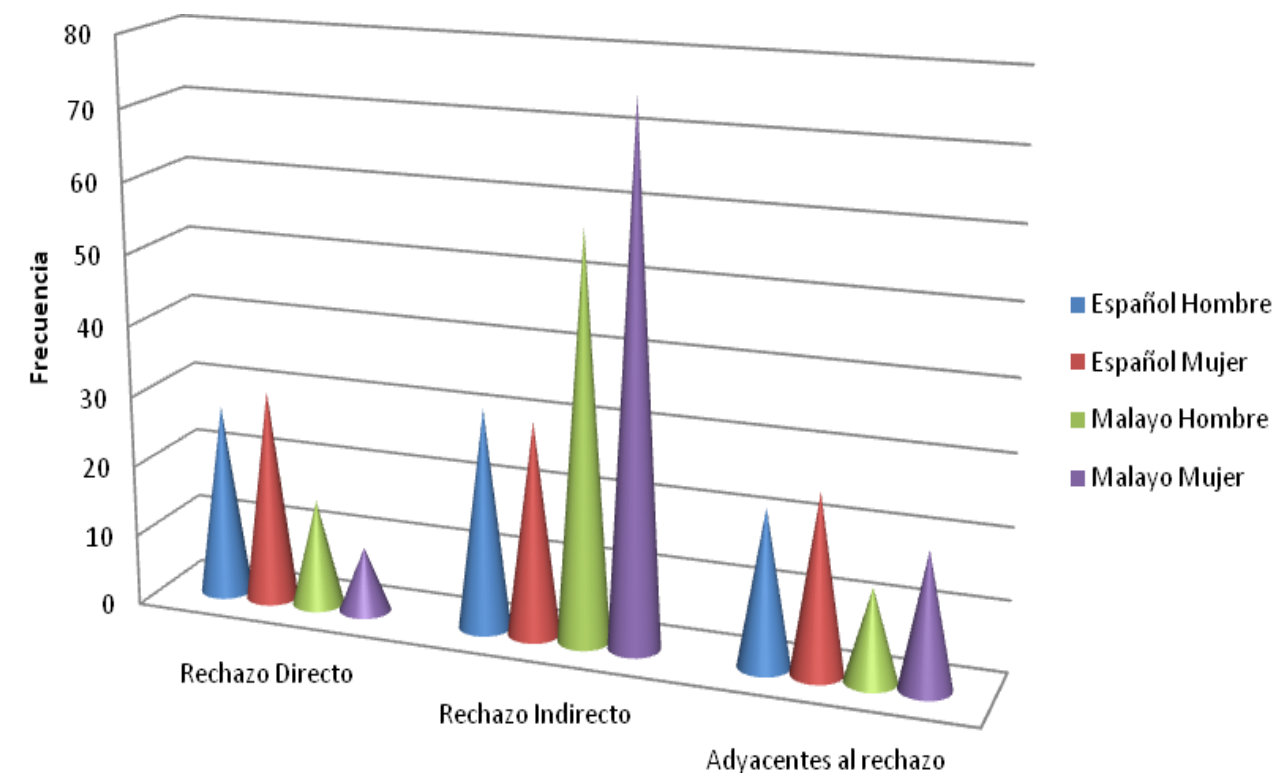

En la cultura española no se establecieron diferencias llamativas, mientras que sí hubo una diferencia importante entre los grupos de género de la cultura malaya. Según la estadística, no existe diferencia significativa entre las medias de ambos sexos, en este caso, en ninguno de los países. 
La distribución de los enunciados en función de las estrategias específicas utilizadas por los sujetos de ambos géneros en la situación que estamos analizando, es la que presentamos a continuación, en la figura 187: 
Figura 187. Distribución de enunciados según las estrategias utilizadas en la situación 2 por los varones y las mujeres de cada cultura

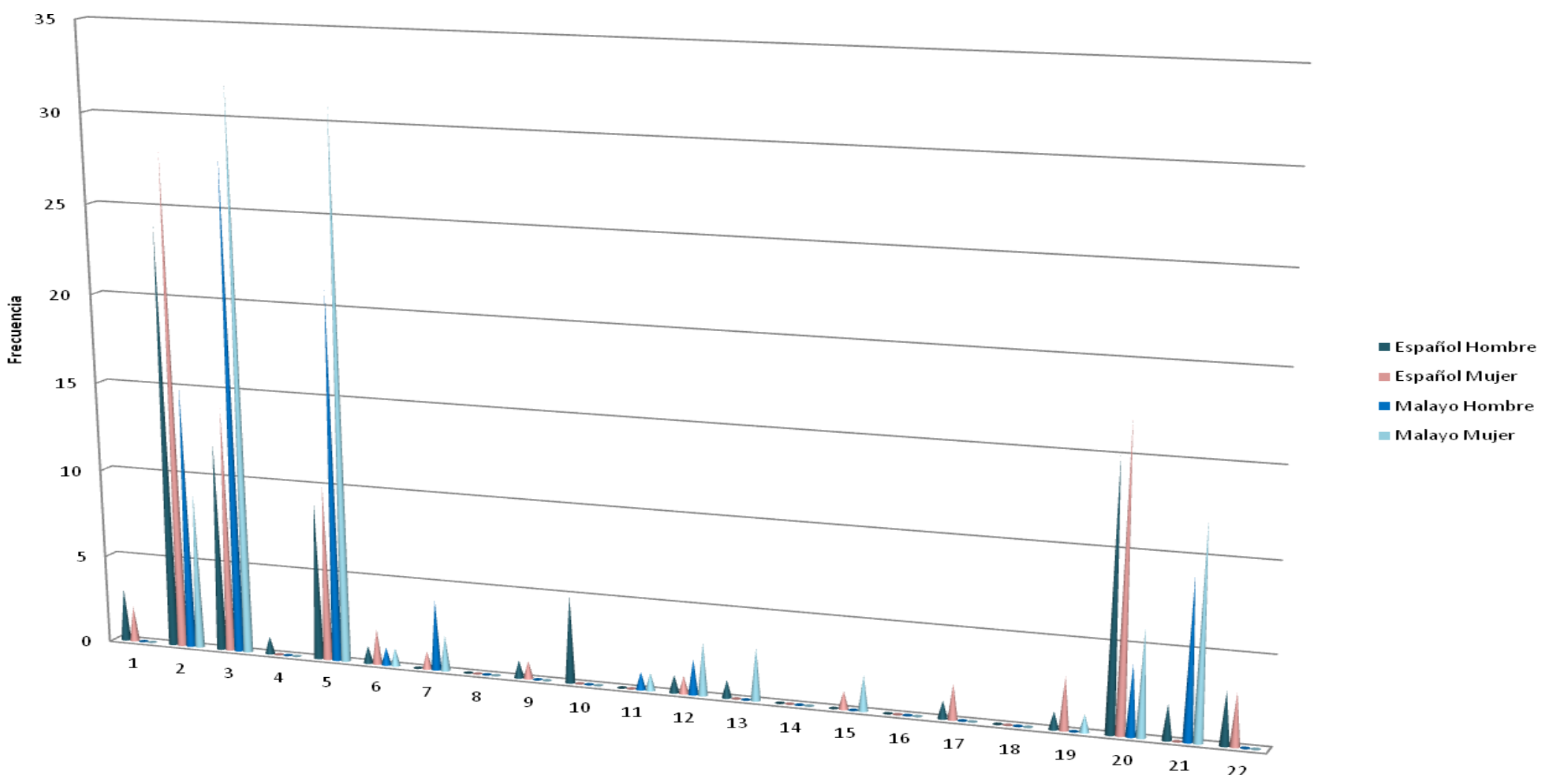

1: No 2: Buena voluntad/capacidad negativa 3: Disculpa 4: Deseo 5: Excusa 6: Declaración de alternativa 7: Conjunto de condiciones para la aceptación pasada/futura 8: Declaración de principios 9: Amenaza o declaración de consecuencias negativas para el emisor 10: Declaración de sentimiento negativo 11: Petición de comprensión 12: Garantía de satisfacción futura del interlocutor 13: Autodefensa 14: Repetición de parte de la petición 15: Aplazamiento 16: Evasivas 17: Declaración de opinión/sentimiento positivo 18: Declaración de empatía 19: Uso de muletillas 20: Agradecimiento 21: Fórmulas de tratamiento 22: Saludos/despedidas corteses 
Tanto los varones como las mujeres españoles, tendieron a aplicar más la estrategia de "Buena voluntad/capacidad negativa" (24 enunciados de los varones y 28 de las mujeres), seguida de las "Agradecimiento" (15 de los varones y 17 de las mujeres), "Disculpa" (12 de los varones y 14 del otro sexo) y "Excusa" (9 y 10 respectivamente). Los participantes de los dos sexos del grupo malayo, por su parte, manifestaron una mayor tendencia al empleo de la "Disculpa" (28 y 32 casos, respectivamente) en su formulación de rechazo, seguida de las estrategias de "Excusa" (21 de los varones y 31 de las mujeres), "Buena voluntad/capacidad negativa" (15 de los varones por 9 de las mujeres) y "Fórmulas de tratamiento" (9 y 12 respectivamente). En este contexto, la diferencia indicada entre las medias de ambos sexos en los dos países tampoco fue significativa.

A continuación, en la Tabla 74, se presenta el ranking de las estrategias aplicadas por los sujetos de los dos géneros de cada grupo cultural en la situación 2. 
Tabla 74. Estrategias utilizadas por los hablantes españoles y malayos en la situación 2 ordenadas según frecuencia de uso (de mayor a menor) en cada subgrupo de sexo

\begin{tabular}{|c|c|c|}
\hline \multirow{2}{*}{$\mathbf{0}$} & \multicolumn{2}{|c|}{ Español } \\
\hline & Varón & Mujer \\
\hline 1 & $>$ Buena voluntad/capacidad negativa & $>$ Buena voluntad/capacidad negativa \\
\hline 2 & $>$ Agradecimiento & $>$ Agradecimiento \\
\hline 3 & $>$ Disculpa & $>$ Disculpa \\
\hline 4 & $>$ Excusa & $>$ Excusa \\
\hline 5 & $>$ Declaración de sentimiento negativo & $\begin{array}{l}>\text { Uso de muletillas } \\
>\text { Saludos/despedidas corteses }\end{array}$ \\
\hline 6 & $\begin{array}{l}>\text { No } \\
>\text { Saludos/despedidas corteses }\end{array}$ & $\begin{array}{l}>\text { Declaración de alternativa } \\
>\text { Declaración de opinión/sentimiento positivo } \\
>\text { No }\end{array}$ \\
\hline 7 & $>$ Fórmulas de tratamiento & $\begin{array}{l}>\text { Conjunto de condiciones para la aceptación } \\
\text { pasada/futura } \\
>\text { Amenaza o declaración de consecuencias } \\
\text { negativas para el emisor } \\
>\text { Garantía de satisfacción futura del } \\
\text { interlocutor } \\
>\text { Aplazamiento }\end{array}$ \\
\hline 8 & $\begin{array}{l}>\text { Deseo } \\
>\text { Declaración de alternativa } \\
>\text { Amenaza o declaración de } \\
\text { consecuencias negativas para el emisor } \\
>\text { Garantía de satisfacción futura del } \\
\text { interlocutor } \\
>\text { Autodefensa } \\
>\text { Declaración de opinión/sentimiento } \\
\text { positivo } \\
>\text { Uso de muletillas }\end{array}$ & - \\
\hline \multirow{2}{*}{$\mathbf{0}$} & \multicolumn{2}{|c|}{ Malayo } \\
\hline & Varón & Mujer \\
\hline 1 & $>$ Disculpa & $>$ Disculpa \\
\hline 2 & $>$ Excusa & $>$ Excusa \\
\hline 3 & $>$ Buena voluntad/capacidad negativa & $>$ Fórmulas de tratamiento \\
\hline 4 & $>$ Fórmulas de tratamiento & > Buena voluntad/capacidad negativa \\
\hline 5 & $\begin{array}{l}\text { Conjunto de condiciones para la } \\
\text { aceptación pasada/futura } \\
>\text { Agradecimiento }\end{array}$ & $>$ Agradecimiento \\
\hline 6 & $\begin{array}{l}\text { Garantía de satisfacción futura del } \\
\text { interlocutor }\end{array}$ & $\begin{array}{l}>\text { Garantía de satisfacción futura del } \\
\text { interlocutor } \\
>\text { Autodefensa }\end{array}$ \\
\hline 7 & $\begin{array}{l}\text { Declaración de alternativa } \\
>\text { Petición de comprensión }\end{array}$ & $\begin{array}{l}\text { Conjunto de condiciones para la } \\
\text { aceptación pasada/futura } \\
>\text { Aplazamiento }\end{array}$ \\
\hline 8 & - & $\begin{array}{l}>\text { Declaración de alternativa } \\
>\text { Petición de comprensión } \\
>\text { Uso de muletillas }\end{array}$ \\
\hline
\end{tabular}




\subsubsection{Situación 5}

En la situación 5, un estudiante universitario le pide a su compañero de curso que le preste su portátil porque ha entrado un virus en el suyo. El grado de familiaridad es alto (conocido), ya que es un amigo y hay igualdad de poder social.

\section{A) Español frente a malayo}

Los datos obtenidos muestran que los españoles produjeron menos enunciados que los malayos (175 de los españoles frente a 198 de los malayos). Sin embargo, los españoles aplicaron más estrategias diferentes que los malayos (encontramos 15 tipos diferentes en las respuestas de los españoles y 14 en las de los malayos). En esta situación, los españoles aplicaron más estrategias directas que los malayos (28 enunciados de los españoles en comparación con solo 13 de los malayos). Así, las estrategias indirectas (128 casos de los españoles en contraste con los 163 de los malayos) y las de adyacentes al rechazo (19 ejemplos recogidos de los españoles y 22 de los malayos) las utilizaron menos que los malayos, como se puede observar en la gráfica que se presenta a continuación, y que recoge la distribución de los enunciados formulados en la situación 5, según las estrategias de rechazo más o menos indirectas empleadas: 
Figura 188. Distribución de enunciados, según grado de (in)dirección de las estrategias elegidas, producidos en la situación 5 por los sujetos de los dos grupos principales

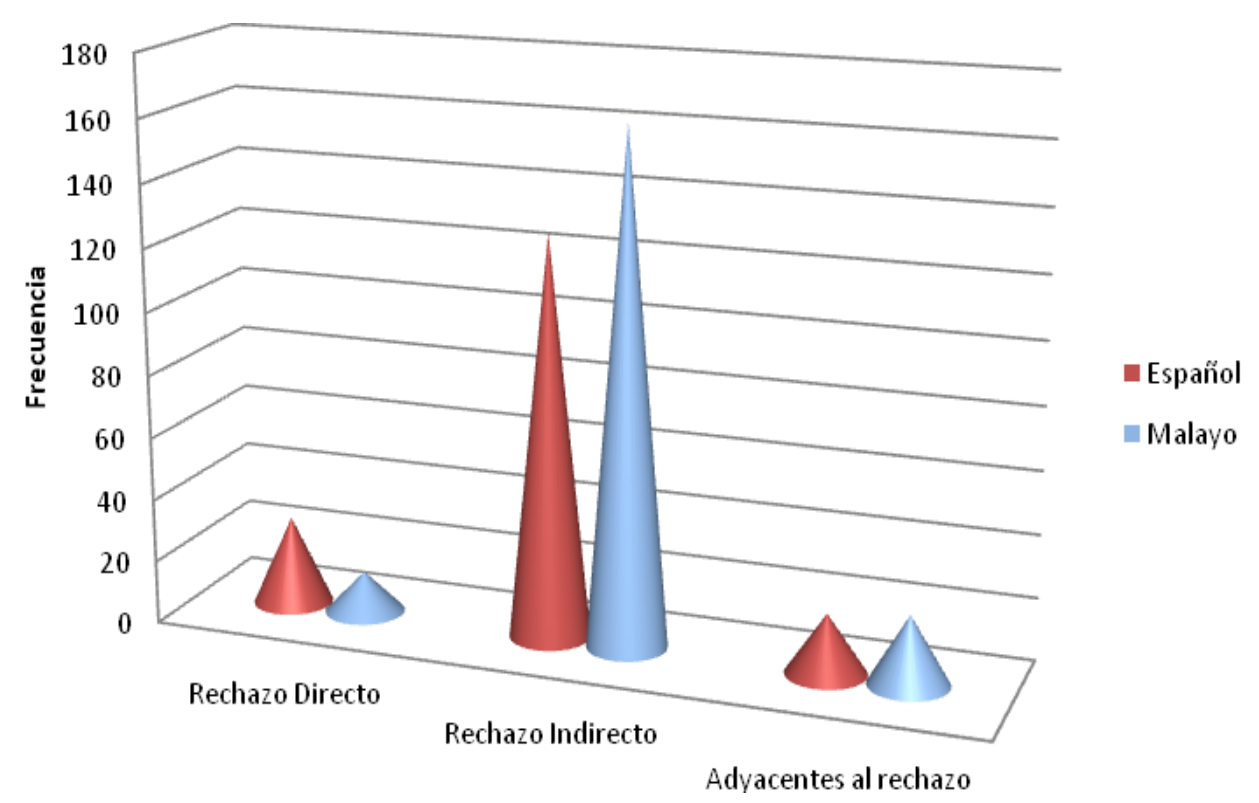

La diferencia entre ambas sociedades fue evidente en el caso del "Rechazo indirecto" pero no lo fue tanto en los otros dos casos, "Rechazo directo" y "Adyacentes al rechazo". Las pruebas estadísticas mostraron que las dos culturas analizadas se diferenciaron significativamente en la comparación de los promedios del grado de (in)dirección: $X^{2}=8.531 \mathrm{p}=.014(\mathrm{p}<.05)$.

En cuanto a las estrategias concretas empleadas por los hablantes en sus enunciados, la tabla siguiente nos muestra la distribución en cada uno de los grupos culturales de nuestro estudio: 
Figura 189. Distribución de enunciados según las estrategias utilizadas en la situación 5 por los sujetos participantes de cada cultura

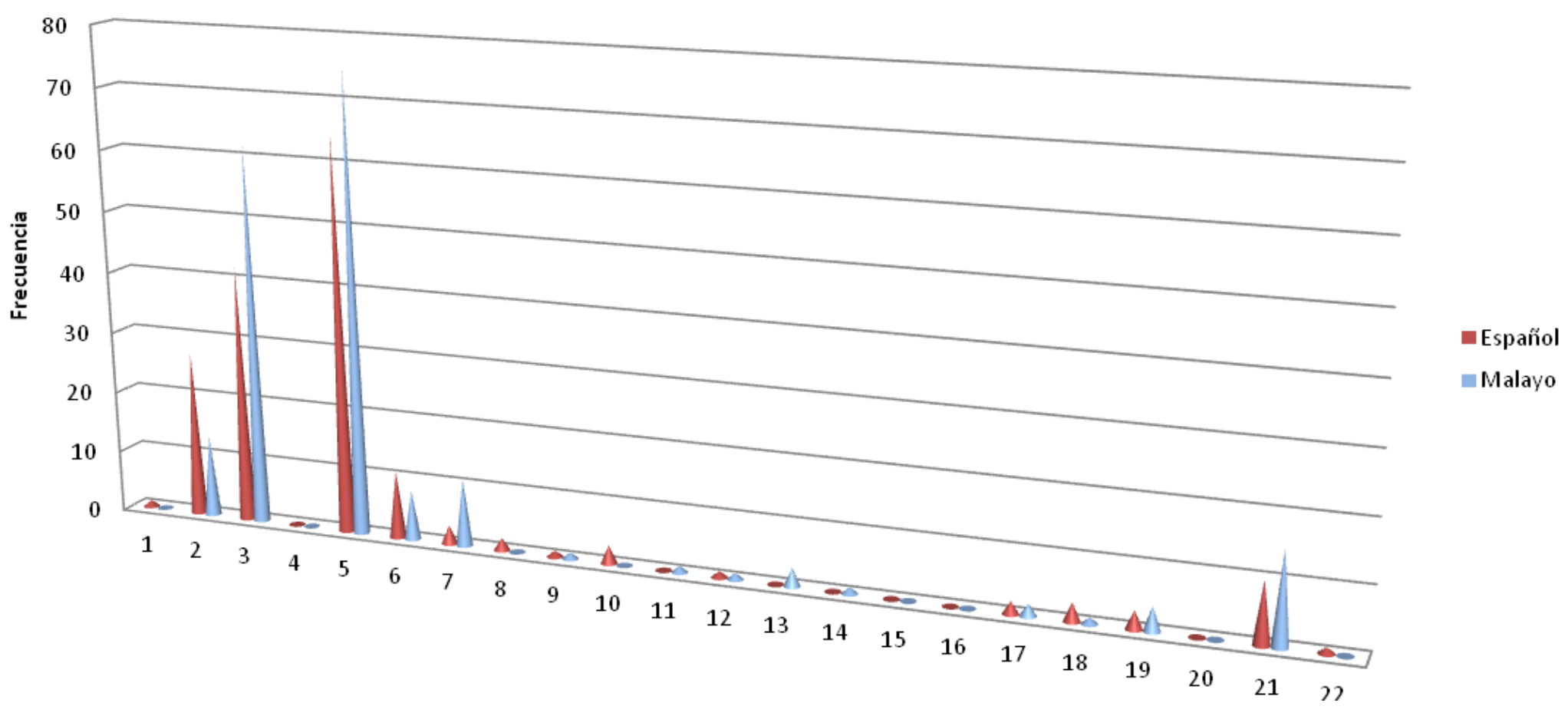

1: No 2: Buena voluntad/capacidad negativa 3: Disculpa 4: Deseo 5: Excusa 6: Declaración de alternativa 7: Conjunto de condiciones para la aceptación pasada/futura 8: Declaración de principios 9: Amenaza o declaración de consecuencias negativas para el emisor 10: Declaración de sentimiento negativo 11: Petición de comprensión 12: Garantía de satisfacción futura del interlocutor 13: Autodefensa 14: Repetición de parte de la petición 15: Aplazamiento 16: Evasivas 17: Declaración de opinión/sentimiento positivo 18: Declaración de empatía 19: Uso de muletillas 20: Agradecimiento 21: Fórmulas de tratamiento 22: Saludos/despedidas corteses 
Los españoles utilizaron la estrategia de "Buena voluntad/capacidad negativa" con mucha más frecuencia que los malayos, con 27 casos encontrados por tan solo 13 de los malayos. En cambio, los malayos aplicaron la "Disculpa" en mayor proporción que los españoles, con 62 apariciones en los enunciados de los primeros por solo 42 en los de los segundos. En esta situación, los dos grupos emplearon la "Excusa" con mayor frecuencia (65 veces en los datos españoles y 75 veces en los datos malayos) en comparación con el uso que se hizo de ella en el resto de situaciones de rechazo.

Las tres estrategias más utilizadas por los españoles para expresar rechazo en esta situación del cuestionario fueron las de "Excusa" (65 veces), "Disculpa" (42) y "Buena voluntad/capacidad negativa" (27). Por otro lado, los malayos utilizaron la "Excusa" (75 veces) como opción más frecuente, seguida por la "Disculpa" (62) y las "Fórmulas de tratamiento" (15) en su formulación de rechazo. La diferencia entre los promedios de las estrategias aplicadas no fue significativa.

El ranking de las estrategias empleadas por los hablantes de los dos grupos se presenta en la Tabla 75: 
Tabla 75. Estrategias utilizadas en la situación 5 en cada cultura ordenadas según frecuencia de uso (de mayor a menor)

\begin{tabular}{|c|c|c|}
\hline $\mathbf{O}$ & Español & Malayo \\
\hline 1 & $>$ Excusa & $>$ Excusa \\
\hline 2 & $>$ Disculpa & $>$ Disculpa \\
\hline 3 & $\begin{array}{l}\text { Buena voluntad/capacidad } \\
\text { negativo }\end{array}$ & $>$ Fórmulas de tratamiento \\
\hline 4 & $>$ Declaración de alternativa & $>$ Buena voluntad/capacidad negativa \\
\hline 5 & Fórmulas de tratamiento & $\begin{array}{l}\text { Conjunto de condiciones para la } \\
\text { aceptación pasada/futura }\end{array}$ \\
\hline 6 & $\begin{array}{l}\text { Conjunto de condiciones para la } \\
\text { aceptación pasada/futura } \\
>\text { Declaración de sentimiento } \\
\text { negativo } \\
>\text { Declaración de empatía } \\
>\text { Uso de muletillas }\end{array}$ & $>$ Declaración de alternativa \\
\hline 7 & $\begin{array}{l}\text { Declaración de principios } \\
\text { Declaración de } \\
\text { opinión/sentimiento positivo }\end{array}$ & $>$ Uso de muletillas \\
\hline 8 & $\begin{aligned} & \text { No } \\
& \text { Amenaza o declaración de } \\
\text { consecuencias negativas para el } & \text { emisor } \\
& \text { Garantía de satisfacción futura del } \\
& \text { interlocutor } \\
> & \text { Saludos/despedidas corteses }\end{aligned}$ & $>$ Autodefensa \\
\hline 9 & - & $\begin{array}{l}\text { Declaración de opinión/sentimiento } \\
\text { positivo }\end{array}$ \\
\hline
\end{tabular}

\section{B) Mayor frente a menor}

Al analizar los datos teniendo en cuenta la variable de edad, se observa que los mayores españoles formularon menos enunciados que los menores (85 frente a 90). En cambio, los mayores malayos emplearon más que los menores (100 enunciados de los mayores frente a 98 de los menores). Respecto a los diferentes tipos de estrategias aplicados, los participantes mayores en los dos grupos, 
español y malayo, emplearon más estrategias distintas que los más jóvenes (14 frente a 11 en el primer grupo, y 12 por 10 en el segundo).

También se nota que en esta situación, tanto los mayores españoles como los malayos, utilizaron menos estrategias directas que los menores (13 enunciados frente a 15 en el primer caso, y 9 frente a 4 en el segundo caso). En lo que concierne a las estrategias indirectas, los mayores españoles las aplicaron menos que los menores (61 casos de los primeros y 67 de los segundos). En cambio, en las respuestas de los mayores malayos encontramos más casos que en las de los menores (81 y 80 respectivamente). Ocurre lo contrario en la tercera categoría, es decir, en el uso de las adyacentes al rechazo, ya que los mayores españoles las utilizaron más que los menores (11 enunciados frente a 8 ), mientras que los mayores malayos las utilizaron menos que los menores ( 8 frente a 14). Las diferencias entre los subgrupos de edad en ambas culturas a través de la comparación de los promedios de las tres formas utilizadas no fueron significativas.

En las tablas que presentamos a continuación se recoge la distribución de los enunciados producidos en la situación 5, tanto en los tres grandes grupos de estrategias aplicadas en la expresión del rechazo según el grado de (in)dirección (Figura 190), como en cada 
una de las 22 estrategias con las que estamos trabajando en nuestro análisis (Figura 191).

Figura 190. Distribución de enunciados, según grado de (in)dirección de las estrategias empleadas, producidos en la situación 5 por los sujetos mayores y menores de cada grupo cultural

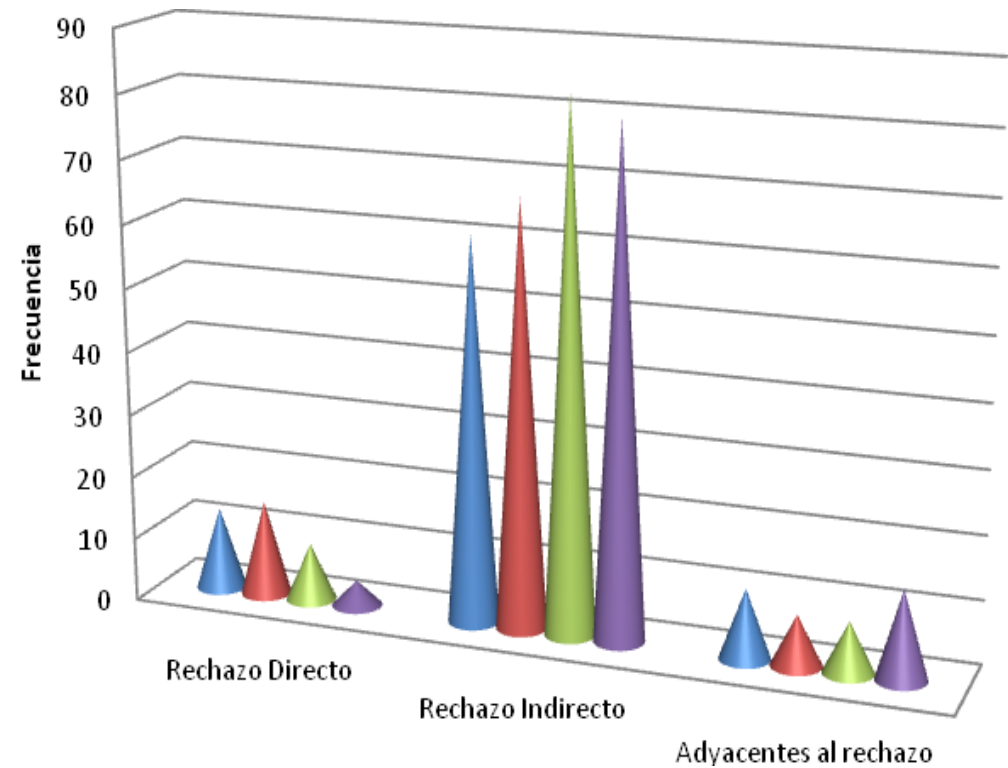

- Español Mayor

Español Menor

Malayo Mayor

Malayo Menor 
Figura 191. Distribución de enunciados según las estrategias utilizadas en la situación 5 por los sujetos mayores y menores de cada cultura

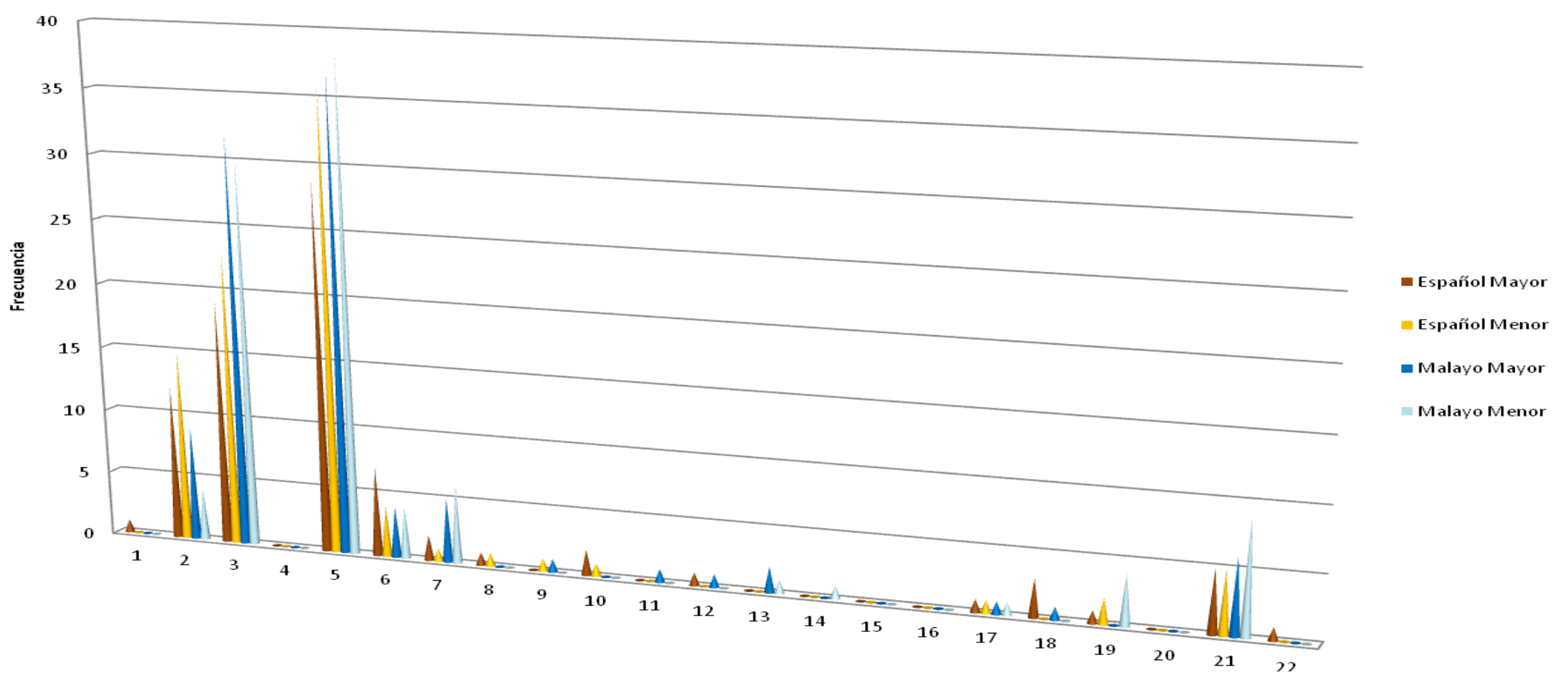

1: No 2: Buena voluntad/capacidad negativa 3: Disculpa 4: Deseo 5: Excusa 6: Declaración de alternativa 7: Conjunto de condiciones para la aceptación pasada/futura 8: Declaración de principios 9: Amenaza o declaración de consecuencias negativas para el emisor 10: Declaración de sentimiento negativo 11: Petición de comprensión 12: Garantía de satisfacción futura del interlocutor 13: Autodefensa 14: Repetición de parte de la petición 15: Aplazamiento 16: Evasivas 17: Declaración de opinión/sentimiento positivo 18: Declaración de empatía 19: Uso de muletillas 20: Agradecimiento 21: Fórmulas de tratamiento 22: Saludos/despedidas corteses 
Las tres estrategias más comúnmente utilizadas tanto por los mayores españoles como por los menores fueron las de "Excusa" (29 enunciados registrados de los mayores y 36 de los menores), "Disculpa" (19 de los mayores y 23 de los menores) y "Buena voluntad/capacidad negativa" (12 de los primeros y 15 los segundos). En el caso malayo, y de manera similar al español, la estrategia más frecuentemente usada por los de más edad fue la de "Excusa" (37), seguida de las de "Disculpa" (32) y "Buena voluntad/capacidad negativa" (9). Por otra parte, los menores tendieron a usar más la de Excusa" (38), seguida de las de "Disculpa" (30) y "Fórmulas de tratamiento" (9). La diferencia entre los promedios de las estrategias usadas por los hablantes mayores y los menores no fue significativa en los datos de ninguno de los grupos.

La tabla que presentamos a continuación refleja el ranking de cada estrategia utilizada por los sujetos de más y menos edad de cada grupo: 
Tabla 76. Estrategias utilizadas por los hablantes españoles y malayos en la situación 5, ordenadas según frecuencia de uso (de mayor a menor) en cada subgrupo de edad

\begin{tabular}{|c|c|}
\hline $\mathbf{O}$ & Español Mayor \\
\hline 1 & $>$ Excusa \\
\hline 2 & $>$ Disculpa \\
\hline 3 & $>$ Buena voluntad/capacidad negativa \\
\hline 4 & $>$ Declaración de alternativa \\
\hline 5 & $>$ Fórmulas de tratamiento \\
\hline 6 & $>$ Declaración de empatía \\
\hline 7 & $\begin{array}{l}\text { Conjunto de condiciones para la } \\
\text { aceptación pasada/futura } \\
>\text { Declaración de sentimiento negativo }\end{array}$ \\
\hline 8 & $\begin{aligned} & \text { No } \\
> & \text { Declaración de principios } \\
& \text { Garantía de satisfacción futura del } \\
& \text { interlocutor } \\
> & \text { Declaración de opinión/sentimiento } \\
& \text { positivo } \\
> & \text { Uso de muletillas } \\
> & \text { Saludos/despedidas corteses }\end{aligned}$ \\
\hline
\end{tabular}

\begin{aligned} \multicolumn{1}{c}{ Español Menor } \\ $>$ Excusa \\ $>$ Disculpa \\ $>$ Buena voluntad/capacidad negativa \\ $>$ Fórmulas de tratamiento \\ $>$ Declaración de alternativa \\ $>$ Uso de muletillas \\ $>$ Conjunto de condiciones para la \\ aceptación pasada/futura \\ $>$ Declaración de principios \\ $>$ Amenaza o declaración de \\ consecuencias negativas para el emisor \\ $>$ Declaración de sentimiento negativo \\ $>$ Declaración de opinión/sentimiento \\ positivo \end{aligned}

\begin{tabular}{|c|c|c|}
\hline 0 & Malayo Mayor & Malayo Menor \\
\hline 1 & $>$ Excusa & $>$ Excusa \\
\hline 2 & $>$ Disculpa & $>$ Disculpa \\
\hline 3 & $>$ Buena voluntad/capacidad negativa & $>$ Fórmulas de tratamiento \\
\hline 4 & $>$ Fórmulas de tratamiento & $\begin{array}{l}\text { Conjunto de condiciones para la } \\
\text { aceptación pasada/futura }\end{array}$ \\
\hline 5 & $\begin{array}{l}\text { Conjunto de condiciones para la } \\
\text { aceptación pasada/futura }\end{array}$ & $\begin{array}{l}>\text { Buena voluntad/capacidad negativa } \\
>\text { Declaración de alternativa } \\
>\text { Uso de muletillas }\end{array}$ \\
\hline 6 & $>$ Declaración de alternativa & $\begin{aligned} & \text { Autodefensa } \\
& \text { Repetición de parte de la petición } \\
& \text { Declaración de opinión/sentimiento } \\
& \text { positivo }\end{aligned}$ \\
\hline 7 & $>$ Autodefensa & - \\
\hline 8 & $\begin{array}{l}\text { Amenaza o declaración de } \\
\text { consecuencias negativas para el } \\
\text { emisor } \\
>\text { Petición de comprensión } \\
>\text { Garantía de satisfacción futura del } \\
\text { interlocutor } \\
>\text { Declaración de opinión/sentimiento } \\
\text { positivo } \\
>\text { Declaración de empatía }\end{array}$ & - \\
\hline
\end{tabular}




\section{C) Varón frente a mujer}

En este último punto del análisis de la situación 5 se encuentra que los varones de ambos grupos, español y malayo, formularon menos enunciados que las mujeres (82 y 93 , respectivamente, de los españoles, y 87 y 111 de los malayos). El análisis muestra que los varones españoles utilizaron más estrategias diferentes que las mujeres (13 tipos distintos frente a 11). En cambio, los hablantes de los dos géneros en el grupo malayo utilizaron el mismo número de estrategias diferentes (ambos aplicaron 11).

En lo que respecta a las estrategias directas, los sujetos de ambos sexos en el grupo español las usaron con la misma frecuencia (se recogieron 14 enunciados de cada subgrupo). En el grupo malayo, los varones las aplicaron menos que las mujeres (4 casos en los varones por 9 en las mujeres). En cuanto a las indirectas y las de adyacentes al rechazo, tanto los varones españoles como los malayos las utilizaron menos que las mujeres. (59 y 69 en el primer caso, y 9 frente a 10 en el segundo, en el grupo español, y 77 frente a 86 en el primer caso, y 6 por 16 en el segundo en el grupo malayo). Esta distribución de enunciados es la que se muestra en la figura que aparece a continuación: 
Figura 192. Distribución de enunciados, según grado de (in)dirección de las estrategias aplicadas, producidos en la situación 5 por los varones y mujeres de cada grupo cultural

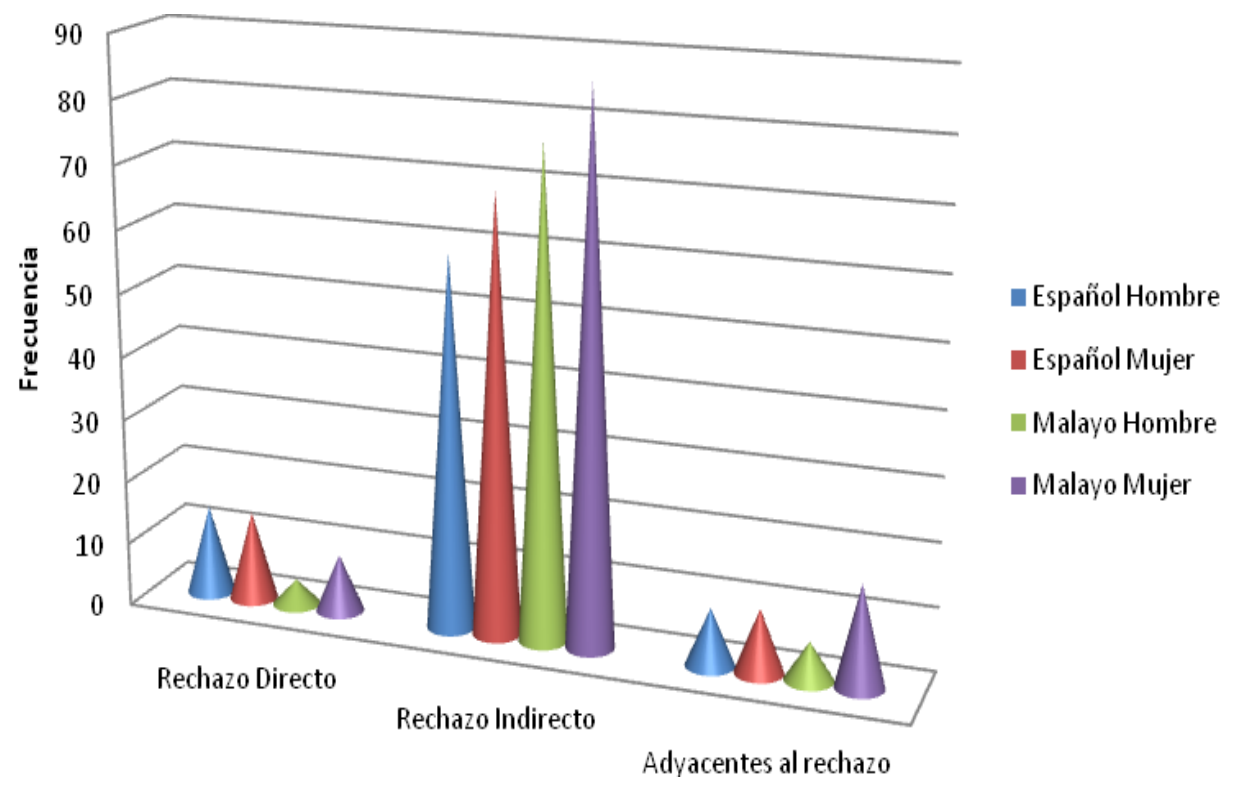

En esta situación no encontramos grandes diferencias entre los subgrupos españoles en la clasificación de los enunciados por las estrategias más o menos directas empleadas, excepto en el caso del "Rechazo indirecto". En la cultura malaya, en cambio, los datos sí muestran una diferencia más llamativa. Podemos añadir, además, que, desde el punto de vista del contraste entre culturas, se nota una diferencia importante, pero no se han encontrado diferencias estadísticas significativas entre los subgrupos de sexo de cada país.

Los datos que se presentan en la tabla que aparece a continuación son los que corresponden a las estrategias aplicadas por los hablantes de ambos sexos de cada cultura en la situación 5: 
Figura 193. Distribución de enunciados según las estrategias utilizadas en la situación 5 por los varones y mujeres de cada cultura

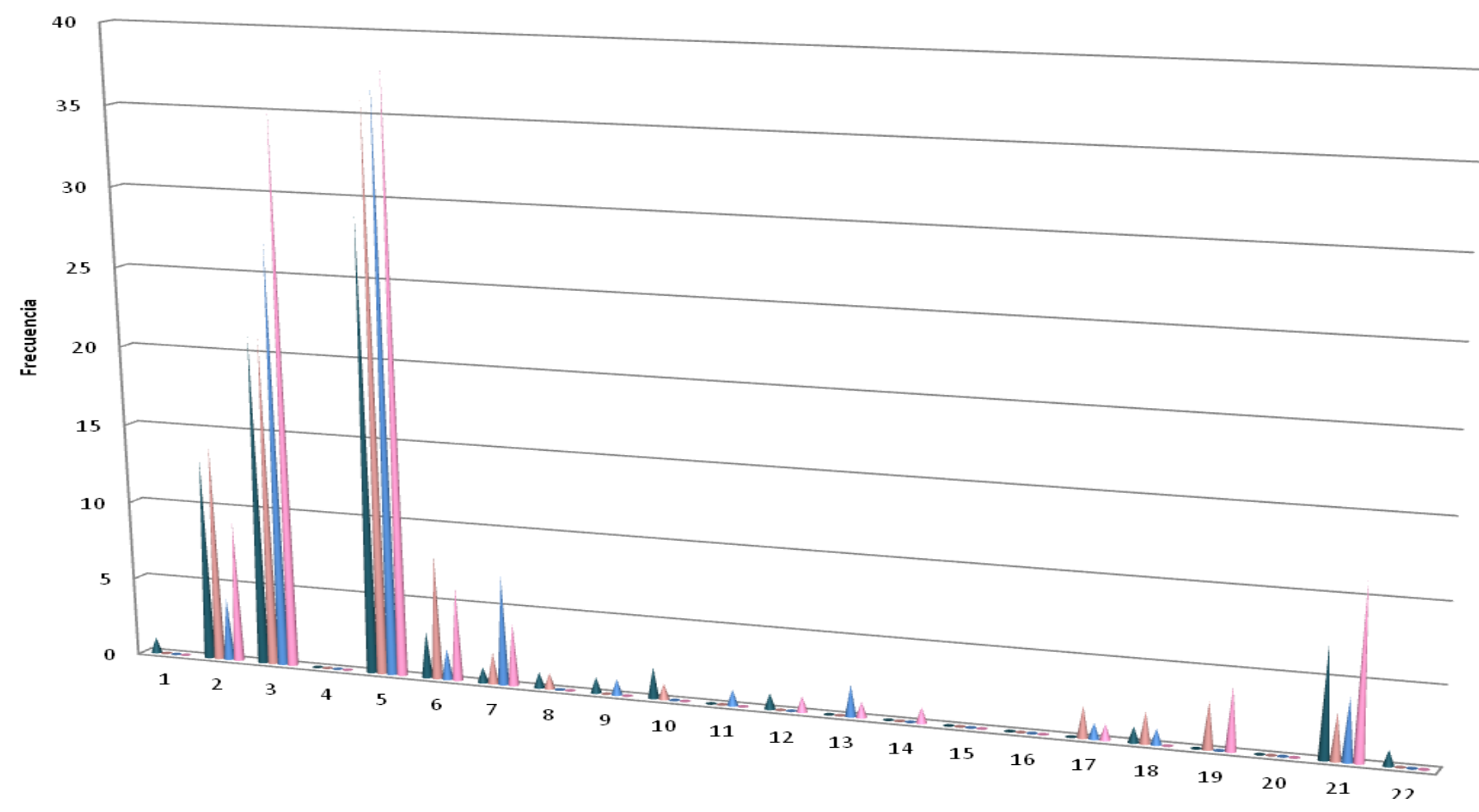

\author{
- Español Hombre \\ Español Mujer \\ Malayo Hombre \\ Malayo Mujer
}

1: No 2: Buena voluntad/capacidad negativa 3: Disculpa 4: Deseo 5: Excusa 6: Declaración de alternativa 7: Conjunto de condiciones para la aceptación pasada/futura 8: Declaración de principios 9: Amenaza o declaración de consecuencias negativas para el emisor 10: Declaración de sentimiento negativo 11: Petición de comprensión 12: Garantía de satisfacción futura del interlocutor 13: Autodefensa 14: Repetición de parte de la petición 15: Aplazamiento 16: Evasivas 17: Declaración de opinión/sentimiento positivo 18: Declaración de empatía 19: Uso de muletillas 20: Agradecimiento 21: Fórmulas de tratamiento 22: Saludos/despedidas 
Los sujetos de los dos géneros en cada grupo tendieron a utilizar más las estrategias de "Excusa" (29 y 36 casos, respectivamente, del grupo español y 37 y 38 , del grupo malayo) y "Disculpa" (21 ejemplos recogidos en cada subgrupo de sexo español, y 27 y 35 , en el subgrupo malayo de hombres y de mujeres, respectivamente) para formular rechazos. Sin embargo, la estrategia que ocupa el tercer lugar por orden de preferencia fue diferente en cada género en ambos grupos: "Fórmulas de tratamiento" en los varones españoles (7 veces) y "Declaración de alternativa" en las mujeres (8 veces), y, en el grupo malayo, "Conjunto de condiciones para la aceptación pasada/futura" en los varones (7 veces) y "Fórmulas de tratamiento" en las mujeres (11 veces). La diferencia indicada entre las medias de ambos sexos en los dos países tampoco fue significativa.

El ranking de cada estrategia empleada por los hablantes de los dos géneros en cada grupo se muestra en la Tabla 77. 
Tabla 77. Estrategias utilizadas por los hablantes españoles y malayos en la situación 5, ordenadas según frecuencia de uso (de mayor a menor) en cada subgrupo de sexo

\begin{tabular}{|c|c|c|}
\hline $\mathbf{0}$ & Español Varón & Español Mujer \\
\hline 1 & $>$ Excusa & $>$ Excusa \\
\hline 2 & $>$ Disculpa & $>$ Disculpa \\
\hline 3 & $\begin{array}{l}\text { Buena voluntad/capacidad } \\
\text { negativa }\end{array}$ & $>$ Buena voluntad/capacidad negativa \\
\hline 4 & $>$ Fórmulas de tratamiento & $>$ Declaración de alternativa \\
\hline 5 & $>$ Declaración de alternativa & $\begin{array}{l}\text { Uso de muletillas } \\
>\text { Fórmulas de tratamiento }\end{array}$ \\
\hline 6 & $\begin{array}{l}\text { Declaración de sentimiento } \\
\text { negativo }\end{array}$ & $\begin{array}{l}\text { Conjunto de condiciones para la } \\
\text { aceptación pasada/futura } \\
\text { Declaración de opinión/sentimiento } \\
\text { positivo } \\
\text { Declaración de empatía }\end{array}$ \\
\hline 7 & $\begin{array}{l}\text { No } \\
\text { C Conjunto de condiciones para la } \\
\text { aceptación pasada/futura } \\
\text { Declaración de principios } \\
\text { D Amenaza o declaración de } \\
\text { consecuencias negativas para el } \\
\text { emisor } \\
\text { D Garantía de satisfacción futura del } \\
\text { interlocutor } \\
\text { Declaración de empatía } \\
\text { D Saludos/despedidas corteses }\end{array}$ & $\begin{array}{l}>\text { Declaración de principios } \\
>\text { Declaración de sentimiento negativo }\end{array}$ \\
\hline 0 & Malayo Varón & Malayo Mujer \\
\hline 1 & $>$ Excusa & $>$ Excusa \\
\hline 2 & $>$ Disculpa & $>$ Disculpa \\
\hline 3 & $\begin{array}{l}\text { Conjunto de condiciones para la } \\
\text { aceptación pasada/futura }\end{array}$ & $>$ Fórmulas de tratamiento \\
\hline 4 & $\begin{array}{l}\text { Buena voluntad/capacidad } \\
\text { negativa } \\
>\text { Fórmulas de tratamiento }\end{array}$ & $>$ Buena voluntad/capacidad negativa \\
\hline 5 & $\begin{array}{l}>\text { Declaración de alternativa } \\
>\text { Autodefensa }\end{array}$ & $>$ Declaración de alternativa \\
\hline 6 & $\begin{array}{l}\text { Amenaza o declaración de } \\
\text { consecuencias negativas para el } \\
\text { emisor } \\
>\text { Petición de comprensión } \\
>\text { Declaración de } \\
\text { opinión/sentimiento positivo } \\
>\text { Declaración de empatía }\end{array}$ & $\begin{array}{l}\text { Conjunto de condiciones para la } \\
\text { aceptación pasada/futura } \\
>\text { Uso de muletillas }\end{array}$ \\
\hline 7 & - & $\begin{aligned}> & \text { Garantía de satisfacción futura del } \\
& \text { interlocutor } \\
> & \text { Autodefensa } \\
> & \text { Repetición de parte de la petición } \\
> & \text { Declaración de opinión/sentimiento } \\
& \text { positivo o acuerdo }\end{aligned}$ \\
\hline
\end{tabular}




\subsubsection{Situación 8}

En la situación 8, en la que un hermano menor pide a su hermano mayor que le acompañe a la fiesta de cumpleaños de su amigo, el grado de familiaridad es muy alto, ya que en el cuestionario se especifica que el interlocutor tiene una relación muy estrecha con su hermano menor.

\section{A) Español frente a malayo}

El análisis revela que, en total, las estrategias utilizadas por los españoles fueron menores en número que las de los malayos (los españoles aplicaron 197 estrategias por 228 aplicadas por los malayos). No obstante, los sujetos españoles utilizaron más tipos diferentes de estrategias que los malayos (17 de los españoles frente a 14 de los malayos). Además, los españoles utilizaron más estrategias directas que los malayos (42 de los españoles en contraste con 29 de los malayos). Las indirectas y las de adyacentes al rechazo, los españoles las emplearon menos que los malayos (solo 116 de los españoles frente a 140 de los malayos del primer tipo, y 39 y 59, respectivamente, en el segundo). La distribución de las estrategias de rechazo formuladas para la situación 8 en los dos grupos principales se indica en la Figura 194. 
Figura 194. Distribución de enunciados, según grado de (in)dirección de la estrategia seleccionada, producidos en la situación 8 en cada grupo principal

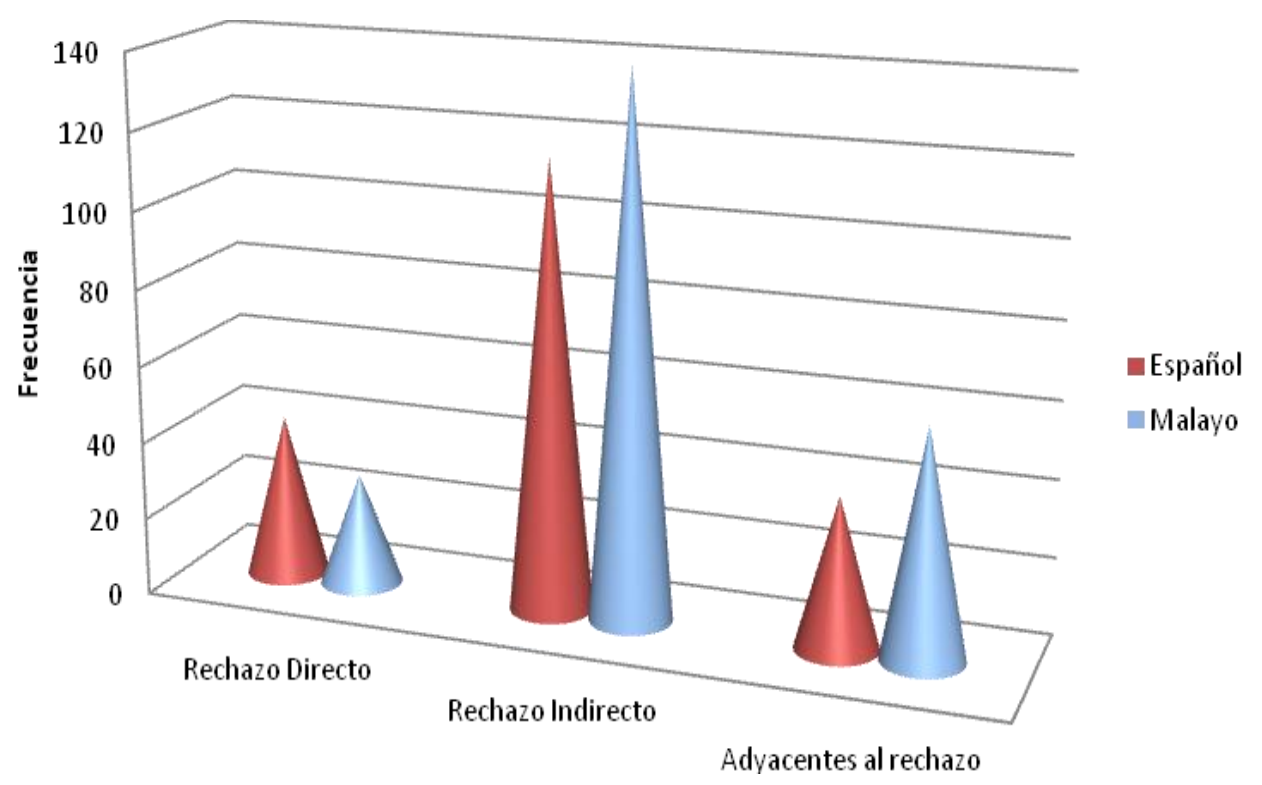

Como se ve en la Figura 194, hay una diferencia significativa entre las dos culturas en las tres categorías, "Rechazo directo" "Rechazo indirecto" y "Adyacentes al rechazo". Las dos culturas analizadas se diferenciaron significativamente en la comparación de los promedios de los tipos de estrategias aplicados: $X^{2}=6.485 p=.039(p<.05)$.

Al analizar los enunciados teniendo en cuenta la subclasificación de las estrategias en 22 subtipos, los resultados numéricos obtenidos fueron los que aparecen en la figura que se presenta a continuación: 
Figura 195. Distribución de enunciados según las estrategias utilizadas para la situación 8 en cada grupo principal

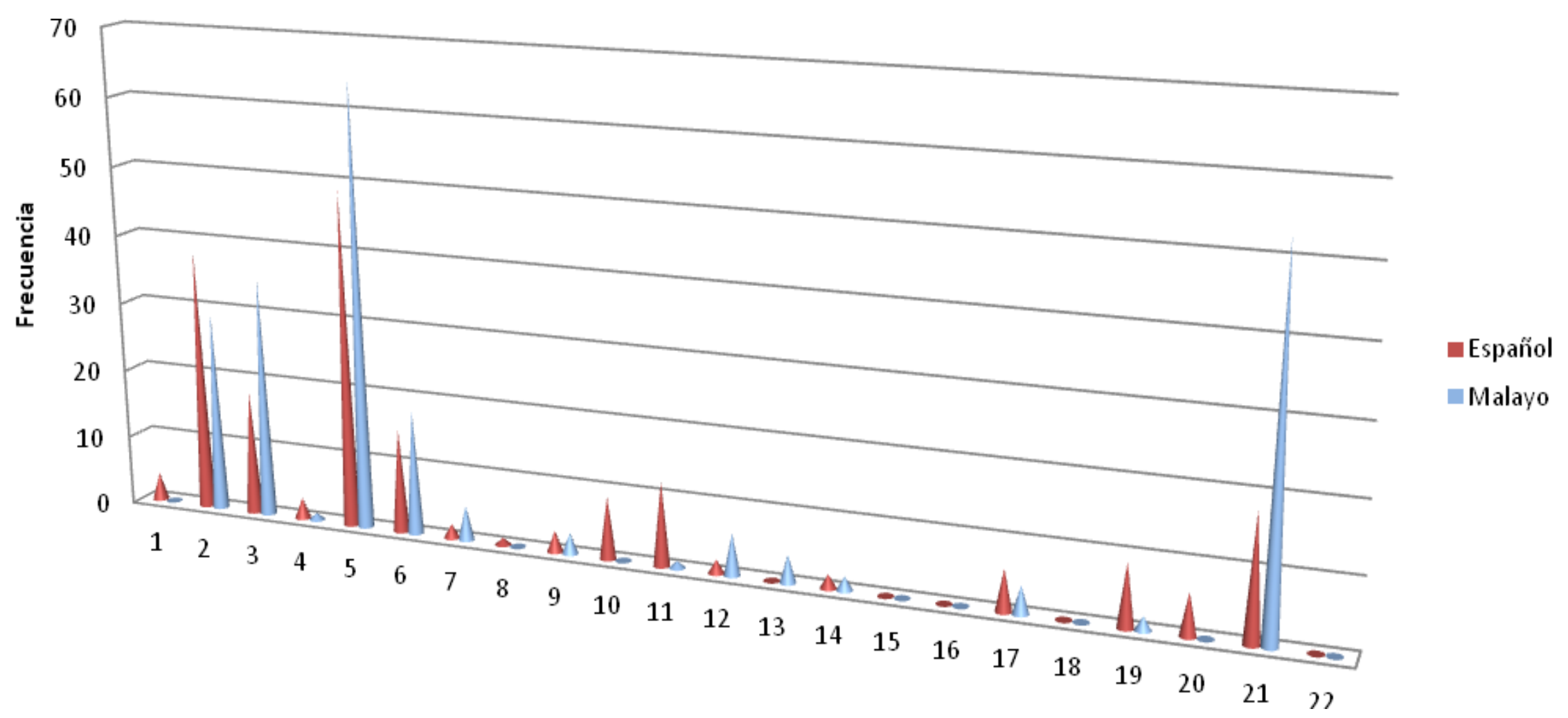

1: No 2: Buena voluntad/capacidad negativa 3: Disculpa 4: Deseo 5: Excusa 6: Declaración de alternativa 7: Conjunto de condiciones para la aceptación pasada/futura 8: Declaración de principios 9: Amenaza o declaración de consecuencias negativas para el emisor 10: Declaración de sentimiento negativo 11: Petición de comprensión 12: Garantía de satisfacción futura del interlocutor 13: Autodefensa 14: Repetición de parte de la petición 15: Aplazamiento 16: Evasivas 17: Declaración de opinión/sentimiento positivo 18: Declaración de empatía 19: Uso de muletillas 20: Agradecimiento 21: Fórmulas de tratamiento 22: Aplazamiento 16: Evasivas 17: Declaración de opinion/sentimiento positivo 18: Declaración de empatía 19: Uso de muletillas 20: Agradecimiento 21: Formulas de tratam Saludos/despedidas 
Los españoles usaron "Buena voluntad/capacidad negativa" más que los malayos (se encontraron 39 casos de los españoles y 29 de los malayos) al formular sus rechazos. En cambio, los malayos utilizaron un mayor número de enunciados con la estrategia de "Disculpa" (35 de los malayos frente a tan solo 18 de españoles) y con la de "Fórmulas de tratamiento" (53 de los malayos en comparación con tan solo 18 de los españoles) que los españoles. Otras estrategias en cuya frecuencia de uso también hay una gran diferencia entre los dos grupos fueron las de "Excusa" (49 enunciados de los españoles y 65 de los malayos), "Declaración de alternativa" (18 de los españoles y 35 de los malayos) y "Petición de comprensión" (12 de los españoles en comparación con tan solo una de los malayos).

Las estrategias más comúnmente utilizadas para realizar rechazos en el grupo español fueron las de "Excusa" (49 veces), "Buena voluntad/capacidad negativa" (39 veces), "Fórmulas de tratamiento" (18 veces) y "Disculpa" (18 veces). Por otro lado, las estrategias más frecuentemente utilizadas en el grupo malayo fueron las de "Excusa" (65 veces), "Fórmulas de tratamiento" (53 veces), "Disculpa" (35 veces) y "Buena voluntad/capacidad negativa" (29 veces). Los promedios comparados entre los dos países según el uso de estrategias indicaron diferencia significativa: $X^{2}=54.097 \mathrm{p}=.000$ $(p<.05)$. 


\section{A continuación, se presenta el ranking de cada estrategia}

aplicada por los sujetos en los dos grupos, español y malayo, en la

\section{Tabla 78.}

Tabla 78. Estrategias utilizadas en la situación 8 en cada cultura ordenadas según frecuencia de uso (de mayor a menor)

\begin{tabular}{|c|c|c|}
\hline $\mathbf{0}$ & Español & Malayo \\
\hline 1 & $>$ Excusa & $>$ Excusa \\
\hline 2 & $\begin{array}{l}\text { Buena voluntad/capacidad } \\
\text { negativa }\end{array}$ & $>$ Fórmulas de tratamiento \\
\hline 3 & $\begin{array}{l}>\text { Disculpa } \\
>\text { Fórmulas de tratamiento }\end{array}$ & $>$ Disculpa \\
\hline 4 & $>$ Declaración de alternativa & $>$ Buena voluntad/capacidad negativa \\
\hline 5 & $>$ Petición de comprensión & $>$ Declaración de alternativa \\
\hline 6 & $\begin{array}{l}>\text { Uso de muletillas } \\
\text { Declaración de sentimiento } \\
\text { negativo }\end{array}$ & $\begin{array}{l}\text { Garantía de satisfacción futura del } \\
\text { interlocutor }\end{array}$ \\
\hline 7 & $\begin{array}{l}\text { Declaración de } \\
\text { opinión/sentimiento positivo } \\
>\text { Agradecimiento }\end{array}$ & $\begin{array}{l}\text { Conjunto de condiciones para la } \\
\text { aceptación pasada/futura }\end{array}$ \\
\hline 8 & $>$ No & $\begin{array}{l}\text { Autodefensa } \\
\text { Declaración de opinión/sentimiento } \\
\text { positivo o acuerdo }\end{array}$ \\
\hline 9 & $\begin{array}{l}\text { Deseo } \\
\text { Amenaza o declaración de } \\
\text { consecuencias negativas para el } \\
\text { emisor }\end{array}$ & $\begin{array}{l}\text { Amenaza o declaración de } \\
\text { consecuencias negativas para el } \\
\text { emisor }\end{array}$ \\
\hline 10 & $\begin{array}{l}\text { Conjunto de condiciones para la } \\
\text { aceptación pasada/futura } \\
>\text { Garantía de satisfacción futura del } \\
\text { interlocutor } \\
>\text { Repetición de parte de la petición }\end{array}$ & $\begin{array}{l}>\text { Repetición de parte de la petición } \\
>\text { Uso de muletillas }\end{array}$ \\
\hline 11 & $>$ Declaración de principions/filosofía & - \\
\hline
\end{tabular}




\section{B) Mayor frente a menor}

Al analizar los datos tomando en consideración la variable de edad, vemos que los mayores españoles formularon más enunciados (101 de los mayores frente a 96 de los menores) y más estrategias diferentes (17 frente a 14) que los menores. Por el contrario, los mayores malayos usaron menos enunciados (106 de los mayores frente a 122 de los menores) y menos estrategias diferentes que los menores (11 y 13 , respectivamente).

En esta situación los encuestados de más edad de ambos grupos aplicaron más estrategias directas que los más jóvenes (23 casos de los mayores españoles frente a 19 de los menores, y 18 de los mayores malayos en comparación con 11 de los menores). En cuanto a las indirectas, los mayores en el grupo español las utilizaron más que los menores (60 enunciados registrados de los mayores por 56 de los menores). En cambio, los mayores malayos las utilizaron menos que los menores (67 de los mayores por 73 de los menores). En el caso del tercer tipo, es decir, en el de las adyacentes al rechazo, tanto los mayores españoles como los mayores malayos las utilizaron menos que los menores (18 y 21 ejemplos registrados, respectivamente, del primer grupo y, 21 y 38 respectivamente del segundo). Esta distribución de enunciados en cada subgrupo de ambas culturas queda reflejada en la Figura 196. 
Figura 196. Distribución de enunciados según el grado de (in)dirección de las estrategias empleadas en la situación 8 por los hablantes mayores y menores en cada cultura

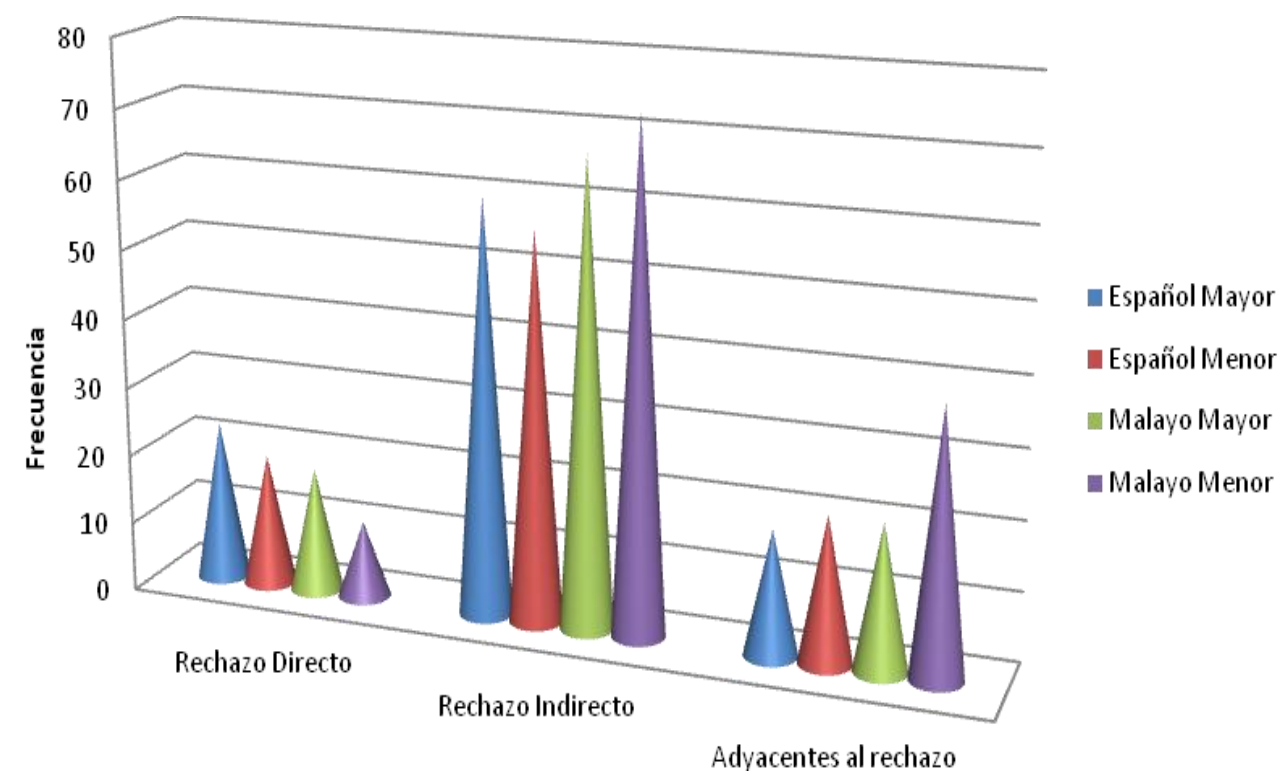

En este escenario, los sujetos de los dos subgrupos españoles no difirieron tanto entre sí. En cambio, sí que hubo diferencias más notables entre los subgrupos de la sociedad malaya, aunque los promedios comparados no indicaron ninguna diferencia significativa.

Respecto a las estrategias concretas empleadas por los mayores y los menores de cada cultura para la formulación del rechazo en la situación 8, la Figura 197 que se presenta a continuación muestra su distribución, según el número de casos en los que son utilizadas. 
Figura 197. Distribución de estrategias utilizadas para la situación 8 por los mayores y los menores en cada cultura

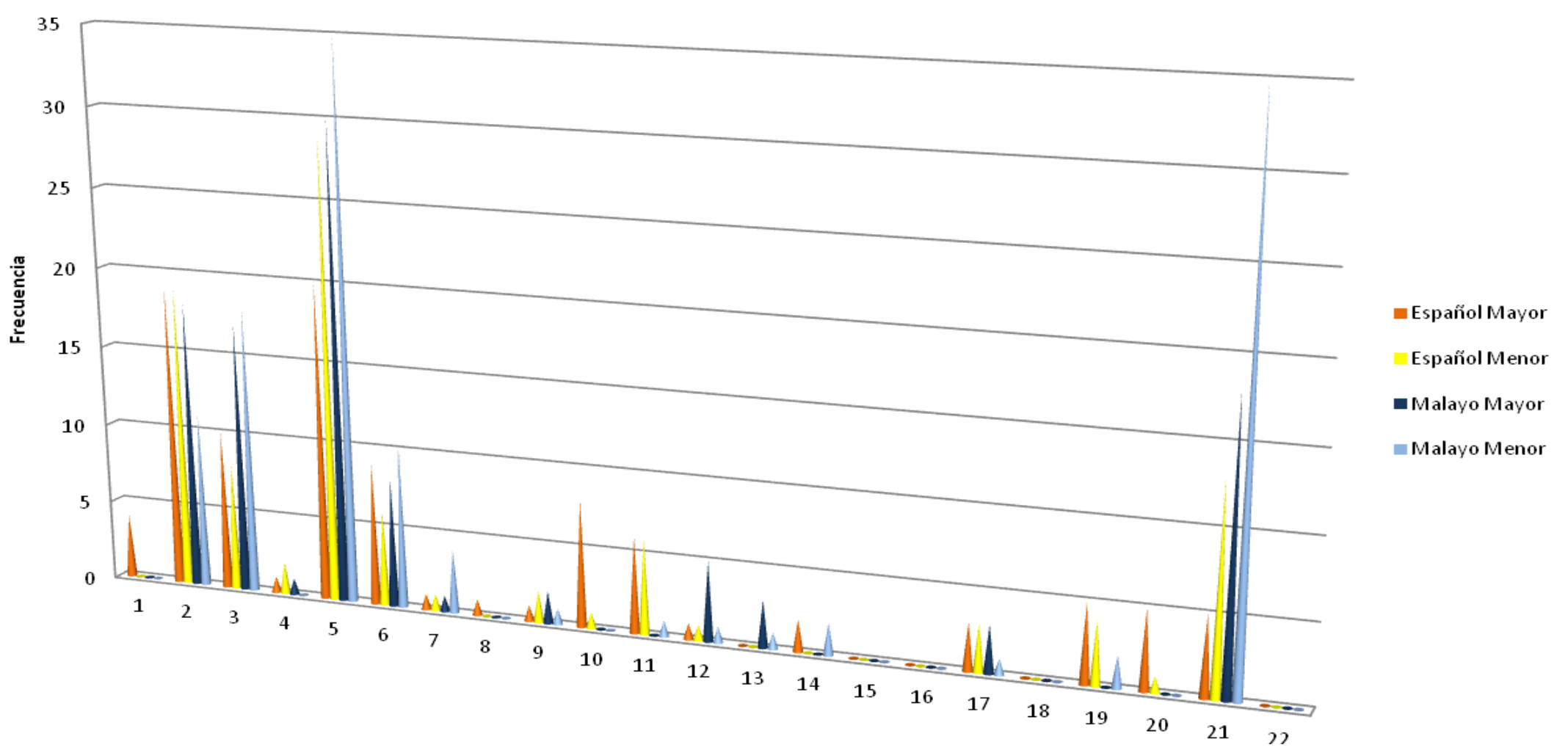

1: No 2: Buena voluntad/capacidad negativa 3: Disculpa 4: Deseo 5: Excusa 6: Declaración de alternativa 7: Conjunto de condiciones para la aceptación pasada/futura 8: Declaración de principios 9: Amenaza o declaración de consecuencias negativas para el emisor 10: Declaración de sentimiento negativo 11: Petición de comprensión 12: Garantía de satisfacción futura del interlocutor 13: Autodefensa 14: Repetición de parte de la petición 15: Aplazamiento 16: Evasivas 17: Declaración de opinión/sentimiento positivo 18: Declaración de empatía 19: Uso de muletillas 20: Agradecimiento 21: Fórmulas de tratamiento 22: Saludos/despedidas

corteses 
En esta situación los mayores españoles tendieron a aplicar más la "Excusa" (20 veces) para expresar rechazos, estrategia que, en el orden de frecuencia, va seguida de las de "Buena voluntad/capacidad negativa" (19 veces), "Disculpa" (10 veces) y "Declaración de alternativa" (9 veces). En los rechazos de los jóvenes se observa la misma tendencia, ya que también muestran una mayor preferencia hacia el uso de la "Excusa" (29 veces), seguida de las estrategias de "Buena voluntad/capacidad negativa" (19 veces), "Fórmulas de tratamiento" (13 veces) y "Disculpa" (8 veces).

En el grupo malayo, por su parte, los sujetos de más edad tendieron a utilizar más la "Excusa" (30 veces) al rechazar, seguida de "Fórmulas de tratamiento" (18 veces), "Buena voluntad/capacidad negativa" (18 veces) y "Disculpa" (17 veces). Los de menos edad, por su parte, tendieron a aplicar más las estrategias de "Excusa" y "Fórmulas de tratamiento" (35 casos de cada una), seguidas de las de "Disculpa" (18 veces) y "Buena voluntad/capacidad negativa" (11 veces). En este contexto, los promedios comparados tampoco indicaron ninguna diferencia significativa en ninguno de los países.

La Tabla 79, que se presenta a continuación, muestra el ranking de cada estrategia aplicada por los sujetos mayores y los más jóvenes de cada grupo. 
Tabla 79. Estrategias utilizadas por los hablantes españoles y malayos en la situación 8, ordenadas según frecuencia de uso (de mayor a menor) en cada subgrupo de edad

\begin{tabular}{|c|c|c|}
\hline $\mathbf{0}$ & Español Mayor & Español Menor \\
\hline 1 & $>$ Excusa & $>$ Excusa \\
\hline 2 & $>$ Buena voluntad/capacidad negativa & $>$ Buena voluntad/capacidad negativa \\
\hline 3 & $>$ Disculpa & $>$ Fórmulas de tratamiento \\
\hline 4 & $>$ Declaración de alternativa & $>$ Disculpa \\
\hline 5 & $>$ Declaración de sentimiento negativo & $\begin{array}{l}>\text { Declaración de alternativa } \\
>\text { Petición de comprensión }\end{array}$ \\
\hline 6 & $>$ Petición de comprensión & $>$ Uso de muletillas \\
\hline 7 & $\begin{array}{l}>\text { Uso de muletillas } \\
>\text { Agradecimiento } \\
>\text { Fórmulas de tratamiento }\end{array}$ & $>$ Declaración de opinión/sentimiento positivo \\
\hline 8 & $>\mathrm{No}$ & $\begin{array}{l}\text { Deseo } \\
\text { Amenaza o declaración de consecuencias } \\
\text { negativas para el emisor }\end{array}$ \\
\hline 9 & $\begin{array}{l}\text { Declaración de opinión/sentimiento } \\
\text { positivo }\end{array}$ & $\begin{array}{l}\text { Conjunto de condiciones para la aceptación } \\
\text { pasada/futura } \\
>\text { Declaración de sentimiento negativo } \\
>\text { Garantía de satisfacción futura del } \\
\text { interlocutor } \\
>\text { Agradecimiento }\end{array}$ \\
\hline 10 & $>$ Repetición de parte de la petición & - \\
\hline 11 & $\begin{array}{l}\text { Deseo } \\
\text { Conjunto de condiciones para la } \\
\text { aceptación pasada/futura } \\
\text { Declaración de principios } \\
>\text { Amenaza o declaración de } \\
\text { consecuencias negativas para el emisor } \\
\text { Garantía de satisfacción futura del } \\
\text { interlocutor }\end{array}$ & - \\
\hline $\mathbf{0}$ & Malayo Mayor & Malayo Menor \\
\hline 1 & $>$ Excusa & $\begin{array}{l}>\text { Excusa } \\
>\text { Fórmulas de tratamiento }\end{array}$ \\
\hline 2 & $\begin{array}{l}>\text { Fórmulas de tratamiento } \\
>\text { Buena voluntad/capacidad negativa }\end{array}$ & $>$ Disculpa \\
\hline 3 & $>$ Disculpa & $>$ Buena voluntad/capacidad negativa \\
\hline 4 & $>$ Declaración de alternativa & $>$ Declaración de alternativa \\
\hline 5 & $\begin{array}{l}\text { Garantía de satisfacción futura del } \\
\text { interlocutor }\end{array}$ & $\begin{array}{l}\text { Conjunto de condiciones para la aceptación } \\
\text { pasada/futura }\end{array}$ \\
\hline 6 & $\begin{array}{l}\text { Autodefensa } \\
\text { Declaración de opinión/sentimiento } \\
\text { positivo o acuerdo }\end{array}$ & $\begin{array}{l}\text { Repetición de parte de la petición } \\
>\text { Uso de muletillas }\end{array}$ \\
\hline 7 & $\begin{array}{l}\text { Amenaza o declaración de } \\
\text { consecuencias negativas para el emisor }\end{array}$ & $\begin{array}{l}\text { Amenaza o declaración de consecuencias } \\
\text { negativas para el emisor } \\
>\text { Petición de comprensión } \\
>\text { Garantía de satisfacción futura del } \\
\text { interlocutor } \\
>\text { Autodefensa } \\
>\text { Declaración de opinión/sentimiento positivo }\end{array}$ \\
\hline 8 & $\begin{array}{l}\text { Deseo } \\
\text { Conjunto de condiciones para la } \\
\text { aceptación pasada/futura }\end{array}$ & - \\
\hline
\end{tabular}




\section{C) Varón frente a mujer}

Al tener en cuenta la variable de género en el análisis de los enunciados producidos en esta situación, se encuentra que los varones de los dos grupos, español y malayo, usaron menos estrategias que las mujeres (93 frente a 104, en el caso de los españoles, y 104 frente a 124, en el de los malayos). Los hablantes de ambos géneros en el grupo español aplicaron el mismo número de estrategias diferentes (15 cada subgrupo). Por otra parte, en el grupo malayo, los varones aplicaron menos estrategias diferentes que las mujeres (12 de los varones en comparación con 13 de las mujeres).

En el grupo español, los dos géneros apenas se diferencian en el uso de estrategias directas ( 20 de los hombres y 22 de las mujeres) pero sí hay una mayor variación en el uso de las indirectas (54 y 62 , respectivamente). $Y$ en el empleo de las de adyacentes al rechazo se diferenciaron también muy poco (19 y 20, respectivamente). En el grupo malayo, por su parte, los dos géneros utilizaron estrategias directas casi en el mismo número de casos (15 y 14 , respectivamente) pero se distinguieron de forma clara en el uso de las indirectas y las de adyacentes al rechazo (65 casos de los varones en comparación con 75 de las mujeres, en lo que respecta al primer tipo, y 24 en contraste con 35, en el segundo). La Figura 198, 
muestra la distribución de enunciados en los tres grandes tipos de estrategias de rechazo utilizados por los hablantes de cada género en ambas culturas en la situación 8.

Figura 198. Distribución de enunciados según estrategias de rechazo empleadas en la situación 8 por los hablantes de cada género en cada cultura

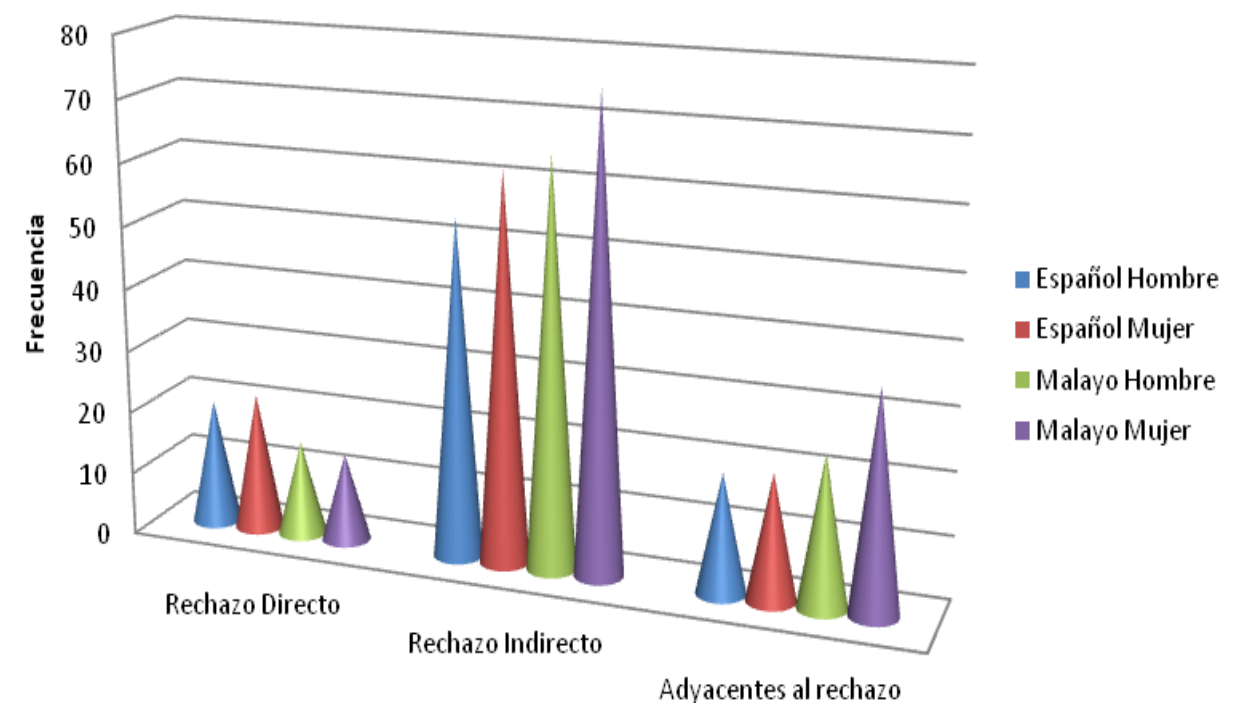

Según la Figura 198, las diferencias mostradas entre los sujetos de los dos sexos en ambas culturas no fueron tan llamativas como las encontradas al comparar los grupos principales; es decir, las diferencias entre los grupos culturales fueron más grandes que las halladas entre los subgrupos dentro de la misma cultura. En los promedios de las estrategias empleadas entre los hombres y las mujeres, la diferencia no fue significativa ni en el resultado español ni en el malayo. La Figura 199 que sigue, muestra la distribución de las estrategias usadas por los hablantes de cada género en cada grupo en la situación 8. 
Figura 199. Distribución de estrategias utilizadas en la situación 8 por los sujetos de cada género en cada cultura

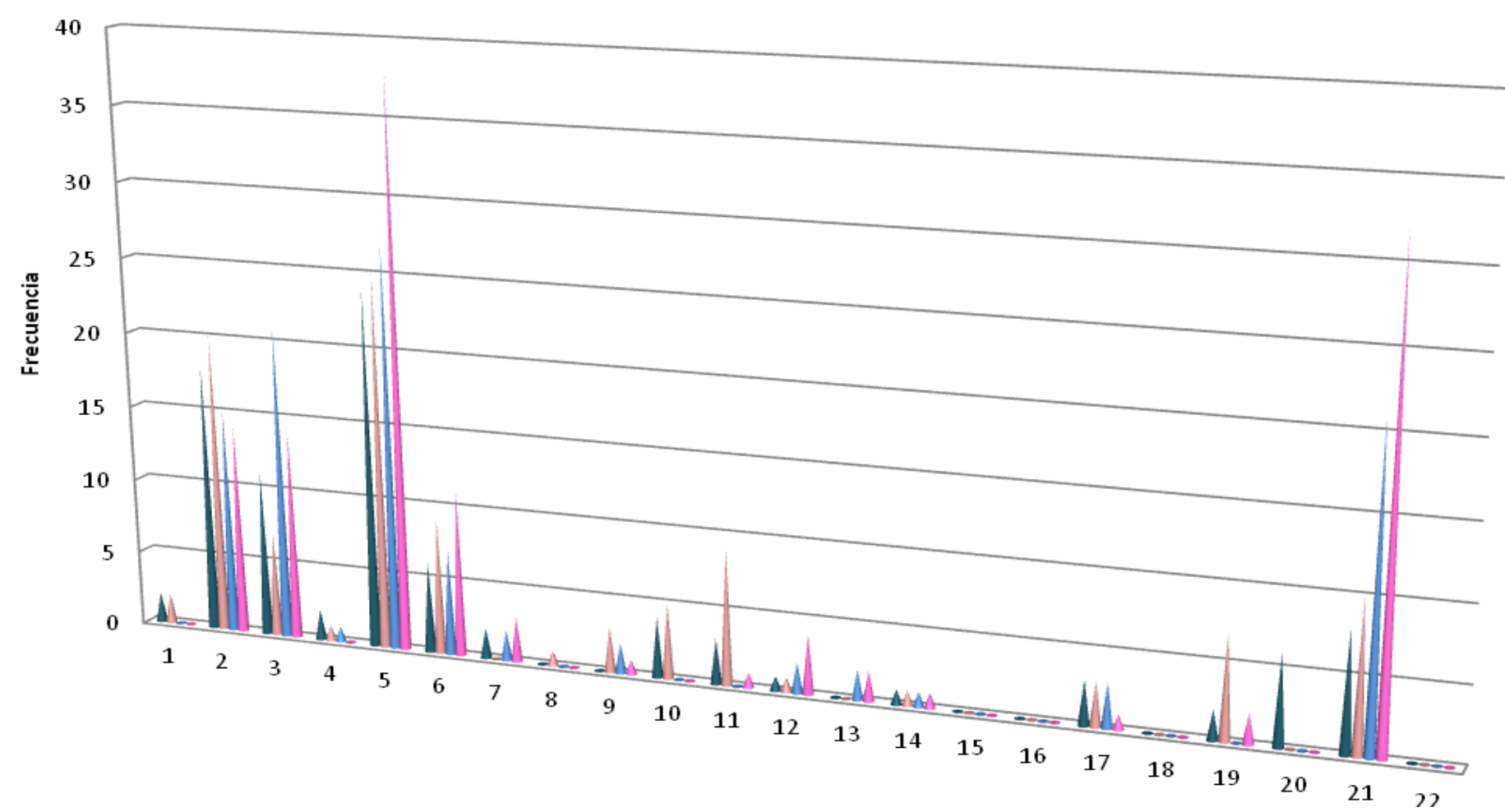

Español Hombre

Español Mujer

Malayo Hombre

Malayo Mujer

1: No 2: Buena voluntad/capacidad negativa 3: Disculpa 4: Deseo 5: Excusa 6: Declaración de alternativa 7: Conjunto de condiciones para la aceptación pasada/futura 8: Declaración de principios 9: Amenaza o declaración de consecuencias negativas para el emisor 10: Declaración de sentimiento negativo 11: Petición de comprensión 12: Garantía de satisfacción futura del interlocutor 13: Autodefensa 14: Repetición de parte de la petición 15: Aplazamiento 16: Evasivas 17: Declaración de opinión/sentimiento positivo 18: Declaración de empatía 19: Uso de muletillas 20: Agradecimiento 21: Fórmulas de tratamiento 22: Saludos/despedidas corteses 
En los datos españoles de los hablantes de los dos géneros se da la misma tendencia a utilizar más comúnmente las estrategias de "Excusa" (24 ejemplos de los varones y 25 de las mujeres), "Buena voluntad/capacidad negativa" (18 de los varones y 20 de las mujeres) y "Fórmulas de tratamiento" (8 de los primeros y 10 de las segundas). En los datos malayos, en cambio, sí se halló diferencia entre las preferencias de ambos subgrupos. De esta forma, los varones tendieron a utilizar más las de "Excusa" y "Disculpa" (ambas 27 veces), seguidas de las de "Fórmulas de tratamiento" (21 veces) y "Buena voluntad/capacidad negativa" (15 veces). Por otro lado, las mujeres prefirieron la de "Excusa" (38 veces), seguida de las de "Fórmulas de tratamiento" (32 veces), "Disculpa" (14 veces), y "Buena voluntad/capacidad negativa" (14 veces). Al comparar los promedios de las estrategias empleadas entre los sexos, la diferencia tampoco fue significativa en ambas culturas.

A continuación, en la Tabla 80, se muestra el ranking de cada estrategia correspondiente a la situación 8 en cada subgrupo de género. 
Tabla 80. Estrategias utilizadas por los hablantes españoles y malayos en la situación 8, ordenadas según frecuencia de uso (de mayor a menor) en cada subgrupo de sexo

\begin{tabular}{|c|c|c|}
\hline \multirow{2}{*}{$\mathbf{0}$} & \multicolumn{2}{|c|}{ Español } \\
\hline & Varón & Mujer \\
\hline 1 & $>$ Excusa & $>$ Excusa \\
\hline 2 & $>$ Buena voluntad/capacidad negativa & $>$ Buena voluntad/capacidad negativa \\
\hline 3 & $>$ Disculpa & $>$ Fórmulas de tratamiento \\
\hline 4 & $>$ Fórmulas de tratamiento & $\begin{array}{l}>\text { Declaración de alternativa } \\
>\text { Petición de comprensión }\end{array}$ \\
\hline 5 & $\begin{array}{l}>\text { Declaración de alternativa } \\
>\text { Agradecimiento }\end{array}$ & $\begin{array}{l}>\text { Disculpa } \\
>\text { Uso de muletillas }\end{array}$ \\
\hline 6 & $>$ Declaración de sentimiento negativo & $>$ Declaración de sentimiento negativo \\
\hline 7 & $\begin{array}{l}>\text { Petición de comprensión } \\
\text { Declaración de opinión/sentimiento } \\
\text { positivo }\end{array}$ & $\begin{array}{l}\text { Amenaza o declaración de consecuencias } \\
\text { negativas para el emisor } \\
>\text { Declaración de opinión/sentimiento positivo }\end{array}$ \\
\hline 8 & $\begin{array}{l}\text { No } \\
>\text { Deseo } \\
>\text { Conjunto de condiciones para la } \\
\text { aceptación pasada/futura } \\
>\text { Uso de muletillas }\end{array}$ & $>\mathrm{No}$ \\
\hline 9 & $\begin{array}{l}\text { Garantía de satisfacción futura del } \\
\text { interlocutor } \\
>\text { Repetición de parte de la petición }\end{array}$ & $\begin{array}{l}>\text { Deseo } \\
\text { Conjunto de condiciones para la aceptación } \\
\text { pasada/futura } \\
>\text { Garantía de satisfacción futura del } \\
\text { interlocutor } \\
>\text { Repetición de parte de la petición }\end{array}$ \\
\hline \multirow{2}{*}{$\mathbf{0}$} & \multicolumn{2}{|c|}{ Malayo } \\
\hline & Varón & Mujer \\
\hline 1 & $>$ Excusa & $>$ Excusa \\
\hline 2 & $\begin{array}{l}>\text { Disculpa } \\
>\text { Fórmulas de tratamiento }\end{array}$ & $>$ Fórmulas de tratamiento \\
\hline 3 & $>$ Buena voluntad/capacidad negativa & $\begin{array}{l}>\text { Buena voluntad/capacidad negativa } \\
>\text { Disculpa }\end{array}$ \\
\hline 4 & $>$ Declaración de alternativa & $>$ Declaración de alternativa \\
\hline 5 & $\begin{array}{l}\text { Declaración de opinión/sentimiento } \\
\text { positivo o acuerdo }\end{array}$ & $\begin{array}{l}>\text { Garantía de satisfacción futura de } \\
\text { interlocutor }\end{array}$ \\
\hline 6 & $\begin{array}{l}\text { Conjunto de condiciones para la } \\
\text { aceptación pasada/futura } \\
\text { Amenaza o declaración de } \\
\text { consecuencias negativas para el } \\
\text { emisor } \\
>\text { Garantía de satisfacción futura del } \\
\text { interlocutor } \\
>\text { Autodefensa }\end{array}$ & $\begin{array}{l}\text { Conjunto de condiciones para la aceptación } \\
\text { pasada/futura }\end{array}$ \\
\hline 7 & $\begin{array}{l}>\text { Deseo } \\
>\text { Repetición de parte de la petición }\end{array}$ & $\begin{array}{l}>\text { Autodefensa } \\
>\text { Uso de muletillas }\end{array}$ \\
\hline 8 & - & $\begin{array}{l}\text { Amenaza o declaración de consecuencias } \\
\text { negativas para el emisor } \\
>\text { Petición de comprensión } \\
\text { - Repetición de parte de la petición } \\
>\text { Declaración de opinión/sentimiento positivo } \\
\text { o acuerdo }\end{array}$ \\
\hline
\end{tabular}




\subsubsection{Situación 11}

En la situación 11, en la que el sujeto le pide a uno de sus colegas que vaya a pescar con él a un río, el poder social entre los interlocutores es igual, puesto que son compañeros de trabajo.

\section{A) Español frente a malayo}

En este contexto, se identifican 18 estrategias diferentes en la formulación de rechazos en los datos españoles, por solo 15 en los datos malayos. Sin embargo, en total, los malayos emplearon más enunciados que los españoles ( 213 de los malayos frente a 183 de los españoles). Los españoles y los malayos utilizaron el mismo número de estrategias directas (33 de los dos), pero, las indirectas, los españoles las aplicaron menos que los malayos (tan solo 112 casos de los españoles en comparación con 146 de los malayos). En el caso del tipo de adyacentes al rechazo, aparecen más en los datos españoles que en los malayos (38 y 34 casos, respectivamente). La Figura 200, presenta la distribución que acabamos de describir. 
Figura 200. Distribución de enunciados formulados como rechazo para la situación 11 en cada sociedad según grado de (in)dirección de la estrategia seleccionada

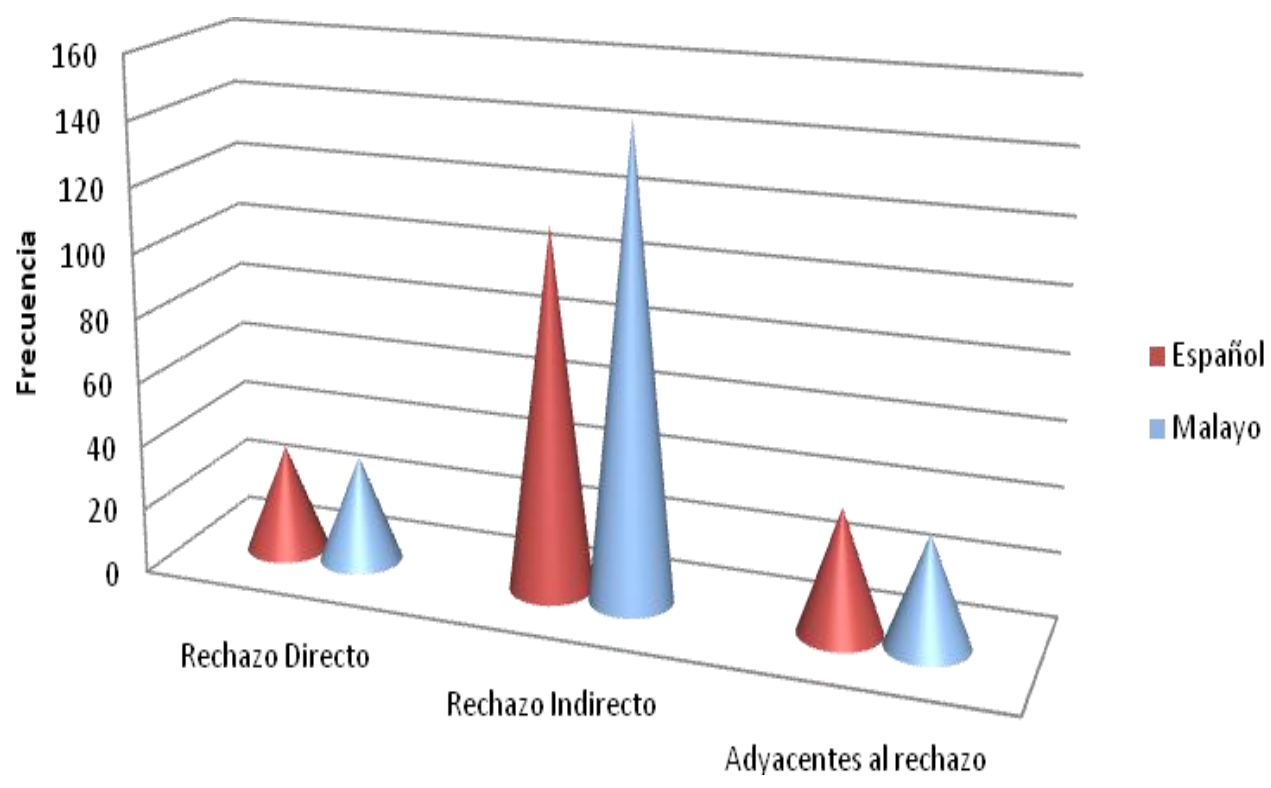

Como se observa en la Figura 200, la gran diferencia entre las dos culturas se nota en la categoría de "Rechazo indirecto", ya que, en la de "Rechazo directo" no hay ninguna, y en la de "Adyacentes al rechazo" es muy pequeña. La diferencia entre los promedios de las categorías aplicadas por ambas sociedades no fue significativa.

Respecto a la distribución de estos mismos enunciados producidos en la situación 11, pero teniendo en cuenta los 22 subtipos de estrategia que se han utilizado en las respuestas del cuestionario, la Figura 201 nos muestra la clasificación en función de los datos numéricos. 
Figura 201. Distribución de estrategias utilizadas en la situación 11, según número de enunciados, por los sujetos de cada sociedad

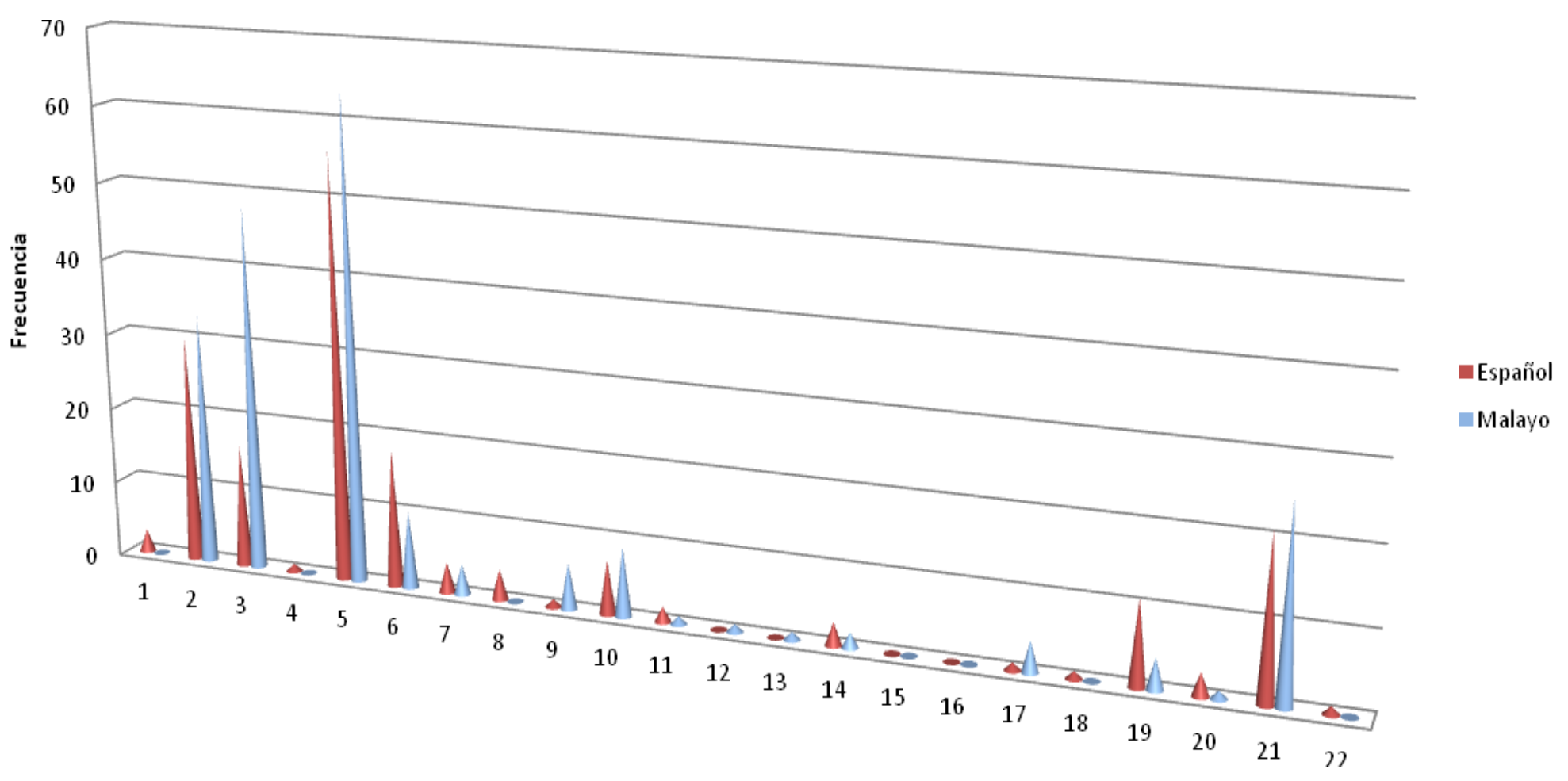

1: No 2: Buena voluntad/capacidad negativa 3: Disculpa 4: Deseo 5: Excusa 6: Declaración de alternativa 7: Conjunto de condiciones para la aceptación pasada/futura 8: Declaración de principios 9: Amenaza o declaración de consecuencias negativas para el emisor 10: Declaración de sentimiento negativo 11: Petición de comprensión 12: Garantía de satisfacción futura del interlocutor 13: Autodefensa 14: Repetición de parte de la petición 15: Aplazamiento 16: Evasivas 17: Declaración de opinión/sentimiento positivo 18: Declaración de empatía 19: Uso de muletillas 20: Agradecimiento 21: Fórmulas de tratamiento 22: Saludos/despedidas corteses 
Los datos recogidos en la Figura 201 demuestran que las estrategias más frecuentemente utilizadas para formular rechazos en los dos grupos fueron similares, pero variaron en la frecuencia y en el ranking. Los españoles mostraron una mayor preferencia por la estrategia de "Excusa" (56 veces), seguida de "Buena voluntad/capacidad negativa" (30 veces), "Fórmulas de tratamiento" (21 veces), "Declaración de alternativa" (18 veces), y "Disculpa" (16 veces). Los malayos, por su parte, utilizaron más frecuentemente la de "Excusa" (64 veces), seguida de "Disculpa" (48 veces), "Buena voluntad/capacidad negativa" (33 veces), "Fórmulas de tratamiento" (25 veces) y "Declaración de alternativa" (10 veces). Las pruebas estadísticas señalaron diferencias significativas entre las medias obtenidas por España y Malasia: $X^{2}=39.686 p=.004(p<.05)$.

El ranking de cada estrategia aplicada para la situación 11 se muestra en la tabla siguiente: 
Tabla 81. Estrategias utilizadas en la situación 11 en cada cultura ordenadas según frecuencia de uso (de mayor a menor)

\begin{tabular}{|c|c|c|}
\hline $\mathbf{0}$ & Español & Malayo \\
\hline 1 & $>$ Excusa & $>$ Excusa \\
\hline 2 & $\begin{array}{l}\text { Buena voluntad/capacidad } \\
\text { negativa }\end{array}$ & $>$ Disculpa \\
\hline 3 & Fórmulas de tratamiento & $>$ Buena voluntad/capacidad negativa \\
\hline 4 & $>$ Declaración de alternativa & $>$ Fórmulas de tratamiento \\
\hline 5 & $>$ Disculpa & $>$ Declaración de alternativa \\
\hline 6 & Uso de muletillas & $>$ Declaración de sentimiento negativo \\
\hline 7 & $\begin{array}{l}\text { Declaración de sentimiento } \\
\text { negativo }\end{array}$ & $\begin{array}{l}\text { Amenaza o declaración de } \\
\text { consecuencias negativas al emisor }\end{array}$ \\
\hline 8 & $\begin{array}{l}\text { Conjunto de condiciones para la } \\
\text { aceptación pasada/futura } \\
\text { Declaración de principios }\end{array}$ & $\begin{array}{l}\text { Conjunto de condiciones para la } \\
\text { aceptación pasada/futura } \\
\text { Declaración de opinión/sentimiento } \\
\text { positivo o acuerdo } \\
>\text { Uso de muletillas }\end{array}$ \\
\hline 9 & $\begin{array}{l}>\text { No } \\
>\text { Repetición de parte de la petición } \\
>\text { Agradecimiento }\end{array}$ & $>$ Repetición de parte de la petición \\
\hline 10 & Petición de comprensión & $\begin{array}{l}>\text { Petición de comprensión } \\
>\text { Garantía de satisfacción futura del } \\
\text { interlocutor } \\
>\text { Autodefensa } \\
>\text { Agradecimiento }\end{array}$ \\
\hline 11 & $\begin{array}{l}\text { Deseo } \\
\text { Amenaza o declaración de } \\
\text { consecuencias negativas para el } \\
\text { emisor } \\
>\text { Declaración de } \\
\text { opinión/sentimiento positivo } \\
>\text { Declaración de empatía } \\
>\text { Saludos/despedidas corteses }\end{array}$ & $>$ Excusa \\
\hline 12 & 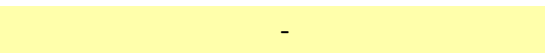 & $>$ Disculpa \\
\hline
\end{tabular}

\section{B) Mayor frente a menor}

En total, los mayores españoles formularon más enunciados que los menores (93 y 90, respectivamente), pero menos estrategias diferentes que los menores (13 tipos, frente a 14). En el grupo 
malayo por otro lado, los mayores fueron menos productivos lingüísticamente que los menores (se recogieron 105 enunciados de los mayores por 108 de los menores) y los dos subgrupos malayos aplicaron el mismo número de estrategias diferentes (ambos utilizaron 13).

Los mayores españoles aplicaron más estrategias directas que los menores (aparecen 17 veces en los mayores por 16 en los menores). En cambio, los participantes mayores malayos las usaron menos que los menores (16 frente a 17). En la segunda categoría, la de las estrategias indirectas, los mayores del grupo español las utilizaron más que los menores (59 casos frente a 53). Por el contrario, los sujetos de más edad del grupo malayo las aplicaron menos que los menores (70 frente a 76). En relación con la tercera categoría, es decir, las de adyacentes al rechazo, los hablantes mayores españoles las emplearon menos que los menores (17 de los mayores en comparación con 21 de los menores). En cambio, los mayores malayos las utilizaron más que los menores (encontramos 19 ejemplos en los primeros y 15 en los segundos). En la comparación de los promedios de las categorías aplicadas por los subgrupos de edad en ambas sociedades, la diferencia no fue significativa. 
La clasificación de los enunciados producidos como rechazo en la situación 11 , según el empleo de estrategias más o menos directas, se presenta en la Figura 202, mientras que la Figura 203 que aparece a continuación, muestra la distribución según los 22 tipos de estrategias aplicadas por los mayores y los menores en cada grupo.

Figura 202. Clasificación, según grado de (in)dirección de los enunciados de rechazo producidos en la situación 11 por los sujetos mayores y menores en cada cultura

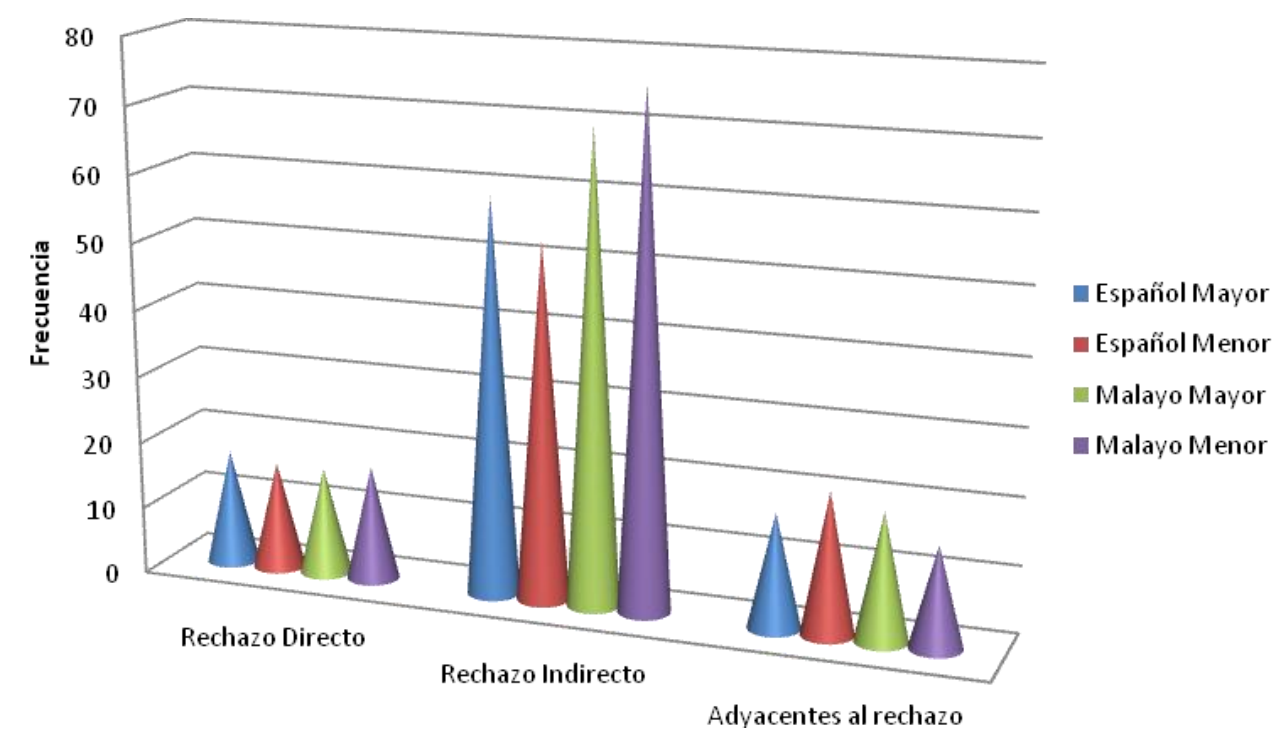


Figura 203. Distribución de enunciados según las estrategias utilizadas para la situación 11 por los mayores y los menores en cada cultura

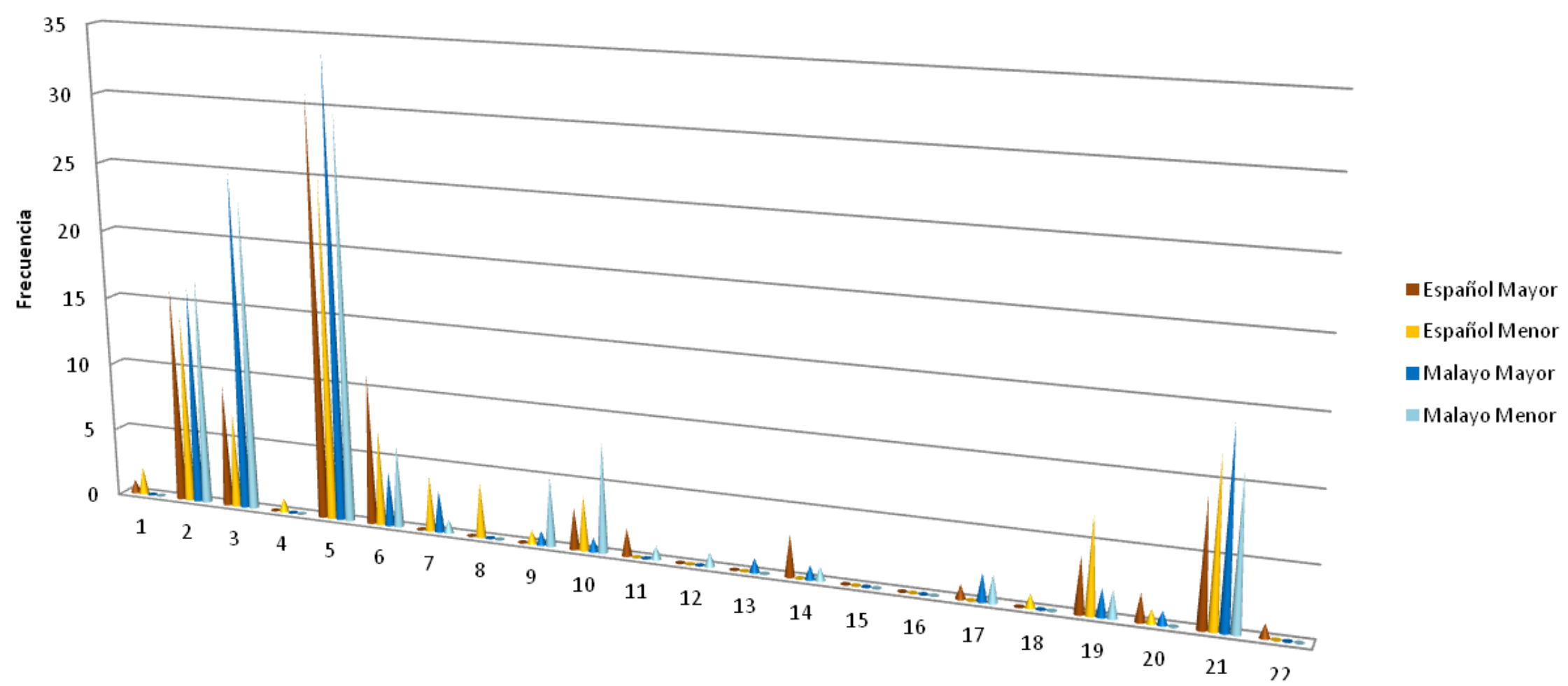

1: No 2: Buena voluntad/capacidad negativa 3: Disculpa 4: Deseo 5: Excusa 6: Declaración de alternativa 7: Conjunto de condiciones para la aceptación pasada/futura 8: Declaración de principios 9: Amenaza o declaración de consecuencias negativas para el emisor 10: Declaración de sentimiento negativo 11: Petición de comprensión 12: Garantía de satisfacción futura del interlocutor 13: Autodefensa 14: Repetición de parte de la petición 15: Aplazamiento 16: Evasivas 17: Declaración de opinión/sentimiento positivo 18: Declaración de empatía 19: Uso de muletillas 20: Agradecimiento 21: Fórmulas de tratamiento 22: Saludos/despedidas corteses 
Las estrategias más comúnmente utilizadas en cada grupo fueron similares a las empleadas en situaciones anteriores. No obstante, variaron en la frecuencia y el ranking. Los mayores españoles utilizaron más la estrategia de "Excusa" (31 veces), seguida de "Buena voluntad/capacidad negativa" (16 veces), "Declaración de alternativa" (11 veces) y "Disculpa" (9 veces). Los menores, por otro lado, usaron más "Excusa" (25 veces), seguida de "Buena voluntad/capacidad negativa" (14 veces), "Fórmulas de tratamiento" (12 veces) y "Disculpa", "Declaración de alternativa" y "Uso de muletillas" (las tres aparecen 7 veces).

En el grupo malayo, por su parte, los mayores aplicaron más la "Excusa" (34 veces), seguida de "Disculpa" (25 veces), "Buena voluntad/capacidad negativa" (16 veces) y "Fórmulas de tratamiento" (14 veces), mientras que los menores utilizaron más las estrategias de "Excusa" (30 veces), seguida de "Disculpa" (23 veces), "Buena voluntad/capacidad negativa" (17 veces) y "Fórmulas de tratamiento" (11 veces). En este caso, los promedios comparados tampoco indicaron ninguna diferencia significativa en ninguna de las dos sociedades.

El ranking de cada estrategia aplicada para esta situación por los subgrupos de edad en cada grupo se expone en la Tabla 82. 
Tabla 82. Estrategias utilizadas por los hablantes españoles y malayos en la situación 11 ordenadas según frecuencia de uso (de mayor a menor) en cada subgrupo de edad

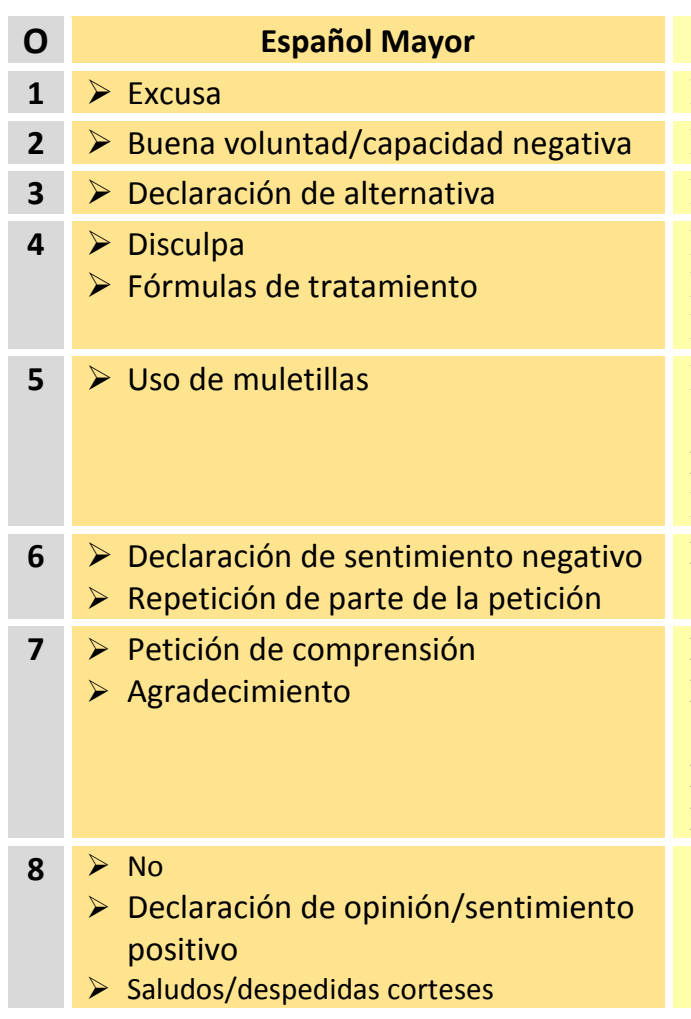

Español Menor

$>$ Excusa

$>$ Buena voluntad/capacidad negativa

$>$ Fórmulas de tratamiento

$>$ Disculpa

$>$ Declaración de Iternative

$\checkmark$ Uso de muletillas

$>$ Conjunto de condiciones para la aceptación pasada/futura

$>$ Declaración de principios

$>$ Declaración de sentimiento negativo

$>$ No

$>$ Deseo

$>$ Amenaza o declaración de consecuencias negativas para el emisor $>$ Declaración de empatía

$>$ Agradecimiento

\begin{tabular}{|c|c|c|}
\hline $\mathbf{0}$ & Malayo Mayor & Malayo Menor \\
\hline 1 & $>$ Excusa & $>$ Excusa \\
\hline 2 & $>$ Disculpa & $>$ Disculpa \\
\hline 3 & $>$ Buena voluntad/capacidad negativa & $>$ Buena voluntad/capacidad negativa \\
\hline 4 & $>$ Autodefensa & $>$ Fórmulas de tratamiento \\
\hline 5 & $>$ Declaración de alternativa & $>$ Declaración de sentimiento negativo \\
\hline 6 & $\begin{array}{l}\text { Conjunto de condiciones para la } \\
\text { aceptación pasada/futura }\end{array}$ & $>$ Declaración de alternativa \\
\hline 7 & $\begin{array}{l}\text { Declaración de opinión/sentimiento } \\
\text { positivo o acuerdo } \\
>\text { Uso de muletillas }\end{array}$ & $\begin{array}{l}\text { Amenaza o declaración de } \\
\text { consecuencias negativas para el emisor }\end{array}$ \\
\hline 8 & $\begin{aligned} & \text { Amenaza o declaración de } \\
& \text { consecuencias negativas para el } \\
& \text { emisor } \\
> & \text { Declaración de sentimiento negativa } \\
> & \text { Autodefensa } \\
> & \text { Repetición de parte de la petición } \\
& \text { Agradecimiento }\end{aligned}$ & $\begin{array}{l}\text { Declaración de opinión/sentimiento } \\
\text { positivo } \\
>\text { Uso de muletillas }\end{array}$ \\
\hline 9 & - & $\begin{aligned} & \text { Conjunto de condiciones para la } \\
& \text { aceptación pasada/futura } \\
& \text { Petición de comprensión } \\
& \text { Garantía de satisfacción futura del } \\
& \text { interlocutor } \\
& >\text { Repetición de parte de la petición }\end{aligned}$ \\
\hline
\end{tabular}




\section{C) Varón frente a mujer}

Igual que en las situaciones analizadas anteriormente, los varones de los dos grupos, español y malayo, utilizaron menos enunciados que las mujeres en su formulación del rechazo. Los varones españoles produjeron un total de 84 enunciados y, las mujeres, 99, mientras que en los datos de los varones malayos se registraron 95 enunciados, en comparación con los 118 de las mujeres. Y tanto los varones españoles como los malayos utilizaron más estrategias diferentes que las mujeres (16 de los varones frente a 15 de las mujeres en el primer grupo, y 13 frente a 12, en el segundo).

En lo que atañe a las estrategias directas, los varones en ambos grupos las emplearon menos que las mujeres (13 y 20 casos, respectivamente, en los dos grupos). También se encuentra que los varones en ambos grupos recurrieron menos a las estrategias indirectas que las mujeres al rechazar (52 ejemplos de los varones españoles y 60 de las mujeres, y 67 de los varones malayos por 79 de las mujeres). En cuanto a las de adyacentes al rechazo, los hablantes españoles de ambos géneros las aplicaron el mismo número de veces (19 en los dos casos), mientras que los varones malayos las emplearon menos que las mujeres (15 enunciados de los varones por 19 de las mujeres). Al comparar los promedios de las 
estrategias aplicadas entre los subgrupos de sexo, la diferencia no fue significativa en el resultado de ambos grupos.

La clasificación de datos numéricos mencionada se presenta en la Figura 204 que aparece a continuación.

Figura 204. Distribución de enunciados de rechazo producidos en la situación 11 por los hablantes de cada género en cada cultura

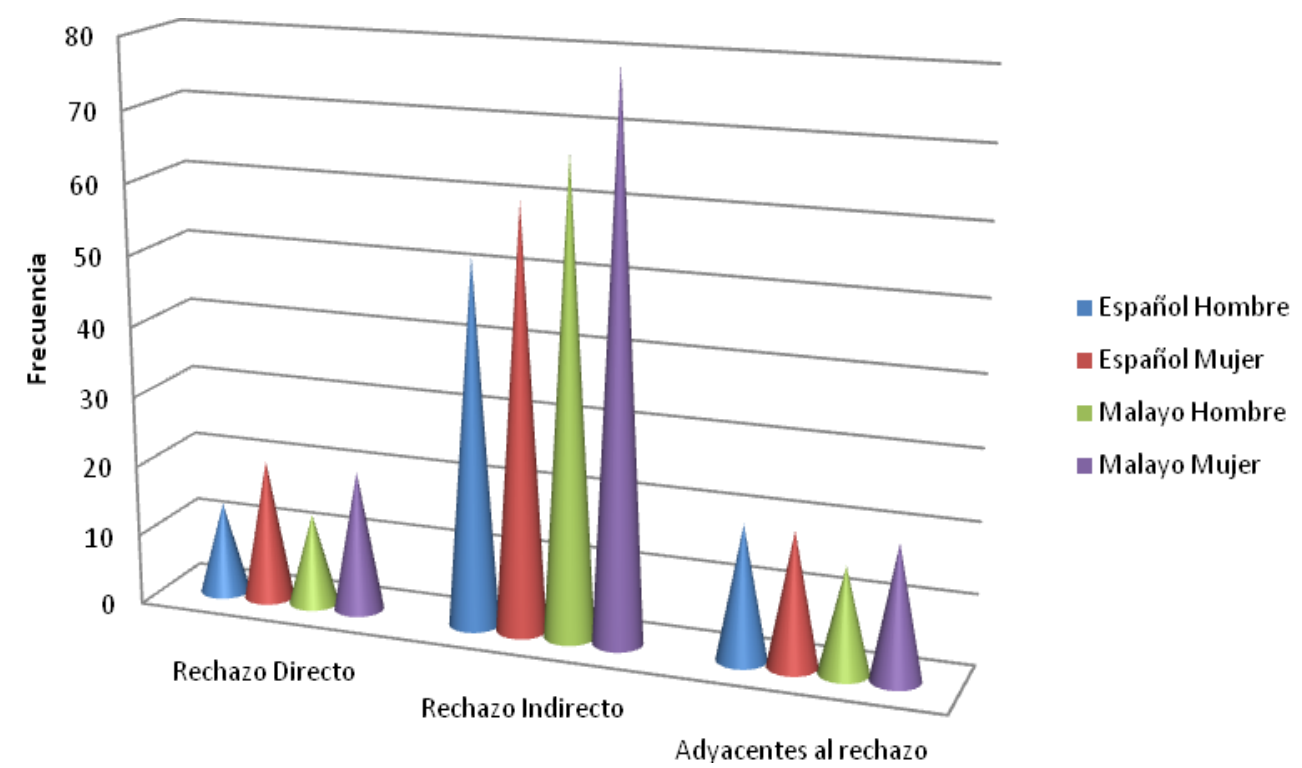

La diferencia entre los subgrupos dentro de una misma cultura no fue llamativa, pero ocurre lo contrario al contrastar las dos culturas. Los datos correspondientes a los tipos de estrategias empleadas por los participantes de cada género en cada sociedad en la situación 11, teniendo en cuenta las 22 opciones con la que venimos trabajando en nuestro estudio, aparecen reflejados en la Figura 205. 
Figura 205. Distribución de estrategias utilizadas en la situación 11 por los sujetos de cada género en cada sociedad

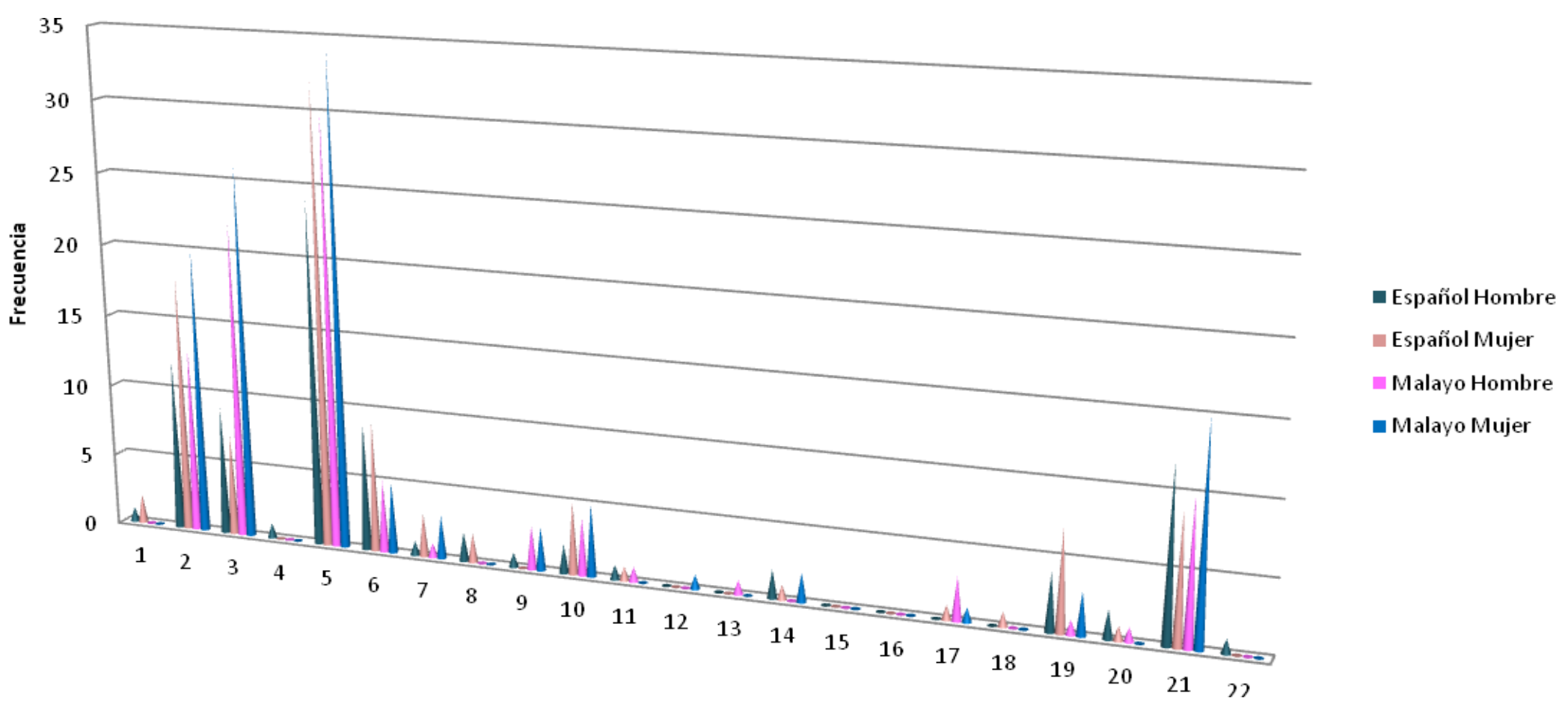

1: No 2: Buena voluntad/capacidad negativa 3: Disculpa 4: Deseo 5: Excusa 6: Declaración de alternativa 7: Conjunto de condiciones para la aceptación pasada/futura 8: Declaración de principios 9: Amenaza o declaración de consecuencias negativas para el emisor 10: Declaración de sentimiento negativo 11: Petición de comprensión 12: Garantía de satisfacción futura del interlocutor 13: Autodefensa 14: Repetición de parte de la petición 15: Aplazamiento 16: Evasivas 17: Declaración de opinión/sentimiento positivo 18: Declaración de empatía 19: Uso de muletillas 20: Agradecimiento 21: Fórmulas de tratamiento 22: Saludos/despedidas corteses 
Las estrategias más comúnmente empleadas en cada subgrupo de género fueron similares a las de las situaciones anteriores. Los varones españoles tendieron a aplicar más las de "Excusa" (24 veces), seguida de "Buena voluntad/capacidad negativa" y "Fórmulas de tratamiento" (12 veces para cada una), y "Disculpa" y "Declaración de alternativa" (9 veces para cada una). Por otro lado, las mujeres prefirieron más la "Excusa" (32 veces), seguida de "Buena voluntad/capacidad negativa" (18 veces), "Declaración de alternativa" y "Fórmulas de tratamiento" (9 veces para cada una).

En el grupo malayo por su parte, la estrategia más frecuentemente utilizadas tanto por los varones como por las mujeres fue la de "Excusa" (30 casos de los varones y 34 de las mujeres), seguida de "Disculpa" (22 de los varones por 26 de las mujeres), "Buena voluntad/capacidad negativa" (13 de los primeros y 20 de los segundos) y "Fórmulas de tratamiento" (10 y 15 respectivamente). En este caso, la diferencia de los promedios comparados de las estrategias empleadas tampoco fue significativa ni entre los subgrupos de sexo españoles ni entre los subgrupos malayos. A continuación, se presenta el ranking de cada estrategia usada para la situación 11 por los sujetos de ambos sexos en cada grupo. 
Tabla 83. Estrategias utilizadas por los hablantes españoles y malayos en la situación 11 ordenadas según frecuencia de uso (de mayor a menor) en cada subgrupo de sexo

\begin{tabular}{|c|c|c|}
\hline $\mathbf{0}$ & Español Varón & Español Mujer \\
\hline 1 & $>$ Excusa & $>$ Excusa \\
\hline 2 & $\begin{array}{l}>\text { Buena voluntad/capacidad negativa } \\
>\text { Fórmulas de tratamiento }\end{array}$ & $>$ Buena voluntad/capacidad negativa \\
\hline 3 & $\begin{array}{l}>\text { Disculpa } \\
>\text { Declaración de alternativa }\end{array}$ & $\begin{array}{l}\text { Declaración de alternativa } \\
>\text { Fórmulas de tratamiento }\end{array}$ \\
\hline 4 & $>$ Uso de muletillas & $\begin{array}{l}>\text { Disculpa } \\
>\text { Uso de muletillas }\end{array}$ \\
\hline 5 & $\begin{array}{l}>\text { Declaración de principios } \\
>\text { Declaración de sentimiento negativa } \\
>\text { Repetición de parte de la petición } \\
>\text { Agradecimiento }\end{array}$ & $>$ Declaración de sentimiento negativo \\
\hline 6 & $\begin{array}{l}>\text { No } \\
>\text { Deseo } \\
>\text { Conjunto de condiciones para la } \\
\text { aceptación pasada/futura } \\
>\text { Amenaza o declaración de } \\
\text { consecuencias negativas para el emisor } \\
>\text { Petición de comprensión } \\
>\text { Saludos/despedidas corteses }\end{array}$ & $\begin{array}{l}\text { Conjunto de condiciones para la } \\
\text { aceptación pasada/futura }\end{array}$ \\
\hline 7 & 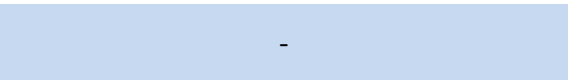 & $\begin{array}{l}>\text { No } \\
>\text { Declaración de principios }\end{array}$ \\
\hline 8 & - & $\begin{array}{l}\text { Petición de comprensión } \\
>\text { Repetición de parte de la petición } \\
>\text { Declaración de opinión/sentimiento } \\
\text { positivo o acuerdo } \\
>\text { Declaración de empatía } \\
>\text { Saludos/despedidas corteses }\end{array}$ \\
\hline $\mathbf{0}$ & Malayo Varón & Malayo Mujer \\
\hline 1 & $>$ Excusa & $>$ Excusa \\
\hline 2 & $>$ Disculpa & $>$ Disculpa \\
\hline 3 & $>$ Buena voluntad/capacidad negativa & $>$ Buena voluntad/capacidad negativa \\
\hline 4 & $>$ Fórmulas de tratamiento & $>$ Fórmulas de tratamiento \\
\hline 5 & $>$ Declaración de alternativa & $\begin{array}{l}>\text { Declaración de alternativa } \\
>\text { Declaración de sentimiento negativo }\end{array}$ \\
\hline 6 & $>$ Declaración de sentimiento negativo & $\begin{array}{l}\text { Conjunto de condiciones para la } \\
\text { aceptación pasada/futura } \\
\text { Amenaza o declaración de consecuencias } \\
\text { negativas para el emisor } \\
>\text { Uso de muletillas }\end{array}$ \\
\hline 7 & $\begin{array}{l}\text { Amenaza o declaración de } \\
\text { consecuencias negativas para el emisor }\end{array}$ & $>$ Repetición de parte de la petición \\
\hline 8 & $\begin{array}{l}\text { Declaración de opinión/sentimiento } \\
\text { positivo o acuerdo }\end{array}$ & $\begin{array}{l}\text { Garantía de satisfacción futura del } \\
\text { interlocutor } \\
\text { Declaración de opinión/sentimiento } \\
\text { positivo o acuerdo }\end{array}$ \\
\hline 9 & $\begin{array}{l}\text { Conjunto de condiciones para la } \\
\text { aceptación pasada/futura } \\
>\text { Petición de comprensión } \\
\text { > Autodefensa } \\
\text { D Uso de muletillas } \\
>\text { Agradecimiento }\end{array}$ & - \\
\hline
\end{tabular}




\subsubsection{Situación 14}

En la situación 14, un estudiante universitario le pide a su profesor que le preste una tesis de un estudiante anterior que tiene guardada en su despacho. El interlocutor del escenario (el profesor universitario) se sitúa en una posición social más alta.

\section{A) Español frente a malayo}

En total, los españoles emplearon menos enunciados que los malayos. Se encontraron 158 en los rechazos españoles por los 165 de los malayos. Pero utilizaron más estrategias diferentes que los malayos (13 de los españoles y 12 de los malayos). Al prestar atención a la primera clasificación, en formulaciones directas, indirectas y adyacentes al rechazo, se observa que los españoles aplicaron más estrategias directas que los malayos (28 casos de los españoles en comparación con 22 en los malayos). No obstante, usaron menos las indirectas y las adyacentes al rechazo que los malayos (120 de los españoles en comparación con 130 de los malayos del primer tipo, y 10 frente a 13 del segundo tipo). En la Figura 206 que presentamos a continuación, se expone la clasificación de estos enunciados producidos por los hablantes de 
cada cultura, teniendo en cuenta el grado de (in)dirección de las estrategias empleadas.

Figura 206. Distribución de estrategias empleadas en la formulación del rechazo en la situación 14 por los sujetos de cada grupo principal

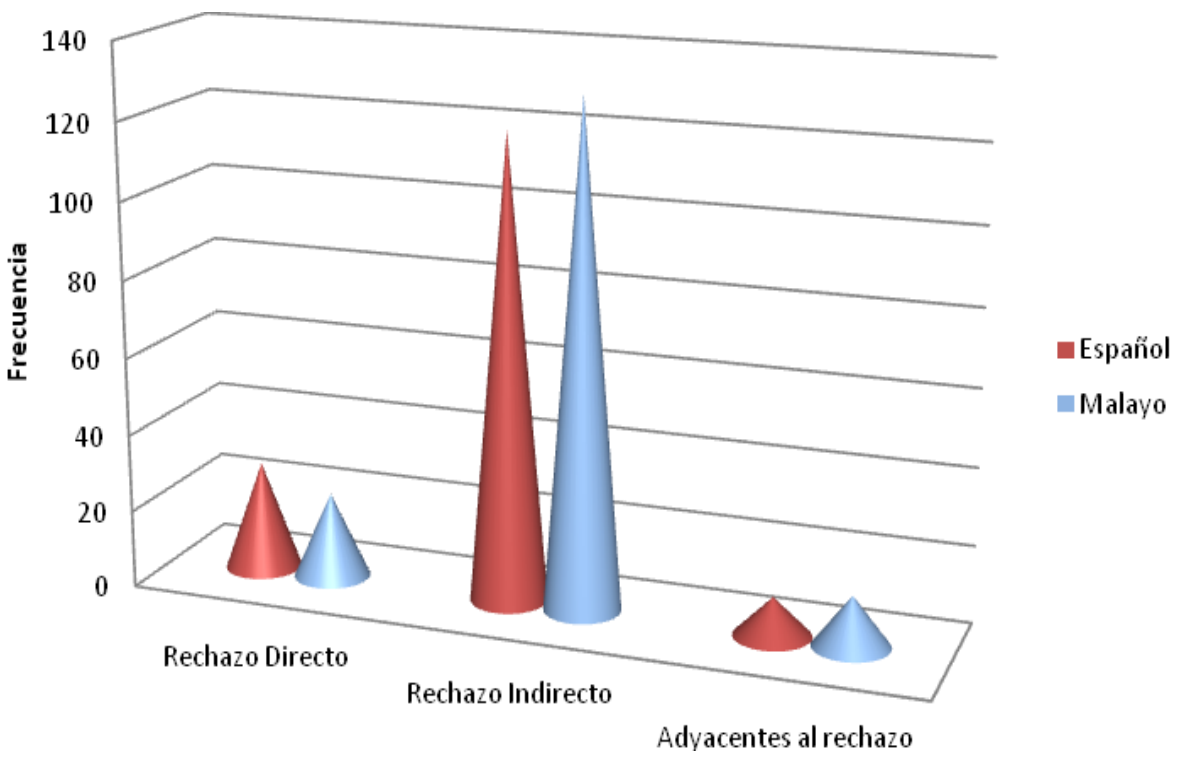

A diferencia de las figuras anteriores, esta otra demuestra que, en este contexto, las dos culturas no difirieron mucho entre sí. Así pues, la diferencia entre los promedios de las categorías utilizadas por ambos grupos de hablantes no fue significativa.

A continuación, en la Figura 207, se muestra la distribución de enunciados según los tipos de estrategias empleadas por los hablantes de cada grupo. 
Figura 207. Distribución de estrategias utilizadas en la situación 14 por los hablantes de cada cultura

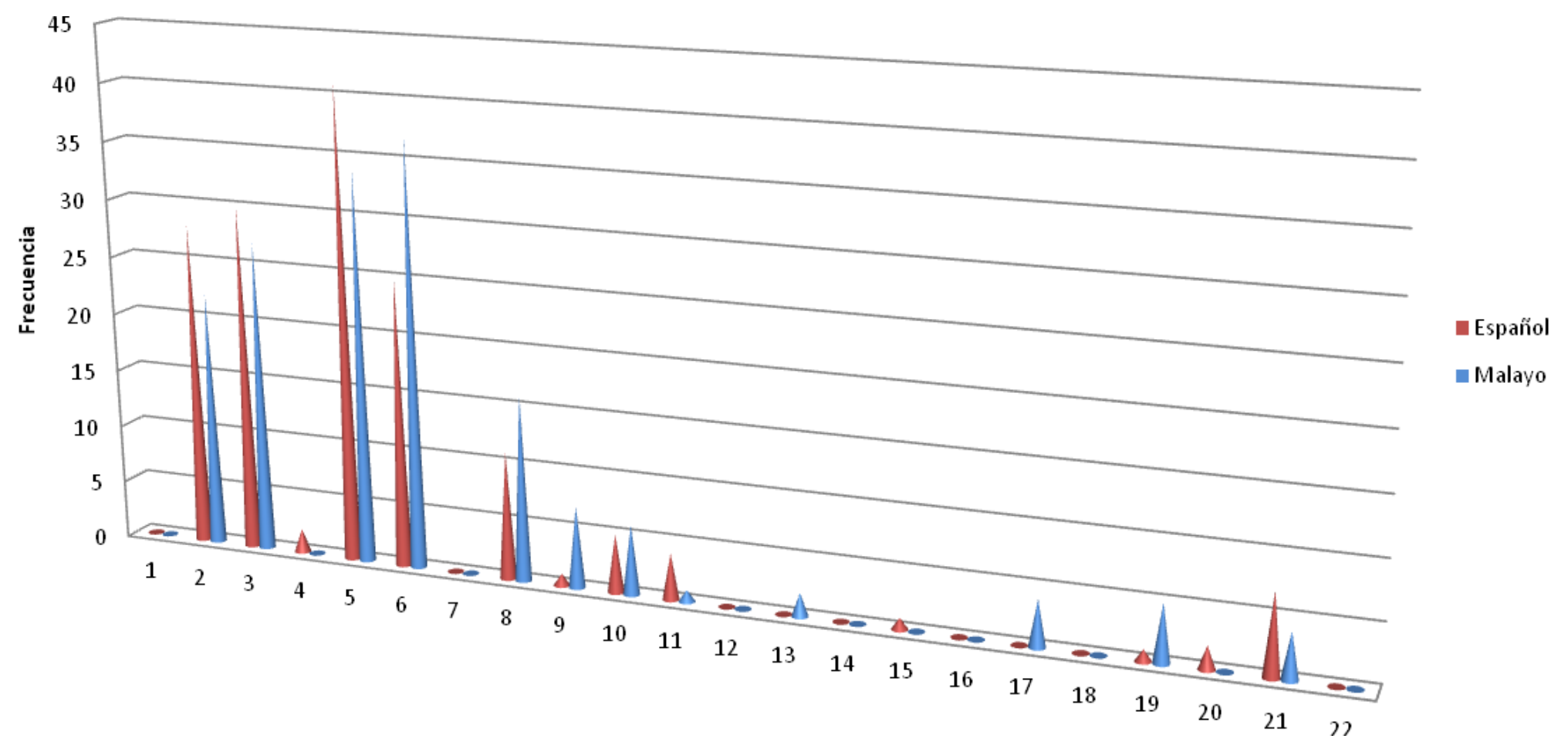

1: No 2: Buena voluntad/capacidad negativa 3: Disculpa 4: Deseo 5: Excusa 6: Declaración de alternativa 7: Conjunto de condiciones para la aceptación pasada/futura 8: Declaración de principios 9: Amenaza o declaración de consecuencias negativas para el emisor 10: Declaración de sentimiento negativo 11: Petición de comprensión 12: Garantía de satisfacción futura del interlocutor 13: Autodefensa 14: Repetición de parte de la petición 15: Aplazamiento 16: Evasivas 17: Declaración de opinión/sentimiento positivo 18: Declaración de empatía 19: Uso de muletillas 20: Agradecimiento 21: Fórmulas de tratamiento 22: Saludos/despedidas corteses 
Las estrategias más comúnmente utilizadas en los sujetos españoles, por orden de frecuencia de aparición, fueron las de "Excusa" (41 veces), "Disculpa" (30 veces), "Buena voluntad/capacidad negativa" (28 veces), "Declaración de alternativa" (25 veces) y "Declaración de principios" (11 veces). Por su parte, las estrategias más frecuentemente aplicadas en los sujetos malayos, fueron "Declaración de alternativa" (37 veces), "Excusa" (34 veces), "Disculpa" (27 veces) "Buena voluntad/capacidad negativa" (22 veces) y "Declaración de principios" (16 veces). El resultado de las pruebas estadísticas en este caso indicó una diferencia significativa entre los españoles y los malayos: $X^{2}=24.620$ $p=.026(p<.05)$.

Se puede ver con más claridad el ranking de cada estrategia aplicada en cada grupo en la tabla siguiente. 
Tabla 84. Estrategias utilizadas en la situación 14 en cada cultura ordenadas según frecuencia de uso (de mayor a menor)

\begin{tabular}{|c|c|c|}
\hline $\mathbf{0}$ & Español & Malayo \\
\hline 1 & $>$ Excusa & $>$ Declaración de alternativa \\
\hline 2 & $>$ Disculpa & $>$ Excusa \\
\hline 3 & $>$ Buena voluntad/capacidad negativa & $>$ Disculpa \\
\hline 4 & $>$ Declaración de alternativa & $>$ Buena voluntad/capacidad negativa \\
\hline 5 & $>$ Declaración de principios & $>$ Declaración de principios \\
\hline 6 & $>$ Fórmulas de tratamiento & $\begin{array}{l}\text { Amenaza o declaración de consecuencias } \\
\text { negativas para el emisor }\end{array}$ \\
\hline 7 & $>$ Declaración de sentimiento negativo & $>$ Declaración de sentimiento negativo \\
\hline 8 & $>$ Petición de comprensión & $>$ Uso de muletillas \\
\hline 9 & $\begin{array}{l}>\text { Deseo } \\
>\text { Agradecimiento }\end{array}$ & $\begin{array}{l}\text { Declaración de opinión/sentimiento } \\
\text { positivo o acuerdo } \\
>\text { Fórmulas de tratamiento }\end{array}$ \\
\hline 10 & $\begin{array}{l}\text { Aplazamiento } \\
\text { Uso de muletillas } \\
\text { Amenaza o declaración de } \\
\text { consecuencias negativas para el emisor }\end{array}$ & $>$ Autodefensa \\
\hline 11 & - & $>$ Petición de comprensión \\
\hline
\end{tabular}

$\mathrm{O}=$ Orden

\section{B) Mayor frente a menor}

En total, los sujetos españoles de más edad utilizaron más estrategias que los menores ( 80 de los mayores en comparación con 78 de los menores). En contraste, los hablantes mayores del otro grupo utilizaron menos estrategias que los menores (82 de los mayores frente a 83 de los menores). Lo que resulta interesante de esta situación, es que los cuatro subgrupos aplicaron el mismo número de estrategias diferentes (11 tipos, en todos los casos). En lo que se refiere a la clasificación general en tres tipos de estrategias empleadas en la formulación del rechazo "Directas", "Indirectas" y "Adyacentes al rechazo" el análisis revela que tanto los participantes 
mayores tanto españoles como malayos emplearon menos estrategias directas que los menores (13 casos en comparación con 15 del primer grupo, y 7 frente a 15 del segundo). Por el contrario, el análisis muestra que, en el caso de las estrategias indirectas, los mayores de los dos grupos utilizaron menos que los menores (64 frente a 56 del primer grupo, y 70 frente a 60 del segundo). $Y$ los mayores de ambos grupos emplearon menos las estrategias de adyacentes al rechazo que los menores ( 3 ejemplos de los mayores españoles frente a 7 de los menores y 5 de los mayores malayos frente a 8 de los menores). A continuación, en la Figura 208, mostramos los datos numéricos relativos a los enunciados producidos por los sujetos mayores y menores de cada, teniendo en cuenta la triple clasificación que hemos mencionado más arriba.

Figura 208. Distribución de enunciados, producidos en la situación 14 por los sujetos mayores y menores de cada cultura, según el grado de (in)dirección de las estrategias empleadas

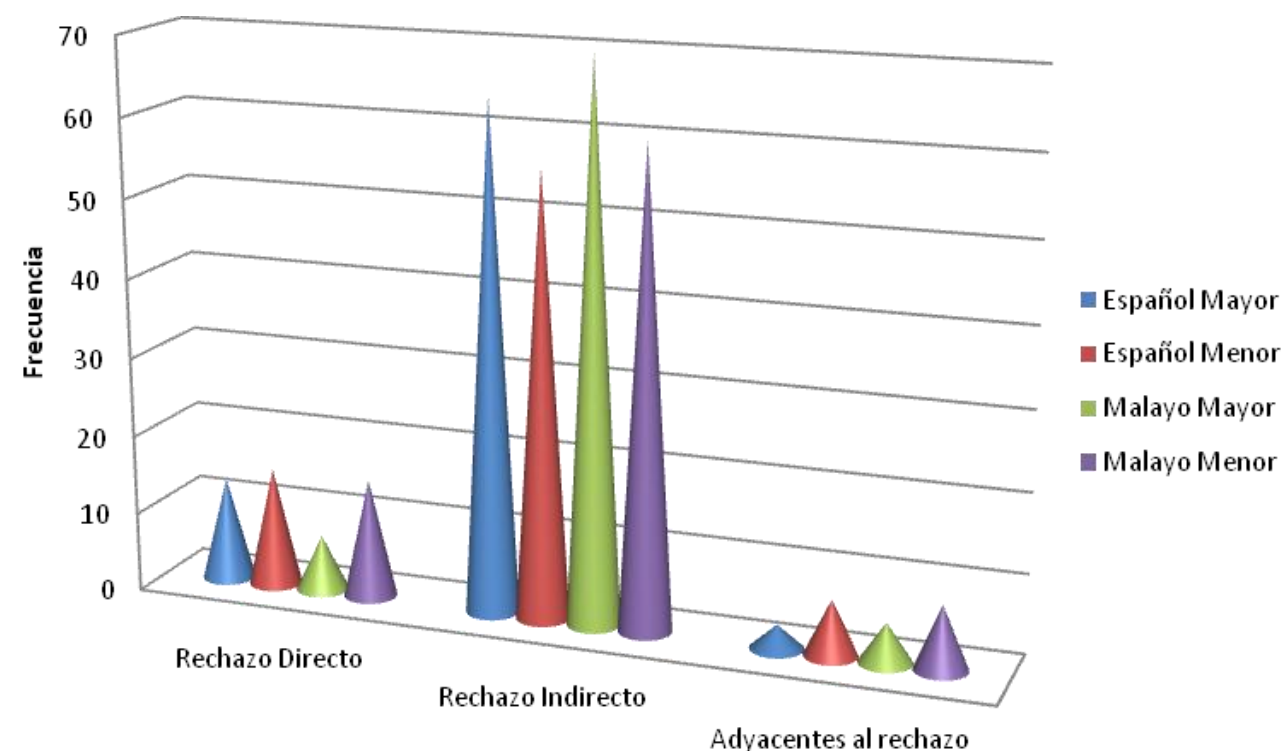


En la distribución de la Figura 208, se aprecia que, como el caso de los grupos principales, en esta situación no se ve tanta diferencia entre los subgrupos de cada sociedad. Así, la comparación de los promedios de las categorías empleadas por los subgrupos de edad no indicó una diferencia significativa ni en el grupo español ni en el malayo.

La Figura 209 que se presenta a continuación, muestra los datos correspondientes a la situación 14, pero teniendo en cuenta los subtipos de estrategia aplicados por los participantes mayores y menores de cada cultura. 
Figura 209. Distribución de estrategias utilizadas en la situación 14 por los hablantes mayores y los menores en cada sociedad

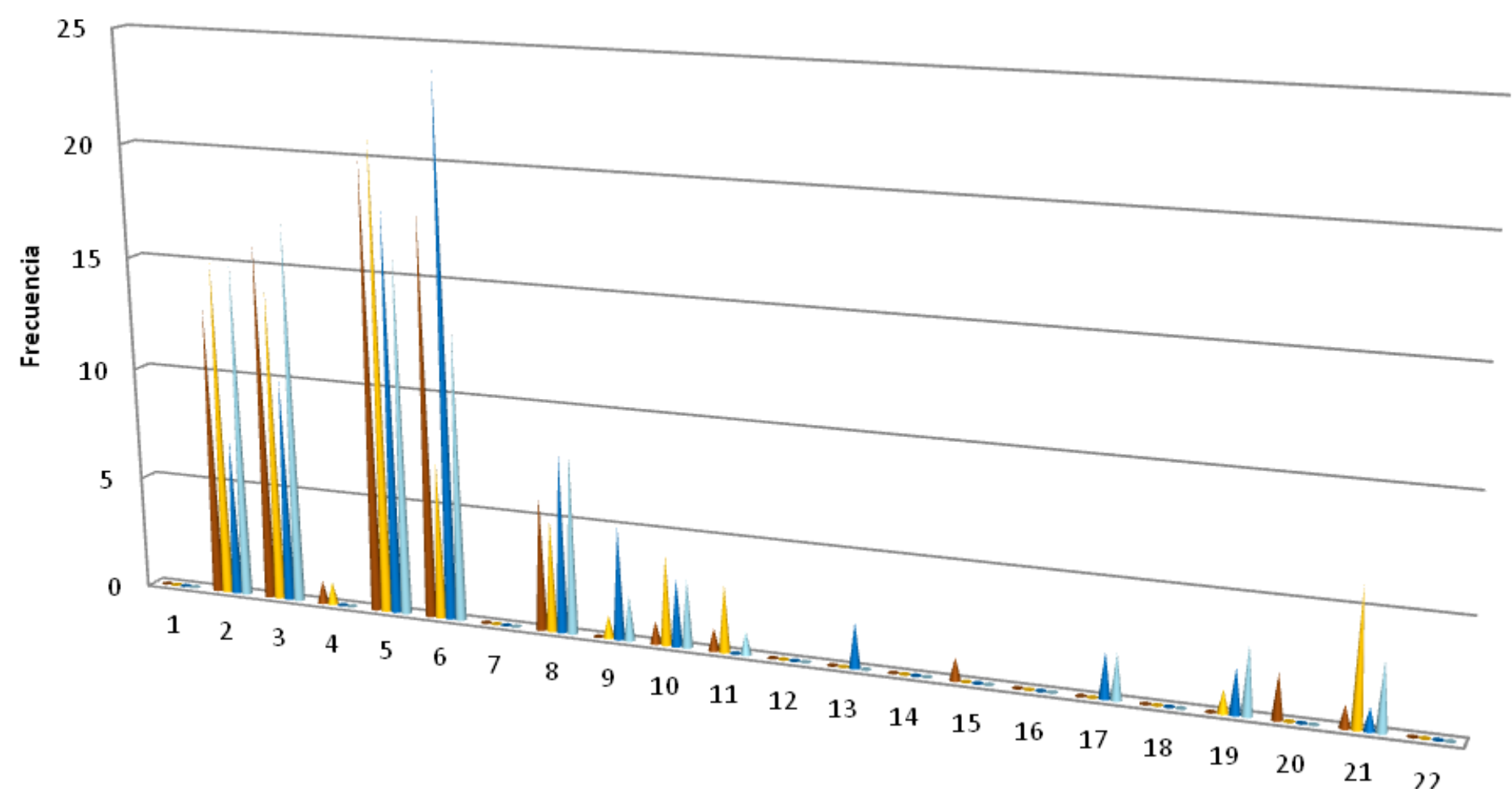

- Español Mayor Español Menor

- Malayo Mayor

Malayo Menor

1: No 2: Buena voluntad/capacidad negativa 3: Disculpa 4: Deseo 5: Excusa 6: Declaración de alternativa 7: Conjunto de condiciones para la aceptación pasada/futura 8: Declaración de principios 9: Amenaza o declaración de consecuencias negativas para el emisor 10: Declaración de sentimiento negativo 11: Petición de comprensión 12: Garantía de satisfacción futura del interlocutor 13: Autodefensa 14: Repetición de parte de la petición 15: Aplazamiento 16: Evasivas 17: Declaración de opinión/sentimiento positivo 18: Declaración de empatía 19: Uso de muletillas 20: Agradecimiento 21: Fórmulas de tratamiento 22: Saludos/despedidas corteses 
Los sujetos mayores españoles tendieron a aplicar más la estrategia de "Excusa" (20 veces), seguida de "Declaración de alternativa" (18 veces), "Disculpa" (16 veces) y "Buena voluntad/capacidad negativa" (15 veces) para formular sus rechazos. Los jóvenes, por su parte, utilizaron más frecuentemente la de "Excusa" (21 veces), seguida de "Buena voluntad/capacidad negativa" (15 veces), "Disculpa" (14 veces) y "Declaración de alternativa" (7 veces).

Los participantes malayos del subgrupo de más edad, en cambio, prefirieron más la de "Declaración de alternativa" (24 veces), seguida de "Excusa" (18 veces), "Disculpa" (10 veces) y "Declaración de principios" (8 veces), mientras que las estrategias más comúnmente utilizadas por los jóvenes fueron las de "Disculpa" (17 veces), "Excusa" (16 veces), "Buena voluntad/capacidad negativa" (15 veces) y "Declaración de alternativa" (13 veces). En este caso, la comparación de los promedios de las categorías empleadas tampoco indicó una diferencia significativa en ambos grupos.

El ranking de cada estrategia aplicada para hacer rechazos en la situación 14 por los participantes mayores y los jóvenes se presenta en la Tabla 85. 
Tabla 85. Estrategias utilizadas por los hablantes españoles y malayos en la situación 14 ordenadas según frecuencia de uso (de mayor a menor) en cada subgrupo de edad

\begin{tabular}{|c|c|c|}
\hline \multirow{2}{*}{$\mathbf{0}$} & \multicolumn{2}{|c|}{ Español } \\
\hline & Mayor & Menor \\
\hline 1 & $>$ Excusa & $>$ Excusa \\
\hline 2 & $>$ Declaración de alternativa & $>$ Buena voluntad/capacidad negativa \\
\hline 3 & $>$ Disculpa & $>$ Disculpa \\
\hline 4 & $>$ Buena voluntad/capacidad negativa & $>$ Declaración de alternativa \\
\hline 5 & $>$ Declaración de principios & $>$ Fórmulas de tratamiento \\
\hline 6 & $>$ Agradecimiento & $>$ Declaración de principios \\
\hline 7 & $\begin{array}{l}>\text { Deseo } \\
>\text { Declaración de sentimiento negativa } \\
>\text { Petición de comprensión } \\
>\text { Aplazamiento } \\
>\text { Fórmulas de tratamiento }\end{array}$ & $>$ Declaración de sentimiento negativo \\
\hline 8 & - & $>$ Petición de comprensión \\
\hline 9 & - & $\begin{array}{l}>\text { Deseo } \\
\text { Amenaza o declaración de } \\
\text { consecuencias negativas para el emisor } \\
>\text { Uso de muletillas }\end{array}$ \\
\hline
\end{tabular}

\begin{tabular}{|c|c|c|}
\hline \multirow{2}{*}{$\mathbf{0}$} & \multicolumn{2}{|c|}{ Malayo } \\
\hline & Mayor & Menor \\
\hline 1 & $>$ Declaración de alternativa & $>$ Disculpa \\
\hline 2 & $>$ Excusa & $>$ Excusa \\
\hline 3 & $>$ Disculpa & $>$ Buena voluntad/capacidad negativa \\
\hline 4 & > Declaración de principios & $>$ Declaración de alternativa \\
\hline 5 & $>$ Buena voluntad/capacidad negativa & $>$ Declaración de principios \\
\hline 6 & $\begin{array}{l}\text { Amenaza o declaración de } \\
\text { consecuencias negativas para el } \\
\text { emisor }\end{array}$ & $\begin{array}{l}>\text { Declaración de sentimiento negativa } \\
>\text { Uso de muletillas } \\
>\text { Fórmulas de tratamiento }\end{array}$ \\
\hline 7 & $>$ Declaración de sentimiento negativo & $\begin{array}{l}>\text { Amenaza o declaración de } \\
\text { consecuencias negativas para el emisor } \\
>\text { Declaración de opinión/sentimiento } \\
\text { positivo }\end{array}$ \\
\hline 8 & $\begin{array}{l}>\text { Autodefensa } \\
\text { Declaración de opinión/sentimiento } \\
\text { positivo o acuerdo } \\
>\text { Uso de muletillas }\end{array}$ & $>$ Petición de comprensión \\
\hline 9 & $>$ Fórmulas de tratamiento & \\
\hline
\end{tabular}




\section{C) Varón frente a mujer}

En este escenario, no se halló ninguna diferencia entre las respuestas de los hablantes de los dos sexos en el corpus español. Ambos utilizaron el mismo número de enunciados (79 en cada caso) y también el mismo número de estrategias diferentes (ambos usaron 11 estrategias). Por su parte, en el corpus malayo, los varones produjeron menos enunciados que las mujeres (se registraron 78 de los varones y 87 de las mujeres) y también usaron menos estrategias diferentes que las mujeres en la expresión de rechazo (utilizaron solo 10, en comparación con los 12 tipos elegidos por las mujeres).

Al subdividir las estrategias empleadas en directas, indirectas y de adyacentes al rechazo, se observa que los sujetos españoles de ambos sexos formularon exactamente el mismo número de enunciados con cada una de ellas (14 con el primer tipo, 60 con el segundo y 5 con el tercero). Por otro lado, los varones malayos aplicaron más estrategias directas que las mujeres (12 de los varones por 10 de las mujeres), aunque utilizaron menos que las mujeres las indirectas (60 y 70 , respectivamente) y, en el tercer caso, las de adyacentes al rechazo, ocurrió lo mismo (6 frente a 7).

La Figura 210 representa esta distribución que acabamos de describir. 
Figura 210. Distribución, según grado de (in)dirección de las estrategias empleadas, de enunciados formulados en la situación 14 por los hablantes de cada género en cada cultura

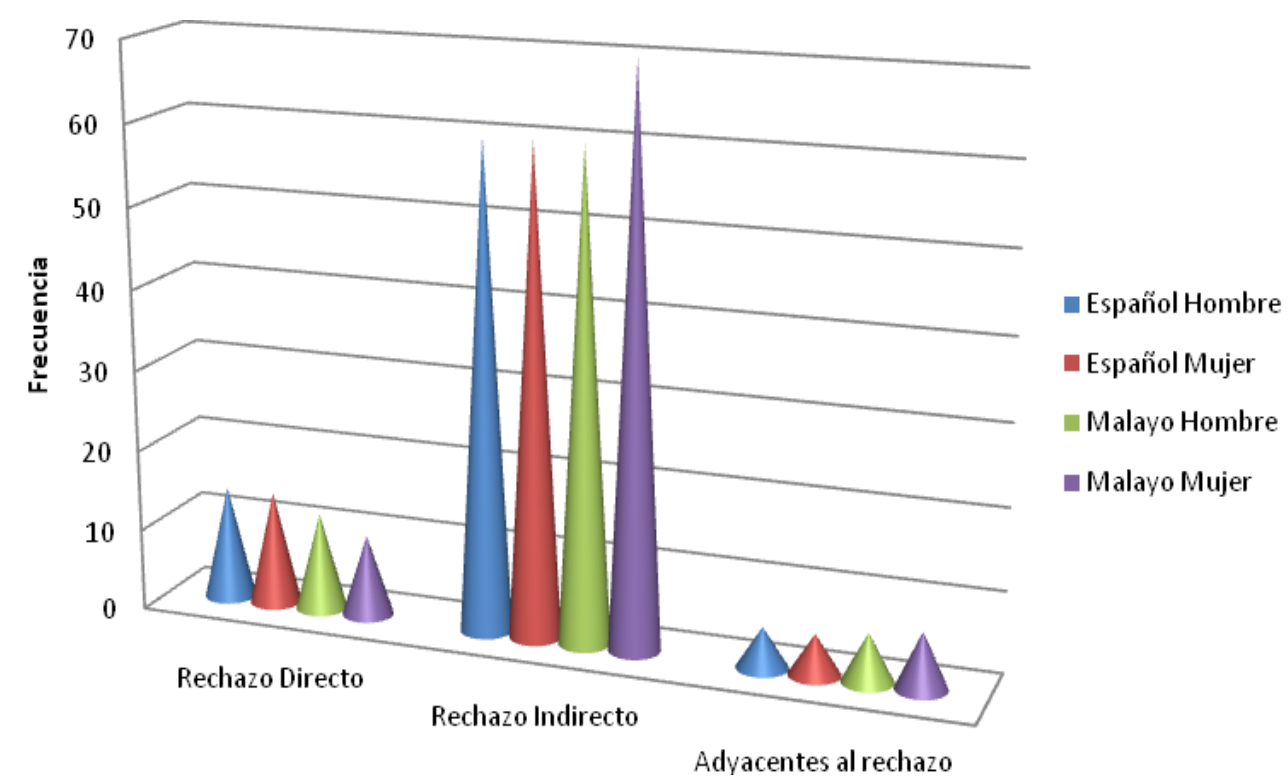

Hay una gran similitud en las respuestas de los hablantes de todos los subgrupos, excepto en el caso de las mujeres malayas, que utilizan más el "Rechazo indirecto". Los promedios de las categorías aplicadas entre los subgrupos de sexo no muestran una diferencia significativa en ninguno de los corpus.

A continuación, en la Figura 211 , se presenta la distribución de todas las estrategias aplicadas por los sujetos de cada género. 
Figura 211. Distribución de estrategias utilizadas en la situación 14 por los hablantes de cada género en cada cultura

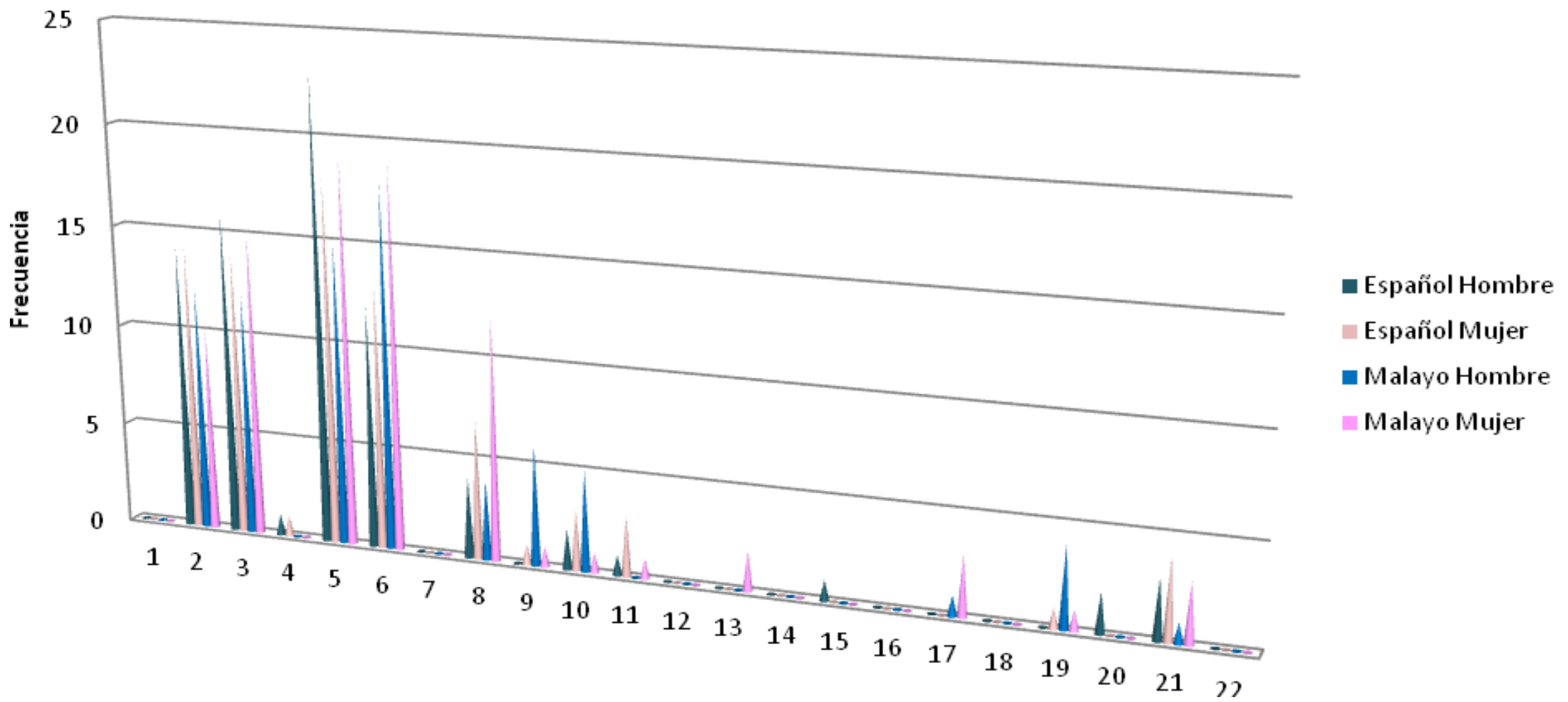

1: No 2: Buena voluntad/capacidad negativa 3: Disculpa 4: Deseo 5: Excusa 6: Declaración de alternativa 7: Conjunto de condiciones para la aceptación pasada/futura 8: Declaración de principios 9: Amenaza o declaración de consecuencias negativas para el emisor 10: Declaración de sentimiento negativo 11: Petición de comprensión 12: Garantía de satisfacción futura del interlocutor 13: Autodefensa 14: Repetición de parte de la petición 15: Aplazamiento 16: Evasivas 17: Declaración de opinión/sentimiento positivo 18: Declaración de empatía 19: Uso de muletillas 20: Agradecimiento 21: Fórmulas de tratamiento 22: Saludos/despedidas corteses 
Las estrategias más comúnmente aplicadas tanto en los datos de los varones como en los de las mujeres españoles fueron las de "Excusa" (23 casos de los varones y 18 de las mujeres), "Disculpa" (16 de los varones por 14 de las mujeres), "Buena voluntad/capacidad negativa" (14 ejemplos en cada subgrupo) y "Declaración de alternativa" (12 de los varones y 13 veces de las mujeres).

Por su parte, en los datos malayos, los varones tendieron a utilizar más la "Declaración de alternativa" (aparece 18 veces), seguida de "Excusa" (15 veces), "Buena voluntad/capacidad negativa" y "Disculpa" (12 veces para cada una). Las mujeres, por otro lado, también tendieron a utilizar más la "Declaración de alternativa" y la "Excusa" (19 veces cada una), seguidas de "Disculpa" (15 veces) y "Buena voluntad/capacidad negativa" (10 veces), en su formulación de rechazos. Al comparar los promedios de las estrategias utilizadas, la diferencia no fue significativa entre ambos sexos, ni en el resultado español ni en el malayo.

El ranking de cada estrategia empleada para la situación 14 según el género en cada grupo se presenta en la Tabla 86. 
Tabla 86. Estrategias utilizadas por los hablantes españoles y malayos en la situación 14 ordenadas según frecuencia de uso (de mayor a menor) en cada subgrupo de sexo

\begin{tabular}{|c|c|c|}
\hline \multirow{2}{*}{0} & \multicolumn{2}{|c|}{ Español } \\
\hline & Varón & Mujer \\
\hline 1 & $>$ Excusa & $>$ Excusa \\
\hline 2 & $>$ Disculpa & $\begin{array}{l}>\text { Buena voluntad/capacidad negativa } \\
>\text { Disculpa }\end{array}$ \\
\hline 3 & $\begin{array}{l}\text { Buena voluntad/capacidad } \\
\text { negativa }\end{array}$ & $>$ Declaración de alternativa \\
\hline 4 & $>$ Declaración de alternativa & $>$ Declaración de principios \\
\hline 5 & $>$ Declaración de principios & $>$ Fórmulas de tratamiento \\
\hline 6 & $>$ Fórmulas de tratamiento & $\begin{array}{l}>\text { Declaración de sentimiento negativa } \\
>\text { Petición de comprensión }\end{array}$ \\
\hline 7 & $\begin{array}{l}\text { Declaración de sentimiento } \\
\text { negativa } \\
>\text { Garantía de satisfacción futura del } \\
\text { interlocutor }\end{array}$ & $\begin{array}{l}>\text { Deseo } \\
\text { Amenaza o declaración de } \\
\text { consecuencias negativas para el } \\
\text { emisor } \\
>\text { Uso de muletillas }\end{array}$ \\
\hline 8 & $\begin{array}{l}>\text { Deseo } \\
>\text { Petición de comprensión } \\
>\text { Aplazamiento }\end{array}$ & - \\
\hline \multirow{2}{*}{$\mathbf{0}$} & \multicolumn{2}{|c|}{ Malayo } \\
\hline & Varón & Mujer \\
\hline 1 & $>$ Declaración de alternativa & $\begin{array}{l}>\text { Excusa } \\
>\text { Declaración de alternativa }\end{array}$ \\
\hline 2 & $>$ Excusa & $>$ Disculpa \\
\hline 3 & $\begin{array}{l}>\text { Disculpa } \\
\text { Buena voluntad/capacidad } \\
\text { negativa }\end{array}$ & $>$ Declaración de principios \\
\hline 4 & $\begin{array}{l}\text { Amenaza o declaración de } \\
\text { consecuencias negativas para el } \\
\text { emisor }\end{array}$ & $>$ Buena voluntad/capacidad negativa \\
\hline 5 & $\begin{array}{l}\text { Declaración de sentimiento } \\
\text { negativo }\end{array}$ & $\begin{array}{l}\text { Declaración de opinión/sentimiento } \\
\text { positivo o acuerdo } \\
>\text { Fórmulas de tratamiento }\end{array}$ \\
\hline 6 & $\begin{array}{l}>\text { Declaración de principios } \\
>\text { Uso de muletillas }\end{array}$ & $>$ Autodefensa \\
\hline 7 & $\begin{array}{l}\text { Declaración de } \\
\text { opinión/sentimiento positivo o } \\
\text { acuerdo } \\
>\text { Fórmulas de tratamiento }\end{array}$ & $\begin{array}{l}>\text { Amenaza o declaración de } \\
\text { consecuencias negativas para el } \\
\text { emisor } \\
>\text { Declaración de sentimiento negativa } \\
>\text { Petición de comprensión } \\
>\text { Uso de muletillas }\end{array}$ \\
\hline 8 & $>$ Declaración de alternativa & $\begin{array}{l}>\text { Excusa } \\
>\text { Declaración de alternativa }\end{array}$ \\
\hline
\end{tabular}




\subsubsection{Situación 17}

En la situación 17, un profesor universitario le pide a un estudiante que está haciendo una investigación bajo su dirección que cambie el método de estudio. El dominio de poder social es del interlocutor, puesto que, en este contexto específico, los informantes se sitúan en una posición inferior frente al profesor.

\section{A) Español frente a malayo}

En total, los españoles utilizaron menos enunciados que los malayos (los españoles produjeron 166, y, los malayos, 212). Sin embargo, los españoles aplicaron más estrategias diferentes que los malayos (19, en comparación con las 17 de los malayos). En este contexto, los españoles emplearon menos estrategias directas que los malayos (se encontraron 11 casos, frente a los 15 de los datos malayos). Cabe mencionar que es la única situación donde los malayos rechazaron de manera más directa que los españoles. Las estrategias indirectas, los dos grupos las aplicaron en el mismo número de ocasiones (ambos las emplearon 120 veces), y las de adyacentes al rechazo, los españoles las usaron mucho menos que los malayos (tan solo 35 veces en comparación con las 77 veces en las que 
aparece el corpus del otro grupo). En la Figura 212 se muestran los datos numéricos correspondientes a esta triple clasificación.

Figura 212. Distribución de enunciados producidos en la situación 17, según el grado de (in)dirección de las estrategias empleadas por los hablantes de cada grupo principal

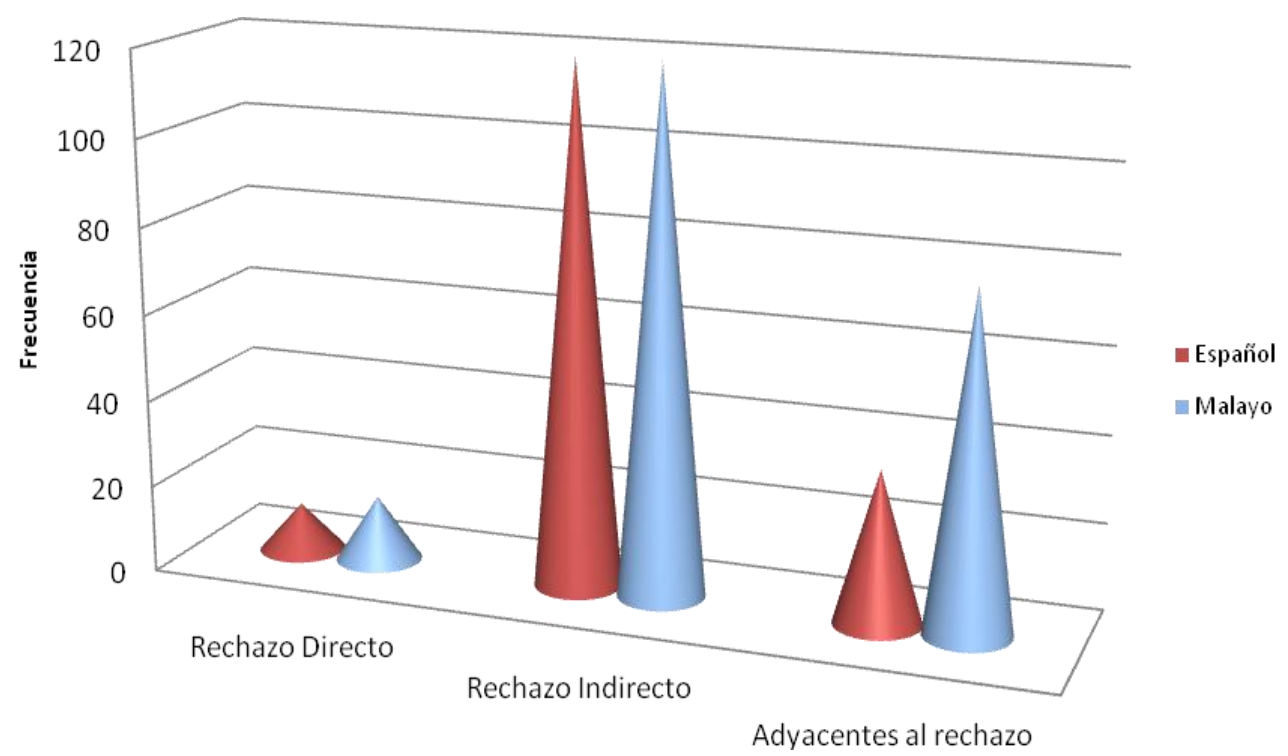

En este caso, la diferencia más llamativa entre las dos sociedades la encontramos en el empleo de las estrategias de "Adyacentes al rechazo". La diferencia en el empleo del "Rechazo directo" fue muy pequeña, y en el caso de las "Indirectas", inexistente. Aun así, la diferencia en los promedios de las fórmulas empeladas, entre los grupos analizados, sí que fue significativa: $X^{2}=10.929 p=.004(p<.05)$.

Los datos numéricos obtenidos respecto a las estrategias empleadas en la situación 17 están recogidos en la Figura 213. 
Figura 213. Distribución de estrategias utilizadas en la situación 17 por los sujetos de cada grupo principal

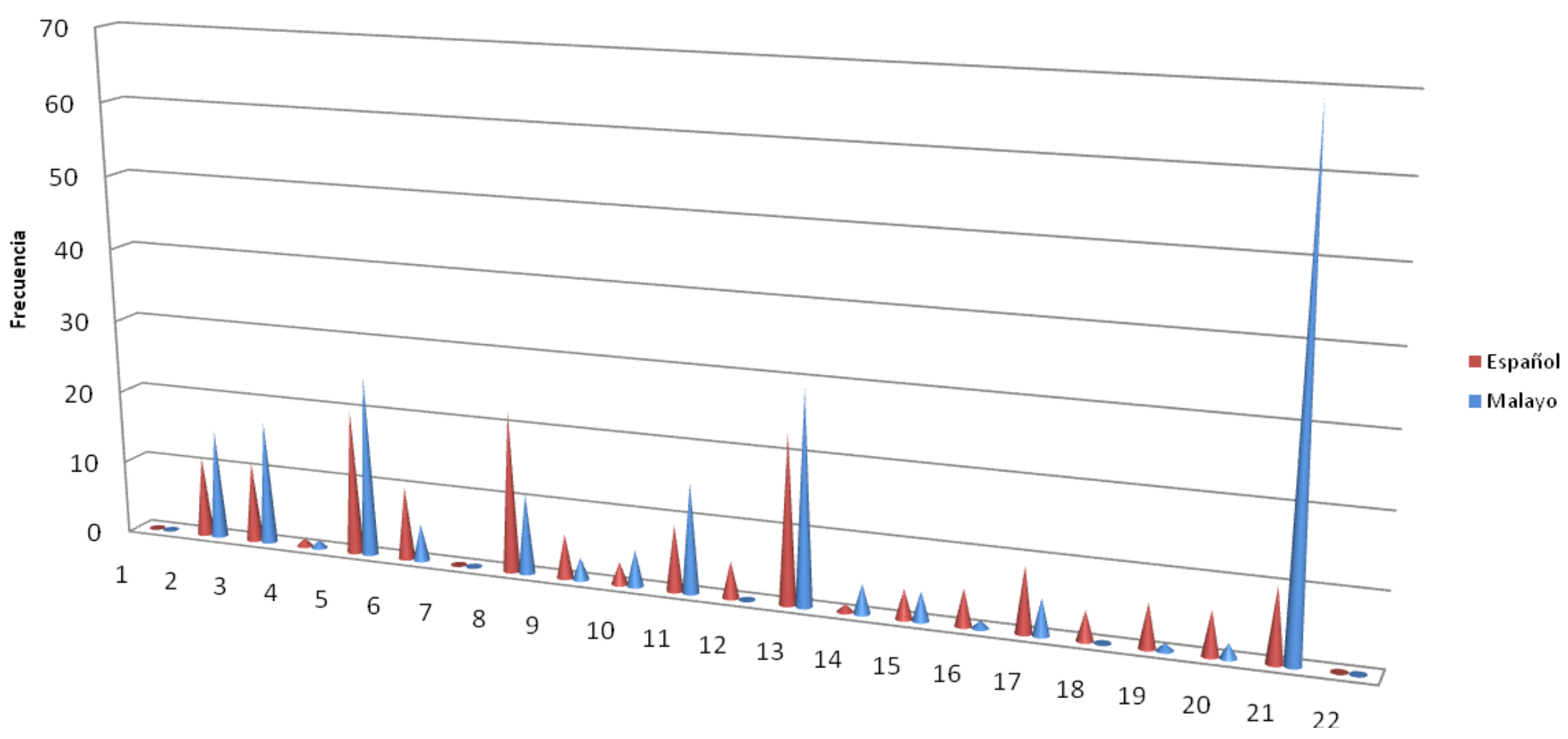

1: No 2: Buena voluntad/capacidad negativa 3: Disculpa 4: Deseo 5: Excusa 6: Declaración de alternativa 7: Conjunto de condiciones para la aceptación pasada/futura 8: Declaración de principios 9: Amenaza o declaración de consecuencias negativas para el emisor 10: Declaración de sentimiento negativo 11: Petición de comprensión 12: Garantía de satisfacción futura del interlocutor 13: Autodefensa 14: Repetición de parte de la petición 15: Aplazamiento 16: Evasivas 17: Declaración de opinión/sentimiento positivo 18: Declaración de empatía 19: Uso de muletillas 20: Agradecimiento 21: Fórmulas de tratamiento 22: Saludos/despedidas corteses 
Los españoles recurrieron, en mayor medida, al empleo de la "Autodefensa" (23 veces), "Declaración de principios" (22 veces), "Excusa" (20 veces), "Buena voluntad/capacidad negativa" y "Disculpa" (11 veces respectivamente), para formular su rechazo en esta situación, mientras que los malayos usaron más comúnmente las de "Fórmulas de tratamiento" (69 veces), "Autodefensa" (29 veces), "Excusa" (25 veces) y "Disculpa" (17 veces). Es relevante la diferencia estadística entre las dos culturas con relación al empleo de las estrategias de "Fórmulas de tratamiento" (tan solo 10 enunciados de los españoles frente a 69 de los malayos) y "Declaración de principios" (22 de los españoles en comparación con 11 de los malayos). La comparación de los promedios entre las estrategias empleadas por los grupos de ambos países indicó una diferencia significativa: $X^{2}=71.183 \mathrm{p}=.000(\mathrm{p}<.05)$.

La tabla 87, que presentamos a continuación, refleja el ranking de cada estrategia utilizada en cada grupo. 
Tabla 87. Estrategias utilizadas en la situación 17 en cada cultura ordenadas según frecuencia de uso (de mayor a menor)

\begin{tabular}{|c|c|c|}
\hline $\mathbf{O}$ & Español & Malayo \\
\hline 1 & $>$ Autodefensa & $>$ Fórmulas de tratamiento \\
\hline 2 & $>$ Declaración de principios & $>$ Autodefensa \\
\hline 3 & $>$ Excusa & $>$ Excusa \\
\hline 4 & $\begin{array}{l}\text { Buena voluntad/capacidad } \\
\text { negativa } \\
>\text { Disculpa }\end{array}$ & $>$ Disculpa \\
\hline 5 & $\begin{array}{l}\text { Declaración de alternativa } \\
>\text { Fórmulas de tratamiento }\end{array}$ & $\begin{array}{l}>\text { Buena voluntad/capacidad negativa } \\
>\text { Petición de comprensión }\end{array}$ \\
\hline 6 & $\begin{array}{l}>\text { Petición de comprensión } \\
>\text { Declaración de } \\
\text { opinión/sentimiento positivo }\end{array}$ & $>$ Declaración de principios \\
\hline 7 & $\begin{array}{l}\text { Amenaza o declaración de } \\
\text { consecuencias negativas para el } \\
\text { emisor } \\
>\text { Uso de muletillas } \\
>\text { Agradecimiento }\end{array}$ & $\begin{aligned} & \text { Declaración de alternativa } \\
& \text { Declaración de sentimiento negativo } \\
& \text { Declaración de opinión/sentimiento } \\
& \text { positivo o acuerdo }\end{aligned}$ \\
\hline 8 & $\begin{array}{l}>\text { Garantía de satisfacción futura del } \\
\text { interlocutor } \\
>\text { Evasivas }\end{array}$ & $\begin{array}{l}>\text { Repetición de parte de la petición } \\
>\text { Aplazamiento }\end{array}$ \\
\hline 9 & $\begin{array}{l}>\text { Aplazamiento } \\
>\text { Declaración de empatía }\end{array}$ & $\begin{array}{l}\text { Amenaza o declaración de } \\
\text { consecuencias negativas para el } \\
\text { emisor }\end{array}$ \\
\hline 10 & $\begin{array}{l}\text { Declaración de sentimiento } \\
\text { negativo }\end{array}$ & $>$ Agradecimiento \\
\hline 11 & $>$ Deseo & $\begin{array}{l}>\text { Deseo } \\
>\text { Evasivas } \\
>\text { Uso de muletillas }\end{array}$ \\
\hline 12 & $>$ Repetición de parte de la petición & $>$ Fórmulas de tratamiento \\
\hline
\end{tabular}

\section{B) Mayor frente a menor}

En este caso, se encuentra que, en total, los hablantes españoles de más edad produjeron menos enunciados que los menores (los ancianos emplearon 81 , por los 85 veces de los menores) y también utilizaron menos estrategias diferentes que los menores (16 de los 
ancianos en comparación con 18 de los menores). Por el contrario, los mayores malayos usaron muchos más enunciados que los menores (123 de los mayores por solo 89 de los menores) y también aplicaron más estrategias diferentes que los menores (15 de los mayores y 14 de los menores).

En cuanto a la triple clasificación en rechazos directos, indirectos y adyacentes al rechazo, los datos analizados revelan que los participantes de más edad en ambos grupos, español y malayo, utilizaron menos estrategias directas para rechazar que los jóvenes ( 3 casos frente a 8 veces en el grupo español, y 4 frente a 11 veces en el grupo malayo). Por el contrario, en el empleo de las estrategias indirectas, tanto los mayores españoles como los malayos las aplicaron más que los menores (63 enunciados frente a 57 , en el primer grupo y 69 , en contraste con 51 , en el segundo). En el tercer tipo, las de adyacentes al rechazo, los mayores españoles las emplearon menos que los jóvenes (15 veces frente a 20), y en cambio, los mayores malayos las emplearon más que los menores (50 casos, en comparación con los 27 de los más jóvenes). La distribución de enunciados, según esta clasificación en tres grandes bloques, se expone en la Figura 214. A continuación, en la Figura 215, se presenta la clasificación según los 22 tipos de estrategias que estamos utilizando en este estudio. 
Figura 214. Distribución de enunciados producidos en la situación 17 por los hablantes mayores y menores de cada cultura en su formulación del rechazo, según el grado de (in)dirección de la estrategia elegida

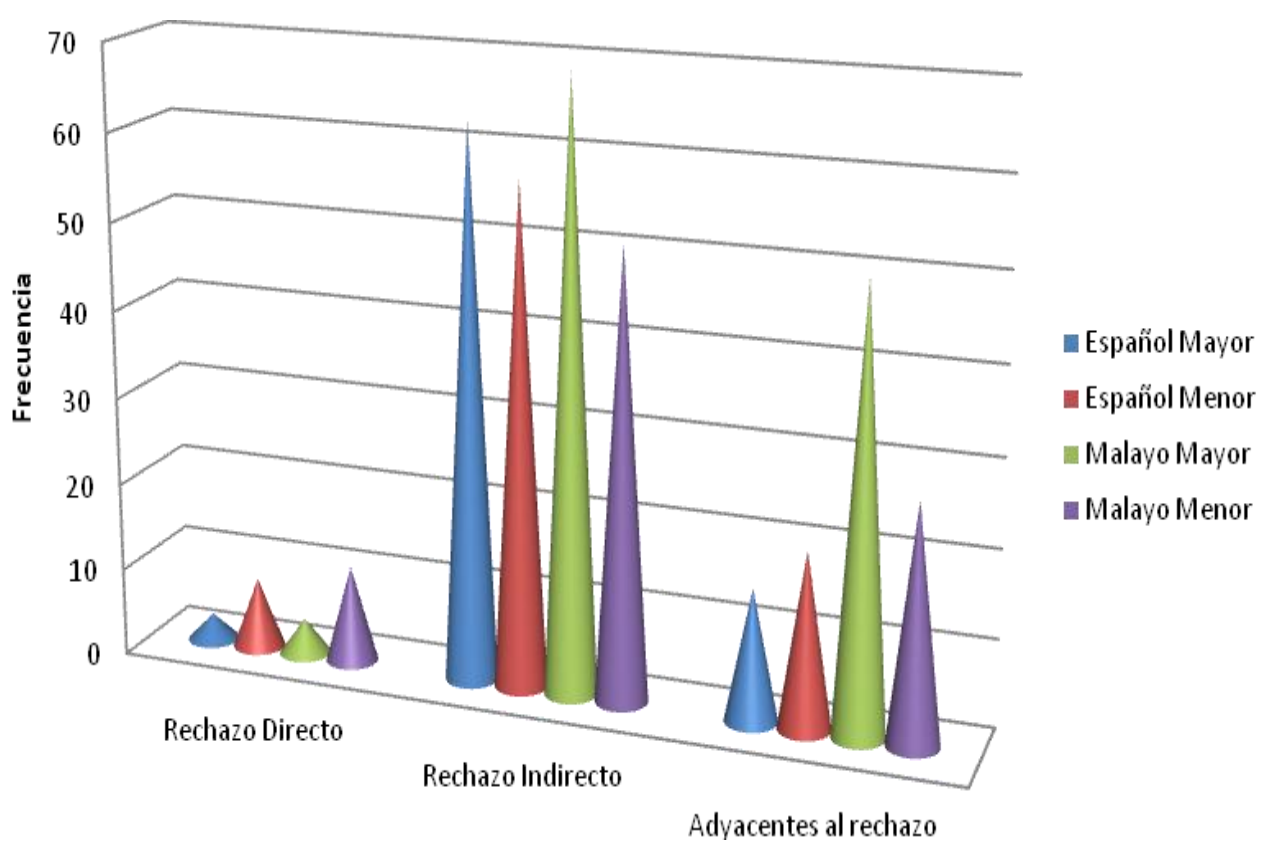

Como vemos en la figura, las mayores diferencias se encuentran entre las respuestas proporcionadas por los sujetos malayos, siendo, las de los españoles, más parecidas. La comparación entre los subgrupos de edad de los promedios de las categorías aplicadas no reveló una diferencia significativa en el resultado español, pero sí en el malayo: $X^{2}=7.579 p=.023(p<.05)$. 
Figura 215. Distribución de estrategias utilizadas en la situación 17 por los sujetos mayores y menores en cada cultura

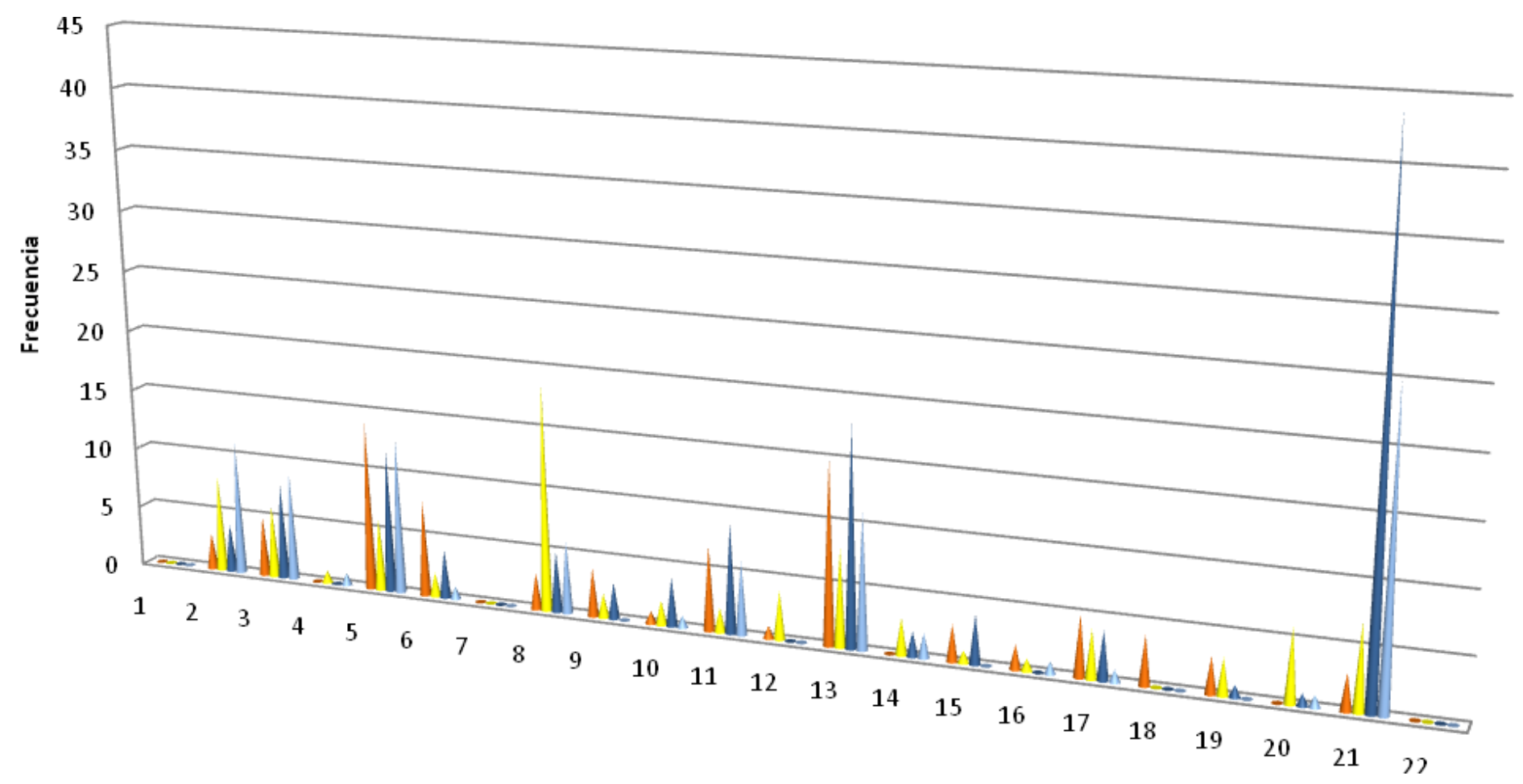

Español Mayor

Español Menor

Malayo Mayor

Malayo Menor

1: No 2: Buena voluntad/capacidad negativa 3: Disculpa 4: Deseo 5: Excusa 6: Declaración de alternativa 7: Conjunto de condiciones para la aceptación pasada/futura 8: Declaración de principios 9: Amenaza o declaración de consecuencias negativas para el emisor 10: Declaración de sentimiento negativo 11: Petición de comprensión 12: Garantía de satisfacción futura del interlocutor 13: Autodefensa 14: Repetición de parte de la petición 15: Aplazamiento 16: Evasivas 17: Declaración de opinión/sentimiento positivo 18: Declaración de empatía 19: Uso de muletillas 20: Agradecimiento 21: Fórmulas de tratamiento 22: Saludos/despedidas corteses 
En el grupo español, los participantes de más edad utilizaron más frecuentemente las estrategias de "Autodefensa" (15 veces), "Excusa" (14 veces), "Declaración de alternativa" (8 veces) y "Petición de comprensión" (7 veces). Los menores, por su parte, aplicaron más las de "Declaración de principios" (19 veces), "Buena voluntad/capacidad negativa" y "Autodefensa" (ambas en 8 ocasiones), y "Fórmulas de tratamiento" (7 veces).

En el caso malayo, las estrategias más comúnmente utilizadas en las respuestas de los sujetos mayores fueron las de "Fórmulas de tratamiento" (44 veces), "Autodefensa" (18 veces), "Excusa" (12 veces) y "Petición de compresión" (9 veces). Por otro lado, los menores prefirieron las "Fórmulas de tratamiento" (25 veces), seguidas de "Excusa" (13 veces), "Buena voluntad/capacidad negativa" y "Autodefensa" (11 veces). A diferencia del caso anterior, en este caso, los promedios comparados indicaron una diferencia significativa en el grupo español: $X^{2}=43.348 p=.001(p<.05)$, pero no en el grupo malayo.

A continuación, se presenta el ranking de cada estrategia utilizada en la situación 17 por los hablantes de más y menos edad. 
Tabla 88. Estrategias utilizadas por los hablantes españoles y malayos en la situación 17 ordenadas según frecuencia de uso (de mayor a menor) en cada subgrupo de edad

\begin{tabular}{|c|c|c|}
\hline \multirow{2}{*}{$\mathbf{0}$} & \multicolumn{2}{|c|}{ Español } \\
\hline & Mayor & Menor \\
\hline 1 & $>$ Autodefensa & $>$ Declaración de principios \\
\hline 2 & $>$ Excusa & $\begin{array}{l}>\text { Buena voluntad/capacidad negativa } \\
>\text { Autodefensa }\end{array}$ \\
\hline 3 & $>$ Declaración de alternativa & Fórmulas de tratamiento \\
\hline 4 & > Petición de comprensión & $\begin{array}{l}>\text { Disculpa } \\
>\text { Excusa } \\
>\text { Agradecimiento }\end{array}$ \\
\hline 5 & $\begin{array}{l}\text { Disculpa } \\
\text { Declaración de opinión/sentimiento } \\
\text { positivo }\end{array}$ & $\begin{array}{l}>\text { Garantía de satisfacción futura del } \\
\text { interlocutor } \\
\text { Declaración de opinión/sentimiento } \\
\text { positivo }\end{array}$ \\
\hline 6 & $\begin{array}{l}\text { Amenaza o declaración de } \\
\text { consecuencias negativas para el emisor } \\
>\text { Declaración de empatía }\end{array}$ & $\begin{array}{l}>\text { Repetición de parte de la petición } \\
>\text { Uso de muletillas }\end{array}$ \\
\hline 7 & $\begin{array}{l}>\text { Buena voluntad/capacidad negativa } \\
>\text { Declaración de principios } \\
>\text { Aplazamiento } \\
>\text { Uso de muletillas } \\
>\text { Fórmulas de tratamiento }\end{array}$ & $\begin{array}{l}\text { Declaración de alternativa } \\
\text { Amenaza o declaración de consecuencias } \\
\text { negativas para el emisor } \\
>\text { Declaración de sentimiento negativo } \\
>\text { Petición de comprensión }\end{array}$ \\
\hline 8 & $\begin{array}{l}>\text { Evasivas } \\
>\text { Declaración de sentimiento negativo } \\
\text { Garantía de satisfacción futura del } \\
\text { interlocutor }\end{array}$ & $\begin{array}{l}>\text { Deseo } \\
>\text { Aplazamiento } \\
>\text { Evasivas }\end{array}$ \\
\hline
\end{tabular}

\begin{tabular}{|c|c|c|}
\hline \multirow{2}{*}{$\mathbf{0}$} & \multicolumn{2}{|c|}{ Malayo } \\
\hline & Mayor & Menor \\
\hline 1 & $>$ Fórmulas de tratamiento & $>$ Fórmulas de tratamiento \\
\hline 2 & $>$ Autodefensa & $>$ Excusa \\
\hline 3 & $>$ Excusa & $\begin{array}{l}>\text { Buena voluntad/capacidad negativa } \\
>\text { Autodefensa }\end{array}$ \\
\hline 4 & $>$ Petición de comprensión & $>$ Disculpa \\
\hline 5 & $>$ Disculpa & $>$ Declaración de principios \\
\hline 6 & Declaración de principios & $\begin{array}{l}\text { Garantía de satisfacción futura del } \\
\text { interlocutor }\end{array}$ \\
\hline 7 & $\begin{array}{l}>\text { Buena voluntad/capacidad negativa } \\
>\text { Declaración de alternativa } \\
>\text { Declaración de sentimiento negativa } \\
>\text { Aplazamiento } \\
>\text { Declaración de opinión/sentimiento } \\
\text { positivo o acuerdo }\end{array}$ & $\begin{array}{l}>\text { Petición de comprensión } \\
>\text { Repetición de parte de la petición }\end{array}$ \\
\hline 8 & $\begin{array}{l}\text { Amenaza o declaración de } \\
\text { consecuencias negativas para el emisor }\end{array}$ & $\begin{array}{l}>\text { Deseo } \\
>\text { Declaración de alternativa } \\
>\text { Declaración de sentimiento negativo } \\
>\text { Evasivas } \\
>\text { Declaración de opinión/sentimiento } \\
\text { positivo } \\
>\text { Agradecimiento }\end{array}$ \\
\hline
\end{tabular}




\section{C) Varón frente a mujer}

Al analizar los enunciados producidos en esta situación desde el punto de vista del sexo de los hablantes, se observa que los varones de ambas culturas utilizaron menos estrategias para realizar rechazos que las mujeres (79 a 87, en la cultura española, y 100 frente a 112 en la otra). Sin embargo, en el grupo español, los varones utilizaron más estrategias diferentes que las mujeres (19 de los varones y 16 de las mujeres). En el grupo malayo, por su parte, los varones aplicaron menos estrategias diferentes que las mujeres (13 de los varones por 16 de las mujeres).

Al agrupar las estrategias aplicadas en la formulación del rechazo en directas, indirectas y adyacentes al rechazo, resulta que los varones de las dos culturas aplicaron más estrategias directas que las mujeres (se encontraron 8 casos frente a 3, en la española, y 10 frente a 5, en la malaya). En cambio, tanto los varones españoles como los malayos usaron menos estrategias directas que las mujeres (55 enunciados frente a 65, en el primer caso, y 54 frente a 66 , en el segundo). En el caso de las de adyacentes al rechazo, también los varones de ambas culturas las emplearon menos que las mujeres (16 veces frente a las 19 de las mujeres, en el caso español, y 36 veces frente a 41, en el malayo). En la Figura 216, que presentamos a continuación, se recogen estos datos numéricos relativos al grado de 
(in)dirección de las estrategias empleadas por los sujetos de cada subgrupo de género en la formulación del rechazo en la situación 17.

Figura 216. Distribución de enunciados según el grado de (in)dirección de las estrategias de rechazo aplicadas en la situación 17 por los sujetos de ambos géneros en cada cultura

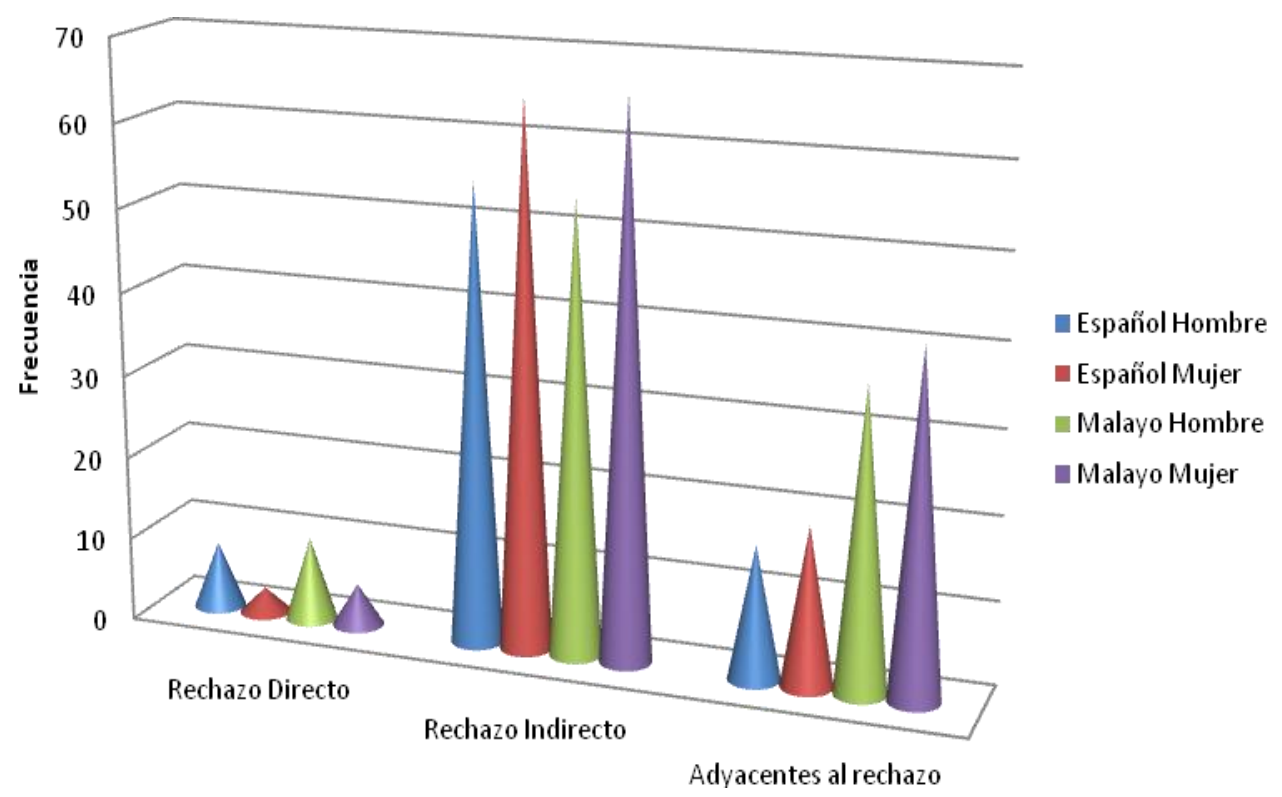

Todos los subgrupos coinciden en un mayor número de rechazos indirectos (especialmente los subgrupos de mujeres) y en una baja frecuencia de los directos (también más notable en las mujeres, sobre todo en las españolas). Respecto a los adyacentes al rechazo, aunque en ambas sociedades su frecuencia de uso está en una posición intermedia en la relación con los rechazos directos e indirectos, podemos destacar una diferencia considerable entre el empleo que hacen de ellos españoles y malayos, ya que frente a los 36 enunciados recogidos en los datos de los varones malayos, y los 
41 de las mujeres de la misma sociedad, encontramos 16 de los varones españoles y 19 de las mujeres del mismo grupo. Los valores de los promedios propusieron que en este caso no existieron diferencias estadísticas significativas entre los varones y las mujeres en ambos grupos.

La distribución de las estrategias aplicadas por cada género en cada cultura para la situación 17 se presenta en la Figura 217. 
Figura 217. Distribución de estrategias utilizadas en la situación 17 por los hablantes de ambos géneros en cada cultura

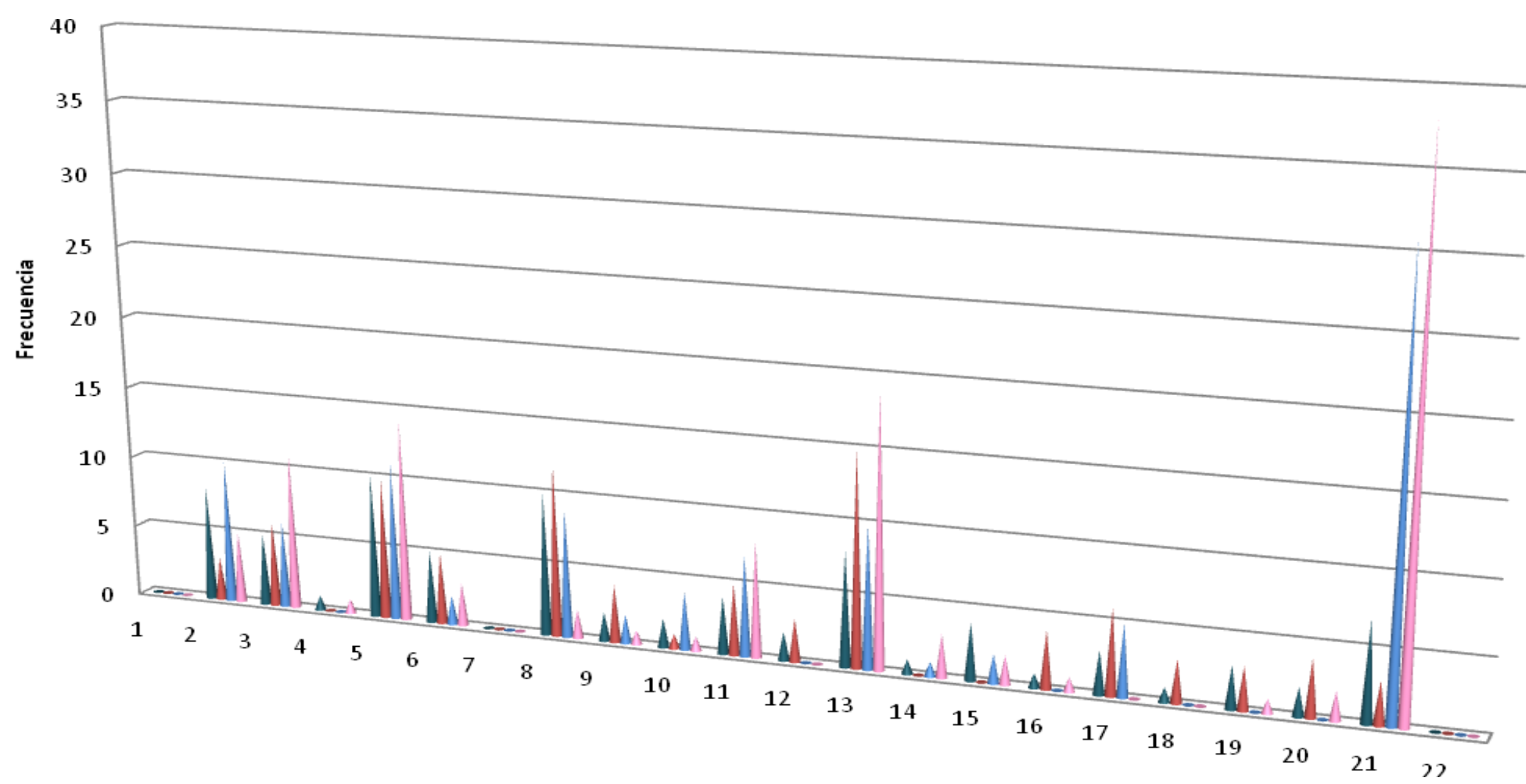

Español Hombre - Español Mujer Malayo Hombre Malayo Mujer

1: No 2: Buena voluntad/capacidad negativa 3: Disculpa 4: Deseo 5: Excusa 6: Declaración de alternativa 7: Conjunto de condiciones para la aceptación pasada/futura 8: Declaración de principios 9: Amenaza o declaración de consecuencias negativas para el emisor 10: Declaración de sentimiento negativo 11: Petición de comprensión 12: Garantía de satisfacción futura del interlocutor 13: Autodefensa 14: Repetición de parte de la petición 15: Aplazamiento 16: Evasivas 17: Declaración de opinión/sentimiento positivo 18: Declaración de empatía 19: Uso de muletillas 20: Agradecimiento 21: Fórmulas de tratamiento 22:

Saludos/despedidas corteses 
Las estrategias más comúnmente utilizadas en los datos de los varones españoles fueron las de "Declaración de principios" (17 veces), "Excusa" (9 veces), "Fórmulas de tratamiento" (8 veces), y "Buena voluntad/capacidad negativa" (7 veces), mientras que en los datos de las mujeres se aplicaron más frecuentemente las de "Declaración de principios" (15 veces), "Autodefensa" (12 veces), "Agradecimiento" (10 veces) y "Buena voluntad/capacidad negativa" (9 veces). Los géneros se diferenciaron de manera más destacada en el empleo de la estrategia de "Autodefensa", en cuyo uso la tasa de los varones fue 7 veces inferior a la de las mujeres ( 5 casos frente a 12).

En los datos malayos por su parte, es notable la diferencia mostrada entre los sujetos de los dos géneros en el uso de algunas estrategias. En primer lugar, las mujeres malayas mostraron más tendencia en sus rechazos hacia el uso del "Título", como Tuan/puan ('Señor/señora'), Encik/cik ('Señor/señorita'), y esto se ve al utilizar más "Fórmulas de tratamiento" que los varones (41 ejemplos de las mujeres en comparación con 25 de los varones). Además, para rechazar las peticiones de los interlocutores, las mujeres eligieron defenderse a sí mismas y enfatizar de alguna manera lo que la petición tiene de injusto. En cambio, los varones prefirieron declarar sus principios para rechazar las peticiones en este escenario. Así, el uso de la "Autodefensa" en el caso de las mujeres fue más 
alto que en el de los varones (la encontramos en 19 ocasiones en los datos de las mujeres, frente a solo 9 veces en los del otro sexo). Y el empleo de la "Declaración de principios" fue mayor en los varones (aparece 11 veces) que en las mujeres (tan solo 2 veces). Las de "Excusa" y "Disculpa" también se utilizaron con una frecuencia distinta, ya que la primera aparece 9 veces en las respuestas de los varones y 15 en las de las mujeres, y la segunda fue empleada por los varones en 9 ocasiones, frente a las 17 veces en que lo hacen las mujeres. Entre los promedios de las categorías aplicadas entre los subgrupos de sexo, la diferencia no fue significativa en ninguno de los países.

La tabla 89 presenta la diferencia del ranking de las estrategias aplicadas por los participantes de ambos géneros en cada grupo. 
Tabla 89. Estrategias utilizadas por los hablantes españoles y malayos en la situación 17 ordenadas según frecuencia de uso (de mayor a menor) en cada subgrupo de sexo

\begin{tabular}{|c|c|c|}
\hline \multirow{2}{*}{$\mathbf{0}$} & \multicolumn{2}{|c|}{ Español } \\
\hline & Varón & Mujer \\
\hline 1 & $\begin{array}{l}>\text { Excusa } \\
>\text { Declaración de principios }\end{array}$ & $>$ Autodefensa \\
\hline 2 & $\begin{array}{l}>\text { Buena voluntad/capacidad negativa } \\
>\text { Autodefensa }\end{array}$ & $>$ Declaración de principios \\
\hline 3 & $>$ Fórmulas de tratamiento & $>$ Excusa \\
\hline 4 & $\begin{array}{l}>\text { Disculpa } \\
>\text { Declaración de alternativa }\end{array}$ & $\begin{array}{l}>\text { Disculpa } \\
\text { Declaración de opinión/sentimiento } \\
\text { positivo }\end{array}$ \\
\hline 5 & $\begin{array}{l}>\text { Petición de comprensión } \\
>\text { Aplazamiento }\end{array}$ & $\begin{array}{l}>\text { Declaración de alternativa } \\
>\text { Petición de comprensión }\end{array}$ \\
\hline 6 & $\begin{array}{l}>\text { Declaración de opinión/sentimiento } \\
\text { positivo } \\
>\text { Uso de muletillas }\end{array}$ & $\begin{aligned} & \text { Amenaza o declaración de consecuencias } \\
& \text { negativas para el emisor } \\
> & \text { Evasivas } \\
> & \text { Agradecimiento }\end{aligned}$ \\
\hline 7 & $\begin{array}{l}>\text { Amenaza o declaración de } \\
\text { consecuencias negativas para el emisor } \\
>\text { Declaración de sentimiento negativo } \\
>\text { Garantía de satisfacción futura del } \\
\text { interlocutor } \\
>\text { Agradecimiento }\end{array}$ & $\begin{array}{l}>\text { Buena voluntad/capacidad negativa } \\
>\text { Garantía de satisfacción futura del } \\
\text { interlocutor } \\
>\text { Declaración de empatía } \\
>\text { Uso de muletillas } \\
>\text { Fórmulas de tratamiento }\end{array}$ \\
\hline 8 & $\begin{array}{l}>\text { Deseo } \\
>\text { Repetición de parte de la petición } \\
>\text { Evasivas } \\
>\text { Declaración de empatía }\end{array}$ & $>$ Declaración de sentimiento negativo \\
\hline \multirow{2}{*}{$\mathbf{0}$} & \multicolumn{2}{|c|}{ Malayo } \\
\hline & Varón & Mujer \\
\hline 1 & $>$ Fórmulas de tratamiento & $>$ Fórmulas de tratamiento \\
\hline 2 & $>$ Autodefensa & Autodefensa \\
\hline 3 & $>$ Excusa & $>$ Excusa \\
\hline 4 & $>$ Disculpa & $>$ Disculpa \\
\hline 5 & $\begin{array}{l}>\text { Buena voluntad/capacidad negativa } \\
>\text { Petición de comprensión }\end{array}$ & $\begin{array}{l}>\text { Buena voluntad/capacidad negativa } \\
>\text { Petición de comprensión }\end{array}$ \\
\hline 6 & $>$ Declaración de principios & $>$ Declaración de principios \\
\hline 7 & $\begin{array}{l}>\text { Declaración de alternativa } \\
>\text { Declaración de sentimiento negativo } \\
>\quad \text { Declaración de opinión/sentimiento } \\
\text { positivo o acuerdo }\end{array}$ & $\begin{array}{l}>\text { Declaración de alternativa } \\
>\quad \text { Declaración de sentimiento negativo } \\
>\text { Declaración de opinión/sentimiento } \\
\text { positivo o acuerdo }\end{array}$ \\
\hline 8 & $\begin{array}{l}>\text { Repetición de parte de la petición } \\
>\text { Aplazamiento }\end{array}$ & $\begin{array}{l}>\text { Repetición de parte de la petición } \\
>\text { Aplazamiento }\end{array}$ \\
\hline 9 & $\begin{array}{l}\text { Amenaza o declaración de } \\
\text { consecuencias negativas para el } \\
\text { emisor }\end{array}$ & $\begin{array}{l}\text { Amenaza o declaración de } \\
\text { consecuencias negativas para el emisor }\end{array}$ \\
\hline
\end{tabular}




\subsubsection{La influencia de las variables sociales}

Esta sección examina la influencia del estatus social y la distancia social, de haberla, en las estrategias empleadas al rechazar tanto en el grupo malayo como en el grupo español. Primero, se presenta la influencia del estatus social, en su caso, en el empleo de las estrategias en los rechazos españoles y los rechazos malayos. Después, se muestra la influencia de la distancia social, si la hay, en los rechazos de los hablantes de las dos culturas.

\subsubsection{Estatus social}

Figura 218. Distribución de los enunciados formulados como rechazos según estatus social en el caso de español versus malayo

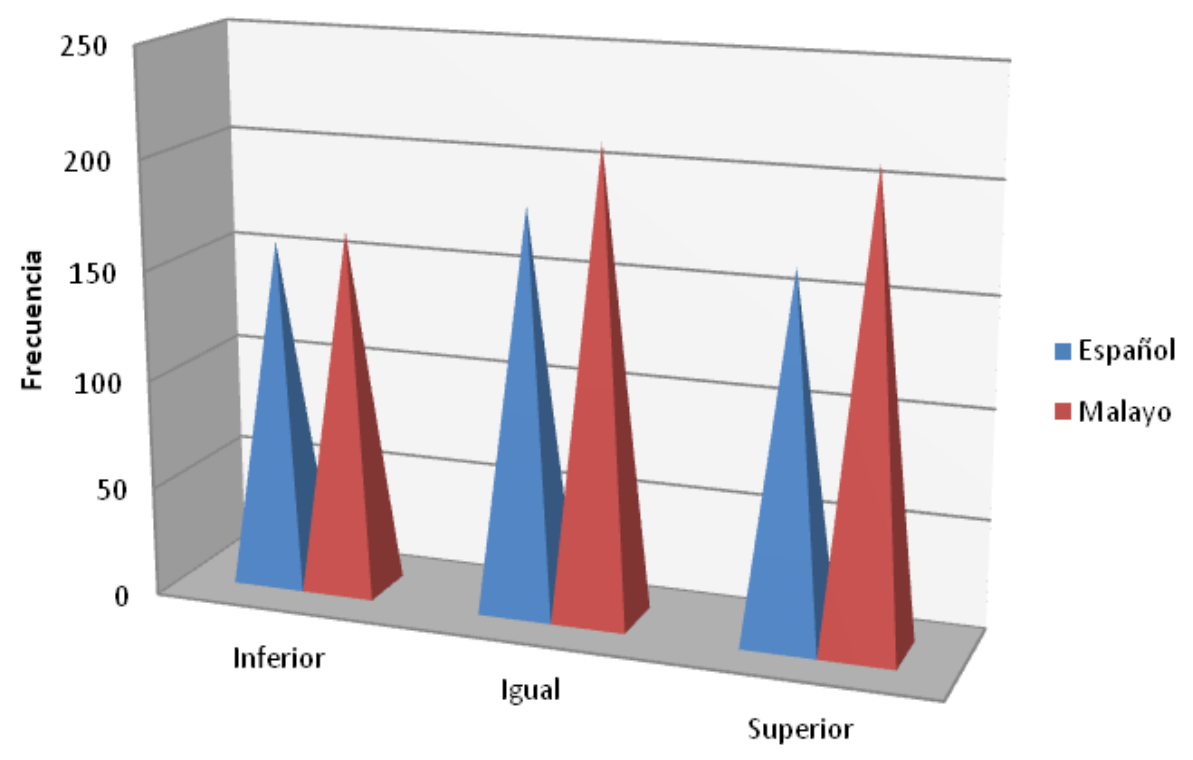


Tal y como se observa en la Figura 218 , tanto los españoles como los malayos tendieron a utilizar más enunciados al rechazar la petición de una persona del mismo estatus (situación 11, en que se pide a un colega que vaya a pescar a un río), y menos cuando rechazaron la de una persona de rango superior (situación 17, en que un director de investigación pide a su estudiante que cambie el método de estudio). Pero el menor número de enunciados se da en los rechazos dirigidos a una persona de estatus inferior (situación 14, en que un estudiante universitario pide prestada una tesis de un estudiante anterior que se guarda en el despacho de su profesor). La comparación de los promedios de los enunciados empleados no indicó ninguna diferencia significativa en ninguna de las sociedades.

Figura 219. Distribución de enunciados en las tres categorías de grado de (in)dirección del rechazo, según estatus social en el caso de español versus malayo

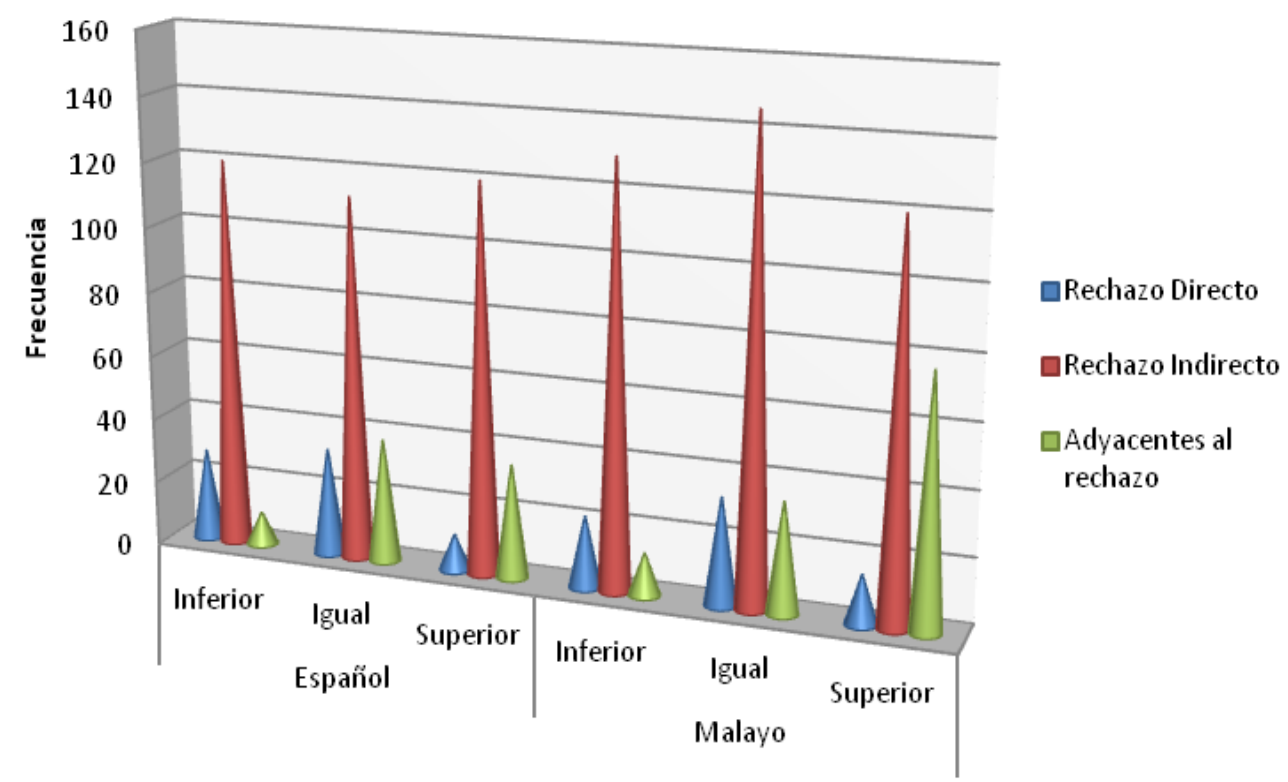


Tanto los sujetos españoles como los malayos utilizaron más estrategias directas cuando rechazaron la petición de una persona del mismo estatus, menos al rechazar la de una persona de posición social inferior y, todavía con menos frecuencia, cuando lo hicieron a las de una persona de rango superior.

Las estrategias indirectas, los españoles las emplearon más al rechazar la petición de una persona de nivel social inferior y superior, pero menos cuando rechazaron la de una persona del mismo estatus. Por el contrario, los malayos aplicaron más estrategias indirectas cuando rechazaron la petición de una persona del mismo estatus, menos al rechazar la de una persona de rango inferior y el menor número al rechazar la de una persona de posición social superior.

En el tercer caso, es decir, en el de las de adyacentes al rechazo", los informantes españoles tendieron a utilizar más estrategias de este tipo al rechazar la petición de una persona del mismo estatus, menos cuando rechazaron la de una persona de nivel social superior $y$, el menor número ellas, al rechazar la de una persona de estatus inferior. En cambio, los informantes malayos recurrieron más a estrategias de adyacentes al rechazo" cuando no aceptaron la petición de una persona de rango superior, menos con una persona del mismo estatus y, el menor número, al rechazar la de 
una persona de una posición social inferior. Los promedios de las formas aplicadas muestran una diferencia significativa en ambas culturas: $X^{2}=27.068 p=.000(p<.05)$ en el español, y $X^{2}=53.431$ $p=.000(p<.05)$, en el malayo.

Figura 220. Distribución de enunciados formulados como rechazos según estatus social en el caso de mayor versus menor

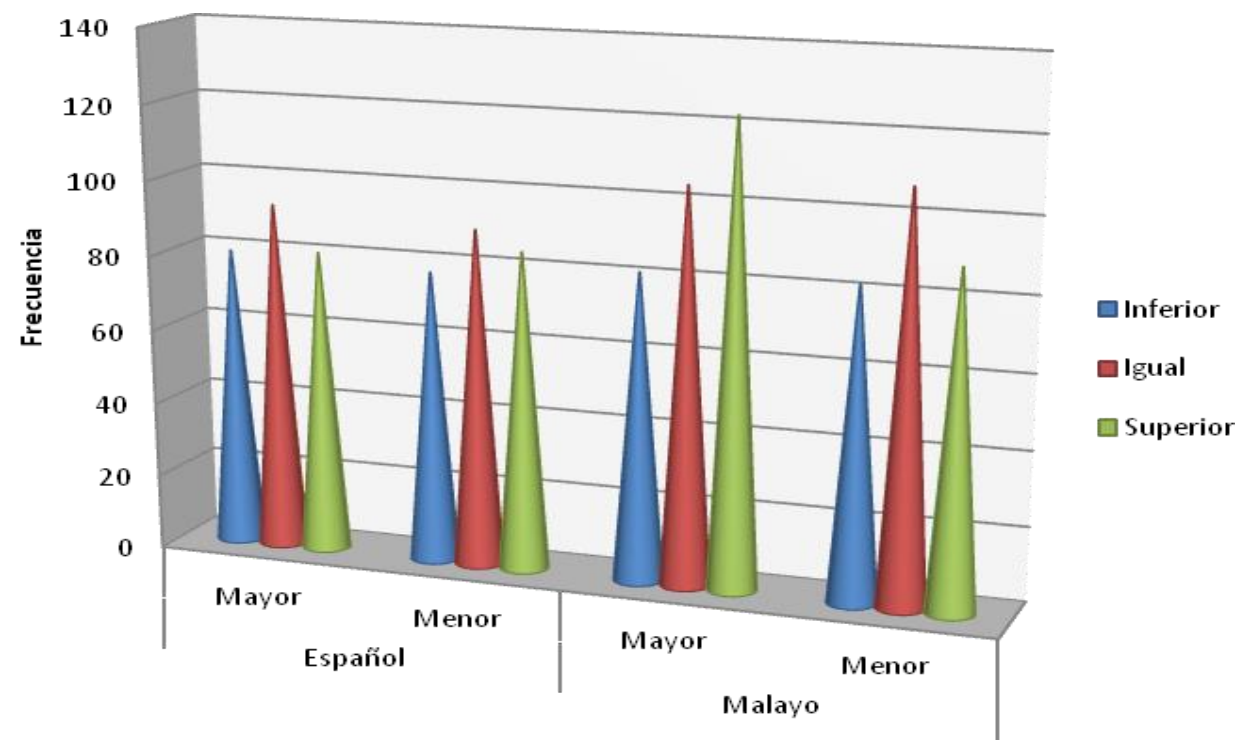

Desde la variable mayor versus menor, los datos obtenidos y proyectados en la Figura 220 demuestran que tanto los españoles de más edad como los más jóvenes utilizaron más enunciados cuando rechazaron la petición de una persona del mismo estatus, menos al rechazar la de una persona de estatus superior y el menor número de este tipo de estrategias, al hacer lo mismo con la de una persona de nivel social inferior. Por su parte, 
los sujetos mayores malayos aplicaron más estrategias en los rechazos dirigidos a una persona de rango superior, menos con una persona del mismo estatus y, todavía con menos frecuencia, al habla con una persona de una posición social inferior. En cambio, los participantes menores malayos aplicaron más estrategias al mostrar su rechazo con una persona del mismo estatus, menos con una persona de estatus superior, y un número de estrategias aún menor, al dirigirse a alguien de estatus inferior. La diferencia entre los participantes mayores y los menores con interlocutores de estatus social diferente no fue estadísticamente significativa ni en el corpus español ni en el malayo.

Figura 221. Distribución de enunciados producidos como rechazos según estatus social en el caso de varón versus mujer

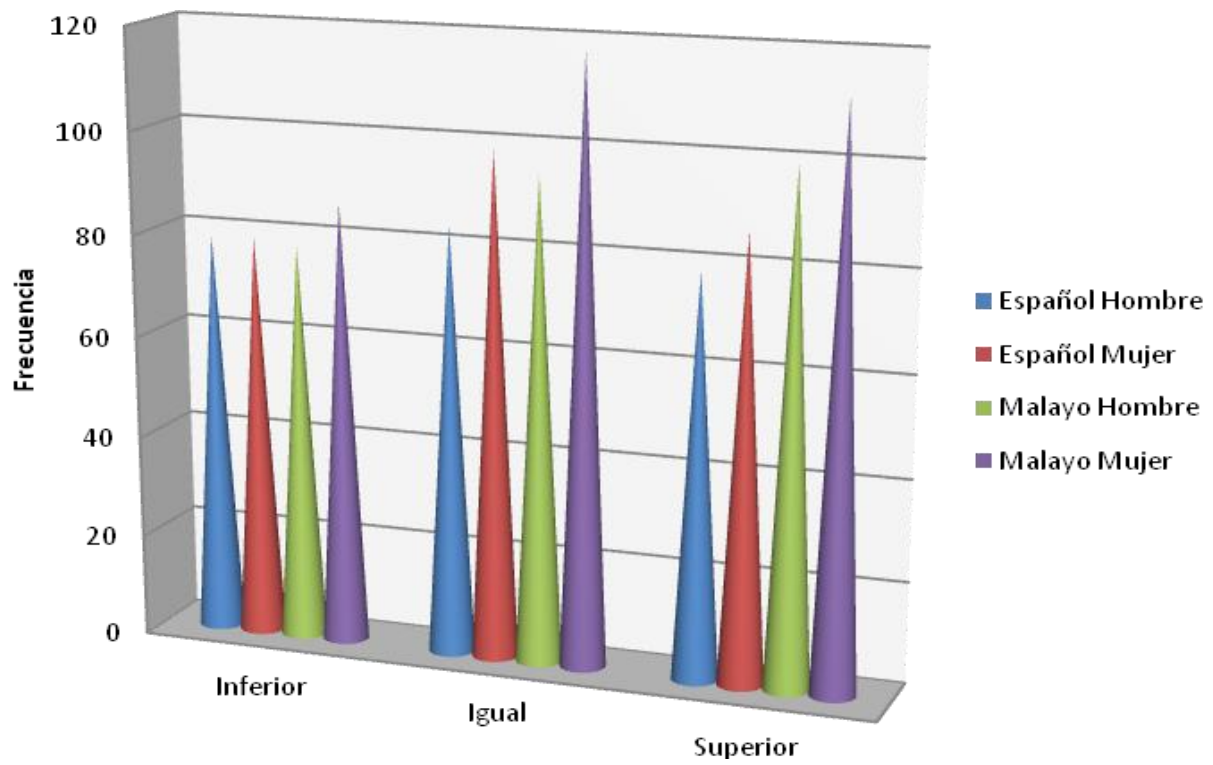


Cuando se compara la influencia del estatus social en las estrategias utilizadas por los participantes de ambos géneros para formular rechazos, lo que se ilustra en la Figura 221, resulta que tanto los varones como las mujeres del grupo español formularon un mayor número de enunciados en los rechazos dirigidos a una persona del mismo estatus, menos con una persona de estatus superior $\mathrm{y}$, el menor número, con una persona de nivel social inferior. Por otra parte, los varones del grupo malayo utilizaron más estrategias al rechazar la petición de una persona de rango superior, menos al hacerlo con la de una persona del mismo estatus y, el menor número se registró en las respuestas a una persona de una posición inferior. En cambio, las mujeres tendieron a aplicar más estrategias en sus rechazos al habla con una persona del mismo estatus, y menos con un interlocutor de estatus superior e inferior. Los promedios de las categorías aplicadas en ambos sexos no mostraron una diferencia significativa ni en el resultado de los españoles ni en el resultado de los malayos. 
Tabla 90. Distribución de estrategias utilizadas según estatus social en cada cultura

\begin{tabular}{|c|c|c|c|c|c|c|}
\hline \multirow{3}{*}{ Estrategias } & \multicolumn{6}{|c|}{ Situaciones de Estatus Social } \\
\hline & \multicolumn{3}{|c|}{ Español } & \multicolumn{3}{|c|}{ Malayo } \\
\hline & 14 & 11 & 17 & 14 & 11 & 17 \\
\hline Rechazo Directo & 28 & 33 & 11 & 22 & 33 & 15 \\
\hline No & - & 3 & - & - & - & - \\
\hline Buena voluntad/capacidad negativa & 28 & 30 & 11 & 22 & 33 & 15 \\
\hline Rechazo Indirecto & 120 & 112 & 120 & 130 & 146 & 120 \\
\hline Disculpa & 30 & 16 & 11 & 27 & 48 & 17 \\
\hline Deseo & 2 & 1 & 1 & - & - & 1 \\
\hline Excusa & 41 & 56 & 20 & 34 & 64 & 25 \\
\hline Declaración de alternativa & 25 & 18 & 10 & 37 & 10 & 5 \\
\hline $\begin{array}{l}\text { Conjunto de condiciones para la aceptación } \\
\text { pasada/futura }\end{array}$ & - & 4 & - & - & 4 & - \\
\hline Declaración de principios & 11 & 4 & 22 & 16 & - & 11 \\
\hline $\begin{array}{l}\text { Amenaza o declaración de consecuencias } \\
\text { negativas para el emisor }\end{array}$ & 1 & 1 & 6 & 7 & 6 & 3 \\
\hline Declaración de sentimiento negativo & 5 & 7 & 3 & 6 & 9 & 5 \\
\hline Petición de comprensión & 4 & 2 & 9 & 1 & 1 & 15 \\
\hline Garantía de satisfacción futura del interlocutor & - & - & 5 & - & 1 & - \\
\hline Autodefensa & - & - & 23 & 2 & 1 & 29 \\
\hline Repetición de parte de la petición & - & 3 & 1 & - & 2 & 4 \\
\hline Aplazamiento & 1 & - & 4 & - & - & 4 \\
\hline Evasivas & - & - & 5 & - & - & 1 \\
\hline Adyacentes al rechazo & 10 & 38 & 35 & 13 & 34 & 77 \\
\hline Declaración de opinión/sentimiento positivo & - & 1 & 9 & 4 & 4 & 5 \\
\hline Declaración de empatía & - & 1 & 4 & - & - & - \\
\hline Uso de muletillas & 1 & 11 & 6 & 5 & 4 & 1 \\
\hline Agradecimiento & 2 & 3 & 6 & - & 1 & 2 \\
\hline Fórmulas de tratamiento & 7 & 21 & 10 & 4 & 25 & 69 \\
\hline Saludos/despedidas corteses & - & 1 & - & - & - & - \\
\hline Total & 158 & 183 & 166 & 165 & 213 & 212 \\
\hline
\end{tabular}


Los datos presentados en la Tabla 90 indican las estrategias empleadas por los sujetos de cada grupo según el diferente estatus social en cada una de las tres situaciones. En la situación 14 el estatus superior corresponde al sujeto participante. En la 11, el estatus de hablante y oyente es el mismo, y en la situación 17, le corresponde al sujeto el estatus inferior. Como se refleja en la tabla correspondiente, los españoles tendieron a utilizar la "Excusa" en sus rechazos a una persona de estatus inferior y del mismo estatus, mientras que para rechazar la petición de una persona de rango superior prefirieron la estrategia de "Autodefensa". Por su parte, los malayos prefirieron la "Declaración de alternativa" con una persona de estatus inferior, la de "Excusa" al dirigirse a alguien del mismo estatus y, con los interlocutores de rango superior utilizaron más la de "Fórmulas de tratamiento". La "Excusa", la estrategia más común, fue utilizada más por los sujetos de ambos grupos cuando rechazaron la petición de una persona del mismo estatus, menos cuando rechazaron la de una persona de rango inferior $\mathrm{y}$, el menor número, al rechazar la de una de estatus superior.

Las estrategias menos aplicadas en el grupo español en los rechazos dirigidos a una persona de estatus inferior fueron las de "Amenaza o declaración de consecuencias negativas para el emisor", "Aplazamiento" y "Uso de muletillas" (solamente se emplea una vez 
cada una). En su rechazo a alguien del mismo estatus, los españoles recurrieron menos a las estrategias de "Deseo", "Amenaza o declaración de consecuencias negativas para el emisor", "Declaración de opinión/sentimiento positivo", "Declaración de empatía" y "Saludos/despedidas corteses" (con solo un ejemplo de cada una). Y con un interlocutor de rango superior, los españoles aplicaron menos las de "Deseo", y "Repetición de parte de la petición" (una vez cada una).

Por otro lado, las estrategias menos utilizadas en el grupo malayo al dirigirse a alguien de rango inferior fueron las de "Petición de comprensión" (una vez) y "Autodefensa" (2 veces). Con una persona del mismo estatus, utilizaron menos las estrategias de "Petición de comprensión", "Garantía de satisfacción futura del interlocutor", "Autodefensa" y "Agradecimiento" (una vez cada una). $\mathrm{Y}$, con alguien de una posición social superior, aplicaron menos "Deseo" y "Evasivas" (una vez cada una).

Las estrategias de las que no se han encontrado ejemplos de uso en los rechazos formulados por españoles a una persona de estatus inferior fueron "No", "Conjunto de condiciones para la aceptación pasada/futura", "Garantía de satisfacción futura del interlocutor", "Autodefensa", "Repetición de parte de la petición", "Evasivas", "Declaración de opinión/sentimiento positivo", 
"Declaración de empatía" y "Saludos/despedidas corteses". Las que no están presentes en los rechazos a una persona del mismo estatus fueron "Garantía de satisfacción futura del interlocutor", "Autodefensa", "Aplazamiento" y "Evasivas", y en los dirigidos a un interlocutor de rango superior no utilizaron las estrategias de "No", "Conjunto de condiciones para la aceptación pasada/futura" y "Saludos/despedidas corteses".

Por su parte, los malayos nunca aplicaron las estrategias de "Deseo", "Conjunto de condiciones para la aceptación pasada/futura", "Garantía de satisfacción futura del interlocutor", "Repetición de parte de la petición", "Aplazamiento", "Evasivas", "Declaración de empatía" y "Agradecimiento" en sus rechazos a una persona de estatus inferior. Con una persona del mismo estatus, los malayos nunca utilizaron "Deseo", "Declaración de principios", "Aplazamiento", "Evasivas" y "Declaración de empatía", mientras que en sus rechazos a una persona de posición social superior, no se encuentran las estrategias de "Conjunto de condiciones para la aceptación pasada/futura", "Garantía de satisfacción futura del interlocutor" y "Declaración de empatía". 


\subsubsection{Distancia social}

Figura 222. Distribución de estrategias utilizadas según distancia social en el caso de español versus malayo

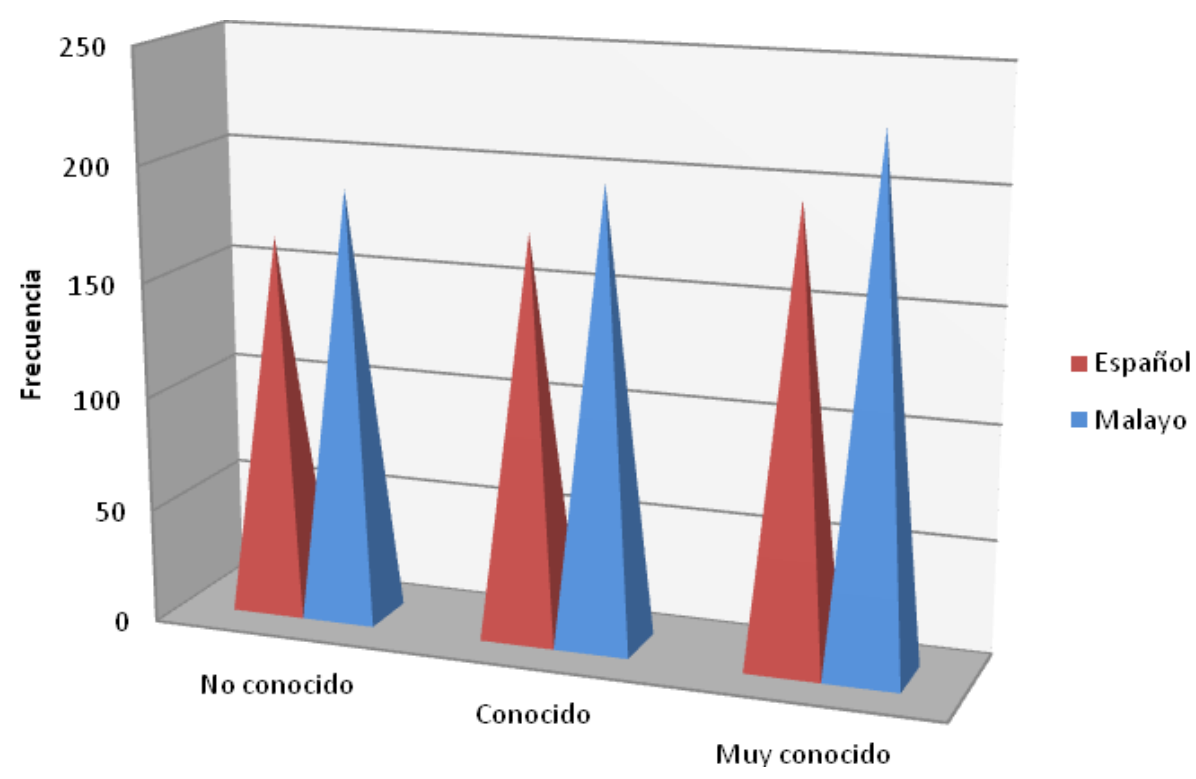

Tanto los españoles como los malayos tendieron a utilizar más estrategias en los rechazos dirigidos a una persona muy conocida (situación 8, en que un hermano menor pide a su hermano mayor que le acompañe a la fiesta de cumpleaños de su amigo), menos al hablar con un conocido (situación 5, en que un compañero de curso pide que se le preste portátil) y el menor número de estrategias al dirigirse a un extraño (situación 2 , en que un agente de una compañía de telefonía móvil quiere convencer al interlocutor de que se compre el nuevo paquete del servicio). Al comparar los promedios de las categorías aplicadas la diferencia no fue significativa. 
Figura 223. Distribución de enunciados en las tres categorías de rechazo, según grado de (in)dirección) y según distancia social, en el caso de español versus malayo

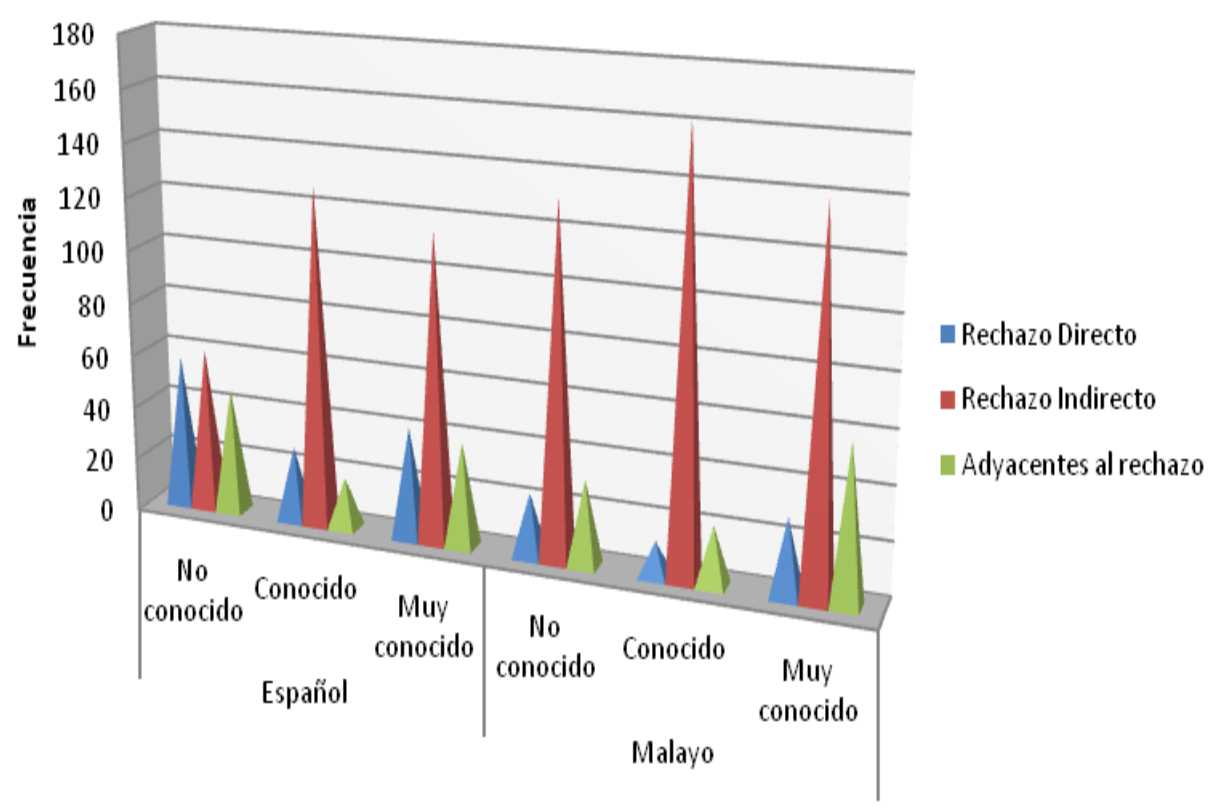

Los españoles tendieron a aplicar más estrategias directas al rechazar a un extraño, menos cuando rechazaron a una persona muy conocida y, el menor número, al rechazar a un conocido. Por el contrario, los malayos tendieron a utilizar más estrategias directas cuando expresaron rechazo con una persona muy conocida, menos con un extraño y aún menos con un conocido.

En la categoría de estrategias indirectas, tanto los españoles como los malayos las emplearon más al rechazar a un conocido, menos cuando rechazaron a una persona muy conocida y, el menor número, al rechazar a un extraño. Sin embargo, el número 
de enunciados con cada uno de los tipos de estratega empleada, varió de un grupo a otro.

En el análisis de las estrategias de adyacentes al rechazo, se encuentra que, los españoles utilizaron más estrategias cuando rechazaron la propuesta de un extraño, menos con una persona muy conocida y, aún en un menor número de ocasiones, al dirigirse a un conocido. Por el contrario, los malayos aplicaron más estrategias de adyacentes al rechazo con persona muy conocida, menos con un extraño y, el menor número, con un conocido. La diferencia entre los sujetos españoles y los malayos respecto al uso de las tres formas de petición con distancia social diferente fue estadísticamente significativa ni en ambos corpus: $X^{2}=46.375 p=.000(p<.05)$, en el español, y $X^{2}=24.156 p=.000(p<.05)$, en el malayo.

Figura 224. Distribución de enunciados producidos como rechazo, según distancia social en el caso de mayor versus menor

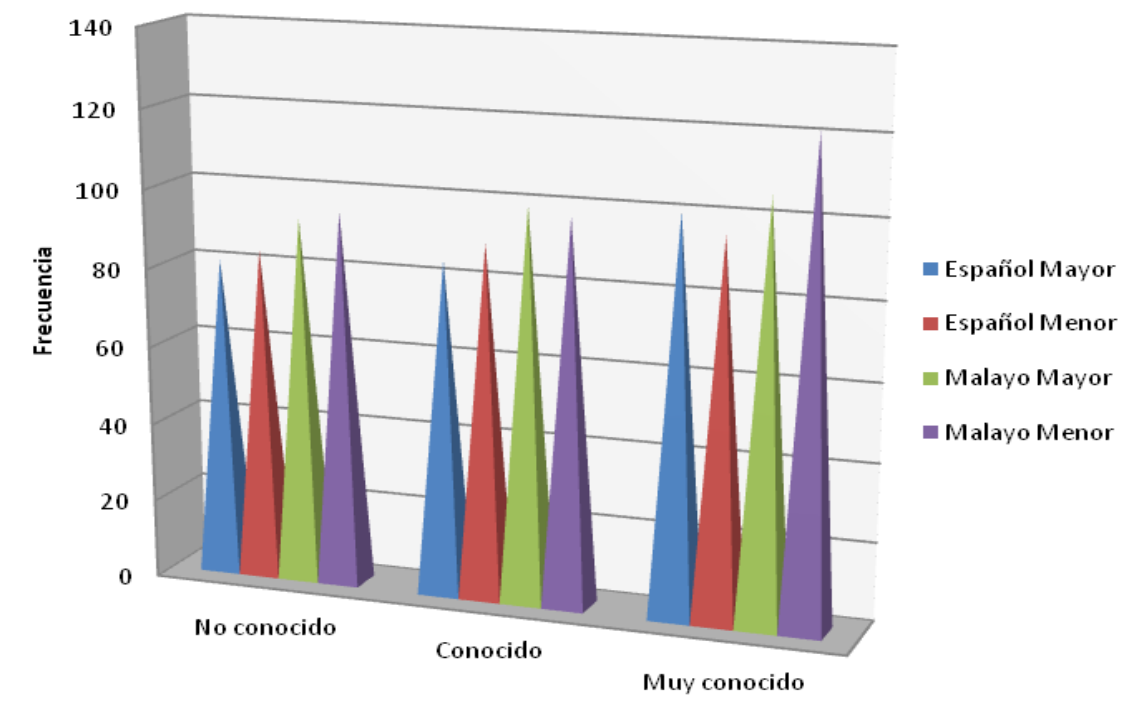


Los datos del contraste "mayor versus menor" demuestran que tanto los hablantes mayores españoles como los menores emplearon más estrategias en sus rechazos dirigidos a una persona muy conocida, menos al habla con un conocido y el menor número cuando rechazaron la propuesta de un extraño. Los sujetos malayos de más y menos edad se expresaron de forma similar a los españoles. Sin embargo, el número de enunciados producidos por los sujetos de cada grupo fue diferente. Entre los promedios de las estrategias utilizadas, la diferencia no fue significativa en ninguno de los subgrupos de edad de ambos países.

Figura 225. Distribución de enunciados producidos como rechazos, según distancia social en el caso de varón versus mujer

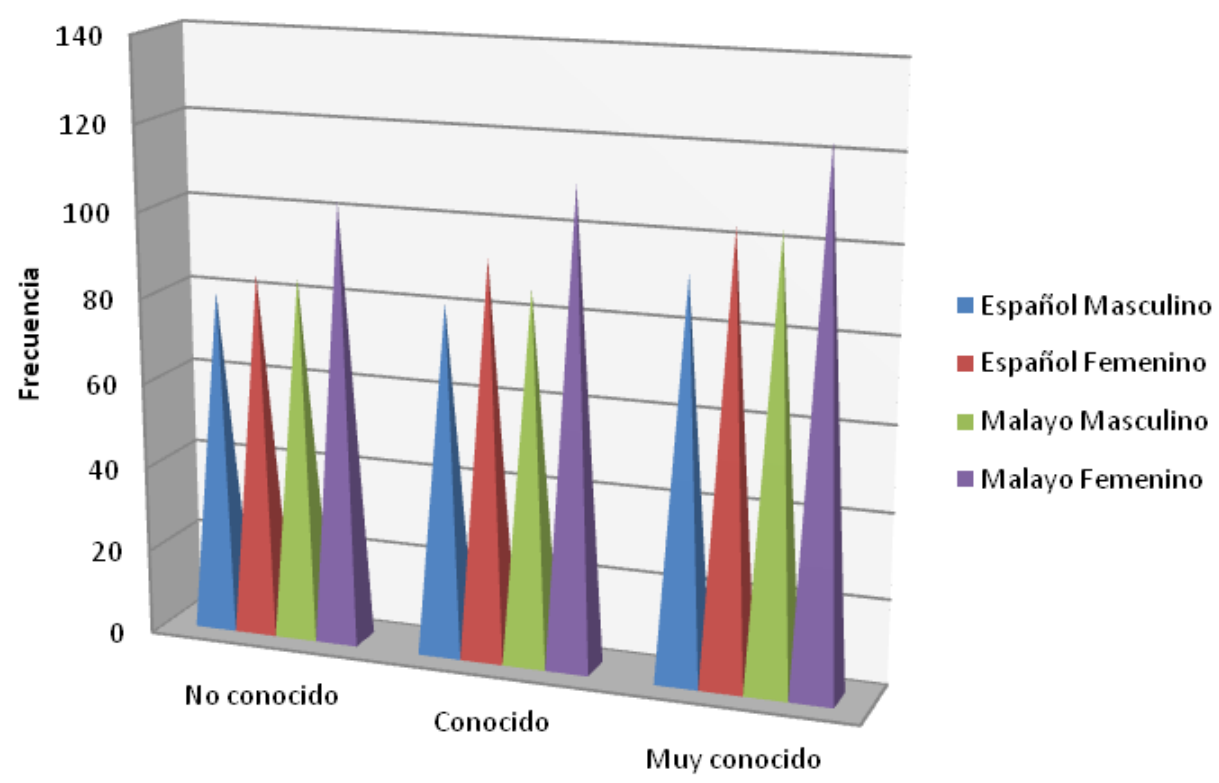


Como se ilustra en la Figura 225, aunque la frecuencia con la que los sujetos de cada subgrupo de género utilizaron los enunciados para producir rechazos en cada contexto fue diferente, todos los subgrupos mostraron un patrón similar. Es decir, utilizaron más estrategias en los rechazos dirigidos a un interlocutor muy conocido, menos con un conocido $\mathrm{y}$, el menor número, cuando rechazaron la propuesta de un extraño. Al comparar los promedios de las estrategias utilizadas, la diferencia no fue significativa en ninguno de los subgrupos de sexo de ambos países. 
Tabla 91. Distribución de estrategias utilizadas según estatus social en cada cultura

\begin{tabular}{|c|c|c|c|c|c|c|}
\hline \multirow{3}{*}{ Estrategias } & \multicolumn{6}{|c|}{ Situaciones de Distancia Social } \\
\hline & \multicolumn{3}{|c|}{ Español } & \multicolumn{3}{|c|}{ Malayo } \\
\hline & 2 & 5 & 8 & 2 & 5 & 8 \\
\hline Rechazo Directo & 57 & 28 & 42 & 24 & 13 & 29 \\
\hline No & 5 & 1 & 4 & - & - & - \\
\hline Buena voluntad/capacidad negativa & 52 & 27 & 38 & 24 & 13 & 29 \\
\hline Rechazo Indirecto & 61 & 128 & 116 & 132 & 163 & 140 \\
\hline Disculpa & 26 & 42 & 18 & 60 & 62 & 35 \\
\hline Deseo & 1 & - & 3 & - & - & 1 \\
\hline Excusa & 19 & 65 & 49 & 52 & 75 & 65 \\
\hline Declaración de alternativa & 3 & 11 & 15 & 2 & 8 & 18 \\
\hline $\begin{array}{l}\text { Conjunto de condiciones para la aceptación } \\
\text { pasada/futura }\end{array}$ & 1 & 3 & 2 & 6 & 11 & 5 \\
\hline Declaración de principios & - & 2 & 1 & - & - & - \\
\hline $\begin{array}{l}\text { Amenaza o declaración de consecuencias } \\
\text { negativas para el emisor }\end{array}$ & 2 & 1 & 3 & - & 1 & 3 \\
\hline Declaración de sentimiento negativo & 5 & 3 & 9 & - & - & - \\
\hline Petición de comprensión & - & - & 12 & 2 & 1 & 1 \\
\hline Garantía de satisfacción futura del interlocutor & 2 & 1 & 2 & 5 & 1 & 6 \\
\hline Autodefensa & 1 & - & - & 3 & 3 & 4 \\
\hline Repetición de parte de la petición & - & - & 2 & - & 1 & 2 \\
\hline Aplazamiento & 1 & - & - & 2 & - & - \\
\hline Evasivas & - & - & - & - & - & - \\
\hline Adyacentes al rechazo & 47 & 19 & 39 & 32 & 22 & 59 \\
\hline Declaración de opinión/sentimiento positivo & 3 & 2 & 6 & - & 2 & 4 \\
\hline Declaración de empatía & - & 3 & - & - & 1 & - \\
\hline Uso de muletillas & 4 & 3 & 9 & 1 & 4 & 2 \\
\hline Agradecimiento & 32 & - & 6 & 10 & - & - \\
\hline Fórmulas de tratamiento & 2 & 10 & 18 & 21 & 15 & 53 \\
\hline Saludos/despedidas corteses & 6 & 1 & - & - & - & - \\
\hline Total & 165 & 175 & 197 & 188 & 198 & 228 \\
\hline $2=$ No conocido & $8=N$ & ly con & ido & & & \\
\hline
\end{tabular}


La Tabla 91 presenta los datos obtenidos en relación con las estrategias empleadas por los sujetos de cada grupo en las tres situaciones en las que se considera la distancia social. En la situación 2 el interlocutor es un extraño, en la 5 se trata de una persona conocida y en la 8 , el sujeto se dirige a una persona muy conocida. Los españoles tendieron a utilizar más las estrategias de "Buena voluntad/capacidad negativa" en sus rechazos a un extraño y la de "Excusa" al hablar con una persona conocida y muy conocida. Por su parte, los malayos prefirieron la estrategia de "Disculpa" para rechazar la propuesta de un extraño, e igual que en el caso de los españoles, los malayos tendieron a aplicar la de "Excusa" al dirigirse a un conocido y una persona muy conocida. En este caso, la estrategia de "Excusa" también fue la más común en ambos grupos, español y malayo, y fue más utilizada con un interlocutor conocido, menos con uno muy conocido y, el menor número de casos se dio al hablar con un extraño.

Las estrategias menos utilizadas en el grupo español al rechazar la propuesta de un extraño fueron las de "Deseo", "Conjunto de condiciones para la aceptación pasada/futura", "Autodefensa" y "Aplazamiento" (aparecen una vez cada una). Cuando dirigieron sus expresiones de rechazo a conocidos los españoles aplicaron menos las de "No", "Amenaza o declaración de consecuencias negativas para el emisor", "Garantía de satisfacción 
futura del interlocutor" y "Saludos/despedidas corteses" (se encontró un ejemplo de cada una). $Y$ en su rechazo a una persona muy conocida, los españoles utilizaron menos el "Conjunto de condiciones para la aceptación pasada/futura", "Declaración de principios", "Garantía de satisfacción futura del interlocutor" y "Repetición de parte de la petición" (una vez cada una).

Por su parte, los malayos emplearon menos las estrategias de "Uso de muletillas" (una vez), "Declaración de alternativa", "Petición de comprensión" y "Aplazamiento" (dos veces cada una) cuando rechazaron la propuesta de un extraño. Al rechazar la petición de un conocido, los malayos aplicaron menos las de "Amenaza o declaración de consecuencias negativas para el emisor", "Petición de comprensión", "Garantía de satisfacción futura del interlocutor", "Repetición de parte de la petición" y "Declaración de empatía". Cuando rechazaron la petición de una persona muy conocida los malayos utilizaron menos "Deseo", "Petición de comprensión", "Repetición de parte de la petición" y "Uso de muletillas" (aparecen una vez cada una).

Las estrategias que nunca se utilizaron en los datos españoles para rechazar la propuesta de un extraño fueron las de "Declaración de principios", "Petición de comprensión", "Repetición de parte de la petición" y "Evasivas". En sus rechazos a conocidos los 
españoles nunca aplicaron las de "Deseo", "Petición de comprensión", "Repetición de parte de la petición", "Aplazamiento", "Evasivas" y "Agradecimiento", mientras que al dirigirse a una persona muy conocida, los españoles nunca utilizaron las estrategias de "Autodefensa", "Aplazamiento", "Evasivas", "Declaración de empatía", y "Saludos/despedidas corteses".

En los rechazos a extraños de los datos malayos no se encontró ningún ejemplo de uso de las siguientes estrategias: "Deseo", "Declaración de principios", "Amenaza o declaración de consecuencias negativas para el emisor", "Declaración de sentimiento negativo", "Repetición de parte de la petición", "Evasivas", "Declaración de opinión/sentimiento positivo" y "Declaración de empatía". Al dirigirse a un conocido los malayos nunca utilizaron las estrategias de "Deseo", "Declaración de principios", "Declaración de sentimiento negativo", "Aplazamiento", "Evasivas" y "Agradecimiento". Y en las respuestas a una persona muy conocida, no se encontraron las estrategias de "Declaración de principios", "Declaración de sentimiento negativo", "Aplazamiento", "Evasivas", "Declaración de empatía" y "Agradecimiento". 


\subsection{Análisis del contenido}

Esta sección presenta las diferencias encontradas al comparar el contenido de los enunciados formulados como rechazos entre los dos grupos estudiados, español y malayo. En primer lugar, y debido a su alta frecuencia de uso, se analiza pormenorizadamente la estrategia de "Excusa". A continuación, en el apartado de la "Discusión general", se examinan las diferencias entre los grupos comparados en el empleo de otras estrategias.

\subsubsection{Resultados y análisis total del contenido de los rechazos analizados}

Al analizar los rechazos recogidos en el cuestionario, se observó que, la mayoría de ellos, contaba con la presencia de una "Excusa". Esta estrategia ha sido, por tanto, el eje alrededor de cual ha girado la elaboración de este apartado que, en primer lugar, expone los resultados obtenidos de manera general en el análisis del empleo de excusas en todas las situaciones planteadas, para, posteriormente centrar el análisis en cada una de esas situaciones. 


\subsubsection{Análisis general del empleo de la "Excusa"}

La "Excusa" fue la estrategia más comúnmente utilizada para rechazar una petición. Los malayos utilizaron más excusas que los españoles en casi todas las situaciones, excepto en la situación 14, contexto este en el que fueron los españoles los que más se sirvieron de dicha estrategia. En algunas situaciones, sin embargo, se recogieron menos enunciados formulados como "Excusa", que en las otras. La Figura 226, que se presenta a continuación, recoge los datos relativos el empleo de la "Excusa" en cada grupo al rechazar.

Figura 226. Distribución del número de enunciados formulados como "Excusa" en las respuestas de los españoles y los malayos en las seis situaciones de rechazo

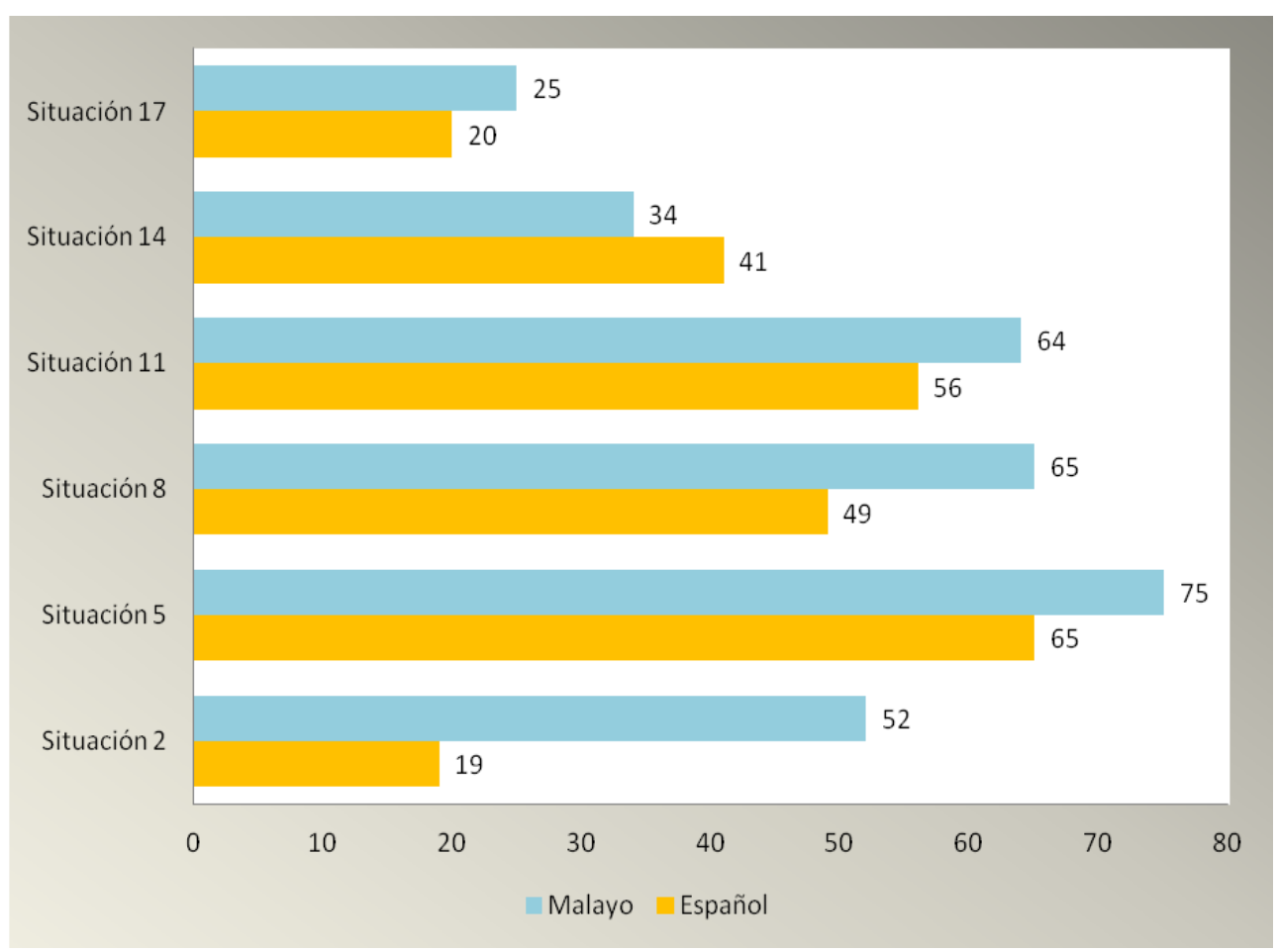


El uso de la "Excusa" coincide con los resultados obtenidos por Bardovi-Harlig y Hartford $(1991,1992)$ en su estudio de rechazos formulados por nativos y no nativos ingleses recogidos en sesiones de asesoramiento académico. Estos investigadores hallaron que la "Excusa" era la estrategia más frecuentemente utilizada para el rechazo, tanto por los estudiantes nativos como por los no nativos.

En nuestro estudio, malayos y españoles utilizaron excusas como estrategias de sus rechazos, pero el grado de precisión fue diferente en cada una de ellas. Las excusas españolas fueron más específicas que las malayas. Por ejemplo, en la situación en la que un hermano menor pide a su hermano mayor que le acompañe a la fiesta de cumpleaños de su amigo, un español respondió, "que no conozco a nadie y me voy a aburrir, además no pinto nada allí", otro dijo "mañana tengo examen de mates y quiero hacer muchos ejercicios para que me salga bien", y las excusas de otros fueron "no me llevo bien con tu amigo y no quiero que te sientes incomodo", "no tengo tanta relación con tu amigo y me parece que no pinto nada en la fiesta" o "tu amigo no me ha invitado a mí y creo que está de más que yo aparezca por allí".

En contraste con las excusas españolas, las utilizadas por los malayos fueron menos específicas. Por ejemplo, la mayor parte de los sujetos malayos utilizaron "tengo trabajo", "ya he quedado", 
"estoy ocupado", "tengo cosas que hacer", "no me encuentro bien", o "tengo otro plan" como excusas para rechazar la petición del hermano menor para acompañarle a la fiesta de su amigo. Estas respuestas reflejan probablemente las diferencias culturales entre los españoles y los malayos en sus percepciones sobre qué excusas parecen más convincentes.

Del mismo modo, la mayoría de los participantes del grupo malayo dio excusas vagas como "lo necesito", "tengo trabajo que hacer", etc. al rechazar la petición de un compañero de curso que quiere que le preste el portátil. Los sujetos del grupo español, por su parte, tendieron a dar más detalles en sus excusas, por ejemplo, "no tengo el cable de la batería, está en casa de mis padres", "tengo miedo de que entres en una página web y te entre un virus", "lo comparto con mi hermano y él lo está utilizando estos días" o "he de entregar un informe de prácticas mañana mismo y estoy un poco pillado de tiempo". Este contraste puede tener su origen en las diferencias características entre las culturas occidentales y orientales. En las culturas occidentales, la mayoría de la información necesaria se menciona explícitamente. Una cultura oriental como la malaya, en cambio, tiende a dar poca información y a una vaga expresión porque creen que los detalles de sus rechazos son cosas personales y no tienen por qué contárselas a otros (Triandis, 1995). 
Los españoles tendieron a ser más directos en sus excusas y se refirieron a sus ocupaciones más prioritarias como motivos del rechazo, mientras que los malayos tendieron a ser menos directos y a recurrir a otros motivos, además de sus propias prioridades, al rechazar. Por ejemplo, los malayos utilizaron muy comúnmente motivos relacionados con otras personas en sus excusas, como "tengo que hablar con mi esposa primero", "tengo cita con un cliente", "tengo que ver a mi jefe", o "ya he prometido a mi compañero que quedaría con él", sin tener en cuenta la situación. Los españoles, por su parte, dieron excusas referidas a sus ocupaciones más prioritarias como "tengo que estudiar", sin tener en cuenta la situación. Tales diferencias existen por diferencias culturales. La cultura malaya es considerada una cultura colectivista, en la que el interés del grupo es más importante que el interés individual y la armonía entre los miembros del grupo es de suma importancia (Badli Esham Ahmad, 2010). En contraste con ello, la cultura occidental ( $y$, por ende, la española) es considerada una cultura individualista en la que el interés individual es más importante que el interés del grupo.

In individualistic cultures, the self is autonomous and separate from the group, while in collectivistic cultures, people are attached to fewer groups, but the attachment is highly defining of one's identity. (Triandis, Brislin, y Hui, 1988, p. 273) 
Como consecuencia de esta diferencia cultural, los malayos utilizaron excusas incontestables (p.ej. referidas al jefe, a un compromiso) como base de sus explicaciones. Por ejemplo, utilizaron asuntos laborales que consideran más allá de su control como excusa. Los españoles también utilizaron dichos motivos, pero menos a menudo que los malayos.

Las respuestas malayas incluyeron un porcentaje más alto de excusas de tipo familiar en algunas situaciones. En la situación 2, en la que un agente de una compañía de telefonía móvil va a la casa del sujeto e intenta convencerle de que se compre el nuevo paquete del servicio, 6 de las 52 excusas malayas (12\%) contenían motivos relacionados con la familia, como "tengo que hablar con mi esposa primero", "tengo que recoger a mis hijos del colegio" y "mi familia ya lo tiene". En cambio, solo una de las 19 excusas españolas (5\%) presentaba este tipo de motivos. En la situación 11, en la que un colega le pide a otro que se vaya a pescar con él a un río, 10 de las 64 excusas malayas (16\%) incluía asuntos familiares, mientras que esto ocurrió solo en una de las 56 (2\%) excusas españolas. Sin embargo, en la situación 5, cuando un estudiante universitario le pide a su compañero de curso que le preste su portátil porque ha entrado un virus en el suyo, 6 de las 65 excusas españolas (9\%) se refería a asuntos familiares, mientras que ninguna de las 75 excusas malayas se basaba en dicho motivo. 
Esta inclinación a utilizar excusas relacionadas con la familia podría deberse también a distintas diferencias culturales. Los malayos dieron a las circunstancias relacionadas con la familia la mayor prioridad, y la importancia en sus excusas refleja el valor de la familia en esta cultura. La lealtad y el deber a la familia son mayores que cualquier otra responsabilidad relacionada con lo social o lo comercial, porque la imagen del individuo en Malasia viene determinada por su vinculación con los miembros del grupo familiar, pueblo y tribu, y no por su capacidad individual. Los españoles, por su parte, se mostraron más preocupados por sus propios intereses individuales que por los del grupo.

\section{A) Mayor frente a menor}

Al comparar los enunciados producidos como excusa de un rechazo por los hablantes mayores y menores, los sujetos mayores españoles utilizaron más excusas que los menores en tres situaciones: 2,11 y 17. En las otras tres situaciones, 5,8 y 14 , los participantes menores españoles utilizaron más que los mayores. Por otra parte, los hablantes del grupo malayo de mayores también aplicaron más excusas que los del grupo de menores en las situaciones 2,11 y 14 , mientras que en las otras tres situaciones, 5,8 y 17, ocurrió lo contrario. Los datos numéricos relativos al empleo de la estrategia de 
"Excusa" obtenidos en cada subgrupo de edad en ambas culturas se muestran en la Figura 227.

Figura 227. Distribución del número de enunciados producidos como "Excusa" por los participantes mayores y menores en ambas culturas en las seis situaciones de rechazo

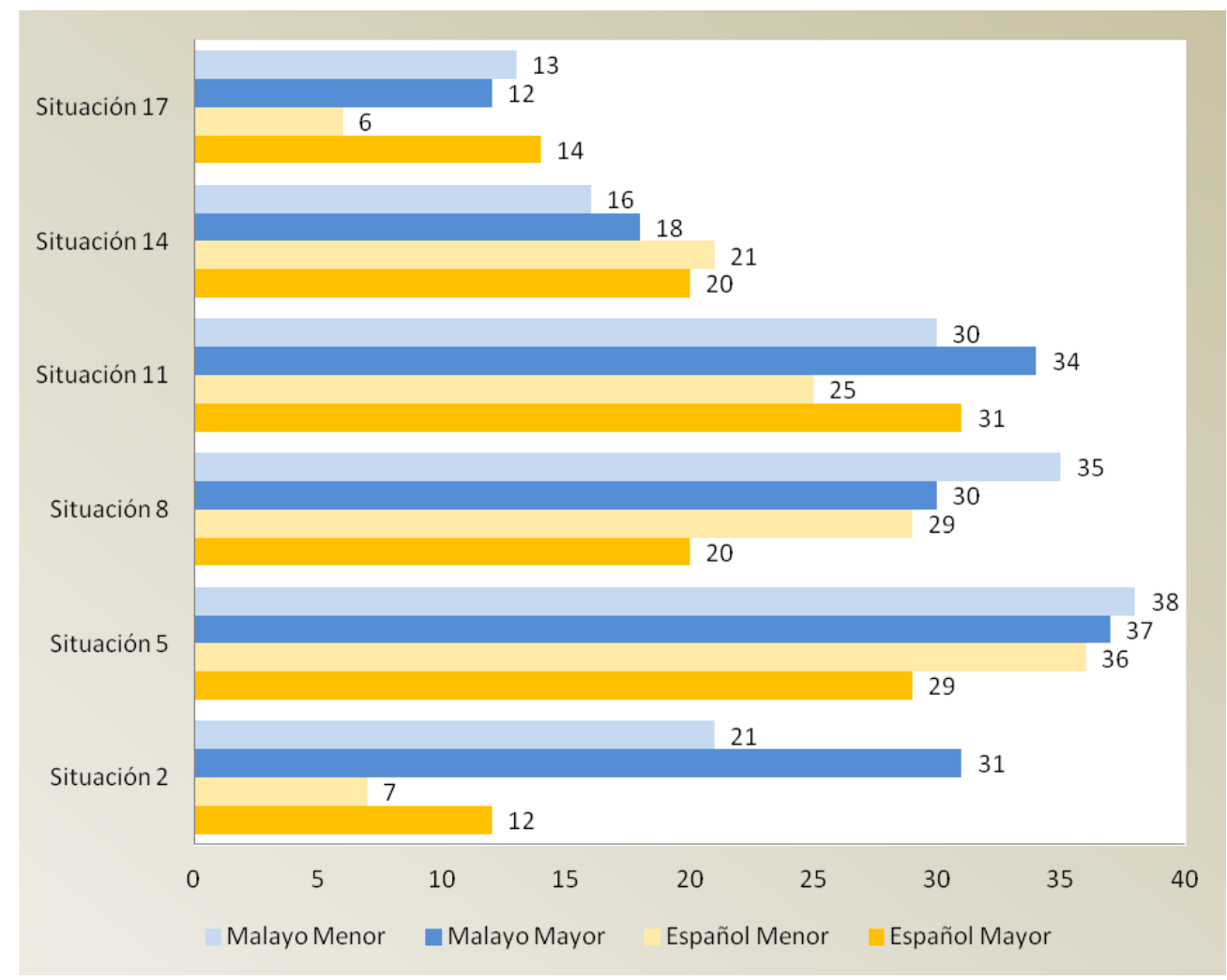

Al rechazar, los participantes españoles de más edad generalmente dieron excusas más vagas, es decir, más generales que los menores, como "lo necesito" o "tengo trabajo que hacer". En cambio, los menores tendieron a explicar con más detalle al dar excusas en la misma situación, como "lo comparto con mi hermano y él lo está utilizando estos días para un trabajo de clase" o "tengo miedo de que entres en una página web y te entre un virus". 
No obstante, en el grupo malayo, no había tanta diferencia entre los dos subgrupos, mayores y menores, al presentar excusas al rechazar. En algunas situaciones se encuentra que los mayores dieron motivos más vagos que los menores y, al revés, en las otras dieron detalles más específicos que los menores. Por ejemplo, en la situación 11, en la que un colega le pide a otro que se vaya a pescar con él a un río, los mayores dieron motivos más vagos, como "estoy cansado" o "me da pereza", mientras que los menores tendieron a decir "mi madre me ha invitado a una cena" o "no tengo transporte, además mi madre me ha pedido que vaya a su casa". Pero, en la situación 8, en la que un hermano menor le pide a su hermano mayor que le acompañe a la fiesta de cumpleaños de un amigo, los mayores dieron detalles más específicos, como "tengo una cita muy importante con un cliente" o "tengo que ir a la oficina para hablar de un asunto con mi jefe", en comparación con los menores, que fueron más generales en sus excusas, como "tengo trabajo" o "tengo cosas que hacer". 


\section{B) Varón frente a mujer}

Al analizar las diferencias teniendo en cuenta el sexo de los sujetos participantes, las mujeres del grupo español aplicaron más excusas que los varones en casi todas las situaciones excepto en la número 14, para la que presentaron más los varones. Por su parte, las mujeres malayas aplicaron más excusas que los varones en las seis situaciones. La Figura 228, que presentamos a continuación, expone la distribución del número de enunciados formulados como "Excusa" por los hablantes de los dos sexos en cada grupo.

Figura 228. Distribución del número de enunciados producidos como "Excusa" por los varones y las mujeres en ambas culturas en las seis situaciones de rechazo

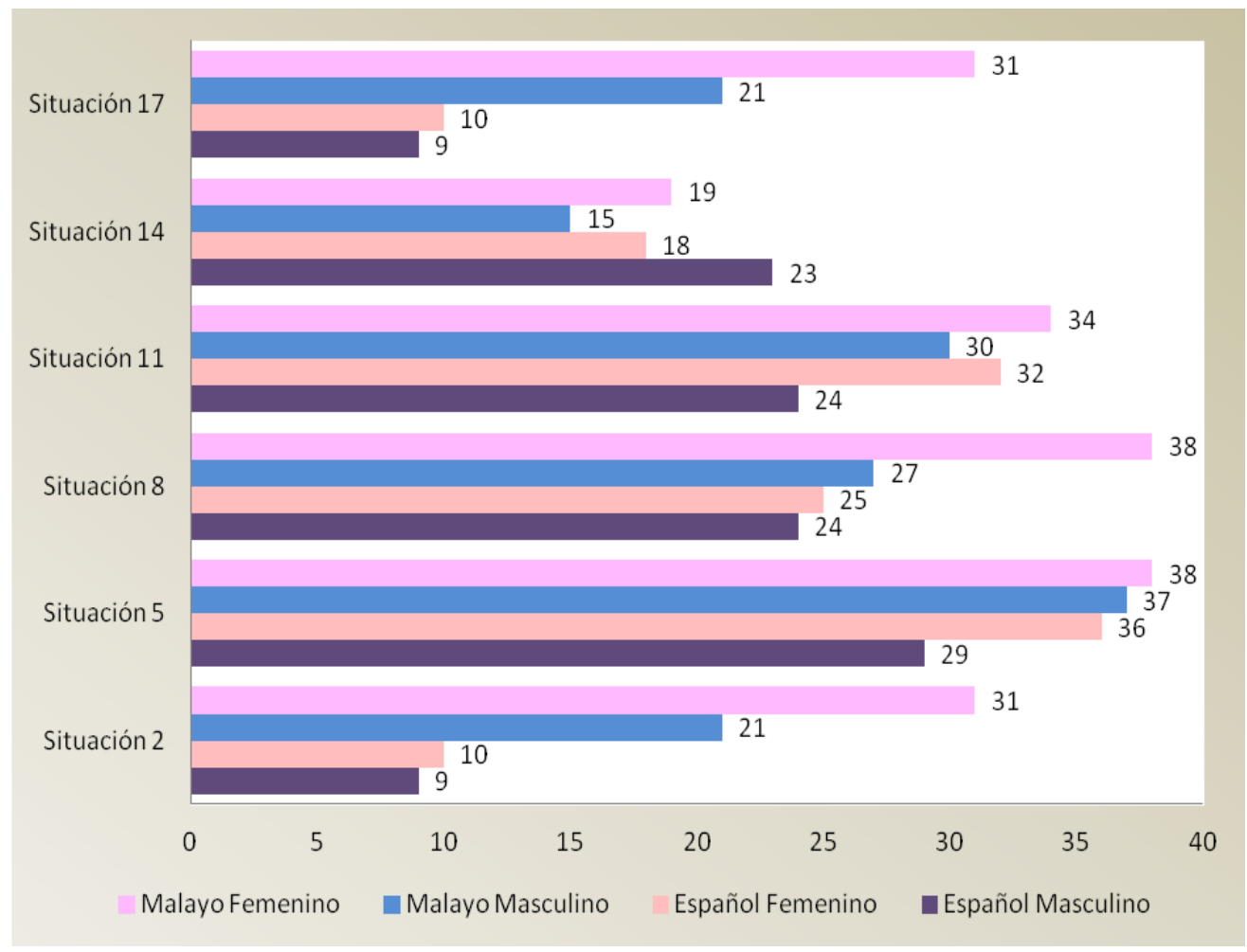


Al ofrecer excusas, los varones dieron motivos más vagos que las mujeres en los rechazos de los dos grupos, español y malayo. Esto es, los varones tendieron a dar explicaciones bastante generales, como "lo necesito" o "tengo trabajo que hacer", mientras que las mujeres aportaron detalles más específicos en sus excusas en la misma situación, como "me parece que es una cosa muy personal y me da cosa que queda pueda estropearse, además el mío tampoco funciona demasiado bien" o "no tengo el cable de la batería, está en la casa de mis padres".

\subsubsection{Análisis situacional del empleo de la "Excusa"}

En las líneas que siguen, se van a detallar los resultados del análisis del contenido de las 6 situaciones de rechazo que componen el cuestionario. Como se ha dicho más arriba el análisis está centrado en el empleo de "Excusas" ya que fue la estrategia más recurrente en la cumplimentación del cuestionario, en los contextos propuestos para la generación de actos de habla de rechazo $(2,5,8,11,14$, 17). 


\subsubsection{Situación 2}

En la situación 2, un agente de una compañía de telefonía móvil (versión española) o de seguros (versión malaya) va a casa del sujeto e intenta convencerle al sujeto para que se compre el nuevo paquete del servicio. En este escenario la distancia social entre los interlocutores es grande, y la familiaridad es baja (son desconocidos). 
Figura 229. Distribución de los tipos de "Excusa" utilizados en el grupo español y el grupo malayo en la situación 2
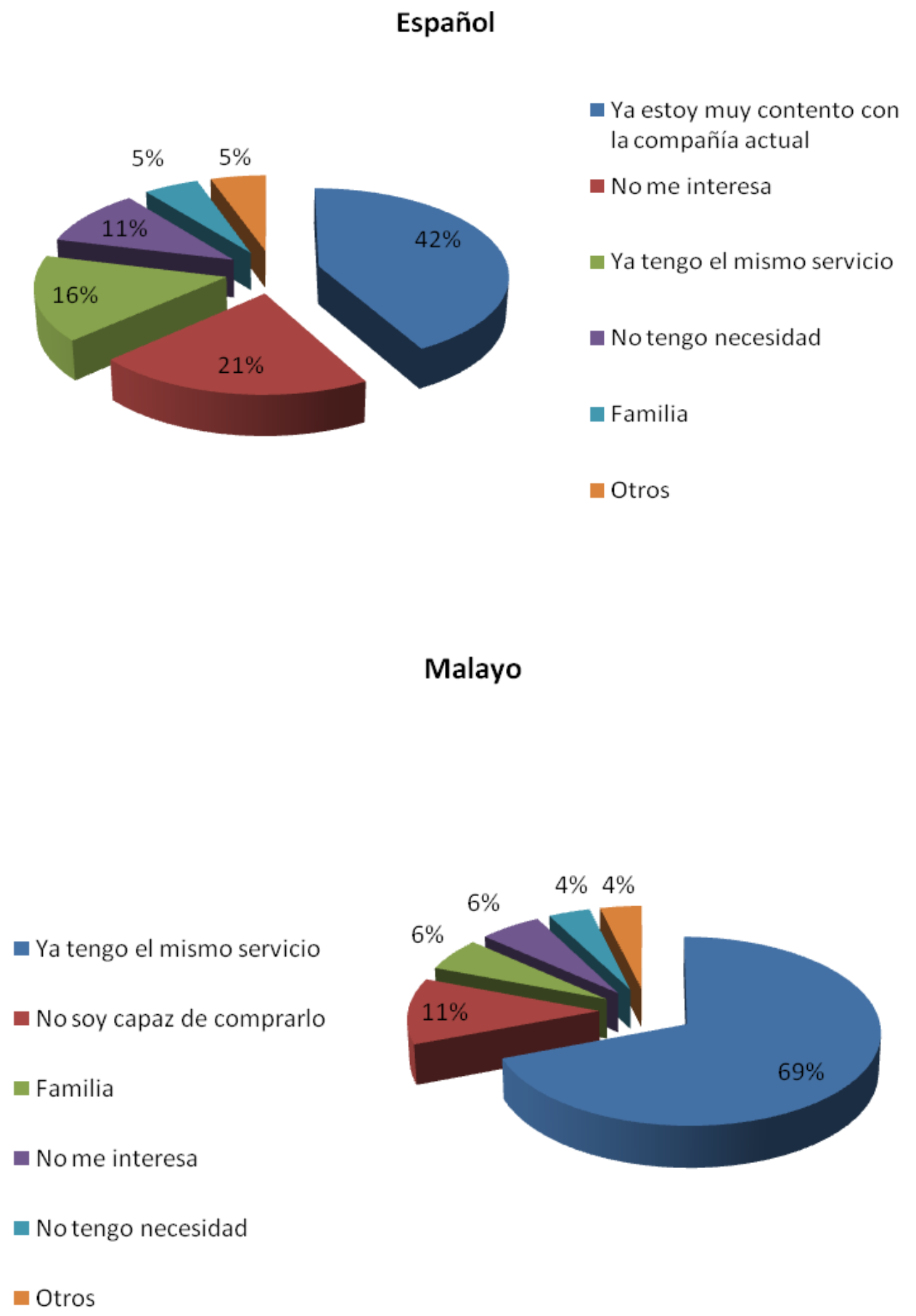
Según la Figura 229 que acabamos de exponer, hubo cinco motivos aportados en las excusas utilizadas en los rechazos de ambos grupos, español y malayo. Los españoles tendieron a decir "ya estoy contento con la compañía actual" (42\%), motivo que no apareció en las excusas de los malayos, que prefirieron otras como "ya tengo el mismo servicio" (69\%). Por otro lado, la excusa de "no me lo puedo permitir" no está presente en los datos españoles, pero sí es utilizada por el $11 \%$ de los sujetos malayos.

En esta situación los varones mayores, las mujeres mayores y los varones menores del grupo español se inclinaron más por la excusa de "ya estoy muy contenta con la compañía actual", mientras que las mujeres menores tendieron a dar como excusa la de "ya tengo el mismo servicio". Lo interesante es que el motivo familiar solo fue utilizado por un varón mayor cuando dijo "mi mujer trabaja en una compañía de la competencia y tengo condiciones especiales" como excusa para rechazar el servicio ofrecido por el agente de la compañía de telefonía móvil. Otro hecho que conviene destacar es que la excusa de "ya tengo el mismo servicio" solo fue utilizada por los sujetos menores, mientras que solamente los mayores recurrieron a la de "no tengo necesidad".

Por su parte, en el grupo malayo, todos los subgrupos tendieron a decir "ya tengo el mismo servicio" como excusa en sus 
rechazos. Cabe señalar, que en este grupo, el motivo familiar solo se encontró en los datos de los varones menores y las mujeres mayores. Por ejemplo, un varón del grupo de menos edad dijo "necesito hablar con mi mujer primero", mientras que dos mujeres mayores dijeron "tengo que ir al colegio para buscar a mi hijo" y "tengo de prisa, necesito recoger a mi niño ahora". Por el contrario, la excusa de "no me interesa" solo existe en los datos de los varones mayores y mujeres menores, mientras que la de "no tengo necesidad" solo fue usada por las mujeres menores.

En cuanto a la estructura de los rechazos, se aprecia que, en el grupo español, todos los subgrupos comenzaron sus rechazos mayoritariamente diciendo "Lo siento", y continuaron con enunciados en los que empleaban la estrategia de "Buena voluntad/capacidad negativa", como en "Lo siento, no me interesa", excepto las mujeres del grupo de menor edad, que tendieron a comenzar sus rechazos diciendo "Gracias", y añadiendo después también la estrategia de "Buena voluntad/capacidad negativa", como en "Gracias, pero no estoy interesada". Por su parte, todos los subgrupos del grupo malayo, dijeron mayoritariamente "Lo siento" al comenzar sus rechazos, expresión que fue seguida de las "Excusas". Por ejemplo, un varón menor dijo "Maaf, saya sudah ada" ('Lo siento, ya lo tengo'), otro varón, pero esta vez mayor se excusó diciendo "Maaf, saya perlu berbincang dengan isteri saya dulu" ('Lo siento, tengo 
que hablar con mi mujer primero'), y la respuesta de una mujer joven fue "Maaf, saya sudah ada insuran, dah tak mampu untuk membeli insuran yang lain" ( 'Lo siento, ya tengo seguro, no me puedo permitir otro más'), mientras que una mujer mayor respondió "Maaf, ...saya perlu segera ambil anak di sekolah" ('Lo siento, ...tengo que recoger a mi niño del colegio en seguida').

El uso de la expresión "lo siento" como encabezado de los rechazos parece atender a una necesidad, por parte del hablante, de minimizar el rechazo. La expresión "lo siento" ha pasado al lenguaje ordinario (tanto en español como en malayo) como forma de cortesía general ante cualquier rechazo, especialmente en contextos en los que hay distancia social o una gran diferencia de estatus.

\subsubsection{Situación 5}

En la situación 5, en la que un estudiante universitario le pide a su compañero de curso que le preste su portátil porque ha entrado un virus en el suyo, el grado de familiaridad es alto (conocido), ya que es un amigo. 
Figura 230. Distribución de los tipos de "Excusa" utilizados en el grupo español y el grupo malayo para la situación 5

\section{Español}

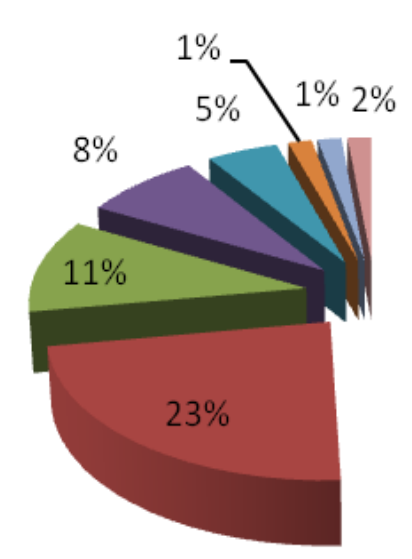

- Lo necesito

- Tengo trabajo que hacer

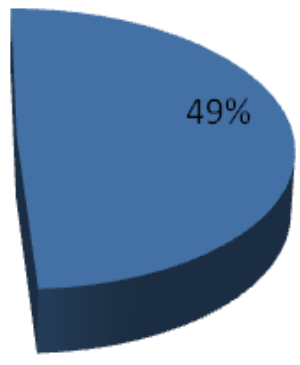

namilia

- Sin batería

- No quiero que se lo estropee

No lo tengo

Otros

\section{Malayo}

- Tengo trabajo que hacer
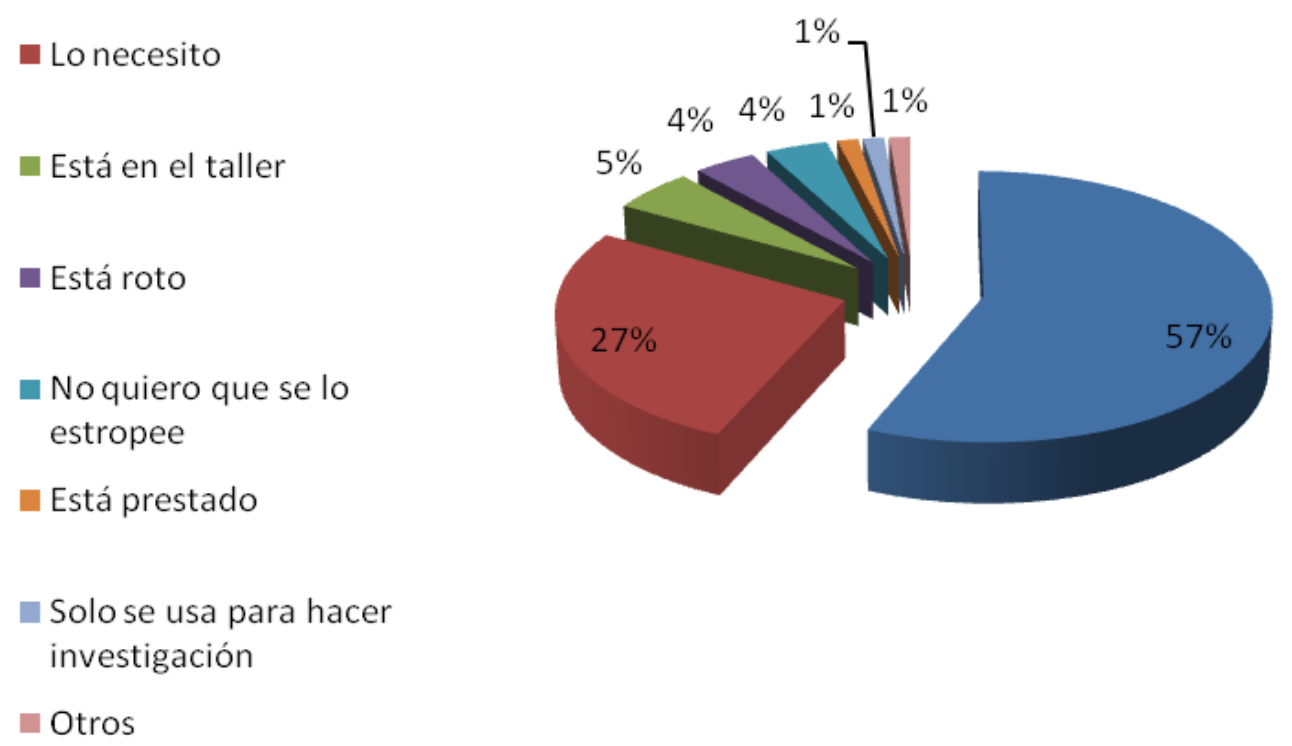
Como se indica en la Figura 230, se aplicaron siete tipos de excusas en los rechazos de ambos grupos, español y malayo. Los españoles tendieron a decir "lo necesito" (en un $49 \%$ de los casos) como excusa para rechazar la petición de su compañero de curso, mientras que los malayos dieron, de forma mayoritaria, la excusa de "tengo trabajo que hacer" (57\%). Las excusas que solo utilizaron los sujetos españoles fueron cuestiones familiares $(11 \%)$, estar sin batería (8\%) y no tener el ordenador solicitado (1\%). En cambio, las excusas que fueron encontradas únicamente en los datos malayos fueron "está en el taller" (5\%), "está prestado" (1\%) y "solo se usa para hacer investigación" (1\%).

Hay que llamar la atención en esta situación sobre el uso que hacen los sujetos españoles de los motivos familiares como excusa, que aparecen en los datos de los varones mayores, los varones menores y las mujeres menores, pero de los que no se hizo ningún registro en los datos de mujeres mayores. Los varones mayores y las mujeres menores utilizaron a su padre como excusa, mientras que los varones menores recurrieron a sus hermanos como excusa al rechazar. Por ejemplo, un varón mayor dijo "lo necesita mi padre", una mujer menor dijo "lo necesita mi padre para estudiar" y otra dijo "es de mi padre", mientras que un varón menor dijo "lo comparto con mi hermano", otro dijo "mi hermano lo está utilizando" y otro "ya se lo presté a mi hermana". Las excusas de "no lo tengo" 
y "está roto" solo se encontraron en los datos de los sujetos menores.

Por su parte, en el grupo malayo, cabe destacar que se da la misma tendencia en todos subgrupos a responder más comúnmente "tengo trabajo que hacer" al rechazar la petición de su compañero de curso. Aparte de eso, debemos señalar, asimismo, que la excusa de "está prestado" solo fue utilizada por un participante varón menor y la de "solo se usa para hacer investigación" aparece únicamente en la respuesta de una mujer mayor. Las excusas de "está en el taller" y "no quiero que se estropee" solo se encontraron en los datos mayores, mientras que la de "está roto" solo fue empleada por un varón menor y una mujer mayor.

En lo que concierne a la estructura de los rechazos, los participantes de todos los subgrupos, tanto en el grupo español como en el malayo, comenzaron mayoritariamente sus rechazos con una "Disculpa", seguida de "Excusas", como en "Lo siento, pero es que mi portátil lo voy a utilizar yo porque tengo que hacer un trabajo", "Lo siento, pero es que lo necesito yo porque todavía no he terminado el trabajo que nos mandaron...", "Lo siento mucho, pero tengo que hacer yo unas cosas con él" o "Lo siento, pero lo necesito para un trabajo importante". En los datos malayos, por su parte, hay 
expresiones como "Maaf, saya sedang menyiapkan assignment yang perlu dihantar segera" ( 'Lo siento, estoy terminando el trabajo que hace falta entregar en seguida'), "Maaf, tapi saya sedang menggunakannya" ( 'Lo siento, pero estoy utilizándolo'), "Maaf, saya banyak kerja dan kerja ni kena guna laptop..." ( 'Lo siento, tengo mucho trabajo que hacer y todo con portátil... ') o "Maaf, laptop saya ada di kedai sekarang, sebab ia dah rosak" ( 'Lo siento, mi portátil está en el taller ahora, porque ya está roto').

\subsubsection{Situación 8}

En la situación 8 , en la que un hermano menor pide a su hermano mayor que le acompañe a la fiesta de cumpleaños de un amigo, el grado de familiaridad es alto (muy conocido), ya que en el cuestionario se especifica que el interlocutor tiene una relación muy estrecha con su hermano menor. 
Figura 231. Distribución de los tipos de "Excusa" utilizados en el grupo español y el grupo malayo para la situación 8

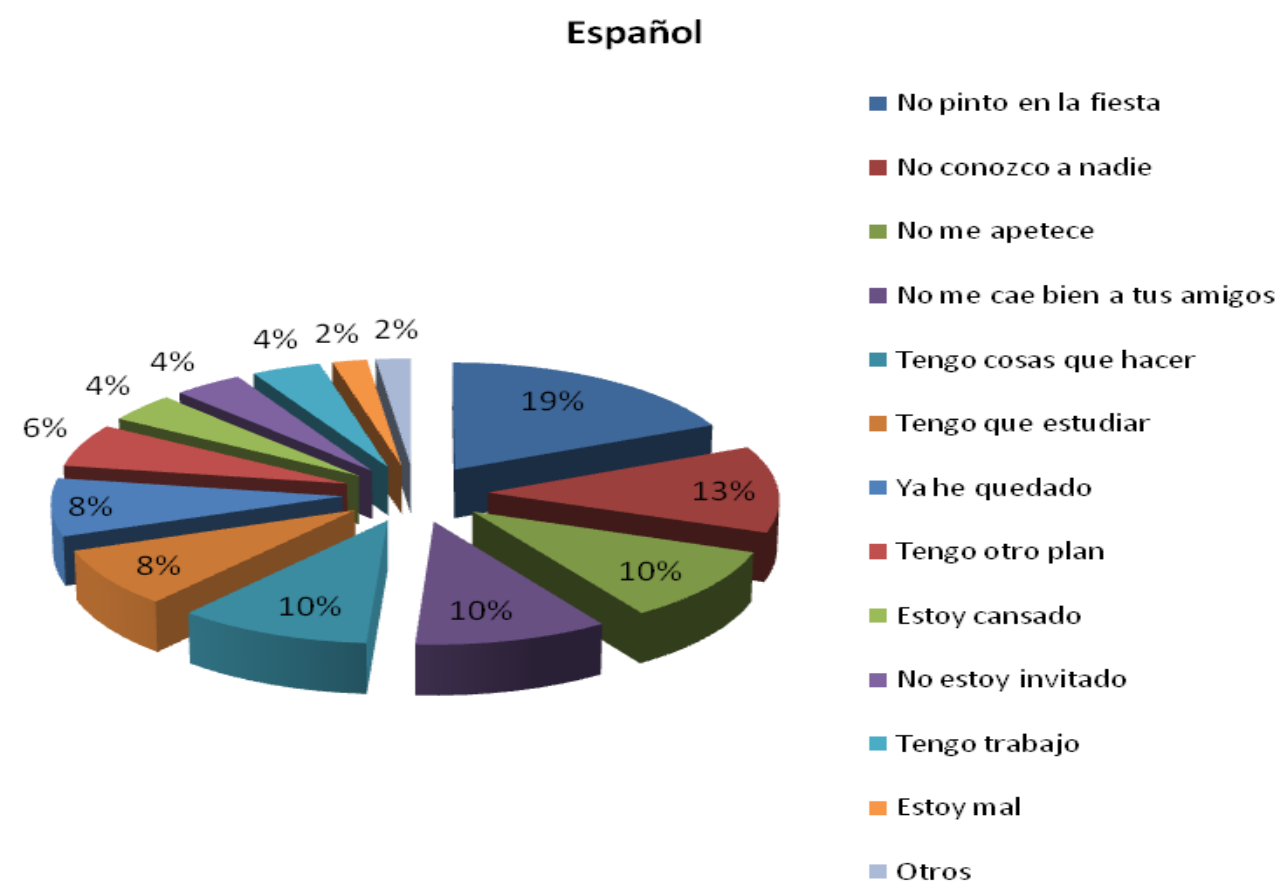

\section{Malayo}

- Tengo trabajo

No pinto en la fiesta

No conozco a nadie

- Tengo otro plan

- Yahe quedado

Estoy ocupado

Tengo cosas que hacer

Estoy mal

No me cae bien a tus amigos

Otros

No estoy invitado

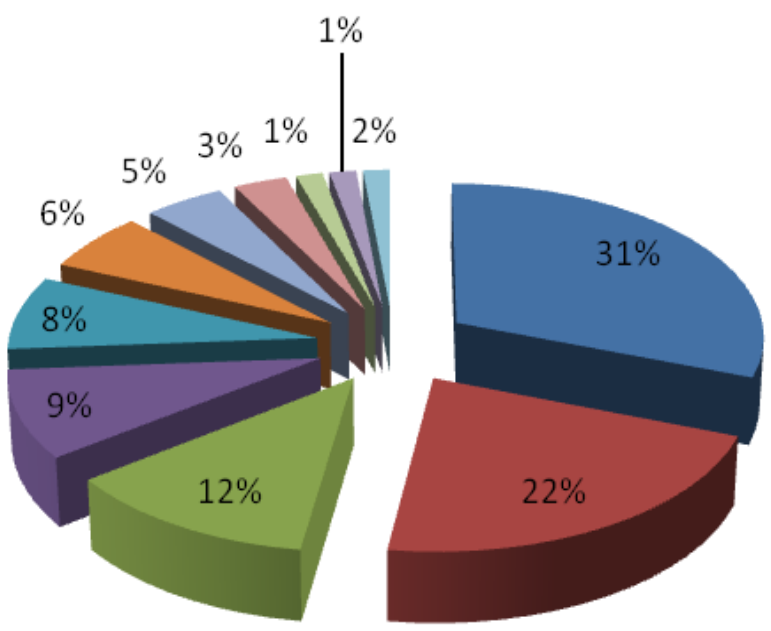


Los informantes españoles presentaron once excusas diferentes, frente a los nueve motivos alegados por los sujetos malayos para rechazar la petición de su interlocutor. La mayoría de los informantes españoles se excusaron con explicaciones del tipo "no pinto nada en la fiesta" (19\%) para no acompañar a su hermano menor, mientras que los informantes malayos utilizaron mayoritariamente la excusa de "tengo trabajo" (31\%). Lo que resulta interesante es que, mientras que en el grupo español la excusa de "tengo trabajo" se utilizó solo dos veces, lo que corresponde al $4 \%$ de las excusas aplicadas, aparece en un alto porcentaje de las respuestas de los sujetos malayos de más edad (50\%), algo que se puede explicar por el alto nivel de sensibilidad hacia la jerarquía social en la cultura malaya, en comparación con la cultura española. Por eso, los mayores malayos por el gran sentimiento de ser los hermanos mayores mostraron, en este escenario, una mayor tendencia hacia sus propias prioridades al dar excusas al producir los rechazos. En cambio, la ausencia de "tengo trabajo" entre los datos españoles puede ser explicada por los hábitos de ocio de la cultura española, que en general está radicalmente separada del tiempo de trabajo.

Las excusas que solo aparecen en las respuestas del grupo español son las de "no me apetece", "tengo que estudiar" y "estoy cansado". Por el contrarío, la excusa que sí aparece en los 
datos del grupo malayo pero no está presente en los del grupo español es la de "estoy ocupado".

Se nota, en el grupo español, que las excusas de los participantes varones mayores presentaron cierta variedad. No podemos hablar, así pues, de una tendencia hacia un motivo concreto en las excusas presentadas, sino que se recurrió a explicaciones diversas. Los sujetos varones menores, por su parte, prefirieron alegar motivos como "tengo cosas que hacer" y "ya he quedado" como excusa en sus rechazos. En los datos del otro sexo, tanto las mujeres mayores como las menores tendieron a poner la excusa de "no pinto nada en la fiesta" para decir que no a la petición de su hermano menor. Las excusas de "tengo cosas que hacer", "ya he quedado" y "tengo otro plan" solo fueron utilizadas por los sujetos varones, mientras que las de "estoy cansado" y "no está invitado" solo fueron utilizadas por las mujeres. La excusa de "estoy mal" solo fue aplicada una vez por un varón mayor.

Por otro lado, en el grupo malayo, hubo más variedad en los motivos alegados para rechazar la petición del interlocutor, al comparar las respuestas de los diferentes. Los varones mayores tendieron a dar las excusas de "ya he quedado", mientras que los varones menores utilizaron frecuentemente la de "tengo trabajo". Por otra parte, la mayoría de las mujeres mayores dieron la excusa 
de "no conozco a nadie" para rechazar la petición del hermano menor, mientras que las mujeres menores recurrieron al "no pinto nada en la fiesta" como excusa al rechazar. Solamente los varones se excusaron diciendo "tengo cosas que hacer", mientras que "no estoy invitado" y "no me cae bien a tus amigos" son motivos que aparecen únicamente en los datos mujeres.

La estructura de los rechazos en esta situación fue diferente entre los subgrupos en ambas culturas, española y malaya. En el grupo español, se aprecia que la mayoría de los sujetos varones mayores comenzaron sus rechazos diciendo "Lo siento", expresión que aparece seguida de una fórmula empleada como estrategia de "Buena voluntad/capacidad negativa", por ejemplo, "Lo siento, no quiero ir". Los varones menores por su parte tendieron a comenzar sus rechazos con la "Buena voluntad/capacidad negativa", seguida de las "Excusas", como "No quiero ir porque tengo otros planes". Las mujeres mayores tendieron a emplear una "Declaración de sentimiento negativo" o recurrieron al "Uso de muletillas", para seguir con una fórmula de "Buena voluntad/capacidad negativa", como en "¿Tú crees que no tengo otra cosa que hacer que ir de fiesta contigo? Sabes que me es imposible" o "iAyy! No me apetece nada", mientras que las mujeres menores tendieron a comenzar con el "Uso de muletillas", seguido de una "Excusa" o una fórmula de "Buena voluntad/capacidad negativa", como en "Ay, es que estoy 
cansadísima" o "Mira, paso". En el grupo malayo, por otra parte, todos los subgrupos tendieron a comenzar sus rechazos diciendo "Lo siento", seguidos del uso de "Fórmulas de tratamiento" y "Buena voluntad/capacidad negativa", como "Maaf adik, abang tak boleh pergi" ('Lo siento hermanito, no puedo ir'), excepto los hablantes del subgrupo de mujeres menores, que comenzaron mayoritariamente sus rechazos con "Fórmulas de tratamiento", seguidas de "Disculpa" y "Excusas", como en "Adik, maaf, kakak ada kerja petang ni" ('Hermanito, lo siento, tengo trabajo esta tarde').

\subsubsection{Situación 11}

En la situación 11, en la que un compañero de trabajo le pide al sujeto que se vaya a pescar con él a un río, el poder social entre los interlocutores es igual, puesto que en este contexto que se les ha proporcionado a los encuestados, se sitúan en la misma posición que su colega. 
Figura 232. Distribución de los tipos de "Excusa" utilizados en el grupo español y el grupo malayo para la situación 11

\section{Español}

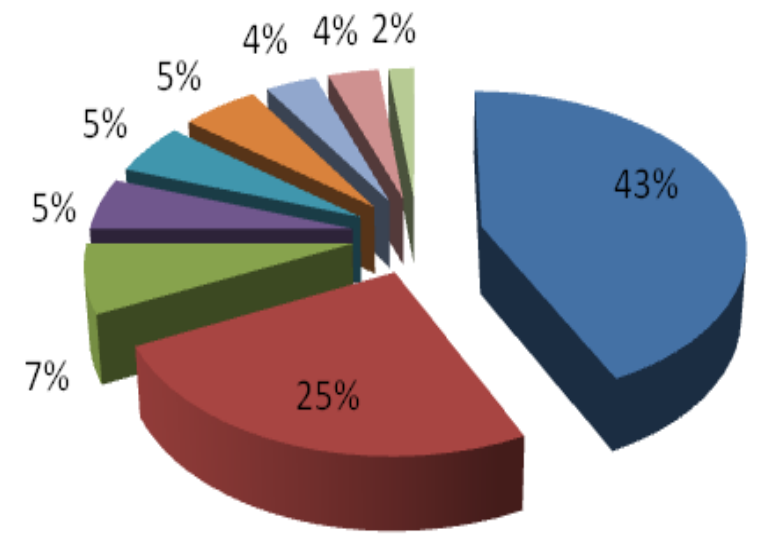

चstá lejos

- No me gusta pescar

- Ya tengo compromiso/plan

- Estoy cansado

- Tengo cosas que hacer

- Tengo trabajo

n Estoy perezoso

- Tengo que estudiar

- Familia

\section{Malayo}

\section{no me gusta pescar}

- Está lejos

Familia

- Tengo trabajo

- Tengo cosas que hacer

- No estoy bien

- Ya tengo compromiso/plan

- Estoy cansado

n Estoy ocupado

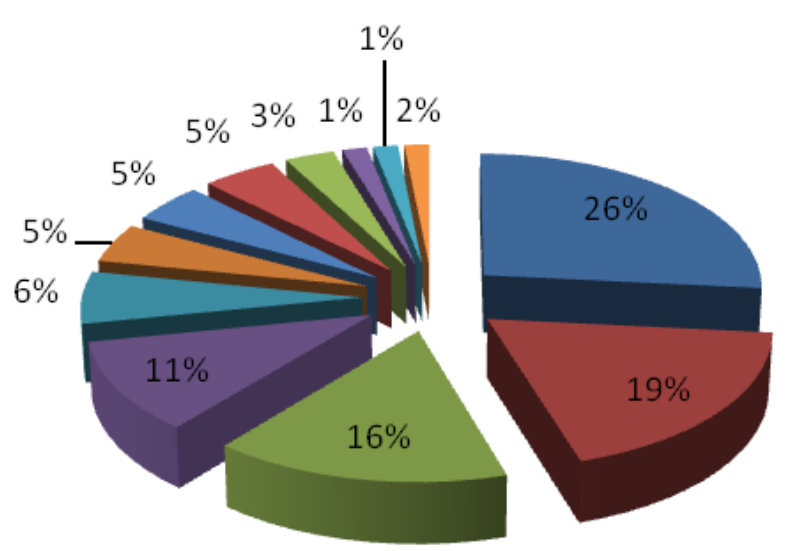

No tengo transporte

atros

nstoy perezoso 
El tipo de excusa con mayor porcentaje de aparición en el caso español corresponde a "está lejos", con un $43 \%$ del total de las respuestas, y en el malayo a "no me gusta pescar", con un $26 \%$. Hubo nueve tipos de excusas distintas encontradas en el caso español frente a las once del malayo, para rechazar la petición del colega. Un motivo que alegaron los españoles, pero que no aparece en los datos malayos fue "tengo que estudiar", mientras que los que sí aparecen en las respuestas de los sujetos de la sociedad malaya, pero no en las del otro grupo cultural son "no estoy bien", "estoy cansado" y "no tengo transporte".

En este contexto, en cada subgrupo español, excepto en el de los varones menores, la tendencia fue a dar la excusa de "está lejos". En cambio, la mayoría de los participantes del subgrupo de varones menores prefirieron "no me gustar pescar" como excusa en sus rechazos. Los varones mayores utilizaron casi todos los tipos de excusa expuestos en la gráfica, excepto los de "tengo que estudiar" y "tengo trabajo". El motivo familiar fue aplicado solamente por un varón mayor, cuando dijo "tengo alguna actividad con los niños" en su rechazo a la petición de ir a pescar a un río. Fue el único motivo familiar encontrado en las excusas españolas. Por otro lado, la excusa de "estoy perezoso" solo apareció en los datos de los participantes de más edad, y era de esperar la aparición exclusiva de "tengo que estudiar" en los menores, puesto que todos los 
participantes jóvenes eran estudiantes y dicha excusa parece la más lógica en la vida de un estudiante. Solo las mujeres mayores recurrieron al "tengo trabajo", mientras que "estoy cansado" es algo que solamente dijeron los varones mayores y las mujeres menores.

En el caso malayo por su parte, se observa una cierta tendencia hacia algunos motivos según el subgrupo de edad, sin tener en cuenta el sexo. La mayoría de los mayores utilizaron la excusa de "no me gusta pescar", mientras que los menores utilizaron "está lejos" en la mayoría de los casos. También hay que señalar que la excusa de "ya tengo compromiso/plan" solo apareció en los rechazos de los mayores, mientras que las de "no estoy bien" y "estoy ocupado" solo fueron utilizadas por los varones. "Tengo cosas que hacer" y "estoy cansado" son motivos que aparecieron en casi todos los subgrupos excepto en el de las mujeres menores.

En esta situación, es preeminente el uso de un motivo familiar como excusa en el grupo malayo, ya que aparece en las respuestas de todos los subgrupos. Sin embargo, recurrieron a distintos miembros de familia como causa del rechazo a la petición de su colega. Por ejemplo, un sujeto del subgrupo varón mayor puso a su mujer como excusa, como en "ya he prometido a mi mujer que saldría con ella". Por otro lado, algunas mujeres mayores recurrieron a su marido y su hijo, como en "mi marido y mi hijo me están 
esperando en casa" o "quiero descansar con mi marido y mi hijo". Los sujetos del subgrupo menor, por su parte, tanto varones como mujeres, hablaron de su madre, como en "mi madre me ha invitado para cenar con ella", "mi madre me ha pedido que cuide a mi hermano menor" o "este fin de semana quiero visitar a mi madre en el pueblo". Es lógico el resultado obtenido, ya que los malayos son muy leales a su familia, y siempre se le da la máxima prioridad en la vida. Así, los malayos tienden a citar o mencionar a su familia como deber inexcusable en sus rechazos.

Por último, analizamos la estructura de los rechazos producidos en cada subgrupo para este contexto. En el caso español, los hablantes varones mayores no mostraron ninguna tendencia específica, sino que utilizaron estructuras muy diversas, casi tantas como respuestas registradas. Así, encontramos desde estructuras bastante complejas, como en el ejemplo "Hola X. Gracias por la invitación. La verdad es que me parece que está lejos y prefiero quedarme.", en el que aparece la estructura "Saludo + Fórmula de tratamiento + Agradecimiento + Excusa + Buena voluntad/capacidad negativa", hasta otras más simples como en "Lo siento, pero no me gusta pescar" ("Disculpa" + "Excusa"), o incluso respuestas en las que únicamente aparece la excusa en sí misma ("Tengo alguna actividad con los niños"). Las mujeres mayores, por su parte, comenzaron la mayor parte de sus rechazos con una "Disculpa", que 
se presenta seguida de "Excusas", como en "Lo siento, pero el sitio está muy lejos", mientras que los varones y las mujeres menores mostraron preferencia por comenzar sus rechazos aplicando la estrategia de "Buena voluntad/capacidad negativa", seguida de la "Excusa", como en "No quiero ir, que tengo que hacer unas gestiones". Por otro lado, en el caso malayo, hay la misma tendencia en cada subgrupo hacia el uso de una "Disculpa" al comenzar los rechazos, pero las estrategias utilizadas a continuación variaron no solo entre los subgrupos sino también dentro de cada subgrupo en sí mismo. De esta forma, algunos tendieron a continuar con una "Excusa", y algunos con una fórmula de "Buena voluntad/capacidad negativa", diciendo, por ejemplo, "Maaf, saya tak minat memancing" ('Lo siento, no me gusta pescar') o "Maaf, saya tak dapat pergi" ('Lo siento, no puedo ir').

\subsubsection{Situación 14}

En la situación 14, en la que un estudiante universitario le pide a su profesor que le preste la tesis de un estudiante anterior, que se guarda en su despacho, el interlocutor del escenario (el profesor universitario) se sitúa en una posición social más alta. 
Figura 233. Distribución de los tipos de "Excusa" utilizados en el grupo español y el grupo malayo para la situación 14

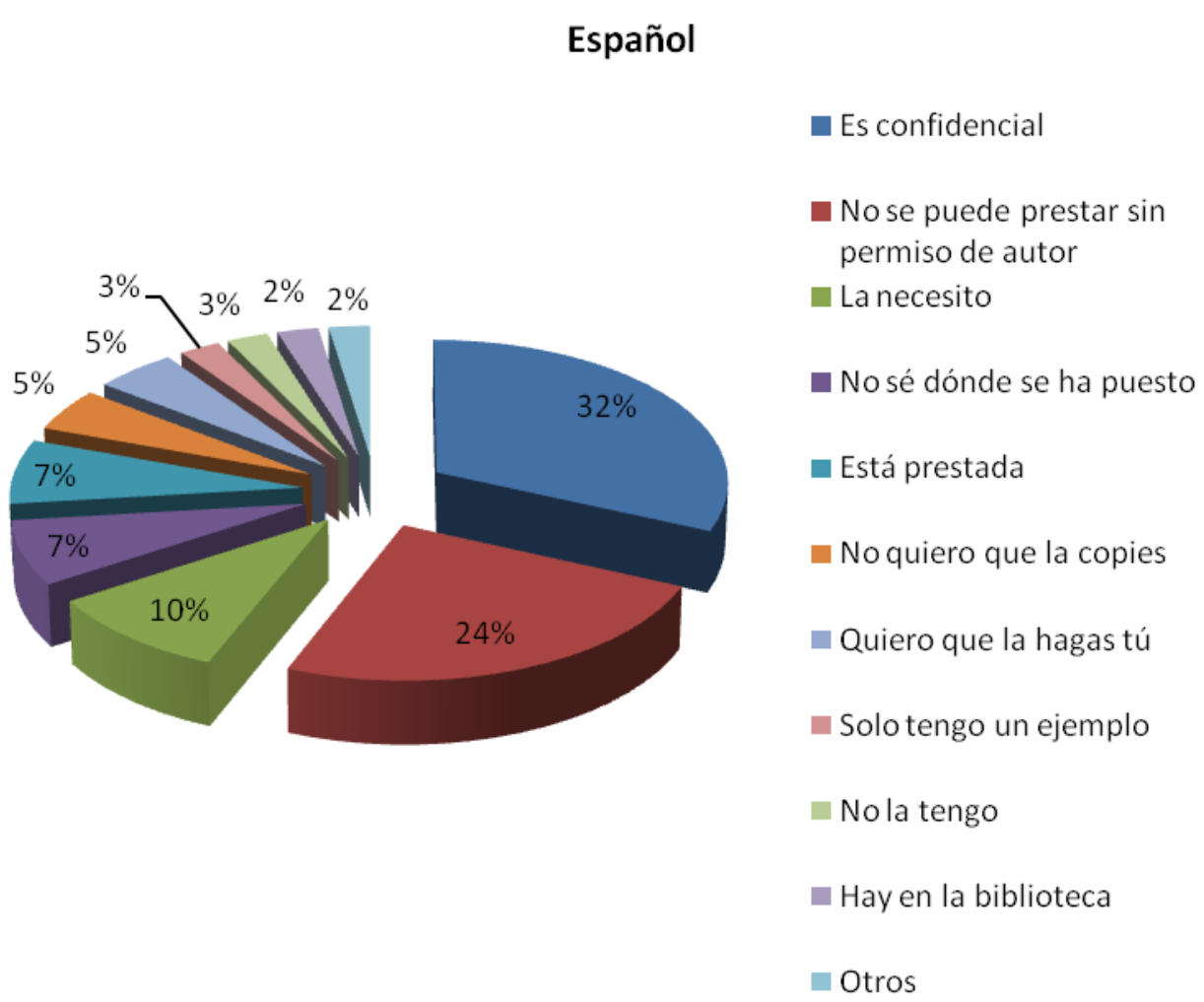

\section{Malayo}

- Quiero que la hagas tú

Es confidencial

No se puede prestar sin permiso de autor

- Hay en la biblioteca

- Está prestada

Nola tengo

- No quiero que la copies

Otros

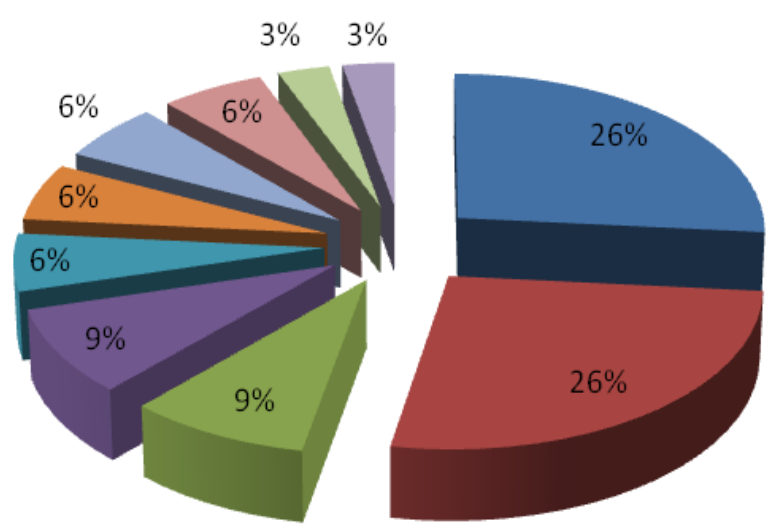

No sé dónde se ha puesto

- La necesito 
Las excusas españolas presentaban diez tipos de motivos frente a los nueve de las malayas. Los españoles mostraron una mayor preferencia hacia la excusa de "es confidencial" (32\%) para rechazar la petición del estudiante. Por otro lado, además de "es confidencial" (26\%), los malayos también prefirieron decir "quiero que la hagas tú" (también en un $26 \%$ de los casos) como excusa en su rechazo. Ningún sujeto malayo aplicó la excusa de "solo tengo un ejemplar", pero sí lo hicieron el 3\% de los sujetos españoles. El resto de los motivos aparecen en las respuestas de los dos grupos.

En este escenario, las dos excusas más comunes en el grupo español, "es confidencial" y "no se puede prestar sin permiso del autor", fueron utilizadas por los hablantes de todos los subgrupos, aunque los sujetos del subgrupo de varones tendieron a emplear la primera, mientras que los del subgrupo de mujeres prefirieron la segunda. Los motivos de "no la tengo" y "quiero que la hagas tú" solo aparecieron en los datos de los varones menores, mientras que los de "solo tengo un ejemplar" y "hay en la biblioteca" solo se encontraron en los de los sujetos varones mayores. Las mujeres mayores aplicaron casi todos los motivos, excepto los cuatro mencionados, mientras que las mujeres menores utilizaron dos motivos solamente que fueron los más comunes en el grupo principal. 
En cuanto a los motivos preferidos en cada subgrupo malayo, se nota, en las mujeres mayores, una tendencia hacia el uso de "quiero que la hagas tú" al dar excusas, mientras que las mujeres menores respondieron en más ocasiones con "es confidencial". Además, las mujeres menores aplicaron los motivos de "hay en la biblioteca" y "quiero que la hagas tú", que no se encontraron en los datos de los otros subgrupos. Los motivos de "no se puede prestar sin permiso del autor", "está prestada", "no sé dónde está" y "no la tengo" solo aparecieron en los sujetos varones. De manera similar al caso español, las mujeres menores malayas también emplearon solo dos motivos, que fueron los más comunes en el grupo principal.

Nos parece importante mencionar que en algunas facultades universitarias, tanto en España como en Malasia, se permite tomar prestadas las tesis de los alumnos anteriores, pero en algunas otras facultades está prohibido. No es de extrañar, por lo tanto, la existencia de varias respuestas en los encuestados como "Es confidencial" y "No se puede prestar sin permiso del autor", y otras contestaciones que implican dejarse prestar como "Está prestada" y "Hay en la biblioteca". En nuestra opinión, los sujetos respondieron a la situación proporcionada según su experiencia con su propio profesor, su entorno o quizás por las normas fijas de la facultad de cada encuestado. 
Para terminar con el análisis de este escenario analizamos la estructura de los rechazos de cada subgrupo en ambos grupos, español y malayo. En el grupo español, se nota la misma preferencia hacia el uso de una "Disculpa" como encabezamiento del rechazo en todos los subgrupos, pero las estrategias utilizadas a continuación defirieron entre sí. En los varones mayores, la tendencia fue hacia el uso de las fórmulas de "Buena voluntad/capacidad negativa" o "Declaración de principios" o "Excusa", después de la "Disculpa", como en "Lo siento, no puedo prestártela" o "Lo siento, pero las normas no permiten que las tesis doctorales salgan de la universidad" o "Lo siento, necesito la tesis", mientras que en los varones menores se observa una mayor tendencia a colocar, inmediatamente después, la "Excusa", como en "Lo siento, pero las tesis son confidenciales". Por otro lado, las mujeres mayores tendieron a utilizar la estrategia de "Buena voluntad/capacidad negativa" o "Excusa" después de la "Disculpa", como en "Lo siento, no voy a prestártela porque ahora la necesito", mientras que las mujeres menores prefirieron la "Buena voluntad/capacidad negativa", como en "Lo siento, pero no puedo dejártela".

Por otra parte, en el grupo malayo, también se da en cada subgrupo la misma tendencia a comenzar los rechazos con una "Disculpa". El patrón fue casi similar al del grupo anterior, ya que los varones mayores tendieron a utilizar la "Buena voluntad/capacidad 
negativa" o "Alternativa" después de una "Disculpa", como en "Maaf kerana saya tak dapat pinjamkannya kerana saya perlukannya, tapi anda boleh membacanya sekarang" ( 'Lo siento, no puedo dejártela porque la necesito, pero puedes leerla ahora'), mientras que los varones menores prefirieron una fórmula de "Buena voluntad/capacidad negativa" o una "Excusa", como en "Maaf saya tak boleh bagi pinjam sebab dah ada orang pinjam" ( 'Lo siento, no puedo prestártela porque ya está prestada'). En los datos de las mujeres mayores se nota una mayor tendencia hacia el uso de una "Declaración de principios" o "Autodefensa", después de la "Disculpa", como en "Maaf, tesis ini bukan untuk dipinjam" ('Lo siento, esta tesis no se presta'), mientras que las menores se inclinan más al empleo de una "Declaración de principios" o a aplicar la estrategia de "Buena voluntad/capacidad negativa", como en "Maaf, pihak jabatan tidak membenarkannya dipinjam oleh pelajar" ('Lo siento, no la deja prestar el departamento').

\subsubsection{Situación 17}

En la situación 17, en la cual un profesor universitario le pide a un estudiante que está haciendo una investigación bajo su dirección, que cambie el método del estudio, el dominio de poder social es del 
interlocutor, puesto que, en este contexto específico, los informantes se sitúan en una posición inferior frente al profesor.

Figura 234. Distribución de los tipos de "Excusa" utilizados en el grupo español y el grupo malayo para la situación 17

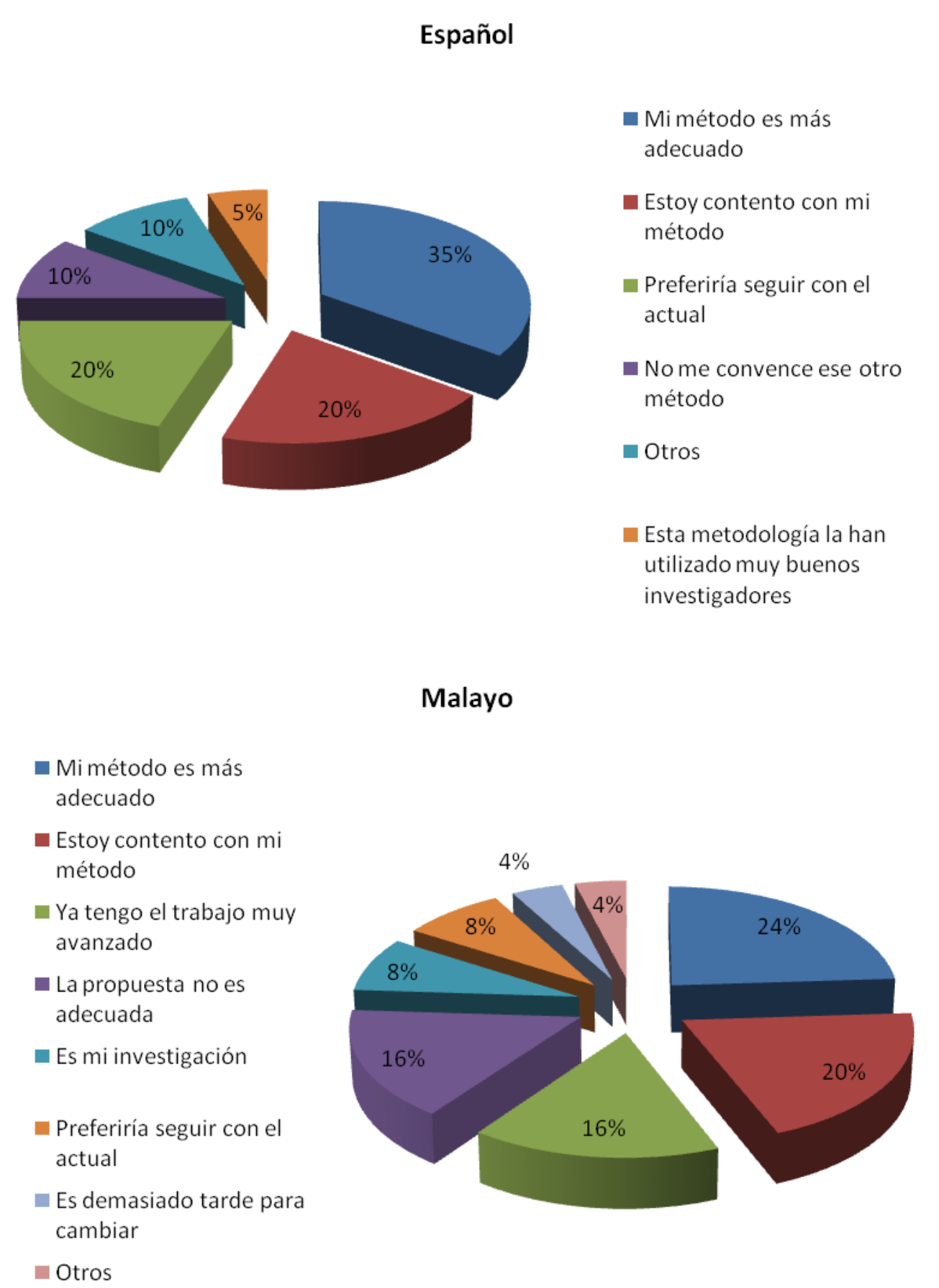


Como se ilustra en la Figura 234, en ambas sociedades se impuso la misma excusa, que fue "mi método es más adecuado" (así responden el $35 \%$ en los españoles y el $24 \%$ en los malayos). De hecho, la segunda excusa más utilizada en los dos grupos también coincidió estadísticamente (ambos utilizaron "ya estoy satisfecho con mi método" en un $20 \%$ de los casos). Sin embargo, en los datos españoles se encontraron solamente cinco excusas distintas, mientras que en los de los malayos aparecen hasta 7 tipos. La excusa presente en los datos españoles pero no encontrada en los datos malayos fue "el viejo método ya ha sido utilizado por muchos investigadores". En cambio, las que no se encontraron en los datos españoles pero estuvieron presentes en los datos malayos fueron "ya tengo el trabajo muy avanzado", "la propuesta no es adecuada", "es mi investigación" y "demasiado tarde para cambiar".

Al rechazar la propuesta del profesor universitario, los sujetos de todos los subgrupos en la sociedad española, excepto en el subgrupo de mujeres menores, tendieron a utilizar más "mi método es más adecuado". Las encuestadas de menos edad, sin embargo, prefirieron "ya estoy satisfecha con mi método" para rechazar la petición de cambiar el método. De hecho, este subgrupo utiliza solo este tipo de excusa en sus rechazos. Por el contrario, las mujeres mayores aplicaron todos los tipos de excusas presentas en la figura, y la de "el viejo método ya ha sido utilizado por muchos 
investigadores" solo se encontró en los datos de este subgrupo. Los tipos de "preferiría seguir con el actual" y "no me conviene el nuevo método" solo aparecieron en las respuestas de los encuestados varones menores y las mujeres mayores.

Por otra parte, en el grupo malayo, se hacen evidentes las siguientes tendencias: los varones mayores tendieron a aplicar "mi método es más adecuado" como excusa en este contexto de rechazo a un profesor universitario. Los varones menores, por otro lado, mostraron una mayor tendencia a excusarse con "es mi investigación", a la misma petición. En el subgrupo de mujeres mayores, hay una mayor inclinación hacia las excusas de "ya está satisfecho con mi método" y "ya tengo el trabajo muy avanzado", mientras que las mujeres menores prefirieron otras como "mi método es más adecuado" y "ya estoy satisfecha con mi método", al rechazar. Dos tipos de excusa, "demasiado tarde para cambiar" y "preferiría seguir con el actual" solo están presentes en los datos de los encuestados varones mayores.

Finalmente, el análisis de la estructura de los rechazos en cada grupo revela que, en el caso español, no hubo una estructura común en las respuestas de ninguno de los subgrupos, sobre todo en los de los mayores, tanto varones como mujeres, en cuyas respuestas hubo una gran variedad de combinaciones de estrategias. 
Así, es bastante complejo encontrar una estructura que esté más presente que otra en las respuestas de los hablantes del subgrupo. Algunos comenzaron sus rechazos con una "Autodefensa" seguida de una "Alternativa" o "Petición de comprensión", como en "Creo que el método que estamos siguiendo actualmente puede dar resultados satisfactorios, ¿no podríamos continuar y ver los primeros resultados antes de cambiar?", otros utilizaron una "Disculpa" seguida de una "Autodefensa", o una "Declaración de empatía" seguida de una "Autodefensa", como en "Lo siento, a mí me parece adecuado este método" o "He estado analizando el nuevo método, veo que lo que estábamos utilizando ahora proporcionaba una mayor fiabilidad". Lo cierto es que la estrategia de "Autodefensa" se utilizó más frecuentemente en este escenario en comparación con el resto de las situaciones presentadas, tanto en el grupo español como en el malayo. Por otro lado, la estructura de los rechazos en los datos de los subgrupos menores fue más estable. Los varones menores comenzaron más frecuentemente sus rechazos con una "Disculpa" seguida de una "Declaración de principios", como en "Lo siento, creo que mi método está bien", mientras que las mujeres menores prefirieron una "Declaración de principios" para comenzar sus rechazos, seguida de una "Declaración de opinión/sentimiento positivo o acuerdo" como en el ejemplo "Yo creo que mi método es bueno, aunque el que tú das también estaría bien". 
En el grupo malayo, aparece el mismo patrón. Es muy difícil determinar cuál es la estructura más común en los subgrupos mayores por la gran variedad de combinaciones entre las estrategias en sí. Si embargo, casi todos los mayores comenzaron su rechazo a la petición de un profesor universitario con "Fórmulas de tratamiento", pero seguidas de diversas estrategias. Algunos emplearon una "Declaración de opinión/sentimiento positivo o acuerdo", seguida de una "Amenaza o declaración de consecuencias negativas al emisor", como en el caso de "Profesor, cadangan prof tu bagus tapi saya rasa kalau tukar akan melambatkan kajian saya" ('Profesor, su propuesta es buena, pero creo que cambiar el método va a retrasar mucho el trabajo'), otros comenzaron con una "Excusa" seguida de "Fórmulas de tratamiento" y una "Autodefensa" o al revés, con una "Autodefensa" seguida de una "Excusa" o "Alternativa", como en "Prof, metod sekarang ni dah ok, saya nak teruskannya" ('Profesor, el método actual me funciona bien, quiero seguir con él'), y varias combinaciones más. Sin embargo, las estructuras de rechazo analizadas en las respuestas de los subgrupos menores fueron más uniformes. Los varones menores tendieron a comenzar sus rechazos con una fórmula de "Buena voluntad/capacidad negativa", seguida de "Fórmulas de tratamiento" y una "Excusa", como en "Saya tak setuju prof, cadangan tu tak sesuai" ('No estoy de acuerdo profesor, la propuesta no es adecuada'), mientras que las mujeres menores prefirieron la 
"Disculpa" para comenzar sus rechazos, seguida de "Fórmulas de tratamiento" y una "Autodefensa", como en el ejemplo "Maaf, prof, saya hanya mampu lakuan metod ni sahaja" ( 'Lo siento profesor, solo soy capaz de utilizar este método'). Hay que destacar, además, en casi todas las respuestas malayas, la aparición de "Fórmulas de tratamiento", estrategia que, por otro lado, hemos de señalar que se utiliza con mucha mayor frecuencia en esta situación que en el resto de los escenarios descritos.

\subsection{Discusión general}

Del análisis realizado en este capítulo se derivan algunas tendencias que resultan llamativas. Primero, los sujetos malayos nunca utilizaron la respuesta directa "No" en sus rechazos. En contraste, los españoles sí que la utilizaron en 13 ocasiones con interlocutores del mismo estatus, y de todos los grupos posibles en cuanto a la distancia social (no conocido, conocido, muy conocido). En este estudio se ha descubierto que la declaración "No" y la declaración de la capacidad negativa o incapacidad "No puedo" son casi las utilizadas exclusivamente en primer lugar por los sujetos españoles en todas las situaciones. La frecuencia de uso más alta se encontró al rechazar las peticiones o propuestas de los interlocutores desconocidos (5 veces), seguida por los íntimos (4 veces); en el caso 
de los interlocutores conocidos, se utilizaron solamente una vez. Con los interlocutores del mismo estatus, la frecuencia registrada fue de 3 casos. Atendiendo a los distintos tipos de situaciones, los españoles utilizaron la respuesta directa "No" un mayor número de veces en situación 2 , al rechazar la petición de comprar el nuevo paquete del servicio de teléfono móvil. Los mismos datos son los que recogió José Ramos (1991) en su estudio de rechazos entre los hablantes nativos españoles en Puerto Rico.

La tendencia de los sujetos malayos a evitar la respuesta directa "No" puede deberse al hecho de que, para ellos, es de suma importancia conservar la armonía en las relaciones humanas, mientras que los españoles antepusieron la sinceridad y la exactitud a la armonía. Los malayos consideran la respuesta directa "No" como un modo descortés de negarse, que podría afectar a la relación social entre los dos interlocutores. Decir "No" a alguien a la cara se interpreta como un insulto a la otra persona y causaría la ruptura de las relaciones sociales. Los malayos, como otras culturas colectivistas, consideran la armonía en las relaciones humanas más importante que la sinceridad. Este hallazgo coincide con lo encontrado por Nguyen (2006) en su investigación sobre los rechazos de australianos y vietnamitas. Según Nguyen (2006), como los vietnamitas pertenecen a una cultura asiática, intentaron evitar utilizar "No" para no perjudicar la imagen del interlocutor. 
El presente estudio ha revelado que los malayos tienden, más que los españoles, a comenzar sus rechazos con una "Disculpa" al responder a una petición. Los malayos entienden el rechazo a una persona como un acto que afecta a la imagen. En su opinión, la "Disculpa" transmite sentimiento de culpa por no poder acceder a la petición de alguien. Por consiguiente, usaron la "Disculpa" para compensar el perjuicio a la imagen del interlocutor. Este comportamiento podría mostrar que los malayos no quieren que, bajo ningún concepto, los interlocutores se sientan humillados, y les apena no cumplir con el deseo de otro miembro de su grupo. Por ello, protegen su imagen y también la imagen del oyente.

Los españoles mostraron un mayor uso que los malayos de la "Declaración de principios" para realizar rechazos. La "Declaración de principios" es, probablemente, el modo español de mostrar que la situación escapa al control del hablante y, por lo tanto, evita un rechazo directo. La tendencia de los sujetos españoles a declarar principios también se debe, probablemente, a que acatan fuertemente las normas y los principios establecidos. Este comportamiento refleja la buena disposición por parte de los sujetos españoles a referirse a los principios sociales como leyes y órdenes. En los sujetos malayos, por el contrario, hubo una fuerte tendencia a actuar teniendo en cuenta la armonía social. Esto también explica por qué los rechazos malayos incluyen muchas más "Excusas", en 
lugar de una "Declaración de principios". Con el fin de evitar decepcionar a sus interlocutores, dan una gran variedad de razones o excusas.

En cuanto al uso del "Agradecimiento", Nelson, Al Batal y El Bakary (2002) descubrieron que las personas de origen occidental (en su estudio los participantes eran ingleses) usaron el "Agradecimiento" con mucha más frecuencia que las orientales (los otros participantes eran árabes) para rechazar invitaciones, ofertas, y sugerencias. Igualmente, el presente estudio muestra que los sujetos españoles utilizaron mucho más el "Agradecimiento" que los malayos (49 casos frente a 13). Los españoles tendieron a comenzar sus rechazos diciendo "gracias", y continuaron con las excusas. Los malayos, por su parte, tendieron a decir "lo siento" o "discúlpame" al comenzar sus rechazos. Los porcentajes más altos de uso del "Agradecimiento" se encontraron en la situación 2, en la que un agente de una compañía de telefonía móvil va a casa del sujeto e intenta convencerle para que se compre el nuevo paquete del servicio. Para los españoles, la petición de alguien, sin importar cuál sea su estatus social, implica un grado de reconocimiento, por lo que tienden a comenzar su respuesta dando las gracias. Los malayos, por el contrario, no consideraron necesario agradecer la petición. La práctica común entre la sociedad malaya es invitarse mutuamente a salir o a sus respectivas fiestas. Pero tienden a comenzar sus 
rechazos con una disculpa porque se sienten culpables al declinar las peticiones o invitaciones del otro miembro de su grupo.

Por último, una de las diferencias más llamativas entre ambas culturas, fue el uso de "Fórmulas de tratamiento" al realizar rechazos. El estudio revela que los sujetos malayos utilizaron muchas más "Fórmulas de tratamiento" que los españoles. El número de enunciados con "Fórmulas de tratamiento" en los rechazos malayos fue 187, en comparación con solo 68 en los rechazos españoles. Cuando los malayos hablan con una persona de posición más elevada, utilizan honoríficos repetitivamente, sustituyendo el pronombre de la segunda persona usted. Al examinar las respuestas españolas y las respuestas malayas, encontramos que tan solo 7 $(12 \%)$ de los sujetos españoles utilizaron honoríficos del tipo "Título", como Señor/a, Profesor/a, Don/Doña, Doctor/a, por ejemplo en "Señor, este método no me conviene" o "Profesor, no estoy de acuerdo porque pienso que mi método es mejor". En contraste, 46 (77\%) de los malayos emplearon las "Fórmulas de tratamiento" de Profesor o Doktor ('Doctor/Doctora') o Tuan/Puan ('Señor/Señora') antes de añadir la "Excusa" o la "Disculpa", por ejemplo en "Dr., saya rasa metod saya lebih sesuai untuk kajian ini" ('Dr., creo que mi método es más adecuado para esta investigación") o "Profesor, saya rasa tak perlu tukar. Saya dah selesa dengan metod ini" ( 'Profesor, creo que no hace falta cambiar. 
Ya estoy contento con este método') o "Maafkan saya tuan, saya rasa saya nak teruskan dengan metod kajian ini" ( 'Lo siento señor, creo que voy a seguir con el actual' '). Los malayos son muy sensibles a la edad y el estatus. En Malasia, si hay que dirigirse a un extraño, se siguen las siguientes normas: se utiliza Encik/Tuan ('Señor'), o Puan ('Señora'), si son adultos. Si el extraño parece un estudiante en la adolescencia, se puede llamar a los chicos Abang ('Hermano mayor'), y a las chicas Kak ('Hermana mayor'); a los chicos de la misma edad también se les puede llamar tradicionalmente Saudara ('Amigo ), mientras que a las chicas se las llama Saudari ('Amiga'). Al dirigirse a preadolescentes, es común el empleo de la forma Adik ( Hermano/a menor'). No se llama a nadie por su nombre, excepto a los íntimos, a los interlocutores de la misma edad y a los del mismo estatus.

\subsection{Conclusión}

Este estudio revela que tanto los sujetos malayos como los sujetos españoles emplearon casi las mismas estrategias en sus rechazos, excepto en el empleo de la respuesta directa "No", y el de adyacentes al rechazo "Saludos/despedidas corteses", que no aparecen en los datos malayos. Sin embargo, sí que se diferenciaron en el contenido de las excusas. Los españoles fueron más específicos 
y se expresaron con más detalle en sus excusas, mientras que los malayos dieron explicaciones vagas que resultaban ambiguas, lo que significa que los españoles estaban más preocupados por la claridad del mensaje de rechazo que los malayos. A diferencia de los españoles, los malayos se muestran, en el cuestionario, muy preocupados por la aprobación social, y se esfuerzan por obtenerla. Sienten vergüenza cuando dejan de aceptar una petición de los demás. Los españoles aprecian el individualismo y la igualdad, y, por tanto, su manera de vincularse a los demás es más simple y directa. Los malayos por su parte, valoran el colectivismo y la jerarquía social, por lo que tratan de ser agradables y son más reservados en la comunicación social.

En general, los malayos sienten que su relación con los otros es más importante que su propia realización personal. Sacrificarían con mayor probabilidad su interés en beneficio del grupo, y su felicidad depende más de la felicidad de quienes les rodean. Por lo tanto, preferirán quedarse con un grupo que los necesita, incluso aunque haciéndolo no sean felices personalmente. En el mundo malayo, la cortesía es un elemento de expresión de solidaridad (Asmah, 1987), y por ello, en general, no se acepta ninguna forma de desacuerdo (Lim, 2005). Lim (2005) añade que, "lo importante no es actuar con sinceridad, sino ocultar todos los aspectos disonantes de una relación" (2005:76). Los malayos 
prefieren no decir la verdad si esta puede doler o es dura. A los ojos de los malayos, la compenetración no se logra cuando se revela una verdad dura; eso solamente lleva a un enfrentamiento (Jamaliah 2002).

En contraste con ello, en general, los occidentales ( $y$, por tanto, los españoles) sienten que pueden hablar de manera sincera y natural en un grupo. Tienden a sentirse cómodos siendo distinguidos con elogios o recompensas, y disfrutan siendo únicos y diferentes del resto.

The top collectivist's values are: Harmony, Facesaving, Filial piety (duty toward parents), Modesty, Moderation, Thrift, Equality in the distribution of rewards among peers, and Fulfilment of other's needs. The top individualist values are: Freedom, Honesty, Social recognition, Comfort, Hedonism, and Equity (to each according to hid/her contributions to group performance) (Triandis et al., 1988, p. 277).

Esto se evidenció en el contenido de sus excusas. Por ejemplo, utilizaron estudiar para los exámenes, exceso de trabajo y su propio sentimiento como excusas para sus rechazos, dirigidos todos ellos a su propio bien y no al del grupo. Los españoles tampoco tuvieron problema en utilizar la respuesta directa "No" en sus rechazos. En cambio, los sujetos malayos nunca recurrieron a ella. Los malayos consideran dicha respuesta como un modo 
descortés de negarse y que podría afectar a la relación social entre los dos interlocutores.

En cuanto a las comparaciones entre los rechazos producidos en ambas culturas por los sujetos de los subgrupos de edad, mayor versus menor, y los subgrupos de sexo, varón versus mujer, los datos analizados no muestran diferencias llamativas entre los mayores y los más jóvenes, pero sí dejan ver diferencias estadísticamente significativas entre los varones y las mujeres. Las mujeres de ambas sociedades utilizaron más estrategias que los varones, y también fueron más indirectas en sus rechazos que ellos. Además, se diferenciaron en el contenido de los rechazos. Los varones tendieron a emplear excusas más vagas que las mujeres, mientras que las mujeres utilizaron detalles más específicos.

Con respecto a la influencia de las variables sociales, los nativos en los dos países, España y Malasia, muestran el mismo patrón de uso de las estrategias al rechazar las peticiones de personas de los tres estatus sociales y de los que los separan las tres distancias sociales con las que se ha trabajado en este estudio. Pero los nativos malayos son más sensibles a la mención del estatus social de los interlocutores, mientras que los españoles son más sensibles a la distancia que los separa de ellos. Los informantes malayos se muestran dispuestos a recibir y dar los títulos que denotan estatus 
antes que nombres con un título general como "Profesor Ismail" ('Profesor Ismail'). Con mucha frecuencia, los malayos retienen de por vida el título profesional más alto que se haya alcanzado. Esto también sucede en España, pero su ámbito de influencia está limitado al campo profesional de la persona.

Para finalizar este apartado, presentamos, en las tablas siguientes, los resultados principales obtenidos en el análisis de los datos del rechazo:

Tabla 92. Resultados principales obtenidos en el contraste de español frente a malayo

\begin{tabular}{|c|c|c|c|c|}
\hline Análisis & Artículos & Detalles & Español & Malayo \\
\hline \multirow{10}{*}{ Cuantitativo } & \multirow{3}{*}{ Frecuencia } & $\mathrm{RD}$ & Más & Menos \\
\hline & & RID & Menos & Más \\
\hline & & $A R$ & Menos & Más \\
\hline & \multicolumn{2}{|c|}{ (In)dirección } & Más directa & Menos directa \\
\hline & \multicolumn{2}{|c|}{ Estrategia más usada } & \multicolumn{2}{|c|}{ Excusa: malayo más que español } \\
\hline & \multirow{3}{*}{ Estatus Social } & Superior & \multicolumn{2}{|c|}{ Rechazos indirectos } \\
\hline & & Igual & \multicolumn{2}{|c|}{ Rechazos indirectos } \\
\hline & & Inferior & \multicolumn{2}{|c|}{ Rechazos indirectos } \\
\hline & \multirow{2}{*}{ Distancia social } & Corta & \multicolumn{2}{|c|}{ Rechazos indirectos } \\
\hline & & Larga & \multicolumn{2}{|c|}{ Rechazos indirectos } \\
\hline \multirow{5}{*}{ Cualitativo } & \multirow{4}{*}{ Excusa } & Contenido & $\begin{array}{l}\text { Específico y } \\
\text { detallado }\end{array}$ & General y vago \\
\hline & & Motivo & $\begin{array}{l}\text { Ocupaciones } \\
\text { más prioritarias }\end{array}$ & $\begin{array}{l}\text { Disculpa a } \\
\text { terceras } \\
\text { personas }\end{array}$ \\
\hline & & (In)dirección & $\begin{array}{l}\text { Directa y } \\
\text { explícita }\end{array}$ & $\begin{array}{c}\text { Indirecta y } \\
\text { implícita }\end{array}$ \\
\hline & & Orientación & A sí mismo & A otra persona \\
\hline & \multicolumn{2}{|c|}{ Estructura } & $\begin{array}{l}-R I D+R I D+R I D \\
-R I D+R D+R D\end{array}$ & $\begin{array}{l}-R I D+R I D+R I D \\
-R I D+A+R I D\end{array}$ \\
\hline
\end{tabular}


Tablas 93 y 94 . Resultados principales obtenidos en la comparación de sujeto mayor frente a sujeto menor

\begin{tabular}{|c|c|c|c|c|}
\hline \multicolumn{5}{|c|}{ Español } \\
\hline Análisis & Artículos & Detalles & Mayor & Joven \\
\hline \multirow{10}{*}{ Cuantitativo } & \multirow{3}{*}{ Frecuencia } & $\mathrm{RD}$ & Menos & Más \\
\hline & & RID & Más & Menos \\
\hline & & $A R$ & Menos & Más \\
\hline & \multicolumn{2}{|c|}{ (In)dirección } & Menos directa & Más directa \\
\hline & \multicolumn{2}{|c|}{ Estrategia más usada } & \multicolumn{2}{|c|}{ Excusa: mayor más que menor } \\
\hline & \multirow{3}{*}{ Estatus Social } & Superior & \multicolumn{2}{|c|}{ Rechazos indirectos } \\
\hline & & Igual & \multicolumn{2}{|c|}{ Rechazos indirectos } \\
\hline & & Inferior & \multicolumn{2}{|c|}{ Rechazos indirectos } \\
\hline & \multirow{2}{*}{ Distancia social } & Corta & \multicolumn{2}{|c|}{ Rechazos indirectos } \\
\hline & & Larga & \multicolumn{2}{|c|}{ Rechazos indirectos } \\
\hline \multirow{5}{*}{ Cualitativo } & \multirow{4}{*}{ Excusa } & Contenido & \multicolumn{2}{|c|}{$\begin{array}{l}\text { Lo de los mayores es más } \\
\text { específico y detallado que lo de los } \\
\text { jóvenes }\end{array}$} \\
\hline & & Motivo & \multicolumn{2}{|c|}{ Ocupaciones más prioritarias } \\
\hline & & (In)dirección & \multicolumn{2}{|c|}{$\begin{array}{l}\text { La de los mayores es menos directa } \\
\text { y explícita que la de los menores }\end{array}$} \\
\hline & & Orientación & \multicolumn{2}{|c|}{ A sí mismo } \\
\hline & \multicolumn{2}{|c|}{ Estructura } & RID + RID + RID & $R I D+R D+R D$ \\
\hline
\end{tabular}

$\mathrm{RD}=$ Rechazo Directo $\quad \mathrm{RID}=$ Rechazo Indirecto $\quad \mathrm{AR}=$ Adyacentes al Rechazo

\begin{tabular}{|c|c|c|c|c|}
\hline \multicolumn{5}{|c|}{ Malayo } \\
\hline Análisis & Artículos & Detalles & Mayor & Joven \\
\hline \multirow{10}{*}{ Cuantitativo } & \multirow{3}{*}{ Frecuencia } & RD & Menos & Más \\
\hline & & RID & Más & Menos \\
\hline & & $A R$ & Menos & Más \\
\hline & \multicolumn{2}{|c|}{ (In)dirección } & Menos directa & Más directa \\
\hline & \multicolumn{2}{|c|}{ Estrategia más usada } & \multicolumn{2}{|c|}{ Excusa: mayor más que menor } \\
\hline & \multirow{3}{*}{ Estatus Social } & Superior & \multicolumn{2}{|c|}{ Rechazos indirectos } \\
\hline & & Igual & \multicolumn{2}{|c|}{ Rechazos indirectos } \\
\hline & & Inferior & \multicolumn{2}{|c|}{ Rechazos indirectos } \\
\hline & \multirow{2}{*}{ Distancia social } & Corta & \multicolumn{2}{|c|}{ Rechazos indirectos } \\
\hline & & Larga & \multicolumn{2}{|c|}{ Rechazos indirectos } \\
\hline \multirow{5}{*}{ Cualitativo } & \multirow{4}{*}{ Excusa } & Contenido & \multicolumn{2}{|c|}{$\begin{array}{c}\text { Lo de los jóvenes es más general y } \\
\text { vago que lo de los mayores }\end{array}$} \\
\hline & & Motivo & \multicolumn{2}{|c|}{ Disculpa a terceras personas } \\
\hline & & (In)dirección & \multicolumn{2}{|c|}{$\begin{array}{l}\text { La de los mayores es más indirecta } \\
\text { y implícita que la de los jóvenes }\end{array}$} \\
\hline & & Orientación & \multicolumn{2}{|c|}{ A otra persona } \\
\hline & \multicolumn{2}{|c|}{ Estructura } & RID + RID + RID & $R I D+A+R I D$ \\
\hline
\end{tabular}

$\mathrm{RD}=$ Rechazo Directo $\quad \mathrm{RID}=$ Rechazo Indirecto $\mathrm{AR}=$ Adyacentes al Rechazo 
Tablas 95 y 96. Resultados principales obtenidos en el caso de la aplicación de la variable hombre frente a mujer

\begin{tabular}{|c|c|c|c|c|}
\hline \multicolumn{5}{|c|}{ Español } \\
\hline Análisis & Artículos & Detalles & Hombre & Mujer \\
\hline \multirow{10}{*}{ Cuantitativo } & \multirow{3}{*}{ Frecuencia } & $\mathrm{RD}$ & Menos & Más \\
\hline & & RID & Menos & Más \\
\hline & & $\mathrm{AR}$ & Menos & Más \\
\hline & \multicolumn{2}{|c|}{ (In)dirección } & Más directa & Menos directa \\
\hline & \multicolumn{2}{|c|}{ Estrategia más usada } & \multicolumn{2}{|c|}{ Excusa: mujer más que hombre } \\
\hline & \multirow{3}{*}{ Estatus Social } & Superior & \multicolumn{2}{|c|}{ Rechazos indirectos } \\
\hline & & Igual & \multicolumn{2}{|c|}{ Rechazos indirectos } \\
\hline & & Inferior & \multicolumn{2}{|c|}{ Rechazos indirectos } \\
\hline & \multirow{2}{*}{ Distancia social } & Corta & \multicolumn{2}{|c|}{ Rechazos indirectos } \\
\hline & & Larga & \multicolumn{2}{|c|}{ Rechazos indirectos } \\
\hline \multirow{5}{*}{ Cualitativo } & \multirow{4}{*}{ Excusa } & Contenido & \multicolumn{2}{|c|}{$\begin{array}{l}\text { Lo de las mujeres es más específico } \\
\text { y detallado que lo de los hombres }\end{array}$} \\
\hline & & Motivo & \multicolumn{2}{|c|}{ Ocupaciones más prioritarias } \\
\hline & & (In)dirección & \multicolumn{2}{|c|}{$\begin{array}{l}\text { La de los hombres es más directa y } \\
\text { explícita que la de las mujeres }\end{array}$} \\
\hline & & Orientación & \multicolumn{2}{|c|}{ A sí mismo } \\
\hline & \multicolumn{2}{|c|}{ Estructura } & $R I D+R D+R D$ & RID + RID + RID \\
\hline
\end{tabular}

\begin{tabular}{|c|c|c|c|c|}
\hline \multicolumn{5}{|c|}{ Malayo } \\
\hline Análisis & Artículos & Detalles & Hombre & Mujer \\
\hline \multirow{10}{*}{ Cuantitativo } & \multirow{3}{*}{ Frecuencia } & $\mathrm{RD}$ & Más & Menos \\
\hline & & RID & Menos & Más \\
\hline & & $\mathrm{AR}$ & Menos & Más \\
\hline & \multicolumn{2}{|c|}{ (In)dirección } & Más directa & Menos directa \\
\hline & \multicolumn{2}{|c|}{ Estrategia más usada } & \multicolumn{2}{|c|}{ Excusa: mujer más que hombre } \\
\hline & \multirow{3}{*}{ Estatus Social } & Superior & \multicolumn{2}{|c|}{ Rechazos indirectos } \\
\hline & & Igual & \multicolumn{2}{|c|}{ Rechazos indirectos } \\
\hline & & Inferior & \multicolumn{2}{|c|}{ Rechazos indirectos } \\
\hline & \multirow{2}{*}{ Distancia social } & Corta & \multicolumn{2}{|c|}{ Rechazos indirectos } \\
\hline & & Larga & \multicolumn{2}{|c|}{ Rechazos indirectos } \\
\hline \multirow{5}{*}{ Cualitativo } & \multirow{4}{*}{ Excusa } & Contenido & \multicolumn{2}{|c|}{$\begin{array}{c}\text { Lo de los hombres es más general y } \\
\text { vago que lo de las mujeres }\end{array}$} \\
\hline & & Motivo & \multicolumn{2}{|c|}{ Disculpa a terceras personas } \\
\hline & & (In)dirección & \multicolumn{2}{|c|}{$\begin{array}{l}\text { La de las mujeres es más indirecta y } \\
\text { implícita que la de los hombres }\end{array}$} \\
\hline & & Orientación & \multicolumn{2}{|c|}{ A otra persona } \\
\hline & \multicolumn{2}{|c|}{ Estructura } & $R I D+R I D+R I D$ & $R I D+A+R I D$ \\
\hline
\end{tabular}


Como conclusión a este capítulo, sumamos los resultados principales de los datos del rechazo en las líneas que siguen. Los rechazos formulados por los encuestados españoles fueron directos, las excusas de su rechazo fueron más específicas y detalladas, no fueron sensibles al estatus ni distancia social, y las estructuras usuales fueron "Rechazo Indirecto" + "Rechazo Directo" + "Rechazo Directo" y "Rechazo Indirecto"+ "Rechazo Indirecto" + "Rechazo Indirecto".

Por otro lado, los rechazos malayos fueron menos directos que los españoles, recurrieron a excusas más generales y vagas, tampoco fueron sensibles a las variables sociales, y las estructuras más comunes de sus rechazos fueron "Rechazo Indirecto" + "Rechazo Indirecto" + "Rechazo Indirecto" y "Rechazo Indirecto" + "Adyacentes al rechazo" + "Rechazo Indirecto".

Según los resultados obtenidos en lo referente a los subgrupos de edad, los jóvenes españoles fueron más directos que los de más edad, ya que utilizaron más estrategias directas, sus excusas también fueron más directas pero menos específicas que los participantes mayores, y la estructura habitual en las respuestas de los sujetos de más edad fue, "Rechazo Indirecto" + "Rechazo Indirecto" + "Rechazo Indirecto", mientras que en las de los jóvenes fue, "Rechazo Indirecto" + "Rechazo Directo" + "Rechazo Directo". 
De manera similar al caso español, los jóvenes malayos también aplicaron más estrategias directas que los sujetos mayores, así pues fueron más directos en su rechazo en comparación con los mayores. Respecto a la estrategia de "Excusa", en los jóvenes fue más vaga y más general que en los mayores. La estructura común de los rechazos entre los encuestados mayores fue, "Rechazo Indirecto" + "Rechazo Indirecto" + "Rechazo Indirecto" y entre los jóvenes fue, "Rechazo Indirecto" + "Adyacentes al rechazo" + "Rechazo Indirecto".

Por último, en lo que concierne a la producción del rechazo según el sexo de los hablantes, en el corpus español, las mujeres utilizaron más estrategias directas que los hombres, por lo que se considera que fueron más directas que los hombres. Aun así, en general produjeron más enunciados que los hombres y sus excusas fueron más específicas pero menos directas que las de los hombres. Y la estructura típica en los hombres fue, "Rechazo Indirecto" + "Rechazo Directo" + "Rechazo Directo", mientras que la en las mujeres fue, "Rechazo Indirecto"+ "Rechazo Indirecto" + "Rechazo Indirecto".

En el corpus malayo, por su parte, los rechazos de los hombres se consideran más directos, ya que aplicaron las estrategias directas con mayor frecuencia que las mujeres, y en general usaron 
menos enunciados. Con respecto a las excusas utilizadas por ambos sexos, las de los hombres fueron más vagas y más generales que las mujeres. Finalmente, la estructura común de los rechazos producidos por cada sexo fue, "Rechazo Indirecto" + "Rechazo Indirecto" + "Rechazo Indirecto" en los hombres, y "Rechazo Indirecto" + "Adyacentes al rechazo" + "Rechazo Indirecto" entre las mujeres. 



\section{CAPÍTULO 7}

\section{CONCLUSIONES}

Este capítulo presenta un resumen del estudio realizado que incluye, además del propósito y el diseño de la investigación, los resultados obtenidos. Explicaremos también las implicaciones pedagógicas del estudio y presentaremos algunas recomendaciones para futuras investigaciones.

\subsection{Resumen de la investigación}

En este estudio se han investigado las diferencias entre hablantes malayos y españoles en la selección de estrategias y en las modificaciones aplicadas, tanto externas como internas (es decir, de contenido), al llevar a cabo tres actos de habla, petición, mandato y rechazo. La elección de estos tres actos de habla para nuestro 
trabajo se funda en algunos de sus rasgos: son actos amenazadores de la imagen pública (face-threatening acts), más propensos a malentendidos, y que constituyen el principal desafío transcultural para hablantes no nativos, ya que requieren un alto nivel de competencia pragmática.

Hemos examinado también las diferencias entre los participantes mayores y jóvenes, y entre hombres y mujeres, en la producción de dichos actos en cada sociedad. Además, la influencia de las variables sociales, es decir, estatus y distancia social, sobre la formulación de esos tres actos de habla, ha sido también uno de los objetivos de la investigación.

A fin de ampliar el marco teórico, esta investigación emplea elementos de la pragmática y la sociolingüística, tanto para argumentar como para ayudar a entender los problemas existentes en el análisis de los patrones de petición, mandato y rechazo. La conciencia de la diversidad de comportamientos sociolingüísticos hace posible percibir las diferencias como tales, y no como fruto de inferioridad o anormalidad. Sin el conocimiento explícito de otras culturas, hay una cierta propensión en los hablantes a los malentendidos. Aprender algo sobre estas diferencias puede reducir una hostilidad innecesaria hacia otros grupos debido a la falta de conocimiento de otras culturas. Tal aprendizaje puede fomentar la 
tolerancia hacia distintos modelos de comportamiento y ayudar a prevenir percepciones etnocéntricas.

Sesenta hablantes nativos de español y sesenta hablantes nativos de malayo, que, en el momento de la recogida de datos eran estudiantes y profesores universitarios, han participado en este estudio. Los datos se recogieron mediante un Test de rellenado del discurso que consta de seis situaciones de petición, seis de mandato y seis de rechazo. En el Test de rellenado del discurso, se planteaban situaciones provocativas, y se pidió a los participantes que leyeran las descripciones de la situación y escribieran en su lengua materna, es decir, español y malayo, lo que ellos dirían, de la forma más real y natural posible, en cada caso.

Los artículos del Test de rellenado del discurso se desarrollaron tomando como base dos variables sociales: estatus y distancia social. En el estatus social se distinguen tres niveles, dependiendo de si el hablante está en una posición superior, igual o inferior al oyente. La distancia social, en cambio, se refiere al grado de familiaridad que existe entre los interlocutores. En la distancia social también se establecen tres niveles. Así, los interlocutores pueden no conocerse, conocerse o conocerse muy bien. 
Los datos de petición y mandato fueron analizados usando el esquema de clasificación de los marcos de análisis de CCSARP (Blum-Kulka, House y Kasper, 1989), mientras que, para los de rechazo, se aplicó el de Beebe at al. (1990). Se calculó la frecuencia de uso de cada una de las estrategias en cada situación, y se describieron y se compararon las características lingüísticas de las producciones de los dos grupos y los subgrupos en cada situación.

En el desarrollo del trabajo se han percibido algunos inconvenientes en relación al método utilizado en la recogida de datos para este tipo de estudios, como ha sido mencionado anteriormente en el Capítulo 3. El más importante es que es difícil describir cuán representativas son las respuestas escritas de lo que los sujetos dicen realmente en conversaciones espontáneas. Los sujetos, incluso, pueden elegir formas lingüísticas específicas en función de la familiaridad con la ortografía de una palabra más que de otra. Es más, los sujetos pueden percibir la escritura como una actividad más formal que el habla, y por tanto elegir un lenguaje también más formal en el cuestionario.

No obstante, el cuestionario presenta contextos controlados para recoger datos lingüísticos que representan un abanico de estrategias extraídas de muchos sujetos en ambas lenguas. Ya que este estudio investiga las diferencias en el empleo 830 
de estrategias de petición, mandato y rechazo en dos culturas distintas, se comparan las distintas normas en los actos de habla mencionados en las diferentes culturas. La comparabilidad transcultural necesita respuestas estereotipadas, y éstas pueden obtenerse mediante técnicas escritas de obtención de datos. Se reúne una gran cantidad de datos para comparar los comportamientos de discurso específicos en grupos diferentes, y esto es prácticamente imposible de hacer utilizando el discurso espontáneo. Además, la recolección de datos de tipo natural es muy difícil, ya que la aparición de ciertos actos de habla es arbitraria e imprevisible. Sería casi imposible y muy ineficaz recoger datos para analizar el comportamiento en el discurso teniendo en cuenta las variables de interés. Así, considerando las necesidades de control experimental y eficacia práctica, la prueba de rellenado por escrito de un fragmento de discurso era el instrumento metodológico más apropiado para este estudio.

Los resultados obtenidos en la presente investigación, que pasamos a exponer en el siguiente apartado, han revelado las similitudes y las diferencias en los tres actos de habla sometidos a estudio realizados por los hablantes nativos de los dos idiomas en cada contexto específico. 


\subsection{Resultados principales obtenidos sobre la petición}

\section{Español frente a malayo}

a) En general, los hablantes malayos produjeron un mayor número de enunciados, $y$, por tanto, emplearon un mayor número de estrategias en comparación con los españoles.

b) Los dos grupos mostraron tendencia a formular sus peticiones mediante el empleo de estrategias que denominamos "Convencionalmente indirectas".

c) La estrategia del acto principal más utilizada en ambos grupos en todas las situaciones de petición propuestas en el cuestionario fue la "Interrogación preparatoria", excepto en la situación 4 (los interlocutores tiene buena relación entre sí) y la 7 (la relación es muy estrecha entre los interlocutores), en las que los malayos participantes aplicaron, en la mayor parte de los casos, la estrategia de "Fórmula de sugerencia".

d) En el grupo español se utilizaron tres tipos de "Interrogación preparatoria, a saber, "Capacidad/posibilidad", "Buena voluntad" y "Predicción de acción futura del oyente", siendo la de "Capacidad/posibilidad" la que aparece en un mayor número de ocasiones. En las respuestas del grupo malayo, en cambio, solamente aparece la de "Capacidad/posibilidad". 
e) Los sujetos malayos produjeron enunciados más largos utilizando más movimientos de apoyo que los españoles.

f) El movimiento de apoyo más aplicado en el grupo español fue el de "Presentación/saludos", mientras que el más usado en el grupo malayo fueron las "Fórmulas de tratamiento".

g) La estructura común de las peticiones de los nativos de los dos países fue similar, es decir, ambos comenzaron su petición con un movimiento de apoyo y luego pronunciaron el acto principal. Después, continuaron con un movimiento de apoyo ("movimiento de apoyo + acto principal + movimiento de apoyo").

h) La diferencia de estatus social tuvo una influencia más significativa en la preferencia de estrategia del acto principal, en comparación con la de la distancia social, ya que la mayoría de los participantes de los dos países usaron las estrategias "No convencionalmente indirectas" con personas de estatus superior y utilizaron mayoritariamente las estrategias "Convencionalmente indirectas" al hacer la petición a personas del mismo estatus y de estatus inferior. Pero, al considerar la distancia social, no hubo diferencias relevantes, puesto que las estrategias más elegidas fueron las "Convencionalmente indirectas", tanto al realizar la petición a personas con las que el sujeto, al colocarse en la situación planteada, mantiene una relación de baja familiaridad, como con las de alta familiaridad. 
i) En cuanto a las modificaciones internas, podemos hacer las siguientes observaciones:

- La fórmula nominal más común entre los participantes españoles fue el uso del "Nombre de pila", que se utilizó, principalmente, al dirigirse a los interlocutores de estatus inferior (situación 13) y a los muy conocidos (situación 7), mientras que la más común entre los malayos fue el "Título", que se aplicó de manera frecuente, obviamente, al tratar a un interlocutor de estatus superior (situación 10).

- Los españoles tendieron a emplear la fórmula pronominal tú al dirigirse a los interlocutores en todas las situaciones de petición, excepto en la situación 10, en la que un alumno pide a su ex profesor universitario que redacte una carta de recomendación. Los malayos, por su parte, se inclinaron hacia el uso de awak (equivalente a $t \boldsymbol{t} \hat{u}$ ) en todas las situaciones, excepto en la situación 10, en la que aplicaron mayoritariamente el "Título".

- Los españoles modificaron su petición por el uso mediante la forma Condicional del verbo, mientras que los malayos la modificaron mediante la utilización de partículas y los sufijos.

- La mayoría de las expresiones en las peticiones españolas tienen su orientación hacia el oyente, mientras que las expresiones de las peticiones malayas estaban orientadas mayoritariamente hacia el hablante. 
Variación etaria: sujetos de más edad frente a menos edad

a) En general, los participantes mayores de las dos culturas aplicaron mayor número de estrategias que los jóvenes.

b) Los participantes de los dos subgrupos mostraron tendencia a realizar la petición utilizando estrategias "Convencionalmente indirectas".

c) La estrategia del acto principal más empleada en los datos de ambos subgrupos de edad del corpus español en todas las situaciones de petición fue la "Interrogación preparatoria", excepto en la situación 10, donde los participantes mayores y los menores aplicaron con mayor frecuencia, la estrategia de "Indicio fuerte". Sin embargo, en el corpus malayo, hubo variaciones. Los hablantes de los dos subgrupos de edad coincidieron en mostrar su inclinación hacia el uso de la "Interrogación preparatoria" en la situación 1 y la 16 (hay igualdad del poder relativo entre los interlocutores). En las situaciones 4 y 7, prefirieron, en ambos casos, formular la petición con una "Fórmula de sugerencia". En la situación 10, al igual que los participantes de los dos subgrupos de edad españoles, los de los subgrupos malayos también optaron, en primer lugar, por la utilización de un "Indicio fuerte". Sin embargo, en la situación 13 , los participantes mayores y los menores mostraron preferencia hacia estrategias distintas, los 
primeros hacia la de "Imperativo", y los segundos hacia la "Interrogación preparatoria".

d) Pese a que los dos subgrupos de edad españoles mostraron preferencia por las formas de "Capacidad/posibilidad", aparecen aún con mayor frecuencia en el caso de los hablantes mayores, en comparación con los más jóvenes, mientras que el análisis según el factor edad en este aspecto en el grupo malayo nos revela que no hubo diferencias relevantes entre sujetos mayores y menores.

e) El movimiento de apoyo más utilizado entre los españoles de más edad fue el de "Presentación/saludos", mientras que entre los jóvenes fue el de "Razones". En el grupo malayo, por su parte, mayores y jóvenes manifestaron la misma preferencia por el empleo de las "Fórmulas de tratamiento".

f) Los sujetos de más edad tanto del grupo español como del malayo, produjeron enunciados más largos utilizando más movimientos de apoyo que los jóvenes.

g) La estructura común de petición en los datos de los subgrupos de ambos países fue similar, es decir, movimiento de apoyo + acto principal de petición + movimiento de apoyo.

h) En el caso español, la mayoría de los participantes mayores recurrieron a las estrategias "No convencionalmente indirectas" con las personas de estatus superior y utilizaron mayoritariamente las estrategias "Convencionalmente indirectas" 836 
al hacer la petición a personas del mismo estatus y de estatus inferior, mientras que la mayoría de los sujetos menores aplicaron las estrategias "Convencionalmente indirectas" con todos sus interlocutores. En cuanto a la distancia social, tanto los sujetos españoles mayores como los más jóvenes aplicaron mayoritariamente estrategias "Convencionalmente indirectas", al realizar la petición a personas tanto de baja como de alta familiaridad. En cambio, en el caso malayo, fueron los jóvenes los que utilizaron frecuentemente las estrategias "No convencionalmente indirectas" con las personas de estatus superior y utilizaron mayoritariamente las estrategias "Convencionalmente indirectas" al hacer la petición a personas del mismo estatus y de estatus inferior. Por otro lado, los informantes mayores del grupo malayo utilizaron las estrategias "Convencionalmente indirectas" con personas de estatus superior y del mismo estatus, pero con las de estatus inferior tendieron a utilizar más estrategias "Directas". Respecto a la distancia social, ocurrió lo mismo que en el caso español.

i) Los resultados de las modificaciones internas fueron los siguientes:

- Los encuestados españoles de más edad usaron más el "Nombre de pila" que los de menos edad, mientras que los encuestados mayores malayos utilizaron la forma de "Título" con mayor frecuencia que los menores. 
- Los hablantes mayores mostraron tendencia hacia el uso de la forma tú en mayor medida que los jóvenes, mientras que los sujetos malayos mayores recurrieron al uso de la forma awak más que los menores.

- En el corpus español, fueron los participantes de más edad los que mostraron una mayor inclinación a modificar su petición mediante el empleo de la forma Condicional del verbo, en comparación con los menores, y, en el corpus malayo, también fueron los sujetos mayores los que utilizaron más partículas y sufijos para modificar su petición.

- Los dos subgrupos de edad españoles tendieron a utilizar expresiones en sus peticiones centradas en el oyente, mientras que en los subgrupos malayos encontramos que los hablantes de más edad las focalizaron en el hablante, pero las expresiones elegidas por los menores fueron impersonales.

\section{Varón frente a mujer}

a) En general, las mujeres, tanto en el grupo español como en el malayo usaron más estrategias que los hombres.

b) Los hombres y las mujeres en ambas culturas mostraron la misma tendencia a realizar su petición mediante estrategias "Convencionalmente indirectas". 
c) La estrategia de acto principal mayoritaria en ambos subgrupos de sexo en la sociedad española en todas las situaciones de petición fue la "Interrogación preparatoria", excepto en la situación 10, en la que los hombres la aplicaron con mayor frecuencia, mientras que las mujeres prefirieron servirse de la estrategia de "Indicio fuerte". En la sociedad malaya por su parte, los sujetos de los dos subgrupos de sexo coincidieron en mostrar preferencia por el uso de una "Interrogación preparatoria" en las situaciones 1,13 y la 16 . En la 4 y la 7, en cambio, prefirieron hacer la petición mediante una "Fórmula de sugerencia". En la situación 10, al revés de lo que ocurrió en el caso español, los hombres malayos optaron en primer lugar por el empleo de un "Indicio fuerte", mientras que las mujeres recurrieron más a la "Interrogación preparatoria".

d) Con respecto a las formas de "Capacidad/posibilidad", no hubo una diferencia estadística importante entre los dos géneros ni en el corpus español ni en el malayo.

e) El movimiento de apoyo preferido entre los hombres españoles fue el de "Presentación/saludos", mientras que las mujeres se inclinaron a usar la estrategia de "Fórmulas de tratamiento". Del otro lado, hombres y mujeres malayas, mostraron la misma tendencia hacia el uso de "Fórmulas de tratamiento".

f) Las mujeres de ambas culturas produjeron enunciados más largos utilizando más movimientos de apoyo que los hombres. 
g) La estructura mayoritaria de petición tanto entre los hombres como entre las mujeres de ambos países fue "movimiento de apoyo + acto principal de petición + movimiento de apoyo".

h) En el grupo español, los hombres recurrieron mayoritariamente a las estrategias "Convencionalmente indirectas" con todos sus interlocutores, mientras que la mayoría de las mujeres eligieron realizar su petición a personas de estatus superior a través de las estrategias "No convencionalmente indirectas" y utilizaron mayoritariamente las estrategias "Convencionalmente indirectas" al formular la petición a personas del mismo estatus y de estatus inferior. En lo que se refiere a la distancia social, los participantes españoles de ambos sexos aplicaron mayoritariamente estrategias "Convencionalmente indirectas", tanto al realizar la petición a las personas de baja familiaridad como a las de alta familiaridad. En cambio, en el caso malayo, fueron los hombres los que utilizaron con mayor frecuencia las estrategias "No convencionalmente indirectas" con las personas de estatus superior, y utilizaron mayoritariamente las estrategias "Convencionalmente indirectas" al hacer la petición a personas del mismo estatus y de estatus inferior, mientras que las mujeres usaron comúnmente las estrategias "Convencionalmente indirectas" con todos sus interlocutores. En cuanto a la distancia social, ocurrió lo mismo que en el caso español. 
i) Con respecto a las modificaciones internas, los resultados a los que hemos llegado son los siguientes:

- Las mujeres españolas optaron por el uso del "Nombre de pila" más que los hombres, mientras que las mujeres malayas recurrieron en mayor medida la forma de "Título", en comparación con los hombres.

- Los hombres españoles usaron más tú que las mujeres; en cambio, las mujeres malayas aplicaron awak más que los hombres.

- En cuanto a las modificaciones gramaticales, fueron las mujeres de los dos países, las que mostraron mayor tendencia que los hombres a modificar su petición con la forma Condicional (en el caso del español), y mediante el uso de partículas y sufijos (en el caso malayo).

- En cuanto a la orientación de las expresiones lingüísticas utilizadas en la petición, los sujetos españoles de ambos sexos las orientaron mayoritariamente hacia el oyente, mientras que en el grupo malayo, la mayoría de las expresiones de los hombres fueron de tipo impersonal, y las mujeres tendieron a orientar sus expresiones hacia el hablante. 


\subsection{Resultados principales obtenidos sobre el mandato}

\section{Español frente a malayo}

a) A diferencia de lo que ocurrió en el caso de la petición, en este caso, fueron los españoles los que recurrieron a un mayor número de estrategias de mandato en comparación con los malayos.

b) Los hablantes de ambas sociedades mostraron preferencia por formular su mandato mediante estrategias "Directas".

c) En general, la estrategia de acto principal más común en ambas culturas fue la del "Imperativo". Ahora bien, la estrategia que ocupó el primer lugar de preferencia en cada situación de mandato propuesta en el cuestionario, fue variable. En la situación 3 , en la que se expresa un mandato a un secretario nuevo, la mayoría de los españoles aplicaron la estrategia de "Declaración de deseo", mientras que la estrategia mayoritaria en los datos malayos fue el "Imperativo". En la situación 6, en la que los encuestados tenían que mandar a uno de sus estudiantes que viniera pronto a clase, los españoles optaron en mayor medida por la estrategia de "Indicio fuerte", mientras que los malayos optaron por la "Declaración de deseo". A continuación, en la situación 9, en la que los participantes tenían que hacer el mandato a su hijo adolescente, los españoles tendieron a usar la 842 
estrategia de "Imperativo", pero los malayos mostraron tendencia hacia la "Declaración de obligación". En la siguiente situación, la 12 (mandar a un alumno nuevo que cambie una asignatura), los sujetos de las dos culturas coincidieron en mostrar preferencia hacia el uso de la estrategia de "Fórmula de sugerencia". En la situación 15, con un mandato a un trabajador a tiempo parcial, la estrategia preferida en los datos españoles fue la "Declaración de obligación", mientras que la más usada en los malayos fue el "Imperativo". Finalmente, la situación 18, en la cual un padre/una madre tiene que mandar a su niño que se acueste pronto, los hablantes de ambos países coincidieron otra vez en mostrar tendencia hacia el uso de la estrategia de "Imperativo".

d) El español posee una forma gramatical específica para el mandato. Es la forma del "Imperativo" (canta), que en prohibiciones o mandatos negativos es reformulado por el Presente de Subjuntivo (no cantes), lo mismo que cuando el acto de habla se dirige a una tercera persona (que cante). En cambio, la formulación del imperativo malayo se realiza simplemente mediante la forma del Infinitivo del verbo. Además, hay algunas partículas, sufijos y el uso del verbo tolong (ayudar), delante del verbo correspondiente, para mitigar la fuerza impositiva inherente al imperativo. 
e) El movimiento de apoyo más elegido entre los españoles fueron las "Fórmulas de preparación", mientras que el más empleado entre los malayos fue el de las "Razones".

f) Al contrario de lo que ocurrió en la petición, en este caso, fueron los españoles los que produjeron más enunciados de movimientos de apoyo que los malayos.

g) Los participantes malayos tendieron a utilizar solo un movimiento de apoyo o a prescindir de ellos. Así pues, la estructura mayoritaria aplicada por los malayos fue "movimiento de apoyo + acto principal". Los españoles, por su parte, tendieron a comenzar su mandato con un movimiento de apoyo, siguieron con un acto principal y terminaron con otro movimiento de apoyo ("movimiento de apoyo + acto principal + movimiento").

h) La influencia de la distancia social en el uso de las estrategias de mandato debe ser considerada relevante, ya que, en ambas sociedades, se usaron estrategias "Directas" con las personas con las que existía una distancia más corta, y estrategias "Convencionalmente indirectas" al dirigir el mandato a interlocutores más alejados socialmente del sujeto.

i) Con respecto a las modificaciones internas, tras el estudio realizado se puede afirmar que:

- La mayoría de los participantes de ambos países, usaron el "Nombre de pila" al dirigirse a los interlocutores. 
- Igual que en el caso de la petición, los españoles tendieron a emplear la segunda persona tú al dirigirse a los interlocutores en todas las situaciones de mandato. Los malayos, por su parte, mostraron tendencia hacia el uso de awak, que equivale a tú, en todas las situaciones.

- También de manera similar al caso de la petición, los españoles recurrieron al Condicional en la formulación de su mandato, mientras que los malayos modificaron sus enunciados mediante la utilización de partículas y sufijos.

- La mayoría de las expresiones en los mandatos españoles estaban enfocadas hacia el oyente, mientras que las expresiones mayoritarias de los mandatos malayos estaban centradas en el hablante o eran de tipo impersonal.

\section{Variación etaria: sujetos de más edad frente a menos edad}

a) En este caso, fueron los participantes de más edad los que recurrieron a más estrategias de mandato en comparación con los jóvenes, en ambas culturas, española y malaya.

b) Los participantes de los dos subgrupos de edad de ambas sociedades mostraron preferencia por hacer su mandato mediante estrategias "Directas". 
c) En general, la estrategia de acto principal preferida en los dos subgrupos, tanto españoles como malayos, fue el "Imperativo". Ahora bien, la estrategia que ocupó el primer lugar de preferencia en cada situación de mandato propuesta en el cuestionario, fue diferente en cada caso. En la situación 3, la mayoría de los españoles tanto mayores como menores aplicaron la estrategia de "Declaración de deseo", mientras que la estrategia mayoritaria entre los malayos mayores fue la "Interrogación preparatoria" y, entre los jóvenes, el "Imperativo". En la situación 6, los españoles de más y menos edad optaron en mayor medida por la estrategia de "Indicio fuerte", mientras que en el grupo malayo los informantes mayores eligieron mayoritariamente la estrategia de "Indicio fuerte", y los menores la "Declaración de deseo". En la situación 9, los dos subgrupos de edad españoles mostraron la misma tendencia hacia la utilización de la estrategia de "Imperativo", mientras que los subgrupos malayos se diferenciaron entre sí, empleando los mayores principalmente la "Declaración de obligación", y los menores el "Imperativo". En la siguiente situación, la 12, ambos, mayores y menores, tanto en el grupo español como en el malayo, coincidieron en mostrar preferencia hacia el uso de la estrategia de "Fórmula de sugerencia". En la situación 15 , la estrategia preferida entre los españoles mayores fue la "Declaración de obligación", mientras que la más usada 846 
entre los jóvenes españoles, y los sujetos malayos mayores y menores, fue el "Imperativo". Finalmente, en la situación 18, los participantes de los dos subgrupos de edad de ambos países coincidieron en mostrar un uso más frecuente del "Imperativo", respecto a otras estrategias.

d) El movimiento de apoyo más elegido entre los dos subgrupos de edad españoles fueron las "Fórmulas de preparación", mientras que el más empleado entre los malayos fue el de "Razones".

e) Los sujetos mayores, tanto en el ámbito español como en el malayo, fueron los que produjeron más enunciados usando más movimientos de apoyo que los jóvenes.

f) Los jóvenes malayos tendieron a usar solo el acto principal en su realización de mandato. Así pues, su mandato solo consistió en el acto principal. Los mayores malayos, y los dos subgrupos españoles, por su parte, tendieron a comenzar su mandato con un movimiento de apoyo, seguido del acto principal primero y de otro movimiento de apoyo después ("movimiento de apoyo + acto principal + movimiento de apoyo").

g) En cuanto a la influencia de la distancia social en el uso de las estrategias de mandato, ambos, hablantes mayores y menores, en ambas sociedades, usaron las estrategias "Directas" con las personas de las que los separaba una distancia corta, mientras que al dirigir el mandato a las personas situadas a mayor 
distancia, se aplicaron las estrategias "Convencionalmente indirectas", también en los dos grupos culturales.

h) En lo que atañe a las modificaciones internas, hemos llegado a las siguientes conclusiones:

- Pese a que los dos subgrupos de edad de ambos países, usaran mayoritariamente el "Nombre de pila" al dirigirse a sus interlocutores, fueron los hablantes mayores los que lo aplicaron con mayor frecuencia en el grupo español. Al contrario, en el grupo malayo, fueron los jóvenes los que lo utilizaron más.

- Los participantes de más edad de la sociedad española tutearon al interlocutor más que los menores. En la sociedad malaya, por su parte, los jóvenes aplicaron más la forma de awak (equivalente a $t \hat{\imath})$ que los hablantes mayores.

- No hubo diferencias relevantes entre sujetos mayores y menores en cuanto al uso del Condicional en el corpus español, de la misma manera que en el corpus malayo tampoco hubo diferencias importantes entre los subgrupos de edad en el uso de las partículas y los sufijos.

- La mayoría de las expresiones en los mandatos de los dos subgrupos españoles se centran en el oyente, mientras que las expresiones mayoritarias de los mandatos de los subgrupos malayos fueron de tipo impersonal. 


\section{Varón frente a mujer}

a) Las mujeres recurrieron a más estrategias de mandato en comparación con los hombres, en ambos grupos, español y malayo.

b) Los subgrupos de sexo de ambas sociedades mostraron preferencia hacia la formulación de su mandato mediante estrategias "Directas".

c) En general, la estrategia de acto principal mayoritaria entre los participantes de los dos subgrupos de sexo en ambas culturas fue el "Imperativo". Ahora bien, la estrategia más utilizada en cada situación de mandato propuesta en el cuestionario, fue variable. En la situación 3, la mayoría de los hombres españoles se inclinó por la "Declaración de deseo", mientras que las mujeres lo hicieron hacia la "Interrogación preparatoria. Los hablantes de ambos sexos malayos optaron con mayor frecuencia por el uso de la estrategia de "Imperativo". En la situación 6 , los hombres y las mujeres españolas mostraron la misma tendencia hacia la utilización de la estrategia de "Indicio fuerte", mientras que, en el otro grupo, los hombres recurrieron más al "Indicio fuerte", y las mujeres a la "Declaración de deseo". En la situación 9, los dos subgrupos de sexo españoles emplearon, en la mayor parte de los casos, la estrategia de "Imperativo", mientras que los subgrupos de sexo malayos se 
diferenciaron entre sí, al preferir los hombres la de "Imperativo" y las mujeres la de "Declaración de obligación". En la siguiente situación, la 12, hombres y mujeres, malayos y españoles, coincidieron en un mayor empleo de la estrategia de "Fórmula de sugerencia". En la situación 15, la estrategia preferida entre los hablantes españoles de los dos sexos fue la "Declaración de obligación", mientras que la más usada entre los sujetos malayos, también de ambos géneros, fue el "Imperativo". Finalmente, en la situación 18, los subgrupos de sexo en ambas culturas coincidieron en su preferencia por la estrategia de "Imperativo".

d) El movimiento de apoyo más frecuentemente elegido por los hombres españoles fue el de "Fórmulas de preparación", mientras que el más empleado entre las mujeres fueron las "Razones". Por otro lado, los hombres malayos recurrieron mayoritariamente a las "Razones", mientras que las mujeres tendieron a usar la estrategia de "Fórmulas de tratamiento".

e) Las mujeres, tanto en el ámbito español como en el malayo, produjeron un mayor número de enunciados como movimientos de apoyo que los hombres.

f) Los mandatos de los hombres malayos solo constaban del acto principal. Las mujeres malayas, y los dos subgrupos de sexo españoles, por su parte, se mostraron más expresivos y tendieron a comenzar su mandato con un movimiento de apoyo 850 
seguido de un acto principal y lo terminaron con otro movimiento de apoyo ("movimiento de apoyo + acto principal + movimiento de apoyo").

g) Respecto a la influencia de la distancia social en el uso de las estrategias de mandato, ambos, hombres y mujeres mayores de ambos países, prefirieron realizar el mandato mediante estrategias "Directas" con personas de las que los separaba una corta distancia social, y al dirigir el mandato a personas colocadas en el contexto situacional a una mayor distancia social, tendieron a usar estrategias "Convencionalmente indirectas".

h) El análisis de las modificaciones internas nos ha llevado a las siguientes conclusiones:

- En los datos españoles, fueron los hombres los que mostraron la tendencia más fuerte hacia el uso de la forma del "Nombre de pila" al dirigirse a los interlocutores. En cambio, en los malayos, fueron las mujeres las que aplicaron dicha forma en mayor medida que los hombres.

- Los hombres españoles tutearon a sus interlocutores más que las mujeres, mientras que en la sociedad malaya, las mujeres usaron más la forma de awak (equivalente a $t u \hat{\text { ) }}$ que los hombres.

- De manera similar a lo que ocurrió con los subgrupos de edad, en este caso tampoco hubo diferencias relevantes entre los hombres y las mujeres de la sociedad española en cuanto al 
uso del condicional. Sin embargo, en el corpus malayo, las mujeres mostraron una tendencia más firme hacia el uso de las partículas y los sufijos en comparación con los hombres.

- Al igual que en el caso de los subgrupos de edad, la mayoría de las expresiones de los mandatos formulados por los sujetos de los dos subgrupos de sexo españoles están enfocados hacia el oyente, mientras que las expresiones mayoritarias de los mandatos de los participantes de los subgrupos de sexo malayos fueron impersonales.

\subsection{Resultados principales obtenidos sobre el rechazo}

\section{Español frente a malayo}

a) Los malayos utilizaron las estrategias de rechazo en mayor medida que los españoles en las seis situaciones de rechazo propuestas en el cuestionario.

b) Los sujetos de ambos grupos prefirieron expresar el rechazo con estrategias "Indirectas".

c) Los españoles emplearon más estrategias "Directas" que los malayos, así pues, los malayos recurrieron más que los españoles, a las "Indirectas" y las de "Adyacentes al rechazo". 
d) La estrategia más empleada en los dos grupos fue la "Excusa", ahora bien, fueron los malayos los que la utilizaron con mayor frecuencia que los españoles.

e) Las estrategias de "No" y "Saludos/despedidas corteses" solo aparecen en los datos españoles.

f) Tanto los participantes españoles como los malayos tendieron a comenzar su rechazo con una "Disculpa", pero fueron los malayos los que mostraron una tendencia más fuerte a iniciar sus mandatos con dicha estrategia.

g) Los españoles utilizaron más que los malayos la estrategia de "Agradecimiento", en cambio, los malayos recurrieron en mayor medida a las "Fórmulas de tratamiento".

h) La influencia de la variable social (estatus y distancia) no fue significativa, ya que los informantes de los dos grupos utilizaron estrategias "Indirectas" al rechazar tanto las peticiones 0 propuestas de personas de estatus superior como las del mismo estatus o estatus inferior. Y ocurrió lo mismo en el caso de la distancia social, es decir, se emplearon estrategias "Indirectas" tanto con las personas de baja familiaridad como con las de alta familiaridad.

i) En cuanto al contenido de las excusas, las que pusieron los españoles fueron más específicas y detalladas, mientras que las de los malayos fueron vagas y ambiguas. 
j) Los españoles tendieron a ser más directos en sus excusas y expusieron como motivos del rechazo sus ocupaciones más prioritarias, excusas a las que los malayos recurrieron en un menor número de ocasiones, ya que la tendencia mayoritaria en esa cultura fue poner como disculpa a terceras personas.

\section{Variación etaria: sujetos de más edad frente a menos edad}

a) La diferencia en la frecuencia de uso de las estrategias de rechazo entre los hablantes mayores y los menores de ambos países fue muy pequeña.

b) Los sujetos de más edad y los menores en ambos grupos prefirieron formular el rechazo mediante el empleo de estrategias "Indirectas".

c) Los hablantes mayores de las dos sociedades usaron más estrategias "Directas" y "Adyacentes al rechazo" que los jóvenes, quienes aplicaron más estrategias "Indirectas" que los mayores.

d) La estrategia preferida en los dos subgrupos de ambas culturas fue la "Excusa", ahora bien, fueron los mayores los que recurrieron a ella en un mayor número de ocasiones.

e) La diferencia en la frecuencia de uso de las estrategias de "No" y "Saludos/despedidas corteses" entre los hablantes mayores y los jóvenes españoles fue muy pequeña. 
f) En cuanto a la estrategia de "Disculpa", fueron los de más edad los que más la utilizaron en ambos casos, español y malayo.

g) Los jóvenes españoles emplearon la estrategia de "Agradecimiento" más que los sujetos de más edad. En el grupo malayo, los sujetos de menos edad recurrieron a la estrategia de "Fórmulas de tratamiento" en más enunciados que los mayores.

h) Al igual que el caso del criterio de análisis español versus malayo, la influencia de la variable social (estatus y distancia) no fue significativa, ya que los sujetos de los subgrupos de los dos países utilizaron las estrategias "Indirectas" al rechazar bien las peticiones o propuestas de personas de estatus superior, bien las de interlocutores del mismo estatus o estatus inferior. Y ocurrió lo mismo en el estudio de las respuestas desde el punto de vista de la distancia social, que reveló un empleo mayoritario de estrategias "Indirectas" tanto con las personas de baja familiaridad como con las de mayor familiaridad.

i) Las excusas planteadas por los hablantes mayores españoles fueron más específicas y detalladas que las que expusieron los jóvenes, mientras que en el grupo malayo las excusas producidas por los jóvenes fueron más vagas y ambiguas que las del otro subgrupo.

j) Los participantes de menos edad de ambas sociedades fueron más directos en sus excusas que los de más edad. 


\section{Varón frente a mujer}

a) Las mujeres produjeron más enunciados que los hombres en la expresión de sus rechazos, en ambos grupos, español y malayo.

b) Los dos subgrupos de sexo de ambos grupos prefirieron formular su rechazo mediante estrategias "Indirectas".

c) Las mujeres de la sociedad española produjeron más enunciados que los hombres, tanto con estrategias "Directas", como con "Indirectas" y "Adyacentes al rechazo", mientras que en la otra sociedad, los hombres aplicaron más estrategias "Directas", siendo las "Indirectas" y las "Adyacentes al rechazo" más empleadas por las mujeres.

d) Las mujeres de los dos grupos, recurrieron a la estrategia de "Excusa", más que los hombres.

e) Al igual que en el caso de los subgrupos de edad, la diferencia en la frecuencia de uso de las estrategias de "No" y "Saludos/despedidas corteses" entre los hombres y las mujeres españolas fue muy pequeña.

f) En cuanto a la estrategia de "Disculpa", fueron los hombres los que mostraron mayor tendencia a su uso en el caso español, mientras que en la cultura malaya, fueron las mujeres.

g) Los hombres utilizaron más la estrategia de "Agradecimiento" en el grupo español, y, las mujeres usaron en mayor medida la estrategia de "Fórmulas de tratamiento", en el grupo malayo. 
h) Respecto a la influencia de la variable social (estatus y distancia), el resultado fue el mismo que el del caso anterior, es decir, el obtenido al contrastar las respuestas de los participantes mayores y menores.

i) Las excusas de las mujeres españolas fueron más específicas y detalladas que las de los hombres, mientras que en el grupo malayo las excusas formuladas por las mujeres fueron menos vagas y ambiguas que las de los hombres.

j) Los hombres de los dos países fueron más directos en sus excusas que las mujeres.

\subsection{Conclusión final}

Los resultados revelan las semejanzas y diferencias en los tres actos realizados por los hablantes nativos de los dos idiomas estudiados, en cada contexto específico planteado. En general, los nativos de ambas culturas emplearon las mismas estrategias pero su distribución varió según el contexto, y los grupos comparados se diferenciaron en cuanto al contenido de las estrategias y las modificaciones aplicadas.

Según los resultados obtenidos en lo referente al acto de habla de la petición, en general, los participantes españoles fueron 
más directos, utilizando la estrategia más directa, el "Imperativo", con mayor frecuencia, en comparación con los malayos, y aplicaron menos movimientos de apoyo que aquellos. Los hablantes de los dos países coincidieron al seleccionar las estrategias de petición, tanto en la estrategia más utilizada como en el uso de otras estrategias, en todos los contextos propuestos en el cuestionario. Ahora bien, los españoles y los malayos se diferenciaron respecto a las modificaciones aplicadas, tanto externas como internas, para reducir la intensidad ilocucionaria de la petición.

A diferencia de lo encontrado en la petición, en el caso del mandato, los hablantes malayos fueron más directos, ya que utilizaron en mayor medida el "Imperativo", en comparación con los españoles, y usaron menos movimientos de apoyo que los españoles. Aun así, basándonos en el análisis situacional, la tendencia y la preferencia demostrada varía transculturalmente. Al igual que ocurrió con la petición, los grupos comparados difirieron en cuanto a las modificaciones, externas e internas, al realizar el mandato.

En el caso del acto de habla de rechazo, en general, los españoles fueron más directos, lo que se pone de manifiesto en una mayor frecuencia de las estrategias "Directas", en comparación con los malayos. Y la frecuencia de uso de las estrategias de rechazo en los datos españoles fue menor que en los malayos. En este caso, la 858 
preferencia mostrada por las dos comunidades de habla también fue similar. Sin embargo, los participantes de ambas sociedades se diferenciaron con respecto al contenido de la estrategia más recurrente, la "Excusa".

En lo que concierne al uso de las estrategias de petición, mandato y rechazo, los resultados de la presente investigación demuestran que fueron los españoles los que manifestaron una mayor tendencia al uso de las estrategias de "Agradecimiento" y "Saludos", mientras que los hablantes del otro grupo emplearon de manera más frecuente las "Fórmulas de tratamiento", en la realización de dichos actos de habla, lo que implica que los españoles suelen saludar o dar las gracias a los interlocutores como una manera de expresar la cortesía, mientras que los malayos recurren a las "Fórmulas de tratamiento" para tal fin.

Según nuestros datos, no hubo una evidencia considerable respecto a los efectos de la diferencia de edad y sexo de los encuestados de ambas culturas ni en la elección de estrategias ni en el contenido o las modificaciones aplicadas, al realizar los tres actos sometidos a estudio. Tanto los sujetos de más edad como los menores, y tanto los hombres como las mujeres, en ambos grupos, español y malayo, utilizaron las mismas estrategias, mostraron las mismas preferencias y modificaron su petición, mandato y rechazo 
de manera idéntica. Tampoco resultan relevantes las diferencias estadísticas encontradas entre los dos subgrupos, edad y sexo, en ninguno de los dos países.

En cuanto a las variables sociales, el estudio ha demostrado que la diferencia de estatus social y el grado de familiaridad entre los interlocutores, tiene una influencia significativa en la preferencia por uno u otro tipo de estrategia en los actos de habla investigados y formulados por los sujetos de ambos países. En las peticiones de los participantes españoles se encontró como patrón el empleo del verbo en la forma Condicional, y la fórmula de tratamiento pronominal usted al dirigirse a personas desconocidas y de estatus superior. Pero el empleo de dichos recursos se redujo considerablemente al realizar la petición a personas conocidas y a las del mismo estatus o de estatus inferior. En los datos malayos, las peticiones a personas de estatus superior y de baja familiaridad muestran un mayor uso de los "Honoríficos" y los "Términos de cortesía" para dirigirse a los interlocutores. En cambio, cuando se trata de personas del mismo estatus o estatus inferior, y personas de alta familiaridad, el empleo de dichas formas bajó significativamente.

Por último, es necesario destacar que cada cultura tiene unos usos culturales específicos en sus peticiones, mandatos y rechazos. Por ejemplo, cuando los malayos hablan con una persona 860 
de estatus social superior, tienden a la repetición del uso de fórmulas de tratamiento de "Título", como profesor o "Término de cortesía" encik/puan ('señor/a ), mientras que en español, se recurre al pronombre usted, precisamente para no repetir esa forma nominal.

Ser consciente de las similitudes y las diferencias puede ayudar a resolver los posibles malentendidos en la comunicación transcultural, y permitirá a los hablantes de una segunda lengua realizar los actos de habla mencionados de forma acorde con las reglas de la lengua meta, para que puedan lograr la mejor manera sus objetivos sin parecer ser descorteses.

Thomas (1983) y Wolfson (1989) enfatizan la importancia de la violación de las reglas del habla. A diferencia de los errores gramaticales, que son atribuidos a una deficiencia lingüística, los errores pragmáticos se pueden juzgar como una manifestación de trastornos de la personalidad. La falta de entendimiento de la diversidad sociolingüística de otras culturas conduce a malentendidos transculturales serios, y al tener Malasia y España dos tipos muy diferentes de culturas mayoritarias, los miembros de estas sociedades son propensos a interpretar mal la intención del otro durante una interacción. 
Finalmente, cabe mencionar que este estudio, como consecuencia del análisis de las diferencias entre los españoles y los malayos en el empleo de las estrategias de los tres actos estudiados, también ha podido revelar diferentes características de cada cultura que se reflejaron en el empleo de estrategias de los actos de habla examinados. El reconocimiento de diferentes valores y normas ligadas al comportamiento en el habla puede ayudar a minimizar potenciales malentendidos transculturales, así como facilitar el desarrollo de la tolerancia hacia los que son diferentes.

\subsection{Aplicaciones de esta investigación}

Aunque se han realizado muchos estudios contrastivos sobre actos de habla, todavía no existe ningún estudio en el que se haga una comparación de la formulación de actos de habla específicos entre hablantes españoles y malayos. Las peticiones, los mandatos y los rechazos malayos tienen semejanzas con los del japonés, chino, y son también similares a los que Bardovi-Harlig y Hartford (1991) encuentran entre los hablantes no nativos del inglés. Este estudio supone un paso más en la investigación dedicada a la pragmática transcultural, ya que son escasas las investigaciones centradas en actos de habla, sobre todo en aquellos realizados por malayos. Los

resultados de este estudio se pueden comparar con el trabajo 862 
anterior llevado a cabo en esta área y proporcionar campos de investigación futura.

El presente estudio también contribuye al entendimiento transcultural. Tomar conciencia de las diferencias entre los actos de habla analizados de una y otra cultura puede minimizar potenciales malentendidos. Por ejemplo, si los malayos no expresan ninguna muestra de agradecimiento en su petición a los interlocutores con los que mantienen un alto grado de familiaridad, los españoles deberían ser conscientes de que en la cultura malaya, la expresión manifiesta de apreciación se utiliza rara vez con los familiares y los amigos íntimos. Incluso si los malayos dan explicaciones muy vagas que no se consideran aceptables desde el punto de vista español, no es que sean poco sinceros o mentirosos, simplemente es su estilo de comunicación. Los malayos, por otra parte, deberían ser conscientes de que aludir a sus propias ocupaciones prioritarias a la hora de poner una disculpa es algo aceptable entre españoles y no deberían sentirse heridos al afrontar esta situación. Sin un conocimiento explícito sobre otras culturas, los hablantes que participan en la comunicación son propensos a interpretar mal las intenciones de sus interlocutores en ambientes culturales diferentes, ya que la gente probablemente interpretará los comportamientos de los demás dentro de su propio conjunto de valores y normas. 
Los presentes resultados también pueden contribuir a la enseñanza y aprendizaje de un idioma, ayudando a aquellos cuya profesión conlleva la enseñanza de lenguas extranjeras. La fluidez en una lengua requiere más que un dominio del conocimiento lingüístico. A los estudiantes de una lengua no solo se les debe enseñar el empleo de unas formas lingüísticas correctas, sino también todo lo relativo a mantener un discurso adecuado. Los estudios en el campo de la Pragmática interlingüísitica revelan que hasta los estudiantes avanzados de lenguas carecen de la competencia pragmática necesaria. Además, los libros de texto existentes a menudo describen con poca exactitud el uso de la lengua (Bardovi-Harlig, Hartford, Mahan Tayor, Morgan y Reynolds, 1991). Así, los profesores deben disponerse a ayudar a los estudiantes a adquirir competencia pragmática en el idioma de destino (Bardovi-Harlig, 1992).

Los resultados de este estudio pueden ayudar a los profesores a darse cuenta de las diferencias sobre cómo pedir y negarse adecuadamente en cada cultura. Se aconseja, por ejemplo, a los estudiantes malayos que quieran estudiar en España formular la negación más directamente y dar explicaciones más explícitas.

Algunas respuestas españolas como, "¿Vienes a mi casa?", "¿Me acompañas a la compra?", "¿Me prestas tu móvil?", etc., 864 
podrían no interpretarse como peticiones por los malayos ya que no tienen sentido de petición en la lengua malaya y pueden causar malentendidos. Los malayos pueden aprender a tomar estas respuestas como petición cuando vienen de españoles. Por su parte, los españoles deberían no solo recibir con exactitud los mensajes comunicados, sino también tratar de no formular rechazos demasiado directos. Los malayos probablemente tomarán un rechazo frontal como algo que les avergüenza. También se aconseja a los españoles utilizar motivos no basados en sus propias preferencias a la hora de rechazar. Por ejemplo, expresiones como "tengo mucho trabajo que hacer" no deberían utilizarse como respuestas a peticiones malayas. Al oír esta excusa, un malayo probablemente pensará que los españoles son muy fríos, y esta percepción será perjudicial para la relación. En otras palabras, debería proveerse a los estudiantes de idiomas de nociones básicas sobre los modelos generales de peticiones, mandatos y rechazos en diferentes culturas, a fin de poder llegar a relacionarse con éxito con gente de entornos diferentes. 


\subsection{Orientación para futuras investigaciones}

Blum-Kulka y House (1989) encuentran que los factores internos del contexto, como los tipos de objetivo de la petición, el grado de imposición que implica para el hablante en relación al objetivo específico, y los requisitos previos necesarios para el acuerdo, son importantes a la hora de determinar el nivel de (in)dirección de las estrategias seleccionadas para llevar el cabo el acto de habla, así como factores externos de contexto como la distancia o el estatus social. Brown y Levinson (1978) proponen diferenciar las culturas en virtud del peso relativo que se da a los factores sociales a la hora de determinar las variaciones del comportamiento. Dado que es posible que las percepciones malayas de los factores sociales sean diferentes de las españolas, el grado de imposición que conlleva una situación puede variar de una cultura a otra. Por ejemplo, pedir una carta de recomendación a un profesor universitario puede ser un acto más impositivo para los malayos que para los españoles. Las distintas percepciones sobre una situación influyen en el uso estratégico de modelos de actos realizados. Sin embargo, el análisis de los datos de este estudio se realizó conforme a la asunción de que las interpretaciones de los factores contextuales son las mismas tanto en la cultura malaya como en la cultura española. 
Para entender mejor la relación entre los factores sociales y los patrones de habla, sería útil descubrir cómo valoran las situaciones descritas en el cuestionario los dos grupos culturales. Pidiendo a los sujetos de cada cultura que den su opinión sobre el grado de imposición en una cierta situación, podríamos comparar la manera en que cada cultura percibe las situaciones.

Las variables sociales consideradas en esta investigación son el estatus y la distancia social entre el emisor y el destinatario, de acuerdo con el estudio fundamental de la cortesía lingüística de Brown y Levinson (1987). Sin embargo, podría haber factores adicionales que jugaran un rol en la manera en que los actos de habla son formulados por el hablante, como el sexo y la edad de los interlocutores, por ejemplo. Pero debido a limitaciones de tiempo, este tema queda reservado para futuras investigaciones.

Finalmente, deberían ser llevados a cabo más estudios sobre la universalidad de los actos de habla considerando las diferencias de los patrones de uso en los tres actos examinados, tanto entre el malayo y otros idiomas occidentales, como entre el español y otras lenguas orientales. Estas sugerencias son importantes para ampliar y fomentar estudios profundos en esta área y, especialmente, en el ámbito de la comparación transcultural de lenguas tipológicamente diferentes. 



\section{BIBLIOGRAFÍA}

ABDULLAH HASSAN. (2002). Tatabahasa bahasa Melayu morfologi dan sintaksis. Kuala Lumpur: PTS Publications and Distributors Sdn. Bhd.

ACHIBA, M. (2003). Learning to request in a second language: child interlanguage pragmatics. Clevedon: Multilingual Matters.

ALBELDA, M. (2005). La intensificación en el español coloquial. Valencia: Universitat de Valencia.

AL-ERYANI, A.A. (2007). "Refusal strategies by Yemeni EFL learners". The Asian EFL Journal, Volume 9, Number 2, 19-34.

AL-ISSA, A. (2003). "Sociocultural transfer in L2 speech behaviors: Evidence and motivating factors". International Journal of Intercultural Relations, 27(5), 581-601.

AL-SHALAWI, H. (1997). Refusal strategies in Saudi and American cultures. Unpublished Master's Thesis, Michigan: Michigan State University.

ASMAH HAJI OMAR. (2002). Nahu Melayu mutakhir. Kuala Lumpur: Dewan Bahasa dan Pustaka.

ASMAH HAJI OMAR. (1987). Malay in its sociocultural context. Kuala Lumpur: Dewan Bahasa dan Pustaka.

ASMAH HAJI OMAR. (1986). Bahasa dan alam pemikiran Melayu. Kuala Lumpur: Dewan Bahasa dan Pustaka. 
ASMAH HAJI OMAR. (1982). Language and society in Malaysia. Kuala Lumpur: Dewan Bahasa dan Pustaka.

AUSTIN, W.P. (1975). How to do things with words. Cambridge: Harvard University Press.

AUSTIN, W.P. (1962). How to do things with words. Oxford: Clarendon Press.

BABA, T. y LIAN, L. C. (1992). "Differences between the Chinese and Japanese request expressions". Journal of Hokkaido University of Education, 42 (1), 57-66.

BADLI ESHAM AHMAD y FAIZAH ABDUL MAJID. (2010). "Cultural influence on SDL among Malay adult learners". European Journal of Social Sciences - Volume 16, Number 2, 244.

BALLESTEROS MARTÍN F. J. (2001). "La cortesía española frente a la cortesía inglesa. Estudio pragmalingüístico de las exhortaciones impositivas". Estudios Ingleses de la Universidad Complutense, 9: 171-207.

BALLMER, T. y BRENNENSTUHL, W. (1981). Speech act classification. A study in the lexical analysis of English speech activity verbs. Berlín: Springer-Verlag Berlin Heidelberg.

BARDOVI-HARLIG, K., HARTFORD, B.S. (1990). "Congruence in native and non-native conversations: status balance in the academic advising session". Language Learning 40 (4), 467-501.

BARDOVI-HARLIG, K., HARTFORD, B.S. (1991). "Saying "no" in English: native and nonnative rejections". En Bouton, L., y Kachru, Y. (eds.), Pragmatics and Language Learning. Monograph Series, vol. 2, 41-58.

BARDOVI-HARLIG, K., HARTFORD, B.S., MAHAN-TAYLOR, R., MORGAN, M. J., y REYNOLDS, D.W. (1991). "Developing pragmatic awareness: closing the conversation". ELT Journal, 45, 4-15.

BARDOVI-HARLIG, K., HARTFORD, B.S. (1992). "Refining the DCT: comparing open questionnaires and dialogue completion task". Paper presented to the sixth International Conference on Pragmatics and language Learning. 
BARDOVI-HARLIG, K., HARTFORD, B.S. (2008 [2005]). "Institutional discourse and interlanguage pragmatics research". En Bardovi-Harlig, K., Hartford, B.S., Interlanguage pragmatics, exploring institutional talk. London: Routledge, 7-37.

BARRON, A. (2002). Acquisition in interlanguage pragmatics: Learning how to do things with words in a study abroad context. Philadelphia: John Benjamins.

BEEBE, L.M., y CUMMING, M.C. (1996). "Natural speech act data versus written questionnaire data: how data collection method affects speech act performance". En Gass, S.M. y Neu, J. (eds.), Speech acts across cultures. Berlín: Mouton de Gruyter, 65-86.

BEEBE, L.M., y TAKAHASHI, T. (1987). "The development of pragmatic competence by Japanese learners of English". JALT Journal 8, 131-155.

BEEBE, L.M., y TAKAHASHI, T. (1989). "Sociolinguistic variation in face-threatening speech acts." En Eisenstein, M.R. (eds.), The dynamic interlanguage: empirical studies in second language acquisition. New York: Plenum Press, 199- 218.

BEEBE, L.M., TAKAHASHI, T., y ULISS-WELTZ, R. (1990). "Pragmatic transfer in ESL refusals". En Scarcella, R., Anderson, E. y Krashen, S. (eds.), Developing communicative competence in a second language. New York: Newbury House, 55-73.

BEEBE, L.M., y MARTHA C. CUMMINGS. (1985). "Speect act performance: A funtion of the data collection procedure? Paper presented at TESOL Convention, New York, NY.

BLUM-KULKA y OLSHTAIN. (1984). "Requests and apologies: A cross-cultural study of speech act realization patterns (CCSARP)". Applied Linguisics, 5 (I) 3: 196-214.

BLUM-KULKA, S., DANET, B. y GHERSON, R. (1985). "The language of requesting in Israeli society". En Joseph P. Forgas (eds.), Language and Social Situation, New York: Springer Verlag, 113-141.

BLUM-KULKA, S. (1982). "Learning to say what you mean in a second language: a study of the speech act performance of learners of Hebrew as a second language". Applied Linguistics, 3, 29-59.

BLUM-KULKA, S. (1987). "Indirectness and politeness in request: same or different?". Journal of Pragmatics, 11, 131-146. 
BLUM-KULKA, S. (1989). "Playing it safe: the role of conventionality in indirectness". En Blum-Kulka, S., House, J. y Kasper, G. (eds.), Cross-cultural pragmatics: requests and apologies. Norwood, NJ: Ablex Publishing Corporation, 37- 70.

BLUM KULKA, S. (1990). "You don't touch lettuce with your fingers. Parental politeness in family discourse". Journal of Pragmatics 14, 259-288.

BLUM-KULKA, S. (1992). "The metapragmatics of politeness in Israeli society". En Watts, R., Ide, S. y Ehlich, K. (eds.), Politeness in language: studies in its history, theory and practice. Berlin: Mouton de Gruyter, 255-280.

BLUM-KULKA, S. (1996). "Introducción a la pragmática del interlenguaje". En Cenoz J. y José, F., La competencia pragmática: elementos lingüísticos y psicosociales. Bilbao: Universidad de País Vasco, 155-170.

BLUM-KULKA, S. (1996). "Más allá de los actos de habla: discurso metapragmático y bilingüismo". En Cenoz J. y José, F., La competencia pragmática: elementos lingüísticos y psicosociales. Bilbao: Universidad de País Vasco, 239-258.

BLUM-KULKA, S. (1996). "Variaciones en la formulación de peticiones". En Cenoz J. y José, F., La competencia pragmática: elementos lingüísticos y psicosociales. Bilbao: Universidad de País Vasco, 179-186.

BLUM-KULKA, S., HOUSE, J. (1989). Cross-cultural and situational variation in requesting behavior. En Blum-Kulka, S., House, J. y Kasper, G. (eds.), Cross-cultural pragmatics: requests and apologies. Norwood, NJ: Ablex Publishing Corporation, 123 - 154.

BLUM-KULKA, S., HOUSE, J., y KASPER, G. (1989). "Investigating cross-cultural pragmatics: an introductory overview". En Blum-Kulka, S., House, J. y Kasper, G. (eds.), Cross-cultural pragmatics: requests and apologies. Norwood, NJ: Ablex Publishing Corporation, 1-34.

BODMAN, J., y EISENSTEIN, M. (1988). "May God increase your bounty: the expressions of gratitude in English by native and nonnative speakers". Cross currents, 15 (1), 1-21.

BRAVO, D. (2003). "Actividades de cortesía, imagen social y contextos socioculturales: una introducción". En Bravo, D. y Briz, A. (eds.), Pragmática sociocultural: estudios sobre el discurso de cortesía en español. Barcelona: Ariel, 96-108. 
BRAVO, D. (2004). "Tensión entre universalidad y relatividad en las teorías de la cortesía". En Bravo, D. y Briz, A. (eds.), Pragmática sociocultural: estudios sobre el discurso de cortesía en español. Barcelona: Ariel, 15-37.

BRESNAHAN, M. J., OHASHI, R, LIU, W. Y., NEBASHI, R. y LIAO, C. (1999). "A comparison of response styles in Singapore and Taiwan". Journal of Cross-Cultural Psychology, 30 (3), 342-358.

BROWN, P., y LEVINSON, S. C. (1978). "Universals in language usage: politeness phenomena". En Goody, E., N. (eds.), Questions and politeness. Cambridge: Cambridge University Press, 56-324.

BROWN, P. y LEVINSON, S. C. (1987 [1978]). Politeness. Some universals in language usage. Cambridge: Cambridge University Press.

CANALE, M. y SWAIN, M. (1980). "Theoretical bases of communicative approaches to second language teaching and testing". Applied Linguistics, 1, 1-47.

CHANG Y.F. (2009). "How to say no: an analysis of cross-cultural difference and pragmatic transfer". Language Sciences, 31, 477-493.

CHEN, H. (1996). Cross-cultural comparison of English and Chinese metapragmatics in refusal. Unpublished Doctoral Dissertation, Indiana: Indiana University.

CHEN, S. y CHEN, E. (2007). "Inter-language requests: a crosscultural study of English and Chinese. The Linguistics Journal, 2, 3352.

CHEN, X. y L., ZHANG, Y. (1995). "Refusing in Chinese". En Kasper, G. (eds.), Pragmatics of Chinese as native and target language (Technical Report \#5). Manoa: University of Hawaii Press, 119-163.

CHUNG, S.A. (1995). "A cross-cultural pragmatic exploration of polite request strategies: Chinese and American English". Dissertation Abstracts International, DAIA 56 (04).

COHEN, A. (1996). "Investigating the production of speech act sets". En Speech acts across cultures: challenges to communication in a second language. Berlin, New York: Mouton de Gruyter, 21-43.

COHEN, A. (1996). "Speech acts". En McKay, S. y Hornberger, N. (eds.), Sociolinguistics and language teaching. New York: Cambridge University Press, 383-420. 
COHEN, A. (1987). "Problems in intercultural communication in Egyptian-American diplomatic relations". International Journal of Intercultural Relations, 11, 29-47.

CURCÓ, C. y DE FINA, A. (2002). "Modo imperativo, negación y diminutivos en la expresión de la cortesía en español: el contraste entre México y España". En Placencia, M.E y Bravo, D., Actos de habla y cortesía en español. Lincom Europa, 107-140.

CURCó, C. (1998). "¿No me harías un favorcito?: Reflexiones en torno a la expresión de la cortesía verbal en el español de México y el español peninsular". En Henk Haverkate, Gijs Mulder, y Carolina Fraile Maldonado (eds.), La pragmática lingüística del español, Diálogos hispánicos, 22: 129-172.

DÍAZ PÉREZ, F. J. (2006). "Deixis and verbal politeness in request production in English and Spanish". Cultural Studies Journal of Universitat Jaume 1, Vol III, 161-176.

ECONOMIDOU-KOGETSIDIS, M. (2010). "Cross-cultural and situational variation in requesting behaviour: perceptions of social situations and strategic usage of request patterns". Journal of Pragmatics, 42, 2262-2281.

EISENSTEIN, M. y BODMAN, J. (1986). "I very appreciate': expressions of gratitude by native and non-native speakers of American English". Applied linguistics, 7(2), 167-185.

EISENSTEIN, M. y BODMAN, J. (1995). "Expressing gratitude in American English. En Kasper, G. y Blum-Kulka, S. (eds.)", Interlanguage pragmatics. New York: Oxford University Press, 64-81.

EISENSTEIN, M., BODMAN, J. y CARPENTER, M. (1996). "Crosscultural realization of greetings in American English". En Speech acts across cultures: challenges to communication in a second language. Berlin, New York: Mouton de Gruyter, 89-107.

ELLIS, R. (1993). The study of second language acquisition. Oxford: Oxford University Press.

ERVIN-TRIPP, S., JIANSHENG, G. y MARTIN L. (1990). "Politeness and persuasion in children's control acts". Journal of Pragmatics 14, 307-331.

ESCANDELL VIDAL, MARÍA VICTORIA. (2007). Introducción a la pragmática. Barcelona: Ariel. 
FÉLIX-BRASDEFER, J.C. (2002). Refusals in Spanish and English: $A$ cross-cultural study of politeness strategies among speakers of Mexican Spanish, American English, and American learners of Spanish as a foreign language. Tesis Doctoral, Minnesota: University of Minnesota.

FÉLIX-BRASDEFER, J. C. (2003). "Declining an invitation: a crosscultural study of pragmatic strategies in American English and Latin American Spanish". Multilingua, 22 (3), 225-55.

FÉLIX-BRASDEFER, J.C. (2006). "Linguistic politeness in Mexico: refusal strategies among male speakers of Mexican Spanish". Journal of Pragmatics, 38, 2158-2187.

FÉLIX-BRASDEFER, J.C. (2009). "Pragmatic variation across Spanish: requesting in Mexican, Costa Rican, and Dominican Spanish". Intercultural Pragmatics, 6(4), 473-515.

FLOWERDEW, J. (1990). "Problems of speech act theory from an applied perspective". Language Learning, 40, Issue 1, 79-105.

FRASER, B. (1990). "Perspectives on politeness." Journal of Pragmatics, 14, 219-236.

FUENTES RODRÍGUEZ, C. (2000). Lingüística pragmática y análisis del discurso. Madrid: Arco Libros, S.L.

FUKUSHIMA, S. (2000). Requests and culture: politeness in British English and Japanese. Berlin: Peter Lang.

GARCÍA, C. (1989). "Disagreeing and requesting by Americans and Venezuelans". Linguistics and Education, 1 (3), 299-322.

GARCÍA, C. (2007). "Ché, mirá, vos sabés que no voy a poder": how Argentineans refuse an invitation. Hispania, 90 (3), 551-564.

GARCÍA, C. (1992). "Refusing an invitation: a case study of Peruvian style". Hispanic Linguistics 5, 207-243.

GARCÍA, C. (1993). "Making a request and responding to it: a case study of Peruvian Spanish speakers". Journal of Pragmatics 19, 127152.

GARCÍA, C. (1996). "Reprimanding and responding to a reprimand: a case study of Peruvian Spanish speakers". Journal of Pragmatics 26, 663-697. 
GARCÍA, C. (1999). "The three stages of Venezuelan invitations and responses". Multilingual 18, 391-433.

GASS, S., HOUCK, NOEL. (1999). Interlanguage refusals: a crosscultural study of Japanese-English. New York: Mouton de Gruyter.

GASS, S., NEU, J. (eds.) (1996). Speech acts across cultures: challenges to communication in a second language. Berlin, New York: Mouton de Gruyter.

GEERTZ, H. (1961). The Javanese family: a study of kinship and socialization. New York: Free Press of Glencoe.

GEIS, M., HARLOW, L. (1996). "Politeness strategies in French and English". En Speech acts across cultures: challenges to communication in a second language. Berlin, New York: Mouton de Gruyter, 129-153.

GOFFMAN, E. ([1967] 1982). "On face-work. An analysis of ritual elements in social interaction". Interactional ritual. Essays on face to face behaviour, New York: Anchor Books, 5-45.

GOFFMAN, E. (1961). Encounters: two studies in the sociology of interaction. Mc.Ginnis (eds.), Indiana, Bobbs: Merill Company, INC.

GOLDBECK, D. (2006). The effect of imposition on children making, granting and refusing request. Tesis Master, Ottawa: Simon Fraser University.

GRAHAM S. L. (2007). "Disagreeing to agree: conflict, (im)politeness and identity in a computer-mediated community". Journal of Pragmatics, 39, 742-759.

GRAHAM, J. (1996). "Culture, negotiations and international cooperative ventures". En Speech acts across cultures: challenges to communication in a second language. Berlin, New York: Mouton de Gruyter, 317-338.

GREEN (1988). Pragmatics and natural language understanding. Erlbaum Associates, Incorporated, Lawrence.

GREEN, GEORGIA M. (1975). "How to get people to do things with words". En Peter Cole y Jerry L.M. (Eds.), Syntax and semantics: Vol. 3. Speech acts .New York: Academic Press, 107-141.

GRICE, H.P. (1989). Studies in the way of words. Cambridge: Harvard University Press. 
GRUNDY P. (2008). Doing pragmatics. London: Hodder Education.

GUDYKUNST, W. B., MATSUMOTO, Y., TING-TOOMEY, S., NISHIDA, T., KIM, K., y HEYMAN, S. (1996). "The influence of cultural indvidualism-collectivism, self construals, and individual-values on communication styles across cultures". Human Communication Research, 22, 510-543.

GUDYKUNST, W. B., y NISHIDA, T. (1986). "Attitudinal confidence in high and low-context cultures". Human Communication, 12, 525549.

GUDYKUNST, W.B. y TING-TOOMEY, S. (1988). Cultures and interpersonal communication. California: Sage.

GUIDETTI M. (2000). "Pragmatic study of agreement and refusal messages in young French children". Journal of Pragmatics, 32, 569582.

HALLIDAY, M.A.K. y HASAN, R. (1985). Language, context and text: a social semiotic perspective. Victoria: Deakin University Press.

HARTFORD, B. y BARDOVI-HARLIG, K. (1992). "Experimental and observational data in the study of interlanguage pragmatics". En Bouton, L. y Kachru, Y. (eds.), Pragmatics and language learning. monograph 3, Urbana-Champaign: IL, Deil, 33-50.

HARTFORD, B. y BARDOVI-HARLIG, K. (2005). "Institutional discourse and interlanguage pragmatics research". En Hartford, B. y Bardovi-Harlig, K., Interlanguage pragmatics, exploring institutional talk. New Jersey: Routledge, 7-37.

HAVERKATE, H. (1994). La cortesía verbal. Estudio pragmalingüístico. Madrid: Gredos.

HAVERKATE, H. (2004). "El análisis de la cortesía comunicativa: categorización pragmalingüística de la cultura española". En Bravo, D. y Briz, A. (eds.), Pragmática sociocultural: estudios sobre el discurso de cortesía en español. Barcelona: Ariel, 55-65.

HAYASHI, A. (2000). "Kaiwa hattenno kouzouto syuufukuno sutorateji: Nichi dokugo taishono shitenkara mita "irai" to "kotowari" ni okeru intarakusyon (Conversational structures and strategies for remedial work: Interaction of "requests" and "refusals" from contrastive analysis of Japanese and German)". Bulletin of Tokyo Gakugei University Section II Humanities, 51, 81-94. 
HELD, G. (1992). "Politeness in linguistic research". En Watts, R., Ide, S. y Ehlich, K., Politeness in language. studies in its history, theory and practice. Berlin: Mouton de Gruyter, 131-154.

HERNÁNDEZ FLORES, N. (2002). La cortesía en la conversación española de familiares y amigos: La búsqueda de equilibrio entre la imagen del hablante y la imagen del destinatario. Tesis Doctoral, Aalborg: Aalborg University.

HERNÁNDEZ FLORES, N. (2004). "La cortesía como la búsqueda del equilibrio de la imagen social". En Bravo, D. y Briz, A. (eds.), Pragmática sociocultural: estudios sobre el discurso de cortesía en español, Barcelona: Ariel, 95-108.

BEVERLY, H., IDE, S., SHOKO, I., KAWASAKI, A. y OGINO, T. (1986). "Universals of linguistic politeness: quantitative evidence from Japanese and American English". Journal of Pragmatics 10, 347-371.

HINKEL, E. (1997). "Appropriateness of advice: DCT and multiplechoice data". Applied Linguistics 18 (1), 1-26.

HOLMES, J. (1995). Women, Men and Politeness. London: Longman.

HONG, WEI. (1993). "A cross cultural study of request in Chinese and German". Dissertation Abstract International, DAIA 54 (07).

HONGLIN LI. (2007). "A comparative study of refusal speech acts in Chinese and American English". Canadian Social Science Vol. 3 No.4. 64-67.

HOUCK, N., GASS, S. (1996). "Non-native refusals: a methodological perspective". En speech acts across cultures: challenges to communication in a second language. Berlin, New York: Mouton de Gruyter, 45-64.

HOUSE, J. (1989). "Politeness in English and German: The functions of please and bite". En Blum-Kulka, S., House, J. y Kasper, G. (eds.), Cross-cultural pragmatics: requests and apologies. Norwood, $\mathrm{N} J$ : Ablex, 96-119.

HUI, C. y TRIANDIS, H. (1986). "Individualism-collectivism: a study of cross-cultural researchers". Journal of Cross-Cultural Psychology, $17,225-248$.

HYMES, D. (1972). "On communicative competence". En Pride, J. y Holmes, J. (eds.), Sociolinguistics. Harmondsworth: Penguin. 
IDE, S., et al. (1992). "The concept of politeness: an empirical study of American English and Japanese". En Watts, R., Ide, S., Ehlich, K. (eds.), Politeness in language. studies in its history, theory and practice. Berlin: Mouton de Gruyter, 281-297.

IGLESIAS, S. (2001). "Los estudios de la cortesía en el mundo hispánico. Estado de la cuestión". Oralia, 4, 245-298.

IZAKI, Y. (2000). "Cultural differences of preference and deviations from expectations in requesting: A study of Japanese and French learners of Japanese in contact situations". Journal of Japanese Language Teaching 104, 79-88.

JAKOBSON, R. (1972). "Motor signs for 'yes' and 'no'". Language in Society 1, 91-96.

JAMALIAH MOHD ALI. (2002). "Why we don"t say what we mean: a study of verbal indirection in communication". Journal of Modern Languages, 14, September, University of Malaya. 33-43.

JAWORSKI, A. (1994). "Pragmatic failure in a second language: greeting responses in English by Polish students". IRAL XXX II/ 1, 41-55.

JOSEPH, R. (1991). No...because: a study of pragmatic transfer in refusals among Puerto Rican teenagers speaking English. Unpublished Doctoral Dissertation, Columbia: Columbia University Teachers College.

JULIE CHEN. H. (1996). Cross-cultural comparison of English and Chinese metapragmatics in refusal. Unpublished Doctoral Dissertation, Indiana: Indiana University.

KHADIJAH BT IBRAHIM. (1993). Politeness in Malay directives. Unpublished dissertation, University of Malaya.

KASPER, G. y SCHMIDT, R. (1996). "Developmental issues in interlanguage pragmatics". Studies in Second Language Acquisition, $18,149-169$.

KASPER, G. (1989). "Interactive procedures in interlanguage discourse". En Oleksy W. (ed.), Contrastive pragmatics Amsterdam: Benjamins, 189-229.

KASPER, G. (1990). "Linguistic politeness: current research issues". Journal of Pragmatics 14, 193-218. 
KASPER, G. y DAHL, M. (1991). "Research methods in interlanguage pragmatics". Studies in second language acquisition, 13, 215-247.

KASPER, G. y BLUM-KULKA, S. (1993). "Interlanguage pragmatics: an introduction". En Kasper, G. y Blum-Kulka, S. (eds.), Interlanguage pragmatics. Oxford: Oxford University Press, 3-17.

KASPER, G. y ROSE, K.R. (1999). "Pragmatics and SLA". Annual Review of Applied Linguistics, 19, 81-104.

KASPER, G. (2008). "Data collection in pragmatics research". En Spencer-Oatey, H. (Ed.), Culturally speaking: culture, communication and politeness theory. Continuum, London, 316-341.

KEMPSON, R. (1998). Mental Representation. The Interface between language and reality. Cambridge: Cambridge University Press.

KERBRAT-ORECCHIONI, C. (2004). "¿Es universal la cortesía?" En Bravo, D. y Briz, A. (eds.), Pragmática sociocultural: estudios sobre el discurso de cortesía en español. Barcelona: Ariel, 39-53.

KINJO, H. (1987). "Oral refusals of invitations and requests in English and Japanese". Journal of Asian Culture 1, 83-106.

KITAO, K. (1990). "A study of Japanese and American perceptions of politeness in requests". Doshisha Studies, 50, 178-210.

KOBAYASHI, H. y RINNERT, C. (1999). "Requestive hints in Japanese and English". Journal of Pragmatics 31, 1173-1201.

KOIKE, D. (1994). "Negation in Spanish and English suggestions and requests: mitigating effects?". Journal of Pragmatics 21, 513-526.

KOIKE, D. (1989). "Requests and the role of deixis in politeness". Journal of Pragmatics, 13, 187-202.

KOIKE, D. (1996). "Transfer of pragmatic competence and suggestions in Spanish foreign language learning". En speech acts across cultures: challenges to communication in a second language, Berlin, New York: Mouton de Gruyter, 257-281.

KUBOTA, M. (1996). "Acquaintance or fiancee: pragmatic differences in requests between Japanese and Americans". Working Papers in Educational Linguistics, 12 (1), 23-38. 
LAKOFF, R. (1973). "The logic of politeness; or minding your p's and q's". En Papers from the seventh regional meeting of the Chicago linguistic society, Chicago: Chicago University Press, 292-305.

LAKOFF, R. (1982). "Some of my favorite writers are literate: the mingling of oral and literate strategies in written communication". En Tannen, D. (eds.), Spoken and written language. Norwood, $\mathrm{NJ}$ : Ablex, 239-260.

LE PAIR, R. (1996). "Spanish request strategies: A cross-cultural analysis from an intercultural perspective". Language Sciences, 18, 651-670.

LEECH, N. G. (1983). Principles of pragmatics. Londres: Longman.

LEVINSON, S. (1983). Pragmatics. Cambridge: Cambridge University Press.

LIAO, C., y BRESNAHAN, M.I. (1996). "A comparative pragmatic study on American English and Mandarin refusal strategies". Language Sciences, 18, 703-727.

LIAO, C. (1994). A study on the strategies, maxims, and development of refusal in Mandarin Chinese. Taipei: Crane.

LIAO, C. (1994). "After being refused: response to face-threatening speech acts". Paper presented at the fourth international symposium of Chinese languages and linguistics. July: Academia Sinica, 18-20.

LIAO, C. y BRESNAHAN, M.I. (1994). "Men and women in the use of post-refusal maxims in two areas". Paper Presented at the Third Kentucky Conference on Narrative, Kexington, KY: University of Kentucky, October, 14-16.

LIM, B.S. (2005). "Malay sayings as politeness strategies". Journal of Modern Languages 16, 65-77.

MÁRQUEZ REITER, R. y PLACENCIA, M.E. (2005). Spanish pragmatics. London: Palgrave Macmillan.

MÁRQUEZ REITER, R. (2000). Linguistic politeness in Britain and Uruguay: a contrastive study of requests and apologies. Philadelphia: John Benjamins.

MÁRQUEZ REITER, R. (2002). "Contrastive study of conventional indirectness in Spanish: evidence from peninsular and Uruguayan Spanish". Pragmatics, 12:2.135-151. 
MARTI, L. (2006). "Indirectness and politeness in Turkish-German bilingual and Turkish monolingual requests". Journal of Pragmatics, $38(11)$, 1836-1869.

MATSUMOTO, Y. (1988). "Reexamination of the universality of face: politeness phenomena in Japanese". Journal of Pragmatics 12, 403426.

MATSUMOTO, Y. (1989). "Politeness and conversational universals: observations from Japanese". Multilingual 8, 207-221.

MILLER, L. (1994). "Japanese and American indirectness". Journal of Asian Pacific Communication 5, 37-55.

MILLS, S. (2003). Gender and politeness. Cambridge: Cambridge University Press.

MIR, M. (1993). "Direct requests can also be polite". 7th Annual International Pragmatics Conference. University of Illinois at UrbanaChampaign, 1-3.

MIR, M. (1994). The use of English request by native Spanish speakers and its relation to politeness values. Unpubliched Doctoral Dissertation. University of Illinois at Urbana Champaign.

MORRISON, A., HOLMES, J. (2003). "Eliciting refusals: a methodological challenge". Te Reo 46, 47-66.

MORROW, C. (1995). The pragmatic effects of instruction on ESL learners' production of complaint and refusal speech acts. Unpublished Doctoral Dissertation, Buffalo: State University of New York.

MURILLO, J. (2004). "La cortesía verbal en Costa Rica. Percepciones de los hablantes sobre la (des)cortesía en puestos de atención al público". En Bravo, D. y Briz, A. (eds.), Pragmática sociocultural: estudios sobre el discurso de cortesía en español. Barcelona: Ariel, 181-195.

NAKABACHI, K. (1996). "Pragmatic transfer in complaints: Strategies of complaining in English and Japanese by Japanese EFL speakers". JACET Bulletin, 27, 127-142.

NELSON G. L., AL BATAL M. y EL BAKARY W. (2002). "Directness vs. indirectness: Egyptian Arabic and US English communication style". International Journal of Intercultural Relations, 26, 39-57. 
NELSON, G. L., CARSON, J., AL BATAL, M., y EL BAKARY, W. (2002). "Cross-cultural pragmatics: strategy use in Egyptian Arabic and American English refusals". Applied Linguistics, 23 (2), 163-189.

NGUYEN, THI MINH PHUONG. (2006). Cross-cultural pragmatics: refusals of requests by Australian native speakers of English and Vietnamese learners of English. Unpublished Master's Thesis, Queensland: University of Queensland.

NIETO y OTERO, Ma JESÚS. (2003). "Afectividad y cortesía: análisis de conversaciones políticas venezolanas". En Bravo, D. y Briz, A. (eds.), Pragmática sociocultural: estudios sobre el discurso de cortesía en español. Barcelona: Ariel, 240-256.

NIK SAFIAH KARIM et. al. (2011). Tatabahasa dewan edisi ketiga. Kuala Lumpur: Dewan Bahasa dan Pustaka.

NIK SAFIAH KARIM et. al. (1993). Tatabahasa dewan edisi baharu. Kuala Lumpur: Dewan Bahasa dan Pustaka.

NURIA LORENZO-DUS, N. y BOU-FRANCH, P. (2003). "Gender and politeness: Spanish and British undergraduates' perceptions of appropriate requests". En: José Santaemilia (ed), Género, lenguaje y traducción. Universitat de Valencia/Dirección General de la Mujer, 187-199.

OGIERMA, E. (2009). "Politeness and in-directness across cultures: a comparison of English, German, Polish and Russian requests". Journal of Politeness Research, 5, 189-216.

OLSHTAIN, E. y COHEN, A. (1983). "Apology: a speech act set". En Wolfson N. y Judd E. (Eds.), Sociolinguistics and language acquisition. Mass: Newbury House, 18-35.

OLSHTAIN, E. y COHEN, A. (1989). "Speech act behavior across languages". En Dechert, H.W., Raupach, M. (eds.), Transfer in language production. Norwood, NJ: Ablex, 53-67.

OLSHTAIN, E. (1989). Apologies across languages. En Blum-Kulka, S., House, J. y Kasper, G. (eds.), Cross-cultural pragmatics: requests and apologies. Norwood, NJ: Ablex Publishing Corporation, 155 173.

PALMER, F.R. (2001 [1986]). Mood and modality. Cambridge: Cambridge University Press, $2^{\mathrm{a}}$ ed. 
PLACENCIA, M.E. (1998). "Pragmatic variation: Ecuadorian Spanish vs. Peninsular Spanish". Spanish Applied Linguistics, 2(1), 71-106.

PLACENCIA, M.E. y BRAVO, D. (eds.) (2002). Actos de habla y cortesía en español. Múnich: Lincom Europa.

RAMOS, J. (1991). No . . . because: a study of pragmatic transfer in refusals among Puerto Rican teenagers speaking English. Unpublished doctoral dissertation, Columbia: Columbia University.

REAL ACADEMIA ESPAÑOLA. (2001). Diccionario de la lengua española. Madrid: Espasa/Calpe.

RICHARDS y RICHARD W.S. (eds.) (1990). Language and communication. New York: Longman.

ROBINSON, M. (1992). "Introspective methodology in interlanguage pragmatic research". En Kasper, G. (ed.), Pragmatics of Japanese as native and target language (technical report 3). Honolulu: University of Hawaii, Second Language Teaching and Curriculum Center.

RONG, C. (2001): "Self-politeness: a proposal". Journal of Pragmatics $33,87-106$.

ROSE, K. y REIKO, O. (1995). "Eliciting speech act data in Japanese: the effect of questionnaire type". Language Learning 45, 191-223.

ROSE, K. (1994). "On the validity of DCTs in non-Western contexts". Applied Linguistics 15, 1-14.

ROSE, K. (1996). "American English, Japanese, and directness: more than stereotypes". JALT Journal 18, 67-80.

RUBIN, J. (1983). "How to tell when someone is saying 'no' revisited". En Wolfson, N. y Judd, E. (eds.), Sociolinguistics and language acquisition. Rowley, MA: Newbury House, 10-17.

SCARCELLA, R. (1979). "On speaking politely in a second language". En Yorio, C.A., Perkins, K. y Schachter, J. (eds.), On Tesol '79. Washington, DC: TESOL, 275-287.

SCHRADER-KNIFFKI M. (Ed), (2006). La cortesía en el mundo hispánico. Madrid: Iberoamericana.

SCHRÖDER, U. (2010). "Speech styles and functions of speech from a cross-cultural perspective". Journal of Pragmatics 42, 466-476. 
SCOLLON, R. y SCOLLON, S. W. (1983). Face in interethnique communication. En Richards, J.C. y Schmit, R.W. (eds.) Language and Communication, New York: Longman, 156-191.

SCOLLON, R. y SCOLLON, S. W. (1995). Intercultural communication. A discourse approach. Cambridge: Cambridge University Press.

SCOLLON, R. y SCOLLON, S. W. (2001). Intercultural communication. second ed. Malden: MA: Blackwell.

SEARLE, J.R. (1969). Speect acts: an essay in the philosophy of language. Cambridge: Cambridge University Press.

SEARLE, J.R. (1975). "Indirect speech acts". En Cole, P. y Morgan, J. (eds.), Speech acts (syntax and semantics), New York: Academic Press, vol. 3, 59-82.

SEARLE, J.R. (1979). Expression and meaning. Studies in the theory of speech acts. Cambridge: Cambridge University Press.

SEARLE, J.R. (2007 [1980]). Actos de habla. Madrid: Cátedra.

SEARLE, J.R.; KIEFER, F. y BIERWISCH, M. (eds.) (1980). Speech acts. Theory and pragmatics. Dordrecht: Reidel.

SERRANO, M. (2000). "La producción de la cortesía verbal y la deixis sociocomunicativa". Oralia 3, 199-219.

SIEBOLD, K. (2008). Actos de habla y cortesía verbal en español y en alemán, Estudio pragmalingüístico e intercultural. Frankfurt am Main: Berlin, Bern, Bruxelles, New York, Oxford, Wien.

SIFIANOU, M. (1992). Politeness phenomena in England and Greece. Oxford: Oxford University Press.

SILVA-CORVALÁN, C. (2001). Sosiolingüistica y pragmática del español. Washington, DC: Georgetown University Press.

SINCLAIR, J. McH. y COULTHARD R.M. (1975). Towards an analysis of discourse. The English used by teachers and pupils. Londres: Oxford University Press.

SMITH, C. (1998). Can adults 'Just Say No?': how gender, status and social goals affect refusals. Unpublished doctoral dissertation, Florida: University of South Florida. 
TALBOT, M. (1998). Language and gender: An introduction. Cambridge: Polity Press.

TAKAHASHI, T. y BEEBE, L. M. (1986). "ESL teachers' evaluation of pragmatic vs. grammatical errors". CUNY Forum, 12, 172-203.

TAKAHASHI, T., BEEBE, L.M. (1987). "The development of pragmatic competence by Japanese learners of English". JALT Journal 8, 131155.

TAKAHASHI, T. Y BEEBE, L.M. (1987). "The development of pragmatic competent by Japanese learners of English". JALT Journal, $8,131-155$.

TAKAHASHI, T. Y BEEBE, L.M. (1993). "Cross-linguistic influence in the speech act of correction". En Blum-Kulka, S. y Kasper, G. (eds.), Interlanguage pragmatics. Oxford: Oxford University Press, 138-157.

TATEYAMA, Y. (2001). "Explicit and implicit teaching of pragmatic routines". En Rose, K.R. y Kasper, G. (eds.), Pragmatics in language teaching, Cambridge, UK: Cambridge University Press, 200-222.

TELLO RUEDA, L. Y. (2006). "Análisis contrastivo e interlingüístico de peticiones en inglés y español (Contrastive and interlinguistic analysis of requests in English and Spanish)". Íkala, 11(17), 89-116.

THOMAS, J. (1983). "Cross-cultural pragmatic failure". Applied Linguistics 4, 91-112.

THOMAS, J. (1984). "Cross-cultural discourse as "unequal encounter": towards a pragmatic analysis". Applied Linguistics 5, 226-235.

THOMAS, J. (1995). Theories of politeness, meaning in interaction: an introduction to pragmatics. London: Longman.

TING-TOOMEY, S. (1988). "Intercultural conflict styles: a facenegotiation theory". En Kim, Y. y Gudykunst, W.B. (eds.), Theories in intercultural communication. Newbury Park, CA: Sage, 149-182.

TING-TOOMEY, S., GAO, G., TRUBISKY, P., YANG, Z.Z., KIM, H.S., LIN, S.L. y NISHIDA, T. (1991). "Culture, face maintenance, and styles of handling interpersonal conflict: a study in five cultures". International Journal of Conflict Management 2, 275-296. 
TING-TOOMEY, S. y COCROFT, B.A. (1994). "Face and facework: theoretical and research issues". En Ting-Toomey, S. (eds.), The challenge of facework: cross-cultural and interpersonal issues. Albany, NY: State University of New York Press, 307-340.

TRIANDIS, H.C. (1988). "Collectivism vs. individualism: a reconceptualization of a basic concept in cross-cultural social psychology". En Verma, G.K., Bagley, C. (eds.), Cross-cultural studies of personality, attitudes and cognition. London: Macmillan, 75-82.

TRIANDIS, H.C., BRISLIN, R. y HUI, C.H. (1988). "Cross-cultural training across the individualism-collectivism divide". International Journal of Intercultural Relations, 12, 269-289.

TRIANDIS, H.C. (1995). Individualism y collectivism. UK: Westview Press.

TURNBULL, W. y SAXTON, L.K. (1997). "Modal expressions as facework in refusals to comply with requests: I think I should say 'no' right now". Journal of Pragmatics 27, 145-181.

TURNBULL, W. y SAXTON L.K. (1994). A manual for the coding of request refusals. Unpublished manuscript, Simon Fraser University.

UEDA, K. (1974). "Sixteen ways to avoid saying no in Japan". En Condon, J. y Saito, M. (eds.), Intercultural encounters with Japan, Tokyo: Simul Press, 180-192.

VANDERVEKEN, D. (2009 [1994]). Meaning and speech acts, volume II, formal semantics of success and satisfaction. Cambridge: Cambridge University Press.

VÁZQUEZ ORTA, I. (2000). "A Contribution to the Analysis of CrossCultural Communication: The Case of Politeness Systems in English and Spanish". En Panorama actual de la lingüística aplicada: Conocimiento, procesamiento y uso del lenguaje. Logroño (Spain): Mogar Lynotipe, 2, 435-445.

VERSCHUEREN, J. (2002). Para entender la pragmática. Madrid: Gredos.

VOLLMER, H., J. y OLSHTAIN, E. (1989). "The language of apologies in German". En Blum-Kulka, S., House, J. y Kasper, G. (eds.), Crosscultural pragmatics: requests and apologies. Norwood, NJ: Ablex Publishing Corporation, $197-218$. 
WALTERS, J. (1979). "The perception of politeness in English and Spanish". En Yorio, C., Peters, K. y Schachter, J. (eds.), On TESOL 79. Washington DC: TESOL, 288-296.

WANNARUK, A. (2008). "Pragmatic transfer in Thai EFL refusals". RELC Journal, 39, 318-337.

WATTS, R. (1992). "Linguistic politeness and politic verbal behaviour: reconsidering claims for universality". En Watts, R., Ide, S., Ehlich, K. (eds.), Politeness in language. Studies in its history, theory and practice. Berlin: Mouton de Gruyter, 43-69.

WATTS, R. (2003). Politeness. Cambridge: Cambridge University Press.

WATTS, R., IDE S. y EHLICH, K. (eds.) (2005). Politeness in language. Studies in its history, theory and practice. Berlín: MoutonDe Gruyter.

WIERZBICKA, A. (2003). Cross-cultural pragmatics. The semantics of human interaction. Berlin, New York: Mouton de Gruyter.

WILKINS, D. A. (1976). Notional syllabuses. Oxford: Oxford University Press.

WOLFSON, N. (1981). "Compliments in cross-cultural perspective". En Merrill, V.J. (ed.) (1987): Culture bound: bridging the cultural gap in language teaching. Cambridge, Cambridge University Press.

WOLFSON, N. (1983). "An empirically based analysis of complimenting in American English". En Wolfson, N. y Judd, E. (eds.), Sociolinguistics and language acquisition. Rowley, M A, Newbury House, 82-95.

WOLFSON, N. (1986). Research methodology and the question of validity. TESOL Quartely, 20, 689 - 699.

WOLFSON, N. (1988). "The Bulge: a theory of speech behavior and social distance". En Fine, J. (eds.), Second language discourse: $A$ textbook of current research. Norwood, NJ: Ablex Publishing Corporation, 124-138.

WOLFSON, N. (1989). Perspectives: sociolinguistics and TESOL. Newbury House, Cambridge, MA. 
WOLFSON, N. (1989). "The social dynamics of native and non native variation in complimenting behaviour". En Eisenstein, M. (ed.), Variation in second language acquisition: empirical views. Nueva York: Plenum Press, 219-236.

WOLFSON, N., MARMOR, T., y JOHNS, S. (1989). Problems in the comparison of speech acts across cultures. En Blum-Kulka, S., House, J. y Kasper, G. (eds.), Cross-cultural pragmatics: requests and apologies. Norwood, NJ: Ablex Publishing Corporation, 174 196.

YU, M.C. (1999). "Universalistic and culture-specific perspectives on variation in the acquisition of pragmatic competence in a second language". Pragmatics, 9 (2), 281-312.

YULE, G. (1985). The Study of language. Cambridge: Cambridge University Press.

YULE, G. (1997). Pragmatics. Cambridge: Cambridge University Press.

ZHANG Y. (1995). "Indirectness in Chinese requesting". En: Kasper. (Ed.). Pragmatics of Chinese as native and target language. Honolulu: University of Hawaii Press, 71-118. 



\section{APÉNDICE A}

REQUESTS AND APOLOGIES

Table 1. Request strategy types-definition of coding categories and tokens

(Blum-Kulka y Olshtain, 1984)

Type

\section{Mood derivable}

The grammatical mood of the verb in the utterance marks its illocutionary force as a request.

\section{Explicit performatives}

The illocutionary force of the utterance is explicitly named by the speakers.

\section{Hedged performative}

Utterances embedding the naming of the illocutionary force.

\section{Locution derivable}

The illocutionary point is directly derivable from the semantic meaning of the locution.

\section{Scope stating}

The utterance expresses the speaker's intentions, desire or feeling vis $d$ vis the fact that the hearer do $\mathrm{X}$.

\section{Language specific suggestory formula} The sentence contains a suggestion to $X$.

\section{Reference to preparatory conditions} Utterance contains reference to preparatory conditions (e.g. ability or willingness, the possibility of the act being performed) as conventionalized in any specific language.

\section{Strong hints}

Utterance contains partial reference to object or to elements needed for the implementation of the act (directly pragmatically implying the act).

\section{Mild hints}

Utterances that make no reference to the request proper (or any of its elements) but are interpretable through the context as requests (indirectly pragmatically implying the act)
(5) Leave me alone (S3, AUE)

(6) Clean up this mess, please (S1, BE)

(7) Aveksex lo lehaxnot kan et haoto (I'm asking you not to park the car here) (SIl, H)

(8) Ich bitte Sie denPlatz sofort freizumachen (SII.G)

(9) Tisma, hayiti roca levakes mimxa setakdim et haharcaa selxa besavua (I would like you to give your lecture a week earlier) (S15.H)

(10) Madam, you'll have to move your car (SII, AUE)

(11) Entschuldigen Sie, aber Sie miissen diesen Platzfreihalten(SII,G)

(12) I really wish you'd stop bothering me (S3 AUE)

(13) Ich mochte von Ihnen in Ruhe gelassen werden (S3 G)

(14) Why don't you get lost? (S3, AUE)

(15) How about cleaning up? (SI, AUE)

(16) So, why don't you come and clear up the the mess you made last night!? (SI, BE)

(17) Wie wars wenn Du die Kiiche aufraumen wiirdest? (SI G)

(18) Could you clear up the kitchen, please? (SI, BE)

(19) Would you mind moving your car, please? (SII, AUE)

(20) You've left this kitchen in a right mess (SI, BE)

(21) Fahren Sie nicht auch in die gleiche Richtung! (S7, G)

(22) I'm a nun (in response to the persistent boy, S3, AUE)

(23) Ich bin verheiratet und habe zwei kleine Kinder (same situation as above, S3, G) 



\section{APÉNDICE B}

\section{Classification of Refusals (Beebe et al. 1990)}

Direct Refusal

A. Perfomative (e.g., "I refuse")

B. Nonperformative statement

1. "No"

2. Negative willingness/ability ("I can't" "I won't" "I don't think so")

Indirect Refusal

A. $\quad$ Statement of regret (e.g., "I'm sorry...," "I feel terrible... ")

B. Wish (e.g., "I wish I could help you... ")

C. Excuse, reason, explanation (e.g., "I already have a family gathering that day," "My parents celebrate their silver wedding anniversary.")

D. Statement of alternative

1. I can $X$ instead of $Y$ (e.g., "I'd rather..." "I'd prefer... ")

2. Why don't you do $X$ instead of $Y$ (e.g., "Why don't you ask someone else?")

E. Set condition for future or past acceptance (e.g., "I'll do it next time", if you had asked me earlier, I would have...")

F. $\quad$ Statement of principle (e.g., "I never do business with friends.")

G. Statement of philosophy (e.g., "Such things can happen to anyone")

H. Attempt to dissuade interlocutor

1. Threat or statement of negative consequences to the requester (e.g., "You won't be able to understand my handwriting" to refuse lending class notes)

2. Statement of negative feeling: Criticism of the request/requester, guilt trip (e.g., "you are lazy")

3. Request for help, empathy and assistance (e.g., "I hope you can understand my situation")

4. Let interlocutor off the hook (e.g., "don't worry about it", "That's okay", "you don't have to")

5. Self-defence (e.g., "I'm just following the course program”, "I’m doing my best")

Avoidance

1. Verbal

A. Repetition of part of request, etc. (e.g., "Did you say Monday?")

B. Postponement (e.g., "I'll think about it")

C. Hedging (e.g., "Gee, I don't know." "I'm not sure")

2. Nonverbal
A. Silence
B. Hesitation
C. Do nothing
D. Physical departure

Adjuncts to Refusals

1. Statement of positive opinion/feeling or agreement (e.g., "That's a good idea..."; "I'd love to...")

2. Statement of empathy (e.g., "I realize you are in a difficult situation.")

3. Pause fillers (e.g., "uhhh"; "well"; "oh"; "uhm")

4. Gratitude/Appreciation (e.g., "Thank you very much") 



\section{APÉNDICE C}

\section{Classification of Rejections \\ (Developed by Bardovi-Harlig and Hartford, 1991)}

Direct

$\mathrm{Hm}$. Not actually, I'm avoiding it. (NS)

Well, I've decided not to take them. (NS)

Indirect

Excuse, reason, explanation

That's the one that conflicts with what I have to take. (NS)

Yeah but in Spain they don't offer courses in the structure of language outside the European family. (NNS)

*Q It doesn't matter if I have already taken that course? (NNS)

Statement of alternative

But anyway, I could look into the possibility of having that requirement waived... (NS)

I decided to take these three cour...courses. OK. (NNS)

* $Q$ What would I take in the summer if didn't do that? (NS)

Acceptance that functions as refusal

Unspecific or indefinite reply; Lack of enthusiasm

That might be a solution. (NS)

I don't care about taking it. (NNS)

Avoidance

Hedging

I don't know. (NS)

*Request information (NNS only)

That one's required? (NNS)

*Question requesting repetition of suggestion (NNS only)

Which one is that one? (NNS)

*Postponement, Q

Can I think about it? (NNS)

Um---can I decide it next week? (NNS)

* Indicates categories Bardovi-Harlig and Hartford have added to the taxonomy based on their corpus. 



\section{CUESTIONARIO}

\section{Estimado/a señor/a}

El propósito de este cuestionario es examinar las características lingüísticas del habla española. Rellenar el cuestionario, solamente le llevará, aproximadamente, 15 ó 20 minutos. El cuestionario es anónimo. Las respuestas serán utilizadas, exclusivamente para fines relacionados con la investigación. Si le interesa conocer el resultado del estudio, puede ponerse en contacto conmigo a través del correo especificado a continuación. Muchas gracias por su colaboración.

ris1771@yahoo.com

Universidad de Valladolid, España.

\section{DATOS PERSONALES:-}

Edad:

Sexo:

Profesión:

Carrera:

Nivel de educación (Diplomado/Licenciado/Máster/Doctor):

Lengua nativa:

Lengua nativa del padre:

Lengua nativa de la madre: 


\section{APÉNDICE D}

\section{INSTRUCCIONES:-}

Lea cada situación detenidamente y escriba la respuesta que más se ajuste a la realidad. Si no ha vivido una experiencia similar a las similar dadas, imagínese si estuviera en cada una de las situaciones y escriba lo que diría. Exprésese por favor, con sinceridad y naturalidad. No hay ninguna respuesta correcta o incorrecta. Es libre para escribir lo que sea y es libre para utilizar cualquier puntuación (punto, coma, signos de exclamación, interrogación y otros). $\mathrm{X}$ representa al nombre del interlocutor. Responda, por favor, a todas las situaciones.

1. No tienes escalera para arreglar una lámpara, así que se la quieres pedir prestada a tu vecino. Pero, no le conoces porque acabas de cambiarte de casa. Te acercas y le dices...

2. X es un agente de una compañía de telefonía móvil, y no le conoces. Viene a tu casa y te intenta convencer para que compres el nuevo paquete del servicio. ¿Qué le dirías a X si no quieres comprarlo?

3. Eres un directivo en una firma famosa, mientras que $X$ es tu nuevo secretario. Hoy es el primer día que $X$ trabaja en tu firma y tú y $X$ nunca os habéis encontrado antes. Quieres que $X$ haga fotocopias de algunos documentos. Llamas a $X$ y le dices... 


\section{APÉNDICE D}

4. Piensas ir a comprar y quieres que tu compañero de piso te acompañe. Te acercas y le dices...

5. Eres un estudiante universitario, mientras que $X$ es tu compañero de curso. Le ha entrado un virus en el portátil y por eso te quiere pedir prestado el tuyo. ¿Qué le dirías si no quieres prestárselo?

6. Eres profesor en una universidad, mientras que $X$ es uno de tus estudiantes. $X$ viene tarde a clase y esto no te gusta. Quieres que $X$ llegue a la hora. Le dices a X...

7. Estás solo en casa y quieres que tu mejor amigo venga a hacerte compañía. Le llamas por teléfono y le dices... 


\section{APÉNDICE D}

8. $\mathrm{X}$ es tu hermano menor y tienes una relación muy estrecha con él. $X$ te ha pedido que le acompañes a la fiesta de cumpleaños de su amigo. ¿Qué le dirías si no quieres ir a la fiesta?

9. X es tu hijo, y está llegando a la adolescencia. Te pide permiso para salir con sus amigos. Se lo permites, pero quieres que vuelva pronto a casa. Le dices a X...

10. Necesitas una carta de recomendación para solicitar un trabajo. Piensas pedírselo a tu ex profesor en la universidad. Vas verle y le dices...

11. Tú y $X$ sois colegas. $X$ te pide que vayas a pescar con él a un río. ¿Qué le dirías si no quieres ir? 


\section{APÉNDICE D}

12. Eres profesor en una universidad, mientras que $X$ es un nuevo alumno a tu cargo. $X$ te ve por primera vez para revisar las asignaturas que ya tiene planeado hacer. Examinas la lista de asignaturas que $X$ ha elegido. Quieres que $X$ cambie una de las asignaturas elegidas por otra. Le dices a $\mathrm{X} . .$.

13. Eres director de una empresa. Quieres pedir a uno de tus trabajadores que va a hacer un viaje de negocios a Rusia, que te compre una lata de caviar. Te acercas a él y le dices...

14. Eres profesor en una universidad, mientras que $X$ es estudiante. $X$ quiere pedir prestada una tesis de un estudiante anterior que guardas en tu despacho. ¿Qué le dirías si no quieres prestársela?

15. Eres encargado en un restaurante, mientras que $X$ es trabajador a tiempo parcial. Quieres que $X$ envíe la comida que ha reservado un cliente a su oficina. Le llames a $\mathrm{X}$ y le dices... 


\section{APÉNDICE D}

16. No te queda saldo en tu móvil pero tienes que hacer una llamada. Sabes que tu amigo acaba de recargar su móvil esta mañana. Te acercas a él y le dices...

17. Eres un estudiante universitario, mientras que $X$ es un profesor. Estás haciendo una investigación bajo de la dirección de $X . X$ te sugiere que cambies el método del estudio. ¿Qué le dirías si no estás de acuerdo con él?

18. X es tu hijo y estudia en un colegio. $\mathrm{X}$ ve la tele hasta medianoche. Quieres que $X$ se acueste enseguida. Le dices a $\mathrm{X} \ldots$

\section{MUCHAS GRACIAS}




\section{APÉNDICE E}

\section{BORANG SOAL SELIDIK}

Assalamualaikum,

Tuan/Puan,

Tujuan soal selidik ini adalah untuk mengenal pasti ciri-ciri linguistik dalam pertuturan orang Melayu. Kemungkinan masa yang diperlukan untuk mengisi borang soal selidik ini adalah 15-20 minit. Penyertaan tuan/puan adalah secara sukarela. Jawapan dalam soal selidik ini hanya akan digunakan untuk tujuan kajian semata-mata. Jika tuan/puan berminat untuk mengetahui hasil kajian, tuan/puan boleh menghubungi saya melalui email di bawah. Terima kasih kerana meluangkan masa.

ris1771@yahoo.com

Universidad de Valladolid, España

\section{MAKLUMAT DEMOGRAFI:-}

Umur:

Jantina:

Pekerjaan:

Pendidikan: (Diploma/Ijazah/Master/PhD/Lain-lain):

Bidang: 


\section{APÉNDICE E}

\section{ARAHAN:-}

Sila baca setiap situasi dengan teliti dan tulis apa yang akan anda katakan. Jika anda tidak mempunyai pengalaman seperti dalam situasi yang diberi, bayangkan anda berada dalam situasi tersebut dan tulis apa yang akan anda katakan. Tulislah dengan jujur dan semulajadi. Tiada jawapan betul atau salah. Anda bebas menulis apa sahaja dan bebas menggunakan sebarang tanda bacaan (noktah, koma, tanda seruan, tanda soal dan lain-lain). $\mathrm{X}$ mewakili nama watak di dalam teks. Sila respon terhadap semua situasi.

1. Anda tidak mempunyai tangga untuk membaiki lampu, oleh itu anda berhasrat untuk meminjamnya daripada jiran anda. Namun, anda tidak mengenali jiran tersebut kerana anda baru berpindah. Anda mendekatinya dan berkata...

2. X merupakan ajen insurans yang tidak anda kenali. $X$ datang ke rumah anda dan memujuk anda membeli insurans syarikatnya. Apakah yang akan anda katakan pada $\mathrm{X}$ jika anda tidak mahu membeli insurans tersebut?

3. Anda adalah pengarah sebuah firma terkemuka manakala $X$ adalah setiausaha baru anda. Hari ini adalah hari pertama $X$ bekerja di firma anda. Anda dan $X$ tidak pernah bertemu sebelum ini. Anda mahu $X$ membuat fotokopi beberapa dokumen. Anda memanggil $X$ dan berkata ... 


\section{APÉNDICE E}

4. Anda berhasrat untuk membeli belah dan ingin rakan serumah anda menemani anda. Anda mendekatinya dan berkata...

5. Anda adalah pelajar di universiti manakala $X$ adalah rakan sekursus anda. Laptop $\mathrm{X}$ dimasuki virus, oleh itu $\mathrm{X}$ telah meminta untuk meminjam laptop anda. Apakah yang akan anda katakan pada $\mathrm{X}$ jika anda tidak mahu meminjamkannya?

6. Anda adalah profesor di universiti manakala $X$ adalah salah seorang pelajar anda. $X$ datang lewat ke kuliah dan ini tidak menyenangkan anda. Anda mahu $\mathrm{X}$ datang tepat pada waktu. Anda berkata kepada X...

7. Anda keseorangan di rumah dan ingin sahabat baik anda menemani anda. Anda menghubunginya dan berkata... 


\section{APÉNDICE E}

8. X adalah adik kandung anda dan hubungan anda dengannya sangat rapat. $X$ mengajak anda menemaninya ke majlis hari jadi kawannya. Apakah yang akan anda katakan pada $\mathrm{X}$ jika anda tidak mahu pergi ke majlis tersebut?

9. X adalah anak anda yang sedang meningkat remaja. X meminta izin anda untuk keluar bersama kawan-kawannya. Anda mengizinkannya tetapi mahu $X$ pulang awal ke rumah. Anda berkata kepada $\mathrm{X} . .$.

10. Anda perlukan surat sokongan untuk memohon pekerjaan. Anda berhasrat untuk mendapatkannya daripada profesor anda ketika di universiti. Anda pergi menemuinya dan berkata...

11. Anda dan $X$ adalah rakan sekerja. $X$ mengajak anda pergi memancing dengannya di sebatang sungai. Apakah yang akan anda katakan pada $\mathrm{X}$ jika anda tidak mahu pergi? 


\section{APÉNDICE E}

12. Anda adalah profesor di universiti manakala $X$ adalah pelajar seliaan anda yang baru. $X$ telah datang bertemu anda buat pertama kali bagi mendapatkan pengesahan anda tentang kursus-kursus yang telah dipilihnya. Anda meneliti senarai kursus pilihan $X$. Anda mahu $X$ menukar salah satu kursus yang telah dipilihnya kepada kursus lain. Anda berkata kepada X...

13. Anda adalah pengurus di sebuah syarikat. Anda ingin meminta salah seorang pekerja anda yang akan ke Indonesia atas urusan kerja agar membelikan anda buah salak. Anda mendekatinya dan berkata...

14. Anda adalah profesor di universiti manakala $X$ adalah seorang pelajar. $X$ meminta untuk meminjam tesis pelajar terdahulu yang ada dalam simpanan anda. Apakah yang akan anda katakan pada $\mathrm{X}$ jika anda tidak mahu meminjamkannya?

15. Anda adalah pengurus restoran manakala $X$ adalah pekerja sambilan anda. Anda mahu $X$ menghantar makanan yang telah ditempah pelanggan ke pejabatnya. Anda memanggil $X$ dan berkata.... 


\section{APÉNDICE E}

16. Telefon anda telah kehabisan kredit sedangkan anda perlu membuat satu panggilan. Anda tahu rakan anda baru sahaja menambah kredit telefonnya pagi tadi. Anda mendekatinya dan berkata...

17. Anda adalah pelajar di universiti manakala $X$ adalah seorang profesor. Anda sedang menjalankan satu kajian di bawah seliaan X. X mencadangkan kepada anda agar menukar metod kajian anda. Apakah yang akan anda katakan pada $\mathrm{X}$ jika anda tidak bersetuju dengan cadangannya itu?

18. $\mathrm{X}$ adalah anak anda yang merupakan pelajar sekolah rendah. $\mathrm{X}$ masih menonton televisyen sedangkan hari sudah larut malam. Anda mahu $\mathrm{X}$ masuk tidur dengan segera. Anda berkata kepada $\mathrm{X}$... 